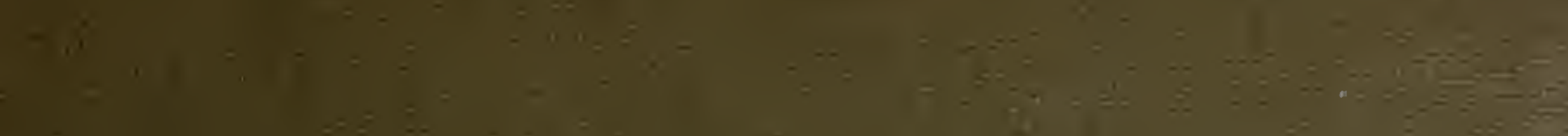

inc $=-9$

6)

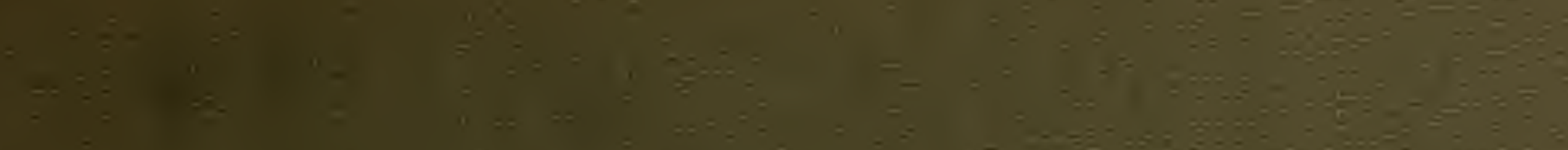

$x+y=0$

$+x$

3

25as

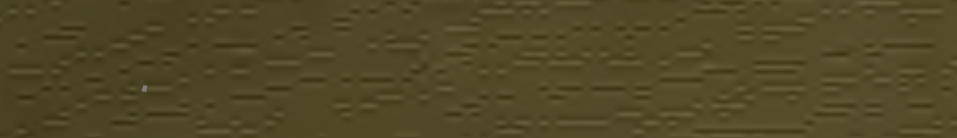

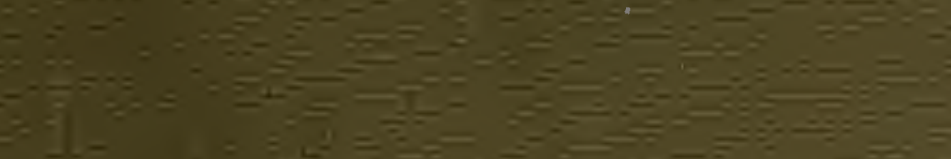

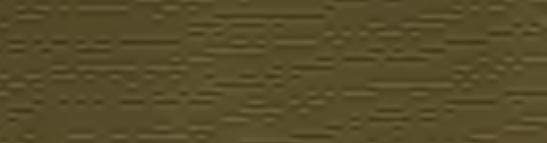

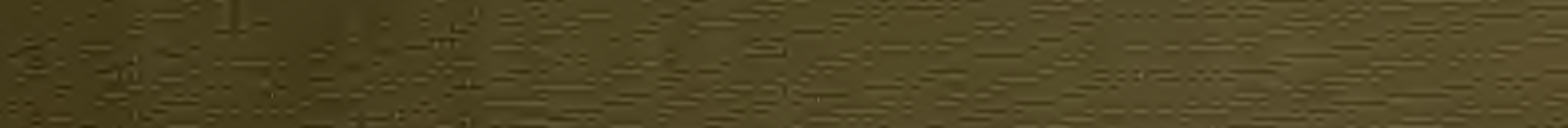
ticis

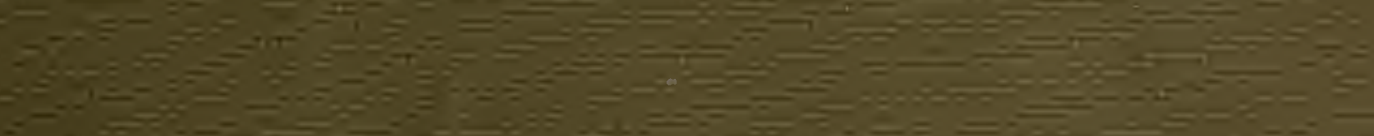

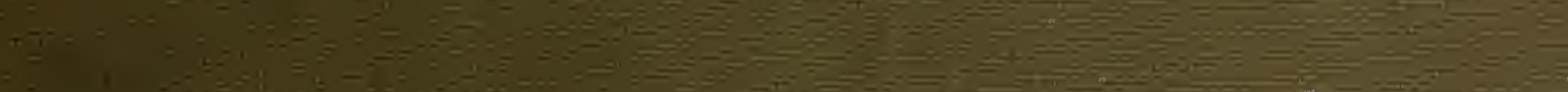

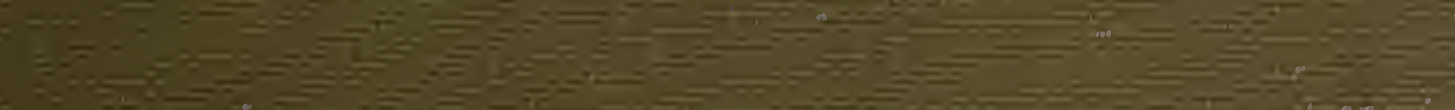

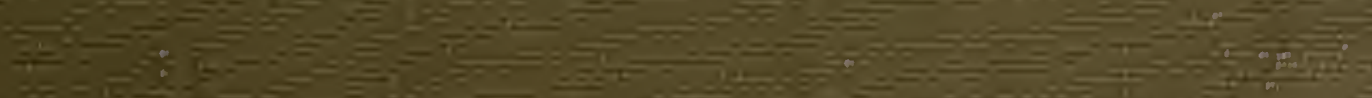




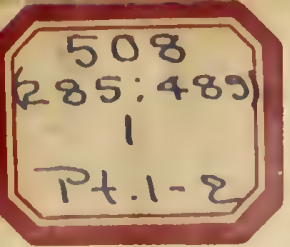

$\left(\begin{array}{c}508 \\ 285: 489 \\ 1 \\ 1+1-2\end{array}\right.$

$B:-8+5.8$

$B \cdot B \cdot, B=1 B+B$

B. 8 is

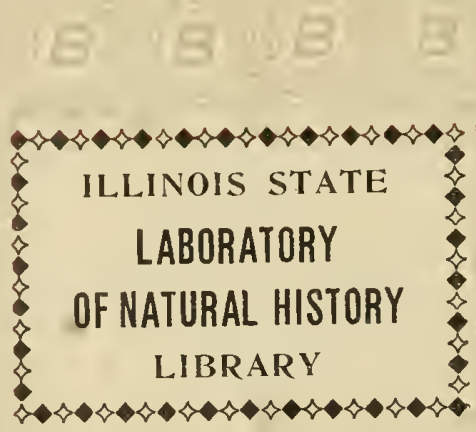

西弪

(8).

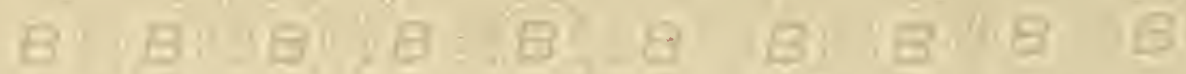

$B^{\prime} \cdot \theta^{\cdot} \cdot \theta^{\prime}=8$

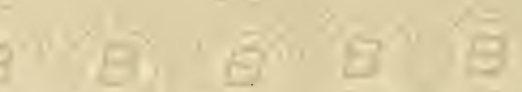

$\dot{B}=\theta \quad \theta \quad E$

B 8 in 8 B

$\frac{2}{8}$

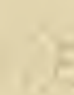

B. B' B'D'

B 8 B $\theta^{\prime} E$

틀

(B) 8 118 



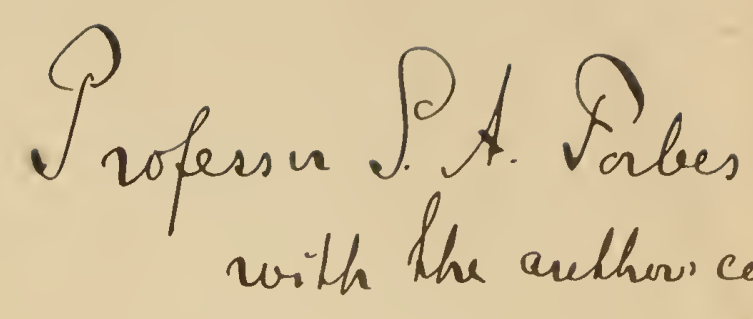

with the authow comp

\section{STUDIER OVER}

\section{DE DANSKE SØERS PLANKTON}




\section{Digitized by the Internet Archive in 2016}





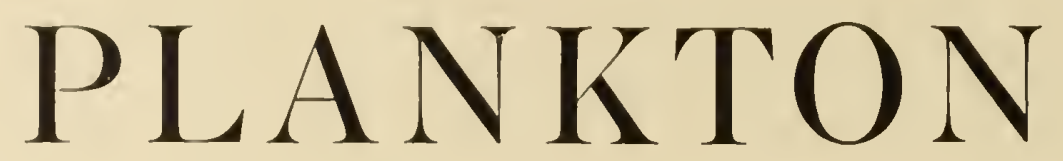

I N V EST IGATIONS

$\mathrm{OF}$

THE DANISH LAKES

BY

DR. C. WESENBERG-LUNI)

ASSISTED BY MR. E. LARSEN IN THE BOTANICAL RESEARCHES

SPECIAL PAR'T

I. TEXT

WITH ENGLISH SUMMARY OF CONTENTS

PUBLISHED BY THE AID OF THE CARLSBERG FUND

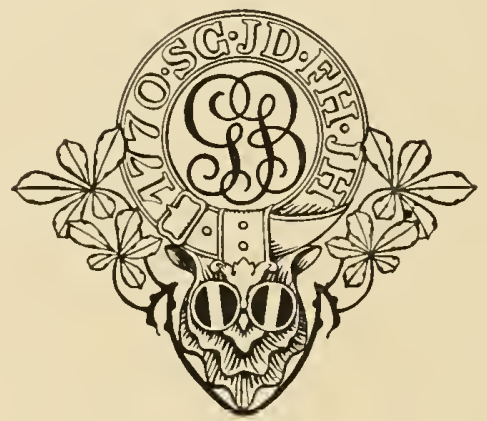

COPENHA GEN

GYLDENDALSKE BOGHANDEL • NORDISK FORLAG

PRINTED BY NIELSEN \& LYDICHE 


\section{STUDIER}

OVER

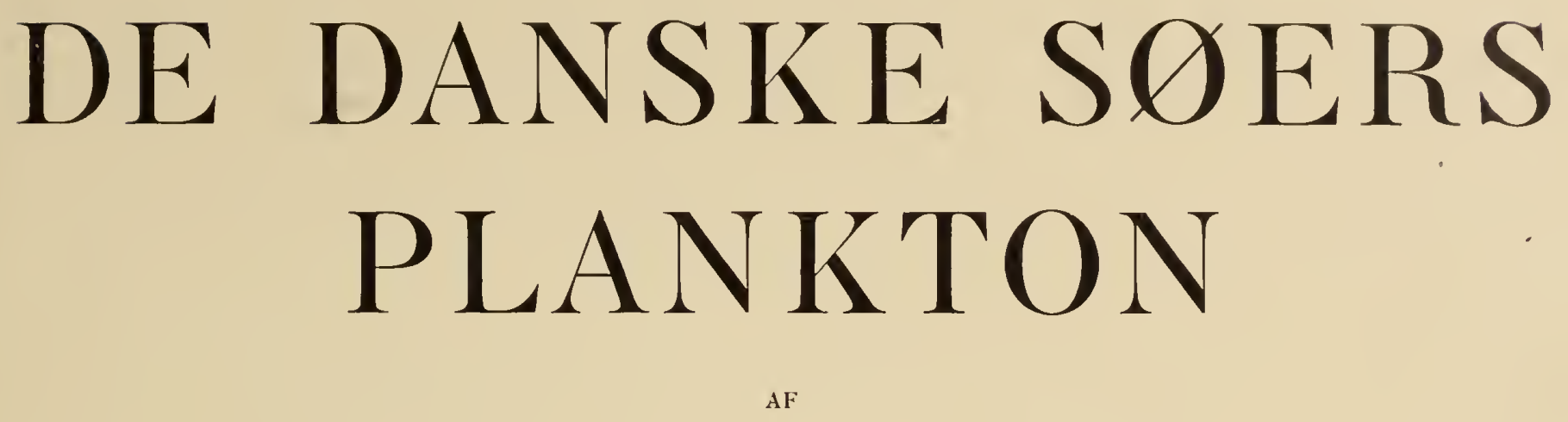

Dr. C. WESENBERG-LUND

FOR DE BOTANISLE AFSNITS VEDKOMMENDE MED BISTAND AF MAG. SC. E. LARSEN

SPECIELLE DEL

I. TEKST

MED ENGELSK RESUMÉ

PAA CARISBERGFONDETS BEKOSTNING

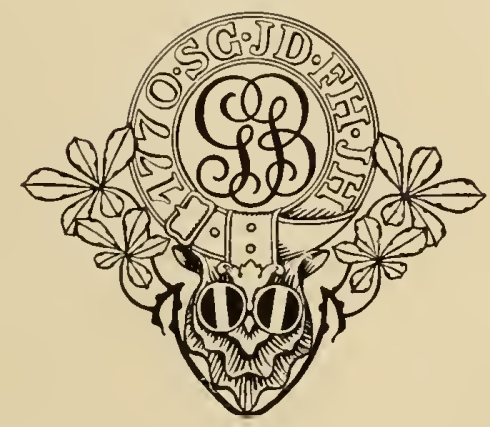

K.J ØBENHAVN

GYLDENDALSKE BOGHANDEL - NORDISK FORLAG 
lira det lierskvands-biologiske Laboraborium er tidligere udkommet:

\section{WESENBERG-LUND:}

J.

1900. Von dem Abhängigkeitsverhïlniss zwischen dem Bau der Planktonorganismen und denı spezifischen Gewicht les Süsswassers.

Biolog. Centralbl. T. 20. p. 606-619 og 644-656.

II.

1901. Sturlier over Sokalk, Bonnenalm og Soggtje i danske Indsoer, med 3 Tavler og engelsli liesumé.

Medrlelelser fra Dansk geologisk Forening Nr. 7. p. $1-180$.

III.

1902. Sur l'existence d'une faune relicte dans le lac de Fureso. Académie Royale des sciences et des lettres de banemark. Bulletin de l'annće 1902 p. 257-303.

IV.

1903. Sur les Egagropila Sauteri du lac de Sorò. ibid. p. $167-204$. 
MINDET OM DEN STORE NATURFORSKER

\title{
JAPETUS STEENSTRUP
}

\author{
I ERBODIGHED OG TAKNEMLIGHED
}

TILEGNET

AF

FORFATTEREN 



\section{INI)HOLDSFORTEGNELSE.}

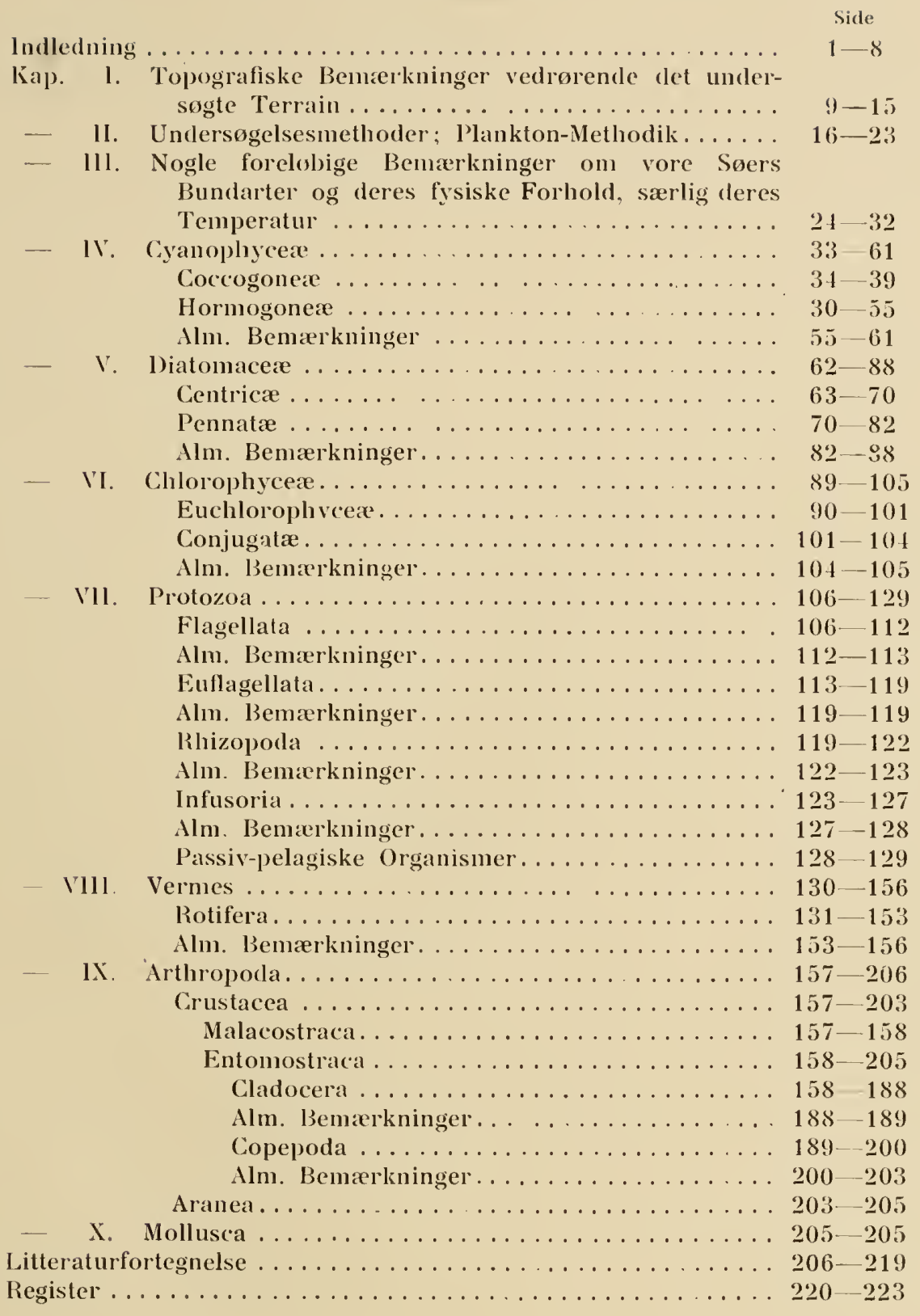





\section{INDLEDNING.}

D A Undersøgelserne fra det Ferskvands-biologiske Laboratorium i Aaret 1897 under iøvrigt ret vanskelige Forhold skulde tage deres Begyndelse, var Kundskaben om de danske Søers Plankton overmaade ringe. Regelmæssige Planktonundersøgelser var ikke anstillede i en eneste Sø; Søernes »Midtvandsformer" var vel nu og da bleven skildrede; særlig havde P. E. Müllers udmærkede Arbejde over Cladocererne, men ogsaa Heibergs over Diatomeerne og Berghs over Peridineerne givet nogle i det hele dog vel sparsomme Oplysninger om disse Gruppers Optræeden i den pelagiske Region. Til de pelagiske Chlorophyceer, Flagellater, Rhizopoder, Infusionsdyr og Rotiferer kendte man absolut intet, og enhver Kundskab om alle de pelagiske Formers Udbredningsforhold indenfor Landets Grænser, om deres Levevis i vore Søer, om Beskaffenheden af de forskellige Samfund af Planktonorganismer, der fandtes i disse, manglede næsten ganske. Kun havde atter her P. E. Müllers Undersøgelser over Cladocererne paa dette enkelte Felt kastet noget Lys; oin de jydske Søers Phytoplankton havde Ostenfeld givet en mindre Meddelelse; gennem Schmidts Arbejde over hormogone Cyanophyceer 1899 øgedes Kendskabet til denne Gruppe. Undersøgelsen over de danske Søers Plankton maatte derfor betragtes som en af det Ferskvands-biologiske Laboratoriums fornemste Opgaver. I Overensstemmelse hermed paabegyndtes i 1898 en regelmæssig 14 Dags Undersøgelse af Furesøens Plankton; det havde oprindelig været Meningen efter Indsamlingernes Afslutning i Dec. 1899 at publicere Resultaterne; denne Bestemmelse opgaves dog senere og af følgende Grunde:

I Tiden fra 1890-1900 var der fra et ikke ringe Antal af det mellemeuropæiske Slettelands Søer fremkommet detaillerede Studier over disse Søers Plankton, og som det var at vente, viste Furesøens Plankton sig $\mathrm{i}$ alt væsentlig at stemme overens med disses. De samme Former paavistes saavel i Furesøen som i de nordtyske Søer; Beliggenheden af Maksima og Seksualperioder var i det hele og store nogenlunde den samme, og da Undersøgelsen iøvrigt kun i ringe Grad kunde bidrage til at øge det almindelige Kendskab til Organismernes Biologi, ansaa jeg Publikation for overflødig.

For mit eget personlige Vedkommende fik disse indledende Studier dog deres store Betydning, idet de bibragte mig Kendskab til Plankton og fremkaldte en Del Spørgsmaal, hvis Løsning blev mig magtpaaliggende, og som senere hen uafbrudt har sysselsat mig.

Paavisningen af de døde Planktonmasser paa dybt Vand gav mer end noget andet Stødet til, at jeg paabegyndte og foreløbig fuldendte Undersøgelserne over Søgytjer og øvrige Bundarter i vore dybere Søer (se herom Litteraturfortegnelsen W.-L. 01).

Iagttagelsen af, at der forud for en Planktonorganismes Seksualperiode næsten altid indtræffer et større eller mindre Maksinum, gav rrig Midler i Hænde til at sikre mig Arten i kønsmoden Tilstand, og i de 


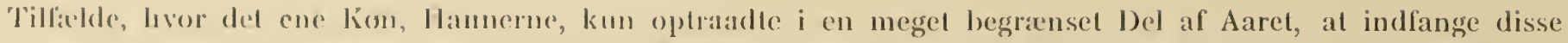

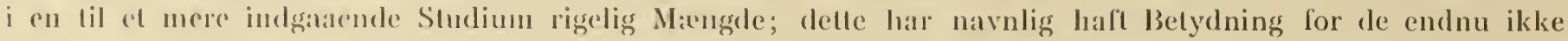
publicerede Studier over Hannerne hos Rotilereme og disses forplantningsforloold (se dog W.-L. 98).

Iagtagelserne over 'Pemporalvariationen los Planklonorganismerne gav det markelige Resultat, at disse Variationere alle foregaar samtidig og pala samme Vis los endogs ganske forskellige Former, samt at den vaesentlig bestatr deri, at Liengrdeakseme oges, og al Sveveapparaterne tiltager i Storrelse om Sommeren og

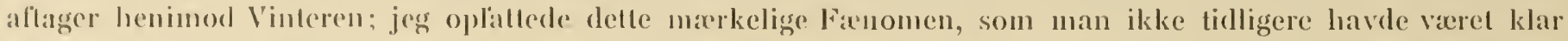
over, som en 'Tilpasning til bestomte yolre Faklorer og formodede, at en al disse var de regelmaessige aarlige Forandringer i Ferskvandels Vargtlylde (se iovrigl W.-L. 00). 1)

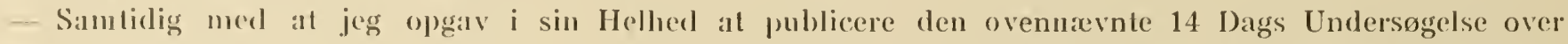
Furesoens P'ankton, stod det mig klart, al, hvis de Planktonundersogelser, der efter Oprettelsen af det Forskinds-loiologislie Laboralorium skulde paabegyndes, vaesentlig skulde kunne forgge Kendskabet lil Ferskiandets Pankton, matle der brydes nye Veje og styres mod nye Maal.

I den senere Tid er der livert Aal fremkommet Beretninger om Undersøgelser over enkelte Søers Plankton; gennem disse Undersogelser far vi at vide, hvilke Arter der findes i vedkommende So, samt Tidspunkitet lor Maks. og Min.s Beliggenled. Vi kan af alle disse talrige Undersøgelser udlede det vigtige Resultat, al et slort Antal Planktonorganismer er falles for disse Søer, og at et ineget mindre Antal kun opträeler sporadisk; endvidere synes det at fremgaa, at de fleste Organismers Maks. og Min. indtraffer nogenlunde samtidig i alle Soerne; dog kender man ikke faa Tilfalde, hvor enkelte Organismer i visse Søer har deres Maks. og Min. beliggende ganske afvigende fra, hvad man i Følge Undersøgelserne andet Steds maa anse for at vere det normale.

Det vil i Laengden ikke lønne sig at fortsatte med den Slags Undersøgelser; det er nu tilstrækkelig konstaleret, at Anabanerne ikke kommer til Udvikling i December og Notholca striata ikke i Juli. Undersøgelser al den Natur er nu kun bereltigede, naar de enten anstilles i meget store Søer eller i Søer beliggende under ganske ekstreme Naturforhold (meget lave eller meget høje Tp. etc.); i det store mellemenropaiske Slettelands gennemgaaende smaa, temmelig lave og ret ensartede Søer er der anstillet saa mange af disse Undersogelser, at flere for dette Terrains Vedkommende vistnok turde siges at vare overflødige.

Det er en Selvfølge, at der ofte i de Planktonarbejder, der er baserede paa Undersøgelser i en enkelt Sø, lilstrabes mere end kun at give en tor Inventarieliste med Fastslaaen af Maks. og Min. Beliggenhed, og at der gores Forsog paa at begrunde, livorfor disse netop indtraffer paa det fastslaaede Tidspunkt. Man har gennem disse Forsøg lige strejfet det Omraade, der nu maa blive det næste og ulige vanskeligere Trin i Planktonundersøgelsernes Historie, nemlig Forstaaelsen af Planktonorganismernes Bygning og Livsæenomener,

1) 1 de to sidste Aar har et stort Antal Forskere beskaftiget sig med disse Sporgsmaal (Brehm 02, Lauterborn 01 og 03, Lemmermann $00 a$ og 03 l., Lozeron 02, Steuer 01, Se hröter og Vogler 01, Baeln mann 03 o. a.). Min Paavisning af, at Lengdeakserne for adskillige Dyts Vedkommende oges om Sommeren og aftager om Vinteren, og at de Bygningsforhold (Torndannelser ete.), hvoraf vi plejer at betragte Planktonorganismernes Svæveevne som aflangig, er stierliest fremtrædende paa Sommerformer og Sommerindivider, er geunemgaaende bekr:eftet. Ligeledes synes alle Planktonundersogere enige om, at Aarsagerne til disse Temporalvariationer maa soges i ydre Forhold, der saa at sige tvinger Organismerne til regelmæssig Variation.

Samtidig med, at jeg fremsatte min Formodning om, at Hovedaarsagen til Variationerne maatte søges i de aarlige Forandringer i Ferskvandets Vagtfylde, der folger med Temperatursvingningerne, kom Chun (00 p. 73) under Studiet af marine Ceratiers forskellige Udseende i Havstromninger af forskellig Vagtfylde til ganske samme Resultat. Det fremgaar nu navnlig af Ostwalds grundlaggende Undersogelser, at den ydre liraft, der sarlig maa antages at virke omformende paa Organismerne, er Vandets Viseositet, en Faktor, der hidtil har været alle Planktonundersøgere ukendt. Denne findes i Planktonarbejder for forste Gang omtalt hos Selıöter og Vogler (01 p. 202). Vistnok samtidig omtales den af Krogh i et Foredrag: Om hydrostatiske Forhold i Dyreriget, looldt i Biologisl Selslial, i Kobenhavn 01. Af det trykte Referat (01 p. 16) ses det i ovrigt, at Forf. anser det for tvivlsomt, on Variationerne i Vandets Vægtfylde og Viseositet staar i Forbindelse med Variationerne i Planktonorganismelnes Storrelse og Form. Eren for at have indfort Laren om Vandets Viseositet i Planktonologien, fremhæuet den som medbestemmende Falitor af Planktonorganismernes Form og gjort Laeren om den almindelig bekendt tilkommer 0 stwald (02 og $03 \alpha-d)$. l dette Varks anden 1)el. der væsentlig omhandler Temporalvariationerne, vil den her n evnte Litteratur blive gjort til Genstand for narmere Omtale. 
Paavisningen af disses Afhangighed af ydre Faktorer, liort sagl det gkologiske Studium. Uaglet det Bidrag, som Planktonundersogelserne paa dette Onraade har søgl al yde, ikke er ubetydeligh, kan der af sikkert indvundne Fakta dog kun noleres yderst faa; i de allerfleste Tilfxelde er man endnu ikke kommen url over Arbejdstheoriernes og de mange lose Hypothesers Standpunkt. Paavisningen af, at en stor Maengde Planktonorganismer, all som Vandtemperaturen sliger, forøger deres Lengleakser og Sveveapparater, Lurle vare el af de sikreste og merkeligste Resultaler af disse Studier.

Man har fra anden Side gjorl gieldende, at sikre Angivelser med Hensyn til ydre Faktorers Indflydelse paa Organismernes Lirsfenomener kun lader sig lilvejebringe ved Studiet i Laboratoriel, fordi man alene her under Elimination af alle ovrige Faktorer er i Stand til udelukkende at arbejde med den enkelte Faktor, medens man ude i Naturen altid maa arbejde med en hel Rakke indlyyrdes kombinerede Faktorer.

Denne Indvendings absolute Berettigelse kan jeg ingenlunde anerkende.

Det er allid en mislig Sag at studere en Organismes Levevis og normale Funklioner paa fangne Individer, altsaa paa saadanne, der lever under Livskaar, som, hvor gode de end efter vort Skøn maa siges at vare, dog ubestridelig paa elhvert afgørende Punkt mer eller mindre afviger fra dem, hvorunder Organismens Organer under normale Forhold funktionerer. Den, der har vænnet sig til saa vidt mulig at anlægge og udføre sin Undersøgelse ude i Naturen, staar uforstaaende overfor den fuldstændige Mangel paa Erkendelse heraf og den dermed forbundne ikke mindre iøjnefaldende Mangel paa Finfølelse over for Objektet, der præger ikke faa Laboratorieundersøgelser, og som giver sig Udslag i en underlig massiv, maskinmæ̇ssig Opfattelse af den levende Organisme. Overalt, hvor Emnets Art har tvunget mig til et næsten udelukkende Studium i Laboratoriet (Forplantningsforholdene spec. Parringsforholdene hos Rotifererne), har det unaturlige i Undersøgelsens hele ydre Apparat allid varel mig paafaldende. Ofte slog den Tanke mig, at de Forsøg, jeg som Zoolog i dette Tilfielde anstillede, egentlig var beslægtede med saadanne for en Psycholog meningsløse Bestrabelser som at ville udrede normalt menneskeligt Sjæleliv efter Studiet af livsvarige Tugthusfanger.

Man bør til alle eksperimentelle Lạboratorieundersøgelser vedrørende Organismernes Levevis og deres Organers Funktioner kunne stille Forlangende om, at Studiet i Laboratoriel saa vidt mulig kombineres med Studiet i Naturen, og at der til Basis for Undersogelsen ikke alene ligger Tanker og Ideer fostrede indenfor Arbejdsrummets fire Vagge, men ogsaa lagtlagelser ude i Naturen selv. Undersøgelserne i Laboratoriet vedrørende Dyrenes Biologi bærer saa vel i deres Anlæg som i deres Resultater ofte i meget følelig Grad Tilfaldighedernes Præg. Grunden herlil er formentlig den, at Iagttageren her uvilkaarlig kommer til at operere med Organismen som et isoleret i sig selv afslultet Element. Kun med Vanskelighed bevarer han den klare Erkendelse af Organismen som et Led af el samlet Hele, omformet og paavirket af de Forhold, hrorunder den lever og selv ovende sin formende Indllydelse paa Omgivelserne.

Kun den, der er kendt med Lokalitelen, hrorpaa den paagxldende Organisme lever og der har søgt at satte sig ind i dens Levevis, vil vare i Stand til i Laboratoriet at planlagge den fortsatte Undersøgelse saaledes, at den giver naturtro Resultater.

Laboratoriestudieme kan i alt Fald tilsyncladende føre til Resultater, der blander ved en langl større Eksakthed end den, man ved Studiet ude i Naturen i Almindelighed er i Stand til at opnaa. Dog maa det erindres, at disse saakaldte eksakte Resultater indvindes ved Forskningsmethoder, der fortrinsvis har deres Styrke i selve deres Ensidighed, men netop ogsaa som Følge af denne tillige i sig skjuler alle de Kilder til Fejlslutninger, der ganske nødvendig udspringer af al ensidig Forskning. Det kan derfor vel betvivles, hvorvidt denne Eksakthed i mange Tilfælde virkelig er mere end el Blændværk, og om de Resultater, der under Hensyntagen til Naturens uendelige Alsidighed indvindes i det Fri, om end de maa fremsætles i en mere prunkløs og mindre distanceblændende Form, derfor har vasentlig ringere videnskabelig Vrerdi.

l vore Dage, da den gennemførte Laboratorieteknik og de ypperlige Kommunikationsmidler, der lillader Forsendelse af fjærne Egnes Dyreformer, saa vel som Studiet af disse under Breddegrader helt forskellige fra dem, hvorunder Dyrene lever, i langt højere Grad end tidligere har gjort Naturforskeren til Stuemenneske, 
ar der Grund til al fremhare Betydningen af forst og fremmest at undersage Organismen, lavor den horer hjemmure, at studere Nilluren i Nalturen selv.

Mint har vel med nogen liet kunnet bebrejde Planklonunderseggerne det noget løse og usikre, der klaber ved deres Undersogelsers Resultater; visse Retninger indenfior Videnskahen har endog mødt disse Studier med uforstatende Kritik og overderen Mistillid. Over for denne Kritik er der dog Grund til skarpt at betone, at der for Planktonnoldersogerne ikke var ande Veje at gat end forst at udarbejde deres Inventarielister over l'lanktonorganismerne og derpaa ude i Naturen at anlegge de Arbejdstheorier, efter hvilke (Organismornes Livslienomener burde studeres. Paa dedte Stadium, hror Kritik er en let Sag, befinder Undersogelserne sig endnu. Den, der i adskillige Aar har studerel Planklonorganismernes Bygning og Liv, kan ikke nere 'Tvivl om, al de okologiske Undersogelser netop paa dette Omrade tidligt vil komme til at hoste nogle al de skonneste og bedste Resultater og kan derfor heller ikke i fjarneste Maade lade sig skiamme al en Kirilk, hvis Udøvere staar uden al dylere Forstaaelse baade af disse Studiers Berettigelse ong konmende Betydning.

Kun sjicldent linder man hos samme Person de forskellige Egenskaber forenede, der kendetegner den omlyygrgelige lagttager i Naturen og den flinke Eksperimentator i Laboratoriet. Jeg for min Del er mig mine bristende Evner som Eksperimentator fuldt bevidst og har altid folt, at mit Virkefelt væsentlig maatte ligge i sche Naturen. Ad de Veje, som jeg i Følge mine Anlæg og min Uddannelse maa følge, kan der derfor kun sjæeldent leveres det saakaklte »strængt videnskabelige Bevis for min Opfattelse af Normer og Variationer i Planktonorganismernes Bygning og Liv, men det har varet mit Haab, at disse Veje kunde lede ind til Spørgsmaal, der ikke for var debatterede, og at der i Undersøgelsen maatte lindes Holdepunkter for Studier, som andre med andre Evner og Anlag maatle kunne føre videre.

Betingelsen for, at man ved Studier ude i Naturen skal kunne komme ud over Planktonundersøgelsernes nuværende Standpunkt, paa livilket de vistnok har staaet noget unødvendigt længe, og give det næste Led i Udviklingen den tillorlige videnskabelige Undergrund, er, at man til sine Planktonstudier raader over Nateriale, der muliggør en Sammenligning. Materialet maa stamme fra et større Antal Søer, det maa være indsamlet samtidigt og ud fra ganske ensartede Principper; endelig maa det samlede Materiale, for at de ledende Synspunkter ikke skal forrykkes, saa vidt mulig bearbejdes af en og den samme; først da vil Mulighederne for at trænge dybere ind i Planktonorganismernes Livsfænomener og disses Afhængighed af ydre Faktorer være girne. Da altsaa regelmæssige Planktonundersøgelser i danske Indsøer skulde tage deres Begyndelse, valgte jeg ud fra de angivne Principper en anden Vej end mine Forgængere og satte Undersøgelserne i Gang ikke i en enkelt Sø, men i et større Antal Søer samtidigt.

I Følge Sagens Natur maatte Undersøgelserne straks sondre sig ud dels i Undersøgelser, der vedrørte Planktonorganismerne, dels i saadanne, der havde et mere indgaaende Studium af de økologiske Faktorer til Genstand. Betingelsen for, at der kunde komme noget tilfredsstillende ud af de sidstnæunte Studier, var log, at jeg havde kunnet raade over Assistance til de fysisk-kemiske Undersøgelser, da saadanne endnu ganske mangler i vore Søer. Da det imidlertid viste sig umuligt at tilvejebringe en saadan, maatle jeg nøjes med de iøvrigt ufuldstandige Temperaturundersøgelser, jeg selv kunde anstille, de Iagttagelser on Søernes Dybde og Bundarter, som jeg gennem mit ovennævnte Arbejde havde kunnet tilvejebringe samt de Oplysninger, jeg paa mine Rejser kunde skaffe til Veje om Søernes Tilløb og Afløb, Islægningsforhold, Vandets Gennemsigtighed saut ou Vegetationsbælterne og deres Beskaffenhed. - Manglen af fysisk-kemiske Undersøgelser af Sørandet har under hele Arbejdet været yderst følelig, men jeg stødte her paa Vanskeligheder, jeg ikke kunde overvinde.

Hvad der yderligere bestyrkede mig i Rigtigheden af samtidig at paabegynde Undersøgelsen i flere Søer var, at jeg, saafremt der til Undersøgelsen valgtes Søer i Landets mest forskellige Egne, derved med et Slag 
vilde kumne give et samlet Overblik over de danske Søers Plankton; det forekom mig, at det i et Land, lnor Planktomundersogelserne i Ferskvand saa at sige var ukendte, maalle vere naturligst at skaffe et saadant Overblik til Veje, før mere detaillerede Undersøgelser log deres Begyndelse. Vort Lands ringe geografiske Udstrekning og gode Kommunikationsmidler borgede for, at en saadan Undersøgelse kunde gennemføres.

I Oktoher 98 og i Maj og Juli 99 foretoges da tre Rejser liver paa c. 14 Dage, hvor de fleste af Landets storre Søer besøgtes. Meningen med disse Rejser var, dels at vinde det foreløbige Overblik over de danske Søer, uden livilket del ikke vilde vare muligt at lage Bestemmelse om, hvilke Søer, der burde medlages i Hovedundersøgelsen, dels at satte mig i Forhindelse med Fiskere, som egnede sig til og var villige lil at vae belijalpelige med Indsamlingen af Prøverne.

Jeg kour paa disse Rejser til det Resultat, at der var Muligheder til Stede for at gennemføre en maanedlig Undersøgelse paa de 4 sjællandske Søer: Furesø, Esromsø, Sorøsø og Tjustrupsø, sant paa 5 jydske Søer nemlig: Viborgsø, Haldsø, Skanderborgsø, Mossøog Julsø. Jeg havde haabet, at den ogsaa skulde have omfattet Raabjergmilesøerne, Madumsø i Nordjylland samt Tuelsø ved Sorø, men jeg stødte for disse Søers Vedkommende paa uovervindelige praktiske Vanskeligheder. I Følge min Plan skulde de 4 sjællandske Søer altid undersøges af mig selv personlig; Planktonprøverne fra de 5 jydske Søer skulde derimod indsamles af de ved disse boende Fiskere; dog var det min Agt saa hyppig som mulig ogsaa selv at indsamle disse Prøver dels for at lære disse Søers Plankton at kende i levende Tilstand, dels for her at øve den nødvendige Kontrol. Undersøgelsen paabegyndtes Dec. 00 og skulde have været afsluttet Dec. 01. I Dec. 01 forelaa da en regelmæssig 14 Dages à 3 Ugers Undersøgelse af Furesøen og en gennemført maanedlig Undersøgelse af de tre andre sjællandske Søer. Prøver blev dog ikke tagne i de Maaneder, Søerne var tillagte.

For de jydske Søers Vedkommende var Resultatet ikke saa gunstigt, navnlig manglede Prøver fra Mossø; fra Skanderborgsø og Haldsø manglede Prøver fra Juni og Juli; alle Maj- og Augustprøver var tagne af mig selv. Først efter Rejsen i August arbejdede det ret store Apparat tilfredsstillende, og da jeg nu var sikker paa at kunne gennemføre Undersøgelsen, besluttede jeg mig i Dec. 01 til at fortsætte denne endnu til Aug. 02 saaledes, at jeg foruden et betydeligt Antal Prøver i Tiden fra Dec. 00 til Aug. 01 for alle Søernes Vedkommende havde en fuldstændig Serie fra Aug. 01 til Aug. 02.

Da det i Følge hele Undersøgelsens Natur var af Vigtighed, at Indsamlingen af Planktonet i de forskellige Søer nogenlunde foregik samtidig, har jeg gjort alt, hvad der stod i min Magt, for at Indsamlingen saa vidt mulig foregik i samme Uge hele Landet over. Helt er dette ikke lykkedes mig, dels fordi jeg navnlig i Begyndelsen arbejdede med for faa Net, dels og navnlig, fordi slet Vejr i Foraars- og Efteraarstiden mange Dage i Træk umuliggjorde Opholdet ude i Søernes pelagiske Region. I de Tilfælde, hvor jeg under ugunstigt Vejr forcerede Tilvejebringelsen af Prøverne, kom jeg som oftest til at fortryde det, da Vandet i vore forholdsvis lave Søer altid efter stærke Storme indeholder store Mængder »Snavs", hvilket vanskeliggør Undersøgelsen af Prøven og udelukker Muligheden af at bruge den mikrofotografisk.

3 Prøver (Furesø 30/8 01, Sorøsø 1/5 02 og Tjustrupsø 1/5 02) blev ødelagte; ved at undersøge Datoerne i Tabellen Pag. 26 vil man iøvrigt se, at Prøverne i de enkelte Søer i alt Fald for et større Antal Søers Vedkommende er tagne omtrent samtidig, og at det som oftest kun er fra et mindre Antal, at Prøverne er indkomne for sent.

Førend jeg selv begav mig paa mine Rejser til de sjællandske Søer - i Almindelighed varede Rejserne 5 Dage - afsendte jeg tillige Glas og Apparater til Fiskerne i Jylland, og det er min Overbevisning, at disse i de allerfleste Tilfælde har gjort, hvad der stod i deres Magt, for at skaffe mig Prøverne til den fastsatte Tid.

For at skaffe et nærmere Kendskab til Planktonet i en Del af de øvrige danske Søer blev Planktonprøver indsamlede paa talrige Rejser 1897-1902, ligesom jeg ogsaa formaaede andre til at tage Prøver paa Lokaliteter, som jeg ikke selv kunde naa at faa undersøgt. 
Der foreligger sambedes Planklomprover lia:

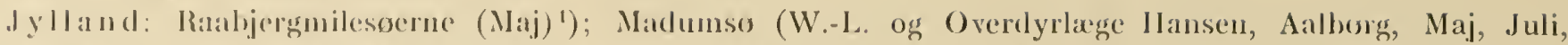
Seplember); Store Oxeso (Maj); Ioldrmpso (Chr. Iybek, September); Rexlss (Chr. Lybek, September); Tjele

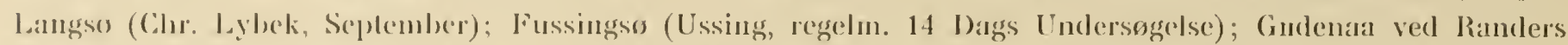

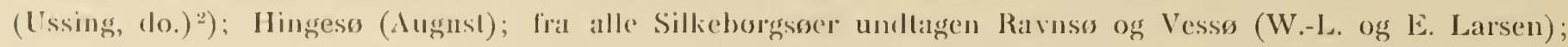
Ködlingso (Juli); Smndsso (Juli); Kragso (Juli); Hedeswer pala Karlsmarsk (Juli); Klilswer ved Varde, páa

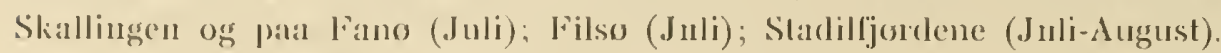

IFyen: Dalumlso, Iamgeso, Arreskosso, Norreso, Hvidkildeso, Ollerupso, Sorujeso, Soloyso, Hjulbyso, Ronningess.

Alle Proverne fra figen er lagne al L. Larsen ogs i Tiden Juli-August.

Sjaflland: Arreso (Maj, Juli, Seplember); et slort Anlal Smásøer i Nordsjalland; al de større markes Sjalso (Seplember); Donsedammene (Oktolser); Sonderso (Brinckmann, L. Larsen, W.-l., April-Oktober); alle de i Finesolistriktel treliggende Soer; Soeme ved Slijoldnasholm og Hvalsø (Oktober); Haralelstedso og Gyrstingeso (April, Maj): Tuelso (Maj, September).

Mon: Smmasoer ved Ulfshale (Maj).

L. olla nd: Mariboso (Frk. Sciclelin, Ausnsi).

1)a jeg til Bedommelse af en Søs Planklon ikke tillargger enkelte Planktonprøver synderlig stor Vardi, har jeg ingenlumle anslrangt mig for, at der skulde foreligge saadanne fra alle danske Søer. Jeg har lagt mine Rejser gennem Landets sørigeste Egne, men har hverken kunnet ofre Tid eller Penge paa Tilvejelningelsen af en enkelt Prove fra fjerntliggende Søer (Norssø, Vestervandetsø, Flyndersø). Unulige Pejrlorhold under Rejserne har hindrel mig i at faa Prøver fra enkelte Søer (Soellojergsø, Stillingsø, Glenslrupso).

Del er en Selvfolge, at Undersøgelsen navnlig i Begyndelsen frembød meget betydelige systematiske Vanskeligheder. Indenfor Begreberne: Polycystis, Melosira, Dinobryum, Brachionus, Anura, Daphnia, Bosuina, Diaptomus o. m. a. herskede der, den Gang disse Undersøgelser paabegyndtes, den størst mulige Forvirring; senere blex Forholdene vel noget udredede for Rotiferernes og Crustaceernes Vedkommende, men den systenatiske Opfattelse af de til de ovennævnte Cyanophycee-Diatomee- og Flagellatslægter hørende Arter er endnu til Dato højst usikker. Der er ingen Trivl om, at Planktonundersøgerne har taget sig den systematislie Side af Undersøgelsen alt for let, men Stoffets store Uensartethed undskylder Forsømmelser i saa Henseende. Jeg maa dog anse alle Meddelelser om de europaiske Diaptomus Arters, om Hyalodaphniernes og Bosminernes Maks. og Seksualperioder samt øvige biologiske Forhold hos alle Planktonundersøgere med Undtagelse af Burckhardt, Steuer samt til Dels Seligo, for ret væerdiløse; i de fleste Tilfælde er det nemlig paa Grund af Mangel paa Afbildninger og Beskrivelser absolut umuligt at afgøre, hvilken Art Undersogerne har haft for sig.

Plankionundersogerne er med Hensyn til Artsbegrebet gaaet en af to Veje; nogle udsondrede el overordentlig stort Antal Arter, hroral resulterede, at Antallet af beskrevne Ferskvands-Mikroorganismer i Aarenes Lob steg megel staerkt. Saalỉnge man savnede alt Kendskab til Planktonorganismernes meget betydelige Lokal- og Temporalvariation, kunde en saadan Fremgangsmaade vel forsvares, men at den iøvigt har øvet sin sliadelige Indllydelse paa Planktonstudierne, tør nappe betvivles. Nutildags, da man ved, at saa rel Temporal- som Lokalvariation for talrige Planktonorganismers Vedkommende saa at sige er condilio sine qua non for deres Optraeden i den pelagiske Region, er det, i alt Fald i mine Øjne, en videnskabelig Forbrydelse vedblivende at belemre Videnskaben med et Utal af vardiløse Artsnavne og med Opstilling af nye Arter, der ofte er slet beskrevne og meget hyppig ikke afbildede. Trods stærk Protest fra mange Sider vedbliver dog dette ganske uvidenskabelige Artmageri endnu indenfor visse Planktonslægter (Dinobryum, Pediastrum o. a.).

1) Hror andre Angivelser ikke findes, er Proverne tagne af mig selv.

2) De to sidstnavnte Proveserier er tagne efter Initiativ af Museumsinspektor Ostenfeld. 
Andre Forskere gik den modsatte Vej og slog maaske noget vilkarigl el for slort Antal Arter sammen; Lil deme Rotuing hører jeg sclv; egne Undersegelser over Temporalvariationer har paa dette Onraade nuligs fort mig for vidt.

I dette mit Hovedarbejde har jeg bestrabl mig for at holde Middelvejen mellem de to Yderpunkter, men foler selv, at jeg i Folge min Naturopfattelse er kommen del sidste naernere end del forste.

Det stod mig klart, al jeg vel vilde kunne opnaa at danne mig en bogrunclet Mening om Artsbegrebet indenfor Zooplanktonet; anderledes stillede det sig derimod med Størsledelen af Phytoplanktonet. Jeg anmodede derfor Hr. Mag. sci. E. Larsen, der den Gang arbejdede paa det Ferskvands-biolog. Laboratorium og lavde gjort Phytoplanktonet til Specialstudium, om at deltage i Bestemmelsen af detle. For yderligere at gore Hyppighedsangivelserne saa sikre som muligt, bad jeg ham tillige om at angive disse for Phyloplanktonets Vedkommende. Vi har derfor med Hensyn lil Phytoplanktonet hver for sig udarbejdel rore Hyppighedsangivelser for hver enkelt Prøve, senere konfereret og i Tvivlstilfalde atler undersogt.

Artsbestemmelsen indenfor alt Phytoplankton skyldes i nasten alle vanskeligere Tilfaclde ham, i enkelte (Polycystis) et Samarbejde mellem ham og mig. Det er ogsaa Hr. Larsens Fortjeneste, at saa mange af de smaa Chlorophyceer er bleven paaviste. Stykket om Gloiotrichia-kuglernes Tilblivelse fremkom red et Samarbejde mellem os. Jeg beder ham med fuld Erkendelse af de vanskelige Forhold, hvorunder han ydede Undersøgelsen sin uegennyttige Hjalp, der ikke kan vurderes højt nok, at modtage min hjarteligste og varmeste Tak. Naar der i Afsnittet over Phytoplanktonet er anvendt Betegnelsen »Vi«, menes altid Hr. Larsen og mig selv.

Litteraturen er kun benyttet til Februar 1902; hvad der senere er kommet til, findes vel anført i Litteraturfortegnelsen, men er ikke blevet anvendt under Udarbejdelsen af Manuskriptet. Jeg har af Planktonarbejderne bestræbt mig for at samle alt, hvad der kunde tjene til Belysning af Arternes geografiske Udbredning, deres Maks. og Min., samt deres Seksualperioder; forsaavidt som der forelaa specielle biologiske Undersøgelser over nogle af de her omhandlede Former, er der taget Hensyn til disse; at jeg paa dette Punkt har overset en Del, derom nærer jeg desværre ingen Tvivl. I øvrigt henvises til Bemærkningerne foran Litteraturfortegnelsen. Jeg har bestrabt mig for, at alle de i europæiske Ferskvande beskrevne Planktonorganismer skulde findes omtalte i Arbejdet; de Arter, der ikke er paaviste herhjemme, vil man finde behandlede under Angivelserne vedrørende Slagten eller Familien.

Da Kendskabet til Forholdet mellem Havets og de ferske Vandes Plankton i det hele synes ringe, og da jeg anser noget Kendskab til marint Plankton som meget betydningsfuld for Studiet af Ferskrands-Planktonet, har jeg for hver enkelt Orden angivet den Rolle, de respektive Reprasentanter for samme spiller, saa vel i Havet som i Ferskvandets pelagiske Region.

Min Ven Magister Søren Jensen, som lange havde arbejdet ned Copepoder, og som for et Arbejde over disse og Ostracoderne havde modtaget Universitetets Guldmedaille, havde lovet mig at vare mig behjæelpelig, vedrørende det noget vanskelige Artsspørgsmaal Diaplonus gracilis-graciloides. Et Samarbejde mellem ham og mig skulde lige begynde, da Døden pludselig rev ham bort; fra hans Manuskript er der hentet enkelte Oplysninger vedrørende Diaptomus og Eurytemoras Forekomst her i Landet. Hr. Inspektør Østrup, der har bestemt nogle vanskelige Diatomeearter, beder jeg modtage min bedste Tak; en lignende retter jeg til de mange, der har overladt mig Planktonindsamlinger fra Søer, som jeg ikke selv fik undersøgl.. Sacrlig skylder jeg Dr. Kolderup-Rosenvinge min Tak for adskillige raerdifulde Bemaerkninger og Oplysninger til de botaniske Kapitler. Sammen med de her publicerede Undersøgelser planlagdes og fuldførtes tillige Studier orer Planktonorganismernes Temporalvariation. E..Larsen har i de forløbne Aar udført over 5000 Maalinger paa Planktondiatomeer, jeg selv c. 1000 paa Ceratium og et meget stort Antal paa Daphnia hyalina, Hyalodaplunia samt Bosmina longirostris og coregoni og fra hver enkelt Prøve aftegnet et forskelligt Antal Individer, der skulde angive de paa vedkommende Tidspunkt i de enkelte Prøver optradende Hovedformer. Sammen med 
Undersogelsen over Trmporal-og Lokalvariationen hos Daphnierne gik tillige Undersugelser over disses Forplantningsforhold, de enkelte Gencrationers Levetid ele.

Det var oprindelig Heusigten, al disse Undersggelser skulde forelegges sammen med de lier publicerede, men nermest af prakliske IIensyn har jeg samlet alle Iagllagelser over Temporalvariationen til en selvsticrnlign anden I)

Da jeg matte anse det for uheldigt al publicere Arbejdets afslultende og sammenfattende Kapitler, for Je variationsslatistislie Undersøgelser var publicerede, har jeg ogsaa udsat Offentliggnrelsen af dem, indtil oventiavinte Studier forelata trykle.

llvad hermed forclagges Offentligheden er vaesentlig en syslematisk Bearbejdelse af de danske Søers Plankton med Angivelse af de enkelte Planktonorganismers Maksima, Minima, Seksualperioder og geografiske Udbredning; i de Oversigler, der følger ofter hver enkelt Orden, er dog Hovedmomenterne til Forstaaelsen af Ligheder og Uligheder i de enkelte Arters Optraden i de forskellige Søer saa vidt mulig udredede.

Bortset lra enkelte Lindringer og Tilføjelser sarlig i Indledningen, i Kapitlet om Methodikken og i Kap. IX indsendtes nervaerende Arbejde i Marts 03 til det Kong. Danske Videnskabernes Selskab med Anmodning om, al del maatle lolive oplaget i dettes Skrifter; paa Grund af de store Bekostninger, der var forbundne med Idgivelsen (se Videns. Selsk. Oversigter 1903 H. 3 p. 51 og 60) kunde Optagelsen dog ikke finde Sted.

Jeg tillader mig at rette min arbodige Tak til Carlsberglondets Direktion, som ved at bevilge den nodvendige Sum muliggjorde Arbejdets Publikation, og min lijærteligste og varmeste Tak til Professor Dr. phil. Eugen WTarming, der mer end nogen anden har varet min Lærer, og som altid utrættelig og uegennyltig har støttet mig med Raad og Daad.

Samme Tak retter jeg til Professor Dr. phil. I. E. V. Boas, som ved mange Lejligheder har vist mig og mine Arbejder sin varme Interesse, og som har sin store Andel i, at det er lykkedes uden unødvendig Forsinkelse al faa dette Arbejde ud.

Jeg har tilladt mig at dedicere Varket til Minde om Professor Japetus Steenstrup, som en ringe Tak for den Velvilje og Interesse, han som gammel Mand viste mig den ganske unge, for hvad jeg har lært af hans Forskningsmetode og fordi han af alle danske Naturforskere er den, med hvem jeg mest føler mig i Sliegt.

1/s 03. I)ansk Ferskvands-biolog. Laboralorium. Furesø, Frederiksdal pr. K. Lyngby. 
KAP. I.

\section{TOPOGRAFISKE BEMARKNINGER VEDRORENDE DET UNDERSØGTE TERRAIN.}

Fo Uresø (se Kort II og III) er $1757^{1}$ ) Tdr. Land, 96965 Hekt., stor; Gennemsnitsbredden er c. $3 \mathrm{Km}$.; Over fladen ligger 198 M. o. H. Den er rimeligvis Danmarks dybeste Sø, c. 38 M. Paa Søens østlige Side strækker der sig to Bugter imod Øst, nemlig en nordlig større: Store Kalven og en sydlig mindre: Lille Kalven; sidstnævnte har i sin Tid været meget større og er naaet ind til den lille Vejlesø ved Holte Station; Store Kalven er c. 2 Kilom. lang; de øvrige Kyster er meget lidt indskaarne, og de Smaabugter, der i tidligere Tid har været, er nu udfyldte.

Søbunden er ret ujærn; 5-800 M. fra Land ligger langs Kysten dels større Stensamlinger, dels Banker, rimeligvis opbyggede af Mollusker; i Søens Midte ligger to Banker, Store- og Langebanken, der fra c. 30 M. Dybde hæver sig op til c. 5 M. fra Vandskorpen. Søens største Dybde ligger noget Nord for disse Banker. De ovennæunte Bugter er lavvandede Partier med en Dybde, der ikke overstiger 5 M. Navnlig i den nordlige Del findes meget stejle Brinker.

Furesøens vigtigste Tilløb og Afløb er Mølleaaen, men den modtager ogsaa Tilløb fra den lille Søllerødsø (Kort II) og fra Vejlesø, begge beliggende øst for Søen og udmundende i Store Kalvens inderste Del.

Mølleaaen (Kort II) er c. $38 \mathrm{Km}$. lang; den udspringer i Uggeløse Sogn, løber i østsydøstlig Hovedretning gennem den lille Bastrupsø, hvorpaa den falder i Farumsø, c. 140 Hekt., Dybde c. 18 M.; den forlader Søen ved Fiskebæk og falder ud i Furesøens nordvestlige Hjørne; Afløbet findes ved Frederiksdal; Retningen er stadig østsydøst, men bliver, fra det Øjeblik den træeler ind i Lyngbysø, 75 Hekt., Dybde 3-4 M. stik Øst; kort før Indløbet har den modtaget Afløb fra Bagsrærdsø, 119 Hekt., Dybde 5 M.. Efter Udløbet af Lyngbysø drejer Aaen stik Nord, men danner derpaa et skarpt Knæ, løber atter mod Øst og falder ud i Sundet ved Strandmøllen.

Esromsø (Kort II og IV) er 3171 Tdr. Land, 1750 Hekt., stor, Højden over Havet er 9,4 M. og Dybden tør næppe anslaas til over $24 \mathrm{M}$. Afløbet er Esromkanal, c. 9 Kilom. lang; den falder ud i Hornbækbugten ved Indløbet til Øresund og optager paa sin højre Side den lille Gurresøs Afløb.

Esromsø er strakt i Retningen Nord-Syd, Læengden er c. $9 \mathrm{Km}$., Bredden kun 2-3. Kysterne er meget lidt indskaarne, navnlig forløber Søens Vestkyst næsten lige; Østkysten har derimod i sin nordlige Del et Par større Bugter. - Bunden er en jæun, nedadskraanende Slette, der næsten intet Steds opviser Banker eller Ujæevnheder og har sit største Dyb beliggende omtrent i Midtlinien. Alle Tilløbene er ubetydelige Smaabakke, der om Sommeren væsenlig er udtørrede.

Sorøsø (Kort V og VI) er 420 Tdr. Land, 23179 Hekt., stor, Højden over Havet er 11 M., den største Dybde er 13 M. Afløbet foregaar i nordøstlig Retning og falder i Tuelsø, der atter afvander til Susaaen.

1) Alle Talangivelser vedrorende Søernes Størrelse, Dybde etc. er kun tilnærmelsesvis nøjagtige; se herom navnlig Erslev (86). De danske Søers Plankton. 
Soen bestare af et storre Midtparti, der indeholder det storste I)yl, og som dels sender en lang, smal Bugl i nordlig Retning, dels an loredere Bngl inod Ost; denne sidste spalter sig igen i en nordlig og en sydøstlig Arm. Alle Bughterne ar laviandede Partier; dette gelder sierlig den nordligste Del af den gstlige Bugt; bybden overstirider ikke her 3- I M. Soen indeholder et P'ar Smaager: Ingemanns Ø og Bøgholne, af hivilie sidstnevente nu naesten cre landfast.

Soroso har i tidligere Tid vaeret negget storre; Byen Sors har oprindelig ligget paa en $\varnothing$, idet den langstrakte Ling, der i Almindelighed betegnes Flommen, i tidligere Tid har varet en Bugl, hvis øverste Ende laar stralit sig lige op til Tuelso; disse Forhold findes endnu angivne paa Videnskabernes Selskalos Korl all $176 \mathrm{is.}$

Inod Nord stod Soen i Forbindelse med den nu nasten udtørrede Petersborgsø, der i fordums Tid kun var en Bugl al Tuelso.

'Tjustrup-13avelseso (Koort V) er c. 2000 Tdr. Land, 110375 Hekt.; den er beliggende c. 7 M. o. H.; dens storste Dybde er c. 18 M. Det er en meget langstrakl, smal Sø, hvis Hovedretning gaar fra Nordvest til Østsydost. I den nordvestlige Ende paa Søens Nordside løber Susaaen ind og forlader Søen i dennes østlige Einde. Den er mod Øst begræenset af den lange, smalle Landtange: Enghaven, der nu næsten ganske skiller den fra den mindre kun 2-3 M. dybe Bavelsesø, med hvilken den tidligere har staaet i aaben Forbindelse. Sclve Tjustrujsø bestaar egentlig af to storre Bredninger, en nordvestlig og en østlig, adskilte fra hinanden ved et smallere Parti, beliggende ud for Landsbyen Vindstrups Jorder. I begge Bredningerne findes Dybder paa c. 18 M., i det smallere Parti kun Dybder paa c. 11 M. Søbunden er ujævn og indeholder adskillige Bakker, navnlig i Søens nordvestlige Del.

Susaaen, hvortil Afløbet fra Sorøsø løber, og som gennemstrømmer Tjustrupsø, angives i Almindelighed al viere c. 80 Kilom. lang; den udspringer imod Øst nær Faxe og løber derpaa i nordvestlig Hovedretning indtil Landsbyen Vrangstrup, hvor den forandrer Retning, bøjer i Vestsydvest og i Knæet modtager Tilløb henholdsvis fra Gyrstingesø og Haraldstedsø samt fra Sorø- og Tuelsø, hvorpaa den falder i Tjustrupsø. Efter at have gennemlølet denne og Bavelse Sø falder den ud ved Næstved.

De i Jylland undersøgte 5 Søer: Viborgsø, Haldsø, Skanderborgsø, Mossø og Julsø afvander alle til Gudenaaen; det turde derfor være naturligst, inden vi gaar over til nærmere at omtale disse Søer, kort at skildre Gudenaaens Lob (Kort VII).

Gudenaaen er Danmarks eneste Aaløb, der til Nød kan gøre Fordring paa at blive betragtet som Flod. Dens Længde er 158 Kilom.; man kan med Lethed skælne mellem et øvre Løb, et mellemste Løb og et nedre Lob. Aaen udspringer c. 63 M. o. H., 25 Kilom. vest for Horsens fra et Mosedrag mellem de to Landsbyer Tinnet og Korstrup; fra samme Mosedrag, kun c. 125 Meter fra Gudenaaens Kilde, udspringer tillige Skernaa, der løber imod Vest; det nørrejydske Hovedvandskel gaar tværs gennem Mosen. Gudenaaen har i sit øvre Løb et starkt Fald, c. 17 M. pr. Mil og et hastigt strømmende Vand; Retningen er først østlig og bliver derpaa mellem Træeden og Vestbirk stik nordlig, hvorpaa den falder ind i Mossøs vestlige Ende. Den optager nær sit Udspring i højre Side Alstedmolleaa og senere Lilleaa; derpaa optager den i venstre Side Mattrupmølleaa, der er Afløb for Stigholmsø, hvis Tilløb Bostbæk tager Vandet fra et Par Smaasøer nær Palsgaard.

Ved Udløbet af Mossø (Kort VIII) er Aaens Hovedretning stadig nordlig; den optager Tilløbet Saltenaa kommende fra den smalle Salten Langsø, 536 Tdr. Land, 29580 Hekt., 21 M. o. H. og næppe over 6-7 M. dyb. Salten Langsøs Tilløb er Saltenaa, der i sin højre Side optager Lystrupaa, Afløbet fra Langsø og Kulsø. Den danner derpaa den lave c. 7 M. dybe Gudensø, 536 Tdr. Land, 29580 Hekt., og 21 M. o. H., modtager Tilløb fra den lille Vessø og danner derpaa en ny, men ret ubetydelig Bredning, Birksø, 79 Tdr., 4359 Hekt., 21 M. o. H. og kun 3-4 M. dyb. Her modtager den et betydeligt Tilløb, der kommer inde fra den lille Pittersø og først gennemstrømmer Vengesø og Ravnsø, 336 Tdr., 1848 Hekt., hvis Dybde er mig ukendt, senere Knudsø, 343 Tdr., 189:9 Hekt., hvis Dybde angives at vere meget betydelig (c. 33 M.); derpaa løber Aaen endnu et Stydke og 
danner sin forste store Bredning Julsø; Retningen er fra Indtradelsen i denne Sø og til Indlubet i Silkeborg Langsø restnordvestlig. Efler at have forladt Julsø danner den sin anden store Bredning Borresø, 364 Tdr., $200_{88}$ Hekl., 21 M. o. H. og nxppe over c. 12-15 M. dyb; i dennes vesllige Hjørne udmunder Tilløbet fra den lange, smalle Thorsø, 364 Tdr., $2008 s$ Hekt., 23 M. o. H. og 11 M. dyb. Gudenaaen forlader Borresø i dennes nordvestlige Hjørne og danner den tredie Bredning Brassø, 193 Tdr., 1065 Ilekt., 21 M. o. H. og kun 4-5 M. dyb, en smal, sterkt tilgroet Sø, der modtager Tilløb fra Almindsø, 100 Tdr., 5519 Hekt.; den angives i Almindelighed til kun at vere c. $20 \mathrm{M}$. dyb, men den er efter mine Maalinger mindst $30 \mathrm{M}$; ; den hører rimeligvis til vort Lands dybeste Søer og er i hvert Fald i Silkeborgterrainet den dybeste. Efter at vare traadt ud af Brassø løber Aaen c. 3 Kilom., inden den falder i Silkeborg Langsø, 421 Tdr., $232_{44}$ Hekt., og 18 M. o. H., men kun 4-5 M. dyb; denne lange og smalle Sø har i sin sydvestlige Ende modtaget Tilløb fra den lille Ørnsø, 79 Tdr., 4365 Hekt., hvis Dybde dog ei mig ubekendt; dennes Tilløb er Funderaa.

Ved Udløbet af Silkeborg Langsø (Kort V1l) forandrer Aaen sin Hovedretning, samtidig med at Nedreløbet begynder. Den løber først et kort Stykke mod Øst, bøjer derpaa imod Nord, modtager i højre Side Tilløbet Gjernaa, i venstre Allingaa, der er Afløbet for de to kun 3-4 M. dybe Smaasøer, Hingesø og Allingsø; derpaa løber den et Stykke i vestlig Retning, bøjer atter mod Nord og optager Tangeaa; fra dette Punkt foregaar Løbet om end i større Bugter væsentlig i østnordøstlig Retning. Den optager inden sit Udløb i højre Side Lilleaa, i venstre den store Nørre-Mølleaa eller Skernaa og udmunder uden at modtage yderligere nævneværdige Tilløb ud ved Randers. Nørre-Mølleaa optager Vandet fra Haldsø, Vedsø samt fra Viborgsø, Loldrupsø og Røddingsø.

Viborgsø er c. 600 Tdr. Land, 33113 Hekt., stor; Højden over Havet er 11 M. Den er delt i to Søer, Viborg Nørresø og Viborg Søndersø, adskilte fra hinanden ved en Chaussee, der dog er gennemboret saaledes, at de to Søer staar i Forbindelse med hinanden. Viborg Nørresø, der er noget mindre end Søndersøen, er c. 15-16 M. dyb. Bunden er, saa vidt vides, ret jævn. Viborg Søndersø er gennemgaaende betydelig lavere; Dybdeforholdene i Søens sydligste Del er mig dog ukendte. Kysterne er lige, uden Indskæringer. Tilløbet finder Sted i Nørresøs nordlige Ende ved Nørremølle; det kommer fra Loldrupsø; Afløbet i den sydøstlige Ende af Søndersø og støder til Nørreaa nær Randrup.

Der angives, at Viborgsø i tidligere Tid gennem Vindmøllesø og Vedsø har staaet i Forbindelse med Haldsø.

Haldsø er 607 Tdr. Land, 33499 Hekt.; Højden over Havet er 9 M., dens største Dyb er mindst 36 M. Søen er lang og smal, den udsender paa sin vestlige Side en lang, smal Bugt, der nu er meget lav, c. 7 -8 M., og som rimeligvis langsomt gror til. I den nordre Del, regnet til en Linie fra Indreøens Spids og ret ind paa Sø̣ens østlige Side, findes næppe Dybder paa over $20 \mathrm{M}$; d denne nordlige Del afspærres fra den sydlige ved en Banke, der fra Indreøens Spids strækker sig tværs over Søen. I den sydlige Del findes, navnlig over mod den østlige Side og noget Nord for Stampen, betydeligere Dybder, meget nær $40 \mathrm{M}$. Søen indeholder ingen Øer.

Tilløbet gaar ind ved Dollerup Mølle i Søens sydlige Ende; Afløbet forlader Søen i den nordlige Ende, løber derpaa til Vedsø, der optager Tiløø fra den lille Vindmøllesø; Afløbet betegnes Nørreaa, som efter at have optaget Tilløbet fra Viborgsøerne fører den samlede Vandmasse ud i Gudenaaen.

Skanderborgsø (Kort VIII) er 1685 Tdr. Land, 9291 Hekt., stor; dens Højde over Havet er 24 M.; Dybden overstiger vistnok intet Steds c. 20 M. Det vigtigste Tilløb er Ringklosteraa, der udmunder paa Sydsiden; Afløbet er Taaningaa, der løber ud fra Søens vestlige Hjørne i vestnordvestlig Retning og ved Fuldbromølle udmunder i Mossø paa dennes Sydside. Skanderborgsø er af de danske Søer vistnok den, der opviser den mest uregelmæssige Form og har de stærkest indskaarne Kyster. Den er delt i en østlig og en vestlig Del, forbundne med hinanden ved et smallere Parti, i hvis vestlige Del den lille Ø, Ebleøen, ligger. I Søens østlige Del ligger den noget større Ø, Fugleholmen, Kalvø; denne Del, som jeg kender bedst, har sit største Dyb mellem Vestermølle og Kalvø; herfra aftager Dybden ret jarnt saa vel op imod Skanderup som ned imod 
Ringkioster. Saa vel Bugten fra Skanderborg og op til Skanderup som den nu afsperrede Bugl, der danner de 10 Suatasoer Lilleso og Sianeso, er meget lavindede Partier, hvis Dybde ikke overskrider 4-5 M. Af enkelte Lodskud i Soens vestlige Del maa jeg formode, at heller ikke dette Parti opviser Dybder paa over $20 \mathrm{M}$. Aflobet lil Mosss, Taaningaa, ('r nu et ringe Vandlob, der, navnlig om Sommeren, kun fører lidt Vand.

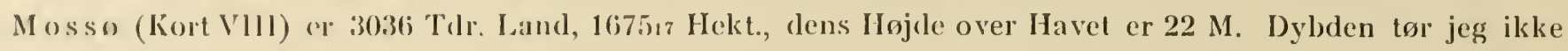
angive med Siklierlied, da jeg ikle har undersøgt Soens midterste Parti; den modtager to Tilløb, lllerupaa, der kommer fra et Moseparti noget Vest for Stilling Sø og Taaningaa; begge løber ind i Søens astlige Hjørne, Illerupaa i det nordøstlige, Taaningaa $\mathrm{i}$ det sydøstlige. Ulløbet er Gudenaaen, der forlader Søen $\mathrm{i}$ (let vestlige Hjorne par dettes Nordside. Søen strakker sig i Retningen Øst-Vest, den er c. $11 \mathrm{Kilom}$. lang, men kun c. 2-3 Kílon. bred. Dens Kyster er lidet indskaarne; en Bugt gaar i nordøstlig Retning op til Alken Station; fra Soens Nordside udspringer to markelige Tanger, Emborgtangen og Lindholm Hoved, hvis Dannelsesmaade forelobig er ukendt. Selv har jeg undersøgt Dybdeforholdene i Søens østlige Del indtil Linien Boes-Hen og Soens vestlige Del indtil midt imellem de to Tanger. Det fremgaar heraf, at Partiet Ost for Linien Fuldbromolle-Søskoven er meget grundt og ikke har Dybder paa over $10 \mathrm{M}$. Sødybet begynder forst lengere mod Vest, men inden for det undersøgte Omraade findes ikke Dybder paa over $20 \mathrm{M}$.

Søens ostlige Del lige til Emborglangen er ligeledes meget grundt og indeholder større Grunde paa kun 2-5 M. Vand. Tangen selv strxkker sig som en lang Sandrevle tværs over Søen og skal i tørre Somre omtrent naa over til den sydlige Kyst. I Følge Holmboe (se Schytte 43 p. 167) kommunicerer de to Dele kun med hinanden gennem en 30 Farne vid Aabning. Søens største Dyb ligger i det midterste Parti tæt uden for Byen Hems Gruncl og angives at være 33 M. (Holmboe); Gennemsnitsdybden er dog næppe over 20 M.

Man finder som oftest angivet, at Gudenaaen er Mossøs betydeligste Tilløb, ligesom Mossø (Erslev 86 p. 217) opfattes som Udvidelse af Gudenaaens Løb.

Saa vidt jeg kan skønne, er disse Angivelser ikke rigtige, Gudenaaens Ind- og Udløb ligger kun fjærnet faa Hundrede M. fra Linanden, og det Parti, hvori Aaen løber ind, er fjærnet fra den egentlige Sø ved den forste af de ovennæunte Tanger. I dette delvis afspærrede Parti, hvis Dybder ikke overstiger 7 M., har Gudenaaen skaaret sig en dyb Rende, hvori en betydelig Del af dens Vandmasser løber. Jeg maa paa Grund af disse Forhold formode, at Gudenaaen kun i ringe Grad influerer paa Mossø, og at Søens Vandstand, sely om Gudenaaen aldeles ikke løb ind i Mossø, i alt væsentlig vilde være den samme som nu. Søen maa næres fra Illerupaa og Taaningaa, men dog ganske særlig fra Kilder i Bunden ${ }^{1}$ ). Den er det store Vandreservoir, der bevirker, at Gudenaa, der som en ret ubetydelig Aa løber ind i Søen, kun faa hundrede Meter hojere oppe forlader Søen betydelig bredere og giver den Præget af en Flod.

J ulsø (Kort VIII) er 1021 Tdr. Land, 56347 Hekt., Højden over Havet er 21 M.; dens største Dyb, beliggende lidt Vest for Møgelø mellem denne og Himmelbjærget, er kun c. 18 M. Søen er langstrakt af Form; den rummer 4 Øer, den store Møgelø og de tre Smaaøer Alø, Bregnø og Lilleø; en 5te, Dynæs er nu landfast. Fra Sydsiden udgaar den lange Halvø Ringholm Hoved, der rimeligvis ogsaa tidligere har været $\varnothing$. Saa vel hele Søens østlige Del begrænset af en Linie fra Dynæs og til Ringholm Hoved, som den vestlige indtil en Linie fra Lilleø og omtrent over til Limbjerggaarde indeholder kun Dybder paa c. 8-9 M. Gudenaaen løber ind i Søens sydøstlige Hjørne og forlader Søen i det vestnordvestlige. I den sydøstlige Del ved Foden af Himmelbjarget foregaar en betydelig Landvinding.

Forud for Hovedundersøgelsen i 01 og 02 gik en anden, som væsentlig har støttet denne.

I 1898 planlagdes og gennemførtes en regelmæssig 14 Dags Undersøgelse af oprindelig 14, senere 11 Damme, hvoraf de 6 var beliggende i Omegnen af Frederiksborg, de 5 mellem Holte og Virum (Kort II). Denne Undersøgelse skulde først og fremmest skaffe Oplysninger om Rotiferernes Forplantningsforhold, men der skulde dog, saa vidt muligt, ogsaa bestemmes alle de i Prøverne værende Mikroorganismer.

1) J. C. Schytte har $(43$ p. 157) fremsat den Anskuelse, at Gudenaaens forste Oprindelse burde soges i Ringliosteraa, samt at den Del af Gudenaaen, der lober ind i Mossø, snarest lurde betragtes som Biflod. 
Der foreloges derfor i 1898 hver 14. Dag, i Reglen Søndag og Mandag, to Rejser, en til Frederikslorg og en til Holte; Proverne hjembragtes, og den indsamlede Mikrofauna og -llora bestemtes saa vidl muligt samıne Dag paa det levende Materiale; senere blev det konserverede Materiale nermere undersøgl.

Hyppigheden blev, efter den ogsaa i delle Arbejde anvendte Skala, angivel for alle Rotiferer, Daphnier, Peridineer, Diatomeer, de vigtigste Cyanofyceer, Infusionsdyr og Flagellater; derimod var mit Kendskab til Chlorophyeer og Copepoder for ringe til, at jeg kunde medtage disse, og da jeg paa det Tidspunkt desværre hverken havde Tid eller Plads til at bevare de talrige Prøver (c. 300), maalle de lidt efter lidt bortkastes.

Resultatet af Undersøgelsen blev el fyldestgørende Kendskab til Rotiferernes Seksualperioder samt Paavisningen af, at selv. vore største Søers udprægede Planktonorganismer ogsaa kan træeffes i Smaasøer og Damme. Jeg stod i 1898 i Begreb med at publicere begge disse Resultater; da udkom Lauterborns Arbejde over Rotiferernes Forplantningsforhold (98) og Zacharias' Arbejde: Untersuchungen über das Planliton der Teichgewässer $(98 \mathrm{~b})$, hvorved yderligere Specialpublikationer herover overflødiggjordes. Undersøgelsen bragte desforuden et betydeligt Antal hidtil ukendte Hjuldyrhanner for Dagen; disse blev aftegnede og beskrevne, og det er mit Haab, at dette Afsnit en Gang maa kunne tilendebringes; desforuden tilvejebragtes en stor Mængde mindre Oplysninger om talrige Mikroorganismer, der er medtagne i dette Arbejde.

Undersøgelsen, der i del følgende betegnes Damundersøgelsen 98, omfattede følgende 11 Smaasøer og Damme :

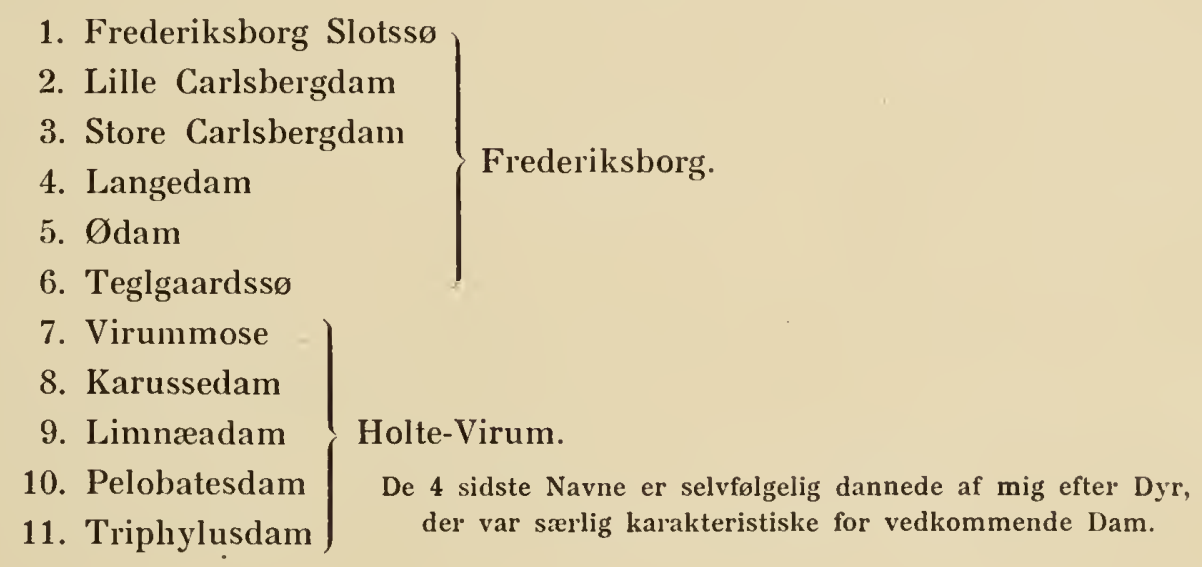

Frederiksborgdammene.

1. Frederiksborg Slotssø, der er den største af de her omtalte Vande, er næppe over $3^{1 / 2}$ M. dyb; Littoralvegetationen er mærkverdig ringe; Planter med Flydeblade findes saa godt som ikke (lidt Polygonum amphibium). Potamogeton-Arter, Batrachium o. a. submerse Planter er sjældne (lidt $P$. crispus); den hyppigst forekommende Plante er Myriophyllum. Søen har i det tidlige Foraar et stort Asterionella-Maks., men er iøvrigt bekendt for sit kolossale Maks. af Polycystis; den er derfor særlig bleven anvendt til Studium af denne Plante; iøvrigt er dens Plankton hovedsagelig karakteriseret ved Brachioner, Hyalodafnier og Bosmina longirostris.

2. Lille Carlsbergdam er en ganske lille, om Sommeren næsten udtørret Dam, beliggende ved Københavnsvejen paa venstre Side af Landevejen fra Frederiksborg; den støder tæt op til den følgende Dam. Den er paa Bredden bevokset med høj Typha; Vandfladen er kun fri i April; fra Maj-November er den dækket med et meget tæet Tæppe af $P$. natans o. a.

I April findes i Dammens centrale Parti et rigt Plankton af Synura, Uroglena, Peridinium tabulatum, Dinobryum; naar Dammen er bleven dækket af Vegetationen, hører dette op, men der findes da inde i Grøden et meget stort Antal Rotiferarter; den valgtes til Undersøgelsen særlig af Hensyn til Ploesoma triacanthum, der hele Sommeren var meget almindelig. 
3. Store Carlsbergalam stoder umiddellart op til foregatende og ligger ud for den gamle Gaard: Cimrlsberg. Phra!miles og Eaguischm limosum er verl at lukke Danmen; Vandstanden er om Sommeren nappe $1 \mathrm{M}$, men der er hele daret et regetationslirit Midtfelt. Her findes i lioraarstiden et. meget rigt l'lankton al' S!mmura, men sarligs af Rotilererue Asplanchna, Synchata, Amurae, Brachionus, Pohyarthra, Triarlhra o. a. On Sommeren danner Coclospharium Kützingianum en tyk Vandl)lomst, og det ret sjaeldne IJjuldyr Schizocerea diversicornis opnatar samtidlig et tenuelig betydeligt Maks.

1. Latugediu ligger iude i Prestevangen ner ovennevnte Landevej og er noget støre end foregaaende; Dybden er on Sommeren nxpe over 3/. M. Den har i Foraarstiden en vegetationsfri Overflade, men daek-

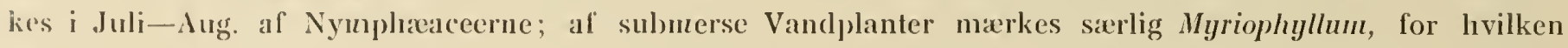
Soen luert Aar mala renses, lıvis den ikke skal gro altfor hurtigt til. Søen er fuldstendig omgivet af Bøgeskov; Overlladen er om Efteraaret undertiden skjult af vissent Bøgeløv.

Plauktonet ligner ganske forcgaaende Dams, men Langedam indeholder tillige det sjaeldne Hjuldyr: Pedalion mirum, levorfor Dammen merltoges i denne Undersøgelse.

5. Ø l a m ligger ligeledes i l'rastevangen nær foregaaende og er noget større end denne. Den indeholder to Smaaoer adskilte fra Land ved delvis stensatte Suakanaler. Dybden er incltil 2 M., som oftest mindre; Dinmen er rund af Form, men med indskaaren Kyst; dens Overflade er kun i Foraarstiden ganske vegetationsfri; ou Somuneren og Efteraaret dækkes en stor Del af Nyıuplucacee-Blade; inde ved Bredden spiller Hydrocharis en ret betydelig Rolle. Ogsaa denne Sø er helt omgiven af Bøgeskov.

I denne Dau findes aldrig Cyanophyceemaks.; i Foraarstiden optræeder et meget stort Asterionella-maks., senere hen er Planktonet sxrlig karakteriseret ved Mallomonas, som findes hele Sommeren og kan farve Vandet gulgront. Mellem de øvrige almindelig forekommende Damformer mærkes særlig det sjældne Hjuldyr Conochilus natans.

6. Teglgalardssoen er næst Slotssøen den største af de hilltil næunte Damme, men er i øvrigt i de senere Aar stierkt vell at gro til; dens største Dyb er c. 2 M. Scirpus, Pltragnites, men ganske særlig Sparganium ramosum indskranker stadig den fri Vandoverflade; uden for Sparganium findes en Krans af Nymphreaceer. Potantogetou natans, Potanuogeton lucens, Batrachium og Myriopluyllum har nu vistnok bredt sig over hele Søen. Et Midtparti er dog endnu omtrent hele Aaret frit for Vegetation. Søens Foraarsplankton er karakteriseret ved store Maks. af Asterionella, Synura, Uroglena, Peridinium. I Forsommeren indtræffer et stort Dinobryum Maks. og store Maks. for de almindelig forekommende Rotiferer, samt for Bosnina longirostris. Sommerens Plankton er karakteriseret ved Diaphanosona brachyurum, Mallononas, en Del Oscillaloria rubescens, samt Ceratium hirundinella. Om Efteraaret opnaar de fleste af Foraarsformerne atter ret betydelige Maks.

Alle de ovennavnte Damme og Smaasøer med Undtagelse af Nr. 2, der intet Afløb har, afvander til Polaaen, der falder i Arreso.

\section{Holtedam mene.}

7. Virummose er nu kun Rester af et i tidligere Tid ret betydeligt Mosedrag; den er beliggende c. 1 Kílom. Nord for Landsbyen Virum og bestaar af et Antal større og mindre Mosehuller, vistnok delvis fremkomne som Følge af Tørveskær; Planktonprøverne stammer fra det største af disse, der er opfyldt af smaa Pltragnuiles-Holme, og hvis største Dybde nxppe overskrider c. 2 M.; der er hele Aaret et vegetationsfrit centralt Parti. Foraarets Plankton dannes overvejende af Peridiuium tabulatum, Synura, Uroglena, Dinobryum samt af de almindelig forekommende Rotiferer. Om Sommeren opnaar Asterionella et meget stort Maks. og flere Infusionsdyr samt Gastropus stylifer spiller en betydelig Rolle. Om Efteraaret kommer en Del af Foraarets Former igen.

8. Karussedam er en ganske lille Dam fuldkommen blottet for Vegetation; den er c. 11/2 M. dyb og ligger ude paa aaben Mark; Kræg og Heste vandes ved den. Vandet er hele Aaret gulgrønt af en Chlamy- 
dononas-Art og andre Flagellater; det indeholder i øvrigl forskellige Iljuldyrformer sarlig Brachionus augularis og Ratlulus bicoruis i stor Mangde. Synura, Uroglena og Peridineer er sjoldne.

9. Limnaadam er en lille omtrent hjertedannet Dam med rigelig Vegetation af Equisetum linosuln langs Bredden og et Pilekrat i Dammens vestlige Ende; temmelig langt ud mod Dammens Centrum spiller Traadalger en betydelig Rolle, dog bliver der alticl et større vegetationsfrit Centralfelt tilbage. I)ammens Dybrle lor ikke angives med Sikkerhed, men den overstiger næppe c. 2 M. Om Foraaret findes et meget rigt Plankton af Syuura, Uroglena, Peridinimm, Ceratium coruulum, Ascomorpha agilis samt af de almindelig forekommende Rotiferer. I August-Oktober er Vandet grødet og gulbrunt af Ceralium hirundinella, et markeligt Eks. paa i hvor ubetydelige Vandmasser denne Form kan finde sig til Rette.

10. Pelobatesdam. Denne lille Dam, der støder nær op til foregaaende, er om Sommeren og Efteraaret fuldkommen drekket af Polannogelon nataus og Lemina; fri Vandoverflade findes kun i April-Maj; Dybden overskrider næppe 1 M. I det tidlige Foraar findes et rigt Plankton af Peridiniuun labulatum, Synura, Uroglena og Eudorina samt de almindeligst forekommende Rotiferer; i April har Ascomorpha agilis et kolossalt Maks. Efter at Vegetationen har dækket Overfladen, er det mikroskopiske Dyreliv mærkelig ringe; Vandet er som overalt, hvor Leuna dominerer, mærkværdig klart.

11. Triphylusdam. Denne lille Dam tørrer om Sommeren fuldstændig ud; Holtonia dækker Bunden, og i Midten findes en Typha-Bevoksning. Vandstanden er næppe nogensinde over c. $1 / 4$ M. I dette meget lille Vandhul, hvis hele Vandmasse selv i det tidlige Foraar næppe kan sættes til ret mange Tønder, rører sig et mærkverdig rigt mikroskopisk Dyreliv; Eudorina, Goniun, Volvox, Paudorina, Ceratium cornutum, Peridinium tabulatuu, Synura, Uroglena og Dinobryum træffes, saalænge der overhovedet er Vand. Dammen er dog særlig karakteriseret ved sit rige Rotiferliv; blandt de sjældnere Former kan nævnes Gaslropus minor, Microcodides dubilum, Scaridium eudactylotum, Copeus caudatus, Triphylus lacuslris, sidstnævnte i stor Mængde. Dammen, der ogsaa indeholder sjældne Oligochæter og Copepoder, er nu som saa mange andre i dette Terrain ødelagt ved Bebyggelse.

De 5 Damme 7-11 ligger alle i det Terrain, der mod Vest og Øst begrænses af Furesø og Virummose, mod Nord af Kaningaardens Jorder og mod Syd af Vejen fra Furesøen op til Virum.

Til Undersøgelsen blev Baad benyttet, hvor det var muligt; paa de fleste Damme manglede dog Baad, og jeg betjente mig i saa Fald af et Kastenet. 


\section{KAP. II. UNDERSØGELSESMETHODER; PLANKTON-METHODIK.}

$\mathrm{D}$ ET vil være indlysende, at hvis den planlagte Undersøgelse af de 9 Søer skulde gennemføres, maatte der stilles andre Fordringer til Methodikken, end dem, man sædvanlig stiller, naar Talen er om Planktonundersøgelser. Enhver, der har været med til i uroligt Vejr midt ude paa større Søer og fra smaa aabne Baade at tage Vertikalprøver, vil vide, at det i de allerfleste Tilfælde er umuligt at tage dem nøjagtigt, og at megen Omhu er nødvendig, hvis Resultatet skal blive blot nogenlunde tilfredsstillende. Da det paa de 5 Søer var overdraget Fiskere at tage Prøverne, og jeg selv som Regel var ude af Stand til at øve Kontrol, turde jeg ikke tillægge de Vertikalprøver, som kom ind fra disse Søer, tilstrækkelig videnskabelig Vardi. Da det i Følge Undersøgelsens Plan var af Vigtighed, at Prøverne saa vidt mulig kom ind samtidig, hvilket kun kunde opnaas, saafremt deres Tilvejebringelse ikke krævede fuldstændig rolig Sø, besluttede jeg mig til for en Del at give Afkald paa Vertikalprøver og kun lægge Vægt paa Horisontalprøver. Jeg har derfor kun anvendt kvalitative Net af den almindelige Konstruktion. Ringens Aabning var $30 \mathrm{~cm}$. Fra de 4 sjællandske Søer har jeg dog med dette Net altid taget Vertikalprøver, og saadanne foreligger ogsaa fra de fleste jydske Prøver, men Tilvejebringelsen af dem har ikke været opstillet som en uafviselig Fordring.

Da det endvidere under de forberedende Undersøgelser viste sig, at der ogsaa i vore Søer var en Del Forskel mellem Planktonet ved Overfladen og i dybere Vandlag, toges der altid to Prøver, en Overfladeprøve og en c. 2 M. over Søbunden paa Søens dybeste Punkt. Ligeledes fremgik det af de forberedende Undersøgelser, at det ved Bestemmelsen af det indsamlede Plankton var af Vigtighed, at denne foregik, medens Planktonet var levende, samt at alt Phytoplankton konserveredes bedst og ypperlig holdt sin Farve og Gelestruktur i Formol. I Overensstemmelse hermed foretoges mine Rejser altid med Mikroskop, og alle Prøver fra de sjællandske Søer er undersøgt levende faa Timer efter Indsamlingen; ligeledes er Maj-, Augustog Oktoberprøverne fra de jydske Søer undersøgt levende. Fremdeles blev der fra alle Søer uden Undtagelse altid taget saa vel Formol-son Alkoholprøver, saaledes at hver Prøve mindst bestod af 4 Glas, 2 Overfladeprøver og 2 Dybdeprøver, dels konserverede i Formol dels i Alkohol; hertil kom endvidere i Almindelighed en Vertikalprøve, der altid konserveredes i Formol. Møllergazen, der anvendtes, var i Begyndelsen Nr. 19, men erstattedes efter Aug. 01 af Nr. 20; dette havde dog kun til Følge, at Mængden af Rhizosolenia, Closterium og Synedra steg kendelig i Efteraarsprøverne 01 og i hele 02.

I Maj 01 blev jeg klar over, at mine Net fangede altfor faa Crustaceer; selv Horisontalprøver, der var taget i Løbet af c. 1 Kvarter, gav mærkelig faa Copepoder, og i Juni-Juli, da Leptodorerne kunde ventes, indfangedes kun et meget begrænset Antal. Jeg prøvede mig da frem med forskellige Numre af Møllergaze, idet jeg filtrerede Planktonprøver gennem disse og nærmere undersøgte, hvad der gik gennem Tøjet, og hvad der holdtes tilbage af dette. Ud fra disse Forsøg valgte jeg mig da Griesgaze Nr. 60, Nr. 40 og Nr. 24 
og konstruerede mig al disse tre Nel, der betegnedes Bosmina-Nettel, IIyalodaphnirn-Netlet og LeplodoraNeltet. Ciennem det første ( $\mathrm{Nr}$, 60) passerede alt Phytoplankton, livorimod Bosminerne, Cihydorus, Ciychops oilhonoides (lil Dels), Asplanchua samt alle storre Planklonorganismer holdtes lillage al dette; det andet (Nr. 40) fangede ikke Bosnima, Chyjdorns, Cyglops oilhonoides og Asplanchua, men derimod Hyjalordaphnin, Daphnia, udvolisne Diaphomus (til Dels) samt alle større Former; det tredie Net (Nr. 20) tog kun Leplodora, Iiylholtephes, de meget store Eks. af Daphnier samt Argulus, Caligus, Hydrachner og Corelhra. Disse lre Net var ikke af konisk Form, men jevnt afrundede i den nederste Del; Posens Laengde var 11/2 M. I Juni 01 toges i Furesøen paa samme Sted og i Løbet af samme Time Vertikalprøver, dels med konisk Net Møllergaze Nr. 20, dels med de tre ovennevnte Net, samt med Apsteins krantitative Net; det fremgik af disse Prover, at de tre Crustaceenel sammenlignelsesvis fangede langt flere Crustaceer end baale det koniske Net og det Apsteinske kvantitative Net. Dette egner sig, saa læenge Apsteins Konstruktion anvendes, aldeles ikke til kvantitative Undersøgelser over Crustaceer; Nettets koniske øverste Parti, der netop skulde bevirke, at dets Filtrationserne blev slørre, skyder de større og bedre Svømmere bort fra Netaabningen, der hos Apstein tilmed sparres af Snorene; heraf resulterer, at der gaar alt for faa Crustaceer ned i Nettet, og at Prøvens Rigdom paa Crustaceer er alt andet end identisk med den Rigdom, der findes i den gennemfiskede Vandmasse. Allerede tidligere har Fuhrmann (99 b) gjort opmærksom herpaa; jeg tvivler ikke om, at det af Fuhrmann lionstruerede Net egner sig langt bedre til Fangst af Crustaceer end Apsteins; Fuhrmanns Net har jeg imidlertid ikke prøvet.

Naar jeg i dette saa vel som i det senere Arbejde kan give saa nøjagtige Meddelelser om Crustaceernes Forplantning og ovrige Livsforhold, skyldes dette udelukkende Brugen af de tre forskellige Slags Crustaceenet. Strængt taget gives der for hver enkelt Organismes Vedkommende et bestemt Nuınmer af Møllergaze, som bedst fisker netop denne Form; et er i hvert Fald sikkert: Net, hvortil der er anvendt Møllergaze Nr. 20, giver os et fuldstændig galt Begreb om den Mængde af Leplodor'a og Bylholrephes, der paa et givet Tidspunkt findes i en Vandmasse; om Vinteren vil Net Nr. 20, navnlig hvis man kun sætter sin Lid til Vertikalprøver, enten aldeles ikke kunne paavise Hyalodaphnia og Daphnia eller i hvert Fald kun ganske enkelte. Endvidere vil Net Nr. 20 saa godt som aldrig fange de sjæeldne Cladoceer-Hanner; naar man indtil Dato stadig hævder, at Bosminerne overvejende er acykliske, og at Hannerne hos Planktonformerne af Slægten Daphuia er yderst sjældne, skyldes det i første Instans, at man aldrig har fisket med de Net, der egner sig til at fange dem; men herom mere senere. - Fra Juli 01 og til August 02 er Prøverne altsaa bleven tagne dels med Pl.net Nr. 20, dels med de tre ovennævnte Crustaceenet. Skulde nu alle 4 Net være anvendte baade i Overfladen og ved Bunden og det indsamlede Materiale dels være konserveret i Alkh. og dels i Formol, vilde Resultatet blive, at hver Prøve kom til at indbefatte 16 Glas foruden Vertikalprøven tagen med Net Nr. 20. Da dette selvfølgelig vilde blive altfor mange Glas, simplificerede jeg efter nøje Overvejelse Forholdet saaledes:

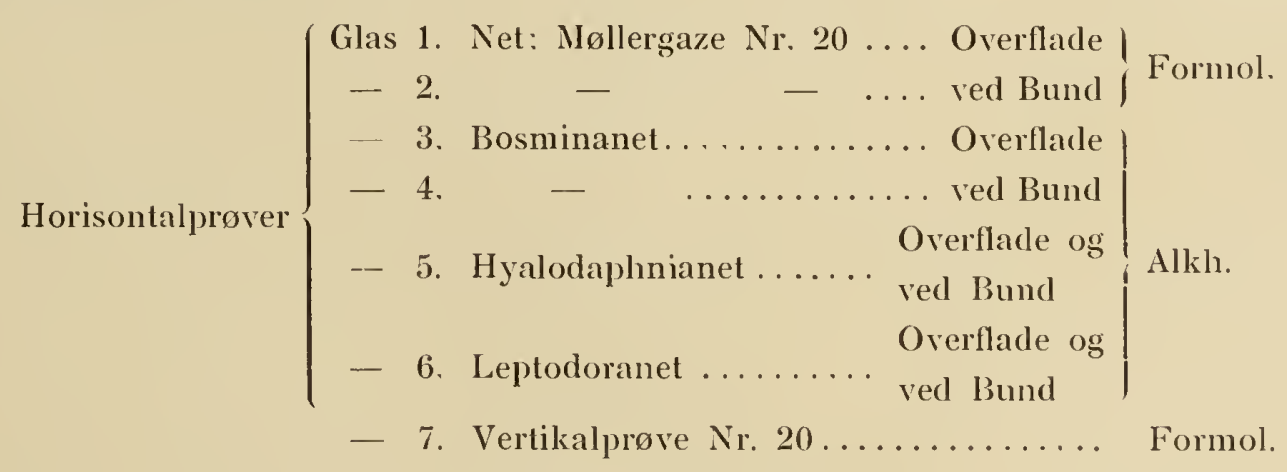

Reduktionen af Glassenes Antal foregik ud fra den Kendsgerning, at alle de grovere Net kun tog Crnstaceer, der absolut konserveres bedst i Sprit. Prøverne 5 og 6 toges paa den Maade, at Nettet først sankedes ned til nogle faa Meter fra Bunden og droges parallelt med denne; derpaa blev det trukliet horisontalt i et 


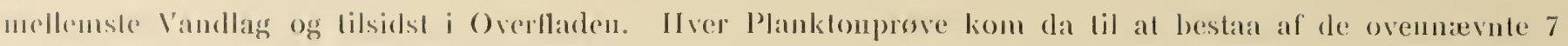
undertiden liun di (ilas ( : Vortikalproven); for de jydske Soers Vedkommende mangler dogn ofte Prøverne

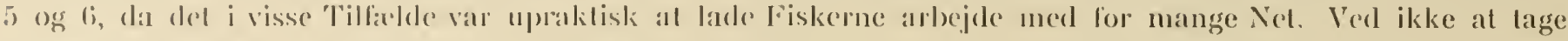

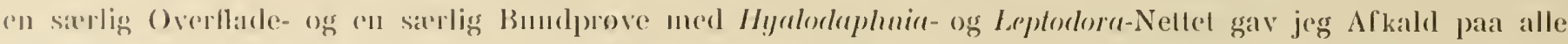
(O)lysuinger on de store Planklonorganismers horisonlale Fordeling i Vandlagene. Jeg er af den For-

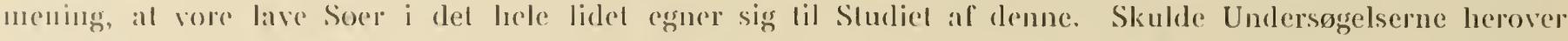

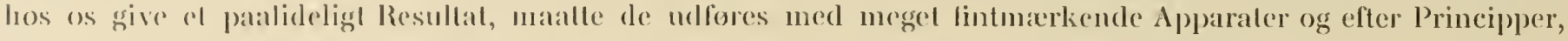
der var gantsise uforenclige med den her planlaggle Undersegelse.

Del sintede Antal opbevarede (ilas med undersogte Planktonprøver er 872.

Alle Proverne er lagne i Socrnes Midte og sala vidt mulig par deres dybeste Punkt. P’áliortene angiver Markiel $\times$ Sterlet, livor Proverne loges.

Sporgsmaaled bliver da, hrortil Prover af den her nernle Beskaffenhed lader sig bruge, hvilke Opgaver man kan soge loste, og hilke man i Folge Materialets Beskaffenhed ganske maa se bort fra.

1. Proverne giver os forsl og fremmest indgaaende Oplysninger om, hvilke Planklonorganismer der findes her i Landet, og da vi herom kun har haft yderst ringe Kendskab, er disse Oplysninger ikke de mindst viglige, som Undersogelsen har bragt frem. Af de 148 paaviste l'anktonorganismer er over Halvdelen ikke for lundel her i Landet; de findes i hvert Falıl ikke omlalt i dansk Litteratur.

Der er paarist saa godt som alle de Planktonorganismer, der overhovedet er angivel fra europxiske Søers pelagiske Region; de faa, som det ikke er lykkedes os at finde - særlig Arter af Slagten Diaptomas samt enkelte Daphnier, enkelte Chlorophyceer og Cycloteller - er alpine Former, der mangler i det mellemcuropaiske Slellelands Soer, og som vi ikke kunde vente at finde her i Landet. De eneste Arter, som jeg vel maa formode lod sig paavise, men som i saa Fald er undgaaet Undersøgelsen, er de to Heterocope-Arter 1I. salieus og H. appendiculata. Det var min afdøde Ven Mag. Søren Jensen som det er mig ubegribeligt, at vi aldrig har fundel disse Former.

2. Sammenholdte med de talrige Enkeltprøver fra større og mindre Søer giver de ovennæunte Prøver os tillige Indtryk af Planktonorganismernes Udbredning og Hyppighed indenfor Landets Grænser. Da Prøverne endvidere saa vidt mulig er tagne samtidig $\mathrm{i}$ alle Søerne, giver de tillige Oplysninger om de Planktonorganismer, der til enliver Tid af Aaret santidig optrader i hvert Fald i en betydelig Brøkdel af Landets større Søer.

3. Ud fra det Kendskab, ri i Øjeblikket har til disses fysiske Forhold, og ud fra de yderligere Oplysninger, som jeg i saa Henseende har søgt at tilvejebringe, og som senere skal omtales, bliver det endvidere muligt netop paa Grund af Provernes Samtidighed at skimte Aarsagerne til, at de enkelte Planktonorganismer med Hensyn til deres Maks. og Seksualperioder ikke forholder sig ens i alle Søerne.

4. Endelig tillader det indsamlede Materiale el indgaaende Studium af Temporalvariationen, saaledes som den foregaar samtidig paa iklie mindre end 9 forskellige Lokaliteter.

Derimod er det indlysende, at man af Materialet aldeles ikke tor drage nogensomhelst Slutning, hverken med Hensyn til den vertikale Udbredning eller til mulige Vertikalvandringer; herom giver denne Undersøgelse saa godt som ingen Oplysninger; i et Land, hvor Planktonundersøgelser hidtil har manglet, bør disse Studier lieller ikke danne Begyndelsen.

Man kunde endvidere formene, at Materiale, der kun bliver indsamlet en Gang maanedlig, i Stedet for som Fordringen plejer at være hver 14. Dag, ikke vilde vare i Stand til at give et fyldestgørende Billede af den enkelte Søs Plankton.

Ud fra min 14. Dags Undersøgelse af Furesøens Plankton i 98 og 99 er jeg tilbøjelig til at tro, at en maanedlig Undersøgelse af vore Søer, anstillet i Tiden fra Nov. til April, ikke vil give synderlig mindre paalidelige Resultater end en 14. Dags Undersøgelse i samme Tidsrum; derimod maa det indrommes, at den maanedlige Undersøgelse i Tiden fra April til Nov. ikke faar alting med; der gives nemlig Former f. Eks. 
Dinobryum, Dilephus, Asterionella o. a., der kan prestere sáa kortvarige Maks., al de ikke rammes af" en matnedlig Undersogelse; en saidan giver heller ikke lilstrakkelige Oplysninger om Storrelsen an de enkelte Maks., da Proverne hyphigere vil trefle paa Randen af disse, end Tilfaldel vil vare ved en 14 . Dags Undersogelse.

Herpar kunde jeg imidlertid ikke raade Bod; at gennemføre en 14. Dags Undersøgelse paa 9 slørre Søer samtidig er for Enkellnand en fysisk Umulighed, og de Midler, der stod til min Raadighed, tillod ikke den nødvendige Assistance. Hvad der har hødet paa Manglerne i saa Henstende, er alter her, at Prøverne er lagne nogenlunde samlidig og paa saa mange Lokaliteter. Fand man saaledes samtidig i en I)el Søer udpragede Maks. og Seksualperioder og paa samme Tid i andre Søer kun en svag Stigning i Anlallet, kunde man med ret stor Sandsynlighed slutte, at Prøven her netop havde ramt Randen af el Maks.

I de Tillacle, hror Prøverne, der altid blev gennemgaaede umiddelbart efter Modtagelsen, for en eller anden Forms Vedkommende viste Forhold ganske alvigende fra del normale, toges Prøver med korte Mellemrum efter hinanden; saaledes blev Furesøens Tabellaria og Dinobrymu studerede i talrige Prøver tagne med faa Dages Mellemrum i Maj-Juni; ganske del samme var Tilfaldet med Haldsøs Asplanclına og Viborgsøs Spharocystis samt til Dels med Esromsøs Kirchneriella. Hvor ganske særlige Forhold krævede en Lokalundersøgelse til en bestemt Aarstid, er en saadan saa vidt mulig foretagen (Giloiotrichia-Kuglernes Tilllivelse, Aphanizomenon-Sporernes Aflejringsmaade: Rejse April-Maj 02).

At udvælge et mindre Antal Søer og paa disse gennemføre en 14. Dags Undersøgelse kunde vel være gjort, men det saaledes indvundne Materiale vilde i saa Fald ikke have egnet sig til at løse de Spørgsmaal, som i et Land, hvor Planktonundersøgelserne ganske havde manglet, efter min Opfattelse først burde lages under Behandling.

Man kunde endvidere formode, at Materiale, der kun var indsamlet horisontalı gennem Vandmasser, hris Størrelse var ganske ukendt, aldeles ikke egnede sig til krantitative Studier af nogensomhelst Art. I Følge den gangse Opfattelse kreves hertil uafviselig Vertikalprøver tagne med kvantitative Net. Jeg indrømmer gærne, at de Resultater, der tilvejebringes ved denne Methode, for adskillige — men nxppe for alle Organismer - er nøjagtigere end dem, jeg har kunnet tilvejebringe.

Det anses $\operatorname{dog}$ nu for en Kendsgaerning, at man i sin Tid har stolet alt for meget paa Nøjagtigheden af de Resultater, som indvandtes ved den Hensenske Methode; det er næp for meget sagt, at vi i Øjeblikket ikke ejer noget Middel til med mathematisk nøjaglige Tal at angive det Antal Organismer, der paa et givet Tidspunkt findes i en given Vandmasse; selvfølgelig er Pumpemethoden den paalideligste, men denne har aldeles ikke kunnet lade sig bringe til Anvendelse ved denne Undersøgelse. Som mange andre er jeg iøvigt tilbøjelig til at tro, at, selv om der en Gang findes en Melhode, der tillader at indfange alle Individer i en gennemfisket Vandmasse og faa dem talte, vil det Resultat, der indvindes under Tælningen, ikke kunne opveje den Arbejdskraft og den Tid, der er anvendt paa Tilvejebringelsen af Resultatet.

Det er i hvert Fald givet, at selv om man i Øjeblikket kunde angive mathematisk nøjagtige Tal, vilde man aldeles ikke kunne anvende dem. Det er altid en tvivlsom Fordel at fremtvinge Resultater, hvis Nøjaglighed er større, end der i Øjeblikket er Anvendelse for; den saaledes indrundne Viden er for Videnskabens nuværende Standpunkt unytlig, og om den vil blive til Gavn for Fremtidens, er el stort Spørgsmaal. De Synspunkter, der netop nu ligger til Grund for Undersøgelsen, behøver nemlig ikke at væere Fremtidens, og i saa Fald kan denne vistnok i de farreste Tilfalde uden viclere drage sig de tidligere Resultater til Nytte; men da bliver Resultatet af den overdrevne Eksakthed kun Ødslen med Tid og Arbejdskraft, som paa andre Felter kunde vaere kommen Videnskaben til Nylte.

Hvor uendelig megen spildt Tid og Arbejde ligger der ikke i le Apsteinske krantitative Tabeller; selv on de der angivne Tal var nøjagtige, hvad Gavn havde i saa Fald Undersøgelsen af disse; hrad Betydning ligger der for Undersøgelsen $\mathrm{i}$ at faa at vide, at der f. Eks. i 1 Kubikm. Vand var 18 Millioner el hundrede og en og tredive tusind syv hundrede og sex og halvfjers Dinobryer. Men dobbelt spildt har alt dette 
Arbejle varent, fordi vi med Kofoids (97 a) Angivelsel for (Xje red, at neppe en Gang det forste af alle disse mange Tal blot lilnarmelsesvis ar nojagligl.

I mange T'ilfidde har den i mine Ojne ganske overdeve Tillid til Vertikalprovernes Altiormatenhed

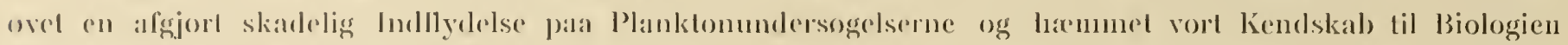

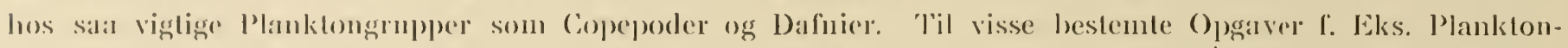

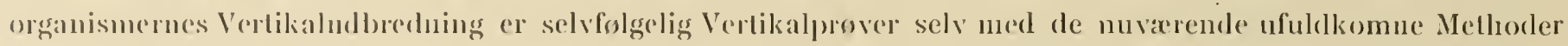
unndvarlige, men man mat ikke vare blind for, at talrige andre Opgaver sarlig saadanne, sonl vedrører Forplantningstorloblel alosolut loses lettere og bedre ved Hjall al Horisontalprever.

For de i mine Planktontabeller anvendte Hyppighedsangivelser har da folgende Betragtninger ligget til (irmul.

Jeg anser det for givet, at naar jeg frat en Sos pelagiske Region raader over mindst 4 og i de fleste Tillixdde (;-7 Planklonprover tagne i de forskellige Vandlag og med Net, livis Maskevidele er afpasset efter de vigligste Planlitonorganismers Storrelse, har jeg i disse Prøver den aldeles overvejende Del al de Planktonorganisuner, der i det givne Ojeblik optreder i Søens pelagiske Region, repraesenterede.

1) (r endvidere nbestrideligh, at der i here Prøve ved første Ojekast lod sig udskille enkelte Former niegel ofle limn en eneste - , som dannede den aldeles overvejende Del al hele Planktonmassen; desuden forekon der altid Individer, der var yderst sjacldne og kun fundtes enkeltvis; jeg anser det for absolut givet, at de lorste har dannet Hovedmassen af alt Søens Plankton, medens de sidste har spillet en ganske forsvindende Rolle.

Endvidere fremborl det heller ingen Vanskeligheder at udskille de almindelige Former og de, der vel fandtes i en Del liks.. men som dog maatte anses for sjeldne; derimod havde jeg ondt ved at finde de rette Benarnelser for de Former, der hverken matte betragtes som sjældne eller almindelige.

Som Hyplighedsangivelser er anvendt de navnlig i marine Planktonundersøgelser brugte Betegnelser "(c (overvejende), cc (meget alm.), c (almindelig), + (hverken sjælden eller alm.), $r$ (sjæelden), r $r$ (enkeltvis). Hyppigliedsgraden angaves for hrert enkelt Glas, der stammede fra samme Prøve, for sig; derpaa blev Listerne over alle de $4-7$ Glas sammenarbejdede, hrorved den i dette Arbejde angivne Hyppighedsscala for hrer enkelt Prøve fremkom.

Soger man ad grafisk Vej at anskueliggøre en Arts Hyppighed til de forskellige Tider i en Sø, vil de Kurver, der kan udarbejdes efter den ovennærnte Hyppighedsscala, i det store og hele være korrekte. Det viser sig nemlig, at Toppunkterne i de enkelte Arters Kurver i de allerfleste Tilfælde indtraffer samtidig i alle de undersøgte Søer; paa det Tidspunk1, da en Arts Kurve viser et Toppunkt i en Sø, viser den meget sjælden en Dál i en anden. Det fremgaar med andre Ord af Undersøgelsen, at de enkelte Arters Maks. og Min. indtrxfer nogenlunde samtidig i alle de undersøgte Søer; men endvidere viser det sig, at de Tidspunkter, hrorpaa Arternes Maks. og Min. indtræffer her i Landet, netop er de samme, hrorpaa Maks. og Min. falder i andre Lande, hror de er bleven paaviste af Undersøgere, der har anvendt langt mere komplicerede Methoder.

Det vil formentlig rære indlysende, at Ensartetheden med Hensyn til Beliggenheden af Maks. og Min. er den bedste Borgen for, at Hyppighedsangivelserne nogenlunde svarer til de virkelige Forhold.

Ved mere komplicerede Methoder kunde man paa Kurverne muligvis have angivet sekundære Maks. og Min., saaledes som de ofte findes afsatte paa Kurver, som er udarbejdede efter nøjagtige Talangivelser; jeg tillagger dog Angivelsen af disse secundere Maks. og Min. en rel ringe Vaerdi, fordi vi i Øjeblikket kun undtagelsesvis er i Stand til at paavise Aarsagerne til dem.

Kun i et Tilfæelde slaar den her anvendte Methode ojensynlig ikke til; den tillader ikke blot tilnærmelsesvis rigtige HyppighedsangiveIser for de Former, der hele Aaret igennem er omtrent lige hyppige, og hvis Kurver derfor aldrig opviser markerede Maks. og Min. Bortset fra alle de Former, der hele Aaret kun forekommer enkeltvis i Planktonet, er dette imidlerticl kun Tilfaldet med en eneste Slæegt nemlig Diuptomus; 
Arterne af denne Sleggt forekommer hele Aaret i stor Menggle i Planktonet, og kun undtagelsesvis har jeg haft Indtrykket al mere markerede Maks. og Min. Jeg har derfor valgl for disse Formers Veelkommende niesten altid at anvende Betegnelsen c'c.

Uniddelhart efler Prøvernes Modtagelse blev der lavel Praparal (helst af Vertikalproyen); der tilsattes Formolen lidt Glycerin, hvorpaa Præparatet tilkitledes. Af Prøverne tagne med Crustaceenettene udskiltes der al hver enkelt Art et støre Antal Individer, helst over 30; disse lagdes i Glycerinpreparater, der holdtes utilkittede. Paa den Maade opstod en Samling paa c. 1000 Preparater. Til Grund for den endelige Udarhejdelse af Manuskriplel laa dels Optegnelserne fra den første Undersøgelse, dels I'rxparatsamlingen, der stadig blev raadspurgt.

Ved al arbejde med Hyppighedsangivelserne hos andre Forf. lik jeg ofte Indtrykket af, at de ovennarnte Betegnelser hos de forskellige Forf. ikke ganske havde samme Vxerdi. Det ligger ogsaa i Sagens Natur, at der paa dette Punkt maatte gøre sig en individuel Opfattelse gældende.

For nu at give andre Forskere et blot nogenlunde tilforladeligt Indtryk af, hvad jeg har forstaaet red de her i Arbejdet meddelte Hyppighedsangivelser, besluttede jeg mig til at mikrofotografere Prøverne og satte mig i den Anledning ind i den mikrofotograliske Teknik.

Jeg henvendle mig da til Hr. Professor C. O. Jensen ved den Kgl. Vetr. og Landhohøjskole, som velvilligst stillede mig sil mikrofotografiske Apparat og Mørkekammer til Raadighed; jeg tillader mig saa vel herfor som for den Vejledning og Hjælp, han i Begyndelsen ydede mig, at bringe ham min bedste Tak.

Man har, saa vidt det er mig bekendt, ikke før anvendt Mikrofotografi til Fremstillingen af den samlede Planktonmasse. Jeg haaber, at de vedlagte Tavler vil kunne afgive Beviset for, at Mikrofolografi virkelig kan anvendes hertil; angaaende den af mig anvendte Methodik skal jeg give følgende Oplysninger.

Alle Fotografier er tagne af mig selv; Fremkaldelse og Kopiering af en Fotograf; Fremkaldelsen skete umiddelbart efter, at hver Plade var tagen; viste en Plade sig utilfredsstillende, blev den straks taget om; ofte toges $4-5$ Plader, før del endelige Resultat ansaas for at væere naaet.

For at anvende den mikrofotografiske Fremstillingsmaade kraves, at Materialet, der skal afbildes, ikke maa vise for store Afvigelser i Henseende til Storrelse og Gennemsigtighed. Det viste sig snart umuligt i samme Billede at medtage saa vel Crustaceer som alt det øvrige Plankton. Af Hensyn til det linere Plankton kunde der ikke arbejdes med Forstørrelser paa under c. 80 Gange, men detle foraarsagede, at et eneste Eks. af Størstedelen af Crustaceerne omtrent dxkkede hele det mikrofotografiske Synsfelt. Elimineredes derimod Crustaceerne, var Størrelsesforskellen mellem det øvrige Plankton dog ikke betydeligere, end at alt dette kunde fremslilles paa samme Plade. Med c. 80 Gange Forstørrelse kan samme Fotografi rumme en Atheya og en Asplanchina.

Det fremgaar dog heraf, at Mikrofotografierne ganske sarlig har Betydning ved Angivelse al PhytoplanktonOrganismernes indbyrdes Mrengdeforhold; Zooplanktonternes kan vel angives paa samme Maade, men Prøverne maa i saa Fald tages ud fra andre Principper end dem, der kunde anvendes ved demme Undersøgelse. Fremgangsmaaden vil dog næppe faa Belydning for Zooplanktonets Vedkommende, da man særlig med Hensyn til de støre Former, Crustaceerne, paa anden Vis (ved Tælning) vil kumne angive de enkelte Planktonters indbyrdes Mrengdeforhold.

Prøven, der skulde mikrofotograferes, undergik da følgende Behandling; af Vertikalprøven, eller hvis en saadan ikke fandtes, af Overfladeprøven og Bundprøven (Net $\mathrm{Nr}_{1}$. 20) ligelig sammenblandede blev en Del udtaget, Crustaceerne udskilte og en Draabe gydt paa Objektglasset. Draaben maa nøjaglig vare af den Størrełse, at Dakglasset lige kan holde den under sine Rande. Under den derpaa følgende Fordampning synker Dækglasset stadig textere ned til Objektglasset. Kunsten at tage gode Mikrolotogralier af Plankton 


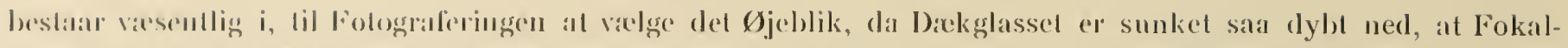
distancen lor alle Planklonorganismer sata vidt mulige er den samme a: at alle ligger i samme Plan, uden al dog derlor nogen al (Organismerne kmuses af Dakglassets Tryk. Naar dette Ojeblik menes at vare indtrultel, lukkes med Asfallak; da Konserveringsviedsken kun er formol, vil denne dog fordampe i logbet

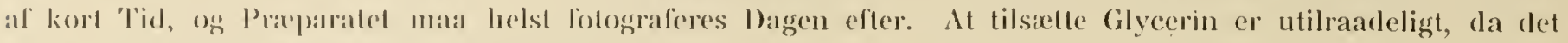

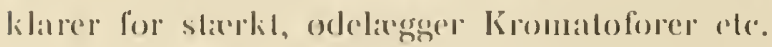

Ved Vialongl al del Sted i l'mapinated, der skal mikrolotograferes, bor man dels lage Hensyn til de fotograliske, dels til de planklologiske Fordringer.

Af Ilensyn til de forste virlges Steder, hror Organismerne er nogenlunde jacunt lordelte, og hvor en saa vidl muligg "msartet lokkaldistance kan opuatas; jegs anser det for urigtigt i Alm. al undgaa Steder, hvor der ligser Dedritus; dette horer med til Planklomproven, og at kende Mangden af dette er ikke uden Betydning.

Ilad do planktologiske Fordringer angaar, gor man efter min Opfattelse bedst i ved Valget al Stedet sirilig an lage Planktonels Hovedformer og disses indbyrdes Mangdeforhold i Betragtning. Iensynet til de sji:clue, de minteressante« Former, lonr altid komme i anden Linie.

Mikrofotogralierne er udforte med Seiberts Mikroskop; mikrofotografiske Linser Obj. I og Oc. I.

Af del sailedes fremkonme Billede blev derpaa den mest passende Del udklippet.

Der er laget Mikrofolograli fra hver Indsamlingsdato, men da jeg gik ud fra, at hver Sø burde have sin Tavle, og at Mikrofologralier fra en Sø paa samme Tavle ikke hurde sammenblandes med Mikrofotografier fra cn anden, matle jeg foretage en vistnok meget uheldig og i hvert Fald meget vanskelig Reduktion af de Billeder, der skulde reproduceres. Reduktionen er vasentlig foregaaet ud fra følgende Principper. I de Tillickle, hior to pais linanden følgende Planktonprover har indeholdt nogenlunde de samme Planktonorganismer i samme Miengdeforhold, er kun den ene bleven mikrofotograferet; Planktonprøver, der tagne efter Storme indeholdt store Miengder af Detritus, eller som paa Grund af Materialets Beskaffenhed var meget vanskelige at mikrofotografere, er ligeledes fortrinsvis udskudte. Forholdsvis faa Vinterprøver er blevne reproducerede, fordi Variationer i Planktonets Sammensæetning paa dette Tidspunkt af Aaret er mindst.

Det er fortrinsvis Proverne fra Aug. 01 til Juli 02, der er bleven reproducerede; af tidligere Prøver er kun saadanne medtagne, hvor tvingende Grunde har talt derfor.

Haalset om gennem Mikrofotografierne at give andre et tilforladeligt Indtryk af, hvad jeg har ment med mine Hyppighedsangivelser, har jeg for adskillige Fotografiers Vedkommende maattet opgive.

Det viste sig nemlig, at adskillige Planktonorganismer enten blev ukendelige eller ganske destruerede uncler Prøvernes Henstand. Til de forste hørte de fleste Infusionsdyr og Flagellater, til de sidste Ceratium hirundinella, der for at konserveres i længere Tid kraver sæerlig stærk Formol. Ligeledes viste det sig meget vanskeligt at give tilforladelige Billeder af saadanne Prøver, der i lige Grad indeholdt Diatomeer og Cyanophyceer.

Det maa endvidere bemærkes, at det i Arbejdet ofte omtalte Tidsrum, i hvilket Diatomeerne forsvinder og Cyanophyceerne endnu ikke er komne til Udvikling, og hvor Plankton som Følge heraf næsten udelukkende dannes af Crustaceer og Rotiferer (Maj-Juni), kun er slet markeret paa Tavlerne (se dog Tab. III Fig. 35, Tab. IV Fig. 46, Tab. V Fig. 58). Grunden hertil er den, at de store Dyr ikke lod sig mikrofotografere ined den valgte Forstørrelse; jeg forsøgte for disse to Maaneder at arbejde med mindre Forstorrelser, men maatte opgive det som upraktisk.

Jeg har bestræbt mig for, at alle med + angivne Former skulde kunne findes paa Mikrofotografierne, men ved vel, at dette ikke altid er lykkedes mig.

Trods de her paapegede Mangler ved den af mig valgte Fremstillingsmaade er det dog mit Haab, at disse Tavler, i hvilke meget Arbejde er nedlagt, vil være af Betydning for enhver, der i Fremtiden vil arbejde med Plankton. De bør lette Begynderen det vanskelige Determinationsarbejde; for talrige Formers Vedkommende, der paa Tavlerne findes afbildede i mange Hundrede Eks., vil de for den viderekommende an- 
give Arteus Gemnemsnitsform og -storrelse i en Rekke mellemeuropaciske Slettelandssner; derved vil disse Tavler i Fremliden faa Betydning som Sammenligningsmateriale med Plankton under andre Naturforhold (alpine Soer, arkliske Soer ele.).

Erindrer man fremdeles, at man i de Tilfaclde, hor der er Uoverensstemmelse mellem Folograli og Hyppighedsangivelse, altid har at holde sig til sidstnavnte, vil Tavlerne dog give et nogenlunde paalideligt og nemt Førsteindtryk af vedkommende Søs skiftende Phytoplanktonsamfund; i et betydeligt Anlal Tilfaclde er nemlig Overensstemmelse mellem Folograli og Hyppighedsskala for Phytoplanktonets Vedkommende gemnemganande tilfredsstillende.

Af det folgende Arbejle vil det fremgaa, at Tavleme endvidere har Betydning som fremstillende de ejendommelige Temporalvariationer hos Ceratier og Diatomeer paa fuldkommen naturtro Maade. Af Hensyn til disse har jeg endvidere laget to Tavler af Furesøens Plankton.

Naar jeg har lagt saa megen Vagt paa at faa nærværende Arbejde ledsaget af de mikrofolografiske Tavler, er det endvidere ogsaa af folgende Grund. Man maa gaa ud fra, at der en Gang i Fremtiden vil komme et Tidspunkı, hvor der vil blive slaaet Bro mellem de videnskabelige Undersøgelser af de ferske Vande og de praktiske Fiskeriundersøgelser. Der vil komme et Tidspunkt, hror man, dels ud fra Kendskab til vedkommende Fisks Natur, dels ud fra Kendskabet til den Sø, hrori Fisken skal udsættes, og ikke mindst til Søens Plankton vil væere i Stand til paa rent videnskabeligt Grundlag at dømme om, hvor vidt vedkommende Sø egner sig for vedkommende Fisk. Det er lidet lysteligt at se, hvorledes for Øjeblikket her hjemme Tusinder af Kroner, der neppe nogensinde giver en Øres Rente, gives ud til Indsatning af Fisk i Søer, hror vedkommende Fisk aldeles ikke kan trives. Man har i disse Tilfxelde villet gaa, inden man kunde krybe; naar vort Ferskrandsfiskeri indtil den seneste Tid har ligget Brak og nxrmest vel maa siges at være gaaet tilbage, dla ligger Aarsagen hertil først og fremmest i, at de ledende Kræefter har staael uden Forstaaelse af de videnskabelige Søundersøgelsers Betydning for dette.

Det var mit Haal, at naar det Tidspunkt en Gang indtræffer, da Beskaffenheden af en Søs Plankton bliver en af Hovedfaktorerne til Bedømmelse af, hvilke Fisk der bør udsættes i en Sø, om hvilke der bør fredes, o. s. v., da vil disse Tavler, der giver et Billede af Planktonet af næsten alle de danske Søer, ved hvilke et større rationelt Fiskeri maa kume drives, ikke være ganske uden Betydning for Lagmanden og for den fiskerikyndige, der mangler Kendskabet til Planktonorganismerne; af Hensyn til samme Tidspunkt har jeg valgt at udgive denne Del af mit Arbejde paa Dansk. 
KAP. III.

\section{NOGLE FORELOBIGE BEMARKNINGER OM VORE SØERS BUNDARTER OG DERES FYSISKE FORHOLD, SARLIG DERES TEMPERATUR.}

$\mathrm{E}$ Sos Plankton afhaenger af Søens Natur, sarlig af dens Dyble, Søvandets Temperatur, Bundartens Beskaffenhed, Søvandets kemiske Beskaffenhed - i første Instans dets større eller mindre Rigdom paa Kalk - af Vandels Gennemsigtighed og Farve, af Vegetationsbaltets Bredde o. a. Faktorer. Vort Kendskab til alle disse Faktorer er endnu højst mangelfuldt, og det var at ønske, at de kemiske, fysiske og til bels ogsia de botaniske Undersøgelser, der skulde supplere de faa spredte Bemxrkninger, som her kan gores, snart maatte komme i Gang.

I det foregaaende liar jeg for hver af de enkelte Søer angivet Søens største Dyb, saaledes som det gennem egne Maalinger er blevet mig bekendt; det havde dog været af betydelig storre Vigtighed, om jeg tillige harde kunnet give en topografisk Fremstilling af hele Søbundens Facies, hvad der imidlertid kun er muligt paa Basis af sxerlige Dybdekaart. Saadanne eksisterer kun over de færreste danske Søer; de bedste er vistnok Amtmand Vedels Kaart over Sorosø og Birkedommer Fiedlers over Esromsø; næppe fuldt saa detaillerede Kaart er udforte over Furesø af Ingeniør Wolff og over Tjustrupsø af Prof. Feddersen. De tre forstnevnte liaart medfolger her, med Hensyn til det fjerde maa jeg lienvise til sidstnevnte (93-94 p. 79).

I de jydske Søer har jeg udført mange Dybdemaalinger og afsat dem paa Generalstabens Maalebordsblade; mit Kendskab til disse Søers Dybdeforhold er derfor større, end det af detle Arbejde fremgaar. Da jeg imidlertid haaber en Gang at faa tilvejebragt Dybdekaart over vore Søer, har jeg gemt mine Iagttagelser desangaaende til et senere Tidspunkt.

Bundartens Beskaffenhed blev i 99-00 nøjere undersøgt i alle de her omtalte Søer; Resultaterne foreligger i Arbejdet (W.-L. 01), til hvilket jeg $\mathrm{i}$ alt ræsentligt indskrænker mig til at henvise. Et af Hovedmomenterne i denne Undersogelse var Kendskabet til den overordentlig store Andel, Planktonet har i Dannelsen af rore Søers dybere Søgytjer; det nære Slægtskal mellem Beskaffenheden af en Søs Søgytje og dens Plankton blev nærmere angivet og udredet. Fọr eller senere vil den langt overvejende Del af alt Plankton enten i bestemmelig Form eller kun som kemisk Forbindelse naa Søbunden, hror det paa en eller anden Maade vil kunne paavises.

Hurtigheden, hrormed det døde Plankton bundfæeldes og omdannes til de simpleste kemiske Forbindelser, virker atter ind paa de Faktorer, hroraf dels Produktionen af levende Plankton, dels dets Livsførelse afhanger.

Det fremgaar heraf, at Studiet af Søens Bundarter ikke er af ringe Betydning for Planktonundersøgelserne, og heldigst vilde det vistnok væere, om Bundundersøgelser altid bler kombinerede sammen med disse; hidtil 
or man ganske gataet uden on Bundundersogelserne og har koncentreret lede Opmarksomlieden par ded levende Plankiton.

Vi kender intetsomlıelst lil den kemiske BeskafTenhed af Vandel i vore Søer; del er at vente, al Kalkholdigheden i Sovandel gennemgataende vil vise sig at vaere meget stor; det fremgaar nemlig af den ovennevnte Undersogelse, al Kalkprocenten i vore Søgytjer i mange Tilfælde er ualmindelig høj (W.-L. 01 p. 93).

Ogsaa on Vegetationslaxllernes Bredde og Beskaflenhed ved vore Srer er vi kun ufuldslandigt underrettede; dog foreligger der Skildringer af Vegetationsbælterne i Skarrilsø af Prof. Warming (97) og af Kølpin Ravn (96) over Silkeborg Langsøterrainet, særlig over Silkeborg Langsø; endvidere findes mange verdifulde Oplysninger i Prof. Warmings Økologi. Alle Skildringerne vedrører dog væsentlig kun den over Vandet synlige Vegetation og giver ingen Oplysninger om de uden for Potamogetoneernes İalte liggende øvrige Bæltcr. En Del Iagttagclser over disse, særlig Characecbæltet, er angivne i mine Bundundersøgelser (01 p. 64).

Der foreligger ingen Undersøgelser over vore Søers Farve og Søvandets Gennemsigtighed. I August 01 undersogte jeg Gennemsigtigheden ved Hjælp af den Forelske Skive; det viste sig da, at Haldsø og Almindso horer til vore klareste Søer, idet Skiven først forsvandt i en Dybde af 10 M. I Sorøsø og Viborgsø forsvandt den allerede i en Dybde af c. 1 M.; i Tjustrupsø ved 2 M.; i Mossø ved 4 M.; i Skanderborgsø og Julsø ved 3 M.; i Esromsø og Furesø forst ved henholdsvis 5 og 6 M. Maalingerne foreloges altid kun i klart Solskin og i Tiden fra 9-12 Morgen.

I Furesø var Skiven i Marts endnu synlig i 9 M.s Dybde; i Juli-September ofte kun i 5 og i December i $7 \mathrm{M}$.

I Sorøsø var den i Marts-April synlig i en Dybde af 5 M., men hele den ørrige Del af Aaret væentlig kun $\mathrm{i}$ en Dybde af c. $1 \mathrm{M}$.

Vandets Gennemsigtighed afhænger i første Instans af Planktonmængden; den er altid størst, naar Planktonmængden er ringest (Marts-April), og mindst, naar denne er størst; (de storé Cyanophycee-maks. i Julso og Viborgsø og Ceratium-maks. i Sorø- og Tjustrupsø begge i August).

Desforuden afhænger Gennemsigtigheden af Vandmassernes Rigdom paa Detritus. Denne er i vore forholdsvis smaa, lave Søer altid betydelig; den er mindst i de dybeste (Hald- og Almindsø) og størst om Sommeren; navnlig efter vedholdende Storme kan den væere saa stor, at Planktonet ikke er brugbart til Undersøgelse. Selv en saa dyb Sø som Furesøen faar efter en Stormperiode blakket Vand. Efter den ualmindelig voldsomme Orkan 25. Decbr. 02 var Furesøens Vand hvidgraat; Afklaringen foregik yderst langsomt i Løbet af mindst 10 Dage. Ogsaa umiddelbart efter Isløsningen kan Mængden af Detritus være meget stor; dette skyldes i saa Fald Littoral-Isen, der har taget Littoral\%onens Plantevækst og Detritus med sig og som efter af Vinden at være ført som Isskodser over Søen har spredt disse ud over hele dens Overflade.

Mængden af Detritus kan imidlertid vistnok ogsaa skyldes endnu en anden Kilde, nemlig det atmosfæriske Støv; dette spiller dog næppe nogen stor Rolle hos os. $22 / 302$ laa jeg midt ude paa Esromsø og foretog min Planktonundersøgelse omgiven af store Isskodser. Søen var blikstille og Overfladen dækket af en kulsort Hinde, hvis Oprindelse straks var mig uforklarlig. Nærmere beset viste den sig tykkest i Nærheden af Isskodserne og lod sig ogsaa paavise dels i Randen, dels paa selve disse. Hinden kan næppe have været andet end det athmosfæriske Stør, som har dannet sig paa Isen i de 40 Dage, denne dækkede Søen, samt opløste Fugleekskrementer, som i stor Mængde fandtes paa Skodserne, og hvis Slim- og Fedtrigdom vistnok var den væsentligste Aarsag til, at Støvet laa som Hinde paa Vandet og var klæbrigl at føle paa. Hinden sværtede Planktonnettene; under Mikroskopet viste den sig at bestaa af lutter formløse smaa Brudstykker, vistnok overvejende dannet af Kulstøv, en Del Koniferpollen og enkelte Diatomeer; dens Tykkelse kunde ikke angives til over en Brøkdel af en Millim. 
26

VOHE SOERS BUNHARTEK OG DHELS FYSISKE FOHHOLD.

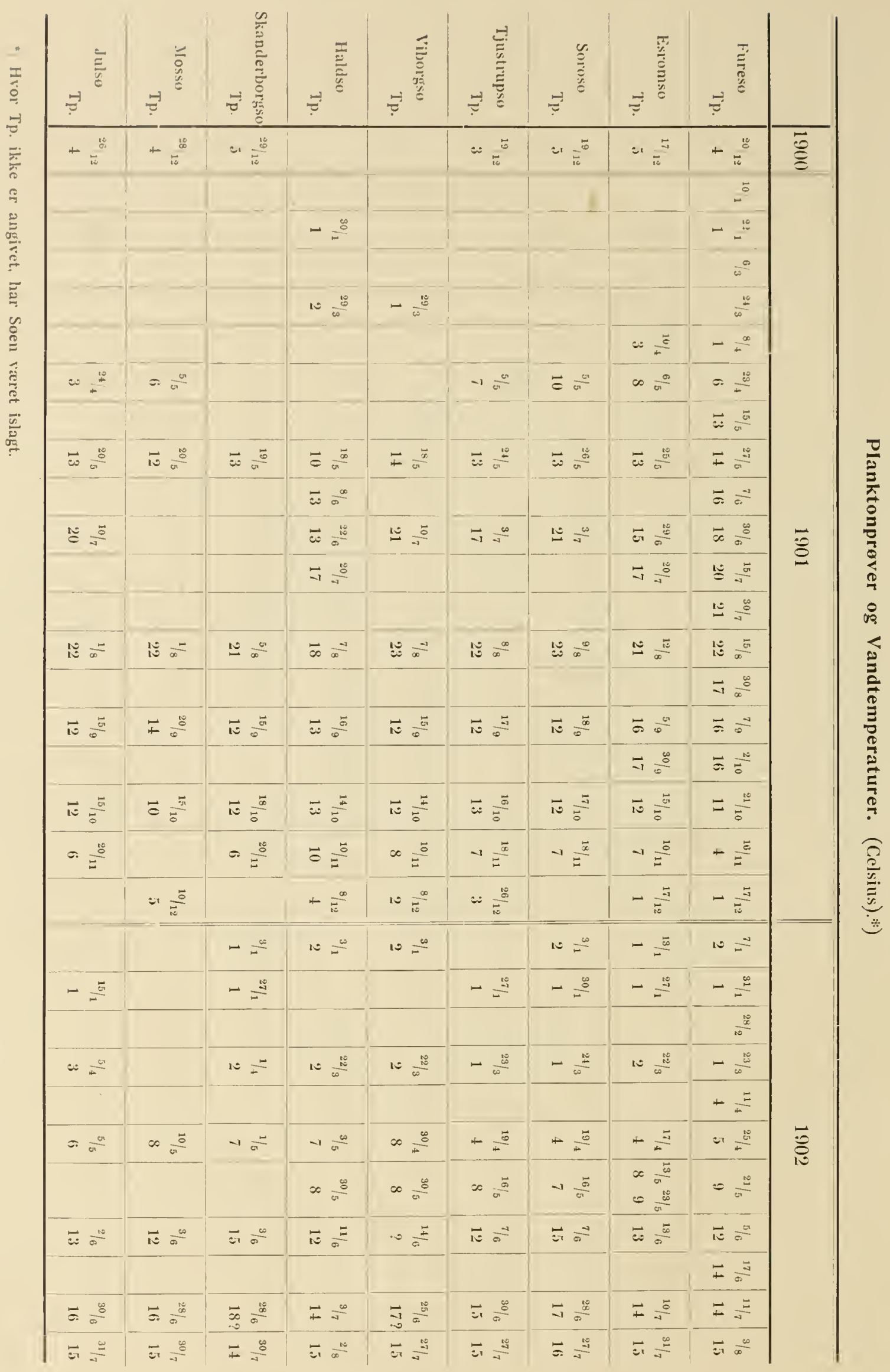


Temperaturundersogelser. Samtidig med al Planklonproverne toges, blev paa samme Sted tillige

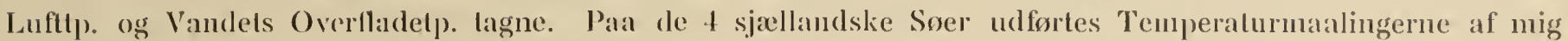
selv, paa de jydske Soer af de respektive Fiskere. 'Thernometrene, der anvendtes, var Svingthermometre (Celsius) af meget tykt Glas og med en i dette indridset Gradestok; denne angav kun lıalve og hele Grader. Paa de 4 sjallandske Soer er Tp. lagne i 'Tiden fra 9-12 Morgen; ved denne Tid blev de i Almindelighed ogsaa tagne paa Hald-Vihorgsøerne; paa de ovrige til mere ubestemt Tid.

!)a Lufll). jo svinger meget staerkt i Lobet af I)øgnet, kan de, naar de ikke tages samtidig, ikke anvendes til Sammenligning; det lar derimod meget mindre at sige, at Vandtp. ikke er tagne samtidig, da disse for Soernes Vedkommende i Døgnets Løb svinger langt mindre, og mindre jo større Vandmassen er.

Skønt Luftt). for saa vidt har haft Betydning, som de har kunnet anvendes som en vis Kontrol over for Vandtp., er de af ovennavnte Grund ikke medtagne i Arbejdet.

Det er indlysende, at Temperaturmaalinger, der udføres med saa primitive Instrumenter og tilmed delvis af Folk, hvem jeg forst maatte laere Brugen af disse, ikke kan gøre Krav paa at anses for nøjagtige; ligeledes følger det af sig selv, at man maa være meget forsigtig med at drage Slulninger af dem.

Naar jeg ikke har bestræbt mig for, at Undersøgelsen skulde levere mere paalidelige Temperaturmaalinger, er det, fordi jeg er gaaet ud fra, at den her publicerede Undersøgelse vil blive efterfulgt af fysisk-kemiske, der før eller senere vil give de manglende eksakte Resultater. Det var ligesaa umuligt for mig selv paa mine Ekskursioner at bæe de mere komplicerede og ret tunge Instrumenter, som det vilde være risikabelt at sende dem over til og give dem i Hænderne paa Fiskerne.

Jeg har ikke med disse Tp.maalinger tilsigtet andet end tilnærmelsesvis at angive den Luft- og Vandtp., ved hvilken vedkommende Planktonprøve blev taget; jeg anser det for højst sandsynligt, at Fejlen meget vel kan vare c. $1^{0}$, men anser det for umuligt, at den, i alt Fald for de sjællandske Søers Vedkommende, kan vare større; i de Tilfaelde, hvor jeg, umiddelbart efter at Fiskerne har angivet mig Tp., selv har maalt denne, har jeg aldrig fundet Tp., der tydede paa, at Fejllæsningen havde beløbet sig til over $1^{0}$. Kun for Haldsøs og Viborgsøs Vedkommende fik jeg i Maj-Juni Maaned angivet meningsløst høje Tp. (højere end Luftp.). Det viste sig da, at der var sket et Uheld med Thermometret, og at et andet var bleven benyttet.

Medens en Methode, der arbejder nıed Fejl paa c. $1^{0}$, selvfølgelig er forkastelig for den, der har sat sig til speciel Opgave at undersøge vore Søers thermiske Forhold, er den næepe absolut forkastelig for Planktonundersøgeren.

For ham gælder det nærmest kun om at kunne udkaste det tilnærmelsesvis nøjagtige Billede af Temperaturforholdene i den Sø, han undersøger; den store Eksakthed kan han i de færreste Tilfælde drage nogensomhelst Nytte af.

Jeg søgte samtidig at skaffe Oplysninger om, hvor længe hver af de paagaldende Søer var islagte. Dette lykkedes ikke tilstrækkelig nøjagtigt for Foraaret 01's Vedkommende, hvorimod Islægnings- og Isløsningsdatoerne for Dec. $01 \mathrm{og}$ Foraaret 02 kan betragtes som absolut nøjagtige.

Der skal nu gives en kort Oversigt over Temperaturforholdene i hver enkelt Sø; i øvrigt henvises til de vedføjede Tabeller.

Furesø. Søen lagde i 01 forst til d. $3 / 1$, men tøede atter op $21 / 1$. Derpaa lagde den atter til $15 / 2$, og den endelige Isløsning fandt da Sted $2 / 4$. Opvarmningen foregik ret langsomt; endnu ${ }^{27} / 5$ var $T$ p. kun 14 ; derpaa steg Tp. strerkt og naaede 15/8 sit Maks., Tp. 22. De meget kolde Dage sidst i August satte atter Tp. ned til 17, men derpaa holdt $\mathrm{T}_{\mathrm{p}}$. sig omtrent uforandret lige til midt i Oktober; det store Tp.fald skete først efter d. ${ }^{15} / 10$, hvor Tp. indtil ${ }^{16} / 11$ faldt fra c. 14 til $4^{0}$. Tp. holdt sig derpaa omkring 2 indtil $027 / 2$, da Søen lagde til; den tøede atter op $18 / 3$ efter at have varet tillagt i 40 Dage. Opvarmningen foregik $\mathrm{i} 02$ meget langsomt; endnu 5/6 var Tp. kun 12, og den liøjeste Tp., der overhovedet blev maalt $\mathrm{i} 02$, var 15 , altsaa 7 Grader under den, der blev naaet 01 . 
Estomso frod i 01 op $1 / 1$. Den forlioldt sig med Hensyn lil sine Temperaturer nasten ganske

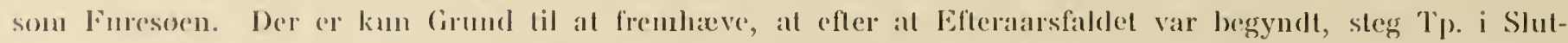

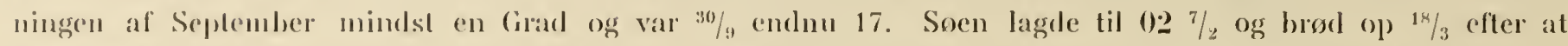
lave varel islagl fo Dage. Opvarmningen i Foraaret 122 foregik meget langsomt, og den hojeste maalte Tp. vall kun 15.

Soroso lrod $\mathrm{i} 01 \mathrm{op} 2 \mathrm{x} / 3$; Opvarmningen foregik meget hurtigt og allerede $3 / 7$ var $\mathrm{T}_{\mathrm{p}}$. 21; den

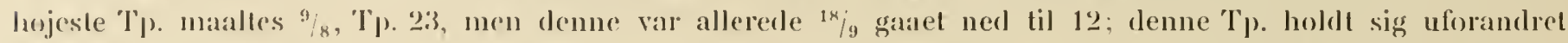

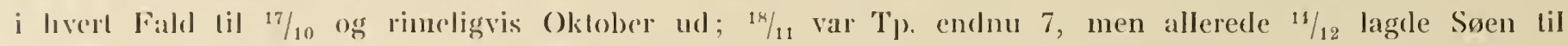

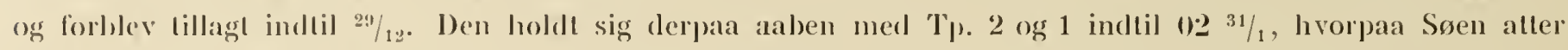
lagde lil. Den loede forst op $20 / 3$. De lo Tillagningsperioder varede henholdsvis 16 og 49 , iall 6j Dage. ()prarmningen foregik meget langsommere (nd i 01, og Maksimaltp., der blev konstateret, var kun $17^{0}$.

Tjustrupsø brod i 01 op 29/3; Opvarmningen gik betydelig langsommere for sig end i Sorøsø; den var (1. $3 / 7$ cndnu kun $17^{\circ}$, men dens Maksimallp. har nappe raret mindre end Sorøsøs; d. $8 / 8$ maaltes Tp. 22; det Tidsrum, inden for hvilket Tp. har varet over 20, har dog rimeligvis vaeret $c$. en Maaned kortere end

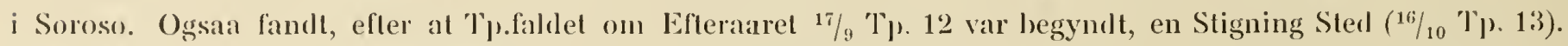
Socn lagle ikke til i Dec. Islagningen legyndte først $0.27 / 2$, Isløsningen $17 / 3$. Opvarmningen foregik meget langsoml, og den hojeste Tp., der maaltes i 02, var 'Tp. 15, 7 Grader under Maksimaltp. i 01.

Viborgso brod $\mathrm{i} 01 \mathrm{op}{ }^{27} / 3$. Opvarmningen maa vare foregaaet meget hurtigt, thi allerede ${ }^{18} / 5$ maaltes Tp. 14 og ${ }^{10} / \tau$ Tp. 21. Den højest maalte $\mathrm{T} p$. var $7 / 8$ Tp. 23. Ogsaa her konstateredes det markelig store Tp.fald 15/9 Tp. 12, men ligesom i Sorøsø holdt denne Tp. sig endnu 14/10 og rimeligvis lige til Begyndelsen af November. Soen lagde til $13 / 12$, Isløsningen fandt Sted $27 / 12$. Søen holdt sig derpaa aaben til $0.229 / 1$, da den lagde til; den endelige Isløsning fandt Sted 20/3. Søen havde varet tillagt i to Perioder paa henholdsvis 15 og 51 Dage, ialt 66 Dage. Opvarmningen foregik i 02 i Begyndelsen ret hurtigl, Tp. var allerede $30 / 48$, men en yderligere Tp.stigning fandt først Sted i Begyndelsen af Juni. Tp. i Juni tør ikke angives med Sikkerhed; ${ }^{27} / 7$ maaltes Tp. 15 ; synderlig højere har den i 02 næp reret, altsaa c. $7-8$ Grader mindre end 01 .

Haldso brod i 01 op allerede $22 / 3$. Islægningen var foregaaet de første Dage i Februar; Opvarmningen gik meget langsomt for sig og var $18 / 5$ endnu kun Tp. 10, den laveste Tp., jeg maalte i Tiden fra ${ }^{18} / 5$ til ${ }^{27} / 5$; endnu $29 / 6$ var $\mathrm{T}_{\mathrm{p}}$. kun 13, og den hojeste Tp., der maaltes, var $\mathrm{T}_{\mathrm{p}}$. 18, $7 / 8$; rimeligvis har denne været Søens Malisimaltp. i 01 , thi allerede $16 / 9$ var den kun 13 ; denne holdt sig nu uforandret til Slutn. af Okt. Søen forbler aaben lige til $0.230 / 1$, da lagde der sig en tynd Isskorpe, der dog kun holdt til 4/2; en stærk Storm brød atter Søen op, og den endelige Islægning fandt først Sted $15 / 2$. Isen laa da til ${ }^{16} / 3$. Søen havde kun veret islagt i 35 Dage. Opvarmningen foregik langsomt, og den højeste Tp. var kun 15, der maaltes ${ }^{2} / 8$.

Skanderborgsø. Temperaturforholdene kan paa det foreliggende Materiale kun studeres i Tiden fra $5 / 801$ til $30 / 702 ; 5 / 8$ er T $T_{l}$. 21, rimeligvis meget nær Søens Maksimaltp.; den er $15 / 9$ falden til 12 , og denne $\mathrm{T}_{\mathrm{p}}$. holder sig uforandret endnu $18 / 10 ; 20 / 11$ er $\mathrm{T}_{\mathrm{p}}$. 6 . Søen var derpaa tillagt fra $16 / 12$ til $27 / 12$, men var aaben indtil $0.231 / 1$ med Tp. $1-2$, hvorpaa Islægning atter fandt Sted; den endelige Isløsning indtraf $22 / 3$. Søen havde altsaa været tillagt $\mathrm{i}$ to Perioder paa henholdsvis 12 og 51 Dage, ialt 63 Dage. ${ }^{28 / 6} 02$ maaltes den noget mistrenkelig høje Tp. 18; men allerede $30 / 7$ blev Tp. igen angivet mig til 14 .

Mossø. Af det foreliggende Nateriale er det umuligt at give nogen Fremstilling af Temperaturforholdene i denne Sø; trods Tilsagn havde man desvarre undladt at give mig Oplysninger om Islægning og Isløsningsdatoer; kun Temperaturerne tagne $0120 / 5,1 / 8,15 / 10$, som er tagne af mig selv, samt Tp. Maj-Juli er sikre; det fremgaar kun af disse, at $\mathrm{T}_{\mathrm{p}}$. $01 \frac{1}{1 / 8}$ var 22 , og at den $02{ }^{30} / 7$ kun var 15 o: $7^{0}$ lavere.

Julsø brød i 01 op i de første Dage i April, men Datoen kan ikke med Sikkerhed angives. Tp. var $20 / 513$, og allerede $10 / 7$ havde den naaet $20 ; 1 / 8$ maaltes $T_{\mathrm{P}} .22$, hvorpaa $\mathrm{T}$ p. faldt strerkt; $15 / 9$ var den kun 12, denne holdt sig endnu $15 / 10$, men faldt derpaa indtil $2 \% / 11$ til 6 . Søen lagde til $13 / 12$, men 
toede atter op ${ }^{29} / 19$. Derpaa holdt den sig aaben indtil $02{ }^{28} / 1$, da Islaegning fandt Sted; den endelige Islosuing foregik 20/3. Søeu havde altsaa vaeret tillagt i 2 Perioder paa henholdsvis 17 og 52 Dage, ialt 69 Dage. Den hojeste $\mathrm{T}$ p. i 02 maaltes $30 / 6$, Tp. 16, men denue var $31 / 7$ sataet ned til 15, 0: 70 mindre end $1 / 801$.

Man vil ved at sammenholde de her givne Meddelelser og ved at betragte de vedføjede Schemata ikke kunne undlade at bemerke, at Temperaturforholdene i vore Søer i visse Henseender er mærkværdig ens, i andre derimod frembyder ganske betydelige Uligheder. Vi skal kort hetragte Aarsagerne til begge disse Fanomener.

Naar vore Søer saaledes i samme Aar næsten alle naar samme Maksimaltp., i $0121-233^{0}$, i $0214-16^{\circ}$, og naar Opvarmning og Afkøling indtil en vis Grad foregaar med lige stor Hurtighed i dem alle, skyldes dette Fxnomen i første Instans, at vore større Søer omtrent alle ligger paa samme Breddegrad (mellem 5.5,10 og 5(;,30), og at Hojden over Havet kun kan variere med c. 30 M. Den Faktor, der først af alle bestemmer Søens Tp., nemlig Lufttp., er over liele Landet saa ensartet, at den ikke er i Stand til at fremkalde større Forskelligheder i vore Søers Tp.

I sit udmarkede Arbejde »Isforholdene ved de norske Indsøer (02 p. 198) har Holmsen inddelt Søerne i 4 Typer:

1. Grunde Søer, hvor det midlere Dyb ikke er større, end at det er nær Grænsen for den daglige Tp.forandring.

2. Middeldybe Søer, hvor det midlere Dyb er støre end Grænsen for den daglige $\mathrm{T}_{\mathrm{p}}$.forandring, men ikke større, end at den aarlige Tp.forandring kan gøre sig gældende til de nederste Lag.

3. Dybe Søer, hror det midlere Dyb er saa stort, at det er nær Grænsen for den aarlige Tp.forandring.

4. Meget dyle Søer, i hvilke der findes et dybt Vandlag, hvor den aarlige Tp.forandring ikke kan gøre sig galdende.

Maanedlige Middeltp. og Afvigelser fra Normaltp. i Tiden Dec. oo-Aug. 02.

\begin{tabular}{|c|c|c|c|c|c|}
\hline & & $\begin{array}{l}\text { Middeltp. } \\
\text { ved } \\
\text { Landbo- } \\
\text { hojskolen }\end{array}$ & & $\begin{array}{l}\text { Afvigelser } \\
\text { fra } \\
\text { Normaltp. }\end{array}$ & \\
\hline December & 00 & 3.5 & 3 & over Normaltp. & \\
\hline Januar & 01 & $\div 1.5$ & & under Normaltp. & \\
\hline Februar & - & $\div 3.4$ & 3 & - & \\
\hline Marts & - & 0.7 & & - & \\
\hline April & - & 6. 2 & & over Normaltp. & \\
\hline Maj & - & 12.2 & 1.8 & - & \\
\hline Juni & - & 14.6 & 0.4 & - & \\
\hline Juli & - & 19.9 & 3.3 & - & ualm. hoj Middeltp., liojeste siden $1861 .{ }^{11 / 7} \mathrm{Tp} .24$. \\
\hline August & - & 17.5 & 1.6 & - & ${ }^{11} / 8-15 / 8$ Tp. 22-30. Slutn. af Aug. og Beg. af Sept. meget kolde, $3-4^{0}$ ir. N. \\
\hline September & 一 & 13.6 & 0.8 & 一 & Slutn. af Sept. ualm. hoj Tp. ${ }^{22} / 9-25 / 95-6^{0}$ o. N. Tp. $16-20$. \\
\hline Oktober & - & 10.3 & 2.3 & - & \\
\hline November & - & 3.4 & & under Normaltp. & \\
\hline December & - & 1.1 & 0.6 & over Normaltp. & Frostperiode $2 / 12-25 / 12$. \\
\hline Januar & 02 & 2.8 & 3.3 & - & 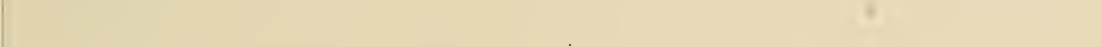 \\
\hline Februar & - & $\div 2.3$ & 1.9 & under Normaltp. & I Frostperiode. \\
\hline Marts & - & 1.7 & 0.6 & over Normaltp. & \\
\hline April & - & 4.6 & 1.1 & under Normaltp. & . \\
\hline Maj & - & 8.7 & 1.9 & - & \\
\hline Juni & - & 14.8 & 0.4 & - & \\
\hline Juli & - & 14.7 & 2 & - & Meget lav Middeltp. 1/7 varmeste Dag, Tp. 18 . \\
\hline August & - & 13.3 & 2.7 & 一 & $\int \quad{ }^{30} / 8$ do. do. Tp. 14.8 \\
\hline
\end{tabular}


Omlrent alle vore Soer tilheree den forste Gruppe og kun ganske enkelte: Haldsø, Almindso og maaske

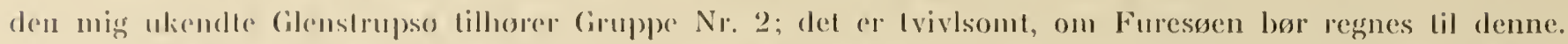

I hove hug cirad alle vore Soer i Virkeligheden ar Smatsser og neppe nok forljener at kaldes Søer, viser sign bedst al, laver ringe Svingningerne i Julttp). behover at vare, lor at de skal kunne merkes i Vandtp). Sijaldent vil der vel nogensinde for vorl Land indtarlfe to pat hinanden folgende Aar, der bedre end Aarene (1) og 02 vil kunne enge sig til at vise Vandlp.s Afhangighed af Luftlp. Aarel 01 udmarkede sig nemlig som bekendt ved sin malmindelig varme Sommer, Aarel 02 derimod ved, at dets Sommer var enestanende kold. Jegg henviser i ovrigt lil omstanende Tabel, udarbejdet efter Meteorologisk Instituts Manedsoversigt over Vejrlorholdene. leg fremhaver kun, al de unormale Tp.forhold 01 forst blev frembardende i Juli

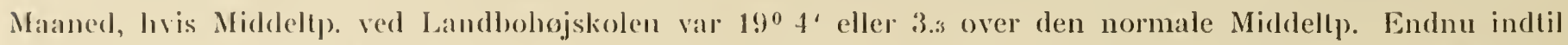
henimod Slutningen af August holdt de ualmindelig hoje Tp. sigg (22/8 maaltes endog 30.5); derpaa fandt et meget sterkt Tp.fald Sted, som holdt sig til noget ind $\mathrm{i}$ Sep. I denne Periode sank Tp. $3-4^{0}$ under Normaltp., derpar fandt atter en meget sterk Tp.stignings Sted; denne kulninerede i Tiden fra ${ }^{22 / 9}-25 / 9$, hror 'Tp. var 20 - 220 eller $5-60^{0}$ for høj; de hoje Tp. holdt sig endnu indtil $5 / 10$. Middeltp. for Okt. var 10.3 eller 2.3 o. Normaltp. Nov. og Dee. frembod ikke nevneverdige Afvigelser; i Tiden fra $2 / 12-25 / 12$ indtraf en kort Frostperiode med Tp. indtil $c . \div 7$.

02 begyndte med en nalmindelig mild Januar c. $3^{1} / 2^{0}$ o. N. og med Middeltp. 2.8; derpaa fulgte en Frostperiode, der varede fra de første bage i Febr. og til noget inden $15 / 3$. Marts Maaneds Middeltp. var omtrenl normal, men April og Maj kolde; derimod blev Juni navnlig paa Grund af sine ret varme Dage i Slutningen al Maaneden omtrent normal med Middeltp. 14.7. Juli og August var ualmindelig kolde, henholdsvis 2 og 3 Grader under Normaltp. Den rarmeste Dag i Juli var $1 / 7$ Tp. 18, men August Maaneds varmeste Dag indtral forst $30 / 8$, og den var kun 14.8 .

Hvor ufuldkomne Tp.maalingerne i vore Søer end er, saa viser de dog, hvor nøje disses Overfladetp. følger med Lufty). Selvfølgelig er vore Søers Maksimaltp. i 01 meget højere end i 02 . I Tiden fra ${ }^{30} / 7$ til 12/8 01 maaltes $\mathrm{i}$ alle vore Søer Tp. 21-22, kun Haldsø naar alene Tp. 18. I Tiden fra $26 / 7$ til $3 / 803$ maaltes oreralt kun $14-16^{0}$ eller $6-7^{0}$ mindre end i 01 . Det pludselige og stærke Fald i Luftp. i Slutn. af Aug. og i Beg. af Sept. 01 traeder overordentlig tydeligt frem i de Vandtp., der er tagne i Tiden fra $5 / 9$ til $20 / 9$. Tp. er i de lleste af Søerne falden til 12, og den højeste Tp., der maaltes, er 16; dette kolossale Tp.fald, som beløber sig til mindst $6^{\circ}$ og mest $11^{\circ}$, synes mig at være ret ubegribeligt og betydeligt over, hvad man skulde vente. De to Tp. i Sorosø og Tjustrupsø $12^{\circ}$ har jeg selv maalt og mener at kunne indeslaa for deres Rigtighed. Ikke mindre interessant er det, at den ualm. høje Lufttp. i Slutn. af Sept. atter er i Stand til dels at sætte Tp. op i nogle Søer (Esromsø ${ }^{30} / 9$, Tjustrupsø ${ }^{16} / 10$ ) dels at bevirke, at Vandtp. i Okt. gennemgaaende ikke er lavere end i Sept.

Den anvendte Methode tillader i øvrigt ikke et nærmere Studium af Maaden, hrorpaa Afkølingen gaar for sig i de forskellige Søer.

Med Hensyn til Islægningstidspunktet forholder Søerne sig derimod meget forskelligt. Det viser sig nemlig, at fire Søer: Sorøsø, Viborgsø, Skanderborgsø og Julsø i December Maaned har en kort Tilfrysningsperiode paa 12-17 Dage, hrorimod en saadan ganske mangler i Furesø, Esromsø, Tjustrupsø og Haldsø. Islægningen finder paa de 4 førstnævnte Søer Sted i Tiden fra $13 / 12^{-16} / 12$, Isløsningen ${ }^{27} / 12-29 / 12$. I Tiden fra c. ${ }^{29} / 12$ og indtil Slutningen af Januar er alle Søerne aabne; i Dagene fra ${ }^{28} / 1$ til $31 / 1$ fryser igen de 4 Søer, der var tilfrosne i December, til, hrorimod de andre først fryser til c. $7 / 2$. Isløsningen finder derpaa over hele Landet Sted i Tiden fra $16 / 3$ til $22 / 3$.

Med Hensyn til det Antal Dage, hvori de ovennæunte 8 Søer er tillagte, kan disse altsaa deles i to Grupper.

Den første, der indbefatter Sorøsø, Viborgsø, Skanderborgsø og Julsø, har to Tilfrysningsperioder, en i Dec. paa c. 12-17 Dage og en i Febr.-Marts paa 49-52 Dage; de er ialt tilfrosne i 63-69 Dage. 
Tilfrysningsperioden i or-02.

\begin{tabular}{|c|c|c|c|c|c|}
\hline & & $\left|\begin{array}{l}\text { Antal } \\
\text { l)age }\end{array}\right|$ & & $\begin{array}{l}\text { Antal } \\
\text { Dage }\end{array}$ & Ialt \\
\hline 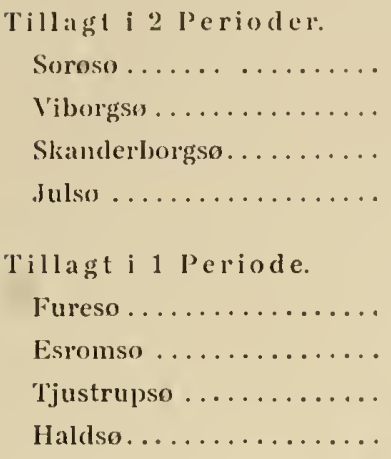 & $\begin{array}{l}14 / 12-29 / 12 \\
13 / 12-{ }^{27} / 12 \\
16 / 12-{ }^{27} / 12 \\
19 / 12-29 / 12\end{array}$ & $\begin{array}{l}16 \\
15 \\
12 \\
17\end{array}$ & $\begin{array}{c}31 / 1-20 / 3 \\
29 / 1-20 / 3 \\
31 / 1-22 / 8 \\
28 / 1-20 / 3 \\
\\
7 / 2-18 / 3 \\
7 / 2-18 / 3 \\
7 / 2-17 / 3 \\
30 / 1-4 / 2 ; 15 / 2-16 / 3\end{array}$ & $\begin{array}{l}40 \\
40 \\
3 ! \\
3 i\end{array}$ & $\begin{array}{l}40 \\
40 \\
39 \\
3.5\end{array}$ \\
\hline
\end{tabular}

Den anden, der indbefatter Furesø, Esromsø, Tjustrupsø og Haldsø, har kun en Tilfrysningsperiode i Febr.-Marts, og den er kun paa 35-40 Dage.

Opvarmningen i Foraarstiden kan ikke narmere studeres, men hen paa Forsommeren faar vi et nyt Bevis for, hvor nøje Søernes $\mathrm{T}_{\mathrm{p}}$. følger Luftens, idet den ubetydelige Sommervarme, der indtraf i Slutn. af Juni, var stor nok til at hæve Vandtp. til $16-18^{\circ}$; allerede i Slutn. af Juli var denne dog igen gaaet ned til $14-16^{\circ}$, og den er sikkert ikke senere paa Aaret bleven højere.

Man vil af ovenstaaende se, at vore Søer, bortset fra Islægningstidspunktet og Antallet af de Dage, hvori de er islagte, med Hensyn til deres Tp.forhold synes at stemme mærkelig overens. Kun en Sø, Haldsø, frembyder særlige Forhold. I denne Sø foregaar Opvarmningen langsommere end i de andre. ${ }^{18 / 5}$ har Søen kun Tp. 10, medens de øvrige Søer i samme Uge opviser Tp. 12-14, den højest maalte Tp. er $18^{0}(7 / 8)$, medens alle de øvrige Søer har 21-23 ${ }^{\circ}$. Afkølingen foregaar langsommere; $\mathrm{T}_{\mathrm{P}}$. er $10 / 11$ 10, medens de andre Søer i Tiden fra $1 \% / 1{ }^{2}{ }^{20} / 11$ er nede paa $6-8$, i Alm. $7^{0}$. Vi ser derfor, at Haldsø af alle de undersøgte Søer er den, der langsomst følger Svingningerne i Lufttp. Det er endvidere den, der, efter at Døgnets Middeltp. er gaaet under 0, behøver det største Antal Dage for at lægge til og den, der af alle er tillagt i det korteste Antal Dage, nemlig 35. En Temperatur af Søbunden optagen med Skraber $7 / 801$ fra 35 M. viste den for vort Land enestaaende lave Tp. af $7^{0}$ (Overfladetp. 18). Søbundtp., der i Tiden fra $1 / 8{ }^{12} / 8$ maaltes i alle Søerne, var i Furesø og Tjustrupsø $12^{\circ}$, i de andre $14-16^{\circ}$ og størst i Viborgsø, $16^{\circ}$.

Ved sine Tp.forhold, Vandets Gennemsigtighed, sine stejle Kyster o. a. F. er Haldsø den af alle de undersøgte Søer, der har mest til fælles med alpine Søer; Almindsø, der $2 / 8$ ligeledes kun viste $18^{\circ}$, har maaske dette i lige saa høj Grad, men denne kender jeg ikke narmere.

Hvori søger vi nu Forklaringen til, at vore Søer i Henseende til Islxgningens Varighed forholder sig saa forskelligt, og at Haldsø afviger saa stærkt fra de andre Søer?

At Aarsagerne med Hensyn til Forskellighederne i Henseende til Islægningens Varighed ikke kan søges i de meteorologiske Forhold, fremgaar alene deraf, at endog Søer, der kun ligger fjærnede 7 Kilom. fra hverandre og i samme Højde o. H. (Viborgsø-Haldsø, Sorøsø-Tjustrupsø) i saa Henseende forholder sig forskelligt. Aarsagerne hertil maa søges i Søerne selv og først og fremmest i deres Dybdeforhold og i deres Form.

Det viser sig nemlig, at den Søgruppe, der har to Tilfrysningsperioder paa ialt c. 65 Dage, indbefatter de to laveste Søer, Sorøsø og Viborgsø samt de noget dybere Skanderborgsø og Julsø; for ingen af disse overskrider Dybet $\operatorname{dog}$ c. $20 \mathrm{M}$. Den anden Søgruppe med kun en Tilfrysningsperiode paa c. 39 Dage indbefatter overvejende alle Søer med Dybder paa 30-40 M. og desforuden Tjustrupsø, hvis Dybde ikke overskrider $20 \mathrm{M}$. 


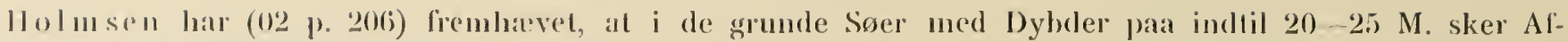
kolingen al Vandnassen solvfolgclig i Lobet af ganske kort Tid; Islaegningen kan som Folge heraf finde

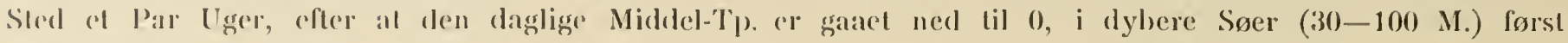
$f$ - 8 l'ger refter dette 'Tidspumkt.

I ()veronsstemmelse hormed forstar vi da, at den forste Sogruppe med bybder paa indtil $20 \mathrm{M}$. faar en 'Tilfysningsperiode i Dece, fordi den ringe Frost, ler indlaadte i denne Maaned, var nok til at afkgle disse Soers Vandmasser sala stierkt, al en Islagning kunde finde Sted.

D) rimod kunde den korte Frostperiode uden sarlig høje Külegrader ikke i de dybe Søer bringe Afliolingen saa langi ned, al en Islaegning kunde finde Sted.

Det symes conlnu kun uforklarligt, at 'Tjustrupsø, som i Henseende til Dybdeforhold slutter sig til den forshavente Gruppe, med Hensyn til Isforholdene følger den sidste, samt at Haldsø er saa meget koldere and de andre Sore og sardig koldere end furesgen.

1) el mig ikke muligt med Sikkerhed namere at angive Grunden til begge disse Fanomener; forelghig indskrenker jeg mig til at gore opmacksom paa, at vi i bogge Tilfaelde lar at gøre med lange, smalle Søer, Irvis Littoral\%one er smal, og hvis Kyster skraner ualmindelig brat ned; dette gaelder ganske saerlig Haldsø; jeg er tilbojelig til i disse Soers lange, smalle Form og i lleres Kysters bratte Heldningsvinkler at søge Aarsagerne lil deres afvigende Temperaturforhold.

Ilvor ufuldkomne end 'Tpmaalingerne er, har jeg $\log$ ment, at de her givne Meddelelser med nogenlunde Sikkerhed kan uddrages af de angivne 'Tal. 


\section{KAP. IV. CYANOPHYCE E.}

$\mathrm{C}$ yanophyceenne spiller en stor Rolle i vore Søers pelagiske Region, ikke saa meget fordi det Antal Arter, der optræder som Planktonorganismer, er synderlig stort, men fordi de enkelte Arter til Tider findes i kolossale Masser; i saa Fald foraarsager de det velkendte Vandblomstfænomen.

Planktonformerne hører ikke til nogen særlig systematisk Afdeling; saa vel indenfor Coccogonece som Hormogonew findes spredt i de enkelte Familier enkelte Slægter, hvoraf sjældent mer end et meget begrænset Antal Arter optræder som Planktonorganismer; de øvrige er fasthæeftede til Littoralzonens Sten eller Planter eller hører i alt Fald hjemme i denne Zone. Et meget hyppigt Fællestræk for Planktonets Cyanophyceer er Tilstedeværelsen af Luftvacuoler, der utvivlsomt maa opfattes som et Tilpasningsforhold til Livet i den pelagiske Region; Bygningsforhold, som maa betragtes ud fra samme Synspunkt, er de tynde Trichomer hos Lyngbya og Oscillatoria; de store og meget hyaline Geledannelser hos Polycystis, Gloiotrichia, Anabana flos aque o. a.; Traadenes Udløben i overordentlig tynde piskeformede Ender (Gloiotrichia). Om Overvintringen kan intet almengyldigt siges.

Den langt overvejende Del, muligvis endog alle Planktoncyanophyceerne, er hjemmehørende i Smaasøer og Danıme. Dette gælder især.Coccogoneœ, af hvilke højst Coelosphıcrium Kützingianum og maaske nogle Chroococcus-Arter træffes som typiske Planktonorganismer i vore større Søer.

I Havets pelagiske Region er Cyanophyceerne i Aln. Diatomeerne langt underlegne; Coccogonece optræer saa vidt vides aldeles ikke som Planktonorganismer i Havet, og af Hormogonece er det vasentlig kun Oscillatorierne, der med Hovedslægten Trichodesnium navnlig i varmere Have kan optræde doninerende. Ferskvandets Planktonnostocaceer og Rivulariaceer kan med Floderne føres ud i Brakvand og optræeder f. Eks. i Østersøen (Aplanizomenon, Gloiotrichia) til Tider i Mængde; i de store aabne Have forekommer de dog ikke; Planktonform i Brakvand er Nodularia spunigena Mertens.

Der er vistnok ingen Tvivl om, at alle i Ferskvandets Plankton optrædende Cyanophyceer har deres nærmeste Slægtninge mellem Ferskvandets fastsiddende Bund- og Bredflora. I mange Tilfælde er intimt Slægtskab mellem Planktonformer og Bundformer umiskendeligt (Anabcrna-Arter, Gloiotrichia echinulata og G. natans); i andre Tilfælde (Coelosphorinum Kützingianum) lader et saadant sig ikke uden videre paavise.

Særlig udprægede Temporal- og Lokalvariationer har man hidtil ikke kunnet paavise hos Planktoncyanophyceerne. 


\section{Coccogonea.}

lntelsteds laar vi stedt paa saa belydelige systemaliske Vanskeligheder som indenfor Gruppen Coccogonere; navulig girlder dette on Beggrebel l'olycyslis. Vi mal med Hensyn lil disse Former sarlig anbefale et nøjere Studium al Mikrofologralierne, hvoraf adskillige er blevel ndførte nelop med disse Former for Oje. Paa Grund al Algernes overordentlig formskiftende Eve anser vi en nacrmere Udsondring i lalrige Arter og

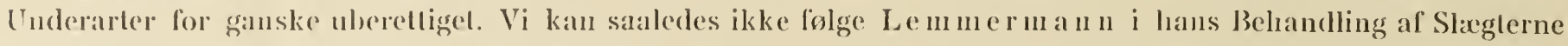

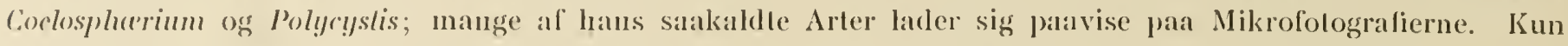
ved Dyrkning vilde man rimeligvis vaere i Stand til at udrede Artsbegrebet indenfor disse Slagter.

\section{Chroococcus.}

Chroococcus-Arleme er overvejende Dam-og Littoralformer; fra støre Søers Plankton angives C. linnelicus L.mnn., C. minulus Nïg., C. lurgidus Näg. (Borge 00 p. 11), C. minulus var. carneus og C. minor var. viridis (Chodal 98 p. 180), Bachmann 00 p. 194-204). I Folge Chodat er C. minulus var. carneus meget karakterislisk for Neuchatelersøen; den plumrede Vandet i Juli 97, fandtes særlig i Overlladen, men Luftvacuoler lod sig i ovrigt ikke paavise; den synes ligesom C. minor at vare almindelig i Schweizersøerne. Kendskabet til Chroococcus-Arterne og deres indbyrdes Slægtskabsforhold er højst ufuldkomment.

\section{C. limmelicus L e m.}

Tab. IX, Fig. 103.

Lemmermann 99 p. 132 . Tab. I, Fig. 22-23.

Sorosø. C. l. paavistes i enkelte Eks. i Foraarsprøverne 02.

Viborgso. C. l. er paavist i enkelte Prover, hyppigst i tidlige Foraarsprover.

Skanderborgso. C. l. er til Stede i alle Prøver, men synes i det hele at spille en underordnet Rolle $i$ Søen.

II osso 01. C. I. forekommer i Prøverne ${ }^{28} / 12$ Tp. 4 og $5 / 5$ Tp. 6 kun enkeltvis; hyppigere $20 / 5$ Tp. 12 , men bliver forst talrig ${ }^{20} / 9$ Tp. 14; den danner ${ }^{15} / 10$ Tp. 10 en stor Del af Planktonet og er ${ }^{10} / 12$ Tp. 5 dominerende. 0.2 $10 / 5$ Tp. 9 er Arten ret almindelig og holder sig omtrent saaledes til $30 / 7$ Tp. 15 .

Julso 01. C. $l$. er meget sjælden i Vinterprøverne, lidt hyppigere i Foraarsprøverne ${ }^{24} / 4$ Tp. 3 og $20 / 5$ Tp. 13 , men er forst ret almindelig ${ }^{10} / 7$ Tp. 20 ; i alle de senere Prøver lige til $15 / 10$ Tp. 12 optræder den omtrent $\mathrm{i}$ samme Mangde, men bliver ${ }^{20} /{ }_{11}$ Tp. 6 noget hyppigere; i 02 er den $15 / 1$ Tp. 1 den dominerende Form. 5/4 Tp. 6 optræder Arten kun enkeltvis og er $\mathrm{i}$ ovrigt ret sjælden $\mathrm{i}$ hele den forste Halvdel af 02.

Cluroococcus limmelicus er tidligere paavist i Nordtyskland af Lemmermann (98c. p. 153, 99 p. 132), men det er vistnok første Gang, at den angives dominerende i en større Søs Plankton.

Om Periodiciteten har man hidtil intet vidst; den synes, at dømme efter Iagttagelserne i Mossø og Julsø, at have sit Maks. beliggende i Begyndelsen af Vinteren ved Tp. 5-2; er delte normalt, vil den heri afvige fra alle andre Planktoncyan., da disses Maks. ligger ved en betydelig højere Tp.

\section{C. minulus (Ḱtz.) Näg. \\ Tab. III, Fig. 36.}

Vi henfører til denne Art en lille blaagrøn Alge, der vistnok lader sig paavise i alle vore Søers pelagiske Region og særlig i Maanederne Maj-Juni; i konserveret Tilstand, naar den stærkt blaagrønne Farve er gaaet tabt, er den meget vanskelig at skelne fra enkelte Celler af Eudorina, Spharocyslis, C. linuelicus o. a. Den er særlig karakteristisk for Esromsøs Plankton i Maj-Juni Maaned.

\section{Merismopedium.}

M. synes intetsteds at være hjemmehørende i de større Søers pelagiske Region; alle Arterne bebor lave, varme Smaadamme, hvor de til Tider optræeder i stor Mrengde (M. glaucum; Zacharias 98 b. p. 104, der 
ogsaa forekommer i Balatonsoens Plankton (Ist vá ffi 98 p. 22)); de fandtes aldrigs dominerende i de i 98 undersogte 1)amme.

Luftacuoler mangler hos Hovedmassen af Arterne; Lem mermann (100 c. p. 31) mener at have páavist saadanne hos M. Marssonii Lem.

M. elegants A. Braun.

Apstein 96 p. 136, Fig. 22.

Denne lille form er paavist sporadisk i enkelte Prover fra Esromso, Sorøso, Mosso og Julsø.

M. . angives af Apstein $(96$ p. 136) fra Dobersdorfersee og Plønersee, sacrlig i Sommerhalvaaret.

\section{Gomphosphæria.}

Slagten taller i større Søer kun een Planktonorganisme G. lacustris Chodat (98 p. 180), der afviger fra den i Damme hyppige G. aponina Kütz., idet den er rosenfarvet og pelagisk. Luftvacuoler er saa vidt vides aldrig paavist hos nogen Gontphosplecria-Art.

\section{G. lacustris Chodat. \\ Chodat 98 p. 181 Fig. 1.}

G. $l$. er paavist i alle de undersøgte Søer med Undtagelse af Haldsø, Skanderborgsø og Mossø, men optræder overalt kun i ringe Mængde; den er funden til alle Aarstider, men er dog hyppigst om Sommeren. Arten lader sig kun med Vanskelighed holde ude fra unge Coelospharium-Kolonier. .

Den angives sjældnere fra de tilgrænsende Lande, muligvis fordi den ofte sammenblandes med Coelosphcrium. Derimod er den øjensynlig almindelig i Schweizersøerne, hvorfra den er næermere undersøgt af Chodat; den er alm. i Genfersøen og optræder i Lac de Joux, »excessivement abondante« (98 p. 182).

\section{Coelosphærium.}

Alle de $\mathrm{i}$ de her omtalte Søer optræedende Coelosplucrium-Individer henføres til C. Kützingianum Nãg.

I Damme optrader ofte en Coelosplccrium-Art, der her kan danne kolossale Maks. Saadanne paavistes af W.-L. i tre af Forsøgsdammene 98. I den ene af disse, Nr. 3, Store Carlsbergdam, landtes Arten hele Aaret; det store Maks. begyndte allerede $1 / 6$, var højst i Aug.-Sept. og vedvarede lige til Okt.; i Tiden fra Aug. til Okt. var Dammen dækket af en meget tyk Vandblomst; i lignende, men ikke saa kolossale Mængder, fandtes Arten i Dammene 4 og 5, men her var Maks. begrænset til Aug. og Beg. af Sept.

Denne Damform er udstyret med et noget tykkere Gelelag end C. Kützingianum, fra hvilken den tillige afviger, ved at Gelelaget er radiærtstribet; det er derfor rimeligst at henføre den til C. Naegelianum Ung.; det er vel i øvrigt tvivlsomt, hvor vidt disse to Arter kan holdes ude fra hinanden.

De $\mathrm{i}$ den nyere Tid beslirevne Arter C. cerngineum (Le m m. 98 c. p. 154), C. pallidum (L.em m. 98 c. p. 154), C. minutissimum (Lemm. 00 f. p. 98), C. natans (Lem m. 00 k. p. 309), C. dubium (Sch mula 98 p. 47 ) er os ubekendte og lader sig overhovedet for Øjeblikket næppe genkende. Luftvacuoler kan næsten altid paavises paa Coelospharium-Individerne; de angives at mangle hos C. pallidum Lemm.; Lagerheim formoder (00 p. 14), at en paa Bjørneøen funden Coelosphcrium-Form muligvis er denne Art.

\section{Kützingianum $\mathrm{N}$ äg.}

Tab. III, Fig. 31.

Nägeli 49 . Tab. I C.

C. K. synes ganske at mangle i Sorøsø; den er meget sjælden i Furesø og Tjustrupsø, er lidet fremtrædende i Haldsø, men almindelig i de øvrige Søer; til visse Tider danner den for en stor Del disse Søers 
Plankion. Da den med flensyn til Periodiciteden, Skanderhorgso undtagen, forholder sig ens i alle Søer har vi, idet ii henviser til Listerne, her behandlet dens (Optreden under et.

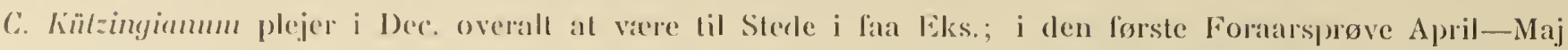
er den colen ikke parvist eller dog kun funden i enkelte Eks. Den er sjacten hele Forsommeren, begynder lorst al dominere i Aug. og natr sjacklent sil Maks., for efter at Luftens Tp. er begyndt at dale (Sept., Begyndelsen af (Okt. Vandets Tp. 17-15). Paal dette Tidspunkt kan den i høj Grad vare Vandblonstdannende. I det sene Elteraar, nar den af Aplanizomenon og Polycystis foraarsagede Vandblomst er ved al forsvinde, bevirker Cochosphurium, at Vandblomstlixnomenet ikke ophorer, on det end ikke er saa tydeliggt som i Aus.

Nalu man par stille Novemberdage iagltager Vandblomstdannelse $i$ vore storre Søers Bugter, skyldes denne vistnok allid C. $K$. Undertiden (Julsø 022) kan den endnu i Januar forekomme ret hypprig.

En Afvigelse lia de her fremstillede Forhold findes for saa vidt i Skanderborgsø, som Arten her allerede val lalrig i Maj 01; i 02 var dette derimod ikke Tilfaldet.

(Ogsaa L.emmermann (00 g. p. 139) angiver for Zwischenahner Meer en ganske lignende Periodicitel som vi.

Arten er i ovrigl funden i talrige holstenske Søer af Lemmermann o. a., i Stuhmersøeme af Seligo og Brno Schroder (00 p. 79), i Vettem af De Toni og Forti (00 p. 801) samt paavist af Chodat (97a. p. 311) i Schwcizersøerne; her er den dog af ganske underordnet Betydning; (se i øvrigt De Toni og Forti 00 p. 802 og Kirchner 96 p. 102). Den angives mrerkelig nok sjaldent i synderlig høj Grad som Vandblomst-dannende.

Valloxensøens Coelosphurium er af Borge $(00$ p. 10) bestemt til C. Nugelianum, der i Følge samme Forf. ogsaa skal forekomme i Müggelsee. Om Formeringen hos Coelospharium se Leitgeb (69 p. 72). Da C. Külzingianum er saa almindelig her i Landet og virkelig har biologisk Betydning for vore Søer, søgte vi at udrede Overvintringsforholdene. Vi kan om disse dog ikke sige andet, end at Arten aldrig ganske mangler i Vinterprøverne fra de Søer, hvor den i større Stil er Vandblomst-dannende, saa lidt som i de Prøver, der er tagne umiddelbart efter Islosningen. IV.-L. formodede, at Antallet af Luftvacuolerne hen paa Efteraaret muligvis reduceredes, hvad der vel maatte have Artens Nedsynken til Følge. Bundprøverne fra Dec. bekræftede ikke denne Formodning; derimod havde han Lejlighed til at iagttage, at en ikke ringe Coelospherinn-Vandblomst i Dec.-Jan. laa fangen i Phragmites-Bæltet i Esromsø og utvivlsomt blev indefrossen, (la Søen faa Dage efter den sidste Iagttagelsesdag lagde til; hvor vidt Kuglerne har taalt denne Indefrysning, maa henstaa uafgjort. - Det synes foreløbig, som om alle Sommerens Individer fremgik af de yderst faa Eks., der fandtes efter Isløsningen; det store Maks. i Sept.-Olkt. arbejder sig langsomt stigende frem lige fra IIaj; en pludselig og stærk Forøgelse iagttager man ikke for denne Arts Vedkommende.

\section{Polycystis.}

Det sýnes af Litteraturen at fremgaa, at det indbyrdes Slægtskabsforhold mellem de til Slægterne Polycyslis Kitz., Anacyslis Menegh., Clalhrocyslis Henfr. og Microcyslis Kitz. henførte Arter endnu ikke er udredet. Sidstnæunte Slægt er af Richter ( 85 p. 18) sikkert med Rette ophævet; vi har i øvrigt fulgt Hansgirg (92 p. 144), der opfører Slægterne Anacyslis og Clathrocyslis som Sektioner under Hovedslægten Polycyslis; deme kommer da til at indbefatte de to Planktonformer P. (Anacystis) flos aque og P. (Clalhrocystis) wruginosa samt andre vesentlig fastsiddende Former, hvortil vi intet Kendskab har. P. flos aqua bliver da en Fallesbetegnelse for alle de uregelmæssig klump- eller kugleformede Celleaggregater uden fast ydre Form, ikke omgivne af et skarpt begrenset Gelelag og set nıed svag Forstørrelse som oftest af en bleggul Farve; under Mikroskopet viser de sig graa (Formol) (Tab. III, Fig. 31). P. cruginosa indbefatter de flade, undertiden langstrakte, pølseformede Kolonier, der altid er omgivne af et skarpt begrænset Gelelag, og hvis Farve saa vel under Mikroskop som med Lupe er spanskgrøn (se særlig Tab. VI). Naar Hansgirg som Væsens- 
forskel mellem Auacystis og Clallnocyslis angiver, al forstnevntes Celleaggregaler aldrig er nelformet sonderdelte, livad der derinod skal vare Kendelegn for Clalhrocystis, da las vi ikke kumet slulte os til denne Oplattelse; navnlig i Sommerprøverne fra Viborgsø findes I’. flos aqum-Former, der er stackt sonderdelte; kun treder detle i Alın. ikke saa tydeligt frem, fordi disse Kolonier mangler den skarpe Begraxsning, som del tydelige Gelelag giver Clathrocystis-Kolonierne.

Lemmerman har paa Basis af Koloniernes Form, og fordi Luftracuoler efter L.s Opfattelse ikke findes hos alle Arter, yderligere søgt at inddele de i Plankton optradende Polycystis-Former i forskellige Arter: P. relicnlala og P. pallida (98 c. p) 153 og 154), P. incerta (01 a. p. 93).

Det er rigligt nok, at begge de to ovennarnte Hovedformer af Polycystis i de forskellige Søer har et uleget forskelligt Udseende; da vi imidlertid formoder, at Tilstedeværelse eller Mangel paa Luftvacuoler ikke kan anvendes som Artsmarke, og da den enkelte Koloni, hvad der kan iagttages i Kulturer, er yderst formskiftende, har vi ikke optaget disse Artsnavne.

Vi holdt oprindelig de to Former $P$. flos aqua og $P$. aruginosa ude fra hinanden; senere hen ved clen endelige samlede Bearbejdelse af Materialet var dette os i Alm. ikke muligt. Det viste sig først og fremmest, at le to Former, naar Esromsø undtages, altid fandtes i samme Sø; i Mossø var de omtrent lige hyppige, i Viborgsø dominerede $P$. cruginosa, men i alle de øvrige var $P$. flos aqua den talrigste; sidstnæevnte optraadte sarlig i Foraarsmaanederne. Endvidere fremgik det af et naermere Studium af Polycystis i Viborgsø (01 $7 / 8$ Tp. 23), at P. flos aquce og P. cernginosa kan være forbundne ved talrige Overgangsstadier, som med lige saa god Ret kan henføres til den ene som til den anden af disse to Former; ikke sjældent iagttager man Kolonier, hvor den ene Halvdel ser ud som $P$. flos aqua, den anden som $P$. aruginosa. Da vi imidlertid kun har set Overgangsstadier tydeligt i Viborgsø, anser vi os desuagtet, saa lange Dyrkningsforsøg ikke foreligger, for uberettigede til at omforme den nuværende Opfattelse af Polycystis-Arternes indlbyrdes Slagtskabsforhold; vi har derfor saa vidt mulig holdt de to Former adskilte; i Listerne er de dog behandlede under et.

Saa vel $P$. flos aqua som $P$. aruginosa har et ret forskelligt Udseende i de forskellige Søer; hos sidstnævinte kan endvidere en tydelig Temporalvariation paavises.

P. flos aquc optræder i Tjustrup- og Sorøsø som regelmæssige Kuglestadier (Tab. IV, Fig. 46 yderst til venstre); Dimensionerne er ringe, men ret konstante; i øvrigt afviger de næppe fra de almindelige, uregelmassigt formede $P$. flos aquผ-Kolonier. I alle Silkeborgsøerne, men navnlig i Mossø, optræder i Tiden fra 01 c. $1 / 8$ til 15/10 druseformede Polycystis-Kolonier (Tab. VIII, Fig. 86 yderst t. h.), hvis Celler er lidt større end almindeligt; Farven er blaalig hvid, Celleindholdet er homogent og lysbrydende; de talrige sorte Korn, man plejer at finde i Polycystis-Koloniernes Celler, mangler her. Da vi kan paavise alle Overgangsstadier mellem den typiske $P$. flos aquce og disse Former, kan vi foreløbig kun opfatte dem som Vakstformer.

P. aruginosa danner i sit mest typiske Stadium 2-3 Millim. store Net eller hulkugleformede Legemer (Tab. VI, Fig. 62), men optræder ogsaa i cylinderformede Kolonier (Tab. VI, Fig. 61), der til Tider kan omdannes til lange, tynde, traadformede Dannelser (Tab. VI, Fig. 72), hvis enkelte Celler er ordnede markelig regelmæssigt saa vel i Henseende til Traadens Langderetning som til dens Tværretning. Det viste sig nu for Viborgsøs Vedkommende, at de cylinder- eller pølseformede Kolonier navnlig var almindelige i Foraarstiden; senere flyder de ud, og der opstaar da store, pladeformede Kolonier, som ved Spalte- og Lappedannelser omdannes til Hulkugler eller Net; fra disses Overflade kan enkelte Lapper hæeve sig frit op, antage Pølseform, og uden at Tværsnitstørrelsen forøges, stadig vokse videre i samme Retning; derved opstaar lange, strangformede Legemer, som efter paafølgende Indsnøringer henfalder i cylinderformede Stykker, der bliver indbyrdes frie, og hvorfra nye Kolonier opstaar.

Hen paa Efteraaret foregaar meget vasentlige Omdannelser, der indleder Vinterens Hvilestadier. Kolonierne skifter Farve og bliver brune eller brungule; de enkelte Celler falder hen i et brungult Pulver, hvilket har til Følge, at Gelehylstrene bliver meget tydeligere; i December træffer man f. Eks. i Slotssøen ved Frederiksborg talløse, skarpt konturerede Gelehylstre, i hvis yderste Flige og Lapper en brungul, pulverformet 
Masse lignel allejpet. Disse (icheliylstre gata i Viuterens Lob til Bunds og destrueres; i hvert Fald lod de sign iklke paravise edter lskesningen i Marts 02.

Det er dog ikke alle P. aruginosa-kíolonier, der omdannes paa denne Maade. I Nov-bec. benarker 11an, al Lappedannelsen i mange al de store Kolonier foregar par en anden Maade end $i$ Sommertiden. Lapperme er nu ikke lange, polscformede Legemer, livis Tvarakse lorholder sig til Laengdeaksen som e. 1 til 20, de polselormede Legemer lrenfalder i lutter korte, sma kugleformede cller elliptiske Stykker, Invor

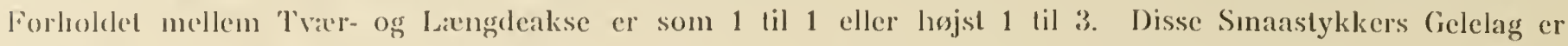
meget tykt og viser ofte en tydeligg Lagdeling (Tah). VI, Fig. 66-138); Indloldet: de talrige enkelte Celler, der under Mikroskopet viser sig hlaasort, har trukket sigs sammen til en kompakt Masse i Gelehylstrets Indre. For disse Legemers Vedkommende finder der i Tiden fra Dec. til lsløsningen ingen Lapledannelse eller Vakst Sted; det er P. aruginosas Overvintringsstadier, der findes i Planktonet hele Vinteren, men som dog rincligvis ogsaa overvintrer paa Bunden.

For Vilorgsos Vedkommende viser der sig tillige den Mrerkelighed, at Hovedmassen af Overvintringsstadierne er dakket med lange, leddede Haar af blaagrøn Farve, som udgaar fra brunrøde Udvækster paa (ielemassen; vi formoder, at vi her har haft at gøre med en os i ovrigt ukendt Epifyt. (Tal). VI, Fig. 66 og 67).

I April Maaned finder man atter Overvintringsstadierne; disse vokser ud til de pølseformede Stadier, hvorpaa kolonidelingen tager sin Begyndelse.

Overvintringsstadiet er rimeligvis set af C. Schröter i Zürichersøen (97 p. 22) og af Amberg i lago di Muzzano (00 a. p. 42).

\section{P. aruginosa K $\mathrm{tz}$ og $P$. flos aque Wittr. Se særlig Tab. VI. \\ Apstein 96 p. 134, Fig. 21. \\ C. Schröter 97. Tab. Fig. 73.}

Fureso. $P$. er med Undtagelse af ganske enkelte Eks. af begge Former ikke paavist i Søen.

Esromsø. $P$. findes kun i ringe Mrengde; det er den eneste kendte danske So, hvor kun $P$. fl. a. forekommer; $P$. $c$. synes ganske at mangle; $P$. er hyppigst i Juli--Sep., men findes endnu i Jan.

Soroso 01. I Proven fra $5 / 5$ Tp. 10 og $26 / 5$ Tp. 13 findes enkelte $P$. fl. $a$. samt nogle $P . \alpha . ; 3 / 7$ Tp. 21 optracter $P$. fl. $a$. i de ovennærnte regelmæssige Gelekugler ret alm.; $9 / 8$ Tp. 23 dominerer $P$. $a$. og danner en væsentlig Del af Planktonet; den optracler ofte i lange, polseformede Kolonier; disse Stadier holder sig indtil ${ }^{17} / 10$ Tp. 12, hrorpaa de aftager i Antal og Størrelse. $023 / 1$ Tp. 2 findes kun Overvintringsstadier. $P$. $f$. $a$. findes vel i alle disse Prover, men faatallige. I Proven efter 1 ste Isløsning $30 / 1$ Tp. 1 findes enkelte Overvintringsstadier af $P$. o . og ligesaa efter 2den Islosning ${ }^{24} / 3$ Tp. 1 . Arten er sjælden lige til $7 / 6 \mathrm{~T}$ p. 15 og forekommer væsentlig som $P$. fl. $a$.; Antallet af sidstnxinte er steget $28 / 6$ Tp. 17 ; den er Hovedform $27 / 7$ Tp. 16 ; samtidig er $P$. $f l$. a. aftaget.

Polycystis er den eneste Cyanophycee, der i Sorøsø kan optræde dominerende i Planktonet.

Tjustrupso. $P$. spiller her kun en ganske underordnet Rolle. Hovedmassen er $P$. fl. a., der fra $015 / 5$ Tp. 7 og lige til 17/9 Tp. 12 væesentlig optræder i de samme kugleformede Kolonier som i Sorøsø; i Foraarstiden er Kolonierne som oftest store og uregelmæssige; hen paa Efteraaret er de kugleformede fremherskende. En Del $P$. $a$. forekommer talrigst efter $01{ }^{16} / 10$ Tp. 13 , dels som store Net, dels som polseformede Stadier; disse sidste findes endnu $02{ }^{27} / 1$ Tp. 1, men er da omgivne af tyk Gele.

$P$. $a$. findes ogsaa her som enkelte, meget store, uregelmæssige Celleaggregater. Efter Isløsningen i $02{ }^{23} / 3$ Tp. 1 findes faa Eks. af begge Former, $P$. $\propto$. i Overvintringsstadier med tyk Gele; i alle de følgende Prøver lige til $27 / 7$ Tp. 15 findes begge, men kun i enkelte Eks.

Viborgso. P. danner her en ilke uvasentlig Del af Phytoplanktonet og findes særlig som P. ceruginosa; Overgangsstadier mellem denne og $P$. flos aqua er set i Proven $017 / 8$ Tp. 23.

$P$. co. optræder i de kugleformede Overvintringsstadier $01 \frac{29}{3} \mathrm{Tp}$. 1, men er meget sjælden; den er hyppig ${ }^{18} / 5$ Tp. 14, især som polseformede Kolonier og findes nu i stor Mængde i alle Proverne lige til $14 / 10 \mathrm{Tp}$. 12, dels som store netformede Kolonier, dels af ovennæunte strængformede Type; ${ }^{11} / 10$ aftager Antallet af disse sidstnæunte, og de store Kolonier deler sig nu i Stykker, noget mindre end Delingsstykkerne om Sommeren; $10 / 11$ Tp. 8 begynder de typiske Vinterstadier at vise sig og tiltager i Antal i Vinterens Lob samtidig med, at de store Kolonier forsvinder; 


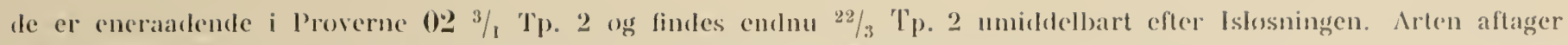
i Antal efter $114 / 10$, men er fog ret alm. hele Vinteren. Forholdene i foratarshalvaaret 02 svarer til Foraarshalvalaret 01; kun er Arten mindre hyppis.

Haldso. P. synes her ganske at mangle.

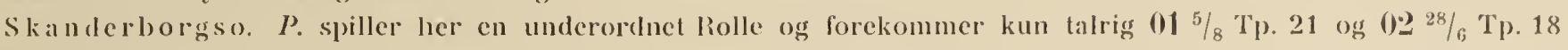
vesentlig som P. fl. $a$.

Ilosso. P. synes at kunne optrade i betyclelig Mangde i Sommermanederne; den findes ontrent lige hyppig i begge lormer, P. R. a. saerlig i let ovenfor omtalte ejendonmelige Stadium; talrige typiske Overvintringsstadier 0110 Tp. 5 .

Julso. $P$. er her af underordnet Betydning; $P$. $/$. $\alpha$. forekommer hyppisst i Forsommeren; $P$. $w$. fincles swerlig om Efteraaret og om Vinteren; den mangler næsten ganske i Foraaret 02 ; talrige typiske Overvintringsstadier 0.2 $15 / 1$ Tp. 1 .

Ogsaa i Smaasøer er P., navnlig i Formen $P$. $/$. a., ret almindelig. Den kan her opnaa uhyre Maks., og ved sine kolossale Masser blive til Gene for Omegnens Beboere samt ødelæggende for Søens Fisk. Et typisk velkendt Eksempel er Frederiksborg Slotssø, der allerede er grøn i Maj og ofte holder denne Farve lige til November. $P$. synes derimod ikke at optrade dominerende i ganske lave Smaadamme; den blev vel paavist ved Damundersøgelsen 98 i 8 af Dammene, men intet Steds i stort Individantal.

Med Hensyn til Artens Periodicitet kan vi altsaa sige, at vore Søers Polycystis-Former kun optrader i faa Eks. umiddelbart efter Isløsningen, og at Antallet derpaa stiger jævnt indtil Juli-August; Maks. synes at falde, noget før Vandet har naaet sin højeste Tp. eller omtrent sammen med denne; hen imod Efteraaret tager Antallet af, men hele Vinteren findes dog en Del Eks. svaevende i den pelagiske Region. Det maa henstaa uafgjort, om der i Plankton optrader to Arter, P. flos aquœ og $P$. aruginosa, eller om disse rettest bør forenes til en Art. Førstnxevnte er vistnok sæerlig en Foraarsform og naar sit Maks. før P. $\omega r u g i n o s a$. Alle Overvintringsstadier synes at opstaa fra sidstnavnte Art.

Polycystis er ogsaa udenfor Danmark meget almindelig. Den naevnes af Schröter (97 p. 22) fra Zürichersøen, af Apstein (96 p. 134), Zacharias (95 d. p. 142, 96 a. p. 59) o. a. fra de holstenske Søer; af Seligo (90 p. 87) fra de nordtyske, af Seligo og Bruno Schrøder (00 p. 54) fra Stuhmersøerne, af Amberg (00 1. 42) fra Lago di Muzzano og Katzensee, af Borge (00 p. 11) fra Valloxensø og af La uterborn (93 $a$. p.8) fra Altrhein.

Hvad Periodiciteten angaar, angiver Amberg, at Arten i Lago di Muzzano danner Vandblomst al den Tid, Søen er isfri; i Valloxensøen synes den at forholde sig paa samme Maade (Borge). I Følge Seligo (p. 54) forekom den i Vinteren 98-99 endog »massenhaft" under Isen i Barlewitzersøen og fandtes $\mathrm{i} ø$ vrigt hele Aaret.

Maks. angives dog i Alm. at indtraffe i Aug.-Sep.

De fleste Forf. synes at slaa de to Arter sammen; de er adskilte hos Apstein og Bruno Schrøder (00 p. 79).

\section{Hormogoneæ. Homocysteæ.}

\section{Oscillatoriaceæ.}

Alle de hidtil i Ferskvands-Plankton fundne Homocysteœ indeslutter i Skederne kun et Trikom; de tilhører alle Gruppen Lyngbyece og henføres til de to Slagter Lyngbya og Oscillatoria; desuden støder man nu og da paa Hormogonier af typisk fastsiddende Former slaaede løs af Bølger og Vind (Phormidium o. a.); se ogsaa Lemmermann (98 $\alpha$. p. 203) og Lagerheim (00 p. 13). Luftvacuoler er kun sikkert paaviste hos Oscillatoria. Lemmermanns Angivelser om Luftvacuoler saa vel hos Lyngbya astuari og i Hormogonier af i øvigt fastsiddende Former (98 a. p. 203) trænger til Bekræftelse. Det maa i øvrigt fremhæes, at alle Plankton-Homocysteæ er ugrenede, med tynde Trichomer; Skederne er; for saa vidt de findes, svagt udviklede. 


\section{Lyngbya.}

df de Lalrige Ferskvandsarder angives i Europa i Aln. 4 som Planktonorganismer; de to Arter L. lacustris lommon. og timnelice kan kun med Vanskelighed holdes ude fra hinanden. Da den i Furesøen almindeligste

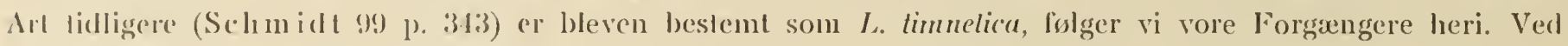
1):mmmdersogelsen !S fandtes ofte Layngb!ja, men Arterne blev ikke nxrmere bestemte.

\section{I.ynglyya timnetica Lem m.}

Tals. I, ling. 10-11.

Le mmermann $98 c$. p. 154.

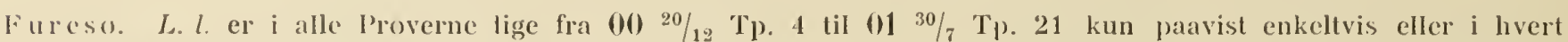
Fald i ringe Mangde. Proven fra sidste Dato indeholdt Arten i ret belydeligt Antal, og $\mathrm{i}$ Tiden fra $30 / 8$ Tp. 17 til 21/10 Tp. 11 optrieder den i saa enorme Masser, at Vandet, naar det ses i et Glas, viser sig brunfarvet. Planktonneflet belagges paa Indersiden med et tykt Lag, der samlet og nedskyllet i Spanden antager en brunrød Farve. 'Trods det cnorme Maks. iagttog man ingen Vandblomst, hvilket heller ikke kunde ventes, da Luftvacuoler mangler. Ved Henstand i hoje Glas samlede Algen sig nede ved Bunden og gik ikke op i Overfladen, som Cyanophyceer med Luftracuoler plejer at gore. $16 / 11$ Tp. 4 var Antallet starkt reduceret, 0 g $\mathrm{i}$ alle de folgende l'over, saa vel i 01 som 02, optraadte Arten kun enkeltvis.

Esromso. L. l. viste sig $\mathrm{i}$ ganske faa Eks. $015 / 9 \mathrm{Tp} .16$ og var ret tạlrig $30 / 9$ Tp. 15, altsaa ved samne Tid og Tp. som i liuresoen; $15 / 10$ Tp. 12 var Maengden sterkt aftaget, og 10/11 Tp. 7 saas (le sidste Eks.; i 02 paavistes den kun enkeltvis $10 / 7$ Tp. 14.

Skanderborgso. L. I. er ligesom i Furesoen perennerende og er paavist i alle Prøver, men Hypjighedsungivelsen er lıer ikke paalidelig paa Grund af samtidig Optraden af andre traadformede Alger (Conferva, Oscillaloria, Lynglya bipunclata). Der er log ingen Tvivl om, at Arten ogsaa her har sit Maks. i Tiden fra 01 15/9 Tp. 12 og til $20 / 11$ Tp. 6, hrorpaa den tager af; i 02 er den sjaetden.

Det fremgaar heraf, at L. limnelica er typisk Planktonorganisme i en Del af vore storre Søer; den er rimeligvis perennerende; Maks. synes altid at ligge i Sep.-Okt. Tp. 16-12 og kan være meget stort.

I de fleste al de orrige Soer optraadte enkelte Eks. af L. lacustris til næsten alle Tider af Aaret; et særligt Maks. lod sig ikke parise; den findes i Mrengde i Maribosø, hvor den først er paavist af Ostenfeld (Schmidt 99 p. 343).

L. timnetica angives ret hyppigt i Planktonarbejderne, saaledes: Le mu merman n, Holsten (98 c. p. 154 o. a.), De Toni og Forti (00 p. 803) i Comosøen og Vettern, Borge (00 p. 9) i Valloxensø.

Lun Borge angiver Periodiciteten: Maks. ligger i Valloxensø ligesom hos os i Sep.-Okt.; intetsteds synes den at optræde i saa stor Mrngde som i Furesøen.

\section{L. bipunctata $\mathrm{L} \mathrm{e \textrm {m }} \mathrm{m}$.}

Tab. VIII, Fis. 94.

\section{Lemmermann 99. Tab. II, Fig. 48.}

Arten er i Folge Lemmermann (99 p. 133) særlig karakteriseret ved, at der i hver Ende af Cellerne ligger et rundt Legeme; paa hver Side af Algetraadens Tværvægge findes altsaa et saadant; ri anser det for tvivlsomt, om Arten kan holdes ude fra L. Lagerheimii (Möb.), Gomont (92 p. 147).

Et stort Antal Planktonindivider er meget skarpt karakteriserede red dette Bygningsforhold; i Prøver, hvor $L$. bipunctata forekommer sammen med $L$. linunetica, er det ikke let at holde de to Arter ude fra hinanden, da de runde Legemer ikke altid er lige tydelige. Man red intet om disse ejendommelige Dannelsers Betydning, heller ikke, om Arten muligvis skulde danne Vandblomst og Legemerne i saa Fald vare et Sræreapparat (Luftracuoler? Oljedraaber?). 
Skanderborgso. L.p. lindes rimeligvis i alle l'rover, men var sjablen i hele ol; den optrablte forst ret alm.

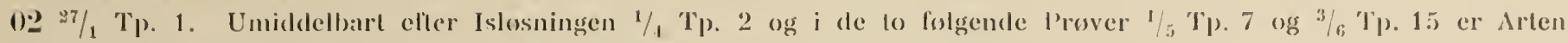
en af Planktonets llovedformer; i de folgende Prover til 30/7 Tp. 14 var den i jevnt Altagende.

l Mosso og fulso optracter L. p. i en Del Prover, men viser intel ret lydeligt Maks.

I ovrigt er den ikke funden andetsteds her i Landel og angives ikke i Planktonarlojeler fra Udlandet.

Lyngbyga contorta Lemm.

Le m mermann $98 \alpha$. 'Tab. V, Fig. $10-13$.

Arten, der vistnok er meget distinkt (Le 11 mermann 98 a. p. 202), optraeder enkeltvis i Furesøens Plankton, livor den tidligere er funden af Schmidt (99 p. 343). E. L. fandt den i stor Mangle i Juli i Arresliovso (Fyen).

Den er i øvigt funden af Lemuermann i "grosse Waterneverstorfer See« (98 a. p. 202). Chodat (00 p. 10) formoder, at L. contorta er en Ulothrichacee: Gloeotila contorta; hans Eksemplarer stammer fra Hofmansgave (Fyen). Lemmermann har senere (01 a. p. 91) fastholdt sin Opfattelse, som vi ogsaa er mest tilbøjelige til at slutte os til.

Det fremgaar altsaa, at vi i Plankton i alt Fald har tre Lyngbya-Arter; disse er rimeligvis perennerende, og hver Art synes at have sit skarpt begransede Maks.; for L. limnetica's Vedkommende ligger dette i Sep.Okt. 'Гр. 16-12, L. bipunclala's i April-Maj $\mathrm{T}_{\mathrm{p}} .2-10$. L. contorta, der er mindst kendt, har rimeligvis sit Maks. ved Vandets højeste T'p.

\section{Oscillatoria.}

De i Plankton optræedende Oscillatorier henføres til talrige Arter. Hovedformen er O. rubescens De Candolle (26 p. 29). Den hler paavist i Lac de Morat, hvor den danner en meget betydelig Vandblomst; senere blev denne Vandblomst undersøgt af Chodat (96 p. 333), og Arten paavist i talrige Schweizersøer dels af Chodat, dels af $\mathrm{Bachm}$ a n $(01$ p. 236). I øvrigt angives følgende Planktonoscillatorier: $O$. nigra Vaucher: Genfersøen (Brun 84 p. 21), O. tenuissima Vaucher: Genfersøen (Chodat 97 a. p. 311), O. limosa Vaucher: Lautikerried \& Lützelsee (IValdvogel 00 p. 46), O. prolifica (Grév) Gomont: Luganersøen og Lac de Morat (Chodat 98 p. 179), O. tenuis Ag.: Grosse Waterneverstorfer See (Lemmermann 98 . p. 203) samt paa Bjørneøen (Lagerheim 00 p. 14) og i Ballatonsee (Istvánffi 98 p. 21). I de holstenske og nordtyske Søers Plankton synes Oscillatorierne, at dømme efter Litteraturen, ikke at spille nogen Rolle. (Se Strodtmann 95 p. 166); Klebahn (95) omtaler dem ikke. Vi formoder, at de i Almindelighed er bleven oversete, og at Grunden hertil er, at Oscillatorierne ikke, som de øvige Planktoncyanophyceer med Luftvacuoler, samler sig oppe i Formolprøvernes øverste Rand, men Maaneder igennem holder sig svavende i Vaedsken og derved giver denne et blakket Udseende. La'gger man ikke Mrerke til denne Ejendonmelighed, faar man alt for lidt med af Algerne i de Prøver, hvorefter Hyppighedsskalaen angives (cfr. ogsaa $\mathrm{B}$ a ch mann $00 \mathrm{p}$. 387 ).

I de danske Søers Plankton spiller Oscillatorierne en ikke ganske ubetydelig Rolle og vistnok en noget større, end det af dette Arbejde fremgaar. Den i Furesøen optradende Form er af Schmidt (99 p. 350 ) hestemt til $O$. rubescens; da vi ikke har kunnet finde nogen Forskel mellem Furesøens Oscillatorie og Oscillatorierne fra de andre her naevnte Søer, har vi henført dem alle til O. rubescens.

Af andre Planktonoscillatorier navner Schmidt i ørrigt den næerstaaende O. prolifica (Grév) Gomont fra den gamle botaniske Have i Koøbenhavn og fra Birkerød samt O. Agardliï Gomont fra Ørstedsparken, København; Hofmansgave, Fyen, og Gudenaaen; (om denne Art se det følgende).

\section{Oscillatoria rubescens De Candolle.}

Tab. II, Fig. 20.

Chodat 96 , Fig. p. 405.

Furesø. O.r. er en af Planktonets Hovedformer og perennerende. Den findes ret almindelig i alle Vinterprøverne 01, ogsaa i Sluseprøverne, tagne, medens Søen var tillagt. Efter Isløsningen stiger Antallet stærkt; sit 


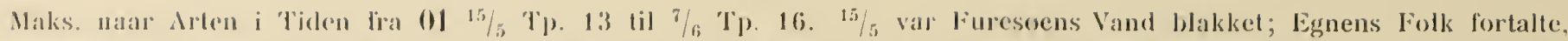
at Socn i stille Morgentimer kunde have ot hyidligt Skaer, men da Maks. faldt sammen med en af Fort.s Jyllandsrejser, bles dette desvirere ikke namere undersugt. Elter ${ }^{7}$ g tog Arten hurtigt al og viste sig forst igen mere

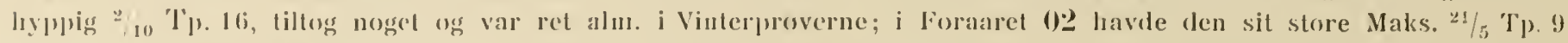

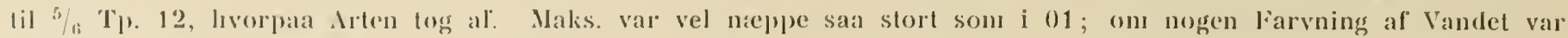
dere i herert lialıl ikke Tale.

I Tojustrupso og II aldso oplreder O. r. i Alm. i ringe Mangle; i begge Soer indtratler Maks. i Maj-Juni. †р. (. 10-12; del cr maerkelig stort i Haldso, 02 3/. Tp. 7.

Skanderborgso. O. r. er lier en af Hovedtormerne og perennerende; den havde et Maks. 01 19/5 Tp. 13, var

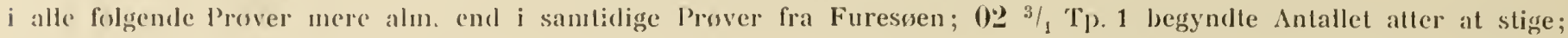
$27 / 1$ 'T). 1 var den meget hyjpig, men markelig nok slaerkt altaget efter lslosningen $1 / \mathrm{q}$ T). 2 og var $\mathrm{i}$ (le senere Prover indlil $30 / 7$ 'Tp. 1.1 reet sjiclden.

I Mosso og dulso er Arten ligetedes perennerende, men synes ikke her at naa saa stort et Maks. som i Skanderborgso; dette lalder i begge Soer og i begge lagttagelsesanene i Tiden fra bec. til Maj.

I Soroso og Esromso synes $O, r$ at mangle; i Viborgsg er enkelte Eks. set i Maj og i Vinteren 02.

I'ol Danundersogelsen 98 paavistes, dels i Teglgaardsso, dels i Frederiksborg Slotsso, en Oscillatoria-Art, rimeligvis O. rubescens; den lavde navnlig i Teglgaardsso et stort Maks. i Tiden fra 15/4 til 1/6.

Det fremgaar heraf, at $O$. rubescens horer til de perennerende Planktonformer, og at den ikke kan siges at vere sjelden i vore større Søers pelagiske Region.

Maks. falder om Vinteren eller i det tillige Foraar, hyppigst i April-Maj ved Tp. 4--10.

Det maa lienstaa uafgjort, om Arten virkelig er saa sjalden i de nordtyske og holstenske Søer, som det af Planktonundersøgelserne synes at fremgaa; den er lijemmehørende i store, klare Alpesøer (se ovenfor).

Naar nuan, som Tilfældet er med Oscillatoria og rimeligvis med Lyngbya, har med Former at gøre, som vel er perennerende, men dog den allerstørste Del af Aaret kun forekommer i ringe Mængde eller $\mathrm{i}$ meget faa Eks., medens de i en kortere og ofte skarpt begrænset Tid optræder i større Antal og inden for dette Tidsrum kan opnaa meget betydelige, til Dels kolossale Maks., der overalt synes at indtræeffe nogenlunde samtidig, maa det, hvor ikke saerlige Formerings- og Overvintringsorganer er os bekendte, nærmest antages, at der er visse Sider af disse Organismers Biologi, som er os ganske fremmede. Snarest er vi tilbøjelige til at tro, at alle disse Former, i alt Fald i vore lave Søer, er Bundformer, der overspinder Dyndbunden med store hvidgraa eller brune Taxpler; til visse Tider og under gunstige Forhold hæver da Luftblærerne større Partier, ler slaas i Stykker af Bølgerne, hvorved de enkelte Traade bliver frie af hverandre og spredes ud over Søen.

At Lyngbyer og Oscillatorier er Slim-overtrakkende, er notorisk, ligesom det ogsaa er velbekendt, at store Partier løsrives og kan fore en pelagisk Tilværelse. Se f. Eks. Lemmermann (98 a. p. 203), Istvánffi (98 p. 64), Lagerheim (00 p. 14). Hvor vidt der nu gives særlige Arter, der har tilpasset sig til ren pelagisk Levevis, eller som en Del af Aaret er Bundformer, og som fremfor andre Arter er tilbøjelige til at hæve sig fra Bunden og i nogle Maaneder føre en pelagisk Tilværelse, maa henstaa uafgjort.

Man kan vanskelig tænke sig, at de enorme Masser af Lyngbya limnetica, der viste sig i Fureso i Slutningen af August 01, alle har kunnet opstaa af de faa Eks., der var til Stede en Maaned tidligere.

For Oscillatoriernes Vedkommende har C. Schröter og Bachman n (01 p. 241) henholdsvis i Zürichersoen og i Baldeggersøen vist, at disse Alger i Sommermaanederne trakker sig ned i Dybet til Vandlag, der ligger dybere end $16 \mathrm{M}$, fra Overfladen; deres tilsyneladende Forsvinden af Plankton skulde da kun bero paa, at Planktonnettet ikke er fort saa langt ned, at det har faaet Oscillatorierne med; naar Efteraaret narmer sig, lıaver de sig atter op til Overfladen.

I vore forholdsvis lavvandede Soer, hvis Overflade ofte i Sommermaanederne er drekket med Vandblomst, og hvor Synsgraensen i hvert Fald ligger meget højere end i Alpesøerne, foregaar slige Vertikalvandringer nappe. Vi raader over Horisontalprøver fra 30-35 M. tagne i Sommermaanederne fra Haldsø og Furesø, og fra 20 M. i Tjustrupsø og Skanderborgsø, men Oscillatorierne er kun paaviste i ringe Mæengde; ofte mangler de ganske. 
Farelabig ser del uil, som om de store Maks. alene fremkommer som linglge af en meget livlig Celledeling og Traadelannelse, der indtraffer, natr Vandet har natet den Tle, som er gunstigst for Algernes Iiornering; frentidige Undersogelser vil rinneligvis kunne give yolerligere Oplysninger.

\section{Hormogoneæ. Heterocysteæ.}

Alle de i Pankton optraedende Heterocystea tillører enten Fam. Nostocacea eller Fam. Riunlariacer; de er alle forsynede med Luftvacuoler; de overvintrer udelukkende eller overvejende som Syorer og er aldrig peremerende (se $\log$ Aphanizomenom).

\section{Nostocaceæ.}

Typiske Planktonformer findes kun indenfor Slagterne Anabana, Aphanizomenon og Nodularia; de fleste dammer Plankton i Ferskvand, men flere af disse typiske Ferskvandsarter (Aphanizomenon o. a.) føres med Floderne ud i Brakvand, f. Eks. Ostersøen; typiske Brakvandsformer er Anabana baltica Schmidt (99 p. 371 ) og Nodularia spumigena Mertens, der begge er Plankton-og Vandblomst-dannende i vore Have (se Schmidt 99 p. 375 о. а.).

Man traffer til Tider i Smaasøer og Moser Nostoc.-Arter, der i Littoralregionen fører en halv pelagisk Tilværelse og undertiden forslaas ud i Bassinernes centrale Partier; som udprægede Bund-og Bredformer hører de dog aldrig hjemme i støre Søers pelagiske Region. Lem mermann (00 c. p. 31) har beskrevet en Planktonform N. Kihlmanni (Peitzer-See, nordlige Rusland), der angives at have Luftracuoler.

\section{Anabæna.}

Slagten Anabe'na indbefatter foruden sine talrige som Overtrak over Underlag optrædende Arter tillige en Del Planktonorganismer, af hvilke i alt Fald een, A. flos aqua, er hjemmehørende i vore største Søers pelagiske Region, hvor den ofte kan danne Vandblomst; de øvrige opnaar deres højeste Maks. i mindre Søer.

Falles for dem alle er foruden Tilstedevaerelsen af Luftvacuoler, at Trichomenerne, saa vidt vides, altid optrader enkeltvis og aldrig er forenede $\mathrm{i}$ et af mange Traade dannet Thallus; $\mathrm{i}$ ørrigt er Traadformen forskellig hos de forskellige Arter (lige A. macrospora, spiralsnoet A. spiroides, nøgleformet oprullet A. flos aqua).

Sporerne optræder til bestemte Aarstider og Temperaturer; naar de øvige Dele af Planten raadner bort, bliver Sporerne tilbage; disse mangler Luftvacuoler, men holder sig desuagtet en lang Tid svaerende i Vandmasserne, idet de enten (A. flos aqu(') ligger aflejrede inde i store Gelehylstre eller (A. macrospora) er forsynede med vingeformede, hyaline Dannelser (Rester af Skederne?).

\section{Anabana flos aqua? (Lyngb.) Bréb. \\ Tab. VII, Fig. 73 og 84 . \\ Schröter 97, Fig. $7 \dot{\text { s. }}$}

Furesø. A. fl. a., der i de tre foregaaende Aar liun var optraadt i ringe Mængde, fandtes $0127 / 5 \mathrm{~T} p .14 \mathrm{i}$ faa Individer og i smaa Spiraler; $/ 6$ Tp. 16 var Antallet steget, Maks. faldt i Tiden fra 30/6 Tp. 18 til $15 / 7$ Tp. $20 ; \mathrm{i}$ dette Tidsrum var Søen, hvad den ikke havde vaeret i mange Aar, navnlig i de tidlige Morgentimer svagt grøn. Arten optraadte paa dette Tidspunkt i de af Kklebahn (95 p. 267) beskrevne edderkopagtige Nogler, Tab. I Fig. 5, som hen imod Slutningen af Maks. var udstyret med Sporer. Disse Stadier dannes, saa vidt vides, af en eneste Traad; i Midten af Noglet ligger alle Sporerne ophobede, Traadpartierne mellem to Sporer gaar slyngeformet udad; derved dannes Stadier af en overordentlig Skønhed og Regelmassighed; det syıes, som om alle foreliggende Tegninger er udforte efter Spriteks,, paa hvilke Traadene skrumper sammen, og Geleen, der kugleformet omgiver Traadnøglet, destrueres. ${ }^{30 / 7}$ Tp. 21 er Arten sjalden; den optracler nu som Gelekugler, omsluttende starkt blaagrønne Sporehobe paa 20-30 Sporer; de ovrige Dele af Traadene er forsvundne; Sporehobene holdt sig endnu i Planktonet til $7 / 9$ Tp. 16, hvorpaa de rimeligvis er bleven bundfaldede. Vandblomstfæenomenet varede ikke over c. 14 Dage og var forsvundet $30 / 7$ Tp. 21; paa dette Tidspunkt blev Overfladen fejet ren, og en stor Mangde raadnede bort i en blaalig- 


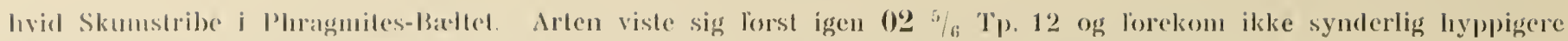
lor $3 / x$ 'lp. $15 ;$ V'andhlomslon var svag; loorholdene var i ovrigt ganske som forrige Aar.

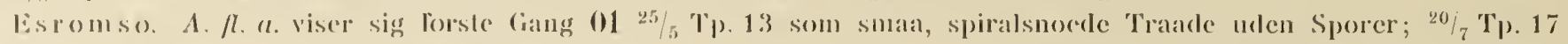
laar Arten sit Malis. og danner paa delle Tidspunkt en svag Vandblomst; nest Conferva er den Socus alnindeligste

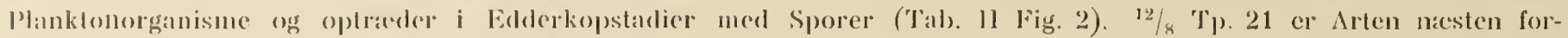

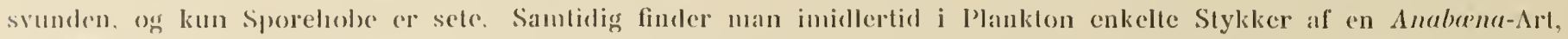
bestatende al lo Iange, strerkt krummede Sporer, adskilte lia hinanden ved en kuglerund lleterocyst.; fra disse

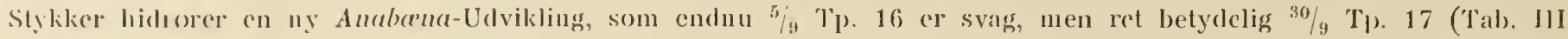
lïg. 29). Trabdene er morkere og tykkere end i Juni; de typiske lidderkopstadier mangler, men der er mange liorle, Iose Tratrle og andre, der er sammenlittecle til ganske uregelmassige og kompakte Nogler. Sporerne er

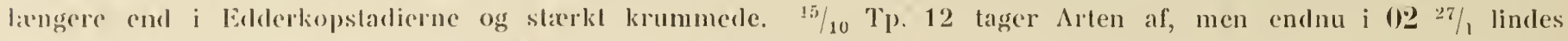
de ovennavnte Sporestadier i Planktonet. Ogsaa i de ovrige Soer er der paavist enkelte Individer med lange, stæerkl krummode Sporer. Vi oplattede en Tid lang disse Individer som A. circinnalis (Kütz), Rabenhorst (se Schnidt 99 p. 368 ligs. 21); men da vi ikke lar kunnet holde dem skarpt udle fra $A$. flos aquo, sammen med livilken de i Alm. Lan panvises, har vi henlort disse Individer til sidstnavnte $\Lambda$ rt; del dobbelte Maks. i Esromso, der, Invad Efteraarsmaks. angar, ikke genfindes $\mathrm{i}$ nogen anden So, og som udelukkende dannes af Former med lange og staerkt krummede Sporer, liunde i ovrigt tyde paa, at denne Oplattelse iklie kan opretholdes. I 0.2 viste $A$. $f l$. $a$. sig i faa, cnkelte Eks. som korte Traade, ${ }^{13} / 5$ Tp. 8 ; ${ }^{10} / 7$ Tp. 14 har Arten sit ikke store Maks., og $31 / 7$ Tp. 15 fincles kun enkelte 'Traadrudimenter og Sporehobe; alle Eks. lader sig henlore lil den typiske $A$. $f l, a$.

Soroso. A. fl. a. optracler kun i ringe Mangde i Soen og danner i hvert Fald en meget kortvarig Vandblomst. 101 viste den sig kun i Tiden fra $26 / 5$ Tp. 13 til $18 / 9$ Tp. 12 ; Maks. indtraf $3 / 7$ Tp. 21 . I 02 viste Arten sig ${ }^{7} / 6$ 'Tp. 15 og forsvandt $27 / 7$ Tp. 16 ; et ret stort Maks. incltraf $28 / 6$ Tp. 17.

T.justrupso. A. fl. $a$. er overmaade sjaclden i Soen; den var hyppigst i Proven $013 / 7$ Tp. 17 og optraadte i Edderkopstadiet; Sporer saas $8 / 8$ Tp. 22.

Viborgso. A. $f$. $a$. har her vistnok en noget storre Betydning, end det af dette Arbejde vil fremgaa; de første Eks. er paaviste 01 18/5 Tp. 14 og bidrager til at danne Vandblomsten 10/7 Tp. 21 og $7 / 8$ Tp. 23, paa hvilket Tidspunkt Sporer er iagttagne. Enkelte Eks. ses markelig nok i Vinterproverne; hele 02 er Arten sjælden i Prøverne, og der syntes slet ikke at indtrade noget Maks. i Juni-Juli; Edderkopstadier er ikke sete; Arten optraadte mest som mindre Spiraler.

Haldso. A. fl. a. viser sig forste Gang $0118 / 5$ Tp. 10 i ganske enkelte sporelose Traade; $8 / 6$ Tp. 13 og $22 / 6$ Tp. 13 tiltager Antallet langsomt, og der er kun faa sporebærende Traade; ${ }^{20} / 7$ Tp. 17 er Antallet derimod steget overmaade stackt, og der findes i Overfladen en ret betydelig Vandblomst, dannet af meget store, elegante Edderkopstadier; de enkelte Slynger staar vidt ud fra hverandre; i Centrum findes Sporer, men ikke i saa stort Antal som i Esromsø. Allerede $T / 8$ Tp. 18 er Arten aftaget, og mange Sporehobe bemærkes; endnu 14/10 Tp. 13 findes en enkelt sporeløs Traad. Derpaa forsvinder Arten til $0230 / 5$ Tp. 8 ; forst $3 / 7$ Tp. 14 stiger Antallet stæerkt, og $6 / 7$ Tp. 14 har $A . f l . a$. et stort Maks., der holder sig endnu $2 / 8$ Tp. 15. Edderkopstadier med Sporer optræder $16 / 7$ og bliver dominerende $2 / 8$. Arten danner Vandblomst i Tiden fra c. $16 / 8-26 / 7$.

Skanderborgso. A. fl. $a$. synes kun at optræde i ringe Mrengde i Soen og var ikke Vandblomst-dannende i 02.

Mossø. A. fl. $a$. var sparsomt repræsenteret i Sommerprøverne, i vinterprøverne har den manglet; det storste Antal fandtes i Juni-Juli, i livilke Maaneder der paavistes Edderkopstadier med Sporer.

Julso. A. fl. a. synes her noget hyppigere end i de to foregaaende Søer; ogsaa her ligger Maks. i Juni-Juli, og Sporer er iagttagne 01 10/7 Tp. 20 samt $0230 / 6$ Tp. 16 og 31/7 Tp. 15; mærkelig nok syntes Antallet i Okt. 一Nov. 01 atter at stige; paa dette Tidspunkt fandtes kun sporeløse, traadformede Kolonier.

A. flos aquœ er endvidere funden i talrige Smaasoer dels paa Sjælland, dels paa Fyen og i Jylland; mange Findesteder angives ogsaa af Schmidt (99 p. 368).

Ved Damundersogelsen 98 blev $A$. $f l$. $a$. paavist i 4 af Dammene uden dog at spille storre Rolle.

I Følge det foregaaende er A. flos aque altsaa en i vore ferske Vande vidt udbredt Art, som selv i større Søer kan danne en ofte ret iøjnefaldende Vandblomst. Den plejer i disse at vise sig c. $15 / 5 \mathrm{~T}$. c. 10; Maks. indtraffer allerede i Juni-Juli (Tp. 16-18); Vandblomst-dannende er A. $f$. $\alpha$. kun i Forsommeren; allerede i Slutningen af Juli er Sporedannelsen i fuld Gang, og i August forsvinder Arten nasten ganske. I de Tilfælde, hvor der i Sep.-Okt. viser sig et nyt Maks., er der Grund til at tro, at man har med en noget afvigende Form at gøre (Esromsø, maaske ogsaa Viborg- og Julsø). Vandblomsten er dog aldrig 
sarlig belydelig, ikke tyk og sammenhaengende, som f'. Eks. Aphanizomenons; den er alticl kortvarig og forsvinder meget pludselig.

For de lleste Soers Vedkommende forlooldt Arten sig nogenlunde ens i den varme Sommer (0)1 og den kolde Sommer 02; $\log$ Var Maks. gennemgataende lidt støre 01; kun i Haldsø syntes Maks. at vare betydelig storre i 02 end 01. Det fremheves, at Arten, naar den i Maj viser sig i Plankton, altid optraeder som smáa, uregelmassig snoede Traade. De af Klebahn omtalte Edderkop-agtige Nøgler kommer først frem hen imod Tidspunktet for Sporedannelsen og plejer at forsvinde omtrent samtidigg med denne; medens Algen endnu er Planktonorganisme nde i Søens centrale Partier, dør Traadene bort, men Sporerne bliver i et Antal af 20-50) tilbage i Gelehylsterel og lıoldes svavende al dette c. 1-2 Maaneder, efter at Algen i øvrigt er dorl ud; rla de senere forsvinder, maa de formentlig bundfældes.

A. flos aque er øjensynlig en over hele det mellemeuropeiske Lavland, Sydsverrig og Finland vidt udbredt Art; at angive de talrige Findesteder anses for overflødigt; i Schweizersøerne, hvor Cyanophyceerne son bekendt er lidet fremtræende, er den i Følge Chodat (97 a. p. 311 o. a.) en af de hyppigst forekommende Planktoncyanophyceer (se ogsaa l3achmann 01); den er ligeledes almindelig i de norditalienske Søer (Garbini 98 b. p. 669); i alpine og subalpine Søer kommer det dog sjældent til nogen Vandblomstdannelse (Lagerheim p. 18).

Apstein (96 p. 136), Zacharias (94 b. Planktontabel p. 100) angiver for Plönersøerne, Seligo (00 p. 54) for Stuhmersøerne, Borge (00 p. 7) for Valloxensøen, Lauterborn (93a. p. 8) for Altrhein samme Periodicitet som vi. Derimod meddeler C. Schröter (97 p. 23 . [Forel]), at Planten dannede Vandblomst i Genfersøen 10. Debr. 96. Strohmeyer (97 p. 22) angiver, at A. fl. a. sammen med Aphanizomenon er den Cyan., der senest 6. Nov. og tidligst 11. Juni danner Vandblomst i Hamburgervandværkernes Bassiner.

Ogsaa Strodtmann (95 p. 151) har iagttaget denne ganske kortvarige Vandblomst i Plönersøen og set, at den kun varer nogle faa Dage.

Om de af C. Schröter o. a. omtalte Vorticeller paa A. flos aqua se senere.

Anabrina spiroides Kle balı n.

Tab. X, Fig. 119 og 120 og Tekstfig. 1 p. 46.

Klebah n 95. Tab. IV, Fig. 11-15.

Den i Gudenaaens Søer og i andre jydske Søer optrædende skruesnoede Anabena-Art er utvivlsomt identisk med den af Klebahn (95 p. 268) beskrevne A. spiroides. Ostenfeld (95 p. 203) har bestemt Arten til den nærstaaende $A$. circinnalis, og Schmidt følger $(99$ p. 368) O. heri. Sporen, son O. ikke havde Lejlighed til at iagttage, er imidlertid kuglerund, saaledes som Klebahn afbilder og beskriver den for $A$ spiroides Vedkommende, og ikke cylindrisk, krum og skev som hos A. circinnalis. Der kan hos A. spiroidles vel optræde Sporer, der ikke er absolut isodiametriske, men vi har aldrig set Sporer, hvor Forholdet mellem Tværog Længdeakse var som $1-4$ (A. circinnalis).

Af $A$. spiroides har Klebahn endvidere beskrevet var. contracta, væsentlig karakteriseret ved sine langt mere tæt trængte Skruer. Skruevidden hos A. spiroides er i de forskellige Søer en Del forskellig; at opstille en særlig Varietet for de smalskruede Former anser vi for overflødigt.

Viborgsø. A. s. optreder $01{ }^{18}:$ Tp. 14 i ganske enkelte Traade med $4-6$ Vindinger; ${ }^{10} / 7$ Tp. 21 er Antallet steget betydelig, og den findes nu som lange, skruesnoede Baand med indtil 20 Vindinger. $7 / 8$ Tp. 23 er Forholdet uforandret; derimod er Arten strerkt aftaget $15 / 9$ Tp. 12; de sidste Smaastykker saas ${ }^{11} / 10$ Tp. 12 . I 02 fandtes $A . s p$. kun i faa Eks. ${ }^{27} / 7$ Tp. 15; Sporer er mærkelig nok ikke sete.

Julsø. A. $s$. findes $0120 / 5$ Tp. 13 i enkelte Smaastykker paa $4-6$ Vindinger. Antallet er steget stærkt ${ }^{10 / 7}$ Tp. 20; meget lange Spiraler paa 20-30 Vindinger er almindelige; 1/8 Tp. 22 er det vistnok yderligere tiltaget, og Sporer er nu hyppige; ${ }^{15} / 9$ Tp. 12 er Antallet omtrent uforandret, men næsten alle Traade berer Sporer. ${ }^{15} / 10$ Tp. 12 findes kun faa Traade i faa Vindinger, Sporer er kun paaviste i enkelte Traade; ${ }^{20} / 11$ Tp. 6 findes kun ubetydelige 


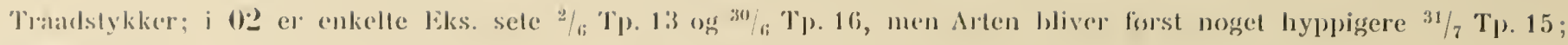
ingern Siporer.

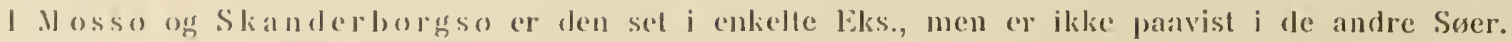

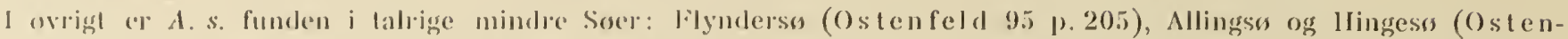

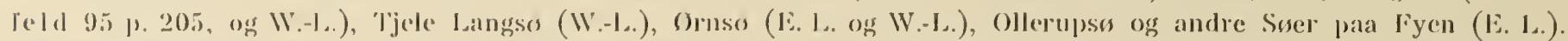

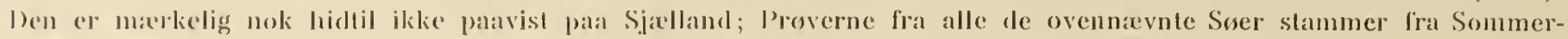
masnederne.

A. s. optrate: i det hele langt mere dominerende i Smaasøer, hvor den ogsaa i højere Grad bidrager til Vandblomstannelsen end i store Socr.

Med Hensy'n lil l’eriodiciteten forholder denne Art sig omtrent som foreganende, dog falder Maks. sammen med Vandets hojeste 'Pp., altsaa en Maaned senere end A. flos aquer's; Sporedannelsen indtraffer først i August.

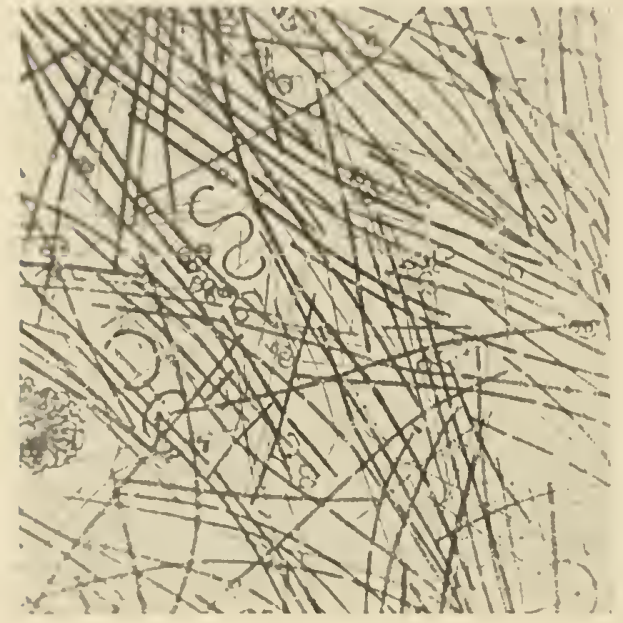

Telistfig. 1 .

Plankton fra Øruso. $3 / 801$

Anabena spiroides og A. macrospora.

Verl at sammenligne Eks. fra Viborgsø og Julsø finder man en karakteristisk Forskel. I Viborgsø er der gennemgaaende 6-8 Spiraler mellem liver Heterocyst, og selv meget store Skruer paa c. 24 Vin(linger har sjaldent mere end 3-4 Heterocyster. I Julsø derimod er der gennemgaaende Heterocyst for hveranden Vinding, og de store Skruer indeholder ofte 10-15 saadanne; Forskellen viser sig i 01 i de Prøver fra begge Søerne, hvori Arten er hyppigst, og lader sig ogsaa parvise paa det ikke store Antal Individer, der blev iagttaget 02.

I Planktonarbejder er A.sp. og A. circinnalis sammenblanderle, men ogsaa i Udlandet synes begge disse Arter i Talrighed at staa tilbage for $A$. flos aqua, ligesom ogsaa deres Evne til at danne Vandblomst dér synes at vare ringe; i Mrengde angives den kun af Seligo (00 p. 54) fra Barlewitzer See, hvor et stort Maks. opstod i Juli. Seligo angiver, at de nærmest Heterocysterne liggende Celler angribes af en Chytridiacee, der faar Cellerne til at svulme stærkt.

Anabana macrospora Klebahn.

Tab. X, Fig. 119 nederst og Tekstfig. 1.

Klebahn 95. Tab. IV, Fig. 16-20.

Den i Gudenaaens Søer optradende, stavdannede Anabcna-Art er af Ostenfeld (95 p. 203) beskrevet som en sxerlig Art, A. stricta; den blev skilt ud fra den omtrent samtidig af Klebahn (95 p. 269) beskrevne A. macrospora, fordi Heterocysterne skulde være udstyrede med en ringformet Vagfortykkelse, som dog langt fra altid var lige stærkt udviklet. Denne Vagfortykkelse larler sig heller ikke konstant paavise i de i Formol konserverede Traade og skyldes rimeligvis et Kontraktionsfanomen i Skeden. (O.s Materiale var konserveret i $1 \%$ Kromsyre, vort i Formol).

A. macrospora var. crassa Klebahn (95 p. 270, Fig. 19-20) findes i mindre Antal i August-Septemberprøverne fra Julsø; at udsondre de herhen hørende tykkere Traade fra den typiske, noget tyndere A. macrospora er formentlig ikke nødvendigt.

Sporeme er hos demne Art - hvad man synes at have overset - omgivne af en mer eller mindre udstaaende vingeformet, hyalin Membran, som rimeligvis er en Del af Skeden og muligvis tjener som Svaveapparat.

Julso. A. m. er paavist i enkelte Eks. $0120 / 5$ Tp. 13; 10/7 Tp. 20 findes en Del; 1/8 Tp. 22 er Arten talrig, og en Del af Traadene er nu udstyrede med Sporer. $15 \%$ Tp. 12 er Antallet gaaet noget tilbage, Sporer findes nu masten i alle Traalene. ${ }^{15} / 10$ Tp. 12 er Arten omtrent forsvunden og kun paavist i ganske korte Stykker uden Sporer. ${ }^{20} / 1$ Tp. 6 saas de sidste Stykker. I 02 fandtes enkelte Eks. ${ }^{2} / 6$ Tp. 13, men Arten var forst ret alm. ${ }^{31} / 7$ Tp. 15 , paa hrilket Tidspunkt en Del Sporer blev sete. 


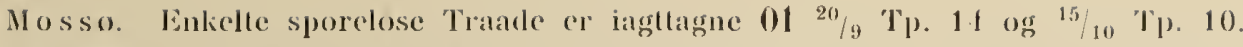

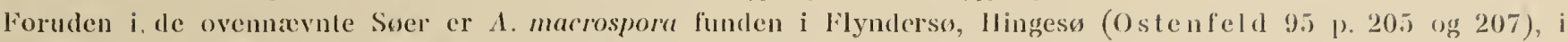
Sonderso, Tjele Lingso, Vindmolleso (Viborg). Ornsø (Silkeborg) af W.-L., Ollerupso og andre fynske Suer af li. L.

Ligesom foregaaende Art hører den vistnok overvejende hjemme i Smaasøer, hvor den kan optrade i høj Grad Vandblomst-dannende, f. Eks. i Ørnsø (01 "//8 T P. 24), hvor en kolossal Vandblomst iagttoges, og hvor den ad Aaen gennem Lysbro i enorme Masser førtes ud i Silkeborg-Langsø.

Ogsaa denne Arts Maks. falder sammen med Vandets højeste Tp., og Sporedannelsen finder først Sted i Aug.-Sep.

Den danner i Følge Seligo (00 p. 54) sammen med A. spiroides kolossale Planktonmasser i l3arlewitzersøen i Juli, men omtales i øvrigt ikke i Udlandets Planktonarbejder.

Det fremgaar altsaa heraf, at vi i vore større Søers Plankton kan paavise i alt Fald tre Anabcha-Arter, af hvilke $A$. flos aque er den hyppigst forekommende; de to andre, A. spiroides og macrospora, er væesentlig hjemmehørende i Smaasøer og synes særlig at forekomme vest for Store Bælt; kun A. flos aqua kan i større Søer være Vandblomst-dannende i stor Stil; dog er dens Vandblomst kun af ringe Varighed.

A. flos aqua's Maks. falder i Juni-Juli, Tp. 16-18, ved hvilken Tp. ogsaa Sporerne dannes; i August plejer Arten at forsvinde. A. spiroides og macrospora's Maks. falder sammen med Vandets højeste Tp., og Sporedannelsen er først livlig ved Tp. c. 20; Arterne holder sig til c. Okt.

Medens A. flos aqua omtrent forholder sig ens i den varme Sommer 01 og den kolde Sommer 02, var de to andre Arter, hvis Maks. falder ved Tp. c. 20, kun almindelige i Sommeren 01, men i 02 lige til 1. Aug. yderst sjældne.

\section{Aphanizomenon.}

Slægten, der i alt Fald her i Landet kun er repræsenteret af een sikker Art $A$. flos aqua, kendes let fra de øvrige Planktoncyanophyceer paa, at den hyppig optræder i Fnug med parallele Trikomer, samt paa, at Sporerne er lange, lige og cylindriske; se i øvrigt Schmidt (99 p. 375).

\section{A. flos aquace Allm.}

Tab. VI, Fig. 64.

Allmann 55, Tab. IlI, Fig. $1-8$.

Viborgsøerne. A. fl. a. er paavist $0129 / 3$ Tp. 1 i ganske enkelte Traade uden Sporer eller Heterocyster; det er rimeligvis overvintrede Traade, som vi her har med at gøre, 18/5 Tp. 14 er Antallet af Traadene kendelig tiltaget; de er meget lange og indeholder vistnok alle mindst een Heterocyst., undertiden to- tre; i Traade med kun een ligger denne i Almindelighed nar Traadens Midtpunkt; ud for Heterocysten viser Traaden, navnlig de lange Traade med mer end een Heterocyst, ofte et linæk, som om den her var ved at gaa over; Sporedannelse mangler; Vandblomsten er yderst svag. ${ }^{10} / 7$ Tp. 21 er Mængden af Traade noget tiltaget, de indeholder stadig Heterocyster, men ingen Sporer. ${ }^{7} / 8$ Tp. 23 er Antallet yderligere tiltaget; den danner nu sammen med Polycystis og Anabænerne en ret betydelig Vandblomst; Heterocyster findes i de fleste Traade, men mangler dog ofte $\mathrm{i}$ de $\mathrm{korte}$, og der er sjæeldent mer end een Heterocyst i hver Traad; santidig viser sig i en Del Traade umodne Sporer. $15 / 9$ Tp. 12 har Planten formeret sig kolossalt og danner en mægtig alt andet Plankton maskerende Vandblomst; der er nu talrige Traade uden Heterocyster; Sporedannelsen er i fuld Gang, og mange Traade bærer umodne Sporer, dog aldrig mer end een Spore i hver Traad; den sidder som oftest nær ved en af Enderne; son Regel finder man ikke Heterocyst og Spore i samme Traad. 14/10 Tp. 12 vedvarer det store Maks. endnu; Heterocysterne er sjældne, en Mangde Traade bærer Sporer, der nu omtrent er modne. 10/11 Tp. 8: Efter Meddelelse fra Fiskeren gik Vandblomsten i disse Dage af Vandet; den blev af Vinden i store Mrengder fejet ind paa Kysten og raadnede bort. Heterocyster er fra nu af sjældne; c. Halvdelen af Traadene bærer Sporer, forsynede med en tyk Væa. Foruden de enkelte Traade (se herom senere) findes talrige sporebæende Bundter eller Fnug; alle Sporer i samme Fnug ligger ud for hverandre, saaledes at der tværs over Fnugget ses et Sporebælte (Tab. VI Fig. 65); ikke sjældent ses kun disse Bælter, idet de øvrige Dele af Traadene er faldne af. I øvrigt findes i Planktonet talrige døde Traade; Traadene destrueres, idet flere og flere Celler tømmes for Indhold og bliver vandklare; disse Traade synes ved en flygtig Betragtning at være 


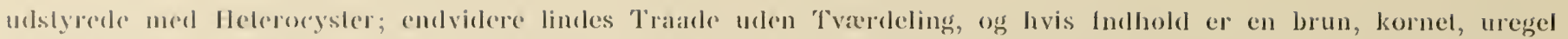

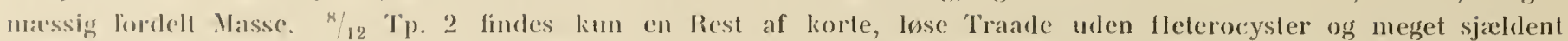

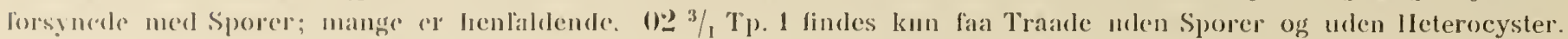

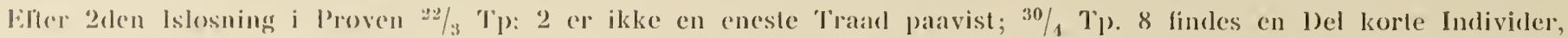

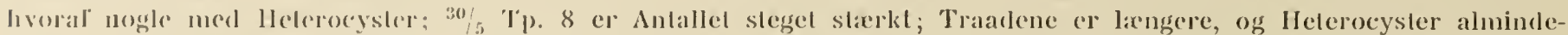

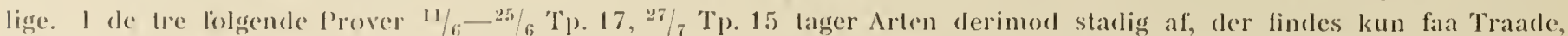
i Alm. med Heterocyster, liskeren medlelte, at der indlil 1. Sep. ikke havale vieret Vandblomst paa den dybere Viborg Norreso, hvorimol en sablan viste sig pá Sondersoen, der, som i lndledningen ontalt, er meget lavere.

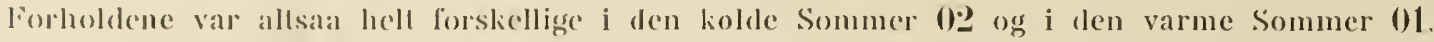

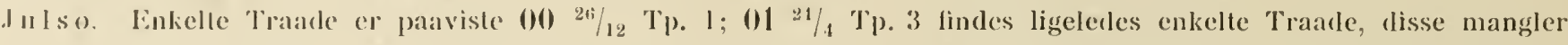
baale Heterocyster og Sporer; $20 / 5$ Tp. 13 ses Aphun. stadig kun med fia Traade, af hvilke len langt overvejende Del og sarlig de lange Traide er lorsynede mel Heterocyster i el Antal af 1-2. 10/7 'p. 20 er Arten bleven dominerencle og danner V'andbfomsl; Storstedelen af Traatene har endnu Heterocyster. 1/8 Tp. 22 danner Algen en meget tyk Vandblomst og maskerer ved sine Masser alt andet Plankton; lleterocyster findes sladig, men en hel Del Trable mangler dog disse. ${ }^{15 / 9}$ Tp. 12 er Ilyppigheden uforandret; Hovermassen af Traadene har endnu Heterocyster, men desforuden indeholder proven talrige lose Heterocyster; hvor vidt disse har drevet om i Vandmasserne eller forst er bleve frie i Proverne under Transporten vides ikke. Sporedannelsen er nu begyndt, den var ikke set i de lidligere Indsamlinger, men Sporerne er endnu umodne. 15/10 Tp. 12 er Hyppigheden vistnok uforandret; Heterocyster mangler i de lleste Traade, og Sporedannelsen er i fuld Gang; Sporebundter (se Viborgsø) er almindelige; $20 / 11$ Tp. 6 er Arten stærkt aftaget, alle længere Traadstykker bierer nu molne Sporer, Heterocyster iagltages kun undlagclsesvis, derimod store Mangder hendøende Aphan.; Proverne indeholder talrige frie Sporer. 02. Efter (len 1ste lsliegning indeholder Proven ${ }^{15 /}$ 'Tp. 1 ganske enkelte Traade uden Sporer og uden Heterocyster, og de mangler hell efter 2den lslosning i Proven $5 / 4$ Tp. 3; enkelte Eks. findes $5 / 5$ Tp. 6 og $2 / 6$ Tp. 13 . Antallet synes ikke tiltaget $30 / 6$ Tp. 16, og forst ${ }^{31} / 7$ Tp. 15 findes en Del Eks. Sporer er ikke set 02 , Heterocyster er yderst sjaldne $5 / 5$, men hyppige $31 / 7$.

Det vil heraf ses, at Aphan. ogsaa i Julsø forholder sig yderst forskelligt i den varme Sommer 01 og i den kolde 02 ganske i Overensstemmelse med Aphan. i Viborgsoerne.

Haldso. Forholdene i Haldsø er overmaade uklare. Indtil $01{ }^{10} / 11$ Tp. 10 paavistes $A$. $f l$. $a$. vel i næsten alle Proverne, men kun enkeltvis; da bliver Algen pludselig almindelig og opnaar $8 / 12$ Tp. 4 et stort Maks., der holder sig indtil $3 / 1$ Tр. 2. Efter Islosningen er den $0.22 / 3$ Tp. 2 meget sjælden, men bliver atter hyppig $30 / 5$ Tp. 8 ; den holder sig derpaa med et mindre Maks. til 11/6 Tp. 12, hvorpaa Arten tager af og næsten ganske forsvinder $3 / 7$ Tp. 14. Hos de i Nov--Dec-Proverne 01 optrædende Individer har vi ikke med Sikkerhed kunnet paavise Heterocyster.

Det ganske markelige Forhold, at en Aphan. opnaar sit Maks. ved Tp. 4-2, medens dette ellers plejer at indtræfe ved Vandets hojeste Tp., tyder stærkt paa, at vi her havde med en egen Art at gore. Denne kunde i saa Fald næppe været nogen anden end Oscillatoria Agardhii, som af P. Richter (96 p. 263) tidligere er bleven erlileret for identisk med sterile Heterocyst-lose Eks. af Aphan. flos aquœ. Formodningen herom er bleven bestridt af Schmidt (99 p. 351), der gor opmarksom paa, at en Hætte altid mangler hos Aphan., medens den er vel udviklet hos O. Agardhii. Da vi aldrig har kunnet paavise Hatte paa Eks. fra Haldsø, henfører vi, idet vi stotter os til Sch midt, forelobig Algen til A. flos aquce, og navnlig fordi de Individer, der atter viste sig i Maj-Juni, var typiske Aphan.-Traade med vel udviklede Heterocyster (Tab. VII Fig. 82 og 83). Hos ingen Aphan. i Haldsø har vi kunnet paavise Sporer, og vi har heller aldrig her set Traadene forenede i Fnug.

Idet vi formoder, at disse Forhold i Haldsø endnu er uforstaaede, gør vi kun opmarksom paa, at Aphan. ogsaa andetsteds er optraadt om Vinteren. Saaledes angiver Magnus (65 p. 129), at Aphan. i Reinichendorfersee nar Berlin havde farvet Isen grøn i de øverste 5 Centin.; i den Anledning beordrede Øvrigheden den narmere undersøgt. Magnus paaviste, at denne Vinter-aphan. manglede Sporer og Heterocyster, ganske som Tilfaldet var i Haldsø, og Richter, der havde Materiale fra Magnus til Eftersyn (96 p. 272), bekrafter dette. Ogsaa Levander angiver, at Aphan. kan optræede om Vinteren dels i den finske Havbugt (00a. p. 13 ) og dels i Lojosøen (00 b. p. 36).

Da Aplınizonenons Maks. ellers, saa vel her i Landet som paa talrige Lokaliteter i Udlandet, nøje er knyttet til Vandets højeste Tp., ser vi i det følgende bort fra Forholdene i Haldsø i Haab om, at disse Vinter-Aphanizomenoner《 senere maa blive naermere undersøgte. 
I alle de ovrige Soer er der, med Undlagelse af Sorøsø, til forskellige 'Tider parvist enkelte Aphan.-'Traade; vi har for disse Soers Vedkommende vistnok altid med tilfeeldig udforte Indlivider al gøre, der ikke er hjemmehørende i vedkommende Sos pelagiske Region. - Ved Damundersøgelsen 98 blev Arlen ikke paavist.

Aphan. er i ovrigt pavist af Rosenvinge i Fortundammen, hvor den dog ikke er dominerende; af W.-l. blev den funden i Mangde i Rundedam i Frederiksborg Slotshave og af E. L. i Langesu og mindre Soer paa Fyen. I Flyndersø og Gudenatomraadet paristes den først af Oslenfeld. Arten er altsaa vidt udbredt her i Landel og findes baade i Søer og Damme, men det er dog undtagelsesvis, al den danner de uhyre Maks. og den alt maskerende Vandblomst.

Angivelserne om dens Optræeden og navnlig om nogen massevis Forekomst i Udlandets Søer er ret sparsomme. Den er saaledes meget lidt fremtrædende i de holstenske Soer, den er ikke paavist i Vettern og synes ganske at mangle i Schweizersøerne og Bodensøen. Derimod er den funden i England og Irland (Allmann 55 p. 21), i Sverrig (Borge 00 p. 7), i Finland (Levander 00 a. p. 13 og 00 b. p. 36), i Nordtyskland (Lemmermann $00 \mathrm{~g}$. p. 141, Magnus 83 p. 129, Richter 96 p. 272 o. a.), talrige Steder i Bøhmen (Hansgirg 92 p. 73) og i Ballatonsø (Istvánffi 98 p. 21). Den forekommer ogsaa i Brakvand ved vore Kyster (se Schmidt 99 p. 376), ved Finlands Kyster (Levander 00 a. p. 13), hvor den skal være Hovedform i den finske Havbugt, ved Nordtysklands Kyster, hvor den optræder massevis i Zwischenahner Meer, Watersneferdorfersee, Kurische Haff og Frische Haff.

Af de her givne Meddelelser kan med Hensyn til Aphanizomenon's Biologi følgende mere almindelige Bemærkninger fremsættes; vi lægger særlig Væglen paa Forholdene i Viborgsø, Julso samt i et Par Smaasøer i Nordsjælland, hvor Arten blev iagttaget af W.-L. De sporebærende Traade, der i Nov.-Dec. dels synker til Bunds, dels af Vinden fejes ind imod Bredden og aflejres her, raadner bort med Undtagelse af Sporerne; ingen eller kun et yderst begrænset Antal Traade holder sig levende Vinteren over; disse mangler Heterocyster og Sporer. I Maj Tp. 10-12 spirer Sporerne, og Traadene viser sig nu i Planktonet; disse Traade har Heterocyster, i Alm. kun een, undertiden to. Antallet af Traade tiltager i Tiden fra Maj-Sep., i Begyndelsen ( $\mathrm{T}$ ). 12-18) ret langsomt, men senere (Tp. 18-22) overordentlig stærkt, hvad der i Aug.-Okt. kan have en kolossal Vandblomst til Følge. Lige til Aug. findes Heterocysterne næsten konstant i Traadene; senere bliver de stadig sjaldnere; i Slutningen af Aug. begynder Sporedannelsen, denne naar sit Maks. i Sep.-Okt. Tp. 12-10, paa hvilket Tidspunkt Heterocysterne kun paavises i faa Eks.; de forsvinder helt i Nov.-Dec.

Sammenligner man Aphan. Optræden 01 med dens Optræeden 02, finder man meget karakteristiske Forskelligheder. I begge Iagttagelsesaarene begynder Udviklingen saa vel i Viborgsø som i Silkeborgsøerne omtrent samtidig $\left(15 / 5-{ }^{30} / 5\right)$. I 01 stiger Antallet jæevnt, og i alle Søerne opviser Arten kolossale Maks. i Aug.-Sep. I 02 hæmmes derimod Udviklingen saạledes, at Antallet i Viborgsø gaar overordentlig stærkt tilbage; tidligst i Aug. begynder igen en svag Stigning; i Julsø synes Maks. ganske at udeblive.

Denne paafaldende Uensartethed i Optræden kan uden Tvivl føres tilbage til de meget forskellige Temperaturforhold 01 og 02 . Spiringstp. (Tp. 10-12) er selvfølgelig til Stede begge Aarene, og Spiringen gaar derfor ogsaa normalt for sig saa vel i 02 som i 01; den høje Sommertp. (Tp. 20--22), som betinger den livlige Dannelse af Hormogonier, og hvoraf det store Maks. med sin kolossale Vandblomst afhæenger, optræeder kun i 01; i Overensstemmelse hermed ser vi da ogsaa, at Vandblomstrenomenet i 02 er svagt udviklet.

Den ovenfor meddelte Periodicitet er den samme, der angives af Borge (99 p. 8-9) for Valloxensø, af Lemmermann (00g. p. 139) for Zwischenahnermeer og af Seligo (00 p. 5is) for Stuhmersøerne. Vandblomsten angives næsten altid at være stærkest udviklet Aug.-Sep.

Angaaẹde Aphan. Optræelen i Viborgsø og Silkeborgsøerne kan endnu følgende tilføjes. Der er ingen Trvivl om, at Aphan. er hjemmehørende i Viborgsø; den føres ikke med noget Tilløb ind i Søen; Hovedtilløbet fra Loldrupsø blev i Aug. 01 undersøgt og indeholdt ikke Aphan. Bundprøver fra Viborgsø, tagne i Vinteren 01, indeholdt talrige Sporer. For Julsøs Vedkommende stiller Forholdet sig noget anderledes. 
Guctenaa lober omtrent planktonfri ind i Mosso og forlader denne So ladet med sammes Plankton; der imidlertid ikke indedolder Aphan. Det er forst gentem Saltenaa, der danner Allobet fra Salten-Langsø, al Aphun. gydes ud i Cindenaien, som derpata forer Algen videre ud gennem Silkeborgsøerne. Ved Aaens Udløl) i Havel (verl Randers) lindes nnder de store Maks. nede i Soeme vel betydelige Aphan. Kvantiteter, men del synes dog, som on den storste Del forbliver i Søerne. Fra Saltenaa og Salten-Langsø foreligger to

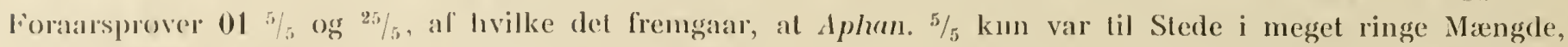
hrorinod Preven indeholdt store Miengder af Melosirer; ${ }^{25} / 5$ viste Prøven en mere ligelig Blanding af disse. Plankinonets IIovedtyper. Endvidere foreligger to Prover fra $9920 / 8$ og $0125 / 8$. I begge fandtes enorme Masser af Aphan.; ikke son Vand, men som en grøn, siruptyk Vadske valter Saltenaa paa dette Tidspunkt ud i Gudchaaen, medforende utrolige Masser al Aphan. Set fra det Sted, livor Saltenaaens og Gudenaaens Vande blandes, er Farveforskellen mellem Vandet i de to Aacr inden og umiddelbart ved Sammenløbet meget iojnelialdende.

Skont alle de Silkehorgsøer, der ligger nord for Saltenaaens Indløb i Gudenaaen, saaledes væsentlig skyłder Salten-Langsøs Aphanizomenon-Masser deres grønne Vand, har (log en stor Del Aphan. øjensynlig erhvervet sig Borgerret i disse og dannes lier.

I Maj 98 og 02 fandt W.-L. nemlig, at der paa talrige Steder af disse Søers Bredder, navnlig paa side, halvt afsperrede Arealer, hvor Strømmen ikke kunde gøre sin Indflydelse galdende, laa ung, svag Vandblomst af Aphan., der nxppe kunde vare dannet paa anden Maade, end ved at de paa vedkommende Lokalitet bundfeldede Sporer her har spiret.

Der indskydes her nogle Bemarkninger vedrørende Heterocyst- (E. L.), Spore- og Fnugdannelsen (W.-L.) hos Aphanizonenon. Angaaende Heterocysterne meddeler E. L. følgende:

Betragter man Aphan. i Prøven 01 18/5 fra Viborgsø, ser man, at de fleste Filamenter viser et Knæk omtrent paa Midten; (len Celle, der sidder i Knækket, afviger altid mer eller mindre fra de øvrige; ved at sammenligne disse Celler fra forskellige Traade med hinanden, ser man, at det er Heterocyster paa forskellige Udviklingstrin.

Ved sin første Fremkomst er Heterocysten næppe til at skæhe fra de vegetative Celler, men farver man Filamentet med Methylenblaat, antager Heterocysten en anden Farvetone end de vegetative Celler; desuden indeholder den unge Heterocyst som oftest færre Luftvacuoler end de vegetative Celler; disse Luftvacuoler har fortrinsvis deres Plads ud mod Heterocystens Vag. Paa lidt æeldre Heterocyster opdager nan (ligeledes lettest ved Farvning) en ganske fin Linie langs Omkredsen; enten fremkommer denne ved, at Heterocysten her har trukket sit Indhold noget sammen, eller ved, at Heterocystens Membran har fortykket sig noget; Luftvacuoler findes endnu, men i ringe Mængde. Paa de følgende Udviklingstrin forsvinder disse samtidig med, at Mlembranen bliver tydeligere, men endnu ser man intet til de for den fuldt færdige Heterocyst karakteristiske, kugleformede Legemer. Mellem Heterocysten og de nærmest tilgrænsende vegetative Celler viser sig derpaa ved hver Ende et lille lysbrydende Punkt, som stadig tiltager i Størrelse, idet det skubber Heterocystens Indhold ind imod dennes Centrum. Punkterne, der efterhaanden bliver mere lysbrydende, er identiske med de kugleformede Legemer eller Knopper, hvis Betydning vi i øvrigt ikke er klare over. Endelig danner der sig i begge Heterocystens Ender en lille Skaal, Ivori de tilgransende vegetative Celler hviler. Heterocystens Membran viser ofte en tydelig ringformet Liste omkring Midten.

De regetative Celler, der granser umiddelbart op til Heterocysten, er gerne mindre, og mere runde end de ørrige; jo fjærnere fra Heterocysten, des længere bliver Cellerne; de yderste Celler er gerne store, oppustede og delvis tømte for Indhold. Heraf fremgaar altsaa, at Celledelingen foregaar livligst i den Region, der støder umiddelbart op til Heterocysten. Et Filament med en Heterocyst har saaledes paa en Maade to Vækstpunkter grænsende umiddelbart op til denne.

Med Hensyn til Heterocysternes Betydning gaar man i Almindelighed ud fra (Kirchner 00 p. 71), at de tjener til at afbryde og begrænse Filamentets Vakst. Det synes ogsaa af det foregaaende at fremgaa, at 
Forbindelsen mellem en Heterocyst og de lilstodende vegetalive Celler er lasere and mellem disse indlyyrdes; al muligt Brud vil derfor lettest kumne finde Sted her. IVad der yderligere styrker denne Opfattelse af Heterocysternes Betydning er dels, at man ofte finder Tratle, der ender i en Heterocyst, hvad der kunde tyde paa, at en Traad lrer har delt sig i to, dels og navnlig, at man hyppig støder paa Filamenter, der netop ud for Heterocysten viser et meget karakteristisk kñek, som om Traaden her var ved at gaa millt over.

Den ovenfor givne Forklaring af Heterocysternes Betydning spreder endvidere noget Lys over et under Viborgso og Julso omtalt mærkeligt Forhold. Vi saa der, at Heterocysterne var almindelige i 'lraadene lige til August, o: indtil det store Maks. med den kolossale Vandblomst var naaet, men at Heterocysterne derpaa gradvis $\log$ af, samtidig med at Sporedannelsen stadig tiltog. Gaar man nu ud fra, at Dannelsen af nye Traade er betinget af eller i hvert Fald i høj Grad lettes ved Tilstedevaerelsen af Helerocysterne, er det forstaaeligt, at Heterocystdannelsen falder sammen med Traadformeringen, og at den ophører paa det Tidspunkt, da Maks. er naaet, og en yderligere Traadforogelse ræsentlig ophørt; naar dette indtraffer, begynder Sporedannelsen. Man har tidligere været i Tvivl om (Allmann 55 p. 23, Richter 96 p. 269 ), hvor vidt en Traad samtidig kunde bære Helerocyst og Spore; paa Sporedannelsens første Stadium kan man iagttage umoden Spore og Heterocyst paa samme Traad (Aug.-Sep.), men der er i øvrigt Grund til at tro, at for de Filamenters Vedkommende, hvor Sporedannelsen er begyndt, indstilles Heterocystdannelsen og derfor ogsaa Dannelsen af nye Traade.

Ved at gaa Littr. efter viste det sig, at Bruno Schrøder $(00$ p. 76$)$ for Stuhmersøernes Vedkommende allerede før os havde paavist, at Heterocysternes Optræden vasentlig hører Forsommeren til og ophører, naar Sporerne dannes; han gør tillige opmærksom paa, at Traadenes Endeceller bliver abnormt forlængede og farveløse fra det Tidspunkt af, da Heterocysterne forsvinder; dette Forhold, som vi havde overset, kan vi efter fornyet Undersøgelse af Materialet bekræfte. Sporedannelsen er nøjere bleven studeret af Allmann (55 p. 21), hvis Resultater vi ganske kan slutte os til. I Midten af August viser der sig i Traadene enkelte stærkt lysbrydende Partier, der fremkommer ved, at en Række Celler delvis tømmes for Indhold; samtidig synes det, som om Grænsen mellen de enkelte Celler forsvinder; vi henviser i øvrigt til Allmanns Fremstilling og Figurer.

Paa Grund af de Mængder af Sporer, der i Nov. viser sig i Planktonet, maatte man gaa ud fra, at disse ogsaa i Mængde vilde kunne paavises i Søgytjen. Særlig formodede vi, at Sporerne, efter at den henraadnende Vandblomst var bleven fejet ind imod Land, vilde blive underkastet en Slemningsproces og fremkalde en Lokalophobning i et Bælte i en vis Afstand fra Land.

Med denne Tanke for Øje undersøgte W.-L. Forholdene i Viborgsø og Julsø (Maj 02), men paa Grund af stormfuldt Vejr kunde en systematisk Undersøgelse ikke gennemfores. I Søgytjen fandtes talrige Sporer, men on deres Allejringsforhold kunde sikre Oplysninger ikke tilvejebringes.

Som bekendt slutter de enkelte Traade sig sammen i større eller mindre Fnug, og lige til den seneste Tid afbildes og beskrives Algen kun i Fnugstadiet. Det er først Undersøgelserne fra de aller sidste Aar (Richter 96 p. 263, Lemmermann $00 \mathrm{~g}$. p. 141), der har belært os om, at Algen tillige optræder som frie Traade. Naar Planten i Maj viser sig i Plankton, findes den, saa vidt vides, kun som enkelte Traade; Fnugdannelsen er et Fænomen, som bliver mere og mere fremtrædende, jo stærkere Formeringen foregaar; den er efter vor Opfattelse betinget af Vandblomstdannelsen og foregaar ikke, før Søen rummer en saa betydelig Aphanizomenon-Mængde, at de enkelte Traade kan støde sammen i Vandspejlet og her klæbes til hverandre.

I 97 havde W.-L. Lejlighed til direkte at iagttage Fnugdannelsen. Rundedam i Slotshaven (Frederiksborg) var en Dag i Juli Kl. 6 Morgen dækket med et sammenhængende, meget tykt Aphanizomenon-Tæppe; en Times Tid senere havde Tæppet under den første svage Morgenbrise opløst sig; ved narmere Betragtning saa man da, at Vandblomsten var bleven forvandlet til talløse c. $2 \mathrm{~cm}$. lange $0 \mathrm{~g} 3 / 4 \mathrm{~cm}$. brede Fnug, til- 
spidsede ud imod linderne ogr svigh skruesnoede; alle linuggene stod lodret i Vandet. KI. 12 Middag, da Vinden var beven starkere, og Soens Overflade var i ualbrudl bevagelse, var Finuggene kun halve sala store, og ide folgende l)age efter sterk Vind af normal Storrelse, ligesom der samlidig fandtes talrige enkelte Traade i Vandet.

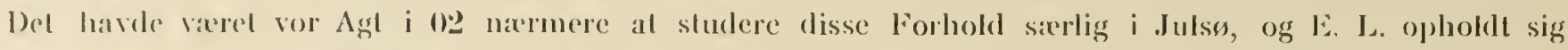
blande andel need dette Formal for Oje i Angust i Laven ved Julsø. Som ovenfor omtalt udeblev Vandblomstdamnelsen 02, og vi kunde derlor ikke laa lagllagelsen fra 97 yderligere bekraflet.

Ví er dog tillojelige til al tro, al $\Lambda$ lgen normall kan forekomme son enkelte Traade, og vi bestyrkes $\mathrm{i}$ denue Oplattelse ved, al de os tilsendte Prover nesten allid kun indeholdt Aphanizomenou som Traade.

Del maa overlades fremtidige Undersøgere at afgøre, om Fnugdannelsen ikke er starkest efter blikstille Vejir, og on Traaddannelsen ikke sarlig opstaar under og efter Storm.

Ahlborn (9) p. 25) har giort den interessante lagllagelse, at Traadene $\mathrm{i}$ Bundterne er $\mathrm{i}$ en glidende Bevergolse i forhold lil hrerandre.

\section{Rivulariaceæ.}

P'anklonorganismer findes indenfor Fam. Rivulariacea kun hos Slægten Gloiotrichia. De fleste Arter af denne Skegl er oprindelig fasthxftede til Sten eller Planter, men rives ikke sjældent løs fra Underlaget og kan navnlig i Smaasøer og Damme til Tider føre en halv pelagisk Tilværelse. Udpræget pelagisk og aldrig fastsiddende er kun den med Luftvacuoler udstyrede G. echinulata.

\section{Gloiotrichia.}

G. echinulata Richter.

Tab. IX, Fig. 108.

Richter 94. Fig. p. 39.

G. echinulata er hidtil her i Landet kun funden af J. P. Jacobsen i Trorupsø i Thy (Nord-Jylland).

Uncler en Ekskursion ude paa Silkeborg-Langsø 02 $1 / 8$ fandt E. L. og W.-L. tre-fire Kugler, som vi straks formodede maatte vere G. echinulata; ved dernæst at underkaste Bredden en nærmere Undersøgelse fandt vi inde mellem Planteræksten adskillig flere Kugler; nærmere beset blev Planten med Sikkerhed bestemt til $G$. echinulata.

Da vi nu vidste, at Gloiotrichia echinulata netop paa dette Tidspunkt burde have sit Maks., og vi desuagtet kun kunde paavise et ringe Antal Kugler i Søen, sluttede vi, at Algen ikke var hjemmehørende i SilkeborgLangso, men med rindende Vand var bleven indfort i denne.

Silkeborg-Langso gennemstrømmes af Gudenaaen og staar ved denne i Forbindelse med de nærmere Aaens Udspring beliggende Søer, Mossø og Julsø. Da vi paa Grund af vort nøje Kendskab til disse Søers Plankton med Sikkerhed vidste, at Gloiotrichia ikke fandtes i disse, maatte vi gaa ud fra, at Algen paa Strakningen Silkeborg-Langsø-Julso maatte blive ført ind i Gudenaaen fra en Sø, der havde Aføb til denne.

Med denne Tanke for Øje berejstes Terrainet, og da de fleste Tilløb fandtes paa Sødragets Sydside, valgte vi først at undersøge denne $\mathrm{g}$ satte Nettene op i hvert eneste Afløb. Vi fandt da $013 / 8$ G. echinulata i Aflobel fra den langstrakte smalle Thorsø; Algerne valtede i enorme Masser gennem dette ind i Borresø, den af Gudenaaens Bredninger, der følger umiddelbart efter Julsø og c. 7 Kilom. fra Silkeborg-Langsø. Derpaa fulgte vi Aflobet op til Thorsø, hvor en Baad blev skaffet til Veje og et rigt Materiale erhvervet.

Alle Kuglerne var beklæedte med Periderm og Filamenterne udstyrede med overordentlig fine Haarspidser; Sporer lod sig endnu ikke paavise. Paa Grund af den oprorte Sø kunde vi ikke faa Vandblomstfænomenet at se. Vandet var grødet af de enorme Masser af Kugler, og i et Øjeblik var selv de grovt maskede Planktonposer tilstoppede. Kun inde mellem Breddens Plantevækst iagttoges en svag Vandblomsi, gulgraa af Farve og lysere end den af Aplanizomenon og de øvrige Cyanophyceer dannede. Algen var vel kendt af Omegnens Folk og kaldtes af disse for $\gg$ Aalexg (!). 
Derpaa blev Algens videre Skabne ude i Gudenaaen narmere fulgt; den passerede med Strømmen gennem Snevringen mellem Borreso og Gudenaaens naste Bredning, Brassø; her fandtes Algen i Maengde opskyllet paa den nordlige Bred; ude i Soens Plankton synes den ikke at vare videre hyppig; fra Brassø blev den med Gudenaaen fort ud i Silkeborg-Langso, lnor en Del Individer blev aflejrede; det Antal, der slipper ud af denne Gudenaaens sidste Bredning og naar ud til Havet, er vistnok meget ringe; i de Prover, som Ostenfeld i 99-00 har ladet lage ved Randers, er Algen ikke paavist.

Det fremgaar allsaa heraf, at Algens Hjemstavn er Thorsø; herfra føres den ind i Gudenaten, livor den gaar til Grunde. Angaaende den æeldre Littr. over G. echinnlata henvises særlig til P. Richters udmærkede Arbejde (94 p. 31). I 92 blev Algen funden af Zacharias i Plønersøeı og her i de følgende Aar nøjere studeret af ham (94 b. p. 106 og 95 b. p. 112), P. Richter (94 p. 31), Strodtmann (95 p. 166), Klebahn (96 p. 192), Lemmermann (96c. p. 181) og Apstein (96 p. 138); endelig er den af Seligo og Bruno Schroder angivet fra de nordtyske Søer Mauersee, Dadeysee, Schwentainersee og Legienersee (00 p. 79), derimod synes den ikke at være funden i Schweizersøeme, i svenske eller finske Søer.

Hovedtrækkene i Artens Biologi, saaledes som vi har lært den at kende gennem Richters, Strodtmanns og Klebalıns Undersøgelser er følgende:

Arten viser sig i Almindelighed i Slutningen af Maj i Plønersøen og de Søer, der gennem Schwentinen staar i Forbindelse med denne; paa dette Tidspunkt finder man sammenhobede Hormogonier, men de regelmæssige Kugler optræeder først fra Midten af Juni (Richter 94 p. 37); i Løbet af c. 14 Dage (Zacharias (94 b. p. 106) kan Arten da tage enormt til og danner derpaa indtil ind i August en saa kolossal Vandblomst, at den endog kan blive generende for Badende; før Sporedannelsen begynder, opholder Algen sig væsentlig i Overfladen og ikke under c. $10 \mathrm{M}$. (Zacharias 95 b. p. 112). Kuglerne mangler paa dette Tidspunkt Periderm (P. Richter 94 p. 38), hvorved forstaas det Lag af Gele, Snavs, Hormogoniespidser etc., som senere omgiver Algen. De enkelte Filamenter løber ud i lange traadfine Spidser, der ofte og navnlig senere hen paa Aaret brydes af, horved Kuglerne faar et pigget Udseende (deraf Artsnavnet: echinulata). Om end Kugleformen er den hyppigste, antager Arten dog ofte Pølseform. Sommermaanedernes rapide og kolossale Maks. skyldes dels den rigelige Formering af det enkelte Traadindivid, dels Formering ved Traadkonglomerater. Fra de ovennæunte Pølsers Polender afsnører der sig Kugler, ligesom der fra Kuglernes Indre skyder sig Kuglesektorer ud, der efter at være bleven frie af Moderkolonien runder sig af til nye Kugler (Richter 94 p. 38 og p. 44). I August iagttages Sporerne; først da udvikler Peridermen sig (Richter (94 p. 38). Algen synker nu dybere ned i Vandet (Zacharias 95 b. p. 114, Strodımann 95 p. 168); den tager derpaa af og er allerede $27 / 8$ (Strodtmann 95 p. 178) ved at forsvinde; Apstein angiver (96 p. 138), at enkelte Eks. endnu kan paavises i Nov.

Man gaar ud fra, at Peridermen, indesluttende Sporerne, synker til Bunds, og at disse overvintrer her; Bundprøver har man dog ikke tilvejebragt; Sporernes Spiring er ukendt; i Planktonprøver fra Slutningen af Maj har Richter (94 p. 41) fundet Sporegrupper sammenholdte af snavsede Gelemasser; i senere Prøver fandtes Traadbundter bestaaende af en af Traade dannet Længdeakse, hvorfra andre Traade udstraalede i alle Retninger; Richter formoder (94 p. 45), at vi her har Begyndelsen til G. echinulata-Kuglerne.

Man vil af dette Litteraturudtog se, at det Punkt, der endnu trængte til at blive nærmere belyst, særlig var Spørgsmaalet om Overvintringen og Kuglestadiets Dannelsesmaade.

Vi lod os da 01 15/9 tilsende Planktonprøver fra Thorsø, men Tidspunktet var for sent valgt, og Algen var næsten ganske forsvunden; der fandtes i Prøverne kun 5-6 Kugler med afstødte Haarspidser. W.-L. rejste da Maj 02 over til Thorsø forsynet med Skraber og Sigteapparat, og det lykkedes nu at skaffe et ypperligt Materiale til Veje til nærmere Studium af Overvintring og Kuglestadiets Damnelse.

E. L. besøgte Thorsø i Aug. 02, men G. echinnlata var da overmaade sjalden; den fandtes kun i enkelte Kugler.

Det fremgik af Bundprøven i Maj 02, at der paa Bunden af Thorso var bundfældet en talløs Mængde 


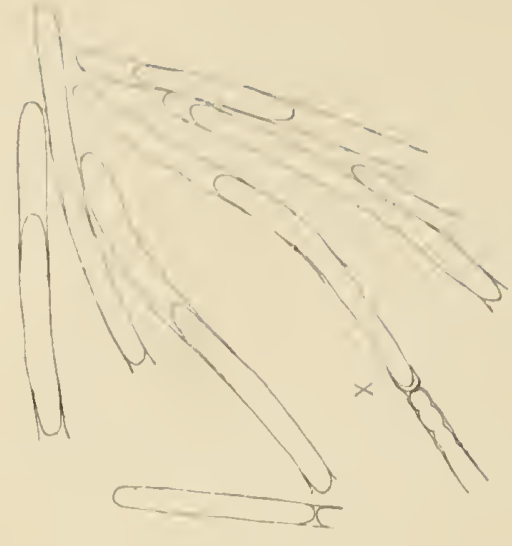

Fig. 1.

Brudstykke af en overvintret Gloiolrichialooloni. Forrige Aars Trable afbrudte, liun lidt af deres Vagge tillage $(x)$. Store sporer og spirende Sporer i cle gamle líader. 'Zeis' Vandim. E. l. del.

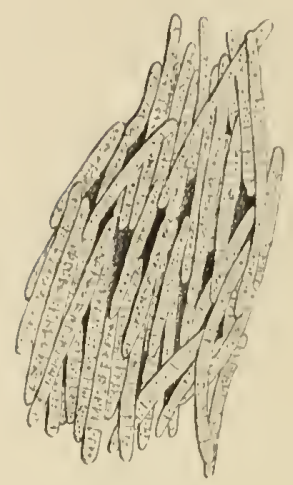

Fig. 2.

linug af (iloiolrichia-kimplanter. 1ste Stadium af den unge kooloni. De cukelte 'Trieliomer er enten Kimplanter eller Hormogonicr, dannede af saadanne. Leitz 4. E. L. del.

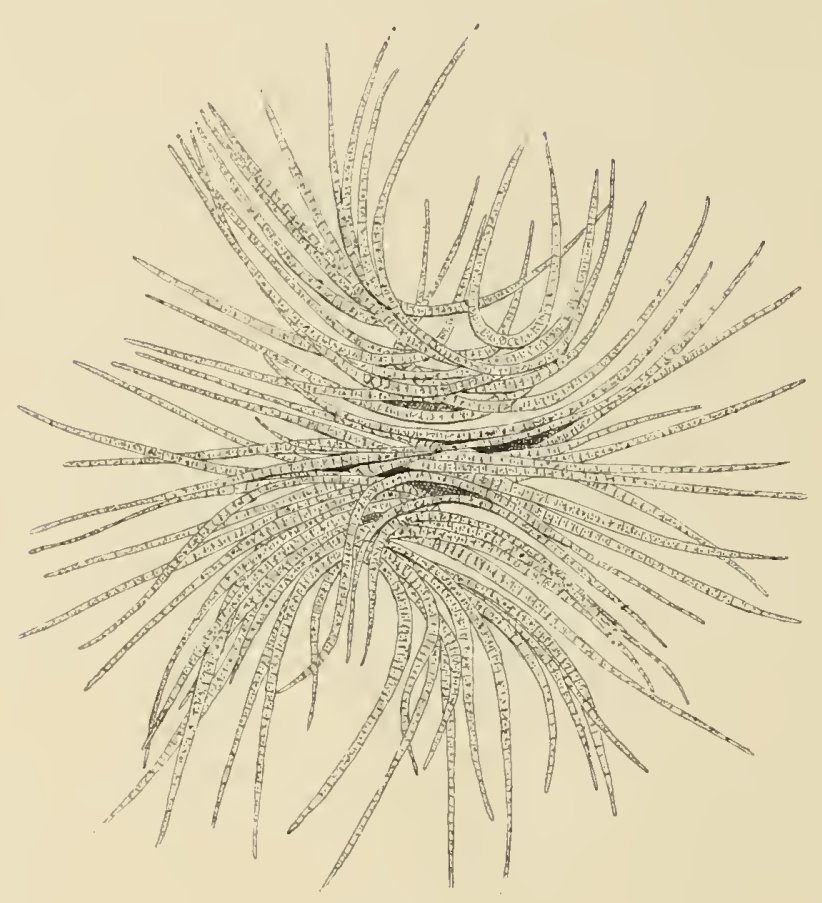

Fig. 4.

Ung Gloiolrichia-lingle, lidt trykket af Diekg]asset, Traadene straaler i Virkeligheden ud i alle Retninger; Traadenes Ender er nu tilspidsede, og Heterocystdannelsen er almindelig $\mathrm{i}$ Midten af hver Traad. Hele Kolonien har, naar den betragtes uden Dækglas, den udvoksnes Form, tydelig stort Gelelag. Leitz 4. E. L. del.

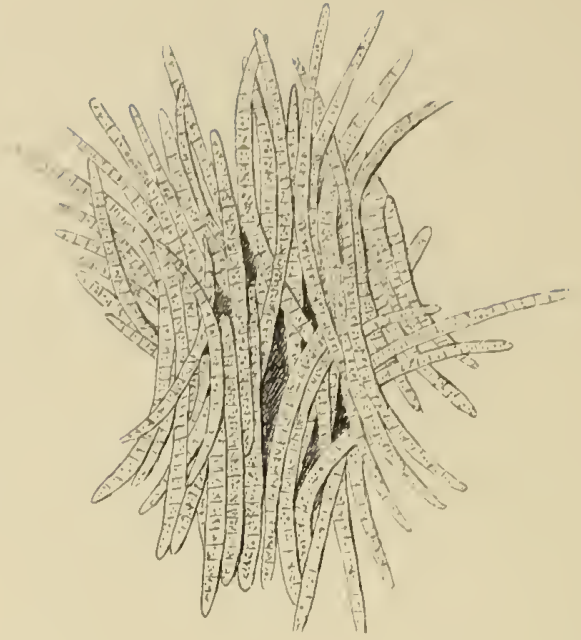

Fig. 3.

Kolonidannelsen videre fremskreden. Traadene krummer sig, Haardannelsen er begyndt. Heterocystdannelsen ligeledes.

Kolonien noget sammentrykt af Diekglasset; Formen er derfor ikke ganske naturlig.

Leitz 4. E. L. del.

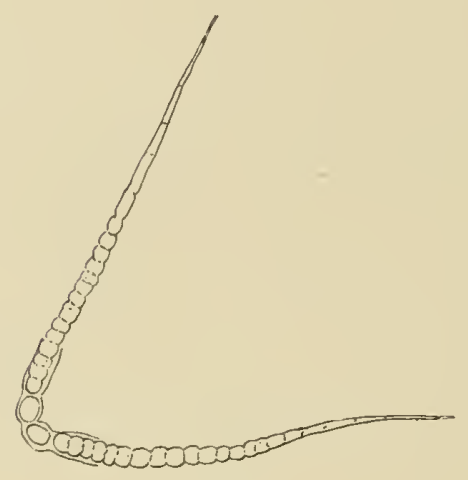

Fig. 5.

Traad af en ung Gloiotrichia-Koloni isoleret ved Knusning og farvet med Eddikesyre, Methylenblaat. To Heterocyster er dannede i Midten af Traaden red Deling af en ny Celle. Skededannelse begyndt. Zeis' Vandim. E. L. del.

G. echinulata-Kugler; de laa spredte over hele Søbunden; Søens Dybde oversteg ikke 9-10 M. og var gennemgaaende betydelig mindre. Gloiotrichia-Kuglerne befandt sig øjensynlig i et Hvilestadium; alle vegetative Traade var afbrudte, og tilbage var kun ${ }^{1}$ ) Heterocyster ved Basis, ${ }^{2}$ ) de derover siddende Sporer indesluttede i tykraggede Skeder, ${ }^{3}$ ) Vaggen af de umiddelbart tilgransende 2-3 vegetative Celler (svarende til Figuren hos Bornet og Thuret: II Fasc. Pl. XLII, Fig. 7), ") og Gelemassen, der omgar alle disse Dele. 
For narmere at folge !rlviklingen blev en Del al disse overvintrende Kugler bragt i Kulturer, der henstilledes dels i Sollys, dels i spredt Dagslys. I Lobet af nogle faa Dage spirede Sporerne; ved at trykke paa Noderkuglen kunde man presse dem frem i stor Mangde, hver af de unge Kimplanter skod liesten al de ovenfor siddende dode Cellers Viegge ud foran sig (Fig. 1). Samtidig fandtes talrige Moderkugler, paa hris Overllade smaa Knipper af unge Kimplanter laa aflejrede; faa Dage senere var vore Kulturer fulde af saadanne Knipper (Fig. 2). (Aphanizontenon-Stadiel).

Vi maa lade det henstaa uafgjort, om disse Knipper umiddelbart dannes af Kimplanter, eller oun der hos disse linder en Hormogoniedannelse Sted; vi haclder dog narmest til den sidste Opfattelse, baarle fordi vi i flere Tilf:elde har observeret en Egenbevagelse, og fordi vi har iagttaget Filamenter af mindre Langde end Kimplanterne (Fig. 1).

Overgangen til det almindelig bekendte kugleformede Gloiotrichia-Stadium gaar nu for sig paa følgende Maade: 1) De enkelte Filamenter i ḱnipperne vokser i Langde, ") Filamentet krummer sig halvmaaneformet (Fig. 3).

Efterhaanden som Filamentet krummer sig og bliver længere, udformes Cellerne paa forskellig Maade; de yderste Celler bliver længere, smallere og mere fattige paa Indhold end Cellerne ind imod Midten; tilsidst prasenterer de sig som de velbekendte fine haaragtige Spidser. Samtidig med disses Dannelse opstaar der i Midten af hvert Filament to Heterocyster; Forbindelsen mellem disse er løs, og paa dette Sted knækker Filamentet over; ved Farvning kan man paavise Begyndelsen til Skededannelsen (Fig. 4 og 5 ).

Slutningsstadiet er den unge Gloiotrichia-Kugle med alle sine Heterocyster ind imod Centrum og sine derfra i alle Retninger udstraalende Filamenter, tykkest mod Basis og enclende i fine Haar ude i Kuglens Omkreds; denne unge Kugle vokser yderligere ved falsk Forgrening.

l en Prøve fra 02 ${ }^{31 / 7}$ fandt E. L. en hel Række Delingsstadier. Allerede med blotte Øjne saa man let, at nogle af Kuglerne var ellipsoidiske og ofte med to--tre mørke Pletter inden for Ellipsoidens Omkreds. Betragtet under Mikroskopet viste det sig, at en Deling finder Sted ved, at Filamenterne i et Bælte omkring Ellipsoidens Midte ordnede sig, som om der var to Kugler inden for den fælles Gelekappe; Ellipsoiden snøres gerne over fra den ene Side, hvorved hele Kolonien ofte faar Udseende af en noget krumnet Pølse.

\section{ALMINDELIGE BEMARKNINGER.}

Man vil af omstaaende Schema se, at der i vore større Søers pelagiske Region optræder 15 Arter af Cyanophyceer; for saa vidt der ikke senere finder en Spaltning Sted af de af os accepterede Artsbegreber, vil Artsantallet næppe øges; en saadan Spaltning vil i øvrigt vistnok være berettiget, særlig inden for Begreberne Chroococcus og Polycyslis, maaske ogsaa for Oscillatoria's og Anabana flos aqua's Vedkommende (s. d.).

Artsantallet er vel ikke stort, men inden for de Tidsrum, hvori de enkelte Arter opnaar deres store Maks., griber de meget føleligt ind i vedkommende Søers Biologi. Saaledes influerer de paa Søvandets Farve; Vandmassernes Overfyldning med organisk Materiale bevirker, at de udviklede Luftarter indvirker skadeligt paa Søens Dyreliv og ofte foraarsager de særlige Søbundsaflejringer (Cyanophyceegytjer).

Kun Gomphospharia lacustris, Merismopedium elegans og maaske Liyngbya contorta har udelukkende floristisk Interesse.

Undersøgelsen over Planktoncynnophyceerne har tilvejelsragt en Del Oplysninger vedrørende de store Maks. og Betingelserne for deres Fremkomst; vi skal kort omtale disse.

1. Planktoncyanophyceernes Maks. ligger ved Temperaturer, der er meget forskellige hos de forskellige Arter, men yderst konstant for den enkelte Art. 
Plankton-Cyanophyceernes Forekomst i de undersogte Soer.

\begin{tabular}{|c|c|c|c|c|c|c|c|c|c|}
\hline & lineso & Esromso & Sorosts & $\begin{array}{c}\text { Tjustrup- } \\
\text { so }\end{array}$ & Viloorgsis & Haldso & $\begin{array}{l}\text { Slsander- } \\
\text { borgsts }\end{array}$ & Mosse & Julso \\
\hline 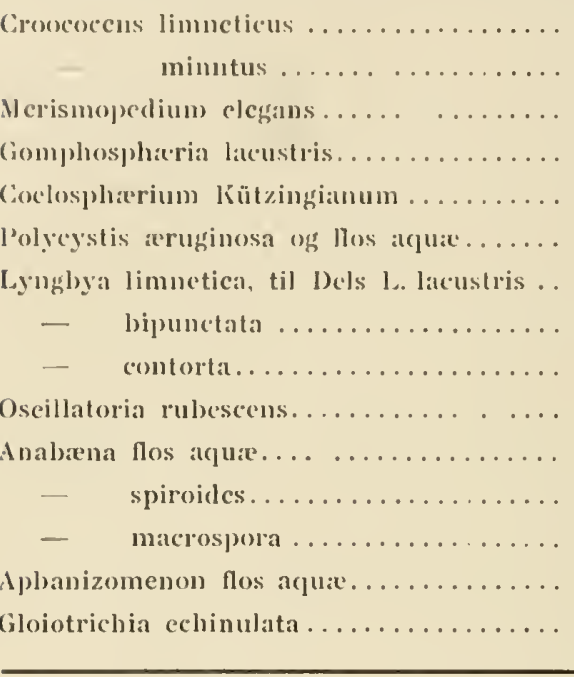 & $\begin{array}{l}(+) \\
(+) \\
(+) \\
(+) \\
\pm \\
(+) \\
\pm \\
+\end{array}$ & $\begin{array}{c}+ \\
(+) \\
(+) \\
+ \\
+ \\
+\end{array}$ & $\begin{array}{l}(+) \\
(+) \\
(+) \\
(+) \\
+ \\
(+)\end{array}$ & $\begin{array}{l}(+) \\
(+) \\
(+) \\
+ \\
(+)\end{array}$ & $\begin{array}{l}(+) \\
(+) \\
(+) \\
\pm \\
\pm\end{array}$ & $\begin{array}{l}+ \\
+\end{array}$ & $\begin{array}{l} \pm \\
\pm \\
\pm \\
\pm \\
+ \\
(+) \\
(+) \\
(+)\end{array}$ & $\begin{array}{l} \pm \\
\pm \\
(+) \\
\pm \\
\pm \\
+ \\
(+) \\
\pm \\
+ \\
+ \\
+ \\
(+)\end{array}$ & $\begin{array}{l}+ \\
(+) \\
(+) \\
(+) \\
\pm \\
+ \\
(+) \\
(+) \\
+ \\
+ \\
(+) \\
+ \\
\pm \\
+ \\
\text { (Borrese) }\end{array}$ \\
\hline
\end{tabular}

+ lyetegner, at Arten optracler konstant og er almindelig.

(+) - - - kun optrader tilfeldig og kun har floristisk (faunistisk) Interesse.

$\pm \quad$ - $\quad$ - er Hovedform og bar biologisk Betydning for Soen.

Ved den laveste TP. 2-5 indtræffer Maks. for Chroococcus limneticus, Lyngbya bipnnctata og Oscillatoria rnbescens; herhen maa ogsaa regnes Vinter-Aphanizomenonernes Maks. Maks. begynder før slægningen hæmmes maaske noget af denne og faar efter Isløsningen (Lyngbya-Oscillatoria) et endnu større Maks., der kan holde sig ved Tp. 10, undtagelsesvis Tp. 14. De tre førstnærnte Former forsvinder eller er dog sjældne fra Slutningen af Maj til Okt., hvorpaa de atter begynder at vise sig. Derpaa følger Anabøna flos aquex's Maks. Tp. 16-18 (Juni-Juli). Ved vore Søers højeste Temperatur (Tp. 20-23) indtræffer Maks. for Anabana spiroides, A. macrospora, Aphanizomenon, Gloiotrichia og rimeligvis ogsaa Polycystis, særlig P. aruginosa; disse Maks. varer fra Aug. til Sep., for Aphanizomenon's Vedkommende noget længere.

Først efter at Vandets Tp. er begyndt at aftage, Tp. 15-12 (Sep.-Okt.) falder Coelospharium Kützingianum's Maks., og snarest lidt senere, Tp. 15-10 (Sep.-Okt.) Lyngbya linnetica's Maks.

Vi indskrænker os her foreløbig til at bemærke, at der i alle vore Søer gives et Tidsrum (Slutn. af Maj og største Delen af Juni), hvor Vintercyanophyceerne er ved at forsvinde, og Sommercyanophyceerne endnu ikke er ret begyndt; vi kommer senere under Diatomeer, Dinobryum og Crustaceer tilbage til dette Tidspunkt.

Under Minimumet forsvinder Cyan. undertiden ganske, dette gxelder narnlig alle sporedannende Cyan.; alle Coccogonew samt Lyngbya og Oscillatoria træffes derimod til enhver Tid af Aaret i Planktonet, uden for Maks. som oftest $\operatorname{dog} \mathrm{i}$ saa overmaade ringe Antal, at det er vanskeligt at tænke sig, hrorledes disse Maks. kan opstaa alene af de faa Eks., som forefindes, saa længe Minimumet varer.

I Orerensstemmelse hermed er Maks. og Min. skarpest markerede hos de Former (Heterocyster ), hror der sammen med Min. er paavist en Hvileperiode og Hvileorganer; derimod gaar Maks. og Min. mere jærnt over i hinanden hos Coccogonex. Alle sporebærende Cyan. har deres Maks. liggende nær ved Vandets højeste Tp.; for saa vidt Planktoncyan. Maks. ligger ved lavere Tp., tilhører de alle enten Coccogonece eller Hormogonea Homocyster.

2. De fleste Planktoncyan. er til Stede i et større Antal af de undersøgte Søer, men deres store Maks. opnaar de kun i et begrænset Antal Søer. 
Sarterles oppreder Chroococens timneticus i is Soer, men kun dominerende i Mosso; Polycystis i 8, kun dominerende i Viborgso, L.yngbya limmetica i 7, kum i en, Oscillatoria rubescens i 7, kun i 2 , Anabarna flos aqua' i 9, kmn i 3, saml dphanizomenon flos atua' i 8, men kum dominerende i 2.

3. Ved Undersogelsen er iklie parvist nogen So, hvor et scrligt stort Anlal Cyanophyceer opnár betyclelige Maks. Soroso og Tjustrupso har overhovedet ikke navnevardige Cyanoplryceemaks.; Lsromsø og Ialdsø har hver el, i begge Tilfielde A. flos aqua, Fureso tre, Litngbyja limnetica, A. flos aqua og Oscillatoria rubescens, Mosso to, Chroococrus limmeticus og Coelospherium, Julso to, Coelosplurium og Aplunnizonenon, Skanderborgso fire, Coelosphurium, Lyngbya bipunctata, linmetica og Oscitlatoria rubescens, og Viborgsø tre, Coelosphurium, Polycystis og Aphanizonenon.

Ingen af de fire Maks. i Skanderborgso hører dog til de betydeligste.

4. Storrelsen af de Maks., som de enkelte Cyan. opnaar i vore Søer, er meget forskellis.

Det højeste Maks. opmas ubetinget af Aphanizomenon i Viborgso og Silkeborgsøerne ovenfor Saltenaa, saerlig i Salten-Langsø. Ogsaa Oscillatoria rubescens' Maks. i Furesø er meget stort og langvarigt.

Store, men meget kortvarige Maks. opviser Lyngtya lintnetica i Furesøen, Gloiotrichia i Thorsø og rimeligvis Chroococcus limneticus i Mosso samt A. flos aque i Haldsø.

Mindre Maks. naas af Polycystis og Coelospherium.

Ḱnn ubetydelige og kortvarige Maks. findes hos A.spiroides og macrospora; i Smaasøer kan de dog opnaa større Maks.

Dobbelt Maks. er her i Landet ikke med Sikkerhed paavist hos nogen Cyan.

5. De enkelte Cyanophycee-Arter opnaar ikke hvert Aar lige store Maks. i samme So.

De store Maks. af Cloiotrichia, Lyngbya limnetica og Aphanizonenon i 01 i henholdsvis Thorsø, Furesø og Viborgso samt Julsø lod sig aldeles ikke parise i 02, og Arter, der som A. spiroides og macrospora opnaede ret store Maks. i 01 , optraadte 02 kun enkeltvis.

Hrad er da Aarsagen til, at Cyanophycee-Arteme, skønt de findes i de fleste af de unclersøgte Søer, kun opnaar deres store Maks. i et begranset Antal af disse, og hvilke Forhold bevirker, at Størrelsen af disse Maks. kan variere saa sterkt fra Aar til Aar, at een Sø har Vandblomst, en anden ikke, og at Vandblomst- fænomenet i samme Sø ikke regelmassigt vender tilbage hvert Aar? Fuldt ud kan disse Spørgsmaal vel ikke besvares, men nærværende Undersøgelse har (log tilvejebragt visse Momenter, som kan bidrage til deres Løsning, og som vi her nærmere skal omtale.

Det fremgaar af 1, at for en ikke ubetydelig Brokdel af Planktoncyan. Vedkommende (Aphanizomenon, Gloiotrichia, A. macrospora, A. spiroides, Polycystes) indtræffer Maks. ved Tp. 20-22. Alene heraf følger, at disse Former aldrig opnaar deres store Maks. i Søer, hvis Tp. kun undtagelsesvis stiger over $18^{0} \mathrm{C}$. I Overensstenmelse hermed ser vi ogsaa, at disse Former kun kommer til Udvikling i lave, varme Søer (Viborgsø, Thorsø, Ørnsø, Salten-Langso), hvor Tp. i 01 i Aug. viste $20-22^{\circ}$ C.; derimod mangler de ganske eller udvikles kun svagt $\mathrm{i}$ de dybe, kolde og klare Soer Haldso, Esromsø, Fureso, Tjustrupso, hvis højeste Tp. i de fleste Aar nappe overstiger $18-19^{\circ} \mathrm{C}$., og som kun i meget varme Somre en kort Tid kan naa Tp. 20 -21.

I en af vort Lands dybeste og koldeste Søer, Almindso, blev de i Aug., selv i den meget varme Sommer 01, aldeles ikke paavist.

Selv i Silkeborgsøerne, af hvilke adskillige (Borreso, Brassø, Silkeborg-Langso) ubetinget maa henregnes til de lave og varme Søer, synes de fleste af disse Cyan. ikke til Stadighed at kunne trives.

Grunden hertil er rimeligvis den, at det Tidsrum, indenfor hvilket disse Søers Tp. er over 20-2‘2, er for kort til, at i alt Fald Gloiotrichia og Anabonerne her kan opnaa deres store Maks.; vi har her med Former at gøre, som fordrer en saa høj Temperatur, at de kun kan eksistere i vore ganske smaa og lave Søer.

Dette fremgik meget tydeligt af vore Undersøgelser i Silkeborgterrainet.

Ovenfor har vi omtalt, at Aphanizomenons kolossale Maks. egentlig opstaar i den kun 4 -5 M. dybe Salten-Langsø, hvorfra den gennem Saltenaa ledes ud i Gudenaaen og af denne føres ind i SilkelorgDe danske Swers Plankton. 


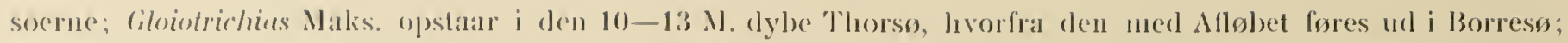

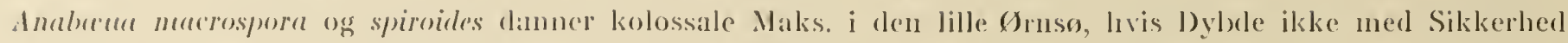
kan angives, men som efter sin Vegetation og sine Solbredelers Heldningsvinkel at domme or en lav Sø, og

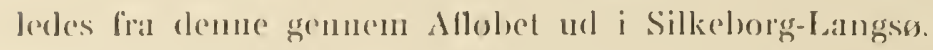

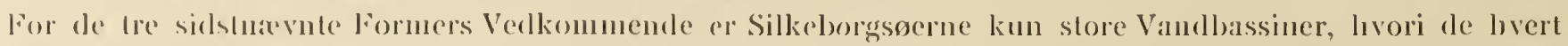
Aar fores ud og dor loort; der er al Cirund til at tro, at hvis der ikke fra Smaasoerne hvert Aar blev ført nyt Materiale ind i disse Soer, vilde de lae former ganske do ud i alle Gutenamens Bredninger. Noget anderledes stiller Forloblet sig rimeligvis med Aphunizonenou (se herom pag. 50).

Pan ganske anden Vis forloolder alle de former sig, livis Maks. falder ved Tp. 15-18. IIerhen hører

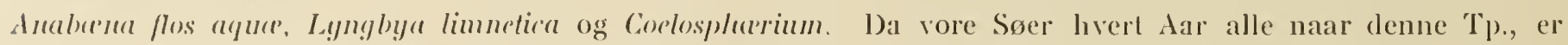
det ikke Temperaturen, der lexgger Hindringer i Vejen for sidstnave Algers Optraeden.

Det viser sig da ogssala, at disse Former opnar deres kolossale Maks. snart i en, snart i en anden Sø, uden at vi derfor er i Stand til nermere at angive Aarsagen til deres Forekomst i den ene Sø eller Grunden til deres Udebliven i den anden. Dog synes det, som om san vel disse som ogsaa de Former, hvis Maks. ligger verl meget lave Tp., f. Liks. Oscillatoria rubescens og maaske Lyngbya bipunctata, fortrinsvis optraeder i vore koldeste og dyleste Soer.

Saaledes er Anaberua flos aqua's Maks. storst i Haldso og Fureso, Lyngbya limnetica's og Oscillatoria's storst i Fureso. Del ligger la ner at antage, at Vandets storre eller mindre Rigdom paa organiske Stoffer er cn vigtig Faktor ved Bestemmelsen af en Arts Maks. i en given Sø.

Det maa blive Fremtidens Sag at bekrafte vor Formodning om, at de Alger, hvis Maks. falder sammen med den hojeste Tp., ogsaa i sxrlig Grad synes at kræve Tilstedevarelsen af opløste organiske Stoffer, og at de Alger derimod, hvis Maks. ligger ved lavere Tp., rimeligvis trives bedst i Vandmasser, der ikke er rige paa saadanne.

Bliver denne Formodning eksperimentelt godtgjort, er dermed et Moment tilvejebragt, som yderligere vil kumne forklare de enkelte Cyanophyceers Optraclen i de forskellige Søer. Man vil nemlig i al Almindelighed kunne gaa ud fra, at Rigdommen paa organiske Stoffer er meget ringere i de større og dybe Søer med deres rene og klare Vand end i lave og varme Smaasoer.

De forste er Hjemstarn for Oscillatorier, Lynghyer og til Dels Anabcena flos aqua: de sidste for Aphanizomenon, Polycystis, Coelospharium, de ovrige Anabener og Gloiotrichia. Paa Grund af visse Cyanophyceers navnlig Rivulariaceers Forkærlighed for Kalk er der ogsaa Grund til at tro, at en særlig Righoldighed paa bestemte mineralske Bestanddele i Søvandet, først og fremmest Kalk, for visse Planktoncyan.s Vedk. vilde kunne fremkalde særlig store Maks,; herom ved ri dog for Øjeblikket absolut intet, men vi tør formode, at Undersøgelser desangaaende, narnlig foretagne med Oscillatoria rubescens som Forsøgsplante, vilde kunne give interessante Resultater.

Vi har her mattet indskrænke os til at paavise den Rolle, Vandmassernes Temperatur spiller med Hensyn til de enkelte Cyanophyceers Optræeden i de forskellige Soer. At denne er overordentlig stor, fremgik tydeligt red Sammenligning af lagttagelserne fra den varme Sommer 01 med lagttagelserne fra den kolde Sommer 02.

Alle de Cyan., hvis Maks. ligger ved Tp. 20-22, opnaaede i deres respektive Søer i 01 overalt kolossale Maks., i 02 var de overmaade sjaldne eller optraadte kun i meget ringe Mængde (Aphanizomenon og Polycystis i Viborgso og Julsø, Gloiotrichia i Thorso, A. macrospora og spiroides i Ørnsø).

De Cyan., hris Maks. faldt ved lavere Tp., forholdt sig i 01 og 02 derimod orervejende ens; Maks. indtraadte omtrent samtidig begge Aarene og har nappe været mindre i 02 end i 01 .

Et mere afgorende Bevis for Temperaturens Betydning for Cyanophyceernes Optræden i vore forskellige Søer og i de forskellige Aar kan Undersogelser ude i Naturen næppe tilvejebringe.

Vi har under hele Undersogelsen over Planktoncyanophyceerne bestrebt os for saa noje som muligt at 


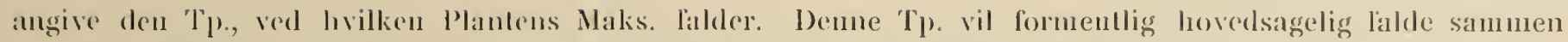
med Tp.optinnmet lor Plantens l'ornering ved kolonideling, IJormogoniedannelse ete.

Det havde varet vort Haal), at Undersogelsen tillige skulde have givet Oplysninger ned Ifensyn til Temperaturen for Brydungen af Cyan. Hvilestadier og sarlig til Sporernes Spiringstp., og ligeledes, at leorsmg desamgatende havde kunnel lorenes med Iagltagelserne ude i Naturen; det viste sig dog snart, at Tiden ikke vilde slaa til til at faa clisse Forsog med.

Salaremt de var komne i Stand, skulde de tillige liave tjent til at vise Maaden, hvorpaa de spirende Planter naaede Overfladen. Af Forsøg med Gloiotrichio og Aphanizomenon synes det dog at fremgaa, at Spiringen altid foregaar paa Bunden, fra hvilken Sporen, der mangler Luftracuoler, ikke kan hæve sig op. Det er rimeligvis Kimplanter, der gaar til Vejrs, men vi savner Undersøgelser, der kunde oplyse om, naar og hrorledes Luftracuolerne opstaar. Hvis vi nu sammenligner de her indvundne Resultater med de $\mathrm{i}$ andre Lande tilvejebragte, kommer vi til ret interessante Resultater.

I Følge Chodat og Bachmann indeholder Alpesøerne, der jo i Alm. er langt større end vore Søer, men navnlig langt koldere, dybere og klarere, kun meget faa Cyanophyceer. I Alpesøerne optrader kun een dominerende Planktoncyan. nemlig Oscillatoria rubescens, den samme, der ogsaa hos os er knyttet til kolde, klare Søer, og hvis Maks. ligger ved en meget lav Tp.

Videst udbredt er i Følge Chodat Anaba'na flos aqua og, saa vidt det af Littr. fremgaar, den eneste, der i Alpesøerne kan fremkalde blaagron Vandblomst; ogsaa denne Art optrader hos os med store Maks. i de klareste og koldeste Søer; dens Maks. ligger under vore Søers højeste Tp.

Endvidere omtales ofte Chroococcus minutns var. carneus (Neuchatelersøen o. a.), til hvilken Form vi intet Kendskab har.

Alle de ørrige Planktoncyan., som netop hos os fremkalder de store Maks. og den nregtige Vandblomst, mangler i Alpesøerne, der i Alm. ikke, i alt Fald ikke tilstrækkelig længe, naar de høje Temperaturer (Tp. 20-22), som disse Alger fordrer.

Vender vi os derimod til det mellemeuropæiske Slettelands Søer, finder vi ganske lignende Forhold som hos os.

Efter de af Apstein, Seligo, Halbfass o. a. anstillede Undersøgelser fremgaar det, at disse Søer med Hensyn til Størrelse og Dybdeforhold ikke ræsentlig afriger fra vore egne, om end selvfølgelig en Del navnlig er betydelig større.

Som Regel spiller Cyan. i alle disse Søer en langt betydeligere Rolle end i Alpesøerne og en lignende som i de danske Søer; dér som her er det de samne Arter, der danner de store Maks. Aphanizomenon, Anabana flos aque og Polycyslis er Hovedformerne; mere sporadisk optræder Gloiotrichia, Lyngbyerne og Coelospltcrilum; vidt udbredt, men i underordnet Mangde forekommer A. spiroides, macrospora, CluroococcusArterne, Merismopedium samt Gomphospluceria lacustris. Oscillatorierne synes at være sjældne; vi anser det ikke for umuligt, at deres Antal er bleret undervurderet.

I de finske og de syd- og mellemsvenske Soer synes efter Trybohms (93-01), Borges, Steenroos, Levanders, Nordqvists o. a. Undersogelser Forholdet vasentlig at være som i de danske.

On de arktiske Søers Cyanophyceer ved vi kun grumme lidt; de angives ikke af Astrid Cleve fra de laplandske Søer. I Søerne paa Franz Josephs Land fandt Borge (99 p. 755) kun Oscillatoria lenuis Ag. og faa Eks. af Coelosplucrium, men ingen andre Planktoncyan. Paa Bjørneøen paaviste Lagerheim (00 p. 15) faa Eks. af en Anabcena-Art, Oscillatoria tenuis Ag. og Coelospharium pallidun Lemm. Det synes heraf at fremgaa, at Cyan. ikke er hjemmehørende i Søer under meget nordlige Breddegrader.

Vi kommer da for Cyan. Vedkommende til følgende Enderesultat:

Hovedmassen af Cyan. hører ikke hjemme i dybe, kolde og klare Soer, Oscillatorierne mulig undtagne; en stor Del er hjemmehørende i de saakaldte Damsøer med lavere og varmere Vand; herhen hører Coelospharium, Anabcua flos aqua og Lyngbyerne; den overvejende Del findes i ganske smaa og lave Soer med 


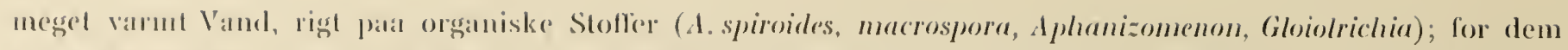
ar de storre Soer, hvori de fores ud med Aflobene, liun en Grav, og kun undtagelsesvis finder de i disse Soer de Lissbetingelser, der udfordres for deres Trisel. Hvor disse Arter danner betyclelige Maks. i starre Soer, skyldes dette for en raesentlig Del Formering af importeret Materiale. Indenfor Luropa er Cyano-

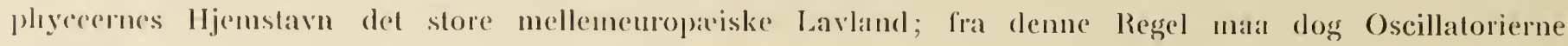
undtinges.

'Til Slutning skal vi cudnu berøre Cyanophyceenes Forhold til Vandblomstfaenomenet, idet Vandblomsten nersten allid foraarsages af Cyanoplyceer. Schmula (96 p. 34) mener, al Vandblomst ogsaa kan dames af Chlorophyceer, sartign Scenedesmus, Selenastrum og Cosmarium; lignende Forlobld er ogsa iagttaget af E. L. for Cosmocladiumis og Pleurolerniun's Vedk. i jydske Søer; se ogsaa under Bolryococcus.

Endvidere kan Pollen fra Naaleskove fremkalde Vandblomstfanomener (Bodensøen: Schröter \& Kirehner. 96 p. 29$)$.

Medens Vandlblomsten i Schweizersoerne overvejende dames af Oscilluloria rubescens (De Candolle, Chodat, bachmann), Chroococcus minulus (Chodat 98 p. 180 ) og kan dannes af Anaberna flos aque (Forel se C. Sclnöter 97 p. 23), er det i det melleneuropeiske Slettelands Soer overvejende Anabener, Aphanisomenon, Polycyslis og Coclospharium, der foraarsager dette Fenomen. Vandblomstfanomenet fremkommer red, al P'lankitoncyanophyceerne paa vindstille Tider af Døgnet lejrer sig paa Overfladen, hvorved denne ligesom overtraklies med en Hinde af vedk. Cyanophycees Farve.

I Folge Klebahns (95-96) og Strodtmanns (95-(96) Undersogelser tor vi vel nu gaa ud fra, at den dylere Aarsag til Fanomenet er de Luftblerer, som Planktoncyanophyceerne indeholder, og som gør dem lettere end det Rumfang Vand, de fortranger ${ }^{-1}$ ).

Medens Planktondiatomeen, naar den ikke udsxttes for ydre Paavirkninger, langsomt synker til Bunds, stiger Planktoncyanophyceen under de tilsvarende Forhold til Vejrs og lejrer sig paa Overfladen, hvor den forbliver, til Bolgebevagelsen driver den nedad.

Vandlblomsten dannes altid overvejende af en enkelt Art, der bestemmer dens Farve. De forskellige Planktoncyan. Vandblomst kan med blotte Øjne skælnes fra hverandre.

Den dybest morkegrønne Vandblomst dannes af Aphanizomenon, tillige karakteriseret ved at være sammensat af Traade eller Fnug, der er synlige, naar man holder en Prøve op for Lyset. Noget lysere er Polycyslis, der viser sig sammensat af store, uregelmassig formede Klatter. Endnu lysere er Anaba'na flos aque's, som oftest af en gulgron Farve og skarpt begraenset til Juni-Juli. Coelosphciriums Vandblomst er mere graalig; en Vandprove af denne viser sig narmest grynet som lutter regelmassige, lige store Prikker. Lettest kendelig er Gloiolrichicis, da de enkelte Kolonier her kan have en Diam. paa 1-2 Millim.; Farven synes nærmest at falde i det gulgraa.

Lyngbyerne danner saa vidt vides ingen Vandblomst; Gomphosplocria og Merismopedinm rimeligvis heller ikke; de to forste mangler Luftracuoler (se dog under Lyngbya); Chroococcus-Arternes Vandblomst har vi ikke haft Lejlighed til at iagttage.

Anabena macrospora og spiroides danner kun Vandblomst i Smaasøer, hvor A. macrospora næppe kan skælnes fra Aphanizontenon.

Vandblomst lader sig bedst iagttage i de tidlige Morgentimer efter en blikstille Nat. KI. 5 Morgen $01{ }^{20} / 6$ var Furesoen over den største Del af sin Overflade dækket med en af Anabcrna flos aqua dannet gulgrøn Vandblomst, der dog ikke var meget sammenhængende; i Vandblomsten fandtes overalt større eller mindre Huller, foraarsagede af de talrige umiddelbart under denne staaende Loje- og Skallestimer, der vistnok for en Del levede af den. Efter at Vandblomsten oprindelig havde veret i absolut Ro, iagttoges pludselig en ganske langsom glidende og rullende Berægelse, der stadig foregik i samme Retning og jevnt tiltog; Vandet

1) Paa det Tidspunkt, da dette Stykke udarbejdedes, var Molisch 03 og lirandts 03 Undersogelser endnu ikke udkomne. 
var spejlblankt, og lagtageren kunde ikke selv marke den ringeste Vind; forst noget efter viste der sigg paa Soen en svag blaa Stribe, hvorpaa Morgenbrisen snarl efter naacde lagtlagelsesstedet, fejende Vandblonsten foran sig i Striber parallele med Vindretningen. Saa vidt WV.-I. kunde se, opstod disse Striber, der ofte er bleven iagltagne, ved, at Vinden ikke blaeste ned lige Styrke over liele Sølladen; hvor Vinden var starkest og havle fremkaldt en Krusning af Vandspejlet, var Vandblomsten slaaet i Stykker og blev nu bevaget frem efter i Vandlaget narmest Overfladen; paa de Partier af Søen, hvor Vandspejlet endnu var urøit o: paa de Lokaliteter, der af Iagtagerne betegnes som Striber, foregik Transporten i selve dette. Resultatet blev, at al Vandblomsten fejedes af Søen og tilsidst laa opholset i Phragmitesbaltet.

Naar Vandblomsten, efter meget varme Dage og efter langere Vindstille med højt Sollys, i massevis har varet allejret paa Vandoverfladen, sker der en pludselig og stark Destruktion af den store Mæengde af organisk Materiale, der har samlet sig i de overste Vandlag. Man ser da, at der i det ensartede grønne Overtrxk opstaar blaahvide Pletter, der tiltager i Størrelse og tilsidst kan forene sig til store Kager. I disse Partier er Vandblomsten død, Cellerne er dræbte, og den blaahvide Farve skyldes rimeligvis den af Cellerne udtraadte Phycocyan. Dødsaarsagen er muligvis det intensive Sollys, men i Pletterne findes tillige talløse Phycomyceter og Bakterier.

Som Følge af Ophobningen af Cyan. i de øverste Vandlag og det hindeagtige Overtræk over Vandspejlet influerer Cyan. overordentlig stærkt saa vel paa Krantiteten son Kvaliteten af den i Vandet varende Luft; som Hinde hindrer de Luftiornyelsen, og paa Grund af den pludselige og meget strerke Destruktion af store Mængder organisk Materiale opstaar Luftarter, der er skadelige for Søens Organismer.

Man er vistnok med Rette gaaet ud fra, at tyk, sammenhængende Vandblomst, der i længere Tid ligger hen over en Søs Overflade, er sundhedsfarlig for Fiskene, idet disse simpelt hen kvales (Kafka 92 p. 89 , Strodtmann 98 p. 206); egne Iagttagelser fra Frederiksborg Slotssø gaar i samme Retning. For denne Søs Vedkommende er det sikkert, at store Mrengder af Skaller, Fliger og Aal er døde bort paa varme, stille Sommerdage, netop i Perioder, hvor Søen har varet daeket af Vandblomst.

Nærmere Undersøgelser foreligger ikke; Vandblomstens skadelige Indflydelse er bleven bestridt af L e mmerm a n n (97 a. p. 99).

I sanitær Henseende er det sikkert uheldigt, at større Byer, f. Eks. Viborg, Frederiksborg, Silkeborg, ligger op til Søer, der Maaneder igennem er spanskgrønne af Farve og navnlig paa lune Sommeraftener udsender en ulidelig Lugt. At raade Bod paa Ondet er kun umuligt, fordi de nølvendige Pengemidler til dets Bekæmpelse i givet Tilfælde næppe vil være disponible.

Dog vil en Befolkning ved i Sommertiden at skaffe Søen hurtigtstrømmende Vand altid have det $\mathrm{i}$ sin Haand at begræense Ondet. For saa vidt Vandblomsten dannes af sporebarende Cyanophyceer, vilde en Afskumning af Overfladen i Aug.-Sep. et Par Aar i Træk sikkert give gode Resultater. Dog kræver denne Fremgangsmaade, at det afskummede Materiale tilintetgores; W.-L. har haft Lejlighed til at se, at dette kun losses af paa Land, hvor det i Foraarstiden atter kan gribes af Bølgerne; i saa Fald er det indlysende, at Arbejdet er fuldstæendig spildt. 


\section{KAP. I. DIATOMACEA.}

$\mathrm{D}$ IATomenisis planktondanuende Betydning er i vore Søer næppe mindre end Cyanophyceernes. De forekommer i et betycleligt Individantal og kan til visse Aarstider danne kolossale Maks.

Planktonformerne tillorer ikke nogen bestemt (iruppe; spredt i de enkelte Familier optræder enkelte Slagter, lıvoraf i Alnindelighed kun et meget ringe Antal Arter er Planktonorganismer; de øvrige er Bundeller Bredformer: $\log$ er Raphidea kun reprasenterede af nogle faa maaske endog næppe helt typiske Planktondiatomeer. Mellem de Karảkterer, der sxrlig udnerker Planktondiatomeerne, maa fremhæves: 1. tynde Cellevagge og stor Hyalinitet (Attheya, Rhizosolenia, Synedra acus, Cyclotella o. m. a.). 2. Torndannelser (Attheya, Rhizosolenia, Stephanodiscus), sylformede Celler (Rhizosolenia, Syıuedra acus, ulna). 3. Geleskærme eller Gelerør (Asterionella, Tabellaria, Diatona, Cyclotella). 4. Kolonidannelser (Kæder: Melosira, Cyclotella, Stephanodiscus, Rhizosolenia, Fragilaria; Stjaerner: Asterionella p. p., Diatoma p. p., Tabellaria p. p.; i uregelmæssige Kolonier: Synedra ulna). 5. Rapheapparat mangler eller er, hvis det undtagelsesvis findes, kun sragt udviklet (Undtagelse: Cymatopteur( elliptica).

Man kender kun overmaade lidt til Hvilestadier hos Ferskvandsdiatomeer, og paa dette Omraade træenges i hoj Grad til nærmere Undersøgelser. Ogsaa Kendskabet til Planktondiat. Auxospordannelse er meget ufuldkomment; lıos mange Arter er Auxosporer endıu ganske ukendte.

I Modsatning til Planktoneyanophyceerne hører Planktondiatomeerne overvejende hjemme i de større Soers pelagiske Region, og liun enkelte Arter danner Plankton i Smaasøer og Damme.

Oprindelsen til Ferskrandets Planktondiat. lader sig paavise med en sjælden Grad af Sandsynlighed.

Da de to Slægter Altheya og Rhizosolenia tilhører store Afdelinger, der saa godt som udelukkende er marine og i Ferskvand kun er repræsenterede af meget faa Planktonarter, medens alle de øvrige er marine Planktondiatomeer, hvoraf flere spiller en ganske dominerende Rolle i de nordlige Haves pelagiske Region, er der den største Sandsynlighed for, at disse to Slagter fra Havet er førte ind i Ferskrand.

Alle de ovrige i Plankton optrædende Forner tillører, muligvis medUndtagelse af Asterionella, Slægter, hvoraf det langt overvejende Antal Arter er Bund-og Bredformer; dette gælder saaledes alle de til Slagterne Melosira, Cuclotella (?), Stephanodiscus, Tabellaria, Diatoma, Fragilaria, Synedra hørende Arter. Ja hvad mere er, flere af de herhen horende Arter, navnlig Tabellaria fenestrata og flocculosa, Diatoma elongatum, Fragilaria virescens, Synedra ulna, optræder dels som fastsiddende, dels som pelagiske Organismer, der under visse i ovrigt lidet kendte Forhold fra fastsiddende gaar over til pelagisk Levevis.

Under denne Overgang skifter Arterne Udseende og bliver fra Kæedekolonier til Stjærnekolonier (se det følgende). 


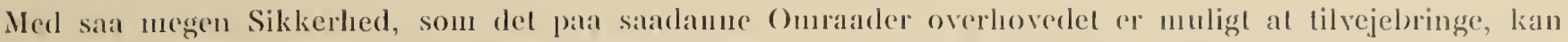
vi altsaa on ferskiandets Planktondiatomeer angive, al disse overvejende stanner fra Sobundens og Sobreddens Diatonecformer; enkelte Arter er indlorte marine Planktondialonecr.

\section{Centricæ.}

Af Ferskvandets Planktondiat. Lilhorer 5 Slangter: Melosira, Cyclotella, Stephanodiscus, Rhizosolenia, Allheya Afdelingen Centrica. De tre forstnevinte thorer ind under Centrica Discoidea og sarlig under Underafdelingen Coscinodiscea, der dels indbefatter lacustrine, dels marine Bund- og Planktondiat., de to sidstnarnte lienholdsvis under Solenoidece og Biddnlphioidea, der begge aldeles overvejende omfatter marine Diat., førstnevnte fortrinsvis Planktonorganismer, sidstnevnte dels Plankton-, dels Bundformer.

\section{Discoideæ Melosirinæ.}

Fam. omfatter overvejende marine og lacustrine Bund- og Bredformer; kun et ringe Antal er Planktonorganismer.

\section{Melosira.}

Slrgten Melosira, der inddeles i talrige Underslægter, indbefatter dels marine, og dels men overvejende lacustrine Arter; Hovedmassen af Ferskvandsmelosirerne er Bundformer. I Plankton angives sarlig følgende Arter: M. crenulala Kütz., granulala (Ehr.) Ralfs., varians Ag., lineolala Grun., dislans Kg., levvissima Grun., arenaria Moore, orichalcea Mert. M. lavissima (= M. dislans var. lavissima angives af Z a charias (95 b. P. 99, 95 d. p. 141 og $96 a$. p. 56) at være Hovedformen i Plönersøerne. I Prøver fra Ĺnudsø (en af Silkeborgsøerne) fandt E. L. en Diatomee, som ikke var bleven paavist i nogen af vore øvrige Prøver. Hr. Inspektør Østrup, der godhedsfuldt undersøgle den, meddelte os, at Formen var $M$. dislans var. levissima; den fandtes i Foraarsprøver fra Knudsø i betydelig Mrngde, nu og da ogsaa i de øvrige Silkeborgsøer. Øjensynlig hersker der med Hensyn til Melosira-Arterne stor Usikkerhed hos de forskellige Forf. De danske Planktonmelosirer har vi henført til nedennærnte 4 Arter, af hvilke de to sidstnæunte dog næppe er Planktonorganismer, men Bundformer, og $\mathrm{i}$ alt Fald hos os uden al planktondannende Betydning.

\section{M. crenulala Kütz.}

Tab. II, Fig. 15 .

Schmidt 74-03. Tab. 181 .

Fureso. M. c. optræeder $0020 / 12$ Tp. 4 med et meget stort Maks., der holder sig en Tid lang, medens Søen er tillagt; da Søen brød op $018 / 4$ Tp. 1, var den stærkt aftaget og var derpaa hele Sommeren og lige til $16 / 11$ Tp. 4 enten til Stede $\mathrm{i}$ enkelte Eks. eller $\log$ kun i ringe Mangde. Maks. indtraf forst ${ }^{17} / 12$ Tp. 1, blev derpaa meget stort $027 / 1$ Tp. 2 og holdt sig $31 / 1$ Tp. 1; da Søen brød op $18 / 3$, var Mangden noget aftaget ( ${ }^{23 / 3}$ Tp. 1), men steg atter noget til 11/4 Tp. 4, hvorpaa den starkt aftog til 25/, Tp. 5; den var nasten forsvunden $21 / 5 \mathrm{Tp} .9 \mathrm{og}$ fandtes fra da af kun enkeltvis.

Esroms ø. M. $c$. er her sjælden; det lille, svagt fremtradende Maks. ligger ganske som $\mathrm{i}$ Furesø 00 17/. Tp. 5 ; Arten optrader enkeltvis hele 01 lige til ${ }^{10} / 11$ Tp. 7, da Antallet stiger svagt; Maks. ${ }^{17} / 12$ Tp. 1 ; i 02 forekommer Arten kun enkeltvis.

Sorøsø. M. c. er her af underordnet Betydning; Maks. ligger 00 19/1, Tp. 5 og holder sig til $015 / 5$ Tp. 10. Arten holder sig $\mathrm{i}$ det hele ret alm. lige til 18/11 Tp. 7, da Vintermaks. begynder; dette blev imidlertid ikke til noget, rimeligvis paa Grund af Asterionellernes kolossale Maks.; i 02 er den sjaelden eller dog kun ret alm.

Tjustrupso. M. $c$. spiller her en underordnet Rolle; der er et svagt Maks. 00 19/12 Tp. 3 , men Arten er sjaclden hele 01 indtil ${ }^{16} / 10$ Tp. 13 ; et Maks. holder sig fra $18 / 11 \mathrm{Tp} .7$ til efter lsløsningen i Proven 02 23/3 $\mathrm{T}$ ). 1 ; den aftager nu jarnt og findes kun enkeltvis indtil $30 / 6$ Tp. 15, da den ved den usarlvanlig lave Vandtp. markelig nok faar et nyt Maks., der om end liun svagt genfindes $2 \pi / 7$ Tp. 15 . 


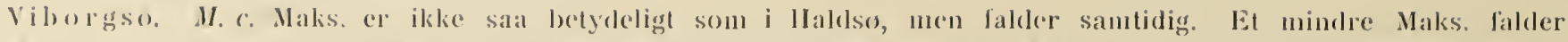

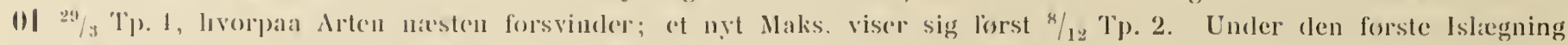

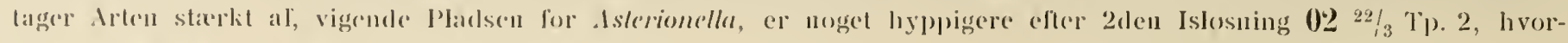
bial der altager ret jaxinl.

Haldso. M. e. re en al Soens vigtigste Planktonformer. Den laar et kolossalt Maks. (0) 30/, Tp. 1; ret liolder

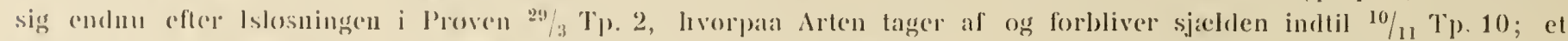

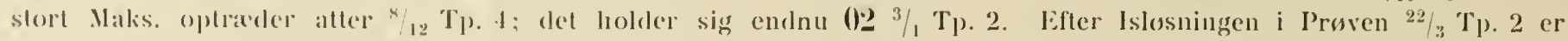
Arten kun ret almindelig, men sjablen i alle senene prover.

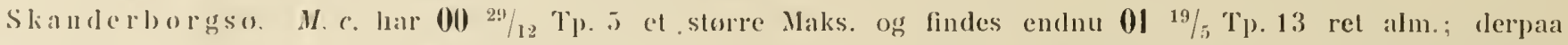

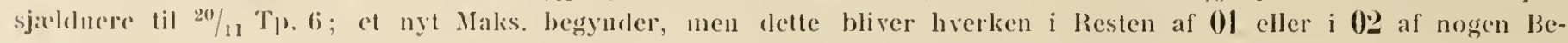
tydning.

Mosiso. M. \&. forholder sig vistnok overvejente som i Skanderborgso og de ovenfor nevnte Sger.

Iulso. M. c. viser i Julso en noget afvigende periodicitet fra den, der forefindes i alle de ovrige Soer; den har

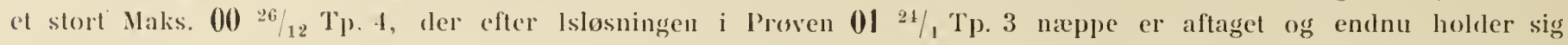

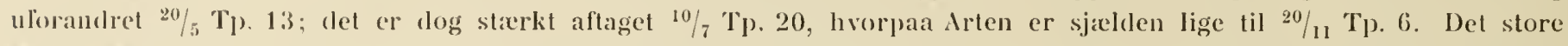
Maks. begynder nu igen, og for sala vidt er Forlobet det samme som i andre Søer. Men dette Maks. holder sig hele Iagltagelsestiden nasten uforandret indtil $0231 / 7 \mathrm{Tp} .15$; (let aftog vel noget efter IsIasningen i Proven $5 / 4$ Tp. 3 , men strg derpaa atter. Vi lan allerede her gore opmarksom paa, at Tp. 02 31/7 var 15 , $011 / 8$ derimod 22.

Det frengaar altsaa, at $M$. cremulata, naar vi ser bort fra de afvigende Forhold $\mathrm{i} J u l s ø$, i vore Søer kun har eet Maks., der begynder i Nov.-Dec. Tp. 6-4; at dette Maks. holder sig Vinteren over, men dog kendelig pavirkes af Islagningen, saaledes at det efter denne $\mathrm{i}$ Alm. er mindre. Arten holder sig $\mathrm{i}$ Reglen ret talrig til hen imod Maj $\mathrm{T}_{\mathrm{l}}$ ). 10-12 (se i ovrigt under Asterionella og senere).

M. granulata (Ehr.) Ralls.

Tab, IV. Fig. 40,

Schmidt 74-03. Tab. 181.

Fureso. M. $g$. synes her merlielig nok ganske at mangle.

Esromso. $M . g$. er til Stede i ringe Mengde eller optræcler kuı enkeltvis i alle Prover 01 lige til $12 / 8 \mathrm{~T}$ p. 21 , da den er ret alm., Maks. begyder $30 / 9 \mathrm{Tp} .17$, stiger strerkt 15/10 Tp. 12 og er endnu meget stort 10/11 Tp. 7 ; saa lalder det pludseligt, hrorpaa Arten i hele 0.2 lige til ${ }^{10} / 7$ Tp, 14 kun forekommer enkeltvis; Antallet stiger da atter vistnok ret pludseligt, og et betydeligt Maks. holder sig endnu $31 / 7$ Tp. 15 .

Soroso. M. g. er alm. 00 19/12 Tp. 5, men er sjælten hele 01 til 18/9 Tp. 12, da Antallet pludselig stiger enormt og resulterer $\mathrm{i}$ et kolossalt Maks., (ler holder sig uforandret $17 / 10 \mathrm{~T}$. 12; derpaa tager Arten lige saa pludsclig af og er $\mathrm{i}$ Resten af 01 saa vel som i hele $\mathbf{0} \mathbf{2}$ yderst sjalıen.

Tjustrupso. M. g. forholder sig i denne ganske som i Soroso, men Maks., der ogsaa her var kolossalt, indtraf forst $01{ }^{16 / 10}$ Tp. 13; til Gengald holdt det sig meget laengere; endnu $0227 / 1 \mathrm{Tp}$. 1 var Arten almindelig, men senere sjæelden i hele 0:2; en svag Stigning viste sig $\log 30 / 6$ Tp. 15.

Viborgsu. M.g. er her af ganske underordnet Betydning; det svage Maks. ligger dog ogsaa her 01 14/10 Tp. 12; i 0.2 blev den saa godt som iklie paavist.

Haldso. M. $g$. er ogsaa her sjaelden $\mathrm{i}$ alle Prover Ira $01 \% \%$ Tp. 1 til $16 / 9$ Tp. 13, da Antallet stiger, indtil et kolossalt Maks. indtræffer ${ }^{14} / 10$ Tp. 13 , dette holıler sig endnu $10 / 11$ Tp. 10 ; saa tager Arten pludselig stæerkt af og viser sig $\mathrm{i}$ alle senere Prover 01 og 02 kun enkeltvis.

I Skanderborgiso, Mosso og Julso er $M . g$. i det hele lidet fremtræectende; noget Maks. lader sig slet ikke paavise i forstnæunte So; i Mosso ligger et svagt Maks. 01 2\% Tp. 14, i Julso 01 15/9 Tp. 12 og 15/ 10 T. 12 , men i orrigt er Arten i alle disse Soer sjæelden.

Det viser sig altsaa, at M. gramulata i alle vore Soer gennemgaaende optrader i ringe Mrengde, undtagen i Maanerlerne Sep.-Okt. Tp. 14-12, da Arten nesten overalt har et Maks., der kan væere svagt, men ogsaa (Sorøso, Tjustrupsø, Haldsø) ganske kolossalt. Saa lange Maks. varede, var Vandets Farve i Sorøsø og Tjustrupsø gulgront; Maks. indtraffer markverdig pludselig og ophører næsten lige saa pludselig; det indtraffer nasten samtidig i alle Soeme. 
M. varians A g.

Apstein 96 . Fig. 28, p. 139.

M. v. er kun paavist i ringe Mangde i enkelle Prover fra Soroso, Tjustrupso, Mosso og Julso.

M. arenariı Moore.

Apstein 96. Fig. 30, p. 140.

M. a. er paavist enkeltvis i Prover fra alle Soerne undagen Viborgss og Skanderborgsa; det er en Bund- og Bredform, der intet har med Plankton at gore.

Vi har altsaa i vore Søers Plankton to Arter, M. crenulata og granulata, der hegge til visse Tider danner uhyre Maks. M. granulata's Maks. ligger ved Tp. $14-12$ i Sep.-Okt., umiddelbart derefter begynder $M$. crenulata's, der dog først naar sin højeste Udvikling i Dec-Jan. c. Tp. 4. Medens M. granulata efter Maks. Ophør i Slutningen af Okt. tager meget kendeligt af, holder M. crenulata sig ofte Vinteren over medl et Maks., der kan vedvare endnu i Maj.

Naar Furesøen undtages, optræeder begge Arter i alle de undersøgte Søer; i intet Tilfæelde falder deres Maks. sammen; i Haldsø følger de to Arter efter hinanden med omtrent lige kolossale Maks., i de fleste andre er enten den ene eller den anden Arts Maks. langt det største.

Det er hævet over enhver Tvivl, at $M$. granulata her i Landet kun har eet Maks. For M. crenulata's Vedkommende kunde Forholdene vel ofte tydes til Gunst for to Maks., idet dels Islægning, dels Konkurrencen med andre Arter kan afbryde Efteraarsmaks., hvorpaa et nyt kan arbejde sig frem efter den sidste Isløsning (Sorøsø, Viborgsø).

Det synes, som om en pludselig lslægning midt under Maks. i Dec. har til Følge, at dette ophører, selv om Isløsningen allerede indtræffer kun c. 14 Dage efter Islægningen (Sorøsø, Viborgsø). Dette kan i saa Fald kun forstaas saaledes, at Melosirerne under de fuldkomment rolige Forhold synker til Bunds, og at andre Arter med større Svæveevne udfylder deres Plads, se under Asterionella. Rettest opfattes dog M. creuulata's Maks. normalt som et sammenhæengende Maks. knyttet til Tp. omkring 4-10.

Begge Arter synes at kunne opnaa lige store Maks. baade i smaa varme og i større kolde Søer, men i de mindre Søer begynder de store Maks. tidligere end i de større; til Gengald er Varigheden i de større i Alm. noget længere; fra begge disse Regler gives der dog Undtagelser.

Af Damundersøgelsen 98 synes det at fremgaa, at Melosirerne i Damme og Smaasøer i det hele kun har en meget underordnet Betydning som Plankton-dannende; de blev i ringe Mængde paaviste i Vinterprøven fra Frederiksborg Slotssø, men i ingen af de øvrige Damme.

Melosirerne er ganske væsentlig knyttede til det mellemeuropæiske Slettelands lave og varme Søer; de mangler ikke i et eneste af de talrige Arbejder, der i de sidste Decennier er fremkonne over disse Søers Plankton; en nærmere Redegørelse for de talrige Findesteder anser vi for overflødig.

Det kan endvidere fastslaas, at Melosirerne kun optræder i meget ringe Mængde i schweiziske Alpesøer og Bodensøen (C. Schröter 97, Schröter \& Kirchner 96, Bachmann 01, Chodat 98 p. 156). Hovedformer er M. catenada (Genfersøen: Chodat 97a. p. 310 og i flere Jurasøer: Pitard 97a. p. 517) og M. orichalcea (Lac de Nantua: Chodat 98 p. 156). De afløses her af Cyclotelleme, og det synes, som om Alperne kan angives som Sydgrænse for Melosirernes massevise Optræden.

1 de norske Søer (Holmboe 00 p. 17), svenske (Borge 00 p. 12, A. Cleve 99 p. 827, De Toni \& Forti 00 p. 551) samt i de finske (Levander 00 b.) synes de at spille en lignende Rolle som hos os, dog optræder de næppe i slet saa stor Mængde og maa navnlig i Norge hyppigere vige Pladsen for Cyclotella og Tabellaria.

De fleste Forf. angiver to Maks., et om Foraaret og et om Efteraaret, men paa Grund af den Usikkerhed, der raader med Hensyn til Bestemmelsen, lønner det sig ikke nærmere at udrede disse Angivelser.

De danske Søers Plankton. 


\section{Discoideæ-Coscinodiscinæ.}

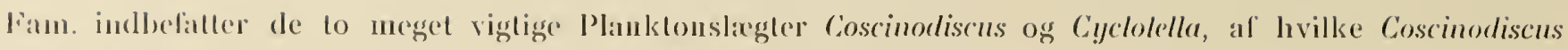
spiller en stor Rolle i det marine, Cugctotella i det lacustrine Pankton.

\section{Cyclotella.}

Af demne overvejende lacustrine Slag er der i Plankton fra Schweizersøerne beskrevet et stort Antal Arter; da cyclotellerme inidlertid kun er meget sragt reprasenterede i vort Ferskvandsplankton, henviser vi, hracl Systemilikiken amgatar, til Schröter (97 p. 32), Bachmann (01 p. 231) og Lemmermann (00c. p. 2.9).

Vi henforer alle hidlil fundne Plankton-Cycloteller fra danske Søer til een Art.

\section{C. comta Ėhr. var. quadrijuncta Schröter.}

Tab. IV, Fig. 44.

Schröter 97. Tab. Fig. 58.

Soroso. (C. c. bler mærkelig nok ikke paavist 01 , men efter Isløsningen 02 fandtes i Proven $24 / 3$ Tp. 1 nogle faa Eks., den var endvidere ret alm. $19 / 4$ Tp. 4 og $16 / 5$ Tp. 7 ; de sidste Eks. saas $7 / 6$ Tp. 15 .

Tjustrupso. C. $c$. fandtes i cnkelte Eks. i Prover $0124 / 5$ Tp. 13 og 3/7 Tp. 17 . I 02 optraadte Arten igen $27 / 1$ Tp. 1, men kun enkeltvis; derimod var Antallet steget $19 / 4$ Tp. 4 ; Maks., der ikke var synderlig stort, naaede Arten $16 / 5$ Tp. $8 ; 7 / 6$ Tp. 12 saas de sidste Els.

I Skanderborgso, Mossø, Julsø optræder C.c. med ganske enkelte Individer, særlig i Vinter- og Foraarsproverne.

I Sorøsø og Tjustrupsø optræder Arten hyppigst i »Pengeruller« paa 4 Individer, men ogsaa paa 2-3, undertiden paa indtil 8 individer.

C. comta har her i Landet øjensynlig kun floristisk Interesse; dens Maks. synes at ligge i April-Maj Tp. 4-8.

Cyclotellernes geografiske Udbredning frembyder Forhold af betydelig Interesse; de angives af Castracane $(94$ p. 71$)$ fra Plönersøerne og er paavist af Bruno Schrøder $(00$ p. 80$)$ i en Del nordtyske Søer. Dog fremgaar det med Tydelighed af alle Arbejder over det mellemeuropæiske Slettelands Søer, at Cyclotellerne $\mathrm{i}$ det hele spiller en ganske underordnet Rolle i disses Plankton, og de danske Søer danner ingen Undtagelse herfra; $C$. maa her overalt vige Pladsen for Melosirerne.

Deres Hjem er de klare, dybe Alpesøer, hvor de til Tider kan danne betydelige Maks., der dog, saa vidt vi forstaar, ikke kan maale sig med Melosirernes hos os.

De optræder saaledes i Massevis i Bodensøen (Kirchner \& Schröter 96 p. 25), i Neuenburgersøen (Fuhrunann 00 p. 94), i Zürichersøen (Schröter 97 p. 33), i Genfersøen (Chodat $97 \alpha$. p. 308), i de allerfleste Schweizersøer (Bachmann 01 p. 231) og i de fleste Jurasøer (Pitard 97 a. p. 516); de blev ligeledes fundne i Rhinen nær Ludwigshafen (Lauterborn 96 p. 14). Endelig paaviste Zacharias (99a. p. 54) enorme, nylig bundfældede Masser i den 49 M. dybe Arendsee i Altmark mellem Salzwedel og Wittenberg. Zacharias formoder, at denne Sø baade ved sin Beliggenhed, sit store Cyclotella-Maks. og sin Mangel paa Melosirer ligesom staar paa Overgangen mellem de alpine og det mellemeuropæiske Slettelands Søer.

1 Sverrig synes Cyclotellerne sjældne (De Toni \& Forti 00 p. 553), men deres alpine Natur fornægter sig ikke i de norske Alpesøer, hvor $\mathrm{Holmboe}(00$ p. 9 og p. 20) har paavist 5 Arter, af hvilke C. comta angives at høre til de alleralmindeligste.

Det er vanskeligt af den for Haanden værende Littr. at udrede, til hvilken Aarstid Cyclotellernes Maks. ligger. I Følge Bruno Schrøder (00 p. 77-79) synes det i de nordtyske Søer at ligge ved lavere Tp). særlig i Okt., til Dels April-Maj; i Neuenburgersee (Fuhrmann 00 p. 94) væsentlig om Vinteren, særlig i 
Marts, i Arendsø (Zacharias 99a.), rimeligvis i Maj. De enkelte Arter forholder sig sandsynligvis noget forskellight.

I Damme er Cyclotellerne, san vidt villes, ikke paaviste.

\section{Stephanodiscus.}

Der er af denne udelukkende lacustrine Slagt, som overvejende indeholder Bunddiatomeer frá Plankton, beskrevel 4 Arler: S. astra Grunn, Hantzschii Grun., Niagar'e Ehrlog. og Zachariasi Brun. Den i Planktonarbejderne hyppigst angivne Art er $S$. aslra'a; Hr. Inspektør Østrup har velvilligst bestemt noget af vort Materiale og har henfort de ham forelagte Eks. til denne Art; han har i øvrigt meddelt os, at de tre førstnavinte Arter vanskelig kan holdes ude fra hverandre.

\section{S. astrera (Ehr.) Grun.}

Schmidt. Tab, 226, p. $1-5$.

Tab. III, Fig. 33 .

Fureso. S. $a$. er paavist i alle Prøver. Den er sjælden $002 \% / 12$ Tp. 4 , men allerede, medens Søen er tillagt $01{ }^{24} / 3$, stiger Antallet; dette tiltager yderligere indtil $23 / 4$ Tp. 6, da Maks. naas; det aftager $15 / 5$ Tp. 13 , og Arten findes nu kun enkeltvis lige til $16 / 11 \mathrm{Tp}$. 4, da Antallet stiger; derpaa er den alm. indtil Islægningen $02{ }^{31 / 1} \mathrm{Tp} .1$, men noget aftaget i Proven umiddelbart efter lslosningen ${ }^{23} / 3$ Tp. 1 . Maks. indtræeffer $11 / 4 \mathrm{Tp} .4$ og holder sig endnu $25 / 4$ Tp. 5, hvorpaa Arten atter aftager og efterhaanden kun optræder enkeltvis.

Esromso. S. a. er en af Soens vigtigste Planktonorganismer. Arten er meget almindelig i Proven $00{ }^{17} / 12$ Tp. 5 og har sit meget store Maks. efter Islosningen $0110 / 4$ Tp. 3; den er stærkt aftaget i Proven $6 / 5$ Tp. 8 og er derpaa sjalden lige til $15 / 10$ Tp. 12 , da Antallet atter begynder at stige; den er ganske almindelig $\mathrm{i}$ alle Vinterproverne 01 og 02 og naar sit Maks. $02{ }^{22} / 3$ Tp. 2, hvorpaa Arten igen tager meget kendelig af.

Soroso. S. a. er her af ganske underordnet Betylning, men er dog set i næsten alle Prover; et svagt Maks. er paavist i 02 i Proverne $30 / 1$ Tp. $1,24 / 3$ Tp. 1 og $19 / 4$ Tp. 4 .

Tjustrupso. S. $a$. forholder sig ganske som i Sorosø; Maks., der er yderst svagt, indtraffer samtidigt.

Viborgso. S. a. forholdt sig i 01 ganske som i de to foregaaende Soer og fandtes kun i ringe Mængde; i 02 viste Arten derimod umiddelbart efter Islosningen i Proven ${ }^{22} / 3$ Tp. 2 et betydeligt Maks., der dog allerede var forsvundet ${ }^{30} / 4$ Tp. 8, hvorefter den kun findes sparsomt. Dog stiger Antallet $27 / 7$ Tp. 15 mærkværdig nok igen; se herom senere.

Haldso. S. $a$. er en af Søens vigtigste Planlitonorganismer. Den er ret alm. 01 30/1 Tp. 1 umiddelbart før Islægningen og er tiltaget i Antal straks efter Isløsningen $012 \% / 3$ Tp. 2, opnaar sit kolossale Maks. ${ }^{18} / 5$ Tp. 10, som holder sig endnu 8/6 Tp. 13; derpaa tager Arten af og findes næsten ikke i Sommermaanederne; den bliver atter ret alm. i Nov.-Dec., men er iklke synderlig hyppig efter Islosningen $02 \frac{22}{3}$ Tp. 2 . $3 / 5$ Tp. 7 indtræffer et kolossalt Maks., der allerede er forsvundet $30 / 5$ Tp. 8 , hyorpaa Arten kun optræder enkeltvis.

I Skanderborgso, Mosso og Julso findes $S$. $a$. vel i de allerfleste Prover, men er af underordnet Betydning og optræder som oftest kun enkeltvis; ogsaa her kan der i Alm. paävises et omencl kun svagt Foraarsmaks.; $S . a$. var hyppigere i Sommerprøverne 02 end i Sommerproverne 01.

Man vil heraf se, at Periodiciteten forløber ensartet $\mathrm{i}$ alle Søer. Med Efteraarets faldende Tp. viser der sig ved Tp. 7-6 ${ }^{0}$ C. en svag Stigning i Antallet; denne foregaar langsomt, men tiltager, medens Søen endnu er tillagt; umiddelbart efter Isløsningen Tp. $4-6^{\circ} \mathrm{C}$. indtræffer det undertiden meget store Maks., der i Alm. forsvinder inden Tp. 10, men dog kan holde sig ved Tp. 13 (Juni 01 Haldsø), hrorefter Arten tager stærkt af $\operatorname{og} \mathrm{i}$ alle Sommermaanederne er sjælden. En Undtagelse herfra danner $S$. $a$. i Viborgsø, vel at mærke dog kun i den kolde Sommer 02, ikke i den varme 01.

S. a. opnaar saaledes sine højeste Maks. i de større, kolde og klare Søer (Furesø, Esromsø, Haldsø), mindre i de lave, varme (Sorøsø, Viborgsø p. p.). Ved Damundersøgelsen 98 blev $S$. $a$. ikke paavist. Den optræer gennemgaaende enkeltvis, men ikke sjælden to og to. I Tiden for det store Maks. i Haldsø og Esromsø indeholder Prøverne dog jævnlig Pengeruller paa 4-6 Individer; muligvis knuses disse Ruller under Filtrationen i Nettet. Lauterborn (96 p. 15) har endog set Kreder paa indtil 10 lnd. Forskellige Forf: Lauterborn (96 p. 15), Bruno Schrøder (99a. p. 23) har iagttaget, at Slephanodiscus brerer talrige, 


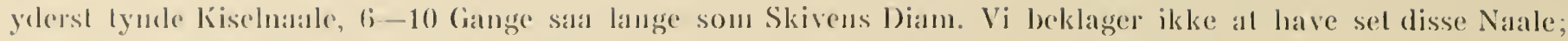
de mat rimeligris vare beven allorudte under friltrationen eller under Transporten.

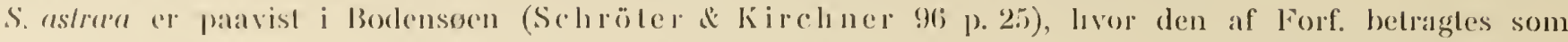

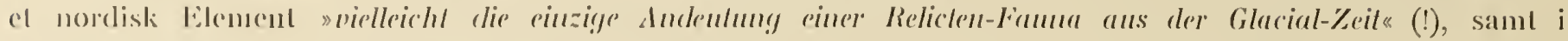

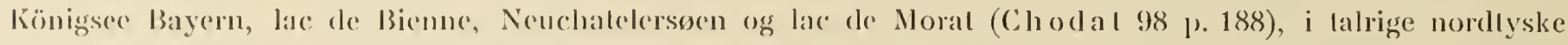
Socr (Sedigo d Bruno Schroder 00 p. 80), i Plönersserne (Castracane 94 p. 50). Fra Mjosen angives S. Haulzscluii (110lmboc (1) p). 22).

Intetsteds meleles der om sai kolossale Malks., som de al os i Hald-, Esrom- og Furesø iagllagne; den synes i del hele her i Landel an vaere langl almindeligere som Planktonorganisme end noget andet Sled.

S. Zachariasi $13 \mathrm{r} \mathrm{n}$.

B run 94. Talb. I, Fig. 10.

Demne lille tondeformede Dialomee, der meget let overses, og som sarlig karakteriseres ved sine enormt lange Torne, har vi lagel i en cnkelt Prøve $0130 / 8$ T'p. 17 i Furesø. Endvidere har I)r. Rosenvinge fundet den i Jan. 02 under lsen i Bolanisk Haves Dan, og E. L. har tagel den dels i Bagsverdsø, dels i Ollerupsø paa Fyen, begge Gange i Aug. Maaned.

Arlen er meget lidt kendt; den er beskrevet fra Plönersøerne, se brun (94 p. 54).

\section{S. IIantzschii var. pusilla $\mathrm{Gr}$ un.}

Schmidl 73-03. Tab. 225, Fig. 27-29.

I Prøverne 01 29/3 Tp. 1 fandtes i Viborgsø en overmaade lille, skiveformet Diatomee, som af Inspektør Østrup Irenfortes til denne Arl; den optraadte paa ovennavnte Tidspunkt i stor Mængde i Planktonet, men blev i øvrigt ikke paavist.

\section{Solenioideæ Rhizosoleniinæ.}

Fam. er udpraget marin og indbefatter aldeles overvejende Planktonorganismer; den taller i Ferskrand kun to Slaggler Rhizosolenia og Cylindrolheca.

\section{Rhizosolenia.}

Marin Planktonslægt, der i Ferskvand i det højeste optræeder med 3 Plankton-Arter: R. longiseta Zach., $R$. longiseta var. stagnalis Zach. og $R$. eriensis H. Sm., alle udprægede Planktonorganismer.

Medens Rhizosolenierne har en overordentlig stor Betydning i Havenes Plankton, er deres Rolle i Ferskvand kun yderst beskeden.

Det maa m. H. t. alle Meddelelserne om denne og rimeligvis ogsaa følgende Slægt erindres, at vi indtil Ang. 02 har benyttet Møllergaze Nr. 19, senere derimod Nr. 20.

\section{R. longiseta Zach.}

Tab. IV, Fig. 43.

Bruno Schrøder 97. Tab. 17, Fig. $2 a .2 b$.

Sorosø. R. l. blev paavist $\mathrm{i}$ en Del Eks. $0019 / 12$ Tp. 5; vi iagttog den ikke i Prøverne 01 for $18 / 11$ Tp. 7 . I 02 fandtes den i alle Proverne; $\mathrm{i}$ størst Mængde optraadte den umiddelbart efter Islosningen ${ }^{24} / 3 \mathrm{Tp} .1$.

Tjustrupso. R. $l$. var ret alm. 00 19/12 Tp. 3, hvorpaa den genfandtes i en Del Eks. 01 $3 / 7$ Tp. 17; den blev atter ret alm. ${ }^{16} / 10$ Tp. 13 og fremdeles $\mathrm{i}$ de to paafølgende Prøver ${ }^{18} / 11$ Tp. 7 og ${ }^{26} / 12$ Tp. 3, men den er mærkelig nok ikke paavist 02 .

Haldso. R. l. er kun paavist i enkelte Eks. $017 / 8$ Tp. 18.

Skanderborgso. R. $l$. paavist i enkelte Eks. $01{ }^{20} / 11$ Tp. 6 og $02{ }^{27} / 1$ Tp. 1.

Julso. R. l. paavist i enkelte Eks. 01 $15 / 9$ Tp. 12.

I storst Mrngde fandtes $R$. l. i Almindso nær Silkeborg 01 3/8 Tp. 18, hvor den sammen med Attheya dannede en vesentlig Del af Planktonet; lỉer paa $3-4$ Individer var ike sjældne. 
I Smatasoer og lamme er Rhizosolenierne ikke parviste. Saafrent Resultatet af Undersogelsen er paalideligt, er Rhizosolenia tongiseda sjadden i vore Suers pelagiske liegion; on Periodiciteten kan intet angives. Hvilesporer er scte i Tjustrupso $01 \quad 18 / 11$ og $26 / 10$.

R. longiseta Zach. var. slagnalis Zacll.

Za a li arias 99 (. p. 85, Fig. 5.

Af denne Form mener E. L. at have set enkelte Eks. i $0221 / 3$ Tp. 1 fra Sorøso.

\section{Biddulphioideæ Eucampiinæ.}

Idpraget marin Fan. med adskillige Planktonorganisuer; kun en af Gruppens Slargter optraeder ogsaa i Ferskvand.

\section{Attheya.}

Marine Planktondiatomeer; kun een Art er Planktonorganisme i Ferskvand.

\section{A. Zachariasi Brun.}

Bruno Schrøder 97. Tab. 17, Fig. 1 a. 1 b.

A. Z. er paavist i Furesø, Sorøsø, Tjustrupsø, Haldsø, Skanderborgsø, Mossø og Julsø. Den optrader overalt kun i et begrænset Antal Prøver og som oftest kun i yderst faa Eks.; den synes at være lyppigst i Aug.-Sep.-Prøverne. I Okt. tager Antallet af, og samtidig viser sig den midt i Cellen beliggende Hvilespore, karakteriseret ved sin tykke, stærkt forkislede Vaeg. Individer merl Hvilespore er endnu i Dec. paavist i Tjustrupsø. Af de ovennæevnte Søer var Arten hyppigst i denne. I størst Maengde fandtes dog Attheya $013 / 8$ Tp. 18 i Almindsø; den optraadte her i uhyre Mængde og var en af Planktonets Hovedformer; ofte fandtes Kxeder paa to Individer. Arten kendes i uglødede Praparater lettest paa det karakteristiske Kromatoforbaand.

Attleya og Rlizosolenia blev forst fundne af Zacharias i Plönersøerne (93 p. 38), Attheya blev næermere undersøgt af Brun (94 p. 53); Fundet vakte en ikke ringe Opmarksomhed. Begge Former blev derpaa genfundne i Plönersøerne (Apstein 96 p. 143) samt i talrige andre holstenske Søer (Apstein 96 p. 143 , Zacharias 98 a. p. 161), ligeledes i »Altwassern des Oberrheins (Lauterborn 96 p. 11), ved Breslau (Bruno Schrøder 97 p. 367), i vestpreussiske Søer (Seligo og Bruno Schrøder 00 p. 81). Endvidere er begge fundne i Finnträsk i Finland (Levander 00 b. p. 11). Attheya angives i Valloxensø (Borge 00 p. 17), i Vettern (De Toni \& Forti 00 p. 550), i Vansjø, Norge (Holmboe 00 p. 22); Rlizosolenia longiseta blev funden af Zacharias i saksiske Fiskedamme (99 c. p. 86), i Le Léman (Chodat 98 p. 183), R. eriensis, tidligere kun kendt fra Eriesøen, blev senere paavist i Como og Genfersøen (Brun. Cit. efter Chodat 98 p. 183) samt i saksiske Smaadamme (Zacharias 99c. p. 86) og i Schlesien (Bruno Shrøder (98a. p.529).

I en al de saksiske Fiskedamme fandt endvidere Zacharias en Form af R. longiseta, som han kalder var. stagrualis (99c. p. 87).

Man ser heraf, at begge Slagter er overordentlig vidt udbredte, men om Mangden, hvori de $\mathrm{i}$ de vedkommende Vandarealer forekommer, ved man endnu kun grumme lidt. Ogsaa Angivelserne om Periodiciteten er yderst sparsomme. Apstein angiver begge Arter som hyppigst i Juli, Zacharias (96 $a$. p. 59 ) i Juli-Aug. La uterborn har (96 p. 13) fundet Rlizosolenia 27. Dec. Tp. 2, da Vandet delvis var islagt.

Rettest tør man vistnok opfalte Altheya som udpraget Sommerform, hvis Maks. omtrent falder sammen med Vandets højeste Tp. Rlizosolenias Periodicitet er hidtil slet ikke udredet; det synes dog, som om den viser en mærkelig Forkærlighed for lave Temperaturer (Lauterborn, vi selv), medens den ogsaa kan have et betydeligt Maks. ved Vandets højeste Tp. (Almindsø (01).

Hvilesporerne, som vi i øvrigt intet tilsvarende har til hos de orrige af Ferskvandets Planktondiatomeer, er ikke det mindst markelige Trak hos disse interessante Former. Hos Atlleya er de paaviste 29/s (La u- 


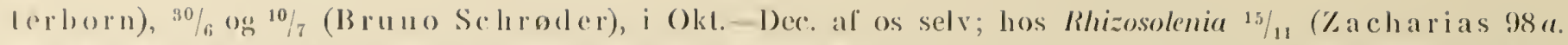
p. 163), ${ }^{14} / 11$ og ${ }^{26} / 12$ af os selk. Kadedannclsen er paravist af Zacharias ${ }^{17} / 12$ (98 a. p). 16ij), Kaederne dannedes al 1 - 1 i Individer.

Bruno Schroder gor (97 Talb. 17, Fig. 1 a. og 1 b.) opmanksom par den store Forskel i Cellernes Bredde. On den marine Rhizosolenia aluta Brightw. meddeler Schütt (00) p. 85), at Auxosporedannelsen forenatar i Augg; Cellens 'Tykikelse er storst i Sep.; fra da af altiger denne stadig lige lil Aug. Conlgende Aar. Ogsara vi har iagltaget den store Forskel i Cellebredden, som maske skal fortolkes paa samme Maade som hos Schlült angivel for de marine Formers Vedkommende. Af Laulerborns, Bruno Schrøders og \%acla arias' lagllagelser fremgaar, at begge Sliegter lige sata vel fincles i lave Smaadamme som i større Søer.

\section{Pennatæ.}

Af Ferskvandets Planktondiat. tilhorer 5 Slexgter: Fragilaria, Synedra, Aslerionella, Tabellaria og Diatoma Afdelingen Penutar. De horer alle ind under Underafdelingen Fragilarioidea. Af Hensyn til Fremstillingen af Kixdedannelsen hos Planktondial. er Fragilarioider Fragilaciince behandlede først.

\section{Fragilarioideæ Fragilariinæ.}

Familien taller et betydeligt Antal Planklonorganismer, deriblandt en udpræget marin, pelagisk Słægt (Thulassiothrix), samt llere Slargter med pelagiske Arter dels i Havet, dels i Fersk vand (Fragilaria, Aslerionella). Arter, ler optreder pelagisk bade i Hav og Ferskvand, kendes ikke; enkelte Ferskrandsformer er paaviste i Brakvand, rimeligvis udforte med Floderne ( $F$. capuzina Desmaz., F. crotonensis Kitton.), Lemmermann (Greifswalder Bodden 01 a. p. (2)).

\section{Fragilaria.}

Af deme, dets marine, dels lacustrine Slacgt er der i Ferskvand beskrevet tre Plankton-Fragilarier, nemlig $F$. crotonensis (Edw.) Kitton., F. virescens Ralfs og F. capuzina Desmaz. Vi har i vore Søer kun kunnet udskille de to forstnxwnte; angaaende sidstnæunte henvises lil Heiberg (63 p. 69).

\section{F. crotonensis (Edw.) Kitton.}

Tab. III, Fig. 25.

C. Schröter 97. Tab. Fig. 13-29.

Fureso. $F . c$. findes i alle Prover. I Tiden fra $00{ }^{20} / 12$ Tp. 4 til $01{ }^{15} / 5 \mathrm{Tp} .13$ holder den sig $\mathrm{i}$ ganske faa Eks. i hver Prove og er navnlig sjælden umiddelbart før og efter Islosningen. Efter $27 / 5$ Tp. 14 stiger Antallet, og Naks. naas $7 / 6$ Tp. 16. I Sommerproverne falder Antallet stadig, men stiger atter $30 / 8 \mathrm{Tp} .17$, og et nyt, meget stort Maks. indtræeder $7 / 9$ Tp. 16, hvorpaa Arten tager af, men dog stadig holder sig med en Del Eks. hele Vinteren 01-02. Foraarsmaks. begynder atter $02{ }^{25} / 4$ Tp. 5 og holder sig til $5 / 6$ Tp. 12 ; denne og folgende Prove ${ }^{17} / 6$ Tp. 14 viser en betydelig Nedgang, hrorpaa der atter finder en Stigning Sted $11 / 7 \mathrm{Tp} .14$ efterfulgt af endnu en Nedgang $3 / 8 \mathrm{~T}$ p. 15.

Esromso. F. $c$. fincles i alle Prover; den er i Tiden fra $00{ }^{17} / 12$ Tp. 5 til $01{ }^{6} / 5$ Tp. 8 sjælden; derpaa stiger Antallet, et stort Maks. naas $29 / 6$ Tp. 15. Antallet tager starkt af $20 / 7$ Tp. 17, men stiger atter $12 / 8$ Tp. 21 og holder sig omtrent uforandret til 30/9 Tp. 17, da Arten tager af og er sjelden hele Vinteren 01-02; Antallet begynder atter at stige $02{ }^{13} / 5 \mathrm{Tp} .8$ og holder sig nu $\mathrm{i}$ nogenlunde ligelig Mrengde til ${ }^{31} / 7 \mathrm{Tp} .15$. Proverne viser $\mathrm{i}$ hele $\mathbf{0 2}$ intet Maks.

Soroso. F. $c$. findes $\mathrm{i}$ alle Prover; den er sjælden $0019 / 12$ Tp. 5 og har sit Naks. $015 / 5$ Tp. 10, men er i ovrigt $\mathrm{i}$ alle de folgende Prover hele 01 og i 02 lige til 19/4 Tp. 4 sjælden. 19/4 findes en Del Eks., men endnu ${ }_{16} / 5$ Tp. 7 og $7 / 6$ Tp. 15 er Antallet ikke stort; forst $28 / 6$ Tp. 17 og $27 / 7$ Tp. 16 optræeder et meget betydeligt Maks., storre end noget tidligere set i Søen.

Tjustrupse. F.c. findes i alle Prøverne; den er sjælden 00 19/12 Tp. 3, Maks. begynder $01{ }^{24} / 5$ Tp. 13 og varer endnu $3 / 7$ Tp. 17 ; i skiftende i Alm. ringe Mrngde holder Arten sig hele Resten af Aaret 01 og hele 02 lige til $16 / 5$ Tp. 8, da indtræeder et nyt, svagt Maks., der atter aftager $7 / 6$ Tp. 12 , stiger stærkt $30 / 6$ Tp. 15 for clerpaa atter at aftage $2 \pi / 7$ Tp. 15 . 
Viborggso. F. C. er patavist i de lleste Prover, men altid kun i enkelte Eks.

11 aldso. $F$. c. er palavist ì alle Proverne: den er sjaclen (0) 30/1 Tp. 1 og umiclelbart efter Islesningen $29 / 3$ Tp. 2; 18/5 T). 10 har Arten el tydeligt Malis., aftager derpata starkt; el svagt Maks. visel sig 7/8 Tp. 18, hvorpaat Arten or sjelden i hele Resten af 01 og i hele (12 lige til 3/5 Tp. 7, da Antallet alter begynder at stige; $30 / 5$ Tp. 8 fincles el storl Maks., der i l’roverne $11 / 6$ Tp, 12, 19/6 og 22/6 gatr noget nedad; Antallet stiger atler $27 / 6$, og i l’rsverne

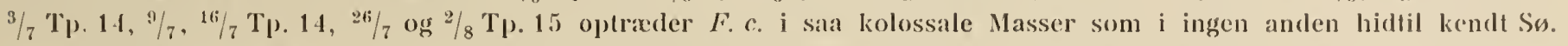

Skanderborgso. F, c. er vel parvist i alle Prover, men synes kun at have underordnet leetydning; el svagt

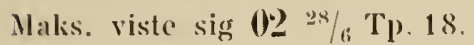

Mosso. F. c. er sel i alle Prover og er muligvis en Hovedform i Soen; i Proverne $0120 / 5 \mathrm{Tp} .120 \mathrm{~g}(1) 228 / 6$ Tp. 16 havde Arten el betydeligt Maks., men optraadte ellers i ringe Mangde.

I u Iso. F. c. synes altid at vere ret sjaclden; et svagt Maks. lod sig paavise $02{ }^{30} / 6$ Tp. 16 .

Ved Damundersogelsen 98 blev Arten paavist i de fleste Damme, men sjalden i stor Mængde og vaesentlig kun i Foraarsproverne.

l)en er ogsaa andetsteds ofte paravist i Damne (Zacharias 98 b. p. 103).

Det vil af ovenstaaende ses, at $F$. crotonensis er vidt udbredt her i Landet, at den paa de fleste Lokaliteter optrader perennerende, og at den til Tider kan danne, som oftest kortvarige, men meget betydelige Maks. Den er overordentlig sjalden i Vintermaanederne ved Tp. omkring Frysepunktet og optraeder altid kun enkeltvis umiddelbart efter Isløsningen. Stigning i Antallet begynder først ved Tp. 5-6, c. en Maaned senere, hvorpa et Foraarsmaks. indtraffer i Tiden $15 / 5{ }^{15} / 6$ Tp. $13-16$; i Sorøsø faldt det noget før (01 $5 / 5$ Tp. 10), men hørte op, da Dinobryernes store Maks. begyndte; i Esromsø $0129 / 6$ og Furesø $017 / 6$ var det meget betydeligt. Saa snart Tp. 18-20 nas, tager Antallet af, og i alle Sommermaanederne 01 var Arten temmelig sjalden. Om Efteraaret 01 ved Tp. c. 16 indtraf et nyt Maks. Furesø ${ }^{7} / 9$, Esromsø ${ }^{12} / 8$ - ${ }^{30} / 9$, Tjustrupsø $17 / 9$; derpaa tog Arten overalt gradvis af.

Undersøgelsens Resultater for 01 og $0^{2}$ drekker hinanden ret godt; kun viser der sig i Sommermaanederne 02 en mærkelig Vaklen m. H. t. Individantallet; Arten er ligesom 01 ved at forsvinde c. $15 / 6$, men idet Tp. paa Grund af den kolde Sommer ingen Steder stiger synderlig over Tp. 16, der synes at angive Grænsen for Artens Maks., udvikler der sig $\mathbf{0 2}$ sekundare Sommermaks, hvortil 01 intet Sidestykke frembyder. Disse Sommermaks, der mer eller mindre gik i Flugt med Foraarsmaks. (Furesø ${ }^{11 / 7}$, Sorøsø $7 / 6$, Haldsø ${ }^{3 / 7}-{ }^{2} / 8$ ), kan være overordentlig store (Haldsø).

Det synes, som om $F$. c. ikke kan trives ved Tp. 16--22; heraf resulterer, at Arten i de fleste af vore Søer og i de fleste Aar her i Landet faar et dobbelt Maks., et i Maj-Juni og et i Sep., begge knyttet til Tp. 13-16; i sarlig kolde Aar (02) kan de to Maks. omtrent naa hinanden og smelte sammen til et.

Bortset fra Baandbredden var Artens Udseende gennemgaaende det samme overalt; kun fremhaves det, at Baandenes Lengde var størst, naar Arten havde sit Maks., navnlig i Maj-Juni; hen paa Efteraaret blev Baandene mindre og mindre, og om Vinteren fandtes kun Brudstykker paa $5-20$ Ind. Zacharias (95 $d$. p. 140) har gjort en lignende Iagttagelse.

F. c. kendes, saa vidt vides, ikke fastsiddende; Arten optraeler altid pelagisk. I Ordningen af Oliedraaberne i to Rakker i Midtfeltet og i det kamformede Udseende, der fremkommer ved, at Midtstykket er bredere end de tynde Endestykker, tør man vistnok se Karakterer, Planktonlivet har medført.

$F$. crotonensis er en overalt i Europa optrædende meget alm. Art, hjemmehørencle saa vel i det mellemeuropxislie Slettelands Søer som i Alpesøerne og de norditalienske Søer; at angive de talrige Findesteder for denne Art anses for unødvendigt; kun benırkes det, at den tilsyneladende ikke gaar saa højt mod Nord som de øvige Diatomeer. A. Cleve (99) omtaler den ikke fra de laplandske Søer, Borge (00 p. 8) kun fra Valloxensø og Holmboe $(00)$ overhovedet slet ikke fra de norske Søer. Saafremt Artens Maks. lionstant ligger ved clen angivne Tp. 13-16, er det jo muligvis Tp. eller de af den aflaengige Faktorer, der satter en Granse for F. c.'s Fremtrangen mod Nord.

Artens Maks. angives i Udlandet til meget forskellig Tid. 
I Zïrichersoen skal Maks. ligge dan.- Maj med Hovedmaks. i Jan. (Schröter 97 Tabel), i Neuenburger-

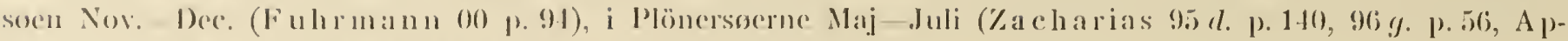
stein !li p. 112), i Stuhmersoerne ()kt. (Seligo 00 p. 57).

\section{F. virescens Ralfs.}

Tal), VI, Fig. 69.

Schröter 97. Tavle Fig. 51.

F. 1. er con Bund- og Bredform, som i Marngde kan findes mellem den submerse Vegetation, hrorfra den forstans ud pai Soernes centrale Partier; den er ikke hjemmehørende i disses pelagiske Region.

Her i Landel or den parvist i hrer eneste Sø, ofte nesten i hver Prøve og er navnlig i Foraarstiden unicldeflart efter Islosningen ikke sjatken. Som saa mange Bund- og Bredformer formerer den sig rimeligvis starkest om Vinteren, livorpar den efter Isløsningen i Foraarsstormene rives løs og for en Tid optrieder son Planktonorganisme (Tjustrupsø (02 $16 / 5$ Tp. 8, Ilaldsø (12 $3 / 5$ Tp. 7). Ved Damundersøgelsen 98 blev den meget ofte paraist.

\section{Synedra.}

Slangten Synedra indbefatter overvejende Bund- og Bredformer, hjemmehørende dels i Fersk-, dels i Saltvand. I Ferskvandets Plankton optrexder hojst tre Arter: S. acus var. delicatissima, S. ulna var. longissima og var. actinastroides samt S. berolinensis Lemm.; sidstnarnte, der er kolonidannende (Lemmermann $00 c$. 1. 31), er os ukendt. Om S. actinastroides Lemm. $(00$ c. p. 30) se under S. ulna.

S. acus var. delicatissima Grun.

Tab. II, Fig. 19. TaI. VIII, Fig. 92.

Schröter 97. Tavle Fig. 49-50.

Denne overordentlig slanke, traadfine Diatomee er paavist i alle de undersøgte Soer og som oftest $\mathrm{i}$ et stort Antal Prøver; vi kunde 01 aldeles ikke blive klare over Periodiciteten, vistnok fordi vi havde benyttet Mollergaze Nr. 19; derimod bler den udredet 02 ved Benyttelsen af Nr. 20; uden Trivl gaar ogsaa et stort Antal Individer igennem sidstnævite. Vi holder os i det følgende vasentlig til Angivelserne fra 02.

Fureso. $S$. $a$. var sjalden før Islægningen $027 / 1$ Tp. 2 og ${ }^{31} / 1$ Tp. 1, men talrig i Sluseproven $28 / 2$ og var noget aftaget efter Islosningen $23 / 3$ Tp. 1; derpaa steg den i Antal $11 / 4$ Tp. 4 og opnaaede et meget stort Maks. ${ }^{23} / 4$ Tp. 5 og $21 / 5$ Tp. 9, var ret alm. $5 / 6$ Tp. 12, men sjælden i senere Prøver.

Soroso. S. $a$. fandtes $\mathrm{i}$ alle Prover 02 med et svagt Maks. ${ }^{16} / 5 \mathrm{~T}$ p. 7.

Tjustrupso. S. $a$. fandtes $\mathrm{i}$ alle Prover 02 og havde ${ }^{16} / 5$ Tp. 8 et meget stort Maks.

Skanderborgso. S. $a$. var her ret alm. efter forste Islægning i Proven $02{ }^{3} / 1$ Tp. 1 samt lige for anden lslægning $27 / 1$ Tp. 1. Efter den endelige Islosning var den i Prøven $1 / 4 \mathrm{Tp} .2$ meget alm. Maks. holder sig konstant til $3 / 6$ Tp. 15, hrorpaa den tager stærkt af.

IIosso. S. a. var ret alm. i alle Foraarsproverne 02 10/5 Tp. 8 til $28 / 6$ Tp. 16 ; derpaa forsvandt den.

Julsø. S. $a$. er paavist 02 i hver Prove med en svag Stigning $2 / 6$ Tp. 13 og ${ }^{30} / 6$ Tp. 16, men fandtes ikke senere.

I Esromso, Viborgso, Halds $\varnothing$ forekommer $S$. $a$. sporadisk i begge Iagttagelsesaarene; den optraadte kun enkeltvis og viste intet Maks.

I Damme er Arten ikke paavist.

Af Iagttagelserne i 01 lader der sig ikke meget udrede; dog maa det fremhæres, at $S$. $a$. optraadte i ret stor Mrengde $18 / 9$ Tp. 12, Sorosø og ${ }^{20} / 11$ Tp. 6, Skanderborgso, hvilket tyder paa et Efteraarsmaks., hvorom de ufuldkomne Methoder kun giver sparsomme Oplysninger.

Man kan af de her girne Meddelelser slutte, at S. acus var, delicalissima er en i vore større Soer alm. forekommende Planktonorganisme, som i de fleste af disse har et tydelig paaviseligt Foraarsmaks. næermest beliggende $\mathrm{i}$ Tiden fra $15 / 4-1 / 6$ ved Tp. 4-10. Maks. kan dog ogsaa begynde ved Tp. $1-3$. 
Arten angives fra en Del ndenlandske Soct, men bliver vistnok ofte overset og dens Betydning under-

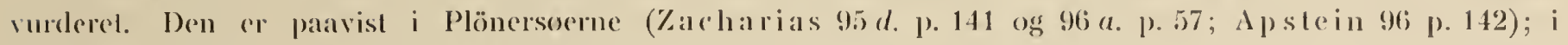
Bodensoen (Schröter Kirchner 96 p. 25); i svenske Soer (de Toni \& Forti o0 p. 5is8); i norske Soer (Holmboe 00 p. 9); i talrige vestpreussiske Søer (Seligo \& Bruno Schroder 00 p. 81), i Zürichersøen (Schröler 97 p. 34). Se i ørigh Schröter \& Kirchner (96 p. 25).

Zacharias er den eneste, der har Angivelser om Periodiciteten. Han meddeler ( 96 a. p).57), at han har set Maks. i Maj, og at Arten er hyppig fra April til Ang.; allerede i Sep. fandtes den kun i faa Eks.; i BischofTse paavistes et stort Maks. i April.

\section{Syuedra ulna Ehr. \\ van Heurck 85. Tab. 38, Fig. 3. \\ Tab. V. Fig. 57.}

Af denne Art, der er en udpreget Bunddiatomee, har man opstillet to Planktonvarieteter, S. ulua var. longissima W. Sm. og var. actinastroides Lemm.

S. ulluc var. longissima er hidtil her i Landet kun funden i Tjustrupso; i 01 blev den kun funden enkeltvis i enkelte Prover, i $0219 / 4$ Tp. 4 derimod i en Del Eks., men $16 / 5$ Tp. 8 var Antallet steget saa starkt, at Arten nu var Planktonets Hovedform og forekom i stor Mrngde; i de senere Prøver forekom den kun enkeltvis. Det bemærkes, at Prøven $16 / 5$ blev tagen af W.-L. selv paa det dybeste Sted i Søens Midte og under og efter blikstille Vejr. Muligheder for Indblanding af Bund- eller Vegetationsmateriale var absolut udelukket.

Var. angices i ørrigt som Planktonorganisme fra Plönersøerne (Zacharias $96 a$. p. 57) og fra norske Søer af Holmboe $(00$ p. 9). I Følge Zacharias (95 d. p. 141) falder Maks. i Plönersøerne Maj-Juni.

Det synes altsaa heraf at fremgaa, at S. ulna som var. longissima virkelig kan optræde som Planktonorganisme, og i saa Fald navnlig i Maj.

S. ulna var. actinastroides Lemm. er en Form, der sammen med Actinastrum Hantzscluii Lagerh. i Følge Bruno Schrøder (99 a. p. 20) skal være karakteristisk for det saakaldte Potamoplankton. Var. aclinastroides er funden i Rhinen og Elben (Lemmermann $00 c$. p. 30) og opstilles her af ham som en egen Art, S. actinastroides Lemm., i Oder (Bruno Schrøder 99 a. p. 20), men er i øirigt ogsaa paavist i Søer, Plönersee, Müggelsec o. a. (Lemmermann 00 c. p. 27). Rimeligris er det ogsaa denne, der angives fra Barlewitzersee (Seligo 00 p. 57). Den er karakteriseret ved, at 4-16 Celler slutter sig sammen til fritsvømmende, bundtformede Kolonier.

E. L. mener at have set $S$. $l$. var. $a$. i Gudenaaen; vi anser det for ganske urimeligt paa Basis af denne Form og af Actinaslrum Hantzschii at opstille et særligt Potamoplankton med disse to buskformede Kolonier som Hovedformer (Bruno Schrøder 99 a. p. 20); lige saa lidt som Schmidle (98 p. 9) anerkender vi Begrebet Potamoplankton og ser i S. ulna var. actinastroides simpelt hen en i buskformede Kolonier voksende Bundform, som en stærkere Strøm har løsrevet fra Bunden, og som derfor, saa længe Kolonien bæres af Strømmen, fører en krasipelagisk Tilvarelse.

\section{Asterionella.}

Slægten tæller, saa vidt vides, kun Planktonorganismer, dels marine, dels lacustrine. I Ferskvand optræder særlig to Arter, A.gracillima Hantzsch. og A. formosa Hassall. Vi har i Overensstemmelse med Whipple \& Jackson (99 a. p. 3) o. a. slaaet disse to Arter sammen; de angives at afvige fra hinanden deri, at Individerne hos A. gracillina berører hinanden $\mathrm{i}$ et Punkt, hos formosa derimod i en Flade. Man kan i de fleste Planktonprøver i saa Henseende paavise alle trenkelige Overgange; i de 4 -straalede Stadier berører Individerne vistnok altid hinanden i et Punkt, i le mangestraalede hyppigst i en Flade.

I Planktonarbejderne er de to Arter snart slaaede sammen, snart behandlede hver for sig. 
Asterionella grecillima Hantzsch.

'al). IV, fig. 12.

Heiberg (i3). Tab. (5, Jig. 1! 20.

C. Sehröler 97. Tab. Fig. 1-12.

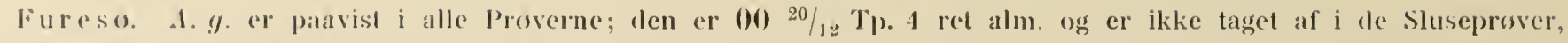
fler loges $0110 / 1$, medens Soen var tillagt; $22 / 1$ Tp. 1, da Soen atter brobl op, var Antallet steget, og medens Søen for

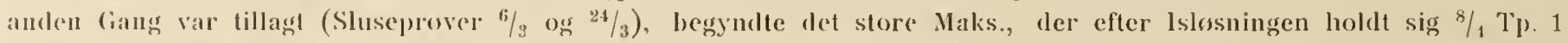
og 2:3/. T). 6; derpar log Arten langsoml af, men var dog hele Sommeren lige til 7/9 Tp. 16 ret alm.; paa dette Tidspunkt indlaal et nyt, men langt svagere Maks., der looldt sig fra $7 / 9$ til 16/11 Tp. 4, hvorpaa den atter var nede paa

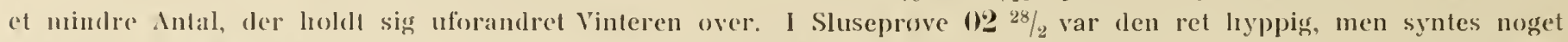

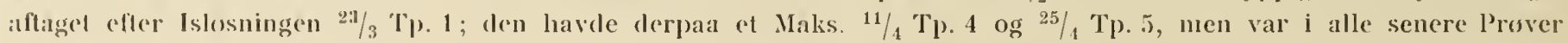
sjaelden.

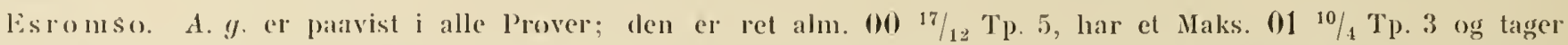
derpan gradvis af; den er sjaclen lige til Slutn. al Juli, men opnar $12 / 8$ Tp. 21 et mærkelig stort Maks. og er i alle de folgende Prover lige til $10 / 11$ Tp. 7 en al de lryppigst forekommende Diatomeer; derpaa tager den af og er Incle Vimferen 01-(0)2 ktm ret alm. 02 22/3 Tp. 2 er Arten efter Islosningen staerkt tiltaget og er nu Hovedform med kolossill Maks. ${ }^{17} / 4$ Tp. 4 ; den aftager starkt i Proverne 13/5 Tp. 8 og 23/5 Tp. 9 og er naesten forsvunden 13/6 Tp. 13 ; $10 / 7 \mathrm{~T}$ ). 11 og $31 / 7 \mathrm{Tp} 15$ moder Arten atter med et stort Maks.

Soroso. A. g. er paavist i alle Prover; (len er ret alm. 00 19/12 Tp. 5 og har et svagt Maks. 01 5/5 Tl. 10, men er $\mathrm{i}$ ovrigt sjaclen hele Aaret lige til ${ }^{18 / 11} \mathrm{~T}$ ). 7 , da den er meget staerkt tiltaget. Soen er derpaa tillagt 14/12-29/12, of $023 / 1$ T p. 2 har Arten et saa kolossalt Maks., at Vandet er grodet; Maks. holder sig uforandret til $30 / \mathrm{Tp}$. 1, een Dag for Soen for anden Gang lagger til. Efter Islosningen i Proven 24/3 Tp. 1 var $A . g$. staerkt aftaget, men var atter meget talrig $19 / 4$ Tp. 4, tog derpaa noget af $16 / 5$ Tp. 7 og var nasten forsvunden $7 / 6$ Tp. 15; derpaa optraalite Arten med et nyt Maks. ${ }^{28} / 6$ Tp. 17 , der var ophort $27 / 7$ Tp. 16.

T.justrupso. A. g. er paavist i alle Prover; den er ret alm. $0019 / 12$ Tp. 3 og har et kolossalt Maks. $015 / 5$ Tp. 7 og $24 / 5$ Tp. 13 ; derpaa tager Arten af og er nasten forsvunden $8 / 8$ Tp. 22; et mindre Maks. viser sig $17 / 9$ Tp. 12 , hvorpar den $\mathrm{i}$ alle Proverne indlil $0227 / 1 \mathrm{~T}$ p. 1 er ret alm. Efter lslosningen i Prove 23/3 Tp. 1 var $A$. $g$. noget tiltaget og havde et stort Maks. $19 / 4$ Tp. 4; dette tog noget af $16 / 5$ Tp. 8 , hvorpaa Arten i de folgende Prover langsomt forsvinder.

Viborgso. A. g. er pasist i alle Prover; den har et Foraarsmaks. 01 29/3 Tp. 1; allerede 18/5 Tp. 14 er Arten naesten forsvunden og er sjalden lige til ${ }^{14} / 10$ Tp. 12 , da et Maks. begynder; dette holder sig endnu, indtil Soen første Gang fryser til 13/12; da den atter bryder op, er Maks. $02 \%$ tiltaget. Efter anden Islosning i Prøve $22 / 3$ Tp. 2 er Antallet endnu stort, men i alle de folgende Prover fra $30 / 4 \mathrm{Tp} .8$ til ${ }^{27} / 7 \mathrm{Tp} .15$ liun ringe.

Haldso. A. g. er paavist i alle Prover; et svagt Foraarsmaks. lader sig paavise 01 $29 / 3 \mathrm{Tp} .2 \mathrm{og} 18 / 5 \mathrm{Tp} .10$; (lerpaa forsvinder den nesten helt og viser sig først $8 / 12$ Tp. 4 med et noget storre Antal; dette holder sig uforandret 02 $3 / 1$ Tp. 2. Efter Islosningen i Prove $22 / 3$ Tp. 2 indtrader et kolossalt Maks., der allerede $3 / 5$ Tp. 7 er staerkt aftaget; Arten er da kun sparsomt repræsenteret til e. ${ }^{22} / 6$, da et nyt Maks. begynder, som er ret betydeligt ${ }^{2 \pi} / 6$; i le folgende Prøver indtil $2 / 8$ Tp. 15 er Antallet kun ringe.

Skanderborgso. A. g. er paavist i alle Prøver; den er ret alm. 00 29/2 Tp. 5 og har et betydeligt Foraarsmaks. 01 19/5 Tp. 13, mangler nasten ganske i Proven $5 / 8$ Tp. 21, men har et nyt, noget svagere Maks. ${ }^{15} / 9$ Tp. 12. 1 hele den orrige Del af 01 og $\mathrm{i}$ hele $\mathbf{0} 2$ indtil $1 / 5$ Tp. 7 findes $A . g$. kun i ringe Mængde. Den har paa dette Tidspunkt et lille Maks., men er i ovrigt sjelden lige til $30 / 7$ Tp. 14 .

Mossø. A. g. er pavist i alle Prover; den er ret alm. $0028 / 1$. Tp. 4, men har et stort Maks. 01 5/5 Tp. 6, der endnu holder sig $20 / 5$ Tp. 12 ; derpaa tager Arten rimeligvis af; den optræeler kun i faa Eks. $1 / 8 \mathrm{Tp} .22 \mathrm{og} 20 / 9 \mathrm{Tp} .14$. Et ringe Maks. viser $\operatorname{sig} 15 / 10$ Tp. $10 ; 10 / 12$ Tp. 5 er den kun set i faa Eks. $02.10 / 5$ Tp. 8 har Arten et stort Maks.; den er hyppig $\mathrm{i}$ de to folgende Prover $3 / 6$ Tp. 12 og $28 / 6$ Tp. 16 , men nasten forsvunden $30 / 7 \mathrm{Tp} .15$.

Julso. A. g. er paavist i alle P'rover, er ret alm. 00 26/12 Tp. 4 og har $0124 / 4$ Tp. 3 et betydeligt Maks., noget aftaget $20 / 5$ Tp. 13 og optraeder derpaa kun enkeltvis lige til $15 / 10$ Tp. 12, da den ligesom i Proven $20 / 11$ Tp. 6 er ret alm.; Soen er nu tilfrossen fra $13 / 12$ til $29 / 12$. $0215 / 1$ Tp. 1 viser Proven et meget stort Maks., (ler holder sig efter anden Islosning og i alle senere Prover indtil $2 / 6$ Tp. 13, hvorpaa Arten tager af $0 g$ g $31 / 7$ Tp. 15 nasten er forsvunden.

A. gracillima synes at vere den enesle Planklondiatomee, som er i Stand til at danne betydelige Maks. i Smaasøer og Dam me. Den blev i 98 paavist i Frederiksborg Slotssø samt i Dammene 3-4-5-6-7-8. Den 
have i Frederiksborg Slotsso el saa liolossall Maks. i Ajril-Maj, at Vandet var groblet; meget store Maks.

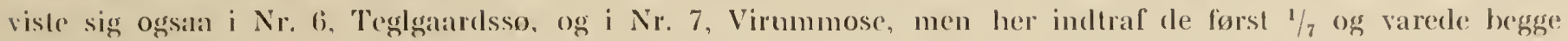
Steder lil e. $1 / 8$. Af ovennevnle Angivelser fremgatr dels, at A. gracitlima saa vel i de storre Sger sonn i mindre 1)amme, horer til de alleralmindeligste Planktonorganismer, og dels, al den overalt optraeder perennerende, lil Tider med meget store Maks

Sammenligner man Iagttagelserne fra $\mathbf{0 1}$ og fra (1)2, vil man se, at disse Maks. snart sagt er beliggencle vel en hvilken som helst 'lpo og lil enhver Tid af Aaret, og det synes, som om Temperaturen kun har en ganske underorlnet Betydning som medbestemmende Faktor ved disse Maksimas Opkomst; det er derfor hojst rimeligt, at de ogsaa er afhangige af ganske andre Faktorer og først og fremmest af Søvandets kemiske Beskaffenher (se herom Whipples 94-00 udmarkede Arbejder).

Af narvarende Undersøgelse kan kun følgende mere alm. Punkter fremdrages.

Af Iagttagelserne i 01 fremgaar clet, at Asterionella i April-Maj Maaned (Tp. 1-12) havle et Maks. i alle vore Soer, hrorpaa der, nar Esromsø undtages, indtraadte et Minimum, der i alle Søerne i hvert Fald holdt sig til Sep.-Okt.; paa dette Tidspunlit viste der sig i Furesø $7 / 9$ Tp. 16, Tjustrupsø ${ }^{17} / 9$ Tp. 12, Viborgso ${ }^{14 / 10}$ Tp. 12 et nyt mindre Maks., der i de ovrige Søer enten var yderst svagt eller ganske urleblev.

l Dec. (1) indtraf en kortvarig Frostperiode, som havde til Følge, at alle de lavere Søer, nemlig Sorøsø, Viborgsø, Skanderborgsø og Julsø, frøs til, hvorimod de dybere og koldere Søer: Furesø, Esromsø, Tjustrupsø og Haldsø holdt sig aalme. Det viste sig nu, at der i tre af de førstnæevnte Søer, Sorøsø, Viborgsø og Julsø, udviklede sig kolossale Asterionellamaks, (ler enten kom op umiddelbart før Islagningen eller lige efter Isløsningen, som indtraf de sidste Dage i Dec.; Maks. holdt sig i disse Søer hele Jan., saa laenge Søerne var aabne, men under den anden Islaegning, der varede fra Slutn. af Jan. 02 til c. 20. Marts, tog Antallet af Arten i Alm. kendeligt af.

I de Søer derimod, der ikke frøs til i Dec., optraadte Asterionellerne paa ganske anden Vis; her viste sig intet navnevardigt Maks. i hele Dec.-Jan., og da disse Søer i Slutn. af Jan. lagde til, var Arten meget sjalden; her udviklede der sig derimod efter Isløsningen i Slutn. af Marts meget store Asterionella-Maks., som holdt sig til 02 c. ${ }^{15} / 4$ Tp. c. 5 .

Som Følge heraf var Asterionella-Mangden i vore Søer i April-Maj meget forskellig. Det kunde synes, som om en af Betingelserne for, at Asterionellerne ved de lavere Tp. skal kunne praestere deres kolossale Malis. er, at Søerne fryser til; de foreliggende Fakta peger i alt Fald i den Retning; sikkert er det i hvert Fald, at Islagningen ikke øver nogen hæmmende Indflydelse paa Asterionella-Maks., der i de ovennæunte Soer var lige saa store umiddelbart efter Isløsningen som før samme. Dette Forhold kan naepe forstaas paa anden Maade, end at Asterionellerne er i Stand til at holde sig svavende i Vandlagene, selv naar disse, saa laenge Søen er tillagt, er i Ro; rimeligvis har de af Max Voigt paaviste Geleskierme i saa Henseende deres store Betydning; man maa endvidere formode, at lrverken Assimilation eller Deling er ganske indstillet, saa laenge lsen ligger.

Det har sin store Interesse at se, hvorledes Søernes Tilfrysning paavirker de to Diatomeeslægter Asterionella og Melosira, (ler her i Landet danner de største Diatomeemaks. paa ganske modsat Vis.

Søernes Tilfrysning synes snarest at virke inciterende paa, hammer i alt Fald ikke Asterionella's Maks., hvorimod Melosirernes Maks. hæmmes eller endog ganske ophører. Melosirerne, der, saa vidt vides, hverken har Geledannelser eller andre Svaveapparater, synker under lslagningen rimeligvis til Bunds. I Jan. Maaned 0:2, da alle vore Søer var isfri, optraadte de store Asterionella-Maks. kun i de Søer, som havde været tillagte i Dec. (Viborgsø, Sorøsø, Julso), og i disse var da Melosirerne i Mindretal; onvendt var Asterionellerne i Jan. (1) kun til Stede i ringe Mængde i de Søer, der ikke havde væerel tillagte i Dec., men til Gengald opnaaede Melosirerne netop i samme Maaned her ofte meget betydelige Maks. (Furesø, Tjustrupsø, Haldsø). 
I Sommeren (0) forlobld Asterionclla sig meget forskelligt i de forskellige Søer og ret afvigende fra Aaret 101.

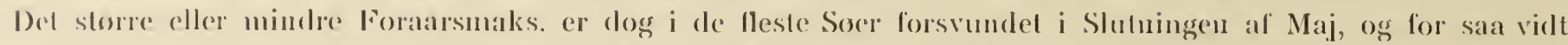

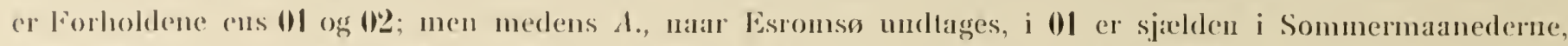
viser der sign i 0"2 i Esromso, Soroso, Vilorgsso og Haldsø ofte meget betydelige Maks., der begynder i Juli og $\mathrm{i}$ Am. ar forsiundue inden Aug. I Esromso loblder dette Maks. sig dog endnu $31 / 7$.

A. gracillima har en overordentlig stor geogralisk Udluredning; den er i Folge A. Cleve (99) p. 827) alm. i de laplandske Soer og pantist i Lago di Cono (Garbini 98 a. p.671); al angive de nesten talløse mellemliggende Findesteder vilde viere overflodigt; vi indskranker os til at bemarke, at Arten i lige Grarl synes at kumne optriede dominerende i det mellemeuropaeiske Slettelands lave og varme Søer son i de kolde, klare, alpine og norditalienske Soer.

De lleste Forf. stemmer overens i, al Asterionella har to Maks., el om Foraaret og et om Lfteraaret; liyppig angives foratares som det sterste og det mest konstante; Efteraarsmaks. kan undertiden indtræffe midt i Sommermamederne. For Plönersoerne angives Maks. 13. Maj og 1. Aug. (\%acharias 96 $\alpha$. p. 57) eller Maij og Slutn, af Juli (Apstein 96 p. 141), Dobersclorfersee April og Okt. (Apstein 96 p. 141), Altrhein Juni og Olit. -Nov. (Lauterborn 93a. p. 6), Stulnersøerne Maj-Juni (Seligo (90 p. 56), Lautikerried Marts, og Sep.-Dec. (Waldvogel 00 p. 47), Neuenburgersee April og Nov.-Dec. (Fuhrmann 00 p. 94), Zürichersoen April-Maj og Nov.-Dec. (C. Schröter 97 Tabel), Valloxensø Maj-Juni og Okt. (Borge 00 p. 11). For de danske Soers Vedkommende kan man ikke uden videre angive to Maks. Forholdene synes her langt mere komplicerede og vil kun narmere kunne udredes ved Undersøgelser af ganske anden Beskaflenhed end den foreliggende.

Som bekendt optræeder Asterionella nesten altid i Stjærner, langt sjaldnere opløst i Baand; fastsiddende er Arten, saa vidt vides, aldrig funden. Antallet af Straaleme ( der til at "lukke Sljærnen synes at hore 8 Individer. Ved at betragte en 8 -tallig Stjarne nærmere, ser man, at det ene Individ altid griber noget hen over det derpaa følgende, hroraf resulterer, at Stjærnen ikke danner en lukket Ring, men en Spiral, hvad allerede Heiberg (63 p. 68 ) har vist; i Tilfalde af, at Stjæernen kommer til at indeholde flere Inclivider, foregaar Vaksten spiralformet; alt efter lndividernes Antal kan Kolonierne bestaa af 1-2-3-4... Ongange; i de Tilfælde, hror disses Antal er ringe (2-3), ligger de i Almindelighed i et Plan, og Kolonien er i saa Fald skiveformet; stiger Antallet, gaar Individerne ud af deres oprinclelige Leje og udstraaler i saa Fald radiært i alle Retninger; Koloniens Form er da ikke længer skive- men kugleformet.

Undertiden er Krredsen ikke lukket med 8 Straaler, men med et frerre Antal 5-6-7; i de Tilfæelde, hvor Liredsen er lukket af 4 , sidder disse over Kors to og to og omtrent i Forlængelse af hinanden (Vinklen $90^{\circ}$ ); i liolonier paa tre Individer er der $120^{\circ}$ mellem .2 Straaler.

De baanddannede (Tab. V'III, Fig. 92) Íolonier er i Almindelighed ikke zigzagformede, saaledes som vi vil finde dem hos Diatoma tenue og Tabellaria fenestrata, men beskrives lettest som sammenhrengende, trestraalede Kiolonier, der danner lange, sammenhængende, som oftest krummede, undertiden lukkede Baand (Julso $0124 / 4$, Mossø $015 / 5$ ). Ved Gennemgangen af det store Materiale viste det sig nu, at den langt overrejende Del af en Sos Asterioneller i samme Prøve altid optrader enten i Baand eller i Stjærner, saml at Antallet af Straaler i Stjærnerne til forskellige Aarstider er meget varierende i de forskellige Søer, men at Antallet af Straalerne i en enkelt Proves samtlige Asterionella-Kolonier som oftest er mærkværdig konstant; de baanddannede Kolonier treffes saaledes kun i April og Maj (Julso, Skanderborgso, Mossø), (le 4-straaledle kun i Maj ( $5 / 5$ Tjustrupsø, Frederiksborg Slotssø, Virummose). De kugleformede, mangestraalede Kolonier er vasentlig dominerende efter det store Foraarsmaks., men kan i øvrigt ogsaa træffes senere paa Aaret. Fra Juli og Iige til Feb. synes det 8 -straalede Stadium at vare det hyppigst forekommende, men undertiden og tilsyneladende ganske regellost bryder mangestralede Kolonier ind i Rakken. 
Endvidere gives der Soer f. Eks. Haldso, lovor Asterionellerne overvejende synes 8-straalede; i andre derimod er de mangestraalede meget liyppige og optraeder lil naesten alle Aarstider. I Esromsn var lifteraars-

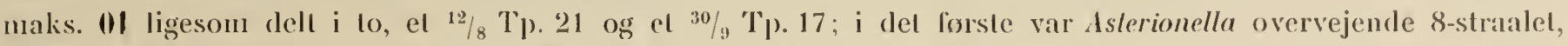
i det sidste saa godt som udelukkende 16-20-30-straalet. Vi maa indskrenke os til al henlerle Opmarksomheden paa disse nurkelige Forhold, som vi for Ojeblikket staar uden nogen Forstaaelse af; de larler sig i ovrigt ikke lose pa Materiale, der kun er indsamlel en Gang on Maaneden; man maatle her rimeligvis arbejde med daglig indsamlet Materiale.

Man kan vistnok gaa ud fra, al det 8-stralede Stadium er det typiske. Naar det da viser sig, at en Sas samllige Asterioneller enten cleler sig i Keder eller bliver 4-straalede eller mangestraalede og endvidere, at delle Fanomen i alt Fald for en Del foregaar til bestemte Aarstider og samtidig i forskellige Søer, kan vi med ret stor Sikkerhed slutle, at ydre Aarsager er medvirkende ved Frenomenets Fremkomst.

Mulighed for, at delte ogsaa kan skyldes indre Faklorer, er i ørrigt ikke udelukket, da adskilligt tyder paa, at der forud for det baand- og 4-straalede Stadium kan vaere foregaaet en Auxosporedannelse, som vi imidlerticl ikke lıar kunnet finde; men denne Side af Sagen hører ind under rle variationsstatistiske Undersogelser, som falder uden for den her publicerede Afdelings Rammer.

Det havde varet vor Agt at angive Straaleantallet i hver 100 Kolonier i de enkelte Prover. Denne Plan matte vi imidlertid opgive. Det viste sig nemlig umuligt at gennemføre en planmæssig Taelning af Kolonierne dels fordi der i hver Prove fandtes et ikke ringe Antal halve eller Kvartkolonier, dels fordi der ved nøjere Besigtigelse af Kolonierne hyppig fandtes 1-22-3 Individer, der var i Deling; begge Tilfæelde vilde under en gennemført Trelning medføre en Vilkaarlighed, som vi ikke saa os i Stand til at raade Bod paa.

I Litteraturen findes vel en Del spredte Angivelser on det skiftende Straaletal hos Asterionellerne, men ingen nærmere Redegørelse. Marsson meddeler (01 p. 113), at A. gracillima i Neue See ved Berlin i Okt. var 8-straalet, 3-8-straalet fra Dec. til Maj og 4-8-straalet den øvrige Del af Aaret; Kieder paa 3-straalerle Kolonier var ret hyppige Dec.-Jan. Bruno Schroder (99 a. p. 23) angiver, at Asterionella i Oderens Foraarsplankton hyppigst er 2-4-straalet, sjældent 6-straalet, i Juni 6-10 eller flerstraalet. Det fremgaar altsaa heraf, at Marson og Bruno Schroder, ligesom vi, finder det ringeste Straaletal i Foraarsmaanederne.

Medens Asterionella her i Europa aldrig har fremkaldt nogen Forurensning af Drikkevandet, er den i New York og andre store amerikanske Byers Vandforsyninger optraadt i saa uhyre Mrengder, at den sammen med andre Diatomeer har givet Vandet en egen fiskeagtig Lugt og umuliggjort det som Drikkevand. Diatomeerne og særlig Asterionella er derfor af Whipple (94-00) bleven underkastede en, navnlig af praktiske Formaal betinget, omfattende Undersogelse, som ogsaa tillige viclenskabelig set har givet meget vigtige Resultater.

\section{Centronella.}

\section{Reichelti M. Voigt.}

Tab. IV, Fig. 43 overst.

Forschungsber. Plön T, 9 02. Tab, 2, Fig. 10.

E. L. havde flere Gange lagt Marke til, at cler i Foraarsprøver fra Sorøsø optraadte en meget lille trestraalet Organisme, som ikke naermere lod sig bestemme.

I det i 02 udkomne Hrefte af Forschungsberichle fra Plöen fandtes denne beskrevet og afbildet af M. Voigt (J.41, Tab. 2, Fig. 10); den angives fra Düpen-See (Krreis Dramburg) i Plussee ved Plöen og i Krummen-Lanke ved Berlin. Den paavistes der i Marts-Juni, men altid kun i ringe Mrengde.

\section{Fragilarioideæ Tabellariinæ.}

Familien taller orervejende marine og lacustrine Bundformer; kun enkelte Arter optrader som l’lanktonorganismer. 


\section{Tabellaria.}

Af Slargtan Tabellaria dindes i Plankion T. Jenestrala og T. flocculosa; begge er lillige fastsiddende Former, sidslnarnle sala gorlt som udelukkende. De to Arler skal i ovrigt efter velvillig Meddelelse fra Hr. Inspektør Oslrup ranskelig lade sig holde nde fra hinanden.

\section{T. fenestrala (Lyngbye) $\mathrm{K}$ ü $1 \%$ \\ 'lab. I, Fig. 2.}

C. Schröler 97. Tab. Fig. 34-48.

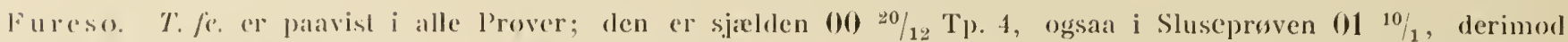
noget hyppigere i proven $22 / 1$ Tp. 1, da Socn lor en kort Tid var isfri, og er ret hypjig i Sluseproverne f/3 og ${ }^{24} / 3$;

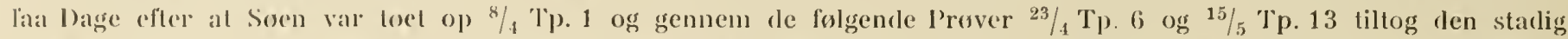
i Antal; den lande sit llaks. ${ }^{15} / 5 \mathrm{~T}$ p. 13 og var paa delte Tidspunkt en af Planktonets Hovedformer; allerede i Proverne $27 / 5$ T p. 14 og ${ }^{7} / 6$ Tp. 16 vall den $\mathrm{i}$ Aftagende og lorl sig nu fra $30 / 6$ Tp. 18 og lige til $2 / 10$ Tp. $16 \mathrm{kun} \mathrm{paa-}$ vise i ganske fai Eks.; den var fra da af, og til Soen efter Islaxgningen brod op (02 22/3 Tp. 1, maaske lidt almindeligere, men maatle dog stadig betegnes som sjalden; el Efteraarsmaks. har i de sidste 5 Aar ikke larlet sig paavise.

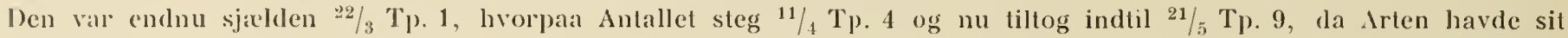
store Maks.; 17/6 Tp. 11 sank Antallet atter en Del, men var 11/7 Tp. 14 steget kolossalt, og et uhyre Maks. paafulgte; allerede $3 / 8$ Tp. 15 var T. fe. igen bleven sjælden.

1 alle de ovrige Soer optreder Arten kun enkeltris; den er navnlig i Foraarsprover paavist i Esıomsa, Sorøso, rjustrupso, Haldso, Skanderborgso og Julso; derimod er den ikke funden i Viborgso og Mossa.

Ved Damundersogelsen 98 blev den ikke parist.

T. Fenestrata er her i Landet øjensynlig ikke synderlig alm. som Planktonorganisme.

Den er som saadan parist i de laplandske Søer (A. Cleve 99 p. 831) og her blandt andet som en ny Varietet geniculala; fra et stort Antal norske Soer (Holmboe 00 p. 26), fra talrige finske Søer (Luevander 00 b. p. 49 o. a.): (len er almindelig i vestpreussiske Soer (Bruno Schrøder \& Seligo 00 p. 81 ) og synes at forekomme hyppig i Vettern (De Toni \& Forti 00 p. 556), i Valloxensø og talrige andre svenske Søer (Borge 00 p. 12). I Schweizersoerne er den (Bachmann 01 p. 241) gennemgaaende ikke hyppig, men i Zürichersoen (Schröter 97 p. 35) viste den sig i Jan. 96 pludselig i uhyre Mrengde. I Plönersøerne synes den kiun at spille en ringe Rolle.

Der er kun faa, der har studeret Artens Periodicitet; Borge (00 p. 12) angiver, at den i Valloxensøen har sit Hovedmaks. i Juni og et mindre i Nov. I Zürichersøen faldt Maks. (97 p. 42) fra Maj til Sep., men den fandes i orrigt altid i Planktonet.

T. fenestrala (cfr. særlig Tab. II) optræder i Planktonet dels som Kæeder, dels som Stjærner, var. aslerionelloides Grunow. I alle Prøverne fra $01{ }^{10} / 1$, indtil Arten naar sit Maks. $01{ }^{15} / 5$, findes den aldeles overvejende som Kæeler; i de Tilfælde, hror Stjærner er paaviste, er disse sjældent mer end 7-8-straalede og i Alm. ikke lukkede. Samtidig med Maks. ${ }^{15} / 5$ optreder flere Stjærner med 7 -8 Straaler, og i de derpaa folgende Prøver ${ }^{2 \pi} / 5$ og $7 / 6$ findes $T$. fenestrata nasten kun som Stjærner med stadig stigende Straaleantal, ${ }^{15} j_{5}$ 10-12-straalede, ${ }^{27} / 5$ og $7 / 6$ 20-30-40-straalede. I den øvrige Del af Aaret findes ligeledes kun Stjærner med rekslende Straaletal (som oftest kun 12-16); forst i Prøverne $02 \%$ og $31 / 1$ begynder Kæederne atter at vise sig. I 02 er Forholdene $\mathrm{i}$ orrigt ganske som 01 . Indtil $25 / 4$ tiltager stadig Baanddannelsen, hrorpaa Delingen i Stjærner begynder; disse er i Alm. 8-straalede ${ }^{21} / 5,12-16$-straalede $5 / 6{ }^{17} / 6$; under det kolossale Maks. $11 / 7$ fandtes overvejende mangestraalede Stjærner.

Man ser heraf, at Asterionella og Tabellaria begge er delt i Kæeder paa samme Aarstid, April-Maj; begge er efter det store Foraarsmaks. mangestraalede, og begge optrader senere paa Sommeren og om Efteraaret med meget vekslende, men som oftest noget mindre Straaletal. Stjærne- og Kædedannelsen foregaar imidlertid hos de to Arter paa ganske forskellig Vis. Medens en Asterionella-Stjærne kan være lukket af 3 eller 4 Individer med Vinkler paa henholdsvis $120^{\circ}$ og $90^{\circ}$ mellem hvert Individ, har vi i Tabellaria-Stjærner 
aldrig sol Kolonier lukkede med mindre end 7 Individer. Bestaar Stjarnen af fierre, fremkommer enten 1/1, $1 / 3$ eller $\% / 4$ Cirkel, alt efter som Stralernes Antal er 3, 4 eller 5. Stiger Antallet af Individerne hos Asterionella og Tabellaria, skyder disse sig spiralformet hen over hinanden, og i hegge 'Tilfáde opstaar da spiralsmoede Baand; men medens Stykker af Spiralerne hos Asterionelta viger ud fra det oprindelige Plan og stiller sig under alle mulige indbyrdes Vinkler, livorved de morgenstjierneformede Kolonier opstair, retter Spiralbaandet hos Tabellaria sig efter nogen 'Tids Forlob ud og slutter siog derpail atter sammen, hvorved der fremkommer en større Cirkel, som nu bliver i Stand til at rumme et støre Antal lndivirler. Morgenstjarneformede Kolonier er aldrig iagttagne hos Tabellaria.

Ogsal Kaderne dannes paa ganske forskellig Vis hos de to Slagter. Hos Asterionella opstaar Kaelerne undtagelsesvis derved, at Individerne omtrent ligger i hinandens Forlangelse - Vinklerne mellem dem er i sala Fald som oftest naer $180^{\circ}$ - i ovrigt ved Sammenkiedning af lutter trestraalede Kolonier. Hos Tabellaria kan Kaderne ogsaa opstaa paa førstnævnte Vis, men i saa Fald er Vinklen mellem to sammenstødende Individer meget spids og sjalden over $45^{\circ}$; herved fremkommer da de karakteristiske Zigzagbaand.

Som oftest bestaar Baandene dog af Halvbuer hver paa 5-6 Individer, der altid er skiftevis ordnede saaledes, at naar den første Halvbues convekse Side vender bort fra Beskueren, vender den næstes indad mod denne o. s. v.; undertiden er der mellem Halvbuerne indskudt en Kade af zigzagstillede EnkeItindivider. 1 de forskellige Maader, hrorpaa Kader og Stjarner er ordnede hos Asterionella og Tabellaria træder de to Arters Ejendommeligheder os i Møde.

Schröter (97 p. 35) er den eneste, der har Meddelelser om Variationen, og har, ligesom vi, fundet Kæeder om Foraaret og senere hen Stjærner; S. har tillige fundet Kæeder om Efteraaret.

Tabellaria flocculosa K $\mathrm{k} \mathrm{tz}$.

Schmidt $74-03$. Tab. 43, Fig. 316.

Denne udprægede Bundform er taget i enkelte Kiæder i et større eller mindre Antal Prøver fra de allerfleste af de undersøgte Søer; som Kæder er den i vore Søers Plankton overalt kun en tilfældig Gxst, der af Bølgeslaget rives løs fra Bredden eller med Vegetationen føres ud paa Søen.

T. f. nærnes her, fordi W.-L. i Maj 99 fandt denne Form som typisk Planktonorganisme med kolossalt Maks. i Store Øxø, c. 4 Kilom. Syd for Skørping i Nord-Jylland; her optraadte den imidlertid overvejende som Stjærner lukkede af 5 Individer, men ogsaa som Baand og halve Stjærner. Søen kan nærmest betragtes som en stor, næppe synderlig dyb Mose med mørkebrunt Vand. T. flocculosa's Farve var mørkegul, nasten brun.

Holmboe $(00$ p. 11) angiver, at $T$. flocculosa ogsaa i Norge kan optrade pelagisk og i saa Fald ogsaa der som Stjærner under en Varietet, han kalder petagica. Den optreder navnlig som saadan i den norske Højfjældssø Gjendin, hvor den i Mangde første Gang blev funden af Huitfeldt Kaas.

\section{Fragilarioideæ Diatominæ.}

Marine og lacustrine Bund- og Breddiatomeer; kun en enkelt Form kan optræede som Planktonorganisme i Ferskvand.

\section{Diatoma.}

Af Slregten Diatoma, der kun taller lacustrine Bundformer, optræder en enkelt Art $I$. elongatum foruden som fastsiddende Form tillige som Planktonorganisme; den kan som saadan føres ud i Brakvand (Greilswalder Bodden: Lemmermann 01 a. p. 92).

\section{D. elongatum $\mathrm{K}$ üt z. var. lenue.}

Tab. IX, Fig. 98.

Schmidt $74-03$. T. 40 og 41 , Fig. 311.

Julsø. D. e. er paavist i alle Prover; den var sjalden 00 ${ }^{26 / 12}$ Tp. 4, men efter at Soen blev isfri i Prove 01

${ }^{24} / 4$ Tp. 3, var den Planktonets Hovedform og vistnok talrigere end den samtidige Asterionella; $20 / 5 \mathrm{Tp} .13$ holdt 


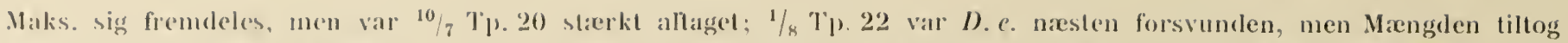

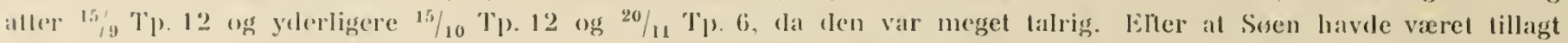

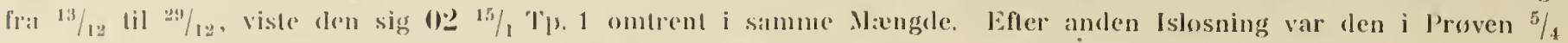
Tp. 3 sanmen med A. groc. Planktonets Hovedform; Iaks. holdt sign i Proverne 5/5 Tp. 6 og $2 / 6$ Tp. 13; Arten var

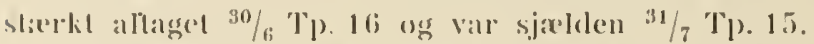

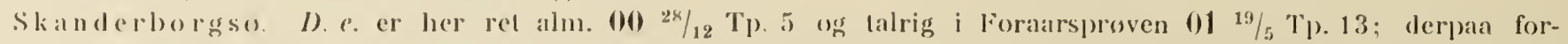

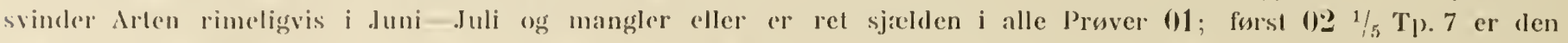

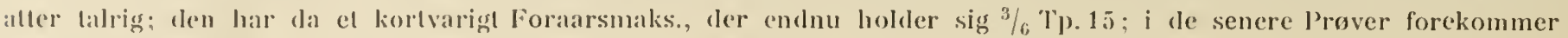
den kun enkellvis.

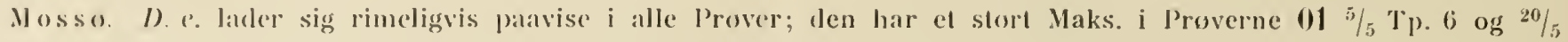

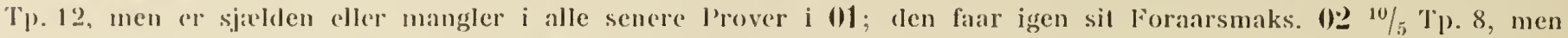
dog mindre end i 111 , og i de senere l'rover er Arten ikke alm.

I Fureso og Tjustrupso findes D. e. sala vel i 01 som i $02 \mathrm{kun}$ i en kortvarig Foraarsperiode fra c. 1. April lil Slutningen af Mạj Tlp. 1 -14. Maks., der i begge disse Soer er ringe, ligger c. 1.-15. Maj Tp. c. 10; i lle bvrige Prover lia disse Soer mangler Arten i Almindelighed.

I Esromso og Viborgso er den kun paravist enkeltvis i enkelte forarsprover.

I Ilaldso og Soroso synes den at mangle.

led Dimumblersogelsen 98 blev I). e. ikke funden.

Det fremgaar heraf, at $D$. elongatum i vore Søer ikke spiller nogen synderlig Rolle som Planktonorganisme; kun i Julsø har den nogen Betydning som saadan. Den synes kun at have eet Maks., der falder i April-Maj Tp. 4-10; den er perennerende i Julsø og muligvis i Skanderborgsø og Mossø, men udenfor April-Juni plejor den at mangle $\mathrm{i}$ de ørrige Søer.

Heller ikke i Udlandet angives Arten fra ret mange Søer, men der er Grund til at tro, at clen ofte er bleven forvekslet med Asterionella. Den er hyppig i Plönersøerne (Zacharias 95 d. p. 140 og 96 a. p. 57 , Apstein 96 p. 142), i Stuhmersøerne (Bruno Schrøder 00 p. 74) sant i adskillige andre restpreussiske Soer; Holmboc angiver den $(00$ p. 62$)$ fra en enkelt Sø i Norge.

Zacharias har i Plönersøerne fundet ganske samme Periodicitet som her til Lands. D. e. viser sig i Fel). og holder sig til Begyndelsen af Juni, danner enorme Maks. i Maj, hrorpaa den meget pludselig forsvinder.

Her i Landet er D. elongatum kun parist som Kreder, aldrig som Stjærner; Kæderne er byggede væsentlig som Asterionella's og bestaar ofte af korte Stykker paa tostraalede Kolonier; hyppig forekommer log ogsaa meget lange kixder sammensatte af lutter trestraalede Kolonier; Kæder kan i ørrigt ogsaa opstaa ved, at Individer stadig kreder sig til foregaaende Individs Endeflade.

I Plönersøerne optræler D. e. i Folge Zacharias ligeledes kun i Kæeder. Af ikke ringe Interesse er Bruno Schrøders Angivelse (00 p. 74), at I), elongatum, der i Barlewitzersee først har sit Maks. i Juni, her optræeler som Stjæerner. Samtlige Iagttagere angiver nemlig, at Tabellaria, Asterionella og Diatoma samtidig i April-Maj er delte i Kreder; derpaa forswinder Diatoma de fleste Steder, og der udvikler sig intet Stjærnestadium; Tabellaria og Asterionella vedbliver derimod at optræde som Planktonorganismer, men findes da saa godt som udelukkende som Stjærner. Bekræftes Bruno Schrøders Iagttagelse, viser det sig, at hvis Diatomas Maks. først falder i Juni ə: paa det Tidspunkt, da Asterionella og Tabellaria optræeder som Stjærner, da danner ogsaa Diatoma Stjærner, og Kædestadiet, der ellers er det typiske for denne Form, udebliver.

Ved Omtalen af de stjærnedannende Planktondiatomeer: Asterionella, Tabellaria fenestrata og flocculosa samt Diatoma elongatum er der i øvrigl Grund til at fremhæe (se ogsaa Holmboe 00 p. 11). at i hrert Fald Tabellaria og Diatoma egentlig er fastsiddende Former; som saadanne optræder de, saa vidt vides, aldrig som Stjærner, men kun som Kæder. Stjærnedannelsen er karakteristisk for Arten som Planktonorganisme, dog synes Stjæernestadiet ikke at indtræede ved de lave Foraarstp. $(1-8)$, men først ved noget højere $\mathrm{T}_{\mathrm{p}}$. $(8-12)$ og, som det synes, samtidig hos alle Former. 
Planklonumdersogelserne har godlgjort, al, naar Diall i Maj--Juni Maaned forsvinder af Planklonel, er del altid som Stjarner; naar de del naste lorate i Mats aller viser sig, findes de derinod aldeles overvejende kun som Kaeder. Der er derfor en Mulighed for, al disse Planklonorganismer hvert Aar rekruteres lia fistsidglende Former, og al disse Dialomeer som Folge heral har el regelmessigl Skifte mellem el kiroledamnende fastsidelende og el stjarmedannel pelagisk Stadium.

Ojensyulig ligger lier en vid Mark aaben for el nermere Studium af, hvad der bevirker, al disse oprindelige Bundformer bliver Planktonorganismer, og hvilke de Forlold er, som forarsager, at Koloniens Form i saa Fald undergatr saa belydelige Forandringer. Hvad her liltranges er dels en regelmassiģ daglig Iagtlagelse ude i Naluren, dels Eksperimenleren i Laboratoriet (saerlig med Lyskilder af lorskellig Styrke); saa laxne begge Dele mangler, forer en yderligere Behandling af Emnel vaesentlig kun til frugtesløse Spekulationer.

\section{Bunddiatomeer i Planktonet.}

Undersogelsen har vist, al der i alle Søerne optracler en Del Bunddiatomeer, der enkeltvis forekommer i et betycleligl Antal Prøver. De vigtigste Former er Campylodiscus hibernicus Ehr., Surirella elegans Ehr. og biseriata Bréb., Cymmatopleura solea W. Sm. og elliptica (Bréb.) W. Sm. De tilhører alle Fam. Naviculoidece og optraeler sarlig i Efteraars-, Vinter- og de tidlige Foraarsprøver. Kun en eneste af disse Former, Cymatopleura elliptica (Tab. II, Fig. 6), synes i visse Søer at kunne optraede som typisk Planktonorganisme. Den er perennerende i Furesøen og optraadte i Foraars- og Efteraarsprøverne 01 og 02 saa talrig, at den til Tider var en af Planktonets Hovedformer. I 98 havde den i April et meget slort Maks. og var næsten lige saa hyppig som Melosirerne. Den nærnes ogsaa af Chodat (97 a. p. 308) som typisk Planktondiatonee i Genfersøen.

Ogsaa andre Forskere angiver nu og da, at Bunddiatomeer kan spille en ret betydelig Rolle i Planktonet. Holmboe (00 p. 10) har saaledes paavist Surirella splendida i talrige Planktonprøver, navnlig i Gudbrandsdalen, og regner den mellem de typiske Planktondiatomeer; Bachmann (01 p. 243) angiver, at han 1000 Meter fra Bred i godt Vejr ude paa Genfersøen fandt talrige Bunddiatomeer, vasentlig de samme Former, som er navnet ovenfor.

Den Tid paa Aaret, da Bund-og Bredformerne ganske sarlig viser sig i Plauktonet, er efter de stærke Efteraarsstorme i Nov--Dec. Det brede Bælte, der i vore Søer næsten altid fincles udenfor Scirpus-Phragnites-Skovene, og som vasentlig dannes af Potamogeton lucens og $P$. perfoliatus, befinder sig paa dette Tidspunkt i en halvraadden Tilstand; det løsnes af Bølgeslaget og føres med Diatomeebelagningerne ind mod Bredden, hvor en bred Bræmme af opskyllet Vegetation opstaar. Naar Søen derpaa stiger, bortskylles denne Bræmme, og de henraadnende Dynger med Sommerens fastsiddende Materiale af Diatomeer, Rivulariaceer, Chlorophyceer etc. spredes da ud over Søen. Planktonprøver fra Dec. fra Tjustrup-, Esrom- og Skanderborgsø, som jeg med Sikkerhed ved er tagne midt ude paa Søen, har indeholdt saa store Mrengder af disse Epifyt-Samfund, at man kunde tro, at Proven var laget i Vegetationszonen incle ved Land.

Bunddiatomeerne optræder sarlig i saadanne større Søer, hvis Dybde er meget ringe; de spiller saaledes en stor Rolle i Ballatonsøens Plankton (Istvánffi 98 p. 22); jeg har sierlig truffet dem i Mrengde i Planktonprøver fra den kun faa Meter dybe Sjaelsø. 
ALMHNDEI,IGE BEMARKNINGER.

Plankton-Diatomeernes Forekomst i de undersogte Søer.')

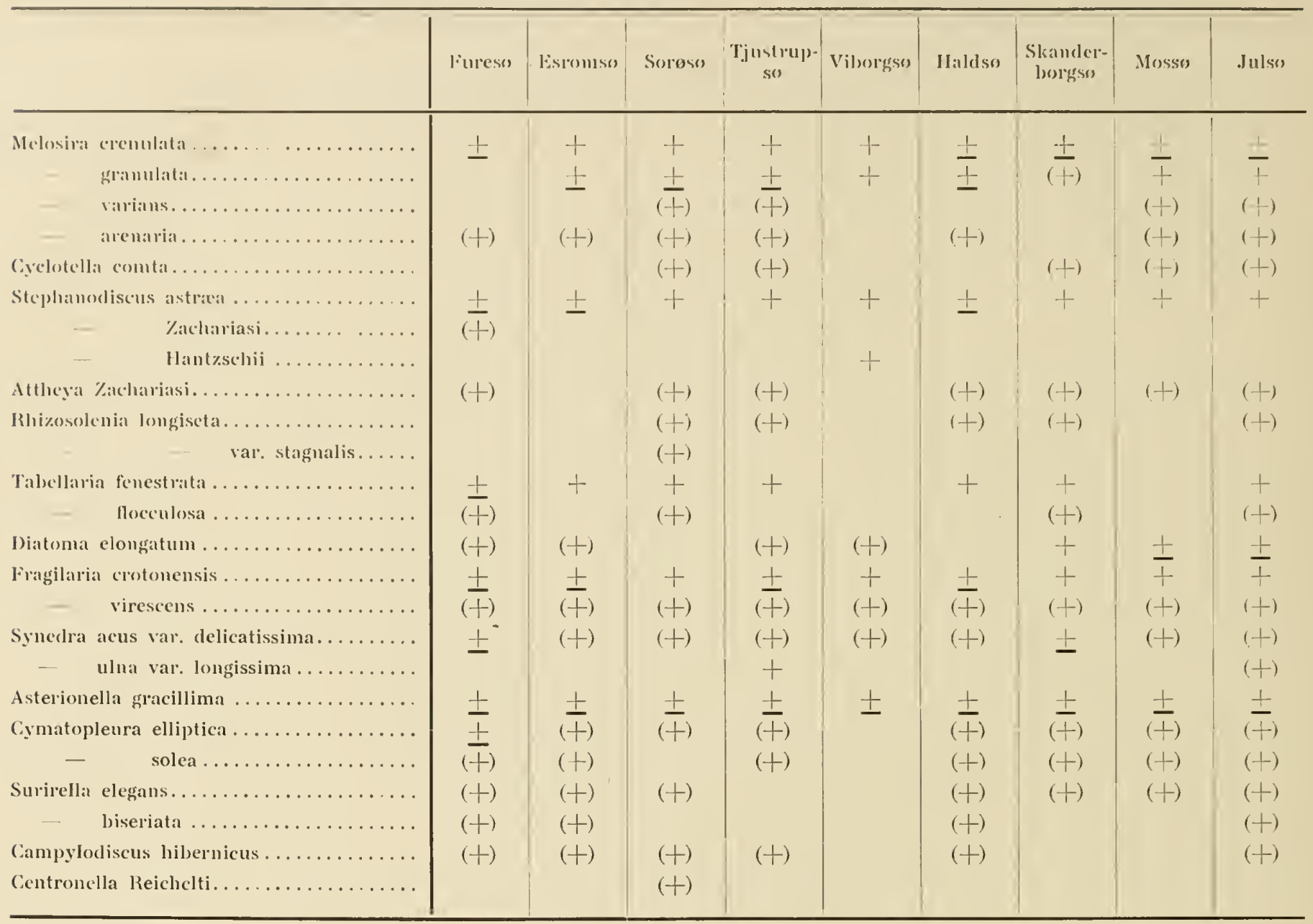

Der er i alt paavist 25 Diatomeearter i Planktonet, men kun de færreste af disse spiller en større Rolle i Søernes pelagiske Region; et stort Antal Former (8) nemlig M. variaus, M. arenaria, Tabellaria floccnlosa, Fragilaria virescens samt alle Pennate med Undtagelse af Cyuatopleura elliptica er tycholimnetiske, der altid kun optræeder enkeltvis; adskillige er sjældne Former som Cyclotella coula, Stephanodiscus Zachariari samt Synedra ulua var. Iongissiuna og Centronella Reichelti; herhen maa rimeligvis ogsaa Attheya og Rhizosolenia regnes, sely om disse maaske er noget hyppigere, end det af dette Arbejle kan synes at fremgaa.

Ogsaa Stephauodiscus astrara, Tabellaria fenestrata, Diatoma elougatum og Synedra acus er, om de end maa anses for almindelige, i de færreste Søer dominerende, og i saa Fald kun i et ret begrænset Tidsr'um. Der bliver saaledes kun 4 Diatomeer tilbage: Melosira crenulata, graunlata, Fragilaria crotoneusis og Asterionella gracilliuı, som i den langt overvejende Del af Søerne over længere Tidsrum danner Hovedmassen af Søernes Plankton.

1. I Modsætning til Cyanophyceernes Maks. falder alle de store Diatomeemaks. ved lavere Tp., sædvanlig ved en $\mathrm{T}_{\mathrm{p}}$., der er under Tp. $10 \mathrm{og}$ aldrig over $\mathrm{T}_{\mathrm{p}}$. 16, se $\operatorname{dog}$ Asterionella; vi kender $\mathrm{i}$ vore Søer intet Eks. paa, at Diatomeer har opnaaet større Maks. ved Vandets højeste $\mathrm{T}_{\mathrm{p}}$.

1) Om Tegnencs Betydning se p. 56. 


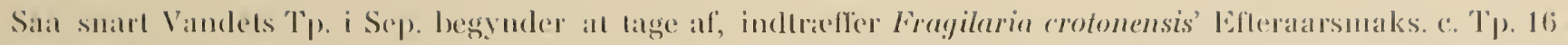

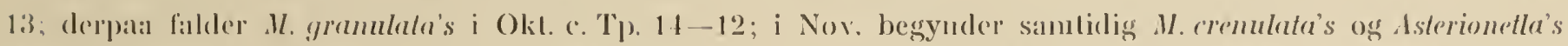

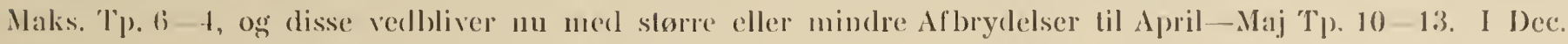

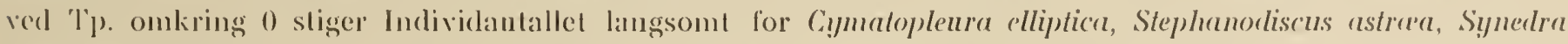
acus vir. delicatissina: Cymatopleura's Maks. er allerede forbi, kort efter at Isen er ganel af Vandel 'Tp. 3-4; Stephanodiscus' egentlige Maks. indtraffer omtrent ved lenne 'Tp. (April), men er allerede ophort i Maj;

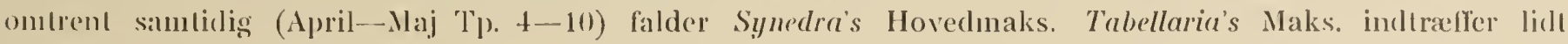
senere 'Tp. 10 13 og sidst Fragilaria crotonensis' Foraarsmaks. c. 15/5-15/6 'Tp. 13-16. Dermed plejer Diatomeerne at forsvinde al' vore Soer; kun Asterionella og undtagelsesvis Melosirerne kan i Sommermaanederne opnala mindre, men lidet undersggte Maks.

Del synes, som on (ler i alle vore Soer ved Tp. omkring 0 staar en Kamp om Overherredømmet mellem 11. crenulata og Asterionella; i Tilfalde af, at Søen lagger til, sejrer Asterionella; forbliver Søen aaben, faar (lerimol Melosira Overtaget (Sorøso, 'Tjustrupso o. a.).

I Modsetning til Cyanophyceerne indtraffer dobbelte Maks. hos Diatomeerne ikke saa sjaldent; jo lıjere den 'Tp. er, ved hvilken en Arts Maks. ligger, des hyppigere vil Arten faa et dobbelt Maks.; har Arten f. liks. et Maks. i Sep., vil den forsvinde ved Vinterens lave Tp., men atter florere, naar Vandet om Foraaret nærmer sig den Tp., ved hvilken dens Maks. faldt om Efteraaret (Fragilaria crotonensis); jo nærmere en Arls Maks. ligger ved 0, des mindre Sandsynlighed er der ogsaa for, at et dobbelt Maks. kan indtrade. Forskellige ydre Forhold, f. Eks. Islægning, Konkurrence med andre Arter etc., kan dog for en Tid standse et Maks. i sin Udvikling og hidføre en Tredeling, der under vedkommende Breddegrad ikke er normal, men fremkaldt red mindre generelle, lokale Faktorer.

Medens Cyanophyceerne under Min. ofte saa at sige ganske forsvinder (se pag. 56), er dette sjældent Tilfaldet med Diatomeerne; de ovenfor omtalte Hovedformer lader sig nasten altid paavise enkeltvis i alle Prover, der falder mellem de store Maks.

2. Medens de fleste Cyanophyceer lader sig parvise i næesten alle de undersogte Søer, er et betydeligt Antal Diatomeer knyttede til en enkelt eller dog et mindre Antal af disse (Cyclotella comta, Stephanodiscus Hantzschii og Zachariasi, Rhizosolenia long. var. stagnalis, Synura nlna var. Iongissima, Cenlronella Reichelti samt Tabellaria fenestrata, som, skønt den er funden i 7 Søer, $\log$ i de fleste af disse kun er paavisı i ringe Mangde).

I Modsatning til de alm. Planktoncyanophyceer (Aphanizomenon, Polycystis o. a.) opnaar de hyppig forekommende Planktondiatomeer store Maks. omtrent i alle de undersøgte Soer (Melosira, Asterionella og til Dels Fragilaria crotonensis).

3. Det synes af Undersøgelsen at fremgaa, at der er visse Søer, hvori det langt overvejende Antal Diatomee-Arter opnaar meget betydelige Maks., og hrori det ene store Diatomeemaks. saa at sige afloser det andet. Delte er saaledes Tilfaldet i Furesø (M. crenulata, Stephanodiscus, Tabellaria, Synedra acus, Fragilaria crotonensis, Asterionella, Cymatoplenra), Haldsø (M. crenulata og granulata, Stephanodiscus, Fragilaria crotonensis og Aslerionella) samt til Dels Esromsø. Omvendt er der Søer, hvor Diatomee-Arterne, ihvorvel de forekommer her, dog kun undtagelsesvis opnaar betydelige Maks. (i Sorøsø kun Melosira og Asterionella, i Viborgsø kun Asterionella og i Julsø kun M. crenulata, Asterionella samt for en kort Tid Diatoma elongalum).

4. De slørste Diatomeemaks. opnaas af Melosira i Furesø, Sorøsø, Tjustrupsø og Haldso samt af Aslerionella i Furesø, Sorøsø og Haldsø.

Store, men mere kortrarige Maks. opviser Stepltanodiscus i Furesø, Esromsø og Haldsø, Tabellaria i Fureso, Dialoma i Silkeborgsøerne og Synedra acus i Furesø og Skanderborgsø.

5. De enkelte Diatomee-Arter opnaar ikke hvert Aar lige store Maks. i vedkommende Sø. I Foraaret $o_{i}$ Sommeren 02 var Maks. i alle Søerne langt større og varede meget langere end i det tilsvarende Tidsrum i 01 .

Vi vil nu ligesom ved Behandlingen af Cyanophyceerne opstille Spørgsmaalene: Hvad er Aarsagen til, at 


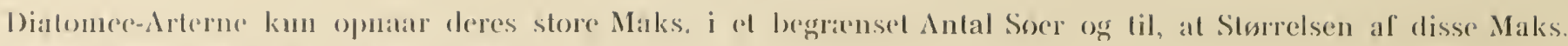
kendeligg kam variere fra Aar til Aar"?

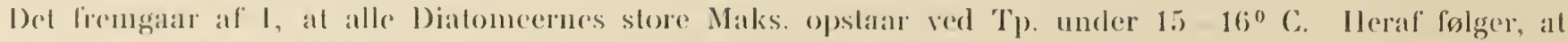
de store Maks. Sierlig lrenkommer i de dybe og kolde Soer. I disse Søer foregaar Opvarmningen nemlig meget langsomt; fra Tidspunktel for Islosningen og indtil Vandel har naact Tp. 16, hengaar saa megen 'Tiul, son er nodvendig, for at de store Maks. skal kunne udvikle sig. Omvendt vil der on Efteraret merlgali sala lang Thid, inden Isliegningen finder Sted, al der ogsaa da bliver Tid til, at disse kan udfolde sig.

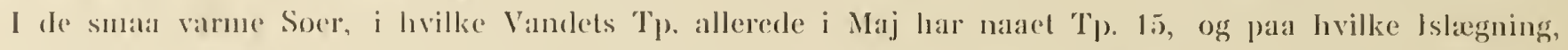
som dog for de fleste Formers Vedkommende synes at virke hammende, allerede kan linde Sted i Nov- Dece, cr Tidsrmmmet, indenfor lovilket Diatomemalis. skal udvikle sigg, for begransel, til at disse Malks. i Mnn, kan blive synderlig slore.

Undersogelsen godlgor nu ogsala tilfulde, at Dialomeerne absolut spiller den største Rolle i vore koldeste Socr. Maks. begynder her tidligst og hører senest op. I Hald-, Tjustrup), Fure- og Esronsø dominerer Diatomeerne allerede i Sep. og vedbliver hermed lige til Juni folgende Aar; kun Oscillatorierne og Lyngbyerne gor den i korte Perioder Rangen stridig; i de lave Soer med høje Sommertp. kommer Diatomeerne langt senere til Udvikling og forsvinder allerede i Maj.

Fra denne alm. Regel galder dog Undtagelser, men disse vedrører nasten alle Asterionella, den eneste Diatomee, der selv i Smaasøer og Damme kan opnaa kolossale Maks., f. Eks. i den lille Sorøsø, og som tillige er den eneste Diatomee, der ved Tp. over 16 opnaar paaviselige Maks. (Esromsø 01 12/8).

Saa lange narmere Undersøgelser mangler, ligger (let nar at formode, at den Faktor, der i første Instans betinger de talrige og store Diatomeemaks. Opkomst $\mathrm{i}$ en So, er Vandets $\mathrm{T}_{\mathrm{p}}$. At $\mathrm{T}_{\mathrm{p}}$. $\mathrm{i}$ hvert Fald $\mathrm{i}$ saa Henseende spiller en meget betydelig Rolle, fremgaar tydeligt ved en Sammenligning af Diatomeemaks. Størrelse og Varighed i 01 og i $\mathbf{0 2}$. I den varme Forsommer ol var alle Diatomeemaks. ophørte allerede $\mathrm{i}$ Slutn. af Maj og i Begyndelsen af Juni; kun Fragilaria crotonensis holdt sig til c. ${ }^{15} / 6$, og Asterionella havde det ovenfor omtalte Maks. i Esromsø. I 02 derimod vedvarede Fragilariernes Maks, i de fleste Søer til Slutningen af Juli; Tabetlaria fenestrata havde et meget stort Maks. i Juli (Furesøen); Melosira dannede i Juli den overvejende Del af Julsøs og Esromsøs Plankton, Stephanodiscus var i Slutn. af Juli talrig i Viborgsø, og Asterionella havde i Juni - Juli store Maks. i de fleste Søer.

Naar adskillige Forskere har formodet, at det i første Instans er Lyset og ikke Tp., der betinger de store Maks. Opkomst, da taler de her anførte Angivelser nxrmest herimod. Antallet af Solskinsdage var i Maanederne Maj-August i 022 langt mindre end i 01; de store Diatomeemaks., som indtraf i disse Maaneder i (0), og som utvivlsomt var unormale for vore Søer, faldt netop i det Aar, hvis samlede Lysstyrke indenfor det omtalte Tidsrum ubetinget var mindst.

Vi har under Afsnittet om Cyanophyceerne set, at disse for en stor Del opnaar deres højeste Maks. i Søer, hris Maksimaltp. ikke er under $20^{\circ} \mathrm{C}$; man vil da heraf forstaa, at Cyanophyceer og Diatomeer, de to store Plantegrupper, der langt danner Hovedmassen af de danske Søers Plankton, sjældent opnaar lige store Maks. i samme Sø; de fleste Søer byder enten den ene eller den anden Gruppe gunstige Betingelser for dens Trivsel, men sjældent lige gunstige for dem begge.

Da vore Søer imidlertid alle til en ris Tid af Aaret frembyder de Temperaturer, der er den første Betingelse for de store Diatomeemaks., medens nogle af dem ikke naar de $\mathrm{T}_{\mathrm{P}}$, der er en af Betingelserno for, at flere af Cyanophyceerne (Aphanizomenon, Gloiotrichia, Anabana spiroides, macrospora, Polycystis) kan trives i dem, er det forklarligt, at Diatomeerne i Vinterhalvaaret næsten overalt opnaar større eller mindre Maks., hrorimod mange Cyanophyceer i Sommerhalvaaret ikke naar til Udvikling i de »kolde Søer«, som serlig karakteriseres ved deres mange og store Diatomeemaks.

De høje Diatomeemaks. er derfor et Fællestræk for alle vore Søer, de høje Cyanophyceemaks. kun for et begræenset Antal Søer 


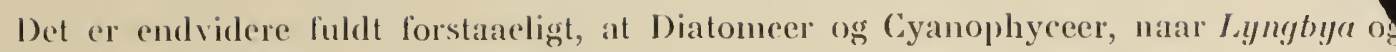
ikke alene er sondrede i Henseende til Sted, men ogsaa til lYid. De store Cyanophyeeegorlt som aldrigs sanmen med de store Diatomee-Maks.; kun Anaberna flos arjue's Maks lige i Slutningen af Fragilaria crotonensis' Foraarsmaks. 'Tp. 13-16; de to Arter kan loreko begge ned store Maks. (Haldso Juli (1)2 o. a.); om Aslerionella se ovenfor.

For llere Soers Vedliommende hander det - i Alm. i Slutningen al Maj -, at de store 1). hatomecmaks. horer op, for de store Cyanophyceemaks. begynder. Saafremt der ikke i disse Soer indtaeder store maks., vil Panktonel aldeles overvejende vise sig at bestaa af Zocplankton: Crustaceer og Rotileren Søerne er paa dette Tidspunkt overmaade planktonfattige og urlmarker sig ved et ualm. klart Vand. Som begynder $\log$ A. flos aquer's Maks, inden Fragilariernes er ophørt, og i saa Fald faar Søen ingen plank tonlattig Forsommerperiode.

I hror høj Grad de lave Tp. begunstiger Diatomee- og hrmmer Cyanophycee-Udviklingen, ses bedst red at sammenligne Forholdene $\mathrm{i}$ Somrene $\mathbf{0 1}$ og 02. Det førstnæunte varme Aar var et Cyanophycee-Aar, i hvilket Diatomeerne fra Maj-. Okt. nasten var forsvundne af Vandmasserne; det sidstnærnte kolde Aar var et Diatomee-Aar, i hvilket Diatomeerne endnu dominerede i Beg. af Aug., medens Cyanophyceerne, bortset fra A. flos aqua, hvis Maks. netop falder sammen med den i 0 2 i alle vore Søer maalte Maksimaltp., overalt spillede en ganske underordnet Rolle.

Naar Aslerionella og i Følge Zacha rias o. a. Rhizosolenia undtages, optrader Planktondiatomeerne som Regel ikke i Damplankton. Dette er saa meget des markeligere, da flere af de Planktondiatomeer, der foruden deres stjærnedannede Planktonstadier tillige har kædedannede Bundstadier, som saadanne optræder i Mængde som Overtrak paa Smaadammenes Vegetation (Diatoma elongatum, Tabellaria fenestrata); det synes, som om de stjærnedannede Planktonstadier kun opstaar i større Søer; her ligger en vid Mark for fremtidige Undersøgere.

Vil man søge Aarsagen til, at Planktondiatomeerne spiller en saa ringe Rolle i Smaasøer og Damme, maa Opmærksomheden vistnok særlig henledes paa de stærke daglige Tp.svingninger, der i Sommerhalvaaret her kan beløbe sig til $10-15^{\circ} \mathrm{C}$.

Af de med disse forbundne Vertikalstrømninger er Planktoncyanophyceerne, der som ovenfor ontalt damner en vasentlig Del af Damplanktonet, paa Grund af deres Luftvacuoler uafhangige. Diatomeerne derimod, der ganske er prisgivet Vertikalstrømningerne, som vistnok overvejende bestemmer deres Plads i Vandlagene, vil vare $\mathrm{i}$ uafbrudt stigende og synkende Bevægelse. Faren for, at Svæveapparater, sierlig Gelemembraner, under Bundfreldningen eller ved Beroring med Vegetationen skal beskadiges eller paa Grund af Mængden af svavende Detritus forurenses og tynges nedad, er ubetinget større i Damme end i store, dybe Søer.

Naar nervarende Undersøgelse altsaa giver det Resultat, at Diatomeerne sarlig er hjemmehorende i de kolde, klare Søer, og at deres Maksimaludvikling falder sammen med de lave Tp., da er dette i Overensstemmelse med alt, hvad der fremgaar af Planktonundersøgelserne i andre Lande.

De europaiske Planktondiatomeer er overalt overvejende de samme, dog synes det, som om Melosirerne dominerer i de lave og varmere Slettelandssøer, og at maaske Tabellaria fenestrata, men sarlig CyclotellaArterne opnaar deres største Udvikling i de koldere alpine Søer (Schweiz, Norge).

Overalt i det mellemeuropæislie Slettelands Søer spiller Diatomeerne i Vinterhalvaaret den største Rolle, og deres Hovedmaks. er beliggende i det tidlige Foraar og om Efteraaret; alt efter Soernes Dyble og Tp.forhold dominerer snart Diatomeerne, snart de Vandblomst-dannende Cyanophyceer; i de alpine Søer har Diatomeerne som oftest Overtaget.

Hvor vidt Diatomeerne opnaar større Maks. i de alpine Soer end i Slettelandets Soer, er maaske trivlsomt; det er nok muligt, at adskillige Former, særlig Asterionella og maaske ogsaa Melosirer, dog stiller visse Fordringer til Tilstedevarelsen af opløste Naringsstoffer i Vandmasserne, som de koldeste og klareste Alpesoer ikke er i Stand til at tilfredsstille; herom ved vi imidlertid i Øjeblikket intet. 
W.-I. Iavde formodel. at man ved paa dylot Vand at tage det døde og døende Melosira-Plankton c. 14 Dage efter, al de store Maks. var forsvundne fra Overlladen, paa dette skulde have kunnet paavise rigelig Anxosporedannelse; denne Formodning slog imidlertid ikke til; det døende Melosira-Plankton blev indfanget paa dylt Vand i Tjustrupso og Furesø i Nov.01, men Auxosporedannelse var ikke synderlig fremtradende. bet martle da antages, at de kuglermule Auxosporer laldt af og sank til Bunds; i den Anledning blev Bundprover optagire Dec. 01 fra Furesoen, men der kunde i disse iklie paavises Auxosporer. Spørgsmaalet forbliver altsaa ulost.

Som bekenlt forekommer der hos marine Diatomeer en anden Slags Sporer, typiske Hvilesporer, ved Schïlts Undersogeiser navnlig velkendte hos Chetoceras; tilsvarende Sporer er ogsaa paaviste hos de i Ferskivand optraelende i ovrigt til marine Familier hørende Slagter Rlizosolenia og Attheya; selv har vi ofte haft Lejlighed til at se disse Sporer.

I den nyere Tid har Newton Coombe (98-99), Mieuel og Whipple \& Jackson (99a. p. 5) paastatel, at Protoplasmaet i Cellerne til Tider trak sig sammen eller henfaldt i smaa, lysbrydende Korn, der for Asterionella's Verlkommende er afbildede hos Whipple (99, Tab. II, Fig. $5 d, e)$ og for Melosira's og andre Ferslivandsdialomeers Vedkommende (Eunotia og Meridion) hos Newton Combe (99, Pl. I, Fig. 7, 8, 9).

Den af disse Forskere udtalte Formodning om, at de smaa Korn skulde vare Hvilesporer, er dog endnu nxmest kun Hypothese, der ikke vinder i Sandsynlighed ved, at man har tillagt disse Sporer ret unaturlige Apparater og Beragelsesmodi. Saaledes paastaar Whipple (99 a. p. 5), at de af ham iagttagne Sporer var bevagelige og at, selv om Cilier ikke kunde ses, var der dog »indications of their presence. Forf. synes ikke at vide, hrpr uforenelig denne Angivelse er merl alt, hvad vi i øvigt verl om Diatomeernes Bygning.

Ganske uforstaaelig er Strohmeiers Angivelse (97 p. 17) 》Melosira trat mussenluaft in dichten Bündeln auf, die einzelnen Individuen nit Fruchtzellen, welche meist zalulreiche Brntzellen entlielten, versehen".

Ser vi bort fra de sikre Hvilesporer hos Attleya og Rhizosolenia, maa vi tilstaa, at vi i øvrigt i Øjeblikket ikke red noget om Hvilestadier hos Ferskrandets Planktondiatomeer og folgelig heller intet positivt kender til deres Hvileperioder; vi verl, at der aarlig indtrader meget markerede Min., men om disse Min. er identiske med Hvileperioder, samt under hvilke Former og hvor disse i saa Fald gennemløbes, derom er os intet bekendi.

Det kan betragtes som en Kendsgerning, at der efter de store Maks. finder en Bundfældning af Diatomeerne Sted. Den langsomme Nedsynken er direkte paavist (WV.-L. 00 p. 650), og Planktondiatomeerne er i Mangde genfunden i Søgytjerne (W.-L. 01 p. 116 o.a.). Det er en bekendt Sag, at Diatomeeplankton, naar del hreldes i Skaale, meget nurtigt bundfreldes og derpa ikke mere stiger til Vejrs; Maaneder igennem holder let sig tilsyneladende levende paa Glassets Bund. Nedsynkningen er direlite studeret af Zacharias, der beregner, at en Melosira-Traad bruger 50 Min. til at synke 1 Meter (95 b. 1). 105). 
Nan de store Maks. (r forbi ude i Naluren, forsvinder Diatomeerne praktisk set nesten ganske, og vi lor efter det ovenfor anforte gaa ud fri, at de bundlixeldes.

Medens vi i Luftracuolerne hos Cyanophyceerne kender det Middel, hrorved disse formaar at have sigg op fra Bunden og holde sig svevende i de averste Vandlag. kender vi ikke med Sikkerhed noget som lielst Niddel, hrormed de en (iang bundfaldede Diatomeer atter sxettes i Stand til at have sig op. Ligeledes er Kendskabet til deres Sraveapparater kun ringe; dog har her Max Voigts (01 p. 36) fortjenstfulde og fortraflelige Lndersøgelser over (icleskiermene hos de stjarnedannende Diatomeer og hos Cyclotellerne spredt noget Lýs. Selv om disse Geleskarme virkelig spiller en Rolle ved Modarbejdelsen af Faldhastigheden i Vandmasserne, er de dog ganske uide af Stand til at bevirke den Opdrift, der er Betingelsen for, at de frar et bundfaldet Starlium skal kunne gala over til et svevende.

Da vi ikke i Øjellikket kender det Middel, hrormed en Gang bundfældede Diatomeer atter hæver sig, staar vi ogsaa uden Forstaaelse af, hvorledes de store Maks. opstaar. Den Pludselighed, hvormed de ofte fremkommer, er et lilstrekkeligt Bevis for, at de ikke kan fremgaa af det ubetydelige Antal Diatomeer, der, som ovenfor omtalt, altid findes i Vandlagene i Tiden mellem de store Maks. Forekomst.

Da man altsaa maa gaa ud fra, at det er hundfældet Materiale, der hæves op, og da dette formentlig sclv mangler Evnen til atter at gaa til Vejrs, har man villet paastaa, at Hærningen foregaar ved Hjælp af Vertikalstrømningerne i Vandmasserne.

Allerede Strodtmann (95 p. 161) har fremsat denne Opfattelse, men det er dog særlig Whipple, der i sine fortraffelige Arbejder over Diatomeernes Optræden i Drikkevandsbassinerne i New York har givet denne Opfattelse fastere Grund.

Whipple gør opmærksom paa, at de store Diatomeemaks. For- og Efteraar falder sammen med det Tidspunkt, da Vertikalstrømningerne naar fra Bund til Overflade, hvorimod deres Min. er beliggende paa de Tidspunkter (Sommer og Vinter), da de nærmest Bunden staaende Vandlag er i Ro; af Vertikalstrømningerne For- og Efteraar sættes Diatomeerne eller Diatomeesporerne (?) til Vejrs, og i de øverste Vandlag under højere Tp. og gunstigere Lysforhold foregaar da en rapid Udvikling af det hævede Materiale.

Sely om man næppe tør tillægge Whipples Anskuelser almengyldig Betydning, indeholder de dog sikkert meget værdifuldt. Vil man nu ogsaa søge at anvende disse paa Forholdene ude i Søerne, er det dog indlysende, at de maa undergaa nogen Modifikation.

I de større Søer kommer Vertikalstrømningerne ganske væsentlig til at spille en Rolle som Diatomeehavende Faktor inde paa disses lavvandede Partier; det følger af sig selv, at i alle de Søer, der er saa dybe, at de rummer Vandlag, til hrilke de aarlige Vertikalstrømninger ikke naar ned, vil der findes store centrale Partier af Søbunden, hvorfra ingen Hævning kan finde Sted.

Men ogsaa i mindre dybe Søer vil det bundfældede Materiale rimeligvis vasentlig løftes op fra et ringformet Areal, der fra Bredden strækker sig et større eller mindre Stykke ud imod Søens Centrum. De Diatomeer, der bundfældes uden for dette Areal, hæves aldrig op efter, men gaar før eller senere deres Opløsning i Møde. Inde paa Søernes lavvandede Partier vil foruden Vertikalstrømningerne rimeligvis tillige Bølgebevagelsen være virksom og i meget væsentlig Grad understøtte disse.

Spørgsmaalet om de store Diatomee-Maks. pludselige Fremkomst kan derfor i Øjeblikket næppe besvares nærmere, end at man har en Formodning om, at de fremgaar som Følge af en rapid Formering af det ved Vertikalstrømningers og Bølgebevægelsen væsentlig fra Søens lavrandede Partier hærede bundfældede Diatomeemateriale ${ }^{1}$ ).

Til Støtte for denne Antagelse tjener ogsaa følgende Iagttagelse. Sammenligner man den Maade, hvorpaa de store Diatomee-Maks. opstaar i dybe Søer, f. Eks. Haldsø, med Maaden, hrorpaa de arbejder sig frem i

1) Jeg henviser i ovrigt til det senere udkomne fortræffelige Arbejde af Gran (02), særlig til Kap. om Inatomeerne p, 21, Planktonelemente p. 75 og til Iagttagelsen af en formentlig Sporedannelse hos Rhizosolenia styliformis p. 173. 
vore mindere, lave Soer, f. Eks. Soroso, viser del sig, al Datomer-Maks. i Haldse udvikler sign ganske lang-

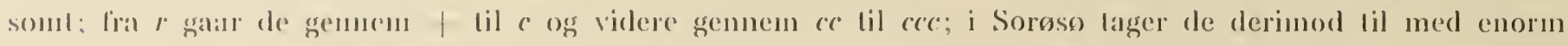

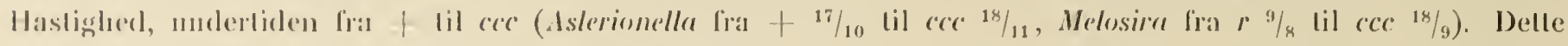
linder i Overensstemumelse med den fremsalte Ansknelse sin naturlige Forklaring i, at der For- og Efteraar i den lave, c. 13 M. dybe Soresso med jiernt skramende Bredder linder en Harning Sted fra héle Sobunden, horimod Havningen i den c. 40 M. dybe Haldsg med dens overmatide brat nedfaldende Skranter kun foregalial fral at mindre ringlormel Baelle.

1 forstnarnte Tilfidele er del hevede Nateriale straks fra Begyndelsen meget stort, i del andet kun ringe og kan som Folge heral kun langsomt arbejde sig op lil el betydeligl Maks.

Al schfolgeligg ogsia andre Forhold, navnlig Vandets kemiske Beskaffenhed og i første Instans dets større eller mindre Rigdon para Nitrater (Whipple 94 p. 222 226), her spiller en liolle med er utvivlsomt; men herom kan vi for det paagaldende Tilfeldes Vedkommende intet meddele. 


\section{KAP. VI. \\ C H LOROPH YCE A.}

$\mathrm{T}$ IL Grund for den systematiske Inddeling af Chlorophyceerne er lagt Chodats udmærkede Arbejde: Algues vertes de la Suisse 02.

Chlorophyceeme spiller her i Landet som overalt en underordnet Rolle i de større Søers pelagiske Region, hvor disse overvejende Damformer som Regel ikke hører hjemme. Nærværende Undersøgelse har derfor vel kumnet konstatere et betydeligt Antal Arter, hvoraf de fleste ikke før har væet paaviste herhjemme, men har i Følge sin Natur ikke kunnet give synderlige Oplysninger om deres Biologi. Saadanne kunde vel vare bleven indvundne ved Damundersøgelsen 98, men disse Former, der paa Grund af deres Liclenhed meget let overses, blev den Gang ikke nærmere studerede.

1 de talrige Planktonprøver, som vi begge i de derpaa følgende Aar har indsamlet fra Damme og Moser, findes talrige af de sjældnere, fra den senere Tid beskrevne, Chlorophyceer, særlig Protococcacece, som hidtil næppe er fundne herhjemme. Da Tiden imidlertid ikke har tilladt os et mere indgaaende Studium af disse Former, og da dette strængt taget ligger i Periferien af den Opgave, vi har stillet os, har vi, tilmed da den ene af os agter at fortsætte Studierne over Chlorophyceerne, her forbigaaet de allerfleste Iagttagelser over alle de Former, som ikke netop er iagttagne ved Søundersøgelsen $00-02$.

Chlorophyceerne vil vistnok fremfor de fleste andre i Plankton optrædende Plante- og Dyregrupper ypperligt egne sig til et mere indgaaende Studium saa vel af de saakaldte Planktonkarakterer (Hyalinitet, Geledannelser, Torndannelser etc.) som af disses Afhængighed af ydre Forhold; særlig vil et indgaaende Studium af Pediastrum-Arterne og deres forskellige Udseende i Vandmasser af forskellig Beskaffenhed give væerdifulde Oplysninger; vi skal i øvrigt her indskrænke os til at henvise til Chodal (02 p. 93-95).

I Havets pelagiske Region spiller Chlorophyceerne $\mathrm{i}$ det hele kun en underordnet Rolle. Kun en eneste Slægt, Halosplacera med Hovedarten $H$. viridis Schmitz, hørende til Fam. Halospharacex, er en udpræget marin, pelagisk Organisme, der navnlig i Foraarstiden danner en betydelig Del saa vel af Nordatlantens som ogsaa af sydlige Haves Plankton. Alle de ovrige Former er af underordnet Betydning og gennemgaaende meget lidt kendte. En Del af Ferskvandets Planktonchlorophyceer føres med Floderne ud i Havet og træefes ret hyppig i mindre Indhave f. Eks. botniske Bugt og Østersøen; en enkelt Form, Botryococcus Braunii Kütz., endog til Tider i ret stor Mrngde.

I Følge Chodat deles Chlorophyceerne i tre store Afdelinger: Euchlorophycea, Conjugater og Siphonece. Siphonew optræder ikke som Planktonorganismer, Conjugate kun i meget ringe Grad; Hovedmassen af de i Plankton levende Chlorophyceer hører til Euchloropleycex.

De danske Suers Plankton. 


\section{Euchlorophycex.}

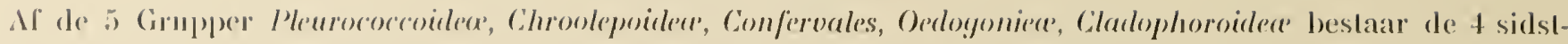

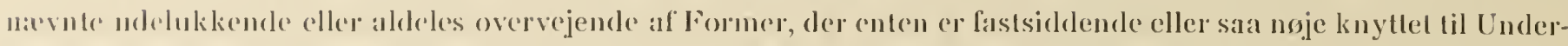

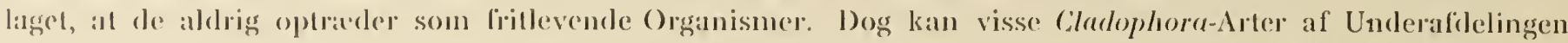

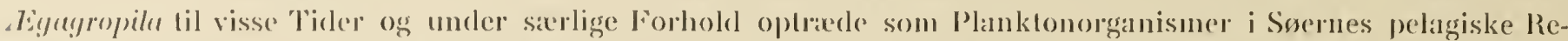

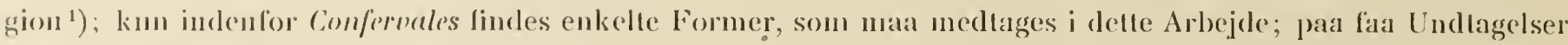

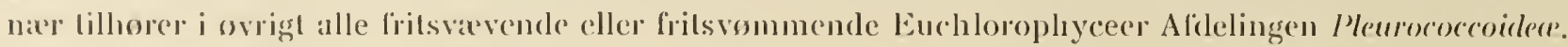

\section{Pleurococcoidex.}

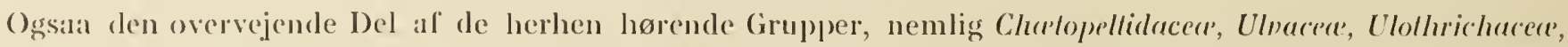

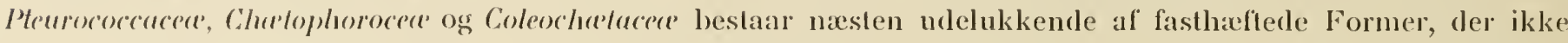
vedkommer os her. Kun mellem L'/ohricharea synes der at optræede Planklonformer, som dog for Ojehlikkel er megel lidt kendle. Ulollurix (IIormospora) limnelica Lemm. (98c. p. 150) skal i Lago di Como kunne danne en betydelig Vandblomsl; den er senere funden i Stulmersøerne og lalrige andre vestpreussiske Søer (Soligo 00 p. 56); her falder dens Maks. i Aus.-Sep. l)enne Form er i øvrigt megel tvivlsom; den er maaske - markelig nok - bleven funden af Lagerheim (00 p). 5) i Ella So paa Bjørnenen. Fra Balatonsocn angiver Istvanffi (98 p. 29) U. sublilis (Kül\%) De Toni.

De i det folgende omtalte Plenrococroidec horer alle lil de tre Familier: Pulmellacere, Volvocaceu og Prolococrucer; udpragede Planktonorganismer i større Søer optrader kun mellem de to førstnavnte.

\section{Palmellaceæ.}

Del har veret os en yclerst vanskelig Sag at udrede de i vore Planktonprover optradende Palmellaceer og P'almella-Stadier af andre Alger. Uden Isolation og paafølgende Dyrkning er det næppe muligt at rede de enkelte Former ud fra hverandre. Vi er bleven staaende ved kun at antage to Slægter: Telraspora og Spharocyslis, hver med een Art: T. lacustris Lemmermann og S. Sclrrocleri Chodat. Utvivlsomt er det første Begreb altor omfattende; det indeholder rimeligvis ret heterogene Bestanddele, men vi anser ikke vorl Kendskab til clisse Former for tilstrakkelig stort, til at vi turde vove en narmere Udsondring.

Chodat har (02 p. 115) formodet, at Tetraspora lacustris kun er en Form af Sphcerocystis Scliroeleri; fremtidige Undersøgelser maa afgøre, om denne Opfattelse er rigtig. I vore Søers Plankton optræeder i hvert Fald to Palmellaceer; hos den ene er Kolonien af uregelmassig Form, hverken Moder- eller Døtrekoloniernes Gelelag viser koncentriske Striber, og Cellerne er grupperede 2-4 sammen. Denne Form anser vi for en Tetraspora og henfører den til den eneste hidtil kendte Planktonart: T. lacus/ris; det maa dog fremhæres, at vi aldrig har set de for denne Slægt karakteristiske Pseudocilier, men formoder, at Grunden hertil er den, at vi kun har haft konserveret Materiale for os.

Hos den anden Form er Kolonien kuglerund, som oftest indeslutlende et større eller mindre Antal Dølrekolonier paa 8-16 Celler, omgivne af koncentriske Gelelag; denne Form mener vi med Sikkerhed er bestemt som Sphorocystis Schroeleri, der ikke før er funden her i Landet; Overgangsstadier mellem Splıcrocystis og Telraspora er os ubekendte; den narmere Udredning af dette sidste Begreb maa Fremtiden om.

\section{Tetraspora.}

Telraspora lacustris L e $\mathrm{mm}$.

Tab. V, Fig. 58.

\section{Lemmermann 99 p. 118 . Tab. 1, Fig. 13.}

T. l. er paavist i Fureso, Esromso, Soroso, Tjustrupso og Mosso; den indfandt sig i 01 i Slutningen af Maj, opnaaede et lille Maks. i Juli og forsvandt derpaa i Okt.-Nov. I 02 paavistes Formen i Maj; dens Maks. var i Aug. endnu vedvarende; den optraadte sarlig hyppig i Esromso.

1) Herom se narmere $W^{r}$.L. $(03$ p. 167$)$. 
T. I. hev palavist af Lemunermann i saksiske Damme (99 p. 118) og bev genfunden af be Toni \& Forli i vellern $(00$ p. 800$)$.

\author{
Sphærocystis. \\ Spharectystis Schoeteri Chodal. $\left.{ }^{1}\right)$ \\ Tab. VI, Fig. 72. Tab. VII, Fïg. 83. \\ Cilodat $97 a$. Tab. 9.
}

S. S. er hidtil kun funden i Viborgso og Haldso; den blev ikke med Sikkerhed paavist 01, men har rimeligvis veret til Stede i Viboroso i Proven 10/7 Tp. 17; den findles lier i enkelte Eks. 02 30/5 Tp. 8; derpaa sterg Antallet, indlil Maks. blev naact 25/6; den var noget aftaget $26 / 7$ Tp. 16 ; 25/6 var den Phytoplanlitonets Hovedform. I Haldsa blev Arten overset i 01; i 02 viste Ien sig forste Gang talrig ${ }^{11} / 6$ Tp. 12 og $19 / 6$ Tp. 13, holdt sig derpaa i omtrent uforandret Mrengde lige til ${ }^{16} / 7$ Tp. 14 , hvorpaa den tog noget af; endnu $2 / 8$ Tp. 15 fandtes en Del Eks.

Arten optrxeler altsaa her i Landet som udpraget Sommerform.

S. S., der er en af de meget faa Chlorophyceer, der er tilpasset til pelagisk Liv selv i de største Søer, blex oprinclelig funclen af Chodat (97a. p. 292) og paavistes senere af Bachmann (01 p. 243) i talrige Schweizersøer; i øvrigt fandtes den i Laco Benaco (Garbini, Citat efter De Toni \& Forti 00 p. 798), i saksiske Damme af Lemmermann $(99$ p. 119), i Lautikerried af Waldvogel $(00$ p. 46$)$, i Legiener- o. a. restpreussiske Søer af B. Schrøder $(00$ p. 83), i Vettern af De Toni \& Forti $(00$ p. 798) og i Følge disse Forf. Angivelser tillige af Wille i Norge, i Katzensee af Amberg $(00$ a. p. 44); samme Forf. angiver (p. 68) den os ukendte $S$. lacustris fra Zürichersøen.

For saa vidt Periodiciteten er bleven studeret, stemmer den overens med vore Angivelser (Waldvogel 00 p. 57. Naks. Juni).

\title{
Volvocaceæ.
}

Den aldeles overvejende Del af Volvocaceerne hører hjemme i smaa lave Damme og Smaasøer; en Del findes paa fugtig Jord (Chlanydomonas-Arter), enkelte paa den evige Sne (Splucrella nivalis Somm.); en Del er marine Planktonformer (Brachiomonas, Splucerella-Arter (?) o. a.). Kun Eudorina elegaus findes som Planktonorganisme i større Søer og er hjemmehørende i disses pelagiske Region. Hovedmassen af Volvocaceerne løører til Damplanktonets mest karakteristiske Representanter (Chlamydomonas-Arter, Placolus, Gonium, Pandoriua, Eudorina og Volvox), men træffes tillige alle ved de større Søers Bredder, hvorfra de forslaas ud i den pelagiske Region, hror de dog, bortset fra Eudorina, i Længden ikke kan trives.

Med Undtagelse af Gonium sociale (Duj.) Warming er de alle paaviste i vore større Søers pelagiske Region, men altid enkeltvis og kun i enkelte Prøver.

Ved Damundersøgelsen $\mathbf{9 8}$ havde der været rig Lejlighed til nærmere at studere disse meget interessante Organismers Levevis; dog lod de meget komplicerede Forplantningsforhold sig ikke nærmere udrede samtidig med de øvrige Opgaver, vi havde stillet os. Medens Gonium og Volvox særlig optræder i Damme udsatte for stærkt Lys, har Pandorina hyppigst haft sine største Maks. i stærkt beskyggede Damme og opnaaede i Juli 98 meget store Maks. i saadanne, der nasten var tilgroede af Equiselum linosun. Af Gonium-Arterne var $G$. pectorale Müller den hyppigste; $G$. sociale synes at være langl sjæeldnere. Den af Lemmermann beskrevne G. angulatun (99 p. 111) er hidtil ikke paavist herhjemme.

Af Volvox-Arterne er V. aureus Ehr. (minor Stein) den, man hyppigst støder paa. Den overvintrer under Isen, men sjældent i større Mængde; alle Kolonierne var paa denne Aarstid vegetative; noget skarpt markeret Maks. blev aldrig paavist, om end Mrengden var størst i Sommerhalvaaret. Zygoter blev først fundne om Efteraaret, paa hvilket Tidspunkt man dels fandt vegetative Volvox-Kolonier, dels saadanne, der indeholdt Zygoter. I det tidlige Foraar, kort efter Isløsningen, fandtes i de fleste Damme en hel Del ganske smaa Kolonier, formentlig fremgaaede af de spirende Zygoter.

Volvox globator's Optræden som fritsvømmende Organisme synes at indskrænke sig til en langt kortere

\footnotetext{
1) cfr. Wille (03 p. 163), Borgesen (01 p. 238) og Borgesen og Ostenfeld (02 p. 617).
} 


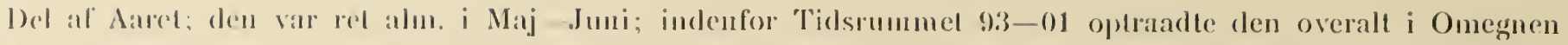
al Frederikstorg i Juni duli med aldeles kolossale Naks., der omtrent indtraf samtidig i alle Onegnens

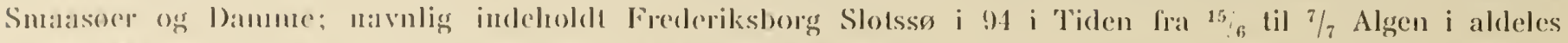
ulyre Masser; Nettene fyldtes med at smaragdgront gyldentglinsende Plankton, nasten udelukkende bestatende af l. g. Algen log derpaal af, og i Slutu. al Juli syntes den ganske at vare forsvunden; efter Sep. bler alle loblpos-Former leenforte til l'anens. Indtil 1. Juni salas kun vegetative Kolonier, men i Slutn. af Juni bar neesten alle Kolonierne \%ygoter. Da Zygoten hos V. glabalor er udstyret med lange Torne, hvor-

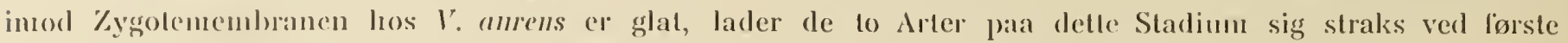
Ojpkast skielue fra hinanden; ellers er dette kun muligt ved en noget nøjere Undersøgelse.

Hvor vidl I. glabalor forekommer sjaldnere end Ir. anrens, maa lienstaa uafgjort; idet larstnxevnte formentlig hiler den storste Del af Aarel som Zygote, faar man let Indtrykket af, at $V$. anrens, der er til Stede hele Aarel, er den hyppigste.

1)e lier givite megel ufuldstendige Meddelelser on vore to Volvox-Arters Optraeden, Maks. og Seksualperioder er kun medlagne, fordi de i al deres Ufuldkommenhed stemmer rel gorlt overens med de Resullater, som klein (89--90) gennent sine udmarkede Undersøgelser er kommen til.

En tredie os ukendt Volpox-Art: V. lertins, er beskrevet af Meyer (96 p. 187).

Slagten Stephanospherra er markelig nok endnu ikke funden her i Landet; den angives især fra Smaapytter paa Klipper og Kilippeøer og er fornylig i stor Mangle funden af Levander (00 c.) i Smaapytter paa den linske Skxergaards Kilippeøer; man maa efter detle formorle, at Stephonosphera lader sig paavise i den nordlige Del af Bornholm.

Den markelige og meget interessante Form Plat!jdorina Kofoid (99 p. 419) er hidtil ikke funden i Europa; den er efter Ḱofoids Angivelser ogsaa en Lavandsform.

\section{Eudorina.}

Der er hidtil kun beskrevet een Art; Chodat formoder (02 p. 152), at Pleodorina illinoiensis Kofoid (98 1. 273) er identisk med et Stadium af E. elegans.

\section{E. elegans Ehr.}

Tab. III, Fig. 25 og Fig. 27.

Chodat 02 p. 151 . Fig. 76.

E. elegans er paavist $\mathrm{i}$ alle de undersogte Soer; den horer rimeligvis overalt til det perennerende Plankton, men forekummer dog i flere Søer kun enkeltvis og $\mathrm{i}$ ganske faa Prøver (Tjustrupso, Skanderborgso og Mosso); nogen tydelig Periodicitet har ikke kunnet paavises i Sorøsø, Viborgsø og Julsø; Periodiciteten er mest fremtræedende i Fureso, Esromso og Haldso, hvor der i Juni-Juli baade i 01 og 02 optræder et betydeligt Antal Individer. Kun $\mathrm{i}$ de to sidstnevnte Soer har den ovet nogen afgorende Indflydelse paa Planktonets Karakter.

Ved Damundersogelsen 98 blev den paavist i alte Dammene, hvor den horte til det perennerende Plankton, men optraadte sjæeldent i større Mængde. Det viste sig desverre umuligt paa Materiale, kun indsamlet hver 14. Dag eller hver Manned, nærmere at studere de komplicerede Forplantningsforhold.

E.e. er paavist som Planktonorganisme fra talrige Søer, særlig fra det mellemeuropæiske Sletteland, men i øvrigt ogsaa i de større Schweizersøer (Bachmann 01 p. 244); i Følge denne Forf. var den talrig i Comosøen, i Følge Schröter \& Kirchner (96 p. 26) i Bodensøen.

\section{Protococcaceæ.}

Den overvejende Del af de i vore større Søers Plankton optrædende Chlorophyceer hører til Familien Prolococcaceci; det er vel lykkedes os at paavise ikke inindre end 23 Arter, af hvilke den langt overvejende Del ikke før er funden i danske Ferskrande; men der er al mulig Grund til at tro, at vi netop for disse Arters Vedkommende har overset adskillige; paa Grund af deres Lidenhed og overordentlig store Hyalinitet sker dette meget let. 


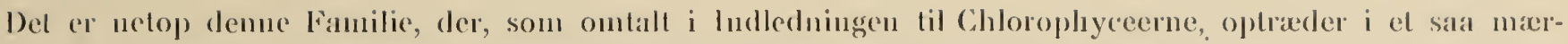
kelig stort Artsantal i Snaasocrnes vegetationsfri centrale Partier, og som mere end nogen anden Grmpe bidrager til at give Dammenes Plankton et fra Soernes forskelligt P'rege. Mange af de lierhen liørende

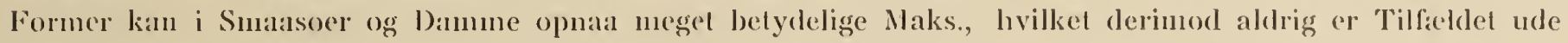
i de store Soers pelagiske Region, hror deres Forekonst altid berer Tilfeldighedens Prag. De fleste Arter er knn parviste i enkelte Søer, som oftest kun i enikelte Prøver og meget ofte kun i ganske fáa Eksemplarer. Hjemmelorende i storre Søers pelagiske Region er meget faa Arter; en skarpt udpraget Periodicitel har ikke kunnet paavises.

\section{Dictyosphærium,}

Der er af Slaggten beskrevet mindst 4 Arter, af livilke kun (le to, D. Elurenbergianum Näg. og I). pulchellum Wood, cr os beliendte; de lader sig kun vanskeligt holde ude fra hinanden. I Modsatning til de fleste andre Protococcaceer har $D$. fritbevægelige Sporer, udstyrede med to Cilier; disse Sporer skal efter De Ton is Angivelse have dannet Vandblomst i Akvarier. Slagten er bleven nojere studeret af Massee (91 p. 457), Zopf (93 p. 15) og Senn (99 p. 74). Førstnxvnte beretter (p. 461), at mange paafølgende Sommergeneralioner opstaar ved Zoosporedannelse; hvor vidı de sidste Zoosporer encysterer sig og overvintrer, har Massee ikke kunnet give Oplysninger om.

Kolonien er altid omgiven af et meget rigeligt Gelelag; ved en vandig Thioninopløsning træder baade Geleen med sin straalede Struktur og Stilkene (cfr. Senn 99 p. 75), der holder de enkelte Celler sammen, tyclelig frem. D. Ehrenbergianum skal efter $\mathrm{Zopf} \mathrm{(93} \mathrm{p.} \mathrm{20)} \mathrm{væere} \mathrm{en} \mathrm{oprindelig} \mathrm{fastsiddende} \mathrm{Form,} \mathrm{som}$ senere river sig løs og antager Kugleform.

\section{D. pulchellum Wood.}

Tab. Ill, Fig 29.

Wood 73. T. 10, Fig. 4.

D. p. er paavist i Esromsø, Sorøsø, Viborgsø, Skanderborgsø, Mossø og Julsø, men synes at mangle i de øvrige Søer. I Sorøsø, Skanderborgsø og Julsø forekommer den kun enkeltvis i enkelte Prøver; i Viborgsø er den paavist i de allerfleste og i Mossø i alle Proverne; den optraeder her ret hyppig $0115 / 10$; men er i ovrigt ogsaa i disse to Søer som oftest kun set i faa Eks. Anderledes er Forholdet derimod i Esromsø, hvor den findes lionstant i alle Prøver; lige til 01 3\% Tp. 17 udgjorde den kun en underordnet Del af Søens Plankton, men blev da pludselig en af Planlitonets Hovedformer; $15 / 10$ Tp. 12 var den noget og 10/11 Tp. 7 - 17/12 Tp. 1 yderligere aftaget. Forholdene var omtrent de samme 02, men Maks. indtraadte her allerede 10/7 Tp. 14 og holit sig endnu 31/7 Tp. 15.

D. $p$. nævnes ikke hyppig i Planktonarbejderne, vistnok fordi den saa ofte er bleven overset; den er rimeligvis overvejende en Damform, men er dog ogsaa paavist i større Søer: Plönersee (Lemme rmann 95 p. 46), Vettern (De Toni \& Forti 00 p. 797) ə: D. Ehrenbergianum, Genfer- og Comosøen (Chodat 02 p. 187).

\section{Oocystis.}

Der er af Slægten Oocystis beskrevet et stort Antal (c. 12) Arter, der meget vanskeligt kan holdes ude fra hverandre; en kritisk Undersøgelse vilde sikkert reducere Antallet meget betydeligt. Slægten er overvejende hjemmehørende i Smaasøer og Damme, og kun en enkelt Art O. lacustris optræeder som Planktonorganisme i store Søer.

\section{O. Naegelii A. Braun. Tab. IV, Fig. 45 .}

Chodat 02 p. 189 . Fig. 104.

$O$. $N$. er paavist i alle de undersøgte Søer med Undtagelse af Tjustrupsø, men altid kun i enkelte Prøver, særlig Sommerprover, og altid kun enkeltvis; da den inidlertid, i alt Fald i vore Søer med deres store Cyanophycee-eller Ceratium-Maks. meget let overses, er Arten maaske noget almindeligere, end man af Listerne skulde formode. 


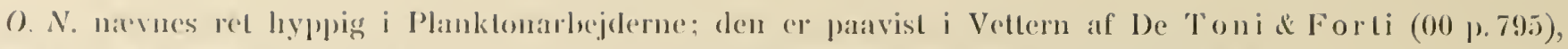

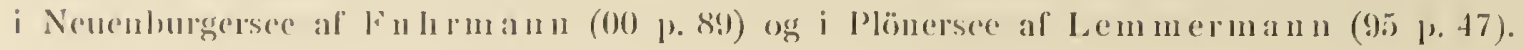

\section{(). lucustris choolat.}

Cillodat 02 p. 190). Fing. 105.

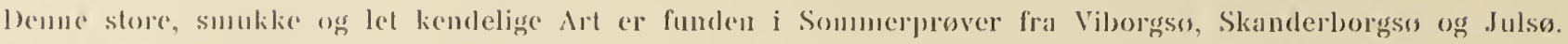

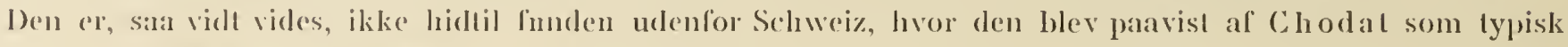
Planktomorganisnce i halrige Soer.

\section{Chodatella.}

Clnodat (1)2 p. 191) angiver 4 Arler som hørende lil denne Slxgl; de er alle hjemmehørende $i$ lave Smatilamme.

$$
\text { C. ciliata (Lagerhein) Le m m. }
$$

Lagerlieim 82. 'Tab. 3, Fig. 33-37.

C. c. er taget i enkelte Sommerindsamlinger i Mosso og Julso.

Den angives af 13 runo Schroder $(00$ p. 84) fra Barlewitzersøen (Juni); i ørrigt er den kun kendt fra Moser og Smaadamme, i lwilke den ogsan her i Landet er paavist paa Fyen.

Der angives al denne Slaggt kun een Art.

\section{Richteriella.}

\section{R. botryoides (Schmidle) Lem m.}

Lemmermann 00 l. Tab. 3, Fig. $1-10$.

R. b. er paavist i enkelte Sommerprover fra Soroso og Mosso.

Den er i orrigl funden i Barlewitzersøen af B. Schrøder ( 00 p. 84) og i Wilmersdorfersee af Marsson (01 p. 91); herfra angives den at optraele fra Okt. til Dec., fra Marts til Maj og derpaa igen at blive talrig i Nov.

Det er overrejende en Damform, der kun undtagelsesvis findes i storre Soers Plankton; som Damform er den paarist af Lemmermann, der har g.jort den til Genstand for et Specialstudium (98 b. p. 303 og 00 (l. p. 90), og af Chodat (02 p. 193).

\section{Nephrocytium.}

Sliegten har neppe mere end een sikker Art.

\section{N. Aghardianum $\mathrm{Naeg.}$ Chodat 02 p. 196. Fig. 113.}

N. A. er kun funden i eet Eks. i en enkelt Sommerprove fra Esromsø.

Den er overvejende en Damform og som saadan kendt fra talrige Findesteder, men synes dog at høre til de Protococcaceer, der ret hyppig forekommer i større Soers Plankton; den er saaledes funden i Neuchatelersoen af Fuhrmann $(00$ p. 89), i Vettern af De Toni \& Forti (00 p. 795) samt i Genfersøen af Chodal (02 p. 197).

\section{Raphidium.}

Af denne Slaggt er der beskrevet et storre Antal Arter, hroraf de fleste hører ind under den yderst formskiftende $R$. fasciculalnm Kütz. Slægten bestaar overvejende af Damformer; en enkelt Art R. nivale Chodat er Sneform; $R$. Braunii var. lacustre Chodat optræeder som typisk Planktonorganisme i talrige Schweizersøer (Chodat 00 p. 200); i Neuchatelersøen er den parist af Fuhrmann (00 p. 89) o. a.; den er ikke funden her i Landet. 
R. fresciculutum kï $\mathrm{ï} \%$

Chodal 02 p. 198. Figs. 114-116.

R. f., der overvejende er Damform, er paavist i enkelte Eks. i Esromsø og Julsø (Foraars- og Somnerprove); i begge lilfaclde lar vi haft den typiske Form for os. Var. spirale er ikke set; derinod er var. aciculare, karakteriseret ved altid at optracle enkeltvis og ved sin lige, slanke Bygning, funden i Bagsvaerdsø i en Prove 99 4/7; den sikkert narstanende Art R. Iongissinum I3. Schrøder (97 p.373) med staerkt udtrukne, haardine Poler er hidtil ikke funden her i Landel.

\section{Kirchneriella.}

Til Slaggten horer 3 Arter, af hvilke en er funden ved denne Undersøgelse.

\section{K. lunaris Moeb. \\ Tab. III, Fig. 30 .}

Chodat 02 p. 202. Fig. 122.

Denne interessante fiorm er paavist i faa Eks. i enkelte Prover fra Viborgso. I Esromso forekom den derinod i noget storre Mrengde; den fandtes her i faa Eks. $0017 / 12$, men blev derpaa først iagttaget $01.29 / 6$ Tp. 15; den var sjalden indil 5/9 Tp. 16, men havde da og indtil 30/9 Tp. 17 et ret betydeligt Maks: og dannede i denne Mellemtid en ikke uviesentlig Del af Esromsos Plankton, lıvorpaa den gradvis tog af; i 02 optraadte den sparsomt 10/7 Tp. 14 og $31 / 7$ Tp. 15. Den er i ovrigt funden i flere mindre Soer paa Fyen, særlig Sobysø (E. L.).

K. l. er en overvejende Damform, der som saadan angives fra talrige Findesteder: fra Vettern af De Toni \& Forti $(00$ p. 796) samt i Følge disse Forf. af Garbini fra Laco Benaco. En nærstaaende Art $K$. obesa Schmidle er funden i Valloxensø (00 p. 8) og i Vettern af De Toni \& Forti $(00$ p. 796$)$.

\section{Selenastrum.}

Af denne Slægt, hvortil adskillige Arter henføres, har vi funden een Art.

\section{S. Bibraimmm Reinsch.}

Cllodat 02 p. 204. Fig. 124.

S. B. er paavist i en hel Del af de undersøgte Søer, nenlig Esromsø, Tjustrupsø, Viborgso, Skanderborgsø, Mossø og Julso, til næsten alle Tider af Aaret, men altid kun enkeltvis, som oftest kun i $1-2$ Eks. og altid kun i enkelte Prøver; den er lige saa lidt her i Landet som andetsteds hjemmehorende i storre Soers Plankton; den angives meget hyppig i Arbejder over Smaasoers og Dammes mikroskopiske Plante- og Dyreliv.

\section{Crucigenia.}

Af de i den senere Tid til denne Slægt henførte Arter er der her i Landet paavist tre; den ene, C.triangularis Chodat, er funden af denne $\mathrm{i}$ en Anderlam ved Hofmansgave paa Fyen (00 p. 8$)$.

\section{C. rectangularis (A. Braun) Chodat.}

Cooke 82-84. Tab. 18, Fig. 13.

C. $r$ : er paavist i faa Eks. fra Esromsø $01 \% \frac{30}{9}$ Tp. 17 og fra Sorøsø $0228 / 6$ Tp. 17.

Den angives ret hyppig i Planktonarbejder fra storre Søer: Plönersee Lemmermann (95 p. 46), svenske Søer Borge (00 p. 19), Vettern De Toni \& Forti (00 p. 192), Luganersøen Chodat (98 p. 206$)$ og desuden fra talrige Smaasøer og Damme.

\section{Lauterborni (Schmidle) Chodat.}

Bruno Schrøder 99. Tab. 10, Fig. $1 a$.

Denne store, ualmindelig smukke Planktonorganisme er paavist i enkelte Sommerprover fra Esromsø saa vel 01 som 02. 
l'aa Grund af dens Cedeligs store Hyalinilet overses den let; det er rimeligt, at vi her har med en for de storre Socrs pelangiske Region typisk Planktonorganisme at gore.

C. L. findes kun sjeddent angivet i l'lanktonarbejer; Bruno Schroder (00 p. 77) meddeler, at han har laget den i slor Mangde i Barlewitzersoen i Juli- Aug. Maaned.

\section{Scenedesmus.}

Al denne omfaltende Sliegt lilhorer alle Arlerne smaa, lave Damme, hvor de til Tider kan oplrxede i ulyyre Mángde; delte var f. Lks. Tilfeldet i Lyngsø ved Silkeborg Juli 02; de er tillige alın. som Bredformer i storre Soer og forslatas i saa Fald ofte ud i disses pelagiske Region, hvor de dog ikke er hjemmehørende. Scencesmus-Arter (S. gualdicuudu, bijugatus og obliquus) er al Lagerheim paaviste i Søerne paa Bjørneøen (00 p. 10).

\section{S. quadricauda ('T'urp.) Brél). \\ Tab. IX, Fig. 104. \\ Hl ansgirg 92 p. 115 . Fig. 62.}

S. q. forekommer i alle undersegte Søer, men som oftest kun i et ringe Antal Prover og altid kun enkeltvis; den nevnes hyppig i Planktonarbejder og vil nappe soges forgaves i Smaasøer og Damme.

Efler La ulerborn (02 p. 519) skal (len indgaa i symbiotisk Forhold til Ferskvandssvampen Carterius Stepanouni og farve denne gron.

\section{S. bijugàtuss (Turp.) Küt\%.}

Tab. X, Fig. 118.

Hansgirg 92 p. 114. Fig. 61.

Arten er paavist i faa Eks. i enkelte Prover fra Esromsø, Sorosø, Skanderborgsø, Mossø og Julsø.

\section{Dimorphococcus.}

Der er af denne Slagt kun beskrevet to Arter, begge hjemmehørende i lave Damme.

\section{D. lnnatus A. Braun.}

Chodat 02 p. 217. Fig. 143.

D. l. er kun funden i et enkelt Eks. i Julsø $02{ }^{30} / 6 \mathrm{Tp} .16$; den nævnes i ovrigt ikke i Planktonarbejder fra storre Soer.

\section{Polyedrium.}

Denne store Slægt tæller overvejende Damformer, af hvilke enkelte nu og da forslaas ud i større Søers pelagiske Region.

$$
\begin{aligned}
& \text { P. regulare (Kütz.) Chodat. } \\
& \text { Chodat } 02 \text { p. } 220 \text {. Fig. } 146 .
\end{aligned}
$$

$P . r$. er kun paavist $\mathbf{i}$ enkelte Eks. i Julso $0230 / 6$ Tp. 16.

\section{P. limnelicum Borge.}

Borge 00. Tab. 1, Fig. 2.

Denne smukke Art er paavist i en Del Planktonprover fra Sorosø, Tjustrupsø, Skanderborgsø, Mosso og Julsø; i Smaasøer er den kun funden i Hvidkildeso og Søbyso paa Fyen; den synes at være en udpræget Sommerform.

P. I. er funden i svenske Søer af Borge $(39$ p. 8); i Zwischenahnermeer o. a. af Lemmermann $(00 \mathrm{~g}$ p. 138).

\section{Pediastrum.}

Denne store Slægt med sine talrigt varierende Arter hører egentlig udelukkende hjemme i Smaasøer og Damme; Hovedmassen af de Individer, man træefer ude i de større Søers pelagiske Region, kan sikkert 
betragles som lillieldigt udfort Materiale. Til Stolte lor denne Opfaltelse ljener lorst og firmmest, at en stor Mangele Kolonicr ved narmere Eftersyn viser sig at vere tomme Coenobier, navnlig Individer, der tages on Vinteren og horer lil l’. boryanums Formkreds; endvidere, at del ikke har vaeret muligt al paavise nogen Iydeligg Periodicitet; Arterne P’. boryunum os duplex var. clalhratum findes i nasten alle P’rbver lil alle Aarslider; de er sandsynligvis noget hyppigere om Sommeren, men det er ikke lel at danne sig en begrundet Mening herom, da det ofte er vanskeligt at bestemme, om man har en levende Koloni eller ct tomt Coenolium for sig.

Den i storre Soers Plankton mest varierende Art er $P$. Inplex, der hyppigst forekommer som Formen 'lathralum; vi er ganske enige med Chodat, naar han (02 p. 228) siger, at de talrige Former al denne Art ikke lorljener at betragtes som Varieteter og Arter, og maa navnlig tage bestemt Afstand fra Lemmermans Forsøg (99 p. 114) paa yderligere at sondre Formkredsene P. clathratum og duplex ud i el stort Antal Arter og Varieleter.

I de aldre Arbejder over Plönersøernes Plankton har Zacharias og Apstein kun angivet to Arter, P. pertusnm (- duplex) og boryanum. Naar Lemmermann senere hen (00 l. p. 523) hæv(er, at han i Planktonprøver fra samme Søer har paavist ikke mindre end 10 »wohlunterschiedene« (!) Former, og i len Anledning anbefaler sine Kolleger at gaa meget forsigtig til Vaerks ved Sammendragningen af Arterne, turde i alt Fald en Del af samme Forf.s Kolleger fristes til at anbefale ham selv, saafremt han ønsker, at man skal følge ham, at dokumentere sin Opfattelse noget mere solidt end hidtil. L. har ingenlunde leveret Bevis for, at disse Former er Arter eller Varieteter endsige wohlunterschiedene .

Det havde været vor Hensigt nærmere at studere Temporal- og Lokalvariationen indenfor Slaeglen Peliastrum, men Arbejdet viste sig at være af en saa vidtløftig Natur, at det ikke lod sig gøre i Forbindelse med de øvrige Opgaver, vi havde stillet os; Maalinger lader sig næppe anvende; bedst løses Opgaven vistnok ved Sammenligning af et meget stort Antal Mikrofotografier eller ved Dyrkning. Saa laenge en saadan Undersøgelse ikke foreligger, opnaas der inlet ved en Udsondring af de gamle Arter i en Maengde nye. Vore Iagtlagelser giver Anledning til følgende Bemarkninger.

De forskellige Arter afviger blandt andet fra hverandre dels i Maaden, hvorpaa de perifere Celler ender (1-2 Spidser, Spidsernes Langde og deres indbyrdes Beliggenhed), dels i Formen af (le centrale Celler ( $X$ formede, $\triangle$ formede og $\square$ formede), hvoraf atter resulterer Tilstedeværelsen af større eller mindre Hulrum mellem de enkelte Centralceller og mellem disse og de perifere Celler; hos visse Arter, f. Eks. P.tetras (Ehr.) Ralfs, er, saa vidt vides, de centrale Celler altid sammensluttede og de perifere Celler ikke forsynede med særlig fremstaaende Spidser; andre, f. Eks. P. simplex, har $\times$ formede Centralceller, store Spalter, og de perifere Celler er udstyrede hver med en lang, stærkt fremspringende Spids; endelig gives der Arter, til Dels $P$. boryanum, men særlig $P$. duplex, der frembyder talrige Variationer saa vel med Hensyn til Centralcellernes som til de perifere Cellers Form; dog synes det, som om begge disse Variationer har en Tendens til at gaa Haand i Haand med hinanden; jo mere $\times$ formede Centralcellerne er; jo mere gennemhullet Coenobiet synes, des langere og mere fremstaaende er ogsaa de perifere Cellers Spidser.

Der er nu ingen Tvivl om, at de kompakte Kolonier overvejende er hjemmehørende i Smaasøer og Damme; Arter som P. tetras, tricornntum Borge, P. Kawraiskyi og for en stor Del, som levende Kolonier, ogsaa $P$. boryanum træffes i Alm. ikke i større Søers Plankton; omvendt findes de meget aabne $P$. simplex-Individer med stærkt gennemhullede Coenobier og lange, torndannede Spidser paa de perifere Celler hyppigst i større Søer.

Vi anser det i øvrigt for givet, at en nærmere Undersøgelse vil konstatere, at Pediastrum-Arterne er underkastede en meget betydelig Lokalvariation.

Med Hensyn til Temporalvariationen er Forholdene endnu meget lidt udredede; dog er det sikkert, at $P$. simplex overvejende er Sommerform. Et nærmere Studium af talrige Individer, regelmassigt indsamlede, vilde kunne vise, hvor vidt de centrale Cellers $\times$ Form og de perifere Cellers Spidser liltog med Vandets stigende Temperaturer, og ligeledes give Oplysninger om P. simplex's Forhold til P. duplex var. clathratum. 
Ud fra det ludtryk, vi har last, efter at mange Tusinde Pediastrum-Individer i Aarenes Løb er kommet os for Oje, ar vi tilbojgelige til i Koloniernes storre eller mindre Deling i Spalter og Huller og i de perifere Collers storre eller mindre Tombeviebning al se Variationer, hvis Bestenmelse er al tilpasse Kolonien efter de Krav, der stilles til den som sverende ()rganisme.

C. Scluroter har (97, Tab. Fig. 86) afliddet en Preliastrum duplex var. clathralum, som paa Spidsen af Randcellerne var udstyrel med et fint Haar; \%acha rias pariste (99c. p. 85), at der sad ikke eet, men el helt Bundt (5-6) af' lange, stive Traade; disse blev ogsaa fundne af Marsson paa Materiale fra Halensee 98 (\%acharias 99( ( ). 86). I disse Traade ser Zacharias et Middel til at forøge Svaveevnen hos ovennavite Former; lagltagelsen bekreftes senere af Bruno Schrøder for samme Forms og Varietets Vedk. fra Barlewitzersoen (0) p, 75). 13. Schroder slutter sig til Zacharias' Opfattelse og mener tilmed, at der maa bestaa cl Afhxugighedsforhold mellem Forekonsten af den enkelte Børste og dybe Søer og et helt Børsteloundt og lave Soer. Waldvogel gor $(00$ p. 49) opmerksom paa, at disse liorster muligvis er sein Begleiterscheinung der Eintrocknung, dasz sich bei der Kontralition des Zellinhalt in dieser Form ergiesst. Ähnliche Gebilde beobachtete ich auch bei Ceratiun und Peridiniun, wie überhaupt das eingetrochnete Plankton slrahlige Auslüufer nicht selten aufiveisk.

'Til disse line Børster har vi gennemganende set meget lidt; tydeligst er de paaviste paa $P$. duplex fra Salten Langsø næer Silkeborg; de blev i Proverne iagttagne paa Eksemplarer, der aldrig havde været indtørrede, derimod gjorde de Indtryk af at være bleven beskadigede, da Kolonierne ofte var sønderrevne.

De Arter, der hyppigst nernes i Planktonarbejderne, er $P$. boryauum og duplex; de angives fra næsten alle de nordtyske, svenske og finske Søer, hvorfra Planktonundersøgelser foreligger; derimod mangler de i Folge Chodat (02), Bachmann (01 p. 243), Fuhrmann (00 p. 89) i Schweizersøerne.

Alle Forf. er enige om, at Pediastrum-Arterne, for saa vidt de forekommer i større Søers Plankton, her er sjældne Former, der spiller en ganske underordnet Rolle, og at deres Hjemstavn er lave Smaasøer eller Bredderne af større Søer. I førstnæunte kan de til Tider, navnlig om Sommeren, opnaa meget betydelige Maks.

Vi har i vore Søer truffet følgende Arter.

\section{P. boryanum (Turp.) Menegh.}

Tab. I, Fig. 2.

C. Schröter 97. Tab. Fig. 84 .

Arten optræder i alle vore Søer og som oftest i alle Prøver; den er hyppigst i de mindste Søer (Sorøsø og Viborgso); meget ofte, navnlig om Vinteren, findes den kun som tomme Coenobier; den er sjældnest i Haldsø.

$P . b$. er Kosmopolit, endog funden paa Bjørneøen af Lagerheim (00 p. 15).

P. duplex M e y e n.

Tab. IV, Fig. 39 og Tab. VI, Fig. 72.

Chodat 02 p. 227. Fig. 151.

$P . d$. er paavist $\mathrm{i}$ alle vore Søer og som oftest $\mathrm{i}$ alle Prover, men altid kun i ubetydeligt Antal; den er rimeligvis hyppigst om Sommeren; tomme Coenobier træffes ofte, dog ikke saa tit som af foregaaende Art.

\section{P. simplex Me yen. \\ Tab. VIII, Fig. 87.}

C. Schröter 97. Tab. Fig. 86 .

$P$. s. er kun paavist i Gudenaaens Soer; den synes at være hyppigst i Skanderborgsø og optræder navnlig i Sommerprover.

\section{$P$. biradialum Meyen. \\ Tab. IX, Fig. 100.}

$P . b$. er kun paavist i Sorøsø og Silkeborgsøerne, hvor den forekommer enkeltvis i en Del Prover til forskellige Tider af Aaret; som oftest findes kun tomme Coenobier. 


\section{I'. Kauraiskyi Schmidle.}

Le emmerunann 01 a. Táb. 4, Fig. 5.

$P$. K. er kun paavist i Silkeborgsoerne, hvor den forckommer enkeltvis i en bel Prover.

Denue ret sjaldne Art er funden i Nordlyskland, Kaukasus og paa Bjørneøen (Lagerheim (00) p. 15).

\section{Coelastrum.}

Alle herhen hørende ret talrige og som oftest meget smukke Former er overvejende Dambeboere, men visse Arter findes dog ogsaa markelig hyppig ude i større Søers pelagiske Region. Om denne Slæxgt cfr. sarlig Senn's smukke Undersøgelser (99 p. 40).

\section{C. microporum $\mathrm{N}$ äg. Senn 99 p. 53, Fig. 6. Tab. VI, Fig. 71.}

C. $m$. er paavist $\mathrm{i}$ alle 9 Søer, som oftest $\mathrm{i}$ et stort Antal Prøver og til alle Aarstider; i Alm. findes den dog kun i ganske enkelte Eks.; herfra undtages Viborgsø, hvor den optræder i ret betydelig Mængde $017 / 8$ Tp. 23 og ved́blivende, men i ringere Antal i alle Aarets folgende Maaneder. I 02 viser den sig straks efter Isløsningen ${ }^{22} / 3$ Tp. 2 og findes derpaa tiltagende $\mathrm{i}$ alle Prøver til ${ }^{25} / 6$ Tp. $17 \mathrm{og}{ }^{27} / 7$ Tp. 15, da Maks. rimeligvis naas.

Den angives fra talrige Smaasøer og fra Bredderne af større Søer, men sjæeldent fra disses pelagiske Region. Af Lagerheim er den funden paa Bjørneøen (00 p. 10).

\section{C. cambricum Archer.}

C. Schröter 97. Tab. Fig. 87.

Denne overmaade smukke Art er paavist i ganske faa Eks. i en enkelt Sommerprøve fra Tjustrupsø og Viborgsø. I en lille Hedemose bag Laven ved Julsø fandtes den i uhyre Mængde i Aug. 01; det er en udpræget Damform.

\section{Hariotina.}

Af denne Coelastrum i hvert Fald meget nærstaaende Slagt er kun een Art beskrevet; cfr. i øvrigt Senn (99 p. 40).

\section{H. reticulata Dang.}

Chodat 02 p. 233. Fig. 160-161.

Denne meget interessante Art, der vistnok er en udpræget Damform, er paavist i ganske enkelte Eks. i en Sommerprøve $0210 / 7$ Tp. 14 fra Esromso.

Senn mener $(99$ p. 40$)$, at $H$. $r$. særlig er en tropisk Art, da den udenfor Troperne kun er funden i Damme i botaniske Haver; de af os paaviste Eks. stemmede nøje overens med de af Chodat afbildede Eks.

\section{Botryococcus.}

Slægten, hvis systematiske Stilling er meget usikker, indsættes her som et Slags Appendix til Afdelingen Pleurococcoidea. Hovedarten er B. Braunii; endvidere har Lemmermann (96c. p. 111) opstillet B. sudeticus, der af Chodat (02 p. 115) anses for at vare en Fornı af Spltcrocystis; Engler har beskrevet en marin Art: B. pelagicus fra Østersøen, identisk med B. Braunii; den er ogsaa funden i det kaspiske Hav (Ostenfeld 01 p. 131).

\section{B. Braunii K üt $\%$.}

Tab. VIII, Fig. 87, de sorte Klatter.

Schröter \& Kirchner 96. Tab. I, Fig. 10.

B. B. er paavist $\mathrm{i}$ alle de undersogte Soer og saa golt som i alle Prover; vi formoder derfor, at denne Form til enhver Tid vil være at finde $\mathbf{i}$ de danske Soers pelagiske Region. I ingen af Søerne optraadte den saa talrig, 
al den i synderlig Cirad inlluerede paa Planktonels almindelige Karakter eller forandrecle Vanclets Farve; talrigst

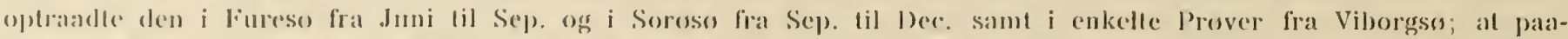
vise nogen l'eriodicited med siorlig mdpragedo Maks. og Min. har i uvrigl ikke vaerel os muligh.

l'bentor de 9) nudersegle Soer er den i storst Mangde funden i Almindsa ved Silkeborg og i Røalsn nxer Viborg: navonlig fra disse Soer dannede Arlen for oven i P'roverne en tyk, rod Ring.

I Modsetuing til alle andre Chlorophyceer er B. Bramii en Vandblomst-dannende Alge, der i stille Vejr lejrer sigs i Overladen. Svaveapparatet er (len rode Olje, som efter Chodals Undersogelser (96 p. 3333) produceres i Celleme og derpaa udskilles og allejres i Gelemasserne.

Endvidere spiller Oljen en Rolle som lysskermende Faklor, der i Folge Chodat er nodvendig, fordi Planten i de slore og klare Soers Vandoverllade ellers vilde være udsat for stærkere Lys, end dens Chlorophylapparat kuncle laale. Man liar fra xeldre Tid vidst, at Algen snart optrxeder grøn, snart rød; I'lantens egenllige farve er gron, og den rode fremkommer kun ved rigelig Aflejring af roul Olje. Chodat har nu vist, at Oljeproduktionen ikke til alle Tider er lige stærk; under og efter en Periorle med klart Solskin vil Produktionen vaere størst, og Algen som Folge heraf vere rød; efter en lengere Graavejrsperiode vil derimod den gronne Farve vire fremherskende. I Overensstemmelse hermed er Algen om Vinteren, der i Schweiz skal have det største Antal klare Dage, i Schweizersøerne overvejende rød, medens den er grøn om Sommeren. Denne Chodats Angivelse bekraftes af Amberg $(00$ p. 45$)$ o. a. Hos os forholder Algen sig med Hensyn lil Farven lige omvendt, idet den om Vinteren aldeles overvejende er grøn, om Sommeren derimod rod. Detle er $\log$ ingenlunde i Strid med Chodats Opfattelse, men synes tværtimod at bekræfte denne. Der kan nemlig ingen Tvivl vare om, at Lyset i vore Søer absolut er mest dxmpet i Vinterhalvaaret, særlig i al den 'Tid, vore Søer er belagte mer? snedxkt ls. Saa vel i Schweiz som her hos os skærmer Algen altsaa sil Chlorophylapparat ved Hjæelp af den røde Olje paa det Tidspunkt af Aaret, da Lyset er mest intensivt.

I visse Søer synes B. B. altid at vare rød: Lago Muzzano (Amberg 00 p. 45), eller dog overvejende rød: Bodensøen (Schröter \& Kirchner 96 p. 33). Lemmermann (95 p. 49) mener at have iagttaget, at de unge ḱolonier er grønne, de aldre gulbrune.

Arten angives fra talrige Søer, men synes intetsteds i det mellemeuropæiske Slettelands Søer at opnaa nogen større Udvikling. Dens Hjem er de kolde, klare Alpesøer med deres rene Vand; den angives fra en Mrengde af disse og danner her undertiden, navnlig on Vinteren, en saa betydelig Vandblomst, at Vandet viser sig rødt. Dette skal især vare Tilfældet med Neuchatelersøen; i Aaret 79-80 lod Neuchatels Municipalraad i den Anledning nedsette en Kommission for at undersøge, hvor vidt det røde Vand var skadeligt for Sundheden (Chodat 98 p. 58).

Lemmermann vil have $(95$ p. 49) fundet Arten fastsiddende paa Bunden af Pytter i Omegnen af Brehmen.

Dens nordligst kendte Findested er i Omegnen af Tromsø (Lagerheim 00 p. 19).

Confervales.

Begrebet Confervales, der her tages i den af Bohlin (01) givne Begræensning, indbefatter kun to Slægter, der vedkommer dette Arbejde; af disse er Ophiocylium en Damform, der ikke sjaldent optræeder i mindre Søers og Smaadammes centrale Partier; i større Søer derimod har vi aldrig fundet den, og den angives, saa vidt vides, heller ikke i Arbejder over disses Plankton. Slægten Tribonema forholder sig derimod paa anden Vis.

Tribonema bombycinum (Ag.) Derb. \& Sol. forma depauperata. n. form. Wille. Tab. III, Fig. 25 og 28.

Da vi ikke saa os i Stand til at bestemme denne Art, anmodede vi Prof. Wille, om han vilde undersøge vort Materiale og sige os sin Mening on den; han har meddelt os følgende, hvorfor vi bringer ham vor bedste 'Tak. Cellernes Bredde $3 \mu$, Læengden 18-33 $\mu$; Cellerne er omtrent cylindriske med svagt indsnørede 


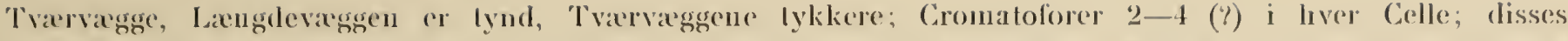
Anlal er ikke set med Sikkerlied. Traalene er flydende uden Hafteskive. Demne overmande spinkle Alge Inenfores retlest som ny form depanperala under Tribonema bombycinum (As.) Derb. \& Sol. Saafrent Cromatoforemes Antal virkelig ikke oversliger 4, nermer Algen sig log snarere til T. minus (Wille) Ha\%en, (la 'T. bomblgcinum liar more end 4 saralamne.

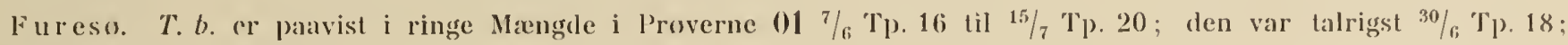
i 02 blev den ikle funden.

Esromso. T. b. er her perennerencle og pasvist i alle prover; den var ret hyppig 00 17/12 Tp. 5 , men sjacklen efter Islosningen l'rove $0110 / 4$ Tp. 3, hvorpata den lingsomt tiltog indtil $25 / 5 \mathrm{~T}_{\mathrm{p}}$. 13 ; (len havde (lerpaa fra $29 / 6$ Tp. 15 indlil 20/7 Tp. 17 et kolossalt Maks., under hvilket alt indet Plankton maskeredes; $12 / 8$ Tp. 21 var Arten starkt aftaget og blev nu sjeclen lige til $0222 / 3$ Tp. 2 umiddelbart efter lslosningen; den var derpaa hele Foraaret ret alm og havde et Maks. ${ }^{10} / 7$ Tp. 14, men dog langtfra saa stort som i $01 ; 31 / 7$ Tp. 15 var Arten endnu ret alm.

Soroso. T. $b$. findes i de fleste Prover; den er her sikkert perennerende, men Antallet er alticl kun ringe; i storste Mangle blev den taget i Prove 01 18/9 $\mathrm{T}_{\mathrm{p}} .12$.

Tjustrupsø. T. b. er kun taget enkeltvis i enkelte Prover.

Viborgso. T. $b$. er kun paavist i en enkelt Prove $017 / 8$ Tp. 23 i faa Eks.

Haldso. T. b. er paavist i de fleste Prøver i Tiden fra $0130 / 1$ Tp. 1 indtil $7 / 8$ Tp. 18, men alticl kun i enkelte Eks.; senere hen var den yderst sjaelden.

Skanderborgso. T. $b$. er paavist i nasten alle Proverne; (len er som oftest ret alm., maaske hyppigst i Forsommeren; men nogen udpraget Periodicitet lod sig ikke iagtlage.

Mosso. T. b. forekonmer i alle Prøverne, er hyppigst i Foraarshalvaaret, men i det hele sjaldnere end i Skanderborgso.

Julsø. T. b. er paavist i de allerfleste Prover, men er altid sjælden; nogen Periodicitet iagttoges ikke.

Man vil heraf se, at $T$. $b$, optraeder som regelmæssig Planktonorganisme i vore større Søers pelagiske Region; i Furesø, Tjustrupsø og Viborgsø er den dog kun taget i enkelte Prøver, i alle de andre er den utvivlsomt perennerende; dens Maks. ligger i Foraarshalvaaret, men er i de fleste Søer ikke synderlig markeret; kun i Esromsø i Tiden 01 29/6 Tp. 15 til $2 \% / 7$ Tp. 17 har Arten et ganske kolossalt Maks. Sværmsporedannelse er aldrig iagttaget.

Paavisningen af $T$. $b$. Optræden soll almindelig og perennerende Planktonorganisme i vore større Søer er et af Undersøgelsens ikke uvigtige Resultater. Bortset fra C. tenerrina Kütz., der af Istvánffi (98 p.116) angives som Planktonorganisme i den lave Balatonsø, hvorfra i øvrigt saa mange Bund- og Bredformer angives i Planktonet, er der os bekendt aldrig paavist Conferva-Arter (i videre Forstand) som Planktonorganismer. Da det forekommer os ret utroligt, at $T$. bombycinum her i Landet i Modsætning til alle andre Steder skulde optræde som Planktonorganisme, og da der fra Nordtyskland angives grønne Traadalger som Planktonorganismer, nærer vi en Formodning om, at disse ved nærmere Eftersyn vil vise sig at væere denne eller en nærstaaende Form. Vi kender intet til Maaden, hvorpaa T. b. tilbringer sine Hvilestadier som Planktonorganisme, hvorledes den kommer ud i den pelagiske Region, og heller intet til Maaden, hvorpaa de kolossale Maks. opstaar og forsvinder. W.-L. har to Aar undersøgt denne Form i Maj-Juni i Esromsø, men da Maks. faldt paa et Tidspunkt, hvor saa mange andre Former (Gloiotrichia, Agagropila, Anabrna, Rotiferer o. m. a.) samtidig skulde studeres, blev Undersøgelsen ikke fardig. Der tilvejebragtes vel en ganske godt funderet Arbejdstheori, brugbar for et mere indgaaende Studium, men da dette endnu ikke er afsluttet, maa Publikationen udskycles.

\section{Conjugatæ.}

Bortset fra nogle enkeltvis forekommende Traade af Spirogyra, Mougeotia (M. gracillima Wittroch i Neuchatelersøen, Fuhrmann 00 p. 89) o. a. tilhører alle de i større Søers Plankton optradende Former Fam. Desmidiacex. Foruden de i det folgende omtalte Slagter og Arter findes i Planktonarbejderne endnu navnt en Del Former navnlig hørende til Slægterne Closteriun, Arthrodesmus, Xanthidium o. a. 
Desmidiacerene horer aldeles overvejende hjemme i Smatasøer, lave Danme og side Moser, Vande med ringe I)ybde, loj 'Tp. og rige para opleste, organiske Stoffer; Hovedhassen er langsomt krybende Bundformer; for sala vidt de forckommer i storre, klare Soer, er det saerlig som Bredformer eller paa Lokaliteter, hror

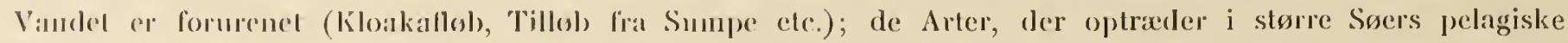
Region, er narmest de samme, som lindes i Snalasoers vegetationsfri centrale Partier; enkelte Former kan vare karaktoristiske for disse sidste (Hydolhece i Koppenteiche i Riesengebirge, Lemmermann () $6 .$, p. (93).

Desmidiateernes Maks. falder vistnok saa vel i Søer som i Damme i Alm. sammen med Vandets hojeste Tp.: yederligere og mere specialiserede Undersøgelser er dog paa delte Omraade ønskelige; det maa bemxeskes, al Lagerlieim (00 p. 19) fra arktiske, alpine og subalpine Søer mener at lave fundet, at Desmidliaceerne her har en korl Blomstringsperiode om Foraaret, Tp. 10.3-11.5, hvorpaa de nxsten ganske forsvinder. Man treffer i Plankton ikke fan Skeletter af Desmidiaceer, isæer af Slaurastrum- og Cosmarium-Arter; disse holder sig øjensynlig meget lange svevende; de er paavist i Mrengde i vore dybere Søgytjer (W.-L, 01 p. 113).

\section{Closterium.}

Bestemmelsen af de i vore Søers Plankton optredende Closterium-Arter har voldt os betydelige Vanskeligheder. Fra andre Søers Plankton beskrives et ikke ringe Antal Closlerinu-Arter; vi har Indtrykket af, at der i Virkeligheden kun lindes faa Planktonarter, men at disse af de forskellige Forf. er beskrevne under forskellige Navne; hvad der øger Vanskeligheden, er, at Plankton Closterierne for det uøvede Øje let forvelisles med Raphidiunt-Arter, og det formodes, at slige Forvekslinger har fundet Sted.

For Schweizersoernes Vedkommende angiver Chodat to Arter, C. gracile Delp. (97 a. Tab. II, Fig. 11 og 12) og C. aciculare West (T. II, Fig. 10); førstnavnte blev senere (98 p. 185) beskrevet som en egen Art, C. Nordstedtii, af Chodat, der angiver, at den er karakteristisk »anx grands lacs de basse région ; sidstnæunte er derimod kun funden i Le Léman. Fra de nellemeuropæiske Søer angiver Lemmermann særlig to Arter, C.losteriun pronum Bréb. var. longissimum Lemm. (96 b. p. 169) og C. limueticum Lemm. (99 p. 123); førstnævnte ophøjer L. senere hen (99 p. 124) til Slægten Closteriopsis longissima; denne Alge skal i Følge Lemmermann (01 a. p. 91) være identisk med Raplidium pyrogenum Chodat; (00a. p. 66) fjærner han Slægten Closteriopsis fra Conjugaterne og forer den nærmere til Raplidium. Alle de af os sete Closterier har været overordentlig smalle og fine, men med sragt buede hyaline Ender; de tilhører utvivlsomt alle en Art, som vi foreløbig betegner som C. ceralium, da de bedst stemmer overens med den af B. Schrøder givne Figur af denne Art; vore Closterier er for lange og tynde og for elegant buede, til at de kan være C. limmeticum Lemm.; den af Chodat afbildede C. aciculare har vi aldrig set; derimod har vi i Silkeborgsøerne fundet Closterium lignende Former, der endte i overordentlig lange, fine Børster; muligvis har vi her haft Closleriopsis longissima for os.

\section{C. ceratinum Perty. \\ Tab. Y, Fig. 156.}

Bruno Schrøder 99. Tab. 10, Fig. $3 b$.

Arten er paavist $\mathrm{i}$ alle de undersøgte Søer, men i Alm. kun i ringe Mængde.

Den synes i Modsætning til de ørrige Chlorophyceer at væe hyppigst om Vinteren og det tidlige Foraar; rimeligvis spiller den en betydelig større Rolle i vore Søers pelagiske Region; men paa Grund af sin overordentlig slanke Form undviger den med Lethed gennem Nettets Porer, saa at kun en Brøkdel kommer med i Prøven.

\section{Cosmarium.}

Af Slrgten Cosmarium, der udelukkende indbefatter Danı- og Lavvandsformer, forslaas en Del Arter undertiden ud i de større Søers centrale Partier; en Del er saaledes funden i Vettern af De Toni \& Forti (00 p. 783), i Schweizersøerne af Chodat (97 a. p. 300) o. a. 
C. scemedesmins $\mathrm{I}$ )elp.

Tab. IX, Figs. 106.

C. Schröler 97. Tab. Fig. 90.

Arten er parist i cnkelle Prover fra Skanderborgso og Mosso.

\section{Staurastrum.}

Ligesom Closterinu er Staurastrmm-Arterne hjemmehørende i ganske lavvandede Smaasøer, Damme og Moser, og de Former, der findes i de større Søers pelagiske Region, er kun forslaaede Individer. Herfra maa dog maske undtages de to Arter S. gracile og S. paradoxuu, der synes konstante Beboere af de saakaldte Damsoers centrale Partier.

\section{S. gracile Ralfs.}

Tab. V1, Fig. 72.

C. Sehröler 97. Tab. Fig. 89.

S. g. er paavist i alle de undersøgte Soer, men spiller en noget forskellig, som oftest meget underordnet Rolle i disse. Naar Vintermaanederne undtages, vil Arten rimeligvis til enhver Tid kunne træffes i Plankton fra Furesø, Esromsø, Sorøso, Tjustrupsø og Viborgsø; i Haldsø og Silkeborgsøerne var den noget sjældnere. Den har sit Maks. liggende nær ved Vandets højeste Tp., Fureso 15/8, Esromso 30/9, Soroso 18/9, Tjustrupsø 17/9, Mossø $1 / 8$.

I alle disse Soer optræder den i underordnet Mængde. I Viloorgso, der mest af alle har Karakteren af en stor, lav Dam, optraadte den $\mathrm{i}$ stor Mangde. Den viste sig $\mathrm{i} 01$ forst $18 / 5$ Tp. 14 og var $7 / 8$ Tp. 23 saa talrig, at den næst efter Cyanophyceerne var Planktonets hyppigste Form; rimeligvis var den lige saa talrig 15/9 Tp. 12, men maskeredes da af Aphanizomenon. ${ }^{14} / 10$ Tp. 12 var den meget alm., aftager 10/11 Tp. 8 og findes derpaa enkeltvis $\mathrm{i}$ alle Proverne lige til $02{ }^{25} / 6$ Tp. 17, da den optræder noget hyppigere; ${ }^{27} / 7$ Tp. 15 har den atter et kolossalt Maks. vistnok storre end 01. I Dec.-Jan. findes hovedsagelig døde, tomme Skaller; under sit Maks. optræder den ofte i Kæder paa 6, undertiden 8 Individer.

S. gracile naevnes i talrige Planktonarbejder, men altid hyppigst fra Damme, Smaasøer eller fra Bredderne af større Søer; i store, klare Søers pelagiske Region hører den ikke hjemme.

Apstein (96 p. 144) synes at vare den eneste, der har iagttaget Periodiciteten; han angiver ligesom vi, at dens Maks. falder sammen med Vandets højeste $\mathrm{T}_{\mathrm{p}}$.

\section{S. paradoxum Meyen var. longipes $\mathrm{N}$ ordst. Tab. III, Fig. 28.}

Borge 00. Tab. 1, Fig. 4.

$S$. p. er paavist i alle de undersøgte Soer undtagen Viborgso og Silkeborgsoerne, men optræder i de fleste kun enkeltvis i nogle faa Prover. Den træffes hyppigst i Esromso, Soroso, Tjustrupso og Haldso, hvor den vistnok forekommer til alle Tider af Aaret, muligvis med Undtagelse af Feb.-Marts; den synes at vare hyppigst i Sep.

S. p. gør her i Landet mere Indtryk af at være Søform end S. gracile, da den netop opnaar sin højeste Udvikling i vore dybeste og koldeste Søer. Den optræder næten altid enkeltvis; højst er der set Kæder paa to Individer.

Den synes at variere ikke saa lidt paa de forskellige Lokaliteter; Variationen vedrører dels Hornenes Langde, dels den Vinkel, hvori disse viger ud fra hinanden; ogsaa Cellens Sculptur er underkastet betydelig Variation.

Udenfor Danmark er Arten oftest paavist i Damme; Zacharias har (98 b. p. 102) fundet den i Masser i en Smaadam. 


\section{ALMINDIEIGE BEMAERKNINGER.}

Plankton-Chlorophyceernes Forekomst i de undersogte Sner. ')

\begin{tabular}{|c|c|c|c|c|c|c|c|c|c|}
\hline & Fineso & lisromso & Soreso & Tyustrup- & Viloorgso & 11aldso & $\begin{array}{l}\text { Skander- } \\
\text { borgsw }\end{array}$ & Mosso & Julse \\
\hline Tetraspora lacustris ............. . . . . . & $(\mid)$ & (1) & $(+)$ & $(+)$ & & & & $(+5)$ & \\
\hline 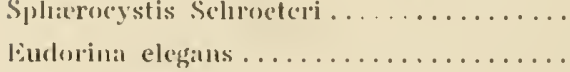 & $(t)$ & + & $(+)$ & $(+)$ & $\begin{array}{c}+ \\
(+)\end{array}$ & $\begin{array}{l}+ \\
+\end{array}$ & $(+)$ & $(+)$ & $(+)$ \\
\hline Dictyosphairium pulchellum............ & & + & $(+)$ & & $(+)$ & & $(+)$ & $(+)$ & $(+)$ \\
\hline 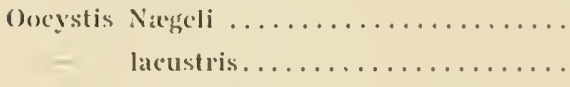 & $(+t)$ & $(+)$ & $(+)$ & & $\begin{array}{l}(+) \\
(+)\end{array}$ & $(+)$ & $\begin{array}{l}(+) \\
(+)\end{array}$ & $(+)$ & $\begin{array}{l}(+) \\
(+)\end{array}$ \\
\hline Choolatcllia ciliat: $\ldots \ldots \ldots \ldots \ldots \ldots \ldots \ldots$ & & & & & & & & $(+)$ & $(+)$ \\
\hline 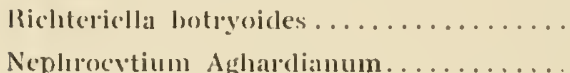 & & $(+)$ & $(+)$ & & & & & $(+)$ & \\
\hline Raphiclium fasciculatum .............. & & $(+)$ & & & & & & & $(+)$ \\
\hline Kirchnericllis lunarris . . . . . . . . . . . . . & & + & & & $(+)$ & & & & \\
\hline 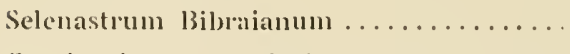 & & $(+)$ & & $(+)$ & $(+)$ & & $(+)$ & $(+)$ & $(+)$ \\
\hline $\begin{array}{r}\text { Crucigenia rectangularis } \ldots \ldots \ldots \ldots \ldots \ldots \\
\text { Laaterborni } \ldots \ldots \ldots \ldots \ldots \ldots \ldots \ldots\end{array}$ & & $\begin{array}{l}(+) \\
(+)\end{array}$ & & & & & & & \\
\hline $\begin{array}{c}\text { Secnedesmus cyuadrieauda ........ } \\
-\quad \text { lijugatus .......... }\end{array}$ & $(+)$ & $\begin{array}{l}(+) \\
(+)\end{array}$ & $\begin{array}{l}(+) \\
(+)\end{array}$ & $(+)$ & $(+)$ & $(+)$ & $\begin{array}{l}(+) \\
(+)\end{array}$ & $\begin{array}{l}(+) \\
(+)\end{array}$ & $\begin{array}{l}(+) \\
(+)\end{array}$ \\
\hline Dimorphococcus lunatus .... & & & & & & & & & $(+)$ \\
\hline $\begin{array}{c}\text { Polyedrium regulare } \ldots \ldots \ldots \ldots \ldots \\
-\quad \text { limneticum } \ldots \ldots \ldots \ldots\end{array}$ & & & $(+)$ & $(+)$ & & & $(+)$ & $(+)$ & $\begin{array}{l}(+) \\
(+)\end{array}$ \\
\hline Pediastrum boryanum... & $(+)$ & $(+)$ & $(+)$ & $(+)$ & $(+)$ & $(+)$ & $(+)$ & $(+)$ & $(+)$ \\
\hline - duplex......... & $(+)$ & $(+)$ & $(+)$ & $(+)$ & $(+)$ & $(+)$ & $(+)$ & $(+)$ & $(+)$ \\
\hline simplex.......... & & & & & & & $(+)$ & $(+)$ & $(+)$ \\
\hline biradiatum..... & & & $(+)$ & & & & $(+)$ & $(+)$ & $(+)$ \\
\hline - Kawraiskyi ... & & & & & & & $(+)$ & $(+)$ & $(+)$ \\
\hline 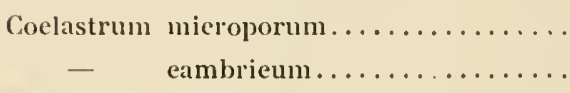 & $(+)$ & $(+)$ & $(+)$ & $\begin{array}{l}(+) \\
(+)\end{array}$ & $\begin{array}{c}+ \\
(+)\end{array}$ & $(+)$ & $(+)$ & $(+)$ & $(+)$ \\
\hline Hariotina reticulata $\ldots \ldots \ldots \ldots \ldots \ldots \ldots$ & & $(+)$ & & & & & & & \\
\hline Botryocoeens Braunii $\ldots \ldots \ldots \ldots \ldots \ldots$. & + & + & + & + & + & + & + & + & + \\
\hline Tribonema bombycinum ............. & $(+)$ & \pm & $(+)$ & $(+)$ & $(+)$ & $(+)$ & \pm & $(+)$ & $(+)$ \\
\hline Closterium ceratium $\ldots \ldots \ldots \ldots \ldots \ldots$ & + & $\mp$ & + & + & + & + & $\mp$ & + & + \\
\hline Cosmarium seenedesmus. & & & & & & & $(+)$ & $(+)$ & \\
\hline Staurastrum gracile ..... & + & + & + & + & + & + & + & + & + \\
\hline - paradoxum. . & + & + & + & + & & + & & & \\
\hline
\end{tabular}

Af ovenstaaende Schema vil man se, at der i de undersøgte Søers Plankton optræder ikke mindre end 33 Arter Chlorophyceer, hvoraf de 29 hører til Euchlorophyceerne, de 4 til Conjugaterne.

Ved at betragte saa vel Schemaet over Chlorophyceerne som Schemata over de enkelte Søer bliver det indlysende, at Hovedmassen af alle disse talrige Former i Søernes Plankton kun er tilfældige Grester (tycholimnetiske), og at de ingenlunde er hjemmehørende i den pelagiske Region. Et større Antal Arter optræeder nemlig kun i ganske faa Søer, som oftest kun i enkelte Prøver og i enkelte Eks; bortset fra, at de fleste Former i al Almindelighed kan betegnes som Sommerformer, kan Periodiciteten i mange Tilfælde ikke paavises; om en saadan kan der kun være Tale hos Spharocystis Schroeteri, Eudorina elegans samt maaske Dictyosphretium pulchellum, Kirchneriella lnuaris og Closterinm ceratium.

1) Om Tegnenes Betydning se 1. 56. 
Hjemmehorende i vore storre Soers centrale Partier er neppe mere end folgende Arler: Tedraspora lacustris, Sparocystis Schrocleri, Eudorina elegans, Diclyospharium pulchellum, Oocyslis lacustris, Crucigeniu Laulerborni, Botryococcus Braunii, Closterinm ceralium, Slaurastrum paradoxum og Tribonema bombycinum; alle de ovrige kan reltest betragles som Dam- og Bredformer, der med Tillob og Bolger er forte ud i den pelagiske Region.

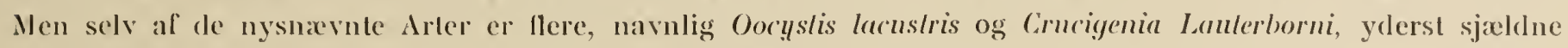
i rore Soer og medlages kun her, fordi de andetsteds i storre Søer optrxder som typiske Planktonalger. Udpragede Planktonorganismer i danske Søer er kun Bolryocorcus Branii, Splueroryslis Schroeleri, Tribonema og mulig Endorina elegans. Men ene Tribonema er i Stand til for langere Tid at danne den hell overvejende Del al' en Sos Plankton; desvarre er det ikke lykkedes os at udrede denne Arts Biologi; sammenlignet med de Resultater, hrortil Planktonundersagerne er komme i andre Lande, synes den hos os at spille en mærkclig stor Rolle. Selv om man hos adskillige af de andre Former kan lale om sarlige Maks., er disse i Alm. ikke synderlig udprægede og som oftest meget kortvarige (Sphuroryslis i Juni-Juli, Vilorgsø, Halelsø; Eudorina i Juni-Juli, Furesø, Esromsø og Haldsø; Dictyospharium pulchellum 01 130/9, Esromsø; Kirchneriella lunaris i Sep., Esromsø).

Chlorophyceernes Betydning som Plankton-dannende Alger i vore større Søers pelagiske Region maa derfor i det hele siges at være temmelig ringe.

Ganske lignende Resultater er ogsaa de fleste Undersøgere i andre Lande komne til; overalt deltager Chlorophyceerne kun i mindre Grad i Dannelsen af de større Søers Plankton, men ligesom hos os har man ogsaa i Udlandet Eksempler paa, at en enkelt Art tilsyneladende ret umotiveret, snart hist snart her kan optræede med betydelige Maks. De større Søers Planktonchlorophyceer er i det hele kun bleven stedmoderlig behandlede; det er derfor vel muligt, at en specielt mod dette Punkt rettet Undersøgelse, navnlig i det mellemeuropæiske Slettelands Søer, vilde give et noget afvigende Resultat.

- Takket rere Chodats Arbejder er de schweiziske Alpesøers Chlorophyceeflora langt bedre undersøgt. Chodat kommer til ganske samme Resultat som vi, dels nemlig, at Chlorophyceerne kun danner en forholdsvis ringe Del af de større Søers hele Planktonmasse, dels at deres Hjem overvejende er mindre Vandmasser, rige paa organiske Stoffer og lidet gennemsigtige.

Naar vi i Modsatning til Chodat, der kun angiver meget faa typiske Planktonchlorophyceer i Schweizersøerne, nemlig Botryococcus og Spharocyslis, i vore Søers pelagiske Region har paavist el saa stort Antal Chlorophyceer, da er netop disses Tilstederaerelse her det bedste Bevis for i hvor høj Grad de danske Søer bærer Dammenes Præg, og hvor lidt de egentlig fortjener Betegnelsen af Søer. Det fremgaar endvidere af Chodats Undersøgelser, at det lille Samfund af pelagiske Chlorophyceer, der optrader i Schweizersøerne, bestaar af Arter, som enten helt mangler hos os eller her i Landet spiller en ganske underordnet Rolle. Saaledes mangler Raphidinm Braunii Naeg. og Closterium Nordstedtii Chod. tilsyneladende ganske i vore Søer, medens de, on end i underordnet Mrengde, findes i Schweizersøerne; endvidere optræer Botryococcus og Spharocystis i langt større Mængde i Alpesøerne end i de lave Slettelandssøer. Omvendt mangler i Alpesøerne næsten ganske flere af de Former, der hyppig træffes i vore Søers pelagiske Region (Pediastrum, Slaurastrum, Closterium ceratinn o. a.).

Vore Dammes fritlevende Chlorophyceeflora er endnu meget lidt undersøgt. Den store Rigdom paa Chlorophyceer er netop et af de Træk, der skarpest adskiller Damplanktonet fra Søplanktonet. I rore Dammes centrale Partier spiller Volvox, Pandorina, Goninm, Endorina, Scenedesmus, Pediastrum, Coelastrum-Arter en meget stor Rolle, og Arter af Slagterne Crucigenia, Golenkinia, Actinastrum er ikke sjeldne. Yderligere Undersøgelser paa dette Felt vil uden al Tvivl kumne berige vor Flora med et stort Antal meget interessante Former og rimeligvis bringe adskillige hidtil ikke beskrevne Typer for Dagen.

Vi henviser i øvrigt til Chodats fortræffelige Studier. 


\section{KAP. VII. PROTOZOA.}

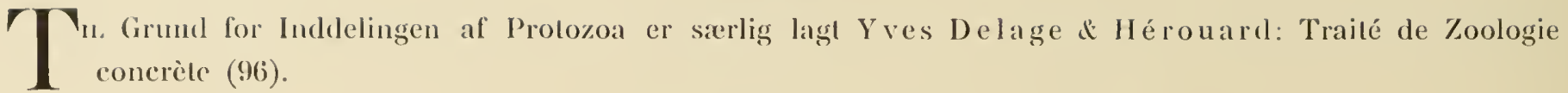

\section{FL, A G E I, I, ATA.}

\section{Dinoflagellata.}

Peridineernes Belydning som Plankton-dannende i vore større Søer kan næppe siges at vaere synderlig slor. Med Undlagelse af Ceratium hirundinella og maaske nogle Giymuodinimn-Arter er alle Ferskvandsp. udpraxgede Damformer og ikke hjemmehorende i større Søers pelagiske liegion; førstnævnte er den eneste Perilinee, som her kan optraede dominerende og med rel kortvarige, men til Gengæld meget store Maks.

Peridineerne er overhovedet aldeles overvejende marine Planktonorganismer og spiller som saadanne en overordentlig stor Rolle. I Ferskvand optraeder de kun med et meget ringe Antal Slægter og Arter, der alle tilhorer de to Fam. Gymuodiniacea og Peridiniacea; Fam. Prorocentracer er udelukkende marin. De fleste lacustrine Slaxgter taller ogsaa marine Arter; enkelte lacustrine Arter (C. limunlinella) synes ogsaa, til Dels under sarlige Varieteter, at høre hjemme i Brakvand.

I Ferskvandsperidineernes Bygning fundes der i Modsatning til Saltvandsperidineernes ingen synderlig fremtraclende Planktonkarakterer. Af saadanne bør kun fremhæeves Torndannelserne hos C. Irirundinella og de store kugleformede Gelelag hos Gymuodinimu. Ferskrandsformerne har alle skarpt markerede Maks. og meget udprægede Hvileperioder; Hvilestadierne er bedre kendte end hos de fleste andre Planktonorganismer.

Varieringsevnen er for flere Arters Vedkommende, sarlig Ceratium hirundinella, overordentlig stor.

\section{Gymnodiniaceæ.}

Af denne overvejende marine Familie optræeder i Ferskvand kun tre Slagter: Gymnodinium, Hemidinimm og Amphidinimm, af hvilke de to sidstnæevnte kun findes i Smaasøer og lave Damme. Planktonorganismer i storre Søer findes kun indenfor Slægten Gymnodinitum.

\section{Gymnodinium.}

Der er af denne Slaggl beskrevet et stort Antal dels marine, dels lacustrine, overvejende usikre Arter; alle de i vore storre Søers Plankton paaviste Former har jeg henført til een Art: G. fuscunu. Som Planktonorganisme har Zacharias $(99$ d. p. 136) paavist den narstaaende Art G. palustre Schilling i »Kleine Ukeleisee« naer Plön.

Hos Gymnodinimm har man iagttaget amoeboide Beragelser med Udskydelse af Plasmatraade, gennem hrilke fast Naering optages. Denne Ernaeringsmaade er bemarket baade hos Former uden Kromatoforer 


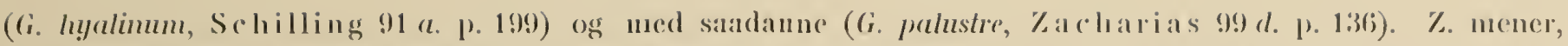
at deme Emaringsmatate sarlig skulde spille en Rolie on Efteranet ved Cystedannelsen, da Cysten er sala meget store end det fritsvommende Dyr.

Deling er iagltaget dels i encysteret liilstand og foregatar i sata Fald indenfor et mexgligh kugleformet

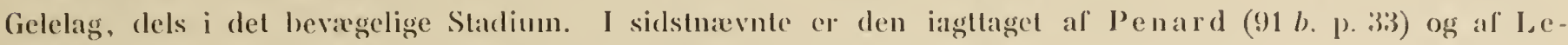
vander (94 a. p. 49), efter hvis Angivelse Delingen varer i c. $1 \frac{1}{2}$ 'Time. Hvilecysten, der er omgivet af en lyk Varg, or indhyllet i et stort Gelelag; den optraeder til forskellige Aarsticler hos de forskellige Arter (Schilling 91 b. p. 41). G. er den eneste Slagh, hos livilken man med nogenlunde Sikkerhed mener at have iagltaget Konjugation (Askenasy, Penard 91 b. p. 34).

Gymnodinierne er rimeligvis mere udpragede Planktonorganismer i støre Søer end de øvrige Peridineer, bortset lia Ceratium hiruudinella; paa Grund af deres overordentlige Skrøbelighed og meget ringe Størrelse overses de dog let. Delingscystens store Gelelag muliggør Individets Forbliven i Vandlagene trods Bevægelsens Ophør. Hvilecysterne er pelagiske; de er som saadanne iagttagne al Zacharias for G. palustre's Vedkommende (99d. p. 136) og af mig selv hos G. fuscum.

\section{G. fuscum Ehr.}

Blochmann 95. Tab. 1V, Fig. 148.

G. f. er funden i alle de undersøgte Søer, men kun i ringe Mængde og sporadisk i Prøver fra Maj til Okt.; en tydelig Periodicitet har jeg ikke kunnet paavise. Grunden til dette noget kummerlige Resultat er rimeligvis den, at Arten kun med Sikkerhed lader sig iagttage i lige indsamlet levende Plankton; saadant har ikke altid kunnet staa til min Raadighed. Den blev ikke paavist ved Damundersogelsen 98.

I de allerfleste Planktonarbejder finder man ingen Angivelser om disse yderst skrobelige Organismer.

G. f. angives af Zacharias (95d. p. 134) fra Plönersee og skal her særlig være hyppig i April. A pstein (96 p. 152) meddeler sammesteds fra, at Arten har sit Maks. i April-Maj, men at den enkeltvis forekommer i de fleste andre Maaneder. Zacharias finder $(98$ b. p. 109) den, om end sjæeldent, i Damplankton.

\section{Peridiniaceæ.}

Fam., der med sit langt overvejende Antal Slægter og Arter optræder som marine Planktonorganismer, er i Ferskvand hos os kun representeret ved 3 Slægter: Glenodinium, Peridinium og Ceratium, der alle tillige findes i Havet; med Undtagelse af $C$. hirundinella tilhører de overvejende Smaasøer og de lave Damme.

\section{Glenodinium.}

Der er beskrevet et dels i Havet, dels i Ferskvand levende større Antal Arter; Ferskvandets Glenodinier hører vistnok alle hjemme i smaa, lave Damme (G. aculum?). Formeringen foregaar, saa vidt den hidtil er kendt, kun ved Deling i encysteret Stadium; Deling i fritbevageligt Stadium er ikke set. Under Encysteringen, og medens Delingen foregaar, synker Organismen til Bunds og mister Svingtraadene (Schilling 91 b. p. 36).

Under ugunstige Forhold opstaar Hvilecysterne, kuglerunde Legemer, med mer eller mindre tyk Væg uden Facettering (Schilling 91 b. p. 40).

\section{G. cinctum Ehr.}

Blochmann 95. Tab. IV, Fig. 147.

G. c. træeffes ved Bredden af de fleste af vore større Søer eller i disses side Bugter; i Søernes pelagiske Region hører den ikke hjemme; den er funden i Furesøen i et Par Foraarsprøver. I de i 98 undersøgte Damme fandtes den i hver eneste.

Et ikke synderlig stort Maks. iagttoges i April-Maj, men noget Efteraarsmaks. lod sig ikke paavise; om Vinteren saa jeg den ikke. Nogen Farvning af Vandet var den intetsteds i Stand til at fremkalde.

Den angives i Alm. ikke fra større Søers Plankton. 
(i. a. er patavist i liureso, Soroso, Haldsa, Mosso og Julso, i Alm. dog kun i enkelle P’over og altid kun i ringe

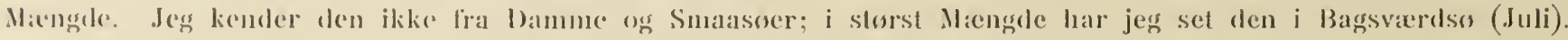

1)en er al Apstein (96 p. 152) linden i Plönersonerne, hvor dens Maks. angives i Juli-Aug., og af

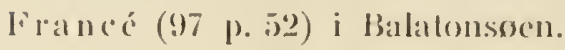

\section{Peridinium.}

Al Sleggten Peridinium er der i den senere Tid beskrevet et ret stort Antal vistnok meget tvivlsomme Arter. Anganende disse lenvises serlig til Schilling (91 b.). Lefter ham har Lemmermann (00 c. p. 28) opstillet nye Arter og Varieteler (I'. Marssonii, I'. aciculifermm, P. bijes Stein var. excisum n. v.) samt Huit-

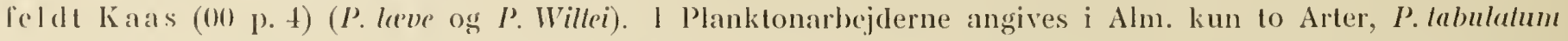
og $P$. ('inclum. Zacharias og A pstein angiver saaledes kun P. tabulalum, der i det hele er den Art, der

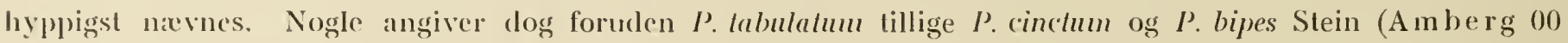
p. 48) eller I'. ('inctum og I'. quadridens Stein (13runo Schrøder, se Seligo o0 p. 83); der er i ørrigt nappe Trivl om, at de to Arter I'. Labulatum og ciuctum ofte sammenblandedes, en Fejl, som ogsaa jeg, navnlig i Begyndelsen af Undersogelsen, ristnok olte har gjort migs skyldig i.

Ingen af de to Former spiller nogen støre Rolle i vore Søer; dog el P. cinctum en mere udpraget Søform end $P$. tabulatum ${ }^{1}$ ).

Formeringen foregaar i Folge Schilling (91 b. p..37) kun ved Deling i encysteret Stadium, idet der før Delingen dannes en kortvarig Cyste, indenfor hvilken en Deling foregaar, hvorpaa Cysten sprænges, og de to Individer bliver frie. Under Encysteringen afkastes Svingtradene, og Cysten hviler, saa vidt vides, medens Delingen foregaar, paa et Underlag (Plantevækst, Bunden). Denne Delingscyste er, hvis jeg har forstaaet Pen ard ret, ogsaa iagltaget af ham, men han opfatter Processen (91 b. p. 40 - 41 ) som en Hudskifteproces. Penard vil (91 b. p. 33) hos P. apiculatmm have iagttaget Deling i let bevagelige Stadium; dog forekommer det mig, at det, denne har set, ogsaa eller rettere i Folge hans Beskrivelser og Tegninger kunde opfattes som en Deling i encysteret Stadium.

Under ugunstige Forhold, naar Vandet ved høje Tp. er ved at tørre bort, men saerlig om Vinteren, dannes Hrilecysterne, som af Form narmest er kuglerunde, og hris Vagge ikke er tavlede, men glatte.

De fleste Pridinim-Arter opfattes rettest som Damformer, der ikke hører de store Søers Plankton til, men som, saafremt de findes, er forslaaede Bredformer eller er førte ind med Tilløbene.

\section{P. cinclum Ehr.}

Tab. IX, Fig. 99.

\section{Schilling 91 b. Tab. III, Fig. 22.}

$P$. c. er parist i alle de undersogte Soer, sarlig i Sommerproverne, men som oftest kun i ringe Mangde og aldrig saa talrig, at Arten bliver dominerende.

Maks. synes at falde i Juni-Juli Maaned; den optreder særlig hyppig i Sommerprøverne $0230 / 6$ Tp. 16 og $31 / 7$ Tp. 15 i Julsø. Jeg har i øvrigt Indtrykket af, at Arten er noget hyppigere i vore Søers pelagiske Region, end det fremgar af dette Arbejde.

\section{P. Labulatum CIap. \& Lachm.}

\section{Blochmann 95. Tab. IV, Fig. 145.}

I vore storre Søers pelagiske Region er $P$. $t$. en ret sjalden Form, men er i gvrigt paavist i alle Søerne; derimod er den overalt alm. i Littoralregionen. I de i 9\$ undersogte 12 Damme fandtes den overalt og er i ovrigt funden i mangfoldige Smaadamme.

1) Herom og om P. Willei se Ostenfeld; Borgesen og ostenfeld (02 p. 613). 
I. 1. optrader perennerende med to meget skarpt begransede Maks., der i de 11 Damme overalt indtraf ganslie samtidig; det forste Maks. varede fra Midten af Marts til c. 1. Maj, det andet faldt i Okt. liorarsmaks. var langt det storste, og der var 'Tider, da Damplanklonel nasten ndelukkende bestod al' P'. I., der verl sine uhyre Masser farvede Vandet lonngrønt; i Sommertiden var Arten i nogle af Dammene ret alm., i de fleste derimod optrable den kun i ringe Mang(le. Efterarsmaks. var i nogle Damme kun svagt, i andre nere fremtradende, men kortvarigere end Foraasmaks.

Formeringen foreganr, sas vidt vides, hele Sommeren igennem verl Deling i et kortvarigt, forbigaaende Encystcringsstadinm. Denne Formeringsmaade foregaar, lıva Schilling (91 p. 38) først har paavist, kun om Nalten; hele Processen varer kun nogle fá Timer. On Dagen har heller ikke jeg nogensinde set dette Hvilcstadium, hrorimod jeg i Mangde har kumnet konstatere det paa Materiale, indsamlet og konserveret om Natten.

Hvilecysterne, indenfor hvilke Individet vegeterer i Uger eller Maaneder, har jeg isar set efter det store Oktobermaks. Arten overvintrer rimeligvis i dette Stadium; en Del Individer kan man dog altid linde fritsiommende under Isen; et ikke ubetydeligt Antal optræeder i Dammene umiddelbart efter Isløsningen. Hvilecyster blev om Sommeren ligeledes paavist i de Damme, der enten tørrede helt ud eller, hvor Vandstanden sank betydeligt og $\mathrm{T}_{\mathrm{p}}$. steg meget højt ( $\mathrm{T}_{\mathrm{p}}$. 28).

Desvarre er vi for Øjeblikket ude af Stand til at skalne de enkelte Peridinimm-Arters Hvilecyster fra hverandre; man kan dog gaa ud fra, at de allerfleste Hvilecyster, man finder efter det store Maks. i Okt., som oftest tilhører P. tabulatum, fordi denne Art, mig bekendt, overalt er den dominerende paa denne Aarstid. I Sommertiden derimod, da Individantallet i det hele er ringe, men Artsantallet langt større, maa Hvilecysterne tilskrives mange forskellige Arter.

P. t.'s Maks. angives af Zacharias $(94$ b. p. $117 \mathrm{og} 95 \mathrm{~d}$. p. 134) samt af Apstein (96 p. 152) i Plönersøerne noget senere, end jeg har fundet det i vore Søer, nemlig Juli-Aug. For den lille Katzensees Vedkommende finder Amberg (00 p. 48) samme Periodicitet som af mig angivet for Dammenes Vedkommende.

\section{Ceratium.}

Af denne overvejende marine Slægt optræder i Ferskvand næppe mere end to Arter, C. cornutum og C. hirundinella; begge er overordentlig varierende, saa vel hvad Tid som hvad Sted angaar, og de talrige Lokalog Temporalvariationer foranledigede, navnlig i aldre Tid, Opstillingen af et betydeligt Antal Arter (se t. Eks. I mh of 87 p. 120 o. a.); ogsaa i den senere Tid er der opstillet nye Varieteter og Arter ( $C$. hirundinella var. furcoides Levander 94 a. p. 53, C. curvirostre Huitfeld Kaas 00 p. 6).

I Modsatning til de ovrige Ferskvandsperidineer foregaar Delingen uden foregaaende Encystering, medens Organismerne svømmer rundt ved deres Svingtraade; Deling efter et foregaaende Encysteringsstadium er ukendt; Kadedannelsen er aldrig paavist hos Ferskvandsformerne; Hvilecyster kendes kun hos C. hirnndinella.

C. cornulum Clap. \& Lach m.

Blochmann 95. Tab. IV, Fig. 144.

C. c. traffes ofte ved Bredderne af vore sturre Soer og kan herfra forslaas ud i den pelagiske Region, hvori den i øvrigt aldeles ikke har hjenme; den er her paavist i Furesø og Sorøsø. Ved Damundersøgelsen 98 blev den funden $\mathrm{i}$ alle de 12 undersogte Damme og $\mathrm{i}$ ovrigt $\mathrm{i}$ en Mangde Smaasoer.

C. c. havde overalt to Maks., et i April-Maj og et i Sep.-Okt., men manglede i øvrigt ikke ganske hverken Sommer eller Vinter; Foraarsmaks. var langt det største.

Deling i det fritbevagelige Stadium kan iagttages i enhrer Indsamling, rig paa denne Art; äen synes at foregaa nasten til enhver Tid paa Dagen og er ikke som hos C. hirundinella bunden til bestemte Nattiner. Delingen er forst paavist men ikke fuldt forstaaet af Bergh (82 p. 214) og er senere narmere studeret af ham (87 p. 76) og af Schilling (91 b. p. 31).

I Skaale med rigeligt Materiale har man, naar Vandet fordamper, og Skaalens Bund er belagt med et 
fingligl, brunl Laga, allid Lejlighed til al se, luvorledes denne Arl afkasier Flagella og indenfor den gamle Skal damner sig en Cyste, i hvilken Organismen vegeterer. Ved Tilsaening af Vand spraenges den gamle Skal, og Cystens Indlokd wokser uden videre Doling ud lil et nyt Individ. Disse Cyster, der er beskrevne hos Scloilling (91 b. p. 4(i), kendes ikke hos C. hirundinella; de oplracler i Naturen saxplig om Sommeren og

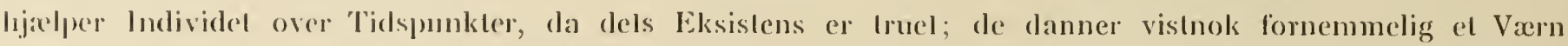
mod Udlorring, lworfor deme udpraxgede l)ambeboer navnlig er udsat. Sxerlige Hvilecyster er ikke paaviste, og on Overvintringen ved man, bortsel fra de enkelte Individer, man sjoctdent forgaves søger under Isen, intet.

\section{C. liirundinella O. F. M.}

Tab. I, rigg. 6.

C. Schröter 97. Tab), 1, Fig. 61-68.

liureso. C. h. er kun paavist $\mathrm{i}$ faa Eks. $00{ }^{20 / 12}$ Tp. 4 og mangler ganske indtil 01 8/4 Tp. 1, luvorpaa den optrader enkeltvis til $7 / 6$ T T). 16 ; forst $30 / 6$ Tp. 18 var Arten alm. og holdt sig nu som en af Planktonets Hovedformer lige til $30 / 8$ T p. 21 . 15/8 Tp. 22 var den allerede aftaget og var stadig $\mathrm{i}$ Aftagende indtil $16 / 11 \mathrm{~T}$ p. 4 , da Aarets sidste Eks. Hev set. I 02 blev Arten forste Gang paavist 25/4 Tp. 5 . I Proverne ${ }^{21} / 5$ Tp. 9, 5/6 Tp. 12 og ${ }^{17} / 6$ Tp. 14 er den meget sjaclden; noget alm. ${ }^{11} / 8$ Tp. 14 , men bliver forst Hovedform $3 / 8$ Tp. 15.

Cyster fiandtes $018 / 4,21 / 10,16 / 11$ og $0225 / 4$.

lesromscr. C. h. er paavist $0017 / 12$ Tp. 5 og $01{ }^{10} / 4$ Tp. 3, men kun som Cyster. I Tiden fra $10 / 4$ til $29 / 6$ Tp. 15 findes den kun i beskedent Antal; lens store Maks. er beliggende fra c. $20 / 7$ Tp. 17 til $12 / 8$ Tp. 21; $5 / 9$ Tp. 16 er den nesten ganske forsvunden og findes kun enkeltvis indtil ${ }^{17} / 12$ Tp. 1 . I 02 er et enkelt Eks. fundet $17 / 4$ Tp. 4, men Arten er stadig sjalden til 10/7 Tp. 14; dens Maks. begynder forst at vise sig 31/7 Tp. 15.

Cyster er paavist $0017 / 12,01 \frac{10}{4}, 15 / 10$ og $10 / 11$.

Sorøsø. C. h. optraadte $0019 / 12$ Tp. 5 i ganske faa Eks., men var allerede $015 / 5$ Tp. 10 ret alm.; den var stærkt tiltaget $26 / 5$ Tp. 13, dominerende $3 / 7$ Tp. 21 og optraadte $\mathrm{i}$ aldeles uhyre Mængder $9 / 8$ Tp. 23. Vandet var paa delte Tidspunkt gulgront og grodet; ${ }^{18} / 9$ Tp. 12 var Arten næsten forsvunden; enkelte Eks. holdt sig endnu ${ }^{18} / 11$ Tp. 7. 102 er $C$. $h$. funden enkeltvis ${ }^{19 / 4}$ Tp. 4 , er sjælden lige til ${ }^{28} / 6$ Tp. 17 , men er da ret alm.; Maks. viser sig først $27 / 7$ Tp. 16 .

Cyster er paavist $015 / 5,18 / 9,17 / 10,18 / 11$ og $0219 / 4$.

Tjustrupsø. C. $h_{\text {. }}$ er paavist $\mathrm{i}$ ganske enkelte Eks. 00 19/12 Tp. 3 ; den er allerede ret alm. $015 / 5$ Tp. 7 og talrig $24 / 5$ Tp. $13 . \quad$ l Proverne $3 / 7$ Tp. 17 og $8 / 8$ Tp. 22 optraadte den ogsaa her i uhyre Mængder og farvede Vandet gulgront. ${ }^{17} / 9$ Tp. 12 er Arten stæerkt aftaget og optrader derpaa $\mathrm{i}$ alle følgende Prover lige til $26 / 12$ Tp. 3 kun enkeltvis. I 02 findes enkelte Eks. i alle Vinter- og Foraarsprøver, men den er først alm. ${ }^{30} / 6$ Tp. 15; det store Maks. paavistes ${ }^{27} / 7$ Tp. 15 .

Viborgso. C. h. er her af ganske underordnet Betydning; den optræeder kun i enkelte Eks. i Tiden fra $011^{10 / 7}$ Tp. 21 til $10 / 1$ Tp. 8 samt enkeltvis i Prøverne 02 $25 / 6$ Tp. 17 og 27/7 Tp. 15.

Haldsø. C. h. er paavist i enkelte Eks. i Proverne $0130 / 1$ Tp. 1, $29 / 3$ Tp. 2 samt $18 / 5$ Tp. 10 ; den er forst ret alm. ${ }^{8} / 6$ Tp. 13, tiltaget $22 / 6$ Tp. 13 og er Hovedform ${ }^{20} / 7$ Tp. 17, optræder i aldeles overvældende Masser $7 / 8$ Tp. 18 og er endnu meget talrig 16/9 Tp. 13; derimod er den næesten forsvunden $14 / 10$ Tp. 13 og holder sig kun med enkelte Eks. til $8 / 12$ Tp. 4. I 02 findes de første Eks. ${ }^{3} / 5$ Tp. 7; den er forst ret alm. ${ }^{30} / 5$ Tp. 8, tiltager ikke synderlig for ${ }^{16} / 7$ Tp. 14 , men dominerer $26 / 7$ Tp. 14 og særlig $2 / 8$ Tp. 15.

Skanderborgso. C. $h$. er her af ret underordnct Betydning; den er meget sjalden i Proverne $00{ }^{29 / 12}$ Tp. 5 og $0119 / 5$ Tp. 13; $5 / 8$ Tp. 21 er den talrig og Hovedform 15/9 Tp. 12; 18/10 Tp. 12 er Arten næsten forsvunden, et enkelt Eks. saas $20 / 11$ Tp. 6 . I 02 er et enkelt Eks. mærkelig nok set $27 / 1$ Tp. $1 ;$ i ovrigt forekommer Arten lige til $30 / 7$ Tp. 14 kun i ringe Mængde.

Cyster er set $0119 / 5,15 / 9,18 / 10,20 / 11$ samt $021 / 5$.

Mosso. C. h. spiller her vistnok en underordnet Rolle; den var kun talrig $\mathrm{i}$ en enkelt Prove 01 1/8 Tp. 22: i 02 var den lige til ${ }^{30 / 7}$ Tp. 15 meget sjælden.

Julso. C. $h$. viser sig her i begge lagttagelsesaarene grumme sparsomt; den er talrigst i Proverne $01{ }^{1} / 8$ Tp. 22 og $02{ }^{31} / 7$ Tp. 15 .

Man vil af ovenstaaende se, at $C$. hirundinella er paavist i alle de undersøgte Søer, men i de lo Søer, hvor Cyanophyceerne opnaar deres højeste Maks., spiller den en ganske underordnet Rolle; noget lignende gælder vistnok ogsaa i Skanderborgsø og Mossø; men særlig for Mossøs Vedkommende er yderligere Iagt- 
tagelser dog onskelige. Den opman derimod megel betydelige Maks. i Funeso oss Esromsa og aldeles kolossale Maks. i Soroso, Tjustrupso og Haldso. Maks. Calder altid sammen med Vandets hojeste Tp. i Aug. Manucl, 'T'p, 18-23.

Veal 1)ammudersogelsen 9S viste det sigs, at C. himudinella manglede i de fleste (8) af Dammene, og at den i en kun fandles ganske enkeltvis. I to var den konstant og havde her et mindre Maks., del i ten

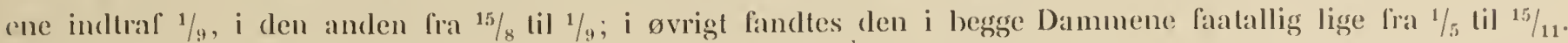
I en enkelt ganske lille Dam (Limnaalam) paa c. 2 M. Dylde, men med et hele Sommeren ganske vegeLationsfrit Centralfelt var Arten til Stede fra $15 / 4$ til 1/12. Den opnaade her i Sep. et kolossalt Maks.

Det symes altsaa at fremgaa, at C. hirundinello nieppe er helt saa alm. i Smaadamme som i storre Sger; af alle Ferskvandsperidineer er denne den mest udpragede Søform og ynder sälig Søer med rent, klart Vand; i Soer med hoje Cyanophyceemaks. synes den ikke al kunne trives; under Forhold, som jeg i øvrigl ikke er klar over, kan den ogsaa i mindre Søer og Smaadamme opnaa meget løøje Maks. (Sorøsø o. a.).

Angaaende Artens Biologi kan endnu følgende tilføjes. C. himmdimella kan her i Landet ikke henregnes til (le peremerende Planklonorganismer; i Tiden fra Dec. til Marts-April er den praktisk set forsunden at vore Søers pelagiske Region; Undersogelsen har vel kumnet parise ganske enkelte Eks. i Dec.prøverne, (0.2 30/1 Haldso og $02 \%$ Skanderborgsø, men disse overvintrende, frithevagelige Individer er dog saa sjældne, at de ikke kan have nogen Betydning for Arten paa vedkommende Lokalitet.

Arten overvintrer hos os som Hvilecyster - de vel kendte 3-4-hornede Cyster —, der navnlig iagttages i Sep.-Olit. efter Maks.; deres Antal aftager henimod Vinteren. Efter Isløsningen viser Hvilecysterne sig igen og findes nu pelagisk indtil Maj-Juni, hvorpaa de forsvinder. De Bundprover, som jeg af Hensyn til Studiel af Gloiotrichia-Kuglerne i Maj optog fra Thorsøs dybeste Partier, viste sig at indeholde store Mængder al hornede Cyster af $C$. hirundinella. Ved Henstand i Glasskaale, udsatte lor rigeligl Dagslys, sprængtes disse Cyster i Løbet af 8 Dage, og Vandet opfyldtes af talløse Ceratier karakteriserede dels ved at mangle Horn, dels ved deres bløde Hud uden tydelig Facettering i Panseret. Senere hen udviklede de sig til typiske Ceratier; Undersøgelser af helt forskellig Art, og som jeg ikke kunde lægge til Side, hindrede mig i at be skreftige mig mere indgaaende med disse Stadier.

Alt $\mathrm{i}$ alt kan der ingen Trivl vare om, at C. hirundinella, i alt Fald her i Landet, overvintrer som Hvilecyster, og at disse efter at have holdt sig svavende i nogen Tid synker til Bunds. Vi kender ikke Spiringsbetingelserne for disse Cyster og ved ikke, om Cyster, bundfreldede paa 40 M. Vand, er i Stand til at spranges, eller om de her gaar til Grunde.

Del fremgaar med Sikkerhed af Planktonundersogelserne, at Cysternes Antal i Vandmasserne aftager om Vinteren, og at det derpaa atter stiger om Foraaret efter de strerke Foraarsstorme. Jeg er tilbojelig til at tro, at disse Cyster stammer fra Littoralregionen og, hæevede af Bølgeslagel, senere er ført ud i den pelagiske Region. Her foregaar da efter min Opfattelse Spiringen; de i April-Maj optraedende yderst faa Individer af C. h. skylder da formentlig disse Cyster deres Oprindelse. Det har sin store Interesse at se, hvor overordentlig langsomt og gradvis det i Juli-Aug. ofte kolossale Maks. arbejder sig frem.

Da Cysterne synes totalt forsvundne af Planktonet i Maj, maa man formode, at der efter denne Maaned ikke klækkes synderlig flere Cyster, og da endvidere Arten indtil Maj overalt er sjælden eller i hvert Fald lidet dominerende, er det Antal Individer, der hvert Foraar fremgaar af Cysterne, forholdsvis ringe. Den ylerligere Stigning i Individantallet fremkommer ved Deling af Individerne i det fritbevagelige Stadium, og denne Deling foregaar øjensynlig med en Intensitet, der stiger samticlig med Vandets Tp.; som Følge heraf opstaar da ved Vandets højeste Tp. (let ofte kolossale Maks. i Juli-Aug. Delingen foregaar som bekendt om Natten og i de tidlige Morgentimer; dette blev først parist af Bergh for Ceratium Iripos' Vedkommende (87 p. 77), og for C. hirmdinella's Vedkommende kom Blanc til samme Resultat (98 p. 230). Lauterborn (95 $\alpha$. p. 177) gav desangaaende yderligere Oplysninger. Karnedelingen finder Sted fra Midnat til \& Morgen (Juli); senere paa Dagen kun meget sjældent. Delingen af Cellen foregaar i Løbet af Formiddagen, 
paia hilken Tid talrige ikke fuldt udvoksede Individer forelindes. Selv har jeg ikke tilstrackelig haft min Opmarksomhed rettet pala delle Punk1; Delingsstadierne er sjeddne i Proverne, fordi de som oftest er tagne efter Ki. 10 liormiddag, men er dog hyppig set i lidlige Morgenprøver fra Furesnen (Juli-Aug.).

Lige sati langsomt som det store Maks. i Juli-Aug. arbejder sig frem, lige saa pludseligt plejer det at forsvinde; dog forholder Arten sig i sáa Henscende ikke ens i alle Sorerne.

Da jer arbejdede med Undersogelsen over Soernes Bundarter, undrede jeg mig over, at de kolossale Maks. af Ceratier ikke g.jorde sig mere giddende i Sobunden, og at man ikke kunde paavise nogen Bundfieldning al Sledetdele over denne. Ved nojere at studere Ceratierne i Slutningen al Maks. o: i Forfaldssladiel, sierlig i Sorøso og Tjustrupsø, viste det sig, at de, medens de endnu er pelagiske Organismer, falder hen, idel Skallen oploser sig i sine enkelte Plader, hvorpaa Indholdet trader ud som formløse gronne Klaller. Oplosningen synes al foregaa overmaade samtidig; i Lobet af faa Dage var Søen opfyldt af talløse Skcletdele. Det bev mig af Fiskeren fra Haldsø meddelt, at Søen efter det store Ceralium-Maks. i Aug. "klarede sign, og al der samtidig inde ved Bredden fandtes store drivende gulbrune Flager, som jeg desvarre ikke fik tilsendt Prover af. Det er ikke usandsynligt, at disse kan viere dannede af Ceratium-Skeletdele; de blev i orrigt eftersogte i Sorøsø og Tjustrupsø, men blev ikke paaviste; cfr. Penard (91 b. p. 45).

Del synes overalt kun at vare et ringe Antal Individer, ler omdannes til Hvilecyster.

C. hirmulinella har en overordentlig stor geografisk Udbredning; den er Plankton-dannende i Norge (Huitfoldt Ka as 00 p. 4), i de norditalienske Søer (Garbini 98 a. p. 673), i meget højtliggende Alpesøer: Daubensee (Jura) 2714 M. o. H. (Pitard 97a. p. 516, Fuhrmann 97 p. 526, Zschokke 00 p. 294) samt i mangfoldige af det mellemeuropaiske Slettelands Soer; en nermere Angivelse af de talrige Findesteder maa derfor anses for overllodig; den er under en sarlig Var. furcoides paavist af Levander i finske Havbugt (94 a. p. 53).

Med Hensyn til Periodiciteten har de fleste Forf. ligesom jeg fundet, at Arten forsvinder om Vinteren men en Del Undersogere, sarlig af sydligere Søer (Asper \& Heuscher i Zürichersøen, 85-86, C. Schröter sammesteds, 97 p. 27, Fuhrmann i Neuchatelersøen, 00 p. 94, Waldvogel i Lautikerried, 00 p. 49 , Amberg i Katzensee, 00 p. 46), angiver, at den er perennerende.

De fleste Forf. stemmer i øvrigt overens i, at C. h. viser sig i Marts-ApriI, har sit Maks. ved Vandets hojeste Tp. (Juli-Aug.), og at den forsvinder i Okt.: Zacharias i Plönersøerne fra 4 paa hinanden lolgende Iagttagelsesaar (96 a. p. 51), A pstein sammesteds fra (96 p. 151), Borge i Valloxensø (00 p. 13), Amberg i Katzensee $(00$ p. 46), Seligo i Stuhmersøerne $(00$ p. 58). Kun Asper og Heuscher skal (Citat efter C. Schröter 97 p. 27) i Thalapsee have funclet to Maks. (22. Maj og 21. Ang.). Cysten iagttages overalt hyppigst i Vinterhalvaaret, sarlig i Slutningen af Efteraaret (Amberg, Seligo o. a.).

\section{ALMINDELIGE BEMARKNINGER.}

Plankton=Peridineernes Forekomst i de undersøgte Søer. ${ }^{1}$ )

\begin{tabular}{|c|c|c|c|c|c|c|c|c|c|}
\hline & Fureso & Esromsi & Soroso & $\begin{array}{c}\text { Tjustrup- } \\
\text { sø }\end{array}$ & Vibol'gso & Haldso & $\begin{array}{c}\text { Skander- } \\
\text { borgso }\end{array}$ & Mosso & Julso \\
\hline $\begin{array}{l}\text { Gymnodinium fuscum } \ldots \ldots \ldots \ldots \ldots \ldots \ldots \\
\text { Glcnodinium cinctum } \ldots \ldots \ldots \ldots \ldots \ldots \ldots\end{array}$ & $\begin{array}{l}(+) \\
(+)\end{array}$ & $(+)$ & $(十)$ & $(十)$ & $(+)$ & $(+)$ & $(+)$ & $(+)$ & $(+)$ \\
\hline$-\quad$ acutum $\ldots \ldots \ldots \ldots \ldots$ & + & & $(+1)$ & & & $(+)$ & & $(+)$ & $(+)$ \\
\hline l'eridinium cinctum $\ldots \ldots \ldots \ldots \ldots \ldots \ldots$ & $(\dashv)$ & $(+)$ & $(+)$ & $(十)$ & $(+)$ & $(+)$ & $(+)$ & $(+)$ & $(+)$ \\
\hline - tabulatum $\ldots \ldots \ldots \ldots \ldots$ & $(+)$ & $(+)$ & $(+)$ & $(+)$ & $(+)$ & $(+-)$ & $(+)$ & $(+)$ & $(+)$ \\
\hline Ceratium cornutum $\ldots \ldots \ldots \ldots \ldots \ldots$ & $(+)$ & & $(+)$ & & & & & & \\
\hline - hirundinella $\ldots \ldots \ldots \ldots \ldots$ & \pm & \pm & \pm & \pm & + & \pm & + & + & + \\
\hline
\end{tabular}

1) Om Tegnenes Bctydning se p. 56. 
Man vil al vedfojede Schema se, at C. hirmulinella er den eneste Peridinee, som kan optracke dominerende i vore storre Soers pelagiske Region; muligvis spiller dog Gymnodinierne en noget storre Rollo i denne end her angivel; de ovrige former er alle mere Dam-og Bredformer og ikke hjemmehgrende ude i de storre Soers centrale l’arlier.

Det synes, som om alle Ferskvandsperidineer her i landet har neget skarpt begransede Maks. og Min., og al alle Arter aldeles overvejende overvintrer i Hvilesporestadier.

En stor bel har vistnok to skarpt udpragede Malis., eet om Foraaret i April-Maj og eet om Efteraaret i Sep. Olit. ("Tp. 10-12). Ceralimm hirmulinella har kun eet Maks. beliggende ved Vandels hojeste 'Tp); el storre Antal al de smaa, lidet undersogte Damperidineer har rimeligvis deres Maks. samtidig.

De ofte meget betydelige Maks. fremkommer som Folge af Deling al det nappe synderlig store Antal Individer, klakkedle af Hvilecysterne. Delingen foregaar enten i encysteret Stadium med afkastet Bevagelsesapparal og i saa Fald som oftest hvilende paa et Underlag eller i det frithevagelige Stadium og i saa Fald i selve Vandlagene, medens Organismerne svommer om i disse; men ogsaa i førstnxvnte Tilfalıle kan Delingen foregaa i Vandlagene, saafremt Delingscysterne er omgivne af store kugleformede Gelelag, der holder Organismerne svaevende, efter at Bevagelsesorganerne er kastede af.

Det har sin ikke ringe Interesse at se, at kun de Former er hjemmehørende i de større Søers pelagiske Region, hvis Delingsprocesser enten af den ene (Gymmodinimm) eller den anden Grund (Ceratimm) kan fuldbyrdes i selve Vandlagene; alle Former, hvis Deling foregaar i hvilende, bundfældede Cyster, er Damformer.

Af Undersøgelserne i Udlandets Søer fremgaar det, at Ceratium hirundinella ogsaa der er den eneste Peridinee, som sikkert er hjemmehørende selv i de største Søers pelagiske Region.

Ludwig har (98 p. 295) opstillet Spørgsmaalet om, hvor vidt Ferskvandsperidineerne lyser; han besvarer det i ovrigt benagtende; Waldvogel kom (00 p. 49) til samme Resultat, som ogsaa jeg fuldtud kan bekræfte. Jeg havde paa Ingolfekspeditionen Lejlighed til, naar det om Natten indfangede Plankton blev konserveret, at se det stærke Lysskær, dette afgav, naar man hæIdte Konserveringsvædsken ned i Havvandet med det levende Plankton.

Flere Gange i Sommer tog jeg af den Grund Plankton, der indeholdt uhyre Mangder af Ceratinn, og lod en Straale Alkohol falde ned i et Glas med talrige levende Ceratier. Forsøget gjordes i Mørkekammer, men der viste sig aldrig det ringeste Lysskar.

\section{Euflagellata.}

Alle de i større Søers Plankton optradende Flagellater hører til Afdelingen Chrysononadinea', den samme, hrortil ogsaa nogle af Havets vigtigste Planktonflagellater, nemlig Phu'ocystis og Dinobryum pellucidun Lev., hører. I Smaasøer og Dammes centrale Partier optræder tillige tahrige Flagellater af andre Grupper, saerlig Euglenaceer, men desforuden adskillige Chrysononadinea, der ikke forekommer i større Soers Plankton (Chrysamoeba o. a.).

Flagellaterne spiller i det hele en meget underordnet Rolle i de større Søers pelagiske Region; kun Dinobryerne er hjemmehørende her og kan optræede med betydelige Maks.

En hel Del Flagellater er fastsiddende paa andre Planktonorganismer og kommer saaledes som passivpelagiske Arter (s. l.) til at tilhøre den pelagiske Region.

Særlig iøjnefaldende Tilpasninger til Planktonlivet, »Planktonkarakterer«, kendes i Øjeblikket ikke og er næppe synderlig frentræedende.

Varieringsevnen er overordentlig stor hos Dinobryerne og til Dels ogsaa hos Mallomonaderne.

Om Overvintringsstadierne se d. llg. 


\section{Chrysomonadineæ.}

\section{Mallomonas.}

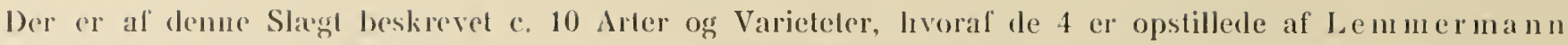
(99 p. 109, 01 (a. p. 87); til Artsadskillelse er anvendt Bagendens Form, Skiellenes Form og Børsternes Liengde; de to sidste Forloble varierer fra So til Sø; Legemsformen er snart langstrakt og smal, snart mere bred. lifter de loreliggende Aflildninger og Beskrivelser er det umuligt at daune sig nogen klar Forestilling om disse Arter.

Indtil 93 var der knn beskrevel 3 Arter: M. Ploessli Perty, M. Fresenii Kent og M. acaroides Zach., der cfter Zacharias' Opfattelse (93 p. 17) rimeligvis alle tilhorte samme Art; den Anskuelse opretholdt \%acharias ogsta fremdeles (94a. p. 73), samtidig med, at han føjecle endnu cu ny Var. til Arten, var. producta Sel.: cfr. Soligo (93 p. 6).

Forst efter Undersogelsens Afslutning laerte jeg I wanof's Afhandling (00 p. 247) at kende. Der synes her for forste (iang at vare givet gode Artsmarker, og at der til Slacgten altsaa maa henføres flere Arter. Jeg har foreløhig fulgl Zacharias og henført alle de danske Former til Arten M. acaroides..

M. acaroides Zach.

Blochmann 95. Tab. IV, Fig. 124.

M. a. er paavist i alle de undersogte Soer undtagen Soroso, Tjustrupso, Viborgso og Skanderborgso.

M. a. viser sig ikke for Maj og holder sig til Okt., men er i alle Søerne kun til Stede i ret ubetydelig Marngde og lindes indenfor den ovennæunte Periode end ikke i alle Prøverne; et tydeligt Maks. har intetsteds ladet sig paarise.

Af de i 98 undersøgte 11 Damme optraadte Arten i de 5; den viste sig her allerede i Beg. af Maj og holdt sig til Beg. af Nov. Maks., der her var meget tydeligt, faldt sammen med Vandets højeste Tp. (Midten af Aug.); det liunde i disse Smaadamme være ganske overordentlig stort, og Vandet som Følge deraf faa en ejendlommelig gulgrøn Farve og vare ganske grødet (Ødam, Præstevang Hillerød). c. 1. Sep. iagttoges de kuglerunde Hvilecyster liggende indenfor Skalbekladningen.

I Maj 0.2 optraalte Arten i Mrengde i Almindso; i det hjembragte Materiale dannedes i mine Skaale talrige Hvilécyster.

Arten narnes sjalden som Beboer af de større Søer, men er rimeligvis ofte paa Grund af sin ringe Storrelse overset (Apstein 96 p. 153). Fra Plönersøerne angiver Zacharias (94a. p. 73), at den viser sig i April, forsvinder i Okt., og at den har sit Maks. i Aug.-Sep.; samme Forf. mener (98 b. p. 105), at Arten er mindre i Damplankton end i større Søer. Den angives af Borge (M. Fresenii) $(00$ p. 8), men som sjælden i Valloxensø; Seligo finder den om Sommeren i Stuhmersøerne (00 p. 58). Balatonsøens Mallomonas-Form beskrives under Narnet M. P'löslii (Francé 97 p. 42).

\section{Dinobryum.}

Slægten Dinobryum er i den seneste Tid gentagne Gange bleven gjort til Genstand for indgaaende systematiske Undersøgelser, som dog alle har givet indbyrdes yderst afvigende Resultater.

Typens store Ensartethed og den indenfor i øvrigt ret snævre Grænser overordentlig stærke Varieringserne gor det næsten umuligt at danne sig en sikker Arlsopfattelse indenfor denne Slægt. I sit interessante Arbejde har Bachmann (01 p. 206 og p. 231) maaske ikke ganske med Urette fremhevet, at særlig Dinobryım og Cyclotella, men ogsaa Ceratium for Øjeblikket befinder sig i en saakaldt » Werdeprozess neuer Formen", paa et Stadium, da Artsdifferentieringen endnu ikke er fuldbyrdet.

Ved Studiet af de sidste Aars talrige Arbejder over Slægten Dinobrıum kan man ikke frigøre sig for den Opfattelse, at Undersøgerens Individualitet ofte i høj Grad er kommen til at influere paa det indrundne Resultat. Skont Formerne indenfor det frelles store Undersøgelsesomraade fra Holsten til Schweizersøerne. 
muligvis med Undtagelse af enkelte alpine Former, rr kosmopolitiske, er dog hver Forf. efter et gjensynlig unegel indgarande Studium kommen til sit fra alle de andres staerkt afvigende Resultat. Man laaner hinandens Maleriale; llere Forf. efler hinauden undersoger Malerialel fra samme So, og hvor den ene kun har kumbel paraise ren Art, melder hans Efterfolger, at han har fundet »zusannuen sieben versehiedene Fornen (Lem-

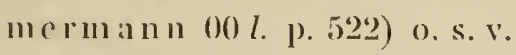

Slagglen Dinobrymu deles i 3 Underslagter: Epipyxis Latuterborn, Dinobryopsis Lemm. og Lublinobryum Lauterborn (cfr. Latulerborn 99 p.380). Af disse indbefatler de to førstnavnte kun Arter med enlige Celler, sidslnarnte kun lioloni-dannende Arter.

Det el sterlig indenfor L'nderslagten Endinobryntu, at Uenigheden med Hensyn lil Artshegrehet kommer frem. Narnlig gor to Opfattelser sig galdende; den ene, der kan betegnes som den axldre, ogs som saerlig cr repraesenterel af $B$ ütschli, Zacharias, Apstein, Senn, mig selvog, som det synes, til Dels ogsaa La uterloorn, anerkender kun et meget begraenset Antal Arler og henfører Hovedmassen af alle de hidtil kencle Former lil de af Ehrenherg og Stein opstillede to gamle og ofte afbildede $D$. sertularia og D. stipitatım.

Den anden yngre, der nu ganske synes at have overfløjet den aldre, tog sin Begyndelse med Imhof (90 p. 483), blev senere havdel af Bachmann (01 p. 204), Brunnthaler. (01 b. p. 293), Chodat (97-98), men fremfor alle af Lemmermann $\left.(00 l \text {. p. } 500)^{1}\right)$; ved disse Forf. faelles Anstrengelser er Artsantallet nu drevet op til c. 30; Forvirringen bliver dog forst fuldstændig derved, at det kun er de allerfarreste af disse nange Artslegreber, Forf. kan blive enige om; jeg indskranker mig her til at henvise til deres Arbejder. Lad end Dinobryım aldrig saa meget ude i Naturen befinde sig i en "Werdeprocess neuer Formen", at sanme derude skulde foregaa ligesaa intensiv, som den for Øjeblikket foregaar i vore Tidsskrifter, derom tor man vel have Lov til at udtale en beskeden Trivl.

Den aldre Retning havder skarpt, og den yngre er villig til at indrømme, at Artsbegrebet ikke kan fastslaas, saa længe man ikke raader over et regelmassigt, hver 14. Dag indsamlet Materiale stammende fra mange forskellige Lokaliteter. Men medens den aldre Opfattelse gaar ud fra, at saa læenge en saadan Undersogelse ikke foreligger, og Beviset for disse talrige Arters og Varieteters Konstans endnu ikke er leveret, er en yderligere Sondring af de to gamle Artsbegreber usikker og uvidenskabelig, paastaar den yngre Retning, at Manglen af en saadan Undersøgelse netop nødvendiggør, at hver lille Variation bør finde sit Udtryk i Nomenklaturen og altsaa herettiger til Opstillingen af en ny Art eller Varietet. Først naar den ovennaernte Undersøgelse foreligger, kan alle disse Arter og Varieteter muligvis sammendrages. Denne Fremgangsmaade, der i sin mest yderliggaaende Form møder os i Lemmermanns Publikationer, er efter Forf. Mening meget uheldig. Erfaringen lærer, at man ad denne Vej kun skaber en i kortere eller langere Tid fremherskende Konfusion, der hindrer det klare Overblik. Den fremkaldte en langvarig Konfusion m. H. t. vor Opfattelse af Hyalodaphnierne og Anuræerne, den har sarlig ved I $\mathrm{m}$ h of A Arbejder vaet nær ved at konfundere Artsbegrebet Ceratiun hirundinella og har ikke haft nogen gunstig Indflydelse paa vor Opfattelse af de to gamle Arter D. sertılaria og stipitatum. Denne Fremgangsmaade kan vel faa Betydning ved, at den endelige Sandhed derved vil kunne underbygges saa meget des solidere, men noget nødvendigt Led i Udviklingen er den ikke.

(01 p. 206) skriver Bachmann: "Als Art bezeichneu wir alle diejenigen Individueu, uvelche in mehrern wichligen Merkmalen so übereinslimmen, dass diese Merkmale auch unter den verschiedensteu Bedingungen bei der Fortpflanzung sich erhalten. Varietäten stimmen in Habitusmerlinualen mit den Arleu ïberein, lassen aber Merkmale hervorlrelen, die in Verlaufe der Fortpflanzıng infolge veräuderter Bediugungen wandelbar siud.« Disse Definitioner er sikkert meget gode, men netop fordi vi m. H. t. Dinobryerne ikke ved, hvor vidt de vigtige Kendetegn, hvorpaa vi grunder Artshegrebet, virkelig holder sig og ikke paavirkes af ydre Forhold.

1) cfr. dog Lemmermanns (03 p. 151) noget æendrede Opfattelse. 
ser jeg ikke, al man kan vare bereltiget til al opretholde del store Arts- og Varietelsanlal. Vort hele Kendskal) lil I)inobrynm-drlerue kan resumeres i folgende Ord: Slaggten Dinobrymm er lokalt overordentlig stackt varicrende, og der er al Cirmol til at Iro, al den ligesom mange andre Planktonorganismer tillige varierer lemporall, folgende de slore livelleslowe for disse Organismers lemporale Variation. Idet vi i Øjeblikket er ude al Stand lil at lobde de mere faste, nedarvede káaraklerer ude fra saalanne, som omformes af ydhe Faklorer, savner enhver yderligere Sonderdeling af Begrebel Dinobryum egentlig videnskabelig Begrundelse. Forehohig bor man dog vistnok bibcholde de to gamle Hovedformer, I). sserlnkeria" og sstipilolmm ; senere Forf.s ladrige Arter er vaesendlig opstataet ved Sonderdeling af disse; jeg har formodet (00) p) (315), at I). slipilatmm er en Sommerlorm al I). divergens, men anser del for rigligst forelglig at holde de to Former ude fra hinanden.

Vore Soer visle sig sala merkelig fattige paa Dinoloryer, at de projekterede variationstatistiske Undersogelser paa Grund af Mangel pai Materiale ikke lod sig gennemfore. Udenfor Tiden 15. April-15. Juni hal Dinohryerne overall varet sai sjexhlne, at thet har varet umuligt at skalfe Materiale til Veje til Maalinger. deg anser det for givel, at jeg i l'roverne har haft Former for mig, der af andre Undersøgere vilde blive betegnede som D. sociole Ehr., cylindrichm Imh., dinergens Imh.; men da jeg intet ved om, hvor vidt disse Former mulig kun er Temporalvariationer, ser jeg forelobig bort fra dem.

1). sertularia" Ehr. og »stipilatmm《 Stein.

Tab. II, Fig, 22, mrk. Hvilecysterne, Tab. IV, Jig. 45.

Ehrenberg 38. Tal). 8, Fig. 8; Stein 78. Tab. 12, Fig. 5.

Fureso. D. sertuluria findes kun $\mathrm{i}$ et enkelt Eks. i Proven $01 \% / 4$ Tp. 1 og vedbliver at være sjælden til $27 / 5$ Tp. 14, dis Arten pludselig i uhyre Mrengde optræeder som l'lanktoncts Hovedform; allerede paa dette Tidspunkt findes mange Kolonier med Cyster; ${ }^{7} / 6$ Tp 16 er Arten nasten forsvunden fra Overfladen, paa c. 20 M. storl den dog endnu, men kun som tomme Buske rigt forsynede med de mørktfarvede Cyster; indtil ${ }^{16} /{ }_{11} \mathrm{Tp} .4$ lindes stadig enkelte Eks. I (12 findes et enkelt Eks. af $D . s .{ }^{23} / 3$ Tp. 1; den er yderst sjielden til $21 / 5$ Tp. 9, da Antallet begynder at stige; sit store Maks. har den $17 / 6$ Tp. 14, men er sjælden i l’roverne $11 / 7$ Tp. 14 og $3 / 8$ Tp. 15.

D). stipitatum fincles i en Del Eks. $0127 / 5$ Tp. $14 \mathrm{og} 7 / 6$ Tp. $16 ; 30 / 6$ Tp. 18 er Arten næsten forsvunden; i 02 er stipitutum set i en Del Sommerprover.

Soroso. D. sertutaria er paavist i et enkelt Eks. $015 / 5$ Tp. $10 ;{ }^{26} / 5$ Tp. 13 findes den pludselig $\mathrm{i}$ aldeles uhyre Nlasser, ller gor Vandet grodet og gulgront; enkelte Individer har Cyster; $3 / 7$ Tp. 21 er den stærkt aftaget og findes fra dil af kun enkeltvis til ${ }^{18} /{ }_{11}$ Tp. 7 . I de fleste Prover forekommer D. stipitatum, men i underordnet Mængde. 102 optrixder $D$. sertuluria med en Del Eks. ${ }^{24} / 3$ Tp. 1; den har sit Maks. ${ }^{16} / 5$ Tp. 7 og findes derpaa stadig $\mathrm{i}$ en Del Eks. endnu ${ }^{27} / 7$ Tp. 16 . D. stipilatum forholder sig som i 01 .

1)inobryerne synes ganske at mangle i Esromsø og Viborgsø; i de ovrige Søer er de kun paaviste i ganske enkelte Eks. og sierlig i Foraarstiden.

Ved 1)amundersøgelsen 98 paavistes Dinobıyerne i alle Dammene, dog sjælden i større Mængde. Maks. laa altid i Forsommeren. I Gentoftesø paavistes i Juni 01 et kolossalt Maks.; Vandet var gulgront.

II. H. t. Dinobryernes Optræeden i vore større Søer lægger man Mærke til, at de helt mangler eller dog er yderst sjæłdne i ikke mindre end 7 af de undersøgte Søer. I de to Søer, Furesø og Sorøsø, hror Dinobryerne optræder i større Mangde, er de skarpt begrænsede til Foraarsmaanederne. I begge Søerne indtraf Maks. i de to lagttagelsesaar c. ${ }^{15} / 5$ og varede til c. $1 / 6$; begge Steder begyndte Maks. mrerkelig pludseligt og tog lige saa pludseligt af. I de c. 14 Dage, det varede, dominerede Dinobryerne over alle andre Planktonorganismer.

Jeg har Indtrykket af, at Hovedmassen af Dammenes og Smaasøernes Dinobryer nærmest falder ind under Begrebet $D$. sertularia, og at stipilulum sarlig optreder i Søer. Lignende Resultat er allerede $Z$ a charias (98 b. p. 105) kommen til.

Dinobryernes geografiske Udbredning er overordentlig stor; de er paaviste af A. Cleve (99 p. 834 ) i laplandske Søer, særlig Virijauresøen; denne Sø, der endnu i Juli delvis var islagt, havde kun faa Dinobryer i den vestlige endnu isfyldte Del, hrorimod Mrengden tiltog i den sydøstlige, hror Isen var optøet. De cr 
endvidere fundne af Garbini (98 $\alpha$. p. 673) o. a. i de norditalienske Soer og i ovrigt vistnok de lleste Steder, hvor Planktonundersogelser er bleven anstillede. De horer til Ilovedformerne i hojtliggende alpine Swers Plinkton (Zschokke 00 p. 294), Pitard (97 a. p. 516 ), lunkof (87 p. 121).

M. H. I. Periodiciteten lyder Meddelelserne mere afvigende end for nogen anden Planktonorganismes Vedkommende.

lEfter Apstein (96 p. 147) har D. divergens i Plönersøerne et Maks. i Maj-Juni, hvorpaa Arten langsomt forsvinder; D. stipitatun har et Maks. i Maj-Juni og el i Aug. I Følge forskellige Angivelser hos \%acharias fremgalar det, at Arterme i Tiden fra Maj-Juni til Aug. kommer og forsvinder, og at navnlig et stort Foraarsmaks. lader sig paavise. I Neuchatelersøen havde Dinobryerne efter Fuhrmann (00 p. 94) et stort Maks. i Maj, hrorpaa de uden at opnaa flere Maks. holdt sig til Sep. I Katzensee mener Amberg $(00$ p. 48) at have iagttaget ikke mindre end 4 Maks. hidrørende fra I). divergens. I Valloxensø har I). stipitatun i Følge Borge $(00$ p. 9) Maks. i Juni. I Zürichersøen har Asper og Heuscher $(85-86)$ paavist Maks. i Maj og Sep. for D. divergens og elongatum, men C. Schröter (97) nævner aldeles ikke Dinobryerne i Zürichersøen. I Folge de lleste Forf. forsvinder de i Vinterhalvaaret, men de er dog fundne perennerende i líatzensee af Amberg og synes efter Waldvogel $(00$ p. 50$)$ ogsaa at være det i Lützelsee.

Ved at sammenligne de forskellige Litteraturangivelser faar man dog nærmest Indtrykket af, at Dinobryerne overalt overvejende hører Sommerhalvaaret til og har deres største Maks. i Maj-Juni (Tp. 12-14) samt undertiden et Efteraarsmaks. i Sep. I Tiden fra Juni til Sep. kan der i øvrigt indtræffe mindre Maks. ว: at rimeligris ydre os ikke narmere kendte Faktorer kan virke inciterende paa den Livlighed, hvormed Celleog dermed ogsaa Kolonidelingen foregaar.

Lemmermanns Opfattelse (00l. p. 519), at Dinobryerne særlig er periodiske i dybe Søer, men snart perennerende og snart periodiske $\mathrm{i}$ mindre, lave Søer, er muligvis rigtig. Apstein (96 p. 149) og Zacharias (99 b. p. 72) søger i Temperaturforhold og i den støre Adgang til saprofytisk Ernæring Aarsagen til, at Dinobryerne kan optræde perennerende og i uhyre Mængder i Smaadamme. Jeg formoder, at disse Forf. heri har Ret, og at navnlig Zacharias med Hensyn til den saprofytiske Ernæring har grebet et meget rigtigt Punkt. Lemmermanns Betragtninger $(00 l$. p. 520) synes mig ikke at kunne afkræfte Zacharias' og Apsteins Opfattelse.

Waldvogel (00 p. 50) mener at have gjort den interessante lagttagelse, at D. sertularia i Aarets Løb snart optraadte som Kolonier, snart enkeltvis, og fremhever udtrykkelig, at dette Forhold ikke skyldtes Transporten; en lignende lagttagelse har jeg gjort for Sorøsøs Vedkommende, men har givet Transport og Konservering Skylden gaaende ud fra, at hverken D. sertularia eller D. divergens normalt kan optræde uden i Kolonier.

\section{Synura.}

Af denne Slægt er der kun beskrevet een Art, S. nvella. Zacharias (97a. p. 5) beskriver en mærkeligg Form, Actinoglena Klebsiana, der, hvad Koloniens og Individernes Udseende angaar, minder om Synura; den skal dog vare udstyret med glasklare, tynde Naale, der skal bestaa af Kiselsyre; Individerne manglede Svingtraade. Lemmermann viste $(99$ p. 110), at dette sidste var fejlagtigt, og henførte derpaa Formen til Synura som S. Klebsiana; han udtaler i øvrigt som Formodning, at disse Naale ikke er konstante Dannelser, og at Arten i saa Fald maa stryges. Lauterborn har (99 p. 383) genfundet Actinoglena og mener ligesom Lemmermann uden, som det synes, at have undersøgt den narmere, at den bør henføres til Synura; den skal efter Lauterborn udfylde Kløften mellem Synura og den mærkelige Chrysospharella, som jeg ikke selv har iagttaget.

\section{S. uvella Ehr.}

Blochmann 95. Tab. IV, Fig. 125.

S. u. optræeder om Foraaret i alle de undersøgte Søers littorale Region og kan i afspærredle lave Partier findes i store Mrngder; den forslaas ofte, navnlig i Foraarstiden, ud i den pelagiske Region, men hører 
albsolnt iklke hijennme her og bor ilke regnes med til de storre Søers Planktonorganismer. I 98 paavistes den i alle de undersogte Damme: den havele her et stort Maks. i Tiden fra 15/3 eller 1/4 lil 1/5 og kunde optrade i mhyre Miengde; om Sommeren forsvandl den eller var meget sjelden; et nyt, men langl svagere Malis. viste sig $\log$ i Nov. Arten looldt sig med en Del liks. under lsen og var, umidclellart efter at Isen vall forsvmelen, til Stecle i ikke ringe Mangle. Paa Tidspunktet for det store Maks. ser man ofte Tvardeling al Kolonierne; liggledes forekommer ofte lange, polseformede Kolonier, som ved svagl Tryk med Drekglasset gatar over i llere mindre kolonier.

Kendskalhet til Synura-Koloniernes Formering og ()pomst er kun ringe. Man ved, at de enkelte Individer formerer sigg ved Laengledeling, og naar disse $\mathrm{i}$ en Koloni er bleven for mange, sker en Deling, hvorved nye Kolonier fremkommer. Derimod ved man intel om, hvorledes Kolonierne oprindelig er opslaaede. Bütschli har (80) p. 767 ) meddelt, at Grim hos Flagellater, der hører til Gruppen Synura, Syncrypla, Uroglena, har set kolonierne falde hen i Enkeltindivider, miste Flagella og blive omdannede til Amoeber, der senere encysterede sig. Indenfor disse Cyster foregik der da en Iivlig Deling, hroraf Resultatet bler Kolonier paa 2--300 Individer. lagltagelsen er ikke senere bleven bekrxeftet.

I April Maned vrimler de ovennevnte 12 Damme af brungule, pxreformede Legemer, udstyrede med Ojeplet og to lige lange Flagella. I samme Vandprøve finder man Kolonier paa 2-3-4-5-8 o. s. v. Individer, der ganske svarer til de enligl forekommende Individler. Stillingen i disse Kolonier er altid den samme; de tilspidsede Ender vender mod hinanden og synes ligesom svagt sammensmeltede; de brede Ender med Cilierne vender ud mod l'eriferien. Jeg har set Kolonier, der bestod af 2-3 Individer, som et enkelt fritsvømmende Individ først omkredsede, og hvortil det saa senere sluttede sig. Fanomenet blev kun iagllagel i April Maaned; jeg formoder, at de enkelte fritsvommende Individer maa vare fremgaaet af overvintrede Cyster, som jeg imidlertid forgreves eftersøgte.

Lauterborn (94a. p. 391) meddeler i en Anmærkning, at han har iagttaget, at Synura i Feb. dannede Cyster med stærk Kiselvag; hvert Individ i en Koloni skal indenfor sit Hylster udskille en kuglerund Cyste med en ganske lille, rund Aabning. Fremtidige Undersøgelser maa afgøre, hvor vidt disse Cyster bliver frie af Moderkolonien, spredes over Søbunden, klækkes i April og frembringer de af mig iagltagne Enkeltinclivider, som efter en Tid lang at have sværmet om forener sig til Smaakolonier, der efter paafølgende Længdedeling af sine Individer frembringer nye Kolonier.

S. uvella angives i Almindelighed ikke i Planktonet fra større Søer; den findes dog opført i Zacharias' Planktontabeller (94 b. p. 100); samme Forf. (98 b. p. 105) har rigtigt fremhæet den som karakteristisk for Damplanktonet.

\section{Uroglena.}

Slregten Uroglena indbefatter kun een Art, U. volvox; Lemmermann har (99 p. 107) opstillet Slæglen Uroglenopsis indbefattende to amerikanske Arter, U. americana Calk. og radiata Calk. (01 a. p. 86) har Lem-

mermann yderligere pointeret Forskellighederne. Nærmere Oplysninger angaaende denne Slægt bør dog afventes.

\section{U. volvox Ehr.}

Blochmann 95. Tab. IV, Fig. 126.

$U$. $v$. er paavist enkeltvis i flere af de undersøgte Søers Plankton; den findes inde ved Bredden og $\mathrm{i}$ de side Bugter og kan her, narnlig i Foraarstiden, optræde i Mængde; herfra forslaas den ud i den pelagiske Region, hvor den i ørrigt ikke hører hjemme.

I 98 optraadte den i 9 af de 11 undersøgte Damme, hvor den hørte til det perennerende Plankton; Arlen havde et stort Maks. i April-Maj, Toppunktet faldt overalt c. ${ }^{15} / 4$; om Sommeren tog den stærkt af, men ud paa Efteraaret indtraf el nyt, men meget svagere Maks.

Jeg har to Aar i Træk søgt at blive klar over Maaden, hvorpaa Uroglena-Kolonierne opstaar. Iagttagelserne skal gøres de første Dage i April ved Tp. c. 5. Det synes, som om Kolonidannelsen er af betydelig 
mere kompliceret Natur end hos Symura; da mine Iagllagelser imidlertid endnu ikke er afsluttede, maá Beretningen udskydes til en senere Lejlighed. Under det store Maks. sker der en livlig beling ján den af Za a ha a ras angivne Máde (95 a. p. 78).

U. v. nev'nes i Mnindeliglıed ikke i Planktonarbejderne. Levander angiver den (94a. p. 34) fra Löfö og Z Za clıarias (94 b. p. 100 T'abel) fra Plönersøerne; (len skal her have et dobbelt Maks., et i Maj og et i Aug. Zaclıarias paistaar (98 b. [). 106), at Arten er meget alm. i den pelagiske Region, men at den falcler fra hinanden i de siedvanlige Konserveringsvedsker. Jeg lıar i dens Maks.periode haft levende Plankton fra alle Soerne; i disse er den i alt Fald til ingen Tider nogen alm. Planktonorganisme, og Zacliarias' Angivelse on, at Arten vanskelig lader sig konservere, synes mig stackt overdreven; i Formol lykkes det meget godt.

Den er efter min Opfaltelse en udpraget Damform, der ikke hører hjemme i større Søers pelagiske Region.

ALMINDELIGE BEMARKNINGER.

Plankton=Euflagellaternes Forekomst i de undersogte Søer. ${ }^{1}$ )

\begin{tabular}{|c|c|c|c|c|c|c|c|c|c|}
\hline - & Fureso & Esromso & Soroso & $\begin{array}{c}\text { Tjustrup- } \\
\text { so }\end{array}$ & Viborgso & Haldsø & $\begin{array}{l}\text { Skander- } \\
\text { borgso }\end{array}$ & Mossø & Julso \\
\hline 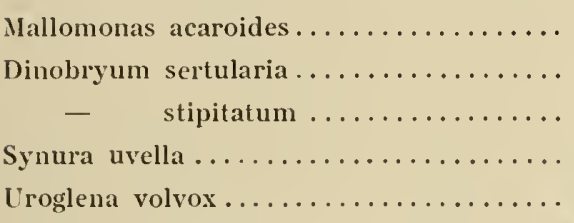 & $\begin{array}{l}+ \\
\frac{+}{+} \\
(+) \\
(+)\end{array}$ & $\begin{array}{l}+ \\
(+) \\
(+)\end{array}$ & $\begin{array}{l}\frac{t}{+} \\
(+)\end{array}$ & $\begin{array}{l}(+) \\
(+) \\
(+)\end{array}$ & $(+)$ & $\begin{array}{c}+ \\
(+) \\
(+) \\
(+)\end{array}$ & $\begin{array}{l}(+) \\
(+) \\
(+) \\
(+)\end{array}$ & $\begin{array}{l}+ \\
(+) \\
(+) \\
(+) \\
(+)\end{array}$ & $\begin{array}{l}+ \\
(+) \\
(+) \\
(+) \\
(+)\end{array}$ \\
\hline
\end{tabular}

Vedføjede Schema viser tydeligt, at Euflagellaterne i vore Søers pelagiske Region er af meget unclerordnet Betydning, og at Dinobryerne er de eneste, hvis kortvarige Maks. virkelig kan faa afgørende Indflydelse paa Planktonets Natur.

Medens Mallomonas Maks. væsentlig falder sammen med Vandets højeste Tp., falder alle de øvrige Formers Maks. overvejende om Foraaret i April-Maj; undertiden lader et Efteraarsmaks. sig ligeledes paavise.

For Dinobryernes Vedkommende ved vi med Sikkerhed, at disse tilbringer deres Min. i encysteret Tilstand som Hvilecyster, samt at disse gaar til Bunds med de tomme Kolonihylstre efter læenge at have staaet svævende i Vandmasserne (cfr. W.-L. 00 p. 650); ganske tilsvarende Forhold findes rimeligvis hos Mallomonas og Synura. Ogsaa for Euflagellaternes Vedkommende maa det henstaa uafgjort, om de paa dybt Vand bundfaldede Cyster eller deres Indhold nogensinde naar Overfladen, og on den ny Rekrutering i den pelagiske Region ikke væsentlig skyldes Cyster bundfældede paa lavt Vand eller fra Materiale udfort fra tilgræensende Smaasøer.

\section{R H I Z O PODA.}

En af de fremtræedende Forskelligheder mellem Havets og de ferske Vandes pelagiske Region er, at Rhizopoderne i Havet har en overordentlig stor Plankton-dannende Betydning, medens de i de ferske Vandes Plankton kun optrader med faa Arter, der saa godt som overalt og til alle Aarstider kun er til Stede $\mathrm{i}$ et grumme ringe Individantal.

Radiolarer og Foraminiferer, af hvilke førstnæunte Gruppe, som bekendt, ganske mangler i Ferskvand, optræeder ikke i den pelagiske Region. En enkelt Slægt af Amoebice (Difflugia) leverer et Par endnu noget

1) Om Tegnenes Betydning se p. 56 . 
trivlsomme peligiske Arler, og kun af Heliozoer optraeder a Del Arter pelagisk, men disse er i øvrigl ulilstridketig studerede. Yderligere Undersogelser vil muligvis liere os en Del hidtil oversete pelagiske Helio\%oer al kende.

\section{Amoebia}

deles i Cignnamoebida og Theramoebida, af hrilke forstnacrute ikke er paavist i Plankton.

\section{Thecamoebida.}

Arcella.

A. valgaris Ehr.

Blochmann 95. Tab. I, Fig. 12.

A. 1. optraeder enkeltvis, sarlig om Efteranct, i de fleste af vore sturre Soer.

Det synes mig, som on alle de undersogte Individer kun var tonme Skaller; i alt Fald er det aldrig lykkedes mig at iagttage Pseudopodier udgaa af Skallen. A.v. angives i øvrigt ikke i lidligere Planktonarbejder og maa ogsaa betragles som eı udpraget Bundform, ikke hịjemmehørende i den pelagiske Region.

Arcella er som bekendt ulstyret med Luftvacuoler i et vekslende Antal fra 2-14. I Følge Engelmanns Undersogelser benytter Arcella Luftvacuolerne dels til at stige til Vejrs, dels til at vencle sig, naar den er konnen i en ugunstig Stilling.

\section{Difflugia.}

Difflugierme er aldeles overvejende Bund- og Bredformer. I lave Søer med Maksimaldybder paa 4-5 M. og med leret Bund kan nran efter stormfuldt Vejr sammen med talrige andre Bundformer træffe et ikke ubetydeligt Antal Difllugier hørende til meget forskellige Arter; til nærmere Studiunı kan særlig Sjælsø og Bagsvardsø tjene. Disse Difflugier har ofte, men ikke altid, en enkelt stor Luftvacuole, i Alm. beliggende umidklelbart bag ved Skalmundingen.

Der er i den senere Tid fra talrige større Søers pelagiske Region angivet Difflugier som konstante Planktonorganismer. De paavistes første Gang i Zürichersøen (Asper \& Heuscher 85, $86 a$., Citat efter Zacharias 97 a. p. 3) og blev senere fundne i andre Schweizersøer af Burckhardt (99 p. 412); derimod synes (le at mangle i Genfersøen (Penard 02 p. 275). Senere beskrev Zacharias (97a. p. 3) D. lyydrostatica fra Plönersøerne, Garbini (98a. p.672, 98 b. p. 667) D. cyclotellina fra lago Maggiore og Levander (00 b. p. 53) 1). Lobostona Leidy. var. linuetica fra forskellige finske Søer. Endelig beskrev Minkewitsch $(00 a$. p. 618) fra Bologoiësøen b. planctonica. De 4 her næernte Former blev alle opfattede som Varieteter af D. loboslonta. I $\sin$ store Monografi har Penard (02 p. 274) bibeholdt D. Lydrostatica Zach., D. Lobostoma Leidy og D. limuetica Levander; D. cyclotellina Garbini anses for at vare identisk med førstnæernte Art. D. planctonica, ler rimeligvis hører sammesteds hen, synes Penard ikke at have kendt.

Der er paavist Difflugier i alle de af mig undersøgte Søer undtagen Furesø, Esromsø, Viborgsø og Skanderborgsø; i de fleste er de dog kun fundne i ganske faa Eks. i en enkelt Prøve og blev da foreløbig betegnede som D. lobosloma; derimod er de aln. i Prøver fra Juni-Juli 01 (Tp. 18-22) fra Tjustrupsø, Haldsø og Julsø; Materialet var her saa stort, at de kunde underkastes en nærmere Undersøgelse. Haldsøs Difflugier er kuglerunde, mørkegule af Farve; en Hals er tydelig, og Mundingen er 3-4-delt; Skallen er drekket med Krartskorn. Tjustrupsøs Difflugia er noget mere aflang og mere hyalin; Halsen er meget svagt afsat; Mundingen er derimod ogsaa her 3-4-lappet. Paalejringen dannes af en overordentlig lille, skiveformet Diatomee, der vistnok er identisk med den lille Stephanodiscus Hantzschii fra Viborgsø, og som vi formodede gik gennem Nettets Porer. I Følge Penard skal Haldsøs Difflugia da rære D. limnetica Levander, Tjustrupsøs D. hydrostutica Zach. Det synes, som om de af Penard angivne Karakterer er konstante; i Haldsø har jeg fundet enkelte Eks., hvis Skaller ganske ræsentlig var drekkede af Cycloteller. Julsøs Difflugier slutter sig til Haldsøs. 
D. linnelica Levander.

Tab. X, lïig. 120 (del sorte Legeme midt i Biltedet).

Penard (1). lig. J). 280.

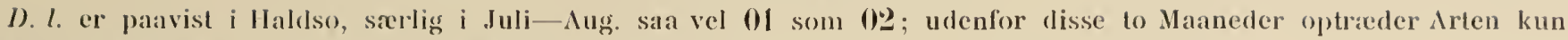
enkeltvis; samme Art var i Juli $0^{\circ}$ ret alm. i Julso.

\section{I). hydrostalica Zach a rias.}

Penard 02. Fig. p. 275.

Arten er parvist i Tjustrupso isaer i Juni-Juli Maaned, sierlig talrig 01, men ogsaa i 02 ; udenfor disse to Maaneder forekommer den kun enkeltvis.

\section{Foraminifera.}

Imperforata.

Cyphoderia.

C. ampulla Ehr.

Tab. IX, Fin. 107.

Apstein 96 p. 153 . Fig. 55.

C. a. er paavist et Par Gange i Furesøs, Tjustrupsøs og Mossøs Plankton, men kun som tomme Skaller.

Den angives fra Plönersøerne (Apstein 96 p. 153) og fra Neuenburgersee (Fuhrmann 00 p. 90 ), dog altid kun i ringe Mrengde. Fra linske Søer er den under Navnet C. margarilacea Schlumb. omtalt af Levander $(00$ b. p. 36$)$.

C. ampulla er en udpraget Bundform, som Bølgeslaget har havet op fra Bunden, og som en kort Tid holder sig svavende i Vandlagene.

\section{Heliozoa.}

Som Planktonorganismer i Ferskvand er mig bekendt hidtil kun beskreven Raphidiophrys pallida F. E. S., Acanlhocystis lemani Pen., lennispina Zach., conspicna Zach., Heterophrys Pavesii Garbini, Aclinophrys sol Ehr. samt Mycelomyxa Zoophï Zach.

Kendiskabet til de allerfleste al disse Formers Bygning er overvejende grumme ringe; deres biologiske Forhold er næsten ganske ukendte, og flere er utilstrakkelig beskrevne (f. Eks. Mycetomyxa Zophii Zach. 93 p. 13). Aclinophrys sol (Apstein 96 p. 153) er ikke Planktonorganisme i større Søer og hører kun hjemme i Damme og Moser, der overhovedet er denne Gruppes rette Hjem; en stor Del af disse meget smukke Skabninger kan om Foraaret indsamles i Pytter med Graesbund, og som senere hen paa Aaret fuldstæendigt udtørres; fra Københavns Omegn kan særlig Smaadamme paa Eremitagesletten anbefales som sardeles Heliozo-rige Findesteder.

Raphidiophrys.

Der er af denne Slægt beskrevet en Del Arter fra Damme og Moser; fra større Søers Plankton kendes kun een Art:

\section{R. pallida F. E. Sch.}

Tab. I, Fig. 9 og 12, Tab. IX, Fig. 101.

Blochmann 95. Tab. II, Fig. 43.

Denne pragtfulde Heliozo er paavist i Furesø, Esromsø, Haldsø og Mossø; den er overalt en Efteraarsform, bunden til Tiden fra Slutningen af Aug. til Begyndelsen af Nov.; den er i de to sidstnæevnte Søer kun paavist i enkelte Individer; i Furesø er den i ovennævnte Tidsrum forbavsende almindelig.

Man angiver i Alm., at $R$. pallida hører hjemme i Tørvemoser, og at den i Modsatning til $R$. viridis og elegans ikke er kolonidannende. Som Planktonorganisme i større Søer er $R$. pallida næsten altid kolonidannende og danner flere Millim. store, sammenhæengende Plader paa ofte c. 50 Individer; disse staar ikke som hos R. elegans i indbyrdes Forbindelse ved Protoplasmaudløbere, men kun ved et fæelles Gelelag og ved de talrige krydsende Pseudopodier. 
R. p. synes al vaere megel sjaclden i Plankton og er her hidtil kun patavist af \%acharias (95 d. p. 131) i Plönersoeme; den ero ogsata her en Elteraarsform og tanner Kolonier paa indtil 80) Individer.

\section{Acanthocystis.}

Don lorste pelagiske Acanthocystis-Arl, A. Lemani, er beskreven af Penard (9) a. p. 152) frat. Genfersøens Planklon. Slexglen rar tidligere kun kendt fra Damme, Sobund og Sobredder. Ved Zacharias' Undersogelser lremkon culnu et Par andre, mere tvivlsomme og ikke lyldestgorende beskrevne Former. A. Lemani var. plochensis (94 a. p. 70), A.: lemuispina (95 a. p. 73) og A. conspicua (97a. p. 1). Prowa\%ek fincler (01 a. p. 1) A. Lemani i Allersee, og Minkiewic\% (00 a. p. (621) beskriver den nye Art A. setifera samt en sierlig Varietet al' denne, var. botogö̈nsis, begge fra Bologojesøen. A. Lemani er hidtil ikke fundet her i Landet; A." lenuispinu kan man vanskelig danne sig nogen Forestilling om. Hvad A. conspicuu angaar, angiver Zalcharias $(97$ a. p. 2), al han inde i Individeme har set roterende, ciliekladte Svarmere, og mener, al man her ikke har haft med Parasitter at gore.

A. conspicua Zacliarias.

Zacharias $97 a$. Talb. I, Fig. $1 a, b, c$.

A. c. er her i Landet kun funden i Furesu, hor den optraadte i ringe Mangde i Tislen frat $018 / 4$ Tp. 1 til $7 / 6$ Tp. 16; de ovennevnte Sramestadier har jeg ikle set noget til.

Den er i orrigl hidtil kun funden i Plönersøerne, hvor den ligeledes kun optræeder i Foraarstiden.

Jeg anser det i det hele for trivlsoml, on man her har med en Rhizopod at gøre.

\section{ALMINDELIGE BEMERININGER.}

Plankton=Rhizopodernes Forekomst i de undersøgte Søer. ${ }^{1}$ )

\begin{tabular}{|c|c|c|c|c|c|c|c|c|c|}
\hline & Fureso & Esromso & Soroso & $\begin{array}{c}\text { Tjustrup- } \\
\text { so }\end{array}$ & Viborgso & Haldsø & $\begin{array}{c}\text { Skander- } \\
\text { borgsø }\end{array}$ & Mosso & Julso \\
\hline 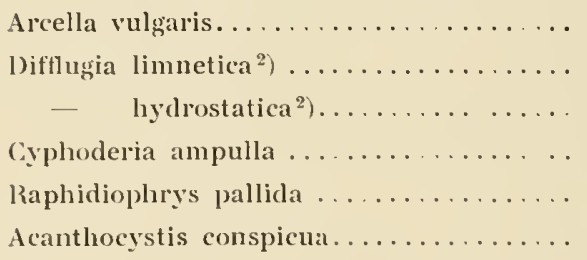 & $\begin{array}{l}+ \\
(+) \\
+ \\
+1\end{array}$ & + & + & $\begin{array}{l}(+) \\
(+)\end{array}$ & & $\begin{array}{l}(+) \\
(+)\end{array}$ & & $\begin{array}{l}+ \\
(+)\end{array}$ & $\begin{array}{l}+ \\
(+)\end{array}$ \\
\hline
\end{tabular}

Det vil af orenstaaende ses, at man for Rhizopodernes Vedkommende kun kan lale om særlige Maks. og Min. hos Difllugierne, Raphidioplurys og Acanthocystis. Førstnæernte maa nærmest anses for perennerende, om end de er sjaldnest i Vinterhalvaaret; deres Maks. som Planktonorganismer synes, i alt Fald her i Landet, nærmest at falde i Forsommeren. De to andre Slxgter forekommer derimod i Planktonet lil meget skarpt begransede Tider, forstnærnte om Efteraaret (Sep.-Okt.), sidstnærnte om Foraaret; uden for disse Tider synes de i Planktonet ganske at mangle.

Af den fuldkomne Regehmassighed, hrormed Raphidiophlugs i Sep.-OKt. viser sig i adskillige af rore storste Søers pelagiske Region, og af det betydelige Individantal, hvori Arten kan optrade herude, fremgaar det tydelig nok, at vi her har med en Organisme at gore, der i alt Fald i en Del al sin Levetid er udpreget

1) Om Tegnenes Betydning se p. $\mathbf{3 6 .}$

2) Se nirmere p. 120. 
Planktonform. Vi ved absolut intet om, hvor og muler livilke former R. P. lilbringer de 10 af Aarets Maaneder, hrorledes de hliver Planktomorganismer, ogs livilke Midler der sactler dem i stand lil at optracte som saadaune; Luftracuoler er ikle paaviste.

\section{N F USORIA.}

\section{Ciliata.}

Infusionslyrene spiller i le større Soers pelagiske Region kun en meget underordnet Rolle. De hypotriche, peritriche og med Undtagelse al en enkelt Slagg (Stamophrya) tillige alle de acinete Infusionsdyr mangle' ganske. Kun af de to Ordner Holotricha og Heterotricha findes en Del Slagter og Arter, men Hovedmassen al' disse er aldeles overvejende Dam- og Bredlormer, der kun undtagelsesvis lor en kort Tid kan optrade som Planktonorganismer i storre Søer.

Den mest udpragede Planktonorganisme og det eneste ejendommelige lnfusionsdyr, Ferskvandsplanktonet ejer, er Staurophrya elegans; størst Betydning som Plankton-dannende har Tintinnidernes Familie, den eneste, der ogsaa er af nogen Betydning i Havets pelagiske Region, og som her optrader med et stort Antal Slagter og Arter.

En hel Del, sxerlig hørende til Ordnen Peritricha, er fastsiddende paa andre i større Søer forekommende Planktonorganismer og kan som passiv limnetiske Arter regnes med til Beboerne af disses pelagiske Region; enkelte synes at have løsrevet sig fra cleres Bærere og optrader overvejende eller udelukkende fritsvømmende (Carchesium, Epistylis); om disse se Afsnittet passiv-pelagiske Organismer.

I Dammenes og Smaasøernes vegetationsfri centrale Partier findes et lille Samfund af liritsvømmende Infusionsdyr, som endnu ikke er synderlig studerede; en af Hovedformerne er her Bursaria truucatella; cfr. L a u terborn (94 a. p. 396).

Srerlige Tilpasninger til Planktonlivet »Planktonkarakterer lader sig i Alm. ikke paavise og er heller næppe synderlig fremtrædende; Opmarksomheden kan kun henledes paa de meget lange Tentakler hos Stauroplurya, som vel næppe er uden Betydning for Artens Svareevne.

Varieringsernen el stor hos Slagten Codenella, men ikke synderlig fremtrædende hos de ovrige Former.

\section{Holotrichidæ.}

En Del Slægter, særlig Coleps, Didinium, Amphileptus, Trachelius, Dileptus og Askenasia er ofte med et ret betydeligt Antal Arter knyttet til Dammenes og Smaasøernes vegetationsfri centrale Partier. Kun en enkelt Art Dileptus trachelioides synes i højere Grad end de øvrige at være hjemmehørende i større Søers pelagiske Region.

\section{Coleps.}

Under Navnet C. viridis Perty forekommer en Coleps-Art ret alm. i Planktonlisterne; denne Art, der nappe afviger fra C. hirtus $\mathrm{i}$ andre Henseender end ved at vare grøn af Farve, er rimeligvis identisk med denne (M a u a s 85 p. 362 ).

\section{C. livtus O. F. M.}

B lochmann 95. Tab. V, Fig. 164.

C. $h$. er paavist i enkelte Prover i de fleste af de undersøgte Soer, men altid kun i ringe Maengde; nogen Periodicitet lar ikke ladet sig paavise. Arten var langt hyppigere i de i 98 undersogte Damme, navnlig i Frederiksborg Slotssø.

Gentagne Gange har jeg haft Lejlighed til at iagtlage, at Coleps udviklede sig i større og større Mrengde i Planktonprøver, der fik Lor til at henstaa i nogle Dage; alt efter som det øvige Plankton døde ud, blev Coleps talrigere og var ofte efter c. 8 Dages Forløl til Stede i uhyre Mrngde. Det er til Dels Rovdyr, der i Akvarierne overfalder Infusionsdyr og Flagellater, men som i størst Mangde samler sig om Aadslerne af Daphnier etc. paa Karrenes Bund; meget hyppig fandt man Individer, hvis bageste Halvdel var mørk med lykt Panser, den forreste lys, vandklar med ganske tyndt Panser, Stadier som er fremkomne efter en foregaaende Deling (Bütschli 80, Tab. 58, Fig. 1 f., Maupas 85, Pl. 17, Fig. 5-6). 
C. niridis er partist som Planklonorganisme i Plönersøerne (Zacharias 93 p. 32 og p. 48), Katzensec (Amberg 00 a. p. 49), Lautikerried (Waldrogel 00 p. 50). Den angives af Zacharias at vace Sommerform, der forsvinder i Sep., all Ambergog Waldvogel at vaere peremnerende, men med Maks. i Sep.-Okt. I Følge Waldvogel skal den gromne Farve saerlig vaere fremtredende om Vinteren.

\title{
Didinium.
}

I). nasutum O. F. M.

\author{
Blochumann 95. T'ab. V, Fig. 165.
}

D. n. er enkelte (range panvist i Furesos og lissomsus Plankton; det er i uvrigt en Damform, hjemmehorende i Smatasoer on Dammes pelagiske Region. D. n. blev olte paraist ved Damundersogelsen 98.

ben medtages her, fordi \%acharias (93 p. 32) angiver, at den om Sommeren forekommer som xogte P'lanktonorganisme i P'lönersøen, og at den (93 p. 46) i Maj !) g ganske pludselig viste sig i stor Mængde. I Folge senere Angivelser (94 b. p. 10.5 og 95 (l. p. 136) skal den i Maj-Juni Maaned hvert Aar regelmæssig optracle i Planklonel, men Maks. er ikke hvert Aar lige stort.

\section{Dileptus.}

D. trachelioides Zacharias.

\section{Zacharias $94 \alpha$. Tab. II, Fig. $1-2$.}

D. 1. er parist i alle de undersogte Soer; den viser sig i Fureso kort efter Islosningen $018 / 4 \mathrm{Tp}$. 1 og har sit Maks. ${ }^{15} / 5 \ldots 27 / 5$ T p. 13-14; den lorsvinder i Juni Tp. 16. Udenfor April—Juni er den i Alm. ikke paavist i en eneste Sø.

Maks. var ringe i 01; i 98, da jeg i Tiden fra $17 / 5,-1 / 6$ berejste Landet fra Skagen gennem hele Jylland, Fyen og Sjælland, faldt Tiden for min Rejse sammen med Dileptus Maks. Det var da højst mærkelig at se, hrorledes denne ellers yderst lidet fremtrædende Form optraadte i Mængde i talrige større og mindre Søer saa vel som Damme. Den havde et stort Maks. i de smaa, lave Klitsoer ved Raabjærgmile og i Raabjærg Kirkeso, endvidere i Viborgsoerne og i Madumsø; den var hyppig i Silkeborgsøerne og havde et stort Maks. i Soroso.

I skarp Modsaetning til dens Optræeden i Søerne viste den sig ved Damundersøgelsen 98 at være perennerende med et tydeligt Maks. i April-Maj og et mindre ikke overalt paaviseligt i Sep.-Okt.

Zacharias er, saa vidt jeg ved, den eneste, der har iagttaget denne Form. Den er alm. i Plönersøerne og optrader her ligesom hos os med et Maks. i April-Maj; dette naas i Følge Zacharias (94b. p. 107) overordentlig hurtigt; den orrige Del af Aaret har han ofte kunnet paarise den i faa Eks.

Zacharias omtaler ( $94 a, p .78)$, at Arten som oftest i Bagenden er forsynet med et større eller mindre Antal grønne, encellede Alger, der farver den bageste Trediedel af Dyret grøn eller blaagrøn; endvidere har Z. paavist, at Mundspalten ofte mangler, og at den saakaldte Snabel ikke som hos nærstaaende Former udforer Folebevegelser ${ }^{1}$ ). Z. formoder, at Dileptus for en stor Del ernærer sig af Zoochlorellerne, der fra Ektoplasmaet, hvor deres oprindelige Plads er, kommer ind i Entoplasmaet og her fordøjes. Faste Bestanddele af anden Beskaffenhed findes i Følge Z. i Alm. hos de fritbevægelige Dyr ikke i dette, derimod hyppigt i encysterede Stadier.

Zoochlorellerne findes i alle de af mig undersøgte Individer, men i meget skiftende Mrngde; Mundspalte har jeg i de fleste Tilfælde ikke kunnet paavise. Hvad den saakaldte Snabel angaar, er den ligesom hele Dyret overordentlig formskiftende; den anvendes ofte til at udføre folende Bevægelser med; den udvider sig, forkorter sig, beræger sig fra højre til venstre etc.

Undertiden lober Forenden ikke ud i eet Føler-formet Vedhæng, men i tre-fire, der danner lange, tynde Traade, ofte langere end den ørrige Del af Legemet, og alle udførende langsomme, spiralformede Bevægelser.

1) cfr. Lauterborn (03 p. 608), til hvis Opfattelse af Zacharias Hypothese (94 a. p. 80) jeg ganske slutter mig. 
Individer af detfe Udseende parvistes ofte paa den ovenuevnte Rejse; de fandtes navulig i uhyre Marngde i Raabjarg Ǩirkeso. Zacharias betegner saadanne Eksemplarer som monstrgse, luvarl jeg ikke tror er rightight; de forekom migg at vaere hyppigst ved Maks. Slutning.

Zacliarias har set Delingsstadier og Cyster; iıgen af disse liar jeg varet saa lıeldig at iagttage; det har varet migs umuligt at konservere denne Form.

\section{Trachelius.}

T. ovum Elir.

Blochn an n 95. Táb. V, Fig. 172.

T. o. angives at vare Plankton-dannende i Plönersee (Zacharias 93 p. 32 og 48); den har sit Maks. om Sommeren. I vore større Søer lıa jeg hidtil ikke set denne Form; derimod iagttoges den hyppig ved Damundersogelsen 9S. I Smaasøer og Dammes vegetationsfri centrale Partier er den øjensynlig et nueget hyppigt forekommende Infusionsdyr.

\section{Heterotrichidæ.}

Alle polytriche Infusionsdyr er overvejende knytlet til Smaasøer og lave Damme, i hvis centrale Partier adskillige optrader som »Planktonorganismer«. Kun to Slagter, Bursaria og Stentor, er undtagelsesvis paaviste i større Soers pelagiske Region. Af Oligotricha optraeder her Tintinnidernes Familie med to Slagter, Codonella og Tintiunidiunı.

\section{Bursaria.}

B. truncatella O. F. M.

Blochmann 95. Tab. 6, Fig. 207.

B. . optræder i Esromsø i Tiden fra $01{ }^{10} / 4-20 / 7$ (Tp. $3-17$ ) og $022^{22} / 3-13 / 6$ (Tp. 2 - 13) regelmæssigt, men ikke i stort Antal. I 98 paavistes den i de 12 Danıme; den var særlig alm. i Foraar og Forsommer.

Denne store, smukke Form, som man paa Grund af dens Hyalinitet kunde formode var en typisk Planktonorganisme, er hidtil ikke angivet som saadan.

Stentor sp.

Tab. III, Fig. 28, det runde, morke Legeme f. n. t. v.; i Gelemasserne er fastholdt Detritus og Anuraa cochlearis.

En enkelt Prøve fra Esromsø $015 \%$ Tp. 16 indeholdt i mærkelig stor Mæengde en Stentor-Art, der desværre ikke nærmere kunde bestemmes, da den kun blev iagttaget $\mathrm{i}$ en konserveret Prøve og som Følge deraf i kontraheret Stand; den var omgiven af et meget tykt Gelehylster. Hverken i den foregaaende eller paafølgende Prove lod Arten sig paavise og er heller ikke funden $i$ nogen af de andre Søer.

Jeg vilde næppe have medtaget denne Form mellem de danske Søers Planktonorganismer, hvis der ikke andetsteds fra ogsaa havde foreligget Meddelelser om Stentor-Arters Optræden i større Søers pelagiske Region.

Saaledes angiver Zacharias $(93 \mathrm{p}$. 48), at $S$. coeruleus forekommer som pelagisk Infusionsdyr i Plönersøerne; her skal den forsvinde i Beg. af Okt.; den er 10. Okt. paavist som flaskeformet, blegblaa Cyste, der afbildes Tab. I, Fig. 12. Endvidere angiver Fu h rmann (00 p. 94) for Neuenburgersøens Vedkommende, at Stentor polyniorpluts fra Nov. til Juni er en regelmassig Beboer af denne Søs pelagiske Region og endog fra Nov. til Feb. danner Hovedmassen af Overfladezonens Plankton.

\section{Tintinnidium.}

\section{T. fluviatile Stein.}

Tab. VII, Fig. 81.

Blochmann 95. Tab. VI, Fig. 213.

T. $f$. er paavist i alle de undersogte Soer.

I Fureso viste enkelte Eks. sig allerede 00 20/12 Tp. 4 ; den fandtes i alle Sluseprøver og havde et svagt Maks. $018 / 4$ Tp. 1; lige efter Isløsningen $27 / 5$ Tp. 14 saas det sidste Eks. I 02 viste det første Eks. sig $31 / 1$ Tp. 1, faa Dage for Islægningen; de sidste paavistes $5 / 6$ Tp. 12. 
lin ganske tilsvarende P'eriodicitel fandtes i alle de undersogte Sorer; Arten viste sig overalt umiddellsart for eller lige clter Lsliegningen og lorsvandf i Maj-Juni Manned. Maks. var gennemganende ringe, kun i Haldsu optraadte (1) $30 / 5$ Tp. 8 uventet of meget stort Maks.; Arten var i Proven en af de hyppigst forekommende Organismer; $i$ den

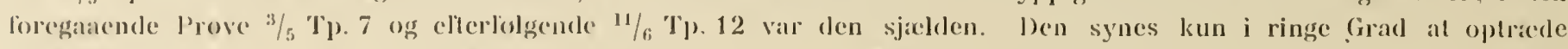
i Damme; al' de 11 i 98 undersogte paivistes den kun i 3; Maks, falut ogsaa her i $\Lambda$ pril-Maj, men var ikke synderlig stort.

T. f. er paa Grumd al sin store Hyalinitet vistnok ofte bleven overset; den angives fra Plönersøerne (Za-

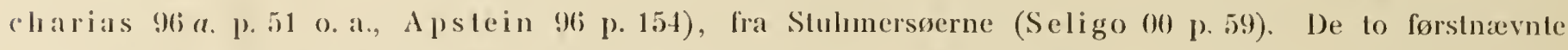
Forf. angiver samme Periolicitet som jeg, Seligo mener, at Maks. ligger i Aug.-Sep. Fra finske Søer naver Levander $(00$ b. p. 21) T. semiciliatum Sterki.

\section{Codonella.}

Af demne overvejende marine Slagt er der i Ferskvand kun beskrevel een sikker Art.

\section{C. lacustris Ent\%.}

Tab, X, Fig. 120.

\section{Blochmann 95. Tab. VI, Fig. 214.}

C. l. er paavist $\mathrm{i}$ alle de undersugte Søer og $\mathrm{i}$ de allerlleste Prover; den horer derfor til de udpræget perenncrende Former, men findes som oftest kun i ringe Mrengde i Proverne, og i de fleste Søer har let ikke været muligt at paavise sæerlige Maks. og Min. Dog er den talrig i Sorøsø i Proverne $015 / 5$ Tp. 10 og 02 28/6 Tp. 17. 198, da Soerne iklie fros til, viste en Vinterprove, hvis Dato desvæerre ikke med Sikkerhed kan angives, fra Esromsø et ganske kolossalt Malis. C. lacuslris optraadte her i enorme Masser som Planktonets Hovedform.

Den fandtes ved Damundersogelsen 98 i alle 11 Damme; ogsaa her var den perennerende, men lidet fremtraclende, hyppigst i Marts-April.

Saa vel i Vinterprøven 98 fra Esromsø som i Prøven $015 / 5$ fra Sorøsø saas Arten ofte i Konjugation; Husenes Munding vendte mod hinanden, og under Konjugationen svømmede Dyrene livligt om; cfr. Apstein (96 Fig. p. 154).

Hos de Eks., der levede i Søer, var Husene gennemgaaende lysere end hos dem, der levede i Damme. Paalægningen af fremmede Bestanddele var meget forskellig $\mathrm{i}$ de forskellige Søer, inen gennemgaaende ringe og Skallens Form noget afvigende fra Sø til Sø; nærmere beset viste det sig dog, at Skallens bageste, kugleformede Parti ontrent var lige stort og overalt af samme Form. Forskellighederne fremkom ved, at det forreste kraveformede Parti var mer eller mindre udviklet og ikke lige skarpt afsat fra det kugleformede Parti; det bestod af et forskelligt Antal Tilvakstringe, undertiden kun 1-2, men ofte 8-10; den hexagonale Struktur var tydeligst fremtræende i Kravepartiet.

Kun Haldsøs Codonella afveg, hvad Skalformen angaar, betydelig fra de øvrige Søers. Skallens bageste l'arti var nemlig her tykkest paa Midten, bagtil indbuet og endte i en skarpt afsat Spids; Kravepartiet var stærkt fremtræende, ndadstaaende, bredere end det bageste Parti og kun forsynet med højst 3-4 Tilrakstringe.

Arten er overordentlig vidt udbredt; at angive alle de enkelte Findesteder i Udlandet anses for overflødigt. Ned Hensyn til Periodiciteten er en samstemmende Opfattelse endnu ikke tilvejebragt. Zacharias angiver for Plönersøemes Vedkommende, at Mæengden i 94 (95 d. p. 136) var størst i Aug.; i 93 var den derimod størst i Jan.; A pstein har sammesteds (96 p. 154) fundet Maks. i April-Juli og Okt.; i Valloxensø har Borge $(00$ p. 13) fundet det i Nov.; i Stuhmersøerne har Seligo $(00$ p. 59) hyppigst set den i Juni og om Efteraaret.

I de fleste Tilfælde synes dog Maks. at indtræffe ved lavere Tp. $\left(8-12^{\circ}\right)$; af $Z$ acharias' og egne Iagllagelser fremgaar det, at det kan indtræffe ved Tp. omkring 0. 


\section{Acineta.}

Afdelingen Aciucta indhelatter et af de meget lan Inlusionsdyr, som udelukkende synes knytlet til større Soers pelagiske liegion, og hvis Slaggtskab til Dam- og Bredlormer ikke narmere lader sig paavise.

\section{Staurophrya.}

S. elegans Zacharias.

Zacharias (9). Tab. I, Fig. 10.

S. e. er kun paivist i Furesoen; den optrader her kun i Foraarsprover i Tiden fra $018 / 4$ Tp. 1 (Sluseprove) til 27/5 Tp. 14 samt fra 02 11/4 Tp. 4 til $5 / 6$ Tp. $12 ; 0217 / 6$ Tp. 14 landtes ganske enkelte Cyster af den hos $\%$ acharias (9.1 b. p. 118 ) nermere beskrevne og afbildede (Tab. I, Fig. 9) Form.

S. ('. er, saa vidt vides, kun funden i Plönersøerne, hvor den først paavistes af Zacha rias (93 p. 18) og senere yderligere blev beskreven (94 b. p. 118); den blev genfunden af Apstein (96 p. 154), der ogsaa fandt den $\mathrm{i}$ andre tilgraensende Soer.

I Folge Zacharias (93 p. 18) skal den kun optraede i Marts-Maj. Apstein meddeler (96 p. 154), at Cysterne viser sig i Nov, Dyrene selv allerede i Jan.; Maks, naas i April, hvorpaa Arten tager al og forsvinder i Juni, paa hvilket Tidspunkt Cysterne paavistes. I Sep. viste Cysterne sig igen og kort derpaa enkelte Dyr; der er altsaa en Mulighed for, at et dobbelt Maks. kan forekomme.

\section{ALMINDELIGE BEMARKNINGER.}

Plankton=Infusionsdyrenes Forekomst i de undersøgte Srer. ${ }^{1}$ )

\begin{tabular}{|c|c|c|c|c|c|c|c|c|c|}
\hline & Fureso & Esromso & Sorasø & $\begin{array}{c}\text { Tjustrup- } \\
\text { so }\end{array}$ & Viborgsø & Halds $\Leftrightarrow$ & $\begin{array}{c}\text { Skander- } \\
\text { borgsø }\end{array}$ & Mossø & Julsø \\
\hline 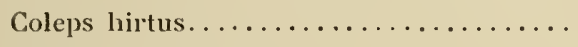 & $(+1)$ & $(-+)$ & & $(-+)$ & $(-+)$ & & $\left(-\frac{1}{-}\right)$ & $(+)$ & $(+)$ \\
\hline Didinium nasutum .............. & $(-+)$ & $(-+)$ & & & & & & & \\
\hline Dileptus trachelioides ............... & $(-+)$ & $(-+)$ & $(-1)$ & $(+)$ & $(+)$ & $(+)$ & $(+)$ & $(+)$ & $\left(-\frac{L}{T}\right)$ \\
\hline Bursaria truncatella ............... & & $(+)$ & & & & & & & \\
\hline 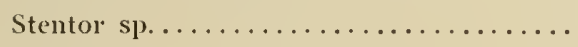 & & $(+)$ & & & & & & & \\
\hline Tintinnidium fluviatile..$\ldots \ldots \ldots \ldots \ldots$ & $(+)$ & $(+)$ & $(+)$ & $(+)$ & $(-+)$ & + & $(+)$ & $(+)$ & $\left(-\frac{1}{1}\right)$ \\
\hline Codonella lacustris $\ldots \ldots \ldots \ldots \ldots \ldots$ & $(-)$ & $-\vdash$ & + & $(-+)$ & $(-H)$ & $(+)$ & $(+)$ & $(+)$ & $\left(-\frac{1}{1}\right)$ \\
\hline Staurophrya elegans ............... & $(+)$ & & & & & & & & \\
\hline
\end{tabular}

Vedføjede Schema viser tydeligı, at Infusionsdyrenes Betydning som Plankton-dannende i vore større Søer kun er grumme ringe; hjemmehørende i disses pelagiske Region er i det højeste kun Stauroplurya elegans, Dileptus tracluelioides, Tintinnidiun flnviatile og Codonella lacuslris.

Sidstnavnte Form maa narmest betragtes som perennerende, alle de øvrige Planktoninfusorier har, bortset fra Coleps liurtus, der absolut iklie hører hjemme her, markvardig korte og skarpt begiræensede Maks., der sjældent striekker sig ud over 1-1\% Maaned, og som i Alm. falder i Foraarstiden (Didinium, Dileptus, Bursaria, Tintinnidiun, Stanrophrya). Udenfor Tidsrummet for Maks. optræder alle disse Arter enten yderst sjaldeut eller lader sig slet ikke paavise. Under Maks. kan de optracle i stor Mrengle og for en kort Tid vare dominerende, men som oftest er disse Maks. kun smaa.

Vi ved kun lidt om, hvor Plankton-Infusionsdyrene opholder sig, og under hvilke Former de optrader, al den Tid de ikke viser sig i Planktonet. Cystedannelser er paavist hos Inileptus, Stentor, Staurophrya, men,

1) Om Tegnenes Betydning se p. 56 . 
sar vidt vides, laveren hos Tintinnidiun eller Codonella. Man maa formode, at de al den Tidl, de ikke lader sig parvise i den pelagiske Region, enten Irviler i encysterede Stadier para Sobunden, eller at de tilbringer den orrige Del af Aarel i Lilloralregionen. Det lorste el vistnok del sandsynligste for Stauroplarya's og maaske lor 'T'untimnidium's, det sidste for Didliniun's, I)ileptus', Bursuria's og Stentor's Vedkommende; alle disse Arter lorekonmer hele Aaret i Smansoer og lave Damme; lra disse bliver de, navnlig i Foraarstiden under deres Maks., med Tillobene fort ud i de storre Soers pelagiske Region, hvor de for en kort Tid vegeterer, men ikke er i Stand lil al holde sig.

Cystestadierne garar rimeligvis alle til Bunds; en Undlagelse herfra danner maaske for en Tid Cysten af Staurophrya, der clter hele sin Bygning kunde formodes at vare delvis pelagisk, og som i Følge Zacharias lorst brydes i det lritsverende Stadium. Det er rimeligvis de paa lavere Vand bundfældede Cyster, der fortrinsvis heves af Bolgeslag og Vertikalstrømninger, og som, efter at være kommen op i Vandlagene, klickkes her.

\section{Passiv=pelagiske Organismer.}

Ved passiv-pelagiske Organismer forstaar man saadanne, som er fastsiddende paa de i Plankton regelmassig optradende Former, bares af disse og af den Grund kommer til at tilhøre den pelagiske Region. Disse Former frembyder mange interessante Forhold, men Kendskabet til dem er ringe.

Saa godl som alle passiv-pelagiske Former er Protozoer, dels Infusionsdyr, dels Flagellater; de omtales derfor naturligst her. Paa Clathrocyslis fra Plönersøerne har dog Apstein (96 p. 135) paavist en Diatomee (Diatoma eller Synthedra).

Alle p.-p. Protozoer fanger, saa vidt vides, overvejende selv deres Føde, og Organismen, hvorpaa de sidder, spiller i de allerfleste Tilfrelde næppe nogen anden Rolle for dem end den at bære dem og muliggore dem Opholdet i den pelagiske Region; derimod er der stor Sandsynlighed for, at disse Smaaskabninger har en ikke ringe Betydning for deres Bærere. Fangeapparatet er nemlig tillige Bevægelsesapparat, ved hvis Virksomhed Diatomeen eller Cyanophyceen, hvorpaa Protozoen sidder, sættes i Bevægelse. Betragter man f. Eks. et levende Asterionella-Plankton, hvor Asterionellerne er besatte med Diploziga frequentissima Zach. (Tal). IlI, Fig. 34), ser man Stjærnerne svømme hurtigt af Sted; en enkelt Iiploziga kan sæette en Asterionella i rolerende Bevagelse og føre den frem i Vandet. Er Stjærnerne besat med 5-6 Eks., bliver Bevægelserne meget hurtige.

Det er mærkeligt at se, hvor nøje de p.-p. Former er knyttede til bestemte Planktonorganismer. 1 et Cyanophyceeplankton, bestaaende f. Eks. af Anabcena og Clalhrocystis, er Anabcena ofte besat med talrige Vorticeller (Tal). I, Fig. 5 og 6), medens Clathrocystis er ganske fri for disse. Saaledes bar Anabcena flos aque overalt i vore Søer i Juni Maaned et stort Antal Vorticeller, ofte 30-50 Eks., medens Clathrocystis altid gik fri. Lignende lagttagelser er anstillede af Apstein (96 p. 136), C. Schröter (97 p. 11). Ganske paa samme Maade er Diploziga frequentissima noje knyttet til Asterionellerne og Birocoeca oculala Zach. til Fragilaria crotonensis (Tab. Il, Fig. 23). Samme Iagttagelser er for Diplozigernes Vedkommende anstillede af Schröter i Zürichersøen (97 p. 11), af Z acharias i Plönersøerne (94a. p. 75) og for Bicocoeca oculala's Vedkommende af Zacharias sammesteds (94a. p. 71); ogsaa Bachmann (01 p. 228) og Prowazek (01 p. 4) omtaler kun Arten fra Fragilaria-Baandene.

I Furesø, hvor Asterionellerne endnu er talrige paa det Tidspunkt, da Tabellariernes Maks. indtræffer, hæerer Asterionellerne altid Diploziga, men denne gaar, som det synes, aldrig over paa Tabellarierne.

Paa Clathrocystis har Zacharias (94a. p. 72) fundet en langstilket Bicocoeca-Art, B. lacustris Clark var. longipes Zach.: den er, saa vidı vides, ikke senere genfunden. En lignende langstilket Bicocoeca-Art optræder konstant paa Steplanodiscus fra Haldsø og Esromsø; Flagellaten plejer i et Antal af 20-30 Individer at sidde regelmæssig ordnet paa Kantsiden; iagttages Diatomeen med svag Forstørrelse, faar man Indtryk af, at der uden om Kanlen ligger en Kreds af lysende Punkter forbundne med denne ved yderst fine Traade. 
Det synes, som om de p.-p. Orenanismers Maks. noje falder sammen med deres Bacreres; detle cr i all

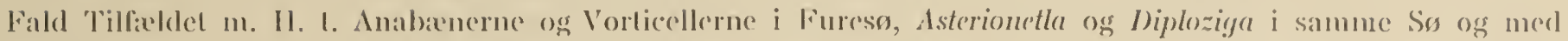
Stephanodiscus og Bicocoece i Haldso og Esromso. Oflo kan Maks. for de p.-p). Orunanismer vaere ganske liolossall; da disse under konserveringen let falder al, kan Proverne undertiolen indeholde dem i ulyere

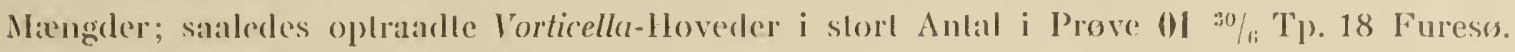

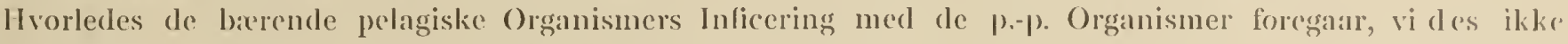
muligvis gaar der forud lor det fastsiddende et ubekendt liritsvommende Stadium.

Meget olle stoder man baale i del levende Planklon og i P'roverne paa Organismer, om hvilke man i Folge hele deres Habitus naa formode, at de i all Fald vaesenllig er passiv-pelagiske, om man end ikke altid er i Stand til at paavise den Organisme, der baerer dem. Herhen horer saaledes Trichodina pediculns Ehr., Colaciunt-Arter, Garchesinn polypinum L. og Epistylis lac'ustris Imh. Trichodina er som hekendt lanasit pal Fisk, Spongiller, Planarier Snegle, Crislatella o. m. a. Den oplraeder ofte fritsvømmende i den pelagiske Region og navnes ogsaa som Planktonorganisme af Seligo (00 p. 59) fra Stuhmersøerne.

Ikke sjaeldent stoder man i Planktonet, navnlig i Vilorgsø og Sorøsø, paa Colacium-Arter. I Smaasøer og lave Damme dakker disse som bekendt ofte Copepoder og Daphnier og farver dem ved deres store Mængder grønne; et tilsvarende Fænomen er sjældnere paa Copepoder fra større Søer, men kan dog ogsaa her forekomme (C. streuuus, Esromso Okt.-Nov. 00).

I Juni-Juli finder man i alle de undersogte Søers Planklon en Carchesium, rimeligvis C. polypinum L. (Tab. IV, Fig. 38), der i Damme og Smaasøer meget ofte sidder fast paa Copepoder. Den var i Juni talrig i Sorøsø og optraadte samtidig pelagisk i uhyre Mrengde i Frederiksborg Slotssø; samme Art omlales ogsaa af Z a charias $(94$ b. p. 124) som pelagisk fra Plönersøerne og af Stenroos (98 p. 37 ) i Nurmijärwisøen o. a.

Epistylis lacustris Imhol (Tab. IV, Fig. 40) falder maaske ikke ganske ind under samme Synspunkt som foregaaende Former; den findes altid i vore Søers Plankton, men er sjaIden om Vinteren; jeg har aldrig set den fastsiddende; muligvis har vi her med en autopelagisk Organisme at gøre. Den er af Zacharias (94 b. p. 124) paavist i Plönersøerne; en egen Art E. procumbens er af Za charias (97a. p. 7) opstillet sammesteds fra, ligesom han ogsaa (97a.p.7) omtaler Zoothannimn pectinatum Zach. fra lille Plönersee.

De hidtil kendte, vigtigste p.-p. Former med deres Barere er folgende:

Bicocoeca oculata Zach. paa Fragilaria crotonensis.

- lacustris Clark. var. longipes Zach. paa Clatlurocystis eruginosa.

Diploziga frequentissima Zach. paa Asterionella gracillina.

Salpingoeca minutus Kent. paa Asterionella gracillima.

Vorticella sp. paa Anabona flos aquoe.

Acineta simplex Zacharias (93 p. 17) paa Fragilaria.

Carchesium polypinum L.,

Epistylis lacustris Imh.,

- procumbens Zach.,

Zoothamnium peclinatum Zach.,

Colacium-Arter,

Asterosiga radiata Zach. (94a. p. 77)
Barere ikke sikkert kendte;

maaske til DeIs autopelagiske Former. 


\section{KAP. VIII. VER M ES.}

I NDis jeg gaar over til at omtale liotifererne - den eneste Ormegruppe, som øver nogen Indflydelse paa Sammensatningen af vore Soers Plankton --, anser jeg det for naturligt kort at nevne dels de andre Orme, der som konsmodne lndivider nu og da traffes i den pelagiske Region, dels ogsaa de Larvestadier af Orme, som vi ud fra foreliggende zoologiske Undersøgelser maa formode konstant optraeder i denne, om end Planktonundersogelserne hilltil ikke har bragt saadanne for Dagen.

Af 'Turbellarier angives en eneste Art, Castrada radiala v. Graff, som Planktonorganisme; den er indfort i Planktonlisterne af $\mathrm{Zacharias}(93$ p. 6 ) og først paavist i Plönersee; senere er den genfunden sammesteds af Apstein (96 p. 155). Den viser sig om Foraaret, naar sit Maks. ved Vandets hojeste Tp. i Aug. og forsvinder i Nor. Castrada radiata er i Sommertiden paavist enkeltvis i Mossø; i Aug.-prøven fra Haldsø (1) var den meget alm. Den optræeder som udpræget pelagisk Organisme og svømmer med stor Kraft.

v. Graff (82 p. 314) angiver, at Arten overalt er sjælden, hvilket dog næppe er Tilfacldet; den er kun ikke bleven eftersogt paa sit naturlige Opholdssted.

Af Nematoder træffes ikke sjældent en Del Individer, som jeg ikke har faaet nærmere bestemt; da jeg hyppigst har set dem i de laveste af de nndersogte Søer (Viborgsø og Sorøsø) og navnlig i sidstnæunte som oftest efter Storm, formoder jeg, at disse Individer er Bundformer, der er førte op med Bølgeslaget.

Af Oligochater træffes ikke sjaldent Stylaria proboscidea og Nais elinguis; begge disse Arter, bl. a. karakteriserede ved deres meget lange Børster, er gode Svømmere, af hvilke Stylaria meget hyppigt findes fritsrommende i Smaasøernes centrale Partier.

Der kan næppe væe Tvivl om, at vore Søers pelagiske Region i ikke ubetydeligt Individantal maa huse Larvestadier af Ormegrupper, der enten som Snyltere er knyttede til Fiskene eller er hjemmehorende paa Littoralzonens Sten- og Plantevækst. Til forstnævnte Gruppe hører Larvestadier af Trematoder, Botrio cephaler og Gordins; flere af disse synes jo red deres kolossalt lange Fimrehaar (Botriocephalus) eller markelige Horndannelser (Bucephalus-Larven) i Følge deres Bygning at vare velskikkede til pelagisk Liv. Botriocephal-Larven har jeg i Sommertiden selv tre Gange set i Plankton fra Furesøen, men de øvrige herhen hørende Larrestadier er af Planktonundersøgerne hidtil ikke bleven iagttagne.

Indenfor Oligocheterne skal der i Folge Ray Lancaster (69 p. 631) hos Eolosoma optrade et fimrekladt, fritsvommende Larvestadium, som man dog kender yderst lidt til, men da Eolosoma i Følge velvillig Neddelelse fra stud. mag. Ditlevsen er alm. længst ude i Furesøens Littoralregion (i Myriophyllum-Baltet), kan Larven muligvis findes i Soens pelagiske Region.

Hos Bryozoerne traffes som bekendt fritsvømmende Larvestadier. Jeg har undersøgt disse noje hos Plumatellerne og hos Crislatella og har andetsteds (96 b. p. 352) vist, at Larvernes Levetid kun strakker sig 
over fá 'liner, at de lrolder sig som hvide Skyer onlkring Kolonierne og vistnok aldrig naar ud i en slorre

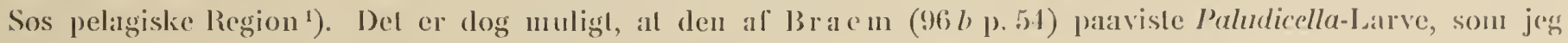
ikke sely har set, forlıolder sig anderledes; herom virles dog intet.

\section{ROTIFERA.}

Rolifererne danner nest efter Crustacecrne den vigligste Del al vore siørre Søers \%ooplankton; desuaglel er deres Bolydning sammenlignel med disse kun ringe, og kun i Maj-Juni Maaned kan dle optraede i saa store Mangder, at de bliver dominerende; pá andre Tider findes de som oftest kun i ganske ringe Maxngde.

Der er i vore støre Søers pelagiske Region paravist et betydeligt Anlal Arter, der alle tilhører Underor(nen Monogononta; nogel narmere Slagtskabsforhold opviser disse Plankionrotiferer i øvrigt ikke; de tilhører indenfor denne Afleling de mest forskellige Familier og Slagter; Ordnen Brachionida og saerlig Familien Brachionilke har dog leveret det største og betydningsfuldeste Kontingent.

Falles for Hovedmassen af Plankton-Rotifererne er, at Huden er tynd og hyalin, hvilket ogsaa galder de Arter, der hører til de saakaldte loricate Rotiferer; Torndannelser er hyppige (Anurcea, Notholca, Triarlhra, Polyarthra), Fasthaftningsapparatet mangler meget ofte eller er strerkt reduceret (Ascomorpha, Synchiela. Hudsonella, Anurca, Notholca, Triarthra, Polyarthra); Hjulorganet, der i øvrigt er af meget forskellig Bysning, reprasenterer indenfor sin Type altid den højeste Udvikling; Geledannelser forekommer hos Melicerlidk og Flosculariadk; Aggene, der hos de øvrige Rotiferer i Alm. aflagges, klæbes i enkelte Tilfalde til andre Planktonorganismer (Ratlulus, Hudsonella o. a.); de er undertiden pelagiske (Ploesoma), dette er ogsaa Tilfaeldet med Hvileaggene (Brachionus og maaske Asplanchna); i en Del Tilfaelde baes de (Anurcea, Notholca, Triarthra, Polyarthra); se det flg. I alle disse Karakterer ser jeg Bygningsforhold, som Livet i den pelagiske Region har medført.

En stor Del af de ovennævnte Rotiferer er tillige udprægede Damformer, der kun enkeltvis forekommer i de større Søers pelagiske Region; selv de Arter, der herude har størst Betydning, findes alle i mindre Smaasøer og Damme, hvor de i Alnı. opnaar højere Maks. end i større Søer. Alt tyder paa — hvad jeg ogsaa andetsteds nærmere har fremhevet (99) —, at Søernes pelagiske Rotiferer hidrører fra Dammenes fritsvømmende Rotiferer, og disse atter fra Bund- og Bredformer.

R. er underkastede en meget betydelig Variation; paa Grund af deres stærke Hyalinitet og ofte laengere Torndannelser staar Individerne fra de større Søer med et eget Prag over for Dammenes Individer. Lokale Variationer er ikke særlig fremtradende hos Individer fra de forskellige støre Søer; derimod kan i alt Fald en enkelt Form (A.priodonla) være underkastet en meget betydelig Temporalvariation (se herom anden Del).

I Havets pelagiske Region spiller R. en meget underordnet Rolle. Hovedslregter er Synchata og Anura R. er i Havet aldeles overvejende knyttede til Fjorde og Indhave og optraeder her med de samme Arter sonı i Ferskvand eller i hvert Fald med Arter, der staar Ferskvandets nae (cfr. Daday 91 b. p. 55, Plate 89 p. 1, Lauterborn 94 c. p. 212 , Levander 00 a. p. 1 og J ägerskiöld 94 p. 17).

\section{Digononta.}

Alle Digononta (Bdelloida og Seisonacea) er krybende eller fastsiddende Dyr; selv om Bdelloida har Svømmeevne, forekommer de dog ikke udenfor Smaadammenes Vegetation; kun Zacharias angiver (00 $a$. p. 463 ), at Actinurns neptunins Ehr, i Planktonet fra Wakenitzfluss (Lübeck) skal kunne optræede i stor Mangde.

1) Spongillarverne forholder sig ganske paa samme Vis.

2) Til Grund for Inddelingen af lotifererne har jeg med Hensyntagen til Webers (98) Arbejde lagt det af mig (99) foreslaaede System. Da det Ferskvands-biologiske Laboratorium oprettedes, og jeg ansattes som dettes Leder, ansaa jeg det for urigtigt $\mathrm{i}$ de forste Aar at anvende den allervæsentligste Del af min Arbejdskraft paa et saa speeielt Felt, som Rotiferernes Systematik og Forplantningsforhold unægtelig er. Jeg ansaa det - i ovrigt mod mine private Onsker - for nodvendigt forelobig at laxgge disse Studier, hvoraf kun den mindste Del er publieeret, til Side og give mit Arbejde til mere generelle Undersogelser. Sáa snart Planktonundersogelserne er afsluttede, haaber jeg - af mere end een Grund - at kunne vende tilbage til disse Studier. 


\section{Monogononta}

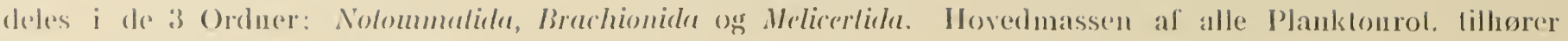

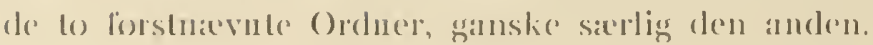

\section{Notommatida}

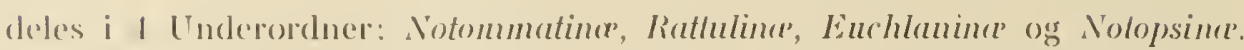

Af disse indbefallor Euchlanine ingen Panklonorganismer i storre Sor; Hovedmassen er krybende eller

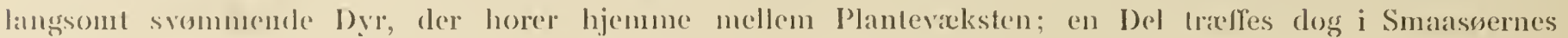

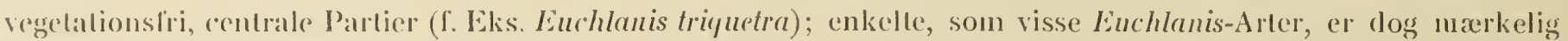
hundue til store Soers lithrale Region, hrorlin enkelte Individer kan forslaas un i den pelagiske Region.

Ogsaa af de lre andre Underordner er Jovedmassen krybende eller langsomil svonmende finormer, der nivnlig lorer lijenne ved Bunden og mellem V'egelation; en ikke ringe Del er Midvandsformer i Smaasøer, nen om cuncl en Del er Planktonorganismer i storre Søer, viser deres nare Slagtskabsforhold med Bund-og Bredformer sigg dog i mange Bygningstrak og biologiske Forhold (se det flg. og IV.-I. 99).

\section{Notommatinæ.}

Underorlnen indluefatter de to Fam. Notommatide og Synchalade.

\section{Notommatidæ.}

Fam. lacler mange krybende Former, hvoraf en Del (Proales, Pleurotrocha, Taplurocampa) kun undlagelsesvis er i Stand til at svomme; kun ganske enkelte, saerlig kraftige Nolommala-Arter, hvis Hjulorgan er udstyret med slore Fimrelapper, kan nu og da traffes i Smaasøernes vegetationsfri Partier; i større Søers Plankton el endnu ingen Notommatide paavist.

\section{Synchætadæ.}

I den af mig (99 p. 134) givne Begransning af Familien indbefatter denne kun de to Slægter (Syıchala og Polyarthra), der begge for en Del hører hjemme i Smaasøer og Damme, men dog ogsaa optræeder i slørre Soers pelagiske Region. Dette gæelder sæerlig P. platyptera og S. pectinata forma grandis.

l Modsatning til alle øvrige Medlemmer af Ordnen Notommatida (se dog Mastigocerca stylata og Sacculus viridis) barer Polyarthra og tillige ofte Synclueterne deres Ag.

\section{Synchæta.}

Der er af Slaegten Synchata i alt beskrevet c. 14 Arter, af hvilke de 4, S. baltica Ehr., S. apus Plate, S. mouopns Plate og S. trioplıthalma Lauterb., er marine. De fleste Forf. er vistnok for Øjeblikket mest tilbøjelige til i Ferskvand at antage 4 Arter: S. pectinata Ehr., S. tremula Ehr., S. stylata IVierz. og S. grandis Zach.

Man kan indenfor Synchæterne udskille to Hovedtyper, en med.hvalvet Hjulskive og Ekskretionskanaler omtrent af Legemets Læengde ( $S$, pectinata) og en med flad Hjulskive og Ekskretionskanaler af c. $1 / 3$ Legemslængde (S. tremula). Medens S. Iremula ikke synes at være underkastet nogen synderlig stærk Variation, er S. pectinala saa vel temporalt som lokalt overordentlig stæerkt varierende. Man har i den senere Tid (Wierzejski 92 b. p. 62 og Zacharias 93 p. 23) opstillet to Arter, S. stylata og S. grandis, der øjensynlig nærmer sig denne Type, i Nærheden af hvilken ogsaa en tredie af Zacharias (01 c. p. 381) opstillet Form, S. neglecla, horer; denne sidste er rimeligvis identisk med den tidligere af mig (00 p. 610) provisorisk betegnede Form S. pectinata forma minor. Det er nu ubestrideligt, at disse Arter er opstillede paa Forhold, der hos denne Slagt dels er underkastet meget betydelige individuelle Variationer, dels henhører under Begrebet Planktonkarakterer. Naar det paa talrige Lokaliteter kan paavises, at man om Vinteren hovedsagelig finder Zacharias' lille S. neglecla, lerpaa i Foraarstiden overvejende den Iypiske S. pectinata og endelig ved Vandels 


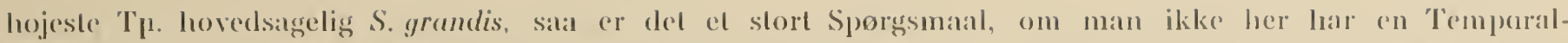
variation for sig. Naar det cudvidere viser sigg, at baengdealisen hos lndividerne af denne liornurake stadig agges i Tiden fra V'inter lil Sommer, skulde det synes, som an vi her har nucl samme lianomen al gere, som genfindes hos el stort Antal Panklonorganismer, og som narmere er fremsat (W.-L. of) p. (i)(f). Ud fra den Oplatlelse, som overalt havdes i delte Arliejde, al der intel vindes ved en Udsondring i Arter, sá laengo

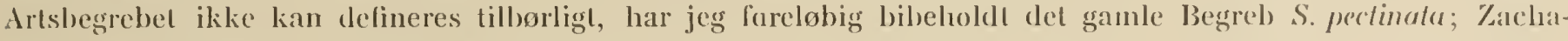
rias' Paastand, at S. grandis hader sig opreholde som en egen Art (01 c. p. 381), vil med den Argumentalion, han anvender, nappe virke overbevisende paa nogen, der allerede har dannet sig en anden ()plattelse ${ }^{1}$ ).

Synchaternes Hjem er Smaasøer med vegetationsfri, centrale Parlier; de er i langt mindre Grad Planktonorganismer i større Søer.

Seksualperiode og Hamner er lidel kendte; ogsaa med Hensyn til Aggene ved man kun ringe Beskel, ogs mig selv er det ikke lykkedes at forstaa disse Forhold.

Den lille Vinterform neglecta baerer sine $\mathrm{Eg}$ i et Antal af 1 -2; hrorvidt de øvrige af de til $S$. pectinalaGruppen hørende Former barer Eggene, vides ikke med Sikkerhed; S. grandis skal efter Zacharias (93 1 . 35) have pelagiske Eg, der aflaggges i Klumper paa 2-3. I Følge Lauterborn (93 $\alpha$. p. 12) er Hvileaggene hos S. pectinata dækkede med lange, børsteformede Haar. Zacharias (01 c. p. 109) har snart fundet, at Arten barer Aggene, og snart at disse er pelagiske. S. slylala har ligeledes pelagiske Eg, dxekkede med lange Børster (Zacharias 01 b. p. 110).

S. tremula skal i Følge Gosse ( 86 p. 128) bxre Eggene; Bilfinger tror (94 p. 41), at dette kun er forbigaaende. I Følge $\mathrm{Zacharias} \mathrm{(01} \mathrm{c.} \mathrm{p.} \mathrm{109)} \mathrm{skal} \mathrm{Arten} \mathrm{afsatte} \mathrm{dem} \mathrm{paa} \mathrm{Melosireme.} \mathrm{Apstein} \mathrm{(96} \mathrm{p.} \mathrm{158)}$ angiver efter Iagttagelser i Jan.-April, at Synchæterne bærer saa vel Sommer-som Hvilexeggene. Desverre har de fleste Forf. i deres Angivelser ikke skarpt sondret mellem Sommer- og Hvileag. Mine egne Iagttagelser er ufuldkomne; $\log$ er det sikkert, at neglecta i Tiden Feb.-Maj meget hyppigg ses barende 1 - 2 Eg. S. pectinata har jeg aldrig set bare Eggene.

\section{S. tremula Ehr.}

We ber 98. Pl. 16, Fig. 17.

$S$. $t$. forekommer kun sparsomt i de storre Søers Plankton; den er paavist i alle de undersogte Søer, nen kun i enkelte Prøver, særlig om Vinteren og i det tidlige Foraar; det er en Damform, der kun forslaas ud i større Søers pelagiske Region.

Ved Damundersøgelsen 98 blev Arten parist i hver eneste Dam og viste sig at høre til clisses alleralmindeligste Rotiferer. Den var overalt perennerende og vistnok den om Vinteren hyppigste Form. Den har to Maks., et i April-Maj og et i Okt.-Nov; sammen med det første, der i alle Damme var det største, faldt overalt en Seksualperiode med talrige Hanner, sammen med det sidste blev disse kun undtagelsesvis paaviste. Om Sommeren kunde Arten nasten ganske forsvinde; i Foraarstiden, inden Vegelationen havde dakket Overfladen af Dammene, optraadte den i uhyre Mrngder; dens Føde er bl. a. Peridiuium labulatum, som den snapper med Tæenderne og sluger hel. S. I. er i øvigt paavist i Hedesøer, Mosehuller, kort sagt overalt, hvor Undersøgelser er bleven anstillede.

Da den væsentlig er Dambeboer, omtales den i Alm. ikke i Planktonarbejder; alle Forf. stemmer overens om, at den er perennerende (Lauterborn 98 p. 174, $93 a$. p. 9; Zacharias 94 b. Tabel. p. 100); sidstnæernte angiver ogsaa Maks. i April.

\section{S. pectinata Ehr.}

\section{IV eber 98. Pl. 16, Fig. 15.}

S. p. er paavist i alle de undersøgte Søer og horer til disses perennerende Plankton; den er vel ikke funden hver enkelt Prove, men dog i Prover tagne til alle Aarstider, og man maa formode, at den til enhver Tid, om end

1) Efter Undersogelsens Afslutning udkom Rousselets omhyggelige Arbejde over Syneliaterne (02 p. 269); efr. ogsaa Lauterborn (03 p. 596); det er vel inuligt, at min Opfattelse af Synchata-Arterne ikke er rigtig; forelobig har jeg dog ikke kunnet aendre den. 
med skiftende Individanal, findes i alle vore storre Socrs pelagiske liegion. Individantallet er i ovrigt aldrig stort;

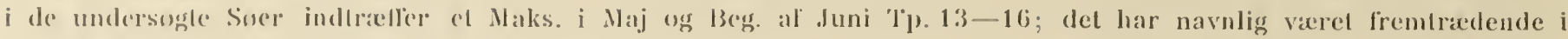

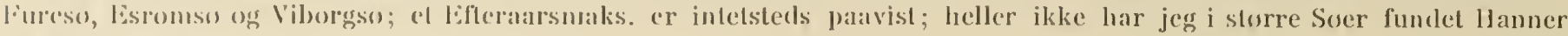
(rller Selisualperiuder.

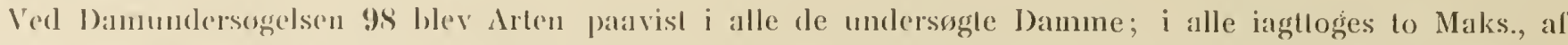

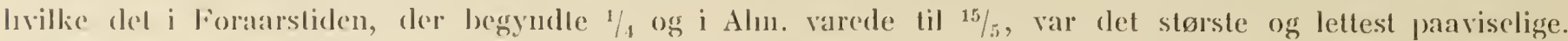

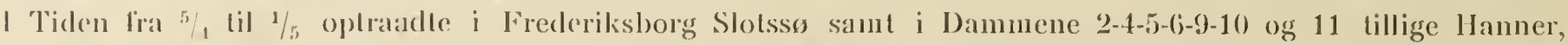
ofle i stor Miengdle. Da jeg i l)an Nr. 6 ogsaa landt llanner i Slutningen af Nov., formoder jeg, at Arten, i hvert Fald i Smalsoer og Damme, er dicylislisk.

S. p. er udbredt over hele Landet og (r langt hyppigere i Smaasøerne end i le storre Søers pelagiske Region; i ovrigt er dens geograliske Udbredning overorlentligs stor; den angives dog ikke fra Grønland (Bergenculal 91); derinod er den alm. i lojlliggende Alpesoer (Zs chokke 00 p. 294).

Alle Forl. undlagen $A$ mberg angiver $S$. $p$. som peremnerende; A. mener, at den i Katzensee er Vinterform (00 p. 51); lian fejler (log, naar han skiver, at baade Zacharias og A pstein angiver, at S. pectinata cr Vinterlorm; (le siger tvaertimod, at den hører til det perennerende Plankton (A pste in 96 p. 158, Zaclia-

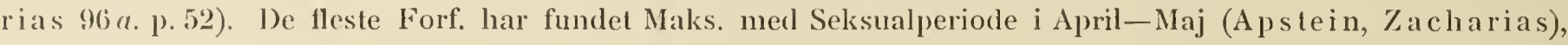
andre i Sep. (Seligo 00 p. (61). Lauterborn (98 p. 180) paaviste Seksualperiode baade i April, Juli ogs Olit.

Rimeligvis er Arten oftest dicyklisk mel den mest udpragede Seksualperiode om Foraaret.

\section{Polyarthra.}

Der er af Slagten Polyarlhra beskrevet 7 Arter og Varieteter; le fleste Forf. antager for Øjeblikket næppe mere end to Arter, nemlig $P$. platyptera med Varieteter og $P$. aptera Hood. (95 p. 672); sidstnærnte, der nungler Torndannelser, er en ret sjalden Form, der kun optrader i Smaadanme, aldrig i større Søer.

\section{P. platyptera E $\mathrm{hr}$.}

Tab. I, Fig. 9.

Weber 98. Tab. 17, Fig. 1.

P. p. er paavist i hver eneste undersøgt So og i nasten alle Prøver; den er altsaa perennerende. Med Undtagelse af Haldso, dulso og Fureso er der i alle de ovrige Søer i Tiden fra $01{ }^{18} / 5$ til $25 / 5$ Tp. 12 - 15 paavist et Maks., og med Undtagelse af Soroso, en samtidig Seksualperiode (Hunner med Hanæg og Hvileag). Foraarsmaks. var særlig i Viborgso og Soroso meget markeret. Et Efteraarsmaks. blev paavist i Furesø $017 / 9$ Tp. 10, Sorøsø 01 17/10 Tp. 12 , hvor det endnu holdt sig $011 \% / 11$ Tp. 7, samt i Skanderborgso $0115 / 9$ T 1 . 12; alle tre Steder paavistes samtidig Seksualper. I Maanederne Juni-Aug. var Arten ikke alm. og sjalınere end om Vinteren, da $P$. $p$. gennemgaaende var et hyppigt optradende Hjuldyr.

I 02 blev Maks. paarist i Tiden fra $16 / 5-30 / 5$ T $.8-10$; i Mosso og Skanderborgso noget senere; Seksualperiode iagltoges i Esromso, Tjustrupso og Viborgsø.

Vi kan heraf med al Sandsynlighed slutte, at Arten i vore større Søer er dicyklisk; da Seksualperioden ojensyulig i Reglen ikke varer over en Maaned, er det ikke til at vente, at en maanedlig Planktonundersøgelse vil kunne paavise Seksualperiode, liver Gang en saadan indtræefer; det yderst ringe Antal Eks., der findes fra .Juni til Sep., tyder bestemt paa, at Arten ingen Steder i større Soer er polycyklisk.

Damundersogelserne $9 S$ gav et ganske forskelligt Resultat. Arten bler selvfølgelig paavist i hrer eneste Dam og som oftest i hrer Prove. Jeg har i disse Damme set Selsualperioder i alle Aarets Maaneder undtagen Jan. og Feb. Om nogen Regelmassighed i deres Forekomst er der for saa vidt kun Tale, som at den forste Selisualperiode konstant indtraffer Marts-April; senere hen taber al Regelmæssighed sig, idet Seksualperiode forekommer baade i Juni, Aug., Olit. og Nov. 1 3 af Dammene har jeg set Selisualperiode i Marts Aug. og Nor.

Arten er altsaa i Smaasøer og Damme polycyklisk. 
l'. pl. varierer kun lidt fra Sted til Sted; Lokalvariationen viser sigs saerlig med Hensyn til fiarren (brungul i Torvenoser, hyalin i storre Soer); derimod (r Arten muligvis underkasted en betydeligg 'T'(omporalvariation,

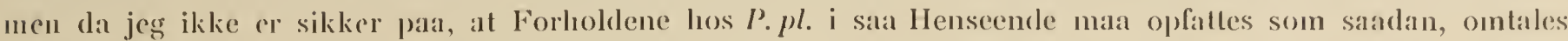
de allerede lıer. Paa Lalrige Lokaliteter, dels storre Soer, men navnlig Smásøer med vegetationsfri l’artier, finder man lia Juni til Sep. en Form, var. euryptera Wier\%, hvis Torne er omndannede til brede Blade, sártakkede paa begge Sider. Var. er dobbelt saa stor som den normale Form og har parallele Sider; den typiske P. pl. er i Alm. noget smallere hagtil. Var. euryplera viser sig ganske pludselig i Flokkene ogs synes, luad jeg forst formodede, ikke gennem gradvise Overgange at udvikle sig af $I$. pl.; den forsvinder i Okt.--Nov.; den barer, saa vidt det er mig bekendl, aldrig Hanæeg eller Hvileag; Hanxeggene synes altid at blive baarne af ganske smaa Individer med glatte Tome og staerkt tilspidset Bagende.

Arten er her i Landet overordentlig vidt udbredt og for ørrigt Kosmopolit i videste Forstand; den er parist af Bergendal (92 p. 168) i Grønland; i løjtliggende Alpesøer af Zschokke (00 p. 294) og Fuhrman n (97 p. 531).

Maks. angives lil meget forskellig Tid: i Neuenburgersee Juni (Fuhrmann 00 p. 95); i Plönersee April til Aug. (Apstein 96 p. 159), i Maj-Juni (Zacharias 94 b. Tabel. p. 100), i Okt. (Zacharias 96 a. p. 52 ); i Dobersdorfersee Juli-Aug. (A pste in 96 a. p. 158); i Vierwaldstädtersee Juli-Aug. (Burck hard t 00 p. 121 ); i Stuhmersøerne Juli (Seligo 00 p. 61); i Oder Marts (Zimmer 99 p. 10). Enkelte Undersøgere har fundet flere Maks.: Kalzensee (A m berg 00 a. p. 50).

Seksualperiode er paavist af Lauterborn i Altrhein (98 p. 179); L. fandt her Seksualperiode dels i Marts, dels i Okt., men undertiden tillige i Juli. I Plönersøerne paaviste Apstein Seksualperiode i MajJuni (96 p. 159).

Ogsaa af Litteraturen synes det altsaa at fremgaa, at Arten, ligesom her i Landet, optraeder med flere Maks. og rimeligvis snart er dicyklisk, snart polycyklisk.

\section{Rattulinæ.}

Rattulince indbefatter to Fam., Rallulide og Dinocharide; den sidste taeller kun Danformer.

\section{Rattulidæ.}

Den nærmere Udredning af de til Fam. Raltulick hørende Slagter og Arter frembyder store Vanskeligheder, navnlig fordi deres Bygningsforhold er bleven misforstaaede og tydede ganske forskelligt af de forskellige Forf. hvorved Systematikken er kommen i fuldstandigt Virvar. At løse disse Vanskeligheder vilde ligge ganske udenfor Opgavens Plan; her følges derfor Hudson-Gosses Inddeling i de tre Slægter: Mastigocerca, Rattulus og Coelopus; jeg kan ikke ganske slutte mig til de af Weber (98 p. 501-503) fremsatte Bemærkninger om Slagternes Begraensning. Fam. bestaar overvejende af Damformer og taller kun tre til forskellige Slagter hørende Arter, som kan optrade i større Soers pelagiske Region. Medens Damformerne i Alm. afsatter deres Eg paa Bunden og paa Vandplanter, afsæetter de tre Planktonarter deres Eg paa andre Planktonorganismer.

Alle Søformerne har deres Maks. liggende ved højeste Tp.

\section{Mastigocerca.}

Der er beskrevet c. 25 Arter, hvoraf mange enten er ukendelige eller sikkert beskrevne to eller flere Gange; dog bliver der altid et mærkelig stort Antal distinkte og fra luverandre meget afvigende Arter tilbage. Hovedmassen er hjenmehørende i smaa, lave Damme med rigelig Vegelation og fører her en langsomt svømmende, halvt fastsiddende Levevis; enkelte Arter, ganske særlig $\boldsymbol{M}$. setifera, er hjemmehorende i Smaasøernes centrale Partier, hror den nu og da kan optræde i uhyre Mrengder. Den bærer sine Fg, Hunæggene, i et Antal af 1-2, Hanæggene i et Antal af 3-4. De fleste er Former med Maks, i Forsommeren (M. carinata Ehr., bicornis Ehr. o. a.). M. seliferas' Maks. og Seksualperiode falder i Juli-Aug. Tp. 24-28; jeg har lkun fundet den i Hjortekserdammen, Eremitagesletten. IJdpraget Planktonorganisme i større Soer er kun een Art: 


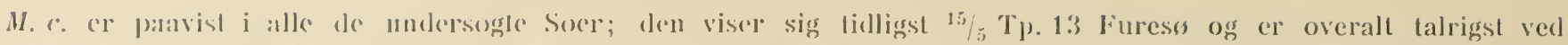

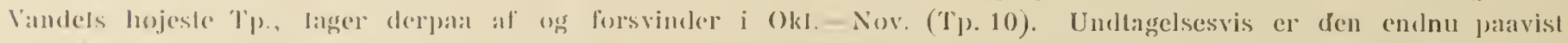

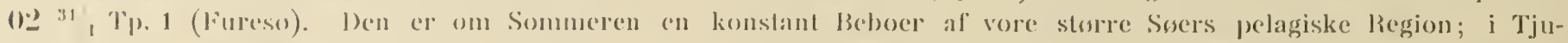

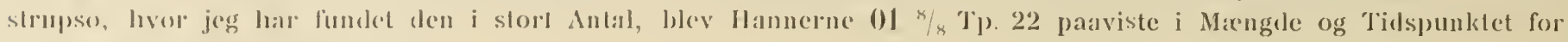
Selisualperioden sialerles fundet.

Ved Damundersogelsen 98 parastes den i de storsle Damme med regetationsfri Partier, nemlig 1-6jog 9. $1 \mathrm{Nr}$. ("Teglgatardsso) var den 1. Sep. orermalde lalrig, men en Seksualperiode blev ikke paavist.

I Folge Lauterborn (98 p. 180) skal Arlen afsette Eggene paa andre Planktonorganismer, navnlig Asptunchune.

Lamgden synes i de forskellige Soer at variere en Del; de lleste Eks., jeg har set, har veret betydelig langere end det hos Apstein (96 p. 160) albildede; se ossaa herom Stenroos (98 p. 142), der formoder, at M. c. i Finland har storre Laengde end i Tyskland.

Arten er vidt udlbredt; samtlige Forf. er cnige om, at den er en Sommerform, der viser sig om Foraaret og forsvinder om Efteraaret. Plönersøeme: Maks. Sep. (Z acharias 94 b. Tab. p. 100); Katzensee: Maj, Nor. (Amberg 00 p. 51); Neuchatelerso: Aug. (Fuhrmann 00 p. 95); ogsaa Lauterborn (98 p. 175) angiver den som Sommerform.

M. (. skal i Følge Zacharias $(98$ b. p. 113) særlig være karakteristisk for Søer i Modsætning til hamata Zach., hudsoni Lauterb., bicornis Ehr, der er Damformer.

\section{Rattulus.}

Sliegten Rattulus tecller et stort Antal lidet kendte Arter, der rimeligvis vil kunne reduceres til ganske faa: liun en enkelt er Planktonorganisme.

R. bicornis Western.

Hood. 95. Tab. 22, Fig. 4.

Demne lille Form er paavist $\mathrm{i}$ alle Socrne, men kun i meget ringe Mrengde; den optræder især i den varmeste Sommertid enkeltvis $\mathrm{i}$ en Del af Proverne. I de storre Socr har jeg ikke kunnet paavise nogen Seksualperiode.

I 99 fandtes den i Dammene 1-2-3-4-6-7-8-9-11. Den viste sig her i Alm. allerede i Begyndelsen af Maj og kunde paavises endnu i Nor., men var altid hyppigst i Aug.-Sep.

I en enkell vegetationsfri 1-2 Meter dyb Dam (Karussedam) havde den et meget betydeligt Maks., der varede fra $15 / 7-1 / 9$. Midt under dette Maks. faldt Seksualperioden. Samme Dam vrimlede af Brachionus angularis, der paa dette Tidspunkt var fuldsındig dækkede`af Eg; Hunnerne kunde bære 18-22 Eg liggende ud over hele Rygskjoldet og orenpaa hverandre. Ved at holde disse Brachioner i hængende Draaber viste det sig, at de af dem klækkede $E \mathrm{Eg}$ tilhørte R. bicornis, og at der af Eggene fremkom baade Hanner og Hunner. Fænomenet varede hele Sommeren, men var mest fremtræende i Juli-Aug.; hvor Hvileægget legges, vides iklie.

R. bicornis er vistnok vasentlig Damform og er, saa vidt vides, hidtil ikke paavist i storre Søer; muligris hører en Del af de under Diurella tigris beskrevne Individer herhen.

\section{Coelopus.}

Der er af denne Slagt beskrevel c. 10 Arter, der alle, med Undtagelse af en enkelt, udelukkende hører h.jenme i Smaadamme. 


\section{C. temuior (iosse.}

'Tab. Y, likg. (i0).

Weloer. 98. 'T. 20, 1). 5.

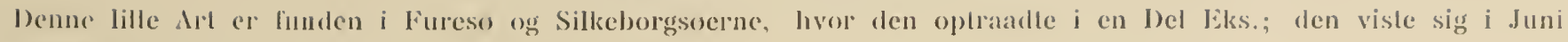
og forsinand igen i Sep). - Okt.

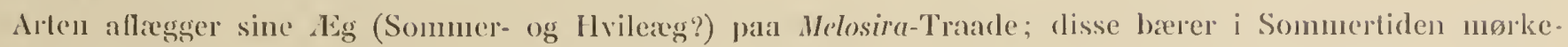
brune, aflange, noget skave Ligg; Arten fincles rineligvis i alle vore Soer, da jeg ogsa hal fundel Aiggene i Soer, lıvor den lidtil ikke er iagltagel.

C. I. er lidligere beskreven som Planklonorganisne af Apstein (96 p). 160), men nuder Narnet Liurella tiyris; Esgel hengende red en Melosiratraad er albildet sammesteds. Den er som alle dens Slagghinge en Danforı, men fincles sarlig i de centrale regetatonsfri Partier; alle de ovrige lil samme Slægl hørende Aıl'• er Bundformer bundne lil Vegetationen.

\section{Notopsinæ.}

Underordnen indbefatler de tre Fam. Notopsida', Asplanclinada og Apsilida, hvoraf sidstnaernte Fam. som fuldroksen taller fastsiddende Organismer; de to andre indeholder kun fritsvømmende Former, men de fleste er Damformer; enkelte er udpragede Planktonorganismer i større Søer.

\section{Notopsidæ.}

Af Grunde, som er angivne i Dannarks Rotifera (99), henføres med den der givne Begransning lil denne Fam. Slxgterne Notops, Triphylus, Hudsonella, Gastroschiza samt som en noget fjernere staaende Gruppe Chromogaster, Ascomorpha og Sacculus. Jeg kan ikke ganske slutte mig til Webers Fremstilling af Slagtskabsforholdet mellen disse Former, men da Begrundelsen af min Opfattelse hviler paa Undersøgelsen over disse Formers anatomiske Bygningsforhold, der ikke hører hjemme i dette Arbejde, vil den fremkonme andetsleds. I Webers og mit Arbejde, der udkom omtrent samtidig, er vi med Hensyn til Begransningen af Slagterne delvis kommen til samme Resultat, men med Hensyn til Valget af Slagtsnavnene til el forskelligt. Jeg skal, for ikke al øge den Forvirring, der hersker med Hensyn til Benæevnelsen af de til denne Familie hørende Slagter og Arter, saa vidt mulig opgive den af mig i 99 valgte Nomenklatur og følge Webers.

Slrgten Hudsonella med de to Arter H. picla Zach. og Rilenbenki Bergend. bør da kaldes Gastropus, og de to Arter G. stylifer Imh. og G. minor Rousselet.

Gastroschiza bør betegnes Ploesoma, og Webers Begransning af Arterne følges (se dog p. 138).

Chromogaster forandres til Anapus; angaaende de to hertil henførte Arter se det følgende.

Paa to Punkter er det mig dog umuligt at følge Weber. Jeg anser det for urigtigl at føre Nolops hyptopus Ehr. ind under Slagten Gastropus sideordnet med G. stylifer (= Hudsonella picla), ligesom jeg heller ikke kan gaa med lil at føre Sacculus viridis Gosse ind under Slagten Ascomorpha; de er i enlver Henseende fuldstandig forskellige. Jeg holder altsaa Nolops med den enkelte Art N. hyplopus og Sacculus med den enkelte Art S. viridis ude fra Gastropus og Ascomorpha. Notops braclionus Ehr. henføres til Fam. Hydatinilue.

I den Begransning, hvori Fam. Notopside tages her, indeholder den vasentlig Damformer, der lırer hjemme i Damme med rigelig Vegetation (Triphylus lacustris Ehr., Gastropus minor Rousselet, Ploesoma triacanlhum Bergend., Anapus ovalis Bergend., Sacculus viridis); en Del hører hjemme i Smaasøernes centrale vegetationsfri Partier (Notops hyplopus, Gastropus stylifer til Dels, Ascomorpha agilis Zach.), og ganske enkelte, som Ploesoma Hudsoni, Gastropus slylifer til Dels og Anapus testudo, er Planktonorganismer i de sløre Søers pelagiske Region.

Falles for nasten hele Familien er, at den saa godt som udelukkende bestaar af Rovdyr, der jager Peridineer, Synura, Uroglena og undertiden Rotiferer. Byttet sluges ikke, men bliver udsuget; de tomme Skaller kastes derpaa bort, og de brune Kromatoforer gaar under Dekomposilionen i Maven over til at blive grønne, livad der forøger disse Formers ofte iøjnefaldende Farver. 
Solormerne hatr alle deres Maks. ved Vandels logjesle Tpr; Damformernes Maks. er laypligst paavist i

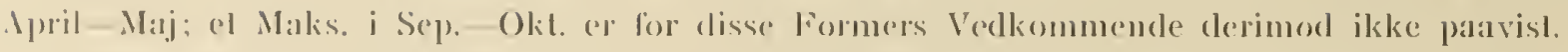

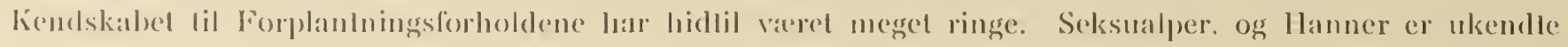

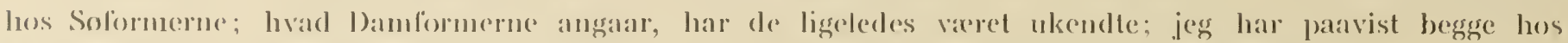

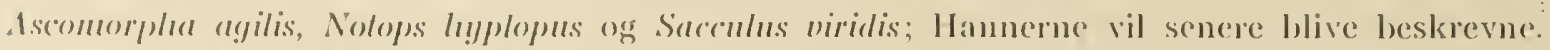

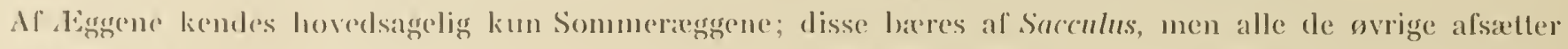
dem enten paa andre l'lanklonorganismer eller har pelagiske dig udstyrede med Sveveapparater (Ploesoma HIII/s(mii).

\section{Gastropus.}

Slaxglen indbefaller lo Arler, G. mimor Rousselel (1)amlorm) og G. slylifer lmh.

\section{G. slylifer $1 \mathrm{ml} \mathrm{l}$.}

Weber 98. Pl. 24, Fig. 14.

fi. s. er parast i alle de undersogte Soer; den viser sig i Slutningen af Maj Tp. c. 14 og forsvinder igen i Okt.Nox. Tp. c. 11-7; den har sikkert sit Maks. og sin Seksualper. omtrent ved Vandets hojeste Tp., men da Mangden, lwori Arten er optrandt i alle vore storre Suer, altid har veret meget ringe, er de ikke blevet paaviste.

Ved Damundersogelsen 98 paavistes G. s. i Frederiksborg Slotssø og i Dammene 6-7-8 og 9 o: alle Damme med centrale regetationslirie Partier. Da flere af disse Damme er ganske smaa og kun 1-2 M. dybe, er (let indlysende, at det ikke er Vandmassens Størelse, men kun en vegetationsfri Flarle, der er en af Hovedbetingelserne for dens Trivsel. G. s. viser sig ogsa her i Maj og forsinder Okt.-Nov. Maks. falder overalt i Juli og Begyndelsen af Aug., men heller ikke her er det lykkedes mig at paavise Seksualper. Arten er i orrigt lunden i talrige jydske Hedesøer og Smaasøer i Silkeborgterrainet, hvor len $98{ }^{27}$ i7 optraadte med et stort Maks.; i Slutn. af Maj var den alm. i Madumsø og i Store Øxesø nar Aalborg.

Maks. falder gerne sammen med Ceralimm hirmudinella's; den lever for en Del af denne, men i øvigt iklie saa udelukkende af Flagellater som dens Slaeghninge; den gør ogsaa Jagt paa Anuraer og Brachioner, som udsuges, og hvis Skaller derpaa bortkastes.

$G$. s. er lidet varierende; dog ma det fremhaves, at de større Søers lndivider gennemgaaende er større end Smaasøernes; den Farvepragt, som har gjort Dyret berømt, er særlig fremtraelende i Smaasøer og Tørvemoser med brunt Vand; Individer fra større Søer er som oftest mere hyaline.

Bevagelsen er den for hele Familien alm., langsomme Rotering om Hovedaksen; naar Zacharias (93 p. 25) siger, at den under Sromningen altid vender Bredsiden til, da er dette kun Tilfæeldet i Vanddraaber, der er saa smaa, at den ikke kan faa Plads til at vende sig, eller naar et paatrykt Dækglas hindrer normal Bevegelse. Eggene, som jeg ikke selv har set, afsattes, saafremt det er Sommerag, paa andre Planktonorganismer (Lroglena, Dinobryon); Hvilexgget, der overalt og paa hele sin Overflade er beklædt med Børster, er clerimod pelagisk (Lauterborn 98 p. 180).

Arten har en meget vid geografisk Udbredelse; (len er dog ikke paavist i Grønland, hror derimod dens Slagtning G. minor er funden (Bergendal 92 p. 45).

Alle Forf. angiver, at Artens Maks. falder i Juli-Aug.: Plönersøerne Zacharias (93 p. 26); Zürichersøen Burckhardt (00 p. 124); Oberrhein Lauterborn (98 p. 174); den er i større Søer kun Sommerform, men i Smaasøer og Damme paastaar La uterborn (98 p. 174 og $94 a$. p. 392) samt Zacharias (99) b. p. 66), at den er perennerende.

Ploesoma.

Weber har (98 p. 732) fortraffelig udredet de til Slægten Ploesoma hørende Arters meget indviklede Synonymi og Bibliografi; jeg formoder dog, at Weber har bibeholdt vel mange Arter (P. lynceum Ehr., $P$. truncatum Levander, der i øvigt menes at vere genfunden af Fulrmann 00 p. 90 i Neuenburgersøen og af 13 urckliardt 00 p. 124 i flere Schweizersøer, P. molle Kellicolt). Den taller tre sikre Arter: P. Ienli- 
culare Herrick., P. Iriacanthum Bergenel. og P. Mudsoni Imb. Af disse kan muligvis forstnaveve optracle som Panklonorganisme i Soer; den er laget i Nemenburgersee (Fulrmann o0 p. 95), sely luar jeg paavist

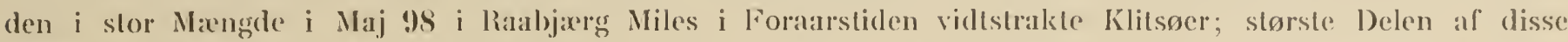
udtorres senere paa Aarot. P. triacantlum, der er yolerst alm. lier i landel, hebor lave, vegetationsfri Damme. P'lankloubeloer af storre Soers pelagiske Region er lios os kun een Art.

\section{IIndsoni I $\mathrm{ml}$ h.}

Weber 98. Tals. 24, Fiss. 11-12.

P. II. er paavist i alle de undersogte Soer, hvor den tilligst viser sig i Slutningen af Maj Tp. e. 11 og sjaldent for Iuni Tp. c. 16-18; den forsvinder i Okt.-Nov. Tp. c. 11-7; Maks. incltrelfer rimeligvis ved Vandets hryjeste Jp. Ien var overalt sjaelden og lod sig ikke paavise i hver Sommerprove; Seksualper. er stadig ukendt. Ifyppigst synes Arten al lave varet i Mlosso, men paa Grund af de faa Prover fra denne Sø kan intet nermere angives. I storst Maxngle er rlen set i Maj 98 i Madumso.

Ved Damundersøgelsen 98 blev den paavist i Dammene Nr. 6 og 7 (Virummose og Teglgaardssø), der begge har større vegetationsfri Partier.

P. H. er et graadigt Rovdyr, der lever af Planktonorganismer, særlig Ceratiun, som den bider Hul paa og udsuger.

Sommeragget er maerkelig nok undgaaet min Opmaerksomhed; det angives af Apstein (96 p. 160) os Zacharias (93 p. 35, Tab. I, Fig. 16) at vare pelagisk; det er udstyret med Svæveapparat »eine geränmige ellipsoidische Hülle von glasartigen Durchsichtigleit welche prall mit Wasser augefüllt ist" (Zacharias). Efter Apstein skal det sarlig staa paa dybere Vand og findes i Aug.-Sep.

Hvileagget er ikke kendt; paa Melosirer i Mossø 01 15/10 fandtes meget ofte et Eg med lysegult Hylster og fasthaftet i en tyk Sokkel af gullig, stivnet Gele; dette $\mathbb{E g}$, der sikkert kan henføres til et Hjuldyr, formoder jeg ma tilskrives $P$. H., der fandtes i en Del Eks. i denne Prøve.

Arten har rimeligvis en megel stor geografisk Udbredelse; den er kendt fra Finland (Levander $94 b$. 1. 25), fra talrige Lokaliteter i Tyskland, fra Schweiz (Weber 99 p. 745); fra højtliggende Alpesøer angiver Z schokke P. lyncemm og lenticulare (00 p. 294).

Alle Forf. er enige om, at P.H. er Sommerform, der viser sig i Maj-Juni, har Maks. i Juli--Aug. og forsvinder i Okt. - Nov.: Plönersøerne (Zacharias 94 b. Tab. p. 100; A pstein 96 p. 160); Rhinen (Lauterborn 98 p. 175); Neuenburgersee (Fulımanı 00 p. 95). Maks. kan øjensynlig vare meget betydeligt (\%acliarias).

\section{Ascomorpha.}

Til denne Slagt henføres kun de to Arter: A. saltans Bartsch og A. agilis Zacharias. Begge Former er meget lidet kendte og den førstnavnte næppe kendelig efter Afbildninger og Beskrivelse.

\section{A. agilis $\mathrm{Z}$ a ch.}

\section{Zacharias 93 . Tal). I, Fig. 3.}

Denne lille Form har jeg et Par Gange set i Furesø, Tjustrupso og Haldsø; den fandtes altid kun i Sommerprover ner Vandets hojeste Tp. og altid sammen med Ceralium's Maks.; den var i Proverne altid sjalden.

I 98 paavistes A. a. i Forsøgsdammene 7-9-10. I sidstnæunte meget lille Dam, der on Foraaret er vegetationsfri, men hvis Overflade senere paa Airet skjules af Potamogeton natans og Lentna trisnlea, optraadte Arten allerede i Feb., blev alm. i Marts og viste sig i April i uhyre Mrengde. Seksualper. indtraf santidig, og utrolige Masser af de hidtil ukendte Hanner indfandt sig i Flokkene. Artens Maks. faldı sammen med Notops luptopus', der dog ikke var helt saa hyppig. Begges Føde var Peridinium tabulutum og Synura uvella. I Juni-Juli forsvandt A. a. samtidig med, at Overfladen dækkedes med Vegetation. I Dammene 7 og 9, der 


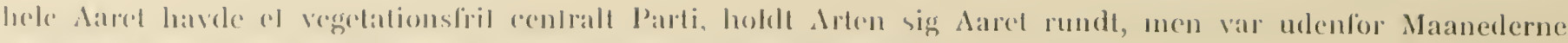

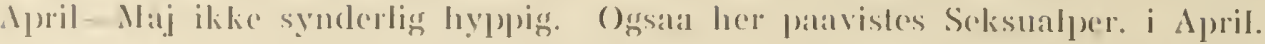

1. a. er an Dambehoer, hjemmehorende i de vergetationsfri eculdale P'artier; kun undtagelsesvis kommer

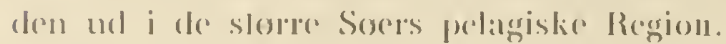

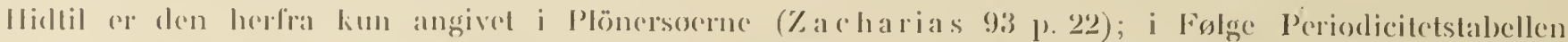

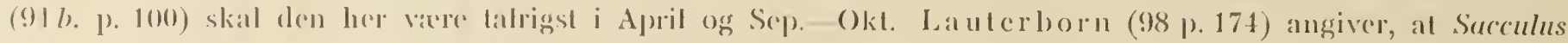
sallans Bartsch, der muligris a identisk med denne Forn, er perennerende, men hyppigst on Sommeren.

Anapus.

Angaancule denne Sleggls meget vanskelige Synonymi se Weber (98 p.75(j-59). Denne angiver to Arter: A. ovalis Brorgendial og A. lesludo Láluterborn.

\section{1. lesludo La n lerloorn.}

l'ab. I, lFig. 9, den morke l'let midt i Billedet.

Weber 98. Pl. 24, Fig. 18-19.

A. I. ('P Laged i Fureso, Esromso, 'Tustrujso og Haldso; den optraalte altid sammen med Ceratium hirundinella's Maks. ved Vandels hojeste Tp. og levede af Ceratierne; den forekom overalt kun i ringe Maengde; det lykkedes mig ilke at se Selisualperiolen saa liclt som llanner eller Eg.

Ved Damundersogelsen 9S blev denne Art ikke funden, derimod fandtes i Danmene 2 og 11, hvis Overllade begse var vegetationsdakkede fra Juni lil Nov, en mere langstrakt og højere Form, som ganske svarede til A. ovalis Bergendal (Weber 98. Pl. 24, Fig. 15-17). Denne Form har jeg aldrig set i Søerne; jeg er i dette Ojeblik i Tvivl om, hvor vidt A. lestudo og A. obulis er to Arter eller Dam-og Soform af samme Art.

\section{Fam. Asplanchnadæ.}

Familien indbefatter kun de to Slagter Asplauchonopus og Asplanchna. Forstnaevnte, der er en meget sjelden Form og endnu ikke funden her i Landet, er Danform og aldrig paavist i større Søers Plankton.

\section{Asplanchna.}

Der er af Stagten Asplanclun opstillet c. 20 Arter, al hvilke nappe mere end 4 kan siges at vare distinkte: A. priodonla Gosse, A. Brighthelli Gosse, A. Sieboldii Leydig. samt den mig ukendte A. Herrichii De Guerne. Mangel paa Kendskab til de individuelle Formforandringer, som Dyrene kan foretage under Brugen af deres forskellige IIuskelgrupper, har bevirket Opstillingen af flere Arter, og Ukendskal til Typens alm. Bygning af endnu llere. A. Briglılwelli og den her i Landet sjældne A. Sieboldii er begge Damformer; sidstnævinte har jeg kun paarist i et lille ubetydeligt Vandhul tæet op til Skolelærerboligen i Harløse, c. ${ }^{1 / 2}$ Mil nord for Frederiksborg. A. priodonla er tillige Planktonorganisme i støre Søer.

Slagten er med Hensyn til de parthenogenetiske Generationer levendefødende; til ret bestemte Aarstider dannes efter Befrugtningen (Erlanger \& Lauterborn 97 p. 452) Hvileaggene, som er af meget forskellig Bygning hos de forskellige Arter; adskilligt kunde tyde paa, at de er pelagiske. Der er rimeligvis, i alt Fald hos Damformerne, to Seksualperioder, en om Foraaret og en om Efteraaret; under disse er $\sigma$ meget alm. Hos A. priodonta har jeg parist en meget gennemgribende Temporalvariation (00 p. 611$)$, som vil blive narmere omtalt og illustreret i dette Arbejdes anden Del.

\section{A. priodoula Gosse.}

Tab. IV, Fig. 37 og Tab. IX, Fig. 108 t. v. f. n.

Weber T. 16, Fig. 7 .

A. $p$. er panvist i alle de undersogte Soer og i Hovedmassen af Proverne; den er perennerende. I 01 er Seksualper. og Maks. ikke paavist i Fureso, Mosso og Julso; Maks. blev derimod i Tiden fra 01 18/5 til 22/6 Tp. 13-15 


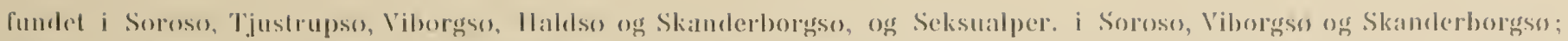

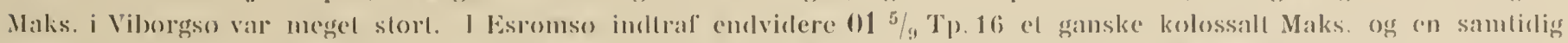

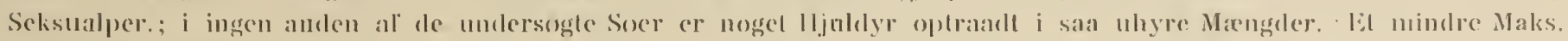

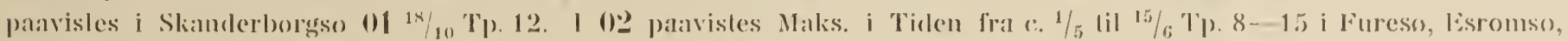
Soroso, Tjustrupso, Viborgso, llaldso og Skanderborgso; i Viborgso fandles samtidigg en Solksualper.

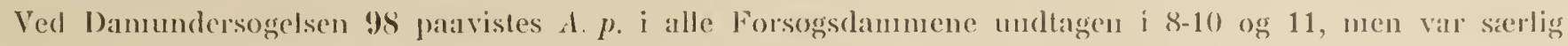
talrig i Frederiksborg Slotsso samt i Dammene Nr. 2-3-4-5-(j-7. Arten vall overalt perennerende og dicyklisk med Seksualper. i Maj-Juni og Sep.-Okt., dog mest udpraeget om Foraaret. A.p. var i Alm. kun til Stede i rimge Maengde on Sonmeren, men derimod et af de hyppigst forekonmende Hjuldyr on Vinteren.

Hanner kan parvises hele Sommeren, og i Dam Nr. 4 har jeg ogsaa set enkelte Eks. i Dec.--Jan.; Hannernes Antal pai disse Aarstider er dog kun ringe og for intet at regne mod den uhyre Mangle, hrori de optracler i For- og Elleraar.

I Maj er den parthenogeneliske Formering overordentlig livlig; Hannerne indfinder sig, hvorpaa Hvileaggene dannes; disse findes endnu i Slutn. af Juni; Sommerens Individer formerer sig overvejende parthenogenetisk, men Formeringen tager forst Fart hen paa Efteraaret, hvorpaa Hvileag atter dannes i Okt.-Nov. Under Vinterminimummet finder man kun parthenogeneliske Ag, men disses Antal er yderst ringe, og de fleste Hunner synes at vare golde.

Det er ikke lykkedes mig at blive klar over, hvor Asplanchnernes Hvileag bliver af; meget i deres Bygning (Skiveformen, Gelehinden og Oljedraaberne hos Egget af A.priodonta, Skalstrukturen hos A. Brightwelli's Hvileagg) tyder paa, at Egget er pelagisk. A.priodonta's Hvileag er ogsaa taget pelagisk i Mosso og Tjustrupsø (se Tab. IV, Fig. 37 L. h. f. o.), men kun i ringe Mrengde; efter det store Maks. i Esromsø kunde jeg ikke paavise Hvileagget pelagisk; muligvis gaar det gennem Nettet.

A. p. er vasentlig Beboer af Damme og Smaasøer; i større Søers pelagiske Region staar den, navnlig paa klare Solskinsdage, ligesom Leptodora lyyalina ofte paa dybere Vand (10-15 M.); (Silkeborgsøerne Maj 98).

A. p. er vidt udbredt her i Landet, men optraeler, saa vidt vides, kun sjaldent eller i ringe Grad i Damme, der tørres ud; den er derfor sjælden eller mangler i Klit- og Hedesøer.

A. $p$. har en meget stor geografisk Udbredning; den angives, men son sjalden fra Grønland (De Guerne \& Richard 89 p. 13) og paristes af Fuhrmann (97 p. 531), 2400 M. o. H. i Tessin, og af Zschokke (00 p. 294) i højtliggende Schweizersøer.

Maks. Beliggenhed og Antal angives yderst forskelligt.

Et enkelt Maks. beliggende Juni-Juli-Aug. angives for Plönersøerne (Apstein 96 p. 157 og Zacharias $9($ a. p. 52); i Okt.-Nov.-Dec. for Hintersee (Seligo 00 p.61) og for lago Benaco (Garbini 95 p. 4). I Vierwaldstädtersøen finder Burckhardt $(00$ p. 118) Maks. i Jan.-Feb., Min. i April og et svagere sekundaert Maks. i Maj--Juni. Et dobbelt Maks. finder Seligo (00 p. 61) i Barlewitzersøen $7 / 4$ og $19 / 9$ samt Lauterborn (93 a. p. 10 og 98 p. 178), der med Hensyn til Asplanchnernes Selisualper. har meget urlforlige Oplysninger.

\section{Brachionida}

indbefatter de to Underordner Brachionince og Microcodince, ler begge omfatter Planlitonorganismer i storre Soel

\section{Brachionina}

indbefatter de to Fam. Hydatinida og Brachionida.

\section{Hydatinidæ.}

Herhen regnes Hydatina med H. senta Ehr. og H. brachionus (= Notops brachionus Ehr.) samt Rhinops.

Fam. taeller ndelukkende Former, der hører hjemme i mer eller mindre tilgroede Damme eller Moddingepytter; jeg har dog set Hydatina senta, navnlig Hannen, optrade som halv pelagisk Organisme i Tuelsø ved Sorø, Maj 99. Jen nings har (00 p. 82) beskrevet en pelagisk Form $N$. pelagicus fra Eriesøen. 
Fam. Brachionidæ.

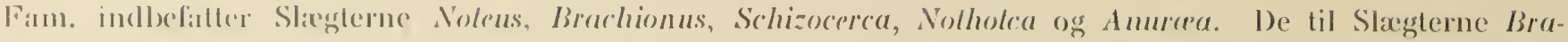
chionns, Amurea ogs Nolholer lorende Arter er underkastede en overordentlig stark Lokal- og Temporalvariation. Uliendskish til defte Forhold har bevirket Opstillingen af en uhyre Miengde Arter, der atter er

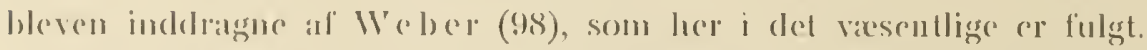

Hovedunassen opholder sig i Smalassers og Dammes vegetationsfri centrale Partier; som l'lanktonorgalnismer i storre Sorr optrader kun Arter af Slangterne Nolholea og Anurara; udpraget Planktonorganisme er kun N. longispina.

Do lleste Arter er vistnok polycykliske eller dicykliske med Scksualper. For- og Efteraar; Arter, der forekommer sali vel i Soer som i Damme, er ofte i Damme polycykliske, men i Søer kun mono- eller dicykliske. Monocykliske er Schizocerca og de fleste Nollolca-Arter; hos førstnacvite falder Seksualper. sammen med Vandets lojeste Tp., los sidsturevite (N. acuminala og strinla) ligger (len ved meget lav Tp). (2-6).

\section{Brachionus.}

Der er af Slanglen Brachionus beskrevet et meget stort Antal, c. 70 Arter, som dog alle lader sig henføre til meget faa, (. 5-6 Arter (se herom Weber 98 p. 665 og liousselet 97 p. 328).

Ingen Brachionus-Art forekomner som Planktonorganisme i større Søer; enkelte Arter, B. Bakeri O. F. M., militaris Ehr., lorer nicrmest hjemme i lave, tilgroede Damme. De to Arter B. angularis Gosse og pala er derimod karakteristiske for Snaasøernes vegetationsfri centrale Partier, hvad ogsaa Zacharias (98 b. p. 114) angiver; de spiller en vightig Rolle i de i 98 undersøgte Damme og optrxder her med to skarpt begrænsede Scksualper.

De lleste, og muligvis alle Brachionus-Arter, har to Maks. med Seksualper., der falder i April-Maj og Sep.-Okt. verl Tp. 10-12. De parthenogenetiske $\mathbb{E g}$ breres, de hunlige i et Antal af 2-6, de hanlige i Kilynger paa 12-20. Af Hvileag barer Humnen aldrig mere end et, og kun for en kort Tid; hos nogle Arter, lwor Egget er udstyret med Torne, aflegges det paa Bunden, hos andre, hvor Torne mangler, er det (B. pala) pelagisk. Lemnermann har (98 $a$. p. 183) udtalt den Opfattelse, at Brachionus-Arterne ligesom Chyldorus sphericus i Chroococcacesøer (Apstein) skal optraede limnetisk, hvorimod de i Dinobryumsøer er littorale. Dette vil ikke sige andet eller mere, end at $B$. kan forekomme som Planktonorganisme i mindre Soer, men at de ikke horer hjemme i større Soers pelagiske Region; de optræder i Smaasøer ofte med meget store Maks., men saa vel i saadanne, (ler har høje Cyanophyceemaks., som hvor disse mangler.

Visse Arter, sierlig B. Bakeri og urceolaris Ehr., rimeligvis ogsaa B.pala, er underkastede en overordentlig stærk Lokalvariation. Temporalvariationen er endnu ikke nærmere studeret, men den er rimeligvis meget udpreget hos Gruppen B. pala-amphiceros.

\section{B. pala Ehr. og amphiceros Ehr. \\ Tab. IX, Fig 98. \\ Weber 98. T. 23, p. 14-17.}

B. p. og B.a. optreder konstant i Viborsses Plankton; (len er sj:elden $01{ }^{29} / 3$ Tp. 1 , danner store Dele af Planktonet ${ }_{18}^{18} / 5$ Tp. 14 og er meget stærkt aftaget ${ }^{10} / \mathrm{T}_{\mathrm{p}} .21$; $\mathrm{i}$ de ovrige Prover optræder den enkeltvis eller $\mathrm{i}$ ringe Mængde; et lidt storre Antal findes ${ }^{14} / 10$ Tp. $12 ; 18 / 5$ var Arten midt i sin Seksualper. Den var svagt fremirxedende 02.

I de ovrige Soer er den især om Foraaret nu og da paavist i en Del Eks., navnlig i Skanderborgsø og Mosso; inde ved Bredden, men sxerlig i de mer eller mindre afsnørede Vige (Julso, Vejlesø ved Furesø) er den i Foraarstiden meget alm. Den er af II ortensen $(00$ p. 52) paavist i Ringkøbing Fjord.

B. p. optreder som bekendt under to Former: B. pala, hos hvilken Bagenden er tornfri, og B. amphiceros, forsynet med Torne, hvoraf de to sidder tiet op til Forlen og to noget højere oppe paa Legemet. Ligesom Zacharias (98 b. p. 114) og Weber (98 p. 673) har jeg set alle Overgange mellem disse to Former. I 98 havde jeg endnu ikke ret Blik for dette Forhold, og det fra Soeme indsamlede Materiale har varel 


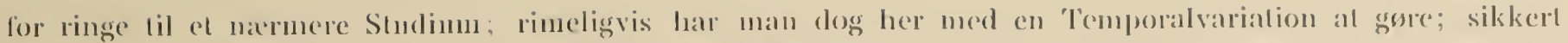

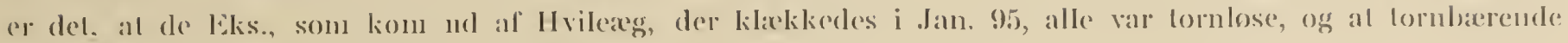
Individer absolut rar liyppiost om Sommeren.

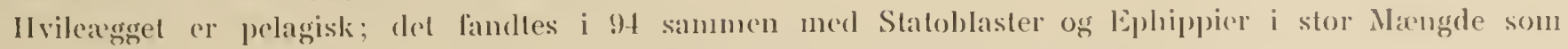

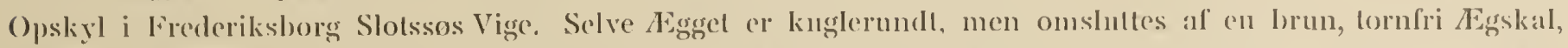

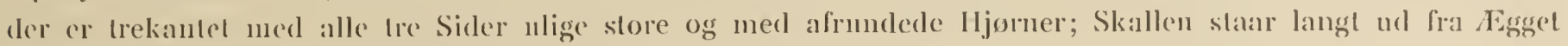

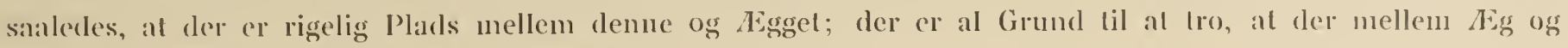
Ligskal er Lult, der betinger dets Sveveevne.

Figgene fros i Vinteren 94-95 inde i Isen sammen med Ephippier og Staloblaster, der i Vigene lavde samlet sig i saa store Masser, at Isen lik en brunsort Farve; Isen blev bragt til Laboratorict og opløet, hvorpai Hvileaggene klakkedes efter 2-3 Dages Forløb.

Arten er overnate alm. og angives fra talrige Findesteder; Zimmer medeler (99 p. 11), at den er Hovelform i Olerens Plankton; Zacharias (99 b. p. 66), La uterhorn (98 p. 174 og 94a. p.392) angiver, at Arten er perennerende, Damform og hyppig om Vinteren. Lauterborn anser Arten for polycyklisk, irlel han finder Hanner og Hvileag i Marts-Maj, i Juli og i Sep.-Okt.

Slregten txller kun een Art.

\section{Schizocerca.}

\section{S. diversicornis (Da da y.).}

Denne interessante Form er ikke paavist i nogen af de undersøgte 'Søer, men medtages her, fordi dens Forekomst kan ventes endog i ret store Søer. Den blev ved Damundersøgelsen 98 paavist i uhyre Mængde i Store Carlsbergdam, hvor dens Maks. og Seksualper. indtraf i Juli-Aug. sammen med Vandets højeste Tp. Den er for ørrigt i de forløbne Aar funden i en Del Smaasøer, alle med vegetationsfri Overflader, med rigelig Cyanophyceeudvikling og Maksimaldybder paa 6-7 M. Den er i saadanne Søer en udpraeget Planktonorganisme.

S. l. er af Zacharias $(98$ b. p. 116) paavist i Smaasøer og Damme i Holsten o. a. St.; i Oder i Tiden fra Juli til Sep. af Zimmer (99 p. 11); i Stuhmersøerne af Seligo $23 / 7$ —3/10 (00 p. 62); i Altrhein bei Roxheim fra Maj til Okt. af Lauterborn (93 p. 8) og narnes af samme (98 p. 175) som Sommerform.

\section{Notholca.}

Der er af Slagten Notholca beskrevet c. 20 Arter, som af Weber (99 p. 716 ) er Irukken sammen til fire, nemlig $N$. foliacea Ehr., N. striata Ehr., N. spinifera Gosse og N. longispina Kellicot. Sidstnaevite Art, der i Modsætning til de øvrige er udpraget Søform, er meget distinkt; $N$. spinifera er lidet kendt; til de to førstnævnte Arter har Weber henført alle de øvrige tidligere beskrevne Arter. Jeg kan her ikke ganske samstemme med Weber. Undersøgelserne ude i Naturen viser, at man i Smaadamme kan paapege to Typer: en kortere, bagtil afrundet Form, N. striata, og en læengere med bagtil udtrukket Skjold uclen særlig afsat Spids, N. foliacea; mellem disse to gives talrige Overgange, og det er muligt, at de rettest burle opfattes som Lokalformer af en og samme meget staerkt varierende Art; Beviser herfor kan dog i Øjeblikket ikke leveres. Desforuden finder man i større Søer endnu en tredie, meget smal Form, der i Planktonundersøgelserne i Alm. betegnes son acuminata Ehr., i Bagenden udstyrel med en skarpt afsat Spids; denne Form har i alle større Søer ganske samme Udseende, men er forbunden med foliacea gennem talrige Overgangsformer, som alle horer hjenme i Damme. Den opfattes rimeligvis rettest som en fra $N$. foliacea afspaltet og fikseret Søform. Foreløbig anser jeg det dog for rigtigst at beholde de tre Arter, N. striata, foliacea og acmminata.

Medens $N$. longispina har sit Maks, og sin Seksualper. i Sommerhalvaaret, har N. striata og acuminata i Modsretning til alle andre Rotiferer (leres Maks. ved meget lav Tp.; for $N$. acuminata's Vedkommende ved vi i alt Fald, at Seksualper. kan ligge ved Tp. c. $2-4$. 


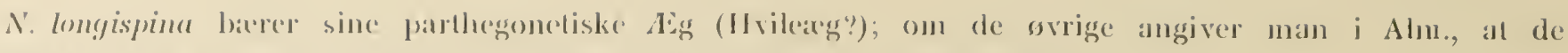

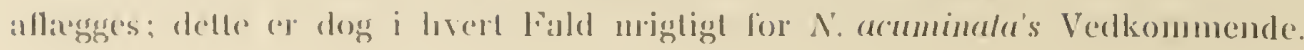

\section{N. striata Eilı.}

Wreber !8. 'Talb. 25, Fing. $16-18$.

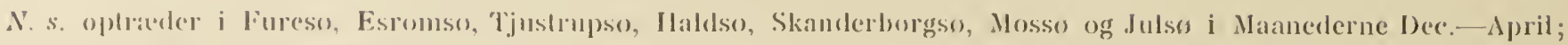

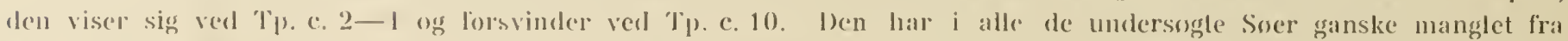

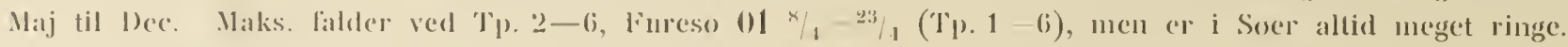

I Dammene (9\$) optratte den i Nr. 3-4-i-11. Her viser den sig i Der.; den findes under lsen, og det ikke synderlight store Maks. optraeder her lige efter, at Isen er gaaet af Vandet (Tl). 2-4); ganske enkelte

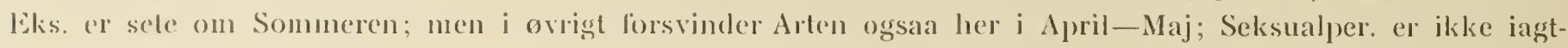
linget nogetsteds.

Samblige forl. stemmer overens i, at Arten er Vinterform: Oder (Zimmer 99 p. 11, N. labis og striata); Damplankton (Zacharias 99b. p. 65); Stuhmersøeme (Seligo 00 p. 633); Plönersøerne (Apstein 96 p. 164); Rhinen ( 1 a a u lerborn 94 a. p. 393).

I Modsetning lil de ovrige Forf. saa vel som til mine egne lagltagelser anser Lauterborn (98 p. 174) den for perennerende, men tilføjer dog, at den er hyppigst om Vinteren.

\section{N. acuminala Ehr.}

Weber 98. 'Tab. 25, Fig. 19.

N. a. er paavist i Fureso, Esromso, Soroso, Haldso, Skanderborgso og Julso i Maanederne Dec.-April; den viser sig ved Tp. c. 2-4, men forsvinder allerede i Slutn. af April Tp. 4-6; i de storre Søer er den aldrig iagttaget i Tiden Ira Maj til Dec. og er sjowlden i Vinterproverne. Maks. var overalt ringe.

1 Dammene bler den i 98 paavist i Nr. 2-3-4-6-7-9-11; i sjallnere Tilfalde lader den sig iagttage i Nor-Dec; den findes under Isen og forsvinder c. 1. Maj.

Medens jeg i 98 herken har set Selisualper. i de større Søer eller i Dammene, var jeg i 99 saa heldig at iagttage denne i Botanisk Haves Dam. $N$. a. fandtes her hele Vinteren ualmindelig talrig og var 1. Marts Tp. 2 overmaade hyppig; i de følgende 14 Dage steg Antallet uafbrudt, hvorpaa Hanneme indfandt sig i stor Mrengde; 1. April var Arten nesten forsvunden. Naar Weber (98 p.718) angiver, at Hunnerne hos Slargten Nolholca, hortset fra N. Longispina, ikke brerer Eggene, er dette i alt Fald ilke altid korrekt. I Botanisk Haves Dam bar Hunnerne i Seksualper. alle 1-2 Eg, ligesom de senere hen gik med Klynger paa 4-5 Hanxeg.

N. acuminata angives nasten altid som Vinterform: Oder (Zimmer 99 p. 11); Damplankton (Zacharias 99 b. p. 65). Kinn Apstein (96 p. 163) har i Juli fundet den i større Mrngde i Plönersøerne, men fremherer i ørrigt ogsaa, at den ellers overvejende findes i Marts- Maj. I Følge Lauterborn (98 p. 174) er ogsaa denne Art perennerende, men hyppigst i den koldere Aarstid.

\section{N. longispina líellicot.}

Tab. I, Fig. 6.

Weber 98. Pl. 25, Fig. 12.

N. I. er paavist $\mathrm{i}$ alle de undersogte Soer og horer rimeligvis til det perennerende Plankton, uagtet den er sjaelden i Vinterproverne og de tidlige Foralsprover. I Tiden fra Maj til Aug. indtræffer Artens Maks.; i Fureso falder dette i Begyndelsen af Juni Tp. 16; i Haldso ontrent samtidig Tp. 13; i Viborgsø ligeledes i Juni Tp. 17; i Skianderborgso fandt jeg forst et Maks. i Juli-Aug. Tp. 21. I Sep. tager Antallet i alle Soer af, og fra Nov.-Dec. ser man den kun enkeltris. I Tjustruj)so kunde jeg, saa længe det megtige Ceratium-Maks. varede, aldeles ikke paarise Arten. 


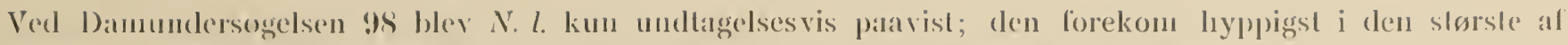
Dammene, Frederiksborg Slolsso; derimod las jeg et Par Gange fundel Arten i Mosehuller naxer Gelskov veel

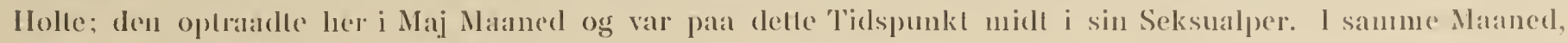
men i forskellige Aar, limdtes Maks. Og Seksualper. i Vejleso ved Holte og i Marlumsø. Hovedloestanden al

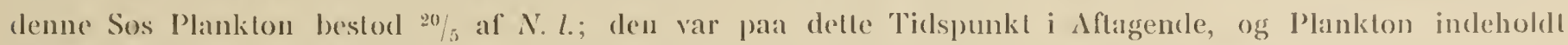

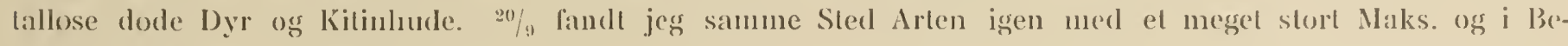
gyndelsen al en Seksualper.

Dot frengaar da leraf, al $N$. Longispina af alle de til Ordnen Brachionida horende Arter fortrinsvis or hjemmehørende i storre Soers pelagsiske Region; den er mindre liyppig i Smaasøer ogs lave Damme; lrvor den trxtles i saadanne, har disse altid et vegetationsfrit Midfelt; mellem Plantevakst traffes den ikke.

Arlen er vistnok perennerende; i støre Søer har den nixple mere end eet Maks. med een Seksualper., der incltreffer i Juni-Juli; i mindre Søer kan den i alt Fald vare dicyklisk (Madumsø). N. l., der i høj Gral afriger fra sine Slaggtninge og vistnok med god Grund kunde opstilles som en egen Slagt, er overordentligs lidt varierende.

Artens Ualbredning er uhyre; den er ikke kendt fra Grønland, men Zschokke angiver den (00 p. 295)) som Hovedform for højalpine Søer endnu 2,436 M. o. H.; Fuhrmann (97 p. 531) fra Tessin 2,500 M. o. H. Den er af Levander (94c. p. 1) angivet under Isen i finske Søer; Lauterborn (98 p. 174) har fundet den percmnerende markelig nok med Maks. om Vinteren.

Denne sidste Angivelse er ikke synderlig overensstemmende med de Resultater, jeg er kommen lil; fra følgende Søer forlyder Meddelelserne i Overensstemmelse med mine Iagttagelser: Plönersøerne (Zacharias $96 a$. p. 52) Juni-Sep., Maks. Juli; (A pste in 96 p. 163) Maks. Juli-Aug.; Neuchatelersøen Juni-Juli (Fu h r mann 00 p. 96); lago Benaco Juli (Garbini 95 p. 4); Vierwaldstädtersøen Juni-Sep. (Burckhard l 00 p. 130$)$; B., der har undersøgl denne Form meget nøje, er kommen til et ganske lignende Resultat som jeg selv; der angives Min. Jan.-Juni, Stigning med Maks. i Aug.-Sep. og Nedgang i Okt.-Nov.; Seligo (00 p.63) angiver Maks. i Juni. Det fremgaar heraf, at Lauterborn staar ganske ene med sin Angivelse om, at Arten skulde have sit Maks. om Vinteren.

\section{Anuræa.}

Der er af Slagten Anurcea beskrevet c. 30 Arter, som alle tilsammen lader sig henføre til 3 højst 4 Arter (se herom IVeber 98 p. 696). Der kan dog for Øjeblikket nappe antages mer end 3 sikre Arter, hvoraf de to, A. aculeata og cochlearis, er underkastede en overordentlig stærk Lokal- og Temporalvariation. Førstnærnte el bleven nærmere studeret af Weber, sidstnavnte for A. cochlearis' Vedkommende af Lauterborn (00 p. 412$)^{1}$ ). Den tredie Art, A.hypelasma, der afviger starkt fra de to andre og vistnok burde henfores til en egen Slagt, synes ikke at vare underkastet nogen Variation; sidstnævnte er overvejende Dam-og Moseform, de to andre Arter er derimod dels Dam- dels Planktonorganismer i større Søer; i størst Mrengde findes de dog førstnævnte Steder. Det er navnlig Dammenes Individer, der er underkastede den starke Variation; hos Soernes er saa vel Lokal- som Temporalvariationen langt ringere. Arterne er i større Søer rimeligvis dicykliske, i Smaasøer polycykliske.

A. cochlearis Gosse.

Tab. V, Fig. 58 .

Weber 98. Tab. 25, Fig. 8.

Arten forekommer i alle de undersøgte Søer og horer til det perennerende Plankton; i de fleste af Proverne er den dog kun til Stede i ringe Mangde, navnlig i den varmeste Sommertid; om Vinteren er den vel en af de hyppigst forekommende Rotiferer, men staar selv paa denne Aarstid i Hyppighed tibage for Crustaceerne og bliver aldrig dominerende; Maks. har i de forskellige Søer ligget saaledes:

1) $\operatorname{og} 03$ p. 529 .

De danske Søers Plankton. 


\begin{tabular}{|c|c|c|c|}
\hline & \multicolumn{2}{|c|}{$19(1) 1$} & 19()$^{2}$ \\
\hline $\begin{array}{l}\text { limeso ...... } \\
\text { lisrounso .... }\end{array}$ & 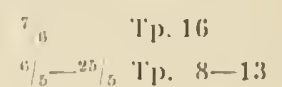 & $21_{10}=2110$ 11). 16-11 & $\begin{array}{l}\text { intet tydeligt Maks. } \\
\text { Tp. } 13\end{array}$ \\
\hline Sorross. & ${ }^{8}{ }_{5}-2 \% / 6$ T) $10-13$ & Tp. 12 & $\%(1), 15$ \\
\hline 'Yjustrujess ......... & $\left.5 / 6-21 / 6]^{0}\right) . \quad 7-13$ & & $16 / 5-7 / B$ Tp. $8-12$ \\
\hline Vilorgsso ........... & $1 N / 5 \quad$ Tp. 1.1 & & $30 / 5 \quad$ Tp. 8 \\
\hline llaldelsu............. & $\mathrm{l}^{\mathrm{p}} \mathrm{p} .13$ & & intel tycleligt Maks. \\
\hline Skinderborgso....... & Tp. 13 & & $28 / 6 \quad$ Tp. 18? \\
\hline Musso $\ldots \ldots \ldots \ldots \ldots$ & Tp. 12 & & $\mathrm{T}_{\mathrm{p}} .16$ \\
\hline Julsu $\ldots \ldots \ldots \ldots \ldots$ & $\mathrm{T}_{\mathrm{p}} .13$ & & $\left.3 / 6-2 / 6, \quad T_{p}\right) . \quad(j-13$ \\
\hline
\end{tabular}

Det vil heral ses, at der $\mathrm{i}$ alte Soeme har varet et tydeligt Foraarsmaks, beliggende ved c. $13^{0}$ C. og i 'Tiden fra c. ${ }^{15} / 5$ til 1/6. I vore dybeste Socr, Fureso og llaldsø, indtreffer Maks, sidst og i 02 gennemgaaende senere end i 01. Et Efteraarsmaks. har jeg kun kunnet paavise i Furesø og Sorøsø, hror det falder i Tiden lia ${ }_{10}$ til ${ }^{21}$ (10 (Tp. 16-11) o: ogsaa omkring Tp. 13. Narkelig nok blev i 01 i vore større Søer ingen Scksualper. paarist, rimeligris fordi denne er falden mellem Proven c. ${ }^{20} / 5$ og naste Prøve. Efteraarets Maks. er i de storre Søer ikke nar saa udpreget. Da jeg i Tiden fra $15 / 5$ til $1 / 6$ og fra $15 / 9$ til $1 / 10$ i Aaret 99 besogte de samme Soer som senere i 010 og 02 , faldt Rejsen netop i det Tidsrum, da A. cochlearis havde sin Seksualper.; llunner med Kreder paa 3-4 Hanæg blev da set om Foraaret i Viborgsø, Skanderborgsø og flere mindre jydske Soer (Vedso ved Hald, Silkeborg-Langsø og Madumsø) samt alter om Efteraaret i Viborgso.

Af Damundersogelsen 98 fremgik det, at A.c. optraadte i alle 12 Damne og til ganske forskellige Aarstider kunde opnaa meget betydelige Maks. Der indtraadte en meget tydelig Seksualperiode i Dammene 1-3-4-5-6-7-8-10-11 i April-Maj og en anden mindre udpraget i Dammene 1-2-3-5-7 i Okt.-Nov. I Nr. 6, Teglgaardsso, paabegyndtes den anden Seksualper. allerede 1. Sep. og kunde paavises endnu 1. Nov. I Nr. 5 fandtes Seksualper. i April, i Aug. og i Okt,; Hanner blev endog paaviste 1. Jan. Ogsaa i de fleste andre Damme har jeg iagttaget Seksualper. udenfor For- og Efteraar.

Vi kan altsaa slutte, at Arten i storre Soer rimeligvis er dicyklisk, om end Efteraarets Seksualper. er meget lidt fremtrædende; i Damme er den derimod vistnok som Regel polycyklisk.

I storre Soer er der set meget lidt til Hvileaggene; de optræder derimod efter en Seksualper. konstant i alle Smaadammene og er $\mathrm{i}$ øvrigt her fundne til alle Aarstider, men talrigst om Vinteren; det synes, at de i Modsætning til de fleste andre Hvilexg bres meget lange.

A. c. findes her i Landet i Vand næsten af enhrer Beskaffenhed, kun synes den at sky Moddingerand. Den findes i Smaadamme paa faa hundrede Kvadratmeter saa vel med vegetationsfri som med regetationsdrekket Overflade. I Damme, der tørlagdes i Juli-Aug., optraadte Arten allerede i Dec. (Tp. 2), efter at Regnvand og smeltet Sne harde samlet sig i Pytter paa den udtørrede Bund. Den er alm. i de vestjydske Ḱlitsøer, i Søerne red Raabjerg Mile, i Hedesoer og i Hedens Vandpytter, der tørrer ind i Juni-Juli; det er en af de faa Arter, der traffes $\mathrm{i}$ de af vore storre Aaer, der ikke danner Aføb for Søer (l. Eks. Karupaa ved Karup, Gudenaa før Mossø, Skjernaa, Vejleaa). Den er ogsaa alm. i Brakvand: Ringkøljingfjord (som Formen tecta: Mortensen 00 p. 52), Stadilfjord, Limfjorden.

Arten er overmaade stærkt varierende. Temporalvariationen er særlig bleven studeret af Lauterboru 1 det af L. undersøgte Terrain (Altrhein bei Neuhofen) udgaar der $(00$ p. 420) fra Stamformen i Foraarstiden tre forskellige Variationsrækker: 1. macracantha-lypica Rakken, 2. hispida Rrkken, 3. irrigularis Rækken. Hos den første bliver i Sommerens Løb Bagtornen stadig kortere og kortere, og Resultatet bliver 
con Form, A. terta, der ganske mangler Bagtorn; hos den anden Rakke besattes l’anseret i starligs stigende Grad med smaa, ophojede Punkler, hvoral til Shutning sterkt tornerle Individer fremgaar. I den tredie. Rackle foregaar der en stadig Forskydning al de enkelte Felter i Rygluanseret, idet den Kol, der hos de to foregianende liokker skiller Carinalpladerne ad og lober lige gennem Ixegemets Midtlinic, indenfor denne tredie Gruppe viser et linak, fordi den hojre forreste Karinalplade skyder sig nedad, hvorved Kolen bojes til venstre; derved opstaar el lium, hvor der dannes en ny l’lade, hos $I$. betegnet som $x$.

L a uterborns Undersogedser er, saa vidt vides, anstillede i lave, mer eller mindre tilgroede Smaasger og lamme, ikke i store Soer paa 10-40 Kvadratkil. med Maksimaldybder paa 20-40 M. Ved mine i 9s anstillede Damundersogelser havde ogsa jeg iagtaget de to første Variationsrakker; den tredie havle jesf derimod ikke haft Øje for; senere har jeg i 01 efter Modtagelsen af L.s Arbejde forvisset mig om dens T'ilstedeverelse, men har i ovrigt ikke naermere undersøgt den.

1 April var Stamformen den typiske i alle 12 Damme. Rakken hispida viste sig først i Juni-Juli, var almindeligst ved Vandets hojeste Tp. og var igen forsvunden i Nov. Rakken tecta opstod ligeledes i MajJuni og var i nogle Damme talrig om Sommeren, men fortrangte aldrig ganske Stamformen; i nogle I)amme $\log$ den af hen imod Vinteren, men i andre holdt den sig og var f. Eks. meget talrig i Frederiksborg Slotssø. Naar La uterborn derfor erlilerer A. tecta for saerlig Sommerform, falder Resultatet af mine Undersøgelser paa dette Punkt ikke ganske sammen med hans.

De i Søerne optracaende A. coclulearis-Individer er langt mindre varierende end Dammenes; hidtil har jeg i disse intet set til A. lispida- eller til irrigularis-Rxkken; A.tecta er derimod funden i Silkeborgsøerne, oftest som Sommerform, men aldrig i Antal, som overgik den typiske Form. Soformerne af A. coclutearis staar i det hele med et eget Prag overfor Damformerne; de er lysere af Farve, er aldrig brungule og har som oftest en lang, undertiden meget lang Bagtorn. Jeg betvivler, at man paa Søformer kan paavise den ovenfor omtalte i forskellige Retninger gaaende Temporalvariation, og formoder, at naar man i større Søers Plankton finder Slutstadierne af disse Variationsrakker, har man her snarere med Materiale at gøre, der med Tilløbene er tiltørt Soerne, end med Former, hvis Begyndelsesstadier skulde stamme fra større Søers pelagiske Region.

Det var denne Regions langtornede, hyaline A. cochlearis-Former, der fik Imhof til at opstille sin Art, A. tongispina (83 p. 470); m. H. t. den ualmindelig stærke Lokalvariation henvises $\mathrm{i}$ ørigt til Weber.

Artens Udbredelse er overordentlig stor; den er Kosmopolit i videste Forstand; selv har jeg taget den i Lagunen paa Jan Mayen, og i højtliggende Alpesøer hører den til de almindeligst forekommende Rotiferer ( $Z$ schokke 00 p. 295).

Periodiciteten angives noget forskelligt hos de forskellige Forf., dog er næsten alle enige om, at Arten er perennerende, men de store Maks. falder i de forskellige Søer øjensynlig til enhver Tid fra 15. April til 15. Okt. Om Seksualper. synes man hidtil ingen Oplysninger at have haft.

\section{Anuraea aculeata Ehr.}

Tab. I, Fig. 2.

Weber 98. Tab. 25, Fig. $1-3,7$ og $10-11$.

A. a. hører ligesom A. coclilearis til vore større Søers almindeligste Rotiferer, men er dog nappe en helt saa konstant Beboer af disses pelagiske Region som denne. Som oftest findes den kun i ringe Maengde og spiller aldrig nogen dominerende Rolle. Dens Maks. falder i de undersøgte Søer saaledes, som omstaaende Scheina (p. 148) viser.

Det fremgaar heraf, at $\mathrm{i}$ de fleste Søer indtraf Maks. 01 c. ${ }^{15} / 5$ ved Tp. c. 8 - 13 ; i 02 faldt det omtrent samtidigt og ved lignende Tp.; merkeligt er det tidlige Maks. ved Tp. 4 19/4 i Sorøso. Jeg har for denne Arts Vedkommende i de større Søer hverken i 01 eller 02 kunnet paavise nogen Seksualperiode; heller ikke i 98 blev en saadan paavist; det kan, hvad denne Art angaar, ikle siges, hvor vidt den i større Søer er mono- eller dicyklisk. 


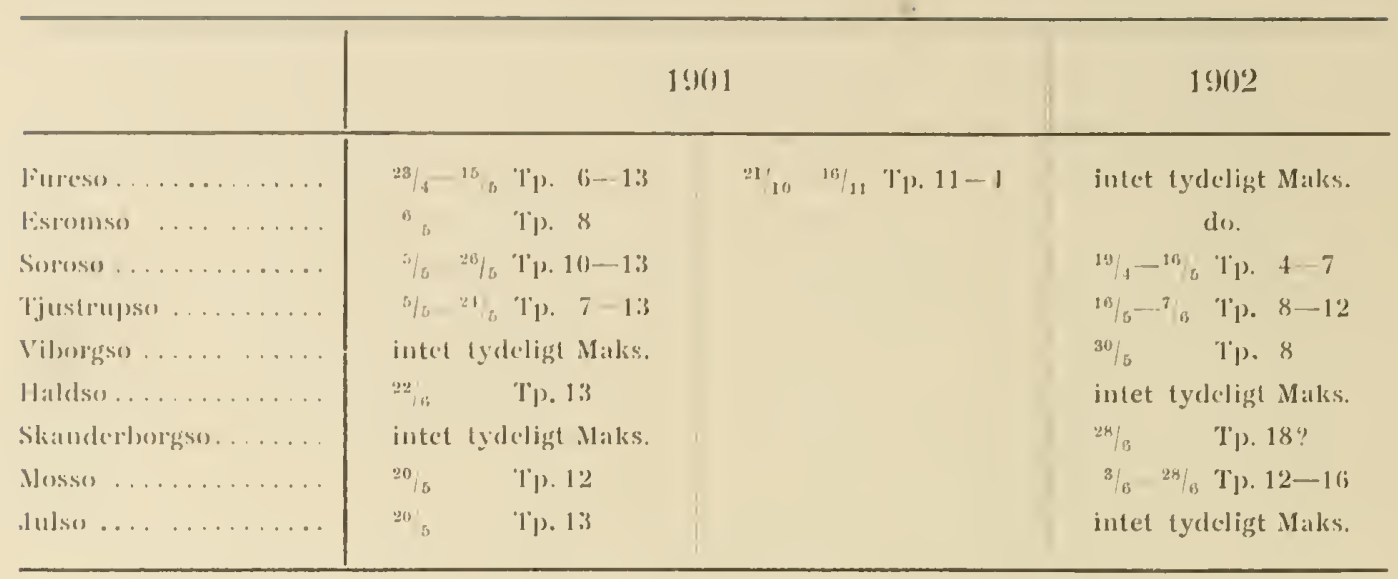

Ved Damundersogelsen parvistes den i alle 12 l)amme; den var lier perennerende med Maks. i April-Maj og med en samtidig Selisualperiode. Maks. blev ogsaa i Okt. paavist i Dammene 1-3-10. Her kan altsaa Arken med Sikkerhed betegnes som dicyklisk; der foreligger ingen sikre Beviser for Polycykli, on end colkelte af kurvernes forlob kunde berettige til en Formodning desanganende.

Hvilexg er ikke iagttagne i storre Soer; i Smaasøer og Damme optrader de derimod konstant efter lomarets og Efteranets Seksualper.; ligeson hos A. cochlearis synes de at bares meget lange.

Angalande Artens Udlbredning her i Landet grelder det samme som om A. cochlearis; den er paavist paa de samme Lokaliteter som denne, men er dog nappe helt saa alm.; i livert Fald søger man den forgaves i addsillige smai Vandhuller, hror A. cochlearis aldrig synes at mangle; ligesom denne hører den i de støre Soer mere hịenme i Littoralregionen end i den pelagiske Region; den er af Mortensen ( 00 1). 52 ) paravist i Ringkobingfjord.

Arten varierer overordentlig stierkt saa vel lokalt som temporalt; men ligesom for A. cochlearis' Vedkonmende er hegge Slags Variationer langt mere fremtradende i Snraasøer og Damme end i store Søer.

Welber henforte 14 Former, tidligere beskrevne som særskilte Arter, til den enkelte Art A. aculecta; alle disse Fonner, sarlig valga Ehr., brevispina Gosse, curvicornis Ehr., serrulata Ehr., falculata Ehr., testudo Ehr. o. a., har ogsaa jeg fundet, men kun i Damme. A. serrulata er nøje knyttet til Sphagnum-Moser med meget brunt Vand, hvor den findes hele Aaret, uden at der i øvrigt $\mathrm{i}$ disse nogen Sinde forekommer andre A. a.Former end netol denne ene; af denne Form har jeg set Hunner baade med Hunæg, med Hanæg og med Hvilexg; da den synes karakteristisk for Splagnum-Moser og aldrig synes at gaa over'i den typiske A. aculeata, er jeg nærmest tilbojelig til at betragte den som en egen Art.

Andre Arter, sarlig A. brcvispina, optræder kun om Sommeren, og i samme Dam kan man fra Foraar lil Sommer paarise denne Forms Udvikling fra A. aculeata; af $A$. $h r$. kender jeg kun Hunner med parthenogenetiske Hunxg og Hanxg.

A. valga, hvis Bagtorne er ulige lange, optræder særlig, samtidig med at $H$ vileæggene dannes, og Hovedmassen af de Hvilexg-bærende Individer tilhører som oftest denne Form.

De allerfleste af disse Former forsvinder hen imod Vinteren, og man træffer da kun den typiske $A$. aculeata: deres Blomstringstid er Sommeren.

Fielles for alle de støre Søers A. aculeata er det hyaline Panser og de lange, ofte meget veludviklede Bagtorne: i Anledning af disse var det, at $\mathrm{Imh}$ of opstillede sin særlige var. regalis (85 p. 325).

A. a. er Kosmopolit i lige saa høj Grad som A. cochlearis og angives fra et Utal af Findesteder. De forskellige Forf. stemmer overens i, at Arten er perennerende; Maks. angives i de forskellige Søer til noget forskellig Tid, dog altid indenfor April-Okt. Lauterborn (98 p. 180) fandt Hvileag i Feb.—April, men desuden i Juni, og fandt ligesom jeg, at de Hvileag-barende Hunner vasentlig tilhørte A. valga. L. formoder for A. a.'s Vedkommende Polycykli eller Dicykli. 


\section{1. hypelasuma Gosse. \\ Tab. VIIl, Fig. 96. \\ Welecr. Tat). 25, rig. $1-6$.}

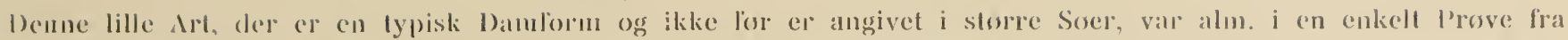

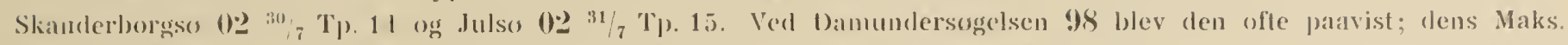
lat lor i Alur. i Slutungen al Juli, noget senere end de andre Anuraees lorste Maks.

\section{Microcodina}

indbefatter de to Fantr. Microcodider og Flosculariode.

\section{Microcodidæ.}

Til denne lille Fam. henregnes kun to Slaegter, Microcodides og Microcodon, begge Dambeboere; Microcodon clants Ehr. er af A pstein $\left(96\right.$ p. 157) i en enkelt Prøve fra ${ }^{20 / 5}$ angivet som Planktonorganisme i Ratzeluurgersee, hvor den fandtes i nhyre Miengde. Vi moder her det atter og atter tilbagevendende Frnomen, at Rotifererne i deres Seksualper. ofte fra Liltoralzonen spredes ud over den pelagiske Region; den er her i Landet en lyppig Damforn, hvis Maks. ligger i Maj-Juni; om Forplantningsforloldene vides intet; den er her saa lirlı som andetsteds Planktonorganisme i større Srer.

\section{Flosculariadæ.}

Hovedmassen af de herhen horende Arter er, hvad de udvoksne Hunner angaar, fastsiddende, alle Hannerne samt Hunnerne i Ungdomsstadierne er fritsvommende, men hører vasentlig hjemme i smaa, tatbevoksede Damme.

\section{Floscularia.}

Af Slagten Floscularia angives tre pelagiske Former hjemmehørende sely i de støre Søers pelagiske Region, nemlig F. mulabilis Bolton, F. pelagica Rousselet og F. libera Zacharias. Arterne traenger alle til en narmere, kritisk Undersøgelse; om deres biologiske Forhold vides saa godt som intet. Markelig nok har jeg herhjemme hidtil kun set $F$. libera, men maa befrygte, at jeg har overset de andre; da disse, saafremt de er distinkte Arter, utvivlsomt findes her, har jeg for fremtidige Undersøgelsers Skyld opført Littr., med hvad der i ørrigt er kendt om dem.

\section{F. libera \% acharias. \\ Tab. III, Fig. 28. \\ Zacharias $94 a$. Tab. Il, Fig. 5.}

F. l. er paavist i Furesø, Esromso, Tjustrupso, Viborgso, Skanderborgsø og Julso, dog altid kun i Sommerhalvaarel samt kun i enkelte Prover og som oftest i ganske enkelte Eks.

$F$. l. er rimeligvis en konstant Sommerbeboer af vore større Søers pelagiske Region, men overses let paa Grund af $\sin$ overordentlige Hyalinitet og ringe Storrelse; jeg har aldrig haft tilstrakkeligt levende Materiale til en nxrmere Undersøgelse; den er, saa vidt vides, hidtil kun funden af Zacharias (94 $\alpha$. p. 83) i Plönersøen, hvor den optraadte i faa Eks. ${ }^{22} / 9$; den markelige, hjæertedannede Form paa Fodens bageste Afsnit gør alen let kendelig.

\section{F. mulabilis Bolton.}

Hudson \& Gosse 86. Tal). 3, Fig. ‘2.

$F$. m. er hidtil ikke funden her i Landet.

Den skal efter Zacharias $(98$ b. p. 110) vare alm. i Smaasøer og Damme, hvor den ogsaa skal findes om Vinteren (99 b. p. 65). Den paavistes af Lauterborn (93 a. p. 9) i Altrhein i Aug. - Sep., af Bilfinger. (94 p. 36) ved Stutgard; af Levander i Finland (94 b. p. 13) og af Jennings (00 p. 74$)$ i de store ame_ rikanske Søer; den angives af Lauterborn (98 p. 17t) at høre til Sommerformerne. 
I. p. er hidlil ikke parvist her i Landel.

Den blev furst funden af Rousselel pelagisk i en lille So ner Keston Common og blev senere genfunden

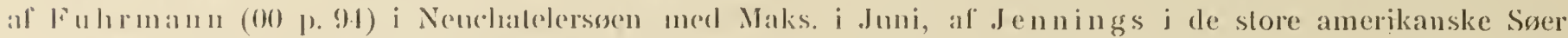
(0) p. 7.1) og af Lovander i lavvand ved kylö, linland (!) b. p. 13); den angives af Lauterborn (98 p. 17t) som Sommerlorm.

\section{Melicertida}

indbelatter de tre Fam. Melicertide, Predalionide og Pterodinide, hvis Slagglskab endnu ikke er fast begrundet.

\section{Melicertidæ}

bestan an overvejende fastsiddende Hjnldyr; kun en enkelt Slaegt er fritsvømmende og pelagisk selv i storre Soer.

\section{Conochilus.}

De to til Slacglen Conochilus horende Hovedformer C. volvox Ehr. og C. unicoruis Rousselet danner begge fritsvommende Kolonier; den første er sæerlig karakteriseret ved at have to Antenner, sidstnevnte ved at Anlennerne her er sammenvoksede til en; C. v., der angives at vare udpræget Damform, skal danne Kolonier paa indtil 100 Individer, C. u., der sxerlig skal optræde som Planktonorganisme i større Søer, paa kun 3-7 Individer. Alle de af mig iagltagne Conochilus-Kolonier har indeholdt talrige, 50 til 100, Individer, og overall, hror jeg har undersogt dem, har jeg fundet to Antenner. Jeg maa derfor formode, at jeg har haft C. volvox for mig.

\section{C. volvox Ehr.}

Tab. II, Fig. 22. 4 Enkeltindivider.

Huds on \& Gosse 86. Tab. 8, Fig. 3.

Arten er paavist i alle Suer og er vistnok perennerencle; den viser sig i Furesø, endnu medens Søen er tillagt, og havde et Maks. $01^{7} / 6$ Tp. 16, hvorpaa Arten igen tog af og kun optraadte enkeltvis; i 02 paavistes sammesteds en Seksualper. ${ }^{17} / 6$ Tp. 14. Arten havde et kolossalt Maks. ${ }^{23} / 5$ Tp. 9 i Esromso og $023 / 5$ Tp. 7 i Haldso. Maks. synes saaledes at ligge i Maj-Juni Tp. 9-14.

198 blev C. v. paarist i 7 af Forsøgsdammene; den havde et kolossalt Maks. i Juni i Teglgaardssø.

De to Arter, C. volvox og C. unicornis, er sikkert ofte sammenblandede; begge har en meget vid geografisk Udbredelse; C. volvox er funden i Grønland (Bergendal 92 p. 20).

C. unicornis navnes i Alm. som Søbeboer; dog angiver Zacharias (99 b. p. 65) at have fundet den i Damme om Vinteren; begge Arters Maks. synes hyppigst at falde om Sommeren. Fuhrmann (97 p. 530 ) har parist den i alpine Søer c. 2000 M. o. H.

C. nalans Seligo.

Tab. III, Fig. 3.) overst.

Tubicolaria natans.

Seligo 00. Tab. 9, Fig. 7.

Seligo har (00 p. 60) beskrevet en Melicertide under Navnet Tubicolaria natans; den angives at vare en enlig levende Planktonorganisme, der svommer rundt med Bagenden fremad; den har lo efter Tegningen meget lange Antenner.

Jeg har i Esromsø saa vel $01{ }^{29} / 6$ Tp. 15 som i Tiden fra 02 $13 / 5$ Tp. 8 til 13/6. Tp. 13, men i øvrigt ikke i senere Prover, fundet en fritlevende, enlig Melicertide, karakteriseret ved sine to usadvanlig lange og meget bevegelige Antenner; Dyret var omgivet af et stori, hyalint Gelehylster; i dettes Bund fandtes ofte $1-3 \mathrm{Ag}$. 


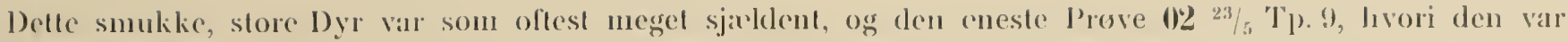
lalrigr, var desvare konserverel og alle Dyrene sterkl kontraberede; nogen nicrmere Undersogelse var unuligs.

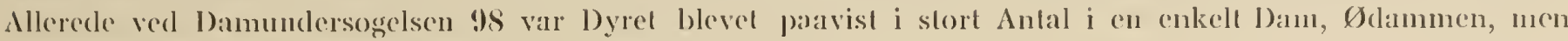
den blev den Giang ikle narnere undersogt; senere loen sogle jeg den forgares.

Samtidig med C. n. optriadle i Plankton et stort, noget aflangr Hvileags med meget smukke Spiral-

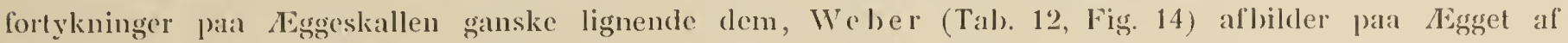
Megalotrocha spinosa; cu cnkell Gang saa jeg del fiestet til Dyrets Bagende.

\section{Pedalionidæ.}

Fam. indbefatter i (len (99 p. 142) givnc Begransning de to Slagter Triarthra og Pedalion, af hvilke sidstncernte aldrig er funden i storre Søers pelagiske Region; den hører hjemme i Smaasøers og Dammes centrale Particr og blev red Damundersogelsen 98 paavist i to Damme; den er saerlig alm. i Langedam, Praestevang ved Hillerod og i Kirsten Pils Kildedam, Dyrehaven; Maks.: Juli-Aug. (cfr. i ovrigt Levander 94 d. p. 1 og Cilaus 95 1. 13).

Triarthra.

Af Slagten Triarthra er der beskrevet c. 9 Arter og Varieteter, hvoraf dog nappe mere end tre, højst fire Arter anerkendes, nemlig: T. longiseta Ehr., T. mystacina Ehr., T. breviseta Gosse og T. brachiata Rousselel; de ovrige er sikkert enten Former af disse eller utilstrakkelig beskrevne. Ligesom We ber (98 p. 408 ) er jeg i Tvivl om T. mystacina er artsforskellig fra T. longiscta, men opforer den lorelobig som egen Art, sæerlig paa Grund al den maerkelige Mundbygning. Kun T. longiseta er Planktonorganisme i vore storste Søer; de ovrige er alle Damformer. T. brachiata (Rousselet 01 p. 143) er Damform og paavistes i 98 i tre af de undersøgte Damme.

Hanæg og parthenog. Hunæg bæres fasthaftede til Legemets Bagende; om Hvileagget se under T. longiseta.

\section{T. longiseta E hr.}

Tab. I, Fig. 4.

Weber 98. Tab. 17, Fig. 3.

T. $t$. er funden i alle de undersogte Søer og i nasten hver eneste Prove; den er perennerende. I Furesø, Esromso, Sorosø, Skanderborgso og Mosso er der 01 i Tiden fra $5 / 5$ til $2 \%$ T p. $10-14$ paavist Maks. med tilhorende Seksualper,; i Juni-Juli tager Arten af, men bliver hen paa Efteraaret noget hyppigere; et egentligt Maks. lader sig dog ikke paavise saa lidt som nogen Efteraars-Seksualper.; i 02 blev et stort Maks. og Seksualper. iagttaget i Esromso 23/5_ ${ }^{13} / 6$ Tp. 9-13 og Tjustrupsø $7 / 6$ Tp. 12; om Vinteren horer den til de hyppigst forekommende Rotiferer, men saas dog ikke saa tit som Polyarthra og Anuraea cochlearis.

Den paavistes i 98 i alle de undersøgte Damme; ogsaa her var den perennerende med Min. midt om Vinteren og Midtsommer. I alle Dammene optraadte et tydeligt Foraarsmaks., der varede fra $15 / 4$ til $15 / 5$, og som overalt faldt sammen med en meget markeret Seksualper, hvor Humnerne bar talrige Hanag, og Hannerne var overmaade hyppige; ligeledes lod et tydeligt Efteraarsmaks. sig paavise i alle Dammene, men Seksualper. blev kun iagttaget i 1-4-6-7. Den er af Morte nsen (00 p. 52) paavist i Ringkøbingfjord.

Man kan af de foreliggende Fakta med ret stor Sandsynlighed slutte, at Arten her i Landet overvejende er monocyklisk i størıe Søer, nen dicyklisk i Smaasøer og Damme; Beviser for Polycykli er hidtil intetsteds givne.

Hunaggene bares i et Antal af 1-3, Hanæggene i en Klynge paa 10-12; disse er overmaade smaa, ligesom Hannerne vistnok er de mest reducerede af alle Hjuldyrhanner. Hvilexgget synes derimod ikke at bares; det findes altid, ligesom Asplanchnernes Hvilexg, inde i Moderdyret; det er sort og ongivet af et Lag store, hyaline luftyldte (?) Kamre. Det er aldrig parist i Plankton, men man maa efter dets Bygning formode, at det er pelagisk; det findes til meget forskellige Aarstider, men er hyppigst om Vinteren og i Juni. 


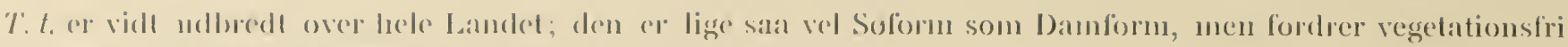
V'andarealer; mellem Plantevelkst forekommer den ikke.

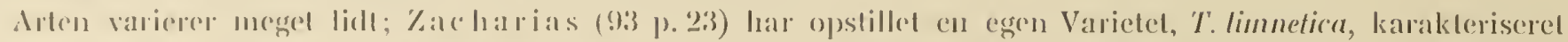

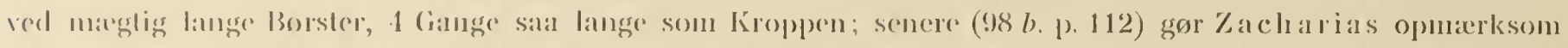

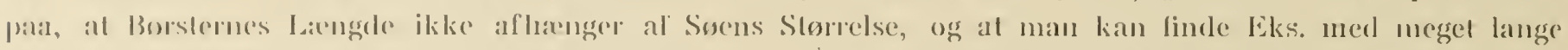
Borster i Smatsuer. Dette er rimedigris rigligl, men for at dame sig en begrundet Mening herom, maa man ratake over Malcriale indsamlet samlidig fra de lorskellige Lokaliteter; saafremt Materialel er. indsamlet lil lorskedlige Aarstider, lan man ikke lage Ilensyn til en mulig Tromporalvariation; Jagttagelser fra finresoen tyder besteml paa, al der m. H. I. Tornenes Laengde lader sig parvise en saadan.

T. l. har ch overordentlig vid geogratisk Udloredning; den er parist i Gronland al De Guerne d Ri(hard (89) p. (3:30) og ar Hovedlorm i hojlliggende alpine Soer (Zschokke 00 p. 294).

Den angives ofte som perennerende, men af adskillige Forf. som manglende i Sommermannederne, en Angivelse, som fiemkonmer ved, at man ved Undersogelserne kun har anvendt Vertikalprøver.

On Periodiciteten har man haft megel lorskellige Opfattelser, livad der er saa meget des markeligere, som den i vore Soer synes at forlobe markverdig ens.

For Pönersocrnes Vedkommente linder Zacharias (96a p. p2) Maks. i Midten af Okt, medens Apstein (96 p. 159) har meget forskellige Angivelser fra de forskellige Aar. I Stuhmersøerne (Seligo 00 p. 60) skal Min. ligge om Vinteren, men Maks. i den ene So i Maj og i den anden i Juli. I Neuchatelersøen fincler Fulumann (00 p. 95) Maks. i Juli; i Oder (Zimmer 99 p. 11) optracler T. I. April-Nov. I Rhinen falder Maks. (Lauterborn 98 p. 179) i Marts-April og i Slutn. af Juli-Okt.; L. meddeler, at han endog fandt Efteraarsmaks. merl Seksualper. i en Koloni, der levede i en mørk Brønd. I Katzensee falder Maks. (Amberg 00 a. p. 50) i Feb., hrorpaa Arten forsvinder hele Sommeren. I Vierwaldstädtersøen kan Burckhardt ( $(00$ p. 12t) paavise Min. Olit. og Maks. Jan.-Feb., hvorpaa følger et Min. i Marts-Maj og et svagere Maks. i Juni-Okt.

De yderst forskellige Resultater skyldes rimeligris ufuldkomne Undersøgelsesmethoder.

\section{Pterodinidæ.}

Til denne Fam. henføres de to Slægter Pompholyx og Pterodina; sidstnævinte Slægt er hjemmehørende i vegetationsrige Damme, sjæeldnere i Smaasøernes vegetationsfri centrale Partier: i Plankton fra større Søer er den aldrig paavist.

\section{Pompholyx.}

Denne markelige Slægt indbefatter to Arter, P. complanata Gosse og $P$. sulcata, af hvilke førstnæernte er alm. i Smaasøer, hvor den ofte findes sammen med P. sulcala; den er her altid Midtvandsform. Begge Arter bærer Eggene, der hver for sig er stilkede paa en lang Ficllesstilk, som gennem et Hul i Bagenden sæenker sig ind i Legemet. Stilken kan skydes ud og ind. Hunnen barer 2-3 Hunæg eller $4-6$ Hanæg. Hrileagget er ukendt.

Mak.s. og Selisualper. falder sammen med Vandets højeste Tp.; Lokal- og Temporalvariation er ukendte.

\section{P. sulcata $\mathrm{Hu}$ ulson.}

Tab. VIII. Fig. 96

Hudson \& Gosse. Tab. 27, Fig. 2.

$P$. s. er paavist $\mathrm{i}$ alle de undersøgte Soer; det er en agte Sommerform, der forst viser sig i Slutningen af Maj. Maks., der sjæeldent er synderlig stort, paavistes i Fureso 01 7/9 Tp. 16, Esromso $20 / 7$ Tp. 17, Soroso $9 / 8$ Tp. 21 , Skanderborgso, hror Maks. var ualmindelig stort, og hvor Sekualperioden blev paavist, "\%/8 Tp. 23. I Okt. forsvandt

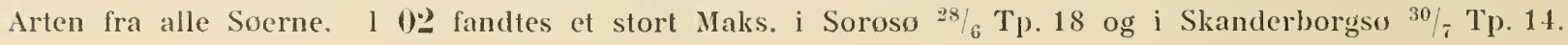


Ved Damundersogelsen parvistes Arten i alle de storre Damme ined vegetationsfri Partier, nemlig $1-6$ og 7 , og i dem alle faldt Scksustper. samticlig, nemligs $1 / 7-15 / 7$; i de mindre Damme aflostes Arten af $I^{\prime}$. complanata.

I.s. lindes ikke hyppigl angivet i Planktonarbejelerne; den er paavist i Dobersdorfersec o. a. (Apstein 96 p. 161) April til Nov. med stort Maks. i Juli; i Neuenburgersec (Fulımann 00 p. 96); i Stuhmersøerne (Seligo 00 p. (11), hvor Arten endnu er funden i Dec.; i Rhinegnene (La uterborn 98 p. 175). Alle Forf. angiver nasten ganske samme Periodicitet som Apstein og jeg.

ALMINDELIGE BEMARKNINGER.

Plankton=Rotatoriernes Forekomst i de undersøgte Srer. ')

\begin{tabular}{|c|c|c|c|c|c|c|c|c|c|}
\hline & Fureso & Esromsø & Sorøsø & $\begin{array}{c}\text { Tjustrup- } \\
\text { sø }\end{array}$ & Viborgsø & Haldsø & $\begin{array}{c}\text { Skander- } \\
\text { borgsø }\end{array}$ & Mosso & Julso \\
\hline Synchæta tremula ........ & + & + & $(+)$ & $(+)$ & + & $(+)$ & $(+)$ & $(+)$ & $(+)$ \\
\hline - pectinata $\ldots \ldots \ldots \ldots \ldots \ldots$ & $(+)$ & $(+)$ & $(+)$ & $(+)$ & $(+)$ & $(+)$ & $(+)$ & $(+)$ & $(+)$ \\
\hline Polyarthra platyptera ............. & + & + & + & + & + & + & + & + & + \\
\hline Mastigocerca capuzina $\ldots \ldots \ldots \ldots \ldots \ldots$ & $(+)$ & $(+)$ & $(+)$ & $(+)$ & $(+)$ & $(+)$ & $(+)$ & $(+)$ & $(+)$ \\
\hline 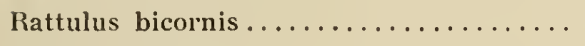 & $(+)$ & $(+)$ & $(+)$ & $(+)$ & $(+)$ & $(+)$ & $(+)$ & $(+)$ & $(+)$ \\
\hline Coelopus tenuior .................. & $(+)$ & & & & & & $(+)$ & $(+)$ & $(+)$ \\
\hline Gastropus stylifer $\ldots \ldots \ldots \ldots \ldots \ldots \ldots$ & $(+)$ & $(+)$ & $(+)$ & $(+)$ & $(+)$ & $(+)$ & $(+)$ & $(+)$ & $(+)$ \\
\hline Ploesoma Hudsoni................. & $(+)$ & $(+)$ & $(+)$ & $(+)$ & $(+)$ & $(+)$ & $(+)$ & + & $(+)$ \\
\hline Ascomorpha agilis $\ldots \ldots \ldots \ldots \ldots \ldots$ & $(+)$ & & & $(+)$ & & $(+)$ & & & \\
\hline Anapus testudo................... & $(+)$ & $(+)$ & & $(+)$ & & $(+)$ & & & \\
\hline Asplanchna priodonta............... & + & \pm & + & + & + & + & + & + & + \\
\hline Brachionus pala $\ldots \ldots \ldots \ldots \ldots \ldots$ & $(+)$ & $(+)$ & $(+)$ & $(+)$ & \pm & $(+)$ & t & + & $(+)$ \\
\hline 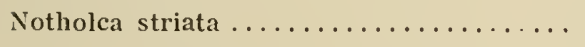 & $(+)$ & $(+)$ & & $(+)$ & & $(+)$ & $(+)$ & $(+)$ & $(+)$ \\
\hline - $\quad$ acuminata.................. & $(+)$ & $(+)$ & $(+)$ & & & $(+)$ & $(+)$ & & $(+)$ \\
\hline - longispina................. & + & + & + & + & + & + & + & + & + \\
\hline 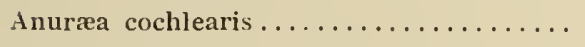 & + & + & \pm & + & \pm & $f$ & + & + & $t$ \\
\hline $\begin{array}{l}\text { aculeata } \ldots \ldots \ldots \ldots \ldots \ldots \ldots \\
-\quad \text { hypelasma } \ldots \ldots \ldots \ldots \ldots\end{array}$ & + & + & + & + & $\mp$ & + & $\begin{array}{c}+ \\
(+)\end{array}$ & + & $\begin{array}{c}+ \\
(+)\end{array}$ \\
\hline Floscularia libera ................ & $(+)$ & $(+)$ & & $(+)$ & $(+)$ & & $(+)$ & & $(+)$ \\
\hline $\begin{array}{c}\text { Conochilus } \\
-\quad \operatorname{volvox} \ldots \ldots \ldots \ldots \ldots \ldots \ldots \ldots \ldots \ldots \ldots\end{array}$ & + & $\begin{array}{c}+ \\
(+)\end{array}$ & $(+)$ & + & + & + & $(+)$ & $(+)$ & $(+)$ \\
\hline Triarthra longiseta $\ldots \ldots \ldots \ldots \ldots \ldots$ & $t$ & + & + & + & + & $t$ & + & + & + \\
\hline Pompholyx sulcata . .............. & + & + & + & + & + & + & + & + & + \\
\hline
\end{tabular}

Af vedlagte Schema vil man se, at der i de undersøgte Søer er paavist 23 Arter af Rotiferer, af hvilke den overvejende Del er paavist i hver enkelt Sø. Kun Coelopus tenuior, Ascomorpha agilis, Anapus testudo, Brachionus pala, Notholca striata og acuminata, Anurea hypelasma, Floscularia libera, Conochilus natans forekommer sporadisk. Hovedmængden af disse Arter er udpragede Damformer, og naar det har været nødvendigt at optage dem nellem vore Søers Planktonorganismer, er dette kun et af de mange Beviser for, i hvor høj Grad vore Søer har Dammenes Karakter; kun Anapus testudo, Notholca acuminata og Floscularia libera kan maaske betragtes som mere udpragede Søformer, der blot paa Grund af deres Lidenhed og Sjældenhed er bleven noget oversete.

1) Om Tegnenes Betydning se p. 56. 
De orrige er de samme Arler, der overalt i de curopariske Sone danner det pelagiske Rotifersamfund;

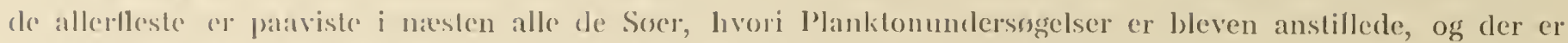

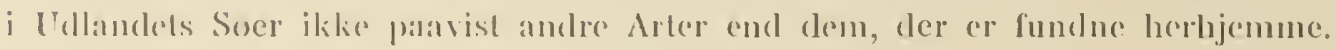

Det palagislie Rotilersamlumel symes overall i Europa at omfatte de samme Arter, aler atter lover for sig

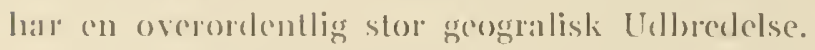

Skont Rotilorerne nass Crustacene or ten vightigste Plankton-dannende Dyregruppe herhjemme saa vel som i Udlandet, er deres Betydning som saalan, i alt Fald i vore Soer, kun ringe, og Crustaceernes langt underlegent.

betle gackler serrlig alle de periodisk forekommente, monocykliske liotiferer, livoraf de allerfleste er Sommerlormer, der viser sig i Maj--Juni og forsvinder i Okt; deres Maks. og Scksualper. falder sammen mod Vamdets hojeste 'Tp. (herhen horer Mastigocerca capuzina, Rattulus bicornis, Gastropus stylifer, Ploesona IHulsoni, Intpus testudo, Floscularia libera og Pompholy.x sulcala); kun to er Vinterformer cller meget tidlige lomatrslormer: Notholea armminata og strinta. Alle disse Rotiferer, maske log med Undtagelse af Pompholyx sulcutu, optrater, saa vislt vi forelobig ved, overalt i vore storre Søer kun i ringe Mæengle. De mangler tolalt i en letydelig Del al Aaret, men selv i Tirlen for (leres Maks. bliver cle aldrig dominerende og staar i Antal langt lilbage for Crustaceerne.

Noget anderledes forholder det sig med de perennerende Rotiferer; man maa formode, at en Del af disse ogsaa i store Soer er dicykliske, men hos mange af dem er Elteraarets Maks. og Seksualper. enten kun svagt fremtradende eller har slet ikke ladet sig paavise; til disse Former maa henregnes Polyarlhra plalyplera, Asplanchna priodonta, Nolholca longispina, Anuree cochlearis og aculeala, Conochilus volvox, Triarthra longisela og muligvis Synchuta peclinata. Men ogsaa disse Former er i storre Soer i den langt overvejende Del af Aaret fra Juni til c. 3 Uger efter Islosningen (c. April) gennemgaaende sjaldne og bliver indenfor dette Tidsrum kun undlagelsesvis dominerende (Asplanchnerne 01 5/9 Esromsø). Dette er derimod i de fleste af vore Soer Tillællet i April-Maj--Juni, (let Tidsrum, da deres Foraarsmaks. indtraffer; naar disse Rotiferer i Foraarsmaanederne virkelig kan opnaa en Førstestilling i vore støre Søers pelagiske Region, skyldes dette nexpe saa meget de enkelte Maks. Størrelse, men snarere, at alle disse Rotiferers Maks. indtraffer omtrent samticlig. Men yderligere skylles delte Resultat, at Maks. indtræffer paa det Tidspunkt, da Planktonmængden i del hele er ringe; Diatomeerne er ved at forsvinde, og Cyanophyceer og Ceratium er endnu ikke komne lil Udvikling. I Slutn. af Maj og Beg. af Juni danner Rotatorierne da sammen med Crustaceerne det ofte markelig rene Zooplankton, der i Maj-Juni er karakteristisk for saa mange af vore større Søer. Naar Efteraarsmaks. saa sjaelden lader sig parise, er det muligris, fordi det falder sammen med de kolossale Melosira-Malis. og maslieres af disse.

Sammenholder man Iagttagelserne fra Damundersøgelsen 98 med Søundersøgelsen 00-02, kan en Del ikke uinteressante Slutninger drages.

Vi træffer i Dammenes vegetationsfri Partier til Dels de samme pelagiske Former, som i Søerne, navnlig alle disses perennerende Arter, som i Dammene opnaar langt betydeligere Maks., altid er dicykliske og undertiden polycykliske, særlig Aspluncluna priodonta, Polyarthra plalyplera, Triartıra longisela og Synchata pectinata: Søernes periodislie Rotiferer, fornemmelig alle Sommerformerne, mangler derimod i Dammene eller opnaar i alt Fald sjældent storre Maks. her end i Søerne; le er ogsaa i Damme monocykliske.

Endvidere traffes i Smaasøers og Dammes centrale vegetationsfri Partier en hel Del Rotiferer, som enten aldrig er parviste i større Søers pelagiske Region, eller i hvert Fald her kun optræder sporadisk; herlıen hører Brachionus pala og angularis, Anurcea hypelasma, Synchata tremula, Notops hyptopus, Asconıorpha agitis, Pomplolyx complanata, Schizocerca diversicornis o. a. Jeg havde ofte Lejlighed til at iagttage, at flere af disse Former, saerlig B. pala, Syuchata tremula og Ascomorpha agilis, navnlig i Foraarsticlen optraadte med en Del Inclivider selv i vore største Søers pelagislie Region; jeg fik det Indtryk, at vi her havde med Arter at gøre, som iklie havde deres Hjem i Søernes pelagiske liegion, men som paa en eller anden Maade var 


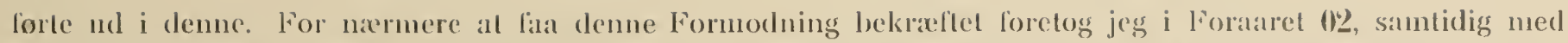
al Planklonprover loges i linesoen, tillige en Undersogelse al Planklonel i den pelagiske liegion ude i Smaasocr, eler afvander lil Furesoen, navnlig V́ejleso og Sollerodso.

Del lykkedes migs da al konslatere folgende Fakla:

1. Arter, der optraade konstant baade i de ovennavernte Smaasoer og i Furesoen, havde i Smaasnerne deres Maks. c. 3 Uger lidligere end ude i den store So (Polyarllura, Triarllura, Asplanchna).

2. Arter, der kun hørle hjemme i Smaasøernes centrale Particr, sarligg Brachiomus pala, angularis, Synchola lremula, Ascomorpha agilis o. a., af hvilke de tre førstnavnte opnaaede meget høje Maks. i Vejlesø, viste sig i Furesøens pelasiske liegion nelop samticlig med disse, men forsvandt derpaa ganske.

3. Maksimalne for disse Former var altid størst i den Del af Søen, der laa Tilløbene nærmest (Store Kalv).

Ud fra 2 og 3 tør man drage den Slutning, at naar der i en større Søs pelagiske Region pludselig viser sig en Del Individer af Arter, som ellers ikke hører hjemme i demme, og disse Arter derpaa ligesaa hurtigt forsvinder, har man med Materiale at gøre, der andetsteds fra er tilført Søen. Det er Former, der herude cnlen gaar lil Grunde eller naar ind i Søens Littoralregion, i hvis afspærrede Vige de i saa Fald finder et nyl Hjem.

Ud fra Iagltagelse 1 kunde man endvidere formode, at ogsaa den i Søen regelmæssigt optræelende Rotiferfauna for en Del rekruteredes af tilført Materiale, samt at denne Fauna, saafremt en saadan Rekrutering ilke fandt Sted, i Længden ilkke vilde vare i Stand til at holde sig i en større Søs pelagiske Region. Dette kan vel vaere muligt, men paa den anden Side er der ingen Trivl om, at der i de større Søers pelagiske Region findes et Rotifersamfund, der opstaar i selve Søen og ikke stammer fra lilgraensende Vandmasser.

Vi har i det foregaaende nemlig ofte fremført Eksempler paa, at de i de større Søer optraedende Individer staar med et eget, skarpt fikseret Præg, der adskiller dem fra de i lave Damme og Smaasøer hjemmehørende Individer. Særlig fremhavedes Tornenes større Længde hos Søformerne, hvilket Forhold fik Imhof til at opstille særlige Arter og Varieteter (Anurua longispina, regalis o. a.), samt det tyndere og langt mere hyaline Panser, der aldrig opviser den gule Farve, som saa ofte karakteriserer Damformerne; men hertil kommer yderligere, at Varieringsevnen i Damme og i Søer giver sig et ganske forskelligt Udslag, hvoraf resulterer, at der hos en Art i Damme ofte opstaar Variationsrakker, der nøje er knyttede til disse og aldrig forekommer i større Søer (Auurca cochlearis, A. aculeala), medens der omvendt i de større Søer indenfor visse Arter kan opstaa Variationsrakker, som ikke viser sig i Smaasøer og Damme (Asplanchua, Synclucela). Naar imidlertid en Søs Rotifererplankton for en stor Del faktisk udvikles i selve Søen, staar vi atter her overfor Spørgsmaalet om Hvilestadier og Hvileperioder.

For de periodiske Rotiferers Vedkommende ved vi, at de totalt forsvinder i 6 - 8 Maaneder af Aaret; de perennerende Botiferer er vel altid til Stede, men Antallet, hvori de optræeder, er i Alm. saa ringe, at det store og pludseligt opstaaende Foraarsmaks. ikke kan tænkes at fremkomme alene ved parthenogenetisk Formering af de faa i Vandmasserne overvintrende Individer. Hos det langt overvejende Antal Arter liar man paavist, at der efter Seksualperioderne opstaar Hvileag, og man tør slutte, at disse dannes hos alle Arter.

Ud fra de Betragtninger, som ogsaa andetsteds er gjort gaeldende, maa det endvidere formodes, at alle de Hvileag, der synker til Bunds ude paa de store Dybder, gaar til Grunde, og at det pelagiske Rotifersamfund Aar efter Aar vasentlig udvikles i Littoralzonen, fremgaaet af de i denne aflejrede Hvilexeg, der haves til Vejrs af Bølger og Vertikalstrømninger.

Paa mine Rejser i Jylland har jeg i Maj Maaned dels i Silkeborgterrainet, dels i det store Sodrag om Viborg-Hald gentagne Gange haft Lejlighed til at se, at de større Søers Rotifermangde var langt betydeligere inde $\mathrm{i}$ de lavvandede Vige end ude paa den aabne Sø; herude opstod forst 8 Dage senere de slore Maks., som formentlig delvis fremkom ved, at Littoralzonens Sværme af Foraarsstormene førtes ud over hele Søen. 
Med Hensyn til Planktonrotiferemes Riglagning skal endnu folgende tilføjes.

Som bekendt klieber den overvejende Del af Rotifereme deres Aig fast til Underlaget. P'lanktonrotifererne, der fierdes i cn Region, lovor Understottelsesflader nangler, mata loxe sig ad paa anden Vis. Vi vil først betragle Maaden, livorjaa Sommeraggene anbringes. En Del skalfer sig dog Underlag for KEgene, idet de kleber dem fist til andre Planktonorganismer; dette er salaledes Tilfaldet med Coelopus, der afsatter Rggene paa Melosirc-Trande, Masligocerca capuzina, der anbringer dem paa Asplanchner, Rallulus bicornis, der afsetter Iem para andre Rotiferer, og Gastropus slylifer, der anbringer dem paa Uroglena volvox. Rimeligvis afsattes diggene ingenlunde altid paa disse Organismer, snarere maa man formode, at de afsæettes paa alle mulige Planktonorganismer. En stor Del Former (Auurcea, Brachionus, Schizocerca, Nollolca, Polyarltera, Triarlhra, Masligocercu selifera, S!̣nchetu lremula!) barer Eggene indtil Kklækning; nogle (Asplanchna) er levendefødende. Hos atter andre er Sommeraggene pelagiske (Synchera grandis, Ploesoma Hudsoni).

Ivad Hvileaggene angaar, er vi med Hensyn til disse kun slet underrettede; men ud fra disse Egs Iyygning maa vi formodle, at de enten er pelagiske eller paa forskellig Vis holdes flydlende i Overfladen, livorlra de af Vinden fores ind i Soernes Vige, livor da Ǩrekningen i Foraarstiden foregaar. Hos Anurcea, Polyarllura, Gastropus slylifer og Synchala stylala er Hvilexgget besat med længere eller kortere Børster; Asplanchna priodonlas' IIvileag er udstyret med to store Oljedraaber (se Tab. IV, Fig. 37). I Hvileagget hos Asplanchna Brightwelli, men sxrlig hos Triarltıra longisela, optræder Skalstrukturer, der ganske minder om de luftyldte Kamre hos Bryozostatoblaster; en lignende Bygning er ovenfor paavist i Hvilexgget hos B. pala. For dette Ags Vedkommende kan jeg meddele, at jeg fra Baaden direkte har iagttaget, hvorledes Vinden fejede Overlladen ren og allejrede det indfejede Materiale i Søens Vige (se p. 143).

En nøjere UndersøgeIse af Søernes Opskyl efter de store Efteraarsmaks. vil rimeligvis give gode Oplysninger om Rotiferernes Hvileag.

Det er indlysende, at hivis den i dette Arbejde ofte hævdede Opfattelse, at de af Planktonorganismernes Hvilestadier, der bundfældes ude paa dybt Vand, her gaar til Grunde, er rigtig, maa det være af største Betydning for Arten, om Hvilestadierne, efter at vare aflagte, ejede Midler til at naa ind i Littoralregionen, Iıvor Bølgeslag og Vertikalstrømninger vilde kunne hæve dem det næste Foraar.

I Maaden, hvorpaa Planktonrotifererne anbringer deres $\mathrm{Eg}$, haves formentlig et smukt Eks. paa, hvorledes en Gruppe af Organismer er i Stand til at føje deres Organisation efter de store Fælleslove, der hersker paa Lokaliteter, hvor Gruppen oprindelig ikke hører hjemme, og efter Invilke den derfor fra først af ikke var tilpasset. 


\title{
KAP. IX. ARTHROPODA.
}

\begin{abstract}
$A^{5}$ Arthropodernes Række optræeder Planktonorganismer kun i tre af Klasserne, nemlig Crustacea, Insecta og Aranea; af disse er de to sidstnævnte i den pelagiske Region endog kun representerede af ganske enkelte Former.

Af Insekterne kan mærkelig nok kun en eneste Form, Larven til Corethra plumicornis Fabr., optræde som Planktonorganisme. Dens Hjem er vel overvejende lave Smaadamme og Moser; Horisontalprøver, tagne med vidmaskede Planktonnet og fra betydelige Dybder, viste dog, at Larven selv i vore største Søer tillige optræder som udpræget Planktonorganisme; den er paavist i Furesø, Esromsø, Sorøsø, Tjustrupsø og Mossø; ofte indeholdt Horisontalprøverne fra Esromsøs største Dybder Larven i Hundredevis. Disse Dybsø-Larver synes altid mindre end Larverne i Smaasøer og Damme; de er endvidere fuldkommen hyaline, ikke gule, som Larverne herfra plejer at være. De skiveformede, cirkelrunde Eggebaade kan om Sommeren i Mængde paavises paa vore Smaasøers Overflade. Saavel over Smaasøernes som over de større Søers Vandspejl færdes i lune Sommernætter og i Døgnets første Timer utallige æglæggende Insekter, ganske særlig Myg (Corethra, Chironomus), men ogsaa Phryganeer og Ephemerider. Jeg haaber ved en senere Lejlighed at komme tilbage til dette højst tiltrækkende, endnu næsten ganske ukendte Insektliv; her vil jeg indskrænke mig til at bemærke, at jeg har Iagttagelser for, at Dybsøens Corethra-Larver stammer fra Eggebaade, der af Moderdyret lægges midt ude i Søernes pelagiske Perioder, hvor Eggene klækkes, og hvorfra Larverne foretager Vertikalvandringen ned i Dybet.

Jeg formoder, at Corethra-Larven vil vise sig at være en lige saa konstant Beboer af de dybere Vandlag i alle det mellemeuropæiske Slettelands Søer som Leptodora og Bythotrephes; kun paa Grund af den altfor ensidige Brug af Vertikalprøver indfangne med fineste Møllergaze, er den hidtil ikke bragt for Dagen og er derfor heller ikke omtalt i Planktonarbejderne.
\end{abstract}

\section{CRUSTACEA.}

\section{Malacostraca.}

Medens Havets pelagiske Region for en meget vasentlig Del befolkes af Malacostracer baade som fuldt udviklede, kønsmodne Dyr (ganske særlig Mysider og Euphausider) og som Larvestadier hørende dels til pelagiske Former, dels og overvejende til Bund- og Bredformer, mangler i Ferskvandets Plankton alle Malacostraker, saavel kønsmodne Former som Larvestadier. Ferskvandets Malocostraker har sat deres fritlevende Larvestadier til.

Nyere Undersøgelser i de Søer, der er beliggende indenfor den Del af vor Jordklode, som under Istiden har været dækket med Is, har dog vist, at der i disse Søers pelagiske Region lever en Malakostrak Mysis 
ocutule Fabr. var. retiala (i. (). S.; det er en I)ybrandsform, der vaesentlig traffes paa 20 25 M., og som

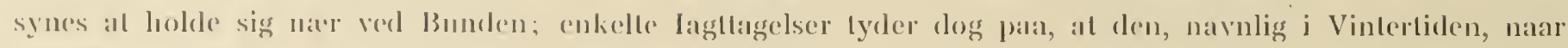
Vimdel i Overlladen er koldt, ogsaa dindes hejere oppe.

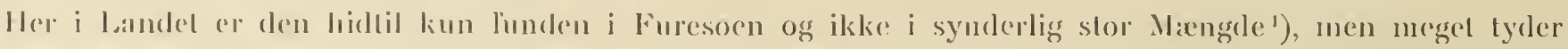
pala, al den i latrige storre og dybere Soer i Nord-og Medleneuropa optraeder i slort Antal; som l'alge af sin for en Planklonorganisme i frerskvand betydelige Storrelse vil den i saa Fald have en ikke ringe be-

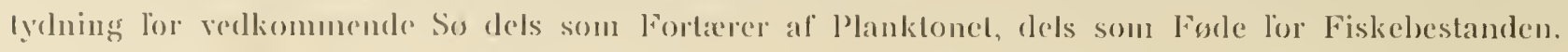

\section{Entomostraca.}

\section{Cladocera.}

Clatorererne spiller 'n megel belydelig Rolle i vore Søers pelagiske Region; sammen med Copepoderne damner de, navnlig i Sommerlialvaarel den langt overvejende bel al Søernes Zooplankton; om Vinteren slaar de dog i Ilangde betydelig tilloage for disse. l'lanktoncladoecrernes Antal er iklie slort, i alt 14, af hvilke de to nappe er lijemmehørende i den pelagiske Region.

Skont Plankloncladocereme ikke lilhører nogen bestemt Underafdeling eller Familie, lortjener det dog at fremlixeses, al Lyncodaphniderne hos os som overalt mangler i Planktonet, og at Lynceiderne kun optrader med con enesle Arl, Chydorus spluricus, der endda ikke tør henregnes til de lypiske Planktoncladocerer; de i rore Soer Iyppligst lorekommende Arter tilhører Fam. Duplutide og Bosnintede. Frelles lor Planktoncladocereme er deres overordentlig store Hyalinitet; Torndannelser forekommer hyppigt (Bythotrephes, alle Medlemmer af Slagten Dapluia) og synes ofte at udvikles hos Planktonvarieteter af Arter, som i ovrigt er Dan- og Bredformer (Scapluoleberis mucronala var. longicornis, Ceriodapluia quadrangula var. Manuata).

Egantallet los de fleste af de herhen hørende Former kan i Foraarstiden vare meget betydeligt, men er (len storste Del af Aarel, og narnlig om Sommeren kun ringe, 1-4. Dyrene er ofte underkastede en meget betyclelig Temporalvariation (Bosmina coregoni, Hyalodapluia og til Dels Daphnia lygalina). Alle disse hyppig forekommende Trak kan rettest tydes som Tilpasningsforhold til Livet i større Søers pelagiske Region. Da Arbejclets anden Del rasentlig behandler Temporalvariationen, omtales den ikke her.

1 Havets pelagiske Region optræder kun faa Slægter, særlig Podon og Evadne, hvis Slægtskabsforhold til Ferskvandets Dafnier er vanskeligt at udrede; som Kystform findes tillige Bosmina maritina P. E. M., der efter de nyeste Undersøgelser synes at være en marin Race af B. obtusirostris, som med Floderne er ført ud i den botniske Bugt (Lilljeborg 00 p. 245).

\section{Calyptomera.}

\section{Ctenopoda.}

Ctenopoda indbefatter de to Fam. Sidider og Holopedida; sidstnærnte tæller kun een Slægt med een Art, IIolopedium gibberum.

Holopediun gibberum Zaddach er ikke paavist i nogen af de her omtalte Søer; den fandtes af P. E. Müller (68 a. p. 103) i Bøgholmsø ved Hellebæk og i Gribsø; begge Steder har jeg i Aarene 00-02 forgaves søgt Arten; paa forstnæernte Sø kunde jeg dog ikke faa Baad; fra Gribsø, hvortil jeg alene med denne Form for Oje har foretaget 5 Ekskursioner, foreligger i Tiden fra Naj til Sep. 5 Planktonprøver tagne i forskellige Vandlag midt ule paa Soen; i ingen af disse Prover har jeg fundet Arten; i Fald det var lykkedes, havde det veret min Hensigt at sxette en 14 Dags Undersogelse i Gang paa Gribsø. Om faa Daphnier er vi nemlig saa daarligt underrettede som om denne Form, navnlig m. H. t., hvorledes Geleklokken dannes (se Sars 65 p. 59), og om den fornyes; ogsaa mange biologiske Forhold trænger til nærmere at udredes.

1) cfr. WV.-L. (02 p. 257). 
Paa en Jyllandsrejse 9S fandl jeg ${ }^{20} / 5$ H. g. i Madumsø ved Skørping Station Syd for Aalborg; Arlen var øjensynlig lige koumen frem: lalrige unge l)yr saas; ingen Hun bar over 2 - 3 Sommerag; Ilanuer nanglede. Narmest i llaal) on al kunne parvise Seksualperioden besogles Søen aller 98 20/9, men Tidspunklet var aabenbart for sent; det lykkedes mig ikke at finde el eneste lndivid.

Ved sin maxglige Geleklokke, et indenfor Crustaceene ganske enestaaende Bygningsforhold, synes II. g. mere end nogen anden Daphnie at vare lilpasset lil livel i Søenes pelagiske Region; den angives ogsaa som Midtrandsform eller som l'lanklonorganisme af P'. E. Mäller (68 a. p. 103), G. O. Sars (65 p. 66) og Lilljeborg (00 p. 63), men navnes ikke i P'lanklonarbejcleme; delle skyldes dog snarest en Tilfxeldighed, idel den som rel sporalisk Form ikle er paavist i de hidlil undersøgle Søer; nxernere Angivelser om Periodicitet, Farvepragt, Opholdssted og om dens Betydning son Fiskeførle findes, saa vidı vides, kun los liric og Várra (94 p. 104-106 ogs 97 p. 39 og $53-55)$.

Lilljeborg (00 p. 63) anser den for sxrlig at vare en højnordisk og alpin Form; de allerfleste Findesleder angives ogsaa fra Norge, Sverrige og Finland; i øvrigt kendes den fra Island og Grønland, se Lilljeborg (00 p. 63); Stenroos (97 p. 42) finder den i de fleste Søer og Damme i Russisk Karelien; paa Grund af sin Storrelse danner den Hovedbestanddelen af Planktonet og skal kunne forekomme i uhyre Masser; den er storst længst imod Nord (Lilljcborg 00 p. 59); Stenroos angiver endog $7 \mathrm{~mm}$. (Klokken medregnel). Zschokke (00 p. 294) anforer den som alm. i Fjældsøer.

\section{Sididæ.}

Planktonorganismer optræder kun indenfor tre af Familiens 7 Slagter, nemlig: Sida, Limnosida og Dialphanosoma. Af disse er Sida crystallina O. F. M. ikke sjaldent truffen pelagisk i vore større Søer, men alticl kun i enkelte Eks. og i ganske faa Prøver. Det er som bekendt en typisk Bredform, der ved Hjælp af sit Hæfteapparat ofle i Tusindvis sidder fast f. Eks. paa Nymphæaceernes og Potamogetoneernes Flydeblade; alle den pelagiske Regions Individer kan sikkert betragles som forslaaede. Burckhardt (99 p. 423) med(leler, at han i Lago Maggiore's og i Lago di Lugano's pelagiske Region har tagel en ny Sida-Form, S. limnetica, særlig karakteriseret ved, at Hæfleapparatet mangler, og desuden afvigende fra S. cryslallina ved en forskellig Haleform og ved sin meget ringe Frugtbarhed (2-1 Æg i Rugehulen). Burckhardı gør endvidere opmærksom paa, at S. crystallina ofte angives soin Planktonorganisme, og formoder sikkert med Relte, at en stor Del af disse Angivelser bør henføres til denne nye Form. Alle de af mig fundne Eks. har haft tydeligl Hæfleapparat; S. linnetica er ikke paavist hos os.

Jeg havde haabet, at Undersøgelsen skulde have beriget vor Fauna med Limnocida fronlosa, en pelagisk Sidide, først funden af G. O. Sars (65 p. 37) i norske Søer, senere i svenske af Lilljeborg (00 p. 34); den er hidlil ikke kendt udenfor norske, svenske og finske (Stenroos 98 p. 178 og 97 p. 41) Søer, hvor den som udpraget Planktonorganisme i Sværme holder til i disses, navnlig de slørre Søers pelagiske Region. Det er dog ikke lykkedes her til Lands at bringe denne Form for Dagen.

\section{Diaphanosoma.}

Der er af Slægten Diaphanosoma i Folge Lilljeborg $(00$ p. 36) beskrevet 5 Arler, af hvilke $\log$ kun de to, D. brachynrum (Liévin) og D. leuchtenbergianum Fischer vedkommer os her. De afviger væsentlig fra hinanden deri, at 2det Par Antenner, naar de bøjes tilbage, hos førstnæevnte ikke naar Valvernes Bagrand, medens de hos D. lenchtenbergianum naar ud over denne. Mindre Forskelligheder lader sig ogsaa paavise i Henseende til Øjnenes Størrelse, Hovedets Form etc.

Allerede P. E. Müller (68 a. p. 101) formoder, at disse to Arter ikke kan holdes ude fra hinanden, men bibeholder dem dog, da han ikke har kunnet finde egentlige Overgangsformer imellem dem. De holdes ogsaa adskilte af Sars (65 p. 44), af Richard (95 p. 361) og af Lilljeborg (00 p. 37); i nyeste Tid har Burckhardt (99 p. 432) anført en Del Grunde for, at de to Arter burde forenes til een. 
D. lenchlemberginum blev af P’. E. Mäller kun lumden i Esromsø, D). brachyurum angives som Inyppig i Socr og Moser nocl rent Vand. Nicrverende Undersogelse har parvist $I$ ). brachyurum i alle de herhen horende Socr, undlagen lisronnso, sant i talrige andre store og mindre Soer, I). lenchlenbergianmm er stadig kun funden i Esromsa: fra de lalrige nye Findesteder er der fremdeles ikke parvist former, der kunde siges at star midt imellem de to Arter. Esromsoens Diaphanosoma er senere beskreven og afbildet af Lilljeborg (00) p. 44, Tab. IV, Fig. 6); (len opfattes ogsaa af lam som D. lenchlenbergiomum, men dog paa Grund af sit hoje Hoved som en sierlig Varietet: fronlosa. Den afviger stackt fra Diaplanosomerne i alle de andre Søer (se P. L. M ïller og I,illjeborg); jeg opfatter derfor stadig D). brachyurum og leuchlenbergianum som to Arter.

\section{D. brachyurum (Lićvin).}

Lilljeborg. Tab. III, Fig. 6-13, Tab. IV, Fig. 1-4.

Fureso. D. b. viser sig forste Gang $0127 / 5$ Tp. 14; clen er endnu ret sjaclden $30 / 6$ Tp. 18 , talrigere $15 / 7$ Tp. 20. Maks. falder fra Slutningen af Juli til $\%$ Tp. 16 ; derpaa tager Arten kendelig af; de sidste Eks. saas $16 / 11$ Tp. 4. I 02 fandtes de forste Eks. $1 / 7$ Tp. 14, og Arten var ikke synderlig hyppig $3 / 8$ Tp. 15.

De Elis., der paavistes ${ }^{27} / 5$, var unge llunner, smaa af Viekst og uden Eg; i Forsommeren var Egantallet $1-2$, lige for Malis. 3-4; (let hojeste Antal Eg var 5; i Juli-Aug. saas talrig Yngel; de første Hanner paavistes $2 / 10$ Tp. 16 , samticlig iagttoges Ilunner med Hvilexg; disse var hyppigere i Proverne ${ }^{21 / 10}$ Tp. 11 og 16/11, men samtidig fandtes dog Hunner med Sommerag.

Soroso. D. b. er paavist i enkelte Eks. $01 \frac{26}{5}$ Tp. 13; Antallet er kendelig steget 3/7 Tp. 21, og $9 / 8$ Tp. 23 danner Daphnella en meget betydelig Iel af Zooplanktonet; allerede $18 / 9$ Tp. 12 er Arten næsten forsvunden; det sidste Eks. er set ${ }^{18} / 11$ Tp. 7. 102 viste det første Eks. sig $7 / 6$ Tp. 15; den var i begge de følgende Prøver $28 / 6$ Tp. 17 og $27 / 7$ Tp. 16 nixerkxerdig sjælden.

Egantallet var storst $(3-4)$ lige før Maks. $3 / 7$, ellers $1-2.18 / 9$ paavistes Hunner med Hvileæg og Hanner, forstnievnte tillige i cle folgende Prover.

Tjustrupsø. D. b. findes i enkelte Eks. $01{ }^{24} / 5$ Tp. 13 ; Antallet er kendelig steget $3 / 7$ Tp. 17 ; Maks. naas i Aug. ${ }_{18}$ Tp. 22 og $\mathrm{i}$ Beg. af Sep.: ${ }^{17} / 9$ Tp. 12 er den noget aftaget, og i de følgende Prøver $16 / 10$ Tp. 13 og $18 / 11$ Tp. 7 findes den kun enkeltvis. I 02 viste $D . b$. sig forste Gang $7 / 6$ Tp. 12 og var ret talrig ${ }^{27} / 7$ Tp. 15.

Eks. fra ${ }^{24 / 5}$ er nasten alle unge Hunner. Eggenes Antal er størst 3/7, i Alm. 3-4 Eg, senere kun $1-2$. Hanner og Hunner med Hvileag optræder $17 / 9$, forstnaevnte tillige $16 / 10 ; 18 / 11$ findes kun golde Hunner.

Viborgsoerne. D. b. viser sig i faa Eks. $01 \frac{18}{5}$ Tp. 14; den er ret alm. 10/7 Tp. 21 og overmaade talrig $7 / 8$ Tp. 23; allerede ${ }^{15} / 9$ Tp. 12 er den sjælden og optrader kun enkeltvis ${ }^{14} /{ }_{10}$ Tp. 12 og $10 / 11$ Tp. 8 . I 02 er et enkelt Eks. set $30 / 4$ Tp. 8 og et ringe Antal $14 / 6$; den er noget hyppigere $25 / 6$ Tp. 17 og meget talrig ${ }^{27 / 7}$ Tp. 15 .

$18 / 5$ findes kun unge Hunner uden $\mathrm{Eg}, 10 / 7$ Hunner med $2-3 \mathrm{Eg}, 7 / 8$ Hunner i Alm. med kun 1 Æg samt talrig Yngel; $15 / 9$ findes nasten kun golde Hunner samt Hanner; disse paavistes endnu 10/11; 14/10 saas enkelte Hunner med Ephippier.

Haldsø. D. b. optræder forst $018 / 6$ Tp. 13 ; den er endnu sjælden $22 / 6$ Tp. 13 , men bliver $20 / 7$ Tp. 17 alm. og naar $7 / 8$ Tp. 18 sit Maks.; ${ }^{16} / 9$ Tp. 13 er Antallet noget aftaget; ${ }^{14 / 10}$ Tp. 13 findes kun enkelte Eks.; de sidste paavistes $10 / 11$ Tp. 10. 102 saas den i faa Eks. ${ }^{11 / 6}$ Tp. 12 , var ret alm. ${ }^{3} / 7-{ }^{16} / 7$ Tp. 14 og optraadte i store Mængder $2 / 8$ Tp. 15 .

$8 / 6$ fandtes kun unge Hunner uden Eg; i Juli-Aug. bærer Hunnerne $2-3$ Æg, og i Aug. er der megen Yngel; $16 / 9$ findes talrige Hanner, der endnu paavistes ${ }^{14} / 10$, samtidig Hunner med Hvilexg; alle Eks. fra ${ }^{10 / 11}$ er golde Hunner.

Skanderborgso. D. b. viser sig i enkelte Eks. i Proven 01 19/5 Tp. 13 ; den er talrig $5 / 8$ Tp. $21 ; 15 / 9$ Tp. 12 er Arten kendelig aftaget, og allerede ${ }^{18} / 10$ Tp. 12 saas de sidste Eks. 102 fandtes de forste Eks. ${ }^{3 / 6}$ Tp. $15 ;$ Antallet var ikke steget $28 / 6$ Tp. 18 , og forst $30 / 7$ Tp. 14 fandtes en Del Eks.

$19 / 5$ fandtes kun unge Dyr, $5 / 8$ Hunner med 2-3 Eg og talrig Yngel; 15/9 talrige Hanner og talrige Hunner med Hvileag; begge var forsvundne $18 / 10$; Eks. fra denne Dato var Hunner uden Eg, Hanner paavistes ikke.

Mosso. Af det i ovrigt utilstrækkelige Antal Prover synes det at fremgaa, at Arten spiller en ganske underordnet Rolle i Sren; den havde ogsaa her kun et ubetydeligt Maks. 01 1/8 Tp. 22.

Julso. $D . b$. er markelig nok ikke paavist i Prøven $012 \%$ Tp. 13 og er sjalden 10/7 Tp. 20; den er talrig $1 / 8$ Tp. 22 og fremdeles $15 / 9$ Tp. 12 ; en Del Eks. findes $15 / 10$ Tp. 12 og enkelle Eks. $20 / 11$ Tp. 6 . I 02 er de forste Eks. paaviste $30 / 6$ Tp. 16, og endnu $31 / 7$ Tp. 15 er Aptallet ringe. 
10/7 fandles en Del liks. med $1-2 \mathrm{dig} ; 1 / 8$ bar de fleste $2-1 \mathrm{Agg} ; 15 / 9$ findes talrige Hunner med Hvileag sant IIanner; begge genlindes $15 / 10 ; 20 / 11$ ses kun golde Humner.

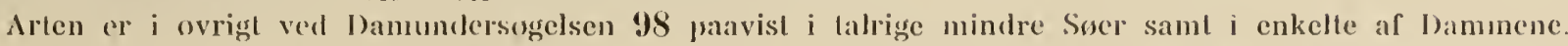

Det fremgaar da al ovenstaaende, at $I$ ). b. overalt viser sig omtrent i Midten af Maj Tp. 13-15; (le forst iagtlagne Individer er sma llumner - Unger uden Aig; i Juni Maaned barer de Iig, men sjaclent mere end eet; senere stiger AEgantallel og er storst i l3egyndelsen al Juli, som oftest ikke over 3-4; Maks. nats ved Vandets højeste Tp. og er størst fra Midten af Juli til Midten af Aug.; allerede i Slutningen al Juli tager Egantallet af og overstiger da sjeldent 1-2; umiddelbart for og i Begyndelsen af Maks. findes en Vrimmrel af Unger; i Sep. tager Arten starkt og pludseligt af, samlidig ( Tp. 15-13) viser Hannerne sig ofte i stor Mangde; en Del Hunner barer tillige Hvileag, men det synes dog kun at vaere en forsvindende Del, der frembringer disse. Hannerne holder sig endnu ind i Okt., undtagelsesvis endog i Nov.; Hunner med Hvileæeg er i Reglen forsvundne i Okt.; de sidste Eks., man iagttager i Nov, er golde Hunner. Fra Slutningen af Nov. og indtil Midten af Maj er der aldrig iagttaget nogen Diaphanosoma i vore Søer. I). brachyurum er altsaa her i Landet periodisk med kun een Seksualperiorle, der falder i Sep._Olkt.

Maks. er vel kortvarigt, men kan vaere meget stort; det var større i den varme Sommer (1) end i len kolde 02.

Foraarets første Eks. tages altid i Overfladen, og det synes, som om den langt overvejende Del af Diaphanosomerne lige til Efteraaret opholder sig her; fra Okt. søger Dyrene derimod ned i Dybet, og alle de i Nov. iagtlagne Eks. stamner fra dybt Vand, 20-40 M.; paa dette Tidspunkt indeholder Overfladen ingen Diaphanosomer.

Lige saa lidt hos denne Art som hos nogen anden Sidide finder nogen egentlig Ephippialdannelse Sted; Hvilexggene omgives, saa vidt vides, ikke af den afskudte Hud, saaledes som det er Tilfældet hos Lynceiderne; de synes simpelt hen at synke til Bunds.

Ogsaa for denne Arts Vedkommende maa det antages, at Foraarets Individer vasentlig fremgaar af de Hvilexg, der er sunkne til Bunds i Littoralregionen, og at de Ag, der er bundfreldede ude paa Dybet, gaar til Grunde; det er dog næppe udelukket, at en Form med saa gode Srømmeredskaber som Diaplıanosoma, i alt Fald i vore lave Søer, ogsaa kan have sig op endog fra disses dybeste Particr.

D. b. angives fra Norge (Sars 65 p. 45), fra talrige Findesteder i Sverrige (Lilljeborg 00 p. 42 ), fra Finland (Stenroos 97 p. 41, 98 p. 178), fra talrige Findesteder over det mellemeuropaiske Sletteland, ligeledes fra en Mængde Schweizersøer; den mangler dog i en Del af disse (Genfersøen, Thunersøen o. a., Burckhardt 99 p. 447), men findes i de norditalienske Søer (Garbini 95 p. 4), se i øvrigt Richard (95 p. 362 ); 0 . synes at mangle i højtliggende alpine Søer og er ikke paavist i Grønland.

De Efterretninger, Planktonundersøgelserne hidtil har bragt om Artens Maks. og Seksualperiode, har kun været sparsomme. Den synes dog overalt at høre til det periodiske Plankton; kun paa det sydligst liggende Punkt, Gardasøen, menes den at være perennerende (Garbini 95 p. 4).

En Del Forf: Apstein (96 p. 166), Fuhrmann (00 p. 96), Seligo (00 p. 64), Birge (97 p. 347$)$, Frič \& Vávra (94 p. 103), angiver ligesom jeg, at Arten viser sig i April-Maj, har Maks. i Aug. og forsvinder i Okt.-Nov.; for Alpnachersee kommer Burckhardt (00 p. 132) til samme Resultat; i Vierwaldstädtersøen viste den sig først de sidste Dage i Aug. (p. 131), men ogsaa her forsvinder den om Vinteren; Burcklhardt finder ligeledes Hannerne $\mathrm{i}$ anden Halvdel af Okt. i et Antal af $5-10 \%$.

D. leuchtenbergianum $\mathrm{F}$ is che $\mathrm{r}$.

Lilljeborg. Tab. IV, Fig. 5-11.

Esromsø. D. . viser sig i enkelte Eks. $0125 / 5$ Tp. 13 ; endnu $29 / 6$ Tp. 15 og $20 / 7$ Tp. 17 spiller Arten en underordnet Rolle, men tiltager dog stadig i Antal; ${ }^{12} / 8$ Tp. 21 er dette steget meget betydeligt, og $D$. $l$. er nu en af Planktonets Hovedformer; Mængden er uforandret $5 / 9$ T. 16, men aftager $30 / 9$ Tp. 17 ; de sidste Eks. saas $15 / 10$ Tp. 12. I 02 paavistes Arten første Gang $10 / 7$ Tp. 14; den var endnu $31 / 7$ Tp. 15 kun fremme i ringe Mangde. 


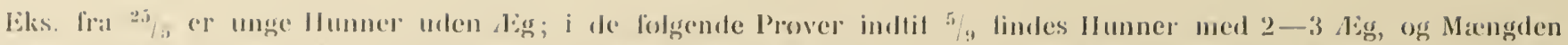

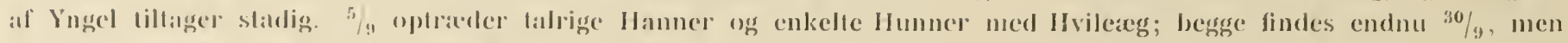

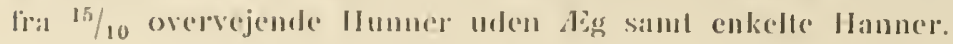

I). l. forluolder sig allsia mod Hensyn til Periodicitet og Forplantuingsforhold ganske som foregaaende.

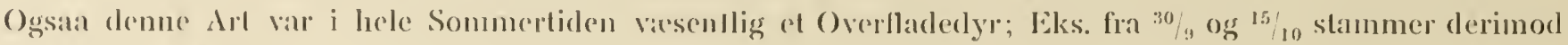
alle fira $20-25 \mathrm{M}$.

\section{Anomopoda.}

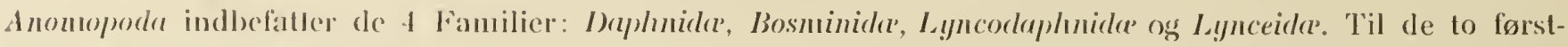
navinte lorer vore Soers vigtigste Planktondaphnier; alle lyncodapluniderne er udpraegede lBund- og J)anformer, der ikke vedkommer os her, og af Iynceiderne kan kun en eneste Art siges at vaere Planktonorganisne i vore socr.

\section{Daphnidæ.}

l'anl. Daphnirla taeller 5. Slaggler: Daphnia med Underslaggler, Scapholeberis, Simocephalus, Ceriodaphnia og Moina. Sá godt som alle de udprägede Planktondaphnider tilhører Slacgten Inolınia, de øvige Slægter er J)am- og Bredformer; en Del af disse danner sammen med visse Daphnia-Arter og Bosminerne den overvejende Del af det Saufund al Cladocerer, der traffes i Smaascernes vegetationsfri, centrale Partier; dette gaelder navulig Ceriodaphnin. Saavel af denne Slaegt som af Scopholeberis har der fra en enkelt Art udviklet sig sarlige Varicteter, der maekelig nok optrader som udprægede Planktonorganismer endog i meget store Søer.

LuLz har saaledes i Følge Stingelin (95 p. 211) i Brienzersøen opdaget en meget konstant Varietet af Scap/holeberis mucronata O. F. M., nemlig var. longicornis, med meget langt Horn; den blev senere af Stingelin (95 p. 211) genfunden pelagisk i Sarnersøen; var. cornuta er efter Lilljeborg (00 p. 155) særlig karakteristisk for støre Søer; ogsaa i Vierwaldstädtersøen har Burckhardt $(00$ p. 146) paavist en S. mucronata, men betoner dog, at det ikke er nogen agte pelagisk Form; den skal her vare monocylisk, mangle om Vinteren og have en Seksualperiode om Efteraaret; i mindre Vandmasser er Arten i hvert Fald dicyklisk, muligvis polycyklisk. Medens S. mucronata saavel i sin typiske Form som i var. cornuta er en i vore Damme og Smaasøer yderst alm. Form, har jeg aldrig set den i større Søers pelagiske Region; var. longicornis synes sarlig at optræede $\mathrm{i}$ alpine Søer. Om S. m.'s Forhold til »lhe surface film« cfr. Scourfield (96 p. 1 og 00 a. p. 309$)$.

\section{Daphnia.}

Det er en velhekendt Sag, at Arterne af Slagten Daphnia varierer overordentlig staerkt. En Del Arter traffes i lave, planteberoksede Damme, i Tørvemoser og ved Bredderne af større Søer, andre er udprægede Planktonorganismer, hjemmehørende i de store Søers centrale Partier. Af de nyere Undersøgelser synes det at fremgaa, at skønt Variationsernen kan være ret fremtræedende hos Arter, der sæerlig lever i Smaasøer (f. Eks. D. pnlex-Gruppen, D. longispina O. F. M.), er den dog langt større hos de udpragede Plantonorganismer (D. hyalina Leydig, D. (Hyalodaplınia) cucullata G. O. Sars).

Først gennem de seneste Tiders Planktonundersøgelser har man faact noget narmere Kendskab til disse Planktondaphnier, deres Varieringsevine, indbyrdes Slagtskabsforhold og Levevis.

Falles for dem alle er den store Hyalinitet og ringe Størrelse (1-2 Millim.); Øjet er temmelig lille, og de enkelte ḱrystallinser rager frit frem af Pigmentet; Pigmentpletten er svagt udviklet og synes i mange TilfaIde ganske at mangle, Bagkropskløerne er, paa en enkelt Undtagelse nar, ikke udstyrede med Tornbesatning (»dents secondaires" Richard 96 p. 191), og Antallet af Torne paa Bagkroppens Bagrand er ringe. Legemets ydre Konturer er underkastede den videst mulige Variation, navnlig m. H. t. Hovedets Form samt Spina's Stilling og Lxengde. Egantallet er i Alm. meget ringe, 1-3. Endvidere kan tilføjes, at de hidtidige Undersøgelser har bragt det Resultat, at Hanner og Ephippie-bærende Hunner er meget sjældne, og at det derfor synes, som on disse Former ganske vasentlig forplanter sig acyklisk (Birge, Burcklardt o. a.). 
Al ovenuante 'lrak kan, da de i storre eller mindre Grad genlindes hos alle Planklonorganismer, flere sicltes i Forbindelse med ldevevisen og tydes som Tilpasning til Omgivelserne, saaledes Hyalinitelen, den ringe Storelse og del ringe Antal Aisg i Rugelunlen. Da det endvidere er konstateret, at Bagkropskløernes 'Tombeswhing og 'Tomenc paa Bagkroppen er langt staerkere udviklede los Ciadocerernes Bund- og Bredformer eud hos Panklonorganismerne, ligger det naer at formode, at Manglen eller svagere Udvikling al disse 'Torne, hrorved Bagkroppens Brug son Krybe- og Fasthaftningsapparal vaesentlig formindskes, er i Overensstemmelse med Livet ude i de ab)ne Vandmasser, hvor Undersløttelsesllader mangler. At ogsaa den vidlgaaende Variation af Legemets Konturer maa tydes som el Tilpasningsforhold lil ydre Faklorer, har jeg andelsteds sogt at vise $(00)$.

Med Hensyn til den formentlige acykliske Forplantning hos Planktondaphnierne tror jeg, at ufuldkomne Methoder har hidført en fejlagtig Opfattelse; hertil skal jeg senere komme tilbage.

Inden man endnu kendte noget til Planktondaphniernes Varieringsevne, maatte man nødvendigvis beskrive el meget stort Antal Arter (c. 40). Idet disse "Arter vasentlig afveg fra hverandre i de yclre Konturliniers Forløb, opfattede man Forskelligliederne i saa Henseende som brugelige Arlsmærker og beskrev Arterne særlig paa Afvigelserne m. H. t. Hovedskjoldets Form og Spinas Plads og Længde.

Lidt efter lidt gik det imidlertid op for selve de Forfattere, der havde været medvirkende ved Opstillingen af nye Arter, eller i alt Fald harde frestet Lid til dem, at hvad man hidtil havde anset for gode Artsmærker ingenlunde kunde fastholdes som saadanne, hvorfor de da ogsaa i senere Arbejder (Sars 90 p. 33 , P. E. Müller 70 p. 7) atter inddrog en Del af disse.

Da derpaa de regelmassige Planktonundersøgelser af større Søer tog deres Begyndelse, paaviste man ved Undersøgelser hver 14. Dag, at Planktondaphnierne i de enkelte Søer er underkastede visse bestemte Formforandringer, der Aar efter Aar forløber paa ganske samme Vis og til ganske samme Aarstid. Da man endvidere nogle Aar senere raadede over regelmassigt indsamlet Materiale fra forskellige Søer (Plönersøerne, Stuhmersøerne, Vierwaldstädtersøen, Lake Mendota og Nurmijärvisøen), saa man red Sammenligning af Materialet, at Formforandringerne dog ikke forløb ganske paa samme Maade i alle Søerne, men at der imellem Materialet fra de enkelte Søer gjorde sig visse Forskelligheder gældende.

Ud fra disse Undersøgelser, foretagne i Aarene 1890-1900, og i hvilke sarlig Zacharias, Birge, Seligo, Burckhardt, Stenroos o. a. deltog, fik man da en noget nærmere Redegørelse af det Fænomen, som allerede P. E. Müller og Sars havde anet, at Planktondaphnierne m. H. t. de ydre Konturforhold er underkastede den videst mulige Lokal- og Temporalvariation. Da Artsmarkerne netop overvejende var hentede fra disse Konturer, blev det indlysende, at vort Artsbegreb paa detle Onraade var ganske urigtigt; »Arterne« maatte reduceres til Saisonformer og Lokalracer. Tidspunktet var da inde for en omfattende Reduktion, der nu er foretaget af Richard, Burckhardt og Lilljeborg.

Man kan som Basis for Reduktionen anlægge forskellige Synspunkter. Man kan lægge Hovedvægten paa Tilvejebringelsen af de reldre Forf.s Originaleksemplarer eller Materiale fra de af dem undersøgte Lokaliteter samtidig med, at man fra talrige nye Findesteder selv indsamler Materiale. Ad denne Vej naar man et nøje Kendskab til Lokalvariationen og kan paa Basis af det derved indvundne Racekendskab foretage en meget omfattende Reduktion. Det er vasentlig denne Vej, Richard har fulgt i sit fortjenstfulde Arbejde: Révision des Cladocères (95-96). Da imidlertid Indsamlingsdatoerne aldeles ikke spiller nogen Rolle for Richard, kender denne saa at sige intet til Temporalvariationen; derfor baner Richards Arbejde vel Vejen for den endelige Opfattelse, men reprasenterer den ikke.

En saadan tilvejebringes kun af den, der raader over et med regelmæssige Mellemrum indsamlet Materiale fra mange forskellige Lokaliteter; kun paa et saadant kan saavel Temporal- som Lokalvariation studeres. Et Materiale af denne Beskaffenhed er baade meget vanskeligt og meget bekosteligt at skaffe til Veje; saivel Burckhardt som Lilljeborg har foretaget deres Reduktion paa Materiale delvis af denne Beskaffenhed; i Overensstemmelse hermed gaar begges Reduktion betydelig videre end Richards. Førstnævnte har 
ratadel over regelmatessigh indsandet Matcriale fra Vierwaldstädtersøen samt Enkeltindsanlinger fra talrige Scluweizersoer.

Lilljeborgh har, sati vidl jegr kan se, ikke halt regelmassigl indsamlet Planklommateriale, men idel han har arbejale pata sin store Monograli i nesten 50 Aar, givel de talrige, instruklive Afbildninger og for hver Beskrivelse og 'Tegning noje angivel lokalitel og Fangstelalo, er der, om end ikke for samme Airl, sala dogg fra samme Lokaliteler gennem en Aarrekke indsamlet Materiale til mange forskellige Aarstider. I sit Vark har Lilljeborg for Slaeglen Inphnius Vedkommende lige saa meget haft el aabent Øje for Temporal- som for Lokalvariationen.

ldet den forchiggende Undersogelse laader over el 2aarigt, c. hver 3. Uge indsamlet Materiale fra Furesøen, mancdlige Indsamlinger i 1-11/2 Aar fra 8 andre Sger, har Forf. haft et langt støre og bedre Materiale al arbejde med end tidligere Undersøgere. Hvad der oger Materialets Brugbarhed er, dels at Datoen for Indsamlingerne for alle () Lokaliteter omtrent er (len samme, dels at der foruden Vertikalprøver ogsaa er laget Horisontalprover saivel pai Søons dybeste Partier som i Overlladen. Det maa (log bemærkes, at alle Indsamlinger stammer fra storre Søers pelagislie Region. Det havde vel varet onskeligt, om der tillige regelmassigh var blevel indsamlel Materiale fra forskellige Smaasøers centrale Partier, idet visse Damracers Forhold lil pelagiske lacer derved kunde være bleven fastslaaede; dog viste denne Gren af Undersøgelsen sig, saafremt de ovrige blot nogenlunde skulde gennemføres, uoverkommelig.

lnden der gores liede for mine egne Undersøgelser over Plankton-Daphnierne, skal de Resultater, hrortil de tre ovennaevinte Forf. er komne, korl omtales.

Richard deler Daphnia-Gruppen i to Slagter, Daphnia og Hyalodaphnia; sidstnæunte, der opstilledes af Schödler, afviger fra Daphnia ved en forskellig Hovedform og ved at mangle Øjeplet; det har altid ræeret en omstridt Sliegl, og mange Forf. (f. Eks. P. E. Müller 68 a. p. 107) anerkender den ikke; samtidig ined, at liichard (95 p. 326) betoner, at den ikke har samme Vardi som de orrige Slægter indenfor Familien Daplunider, mener han dog, vasentlig af praktiske Grunde, at den bør opretholdes.

Slagten Dapluia er derpaa heldigt delt i to store Grupper, alt efter som Bagkropskløerne bærer Tiender eller ikke; den forste Cruppe indbefattede endnu, da Richard skrev sil Arbejde, indenfor Europa kun Dam- og Bredformer, men Aar 00 beskrev Burckhardt (99 p. 448) en enkelt Form, D. pulex De Geer var. pulicarioides, som Planktonorganisme fra Luganersøen; den er, saa vidt vides, ikke funden andre Steder. Til den Gruppe, der ikke bærer Trender paa Bagkropskløerne, og som alene vedkommer os her, hører alle de øvrige Planktondaphnier; bortset fra tre i den nyeste Tid opstillede og lidet kendte Arter indbefatter denne særlig 4 Arter: D. longispina (O. F. M.) Sars, I). Iacustris G. O. Sars, D. hyalina Leydig og D. galeata G. O. Sars.

Slægten Hyalodaphnia bestaar, fornden af den lidel kendte, for nylig opstillede H. retrocurva Forbes, af to Arter, H. Jardinei Baird og cristata G. O. Sars.

Alle de xeldre Tiders talrige Plankton-Daphnier sammendrages saaledes til 6 Arter.

Artsmarkerne hentes særlig fra Rostrums Form, 1ste Par Antenners Plads, Spinas Stilling, Hovedskjoldets Form samt Forholdet mellem Bredde og Længde af Valverne; de tre sidstnæunte Karakterer er særlig anrendte til Begrænsning af Arterne indenfor de to Slægter; det er dog netop disse Karakterer, som er underkastede den store Temporalvariation, hvoraf atter følger, at vedkommende Arter ikke lader sig opretholde. Richard har vistnok selv folt dette; thi 96 p. 192 siger han, at Artsdiagnosen aldrig hviler paa en enkelt af disse Karakterer, men paa »det Ensemble, der tilvejebringes ved deres Samvirken«.

Ud fra sine Undersøgelser saavel over Temporal- som Lokalvariationen foretager Burckhardt en langt mere omfattende Reduktion.

Slagten Hyalodaphuia inddrages, og dens Arter, af hvilke Burckhardt kun behandler den ene, D. cucullala Sars (= Hyalodaphnia Jardinei), henføres til Slægten Iaphnia.

Ved sine regelmæssige Planktonundersøgelser viser nu Burckhardt, at af de 4 ovennarnte Planktondaphnier, D. longispina, D. lacustris, I). Lyalina og D. galeata, horer de to førstnarnte sammen til een Art, 
D. Iongispina, de to andre lil cen, I). hyalina; Burckhardt er tilbojelig lil at gaa endnu et Skrilt videre ogs mener (99 p. 457), at endog disse to Arter rellest burde sammendrages til een; af forskellige Grunde foretager B. dog ikke deme sidste Reduktion, men bibeholder stadig de to Arter, D. Iongispina og D). hyalina.

Sliegten Daphnia kommer salaledes, bortset fra de i den nyeste Tid opstillede og lidet kendte Former, til al bestar af 1 Arter, D). tongispina, D). hyalina, D). (- Myglodaphmia) Jardinei og I). (= Myalodaphnia) (ristata. De Lalrige $i$ aldre Tid opstillede Arter er altsaa nu reducerede til 4.

Lilljeborg er i flere Henseender kommen til samme liesultat som liurcklar(lt. Ligeson dennc ophever han Slagten Myjalodaphmia, men den derved opslaaede Slaegt Daphmia deles af ham i 3 Underslagter: Daphnia s. str., Hyalodaphinia og Cephaloxus; disse adskilles vasentlig paa Udseendet og Retningen af Ablominalprocesserne og paa 1ste Par Antenners nxermere eller fjxrnere Indføjning ved Rostrums Spids.

Underslagten Daplnia har ogsaa Lilljeborg i Overenstemmelse med Richard delt i de samme to Grupper som denue og underafdelt Gruppen uden Tander paa Kløerne i de to Arter I). Iongispina O. F. M. og D. hyalina Leydig, vasentlig svarende til de samme to Arter som hos Burckhardt. Lilljeborg fremlıxer imidlertid yderligere, at I). tongispina ${ }^{1}$ ) er Dam- og Bredform, D. hyalina Planktonorganisme i større Søer.

Underslagten Hyalodaplinia indbefatter kun een Art, H. cucullataG. O. Sars, identisk med H. Jardinei hos Richard og D. cuçullatı hos Burckhardt. Til Underslagten Cephaloxus, som Sars (61 p. 8) oprindelig opstillede, men senere (90 p. 35) atter inddrog, har Lilljeborg henført den hos Richard narmere behandlede Hyalodaphinia cristata, som ikke omtales hos Burckhardt.

Medens de til Underslægterne Hyalodaphnia og Cephaloxus hørende Arter ikke nærmere deles, inddeler Lilljeborg det overordentlig store Antal Lokal- og Temporalformer, der henføres til D. lıyalina, yderligere i 4 Underarter, nemlig: liyalina Leyd. s. str., pellucida P. E. M., lacustris G. O. S. og galeala G. O. S.; til Adskillelse af disse Underarter hentes Karaktererne vasentlig l'ra Hovedskjoldets Form.

Min egen Opfattelse af Planktondaphniernes indbyrdes Slægtskabsforhold er nærmest i Overensstemmelse med Lilljeborgs, hvis System i det hele taget forekommer mig at være det mest afklarede; paa et enkelt Punkt er jeg dog kommen til et afvigende Resultat. Jeg anvender i det følgende Lilljeborgs System.

I vore større Søers pelagiske Region optræeder kun to Arter af Daphnier; i Sommertiden støder man overalt paa uhyre Mængder af Daphnier uden Øjeplet og med Antennerne siddende ude paa Rostrums Spids; de repræsenterer den typiske Dapluia Subgen. Hyalodaphnia cucullala G. O. S., der i det følgende for Kortheds Skyld ofte simpelthen betegnes som Hyalodaphnierne. Bortset fra Forskellighederne i Størrelse ligner alle vore større Søers Hyalodaphnier hverandre scerdeles meget; det er, som vi i den følgende Del af dette Arbejde skal se, Former, der er underkastede en stark Temporalvariation, men hvis Lokalvariation er ringe.

Former med Øjeplet og 1ste Par Antenner siddende et Stykke bag Rostrums Spids synes her i Landet at være langt sjældnere, i alt Fald i alle vore større Søer. De henføres alle til Arten Daphnia hyalina og er paaviste i Esromsø, Sorøsø, Tjustrupsø, Viborgsøerne og Haldsø, men mangler i alle de af Gudenaaens Søer, del har varet underkastede regelmæssige Planktonundersøgelser, samt i Furesø; i en enkelt Indsamling fra Almindsø $01 \%$ har jeg dog fundet en herhen hørende Form, og andre er fundne i Planktonprøver fra adskillige jydske Søer omkring Viborg og i sydfynske Søer, men er ikke bleven narmere undersøgte.

Saavel i Sorøsø som i Tjustrupsø har disse Former i 01 - 02 kun vaeret til Stede i ganske ringe Antal og i en forholdsvis kort Tid af Aaret; derimod har de i de tre andre ovennæevnte Søer, navnlig i Esromsø, haft meget store Maks. I ingen af Søerne har de varet underkastede en saa betydelig Temporalvariation som Hyalodaphnierne; i Sorøsø og Tjustrupsø lod en saadan sig aldeles ikke paavise; derimod har de i de forskellige Søer afveget meget stærkt fra hverandre, og det synes, som om der i hver Sø har udviklet sig en

1) Mangel paa Materiale fra Smaasøer bevirker, at jeg i det flg. maa se bort fra denne Art; den er i ovrigt meget alm. i Smaasoer med rent, klart Vand; i storre Søer har jeg aldrig fundet den (cfr. P. E. Müllers fortriefielige Fremstilling 68a. p. 112; G. O. Sars 90 p. 32 ; Lilljebor'g 00 p. 94). 
sarrig Race; for Daphnia hyglina's Vedkommende har vi altsata at gore med en meget udpraget Lokalvariation; Temporalvariationen er derimod kun ringe.

1)e 10 Arter Daphnia lugalina og I). (I!yalodaphinia) cucullala er meget distinkte Arter, der alt efter Manglen celler Tilstedeverelsen al (Ojeplet og 1 ste Antenners Plads til de allerlleste Tider af Aaret med Lethed vil limne slielues fra hinanden. Fra Juni og indlil Nov. vil man som Regel ikke behøve at ty til disse finere lientetern; alene den ganske forskellige Hjelndannelse hos de to Arter vil vare tilstrakkelig til ved forste Ojelast at adskille dem fia hinanden. I hele det ovenfor angivne Tidsrum er Hyalodaphniernes Hjalm i de al mig undersoggte Soer fra 1/3 lil 1/2 af'Totallangden; en sierlig Spids er ikke alsat, men alt efter den større eller mindre Hojde danner Hjahmen en ligesidet eller høj ligehenel Trekant. Hos I). hyalinu forekommer derimod olle alcleles ingeu lljidmdannelse (Sorøsø, Tjustrupsø), men naar den forefindes, fremkommer den enten ved, al Hoverlskjoldet fortil berer en ofte meget skarpl afsat Spids (Esromsø), eller ved at hele Hovedskjoldet vel er vokset ud i Højde til en verilabel Crista, men dog i Spidsen er jaevnt afrundel (Haldsø, Viborgsø).

Naar Vinterlabaarel kommer, reduceres Hjalmiannelsen hos alle Planklondaphnierne, og de to Arter naermer sig da i ydre Form hinanden; endnu indtil Dec. kan de dog ved de to ovennavnte Kendetegn skelnes fra hinanden. Den Generation derimod, der føcles af den sidste Efteraarsgeneration, og som unge Dyr overvintrer under Isen, bliver køusmoden i April-Maj og dør ud i Juni, er i høj Grad ens udseende hos begge Arter. Rostrum, der hos Hyalodaphnierne ellers altid er mer eller mindre nedadbøjet og tiltrykt Valverue, er her hos denne Generation i alt Fald i Marts-April frit fremstaaende; Hovedskjoldets Bugrand er indadbuet, og Antennernes Plads kan hos disse Hyalodaphnier undertiden være noget fjærnet fra Rostrums Spids. Omvendt er Pigmentpletterne ikke altid kendelige hos D. hyalina-Formerne, og det kan saaledes paa det Materiale, der indsamles i Jan.-April, ofte være ret vanskeligt, undertiden umuligt, at holde de to Arter ude fra hinanden.

Af de 4 Underarter, hvori D. Ityalina deles hos Lilljeborg, har jeg genfundet de tre, nemlig pellucida, lacustris og galeata. Pellucida optræder i sin typiske Form i Sorøsø, ligesom ogsaa de faa Eks. fra Tjustrupsø, om end mindre sikkert, henføres til denne Form. Esromsøens D. hyalina-Form er subsp. galeata, der her findes i uhyre Mengde. Den i Viborgsø og Haldsø optrædende Daphnia hyalina-Form, der, skønt den i de to Søer opviser visse smaa Forskelligheder, dog er af samme Type, henfores til D. hyalina subsp. lacustris. Hvad Lilljeborgs 4de Underart, D. hyalina s. str., angaar, har jeg vel haft lndivider for mig, der maatte henføres til denne Form; de optræeder i alle de Søer, hvor Slægten Daplntia s. str. findes, men kun i Forsommeren og er efter c. ${ }^{15} / 6$ kun paavist i enkelte overlevede Individer (Esromsø 01 29/6 og $3 / 7$ ); jeg opfatter dem dog kun som Saisonformer af de ovrige Underarter, navnlig D. Iyjalina subsp. galeata og lacustris, men ikke som særlige Racer, der kunde berettige til Opstillingen af en Underart.

D. hyalina subsp. pellucida blev oprindelig af P. E. M üller (68 a. p. 116) opstillet som en egen Art, 1). pellucida, men inddroges senere (70 p. 6) og henførtes til Arten D. hyalina; Sars følger ham heri. Müllers Findested, Sorøsø, er ogsaa et af mine; i over 30 Aar har denne Form holdt sig ganske uforandret paa samme Lokalitet; i de to Søer, hvori jeg har fundet den, optræder ingen andre D. hyalina-Former, og den er ikle paarist i de øvrige Søer, hvori disse forekommer.

Lilljeborgs tredie Underslægt Cephaloxus er hidtil ikke paavist her i Landet; den indbefatter alle Planktondaphnier med 1ste Par Antenner fjæernede fra Rostrums Spids, og som mangler Øjeplet; Richard fører dem ind under hans Slægt, Hyalodaphnia, som H. cristata; Sars skabte for dem Slregten Cephaloxus, men har senere atter inddraget denne. Lilljeborg opstillede den igen og henførte til samme de to Arter C. longiremis G. O.S. og C. cristata G. O.S. Hvad der i Modsætning til de ovrige Planktondaphnier særlig skal karakterisere denne Underslægt er i Følge Lilljeborg de svagt udviklede Abdominalprocesser, af hvilke der kun findes een forreste vel udviklet og to bageste rudimentiere $(00$ p. 136).

Abdominalprocessernes Udseende og Stilling er tidligere bleven anvendt i Systematikkens Tjeneste; det er bløde, handskefingerformede Organer, hvis Udseende er ret varierende fra Individ til lndivid. Studeres de 
til forskellige Tider af Aaret, kan man tilned ikke varege sig mod den 'T'anke, al de ogsaa varierer betydeligh til de forskellige Aarstider. De er vel neppe underkastede nogen direkte Temporalvariation, men deres Stilling

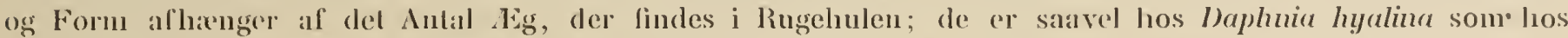
1). (Ilyalod(tphuia) svagt fremtredende paa den sidste golde, døende Efteraarsgeneration i Dec.-Jan. Maaned

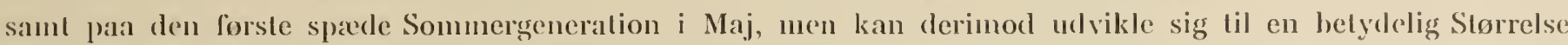
hos senere Sommergenerationer. Jo mere Rugeluten enten er oplyldt al Lig, Unger eller en enkelt meget stor Unge, des mere presses Bagkroppens Rygside i det Parti, der danner Rugehulens Bund, nedad; santidig hralver Rygsidens hageste Parti, der danner Rugehulens Bagrand, sig opad og fremad. Herved skyder 1ste Abdominalproces sig i Vejrel, krummer sig opad og trakker under denne Krumning 2den Abdominalproces med sig. Den strerkere eller svagere Grad, hrori delle foregaar, er aflaengig af den storre eller mindre Udfyldning i Rugehulen.

Jeg kan vel vare enig med Lilljeborg og lidligere Forf. i, at Abdominalprocessens Stilling og Form ilike er den samme hos D. hyalina og Hyalodaphnia; dog tror jeg ikke, at de, paa Grund af deres meget uregelmassige Form og sliftende Stillinger, egner sig til at anvende systematisk; i hvert Fald mener jeg, at Lilljelorg ved at stille dem i forste Række og anvende dem som Hovedkarakter til at holde de tre Underslagter ude fra hinanden har givet dem en altfor fremskudt Plads. I Virkeligheden adskiller Ceplıaloxus sig blot fra Hyalodaphnia ved kun at have een vel udviklel Abdominalproces, de øvrige er oblittererede; men Planktondaphnier med een eller ingen Abdominalprocesser er i Vinterhalvaarel intet sjældent Fænomen; jeg er derfor paa dette Punkt tilbøjelig til at følge Sars og betragter de to til Underslagten Ceplaaloxus hørende Arter C. cristata og longirentis som henhørende til Underslægten Hyalodaplnia.

Det har markelig nok ikke varet mig muligt at paavise disse Former her i Landet; heller ikke P. E. Müller har kunnel finde dem; af de Findesteder, som Lilljeborg angiver, synes del at fremgaa, at vi her vaesentlig har med arktiske Former at gøre.

Alı hvad der fra Planktonundersøgernes Side hidtil er fremkommet angaaende Planktondaphniernes Udbredningsforhold, Leveris, Forplantningsforhold etc. maa ganske omarbejdes; thi Hyalodaphnicrne og Daphnia ltyalina er vistnok overalt sammenblandede, og da der sjældent i Planktonarbejderne forefindes gode Tegninger af disse Former, ved man ikke, om hvilken af de to Arter der tales; det vilde derfor være, ørkesløst af Litteraturen nærmere at søge Oplysninger on deres Udbredningsforhold etc.

Det eneste Planktonarbejde, som kan benyttes, er selvfølgelig Burckhardts fra Vierwaldstädtersøen men han har kun nærmere undersøgt $D$. hyalina.

Selv har jeg i alle Søerne nøje fulgt Forplantningsforholdene for begge de to Arter og studeret deres Periodicitet, baade med Hensyn til Temporal- og Lokalvariationen, og mener at have udredet Seksualperiodernes Forhold til Temporalformerne, Generationernes Antal og det Antal Kuld, der hører til hver Generation.

Det er dog kun en mindre Del af disse Undersøgelser, der medtages i dette Arbejole, den langt overvejende Del henlagges til det følgende, i hvilket samtidig de talrige Tegninger, uden hvilke disse Forhold ikke kan anskueliggøres, vil blive publicerede.

Daphnia hyalina Leydig subsp. galeata G. O. Sars.

L illjeborg 00. Tab. 17 og 18.

Esromsø. D. h. subsp. g. er paavist i faa Eks. $0017 / 12$ Tp. 5; den er sjælden i alle Foraarsproverne 01 indtil ${ }^{29} / 6$ Tp. 15, da den ret pludselig viser sig i store Mængder og danner Hovedmassen af Søens Zooplankton. Arten tager noget af $20 / 7$ Tp. 17 og er ret sjalden hele Sommeren i Prøverne 12/8 Tp. 21, 5/9 Tp. 16 og $30 / 9$ Tp. 17; derimod synes den atter at have et mindre Maks. ${ }^{15} / 10$ Tp. 12 og $1 \%$ Tp. 7 ; senere tager Arten gradvis af og er $\mathrm{i}$ hele 0 ? lige til ${ }^{10} / 7$ Tp. 14 sjælden; den har da et meget stort Maks., men er noget mindre hyppig $31 / 7$ Tp. 15.

I Slutn. af Juni og Begyndelsen af Juli indtræeffer en meget tydelig Seksualper. med Hanner og en Del Ephippiebaerende Hunner; den er paavist baade $01 \mathrm{og} 02$; i 01 saas her ogsaa i Okt.-Nov. Ephippie-barende Hunner, men kun i ringe Mængde. 
Formen er allerede lidligere funden i Esromso al P. L. M ïller, der kaleler den I). gateala ((j8 a. p. 117);

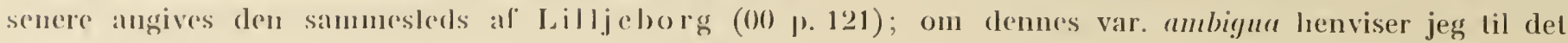
scricre Irlocjele.

\section{Luyalina Leydig subsp). pelfucida P. LE. Mäller.}

P. F. Mïller (j8 a. Tab. I, lïig. j).

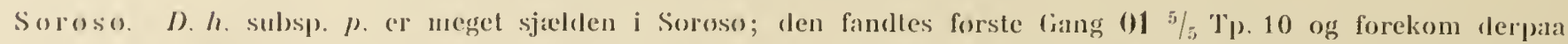
i de lleste al Proverne indtil 18/11 Tp. 7 ganske enkeltvis; kun 9/8 lp. 23 blev en bel liks. paaviste; den manglede i Tiden fra (1: $3 / 1$ Tp. 2 til ${ }^{7}$; Tp. 15 , fandtes i sidste Prove $27 / 7$ Tp. 16, men altid kun enkeltvis. Seksualperioden (or lere unclugatel mig.

T.justrupso. D. h. subsp. \%. (r vistnok licr perennerende, men lorekommer alticl kun i meget ringe Mangle; den er funden i de fleste l'rover, men er kun ret liyppig i Proven 01 \%/8 lp. 22 . Arten er markelig nok ogsaa

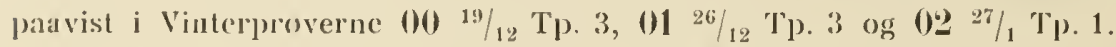

I Proven 01 19/12 parvistes Hanner, i l'roven 01 26/12 Hanner og desuden Hunner med Eplippier.

P. E. Müller (27 p. 116) har lorst fundet denne Form og beskriver den som I). pellucida; hans Eks. slammer fra Soroso og Tuelsø, og lan angiver, at den lever som Søform, $\log$ kun i ringe Mangde.

Med Ilenblik paa Planktondaphniernes store Variabilitel er det formentlig ikke uden Interesse at erfare, at I). Lyjalina var. pellucida m. H. I. Udseende, Forekomst og Hyppighed paa samme Lokalitel har holdt sig uforandret i c. 35 Aar.

\section{Luyalina Leydig subsp. lacustris G. O. Sars.}

Medens jeg med Hensyn til I). Injalina i Esromsø, Tjustrupsø og Sorøsø føler mig overtydet om, at jeg her har haft de to Underarter D. galeata og pellucida for mig, er det tvivlsomt, om Viborg- og Haldsøernes I). Lygalina-Former kan henfores til Underarten lacus/ris. Egentlig kender jeg ingen Afbildninger eller Beskrivelser, (ler fuldtud passer paa disse ogsaa i biologisk Henseende ret mærkelige Former; jeg fører dem $\operatorname{dog}$ foreløbig herhen og skal andetsteds gennem talrige Tegninger dokumentere deres Temporalvariation.

Viborgso. D. h. subsp. lacustris er sjalden 01 18/5 Tp. 14 samt $10 / 7$ Tp. 21 ; den er derimod talrig $7 / 8$ Tp. 23 og fremdeles hele Sommeren; den optræder i stor Mængde $8 / 12$ Tp. 2 og er endnu talrig $023 / 1$ Tp. 2 , men efter Isløsningen i Proven 22/3 Tp. 2 sjalden; Arten begynder forst at blive mere alm. ${ }^{25} / 6$ Tp. 17 og er meget talrig $27 / 7$ Tp. 15 .

Trods ivrig Eftersogen og skont Tusinder af Eks, har passeret under min Lupe, har jeg aldrig set Hanner eller llunner med Ephippier.

Haldsø. D. h. subsp. lacustris er forst paavist $0118 / 5$ Tp. 10 ; den er endnu ret sjælden $8 / 6$ Tp. 13, men hyppig i Tiden fra $22 / 6$ Tp. 13 til $7 / 8$ Tp. 18 . Hovedmaks. synes at ligge $20 / 7$ Tp. 17 , derpaa aftager Antallet atter; $D$. $h$. holder sig ret alm. indtil $8 / 12$ Tp. 4, men Mængden er da meget betydelig; ligesaa $023 / 1$ Tp. 2 ; mærkelig nok er den ret alm. 22/3 Tp. 2, hvorpaa Antallet stadig er jævnt stigende; den findes i stor Mængde i alle Proverne indtil $2 / 8$ Tp. 15.

I Proven 02 3\% Tp. 8 viste sig enkelte Hanner, men ingen Hunner med Ephippier.

Man ser altsaa, at de tre Underarter af D. liyalina med Hensyn til Hyppighed, Periodicitet og Seksualperioder forholder sig ganske forskelligt.

Galeata har et dobbelt Maks.; begge afsluttes med en Seksualper. beliggende Forsommer og Efteraar; pellucida har et svagt Maks. ved Vandets højeste Tp.. men Seksualper. er først paavist sent om Efteraaret; lacustris har i Viborgsø stort Maks. hele Sommeren og atter et stort Maks. hen imod Vinteren, hyorpaa den ganske forsvinder; i Haldsø har den stort Maks. i Forsommeren, et mindre henimod Vinteren og holder sig derpaa ret hyppig hele Vinteren; Seksualper. indtræffer muligvis om Foraaret.

Vi kencler her i Landet intet andet Eks. paa, at en Art paa forskellige Lokaliteter m H. t. Seksualper. og Maks. forholder sig saa højst forskelligt; paa Grund af Undersøgelsesmethodernes Mangler anser jeg del dog ikke for tilraadeligt nærmere at fremdrage de Resultater, som disse Undersøgelser synes at pege hen imod; jeg forholder mig derfor her kun refererende.

Vierwaldstädtersøens D. hyjalina synes efter Burckhardts Tegninger (99 Tab. 19) nærmest at høre ind under subsp. galeala og subsp. lacushris; ogsaa han (00 p. 136) har fundet Maks. Nov.-Jan., derpaa hurtig 
Aflagen og cfler Min. Fel, - Marls langsom Sligning indtil Nov; omtrent paa samme Matale forlobler lacustris sign i Hald- og Viloorgsocrue.

Burckla ardl landl Hanner i Okl.-- Nove, men saa aldrig Ephippier.

Daphria (Hyalodaphria) cucullala G. (). Sa r's.

I.illiebol'g 00. 'Tab, 19, Fig. 5-17. Tal), 20, Fig. 1-12.

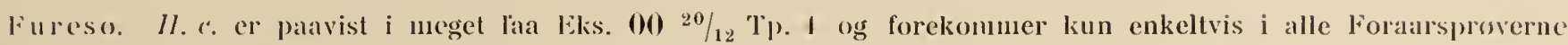
lige til $01 \%$ Tp. 16; den er da ret alm. og stiger stadig i Autal inclil $30 / 6$ Tp. 18 , la den er en af Panktonets Ilovedformer med meget stort Maks.; den tager derpaa af, men er dog endnu talrig 2/10 Tp. 16, endog rel alın. i alle Vinterproverne $010 \mathrm{og} 02$, men sjelden $\mathrm{i}$ det tidlige Foraar $0223 / 3$ Tp. 1 indtil $21 / 5$ Tp. 9; den er nogel hyppigere ${ }^{5}$ i Tp. 12, tallrig 17/ Tp. 14 og har et betydeligt Maks. ${ }^{11} / 7$ Tp. 14 og $3 / 8$ Tp. 15.

llverken i 01 eller 02 sa jeg noget til llanner eller til Hunner med Hvileag; Seksualper. er altsaa ikke paavist.

Esromso. Det har iklie vaeret mig muligt i Proverne fra Aarets lorste Maaneder at holde Hyalodaphnierne ude lia Daphnia hyalina (cfr. p. 166); de forste sikre Hyalodaphnier viser sig 01 25/5 Tp. 13, men de er sjæeldne; derpaa tiltager Antallet starkt og er i Tiden fra $29 / 6 \mathrm{Tp} .15$ til $30 / 9 \mathrm{Tp} .17$ meget stort og stadig stigende; $15 / 10 \mathrm{Tp} .12$ er Arten strerkt aftaget; de sidste sikre Eks. sais 10/11 Tp. 7 . I Tiden fra $17 / 12$ Tp. 1 og til 02 23/5 Tp. 9 har Hyalodaphnierne ikke kunnet skelnes fra $D$. hyalina; de forste Eks. paavises $23 / 5$ Tp. 9 ; Arten tiltager kun langsomt i Antal, Maks. er begyndt ${ }^{31} / 7$ Tp. 15 .

Hverken i 01 eller 02 blev der paavist Seksualper. om Foraaret; derimod indtraadte en meget tydelig Seksualper. i Tiden $015 / 9$ Tp. 16 indtil $3 \%$ Tp. 17. Hannerne er $5 / 9$ overordentlig alm. og Hunner med Ephippier ret talrige; begge er noget sjaeldnere $3 \%$, men endnu $15 / 10$ Tp. 12 er Eks. af begge sete.

Soroso. H. c. er ret alm. $0019 / 12$ Tp. 5, men er sjæelden i Foraarsprøverne; Maks. falder i Tiden fra $013 / 7$ Tp. 21 og til 18/9 Tp. 12; den tager derpaa noget al, men er igen markelig hyppig 18/11 Tp. 7 og endnu i Proven $0^{2} 3 / 1$ Tp. 2 efter den lorste Islosning; $i$ alle de folgende Prover lige til $7 / 6 T_{p}$. 15 er Arten sjaelden, men er atter talrig $7 / 6$ Tp. $15,28 / 6$ Tp. 17 og $27 / 7$ Tp. 16.

En Seksualper. med Hanner og Ephippie-bærende Hunner er paavist 01 17/10 Tp. 12 og $18 / 11$ Tp. 7 ; i sidste Prøve fandtes talrige Ephippie-bærende Hunner.

Tjustrupsø. H. c. er ret alm. 00 19/12 Tp. 3, sjælden i Foraarsproverne 01, men stiger i Antal og har sit Maks. i Tiden fra $013 / 7$ Tp. 17 til 18/11 Tp. 7; clen er ikke paavist i Prøven 26/12 Tp. 3, hvilket sikkert 1kke er i Overensstemmelse med Forholdene i Naturen. I ovrigt er den sjælden i alle Foraarsprover 0.2 og endnu ret sjælden ${ }^{\top} / 6$ Tp. 12, men talrig 30/6 Tp. 15 og har et stort Maks. ${ }^{27} / 7$ Tp. 15.

Seksualper. er paavist 01 16/10 Tp. 13; der er vasentlig set Hanner, men kun enkelte Hunner med Ephippier.

Viborgsø. HI. . er ikke funden i Proven 01 29/3 Tp. 1 og er sjælden 18/5 Tp. 14 ; den er talrig $10 / 7$ Tp. 21 og har sit Maks. indtil 15/9 Tp. 12, er sjæeldnere i Efteraarsproverne 11/10 Tp. 12 og 10/11 Tp. 8, men mærkelig hyppig $8 / 12$ Tp. 2. Arten synes at mangle $\mathrm{i}$ alle Vinter- og de lorste Foraarsprover 02 og er i hvert Fald meget sjalden lige til $25 / 6$ Tp. 17 ; den er forst talrig $26 / 7$ Tp. 15.

En Seksualper. paavistes $01 \frac{14}{10}$ Tp. 12; der saas en Del Hanner, men Hunner med Ephippier fandtes ikke.

Haldso. H. c. er ikke paavist i Vinterprøverne 01; de forste Eks. viser sig 18/5 Tp. 10, men Arten er sjæelden lige til $20 / 7$ Tp. 17, dens Maks. vedvarer indtil 16/9 Tp. 13, hvorpaa den tager af; i Tiden Ira $023 / 1$ Tp. 2 og mærkelig nok $\mathrm{i}$ alle senere Prover er den stadig sjalden eller i hvert Fald kun til stede i ringe Mængde.

let er ikke lykkedes mig at parise nogen Seksualper.

Skanderborgsø. H. $c$. er paavist i ganske faa Eks. 00 29/12 Tp. 5 og er sjalden i Proven 01 19/5 Tp. 13; i Proven $5 / 8$ Tp. 21 har den et stort Maks., (ler holder sig lige til 20/11 Tp. 6; den er endnu markelig talrig 02 $3 / 1$ Tp. 1, men sjalden $\mathrm{i}$ alle senere Prover af 02 indtil $28 / 6$ Tp. 18, da den ligesom $30 / 7$ Tp. 14 er meget talrig.

Da jeg i Prøverne 01 18/10 og $20 / 11$ har kunnet paavise ganske enkelte Hanner, maa jeg formode, at der paa dette Tidspunkt har ligget en Seksualper.; Hunner med Ephippier er i ovrigt ikke sete.

Mossø. H. c. er paavist i meget faa Eks. $0028 / 12$ Tp. 4 og er endnu ret sjælden 01 20/5 Tp. 12; den har et Maks. $1 / 8$ Tp. 22 og $20 / 9$ Tp. 14, men er i alle senere Prover af 01 og i alle Prøver fra 02 meget sjælden; i to Prover er den slet ikke funden; den er først alm. $023 \%$ Tр. 15.

Seksualper. er ikke paavist.

1)e danske Sgers Planklon. 


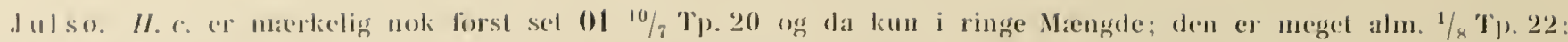

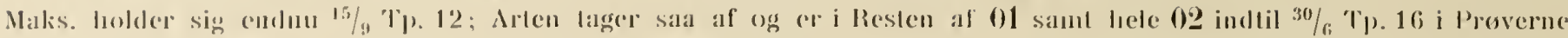
liun lunder i meget fila liks.: $31 / 7 \mathrm{Tp}$. 15 cre den aller talrig.

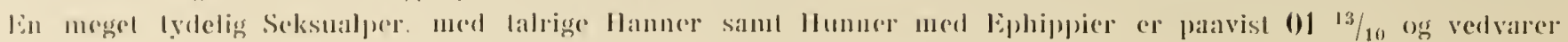
('ndisul $20 / 11$.

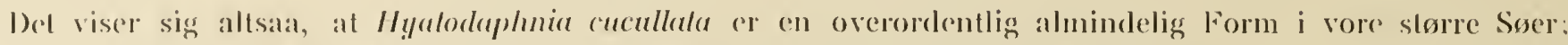
allerede tidligsere er P. L. M ̈̈ller (68 a. p. 120-21) kommen til samme Resultat.

Angataende Artens biologi vil jeg lee indskrenke mig til følgende kortfattede Meddelelser.

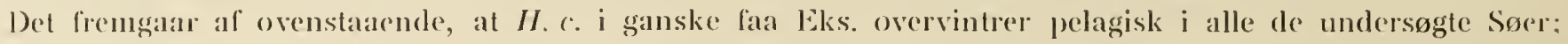
de fia 'lifficlde, i hrilke den om Vinteren og i det lidlige foraar nu og da mangler i enkelte Prøver, viser kun, at Arten pat denne Aarstid er meget sjalden, men nxppe, at den totalt forsvinder; den tager langsomt lil i foratarstiden og nalar sit Maks. i Slutn. af Juni Tp. 16-18; dette varer til a ${ }^{15} / \mathrm{g} \mathrm{T}_{\mathrm{p}}$. $12-14$ og er i Alm. storst red hojeste Tp.; der er i Esromsø, Sorøsø, Tjustrupsø, Viborgsø, Skanderborgsø og Julsø paarist Selsualperiode; i Nov. tager H. c. kendeligg af; jeg maa i ørrigt henvise til Arbejdets anden Del.

\section{Ceriodaphnia.}

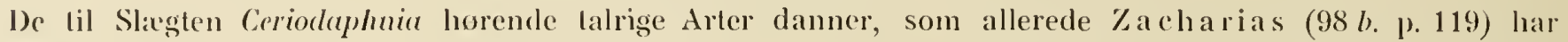
bemerket, en meget varsentlig Del af Damplanktonet. Kiun to Arter er hidlil trufne i vore større Søers pelagiske Region.

C. prelchella G. O. Sars.

Lilljeborg 00. Tab. 28, Fig. (5-18.

Esronso. C. p. optrerler sporadisk i Proverne $0112 / 8$ Tp. 21, $5 / 9$ Tp. 16 og 30/9 Tp. 17, falrigt i Proven $15 / 10$ T11. 12; i sidstnevnte er der taget Hunner med Ephippier, i alle de ovrige kun Hunner med Sommeræg; Hanner er ikke sete.

Viborgso. C.p. optracler sporadisk i Proverne $0110 / 7$ Tp. 21, $7 / 8$ Tp. 23 og $15 / 9$ Tp. 12 samt i Proven $02{ }^{14} / 6$ : der er kun set Hunner med faa Eg.

P. E. Müller har (68 a. p. 129) fra Esromso beskrevet en ny Art, C. punclala, der, saa vidt vides, ikke sencre er genfunden. Lilljeborg, der (00 p. 197) angiver, at han har indsamlet Ceriodaphnier i Esromsø, har heller ikke kunnet paavise demne Art, men har kun truffet C. pulchella; selv har jeg aldrig set Former, som ikke lod sig henføre til denne. Lilljeborg formoder, at Müllers punctala horer ind under C. quadrangula var. hamala; dette er vel muligt, men jeg maa dog bemærke, at jeg i Esromso aldrig har truffet Former med Torne paa Fonices.

C. pulchella er en agte 1)ambeboer, der ved Undersogelsen 98 i Mængde paaristes i alle Dammene; den angives af Zacharias (94 b. Tab. p. 100) fra Plönersøerne, af Fuhrmann (00 p. 96) fra Nenenburgersee, men altid kun sporadisk; Stingelin mener (95 p. 216) at kunne paavise en svag Temporalvariation, idet Hunnerne i Ang. omtrent er kredsrunde, i Okt. derimod mere aflange.

Arten er i Smaasøer og Damme i hvert Fald dicyklisk; om nogen sarlig Periodicitet er der i større Soer nappe Tale.

Den hører som saa mange andre Dam- og Littoralformer til de alpine Søers Plankton (Zschokke 00 1. 294).

\section{C. quadrangula O. F. M.}

Lilljeborg. Tab. 27, Fig. 16-25. Tab. 28, Fig. 1-5.

Sars opstillede $(90$ p. 36$)$ en ny Ceriodaphnia-Art, C. hamala, afvigende fra den nærstaaende C. quadrangula ved en ejendommelig hageformet Torn paa Fornices ovenover 2det Par Antenners Basis. Lilljeborg (00 p. 196) henfører Sar's' Art som var. hamala til C. quadrangula og angiver, at den snarest er hyppigere i større Søer end selve Hovedarten; C. quadrangula, der er en typisk Damform og meget alm. i vore mindre 
Soer og Damme, lindes kun sporadisk i de slore Soers pelagiske Region; var. homato derimod kan lier spille cu ret betydeligs liolle.

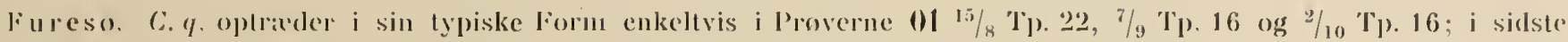
prove findes Hunner ned liphippier.

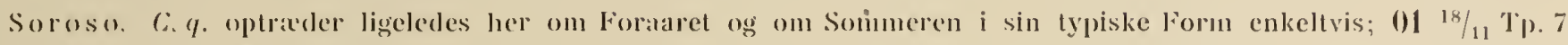
tindes Hunner med Ephippier.

Tjustrupso. C. q. er i sin lypiske lormu funden i ginske enkelte liks. i Proverne 01 16/10 Tp. 13, 18/11 Tp. 7 og $26 / 12$ Tp. $3 ; 18 / 1$ fandles en Hun mel Ephippie.

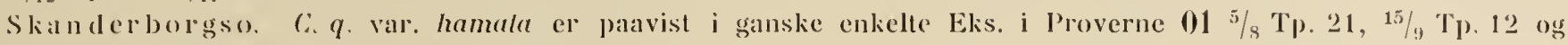
1s/10 Tp. 12; Humner med Ephippier salas iklie.

Ilosso. C. q. Var. hamala spiller en markelig stor Rolle i Mossos Plankton. Einlielte IIunner fincles ()1 20/a Tp. 12; den er meget talrig $1 / 8$ Tp. 22, noget aftaget $2 / 9 \mathrm{~T}_{\mathrm{p}} 14$, men atter talrig $15 / 10$ Tp. 10 ; den findes enunu, men

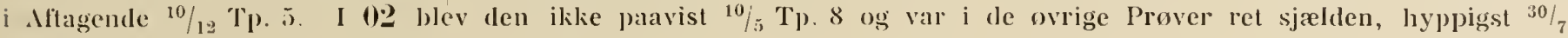
T). 15.

0) $20 / 5$ paristes kun unge Hunner, men med 5-6 Eg; under Maks. $1 / 8$ bar Hunnerne sjaeldent mer end 1 - 2 .Eg. 15/10 fandtes talrige Ephippie-barende Hunner, og Hanner i stor Irengde; Hunner med Ephippier saas endnu 10/12.

C. q. danner $1 / 8$ en meget vaesentlig Del af Mossos l'lankton, markelig noli manglede den nasten ganske i Overllarlen, hvorimod den $\mathrm{i}$ stor Mangde stod paa 15-20 M. Yand.

JuIso. C. q. var. hamala el i Julso mindre fremtradende end i Mosso; de forste Elis. paavistes 01 1/8 Tp. 22; den er endnu sjaclen 15/9 Tp. 12, noget hyppigere 15/10 Tp. 12 og $20 / 11$ Tp. 6; et enlielt Elis. er set ()2 15/. Tp. 1 ; i ovrigt var Arten, i alt Fald tilsyneladende, sjaldnere, enkelte Eks. saas $5 / 5 \mathrm{~T}$ ). 6 og $31 / 7$ Tp. 15.

Ephippie-baerende Hunner samt Hanner parvistes $012 \% 11$.

Det symes efter de her tilvejebragte Oplysninger utvivlsomt, at C. quadrangula i Varieteten haumata er en virkelig Planktonorganisme i større Søer; medens der i disse m. H. t. den typiske C. quadramgnla nappe kan vare Tale om nogen Periodicitet eller Seksualper., synes var. Lanuata at vise sig omkring April-Maj; Maks. lalder i Juli-Aug. og en vel markeret Seksualper. i Okt.-Nor.; i Tiden fra Jan. til Maj manglel den rimeligvis i Plankton.

Theoretisk set er det ikke uden Interesse, at demne Planktonvarietet af C. quadronguln kun afviger fra den typiske Form ved den ejendommelige, ofte meget betydelige Torn paa Fornices, en Dannelse, som man, ligesom Hornet hos Scopholeberis mucronata var. longicornis, vistnok tor anse lor en Planktonkarakter.

\section{Bosminidæ.}

\section{Bosmina.}

Med Rette bemarker Stingelin (95 p. 22:3), at Slagten Bosmina har vaeret en stadig Radsel for alle de Forskere, der har givet sig al med Cladocerer; der er i Aarenes Lob opstillet et meget stort Antal Arter, e. 60, men de farreste af disse kan elter de foreliggende Afbildninger og Beskrivelser genkendes.

Medens det for Slagten Daphnias Vedkommende m. H. t. den langt overvejende Del af de opstilledle Arter vel var muligt at foretage Reduktionen og med ret stor Siklierhed indrangere dem paa deres Plads i Nutidens Systemer, er dette iklie muligt for Bosminernes Vedkommende; thi de Karakterer, hrorpaa Nutidens Systematik hviler, enten kendtes ikke al aldre Undersøgere eller blev i hvert Fald ikke tilbørlig vurderede. Hvad man sarlig savner hos de aldre Forl., er en paa gode Tegninger støttet nøjagtig Beskrivelse af Bagkroppen og Bagkropkløernes Bygning; narmest paa Grund af denne Mangel er Slagten Bosmina bleven en al Systematikkens gordiske Knuder, der nappe kan løses, men vel kan hugges over.

Det vil lor de tleste Cladocerforskere vare en velkendt Sag, at man omtrent i hver eneste Sø, Smaaso og Dam støder paa en eller anden Bosmina-Form; alle de i en og samme Vandmasse levende Bosminer ligner som oftest hrerandre, og det er sjaldent, at man i en saadan linder mere end een Art; herfra undtages dog større Søer, i hvilke man i Alm. kan paavise dels en pelagisk, dels en mere littoral Type. 
Sammenligner man Bosminer al' samme Ant fra forskellige Vandmasser med hverandre, linder man endvidere, at de navolign i Legemets konturer, 1ste Par Antemuers Liengde og Krumning, Øjets Størrelse, Lurystallinsernes Antal og i Kitinstrukluren frembyder lalrige Forskelligheder; Lokalvariationen er enorm; paa Basis af de ovemnerente yderst varierende Bygningsforhold bler det meget store Antal Arter opstillet.

Indsanler man endvidere Bosminerne med regelmassige Mellemrum par mange forskellige Lokaliteter, viser det sig, at de i loblet af Aarel paa nogle Lokaliteter i høj Grad skifter Udseende, medens de paa andre omtrent ser ens ud i alle Aarets Mameder. Paa visse Lokaliteter er de altsaa underkastede en meget tydelig Temporalvariation, paa andre mangler en saadm. Temporalvariationen kommer ikke alene frem i et forskelligh Forhold mellem Højde og Laengile, men ogsata i Ojets Størrelse, i Antennernes Laxngde og Krumning, i Skislstrukturen 0. m. a.

Medens man nu til Dags or klar over, at der sal godt som pa her rnkelt Lokalitet udvikler sig en saerlig Bosminu-Rarer, der dog ingenlunde fortjener at opfattes som en egen Art, har man til Dato en yderst mangelfuld Opfattelse af 'Temporalvariationen. Heraf folger atter, at vi endnu ikke er i Stand iil at foretage den endelige Reduktion af Bosmina-Arterne med samme Sikkerhed som for Daphniernes Vedkommende, og at Forf., der i ovrigt har et aalent Øje for en saadan Reduktions Nodvendighed, stadig staar løvende overfor samme.

Der foreligger i Lilteraturen i Virkeligheden kun eet Forsøgs paa en saadan Reduktion; dette er foretaget af Burckhardt (99 1).510), men Reduktionen er dog allerede paabegyndt hos Stenroos (98 p. 182) og Stingelin (95 p.222). Richard: Révision des Cladocérer $(95-96)$ er endnu ikke naaet til Bosminerne; i sin Monografi over Cladocereme har Lilljelorg $(00$ p. 222) desvarre ikke turdet indlade sig paa nogen synderlig Reduktion.

Burckhardts Forsøg er overordentlig fortjenstfuldt, men det er kun udført paa Schweizerbosminerne og uden narmere Undersøgetse af Bosminerne udenfor Schweiz; direkte at overføre hans Resultater paa vore ferske Vandes Bosminer lader sig ikke gøre.

Man har i Folge Burckhardt i Schweiz paavist mindst 40 forskellige Bosmin-Racer eller »Arter", der lader sig henføre til to Grupper (1), de saakaldte store og middelstore Bosminer, og (2) de smaa Bosminer; sidstnernte indbefaltes alle under Artsnavnet B. longirostris O.F.M., forstnernte under Artsnavnet B. coregoni Baird.

Faclles for B. longirostris-Formerne er (p. (615), at Halekløerne paa to Steder viser et tydeligt Knæk. I det alleryderste Parti er disse glatte; proksinalt er de udstyrede med lange, fine, skraatstillede Børster, distalt med c. 10 lodret staaende Tander; Rostrum er forlænget og maaler mindst 1/5 af Legemslangden, Pandebørsten er fjærnet betydeligt fra Spidsen af Rostrum, og Legemslængden er ikke over $550 \mu$.

Hos B. coregoni er Halekløerne javnt buede uden Knæk, de proksimale Børster er meget svagt udviklede, der er kun 6-8 noget skraatstillede Tander, og uden for disse findes igen en Række yderst fine Haar (»Strichelung«, Burckliardt). Rostrum er kort, aldrig $1 / 5$ af Legemslangden, Pandebørsten staar meget nær Rostrums Spids. Størrelsen er over $550 \mu$.

Burckhardt gik oprindelig (p. 511) ud fra, at B. coregoni-Gruppen indeholdt to Underafdelinger, B. longispina-boltenica og B. coregoni s. str., førstnærnte omfattende de saakaldte middelstore Bosminer, sidstnærnte de store Bosminer. Sidstnarnte Gruppes mest aberrante Former lader sig ogsaa med Lethed sondre fra førstnærnte verl deres store Højde, den totale Mangel paa Mucro, det meget lille Øje og 1ste Par Antenners elegante Krumning; men Burckhardt viser paa Basis af et meget stort og udmærket tilrettelagt Materiale, at der mellem disse to Grupper forekommer alle tænkelige Overgange (p. 627), saa at Resultatet bliver, at en yderligere Sondring af $B$. coregoni i to Arter alligevel ikke er tilraadelig.

Det fremgaar nu af Burckhardts Arbejde, at Schweizersøernes pelagiske Region dels befolkes af B. longirostris, dels af B. coregoni, men kun af de Former, der hører til Gruppen B. Iongispina-bohenica, hvorimod alle de saakaldte store Bosminer næsten ganske mangler i Schweizersøerne. Den langt overvejende Del af Plankton-Bosminerne tilhører i Schweiz Gruppen B. longispina-bohenica.

Undersøgelseme over vore egne Søers Planktonbosminer har givel et fra Burckhardts Studier ganske afvigende Resultat. 
Vel optrieder ogsaa i vore Soer saa vel B. Longibostris som B. coregoni, men B. longirostris spiller i alle vore storre Soers pelagiske Region kun en ganske underordnet Rolle, og af B. coregoni synes hele Gruppen longispiun-bolomica ganske at mangle; vore Søers Planktonbosminer tilhører aldeles overvejende nelop Coregoni-Gruppen eller de store Bosmincr, der nesten ganske mangler i Schweizersøerne. Endvidere er de store Bosminer lier i Landel udprigede Søformer, der, saa vidt vides, endnu ikke er tagne i Smaasøer; disses centrale Partier befolkes derimod af B. longirostris, ganske sarlig af Formen cormuta, dler vistnok hører til vore almindeligste Cladocerer.

Det har fra forste Fard veret mig paafaldende, at del trods det store Materiale, jeg raadede over, aldrig lnar varet mig muligt at parise et eneste Eks. af B. longispina-bohemica-Gruppen. Naar jeg desuagtet tror, al det liesullat, Undersogelsen har givet, noget naer trafler det rette, er det, fordi dette Resultat synes at viere i Overensstemmelse med, livad Undersøgelserne fra le tilgræensende Lande har bragt frem, og for vort eget Lands Vedkommende ogsaa svarer til det, P. E. M üller i sin Tid naaede til.

Der kan nemlig ingen Tvivl vere om, at hans tre Arter, B. longiroslris (O. F. M.), B. cornuta (Jurine) os B. microps P. E. M., alle er Former af Nutidsbegrebet B. longiroslris; ligesom jeg selv synes ogsaa P. E. Müller orervejendc at have taget disse Former i mindre Vande.

Heller ikke kan der vare Tvivl om, at de to Arter B. diaphana P. E. M. og B. Liltjeborgii Sars tilhører Coregoni-Gruppen; vi vil andetsteds komme til at beskaftige os narmere med disse; baade P. E. Müller og jeg sely har fundet dem i Søer; mine Eks. stammer til Dels fra hans Findesteder.

Fremdeles omtaler imidlertid P. E. M üller (68 a. p. 149) to Arter, B. maritima og B. breviroslris, begge opstillede af ham. Disse tilhører i Virkeligheden efter al Rimelighed longispina-boltemica-Gruppen; den førstnxvnte er dog hidtil kun tagen marin og vedkommer os ikke her; den anden er kun funden paa en eneste Lokalitet, en lille Skovsø i Nordsjælland (68 a. p. 150). ${ }^{1}$ )

lnden vi narmere omtaler denne Form, vil det vare formaalstjenligt at gøre Rede for Lilljeborgs Opfattelse af de svenske Søers Bosminer, saaledes som den er fremstillet i hans Monografi (00 p. 222 ). Lilljeborg omtaler 9 Arter, der atter falder i et større eller mindre Antal Varieteter.

Af disse 9 Arter tilhører de to, B. crassicornis og B. globosa, begge opstillede af Lilljeborg, en ny Gruppe af Bosminer karakteriserede ved overordentlig korte og tykke 1ste Par Antenner; de var med Undtagelse af et enkelt Sted i Nordtyskland ikke tidligere fundne udenfor Sverrige, men fandtes i 01 i Silkeborgsøerne i faa Eks.; de vil andetsteds blive nærmere omtalte. Af de øvrige 7 Arter hører B. longirostris O. F. M. og B. longicornis E. Schoedler utvivlsomt ind under $\mathrm{Burckhardts} \mathrm{Begreb} \mathrm{B.} \mathrm{longirostris} \mathrm{O.} \mathrm{F.} \mathrm{M.;} \mathrm{dette} \mathrm{er} \mathrm{hos}$ Lilljeborg kun sondret ud $\mathrm{i}$ to Arter. Ligesaa utvivlsomt hører B. mixta Lilljb. nov. nomen og B. coregoni Baird til coregoni-Gruppen af $B$. coregoui og B. longispina Leydig, samt B. insignis Lilljeb. til longispinabohenica-Gruppen af samme Art.

Tilbage bliver kun een Art, B. obtusirostris G. O. Sars; denne Art synes ganske at mangle i Schweiz saa vel som i hele Nord-og Mellemtyskland; den hører derimod til den skandinaviske Halvøs almindeligste Arter, er vidt udbredt over Finland og forekommer endvidere paa Kolahalvøen, paa Island, i Grønland og paa Behring-Øen (Lilljeborg 00 p. 256). Vi har her med en nordisk til Dels arktisk Form at gore, overordentlig alm. over hele sit Udbredningsomraade og indenfor den arktiske Region maaske den eneste dér optradende Bosmin; den er underkastet en overordentlig stark Variation og angives med ikke mindre end 7 Synonymer, hvoraf de 6 er opstillede af nordiske Forskere. Til denne Art bør i Folge Lilljeborg ogsaa P. E. Müllers ovenfor anførte to Arter, B. brevispina og maritima, henfores; sidstnavnte er (cfr. Lilljeborg 00 p. 245) kun en med Floderne i den botniske Bugt udfort B. oblusiros/ris, der her har akklimatiseret

1) P. E. Müller har selv senere (70 p. 8) henfort B. brevirostris P. E. M. til B. longispina Leydig. Han har dog markelig nok her glemt det af ham selv givne Artsnavn og kalder med Henvisning til den Side, hvor B. brevirostris er beskreven, Arten for B. lacustris. 
sig lil Livel i Bralivand, spredt sig ud over (Osterswen og indlil den sydlige bel af Kallegaltet; her og i Sundet udvikler sig en saerlign Race, der ligger til Grund for P. E. Müllers Beskrivelse af Is. maritinar ${ }^{1}$ ).

1)el limengar nu af Lilljeborgs Angivelser, al de i Sverrig hyppigst forekommende: Bosminer, foruden B. oblnsirestris, er B. longirostris samt Coregoni-Gruppen al B. coregoni. Longispina-bohemica-Gruppen, der i

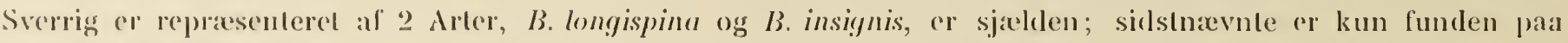
fint Lokaliteler.

Bortsel fra B. obthsirostris or allsaa Lilljeborg m. H. I. Sverrig kommen til samme Resultat som P. La. M üller og jeg selv for Dannarks Vedliommende; on de norske Bosminer lader der sig endnu intet sige med Siklierhed; mbivlsomb spiller dog B. oblusirostris her en meget stor liolle (G. O. Sars 90 p. 40).

If de lalrige Cladocerundersøgelser over hele Nord- og Mellemtyskland samt af Planktonundersggelserne frengan det tydeligt nok, at Bosminerne i disse Landstrakninger overvejende forholder sig som i I)anmark; Iovedlormerne er B. Longirostris og Coregoni-Gruppen af B. coregoni; Longispina-bohemica-(iruppen angives som meget sjactlen.

Vi kan da for Bosminernes Vedkommende skelne imellem 3) (iebeter, el nordligt, til Dels arklisk () mratle vesentligt karakteriseret ved Bb. oblusirostris i dennes mangfoldige Racer: longirostris-bollemica(iruppen af B. coregoni er sjalden; B. coregoni-Gruppen er derimod rel hypjigs, men synes dog at blive sjixldnere, jo hojere man liommer mod Nord, hror B. obtnsirostris rimeligvis til sidst bliver eneraadende: Omraalel indbelatler den skandinaviske Halvø, Nordrusland samt Polarlandene.

1) 1 mellemeuropiske Omraade karakteriseres ved at mangle B. oblnsirostris; i hvert Fald er den meget sjactlen: det samme gxelder om longirostris-bohenica-Gruppen: derimod opnaar indenfor delte Omraade B. corgoni-Gruppen en megel stor Udbredelse og findes her i et slort Antal forskellige Racer; Alperne angiver rimeligvis detle Omraades Sydrand.

Det sydligste Omraade er karakteriseret ved longispina-bohenica-Grupen, der her naar sin stærkeste L'dvikling. Coregoni-Gruppen mangler nasten ganske, og B. oblusirostris er aldrig paavist.

B. longirostris synes sarlig gennem Formen cornula at vare spredt ud over hele delte uhyre Omraade.

Der paatranger sig nu uvilkaarlig del Spergsmaal: Hvad er B. obtusirostris" i hvilkel Forhold staar denne Arl lil B. longirostris og B. coregoni. I Følge Lilljeborgs Angivelser stemmer B. oblusirostris saa vel m. H. I. Antennehørstens Plads som til Halekløernes Krumning og Tornbesxtning paa det nøjeste overens med B. coregoni; L. skriver saaledes: Acnlei mnguitun candalinm femincr lanlummodo mnam seriem, nempe basalem formant. L'ngnes candales femina non prope basin sinnati. Seta capitis inferioris parva sensitiva utrinque prope linean sejunctionis antennarnm 1:mi paris posita (p. 237). Idet nu hverken Lilljeborg eller, saa vidt det er mig bekendt, nogen anden Forsker nogetsteds har paapeget særlige Karakterer, der lod sig anvende til at afgranse B. obthsirostris fra B. coregoni, skønner jeg ikke rettere, end at man for Øjeblikket maa henføre forstnevnte under B. coregoni og sarlig under Iongispina-bohenica-Gruppen. De Karakterer, som man hidtil har anvendt til at udsondre B. oblusirostris, er Antennernes Langde og Mucrones, Bygningsforhold, som vi elter Burckhardts Undersøgelser ved er underkastede den videst mulige Variation. Inden denne Reduktion kan foretages, bør dog det store arktiske og nordiske Materiale af B. obhnsirostris nøje undersøges og sammenholdes med schweizisli Materiale af B. tongispina-bohemica-(iruppen; selv er jeg ude af Stand til at foretage dette, fordi oblnsirostris, i alt Fald her i Landet, er meget sjæelden; medens jeg kender den fra Grønland (94 p. 119 og 120), har jeg nxpe set den i danske Søer; jeg troede i sin Tid (94 p. 122), at jeg i Damme omkring Frederiksborg havde haft demne Art for mig, men har, efter at have lart Burckhardts og Lilljelorgs Angivelser al kende, herom faaet mine Trivt.

Viser det sig, at B. oblnsirostris ikke kan holdes ude fra longispina-bohemica-Gruppen af B. coregoni, og al obtusirostris kun er de nordiske Forskeres Narn for den Form, der findes i Schweizersøerne, da vil det vise

1) Om dens Optrieden indenfor Skagen se S. Jensen (03 p. 311). 
sig, al vi m. I. I. Bosminernes geografiske Udbredning i Europa kun kan lale om to Udloredningsomraader: el nordligat-arktisk-alpinl og et mellemenropecisk Slettelands Onıarde; de kolde, klare, arkliske og alpine Søer med deres ringe Temperatursvingninger er karakteriserede ved B. coregoni i Gruppen longispina-bohemica, de varme Slettelands-Soer med deres sterke Temperalursvingninger og deres paa Detritus og Plankton meget righoldige V'and ved B. coregoni i Gruppen coregoni; B. longirostris synes at lrives i hegge Søgrupper. I anden Del skal jeg parvise, al de arklisk-alpine Coregoni-Former er underkastede en meget belydelig Lokalvarialion, men forholdsvis ringe Temporalvarialion, hrorimod de lave Slettelandssøers Coregoni-Former er underkastede en Temporatvarialion, on hris Udstrekning man i Ojeblikkel nappe har nogen Anelse, men hris Lokalvarialion til Gengadd er noget mindre; jeg vil endvidere da faa Lejlighed til at paapege, hrad der i orrigt allerede berøres i delte Arbejde, at B. Longirostris i Slettelandssøerne overvejende er Dam- og Bredformer, og al den $\mathrm{i}$ all Fald kun ved lave $\mathrm{T} p$. er Planktonorganisme $\mathrm{i}$ større Søer; $\mathrm{i}$ de alpine og arktiske Søer er den derimod, saa vidt Planktonundersøgelser foreligger, konstant Planktonorganisme.

Vi herører her Sporgsmaal af vidtrakkende almen-zoologisk Betydning, som kun vil kunne løses med Hensyntagen til mange forskellige Undersøgelsesomraader; særlig maa disse Dyrs Forplantningsforhold nærmere udredes og Temporalvariationen behandles udførlig, samtidig med at denne sidste gøres til Genstand for billedlig Fremstilling; navnlig dette sidste ligger udenfor dette Arbejdes Rammer og opsattes til det senere, hror der ogsaa vil blive Lejlighed til nærmere at komme ind paa Steners (01) Bidrag til Bosminernes Udluredelse og den Opfatlelse, han har dannet sig $m$. H. t. samme.

\section{B. coregoni Baird.}

For B. coregoni's Vedkommende er Temporalvariationen saa betydelig og forløber saa forskelligt i de forskellige Søer, at det er meget vanskeligt at give gode Habitusbilleder af denne Form, ligesom det er ret umuligt i Littr. at finde Afbildninger, der passer paa de hos os forekommende Former.

Jeg indskræenker mig foreløbig til at henvise til P. E. Müllers $(68$ a.) Tegning af Sorøsos B. coregoni (Tab. II, Fig. 1) under Navn af B. Lilljeborgii og Furesøens (Tab. II, Fig. 3) under Navn af B. diaphana.

Furesø. B. c. er endnu $002 \%$ Tp. 4 en alm. Form, der nast Diaptomus er den hyppigst forekommencle Crustacee; allerede $0122 / 1$ Tp. 1 er den dog ret sjalden og er yderligere aftaget $8 / 4$ T. 1 ; den er stæerkt tiltaget ${ }^{23} / 4$ Tp. 6 og er vedblivende en af Planktonets Hovedformer indtil $0231 / 1$ Tp. 1, men naar dog aldrig i Sommertiden Hyalodaphnierne i Hyppighed; talrigst er den vistnok sent paa Efteraaret. B. c. findes ligeledes i alle Proverne 02. men er dog sjældnere end i 01 og kun talrig $\mathrm{i}$ den sidste Prove $3 / 8$ Tp. 15.

Seksualper. er paavist i Dec.; paa dette Tidspunkt er der baade i 00 20/12 og 01 17/12 paavist Hunner med Ephippier, men maekelig nok ikke Hanner.

Soroso. B. c. er endnu $0019 / 12$ Tp. 5 ret alm.; den er yderst sjalden $015 / 5$ Tp. 10 ; fra $26 / 5$ Tp. 13 stiger Antallet langsomt; endnu $9 / 8$ T p. 23 er den ikke nogen hyppig Form; det store Maks. naas forst 17/10 Tp. 12, 18/11 Tp. 7 , og vedvarer endnu $023 / 1$ Tp. 2; den er stadig talrig $30 / 1$ Tp. 1, men efter sidste Islosning $24 / 3$ Tp. 1 y(lersì sjæelden. Antallet stiger nu stærkt, og i Sommerproverne $7 / 6 \mathrm{Tp} .15$ til $27 / 7$ Tp. 16 er den markelig talrig.

Seksualper. er paavist i Nov.; paa dette Tidspunkt findes en Del Hunner med Ephippier, ligeledes adskillige Hanner.

Tjustrupsø. B. $c$. er ret alm. (00 ${ }^{19} / 12$ Tp. 3, men meget sjælclen i alle Foraarsprøver og ikke synderlig alm. i Sommerproverne 01; Maks. falder forst ${ }^{16} / 10$ Tp. 13 og $18 / 11$ Tp. 7, derpaa tager Arten stærkt af og er i hele 02 lige til $30 / 6$ Tp. 15 kun til Stede $\mathrm{i}$ ringe Mrengle; den er talrig $27 / 7 \mathrm{Tp} .15$.

Seksualper. er paavist $01 \frac{16}{10}$ og $18 / 11$; der er set adskillige Hunner med Ephippier samt Hanner.

Viborgsoerne. B. c. spiller her kun en underordnet Rolle; den er vel paavist i alle Proverne, men er af alle Crustaceer den, der forekommer i det mindste Individantal; der spores et svagt Maks. 01 10/11 Tp. 8 og 8/12 Tp. 2. Seksualper. er ikke paavist.

Haldso. B. . er kun funden i et enkelt Eks. $013 \% / \mathrm{T}$, 1 og er endnu efter Islosningen 29/3 Tp. 2 meget sjalden; derimod er clen markelig talrig i Proverne $18 / 5$ Tp. $10 \mathrm{og}$ indtil $22 / 6$ Tp. 13, hvorpaa Arten tager stackt af og lige til

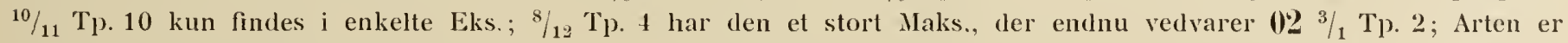
derpaa ret sjalden, men holder sig dog med en Del Eks. indtil ${ }^{11} / 6$; i de folgende Prover forekommer den kun enkeltvis.

Seksualper. er mærkelig nok ikke paavist. 


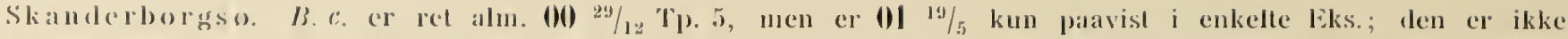

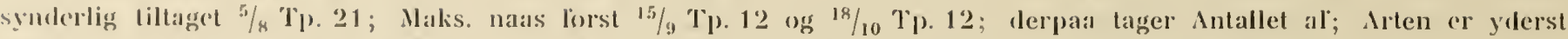

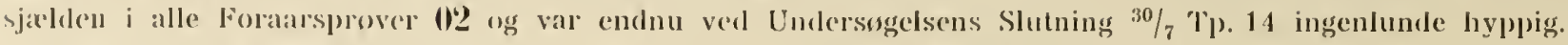

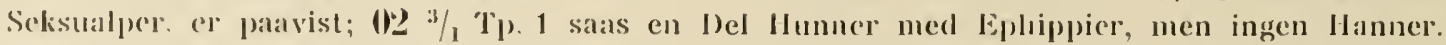

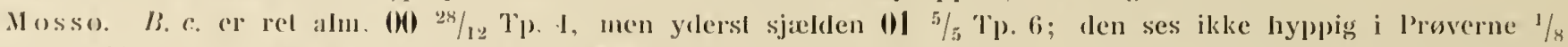

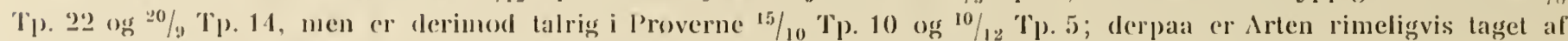

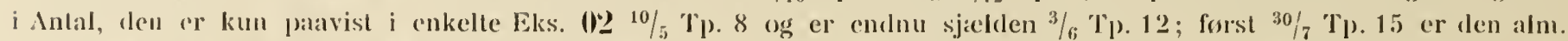

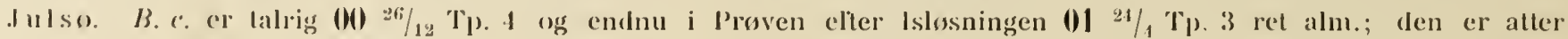
talrig $20 / 5$ Tp. 13, livorpar Antallet lager starkt al; i Sommerproverne $10 / 7$ Tp. 20 og $1 / 8$ Tp. 22 findes kun laa Eks., men Antallet stiger 15/. Tp. 12. Arten lar at neget stort Maks. 15/10 Tp. 12 og 20/11 Tp. 6; (len er endnu talrig i

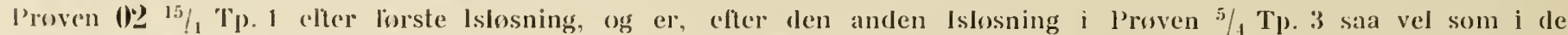

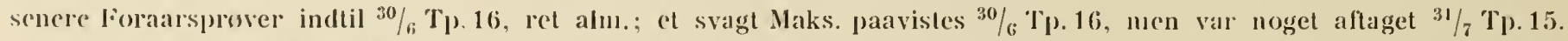

Scksualper. (P panvist (M) $26 / 12$; samtidig saas adskillige Hunner med Ephippier og enkelte Hanner. O/ $20 / 11$ paa-

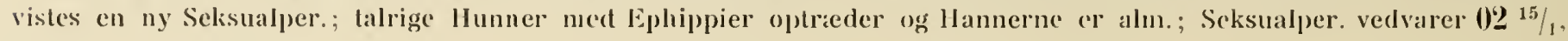
men afslultes inden $5 / 9$.

Af de ovenfor givne Meddelelser indskranker vi os foreløbig til at uddrage følgende 'Traek.

B. coreyoni cr paavist i alle de undersøgle Søer med Undtagelse af Esronisø og maa sikkert siges at vaere (n) i rore storre Søer vidt udbredt Form.

I alle Socrne ligger el neget udpragget Min. umiddelbart efter Isløsningen i April; derpaa synes der i de lleste Soer at indtralle et ret belydeligt Maks. i Maj og Beg. af Juni; i Sommertiden bliver Arten i Alm. sjaeldnere, men findes dog altid i ret betydeligt Antal; dette stiger igen om Efteraaret, indtil det store Maks. indraller i Nov.; undertiden varer dette til ind i Jan. (Julsø).

Seksualper, er aldrig paavist on Forıaret; om Efteraaret er en saadan derimod paavist i Furesø, Sorøsø, Tjustrupso, Skanderborgsø og.Julsø; som oftest fandtes kun et ringe Antal Hunner med Ephippier, sjældnere Hamner; kun i Julsø rar begge talrige; Seksualper. kan strakke sig ind i Jan.; om Ephippierne cfr. Scourlield (01 a. p. 51).

For Vierwaldstädtersøens Vedkommende angiver Burckhardt en meget lignende Periodicitet (00 p. 137 ). Ogsáı B. finder et Foraarsmin. i Marts-April og derpaa et Maks., der dog falder noget senere end hos os (Slutn. af Juni og Juli); dette efterfølges af et Min., der svarer til vort Sommermin., men som der indtræffer Sep.-OKt.; til Slut kommer det store Vintermaks. i Beg. af Feb., - hos os allerede begyndt i Okt. og kun undtagelsesvis vedvarende til Jan.

Man ser altsaa, at Burckhardt saa vel som jeg selv har fundet to Maks. og to Min., men i danske Soer er disse forskudt noget fremefter og indtræffer 1-2 Maaneder førend i Schweiz.

Burckhardt har saa lidt som de øvrige Planktonundersøgere kunnet paavise Seksualper.; Grunden hertil er vistnok den, at de alle kun har benyttet Materiale hidrørende fra Vertikalprøver og taget med altlor fintmaskede Net.

\section{B. lonyirostris (O. F. M.)}

III. se 2den Del.

Fi ureso. B. $l$. optræaler enkeltvis $(0020 / 12$ Tp. 4 og fremdeles i nogle af Proverne til (01 23/4 Tp. 6; derpaa tiltager Arten og er ret alm. indtil $7 / 6$ Tp. 16 , forsvinder saa totalt og viser sig ikke for $2 / 10$ Tp. 16 ; den har et Maks. $16 / 11$ Tp. 4, tager noget af, men er dog ret alm. i Vinterproverne; den bliver derpaa talrig $02{ }^{11} / 4$ Tp. 4 og har et stort Maks. $5 / 6$ Tp. 12: ${ }^{17} / 6$ Tp. 14 er den yderst sjalden, og $\mathrm{i}$ de senere Prover er den forsvunden.

Esromso. B. l. spiller en ganske underordnet Rolle i Soen; den mangler i Tiden fra (01 29/6 Tp. 15-5/9 Tp. 16 og lindes i 02 ikke efter ${ }^{13} / 6$ Tp. 13; i le ovrige Prover optrader den kun i ringe Mangde; den er hyppigst i Efteraarsog Sommerprover.

Soroso. B. l. er af underordnet Betydning i Soens Plankton; den har et Maks. 01 26/5 Tp. 13, hvorpaa den totalt forsvinder indtil $18 / 9$ Tp. 12 , da et eneste Eks. er set; den er sjælden hele lifteraaret og Vinteren, men har atter et Maks. 0 2 $16 / 5$ Tp. 7 ; efter $7 / 6$ Tp. 15 forsvinder den fuldstendig.

Tjustrupsø. B. l. har ogsaa her et svagt Foraarsmaks. i Proverne $015 / 5$ Tp. 7 og ${ }^{24} / 5$ Tp. 13; et Par Eks. er sete $3 / 7$ Tp. 17 , men $\mathrm{i}$ ovrigt el den totalt forsvunden indtịl 16/10 Tp. 13; den findes sporadisk og enkeltvis $\mathrm{i}$ Resten 


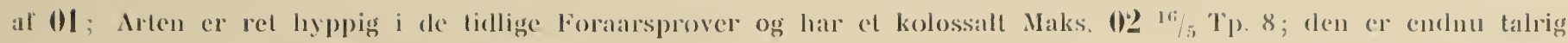
i/, Tp. 12, men lorsvinder derpan ganske.

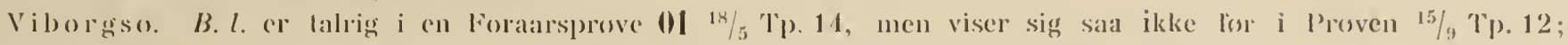

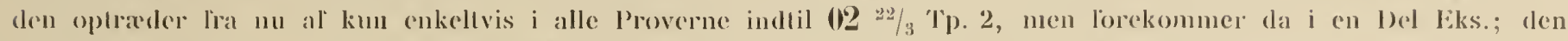

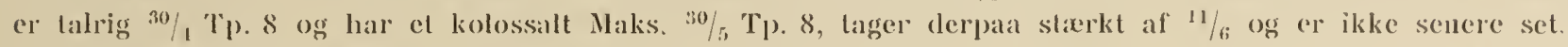

Haldso. B. l. oplraeder uden saerlige Maks. i adskillige prover og altid kun enkeltvis; den er maerkelig nok ogssala pasvist i laa liks. $112 \% / 7$ Tp. 17 og $7 / 8$ Tp. 18.

Skanderborgso. B. L. viser ikke noget Maks. (1) 19/5 Tp. 13; det er muligvis indtrulfet senere; den mangler i Proven $5 / 8$ Tp. 21, men findes enkeltvis eller i ringe Miengde hele Elteraaret og i 02 indtil $3 / 6$ Tp. 15), da (len optrader med et meget stort Maks,; $28 / 6$ Tp. 18 findes kun ganske enkelte Eks., og 30/7 Tp. 14 er alen lorsvunden.

Mosso. If de sparsomme Prover fremgar det kun, at B. l. har et Maks. (1 20/5 Tp. 12; den mangler i Proverne

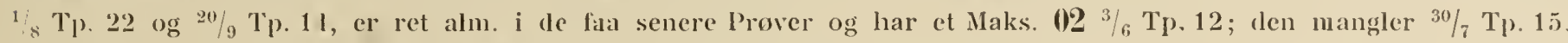

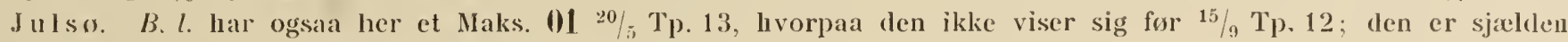
hele Efteraret og har i 02 forst et Maks. $2 / 6$ Tp. 13 ; senere er den ikke paavist.

Det fremgaar da lieraf, at B. longirostris frembyder folgende ret markelige Forhold.

B. . findes som Planktonorganisme i alle de undersøgte Søer. I alle Søerne (undtagen Haldsø) er del i Maj og Beg. af Juni parvist et Maks,, som kan vare overordentlig stort; efter dette forsvinder Arten pludseligt og totalt af den pelagiske Region, kun i Haldsø er et Par Eks. sete i Juli-Aug.; den viser sig ikke igen før midt i Sep. og findes nu i de allerfleste Søer enkeltvis eller i ringe Mængde hele Efteraaret; Arten kan vare ret hyppig i Vinter-og Foraarsprøverne og har da atter sit Maks. i Maj-Juni; i Furesø er et mindre Maks; paavist om Efteraaret.

I ingen af Søerne er der paavist Seksualper.; Hanner er ikke sete, ej heller Hunner med Eplippier.

Ved Damundersøgelsen 98 blev Arten hele Aaret paavist i Mængde i Smaasøernes centrale Partier; Maks. faldt ogsaa her i Forsommeren; ligeledes fandtes i alle de undersøgte Søer $B$. $l$. hele Sommeren som Littoralform, men var som saadan dog ikke synderlig talrig; der synes fra Littoralzonen i April-Maj at finde en Udvandring Sted til den pelagiske Region, men jeg indskranker mig her til at konstatere dette. Jeg skal $\mathrm{i}$ anden Del søge at forklare, hvorfor B. longirostris om Sommeren ikke kan vaere pelagisk Organisme i vore og som det synes heller ikke i det øvige mellemeuropæiske Slettelands Søer.

\section{Lynceidæ.}

Fam. Lynceide indbefatter nasten udelukkende Bund- og Bredformer, og kun en eneste Slaegt, Chydorus, traffes konstant i større Søers pelagiske Region, hvor Arter af Slagterne Pleuroxus og Alona samt Acroperus leucoceplaalus (Koch) i øvrigt nu og da forekommer; de er her i alt Fald paaviste i adskillige af vore Søer. I Følge Zschokke o. a. (00 p. 296) optræder disse Former saa vel som andre Littoraldyr pelagisk i højtliggende alpine Søer.

\section{Chydorus.}

Der er af denne Slægt i Følge Lilljeborg beskrevet (00 p. 547) c. 20 Arter; P. E. M üller (68a. p. 194) angiver her i Landet to Arter, C. sphtricus og C.globosus Baird.; sidstnavnte er en udpraeget Damform.

C. spharericus (O. F. M).

Lill jeborg 00. Tals. 77, Fig. 8-25.

Sorøsø. C. s. er perennerende; den forekommer i Planktonet ganske enkeltvis i det forste Halvaar 01, men tiltager i Aug. og viser sig 18/9 Tp. 12 i Overfladen i stor Mangde; talrige Unger ses, og de storre Eks. indeholkler 2-3 Eg eller Unger; Hanner blev ikke paaviste; allerede ${ }^{17} / 10$ Tp. 12 or Antallet stærkt aftaget. C. $s$. lincles enclnu 18/11 Tp. 7, nien kun i faa Eks.; den er ikke fünden i Jan.prøverne 0 2 , men sporadisk 24/3 Tp. 1, hvorpaa den viser sig i alle folgende Prover, i Alm. dog kun i ringe Mængde.

Tjustrupsø. C. $s$. synes ikke at være nogen konstant Beboer af Søens pelagiske Region; den er kun paavist enkeltvis i enkelte Prøver; hyppigst $01{ }^{17} / 9$ Tp. 12.

De danske Sners Plankton. 


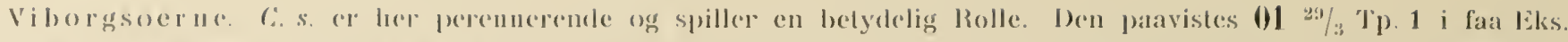

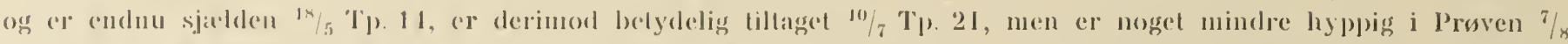

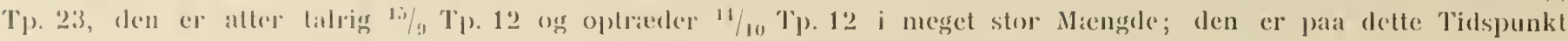

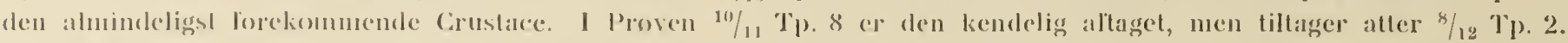

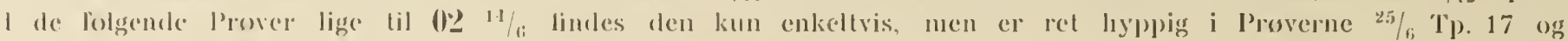
$97 / 7$ T). 15

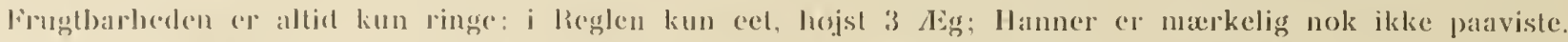

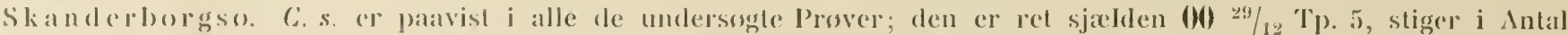

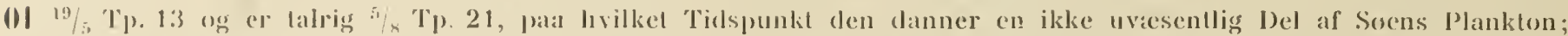

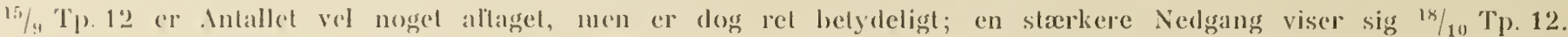

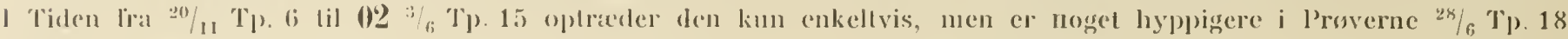

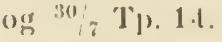

Mosso. C.s. er rimeligvis perennerente; den er parast i ringe Antal i Proven 01 20/5 Tp. 12 . I Proven 1/8

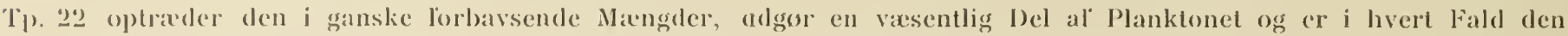
hyppigst lorekommende Crustacee. I alle folgende Prover i 01 og lige til $02 \mathbf{2} 30 / 7$ T. 15 er den sjaxlen, men optraeder da aller med el megel stort Malis. Ontrent som (0) $1 / 8$.

dulso. C.s. er rimcligvis perennerende; $0120 / 5$ Tp. 13 er Arten ret aln., men optreder allerede i Proven $10 / 7$ T). 20 i neget stor Mangde og er paa dette Tidspunkt den hyppigste Crustace; den er endnu talrig $1 / 8$ Te. 22 , hvorpat den igen tager stiurkt af og i alle prover lige til $0231 / 7$ Tp. 15 stadig er sjalden; $31 / 7$ er den noget hyppigere, men opnaar ikke saa stort et Maks. som i 01 .

I Ifureso, Es roms og Haldso er C. s. ikke paavist.

Naar der i let foregaaende er brugt det Udtryk, at C. s. ikke er paavist i vedkommende So, menes dermed selvlolgelig, at den ikke er funden som Planktonorganisme i denne; inde ved Bredden er C. s. paavisi i hyer eneste So og er f. Eks. baade i Fureso og Esromso overalt i Scirpus Phragmites-Baltet og i Myriophyllum-Baeltet en overmaade alm. Skabning. Som en af Landets almindeligste Daphnier blev den paavist overalt ved Damundersogelsen 98; den var ogsaa her meget olte en konstant Beboer af Dammenes centrale Partier.

Som Planktonorganisme er det en Overfladeform, der ganske synes at mangle i dybere Vandlag.

Det fremgat da af de ovenfor girne Meddelelser, at vi i Chydorus sphwricus har en Littoral- og Bundform for os, som hele Aaret og altid i betydelig Mrngde lever inde ved Søbredden; den er i visse Søer altid Littoralform, i andre derimod optraeder den tillige som Planktonorganisme, der vel den største Del af Aaret er sjaclen som saadan, men til Gengæld indenfor en vis skarpt begranset Tid kan optrade i saa uhyre Mangder i den pelagiske Region, at den bliver Planktonets dominerende Crustacee.

Alt i alt tor man vel sige, at dette Frnomen er sjældnest i dybe, kolde og klare Søer (Furesø, Esromsø, Tjustrupso, Haldsø), men at det i hvert Fald kan vare meget markeret i Søer med høje Cyanophyceemalis. (Viborgso, Julso). Paa intet af disse Forhold hør man dog laegge for megen Vagt; intetsteds opnaar C. s. saa stort et Maks. som i Mossø, den storste af de undersøgte Søer, der ligesaa lidt som Sorøsø kan opvise synderlig hoje Cyanophyceemaks.

Baade i Skanderborgsø, Mossø og Julsø falder Tiden for C. s.' Optreden som Planktonorganisme i Sluln. af Juli og i Beg. af Aug., i Viborgso derimod betydelig senere: i Okt.

I alt Fald for de tre førstnaernte Søers Vedkommende indtreffer Perioden som Planktonorganisme paa samme Tid i de to Iagttagelsesaar. Navnlig for Mossos Vedkommende er det ganske markeligt at se denne i den pelagiske Region i ovrigt sjacldne Art her opvise sit kolossale Maks. 01 $1 / 8$ og et ikke meget mindre Maks. 0² ${ }^{30} / 7$; i alle de øvrige Prøver optrader den kun enkeltvis.

Rettest bor man vistnok opfatte Frnomenet som en Vandring, idet C. s., som det synes, til ret bestemte Tider fra Littoralzonen trækker ud i Søernes pelagiske Region. Aarsagerne hertil er os ganske ukendte; i Analogi med V'andringsfonomener hos andre Dyr matte man nermest tanke sig, at denne Vandring enten skyldes Ernarings- eller Forplantningsforhold. Selr heldede jeg nxrmest til den sidste Opfattelse og har derfor overalt i det indsamlede Materiale omhyggelig eftersøgt Hannerne; ikke desmindre har jeg aldrig taget disse som Planktonorganismer i større Søer; Hrilexg synes ikke at dannes, saa længe Arten opholder sig i den 
pelagiske Region; derimod loregata den parthenogenetiske Formering meget livligh, Vandet vrimler af unge byr uden digg. Hvor vidt vi her har en Ermaringsvandring for os, kunde Tarmundersogelser dels til forskellige darstider og dels paa Eks. stammende batale fra Littoral- og fra den pelagiske Region muligvis give niermere (Oplysunger on.

Mulig skyldes Fanomenet knn en Overbefolkning i Littoralregionen, men jegs blev desvarre for sent klar over dets Almengyldighed, lil at Undersogelser desanganende kunde sáttes i Gang.

Ligesom Stingelin (95 p. 262 ) har jeg iagttagel, at der er stor Forskel i Hensecnde til Individernes Udsecnde navnlig m. H. I. Laengde- og Højdeforholdel; en Del Eks. er nasten kuglerunde, hos en Del, og vistnok navnlig de yngre, er Laengilen betydeligs større end Højden; der gives dog alle Overgange mellem dem.

C. s. synes ikke at optraede pelagisk i de store europaeiske Søer; den angives i alt Fald ikke som saadan i Schweizersøerne; i let mellemeuropæiske Slettelands Søer optræeler den, ogsaa udenfor Danmark, snart som Littoralform, snart som Planktonorganisme. Apstein har ment (96 p. 95), at Clydorus særlig skulke vere pelagisk i hans saakaldte Croococcaceesøer, men derimod liltoral i hans Dinobryum-Søer. Vi har ovenfor set, at Clydorus som pelagisk Organisme i Søer nied høje Cyanophyceemaks. kan opnaa høje Maks., men at saadanne ogsaa kan fremkomme i Søer, lıvor Cyanophyceerne ikke spiller nogen synderlig Rolle; Apsteins Opfattelse kan derfor ikke fuldt ud opretholdes; den er $\mathrm{i}$ øvrigt i det vaesentlige tiltraadt af Birge (97 p. 349-350), der har iagttaget, at C. s. var sarlig alm. i de Aar, da en rigelig Udvikling af Anabcha o. a. Cyanophyceer havde fundet Sted. Ogsaa Birge opfatter den som Littoralform og angiver, at Antallet i den pelagiske Region øgedes kolossalt i Dagene mellem den 8. og 10. Juni efter en særlig stærk Nord- og Nordvestvind.

Allerede P. E. Müller (68 $\alpha$. p. 194) omtaler Arten som en mindre udpraget Bundform end de øvrige Lynceider; den er ogsaa senere funden som Midtvandsform i Plönersø (Zacharias 93 p. 32), Stuhmersøerne (Seligo 00 p. 67) o. a.; saa vel Apstein (96 p. 174) som Seligo angiver, at dens Maks. ligger i Sommerhalvaaret; ogsaa i Følge Apstein er C. s. som Planktonorganisme acyklisk; i Smaadamme skal den i Følge Weismann (76-79 p. 393) kunne være polycyklisk, men dog paa mange Lokaliteter ogsaa optræde acyklisk.

Arten er Kosmopolit; den er overmaade alm. i Grønland, hvor Hannerne forekommer i stor Mangde (W.-L. 95 p. 126).

\section{Gymnomera.}

\section{Onychopoda.}

\section{Polyphemidæ.}

Fam. indbefatter 4 Slagter, hroraf de to, Podon og Evadne, er marine; af de to øvige er Bythotreplies en udpræget pelagisk Organisme, Polyplemus, Hovedart P. pediculus (Linné), en Dam- og Mosebeboer, der dog ogsaa findes i større Søers Littoralregion; herfra forslaas den undertiden ud i den pelagiske Region, hvor den dog ikke hører hjemme. I mindre Vandmasser ser man den ofte staa i smaa, skarpt begransede Svarme paa aabne, solbelyste Pletter imellem Vegetalionen; kun en enkelt Gang har jeg set denne Art optræde i større Mængde $\mathrm{i}$ en Søs pelagiske Region. Prøver fra Almindsø $01{ }^{3 / 8}$ Tp. 18 indeholdt $P$. $p$. i stort Antal; den iagttoges ude paa Søens centrale Partier; Arten var midt i sin Seksualperiode, og der fandtes talrige Hanner; Almindsø, der hører til vore dybeste Søer, er smal og har slejlt nedfaldende Bredder, altsaa en meget smal Littoralzone.

\section{Bythotrephes.}

Der er af Slægten Bythotrephes beskrevet en Del Arter, som efter Lilljeborg alle henføres til to, B. longimanus, der er den alm. forekommende, og B. Cederstrømii Schoedler, der ikke skal findes udenfor den skandinaviske Halvø; begge opløser sig i øvrigt i en Del Varieteter, af hvilke man sarlig lagger Marke til Var. arcticus, 
kamaliteristisk for den skandinaviske Halvos arktisk-alpine Fjaddvande; den naar i Følge Lilljeborg

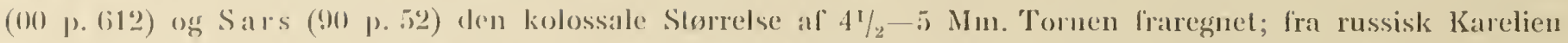

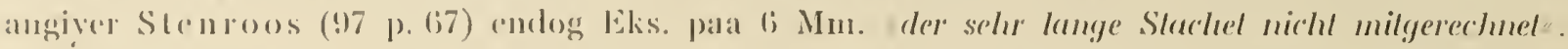

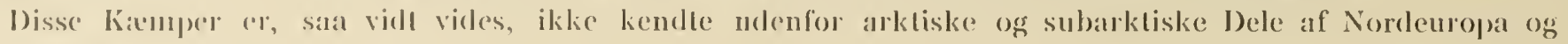
fincles lecller ilike loos os.

P. E. Müller, der forst fandt Ryghotrephes herhjemme, bestente sine Eks. fra Esromsø lil B. Cederstrsmii (bisa. p. 20:3); Lilljeloorg, der holder de to Arter ude fra hinanden ved, at Tornen hos B. Longimanus er ganske

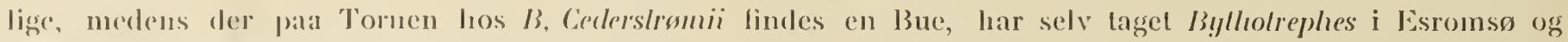

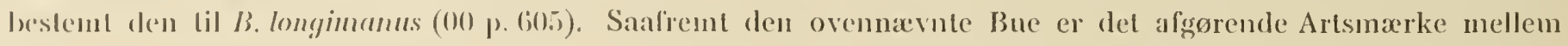

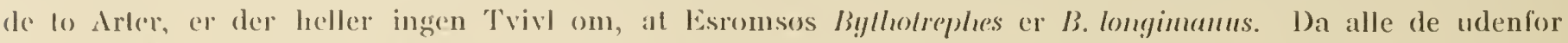
Nordenropa fundne Bythotrepher efter Lilljeborg bor henføres til denne Art, retter jeg P. E. Müllers Bestemmelse og henforer ogsan vore Bythotrepher til B. Ionginanus; Müller kunde, da han skrev sit Arbejde, nappe med Sikkerhed bestemme Arten, se herom M ïller (68 a. p. 204).

\section{B. Ionginanus Leydig.}

Lilljeborg 00. Tab. 80, Fig. 10.

Fureso. B. l. blev paa en mig uforklarlig Maade overset i 01; Arten fandtes i Slutn. af Aug. 02 af Mag. llenning Petersen; den syntes kun at opholde sig $\mathrm{i}$ dybere Vandlag, men var selv i Prover, tagne med vidmaskede Net, og som i lengere Til var trukne horisontalt, ikke hyppig; Mængden var omtrent uforandret i Sep.; de sildste liks. Salas i Slutn. af Okt.

Esroms G. B. l. viser sig i enkelte Eks. i Proven (01 25/5 Tp. 13; $29 / 6$ Tp. 15 synes Antallet ikke synderlig storre, men $\log$ noget steget ${ }^{20} / 7$ Tp. 17 ; det tiltager stierkt i Proverne ${ }^{12} / 8$ Tp. 21 og $5 / 9$ Tp. $16 ; 30 / 9$ Tp. 17 er Arten betydelig aftaget og yolerligere ${ }^{15} / 10$ Tp. 12 ; de sidste Eks. er sete ${ }^{10} / 11$ Tp. 7. I 02 fandtes de første Eks. ${ }^{13} / 6$ Tp. 13; Antallet var ringe endnu $10 / 7 \mathrm{~T}$ p. 14 , men betydeligt $31 / 7$ Tp. 15 .

De faa liks. fra $0125 / 5$ er unge Hunner uden $\mathrm{Ag}$; i Proven $20 / 7$ indeholder de fleste Hunner kun to $\mathrm{Eg}$, hrorimod Hunnerne fra 12/8 -5/9 næsten alle har $4 \mathrm{Eg}$ eller Embryer; samtidig viser der sig en meget talrig l'ngel; Hvilexg paavises forst $15 / 10$, af disse findes kun to; Eks. fra $11 / 11$ er golde; Hannerne er markelig nok undgaaede min Opmærksomherl.

Skanderborgso. B. l. er paavist i ganske faa Eks. i en enkelt Prove fra 01 5/8 Tp. 21.

Julso. B. l. paavistes i enkelte Eks. 01 $10 / 7$ Tp. 20; Antallet var storre i Proven $1 / 8$ Tp. 22, men atter ringe 15/9 Tp. 12. I 02 fandtes den $\mathrm{i}$ faa Eks. ${ }^{2} / 6$ Tp. 13 og $30 / 6$ Tp. 16; den var noget hyppigere $31 / 7$ Tp. 15. Der saas kun Hunner med Sommeræg.

I storst Nlængle fandtes (log Bythotrephes i Almindso $013 / 8$ Tp. 18 . Den optraadte her i uhyre Mrengde og stor saa godt som udelukkende paa dybt, 20-30 M. Vand.

Naar Oplysningerne om B. longimanus er saa ufuldkomne, skyldes del vasentlig, at der ikke overalt er anvendt vidmaskede Planktonposer.

B. I. er sikkert vidt udbredt i vore større Søer; om dens Udbredelse i mindre ved vi foreløbig intet; den kommer rimeligvis frem i Maj, har sil Maks. ved Vandets højeste 'Tp., sin Seksualper. i Okt.-Nov. og forsvinder derpaa; fra Slutn. af Nor. og indtil Maj er B.l. ikke iagttaget.

I Følge mine lagltagelser er Byllolrephes longimanus mere udpreget Dybvandsform end nogen anden. Daphnie, ja end nogen anden Planktonorganisme i Ferskvand; den tages i størst Mængde paa 15-25 M Vand. P. E. M üller er kommen til et noget andet Resultat; han angiver nemlig, at Esromsøens Byllıolrepltes er almindeligst i Vandlag fra $1 / 3$ M. til $1 \frac{1}{2}$ M. (68 a. p. 214); i Overfladen og i større Dybder har P. E. M üller ikke taget den. Det kan bemærkes, at alle Eks. fra 01 25/5 kun havde eet Par Caudalkløer; det storste Antal, man har iagttaget, er tre, hvilket var det sxdvanlige senere hen paa Sommeren. Angaaende disse Caudalkløer se P. E. M üllers smukke Iagttagelser (68 a. p. 66).

B. longinianus synes at have sin videste Udbredelse over Nordeuropa: Lillje borg (00 p. 616); i Plönersøerne angives den at rære sjælden: Apstein (96 p. 176); den er alm. i Bodensøen: Weismann (77 p. 381), 
Bruno Hofer (99 p. 16); Arten er ligeledes parvist i Neuenburgersec : li ulumann (00) p. 121$)$ og i lalrige

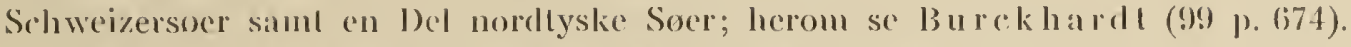

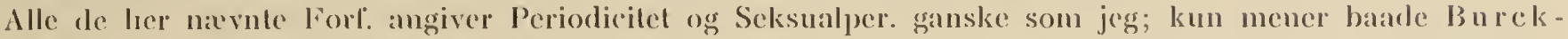

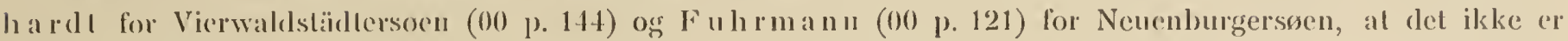
afgiort, at Bylholrephes dor ud om Vinteren. I forstnovnte Sø bler den nemlig parvist i alle Mancder undlagen Fol)., i sidstnavernte $\mathrm{i}$ alle Maneder undlagen Jan.

()m den vertikale Udbredning se Burcklardt (00 p. 210-213) ogs Bruno Hofer (99) p. 44). Meget interessint or Burckhardts Pavisning al unge Bylhotrepher i den abyssate Region i Marts; B. fornocler, at lan her har haft med Dyr at gore, der er klackede af Hvileags og bundfoldede i den abyssate Region.

\section{Haplopoda.}

\section{Leptodoridæ.}

Fan. Leplodoride indloefalter kun een Slaegt med een Art, Leplodora Kindiii (Focke); den synes at vare underkastet en ret betydelig Variation og navnlig i Søer med ganske svag Saltholdighed at frembyde Bygningsforhold, der ikke uvasentlig afviger fra de normale (Sandmann 43 p. 1).

\section{Leplodora Kindlii (Focke).}

Weismann 74. Tab. 34, Fig. 3.

Furesø. $L . K$. viser sig første Gang $01 \% / 6$ Tp. 16; den er endnu lidet liyppig $30 / 6$ Tp. 18 , men er fra $15 / 7$ Tp. 20 til $2 / 10$ Tp. 16 meget talrig, ravnlig paa dybere Vand; den er strerkt aftaget $21 / 10$ Tp. 11; de sidste Eks. saas $16 / 11$ Tp. 4. I 02 viser den sig forste Gang $17 / 6$ Tp. 14; den er endnu kun ret alm. $3 / 8$ Tp. 15.

Hanner samt Hunner og Hvilexg er iagttagne $0121 / 10$ og $16 / 11$.

Esromsø. L. $K$. viser sig forste Gang i ringe Mængde $0129 / 6$ Tp. 15; den er betydelig hyppigere $20 / 7$ Tp. 1F, danner store Masser af Zooplanktonet $12 / 8$ Tp. $21 \mathrm{og} 5 / 9$ Tp. 16; Arten er stærlit aftaget $30 / 9$ Tp. 17 og er sjælden 15/10 Tp. 12; den forsvinder i Proverne efter 10/11 Tp. 7 . 102 er Arten paavist enkeltvis ${ }^{13} / 6 \mathrm{Tp} .13,{ }^{10} / 7 \mathrm{Tp} .14 \mathrm{og}$ er talrig $31 / 7$ Tp. 15 .

Hanner samt Hunner ned Hvileag er iagttagne $015 / 9-30 / 9$ og $15 / 10$.

Soroso. $L$. $K$. viser sig her sparsomt allerede 01 $5 / 5 \mathrm{Tp} .10$; den er lidt hyppigere $26 / 5$ Tp. 13 og er yderligere tiltaget $3 / 7$ Tp. 21; sit Maks. naar den i Aug.-Sep. (Prøverne $9 / 8$ Tp. 23 og $18 / 9$ Tp. 12) og optræder da i uhyre Mængder. ${ }^{17} / 10$ Tp. 12 er Arten stærkt aftaget; de sidste Eks. saas ${ }^{18} / 11$ Tp. 7 . I 02 viser de første Eks. sig $7 / 6$ Tp. 15 ; den er meget alm. i Prøverne $28 / 6$ Tp. 17 og ${ }^{27} / 7$ Tp. 16.

18/9 findes talrige Hanner; disse saa vel som Hunner og Hvileag er ligeledes paaviste ${ }^{17} / 10$ og $18 / 11$.

Tjustrupsø. L. K. er mærkelig nok forst paavist $013 / 7$ Tp. 17, skont det maa formodes, at den allerele liar varet til Stede, da Proven $24 / 5$ Tp. 13 toges; den er starkt tiltaget $8 / 8$ Tp. 22 og har sit Maks. fra da af og til 17/9 Tp. $12 ; 16 / 10$ Tp. 13 er den i Aftagende, og de sidste Eks, ses $18 / 11$ Tp. 7 . I 02 paavistes de forste Eks. $7 / 6$ Tp. 12 ; Arten var ret alm. ${ }^{30} / 6$ Tp. 15 og talrig $27 / 7$ Tp. 15.

De forste Hanner saas $17 / 9$ og var talrige i denne og den folgende Prove; enkelte Hanner og Hunner samt Hvileæg findes endnu $18 / 11$.

Viborgsø. L. K. optraeder ogsaa her først $01 \frac{1 \%}{7}$ Tp. 21; den er først talrig $7 / 8$ Tp. 23, men allerede stærkt aftaget $15 / 9$ Tp. 12 ; den er sjælden ${ }^{14} / 10$ Tp. 12 , og de sidste Eks. saas ${ }^{10} /{ }_{11}$ Tp. 8 . I 02 viser $L$. $K$. sig enkeltvis ${ }^{14} / 6$ og synes kun ret alm. ${ }^{27} / 7$ Tp. 15.

Hanner er iagttagne $14 / 10$, men kun i ringe Mængle.

Haldsø. L. $K$. viser sig første Gang $018 / 6$ Tp. 13 tiltager i Antal $22 / 6$ Tp. 13 og 20/7 Tp. 17. Maks. naas $7 / 8$ Tp. 18 og $16 / 9$ Tp. 13; derpaa tager den af ${ }^{14} / 10$ Tp. 13, men findes endnu $\mathrm{i}$ en hel Del Eks. 10/11 Tp. $10 . \quad \mathrm{I}^{2} 2$ optræeder Arten første Gang ${ }^{11} / 6$ Tp. 12, men er endnu ikke synderlig hyppig $2 / 8$ Tp. 15.

Hanner samt Hunner og Hvilexg er paaviste $16 / 9$ og $\mathrm{i}$ de følgende to Efteraarsprover.

Skanderborgsø. L. K. er først paavist $015 / 8$ Tp. 21, men har sikkert været fremme længe før; den er meget talrig og danner endnu store Dele af Planktonet $15 / 9 \mathrm{~T} p .12 ; 18 / 10 \mathrm{Tp} .12$ er den sjælden og ikke senere paavist. I 02 er den funden $3 / 6$ Tp. 15; den er talrig ${ }^{28 / 6}$ Tp. 18 og tiltager i Mængde $30 / 7$ Tp. 14.

Hanner saa vel som Hunner og Hvileæg paavistes 01 15/9 $0 \mathrm{~g} 18 / 10^{\text {. }}$ 


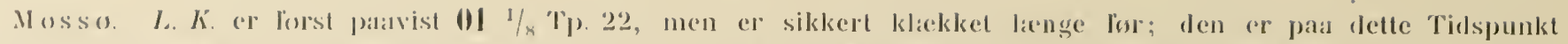

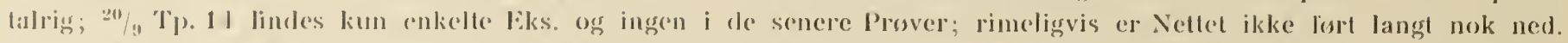

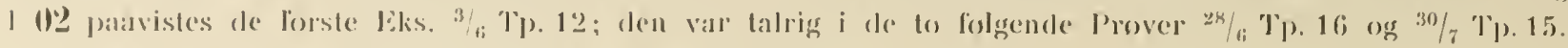

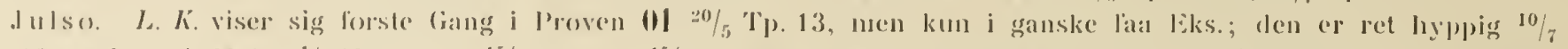

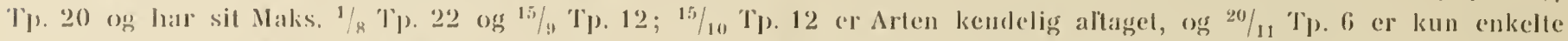

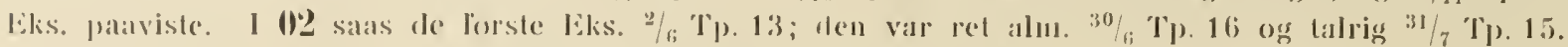

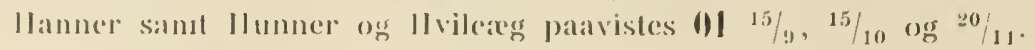

Inden jes galar over til al samle Resultaterne al ovenstaaende Oplysninger vedrorende Leptodora Kindtii, vilde det formentlig vare rigligst her al gore Recle for, loval man kender til denne markelige Daphnides Biologi.

I Tiden fra 1860-74 gax Lilljeborg (61), P. L. Näller (68 a og b), Sars (73) og Weismann (74 og $76-79)$ en laxkle megel vardifulde Oplysninger vedrørende Dyrets Bygning, Forplantningsforhold og Biologi; her som saa ofte har de sidste Decenniers l'lanktonundersøgelser km i ringe Grad bidraget til al uddybe det Kendskab, aldre Forskere tilvejebragle; kun hos Ajstein (96) og Birge (97) findes, som vi senere skal se, ct Par vigtige Bidrag. Fa den nyeste Tid foreligger M. Sa mters desvarre endnu ikke afsluttede Undersogelser over Udviklingshistorien (00 p. 169) samt den lille interessante Meddelelse om liugehulens Form og Stilling under Udviklingen (9; p: 334 ).

Man er for Ojeblikkel tilbojelig til at tro, at Leptorlora er en Form, om hvis Biologi og Anatomi man sennemgataende ved god Besked; saaledes fremhæver Sandman (99 p. 3 og 4), al xldre Forskere har oflentliggjort saa detaillerede Studier vedrørende Arten, "att nagot $i$ egentlig mening nyll om densamma numera torde vara svart att anförar.

Jeg kan, og det af folgende Grunde, aldeles ikke være enig med Sandman og andre heri.

Gennem Sar's' Undersogelser ved vi, at der i Søer, hvori Leptodora findes, i Maj Maaned optræder et mierkeligt Larrestadium karakteriseret ved meglige 2det Par Antenner, meget slor Nandibelpalpe og Nauplieøje; dette Larvestadium, som efter hele sin Bygning umuligt kan være det første udviklede Stadium, har Sars fulgt og vist, at det omdannes til L. Kindtii; mange Aar tidligere (73 p. 8) havde Sars fundet en Larve, som han den Gang ikke kunde bestemme, men som han nu, og sikkert med fuld Ret, anser for et endnu tidligere Larvestadium af samme; men rimeligvis er heller ikke dette Stadium, efter hvad Sars selv formoder, den første, umiddelbart af Egget klækkede Larve; denne er i Virkeligheden stadig ukendt. Sars slutter, og utrivlsomt med Rette, at hans Larvestadier er fremgaaede af Hvilexggene, men Klakningen har han ikke set, og selve Hvileaggene var ham ganske ukendte.

Endvidere viste Sars, at Nauplieøjet kun forefindes paa Eks. fra Forsommeren, hvorimod man aldrig finder det paa Eks. tagne senere paa Aaret (p. 2-3); heri har Sars fuldkommen Rel; han angiver, at »lidlig om Vaaren" (p. 3) fandtes alle Eks. med Øjeplet; "Nogle Dage senere" (p. 3) fandt han. at alle Søens Leptodorer nu manglede Ojeplet, og slutterle saa af et enkelt Fund (en gammel Hun med Øjeplet, i hvis Matrix der fandtes Unger uden Øjeplet), at denne kun optræder hos det Kuld, der er klækket af selve Hvileægget, medens det nuangler hos alle andre Kuld; denne Slulning synes mig noget hazarderet; det er ingenlunde utrenkeligt, at denne Øjeplet simpelthen gaar tabt under et Hudskifte; ud fra alt, hvad vi kender til andre monocykliske Daphniers Udviklingsforhold, er det ikke rimeligt, at det af Hvilergget klækkedle Kuld skulde dø ud paa et saa tidligt Tidspunkt; det lever rimeligvis meget langere.

Gennem den nyere Tids Planktonundersøgelser viser det sig, at L. Kindiii er et overordentlig vidt udbredt Dyr, der sarlig holder til i støre Søers pelagiske Region; den er af alle Daphnier og maaske af alle Ferskvandets Organismer den mest udprægede Planktonform. Vi ved endvidere gennem disse Undersøgelser, at Arten har sin Blomstringstid ved Vandets hojeste Tp., men medens aldre Forf., f. Eks. P. E. M üller (68 $a$. p. 231), fremhæver, at Arten ofte findes »i overordentlig Masse«, er de fleste Planktonundersøgere komne til det Resultat, at Arten i Alm. ikke optræder i særlig stort Individantal, Birge (97 p. 404), Burckhardt 


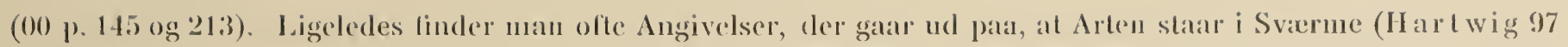

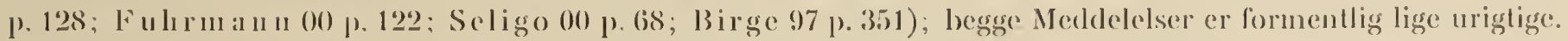

Angatende den vertikale Fordeling angiver Bruno Holer (99 p. 44), at L. K. mangler i ()-2 M., er sjacken i 2-5 M., og al Hovedmassen staar i Vandlaget 7-10 M.; den forsinder fuldstiendig ved 18-20 M. For Vierwaldstädtersoens Velkommende finder Burckliardt (00 p. 214), at Arten om Dagen mangler eller kun (re reprasenteret al unge Dyr i Vandlaget 0-15 M., og at Hovedmassen staal paa 20-30 M.; nederste Granse ligger red c. 40 M. For P’önersoernes Vedlionmende angiver Apstein (96 p. 80), at Arten er hyppigst i dybere Vandlag; i den lavere Mendotaso kan lBirge (97 p. 405) ikke paavise nogen vertikal liordeling. I Folge Burckhardt (00 p. 213-15) forelager Leplodora Vandringer i Dognet, saaledes at Hovednassen om Natten opholder sigg i (le øverste, 0-2 M. Vandlag, men om Dagen derimod mangler i disse og staar dybere; lor vore nordligere, mindre gennemsigtige og cyanophyceerige Søer har saadanne Vandringer ikke ladet sig parvise.

Med Hensyn til Forplantningen er alle Forf. enige om, at $L$. k. tager af i Antal i Sep., at Hannerne viser sig paa delte Tidspunkt, og at Arten derpaa yderligere tager af; enkelte Hanner kan dog endnu paavises i Nov; efter Dec. forsvinder den ganske; i Tiden fra Slutn. af Dec. til Midten af Maj har man intetsteds, selv iklie i Gardasoen (Garbin i 95 p. 4), iagttaget Leptodorer.

Angaaende Hvilexggets Udseende og Opholdssted ved vi gennem P. E. Müllers (68b.) og Weismanns (74 og 76) Undersøgelser følgende: Hvileregget, saaledes som det findes udenfor Dyrets Legeme, er ualmindelig stort, 0,s-0,9 Millim. Ligesaa lidt hos Leptodora som hos nogen anden af de gymnomere Daphnier overvintrer Egget i en særlig Ephippialdannelse, men medens Hvilexgget hos alle andre Gymnomera er omgivet af en tynd, brunsort Kitinskal, der er haard og fast at fole paa, er Skallen paa Leptodora's Hvileæg hyalin, megel tyk og gelatinøs; paa Sommeragget hos samme er den derimod yderst tynd; selve Blommemassen er af ringe Størrelse; naar derfor P. E. Müller (68 b. p. 302) angiver, at Hvilexgget er nindre end Sommerægget, hvilket ellers ikke er Tilfældet hos Daphnierne, har han, der kun har iagttaget Eggene i Ovarierne, hror Forskellen mellem Eghindernes Tykkelse ikke trader saa tydeligt frem, og ikke pelagisk udenfor Dyrets Legeme, fuldkommen Ret; rigtigere vilde det dog være at sige, at det ikke er Hvileagget, der i sin Helhed er mindre end Sommeræggel, nen at del kun er Blommemassen hos førstnavnte, der er saa meget mindre end hos sidstnævnte; paa Grund af, at Geleomhylningen svulmer op i Vand, bliver Hvileagget pelagisk kolossalt stort.

Egget trader i Følge Weismann (76 p. 58) ud i Rugehulen og holder sig i nogen Tid svaerende i demne, hrorpaa Egget fra Rugehulen trader ud i de omliggende Vandlag; hrad der yderligere bliver af Hvileaggene, ved man ikke; Weismann formoder (76 p. 59), at de enten skylles op paa Stranden eller synker dybere ned og Vinteren over holder sig svaevende i Vandlag narmere Bunden.

Der kan endnu tilføjes, at adskillige Forf. omtaler, at L. Findlii ofte midt om Sommeren nasten ganslie kan forsvinde og enten i samme Aar ikke mere vise sig i Søen eller undertiden senere hen komme igen. Aarsagen til dette Fænomen er en Snylter - en Phycomycet - vistnok forst paavist af P. E. M üller (68a. p. 296), der trænger ind i Dyret, omspinder det med sine Traade og i Lobet af utrolig kort Tid draber del. Jeg har ofte hal't Lejlighed til at anstille ganske lignende Iagttagelser, men skal ikke omtale dem her, da der forhaabentlig fra anden Side nærmere vil blive gjort Rede for Phycomycetangrebene paa Planktonorganismerne.

Leptodora er Rovdyr par excellence; den skal efter Birge (97 p. 351) knuse sit Bytle (Cyclops, Daphnia); i Tarmene findes i Alm. ikke Skeletdele, men kun Tarme og Ovarier af Ofrene.

Man vil af denne Litteraturoversigt se, at vort Kendskab til Leptodora's Biologi endnu er højst mangelfuld; man kender endnu ikke det lørste, af Hvileagget direkte udgaaede Larvestadium; der kan med Grund rejses Tvivl om, hror vidt Sars' Opfattelse af Nauplieøjets Forsvinden i Maj-Juni er rigtig; endvidere er Hvilexggets Skæbne fra det Øjeblik, det er udtraadt af Moderdyret, os absolut ukendt; den gaengse Opfattelse af Leplodora's Hyppighed i Søerne er, som vi skal se, efter al Sandsynlighed urigtig. Endelig har vi 


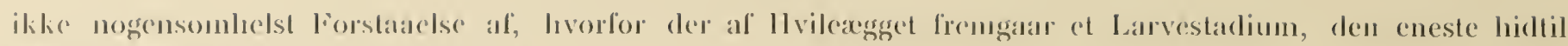
hemelle Laneve indentor Clathocererne.

I Folge den for delle Arbejge lagte Plan vil det viere indlysende, at der ikke her kan vacre Tale om Harmere Redegorelse m. H. I. de Traek i Leptodora's Biologi, som vi for Ojeblikket savner et nojere Kendskal) til. Undersogelsen har dog givet en Del sikre Resultater, der kan tjene til at lienlede Opmarksomheden paa forhold, som tranger til et namere Studium.

L. Kïndlii er orermade udlstedt her i Landet; den viser sig i Planktonet i Slutn. af Maj og Beg. al duni

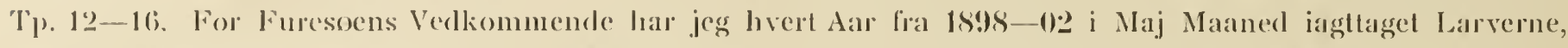
der alle befandl sig paa el fremryket Metanaupliestadium; den første paavistes i 97 af Mag. Soren Jensen, der, efter at have hentet Dyud op fra en storre Dybde og ladet det lienstaa i nogen Tisl, i defte fandt enkelte Metanauplier. Naupliegjet bevares indlil c. ${ }^{15}, 6$, undtagelsesvis ser man cndnu e. $1 / 7$ enkelte Former med Nanplicoje, senere lien har jeg ikke iagttaget dette. Jeg er tilbojelig til at tro, at dette er et Larveorgan, der under et Iludskilte gaar Labt; at det skulde rare et Organ knyttet lil et bestent Kuld, der allerede skulde do ud i Maj--luni, anser jeg for meget usandsynligt.

Hele Sommeren igennem foregar en livlig parthenogenetisk Fornering, hroraf resulterer de store Mangder al Lephodora, der lindes i alle vore Søer ved Vandets højeste TP. eller maaske snarere noget senere, 15. Aug.1. Sep. Ligesom P. E. Müller har jeg Indtrykket af, at der i Sommertiden og det tillige Efteraar findes uhyre Marngder af Lepplodora; nar andre Planktonundersøgere er komne lil det Resultat, at Leptodora kun findes i ringe Mrengde og ofte staar i Svarme, skylcles dette dels, at de har fisket med altfor fine Net, dels overvejende har sat deres Lid til Vertikalprøver. Fisker man derimod horisontalt med vidmaskede Planktonposer, vil man overalt i rore Soer i Juli-Sep. kunne forvisse sig om, at Leplodor findes i store Masser og, saa vidt jeg kan skønne, ganske jarnt fordelt; Srarmdannelser lıar jeg aldrig iagttaget; medens en Vertikalprove med Møllergaze Nr. 20 højst giver 10-20 Leptodorer og undertiden aldeles ingen, alt efter den Hurtighed, hrormed Nettet trakkes, giver en Horisontalprøve taget paa samme Lokalitet med LeptodoraNettet (cfr. p. 17) i to-tre Minutter og med jæun Roning Dyrene i mange Hundreder af Eks.

Her som overalt tor jeg ikke udtale mig om den vertikale Udbredning; jeg har baade paa Graavejrsdage og om Morgenen i højt Solskin taget Leplodora i Horisontalprøver stammende fra det allerøverste, $1 / 2$ Meter dybe Vandlag; dog er jeg tilbøjelig til at tro, at den ogsaa i vore Søer væsentlig opholder sig i dybere Vandlag, da Mrngden af Leptodora gennemgaaende har væet størst i Horisontalprøver fra 10-15 M.; regelmassige Vertikalvandringer i Lobet af Dognet har jeg aldrig iagttaget, men mine Apparaters Ufuldkommenhed har heller ikke tilladt mig nogen saadan Paarisning.

L. k. er ogsaa hos os monocyklisk; Hannerne viser sig i Slutningen af Maks. c. 15 Sep. og kan endnu findes i Slutningen af Nov; de er talrigst i Sep. og forekommer da i store Mængder. Samtidig hermed optrader ogsaa Hvileæggene; disse fincles i Maanederne Sep,-Dec. pelagisk i Vandlagene; de er sjæeldne i Overfladen, og den langt overvejende Del træffes i de mellemste og dybere Vandlag; indenfor det givne Tidsrum er de aldrig søgte forgæres i nogen af de undersøgte Søer. Der er ingen Trivl om, at Egget indenfor Tiden Sep.-Dec. er et rent pelagisk Eg. men da jeg, bortset fra en enkelt Januarprøve fra Haldsø, aldrig har fundet Eg i Prover fra Tiden Jan. og til Sep, tor jeg ikke afgøre, om Egget ogsaa Vinteren over er pelagisk, eller om det i Vinterens Løb bundfældes; Spørgsmaalet maa ristnok søges løst i dybere Søer end de, jeg har kunnet undersøge, og vil til sin Losning kiæeve langt mere fuldkomne Apparater.

Den eneste, der mig bekendt har direkte Meddelelser om Hvilexggenes Opholdssted, er Apstein; han siger (96 p. 176), at Nauplierne altid fremkommer af freischwimmenden Eiern«. Desverre er Apsteins Angivelser on Leplodora's Hvilexg og Forplantning yderst uklare og til Dels selvmodsigende. Apstein meddeler blandt andet, at han allerede finder Nauplier i Juli og afbilder en saadan Nauplie Fig. 100 p. 175. Jeg betvirler, at dette er en Nauplie fremkommen af Hvilexgget, i hvert Fald har den intet tilfelles med de af Sars afbildede; selv har jeg i Juli i Materiale fra Mossø regelmassig sel ganske tilsvarende Stadier i Moder- 
dyrenes Rugchuler; jeg betragler dem langt snarere som Udviklingstrin lige fremkomne al Sommeraeggene; disse Stadier lorekon ogsan frit i Proverne, i hvilke de rinneligvis er komne ud enten verl selv at bane sigs Vej, eller ved at Rugesalken under Konservationen er bristel. I Slutningen af Nov. forsvinder Leptodora ganske og i Tiden fra Nov. til Maj er intet Eks. iagtlaget.

Angaaende den systematiske Opfattelse af Leptodora onsker jeg her at fremsallo foølgende l3emackninger.

Det er ubestrideligh, at der paa alle afgorende l’unkter er den størst mulige Uoverensstemmelse mellem Polyphemider og Leptodora.

Hos Polyphemiderne er 1ste Par Ant. tiltrykte eller ubevargelig fastroksede til Hovedets Underside, fremadrettede og omlrent ensbyggede hos begge liøn; 2det Par Antenners to Grene har som hos lle lleste Daphnier kun el ringe Antal Svommeborster (6-8 hver); Maksiller er til Ste(le; Benparrenes Antal er 4. Det efter de lemmebaerende Segmenter følgende Legemsparti er af meget forskellig lBygning, men altid kort, enten uleddet eller i hvert Fald kun svagt ledlet, staerkest hos Bythotrephes. Hos Polyphemus er Abdomen og Postabdomen smeltel sammen til et kort, uleddet Rudiment uden Kløer; den Udvaekst, der barer de lange Borster, er lang, torndannet; hos Bythotrephes er Postabdomen med Kloerne tydelig, Tornen kolossal, Børsterne meget smaa. Hos Podon og Evadne er ḱløerne meget veludviklede; en Torn er som oftest svagt fremtradende, men Børsterne veludviklede. Et Nakkeorgan er udviklet hos alle Polyphemider og er som oftest meget stærkt fremtræedende. Rugesækkens Bygning er meget forskellig hos de forskellige Former, men da jeg ikke anser den for fuldt udredet og for min Part maa indrømme, at jeg hverken gennem Undersøgelse eller gennem Litteraturstudium er kommen til Klarhed over den, vil jeg her og i det følgende ikke omtale den nærmere. Det fremhaves kun, at Rugesakkens Bund i alt Fald hos Polyphemus og Bylholrephes er udstyret med et Cellevav, en Naeringsbund, der afgiver den Naringsvadske, hroraf Fggets videre Udvikling i Rugesækken afhænger. Hvileægget fremgaar kun af en Kimgruppe (Weisman n 76 p. 135); det er omgivet af en brunsort, kitinagtig Skal; det aflejres, saa vidt vides, paa Søbunden.

Leplodora forholder sig i alle disse Punkter næsten ganske afvigende. 1ste Par Antenner er hos Hannen meget lange, nasten af Legemets halve Langde og meget laengere end Hunnens; de er som oftest bagud rettede, Hunnens korte Antenner er nedad rettede, aldrig fremad eller tiltrykte til Hovedet. 2det Par Antenners to Grene baerer et meget stort Antal Svømmebørster (25-30), hvert Led indtil 10--12; Maksiller mangler; Benparrenes Antal er 6. Det Legemsafsnit, der følger efter de lemmebrende Segmenter, er overmaade langt, tydelig fireledclet med langstrakte, cylindriske Led; sidste Led ender i to meget tydelige Kløer, der dog er bløde og bøjelige og vistnok tør opfattes som rudimentrere Organer. Der er ikke Spor af Torndannelse, og Børsterne er saa smaa, at de kun med Vanskelighed lader sig paavise. Et Nakkeorgan er ikke paavist; det er i livert Fald lidet fremtradende. Rugehulen er ikke udstyret med Naeringsbund; Agskallen hos Hvileaggene er tyk, vandklar og gelatinøs; disse er i alt Fald for en Tid pelagiske; Ungerne heraf kommer frem paa Naupliestadiet. Hvileaggene fremgaar af to eller llere Kimgrupper.

Kommer nu til alle de her fremhævede unægtelig meget betydelige Forskelligheder, at saadanne ogsaa lader sig paavise i mange mindre væsentlige Bygningsforholl, f. Eks. vedrørende Øjet, fristes man stæerkt til nærmere at undersøge, hvad der da har bevirket, at Leptodora og Polyphemiderne er stillede i samme Underorden. Som bekendt deler Sars Daphnierne i to store Afdelinger Calyptomera og Gymmomera og anvender til Adskillelsen Skjoldets Udvikling, Nervesystemet og 2det Par Antenner. Med Rette gør P. E. Müller (68 a. p. 88) opmrerksom paa, at disse Inddelingsprincipper ikke er fyldestgørende; han opretholder dog i det væsentlige Sars's lnddeling, men lagger Hovedvagten paa den store Forskel i Benbygningen og fremhaver, at den første Underorden (Fanı. hos P. E. M üller) indeholder mer eller mindre udpragede Plantesedere, len anden de mest deciderede Rovdyr. Müller havder endvidere, at Sars ved at henføre Polyphemider og Leptodorider til to Fam. har fjernet dem alt for meget fra hinanden, og ønsker dem henførte til en og samme Fam.; som Grund hertil angiver han ganske særlig, at ogsaa Leplodora paa 1ste Benpar har et tydelig udviklet, om end lille indre Vedhang ( 68 a. p. 92), som synes at have varet Sars ukendt. Det kan 


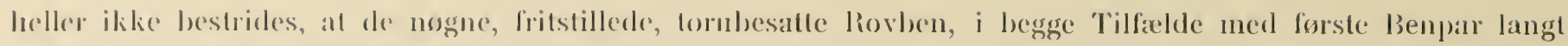

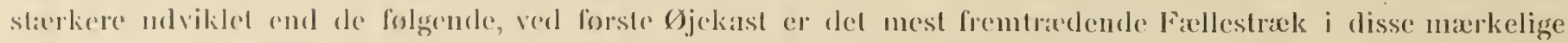

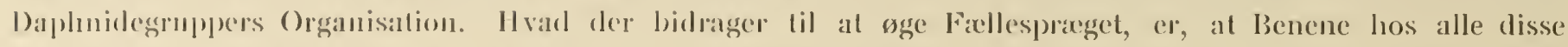
Former og i Modsatning lil alle andre Daphlnier sidder indfinjede efler en Linic, der altid er skavt nedad-

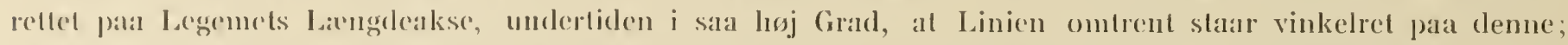
hos alle andre Clatocerer a den Linie, efter hrilken Benene er indfujede, parallel neel Legemsaksen. Dette

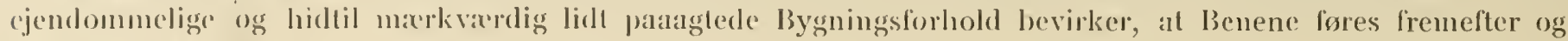
hen under Munden.

Undersoger man inidlertid narmere Benparrenes Bygning hos Polyphemider og Leptodora, finder man ganske gennemgribende Forskelligheder; selv bortset fra ded meget vaesentlige Forhold, at de forste har 4 Par Ben, Leptodora derimod (i, er de enkelte lemmer ganske forskelligt lygggede, navulig hvad angaar 1ste Benpar. Jeg indskranker mig her til at henvise til Afbildninger og Angivelser hos Claus (77), Weismann (74) og Lilljeborg (00). I) synes mig indlysende, at selv om de Omdannelsesprocesser, der har hatt Fremkomsten af Gymnomeremes Rovben til Folge, tilsyneladende har givet et Fællesresultat, saa har dog det omformede Materiale los de to Fanilier Polyphemider og Leptodora oprindelig varet af ganske forskellig Beskaffenhed. I Folge min Opfatlelse er den for begge fielles Stilling af Benene og disses tilsyneladende ensartede Bygning som Rorben Karakterer, som frelles Levevis og fielles Maade at erhverve Føden paa har medført. - Alle Gymnomerer er mere eller mindre pelagiske Daphnier, nedstammende fra Bund- og Bredformer og underkastede de den oprindelige Organisation omformende Frlleslove, efter hvilke alle pelagiske Organismer, on end paa forskellig Vis, maa tilpasse sig. Hos Leptodora saa vel som hos Bytltotrephes og Polyphenus er Benene først og fremmest Fanglen og Rovben, der, medens Dyret staar svaevende i Vandet, er strakte fremad og udad, parate til at gribe den Føde, der føres det i Møde, ligesom de, naar Dyret bevieger sig, er det Fangapparat, hromed det griber Byttet, som det forfolger. Endvidere spiller Benene vistnok en Rolle som "Udliggere «, der hindrer en for hurtig Nedsynken i Vandlagene. Man kan i større Akvarier, der saa vidt mulig bliver ligelig leelyste, for Bythotrephes' og Leptodora's Vedkommende meget tydelig studere Benenes Brug. Hvorledes Lenmerne funktionerer hos Podon og Evadne, er mig ubekendt, da jeg ikke har undersøgt disse Former.

For yderligere at pointere Benenes ensartede Stilling og Bygning som biologiske Karakterer fremkaldte af ensartel Brug og ensartet Levevis, gør jeg opmierksom paa, at man finder en ganske tilsvarende Benbygning indenfor andre Dyregrupper, hyor Benene ligeledes er bestemte til i Flugten at indfange Byttet.

Vi møder den først og fremmest hos mange pelagiske Malakostraklarver, men endvidere træffes den ogsaa hos Insekter, f. Eks. Guldsmedene, der som bykendt overvejende fanger deres Bytte i Flugten. Ogsaa her er Benene fort fremad og ned under Munden, og de er ligeledes Rorben besatte med stærke Torne; i alle disse Tilfrelde skabes der paa Grund af Benenes Stilling og Tornbesæhning Fangkurve, aabne fortil, men lukkede bagtil; i disse fanges Byttet, det være sig i Luft eller Vand; Kurvenes Sider klapper sammen om det, og Spidningen paa de talrige Torne foregaar.

Idet jeg altsaa ikke opfatter den ved første Blik meget iøjnefaldende Ensartethed i Benenes Bygning og Stilling hos Polyphemider og Leptodora som Beviser for fælles Afstamning, men som Fællestræk, en ensartet Leveris har fort med sig, og idet jeg skarpt betoner, at en nærmere Undersøgelse godtgør meget betydelige Forskelligheder, vil det vare indlysende, at jeg ikke kan anerkende Inddelingen af Cladocereme i Calyptomera og Gymnonera. Sars har øjensynlig rigtig set, at den ensartede Benbygning, det mest fremtrædende Fællestræk i Gymnomeremes Organisation, ikke burde anvendes som Inddelingsprincip af 1ste Orden, og i Erkendelse af den store Uoverensstemmelse mellem Polyphemider og Leptodora fjærner han dem saa meget som muligt fra hinanden og stiller dem i to forskellige Tribus. Hrad P. E. Müllers Opfattelse angaar, kan jeg paa dette Punkt aldeles ikke dele den; red at basere Hovedinddelingen af Daphnieme paa Benbygningen og føre Polyphemiderne og Leptodora sammen i een Familie har han efter min Opfattelse ikke forbedret, men forverret Sars's System. Det af P. E. Müller paaviste Vedhæng paa 1ste Benpar hos Leptodora kan ikke 


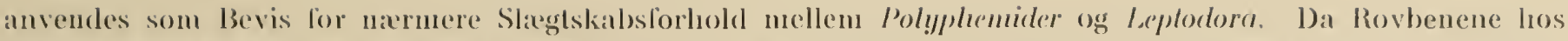

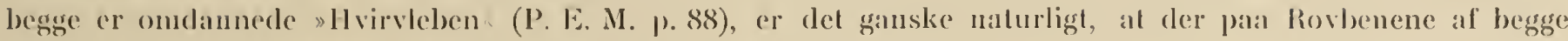
Familier cuduu er bevaret liester al de indre Vedheng, der kamkteriserer Benparrene los alle calyptomere 1):iplinior.

Naar da Begreberne Calyplomora og Gymmomera skal oploses, bliver Sporgsnaalet, om de enkelte Dap)lnidelamilier paa anden og bedre Vis kan grupperes i forloold til hinanden.

Man kan vistnok som Regel gaa ud fra, at en Dyre- eller Plantegruppes primilive liormer nappe traffes mellem demes Planktonorganismer, men netop mellem dens Bund- og Bredformer; for Rotiferernes Verlkonmende har jeg narmere (99 p. 115) søgt at vise, hvorledes der fra Notommatidernes Afleling, der kun indbefatter Bundformer, er opstaiet paralleltobende Sidelinier, som alle ender med Former, dler i hvert Fald er fritsrommende, og hvoraf en stor Del er pelagiske. Paa ganske samme Vis er jeg for Cladocerernes Vedkonmende tilbøjelig til i de krybende Lynceiders Afdeling at søge de primitive Former og i de pelagiske at se de højst specialiserede og vistnok i mange Tilfalde ogsaa de yngste Former. Det er mig i Øjeblikket ikke muligt niermere at udforme min Opfattelse af Cladocerernes indbyrdes Slægtskabsforhold; her maa jeg nøjes med at anvise den Plads, Leptodora bør have i Systemet. - Leptodora er først og fremmest en fra alle andre Daphnier starkt afvigende Form; Bygningen af de bageste Legemsafsnit, Beskaffenheden af Hvilexggets Skal, Nauplien og Dyrets overordentlige Hyalinitet er alle tilsammen Karakterer, hvorved Leptodora staerkt adskiller sig fra alle andre Daphnier. Efter min Opfattelse maa nu alle disse Karakterer føres ind under Begrebet Planktonkarakterer; at Legemsstrækningen og Hyaliniteten hører ind under dette Synspunkt, behøver næppe nogen naermere Paavisning, men desforuden er jeg tilbøjelig til at opfatte baade Hvileaggets Bygning og Nauplien som Forhold, Livet som pelagisk Organisme har fremkaldt.

Hvad Nauplien angaar, maa man erindre, at Ejendommelighederne i Leptodora's Udvikling ikke begynder med denne, men med Hvileagget, som ved sin Bygning afviger fra alle andre Daphniers Hvilexg; særlig lagger man Mrerke til, at af alle Hvileag hos Cladocererne har Leptodora's, saa vidt foreløbig vides, den mindste Blommemasse. Blommemassens Lidenhed er; som bekendt, et Fæellestræk for pelagiske Ag; Betingelsen for, at et Aig kan blive svavende, er enten Reduktion af Blommemasse, der, idet den overvejende bestaar af Eggehvidestoffer, vil drage Egget nedad, eller Forøgelse af de Faktorer, der kan bidrage til Eggets Svæveevne (Torndannelser etc.), eller endelig begge Dele i Forening; ligeledes galder det som en alm. fastslaaet Regel, at det Trin, hvorpaa Ungen forlader Egget, afhæenger af den Naringsmængde, der tilflyder den i Egstadiet, og at der af Ag med ringe Blommemasse fremgaar Individer, der mangler mest $i$ at naa det fuldvoksne Dyrs Bygning.

Overfører man disse Kendsgerninger paa Leptodora, kommer man med Hensyn til Nauplien hos denne til et andet Resultat end de fleste af mine Forgængere.

Idet Leptodora udvikler sig til udpraget Planktonorganisme, afhæenger áens Optraden som saadan i ganske vasentlig Grad af Hvileaggets Bygning og Opholdssted. Sker der, saaledes som Tilfældet synes at være hos Leplodora, en Formindskelse af Blommemassen, har dette til Følge, at det spaede Dyr maa komme ud af Egget paa et tidligere Tidspunkt, end de Former, hvorfra vedkommende Art nedstammer, og hos hvilke der ingen Reduktion finder Sted. Følgelig maa der af Leplodora's Hvilereg fremgaa et Larvestadium, og dette viser sig da at være det for Klassen karakteristiske, nemlig en Nauplius.

Ud fra disse Betragtninger opfatter jeg Nauplien hos Leptodora som en Nyerhvervelse, som Livet i den pelagiske Region har medført.

I hvor høj Grad Leptodora end bærer Præget af at rære en til pelagisk Liv omdannet Daphnide, er Omdannelsen dog ikke mere gennemgribende, end at dens Slægtskabsforhold efter min Opfattelse kan aflaeses med fuldkommen Sikkerhed. Leptodora er en til pelagisk Liv omdannet Sidide. Ligesom hos Leptodora er 1ste Par Antenner hos Sididerne langt stærkere udviklede hos Hannerne end hos Hunnerne; de kan hos førstnæunte næsten naa Legemslængden og har ganske samme Form som hos Leptodora; 2det Par Anten- 
ners ove Gren bacer paa beegge sine Led ikke som los de grrige Daphnier el ringe Antal (5) Svgmmehaar,

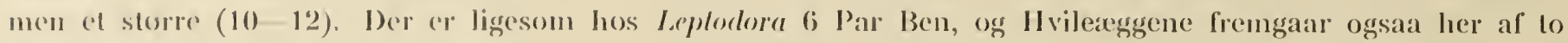
(Aller Here Kimgruper. Findvidere er der i mindre vesentlige Bygningsforhold, f. Eks. Øjets Form, Linsernes Ordning og Hoverlets Form, en stor Overensstemmelse; Diaphanosoma er i mine Ojne Leplodora's nacrmeste Slaxglung. Man vil lacral' liumme lorstaa, at jeg saa meget som muligt divergerer fra den af Weismann

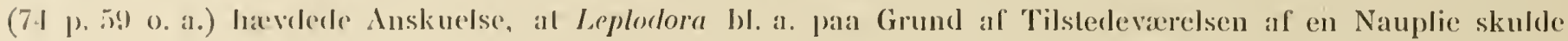
vare en sarlig gammel Form, cu Urdaplnie, som lian kalder den. Weismanns Opfattelse af Leplodora er (d al de markeligste Eksempler, jeg kender, paa en atandfuld og grundig Forskers totale Fejlsyn m. H. t. en ganslie vist meget ejendommelig Forms systematiske Plads.

Jeg er i ovrigt tilbøjelig til at tro, at ligesom Leplodora gennem Diaplanosoma er forbunden med en saa udpraget Bundform som Lalona, "r Bosminerne gennem de af Lilljeborg beskrevne, p. 173 omtalte Former, forlundne med Chyglorus o. a. Lynceider, samt Polyplemus og Byllholreples gennem Moina forbundne med Ceriodaplunia og Daplunia.

Jeg laar i delle Arbejde bibeholdt Sars's Inddeling i Calyplomera og Gymmomera, dels fordi jeg nærer den Anskuelse, at en gennemgribende Endring i vor systematiske Opfattelse af en Dyregruppe ikke vilde vare paa sin P'lads i et Arbejde af denne Natur, dels fordi en saadan Endring nødvendigvis maatte underbygges grundigere, end jeg her har kunnet gøre det; navnlig vilde en anatomisk, morfologisk Undersøgelse af Rugesakkcns Dannelse hos alle Gymnomera vare meget onskelig. Naar jeg desuagtet omtaler mine Ansknelser her, er det, dels fordi Studier af ganske anden Natur vil optage mig i en uoverskuelig Fremtid, dels fordi jeg vil faa Brug for de her fremdragne Forhold i Arbejdets anden Del.

\section{ALMINDELIGE BEMERKNINGER.}

Plankton=Cladocerernes Forekomst i de undersøgte Søer. ${ }^{1}$ )

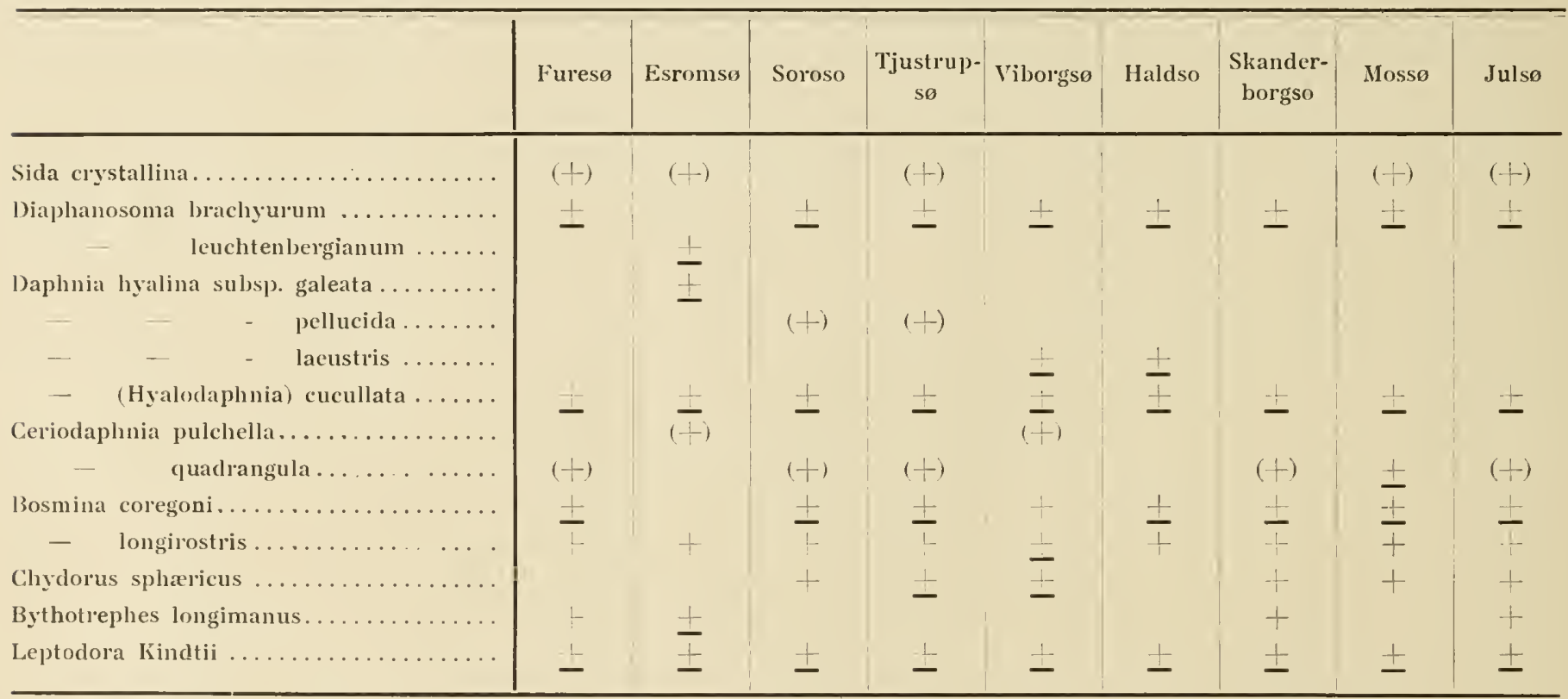

Det fremgaar af vedlagte Schema, at vore større Søers pelagiske Region befolkes af 14 Cladocer-Arter, af hvilke dog i hvert Fald to, Sida crystallina og Ceriodaphnia pulchella, ikke tør betragtes som Planktonorganismer. Sporadisk forekonmer D. leuchlenbergianum, Dapluia lyjalina med sine tre Underarter samt

1) On Tegncnes Betydning se p. 56. 
rimeligvis ogsaa Bytholrephes longimmus. De orrige forekommer sala godt som i hver eneste Sø. Den stsrste Pankton-dannende Rolle spiller Diaphanosona bracluymrum, Hyalodaphnieme, Bosmina coregoni og Leptodorn

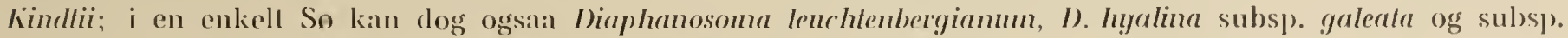

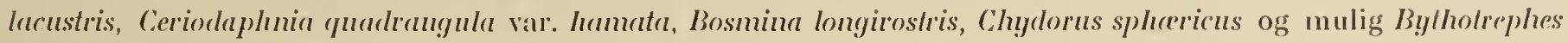
danne megel slore Maks.

Perennerende Planktonorganismer er kun Daphnia hyalina, Hyalodaphnierne og Bosmina corryoni. Hyalo(aplniernes Maks. ligger on Efterataret og Sommeren, B. coregoni's om Vinteren, I). hyalina's til forskellig Tid, (s. d.). Periodiske Planktonorganismer er alle de ovrige; af disse er Diaphanosoma brachyurum og leuchlenbergianm, Bythotrephes og Leptorlora og maaske C. quadrangula udpragede Sommerformer, der forsvinder tolalt i 'Tiden Nov. lil April-Maj; Chydorus sphoricus og Bosmina longirostris er som Planktonorganismer periodiske, men findes Aaret rundt som Littoralformer; de optrader kun til visse Tider af Aaret i Planktonet, Bosminerne kun i Vinterlnalvaaret og i det tidlige Foraar, Chydorus hyppigere i Sommerhalvaaret.

Seksualper. er paavist for alle Daphnierne undtagen I). hyalina var. lacuslris og B. longiroslris; den indtrafler altid om Efteraaret; kun undtagelsesvis er der paavist to Seksualper., D. hyalina subsp. galeala, en om Foraarel og en om Efteraaret; alle vore øvrige Planktondaphnier synes at vare monocykliske. Seksualper. er for de enkelte Arters Vedkommende sjaeldent paavist i alle Søerne, Antallet af Hanner og af Hunner med Ephippier er tilsyneladende ofte kun ringe (Hyalodaphnierne, Daphnia og B. coregoni). Hanner og Hvileag forekommer derimod meget alm. indenfor Seksualper. hos Diaphanosoma, Ceriodaphnia quadrangula og Leplodora; naar Hannerne ikke er paaviste hos Bythotrephes, skyldes dette kun, at jeg har overset dem.

De perennerende Daphnier findes vel hele Vinteren, men er i Antal stærkt formindskede og har alle $\mathrm{i}$ Marts-April Maaned et meget tydeligt Min. I Maj falder B. Iongirostris', i sjæeldnere Tilfæelde tillige B. coregoni's Maks.; i Sommerens Løb indtraffer Maks. for Diaphanosoma, Hyalodaphnierne, Ceriodaphnia, Bythotrephes og Leplodora; idet samtidig Mangden af D. hyalina og B. coregoni tiltager, opstaar Eftersommerens kolossale Cladocermaks., under hvilke Cladocererne danner en saa overvejende Del af vore Søers Plankton og den absolut overvejende Del af Sommerens Zooplankton; kun Diaplomus-Arterne kan i saa Henseende til Tider gøre dem Rangen stridig.

Hen paa Efteraaret forsvinder alle Sommerformerne, og Copepoderne faar nu mere og mere Overtaget; dog er stadig B. coregoni, Daphnia hyalina og undertiden Hyalodaphnierne talrigt repræsenterede. Om Vinteren er Copepoderne nasten eneherskende; af Daphnier, der forefindes i nævneværdig Mangde, kan kun anføres B. longirostris og B. coregoni. Der er nappe Tvivl om, at Diaphanosoma, Bythotrephes og Leptodora liun

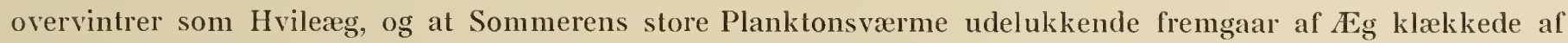
disse. Hvileaggene synker til Bunds, men er dog hos Leptodora i alt Fald for en Tid pelagiske. Da vi her har med kraftige Svømmere at gøre, kan det formodes, al der i alt Fald i vore lave Søer ikke behøver at gaa $\mathrm{Eg}$ til Grunde, om de end bundfæeldedes paa disses dybeste Partier.

For de perennerende Cladocerer synes Hvileaggene at spille en ganske underordnet Rolle; Sommerens Planktonsverme fremkommer som Følge af den kolossale Frugtbarhed hos de overvintrede Humner, hvis parthenogenetiske Formering tager Fart i April-Maj; herom maa jeg dog henvise til det følgende Arbejde.

Vor pelagiske Cladocerfauna slutter sig nær til Faunaen i det mellemeuropxiske Slettelands Søer; nordiske og alpine Former som : Holopedium, Limnosida, de store Bythotrephes, longispina-bohemica-Gruppen af B. coregoni, mangler eller er sjældne hos os; mest karakteristisk for vore Søer er maaske den meget staerke Udvikling af coregoni-Gruppen af $B$. coregoni.

\section{Copepoda.}

Med Hensyn til den systematiske Inddeling af Copepoderne har jeg fulgt CIaus; det nye af Gieshrechl foreslaaede Inddelingsprincip kan vaesentlig kun bruges for de pelagiske Copepoder; Sars's Inddelingsprincip) (02 p. 2) er kun antydet, men er paa dette Tidspunkt (02) endnu ikke nærmere udarbejdet. 


\section{Eucopepoda gnathostomata.}

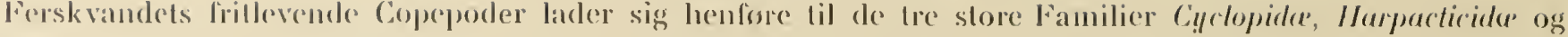

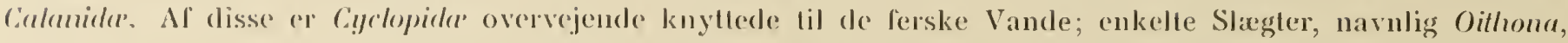
spiller dog en stor Rolle i Havets pelagiske Region; Harpacticide indbefatter sala vel Fersk- son Saltvandsformer; til Calunider sala vel som til Pontellida, der ikke er reprasenterede i Forskvand, horer den langl overvejende bel al llavets pelagiske Copepoder.

Harpacticiderne, der i Ferskvand udelukkende cr Bundformer, vedkommer os ikke her. Alle de i Søernes

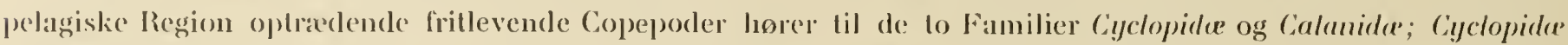
indbefatter vesentlig Dam- og Smaasoformer; den langt overvejende Del af Ferskvandets pelagiske Copepoder lillorer Fam. Calanider.

\section{Fam. Cyclopidæ.}

\section{Cyclops.}

I vore storre Soers pelagiske Region optrader kun tre Cygclops-Arter: C. Lenckarti Claus, C. strenums og C. oithonoides. Af disse er forstnxunte vel paavist i alle de undersøgte Søer, men Mrengden var overalt kun ringe, og om storre Maks. er der nappe Tale; der synes til alle Aarsticler at optrade Hunner med Kig, dog hyppigst om Sommeren, da Arten i det hele taget forekommer i størst Antal. Den nævnes i Alm. ikke i Planktonarbejderne, vistnok fordi den sammenblandes dels med C. oithonoides og dels med C. strenuus, se Seligo (00 p. (33); dens Biologi er kun studeret for Vierwaldstädtersøens Vedkommende (Burckhardt 00 p. 151); den har her sit Maks. og sin Seksualper. om Sommeren; fra Okt. til April iagttog Burckhardt hverken Hunner med Fig eller Hanner.

\section{Cyclops oithonoides G. O. Sars.}

Schmeil 92. Tab. IV, Fig. 6-14.

Fureso. C. o. er sjæelden i Prøven $00{ }^{20} /{ }_{12}$ Tp. 4 og findes kun enkeltvis eller i ringe Mængde lige til $01{ }^{15} / 5$ Tp. 13; Antallet er dog ikke synderlig stort for ${ }^{30} / 7$ Tp. 21 ; det holder sig endnu $15 / 8$ Tp. 22 , men tager derpaa gradvis af; Arten er sjælden hele Vinteren 01 og 02 ; Antallet stiger noget $0211 / 4 \mathrm{Tp} .4$, men synes atter at aftage i senere Sonmerprover.

Hanner er talrigst $0130 / 7$ og 30/8; Hunner med Eg er paaviste hele Aaret.

Esromso. C. o. spiller en meget ringe Rolle i Esromsøs Plankton; den er ret hyppig i Tiden fra $01{ }^{12} / 8$ Tp. 21 til $5 / 9$ Tp. $16 ; 12 / 8$ Tp. 21 findes et meget stort Antal Hanner.

Soroso. C. o. er sjæelden indtil $01{ }^{26} / 5$ Tp. 13, da et svagt Maks. indtreder. I alle Proverne fra 01 optræeder den i ovrigt kun i ret ringe Mængde. I 02 er den set lige efter Isløsningen ${ }^{24} / 3 \mathrm{TP}$. 1; Arten har et meget tydeligt Maks. ${ }^{19} / 4$ Tp. 4 og $16 / 5$ Tp. 7 , hvorpaa den tager jævnt af; den er sjælden ${ }^{27} / 7$ Tp. 16.

I Tiden fra 02 $30 / 1$ til 19/4 har jeg ikke set Hunner med Ag og heller ikke Hanner; $19 / 4$ viser disse sig; $16 / 5$ berer nasten alle Hunner Eg, og Hannerne er alm.; $7 / 6$ er der faa Hunner med $\mathbb{E g}$, og Hanner er sjældne.

Tjustrupso. C. o. er ret alm. $00{ }^{19} / 12$ Tp. 3 og $015 / 5$ Tp. 7 ; den har et stort Maks. ${ }^{24} / 5$ Tp. 13 ; i de følgende l'rover tager Arten af; et nyt, men svagere Maks. viser sig ${ }^{16} / 10$ Tp. 13; derpaa forsvinder Arten næsten ganske og er endnu lige efter Islosningen $02{ }^{23} / 3$ Tp. 1 sjælden; Proverne ${ }^{19} / 4$ Tp. 4 og $16 / 5$ Tp. 8 viser atter et kolossalt Maks., der dog nasten ganske er ophort $7 / 6$ Tp. 12 .

Endnu $0019 / 12$ bærer de fleste Hunner Eg, og Hanner er ikke sjældne; i $015 / 5$ findes vistnok kun unge, ikke konsmodne Dyr, og det store Maks. ${ }^{24} / 5$ dannes aldeles overvejende af disse; Hanner og ægbærende Hunner er yderst sjældne, men bliver alm. efter det store Maks. $3 / 7$. Alle Sommerens Eks. er væsentlig kønsmodne Dyr; der er kun lidt Yngel; det secundære Maks. ${ }^{16} / 10$ dannes overvejende af Yngel; en Del kønsmodne Eks. optræder $02{ }^{27} / 1$; under det store Maks. ${ }^{23} / 3$ findes næsten ingen Hunner med $\mathrm{Eg}$, men derimod adskillige Hanner; $19 / 4$ bæerer alle Hunnerne Eg, Hannerne er noget sjældnere; deres Maks. har ligget mellem de to Prover; Hanner og Hunner holder sig i de senere Prøver, men samtidig viser sig megen, men spæd Yngel.

Viborgsoerne. C. o. spiller en ganske underordnet Rolle i Soen; den har haft et Maks. 01 18/5 Tp. 14 og ${ }^{10 / 7}$ Tp. 21, rimeligvis med Selsualper.; i alle de øvrige Prøver er den sjælden. 
Il aldso. C. o. har ogsaa i Hakdso kun ringe Belychning; jeg laa aldeles ikke kunnet paavise den i Vinterproverne, uagiel den selvlolgelig lindes i Soen; den har i Proverne (01 20/7 Tp. 17 og $7 / 8$ Tp. 18 el svagt Maks. merl talrige llanner sai vel som Hunner med Aig; i alle de ovrige Prover er den sjaelden.

Skanderborgso. C. o. er ret alm. 00 29/1y Tp. 5 og 01 19/15 Tp. 13; den har da rimeligvis haft et Maks. med Seksualper., som ikke er palavist, ela Prover nangler inclit 5/8 tp. 21; den er paa dette Ticlspunkt og i l’roven $15 / 9$

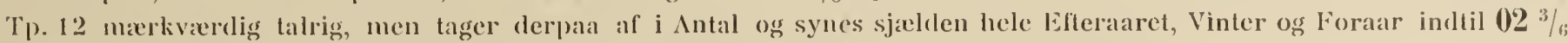
Tp. 15, da et meget stort Maks. indlraeller. I de folgende P’rover var Antallet ringe.

Der er i Sommerproverne 01 lunden Hanner, Hunner med Eg og en betydelig Mangde unge Dyr. Provernes Antal har veret for lia, til at Forholdene liunde udredes. Fra $023 / 1$ til 1/5 er IIanner, ligesom ogsaa Hunner med Leg, yderst sjaeldne; $1 / 5$ er Hanner meget alm., men $3 / 6$ findes nesten kun agharende Hunner.

Mosso. C. o. kan ogsaa her i 01 vanskelig studeres paa Grund af for faa Prøver; den synes dog at have haft et Maks. fra c. ${ }^{20} / 5$ Tp. 12 , som dog er ophort inclen $1 / 8$ 'tp. 22 ; et nyt svagt Maks. er iagttaget i Okt. ${ }^{15} / 10$ Tp. 10 , livorpai Arten tager af i Antal. $021 \% / 5 \mathrm{Tp} .8 \mathrm{er}$ den ret alm., og i de folgende Prover tiltager Antallet stadig; der er et meget stort Maks. ved Undersogelsens Slutning $30 / 7$ Tp. 15.

Talrige Hanner samt Hunner med $\mathrm{Eg}$ el paraviste $01 \% \frac{2}{5}$, ligeledes $15 / 10$ og $0228 / 6$.

Julso. C. o. er en af de i Soen hyppigst forekommende Crustaceer. Den er sjæelden $0026 / 12 \mathrm{Tp} .4 \mathrm{og} 0124 / 4$ $\mathrm{T}_{\mathrm{p}}$. 3, men tiltaget i Antal $20 / 5$ T .13 og opnaar et stort Maks. $10 / 7$ Tp. 20; den er stadig talrig $1 / 8$ Tp. 22 og $15 / 9$ Tp. 12 ; derpaa tager Antallet pludselig og sterkt af, og forst efter Islosningen i Proven $025 / 4 \mathrm{Tp} .3 \mathrm{er} \mathrm{den} \mathrm{alm.;} \mathrm{det} \mathrm{meget}$ store Maks, indtræelfer ${ }^{5} / 5$ Tp. 6, og Arten er fra nu af indtil Undersogelsens Slutning ${ }^{31 / 7}$ Tp. 15 en af de hyppigst forekommende Former.

$012 \%$ findes talrige Hanner og en Del Hunner med Lg; i Sommerproverne var Hanner og agbærende Hunner langt sjaldnere, men Ynglen fremherskende; en Seksualper, indtraffer atter 15/9 Tp. 12. I 02 optrader talrige Hanner $5 / 4 \mathrm{~T}_{\mathrm{P}}$. 3, men faa Hunner med Eg; begge forekommer i stor Mrengde lige til 30/6 Tp. 16, hvorpaa Antallet aftager; samtidig stiger Mrengden af Yngel.

Det er ret vanskeligt af de her givne Meddelelser at danne sig et klart Billede af Artens Leveris i vore Søer.

Vi kan dog betragte følgende Punkter som fastslaaede; C. o. er den i vore større Søers pelagiske Region hyppigst forekommende Cyclops-Art. Den er, som rimeligvis alle andre Copepoder, perennerende, men sjalden om Vinteren; i alle Søerne falder der et meget tydeligt Min. i Tiden fra Nov. til April.

I Tiden fra April til Okt.--Nov. optræeder udprægede Maks. i Furesø, Sorøsø, Tjustrupsø, Skanderborgsø, Mossø og Julsø. Disse Maks. ligger i de forskellige Søer til forskellig Tid; ret konstant er det store Foraarsmaks. (Sorøsø, Tjustrupsø, Viborgsø, Mossø og Julsø); i Sorøsø, Tjustrupsø, Viborgsø og i Mossø afbrydes dette Maks. af et Sommermin., hvorpaa der i alt Fald i Tjustrupsø følger et mindre Efteraarsmaks.

Derimod er der ikke paavist noget Sommermin. i Julsø; her er Individantallet stadig stort, lige fra Maj til Sep.; i Furesø indtræffer Maks. først i Juli-Aug.; paa dette Tidspunkt er Antallet ogsaa størst i lle Søer, hvor Arten er sjælden (Esromsø, Haldsø).

Der synes overalt at være en tydelig Seksualper. i April-Maj, men i øvrigt synes Forplantningsvirksomheden ingensinde ganske at være standset; jeg har nemlig til alle Tider kunnet paavise Hanner samt Hunner nied Eggesække.

Undersøgelsen har ikke med Sikkerhed kunnet fastslaa Tidspunktet for den største Mængde Yngel; det Iør kun siges, at Yngel findes til enhver Tid, og det maa formodes, at Mangden var størst efter det store Foraarsmaks. Det synes, som om Yngel overalt kun forekommer i meget ringe Mangde om Vinteren, men det bliver mig i saa Fald en Gaade, paa hvad Maade det ofte kolossale Maks. i April-Maj kan konme til Udvikling.

Da Generationerne stadig griber ind i hverandre, vil det altid være en meget vanskelig Sag at angive, baade hvor lang Tid en C. oithonoides bruger for at blive kønsmoden, og hvor laenge den overhovedet lever; nærværende Undersøgelse kan ingen Oplysninger give i saa Henseende. Hartwig (01 p. 54$)$ o. a. har gjort opmærksom paa, at Egantallet hos C.o. er forskelligt paa de forskellige Lokaliteter; i Smaasøer og Damme, hvor Arten ofte forekommer, findes som oftest 5-6, undertiden 6-8-14 Eg i hver Eggesak; i kolde, klare 


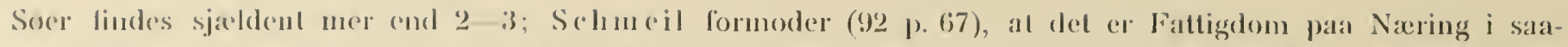

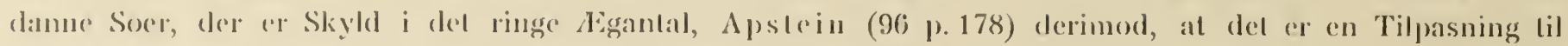

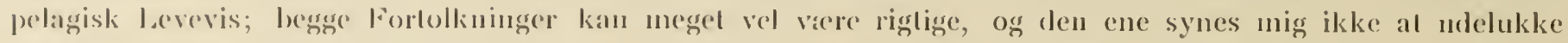

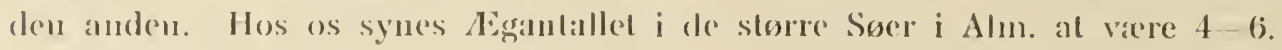

C. oilhonoides or en vidl udloredt Arl og rineligvis hjemmelngrende over hele Europa; den er alm. selv i alpine Soer (Zsclukke 00 p. 295) og nernes i nesten alle Planktonarbejler fra det mellemeuropxiske Sletlelands Socr. Den er overalt en udpragel pelagisk Organisme.

Den eneste, der narmere har studeret dens Levevis, er $A$ pstein, der for Plönersøeme konmer til et lignemele liesultal som jeg for de danske Soers Vedkommende.

Ogsali lian angiver, al Arten er perenuerende, hyppigst i Sommerhalvaaret, sjalden om Vinteren; Foraarsmaks. er konstanl, men over senere Maks. har heller ikke han kunnet opnaa Klarhed; Hannerne er sjældnere end Hunnerne; de findes hyppigst om Sommeren; i Vinterhalvarel er de ikke sete.

Cychops stremus fischer.

Schmeil 92. Tab. II, Fig. 12.

Fureso. C. s. spiller en ganske underordnet liolle i Furessens l'lankton; sarlig i Maj-Juni saa vel i 01 som (102 er (ler paavist en l)el Eks.; i den (wrige Del af Aaret optræeder den kun enkeltvis.

Esrousø. C.s. Udlgor til Tiler en belydelig Del af Søens Crustaceeplankton; den er vistnok ret alm. i Tiden fra $00{ }^{17} / 12$ Tp. 5 til $016 / 5$ Tp. 8, indenfor hvilket Tidsrum der falder en Seksualper. Hannerne er navnlig alm. i April, og der fincles mange IIunner med Eggesække paa c. $20 \mathrm{Eg}$ i hver. I Tiden fra ${ }^{29} / 6$ Tp. 15 indtil ${ }^{15} / 10$ Tp. 12 er Arten yderst sjælden, og forst $15 / 10$ findes en Del Eks., mest unge Dyr. I Proverne $10 / 11$ Tp. 7 og ${ }^{17} / 12$ Tp. 1 er Arten kendelig steget i Antal og befinder sig midt i en Seksualper,; den clanner nu en væsentlig Del af Crustaceeplanktonet; Hanner er talrige, Hunnerne bærer næsten alle Eggesække med $8-10 \mathrm{Kg}$ i hver. Et Min. indtræffer 0.2 $13 / 1$ Tp. 1-23/3 Tp. 2, under hvilket man ikke ser Hunner med Eg, men en Del Hanner. Efter Isløsningen i Proven ${ }^{17} / 4$ Tp. 4 er Arten atter noget hyppigere og holder sig ret alm. til ${ }^{23} / 5$ Tp. 9 ; indenfor dette Tidsrum træffes Hunner med talrige Eg, c. $15-17$ i hver Eggesak, men Hannerne kun i Begyndelsen; i alle Prøver efter ${ }^{23} / 5$ optrecler Arten kun enkeltris.

Det fremgaar da heraf, at C. strenuus i Esromsø har to Maks., et om Efteraaret Nov.-Dec. og et om Foraaret April--Maj; santidig indtræffer Seksualperioderne; Hannernes Maks. ligger før Hunnernes; Egantallet er i Efteraarets Seksualper. (16-20) mindre end i Foraarets (c. 40). I Sommertiden ligger et meget udpræget Min.

Soroso. C.s. forekommer sikkert nok hele Aaret, men gennemgaaende kun i ringe Mængde; den er ret hyppig i Proverne $01{ }^{1 /} / 10$ Tp. 12 og $18 / 11$ Tp. 7 , navnlig paa dybere Vand.

Tjustrupso. C. s. optræder ogsaa her i de fleste Prover kun enkeltvis, noget hyppigere i Efteraarsproverne $01 \frac{16 / 10}{10}$ Tp. 13 og $18 / 11$ Tp. 7.

Viborgso. C. s. er til Tider den i Soen talrigst repræesenterede Crustacee. Den findes kun i ringe Mængde $0129 / 3$ Tp. 1, men er noget tiltaget $13 / 5$ Tp. 14; i ingen af disse Prover har det varet muligl at paavise Seksualper.; de indeholdt vasentlig unge Dyl; efter ${ }^{10} / 7$ Tp. 21 og indtil ${ }^{10} / 11$ Tp. 8 tiltager Arten mærkelig nok stadig; ${ }^{14} / 10$ Tp. 12 er den lige saa alm. som Diaptomus og $10 / 1$ absolut talrigere. $017 / 8 \mathrm{~T}$. 23 mærkes en Seksualper., under hvilken de fleste Hunner bærer Eg, og Hanner er alm.; i de senere Prøver indtil $1 \% / 11$ fincles vasentlig kun Yngel og unge Dyr; efter ${ }^{10} / 11$ indtræder en ny, vel markeret Seksualper.; $8 / 12$ Tp. 2 er C. s. saa godt som forsvunden og er $\mathrm{i}$ de folgende Prover $023 / 1$ Tp. 2 og $22 / 3$ Tp. 2 yderst sjælden; 30/4 Tp. 8 findes Arten med et ganske kolossalt Maks. og milt i en Seksualper.; i alle de følgende Prover er den sjælden.

Det er ikke muligt af de her givne Facta at bestemme Seksualperiodernes Beliggenhed. Proverne fra Aug. 01 har alle varet store og har $\mathrm{i}$ andre Henseender vist sig fuldt paalidelige; snarest maa jeg formode, at vi her har haft med Sværmdannelse at gore, og at Nettet i nogle Tilfælde har truffet i Sværmene, $i$ andre udenfor disse.

Det fremgaar $\log$ af Prøverne, at C. strenuus i 01 har haft en Seksualper. i Nov., Min. om Vinteren og stor Seksualper. om Foraaret; for saa vidt er Forholdene overensstemmende med dem, vi finder $\mathrm{i}$ andre Soer saa vel her i Landet som i Udlandet.

Haldsø. C. s. findes enkeltvis i alle Prøverne; nogen Stigning i Antallet eller sæerlig markeret Seksualper. om Efteraaret er iklie paavist. 
Skanderborgso og Mosso. C.s. findes muligvis i alle Proverne; i lifterars-og Vinterproverne er der paavist en Del liks.

Julso. C. s. Forholder sig her som i de to foregataende Soer, kun synes Maenglen i Proverne 01 15/10 Tp. 12 og $0 / 11$ Tp. 6 at vare nogel storre end $i$ de to andre Soer.

Det fremgan heraf, at C. stremms vel er palisist i alle vore Søers pelagiske Region, men at den som Plankton-damnende kun spiller nogen Rolle i to, nemlig i Esromso og Viborgsø.

Man kan vistnok gaa ud fra, at C, strenums i de fleste danske Soer har to Maks., et stort Efteraarsmaks og el mindre Foraarsmaks.; under Efteraarsmaks. kan den vare ret talrig selv i de Søer, hvor den ellers. kun lader sig paavise enkeltvis; Maks. falder sammen med en Seksualper., sarlig paaviselig i Esromsø og i Viloorgso.

Ogsaa for denne Arts Vedkommende synes Egmangden at vare størst om Foraaret.

Burcklardt (00 p. 146) kommer for Vierwaldstädtersøens Vedkommende til et ganske lignende Hovedresultat som jeg: Maks. med Seksualper. Dec.-Feb., Min. for Hanner fra Jan. til Juni, for Hunner fra Marts til Juni; et nyt, mindre Maks. med Seksualper. indtil Sep., derpaa atter Min., der for Hannernes Vedkommende varer til Nov., for Hunnernes indtil Sep.; det er rimeligvis det mindre Sommermaks., som er bleven parist i Viborgsø.

C. strennis har en meget stor geografisk Udbredelse; den forekommer i Følge Lilljelorg (01 p. 32) i det nordligste Sibirien og paa de Nysibiriske Øer, er meget alm. i højtliggende Alpesøer (Zs chokke 00 p. 295), men ikke minclre hyppig over hele det mellemeuropæiske Sletteland; den forekommer i Smaasøer og som Planktonorganisme i større Søer. C. s. er, som saa mange andre Organismer med vid geografisk Udbredelse, overordentlig starkt varierende. Lilljeborg har (01 p. 29-33) givet en ypperlig Oversigt over Variationerne; Arten er om Vinteren, i alt Fald i det mellemste og sydlige Sverrig, mest luxuriøst udstyret, men bliver hen paa Sommeren mere og mere reduceret; i dybe Søer holder den sig Sommeren over under to Former, der tidligere blev opfattede som sarlige Arter, C. abyssornm og lacnstris, og af hvilke førstnævnte kan betragtes „som en luxurierande Form af vinterformen och den tidiga virformen och den senare siom en sjöform af den reducerade sommerformen (p. 29).

Lilljeborg er tilbøjelig til, bl. a. fordi Vinterformen er den mest luxurierende, i C. strenmus at se en Relikt fra Istiden, og Zschokke (01 p. 33) har, væsentlig støttende sig til, at Seksualper. falder om Vinteren for Eksemplarerne fra de alpine Søer, haft samme Tanke.

\section{Calanidæ.}

Fam. Calanida taller i Ferskvand et ret betydeligt Antal Slægter. I Europa forekommer Limnocalanus, Diaplomus, Heterocope, Eurylemora. Af disse lever den førstnavnte Slægt ogsaa i Havet; Heterocope lever overvejende i rent Ferskvand, og Eurytemora indbefatter Arter, hvoraf nogle lever i Brakvand, andre i rent Ferskvand og atter andre begge Steder; kun Diaptomus synes skarpt begrænset til Ferskvand; den langt overvejende Del af Ferskvands-Calaniderne tilhører Diaplomus; af Limnocalanns forekommer i Europa i Ferskvand kun en sikker Art; af Heterocope og Eurylemora henholdsvis tre Artèr og 1 Art.

Her i Landet er hidtil kun funden Reprasentanter for Diaptomus og Enrytemora. I Følge Oplysninger hentede fra Mag. S. Jensens Manuskript forekommer E. lacinnlata Fischer vel i Ferskvand, men altid i Nærheden af Havet (Botanisk Haves Dam o. a.). E. affinis Poppe er kun paavist som Fjord- og Kystform; E. lacnstris Poppe er kun fundet i faa Eks. i Gudenaaen ved Silkeborg. Limnocalanns kunde som skandinavisk, alpin Form ikke ventes; derimod maatte man i høj Grad formode, at Heterocope, i hvert Fald med sine to Arter H. saliens (Lilljeb.) og appendicnlala G. O. Sars, maatte kunde paavises; førstnæevnte er nemlig kendt fra Nordtyskland, sidstnævnte fra talrige Findesteder i Sydsverrig, Nordtyskland og Holsten (Steue r 01 Tavle 10). Saa vel Mag. Søren Jensen som jeg selv har søgt efter Heterocope-Arterne baade i le Søer, der næevnes i dette Arbejde, og i talrige andre, men det er hidtil aldrig lykledes os at finde dem; dog maa 
jeg gai ud fra, al fremtidige Undersegere vil bringe (lem for Dagen; i Folge Apstein (96 p. 181) forekommer den dog kun sparsomt i Plönersosen.

Som bekendt har de leste al Farskvandets Planklonorganismer en overordentlig stor geografisk Udlbredelse, og Hovedparten kan, elter det kendskal) vi i Ojeblikket har til dem, med god Grund betegnes som Kosmo-

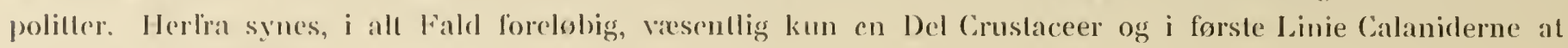
danne on Undlagelse.

M Steuers (01) meget instrnktive og lorțenstfulde Undersøgelser synes det at fremgaa, at de enkelte Arter al Slaxgterne Calcunus, Eurylemora og Heterocope indenfor Europa lar ret skarpt markerede Udbredningsomratade; ud fra sine Studier over Calaniderne og over Bosminerne mener han at kunne udsondre 5 Regioner (01 p. 1.13), af hilke Dammark, som det var al vente, slutter sig nxe til den 2den Region, den nordtyske Slctlelands\%one.

\section{Diaptomus.}

Der er lıer i Landel kun fundel 5 Di(tptomus-Arter (S. Jensens Manuskript), nemlig I). caslor Jurine, superbus Schncil, coeruleus Fischer, gracilis og graciloides. D. caslor er vor hyppigste Damform; superbus og cocrulens liendes ligeledes kun fra mindre Vande, men er kun fundne paa enkelte Lokaliteter; gracilis og graciloiles findes haade i Smaasøer og i større Søers pelagiske Region, men synes dog ganske særlig at ræere hijemmehørende her; der er ingen større Sandsynlighed for, at denne Region skulde huse flere end sidstnavinte Arter. I Nordtyskland traffes pelagisk i større Ferskvands-Søer ligeledes kun disse to Arter; i de norske og svenske Søer lever et betydeligt større Antal Arter, men disse er i saa Fald rasentlig alpine (I). dentlicornis Wier\%, bacillifer Kioelbel., laticeps G. O. Sars). Den i Norge hyppig forekommende I). lacinulatus Lilljb. liavde jeg dog haabet, at Undersøgelsen skulde have bragt for Dagen.

D. graciloides blev først i 1888 af Lilljeborg udskilt fra I). gracilis G. O. Sars; senere hen har man (Vosscler, Brady; se herom Schmeil 96 p. 73) enten betvivet eller direkte benægtet Artens Eksistens; de fleste Forf., deriblandt Schmeil, anser den (log for en god Art.

D. gracilis er i det hele en kraftigere Form end D. graciloides; man angiver i Alm., at sidste Forkropssegment hos I). gracilis er en Del bredere end hos D. graciloides og, navnlig paa renstre Side, vingeformet udbredt; hos graciloides er det jarnt afrundet. 1ste Bagkropssegment er hos Hunnen af I). gracilis som oltest starkt udvidet i sil forreste Parti, medens dette hos I). graciloides kun i meget ringe Grad er Tilfældet. Hovedkendetegnet er dog, at den lille Børste paa 2det Led af 5te Benpars venstre Fods Ydergren er dunformet delt hos Hannen af $\mathrm{I}$. gracilis, medens den hos Hannen af $\mathrm{I}$. graciloides er haarformet.

Den Planktonundersøger, i hvis Søer der kun optræder de to Arter, I). gracilis og graciloides, er, naar han skal søge at udrede de to Arters Biologi, i Virkeligheden ilde stedt. Ved Gennemgang af regelmæssigt indsamlet 14 Dags Materiale viser det sig nemlig snart, at de to mest iøjnefaldende Kendetegn, Bygningen af sidste Forkropssegment og første Bagkropssegment, varierer til de forskellige Aarstider og endvidere ikke er af ganske samme Udseende i de forskellige Søer.

Jeg har nu iagttaget, at 1ste Bagkropssegment er bredt og sidste Forkropssegment vingeformet udbredt hos de Diaptonus-Individer, der forekommer i Viborgsø, Skanderborgsø, Mossø og Julsø, og ved at undersøge den ovennæernte Børste til forskellige Aarstider har jeg forvisset mig om, at den i disse Søer altid er dunformet delt; jeg henfører i Orerensstemmelse hermed disse Søers Diaplonus-Individer til 1). gracilis.

Endvidere har det vist sig, at sidste Forkropssegment er smalt og uden Vinger, samt at 1ste Bagkropssegment er smalt hos Diaplonmus-Individerne fra Sorøsø og Esromsø; den ovennæernte Børste var i disse Søer altid haarformet; Diaplonus bestemmes derfor her til D. graciloides.

I Furesøen har jeg derimod fundet den overvejende Del med de Bygningstrak, der kendetegner D. gracilis, men desforuden et mindre Antal Individer, som jeg formoder burde henføres til D. graciloides.

I Tjustrupsø er Forholdet omrendt; her hører den langt overvejende Del af Individerne formentlig til I). graciloides; af $I$ ). gracilis er typiske Eks. kun sete enkelte Gange. 
I ingen af de to Socr viser J). gracilis en saa slaerk vingeformet Udvidelse af de ovennavnte Segmenter som i de jydske Soer, og ligesom Brady lar jeg fundet, at den ovenuavnte borste ikke altid kan betragtes som afgorende Kriterium m. H. L, hvilken drt man laar for sig.

1 dette Arbej(le har jeg betegnet Furesoens Diaptomus-Individer som I). gracilis, Tjustrupsøs som graciloides og i disse Soer ikke forsogt at holde de to Arter ude fra hinanden. Crunden hertil har vaeret folgende.

Saafremt I). gracilis og I). graciloides kun lod sig skahe fra linanden ved, at (len ovennavnte Borste hos (len ene var dunformet, hos den anden laarformet, vilde det i de Tilfalde, hvor begge Arter lorekommer i samme So, vare umuligt for Planktonundersogeren at udrede de to Arters Forplantningsforhold og $ø v$ rige leveris.

Man matte nemlig i saa Fald forst og fremmest efter Børsten sondre Individerne i to Grupper, en med haarformet og en med dunformet Børste; men da en Oversigt over de to Arters indbyrdes Hyppighed, deres Forplantningsforhold o. s. v. i hver enkelt Prove ikke kunde erhverves, med mindre hver Gruppe talte adskillige Hundrede Eksemplarer, vilde Undersøgeren komme til at staa overfor èt Arbejde, der langt oversteg hans Krrafter.

Her som saa ofte tør Planktonundersogerne ikke udelukkende freste Blikket paa den afgørende systematiske Karakter, men maa særlig rette sin Opmærksomhed paa Bygningsforhold, der, skønt af ringere systematisk Værdi, er saa iojnefaldende, at de uden større Vanskelighed lader sig anvende til hurtigt at skæelne vedkommende Former fra hinanden.

I dette Tilfalde maa han tage Kending af sidste Forkropssegments og første Bagkropssegments Bygning. Undersøgelsen viser nu, at denne hos D. gracilis afhanger af den Egmangde, Hunnen bærer, idet begge Segmenter er stærkest udvidede hos Hunner med et stort Antal Eg; da vi endvidere vil faa at se, at Egantallet i Diaptomus-Flokkene paa ethvert givet Tidspunkt af Aaret nogenlunde er det samme, men forskelligt til de forskellige Aarstider, mindst om Sommeren, størst i det tidlige Foraar, følger heraf, at disse Bygningsforhold kun i en Del af Aaret kan anvendes til at holde de to Arter ude fra hinanden, men desvarre ingenlunde til enhver Tid; orn Foraaret, naar $D$. gracilis er udstyret med de meget store, vingeformede Udbredninger paa sidste Forkropssegment, kan D. gracilis og graciloides altid ved forste Øjekast skelnes fra hinanden, men hele Sommeren og en stor Del af Efteraaret, da der af begge Former overvejende kun findes unge Dyr eller Hunner med ringere Egantal, kan disse Arter alene paa Bygningen af de to Segmenter ikke med Sikkerhed adskilles.

Der gives dog en Karakter, som Systematikeren maaske neppe vil godkende, men som for Planktonundersøgeren ikke er uden Betydning, naar de to Arter skal udsondres af Planktonprøverne. Undersøgelsen viser, at Ægantallet altid er større hos D. gracilis end hos D. graciloides; hos D. gracilis er (let om Foraaret 20-30, om Sommeren 7-10, om Efteraar og Vinter 10-12; hos graciloides er det derimod henholdsvis 12-16, 1-4 og $5-6$. Ved Hjalp af denne Forskel kan man til alle Aarstider vel holde de to Arters kønsmodne og xgbærende Hunner ude fra hinanden, men Hanner og navnlig Yngel frembyder jo derfor ikke faer re Vanskeligheder.

For Tjustrupsøs og Furesøens Vedkommende har jeg i April-Maj kunnet overtyde mig om, at den langt overvejende Del af Diaptomus-Flokkene i førstnævnte Sø dannes af D. graciloides, i sidstnævnte af D. gracilis; i Overensstemmelse hermed er Tjustrupsøs Diaptomus betegnet som D. graciloides og Furesøs ved D.gracilis, men det bemarkes udtrykkeligt, at der om Sommeren i Furesøen optraeder Individer, som vistnok hører til graciloides, og i Tjustrupsø enkelte, der hører til gracilis. Navnlig er det for Furesøens D. gracilis abnormt ringe Egantal vel egnet til at drage Bestemmelsens Fuldstændighed i Tvivl.

Naar jeg alligevel tror, at jeg overvejende har truffet det rette, er det, fordi I). gracilis og graciloides kendelig afviger fra hinanden baade i Henseende til deres Forplantningsforhold og deres Maks.'s Beliggenhed; det viser sig nu, at Furesøens Diaptomus i saa Henseende overvejende forholder sig som D. gracilis, Tjustrupsøs næsten ganske som D. graciloides. 
I de Lalrige l'lanklonarbejder liat Holsten og Nordlyskland er de to Arter vistnok altid sammenblandede; jeg har derfor her ikike lagel Hensyn Iil de Oplysninger, som i disse Arbejder er givet om deres Biologi. I). grucilis er fortreffelig undersogt al Burckhardt (00 p. 153); D. graciloides' Forplantningsforhold etc. har derimod hidtil vitrel ukendte. Ogsal Kendskabel lit disse Forhold hos de lleste ovrige Arter er meget ringe; dog har Burckinardt leveret betydningsfulde Meddelelser om I). lacinulalus og l3irge (97 p. 319) fortrinlige Bidrag lil I), oregonensis Lillilo. Biologi.

Der er af I). gracilis beskrevel 2 Varieleter, var. pardana Burckhardt (99 p. 646) (Lago di Como og Lalgo Mlaggiore) og var. intermedia Steuer (01 p. 13!)) (Triest).

\section{I). graciloides Lilljeborg.}

Schmeil 96. Tab. III, Fig. 1-6.

Ėsoms (). I), gracil. er Soens hyppigst forekommende Crustacee. I Proven 00 17/12 Tp. is findes vasentlig unge Hlunner uden Eg og uden Spermatoforer, en Del Hanner, nesten ingen Nauplier og meget faa senere, ikke konsHodIne Stadier; 01 10/4 Tp. 3 er D. gracil. ojensynlig nidt i en stærk Seksualper.; Hunnerne baerer næsten alle Agg (Aigantal 7-9), hyppig Bundter al Spermatoforer; Hanner findes i stor Mængde, men meget lidt Ýngel. 6/5 Tp. 8 er Forholdene ontrent de samme, kun er Egantallet noget storre (10-12); Hannerne er maaske lidt sjældnere; en Vrimmel af Nauplier og Metanauplier iagttoges, men faa xldre Udviklingsstadier. $25 / 5 \mathrm{Tp}$. 13 er Antallet af konsmodne Dyr kendelig aftaget; Hunnerne baerer kun 4-5 $\mathrm{Eg}$; derimod findes en overordentlig stor Mrengde unge Dyr, der danner IIovedmassen af alt Crustaceeplankton og vistnok overhovedet af alt Plankton; i de følgende Prøver $29 / 6$ Tp. $15,20 / 7$ Tp. 7 og $12 / 8$ Tp. 21 er Antallet af unge Dyr stadig meget stort; Hanner er sjældne, og af Hunner med Eg ses yderst faa (maaske e. 1 til 1000), disse bærer kun c. 4 Eg. 5/9 Tp. 16 og 30/9 Tp. 17 synes Antallet at tage af; flere Individer kan bestemmes som Hanner, men Hunner med Eg (e. 4) er stadig lige sjældne; de to-tre folgende l'rover ${ }^{15} / 10$ Tp. $12,{ }^{10} / 11$ Tp. 7 og $17 / 12$ Tp. 1 giver væesentlig samme Resultat. Hannerne tiltager dog i Antal; Hunner med Eg er endnu 17/12 sjældne, men Egantallet er da 5-6. 02 27/1 Tp. 1 findes adskillige Hunner med Kg (4-6) og talrige Hanner; $22 / 3$ Tp. 2 bærer nesten alle Hunner Eg (7-9); Hanner er talrige; $17 / 4$ Tp. 4 er Forholdet uforandret, kun er Egantallet 12-14 og naar sit Maks. ${ }^{13} / 5 \mathrm{~T}_{\mathrm{p}} .8$ med $10-18$. I hele denne Periode findes Hanner i stort Antal, og Hunnerne bærer ofte hele Klynger af Spermatoforer; tomme, drivende Spermatoforbundter er alm. i Plankton. $23 / 5$ Tp. 9 har de fleste Hunner endnu $\mathbb{E g}$, men kun i Antal af $7-8$; Hanner er sjaldne; fra ${ }^{17} / 4$ Tp. 4 bemærkes senere en stadig stigende Miengle Nauplier og Metanauplier, hvis Maks. falder (c. ${ }^{23} / 5$ Tp. $9 ; 13 / 6$ Tp. 13 ses kun faa voksne Dyr, Egantallet 5-6, men en uhyre Masse halvvoksne Individer; Forholdet er uforandret $10 / 7$ Tp. 14 og $31 / 7$ Tp. 15.

Forplantningsforholdene for D. gracil.'s Vedkommende er i Esromsa ualmindelig klare og letfattelige.

Fra Slutn. af Marts til Slutn. af Maj falder en stærkt udpreget Seksualper., efter hvilken en Masse Ýngel viser sig. der danner Sommerens og Efteraarets store Planktonsvarme af Copepoder; fra Juni og lige til Dee. fincler man kun yderst faa Hunner med Eg; Hannerne tiltager stadig i Antal, men Forplantningsvirksomheden er næeppe stor; jeg slutter dette dels af, at Spermatoforer er sjældne paa Hunnerne, dels af, at Mængden af Nauplier er ringe hele Sommeren; forst fra Dee. begynder Parring igen at blive alm.; Spermatoforer paa Hunnerne er da hyppigere.

Egantallet stiger og falder fuldstændig regelmæssigt i Aarets Lob; det er 5-6 om Vinteren, stiger til $7-9$ i Begyndelsen af Seksualper. (Marts) og er ved Slutningen af denne (Maj) 10-12; derpaa falder det til $7-8$, og i Tiden fra Juni til Dee. træffes sjældent Hunner med over 1 .Eg.

Sorosø. D. gracil. er vistnok Søens hyppigst forekommende Crustacee. Det fremgaar af Proven $00{ }^{19} /{ }_{12}$ Tp. 5 , at Arten nærmer sig en stor Seksualper.; Egantallet er 5-6; der er talrige Hanner, de fleste Hunner synes dog ikke at bære Eg. $015 / 5$ Tp. $10 \mathrm{og}{ }^{26} / 5$ Tp. 13 mærkes en udpræget Seksualper. med talrige Hanner, næsten alle Hunner med .Eg, ofte med Bundter af Spermatoforer og med stort Egantal $(5 / 58-14,24 / 54-6)$; $24 / 5$ findes en Masse Nauplier og Metanauplier. Igennem alle Proverne fra $3 / 7$ Tp. 21 indtil $3 / 1$ Tp. 2 optræder aldeles overvejende unge Dyr: Hannerne er ret alm. fra ${ }^{17} / 10$ Tp. 12 og tiltager stadig i Antal; Hunner med Eg er ydlerst sjældne og Egantallet meget ringe; der findes ofte kun et eneste Eg og sjældent over 2-3. Hunner med Spermatoforer er sjældne. Spæd Yngel ses i hele Perioden kun i ringe Mængde.

02 $3 / 1$ Tp. 2 findes mange Hanner, men kun de færreste Hunner bærer $Æ g(6-7) . \quad 30 / 1$ Tp. 1 ses mange Hunner med Eg (6-8), ligeledes $24 / 3$ Tp. 1, men Egantallet er nu 7-9. $19 / 4$ Tp. 4 optræeler Masser af Hanner med Spermatoforer liggende inden i Legemet; næsten alle Hunner bærer $£ g$ (10-12) og store Spermatoforbundter; 


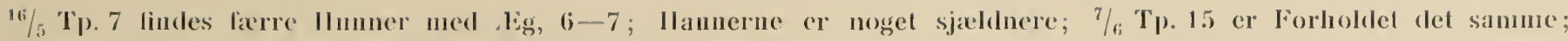
der er nu negen Yngel: Ienne er dominerende i Proverne $28 / 6$ Tp. 17 og $27 / 7$ Tp. 16; men endnu $28 / 6$ findes naxkvardig mange Hamer; Ilunner med Aig mangler nasten ganske, digantal 5-6.

Forholdene er altsaa ganske som i Esromso, kun syues Seksualper, at begynde tidligere og ophore lidt tidligere. Markeligt er det store Antal Hamner $28 / 6$.

'Tjustrupso. D. gracil. er rincligvis Soens lyppigst forekommente Crustacce. 00 19/12 Tp. 3 fincles talrige Ilanner, ogsaa Hunner, men sidstnevnte uden Spermatoforer og nasten uden Leg; Yngel mangler nasten ganske. $015 / 5$ Tp. 7 cr D. gracil. midt i en Seksualper.; Aggesakkene indeholder 10-16 Eg; nasten alle Hunner barer Eg, olle Spermatoforer; llanner ses i Mangle; Proverne $24 / 5 \mathrm{Tp} 13$ giver nermest samme Resultat, !nen 11 unnerne barer kun 5-8 Eg; der lindes nu megen spaed Yngel; 3/7 Tp. 17 er Ynglen halvvoksen; nogle Hunner barer

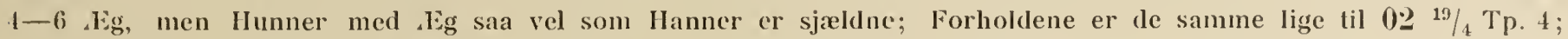
der er Sommer- og Efteraarsprøver, i hvilke man maa undersøge en Masse Eks. for blot at finde en enkelt Hun med Iig, og disses Antal overstiger alırig 6, ja er som oftest kun 3--4; fullvoksne Hanner bliver først alm. hen paa Efteraaret. I Proven 01 16/10 Tp. 13 findes markelig mange Hunner med $4-6 \mathrm{Eg}$, ligeledes en Del Hunner med Spermatoforer; Ynglen er i hele Tidsrummet svagt reprasenteret. $02{ }^{19} / 4$ Tp. 4 bæerer de allerfleste Hunner Eg i et Antal 14-16; Hanner er talrige. Forholdet er uforandret $16 / 5$ Tp. 8, kun er Antallet af Hanner noget aftaget, og Ynglen er bleven alm.; $\%$ Tp. 12 findes uhyre Mangder af Yngel og unge Dyr, men kun et ringe Antal Hanner og agbarende Hunner med $4-6 \mathrm{Kg}$.

Haldsø. D. gracil. synes at vare Soens hyppigst forekommende Crustacee. $01{ }^{30} / 1$ Tp. 1 findes overvejendle Hunner uden Eg og mange Hanner; Egantallet or 4-5. $29 / 3$ Tp. 2 berer de fleste Hunner Eg (c. 10), og Hannerne er alm. ${ }^{18} / 5$ Tp. 10. Seksualper, vedvarer endnu, Egantallet er $10-12$. 1 Tiden fra $29 / 3$ til $18 / 5$ findes talrige Hunner med Spermatoforer; der er kun lidt Yngel; ${ }^{22} / 6$ Tp. 13 findes overvejende Yngel og unge Dyr; de faa agbærende Hunner har kun meget faa $\mathrm{Eg}$; adskillige kun eet; Hannerne er sjældne. Indtil $8 / 12$ Tp. 4 er Agproduktionen yderst ringe; Hunner med lig er sjaldne, Egantallet er højst 4, ofte kun 2 eller 1. Spermatoforer paa Hunnerne ses næsten aldrig; Mængden af udvoksne Hanner tiltager stadig; spæed Yngel er sjælden.

$8 / 12$ Tp. 4 findes talrige fuldt udviklede Hanner, men faa Hunner med $\mathrm{Eg}(4-6)$; ingen nævnevæerdig Forandring 0.2 3/. Tp. 2, men 22/3 Tp. 2 bærer de allerfleste Hunner $\& g$ (6-8), og Hanner optræder i Mængde; Forholdene uforandrede $3 / 5$ Tp. 7, kun er Egantallet 10-13. Yngel er stadig meget sjælden, men begynder dog at vise sig. ${ }^{30 / 5}$ Tp. 8 er der megen spæd Yngel; Hanner er sjaldne, og Hunnerne bærer kun $4-6$ Eg. I Prøverne $11 / 6$ Tp. 12 til $2 / \mathrm{s} \mathrm{T}_{\mathrm{P}}$. 15 findes næsten kun halvvoksen Yngel eller næppe kønsmodne Dyr, men ingen spad Yngel; derimod ganske enkelte Hunner med 2-4 Ag.

Det fremgaar heraf, at D. gracil. i Haldso forholder sig ganske som i de andre Soer.

D. graciloides forekommer altsaa som Planktonorganisme i Esromsø, Sorøsø, Tjustrupsø og Haldsø; muligvis maa ogsaa en Del af Furesøens Diaptomider henregnes til denne Art. I alle disse Søer indtræeffer i Marts-Maj en meget skarpt begrænset Seksualper.; Hanner findes i Mængde; Hunnerne barer næesten alle Eg; der er saa godt som ingen Yngel. I Slutn. af Maj ophører Seksualper., og der viser sig da i alle Søerne uhyre Mængder af Nauplier og Metanauplier; sammen med Rotifererne og de begyndende Sommergenerationer af Daphnier danner de Forsommerens markelig rene Zooplankton, der i større eller mindre Grad karakteriserer vore Søer paa det Tidspunkt, da Diatomeerne er ved at forsvinde, og Cyanophyceer og Ceratier ikke er komne til Udvikling. Sommer og Efteraar dannes Copepodbestanden af unge Dyr; Hunner med Eg er yderst sjældne, fuldtfardige Hanner ligeledes; Hunnerne brer kun undtagelsesvis Spermatoforer, og Spermatoforerne hos Hannerne ligger ikke inde i Legemet, parate til at udskydes, saaledes som Tilfældet er senere hen; af Yngel er der nasten ingen. Forholdene er uforandrede lige til Dec.-Jan., da Hannerne synes at være fuldt udviklede; men Parringen og Formeringen bliver forst alm. i Marts-April efter den endelige Isløsning; intetsteds er der paavist Seksualper. om Efteraaret.

Egmængden er ingensinde betydelig, dog størst i Slutningen af Seksualper. (12 - 14, undtagelsesvis 14-18); derpaa aftager den pludselig stærkt til $6-8$ og er i Sommerens og Efteraarets Løb sjældent over 4, i Aug.Sep. findes ikke sjældent kun $3 \mathrm{Fg}$, ofte kun et eneste; fra Dec._Jan. begynder Ægantallet svagt at stige (5-6), og efter Isløsningen plejer det at vare c. $7-9$.

Da ovennævnte Resumé støtter sig paa Iagttagelser fra 4 forskellige Lokaliteter, og da $D$. graciloides alle Steder 
syues at forholde sig cons, for vi labahe, at det i Hovedsagen rigtigh gengiver forplantuingsforholdene hos (lenue Art. I sai Falel bruger D. graciloides el Aar om sin Udvikling; den fodes i April-Maj, parrer og forplanter sig forst i Marts-Maj det lolgende Aar; den langl overvejende Del af en Søs Bestand af 1). graciloides er jernaldrende, klakket paa samme 'lid. I)en skarpt markerede Seksualper., den naesten Lotale Forsvinden al Hannerne i Juni, de yderst laa aghaerende Hunner i Tiden fra Juni til Dec. og den megel ringe Naengde af Yngel er Fanomener, som indlbyrdes sammenlıoldte ikke tillader nogen anden Tydning.

1). graciloides er en over hele Skandlinavien, Finland, Rusland og Nordtyskland vidt udbredt Art; syd for Mperne er den kun kendt fra laa Findesteder (Steuer 01 p. 139)). Den kan, som allerede Hartwig (01 p. 62) angiver, og som det ogsan er Tilfeeldet hos os, optrede i Damme og Smaasøer, men den synes dog vasentlig. at vere lijemmehorende i vore storre Søers pelagiske Region.

\section{I). gracilis G. O. Sars.}

Schmeil 96. Tab. III, Fig. 7-16.

Fureso. D. grac, er Soens hyppigst forekommende Crustacee. $0020 / 12$ Tp. 4 findes en Del Hunner med 6--8 IEg og Hinner med ikke udskudte Spermatoforer; Yngel mangler ikke ganske, men er ikke talrig; Forholdene er uforandrede indlil $01{ }^{23} / 4 \mathrm{~T}_{\mathrm{p}}$. 6 , da talrige Hunner med Lg (10-14) og en Mxngde Hanner viser sig; Lgantallet er allerede $27 / 5$ T p. 14 nede paa $4-6$, og holder sig uforandret $7 / 6$ Tp. 16 ; man ser stadig mange Hunner med Eg saml IIanner, tillige store Mrengler af Yngel; i Tỉen fra $7 / 6$ til $7 / 9$ Tp. 16 findes overvejende unge Dyr, men dog allicl en ikke ubetydelig Brokclel Hunner med 4--5 Ag, samt en Del Hanner; Nauplier og Metanauplier mangler ganske. I I'roverne $7 / 9$ Tp. 16 og ${ }^{2} / 10$ Tp. 16 indtraffer rimeligvis en svag Seksualper., flere Hunner med $4-5$.Eg iagttages, og Hunnerne barer ofte Spermatoforer; i de folgende Prøver optræder en ikke ubetydelig Del spæd Yngel og unge l)yr (særlig Proven ${ }^{21} / 10$ Tp. 11). I Proverne 16/11 Tp. 4 og ${ }^{17} / 12$ Tp. 1 synes den langt overvejende Del atter at være bleven konsmoden, der er kun faa halvvoksne Dyr; en Del Hunner bærer 6-9 Eg og undertiden Spermatoforer; Hannerne er talrige.

I Tiden fra 02 $31 / 1$ Tp. 1 til $21 / 5$ Tp. 9 findes stadig en stor Miengde Hanner, talrige ægbærende Hunner, men desuden mange uden Lig; Egantallet er stadig stigende, ${ }^{31} / 1$ Tp. 1: $9-12,{ }^{23} / 3$ Tp. 1: $10-12,{ }^{25} / 4$ Tp. 5: 14-16, 21/5 Tp. 9: 14-20, hvorefter Antallet af agbarende Hunner tager af, og Ynglen bliver alm. I de folgende Prøver fra $5 / 6$ Tp. 12 til $3 / 8$ Tp. 15 optrader overvejende unge Dyr, spæedest $5 / 6$ og tilsyneladende fuldvoksne $3 / 8$; der findes dog en Del Hanner og nogle Hunner med Eg, c. 2-4; men desuden i alle Prøverne enkelte Hunner med 12-16 Eg.

Viborgso. D. grac, findes den allerstorste Del af Aaret i uhyre Mængde i Søen. 01 29/3 Tp. 1 møder os overvejencle unge Hunner, Hanner og en Del Yngel; ${ }^{18 / 5}$ Tp. 14 er Arten midt $i$ en Seksualper.; Hanner er talrige, llunmerne baerer Bundter af Spermatoforer samt et stort Antal, 20-28 Eg; der er næsten ingen Yngel; fra 10/7 Tp. 21 til ${ }^{14} / 10$ Tp. 12 findes overvejende unge Dyr, men en Del Hanner samt nogle Hunner med Eg; disses Antal er $7 / 8$ Tp. $236-8,15 / 9$ Tp. 12 c. 10; der er kun faa Hunner med Spermatoforer; i Tiden fra $14 / 10$ Tp. 12 til $023 / 1$ Tp. 2 kommer en ny Seksualper., men de ægbærende Hunners Antal er ikke saa stort som om Foraaret, og Egantallet ikke over $8-10$; i de folgende Prover ${ }^{22} / 3$ Tp. 2 og $30 / 4$ Tp. 8 findes overvejende unge Dyr og yderst faa Hunner med 6-8 Eg; en ny, meget kraftig Seksualper. begynder 30/5 Tp. 8 med talløse Hanner og et storl Antal Hunner med LEg (16-20) og store Spermatoforbundter paa Halen; Ynglen er ringe; allerede 14/6 er Seksualper. nær sit Ophor; der findes nu overvejende unge Dyr og kun faa Hunner med 10-12 .Eg. I Proverne $25 / 6$ Tp. 17 og $27 / 7$ Tp. 15 træffes kun faa Hunner med Eg $(6-8)$; den langt overvejende Del er unge Dyr.

Skanderborgsø. D. grac. spiller en ganske underordnet Rolle i denne Sø. $0029 / 12$ Tp. 5 optrceder overvejende unge Dyr, men dog en Del Hunner med Eg (8-10) og Hanner. 01 19/5 Tp. 13 lindes overvejende Hanner, Hunner med talrige $\mathrm{Eg}$ (c. 20), men meget lidt Yngel; hvorledes Forholdene har varet fra $19 / 5$ til $5 / 8$ vides ikke, men i Proverne $5 / 8$ Tp. 21 og $15 / 9$ Tp. 12 møder os overvejende unge Dyr, dog altid en ikke ringe Del Hanner og en Del Hunner med $\operatorname{Eg}(6-8) ;{ }^{18} / 10$ Tp. 12 og til Dels ${ }^{20} / 11$ Tp. 6 ses betydelig flere Hunner med Eg (e. 10-12) samt mange Hanner, men i Proverne $023 / 1$ Tp. 1 og ${ }^{27} / 1$ Tp. 1 træffes atter overvejende unge Dyr og meget faa Hunner med c. $8 \mathrm{Eg}$. Forst $1 / 5$ Tp. 7 optræder hovedsagelig konsmodne Dyr med talrige Hanner; Hunnerne bærer 12-16 Eg, og Ynglen er svagt representeret; Forholdene er omtrent de samme baade $3 / 6$ Tp. 15 og $28 / 6$ Tp. 18 ; der er fremdeles mærkværdig lidt Yngel, Egantallet derimod ofte stort $(14-16) .30 / 7$ Tp. 14 træffes overvejende unge Dyr, men en Del Hanner og mange Hunner med c. 10-12 .Eg. 


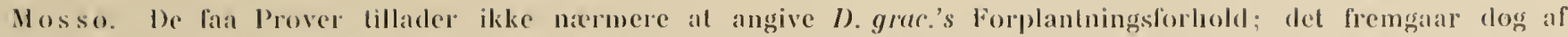

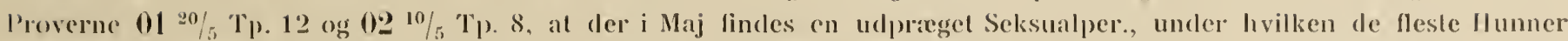

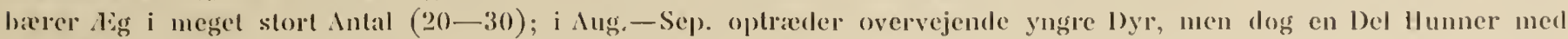
5-6 Jig. Ogsal her indleafter en svag Seksualper. Sep.-Okt., i hvilken adskillige Ilunner baerer $8-10$ dig, hvorpaa der alter findes mange unge Dyr; om Vinteren er iegberende llunner sjaclene; Aigantal 6--8; Hanner fincles liele laret, men talrigst i Maj.

Julso. D. grac, er en af de Crustacer, (ler forekommer i storst Maeng(le. 00 26/12 Tp. 4 findes overvejende unge Dyr, men dog en Del Hanner samt Hunner mol Asg (c. 10-12); i de to folgende Prover 01 24/. Tp. 3 og 20/5 Tp. 13 derimod overvejende Ilanner samt mange Hunner med Aig; Eigantallet er enornt (20-32); der ses naesten ingen Yngel, l Proverne $10 / 7$ Tp. 20 og $1 / 8$ Tp. 22 findes overvejende Yngel eller dog ikke fuldvoksne Dyr, men ogsaa en Del Hunner med maekelig stort Agantal (12-16) samt nogle Hanner. Hunnerne brerer ofte en 1)usk Spermatoforer. 15/9 T). 12 findes atter talrige Hanner samt Hunner med Aig (Aigantal 12-14). I de to paafølgende Prover ${ }^{15} / 10$ Tp, 12 og 2\% $/ 1$ Tp. 6 maerkes overvejende unge Dyr og meget faa Hunner med Eg (10-12). Hele Vinteren og Foraaret 02 optrader Arten kun i mærkelig ringe Mangde; der er stadig en Del Hanner, men forholdsvis faa Hunner med Eg (16-20). En Seksualper. har dog fundel Sted, thi $30 / 6$ Tp. 16 traffes en hel Del Yngel, der genfindes i aldre Stadier $31 / 7$ Tp. 15; samtidig optreder en Del Hanner samt Hunner med $10-12$ Es.

Det fremgaar altsaa heraf, at D. gracilis optrader som Planktonorganisme i Viborgsøerne, Skanderborgsø, Mossø og Julsø; Furesøens Diaptomus maa, om end med nogen Tvivl, henføres til samme Art; den findes rimeligvis, men i ringe Mangde, i Tjustrupsø, da jeg navnlig i Sommertiden her har set enkelte Hunner med 12-16 Eg og med Bygningstræk, der bedst stemmer overens med I). gracilis.

Forplantningsforholdene afviger stærkt fra D. graciloides, men kan ikke angives med samme Sikkerhed som for denne Arts Vedkommende. Vi har ikke som hos denne en skarpt markeret Seksualper., men hele Aaret igennem findes et ikke ubetydeligt Antal agbærende Hunner; Hannerne træffes hele Aaret, og Hunnerne berer Spermatoforer til alle Aarstider; Ynglen mangler aldrig ganske. De agbærende Hunner er dog hyppigst i Maj: samtidig optræder et stort Antal Hanner med mægtig omdannet højre Antenne, og af Yngel findes der paa dette Tidspunkt mindst; endvidere synes det, som om der i alle Søerne indtraffer en Seksualper. i Sep.-Okt., men endnu svagere markeret end Foraarets.

Ogsaa hos denne Art er Egantallet størst om Foraaret og tager derpaa javnt af indtil Efteraaret; det stiger da svagt og falder igen hen imod Vinteren.

- Som ovenfor nærnt er Agantallet meget større end hos D. graciloides, i April-Maj ofte 20-30, og gaar om Sommeren sjældent ned under 10, en Undtagelse danner dog D. gracilis i Furesøen; det stiger gerne til c. 12 om Efteraret og synker derpaa om Vinteren ned til c. 8 .

Skønt Undersøgelsen heller ikke for denne Arts Vedkommende er i Stand til sikkert at angive rel markerede Maks. og Min., synes det dog, som om der i alle vore Søer ligger et meget tydeligt Min. i Maanederne Dec.-Marts; Arten kan i dette Tidsrum (Skanderborgsø, Mossø, Julsø) kun paavises i rent forsvindende Individantal; et noget svagere Min. kan rimeligvis spores i Aug. Min. falder, hvad der ellers ikke plejer at vare Tilfaldet, sammen med en Seksualper.

Burck hardt (00 p. 153) har undersøgt D). gracilis' Forplantningsforhold i Vierwaldstädtersøen meget nøje; han kommer til det Resultat, at D. gracilis' Maks. ligger om Vinteren, hvorpaa følger et meget betydeligt Min., der efterfølges af et svagere Foraarsmaks. og af et Sommermin. Der er en tydelig Seksualper. med talrige Hanner i Begyndelsen af Jan.; Egproduktionen er stærk i Slutningen af samme Maaned, samtidig tager Hannerne af, hvorefter Artens Foraarsmin. indtræder; derpaa folger, hvis jeg har forstaael B. rigtigt, atter en Seksualper., men mindre udpræget end førstnærnte; Hannerne er alm. i Marts-Maj, og Egproduktionen begynder igen i April-Maj; derpaa standser Formeringen læenge; Hanner mangler næsten ganske fra Juli til Sep.; æghærende Hunner saa vel som Hunner med Spermatoforer er efter Juli meget sjaldne; Forholdene synes at være uforandret de samme nasten lige til Jan. det følgende Aar.

Burckhardt forklarer disse Forhold helst saaledes, at der i Aarets Løb opstaar to Generationer; den første Generation fødes i April-Juni og dør ud i Jan.-Feb.; den bruger c. 8 Maaneder til sin Udvikling 


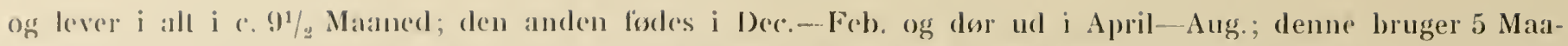

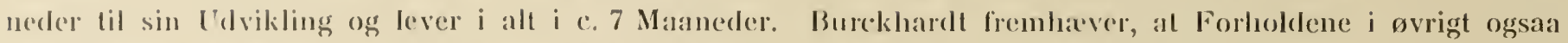
kan lorstalas sataledes, at Individernes Alder noget overstiger et Aar. I saa Fald má man formode, at der i Soen lindes to Fannilier, Woraf den ene fodes i Jan., den anden i Maj; Jan.-Panilien bliver konsmoden i Dece-Peds, Maj-Fanilien forst i det folgende Aars Forarar.

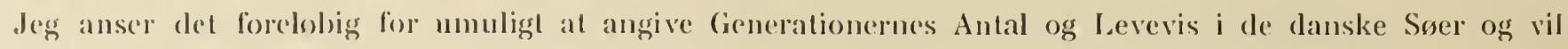
ikke for skarpt fremhave Forskellighederne mellem Burckhardts og mine egne lagttagelser, da jeg ikke ganslie tor stole paa disse sidste. Dog maa jeg anse det for givet, at I). gracilis Hovedmin. hos os ligger i Dec. - Marls, dens Hoverl-Scksualper. i April-Maj, og at Ynglen nasten er forstunden fra Dec. til Maj.

Ogsa Steuer finder (01 p. 37) i allen Donaus Min. om Vinteren, men i Modsæetning lil baade Burckhardl og mine egne lagltagelser har han fundet Hovedmaks. i Aug.-Sep.

\section{ALMINIDELIGE BEMERKNINGER.}

Plankton=Eucopepodernes Forekomst i de undersøgte Søer. ${ }^{1}$ )

lnder Stregen er tillige medlaget de $\mathrm{i}$ detle Kapitel omlalle avrige Plankton-Arthropoder.

\begin{tabular}{|c|c|c|c|c|c|c|c|c|c|}
\hline & Fureso & Esroms & Sorosø & $\begin{array}{c}\text { Tjustrup- } \\
\text { so }\end{array}$ & Viborgso & Haldso & $\begin{array}{c}\text { Skander- } \\
\text { borgss }\end{array}$ & Moss $\theta$ & Julsø \\
\hline 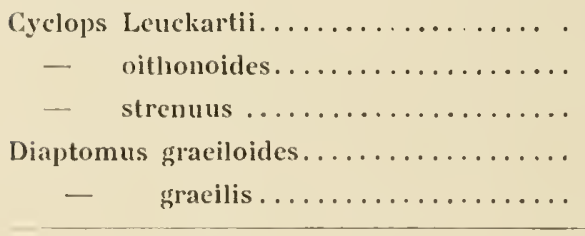 & $\begin{array}{l}(+) \\
+ \\
(+) \\
(+) \\
\pm \\
\end{array}$ & $\begin{array}{l}(+) \\
+ \\
\pm \\
\pm\end{array}$ & $\begin{array}{l}(+) \\
+ \\
+ \\
\pm\end{array}$ & $\begin{array}{l}(+) \\
\pm \\
\pm \\
\pm \\
(+)\end{array}$ & $\begin{array}{l}(+) \\
+ \\
\pm \\
\pm\end{array}$ & $\begin{array}{c}(+) \\
+ \\
(+) \\
\pm\end{array}$ & $\begin{array}{l}(+) \\
\pm \\
(+) \\
+\end{array}$ & $\begin{array}{l}(+) \\
+ \\
(+) \\
+ \\
+\end{array}$ & $\begin{array}{l}(+) \\
\pm \\
+ \\
\pm\end{array}$ \\
\hline 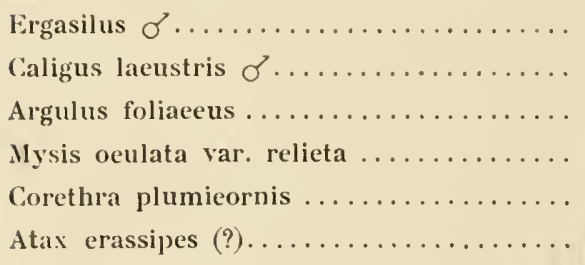 & $\begin{array}{l}(+) \\
(+) \\
(+) \\
+ \\
(+) \\
(+)\end{array}$ & $\begin{array}{c}+ \\
(+)\end{array}$ & $\begin{array}{l}(+) \\
(+)\end{array}$ & $\begin{array}{l}(+) \\
(+) \\
(+)\end{array}$ & $(+)$ & $\begin{array}{l}(+) \\
(+)\end{array}$ & $\begin{array}{l}(+) \\
(+)\end{array}$ & $\begin{array}{l}(+) \\
(+) \\
(+) \\
(+)\end{array}$ & $\begin{array}{c}(+) \\
(+)\end{array}$ \\
\hline
\end{tabular}

Man vil af vellagte Schema se, at det kun er et ringe Antal Copepoder, der optræeder i vore større Søers pelagiske Region. Bortset fra Heterocope-Arterne, som jeg stadig formoder maa kunne findes her i Landet, er dog alle de Arter paaviste, som vi efter Sammenligning med andre Landes Fauna kunde vente at finde her; de i Sverrig og Norge talrige Diaptomus-Arter er arktisk-alpine Former, som næppe forekommer her i Landet, og som ogsaa mangler i det mellemeuropæiske Slettelands Søer.

Mærkeligt er det, at Eurytemora ikke er hyppigere i danske Indsøer, da den er paavist paa talrige Lokaliteter i nordtyske Søer; ligeledes turde man ved Sammenligning med disse Søers Plankton have ventet, at navnlig C. Leuckartii havde spillet en mere fremtrædende Rolle hos os, men at ogsaa C. streuuus og oithonoides var forekonme i større Mængde; jeg formoder, at jeg noget har undervurderet Mrengden af C. oithonoides og C. Leuckartii.

De to Diaptonus-Arter danner en meget væsentlig Del af vore Søers Plankton; de udgør deres fornemste dyriske Planktonorganismer og optræder næslen altid i betydelig Mængde, til Tider endog i kolossale Masser. I de to Diaptomus-Arter er rimeligvis den største Del af de lavere Planktonorganismers Næringsværdier opmagasinerede; de spiller i den Anledning den største Rolle for vore Søers Fiskebestand.

1) Om Tegnenes Betydning se p. 56. 


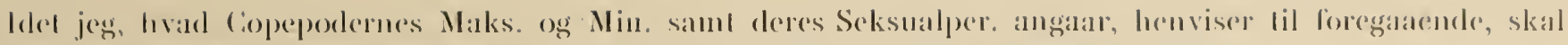

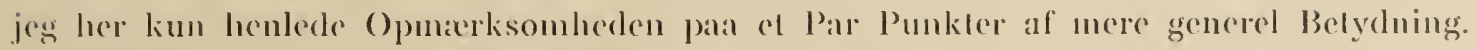

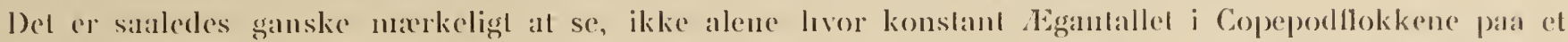

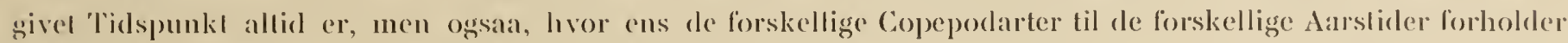

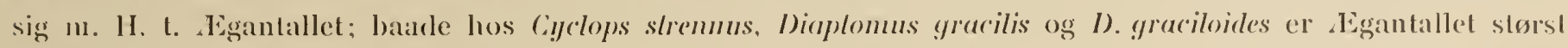
henholdsvis c. $40-50,25-30$ og $14-16-$ om Foriarel, mindst om Sommeren - 20-30, 10-12, 2-1 og derpata aller stigende len para Efteranet.

Men hval der er cnchn markeligere er, at selve Egsgenes Størrelse hos alle lre Arter ubetingel er mindsl om Foraarel, natr Arterne barer de talrige $A \mathrm{~g}$, og storst om Sommeren, naar Antallet er ringe.

Aggets Diameter hos D. graciloides er om Foraret c. 120 $\mu$, om Sommeren dlerimod c. 160-200. Jeg indskrienker mig her til at konstatere Faktum og skal kun bemierke, at da det formodes, at det UdviklingsIrin, hrorpaa Ungen ved Klickningen befinder sig, afhrenger af Størrelsen af den Blommemasse, der er merlgivet Eggel, havke jeg tankt mig, at de Unger, der fremkom al Sommeræggene, i hvert Fald maatte vare storre end de, der udgik af Foraarsaggene, og at der muligris hos de om Sommeren følte Unger vilde kunne paavises et begyndende Svind i Metamorfosen, saaledes at Ungerne ikke kom frem paa et Nauplie-, men paa et Metanampliestadium.

Undersøgelserne herover er dog kun i deres Vorden; Copepodernes udpragede Kannibalisme lagger her store Hindringer i Vejen, idet Moderdyret nasten ojeblikkelig aeder sin egen Ýngel; at dissekere Eggeškkene al og oplevare dem for sigs er ikke heldigt, da bundfældede Eggesæklie altid synes at overtrakkes med Phycomyceter.

Jeg har her kun villet henlede Opmarksomheden paa et Punkt, der i høj Grad tranger til nøjere Undersogelse.

Ved regelmassigt hver Maaned at undersøge vore Søers pelagiske Copepoder vil man ikke kunne undgaa at lagge Marke til, at i alt Fald flere af disse i Aarets Løb skifter Farve. Medens Copepoderne on Sommeren enten er farveløse eller udstyrede med smukke, metalblaa Farver, gives der Arter, der regelmassigt hver Vinter antager en karmoisinrol Farve; dette gæelder for vore Soers Vedkommende navnlig I). graciloides, I). gracilis og C. strenums; i de 4 Søer: Furesø, Esromsø, Tjustrupsø og Sorøsø, hror jeg selv har fisket Plankton og altsaa undersogt dette i levende Tilstand, har jeg hvert Aar i Nov.-Dec. set den røde Farve blive fremherskende, holde sig hele Vinteren og derpaa forsvinde i April-Maj. For D. graciloides Vedkommende maa det formodes, at det er den om Foraaret fodte Generation, der i Nov. skifter Farve og holder sig røl indtil sin Død; Nauplierne, der kommer frem i Forsommeren, er, saa vidt vides, altid røle; naar Dyrene bliver eeldre, svinder den rode Farve og viser sig forst igen i Nov. For Cyjclops strenums'og I). gracilis' Vedkommende, hos hvilke Former det er tilladt at antage to Generationer, ser det ud, som om den røde Farve saerlig er knyttet til den Generation, hvis Seksualper. falder om Vinteren.

Den svagere eller strerkere Farve er direkte afhrengig af Copepodernes Rigdom paa Olje; Oljen lejrer sig i Form af store Draaber vaesentlig langs Rygsiden af Dyrene. Hos D. graciloides i Esromsø fandtes konstant i Forkroppen lidt bagved Øjet en stor forlil ofte trelappet Oljedraabe og i nogen Afstand fra denne et storre eller mindre Antal Oljedraaber grupperende sig omkring og noget bagved Munden; delte Parti var verl Rakker af Draaber forbunclet med et Iredie Parti liggende i den bageste Del af Forkroppen. Den forreste Oljedraabe er konslant hele Aaret, men Oljerigdommen i de to clerpaa folgencle Partier er skiftende til de forskellige Aarstider, log altid betydeligst ved lave Temperalurer; den største Oljerigdom og den derfra hidrørende røde Farve indtraf noget efter de store Diatomeemaks.; ved Sammenligning af den Olje, der fandtes i Melosir $\alpha$-Cellerne, med Oljedraaberne hos Copepoderne, kunde jeg ikke varge mig mod den Tanke, at det var Diatomeeoljen, der genfandtes i Copepoderne; hror vidt disse direkte fortarer Diatomeerne eller lever af Dyr, hvis Hovedføde er Diatomeer, ved jeg ikke, men formoder, at der er et Af hangighedsforlıold 
mellem Diatomeroljen Copepodoljen og Copeporlemes rode Farve, der fremkommer sammen med en stigende Allejring al ()lje i clisses lacenemer (cfr. Chuns Paavisning af, at den i Stomfuglenes Mave opsamlerle Olje stammer fra de rode () ljedraialser i Euphausidernes Legeme, (0) p. 22:3).

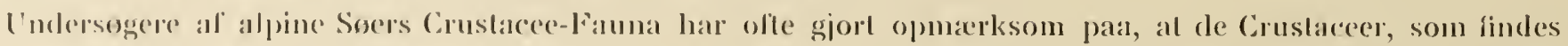
sali vel i alpine Soer som i slettedandssøer, ofte cr rode i de kolde alpine Soer, men farvelose i de dybere liggende og varmere Soer: lagtlagelseme er serlig anstillede paa I). Laciniahus og Bosmina bohemica og skyldes \%schokke (00 p. 170 o. a.), (i. O. Sars (01 p. 92), men dog sarlig Brehm (02 p. 37), der tillige angiver cu Del samstemmente lagtlagelser hos andre forf. (Zacharias, Richard, libic og Vára). I de alpine Soer er Dyrene liele Aarel rode af Farve.

I den senere Tid har of betydeligl Antal Planklonundersggere kumnel paavise, at adskillige af Slettelandssoremes Cirustaceer om Vinteren antog robl larve, og at de mistede denne om Sommeren. Saaledes meddeler Amberg, al Copeporleme i Kalyensee om Vinteren har rol olje, om Sommeren derimod gullig (00 p. 5(i). burckhardl angiver (00) p. 27T), at Vierwaldstädersøens Copepoder overvejende er røde om Vinteren, men farvelose eller hata om Sommeren; hvad angatr Copepoderne i Achensce er Brehm (02 p. 38) kommen til ganske samme Resultat.

Da det allsaa al samstemmende Undersogelser synes al fremgaa, al Crustaceerne og sarlig visse CopepodArter i hojlliggende alpine Soer er rodfarvede hele Aaret, i Slettelandssøerne derimod kun om Vinteren, synes del, som om de role farvestoffer, i Alm. betegnet som Carolin, sierlig optræder ved lavere Temperaturer og muligvis spiller en Rolle for Organismen, saa lienge disse Tp. hersker. Brehm formoder, al disse Farvestoffer har Betydning ved at omsatle Lys til Varme, og sløtler sin Formodning dels til Zschokkes og Blanchards lagllagelser af (se Brehm 02 p. 39), at I). bacillifer og D. denlicornis i høj (rad er positivt heliotropiske Dyr, der i alpine Soer i Solskin trekker i Sverme langs Bredderne og her paa de staerkest belyste Steder fremtreder som rode Pletter synlige selv i større Afstand, dels lil den Kendsgerning, at overvintrende Sporer af talrige ellers gronne Alger (Eudorina, Pandorina, Splucroplea o. a.) her er rode; jeg kan ganske slutte mig til Brehms Antagelse, men tilføjer kun, al der efter min Formodning er en genetisk Forbindelse mellem (len rode Farve og de rigelige Oljemasser, samt at disse atter rimeligvis er identiske med Diatomeeoljer.

\section{Eucopepoda siphonostomata.}

De snyltende Copeporler spiller her i Landet som overalt kun en meget underordnet Rolle som Planktonorganismer; del maa vel formodes, al alle Ferskvandsformerne som Nauplier findes i den pelagiske Region af de Soer, paa hvis Fisk de paa aldre Stadier snylter; ligeledes maa man sammesteds vente at kunne finde Hannerne af de Slægter, hos hvilke alene Hunnerne efter Kønsmodenheden er stationere Parasitter, medens Hannerne er fritsrommende Organismer.

Hrad Nauplier af siphonostome Copepoder angaar, har jeg intet set til disse; formentlig lader de sig ogsaa kun med Yanskelighed skelne fra andre Nauplier; derimod huser vore Søers pelagiske Region Hannerne af to siphonostome Copepoder: Eryasilus og Caligus.

\section{Ergasilus.}

Ergasilns-Hanner er paaviste i Planktonprøver fra Fureso, Esromsø, Tjustrupsø, Haldsø, Skanderborosø og Mosso: Tidspunktet for deres Forekomst er omkring 15. Maj-15. Juli; udenfor denne Tid har jeg aldrig set dem; de horer vel til Planktonels sjaldne Former, men har dog i Horisontalprover fra Tjustrupsø kumnet indsamles $\mathrm{i}$ et Antal af (c. 50. De kendes ved første Øjekast og selv med blotle Øjue paa deres dybe, ultramarinblaa Farve. 


\section{Caligus.}

Caligus lacustcis Stp. \& I,lk.

Hannerne al deme naterkelige Form er ingenlunde sjectlne i Furesøens Plankton; de lorekommer ligeledes kun i Somnertiden; C. I. cr. saa vidt vides, kun kendt fra Fureseen; jeg henviser i ovrigl lil W.-L. (022 p. 277).

\section{Copepoda Branchiura.}

Argulus.

Argulus foliaceus L.

A. Foliacrus nevnes markelig nok aldrig blandt Planktonorganismerne; den er ligesom M!jsis, Cáligus og Coreflur undgatel Planktonundersøgernes Opmarksomhed, fordi de overvejende har arbejlet med Verlikalprover og kun med fintmaskede Net.

Argulus er en konstant Beboer af vore støre Søers pelagiske Region; den synes sarlig at vace et Dybrandsdỵr og forekommer ofte i Horisontalprøver tagne med vidmaskede Net i et Antal af $10-12$ Eks. Jeg har fundet Eks. i alle de undersøgte Søer, dog hidtil kun i Sommerhalvaaret. Et al de markeligste Trak i Arlens Biologi er, at den ikke bærer sine $\mathrm{Eg}$, men afsatter dem paa Blade, Sten, Prele etc.; de findes hele Forsommeren og Sommeren overordentlig hyppigt navulig paa Flydebladenes Underside.

Man har hidtil, men sikkert med Urette, forestillet sig Argulus som en ret stationær Parasit, der vel har Svommeevne, men som dog største Delen af sit Liv sidder fasthæftet til Værten; i hele Sommerhalvaaret regnet fra April til Nov. indeholdt Prøverne meget ofte Hanner, Hunner eller Yngel. Dyret kan efter min Opfattelse nærmest betragtes som en delvis fritlevende Blodsuger, der slaar sig ned paa Fiskene for at suge deres Blod, men som, naar Sulten er stillet, atter forlader disse.

M. H. t. dette Dyrs Biologi er vi meget ufuldstrendigt og til Dels vistnok fejl underrettede.

\section{ARANEA.}

\section{Hydrachnidæ.}

I større Søers pelagiske Region er hidtil kun paavist to Hydrachnider: Atax ctassipes O. F. Mlog Curvipes rotundus Kramer; førstnavnte blev i Følge Piersig (97-00 p. 56) første Gang af Asper paavist som Planktonorganisme i Schweizersøerne og af Pavesi i norditalienske Søer; senere er den af Zacharias (93 p. 32) og af Apstein (96 p. 182) funden i holstenske Søer.

Culvipes rolundus omtales, saa vidt vides, som Planktonorganisme kun af Zacharias.

Her i Landet findes Alax crassipes O.F. M. som konstant Beboer saa vel af vore Smaasøers centrale Partier som endog ude i vore største Søers pelagiske Region. Den viser sig i April, synes at have sit Maks. i Juni-Juli og forsvinder igen i Okt.; Middelarven, som muligvis tør henføres til denne Art, har jeg ligeledes taget hele Sommeren; medens Larverne er Overfladedyr, tages de voksne Dyr nasten udelukkende paa 20-30 M. Horisontalprøver herfra indeholder ofte c. 25 Eks.; Arten er i størst Mrangde funden i Furesø og Esromsø.

Jeg bestemte i sin Tid Arten som Atax crassipes; efter senere at have lart Piersigs Monografi at kende og set hans Afbildning al Alax /iguralis C. L. Koch (Tab. IV) er jeg begyndt at nære Tvivl om, hvor vidt en Del af mine Eks. ikke snarere har hørt til denne Art.

Apstein angiver for Plönersøernes Vedkommende samme Periodicitet som jeg, men formoder (p. 182), at Eggene synker til Bunds og overvintrer der.

Som bekendt aflegger Alax-Arterne deres Eg i Muslingernes Kappehule; for A. crassipes' Vedkommende er Piersig af den Mening, at Eglægningen ikke foregaar i Muslinger, men derimod paa Spongiller. 


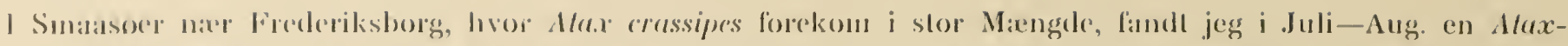

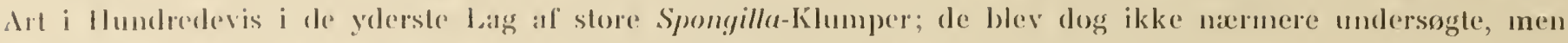

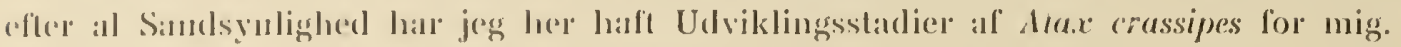

degg lilfojer, al en narmere Undersugelse af vore Swers pelagiske Region utvivlsomt vil bringe adskilligl Here Hydraclener for Dagen end de her nevnte. Jeg har med det groveste Planktonnet paa dybt Vand $i$ de lleste al vore Soer paraist adskillige Iydraclunider, som paa Grund af mil ringe Kendskab til Gruppen ikke blev narmere bestemle. Liggeleles findes i Smasøernes rentrale Partier, som kun kan undersøges fra Band, en halvexlagisk Ilydrachnidefauma, som sikkert fortjener en nermere Undersøgelse. 


\section{KAP. X. M O L L U S C A.}

ER kan i Søernes pelagiske Region kun være Tale om at paavise Larvestadier af tre Mollusker, nemlig Dreyssena, Anodonta og Unio.

Markelig nok synes Dreyssena at mangle i alle vore større Søer; den er, saa vidt vides, kun funden i St. Jørgenssø og de tilgræensende Søer ved København. Selvfølgelig har nærværende Planktonundersøgelse ikke kunnet paavise Larvestadiet. Dette spiller en ikke ringe Rolle i holstenske og nordtyske Søers pelagiske Region (A.pstein 96 p. 182, og Zacharias).

Apstein, hos hvem de fuldstændigste Oplysninger findes, angiver, at Larven viser sig i April-Maj og forsvinder af Planktonet i Okt.; Maks. falder i Aug.-Sep.; Eglægningen finder Sted ved Tp. 5, ${ }^{\circ}$ C., men dog særlig ved højere Tp. i Juni; Eggene aflægges i Hobe. Efter Svømmetiden findes Larverne hæftede til faste Genstande, Undersiden af Aakandeblade etc. (cfr. ogsaa Meisenheimer 99 p. 25 og den der citerede Littr.).

Hrad Glochidium-Larverne angaar, har jeg ofte fundet Skallerne i Planktonet; disse forekommer ogsaa hyppigt i Gytjerne; levende Larver har jeg derimod aldrig taget pelagisk. 


\section{LITTERATURFORTEGNELSE.}

$\mathrm{I}$ mTikaturontegnelsen er fort op til Udgangen af 1903. Ved Udarbejdelsen al Mnskpt. er der kun taget Hensyn til Littr. indtil Febr. 02. En Del senere udkomne Publikationer er log kort omtalte i Anm. u. T. For ikke al gore Listen for stor er saalanne Arbejder, der nermest maa betragtes som Forarbejder til større, i Alm. ikke medtagne; af den ikke europaiske Litteratur er der vasentlig kun taget Hensyn til E. A. Birge's, S. A. Forles', C. Kol'oid's, H. B. Ward's og G. C. Whipple's Arbejder. Litlr., som jeg ikle har kunnet skalfe mig, er market med *; Arbejder, der er citerede efter Sxertryk, med (Sep). Det fede Tal betegner Bindangivelse.

1899. Antbonx (F.), Ucber die Wasserblüthe Byssus flos aqua und ihr Verhalten gegen Druck. Verhandl. d. naturw. Ver. Hamburg, dritte Folge. ๖). 25 .

1855. Aldusix (G. J.), Observations on Aphanizomenon flos aque, Quart. Journ. micr. sci. ;) p. 21.

1900. Ambisc; (O.), Beiträge zur Biologie des Katzensees. I)issert. Zürich. (Sep.).

1903 a. - Biologische Notitz über den Lago di Muzzano. Forschungsber. Plön. 10 p. 7 4. (Sep.).

1903 b. - Untersuchung einiger Planktonproben aus demselben rom Sommer 02. ibid. p. 86. (Sep.).

1896. Ixnerssox (G.), Svenska växtvärldens historia. Stockholm.

1898. - Studier öfver Finlands Torfmossar och fossila Kivartärflora. Bull. de la Commis. géologique de Finlande. Helsingfors. Nr. 8.

1896. Apsteix (C.), l)as Süsswasserplankton. Methode und Resultate der quantitativen Cntersuchung. Kiel u. Leipzig.

1902. - Das Plankton der Osisee. Abhandl. d. Deutschen Seefischerei-Vereins. 7 p. 103. (Sep.).

1883. Arthlr (J. C.), A supposed poissonous seaweed in the lakes of Minnesota. Proc. Amer. Assos. Adr. Science. :32 p. 305 .

1881. Asplen (G.), Wenig bekannte Gesellschaften kleiner Tiere unsrer Schweizerseen. Neujahrsblatt der naturf. Gesell. \%ürich. S:3. (Sep.).
1886. AsPER (G.), Note sur les organismes microscopiques des eaux douces. Arch. des sci. phys. et natur. Génève. III ser. 16 .

1885-87. Asper (G.) \& Heuscher (J.), \%ur Naturgeschichte der Alpenseen I. Ber. der St. Gallischen naturf. Gesellsch.

1886. - Eine neue \%usammensetzung der "pelagischen " Organismenwelt. Zool. Anz. 9 p. 448.

1889. Zur Naturgeschichte der Alpenseen II. Ber. der St. Gallischen naturf. Gesellsch. p. 246 .

1896. Acrivillil's (C.), Das Plankton des baltischen Meeres. Bih. t. Kongl. Svenska Vetensk.-Akad. Handl. 21. Afd. 4. Nr. 8 p. 1. (Sep.).

1898. - Vergleichende thiergeographische Untersuchungen über die Planktonfauna des Skagerracks in (len Jahren 1893-97. Kongl. Svenska Vetensk.Akad. Handl. 30 Nr. 3 p. 1. (Sep.).

1900. Bachmax (H.), Die Planktonfänge mittelst der Pumpe. Biolog. Centralbl. 20 p. 386. (Sep.).

1901. - Beitrag zur Kenntniss der Schwebeflora der Schweizersecn. ibid. உ1 p. 193. (Sep.).

1903. - Botanische Untersuchungen des Vierwaldstädtersees I. Cyclotella bodanica und ihre Auxosporenbildung. Jahrb. f. wiss. Botan. Leipzig. 39 p. 106. (Sep.).

1857. Bannv (W.), Notes on the food of some Freshwater lishes more particularly the vendace (Co- 
regouus albula) and strout (Trulla fario). The Edhoburgh new Philosophical dourmal. (i p. 17.

1892. Bragendal, (D).), Beiträge zur Rotalorienfauna Grönlands. Lunds Universilets darsskrift. 2S p. 1. (Sep.).

1893 a. - Gastroschiza liacanthu. Bih. t. Kongl. Svenska Vetensk. Akat. Handh. IS. Nr. 4 p. 1. (Sep.).

1893 b. - Einige Bencelinggen über die Rotiferengaltungen Gastroschiza di Autpus. Offr. Kongl. Svenska Yelensk. Akad. Föhiandl. Nr. 9 p. 589. (Sep.).

1882. Brkgir (R.S.), I) Or Oranismus del Cilioflagellaten. Morphol. Jalub). Leipzig. 7 p. 177. (Sep.).

1887. - Ueber den Theilungsvorgang bei den Dinoflagellaten. Zoolog. Jahrb. ? p. 76.

1892. Bhlangler (L.), Fin Beitrag zur Rotatorienfauna Württembergs. Jalhresb. des Vereins f. vaterl. Naturk. Württembergs. 49 p. 107. (Sep.).

1894. - Zur Rotatorienfauna Württembergs. ibid. 50 p. 35. (Sep.).

1895. Brike (E. A.), Planktonstudies on lake Mendota I. Transact. of the IVisconsin. Acarl of science, arts and letters. 10 p. 421. (Sep.).

1897. - Planktonstudies on lake Mendota II. ibid. 11 p. 274. (Sep.).

1884. Blanc (H.), Note sur le Ceratium hirundinella. Bull. Soc. Vaud. des sci. nat. Lausanne. 20 p. 1. (Sep.).

1898. - Le plankton nocturne du lac Léman. ibid. it p. 225. (Sep.).

1890. BLANCHARD (R.), Sur une carotine d'origine animale constituant le pigment rouge des Diaplomus. Mém. soc. zool. France. Paris. :3 p. 113.

1895. Blochmax (F.), Die mikroskopische Thierwelt des Süsswassers. Abth. I. Protozoa. Hamburg.

1901. Bohlin (K.), Ulkast til de gröna algernas och arkegoniaternas fylogeni. Dissert. Upsala (Sep.).

1897. Bokoriy (Тн.), Ueber die organische Ernährung grüner Pflanzen und ihre Bedeutung in der Natur. Biolog. Centralbl. 17 p. 1 og 33.

1899. Borge (O.), Süsswasseralgen von Franz JosephLand, gesammelt von der Jackson-Harmsworth'schen Ekspedition. Öfv. Kongl. Svenska Vetensk. Akad. Förhandl. 7 p. 751 . (Sep.).

1900. - Schwedisches Süsswasserplankton. Botaniska Notiser p. 1. (Sep.).

1886-88. Bornet (E.) \& Flahaut (C.), Revision des Nostocacées hétérocystées. Annales des Sciences nat. Botan. ser. VII. :3 p. 178, 7 p. 323.

1896. Brazu (F.), Die geschlechtliche Entwicklung von Paludicella Eltrenbergii. Zool. Anz. 19 p. 54.

1901. BuAND (F.), Benerkungen über Grenzzellen und über spontan rothe Inhaltskörper der Cyanophyceen. Ber. d. Deut. Botan. Gesell. 19 p.152. (Sep.).

1903 a. - C̈ber das osmotische Verhalten der Cyanophyceenzelle. ibid. 21 p. 302. (Sep.).
190:3 b. Brano (F.), Morphologisch-physiologische lielachlutugen über Cyanophyceen. Beih. \%u11 Bolan. Centrallol. I) p. 31 (Sep.).

1899. Braxnt (K.), Ueber den Stoffwerhsel im Meere. Kiel. (Sep.).

1901. - Nordisches l'lankton. Kiel.

1885. Braveis (A.), Bursaria lruncatella unler Bertucksichtigung anderer lleterotrichen und der Vorticellen. Dissert. Boun. (Sep.).

1855. Braux (A), Algarum unicellularum genera nova et minus cognita. Leipzig.

1902. Вивни (V.), Zusammenselzung, Verteilung unct Periodicität des Zooplankton in Achensee. Zcit. d. Ferdinandeums III F. Insbruck. $4(j$ p. 1. (Sep.).

1902. Brenm (V.) und Zenerbater (E.), Untersuchungen über das Plankton des Erlaufsees. Verh. d. Kais. Königg. zool.-bot. Gesell. Wien. 52 p. 388. (Sc).).

1884. BRúx(J.), Végétations pélagíques et microscopiques du lac de Génève au printemps de 1884. Bull. des trav. de la Soc. botan. de Génève. :3 p. 17

1894. - Zwei neue Diatomeen von Plön. Forschungsber. PIön. "2 p. 52.

1900 a. Brunnthaler (J.), Plankton-Studien. Verh. d. Kais. König. zool.-bot. Gesell. Wien. 50 p. 382. (Sep.)

1900 b. - Das Phytoplankton des Donaustromes bei Wien. ibid. 50 p. 308. (Sep.).

1901 a. Brensthaler (J.), Prowazek (S.) und v. WettSTEı, Vorläufige Mittlıeilung über das Plankton des Attersees in Oberösterreich. Oester. botan. Zeit. 引)] p. 1. (Sep.).

1901 b. Bnuswthu, (J.), Die coloniebildenden Dinobryon-Arten. Verh. I. Kais. Königl. zool.-bot. Gesell. Wien. 5) p. 293. (Sep).

1900 a. Bruysat (C.), Sur les variations du plankton au lac Chauvet. Compt. Rend. Acad. Scien. 130 p. 45. (Sep.).

$1900 \mathrm{~b}$. - Prémières recherches sur le plankton des lacs d'Auvergne. Travaux de la Station limnologique de Besse. Revue d'Auvergne. 17 p. 339. (Sep.).

1897. Buyce (D.), Contributions to the Non-Marine Fauna of Spitzbergen. Part II. Report on the Rotifera. Proceed. zool. Soc. of London. p. 793. (Sep.).

1899. Burcknante (G.), Faunistische und systematische Studien über das Zooplankton. Revue suisse de Zool. Génève. 7 p. 353. (Sep.).

1900. - Quantitative Studien über das \%ooplankton des Vierwaldstïdtersees. Mitth. d. Naturf. Gesell. Luzern. :3 p. 1. (Sep.).

1880. Bütschli (O.), Protozoen in Bronns Klassen und Ordnungen des Thierreichs $1880-89$.

1901. Borcilsex (F.), Freshwater Algae of the Faröes. Botany of Færöes. København. 1 p. 198. (Sep.).

1902. Borgesen (F.) \& Ostenfeld) (C. H.), Phytoplankton of lakes in the Faröes. ibid. 2 p. 613. (Sep.). 


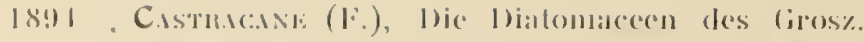

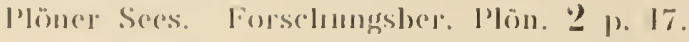

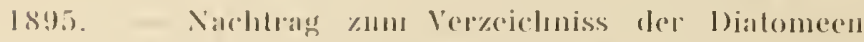
des Ciros\%. l'löner Soes. ibid. :; 1. 71.

Is!s. Las spores des diatomees. Annales de Mi(romraphir. p. :30.

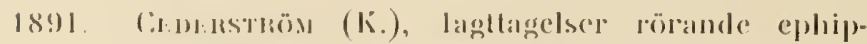
pierna eller vinteräggskapslarne los smäkrält-

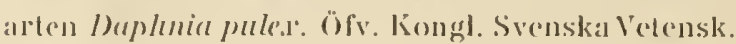

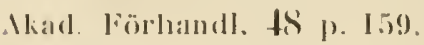

1876. Cists (c.), \%ur kenntuiss der Organisation und des feineren balues der l)aphniden und ver-

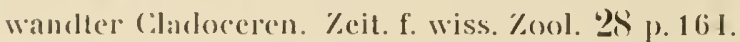

I877. \%nr lienntniss des Batues und der Organisaltion der lolyphemiden. Jenksclı. Kais. Könnign. Akild. d. Wissensch. Wien. :37 p. 137.

1895. - - lienerkungen über Pedelion nirum. Arl). aus (1. zool. Inst. Wien. 11 p. 13.

1896. Ca.tivi: (1.), Recent Freshwater Diatons from Lule Lappmark. Bih. Kongl. Svenska Vetensk. Miadl. llandl. ¿21. Afd. 111. Nr: 2 p. 1. (Sep.).

1899. Notes on the plankton of somc lakes in Lule Lappluarli Sweden. Öf a af Kongl. Svenska Vetensk. Aläl. Förland. Nr. 8 p. 825. (Sep.).

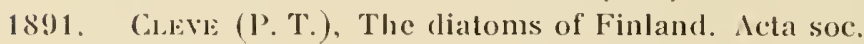
p. fauna et tlora Fennica. Helsingfors. $8 \mathrm{Nr}, 2$ p. 1. (Sep.).

1901. - The seasonal distribution of atlantic planktonorganismes. (iōtebor's. (Sep.).

1896. Chond (R.). Sur la structure et la biologie de deux algues pélagiques. Journ. de Botanique. Paris. 11) p. 333 og p. 405.

1897 a. - Etudes de biologie lacustre. Bull. de l'Herb. Boissier. Gúncive. 5) p. 289.

1897 b. - Mgues pelagiques nouvelles. ibid. 5) p. 119.

1898. - Etudes de biologie lacustre. ibid. (j p. 49 , p. 155, p. 431 .

1900. - Sur trois genres noureaux de Protococcoidées et sur la llorale planktonique d'un étang du Danemark. llém. de I'Herb. Boissier. Génève. p. 1.

1902. - Algues vertes de la Suisse. PleurococcoidesChroolćpoïdes. Berne. (Sep.).

1900. Curv (C.), Aus den Tiefen des Weltmeeres. Jena.

1903. ConN (L.), Untersuchungen über das Plankton des Löwentin und einiger anderer Seen Mlasurens. Zeitschr. f. Fischerei und deren Hilfswissenschatten. Berlin. 10 p. 201.

1878. Conn (F.), Zwei interessante Fïlle von sogenannte Wasserblüthe. Jahrg. d. schlesisch. Gesell. f. vaterl. Cultur. Breslau. 55 p. 144.

1878. - Rivularia fluitans. Hedwigia. Dresden. p. 1.

1901. Combiz: (J.), La llorule des Conjuguées des environs de Toulouse. Compt. rend. du Congrès des Soc. savantes en 1900. Paris. p. 1. (Sep.).

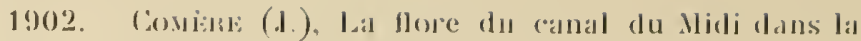
regrion Toulonsaine. ibicl. 01. p. 1. (Sep.)

1903. Je latetion des eanx salces sur la végétation de quelques algries d'anll douree. Nonova Notarisia. l'adoval. 14 p, 18 . (Sep).

1881 - 82. Cookt: (M. C.), Broaking of the meres. Grevillea. london. 11) p. 111.

1882 81. British Freshwaler Algax. London.

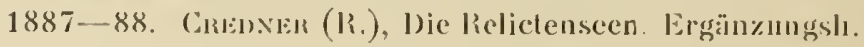
Nr. 86 zu l'etermanns Millheilungen.

1891 a. D.m.1 (İ. v.), Revision der Asplandua-drten und die ungarländischen Reprisentanten Mathem. und Naturw. Ber. aus Ungarn. Budlapest. ! p. (f). (Sep).

$1891 \mathrm{~b}$. - l)ie geographische Verbreitung der im Mecre lebenden liotatorien. ihid. 9 p. 5.). (Sep.).

1892. - Die mikroskopische Thierwelt del Mc\%ösíger Teiche. Termés\%etrajøi linzetek. Budapest. Ij 1). $166 .($ Sep) .

1897 a. - liotatorien in Resultate der wiss. Erforschung des Balatonsees. Budapest. '2 'Th. 1 p. 121 . (Sep.).

1897 b. - Crustaceen. ibicl. ¿2 Th. 1 p. 163 . (Sep.).

1892. DiN(iE.tR) (P.), La nutrition animale des Péridiniens. Le Botaniste. Paris. 3 Ser. Fasc. 1. 1. $7-25$.

1899. - Mémoire sur les Chlamydomonadinćes ou l'Histoire d'une cellule. ibid. 6 Sér. Fasc, 2-6. p. 65. (Sep.).

1826. DE Canboule (A.), Sur la matière qui a coloré en rouge le lar de Morat. Mém. de la Soc. de Phys. et d'hist. nat. Génève. :; p. 29.

1896. DE GEER (G.), Om Skandinaviens geograliska utreckling efter isticlen. Stockholm.

1896. Delage (Y.) \& Hérocano (E.), Traité de \%oologie concrète. 1. La cellule et les Protozoaires. Paris.

1900. DE Tonı (G.) \& For't (A.), Contributo alla conoscenza del Plancton del lago Vetter. Atti del Reale 1stituto Veneto di scienze lettere et arti. 5) p. 537. (Sep.).

1903. Dixon-Nuttall (F. R.) and Freladix (R.), The Rotatorian Genus Diaschiza. A Monographic Study with Description of a New Species. Journ. Roy. Micr. Soc. p. 1. (Sep.).

1884. Eckstein (K.), Die Rotatorien der Umgegend von Giessen. Zeit. f. wiss. Zool. 39 p. 343. (Sej.).

1838. Ehrexis: (C.F.), Die Infusionsthierchen als volliommene Organismen. Leipzig.

1897. Erlanger (R.v.) \& Lautizaris (R.), Ueber die ersten Entwichlungsrorgänge im parthenogenetischen nnd befruchteten Räderthierei. Zool. Anz. 20 p. 452. (Sep.).

1886. Enstev (E.), Jylland. Studier og Skildringer til 1)anmarks Geograli. Kobenhavn.

? Eusibio (A.), Recherches sur la faune des eaux du plateau central. La faune pélagìue des lacs d'Auvergne. (Sep.). 


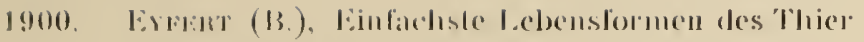

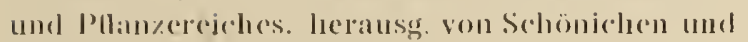
liallserlall. Brunschwrigs.

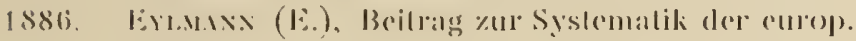
1)aphniden. Boricht. d. naturt: (iesell. Freiburg. 2 j. 1.

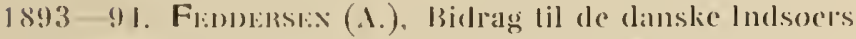
(irograli. Geogralisk Tidsskrilt. I2 p. 79.

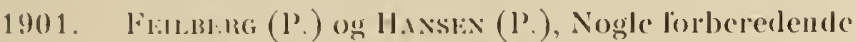
Undersogelser vedrorende Sankningen al Arresocus Vandspejl. (Sep.). Kobenhavn.

1899. Fotcistar (V.), Beiträge \%ur licnutniss der Entwicklungsgeschichte einiger Süszwasser Pcridlnecer. ()ester. bolan. Zeil. Wien. 4!) p. 81.

1893. lonzes (S. A.), A preliminary licport on the acpuntic invertebrale lauma of the vellowstone park. Bull. of the U. S. Fish Commission for 1891. Washington. p. 207. (Sep.).

1885. Foris (F. A.), la Faune profonde des laces Suisses. Mćm. de la soc. Helvetique des scien. nat. ํ!) p. 1.

1892-95-02. - Le Léman. Monographie limnologiçue. 1. 1892 . ․ 1895 . औ. 1902 . I alusanne.

1901. - Handbuch der Secnkunde. Mlgemeine Limnologie. Ratzel: Geograph. Handb. Stuttgard.

1900. Font1 (A.), se De ToNi \& Forti.

1902. - l'rimi appunti per uno studio sul phytoplancton del lago di Scutari d'Albania. Atti del Reale Istituto Veneto. (i1 p. 703. (Sep.).

1894. Frincé (R.), \%ur Biologie des Planktons. Biolog. Centralbl. 14 p. 33. (Sep.)

1897. - Protozoen in Resultate der wissensch. Erforschung des Balatonsees. Wien. ㄹ. Th. 1 p. 1.

? Frexzel (J.), Die Diatomeen und ihr Schicksal. Naturw. Wochenschrift Nr. 14.

1897. Frić (A.) \& VÁvra (V.), Untersuchung zweier Böhmerwaldseen, des schwar\%en und des Teufelsees. Untersuchungen über die Fauna der Gewässer Böhmens. Prag. III. Archiv der naturw. Landesdurchforschung von Böhmen. 10. Nr. 3 p. 1. (Sep.).

1894. - do. IV. Die Thierwelt des Unterpocernitzer und Gatterschlager Teiches. ibid. 9. Nr. 2 p. 1. (Sep.).

1901. - Untersuchungen des Elbeflusses und seiner Altwässer. ibid. 11. Nr. 3 p. 1. (Sep.).

1902. Fritsch (F. E.), Preliminary report on the Phytoplanktou of the Thames. Ann. of Botany. Oxford. 16 p. 1. (Sep.).

1903. - Remarks on the periodical development of the algre in the artificial waters at Kew. ibid. 17 p. 274. (Sep.).

1897. Funrians (O.), Recherches sur la faune des lacs alpins du Tessin. Rev. suisse de Zool. Génève. 4 p. 489 . (Sep.).

De clanske Sners Plankton.

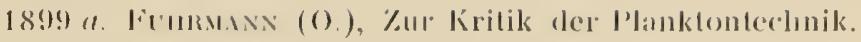
Biol. (Centrallst. 1! p. 581. (Seps.)

18996 b. - l'ropositions lechnipues pour l'clude du Planklon de's lares suisses. Arell. des sci. phy's. el natur. Gencye. ser. IV. S p. 1. (Sep).

1900. - Beilrag \%ur liologic des Neuenburger Ses.

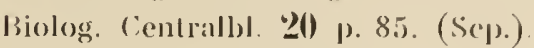

189.). G.anini (A.), Faumal liunetica a profonda del Benaco. Boletlino dei Musei di \%oblogia ed Analomia coupalata. Torino. 10 p. 1. (Sep.).

1898 \%. - Un pugillo di plancton del lago di (Conos. Atti Iel lieale Istituto Veneto. Sel. VII. !) p. 668. (Sep.).

18986 . - Due nuovi Rhizopodi limnetici. \%ool. An\%. 21 p. 667 . (Sep.).

1899. - Alghe neritiche del lago di Garda. Nuoval Notarisia. Padova. Sor. X p. 1. (Sep.).

1878. (iom (C.), Ueber eine die Erscheinung der Wasserblüthe im Meereswasser hervorrufende Rivularia. Hedwigia. 1)resclen. 17 p. 33 og p. 19.

1892. (iomont (M.), Monographie cles Oscillarićes. Anu. des Scien. natur. VII ser. Bot. 15) p. 263 og 16 p. 91.

1886. Gosse: (P. H.), se Hudoson \& Gosse:

1882. (irdF (L. v.), Monographie der Turbellarien. Leipzig.

1902. Grixw (H. H.), Das Plankton des Norwegischen Nordmeeres. lieport on Norwegian Fishery and marine-investigations. Christiania. 2 Nr. 5 p. 1. (Sep.).

1902. (iRINT\%esco (J.), Recherches expérimentales sur la morphologie et la physiologie de Scenedesmus acutus Meyen. Bull. de l'Herb. Boissier. Ser. II. 2. Génève. p. 217. (Sep.).

1889. DE Guerne (J.) \& Ricimizo (J.), Sur la faune des caux douces du Groenland. Compt. Rend. $10 \mathrm{~S}$ p. 630 .

1901. HalbFass (W.), Beiträge zur Kenntniss der Pommerschen Seen. Petermanns Mitteilungen. Ergänzungsheft. Nr. 136. Gotha. (Sep.).

1886-92. Hansging (A.), Prodromus der Algenllora von Böhmen. I-lI. Archiv der naturw. Landesdurchforschung von Böhmen. Prag. Ђ) Nr. 6, (j) Nr. 5 og 8 Nr. 4. Botan. Abth.

1895. Hantwig (W.), Die Krebsthiele der Prowinz Brandenburg. Naturw. Wochenschrift Nr. 43-45. (Sep.).

1897. - Zu1 Verbreitung der niederen Crustaceen in der Provin\% Brandenburg. Forschungsber. Plöen. 5 p. 115.

1898. - do. Zweiter Beiträge. ibid. ( ${ }_{\text {II }}$ p. 140. (Sep.).

1899. - Die niedereu Crustaceen des Müggelsees und des Saaler Boddens während des Sommer's 1897. ibid. 7 p. 29. (Sep.).

1901. - Die freilebenden Copepoden der Provinz Brandenburg. ibid. 8 p. 53. (Sep.). 


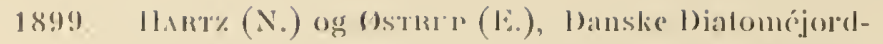
Allejringer. Dammarks gcologislie Undersogelser. I1. H. ). ( $(\mathrm{sep})$

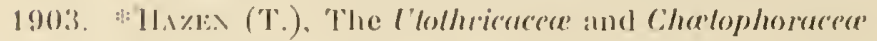
ol the Lnited stales. Men. ol the 'Torrey botan. (ilub. Now-York. Vol. 11. Nr. 2.

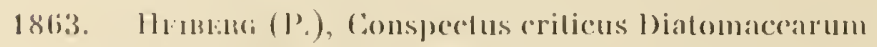
1)anicartum. Kubenharn.

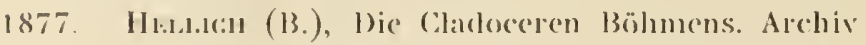
der naturw. Landesclurehlorschung von Böhmen. I’ag. :). AJlh. 1. H, 2. (Sep.).

1887. Hlissi: (Y.), I'cher die Bestimmung des lankIon. V. Ber. Jer lommission \%ur wiss. Lnters. der beutschen Ileeren. licel. p. 1.

$1888 . \quad$ - Das l'kankton der östlichen Nordsee. ibid. Y'l. Ber. 1) 119

1890. - Dic Expedition der Sektion für Küsten- und IIochscelischerei in der östlichen Ostsec. ibicl. v'l. Ber. p. 99.

1885. v. Hiubck (11.), Synopsis des Diatomćes de Belgicpue. Anvers.

1889. \#luscur:k (J.), \%ur Naturgeschichte der Мpenseen. Jahresber, der st, gallischen naturwissensch. Gesellsch.

1890. - Ilydrobiologische Untersuchungen im Kianton St. Gallen. ibid.

1900. H.ın' (J.), Report on Norwegian lishery- and marine investigations, ediled by J. Hjort. Christiania.

1899. Hown (B.), Die Verbreitung der Tierwelt im Bodensee. Schriften des Vereins für Gesehiehte des Bodensees und seiner Umgebung. Lindau. 10. H. 28 p. 1. (Sep.).

1900. Howmbol: (J.), Undersogelser over norske Ferskvandshiatomeer. Archiv for Nathematik og Naturvidlenskab. Christiania. 21. Nr. 8 p. 1. (Sep.).

1903. - Planterester i norske torvmyrer. Videnskabsselskabets Skrifter. Christiania. 1. Math. naturv. Klasse. Nr. 2 p. 1. (Sep.).

1902. Holmsex (A.), Isforholkene ved de norske Indsoer. Videnskabsselskabets Skrifter. Christiania. I. Mathem. naturv. Klasse 1901. Nr. 4. p. 1. (Sep.).

1895. Hoon (J.), On the Rotifera of the County Mayo. Proe. Royal Irish Acad. Dublin. Ser. III. :) p. 664. (Sep.).

1886. Hunson (C. T.) \& Gusse (I. II.), The Rotifera or Wheel-animaleules. London 1886--89.

1898. Hutfeld-Ka.1s (H.), Plankton in now wischen Binnenseen. Biolog. Centralbl. 18 p. 625. (Sep.).

1900. - Die limnetisehen Peridineen in norwegisehen Binnenseen. Videnskabsselskabets Skrifter. Christiania. Mathem. naturv. Klasse. p. 1. (Sep.).

1894. Jexings (H.S.), A list of the Rotatoria of the great lakes. Bull. of the Michigan Fish Commission. Wrashington. Nr. 3. p. 1. (Sep.).
1896 a. .toxwangs (It. S.), Report on the Rolaloria. ibid (i) 1. 1. (Sep.).

1896 b. - 'The early' development of Asplandhnu IIerrickii. Bull. ol the Museum of comparat. \%oology Harward College : 30 p. 1. (Sep.)

1900. Rotatoria of the l'nited States. Bull. ol the U. S. Commiss. of fish and fisheries for 1899 . Washington. p. 67. (Sep.).

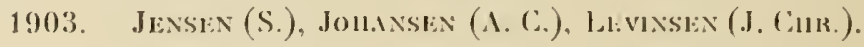
Plitiasi: ( C. G. Jon1.), de danslie liarandes Plankton i Aarene 1898-1901. Kgl. lanske Vidensk. Selsk. Skrifter. Kobenhavo. (i R. nat. math. Afol. 12) p. 223. (Sej).).

1883. Imıro: (O.). Studien \%ur Kenntniss der pelagischen Fama der Schweizerseen, \%ool. An\% (j p. 466. (Sep.).

1884. - Resultate meiner Studien über die pelagische Fauna kleineler und grös\%erer Süs\%asserbechen Schwei\% \%eit. f. wiss. \%ool. 40 j. 154. (Sep.).

1885. - Die Rotatorien als Mitglieder der pelagisehen und Tiefseefauna der Süszwasserbechen. \%ool. An\%. S p. 322. (Sep.).

1886-87. - Studien über die Fauna hochalpiner Seen. Jahresber, d. Naturf. Gesell. Graubünten. Vereinsjahr $1885-86$. 30) p. 45. (Sep.).

1890. - Das Flagellatengenus Dinobryon. \%ool. An\%. 13 p. 483 . (Sep.).

1892. - Die Zusammenset\%ung der pelagischen Fauna ler Süs\%wasserbecken. Biolog; Centralbl. 12 p. 171. (Sep.).

1900-01. Isssi, (R.), Saggio sulla fauna termale Italiana. Atti della R. Accarlemia delle Scien\%e di Torino. :30 p. 1. (Sep.).

1898. Istríxil (J.), Die Kryptogamenflora des Balatonsces. Resultate der wissensch. Erforsehung des Balatonsees. Wien. ¿2. Th. 2 p. 1.

1900. Iwaxorf (L.), Beitrag zur Kenntniss der Morphologie und Systematik aler Chrysomonaden. Bull. de l'Acad. Impér. des Sc. de St. Pétersbourg. V Ser. 11 p. 247. (Sep.).

1894. JïknskiöLd (I. A.), Ueber awei baltische Varictäten der Gattung Anuræa. Zool. An\% 17 p. 17. (Sep.).

$1899 \alpha$. Jougissix (E.), Protophyten und Protozoen im Plankton aus der norwegischen Westküste. Bergens Iluseums Aarbog. Nr. 6 p. 1. (Sep.).

$1899 \mathrm{~b}$. - Ueber die Tintinnoiden der norwegischen Westküiste. ibirl. Nr. 2 p. 1. (Sep.).

1900. - Protistenplankton aus dem Nordmeere in den Jahren 1897-1900. ibid. Nr. 6 p. 1. (Sep.).

1892. Karka (J.), Die Fauna der Böhnischen Teiche Untersuchungen über die Fauna der (iewässer Böhmens. II. Arehiv der naturw. Lamblesdurehforschung ron Böhmen. Prag. S Nr. 2. (Sepr). 
1!100. Ki:Istan (C. v.), Das Planklon des untoren Lumer Sees in Niederösterrech. Verh. d. Kals. Könnigl. zool.-Hot. Ciescll. W'ient. in p. jil1. (Sep.).

1901. \%ur lienuluiss des l'lanklons des Atlersees in

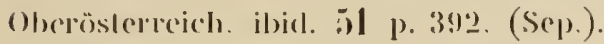

1902 a. \%ur lienntniss des l'lankton des Mlt-Ausscer Sces in Steiormark. ibid. 50 p. 706. (Sep.).

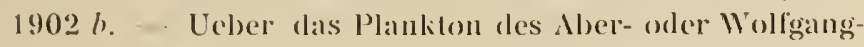

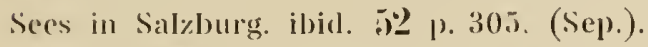

1902 c. - Kiur\%e Viltheilungen übel (las P'hytoplankton des Nussonsces bei Ischl in ()ber-Oesterreich. Oester. Jotan. \%eit. Wien. Jahro. 1902. Nr. 1 1. 1.

1903. - Ucher das I'lankton des Halstäter Sees in Ober-Oesterreich. ibiı. Verh. I. Kais. Königl. zool. bot. Gesell. Wien. 5̈) p. 338 . (Sep.).

1900. Lincusıı (O.), Die Schizophyceen in Englel unal Prantl.: l)ie natürl. Pflanzenfam. Leipzig. I Theil. 1 Ibth. $a$.

$1896-1902$ - - se Śc1Röten \& Kincuxlis.

1895. Klomamx (H.), Gasvaeuolen, ein Bostandtheil, der Zellen der wasserblüthebildende Algen. Flora. Marburg. S() p. 241.

1896. - Ueber wasserblüthebilılende Algen. Forsehungsloer. Plön. \& p. 189.

1897. - Berieht über einige Versuche betreflend dic Gasvacuolen bei Gloiotrichia echinulata. ibid. 引) p. 166.

1895. Klebin (H.) \& Llimmelisin (E.), Vorarbeiten zu einer Flora des Plönersecngebietes. ibid. "3 p. 1.

1883. Kuziss (G.), Ueber die Organisation einiger Flagellaten-Gruppen und ihre Beziehungen zu Algen und Infusorien. Tübinger Ĺntersuchungen. I. p. 233. (Sep.).

1892. - Flagellatenstudien. Zeit. f. wiss. Zool. 50) p. 26.5.

1889 a. KLElN (L.), Mlorphologisehe und biologische Studien über die Gattung Volvox. Pringsheims Jahrb. fül wiss. Botan. ?0 p. 133. (Sep.).

$1889 \mathrm{~b}$. - Neue Beiträge zur Kenntniss der Gattung Volvox. Ber. der Ieut. Botan. GeselI. 7 p. 42. (Sep.).

1890 c. - VergIeichende Untersuchungen über Morphologie und Biologie der Fortpllanzung bei der Gattung Volvox. Ber. d. naturf. GeselI. Freiburg. 5 p. 1. (Sep.).

1897. Kluxzinger (C. B.). Die Lehre von den Schwebewesen des süssen Wassers oder Untersuchungsweisen und Ergebnisse Iler Limnoplanktologie mit besondere liücksicht auf die Fiseherei. Challottenburg.

1901. - Ueber die physikal. chemisehen und biologisehen Lrsachen ler Farbe unserer Gewässer. lahresb. dles Vereins f. vaterI. Naturk, in Württenıberg. Jahrg. 1901.

1902. - Gesehiehte des grünen Feuersees in Stuttgard. ibid. Jahrg. 1902.

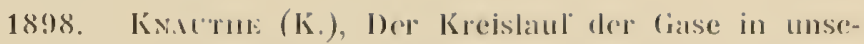
ren (iewässern. Biolog. Centrablol. Is p. 785.

1899. - Beobachtungen äber den (iasgelaalt der (irwässer im Winter, ibill. 1!) p. 783

1901. KNönucn (WV.), Studien über dic birnährungsbedingungen ciniger für dic lischproduction wichliger Mlkroorganismen des Süs\%wassers. fiorsehungsber. Plön. \& p. 1

1897 a. Kolom ( $\therefore$ A.), On some inportant sources of error in the Plankton method. Science. New York. N. S. 6 p. 82!) (Sep.).

$1897 \mathrm{~b}$. - l'lanktonstudies 1. Methods and apparatus in use in Plankton investigations at the biological expertmental station of the university of Illinois. Bull. of the lllinois state laboratory of Nat. hist. ¿) p. 1. (Sep.).

1898. - Planktonsludies II. On Pleodorina illinoisensis, a new species lrom the plankton of the Illinois river. ibirl. 5 p. 273 . (Sep.).

1899. - Planktonstudies III. On Platydorina a new genus of the family Volvocida, from the Plankton of the Illinois river. ibid 5) p. 419 . (Sep.).

1903. - The PIankton of the Illinois river 1894-99 with introduetory notes upon the Hydrography of the Illinois river and its Basin. Part 1. Quantitative investigations and general results. ibid. (6) p. $95-629$. (Sep.).

1902. KolkiviT\% (R.) und M.ılisson (MI.), Grundsät\%e für (lie biologische Beurtheilung des Wassers nach seiner FIoral und Fauna. Mittl. Kigl. Prüfungsanst. f. Wasserversorg. Berlin. H. I p. 33. (Sep.).

1901. KRogu (A.), Om hydrostatiske Forhold i Dyreriget. Kobenbavn. Biologisk Selskabs Forhandlinger. p. 14.

1882. L.ikiнiм (G.v.), Stockholmstraktens Pediastreer, Protococcaceer og Palmellaceer. Öfv. af Kongl. Svenska Vetensk. Akad. Förhandı. 13. 2. p. 47. 1883. - Birlrag til Sveriges Algeflora. ilsid. 14. 2. p. 37. 1900. - Beiträge zur FIora der Bäreninsel. Bilı. til Kongl. Svenska Veteusk. AkarI. Handl. 26. Afd. III. Nr. 11 p. 1. (Sep.).

1901. - Om Lämningal af Rhizopoder, lleliozoer och Tintinnider i Sveriges och Finlands lacustrina K vartäraflagringor. Geol. Fören. Förh. StockhoIm. ?3. 469. (Sep.).

1902. - Untersuchungen über fossile Algen. I-II. ibid. 24 p. 475 . (Sep.).

1899. L.дkоwтz (C.), Die niedersten Pflanzen- und Thierformen des KIostersees bei Karthaus. Sehriften d. Naturf. Gesell. in Danzig. N. F. 10. H. 1 p. 1. (Sep.).

1900. - Die winterliche Mikrofauna und Mikroflora des Ḱlostersees bei Karthaus. ibid. 10. H.2.p. 1 (Sep.).

1899. LANPERT (K.), l)as Leben der Binnengewaisser. Leipzig. 


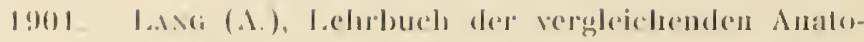
mic der wirbellosen 'Thiere. denas. 2. Aull Protozor.

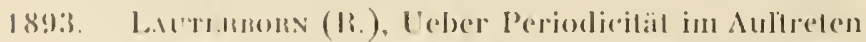

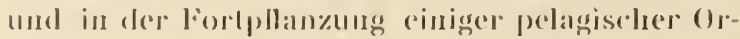
ganismen des lileins mal seiner Altwasser. Verlı. d. Naturh-Nodic. Vereins zu lleidelberg. N. F. 5) 1 man \%,it. l. Fischerei und aleren llillswissensidallen. Berlin. p. 1. (Sep.).

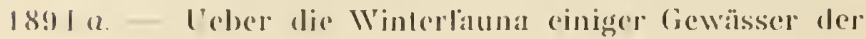

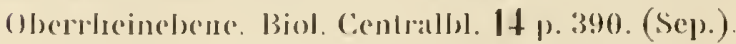

18 s.t b. - Roilräge \% Rolalorienfauna des liheins und seince Mllwasser. \%ool. Jahrl,. Abth. Syst. 7 p. 263.

$1894 \mathrm{c}$ - IIe peligischen J'potomen und Rotatorien Ilelgolands. Wissenscli. Meeresunters. Kiel. I. Biol. Anst. Helgoland. N. F. II. 1 p. 207. (Sep.).

1895 a. - Proto\%onstudien 1. Kern und \%elltheilung ron Ceratium himndinella. \%eil. l. wiss. \%onl. 5) p. 167 . (Sep).

1895 b. - Protozoenstudien J1. Paulinella chromatophora nov. gen. nov. sp. ibid. 59) p. 537. (Sep.).

1895 r. Protozoenstudien lII. Ueber cine Süsswasserart der Gatiung Multicilia. ibid. (b) p. 236. (Sep.).

1896. - Veloer das V'orkommen der Diatomeen-Gattungen Altheya und Rhizosolenia in den Altwassern des Oberrheins. Ber. (l. Deitt. Botan. Gesell. 14 p. 11. (Sep.).

1897. se ERLANGil og LAUTLRBORN.

1898. - Ueber die zyklische Fortplllanzung limnetischer Rotatorien. Biolog. Centralbl. IS p. 173. (Sep.).

1899. - Protozoenstudien IV. Flagellaten aus dem Gebiete des Oberrheins. Zeit. f. wiss. \%ool. (b̆ p. 369. (Sep.).

1900. - ber Formenkreis von Amura cochlearis. I. Verh. d. Naturh.-Medic. Vereins zu Heidelberg. N. F. (j p. 412. (Sep.).

1901. - Beitrāge zur Mikrofauna und -Floa der Mosel. \%eit. f. Fischerei und deren Hillswissenschaften. Berlin. ? p. 1. (Sep.).

1902. - Ein lür J)eutschland neuer Süsswasserschwamm. Biol. Centralbl. 22 p. 519. (Sep.).

1903. - Wer Formenkreis von Anurcea cochlearis. II. Verh. d. Naturh.-Medic. Vereins zu Heislelberg. N. F. 7 p. $529 .($ Sep.).

1879. LeiDJ (J.), Freshwater Rhizopods of North America. United States geolog. survey of the Territories. 10.

1869. Leitgeb (H.), Ceber Coelospharium Nägelianum. Mitth. des naturw. Vereins 1. Steiermark. 2 p. 72.

1895. Lemmermax (E.), Verzeichnis der in der Umgegend von Plön gesammelten Algen. Forschungsber. Plön. "; p. 18.

1896 a. - Rhizosolenin in den Alwassem des Oberrheins. Ber. 1. Deut. Botan. Ges. 14 1) 11.

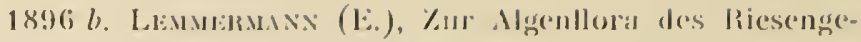
birges, forschumgsber. Plön. 4 p. 88.

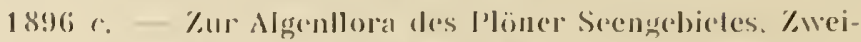
ler Beitrag. ilsil. 4 j). 131.

$1897 a,-$ liesultate eincr biologischen Untersuchung

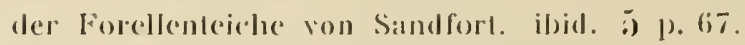

1897 b. - llie Jlanktonalgen des Müggelsees bei Berlin. \%eil. l. Jïscherei und deren llüllswissersehaften. Bcrlin. 1). 177.

18980 . Der grosse Waterneverslorler Binnensece liorsclungsber. Plön. (j p. 16 iti.

1898 b. - Beiträge zur kiennlniss der l'anktonalgen. 1. Hedwigia. 1)resten. "37 p. 303.

1898 c. - Beiträge zur Kenntniss der Planktonalgen. II. Botan. Centralbs. 76 p. 150.

1899. - Das Phytoplankton sächsischer Teiche. liorschungsber. Plön. 7 p. 9(5.

1900 a. - Mgenllora cines Moortünrels bei l’ön. iloil. 8 p. 54.

1900 b. - \%ur Kenntniss der Mgenthora des Saaler Borl(len. ibill. \& p. 74. (Sep.).

1900 c. - Beiträge жur Kenntniss der l'lanktonalgen. III. Neue Schwebalgen aus ler Umgegend ron Berlin. Ber. (l. l)eut. Botan. Gesell. IS p. 24. (Sep.).

1900 d. - B. z. K. A. "P. IV'. Die Coloniebildung von Richteriella botryoides. iljid. 18 p. 90. (Sep.).

1900 e. - B. \%. K. (I. P. V. Die Arten der Gattung Pleromonas. ilsill. 1S p. 92. (Sep.).

1900 f. - I3. z. K. I. Pl. VI. Das Plytoplankton brackischer Gewässer. ibid. 18 p. 94. (Sep.).

1900 g. - B. z. K. d. PI. VII. Das Phytoplankton des \%wischenahner Meeres. ilid. 18 p. 135. (Sep.).

1900 h. - B. z. K. l. PI. VIll. Peridiniales aqua dulcis et marina. Hedwigia. Dresden. 39) p. 115.

1900 j. - B. ะ. K. I. PI. IX. Lagerheimia Marssonii, Centratractus belonophora, Synedra limnetica, Marsoniella elegans. Ber. d. Deut. Botan. Gesell. IS p. 272. (Sep.).

1900 k. - B. z. K. (I. l'l. X. Diagnosen neuer S(-hwel)algen. ibid. 18 p. 306. (Sep.).

1900 I. - B. \%. K. \. PI. XI. Die Gattung Dinobryon. ibid. 18 p. 500. (Sep.)

1901 a. - B z. K. d. Pl. XIl. Notizen über einige Schwebalgen, og Xlll. l)as Phytoplankton des Ryck und des Greifswalder Boddens. ibid. 1!) p. 8.5 . (Sep).

1901 b. - B. z. K. A. PI. XIV. Neue Flagellaten aus Italien. ibid. 19 p. 340. (Šep.).

1902. - Das Phỹtoplankton des Meeres. Abhandl. d. Naturw. Vereins z Bremen. Beilrag I. 16 p. 356. Beilrag 11. 17 p. 341. (Sep.).

1903 a. - B. \%. K. I. I'I. XY. Das Plýloplankton einiger Plöner Seen. Forschungsber. Plön. 10 p. 116. (Sep.). 


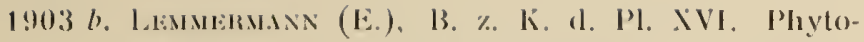
plankton von Simdhem. (Solnwerlen). Botaniska Notiser. Land. p. 65. (Sep.).

1903 c. Brandenburgische Agen. Iledwigia. I)resden. 4) p. 168 . (Scp.).

$1903 d$ - Brandenburgische Algen. \%eit. l. Fischerei und deren Hilswissenschaften. Berlin. ! p. 73. (Sep).).

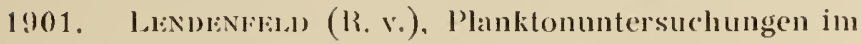
Grossteiche bei llorschberg (Böhmen). Vort. Mittl. Biolog. Centralbl. 21 1) 182. (Sep.).

1894 a. Lavannir (K. M.), Materialen zur Kenntniss der Wasserlauna in der Ungebung ron Helsingfors.

1. Protozod. Acta soc. p. fauna el flora Fennica. Helsingfors. 1'2 Nr. 2 p. 1. (Sep.).

1894 b. . do. Il. Rolaloria. ibid. 1'2 Nr. 3 p. 1. (Sep.). 1894 c. - Kleine Beiträge zur Kenntniss des Thierlebens unter dicher Eisdecke in einigen Gewäissern Finlands. ibid. Medklel. soc. p. fauna et llora Fennica. H. 20 p. 1. (Sep.).

1894 l. - Beiträge zur kenntniss der Pedalion-Arten. Arta soc. etc. 11 Nr. 1 p. 1. (Sep.).

1900 a. - Ueber das Herbst- und Winter-Plankton im finnischen Meerbusen und in der Ảands-See 1898. ibid. $18 \mathrm{Nr}$. 5 p. 1. (Sep.).

1900 b. - Zur Kenntniss der Fauna und Flora finnischer Binnenseen. ibid. 19 Nr. 2 p. 1. (Sep.).

1900 c. Z \% Kenntniss des Lebens in den stehenden kleingewässern auf den Skäreninseln. ibid. 18 Nr. 6 p. 1. (Sep.).

1901. - Zur Kenntniss des Planktons und der Bodenfauna einiger seichten Brackwasserbuchten. ibill. $20 \mathrm{Nr} .5$ p. 1. (Sep.).

1860. Leydici (Fr.), Naturgeschichte der l)aphniden (Cruslacéa, Cladocera). Tübingen.

1853. Lillaborg (W.), De crustaceis ex ordinibus tribus, Cladocera, Ostracoda et Copepoda in Scania occurrentibus. Lund.

1861. Beskrifning öfver tvenna märkliga Crustaceer af Ordn. Cladocera. Öfv. af Kongl. Svenska Vetensk. Akad. Förh. i Aar 1860. p. 265.

1861. - Leplodora hyalina, en märklig hittils obekant Crustacé af ordningen Cladocera. loörh. Skand. Naturf. 8 Mode. Kobenhavn 1860.

1888. Description de deux especes nouvelles de Diaptomus. Bull. soc. Zool. France. Paris. 13 p. 156.

1900. - Cladocera Suecia. Upsala.

1901. Bidrag til en Öfversigl af de inom Sverige iagttagna Arterna af Slägtet Cyclops. Kongl. Srenska Vetensk.-Akad. Handl. 20 J̆ Nr. 4 p. 1. (Sep.).

1901. Lohmanx (H.), Ueber das Fischen mit Netzen aus Müllergaze Nr. 20. Wissensch. Meeresunters. herausg. v. d. Kommission zur Untersuchung der deutschen Meere in Kiel. Abth. Kiel. N. F. j) p. 47. (Sep.).
1902. Lommand (H.), Die Cocoolihophoride, cine Monographic der cocoolithen bildenden Fiagellaten. Arch. f. l'rolistenkunde. Jenı. I. p. 8!). (Sep.).

1903. - Untersichungen über dic 'Tier- und Planzenwelt sowie ïber dic Bodensedimente des Nordatlantischen O\%ans \%wischen dem :38. und 50. (irade nordl. Breit. Sitzungsber. der liönigh Preus. Akademic der Wissensch. P'hys. math. Classe. 201; p. 560 . (Sep.).

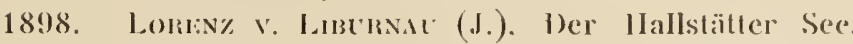
Eine limnologische Studie. Mitth. geogr. (ies. Wien. 4 p. 1. (Sep.).

1902. Lozison (H.), La Répartition verticale du Pancton dans le Lac de Zürich de décembre 1900 à décembre 1901. Dissert. Zürich. (Sep.).

1898. Luwwit (F.), Leuchten unsere Süszwasserper॰dincen? Botan. Centralbl. 76 p. 295.

1894. Lunnbiai (R.), On the postembryonal development of the daphnids. Bih. Kongl. Srenski Vetensk.-Akad. Handl. '2(). Afil. + Nr. 2 p. 1. (Sep.).

1899. I.tuEk (A.), Ueber Chlorosaccus, eine neue Gattung der Süszwasseralgen. Bih. Kongl. Svenska Vetensk.-Akall. Handl. 24. Af(l. 3 Nr. 13 p.1. (Sep.).

1878. LuT\% (A.), Untersuchungen über die Cladoceren der Ungebung von Bern. Mitth. d. naturf. Gesell. Bern. $1877-79$.

1819. I.yncibye: (H. Cirr.), Tentamen Hydrophytologize Danicæ. Hafniæ.

1903. Mansex (V.), Om den glaciale, isdammede So ved Stenstrup paa Fyen. Danmarks geolog. Undersogelse. II. Række Nr. 14.

1883. Magives (I'.), Das Auftreten von Aphanizomenon flos aqua im Eise von Berlin. Ber. d. Deut. Botan. Gesell. 1 p. 129.

1901. Maksson (M.), Zur Kenntniss der Planktonverhältnisse einiger Gewässer der Umgebung von Berlin. Forschungsber. Plön. 8 p. 86 . (Sep.).

1902. -- se liokwit\% und Mansson.

1891. Massle (G.), On the life history of a stipitate freshwater alga. Journ. of the Linn. soc. 27 p. 4.57.

1885. Maupas (E.), Sur Coleps hirlus. Arch. de zool. expér. et géner. Paris. II. ser. :; p. 337. (Sep.).

1890 a. - - Sur la multiplication et la fécondation de l'Hydatina sentu Ehr. Compt. rend. 111 p. 270. (Sep.).

1890 b. - Sur la fécondation de l'Iydatina senta Ehr. ibirl. 111 p. 310. (Sep.).

1891. - Sur le déterminisme de la sexualité chez l'Hydalina senta. ibid. $11: 3$ p. 388 . (Sep.).

1899. Meısenheimek (J.), Zur Eiablage der Dressensua polymorpha. Forschungsber. Plön. 7 p. 25.

18:6. Меуєн (A.), Die Plasmaverbindungen und die Membran von Volvox globalor, aureus und lerlius, mit Rücksicht auf die thicrischen Zellen. Botan. \%eit. Leipzig. H. 11-12 p. 187. 
1898. Ml\%(6.), Miliroskopische llassemalyse. Broslau. Mh:ul, (l'), Des spores des dintomers. le DiaIomiste. 2. Nr. 26.

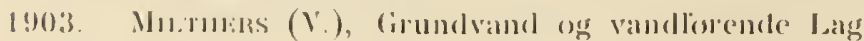

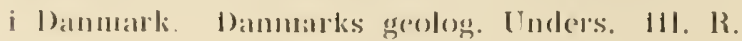
Nir. 1.

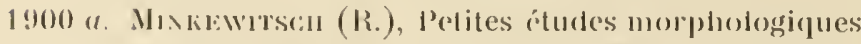
sur le limnoplancton. \%ol. An\%. 2:3 p. 618 . (Sep.).

1900 b. - Nole sur le saison-rlinordisme che\% le Ceralium furce de la mer Noire. ibid. 2); p. 55is. (Sep.).

1887. Molisu's (K.), Systematische barstelfung der Thicle des l'ankitons. l'. Bericht der lommis. \%ur wiss. l'nters. d. Jeutschen Meeren. Kiel. p. 113.

1903. Wo1.scin (11.), Die sogenannten Gasvacuolen und das Schwebon gewisser l'hycochromacen. Botan. \%eitung. I.eiprig. (il p. 17

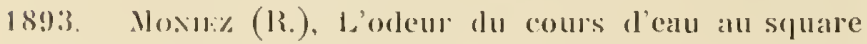
lauban a Lille. Rev. biol. du Norol de Ia france. lille. (i p. 55. (Sep.).

1844. Movraxi: (M. C.), Sur la rubéfaction des caux. Annales des Sciences nat. Botan. IIl. sér. ¿2 p. 332.

1903. Montromens ('Tu. 11.), On the Morphology of the Rolatorian Family liloscularidae. Proceed. of the Acad. of Nat. Science. Philadelphia. p. 363. (Sер.).

1838. Monmen (C.), Recherches physiologiques sur les hydrophytes de la Belgique. Mém. de I'arad. roy. des sciences de Bruxelles. 11 p. 11.

1900. Montexsex (T.), lingkobing Fjords nuvarende og tilligere Fauna. Rambusch: Sturlier over lingkobing Fjord. Koblenhavn. p. 49. (Sep.).

1895-97. Mlunsy (G.), On the reproduction of some marine diatoms. Proceed. Royal Soc. of Edinburgh. 21 p. 207.

1900. MÜlıı (J.), Die Seen am Reschen Scheideck. Penck: Geographische Abhandl. Wien. 7 H. 1 p. 1. (sep.).

18:5. Müılı (O.), Ueber Achsen, Orientierungs- und Symmetrie Ebenen bei den Bacillariaceen. Ber. d. Deut. Botan. Gesell. 13 p. 222.

1785. MC1LER (O.F.), Entomostraca seu insecta testacea. qua in arpuis Dania et Norvegia reperit. Kobenhavn.

1868 a. MÜLlen (P. E.), Dammarks Cladocera, Naturh. Tidsskr. Kobenhavn. 3. R. 5 p. 53. (Sep.).

1868 b. - Bidrag til Cladocerernes Forplantningshistorie. ibid. p. 295. (Sep.).

1870. - Note sur les Cladocères des grands lacs de la Suisse. Arch. des sci. phys. et natur. Génève 2. sér. :̈ p. 1. (Sep.).

1849. Nüriell (C.), Gattungen einzelliger Algen. Zürich. 1901. Necwenler (E.), Beiträge zur Kenntniss schweizerischer Torfmoore. Vierteljahrsschrift d. naturf. Gesell. Zürich. $\mathbf{4}$ p. 35. (Sep.).
1898. Hawton Combl: (a.), De la reproduction des diatomees. Ann. de Micrographie. p. 10.

189!9. The reproduclion of cliatoms. Journ. Roy. Mirer. Sos: p. 1.

1887. Nomugr'se (o.), Jic pelagische Tielsecfauna der grösseren fimnischen Seen. \%ool. An\%. (1) p. 33!). (Se]).).

1888 a. - Ucher Moima balluycola und die grössten Tiefen, in welchen cladoceren gefunden worden. ibid. 11 1. 261 . (Sep.).

$1888 \mathrm{~b}$. - Die Calaniden Finlands. Bidrag till kännedom af finlands natur och lolk. Ilelsingfors. 47 p. 1. (Sep.).

1890. Bidlag lill kännedomen on Bottniska vikens orh norra Ostersjöns evertebrat fauna. Acta soe. p. launa et flora Fennica. 1lelsingfors. 17 p. 83. (Sep.).

1897. Nissisay (M.), Die Entstehung des Geschlechts bei IIydaliua seula. Arch. it. mikrosk. Anat. und Entwicklungsges. I3onn. 49 p, 227. (Sep.).

1863. Nystuöu (C. L.), Iakttagelser rörancle faunan i Jemtlands Vattendrag. Dissert. Stockholm. (Sep.).

1895. Ostenfili) (C. H.), Planteorganismer i Ferskvandsplankton fra dylland. Vid. Medd, naturh. Foren. Kobenharn. p. 198. (Sep.).

1901. - Phytoplankton fra det kaspiske Hav. ibid p. 129. (Sep.).

1903. - Studies on Phytoplankton 1. Notes on Phytoplankton of two lakes in Eastern Norway. Botan. Tidsskr. Kobenhavn. 20̈ p. 235. (Sep.)

1902. Ostwal1) (W.), Zur Theorie des Planktons. Biolog. Centralbl. 22 p. 596. (Sep.).

1903 a. - Zur Theorie der Schwebevorgänge sowie der specifischen Gewichtsbestimmungen schwebender Organismen. Archiv f. die ges. Physiologie. Bonn. 94 p. 251. (Sep.).

1903 b. -- Zur Theorie der Richtungsbewegungen schwimmender niederer Organisınen. ibid. 95 p. 23. (Sep.).

1903 c. - Ueber eine neue theoretische Betrachtungsweise in der Planktologie. Forschungsber. Plön. 10 p. 1. (Sep.).

$1903 d$. - Theoretische Planktonstudien. Zool. Jahrl). Abth. Syst. 18 p. 1. (Sep.).

1889. Overtox (E.), Beitrag zur Kenntniss der Gattung Volvox. Dissert. Zürich. (Sep.).

1897. - Notizen über die Grünalgen des Ober Engadins. Ber. d. schwei\% botan. Gesellsch. Bern. 7 p. 1. (Sep.).

1888. Penard (E.), Recherches sur Ie Ceratium macroceros. Genève. (Sep.).

1890. - Ueber einige neue orler wenig bekannte Protozoen. Jahrb. ler Nassauischen Vereins f. Naturkunde. Wiesbaden. 43 p. 1. (Sep.).

1891 ॥. - Contributions à l'étude des Rhizopodes du Léman. Arch. cles sci. phys. et natur. Génève. உ6 p. 134. (Sep.). 


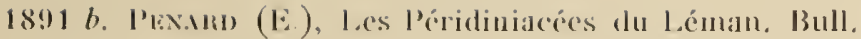
des trax de la Soce botan. de (ieneve lip. 1. (Sep.).

1899. - les lihizopodes de liana profoncle dans le lac Léman. liex suisse de \%ool. (iénève. 7 p. 1. (Sep.).

1900. - Essais de mérolomie sme (puelenes l)iflugies. ibid. S p. 177. (Sep).).

1901 a. - Pluptelios loricala, une Protococeacéce nouvelle. Bull. de l'llerb. Boissier. Génève. sér. 22. 1 p. $67 \%$. (Scp.)

$1901 \mathrm{~b}$. - Sur quelques Iféliozonires des environs de (icnève. lier. suisse de \%ool. (iénève. p). 279. (Sep.).

1901 c. - Notes complémentaires sm les linizopodes (lu Liman. ibid. ! p. 225. (Sep.).

1902. - Faune rhizopodicue du Bassin du léman. Genc̀ve.

1903 a. - Notice sur les khizopodes du Sipitzlorg. Arc. f. Protistenkunde. Jena. ¿2 p. 238 . (Sep.).

1903 b. - Sur quelques protistes roisins des Héliozoaires ou des Flagellates. ibid. ¿2 p. 283. (Sep.).

1903 c. - La Mullicilia lacustris et ses llagelles. Rer. suisse de Zool. Génève. 11 p. 123. (Sep.).

1880-81. Pullull's (W.), Breaking of the meres. Grevillea. London. ? p. 5.

1897-1900. Prissici (R.), Deutschlands Hydrachiniden. Leuckart \& (hun: Zoologica. Stuttgard.

1897 a. Pitari) (E.), Quelques notes sur la florule pélagique de divers laes des Alpes et du Jura. Bull. de l'Herbier Boissier. Génève. 5) p. 504.

1897 b. - A propos du Ceratium limundinella. Areh. des sci. phys. et natur. (iénève. :; p. 52.

1889. Plate (L.), Ueber die Rolatorienfauna des bottnischen Meeresbusens. Zeit. f. wiss. Zool. 4! p. 1. (Sер:).

1862. Post (H. v.), Studier öfer Nutidens koprogena Jordbildningar Gytja, Dy. Torf og Mylla. Kongl. Srenska Vetenskapsak. Handl. N. F. 4.

1899. Prowd\%k (S.), Das Potamoplankton der Moldau und Wotawa. Verh. I. Kais. Königl. zool. bot. Gesell. Wien. 4? p. 416. (Sep.).

1864-68. Rabenhorst (L.), Flora europaa algorum etc. Leiprig.

1850. Ralls (J.), On the Nostochinece. Ann. and Ilag. Nat. Hist. 1I. ser. 5 p. 321.

1896. Ravi Kolple (F.), Exkursionen til jydske Soer og Vandlob i Sommeren 1895. Botan. Tidsskr. Kobenharn. 20 p. 288. (Sep.).

1869. Ray Laxcasten (E.), A contribution to the knowIedge of the lower Annelids. Transact. Linnean Soc. $2 \mathbf{6}$ p. 631 .

1903. REDEke (H. C.), Plankton-onder\%oekingen in hel Zwanenwater bij Callantsoog. Haarlem. (Sep.).

1895-96. Rıcıımo (J.), Revision des Cladocères. Annales des Sciences nat. Zool. Vil. sér. 18 p. 279 og v'lli. sér. உِ 1). 187 .
1885. Ricutik (P.), Microcystis, ein cinzuzieliendes Algengenus. Ifedwigria. 24 p. 18.

1891. - Gloiolrichia éthinulala, eine Wasserblüllıe des gr. und kl. Plönersees. Forschumgsber. Plön. 2 1). 31.

1896. - Beilrägge zur l'hykologie. 1. Aplanizomenon Morren, Oscillatoria Agardlaii Comont, Plectonema Thuret. Hedwigia. 1) res(len. 3;) p. 263.

1892 a. Rolsslelet (C.), Noles on new rotifors. Tlar american month. micr. Iourn. 1:; p. 273. (Sep.).

1892 b. - On Conochilus unicornis. Jour. Quekett micr. (Club. London. ser. 11. 4 p. 367 . (Sep).

1893. - On Floscularia pelagica. Journ. Royal mic $\mathrm{r}$. Soc. p. 144. (Sep.).

1896. - Rallulus collaris and some other rotifers. Journ Quekett micr. Club. London. ser. II. (ip. 265. (Sep.).

1897. - On Brachionus Bakeri and its varieties. ibid 6 p. 328 . (Sep.).

1901 a. - On the specific characters of Asplanchna inlermedia. Hudson. ibid. 8 p. 7. (Sep.).

1901 b. - Triarthra brachiala, a new species of Rotifer. ibid. 8 p. 143. (Sep.)

1902. - The genus Synchata. Journ. lioyal micr. Soc. p. 269. (Sep.).

1903. - Liste der bis jetzt bekannt gewordenen männlichen Räderthiere. Forschungsber. PIön. I0 p). 172. (Sep.).

1892. Røøı.ıм (K.), Saltvandsalluviet i det nordostlige Sjælland. Dammarks geolog. Undersogelse. II. R. $\mathrm{Ni} .2$.

1893. - De geologiske Forhold i det nordostlige Sj:clland. Beskr. til Kortbladene Helsingor og Hillerød. 1. R. Nr. 6.

1899. - Beskivelse til geologisk Kort over Danmark. Kortbladene Kobenhavn og Roskilde. 1. R. Nr. 6.

1895. S.xuteı (M.), Die Veränderung der Form und Lage der Schale von Leplodora lıyalina Lilljb. während der Entwicklung. Zool. Anz. 1S p. 334. (Sep.).

1900. - Studien zur Entwickhungsgeschichte der Leplodora hyalina. Zeit. f. wiss. Zool. (68 p. 169 . (Sep.).

1899. Saxmmsx (J.), Nágra lagttagelser om Leplodorre hyalina i Finland. Acta soc. pro fauna et flor'a Fennica. Helsingfors. 15. Nr.6 p. 1. (Sep.).

1861. Sans (G, O.). On de i Omegnen af Christiania forekommende Cladocerer. Videnskabsselsk. Forhandl. Christiania. p. 144 og 250. (Sep.).

1865. - Norges Ferskvandskrebselyr. 1. Afsnit. Branchiopoda. I. Cladocera clenopoda. Christiania. (Sep.)

1873. - On en dimorf. Udvikling samt Generationsveksel hos Leptodora. Videnskabsselsk. Forhandl. p. 1. (Sep.).

1890. - Oversigt af Norges Crustaceer. Il. Branchiopoda, Ostracoda, Cirripedia. ibid. Nr. 1 p. 1. (Sep.).

1901. - Crustacea of Norway. Christiania. Vol. IV. 


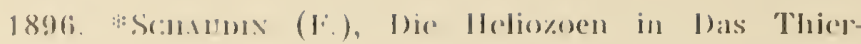
reicili.

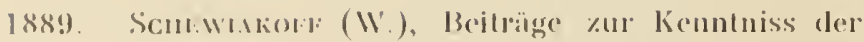

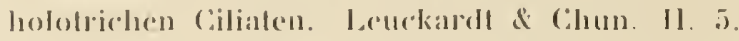
Bibliothereil \%oologic:is. Stullgard,

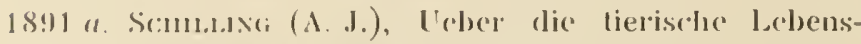
weise ciniger Peridineen. Ber. d. Deut. Botan. (iescll. ! p. 1!)!

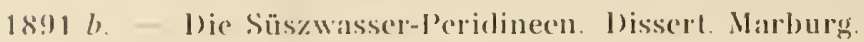
$\left(S c^{2} p\right)$

1892. Scamman. (1).), Deutschlands rieilebende Süszwassereopepolen. leuckardt \& (:hun: Bibliollecea \%oologicas. Stultgarel.

18!)3. Scmmmil: (WV.), Bcitrigge \%ur Algenllora des Silnwarawaldes und der Rheinelone. Bericht d Nalurl. Gesell. Freiburg. 7 p. 68.

18.98. - Die von 1)r. Volkens und D)r. Stuhlmann in Ost-Afrika gesammelten Desmidiaceen Englers Botan. Jahrb. ำ 6 p. 1.

1900. - Beiträge \%ur Kenntniss der Planktonalgen. Ber. d. Heut. Botan. (iesell. 18 p. 144.

1901. Ueber drei Algengenera. ibid. 19) p. 10

1903. - Bemerkungen zu einiggen Süszwasseralgen. ibid. 21 p. 316 . (Sep.).

1874-1903. Scmunt (A.), Allas der Diatomatcenkunde. Leiprig.

1899. Schmm' (.l.), Danmarks blangronne Alger. 1. Hormogoncer. Botan. Tidsskr. Kabenhavn. 202 p. 283. (Sep.).

1897. Scumula (S.), Ueber Wasserblüthen in Oberschlesien. Jahresber. d. Schles. Gesell. f. vaterl. Kiultur (1896). 74. Abth. 11 p. 34.

1898. - Ueber Coelosphorium dubium. Hedwigia. Dresden. $: 37$ p. 47

1900. Schorler (B.), l)as Plankton der Elbe bei Dresden. \%eitschr. f. Gewässerkunde. 3 p. 1.

1897 a. Schrodel (Brixo), Atheya, Rhizosolenia unal andere Planktonorganismen im Teiche des botan. (iartens zu Breslau. Ber. d. Deut. Botan. Gesell. 15 p. 367 . (Sep.).

$1897 b$. - Die Algen der Versuchsteiche des schlesischen Fischereivereins zu Trachenberg. Forschungsber. Plön. 5̄ p. 29.

$1898 a$. - Planktologische Mittheilungen. Biolog. Centralbl. 18 p. 525. (Sep.).

1898 b. - Neue Beiträge zur Kenntniss ler Algen des liiesengebirges. Forschungsber. Plön. (ip. 9. (Sep.).

1899 a. - Das pllanzliche Plankton der ()der. ibid. 7 p. 15. 1899 b. - Planktonpllanzen aus Westpreussen. Ber. d. 1)eut. Botan. Gesell. 17 p. 156.

1900. - se Seligo.

1901. - Untersuchungen über Gallertbildungen der Algen. Verh. d. Naturh.-Medic. Vereins zu Heidelberg. N. F. T. H. 2 p. 139 . (Sep.).
1897. Simoirak (C.), Die Sidnebellowa unserer Seen. Noujalursblatl der naturl' (iesell. Zürich aul das Jahr 1897. (Sep.).

1901. - - Vocit:k, Vartationsstalistische Untersuchung über Fragilaria crolonensis (lidw.). Kilton. in Plankton des \%ürichsees in den lahren $1896-$ 1901. Vierteljahrsschrilt der naturl. (iesell. in \%ürich. 4 (1) p. 185. (Scp.).

1896-1902. - \& Kunchnen (O.), J)ie Vegetation des Bodlensces. Sichrilten d. Vereins l: (ies. des Bodensees und seiner Umgeloung. Lindau. I. 1896 . 11. 1902. (Sep.).

1887. ScıÜTr (Fir.). Ueber die Sporenbillung mariner Peridineen. Ber. d. Deut. Botan. Gesell. ó) p. 364.

1893. - Pllanzenleben der llochsee. Ergelonisse der planktonexpedition. Kicl und Leipzig. I p. 243.

1892. - Analytische Planktonstudien. Kiel und leipzig.

1895. - Die Peridineen der Plankfonexpedition. Elgebnisse der Planktonexped. Ǩiel und Leipzig.

1900. - Bacillariales (Diatomea') Engler Prantl. Natürl. Pllanzenfam. Leipzig. 1. Th. 1. Abth. a p 31.

1843. Scuytti: (J. C.), Skanderborg Amts Beskrivelse. Kobenhavn.

1858. Scuöbler (J.), Die Branchioporlen der Umgegend von Berlin. 1ster Beitrag. Berlin.

1893. Scourfiel1) (D. J.), The Entomostraca ol Wanstead Park. Journ. Quekett Micr. Club. London. Ser. Il. Vol. 5 p. 161. (Sep.).

1896. - Entomostraca and the surface-film of water. Journ. Linnean Soc. Zool. 25 p. 1. (Sep.).

1897 a. - The logarithmic Plotting of certain biological Data. Journ. Quekett Micr. Club. London. Ser. Il. 6 p. 419. (Sep.).

1897 b. - Contributions to the Non-marine Fauna of Spitzbergen. Part 1. Proceed. Zoolog. Soc. of London. p. 784. (Sej.).

1899. - The Winter-Egg of a rare Water-flea (Leyaigia acanlhocercoides Fischer). Journ. Quekett Micr. Club. London. Ser. 11. 7 p. 171. (Sep.).

1900 a. - A hyaline Daphnia. Annual of Microscopy. London. p. 9. (Sep.).

$1900 \mathrm{~b}$. - Note on Scapholeberis mucronata and the surface-film of water. Journ. Quekett Micr. Clul. London. Ser. II. 7 p. 309. (Sep.).

1900 \%. - The swimming peculiarities of Daphnia and its allies, with an account of a new method of examining living Entomostraca and similar organisms. ilsid. p. 395. (Sep.).

1901 a. - The Ephippium of Bosmina. ibid. Ser. II. 8 p. 51. (Sep.).

1901 b. - Hydra and the surface-film of Vater. ilsid. p. 137. (Sep.).

1902. - The Ephippia of the lynceid Entomostraca. ibid. p. 217 . (Sep.). 
1903 a. Scot mitnin (1). I.), Synopsis ol the known Speries ol British Fresh-water Entomostraca. Pars I. Cala(locrril. ibid. p. 1331. (Sep.).

1903 b. - Synopsis ol the known Species of lBritisl) fresh-water Entomostraca. ibid. l’ars II. Copeporla. p. 581 . (Sep.).

1890. Si:laio (A.), Hydrobiologische L'ntersuchumgen. schrilten d. nalurf. (iesell. in l)anzig. N. F. 7. 11.3 p. 13.

1893. Ueber einige Flagellaten des Süszwassers. Dan\%ig.

1900. - Lntersuchungen in den Stuhmer Seen nebst einem Anhang: Das l'flanzenplankton preussischer Seen von Bruno Schroder. Herausgegeben von Westpreuss. Botan. Zoolog. Verein und vom Westpreuss. Fischerei-Verein. Danzig. (Sep.).

1899. Sixn (G.), Ueber einige coloniebilınde einzellige Algem. Botan. Zeil. 57 p. 39.

1900. - Die Flagellaten in Engler \& Prant.: Natürl. Pflanzenfam. Leipzig. 1. Th. 1. Abth. a. (Sep.).

1896. Skonkow (A. S.), liotateurs des environs de Kharkow. (liussisk). p. 1. (Sep.).

1902. - Die Erforschung des Potamoplanktons in Russland. Biol. Centralbl. 202 p. 552. (Sep.).

1893. Steck (Тн.), Beiträge zur Biologie des grossen Moosseedorfsee's. Mitth. d. naturf. Gesell. Bern. p. 1. (Sep.).

1841. Steknstrup (J.), Geognostisk-geologisk Undersøgelse af Skovmoserne Vidnesdam og Lillemose. Vidensk. Selsk. Naturv. Afh. Kobenhavn. 9. (Sep.).

1859-78. Sten (F.), Der Organismus der Infusionsthiere. Leipzig.

1897. Stexroos (K.), Zur Kenntniss der CrustaceenFauna von Russisch-Karelien. Acta soc. pro fauna et flora Fennica. Helsingfors. $15 \mathrm{Nr} .2$ p. 1. (Sep.).

1898. - Das Thierleben in Nurmijärwi-See. ibirl. 17. Nr. 1 p. 1. (Sep.).

1901. Sterer (A.), Die Entomomstrakenfauna der »alten Donau bei Wien. Zoolog, Jahrb. Jena. 15). H. 1 p. 1. (Sep.).

1895. Stix(iElix (Tir.), Die Cladoceren der Umgebung von Basel. Rev. suisse de \%ool. Génève. 3 p. 161. (Sep.).

1897. - Ueber jahreszeiliche, individuelle und lokale Variation bei Crustaceen, nebst einigen Bemerkungen über die Fortpflanzung bei Daphniden und l.ynceiden. Forschungsber. Plön. 5) p. 150.

1901. - Bemerkungen über die Fauna des Neuenburgersees. Rev. suisse de \%ool. Génève. 9 p. 315. (Sep.).

1895. Sthodtulan (S.), Bemerkungen übel die Lebensverhältnisse des Süszwasserplarktons. Forschungsber. Plön. :3 p. 145.

De danske Sners Plankton.
1896. STmomanx (S.), Planktonuntersuclungen in luolsleinischen und mecklenburgischen Seen. ibill. f 1). $27: 3$.

1898. - Ueber dic vermointlirbe Schätlichlacit dor Wasserblütce. ibicl. (; p. 206

1897. Stronmeren (O.), Die Algenflora des IIamburger Wassenwerkes. Leipzig. (Sep.).

1892. Tanver\% (C.), Rotatorien der Lingeloung Basels. Inauguralclissertation. Basel. (Sep.).

1886. Tr:ssix-BüT\%ow (G.), Rotaforien der Umgegend von liostock. Archiv 43 d. Freunde d. Naturg. in Mecklenburg. (iüstrow. (Sep.).

1893. Tкувом (F.), Ringsjön i Malmöhus Län. Merldel. frin Kongl. Landtbruksstyrelsen. 4. (Sep.).

1895. - Sjöarne Noen och Hvalen i Jönköpings Län. ibid. S. (Sep.).

1896. - Sjön B̉nnn i Jönköpings län. ibid. 1. (Sep.). 1899. - Sjön Nömmen i Jönköpings Län.ibid. 2 (Sep.).

1901. - Bexhedasjön, Norrasjön och Näsbysjön i Jönköpings län. ibid. ?. (Sep.).

1901. ULE (W.), I)er Würmsee (Starnbergersee) in Oberbayern. Wissensch. Veröllentlichungen des Vereins für Erdkunde zu leipzig. §). (Sep.).

1903. Ussixg (N. V), Om Jyllands Hedesletter og Theorierne for deres Dannelse. Kigl. Danske Vidensk. Selsk. Forhandl. Kobenhavn. Nr. 2 p. 99. (Sep.).

1899. Yung (E.), Des variations quantitatives du plancton dans le lac Léman. 1. Arch. des sci. phys. et natur. Cénève. sér. IV. S p. 1. (Sep.).

1902. - Des variations quantitatives du plancton dlans le lac Léman. II. ibid. sér. IV. 14 p. 119. (Sep.).

1900. Waldvonel (T.), Das Lautikerried und der Lützelsee. Dissert. Zürich. (Sep.).

1896. WARD (H. B ), A Biological Examination of Lake Michigan in the Traverse Bay Region. Bull. Michigan Fish Comm. Lansing. Nr. 6 p. 1. (Sep.).

1899. Freshwater investigations during the last five years. Studies from the zoological laboratory. University of Nebrasca. Lincoln. 31 p. 261. (Sep.).

? - A comparative study in methods of planktonmeasurement. ibid. 37 p. 227. (Sep.).

1875. W.ınuxi (E.), Om nogle ved Danmarks Kyster levende Bakterier. Vid. Medll. Nat. Foren. Kobenhavn. $\$ 3$ p. 307

1878. - On Farvningen navnlig af Have og ferske Vandle ved smaa Organismer. Tidsskr. for populaer Fremst. af Naturv. København. 5. R. 5) p. 268.

1895. - Plantesamfund. Grundtræk af den okologiske Plantegeografi. Kobenhavn.

1897. - Botaniske Exkursioner. 3. Skarridso. Vid Med. Nat. For. Kobenhavn. 5! p. 164.

1898. Weben (E.), Faune rotatorienne du bassin du Léman. Rev. suisse de Zool. Génève. 5) p. $26+$ og 355. (Sep.). 


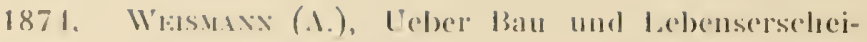

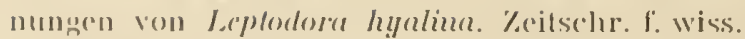
\%ool. et p. 1. (S(р).).

1877 - Das Thierleben im Boclensec. Schriften des Veroins lïr Geschichte des Borlensees. 7p. 1. (Sep.).

$1876-79 .-$ Britrige \%ur Niturgeschichte der l)aphnoidrn. lo(ip)\%ig. (S'pe).

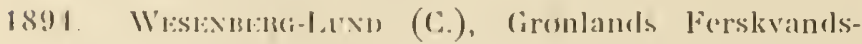
cutomostracia. 1. Phyllopoda branchiopoda et cladocera. Visl. Merl. Nat. For. lisbentarn. ifi p. 82. (Sep.).

1895. - Biologisko Undersogelser over lierskvandsor-

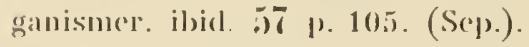

1896 a. - On lerskandsfaunens Kitin- og Kisellevninger i Torvelagene. Mcddel. Tra dansk geolog. loren. Kónenhavn. ; p.51. (Sep.).

18966 b. - Biologiske Studier over Ferskvandsbryozoer. Vid. Med. Nat. For. oS p. 252. (Sep.).

1898. - Über dinische liotileren unol über die liortpllanzungsverhälnisse der liotileren. Zool. Anz. 21 р. 200. (Sep.).

1899. - bammarlis Rolifera. 1. Grundtrakkene i Rotiferernes Okologi, Morlologi og Systematik. Vid. Med. Nat. For. (bl p. 1. (Sep.)

1900. - Von dem Abhängigkeitsverhältniss zwischen dem Bau der Planktonorganismen und dem spezilischen Gewicht des Süszwassers. Biolog. Centralbl. 20) p. 606 og 644. (Sep.).

1901. - Studier over Sokalk, Bonnemalm og Sogytje i danske Indsoer. Medd. fra dansk geolog. Foren. liobenhavn. 7 p. 1. (Sep.).

1902. - Sur l'existence d'une faune relicte dans le lac de Fureso. Bull. de l'Academ. Royale des sc. et des lettr. de Danemark de l'Ann. 02 p. 257. (Sep.).

1903. - Sur les Egagropila Santeri du lac de Sorø. ibid. I'Ann. 03 p. 167. (Sep.).

1894. Whipple (G. C), Some observations on the growth of Diatoms in surface waters. Technology Quarterly. 7 p. 214 . (Sep.).

1895. - Some olservations of the temperature of surface waters; and the elfect of temperature on the growth of micro-organisms. Journ. of the New-England water Works Association. ? p. 202. (Sep.).

1896. - Some observations on the relation of light to the growth of diatoms. ibid. 11 p. 1. (Sep.).

1899 a. - and Jacksox (D.), Aslerionella, its biology, its (hemistry and its ellect on watersupplies. ibid. 14 p. 1. (Sep.).

1899 b. - Chlamydomonas and its effects on water supplies. Transact. of the amer. microscop. soc. 21 р. 97. (Sep.).

1899 c. - The microscopy ol drinking water. New York.

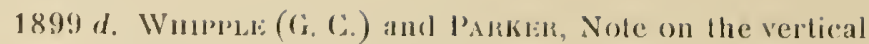
distribution ol Mallomonas. Amer. Naturalist. :3:3 1). 185. (Sep.).

1900. - and Iicksox, A romparative study of the methods used for the measurement of the turbidity ol water. Technology Quarterly. 1:) p. 271. (Sep.),

1892. Wn:nziski (A.), \%ur kenntniss der AsplanchnaArlen. \%ool. An\%. 15) p. 345.

1893 a. - Rotatoria (ialicyi. Krakau.

18936 b. - Alrochus tentacnlahs. Ein Rällerthier ohne Rärlerorgan. \%eit. f. wiss. \%ool. ந̈) p. 69b. (Sep.).

1897. Wusl: (N.), Chlorophycex in Engler und Prantl: Natürliche Pllanzenfamilien. l.eij)isg. Th.1. Abth.'2.

1900. - Algologische Notizen I-VI. Nyt Magazin for Naturv. Christiania. 38 p. 1.

1901. - Algologische Notizen V'll-vill. ibicl. 39 p. 1. 1903. - Algologische Notizen IX-XIV. ibiol. 41 p. 89. (Sep.).

1901. Vorcir (MI.), Ueber eine Gallerthaut bei Asterionella und Tabellaria. Biol. Centralbl. 21 p. 36.

$1902 a$. - Neue Organismen aus Plöner Gewässern. Forschungsber. 1'lön. 9 p. 33. (Sep.).

1902 b. - Beiträge zur Kenntniss des Planktons pommerscher Scen ibid. !) p. 72. (Sep.).

1902 c. - Beiträge zur Methodik der Planktonfischerei. ibiu. 9 p. 87. (Sep.).

1903. - Das \%ooplankton der kleinen Uklei und PlusSees bei Plön. ibid. 10 p. 105.

1901. Vouk (R.), Die bei der Hamburgischen ElbeUntersuchung angewandten Methoden zur quantitativen Ermittelung (les Planktons. Jahrl). d. Hamburg. Wissensch. Anstalten. 18 p. 137. (Sep.).

1903. - Allgemeines über die biologischen Verhältnisse der Elbe bei Hamburg. ibid. 19 p. 63. (Sep.).

1874. Woon (C. A.), A contribution to the history of freshwater algæ North Am. Washington.

1900. Zacharias (E.), Ueber die Cyanophyceen. Abh. a. d. Gels. d. Naturw. herausg. v. naturw. Ver. Hamburg. p. 1.

1887 a. \%AChiliss (O.), Zur Kenntniss der pelagischen und littoralen Fauna norddeutscher Seen. \%eit. f. wiss. \%ool. 45 p. 255.

1887 b. - Faunistische Studien in westpreussischen Seen. Schrif. d. Naturf. Gesell. Danzig. (6.

1893. - Faunistische und biologische Beobachtungen am Gr. Plöner See. Forschungsber. Plön. 1 p. 27.

1894 a. - Faunistische Mittheilungen. ibid. `2 p. 57.

$1894 b$. - Beobachtungen am Plankton des Cir. Plöner Sees. ibicl. "2 p. 91.

1895 a. - Faunistische Mittheilungen. ibid. :3 p. 73.

1895 b. - Ueber die wechselnde Quantität des llanktons im (ir. Plöner See. ibirl. :) p. 97. 
189.5 c. \%achamis (0.), Veber die horizontale und verlikale Verbreitumg limmetischer ()rounismen, ibid. ;) p. 118 .

1895 a. - Fortsetmung der Beobarhlungen äber die Periodicitä der Planklonwesen. ibid. :; p. 129.

1896 a. Quatilative Untersnchungen äber das limnoplankton. ibial. 4 p. 1.

1896 b. E Egebnisse einer biologischen Exkursion an die 110 ohseen des liesengebirges. ibirl. 4 p. 65 .

1897 a. - Neue Beiträge zur Kenntniss des Süs\%wasserplanklons. ibicl. j) p. 1.

1897 b. - Biologische Bcobachtungen an den Versuchsteichen des Schlesischen lischereivereins zu Trachenberg. ibid. ") p. 10.

1897 c. - Zur Mikrolauna der Sandforter Teiche. ibid. j) p. 112 .

1898 a. - Mittheilungen über Altheya \%achariasi und Rhizosolenia longiseta. Biolog. Centralbl. 18 p. 161.

1898 b. - Untersuchungen über das Plankton der Teichgewâsser. Forschungsber. Plön. (; p. 89.

1899 a. - Das Plankton des Arendsees. ibid. 7 p. 50.

$1899 b$. - Ueber die Verschiedenheit der \%usammensetzung des Winterplanktons in grossen und kieinen Seen. ibid. 7 p. 64.

1899 c. - \%ur Kenntniss des Planktons sächsische Fischteiche. ibid. 7 p. 78.

1899 d. - Ueber Pseudoporlienbildung bei einem Dinoflagellaten. ibid. 7 p. 136.

1900. - Trichodina pediculus. Biolog. Centralbl. 20) p. 463 .

1901 a. - Zur Kenntniss des Planktons ciniger pommerschen Seen. Forschungsber. Plön. S p. 125.

1901 b. - Flottierende Synchäten-Eier. Biolog. Centralbl. 21 p. 109.

$1901 c$. Ueber die im Süszwasserplankton vorkommenden Synchäten. ibiı. ㄴ1 p. 381 .

1902 a. - Zur Flora und Fauna der Schilfstengel im Gr. Plöner Sec. Forschungsher. Plön. !) p. 17.

1902 b. - Dic Verbreitung von Attheya Zachariasi Brun. ibid. () p. 110.

$1902 c$, - \%u1 Kenntniss der Planktonverhältnisse des Schöh- und Schluen-Sees. ibid. !) p. 26.

$1903 a$. - Biologische Charakteristik des Klinkerteichs zu Plön. ibìl. 10 p. 201.

1903 b. - Zur kienntniss der niederen Flora und Fauna holsteinischer Moorsümpfe. ibid. 10 p. 223.

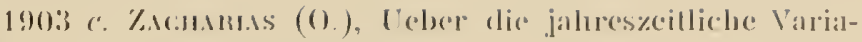
tion von Mycolodaphuire Kahlbergensis Solescell. ilicl. (1) p. 293.

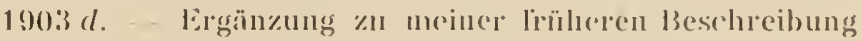
(ler Staurophytya clegans. ibicl. 10 p. 312.

1903 e. Leber die Verbreitung von Tabellaria feneslrata var. asterionelloides (irun. ibid. 10 p. 315.

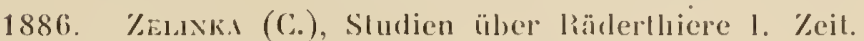
f. wiss. \%ool. 4 [). 41 . (S(e).).

1888. - Studien über Räılerthiere 11. ibiol. 47 p. 141 (Sep.).

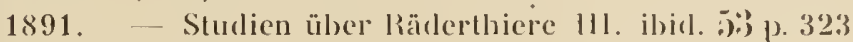
(Sep.).

1901. 7skxow (S. A.), Bemerkung über die Thiere des Planktons der Flüsse Totma und Wjälka des Malmyschk l3ezirks des Gouv. Wjätka. Tagebl. zool. Abth. k. Ges. 1. Fr. 1. Nat. Moskau. :) p. 28. (liussisk).

1899. Zimake (C.), Das tierische Plankton des Oder. Forschungsber. Plön. 7 p. 1.

1893. \%orf (W.), Ueber die eigentümlichen Strukturverhältnisse und den Entwicklungsgang der Dictyospharium-Kolonien. Beitrïge zur Physiologie und Morphologie niederer Organismen. Heft. 3. p. 15.

1900. - Ueber das Polycystin, ein krystallisirendes Carotin aus Polycystis flos aqua, Ber, (1. 1)eut. Botan. Gesell. 18 p. 461.

1894 a. Zschokke (F.), Die Tierwett der Juraseen. Revue suisse de \%ool. (iénève. ¿2 p. 349. (Sep.).

$1894 \mathrm{~b}$. - Die Fauna hochgelegener Gebirgsseen. Verh. d. Naturf. (iesell. Basel. 9 p. 36. (Sep.).

1897. - Fauna helvetica. 2. Heft. Seenfauna. Bibliographie der schweizerischen Landeskunde. Bern. Fasc. 1V. 6 p. 1. (Sep).

1900. - Die Tierwelt der Hochgebirgseen. Denkschr. d. Schweiz. naturf. Gesell. Zürich. :37 p. 1. (Sep.).

1901. - Die Tierwelt der Schwei\% in ihren Beziehungen zur Eiszeil. Basel.

1903 a. ZYKofl (W.), Bemerkung über las Winterplankton der Wolga bei Saratow. Zool. Anz. 26 p. 544.

$1903 \mathrm{~b}$. - Materiali po faune Wolgi i gidro-faune saratofskoi gubernii. "Bidrag til Kundskab om Wolgas Fauna og om Hydrofaunaen i Guvernementet Saratof . (Russisk). Bull. des Naturalistes de Moscou. 


\section{REGISTER.}

\section{A.}

Acanthocystis conspicua \%ach. . 121

A. Iemani Penard .......... 121

A. setifera Minkiew......... 122

A. tenuispina Zach...... . . 121

Actinoglena Klelosiana Zach.... 117

Actinophrys sol. Ehr. . . . . . 121

Actinurus neptunius Ehr. . . . 131

Egagropila .............. 90

Eolosoma . . . . . . . . . . . . 130

Amphidinium . . . . . . . . . . 106

Amphileptus . . . . . . . . . . 123

Anabiena flos aquae (Lyngb.) Bréb. 43

A. Spiroides ḱlebahn ....... 45

A. (circinnalis (Kütz.) Rabenhorst 45

A. Inacrospora Ḱlebahn. ..... 46

A. stricta Ostenfeld......... 46

Anacystis . . . . . . . . . . 36

Anipus ovalis Bergendal . . . . 140

A. Lestudo Lauterb. . . . . . . . 140

Anodontak .............. 205

Anuraa aculeata Ehr. ...... 147

A. brevispina Gosse ........ 148

A. cochlearis Gosse ... . . . . 145

A. curvicornis Ehr. ........ 148

A. falculata Ehr........... 148

A. hypelasma Gosse . . . . . . 119

A. longispina Imh. . . . . . . 147

A. serrulata Ehr. ......... 148

A. tecta Ciosse .......... 146

A. testudo Ehr............ 148

Aphanizomenon flos aquae Allm. 47

Arcella vulgaris Ehr....... 120

Argulus foliaceus L......... 203

Arthrodesmus ............ 101

Ascenasia . . . . . . . . . . . 123

Ascomorpha agilis Zach. . . . . 139

Asplanchna Brightwelli Gosse. . 110
A. Herrickii De Guerne ...... 140

A. priodonta Ciosse . . . . . . . 140

A. Sicholdii Leydig ......... 140

Asplanchnopus . . . . . . . . . 140

Asterionella gracillima Hantzsch. 73

A. formosa Hassal ........ 73

Asterosiga racliata Zach. . . . . 129

Atax crassipes O. F. M. . . . . . 203

A. figuralis lioch.......... 203

Attheya Zachariasi Brun ..... 69

B.

Bicocoeca lacustris Clark .... 129

B. oculata Zach. . . . . . . . . 128

Bosmina brevirostris P.E. Müller 173

[3. coregoni Baird . . . . . . . 175

B. cornuta (Jurine) . . . . . . 173

B. crassicornis Lilljl......... 173

B. diaphana P. E. \üller . . . . 173

B. globosa Lilljb. . . . . . . 173

B. insignis Lilljl. . . . . . . . 173

B. Lilljeborgii G. O. Sars . . . . 173

B. longicornis Schoedler . . . . 173

B. longirostris (O. F. Ml.) ..... 176

B. longispina Leydig ....... 173

B. maritima P. E. Ilüller . . . . 173

B. mixta lilljb. . . . . . . . 173

B. microps P. E. Müller . . . . . 173

B. obtusirostris G. O. Sars . . . 173

Botriocephalus .......... 130

Botryococcus Braunii Küt\%. . . 99

B. pelagicus Engler ........ 99

B. sudeticus Lemm. . . . . . . 99

Brachiomonas ............ 91

Brachionus amphiceros Ehr... . 142

B. angularis Gosse . . . . . . 142

B. Bakeri O. F. .1.......... 142

13. militaris Ehr.......... 142
13. pala Ehr. . . . . . . . . 142

13. urceolaris Ehr........... 142

Bucephalus . . . . . . . . . . 130

Bursaria truncatella O. F. M. . . 125

Bythotrephes............ 179

\section{c.}

Caligus lacustris Stp. \& Ltk. . . 203 Campylodiscus hibernicus Ehr.. 81 Carchesium polypinum L. . . . 129 Castrada radiata v. Grafl..... 130 Centronella Reichelti M. Voigt . 77 Ceratium cornutum Clap \& Lachm. 109 C. curvirostre Huit.-Kaas. . . . 109 C. hirundinella O. F. M. . . . . 110 Ceriodaphnia hamata G. O. Sars 170 C. pulchella G. O. Sars ....... 170 C. punctata P. E. Müller . . . . . 170 C. quadrangula (O. F M.) ..... 170 Chironomus.............. 157 Chlamydomonas ........... 91 Chodatella ciliata (Lagerh.) Lemm. 94 Chroococcus limneticus Lemm.. 34 C. minor (Kütz.) Nïg. ....... 34 C. minutus (Küt\%.) Näg. ..... 34 C. turgidus Näg. .......... 34 Chrysamoeba............ 113 Chrysospharella .......... 117 Chydorus globosus Baird..... 177 C. spharicus (O. F. M.) . . . . 177 Closteriopsis longissima Lemm. 102 Closterium aciculare West.... 102

C. ceratium Perty......... 102

C. gracile Delp............ 102

C. limneticum Lemm... . . . . 102

C. Nordstedtii Chodlat. . . . . . . 102

C. pronum Bréb.......... 102

Codlonella lacustris Ent\%..... 126 
Coelasirum cambricum Areher. 99 C. microporum Näg.......... 99) Coclopms tenuior Gosse . . . . . 137 Coclospharinu aernginemu l.enm. 35 C. đlubinm Sclmmula ........ . 35

C. Kützingianum Näg. . . . . . 35

C. minutissimum l.enm . . . . 35

C. natans l.emm. . . . . . . 35

C. pallidum Lenm. . . . . . . 35

C. Nägclianum Ung. . . . . . . . 35

Colacium . . . . . . . . . . . . . 129

Coleps hirtus (O. F. M.)...... 123

C. viridis Perty........... 123

Conferva tenerrima Küt\%. . . . 101

Conochilus natans Seligo..... 150

C. volvox Ehr............. 150

C. unicornis liousselet . . . . . 150

Corethra plumicornis Fabr..... 157

Cosmarium scenedesmus Delp.. 103

Cristatella ............. 130

Crucigenia Lauterborni (Schmidle)

Chodat.............. 95

C. rectangularis (A. Braun) Chodat 95

C. triangularis Chodat ....... 95

Curvipes rotundus (Kramer) .. 203

C. Leuckarti Claus . . . . . . . 190

C. oithonoides G. O. Sars ..... 190

C. strenuus Fischer ........ 192

Cyclotella comta Ehr. ...... 66

Cylindrotheca .......... 68

Cymatopleura elliptica (Bréb.)

IV. Sm. ........... 81

C. solea W. Sm. ......... 81

Cyphoderia ampulla Ehr. .... 121

\section{D.}

Daphnia cristata G. O. Sars... 164

D. cucullata G. O. Sars. . . . . 169

D. galeata G. O. Sars ....... 164

D). hyalina I.eydig. . . . . . . . 164

1). Jardinei Baird .......... 164

D. lacustris G. O. Sars ....... 164

I). longiremis G. O. Sars ..... 166

D. Iongispina O. F. M. . . . . 165

D. pellucida P. E. Müller ..... 165

D. retrocurva Forbes........ 164

Diaphanosoma brachyurum (Lićvin) $\ldots \ldots \ldots \ldots \ldots \ldots \ldots$

D. leuchtenbergianum Ficsher.. 161

Diaptomus bacillifer Koelbel... 194

D. castor (Jurine) .......... 194

D. coeruleus Fischer ....... 194

D. denticornis Wier\%........ 194

D. gracilis G. O. Sars ... . . . 198
D. graciloides Lilljlo. . . . . . . 196

D. Ia(inulatus l.illjl). . . . . . 194

1). laticeps G. O. Sars ... . . . . 194

D). superlus schmeil........ 194

Diatoma elongatum Küť. . . . . 79

Diclyospharium Ehrenbergianum

Näg. . . . . . . . . . . 93

1). pulchellum IVood ........ 93

Didinium nasutum (O.F. M.) . . 124

Difllugia cyclotellina Garbini . 120

D. Iydrostatica Zach. ....... 120

D. limnetica Levander ....... 120

D. lobostoma leidy . . . . . . . 120

1). planctonica llinkiew. ..... 120

Dileptus trachelioides Zach. ... 124

Dimorphococeuslunatus A. Braun 96

Dinobryopsis ............. 115

Dinobryum cylindricum Imh... 116

D. divergens $\operatorname{Imh} \ldots \ldots \ldots \ldots \ldots 116$

D. elongatum Imh......... 117

D. pellucidum Lev.......... 113

D. sociale Ehr. .......... 116

D. stipitatum Stein ........ 116

Diploziga frequentissima Zach.. 128

Diurella tigris Bory de St. Vincent 136

Dreyssena ............. 105

\section{E.}

Epipyxis............. 115 Epistylis lacustris Imh. . . . . . 129

E. procumbens \%ach. . . . . . . 129

Ergasilus . . . . . . . . . . . . . 202

Euchlanis triquetra Ehr...... 132

Eudinobryum ........... 115

Eudorina elegans Ehr........ 92

Eunotia ................ 86

Eurytemora aflinis Poppe.... 193

E. lacinulata (Fischer) . . . . . 193

E. lacustris Poppe ......... 193

\section{F.}

Floscularia libera Zach. ..... 149

F. mutabilis Bolton ... . . . . 149

F. pelagica Roussclet ... . . . 149

Fragilaria crotonensis (Edw.)

Kitton............. 70

F. capuzina Desm. ........ 70

F. virescens lialfs ......... 72

\section{G.}

Gastropus minor Rousselet.... 138 G. stylifer Imh. . . . . . . . 138 Glenodinium acutum Apstein .. 108 G. cinctum Ehr. . ........ 107
Glochiclium ............ 205

Gloeotilar ............... 11

Gloiotrichia e(hinulata Richter, 52

G. natans (lledow.) liab...... 33

Gomphosphxeria aponina Küt\%. 3.)

G. lacustris Chodat........ 3. 35

Gonium angulatum l.emm.... 91

(i. pectorale (Ehr.)......... 91

G. sociale (1)uj.) WVarming .... 91

Gordius . . . . . . . . . . 130

Gymnodinium fuscum Ehr.... 107

G. hyalinum Schilling ....... 107

G. palustre Schilling........ 106

\section{H.}

Halosphæra . . . . . . . . . . 8 89 Hariotina reticulata Dang .... 99

Hemidinium . . . . . . . . . . 106

Heterocope appendiculata G. O.

Sars ............. 193

H. saliens (Lilljb.) . . . . . . . 193

Heterophrys Pavesii Garbini... 121

Holopedium gibberum Zaddach. 158

Hyalotheca ............. 102

Hydatina senta Ehr. ....... 141

H. brachionus (Ehr.) ....... 141

\section{K.}

Kirchneriella lunaris Moeb. ... 95 K. obesa Schmidle........ 95

\section{L.}

Leptodora Kindtii (Focke).... 181

Limnocalanus . . . . . . . . . 193

Limnosida . . . . . . . . . . . . . 159

Lyngbya xestuarii (Mert.) Liebm. 39

L. bipunctata Lemm. ....... 40

L. contorta Lemm......... 41

L. lacustris Lemm.......... 40

L. Lagerhcimii (Möb.) Gomont . . 40

L. limnetica Lemm......... 40

\section{M.}

Mastigocerca bicornis Ehr. ... 135 M. capuzina Zach. \& Wierz.... 136 M. hamata $7 a c h . . . \ldots \ldots . . .136$ M. Hudsoni Lauterb. . . . . . . 136 M. setifera Lauterb. ........ 135 Mallomonas acaroides Zach. ... 114 M. Fresenii Kent.......... 114 M. Ploessli Perty .......... 114 Megalotrocha spinosa....... 151 Melosira arenaria Moore ..... 65 M. crenulata küı. . . . . . . 63 
M. distans kït\% ......... (bi3

II. Erimulata lihr. (Ralts) .... 6 o

.11. I:rvissima Girun. . . . . . 6 6 :

VI. lincolatio Girun. . . . . . . 6.3

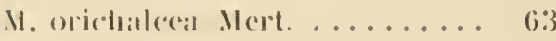

M. varians Ag. .......... (i.

Merillon . . . . . . . . . . sc

Mcrismopedium elegans A. Braun 3.)

.l. ğlatum (Ehr.) Nïg...... 3.

M. Marssonii lomm. ...... 35

slicrocodides . . . . . . . . . . 119

Microcodon rasus bihr. . . . . 119

Nicrocrestis . . . . . . . . . 36

Moina . . . . . . . . . . . . . 162

Ilotegcolia gracillima Wittr..... 101

Mycelomyxa \%opfii \%ach. .... 121

Mysis oculata Falor. ........ 157

\section{N.}

Nais clinguis (). F. . . . . . . 130 Neplorocytium Aghardianum Näg. 91 Nolularia spumigena Mertens.. 43 Nostoc Kihlmanni Lemm. . . . 43 Noteus ............... 142 Notholca acuminata Ehr. . . . . 114 N. foliacea Ehr. ......... 143

N. longispina Kellicot........ 144

‥ spinifera Gosse... . . . . . 143

N. striatal Ehr. . . . . . . . . 141

Notommata .............. 132

Notops hyptopus Ehr........ 137

N. pelagicus Jennings........ 141

\section{o.}

Oithona ............... 190

Oocystis lacustris Chod. ..... 94

O. Nïgelii A. Braun ........ 93

Ophiocytium ............ 100

Oscillatoria Agardhii ..... 41, 48

O. limosa Vaucher ......... 41

o. nigra Vaucher .......... 11

O. rubescens 1)e Candolle.... 41

O. prolifica (Grér.) Gomont ... 41

O. tenuis Ag. .......... 41

O. tenuissima Vaucher...... $\$ 1$

P.

Paludicella............. 131

Pandorina morum Bory...... 91

Pedalion............... 151

P'ediastrum biradiatum Meyen . 98

P. boryanum (Turp) Menegh... 98

l'. duplex Meyen........... 98

1'. Kawaiskyi Schmidle...... 99
1'. simples Meyen .......... 98

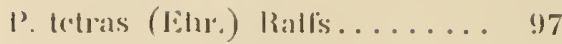

l. tricornutum Borge ....... 97

Peridinium aciculiferum J.cmm. 108

P. apiroulatum l'enard ....... 108

l'. bipes Stein ........... 108

l'. vinclum lihr. ......... 108

P. licve Huitf.-Kaas.......... 108

P. Marssonii l.emm......... I08

l'. efuadridens Stein ......... 108

P. Labulatum Clap. \& Lachm... 108

l'. Willei Huitf.-Kaas ........ 108

Phacotus ............... 91

Phacocystis ............. I13

Phormidium ............ 39

Platydorina caudata Kofoid ... 92

I'leodorina illinoisensis Kofoid. 92

Pleurotrochà ............ 132

Ploesoma IIudsoni Imh. . . . . . 139

P. lenticulare Herrick . . . . . . 138

P. Iynceum Ehr. . . . . . . . 138

P. triacanthum Bergendal . . . . 139

P. truncatum Levander ...... 138

Pollon................. 179

Polyarthra aptera Hood ...... 131

P. platyptera Ehr. . . . . . . . 134

P. aeruginosa Kütz. . . . . . . . 36

Polycystis flos acjuæ Wittr.... 36

P. incerta Lemm. . . . . . . . 37

P. pallida Lemm. ......... 37

P. retieulata Lemm. ........ 37

Polyedrium limneticum Borge . 96 P. regulare (Kütz) Chodat..... 96 Pompholyx complanata Gosse . 152 P. sulcata Hudson . . . . . . . 152 Proales................. 132

Pterodina .............. 152

\section{R.}

Raphidiophrys elegans H. \& L. . 121

R. pallida F. E. S. . . . . . . 121

R. viridis Areh.......... 121

Raphidium Braunii Näg...... 94

R. fasciculatum Kütz........ 95

R. longissimum B. Sehroeder .. 95

R. nivale Chodat.......... 94

R. pyrogenum Chodat ....... 102

Rattulus bieornis Western . . . 136 Richteriella botryoides (Schmidle)

Lemm. . . . . . . . . . . 94

Rhinops ............... 141

Rhizosolenia longiseta Zach.... 68

R. eriensis II. Sm.......... 68

\section{S.}

Saceulus viridis liosse . . . . . 137 S. Saltans Bartso $\ldots . . \ldots \ldots .110$ Salpingoesar minutus ḱent. . . . 129) Scapholcheris mucronata (O. F.

M.) . . . . . . . . . . 162

Scencilesmus bijugatus (T"urp)

Brób. . . . . . . . . . . 96

S. obliçuts (Turp) ḱüt\%...... 96;

S. quadricauda (Turp) l3rćb. .. 996 Schizocerca diversicornis(l)aday) 143 Selenastrum Bibraianum Rieinsch. 95 Sicla (rystallina (O. F. M.) . . . 15!) S. limnetica Burekhardt. . . . . 159 Sinrocephatus . . . . . . . . . 162 Sphaerella nivalis Somm...... 91 Spharocystis Schroeteri Chodat 91 Staurastrum gracile Ralfs .... 103 S. paradoxum Meyen ........ 103 Staurophrya clegans Zach. . . . 127 Stentor sp. . . . . . . . . . 125

S. coeruleus Ehr. ......... 12.

S. polymorphus Ehr. ....... 12. Stephanodiscus astraea (Ehr.)

Grun............. 67

S. Hantzschii Grun. ........ 68

S. Niagaræ Ehr. ......... 67

S. Zachariasi Brun ......... 68

Stephanosphæra .......... 92

Stylaria proboscidea (O. F. M.). 130 Surirella elegans Ehr. ....... 81

S. biseriata Bréb. ........ 81

S. splendiula Kütz.......... 81

Synehreta apus Plate.... . . . 132

S. baltica Ehr. . . . . . . . . 132

S. grandis Zach. ........... 132

S. monopus Plate .......... 132

S. neglecta Zach. .......... 132

S. pectinata Ehr. .......... 133

S. stylata Wierz........... 132

S. tremula Ehr............ 133

S. triophtaIma Lauterb. . . . . . 132

Synedra aeus kítz......... 72

S. actinastroides Lemm....... 72

S. berolinensis Lemm. ....... 72

Synura Kklebsiana (\%ach.) .... 117

S. uvella Ehir. ........... 117

\section{T.}

Tabellaria fenestrata (Lyngbye)

Külz............ 78

T. Hlocculosa kütz......... 79

Taphrocampa ........... 132 
'Tetraspora lacustris Lemm. ... 90

Thallasiothrix . . . . . . . . . 70

Tintinnidium fluvialile Stein... 125

'T. semiciliatum Sterki ...... 120

Trachelius ovum lihr........ 125

Triarthra breviseta Gosse .... 151

T. brachiata Rousselet ....... 151

T. longiseta Ehr.......... 151

T. mystacina EHr........... 151

Tribonema bonbycimum (Ag.)

1)erb. \& Sol............ 100
'T. minus (Wille Hazen ...... 101

Trichodesmium . . . . . . . . . 33

Trichorlina pediculus lihr. . . . 129

\section{U.}

Ulothrix limnetica Lemm. . . . . 90 Unio ................. 205

Uroglena americana Calk. . . . 118

U. radiata Calk. .......... 118

U. volvox Ehr. ........... 118
V.

Volvox aureus lihr. ........ !1

V. globator Ehr.......... \$1

V. minor Stein ......... \$1

V. tertius Meyer .......... 92

Vorticella sp............. 12 !)

$\mathbf{X}$.

Xanthidium ............. 101

$\boldsymbol{z}$.

Zoothamnium pectinatum \%ach. 129 


\section{TILFOJELSER OG RETTELSER.}

p. 11 tillojes: Warming angiver (78 p. 268), at Ulseso ved Bregentved er bleven farvet rod af en Oscillatorie.

- 56. 2den Lin. f. o. slaegningen, laes Islagningen.

63. 13 de - - Ks., laes kïutz.

67. 5te - - Ehrbg., laes Ehr.

72. Synedra acus var. delicalissima Grun., læs Synedra acus Kütz. o.s.v.

91. 9de Lin. f. n. G. pectorale Müller, las G. peclorale (Ehr.).

98. 3dic - - - Tab. IX Fig. 100 udgaar.

99. Under P. Kawraiskyi Schmidle indsættes Tab. IX Fig. 100.

- 107. 4de Lin. f. o. Deling er iagttaget dels i encysteret Tilstand.... tilføj Klebs $(83$ p. 355$)$.

- 121. 16de - f. n. Mycelonyxa Zophii, las Zopfii.

- 170. C. quadrangula O. F. M., læs (O. F. M.). 


\section{SUMMARY OF CONTENTS.}

\section{INTRODUCTION.}

W I1Ex the Frcshwater Biological Laboratory began its investigations in 1897 , very little was known regarding the Plankton of the Danish lakes. Plankton-investigations hat not been regularly carried out in a single lake, and it was only through the studies of the following investigators, viz. P. E. M üll er on Cladocera, H eiberg on Diatoms, Bergh on Peridinea and Schmidt on Cyanophycea, that we arrived at the knowledge of some of the Plankton of our lakes. Ostenfeld had, moreover, published a short communication on the Plankton of the Jutland lakes. In 1898 I bcgan a regular fortnightly investigation of the Plankton of the Furesø. It was originally intended to publish the results after the gatherings in December 1899 were brought to an end, but this was abandoned later on for the following reasons: -

From 1890 to 1900 exhaustive studies of the Plankton of a great many of the lakes from the plains of Central Europe were published, and as was to be expected, the Plankton of the Fureso proved essentially to agree with that of the above-mentioned lakes. The same forms were met with in the Fureso as in the North German lakes; the occurrence of the maxima and the sexual periods were on the whole very much the same in both cases, and as the investigations could only contribute very little towards the general knowledge of the biology of the organisms, I did not think it necessary to publish the results in question.

These preliminary studies were, however, of great importance to me personally as thcy increased my knowledge of Plankton and gave rise to some questions which I felt compelled to solve, and which have kept me busy ever since.

The occurrence of dead masses of Plankton in deep water, was chiefly instrumental in my beginning, and temporarily concluding, the investigations of Lake-gyljes and other bottom deposits of our deeper lakes (sce W.-L. 1901).

The observation of the fact that a smaller or greater maximum almost always precedes the sexual period of a Plankton organism enabled me to procure the species when arrived at puberty; and in such cases wherc one of the sexes, the malcs, occurred only during a very short time of the year, I was able to capture these in great quantities as a basis for a more thorough investigation, and this has been more particularly of importance for the studies not yet published, of the males of the Rotifers and their propagation (see the preliminary note, W.-L., 1898).

De danske Søers Plankton.
The observations of the temporal variations in the Plankton organisms led to an unlooked for result. viz. that all these variations lakc place simultaneously, and in the same manner even in (juite different forms, and that they chiefly consist in the growth of the longitudinal axis, and in the floating apparatus, increasing in size during summer, and decreasing towards winter. I regarded this remarkable phenomenon, which had not previously been clearly understood, as an adaptation to certain outer conditions, and presumed that one of these must be the regular changes which take place yearly in the weight of the freshwater (see W.-L., 1900). ${ }^{1}$ )

At the same time as I altogether abandoned the publication of the above-nentioned fortnightly investigations of the Plankton of the Furesø, I felt convinced,

1) During the two last year's a great many investigators have busied themselves with these questions (B rch m, 1902; L a uterborn, 1901 and 1903 ; Lemmermann, 1900 and 1903 ; Lozeron, 1902; Steuer, 1901 ; Schröter and Vogler, 1901 ; Baehmann, 1903 ; ete.). The faet pointed out by me, that in the case of several of the animals, the longitudinal axis inereases during summer and decreases during winter, and that the formation of the various struetures (the formation of spines, ctc.), which are tliought neeessary to enable the Plankton organisms to float, are more distinetly visible in the summer forms and the summer individuals, have on the whole been aceepted. It also appears that all investigators of Plankton agree in thinking, that the reasons for these temporal variations must be sought for in the outer conditions wlich, so to say, compel the organisms to vary regularly.

At the same time as I brought forward my opinion that the chief reason for the variations must be souglit for in the yearly clianges in the weight of the water oceasioned by the fluetuations of the temperature, Chu in $(1900$, p. 73) arrived at the same result througl his studies of the different appcaranees of marine Ceratium oceurring in ocean currents of different weiglits. It is now proved particularly by 0 stwald's (1902 and $03 a-d)$ important investigations, that tlie outer foree, whieh presumably cliiefly acts as a remodelling ageney on the organisms, is the viseosity of the water, a factor which has hitherto been unknown to investigators of Plankton. This was first mentioned by Slı röter and Vogler (1901, p. 202). I think, that at about the same time, it was mentioned by $\mathrm{krogh}$ in an address $(\mathrm{Om} h y$ drostatiske Forhold $i$ Dyreriget) delivered beforc the Biologieal Society in Copenlagen in 1901. But we learı from the printed report (1901, p. 16), that the autlor regards it as doubtful if the variations in the weight and viseosity of the water have anything to do with the variations in the size and form of the l'ankton organisms. The honour of having introdueed the teaeling of the viscosity of the water in Planktonology - empliasized it as a eo-operative factor regarding the form of the Plankton organism, and made the knowledge of it universally known - is due to Ostwald. In the second part of this work, which will eliiefly deal with temporal variations, the literature mentioned liere will be more fully treated. 
that il the Planklon-investigattons, which were to be started aller the Freshwiter Biological taboratory had becon cstablished, were lo br of any essential use in increasing the knowledge of the lreshwaler l'lankton, new ways and means ought to be cmployed, and new objects held in viow.

latterly, there has been published yearly, accounts of the investigations of the Plankton of the separate lakes, lhese investigalions show which species occur in the lake in question, and the time for the oceurrence of the maxima and minima. These numerous investigations fead us to the important result that a great part ol the Phaliton organisms are common to these lakes, and that a rery small number only oreur sporadically, also it appears that the maxima and minima of the grealer part of the organisms occur fairly simultaneously in all these lakes; a great many cases are known, however, in which the occurrence of the maxima and minima of the single organisms in rertain lakes diller complelely from that which, according to the investigations carried out in other places, should be regarded as the normal one.

In the long run, it will not be worth white to carry on these kinds of investigations; it has been suffieiently prover, that the Anabana do not develope in Deeember and Nolholea striala in luly. Investigations of this nature are now only justifiable when marle either in very large lakes or in lakes under extreme natural conditions (very low or very high temperature, etc.). So many of the investigations have been carried out in the generally small, rather low-lying, and fairly similar lakes of the extensive plains of (entral Europe, that further researches, as regards this distriet, must doubtless be considered as superfluous.

of course the Plankton-researches, based on the investigations of a single lake, often aim at something more, than just giving a dry list of the organisms, and the fixing of the maxima and minima, attempts are made to prove, why these oceur at the time in question. Through these investigations one has just been able to touch a department which will now be the next and much more diffieult step in the history of Planktoninvestigations, viz. the understanding of the structure of the Plankton organisms, their life phenomena and the pointing out of their dependency on outer faetors; in fact the oecological study. Though the Planktoninvestigations have contributed a good deal towards this department, only very few real facts can be recorded; in the greater number of cases the standpoint of numerous vague hypotheses have not been abandoned. The most eertain and remarkable result arrived at through these studies is without doulst the fact that a great many Plankton organisms in proportion as the temperature of the water rises, enlarge their longitudinal axis and their floating apparatus. - It has been argued that authentic knowledge of the influence of the outer factors on the life-phenomena of the organisms can only be gained through laboratory studies, because only in the laboratory is it possible to eliminate all the other factors and work exclusively with the single faetor, while in nature one must ahways work with a whole series of mutually combined factors.

I cannot acknowledge this argument to be absolutely justifiable.
It is always a doubtful matter to base the studies of the mode ol hife and normal functions of an organism, on individuals in captivily, i. e. on such, living in circumstances, which, however favourable they may be thought to be, accorling to our opinion, unguestionably difler more or less in every main point from those under which the organs of the organism work in normal conditions. IJe, who las made it a rule, as far as possible, to plan and carry out his investigations in nature, has great difficulty in appreciating the above methorl of work as also in understanding the obvious want of telicacy towards the object, which characterizes a great many laboratory-investigations, ancl results in a peculiarly eoarse and mechanical interpretation of the living organism.

In reference to all experimental laboratory-investigations as regards the mode of life of the organisms and the function of their organs, one is justified in demanding that the laboratory study, as far as possible should be combined with sturlies in nature, and that the investigations ought not only to be based on the thoughts and ideas bred between the four walls of the study, but also on observations made in nature itself. Laboratoryinvestigations with reference to the biology of animals, very often give one the impression of being somewhat accidental, both in regard to their plan and their results. The reason for this must probably be sought for in the fact that the observer unconseiously works with the individual as an isolated element. He has great difficulty in maintaining a clear perception of the organism as a link of a whole, transformed, and influenced by the circumstanees under which it lives, and in turn exercising a similar influence on its surroundings.

He only, who know's the locality where the organism in question lives, and who has tried to make hinself familiar with its mode of life, will be able to form a plan for its further investigation in the laboratory, so that the results, arrived at, may be true to nature.

Laboratory studies ean at any rate lead to results, which dazzle by a seemingly far greater accuraey than that which is, as a rule, possible to attain through studies in nature. It must, however, be borne in mind, that these so-called accurate results are arrived at by methods of research. which have their strength especially in their one-sidedness, but on account of this, they have also hidden in them all the sourees of erroneous inferences, whieh necessarily arise from all one-sided researehes. We may therefore be justified in doubting how far this accuracy in many cases is anything more than an illusion, and whether the results arrived at in nature, with due consicleration to its endless and manifold qualities, have not on the whole, as great a seientific value, even if the results in question appear in a more unostentatious, and less dazzling form.

In our own day when the perfeetly earried out laboratory technics, and the excellent means of communication which permit the sending of animals from distant countries, as well as the studies of these in latitudes quite different from those in whieh the animals live, induce, in a much higher degree than formerly, the naturalist to carry on his investigations within doors, it is necessary to emphasize the importance of studying the organisms specially in their home; to study nature in nature itself. 
The same person rarely combines the dillerent qualities which chatacterize the careful student of nature, and the clever laboratory experimentalist. $\lambda$ s regards myself 1 am quite aware ol my sloortcomings as experimentalist and have always felt that ny province lies particularly in nature.

Even if the ways, which I must follow consequent to mily talents and training, very rarely give the so-called sstrictly scientifics proofs of my interpretation of the norms and variations in the structure and life of the Plankton organisms, I nevertheless hope, that they may give rise to questions, which have not previously been discussed, and that these investigations may contain matters for studies which others, possessing other powers and talents, may be able to investigate further.

If studies in nature are to be of any use in going beyond the present standpoint as regards the Planktoninvestigations, at which standpoint they have doubtless remained an unnecessary length of time, and in giving the next stage in the development a requisite scientific basis, then it will be necessary to base the Plankton studies on material which allow comparisons. The material must be collected from a large number of lakes; it must be collected simultaneously and on exactly the same principles; moreover, the material collected should, as far as possible, be examined by one and the same person so that the leading views be not disturbed; then only will it be possible to penetrate deeper into the life phenomena of the Plankton organisms, and their dependency on outer factors will be then explained.

Consequently, when the regular Plankton-investigations in the Danish lakes were set on foot, starting from the above-mentioned principles, I chose a different method from my predecessors and began investigations not in a single lake, but simultaneously in a large number of them.

According to the nature of the matter, the investigations had at once to be separate, on the one hand, researches regarding the Plankton organisms, and on the other, a more detailed study of the oecological factors. In order to arrive at a satisfactory result as regards the latter studies, it was, however, necessary that I should have some help as regards the physicalchemical investigations, as the latter are as yet quite wanting in our lakes. But not being able to obtain them, I was obliged after all to rest satisfied with the incomplete investigations of the depth, and the bottom deposits of the lakes, which I had been able to procure through my above-mentioned investigations, and the data I could gather on my journeys as regards the temperature, the outlets and affluents of the lakes; their freezing; the transparency of the water; the vegetation belts and their nature. - Whilst carrying on the investigations I have felt it a great drawback not to have any physical-chemical researches of the water of the lakes at my command, but on this point I met with difficulties which I could not overcome.

What further confirmed my views as to the correctness of simultaneously setting on foot an investigation of several lakes, was the fact, that provided the lakes in question were in many different districts of the country,
I should be able to give at once a total idea of the l'ankton of the l)anish lakes.

In October 1898 and in Maj 1899 three journeys were made, each lasting about a lortnight, during which the greater part of the Iarger lakes of the country were visited. My intention was, on the one liand, to gain a preliminary knowledge ol the l)anish lakes without which it would not be possible to decide which lakes should be included in the main investigations, and on the other hand, to establish a connection with fishermen, who were fit for, and willing to help in, collecting samples.

On these journeys I came to the conclusion that it would be possible to carry through a monthly investigation of the Zealand lakes: - Fures o, Es romso, Sorøsø and Tjustrupsø, and 5 Jutland lakes, viz.: Viborgsø, Haldso, Skanderborgso, Mosso and Julso. I hacl been hoping to include also liaabjeromilesøerne, Madumso in the north of Jutland and Tuelso near Sorø, but with regard to these lakes I met with practical difficulties which proved insurmountable. According to my plan the 4 Zealand lakes were always to be investigated by me personally; the PIankton samples from the 5 Jutland lakes were, on the other hand, to be collected by fishermen living there, but 1 intended as often as possible to collect some samples myself, in the first place, in order to study the Plankton of these lakes in its living condition, and secondly to control the collectings. The investigations began Dec. 1900 and were to have been concluded Dec. 1901. In Dec. 1901 we possessed the result of a regular fortnightly or three weeks investigation of Furesø, and a regular monthly investigation of the three other Zealand lakes. But samples were not collected during the months the lakes were frozen.

With regard to the Jutland lakes the result arrived at was not satisfactory, as samples were wanting from, e. g. Mossø. From Skanderborgsø and Haldsø samples were wanting from June and July; all the May and August samples were collected by me. Not until my journey in August did the fairly large apparatus work satisfactorily, and as I was now certain of being able to carry through the investigations, I made up my mind in Dec. 1901 to continue them till Aug. 1902, so that besides a considerable number of samples from l)ec. 1900 to Aug. 1901, I might have a complete series from all the lakes from Aug. 1901 to Aug. 1902.

To begin with, the investigations presented great systematic difficulties. There is no doubt that Plankton investigators have taken the systematic side of the investigations too easily, but the great heterogeneousness of the material excuses this neglect. In regard to the European Diaptomus species, the Hyalodaphnia and the Bosmina, I must, however, consider all records of maxima and sexual periods and of other biological conditions given by the diflerent Plankton investigators to be almost worthless, excepting, Burckhar l t, S te uer and in part SeIigo; in most of the cases it is especially the absence of figures and descriptions, which make it utterly impossible to decide which species the investigators have had for examination.

With regard to the determination of the species, Plankton investigators have chosen one of two different 
Inchlods; some have separated a considerable number of sprecies, with the result, that in the stacession of years the mumber of described heshwater-microorganisms have greally increised. So long as nothing was known regarding tlac considerable local and temporal variations in the Plankton organisms this manner of proceding would be justiliable, but the fact cannol be suppressed that it lats doubtless exercised an injurious influence on Plankton studies. Now-a-days when it is well-known that temporal as well as local variations in regand to varions P'lankton organisms are, so speaking, conditio sinc qua mon of their accurrence in the pelagic region, it is, at loast to my thinking, a very grave scientific error to keep) on encumbering science with no end of Worthless specilic names and by creating new species, which are olten badly described and very frecpuently not ligured at all. But in spite of strong protests from various sides this utterly unscientilic creation of species is continued withiu certain P'lankton genera (Dinobryum, Pediustrum, etc.).

Other investigators went to the other extreme and united - perhaps somewhat voluntarily - too many species together. I myself must be classed among the latter; my own investigations of temporal variations have possibly carried me too far in regard to this point.

In nIy present main work I have tried to steer between the two extreme points, but I am aware that according to my view of nature, 1 have come nearer to the latter than to the former. As I was afraicl that I should not be able, within a certain time, to attain to a thorough knowledge of the Phyto-plankton, I begged a young botanist, Mr. E. Larsen, to join with me in the determination of it. And to make the records as to the frequency as reliable as possible I asked him also to mention the latter in regard to the Phyto-plankton. We have, therefore, with regard to the Phyto-plankton worked out separately our records as to the frequency occurring in every single sample, and have consulted afterwards and re-examined the doubtful cases.

The species occurring in the Phyto-plankton have been defined by him in all the difficult cases, in a few others (Polycystis) the determination is due to a cooperation between us. We have to thank Mr. Larsen for the fact that so many of the small Chlorophycea have been recorded. The notes on the origin of the globular bodies of the Gloiotrichia have been worked out by us jointly. I tender Mr. Larsen my hearty thanks for the help he has so kindly given me. Whenever I write we in the part on the Phyto-plankton it indicates Mr. Larsen and myself.

The literature used, is that published up to Feb. 1902 , that which has come out subsequently is mentioned in the list of works, but has generally not been used in the preparation of the present paper. I have tried to collect all such papers, which could help to throw light on the geographical distribution of the species; their maxima and minima; and their sexual periods. So far notes have existed on special biological investigations of the forms here mentioned, these notes have been utilised, but many of them, I am very much afraid, have been overlooked. To avoid making the list of works too long I have not included such papers which most properly ought to be regarded as preliminary studies to the main works to be published sub- sequently. Some works are included out of regard to the lortheoming part. In the present paper I have endeavoured to mention all the freshwater Plankton organisms recorted from liurope; the species which have not been observed in Denuark are mentioned in the descriptions touching on the genus of the lamily.

As the knowledge of the relation between the Plankton of the sea and of that of freshwater, appears on the whole, to be slight, and as I regard some knowledge of marine l'lankton to be of great importance for the study of freshwater Plankton, I have in regard to each order, mentioned the part played by its respective representatives, both in the sea and in the freshwater.

Together with the investigations published in the present paper, studies over the temporal variations of the Plankton organisms were lesigned and carried out. It was originally intended to publish these investigations together with those published here, but chielly on practical grounds, I have kept back the observations on the temporal variations, to publish them in a later volume.

As 1 did not think it right to publish the finishing and summing up chapters of the book before an account of the variation-statistic investigations had come out, I have put oll the publication of them till the above studies have been issued.

The present paper contains chielly an account of the systematic investigations of the Plankton of the Danish lakes with statements of their maxima, minima; sexual period; and geographical distribution of the single Plankton organisms; in the general remarks given under each order, the chief points for the understanding of the similiarities and dissimiliarities in the occurrence of each species in the dilferent lakes have been given.

I desire to express my respectful thanks to the Directors of the Carlsbergfond for their having generously supplied the necessary funds for the publication of the present work, and to acknowledge my deep obligations to my master and teacher Professor Eug. Warming for his constant and generous help.

My sincere thanks are also due to Professor I. E.V. Boas for the warm interest he has taken in me, and in my work, and to Dr. Kolderup Rosenvinge for many valuable criticisms and suggestions as regards the botanical part of the work.

I have dedicated this work to the memory of the late Professor Japetus Steenstrup, as a humble thankoffering for the kindness and interest, he, the old man, showed me, the quite young one, and from what I have learnt from his method of research, and because he, of all Danish naturalists, is the one to whom I feel most closely related.

\section{CHAPTER I}

contains a topographical description of the district examined and gives an account of the size and depths of the lakes, their elevation above sea level, their outlets and aflluents. I have not given a résumé of this chapter, as I think that even those, who do not know Danish will have no difficulty in understanding it, besides I beg to refer to the accompanying maps. Before the exploration of the above-mentioned nine lakes went in 1898 an fortnighty exploration of the eleven ponds mentioned on p. $12-15$. 


\section{CHAPTER II. \\ THE METHOD OF RESEARCH. PL.ANKTON METHOIDI.}

The objects I have lad in view with the investigations published in the present paper, do not exactly answer to those which are generally aimed at by llanktoninvestigations. Consecjuently, I have been obliged also to use other methods ol research than those generally used, and accommodated the Plankton-methodic used by me to the objects which doubtlessly ought to be carried out lirst in a country where that kind of investigations has hitherto never been made.

If a Plankton-investigation be started sinultancously in 9 dilferent lakes situated in utterly different parts of the country it is clear that one must have others to help to collect the samples. Further, if one attaches importance to the fact that the samples from these 9 lakes must be collected simultaneously, one cannot take the weather into consideration, but must insist on the samples being collected even if it be blowing a storm. As we have chiefly only small open rowing boats on our lakes, all experts will understand, that I was obliged to abandon the thoughts of taking vertical samples, and base the investigations mainly on horizontal samples taken with qualitative Plankton nets. Anybody, who has tried to take vertical samples from small open boats in stormy weather, will know that in the majority of cases it is impossible to take them accurately; under these circumstances it would, to my thinking, be quite condemnable to ascribe scientific importance to vertical samples taken by persons, who have had no scientific training and who have no idea of scientific accuracy. In order to obtain as good horizontal samples as possible, I proceeded as follows: - To begin with only "Müllergaze« Nr. 19 and 20 were used. But it was soon proved that this caught too few Crustacea, and I therefore experimented with nets of various fineness, and fìnally settled on 》Müllergaze $\mathrm{Nr}$. 20, Griesgauze Nr. 60, Griesgauze Nr. 40, Griesgauze Nr. 24, and constructed four nets out of these. 》Müllergaze« Nr. 20 caught all the Phyto-plankton; Griesgauze Nr. 60 did not take Phyto-plankton, but chiefly Diaptomus, Bosmina, Chydorus, Cyclops oithonoides and the greater part of the Rotifers, especially Asplanchna; Nr. 40 was not well suited to catch all these organisms, but took Daphnia, Hyalodaphnia, Diaptomus (partly) and Cyclops strenuus. Griesgauze Nr. 24 was again not well suited to catch all these forms, but was quite able to retain Leptodora, Bythotrephes, Argulus, Caligus lacustris, Hydrachna and Corethra. As it was further proved that the Plankton at the bottom, and that at the surface differed in quality, each of these four nets were first dragged along the surface and then along the bottom, and as it very soon became evident to me that in regard to many of the Plankton forms it was much easier to work with those preserved in Formol than those preserved in spirit, I used both preserving fluids.

As is well known, forms exist which can hardly be preserved. Therefore, on my own journeys, I always carried a microscope with me, and I had living material sent to me from the Jutland lakes; the Plankton from a very large number of samples have, consequently, been examined in a living state, and all the Planktons from the \& Zealand lakes only a lew hours after they liall been collected. If all llic 4 above-mentioned nets were dragged both along the surlace, and along the botton, and the material collected preserved, partly in spirit, and partly in Formol, the result would be that eacli sample would comprise 16 glasses, besides the vertical sample taken by net $\mathrm{Nr} .20$. As this would make too many glasses, I simplified matters after carclul consideration as follows: -

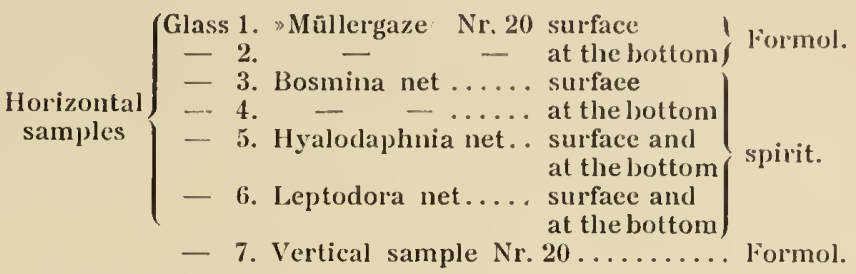

The reduction of the number of the glasses was made on the basis of the fact that all the coarser nets caught only Crustacea, which are unquestionably best preserved in spirit. The samples 5 and 6 were taken by the net being lowered down to some few metres from the bottom, and then dragged parallel to it, then it was drawn horizontally along an intermediate body of water; and finally along the surface. The total number of glasses containing Plankton samples amount to 872 .

It became, moreover, very soon clear, that if the material were to be collected simultaneously from 9 different lakes, as originally intended, and I myself were to gather the Plankton from 4 of them, it would be impossible to collect the material every fortnight; the material has therefore been collected only every inonth; this was not of much importance as regards the winter half-year, but it has proved unfortunate as regards the summer half-year; there is, however, one fortnightly gathering from Fureso, also samples have been collected weekly, for a longer period, from several lakes during the summer half-year. The fact that the material was gathered simultaneously from so many different localities made up for the investigations having been carried out only monthly.

In spite of the deliciencies of the material which I have not been able to remedy, I hope that an invesiigation of it will give, if not a complete picture, yet a fairly satisfactory outline of the Plankton of the 9 lakes in question. It is, further, my hope that the investigation has given us a fairly good knowledge, as to which Plankton organisms occur in our lakes and the time for their occurrence, I hope also that the present work will make it clear that it has given us some information regarding the factors, that play a prominent part in the occurrence of the great maxima, and in the following part I trust to show that the material will be useful for the study of temporal variations.

It may be presumed that material which had only been collected horizontally from bodies of water, the extent of which was quite unknown, would be utterly useless for quantitative stuclies of any kind whatever. According to the general opinion vertical samples, taken by the help of quantitative nets are deemed needful for studies of this kind. I willingly admit, that in the case of several - but hardly all - organisms the results arrived at by means of the latter method, are more 
alceurale llan llose which I have been able lo produce, but on llae ollier hand, mine can hatrolly be regatrded as fuile objectlonable. The frecpuency of oceurrence given in my Planklon tables has been based on the following considerations

I talie lor granted, that taving obtained from the polagio region of a lalic al least 1 , oltencr $6-7$ samples of Pankiton, laken in dillerent layers ol water, with the help of a net, the meshes of which, are adapted to the size ol the chicf Plankton organisms, then by far the greater part of the l'lankton organisms which at that particular noment occur in the pelagic region ol the lake must be represented in these samples.

liturther, cach sample unquestionably contained certain forms - very ollen only a single one - which could be distinguished at a glance and which made up the main part of the l'lankton; moreover, individuals always occurred which were extremely rare and were only met with singly; now, l am quite convinced that the lormer constitutel the main part of the Plankton of the lake, while the latter played a very minor part.

There was no dilficulty in distinguishing the common forms from those which occurred only in several specimens, but which nolwithstanding, must be regarded as rare, but there was some difficulty in classifying those forms which could neither be regarded as rare nor as common.

The freguency of the species is indicated as customary in investigations of marine Plankton: - $c c c$ (dominant), $c c$ (very common), $c$ (common), + (neither rare nor common), $r$ (rare), $r r$ (solitary). The degree ol fre(juency was noted separately for each of the glasses belonging to the same sample; then the lists of all the 1-7 glasses were worked up, which gave the scale of Irecpuency for each sample mentioned in this paper.

On applying the graphical method to illustrate the frequency of a species in a lake at different times, the curves worked out according to the above-mentioned (legree of frequency will on the whole be accurate. It is proved that the vertex in the curve of each species occurs simultaneously in all the lakes examined; at the point of time, when the curve of a species shows a vertex in one lake it very seldom shows a dale (fall) in another. In other words the investigations prove that the maxima and minima of the single species occur somewhat simultaneously in all the lakes examined; and it is further proved that the point of time when the maxima and minima occur in Denmark coincides exactly with the maxima and minima of other countries, where they have been clemonstrated by investigators who have applied far more complicated methods.

I think it must be obvious that the similiarity with regard to the occurrence of the maxima and minima is the greatest security for the records as to the frequency answering fairly well to the real conditions.

In a single case only, the method applied here evidently does not answer its purpose - it does not even give an approximately correct record of the frecjuency of such forms which are of almost equal frequency during the whole year and the curves of which consequently never show any marked maxima or minima, excepting all the forms which only occur singly in the Plankton, this is, however, the case with one genus only, viz. Diaptomus. Species belonging to this genus occur abundantly all the year round in the Plankton and only rarely have I had an impression ol their having a more definite maxima and minima. I have therefore, almost everywhere, chosen 10 put a $c c$ after the names of these forms.

In many cases the great faith put in the usefulness ol the vertical samples has had a decidedly injurious influence on l'lankton-investigations and hampered $u s$ in gaining knowledge of the biology of such inportant l'lankton groups as Copepoda and Cladocera. For certain special objects such as the vertical distribution of the Plankton organisms, vertical samples are of course indispensable, even with our present imperfect methods, but one must not be blind to the fact, that numerous other problems especially such regarding propagation, are solved much more easily and better, by the help of horizontal simples. l am, moreover, inclined to join others in believing, that even if in the future a method be found, by means of which all the individuals in a body of waler, thoroughly fished, be caught and countel, the result arrived at through the counting, will not compensate for the energy and time spent in attaining the result.

It is clear at any rate that even il the numbers can be recorded with accuracy at the present time, one would not be able to utilize them at all. It is always a questionable advantage to enforce results, the accuracy of which is greater than is required at the present time. The knowledge thus attained is useless at the present standpoint of science, and whether it will prove useful in the luture is very questionable, because the views on which the investigations have been based at the present time, need not be those of the future, and in so case the results arrived at now can in most instances hardly be of use in the future, and then the extreme accuracy will only result in a waste of time and energy, which might otherwise have proved useful in other departments of science.

On working with the records of frequency given by other authors the impression was often conveyed to me, that the above-mentioned marks had not the same value with the different authors; the nature of the case leading to an individual interpretation of this point.

To give other investigators a somewhat reliable idea of what I understand by the records of frequency given in this paper, I microphotographed the samples. All the photographs were taken by me; the development and the copying have been done by a photographer. Seibert's microscope and microphotographic lenses Obj. I Oc. 1 were used for the photographing. The same scale of magnification (about 80 times) was used for all the pictures. The photographs were taken at the Bacteriological Laboratory of the Royal Veterinary and Agricultural College; and the head of it, Prof. C. O. Jensen, helped me in the beginning, for which I tender him my best thanks.

The main point in taking good photographs of Plankton is to take them at the moment when the covering glass has sunk so far down that the focal distance for all the Plankton organisms are as far as possible the same, i. e. when they are lying on the same plane, without, however, any of the organisms being crushed by the pressure of the covering glass. In choosing the place in the slide which is to be microphotographed, due 
resard ought to be shown to the photographical, as well as to the planktological claims.

In regard to the former, places should be chosen, where the organisms are somewhat evenly distributed, and where a, as far as possible, uniform focal distance may be obtained; generally, I think it wrong to avoid places containing detritus; this makes up a part of the Plankton sample, and to know the quantity of it, is of some importance.

As regards the Planktological claims, according to niy thinking, the choice of the place ought specially to be dependent on the main forms of the Plankton and their reciprocal abundance. The rare, the »interesting " forms ought always to come second in consideration.

In the photographs, the Phytoplankton has been taken mainly into consideration.

For microphotographical reproduction it is necessary that the material, which is to be figured, should not differ widely in regard to size and transparency. It very soon proved impossible to include in the same picture the Crustacea as well as the rest of the Plankton, as out of regard to the finer Plankton it was necessary to magnify the material about 80 times, but this resulted in a single specimen of the Crustacea almost covering the whole of the microphotographical field of view. But on the Crustacea being excluded, the rest of the Plankton did not differ so widely from each other in size that they could not be represented on the same plate. When magnitied 80 times the same photograph could contain an Attheya and an Asplanchna.

A perfect agreement between the photograph and the records of frequency contained in the tables as regards the Phytoplankton, has not of course been attained; the rare forms are generally absent in the photographs; several of them (Dileplus, Staurophrya, etc.) can only be preserved by special methods, and in the samples where the Diatoms and the Cyanophycees occur in equal abundance, the difficulties of such a mixture proved insurmountable; but in a large number of cases the agreenent between the photographs and the tables as regards the Phytoplankton in generally satisfactory.

It is my hope that these plates upon which much labour has been spent will at least be of importance in giving an intelligible, and fairly reliable, primary idea, of the varying Phytoplankton associations of the lake in question. The many hundreds of pholographs which have been taken of the main forms, should serve to give investigators abroad, an idea of the average shape of these forms here in Denmark, and the plates should therefore be of importance as material for comparison with forms of other places (Alpine lakes; Arctic lakes). They will be an excellent help in studying the variationstatistic investigations published in the following part; and I hope also that they will prove to be of importance for practical investigations regarding the fishery, in helping the leaders to a ready knowledge of Plankton.
CHAP'TER III.

SOME PRIMARY NO'TES ON THE BO'T'TOM SPIECIES AND PHYSICAL, CONIDTIONS OI OUR LAKES, AND ESPIECIAILYY OF T'HEIR TEMPERATURE.

The l'lankton of a lake is dependent on the nature of the lake, especially of its depth; the temperature of the water; the quality of the bottom deposits and the chemical nature of the water - in the first instance its more or less richness in lime - the transparency and colour of the water; the breadth of the vegetationbelt and other factors. In Denmark our knowledge of all these factors is as yet highly deficient, and it is very much to be (lesired, that the chemical, physical and also, partly, botanical investigations may soon be set on foot which would serve as a supplement to these few stray remarks which are all that can be made here.

In Chap. II I have given the depth of each of the lakes which have been examined. The work is accompanied by maps showing the depths of Esromso, Sorøand Furesø. In a previous paper (W.-L., 01 ) I have given an account of the nature of the bottom deposits of our lakes, and shown the great part played by Plankton in the forming of Søgytjes; the close relationship between the quality of the Søgytjes of a lake and of its Plankton was also pointed out.

Sooner or later, by far the greater part of all the Plankton organisms will settle down at the bottom of the lake, either in a form permitting of their being determined, or only as a chemical compound; but it will be possible, somehow or other, to identify their presence therc.

The rapidity with which the dead Plankton sink to the bottom and is transformed into the most simple chemical compounds, influences again the factors, on which the production of living Plankton, as well as its mode of life are dependent.

This proves that the study of the bottom of lakes is of great importance to Plankton-investigations, and it would doubtless be fortunate if bottom-investigations were always combined with Plankton-investigations; bottominvestigations have hitherto been altogether neglected, and all the interest has been concentrated on the living Plankton. Nothing is known regarding the chemical quality of the water in our lakes; but as the percentage of lime in our Sogytjes is very high (W.L., 01, p. 93) the water is probably very calcareous. The vegetationbelt of some of the lakes has been studied by Warming (97) and Kolpin Ravn (96), the Characee-belt by IV.-L. (01, p. 64). But more extensive studies are very much to be desired. Investigations of the colour and transparency of the water are cuite wanting.

The enormous quantities of Plankton colour our lakes from April to November, ycllowish-green. The transparency is studied by means of Forcl's disc. In Aug. 01 a series of morning-investigations were carried out on sunshiny days from 9 to 12 in all the above lakes. The grcatest transparency occurred in Almindso (10 metres); and the least in Sorøsø (1 metre).

In Furesø, in March, the disc was still visible at a depth of 9 metres, in July-September often only at 5 and in December at 7 metres. 
In Soroso it was visible in March-April at a depth ol 5 metres, but the rest of thre year mostly, only al a deptli of about 1 medre.

The transparency ol the water is in the lirst instance dependent on the guantity of the l'lankton; it is always greatest when the quantity of the l'lankton is smallest (March-April); and leasi when the latler is greatest; (the great Cyghophyjeremaximum in Julso and Vihorgso, and the Ceralimm-maximum in Soroso and Tjustrupso, loth in August)

The transparency is, moreover, depentent on the quantity of detritus occurring in the water. In our relatively small, shallow lakes the quantity of the detrilus is always considerahle; it is least in the deepest lakes (Ilaldso and Amindso), and greatest during the summer. lispecially after continuous storms the l'lankton is useless for invesligation. Even in so deep a lake as Fureso the water is not clear after a period of stormy weathor. Alter the unexpectedly severe hurricane of 1)ec. 25th, 02 the water of the Furess lurned whitishgrey, and it cleared very slowly, laking at least len day's. Inmediately after the hreaking up of the ice the yuantity of detritus can also be very great; this is due to the littoral-ice which hrings along with it plants and detritus from the littoral-zone, and after being carried over the lake hy the wind as hummocks, spread them over the entire surface.

The quantity of the detritus may, however, be due also to another source, viz., atmospheric dust; hut this does not play any prominent part with us. On the $22 n d$ of March, 02 I was in the midclle of Esromso (arrying out my Plankton-investigations, surrounded by hummocks. The lake was dead calm, and the surface covered by a jet black film, the origin of which was to begin wilh, unaccountable to me. On a closer examination it proved to be thickest near the hummocks, and occurred, moreover, both along their margins and on the hummocks themselves. The film could hardly have been anything else liut atmospheric dust which had accumulated on the ice during the 40 days it had covered the lake, as well as dissolved excrements of birds which occurred abundantly on the hummocks, and the slime and fat of which have doubtless been chiefly instrumental in the dust occurring as a film on the water and being sticky to feel. The film blackened the Plankton nets. When examined microscopically it proved to consist of nothing else but small, shapeless fragments, doubtless formed mainly of coal-dust, besides some Conifer-pollen and a few Diatoms; in thickness it did not exceed the fraction of a millimetre.

\section{Temperature-investigations.}

At the same time as the Plankton samples were collected, the temperature of the air, and the surface temperature of the water of the place were taken. The temperature of the 4 Zealand lakes were measured by me, but of the Jutland lakes by the respective fishermen. The thermometers used, were common Celsius thermometers, made of very thick glass, and with a scale engraved in the glass; this showed only half and whole degrees. The temperature of the 4 Zealand lakes was taken from 9 to 12 in the morning, it was generally also taken of Hald-Viborg lakes at this time, but of the others it was taken at indefinite times.
11 is clear that measurements of temperature laken with such primitive instruments, and partly by people who load to he first laught the use of them, cannot claim to be alccurate, also it is a matter of course, that one must be very careful in trawing conclusions from them.

The reason why 1 have not exerted myself to get more reliable measurements of temperature, is, because I am convinced, that the investigations published in the present paper will be followed by physical-chemical ones, which will sooner or later give the accurate results that are wanting now. It was as impossible for me, to carry the more complicated and heavy instruments with me, as it was risky to send them over to the fishermen to (lo as they liked with then. On p. 26 there is a table of all the Plankton samples, ancl the surface temperature of the water; on plp. $29-31$ there is an account of the thermal conditions prevailing on the lakes, churing the two years the investigations were carried out. This shows that almost all our lakes reach the same maximum temperature in the same year, viz. in $01,21-23^{\circ}$; in $02,14-16^{\circ}$; and when the heating and the cooling, up to a certain degree take place with the same rapidity in all of them, then this phenomenon is in the first instance occasioned by the fact, that almost all our larger lakes are situated in the same latitude (between $55,20$ and 56,30$)$ and that the height above sea-level only varies about 30 metres. The chief factor in determining the temperature of a lake, viz. the temperature of the air, is so uniform over the whole country, that it is not capable of producing any great difference in the temperature of our lakes.

All our lakes are, moreover, very small and shallow (greatest depth 40 metres), and it applies to all of them that the depth is not greater than the boundary for the daily change of temperature, and only a few (Haldso and perhaps Furesø) belong to the middling deep lakes, where the depth in the centre is greater than at the boundary for the daily change, but not greater than that the yearly change of temperature can be felt down to the lowest layer (cp. Holmen's excellent work, 02 p. 198).

That all our lakes are in reality very small, so small that they hardly deserve to be called lakes, is proved by observing how very slight a fluctuation in the temperature of the air is necessary to affect the temperature of the water. Rarely with us will there occur two consecutive years so favourable for the proving of the dependency of the temperature of the vater on the temperature of the air, as the years 01 and 02 . As is well-known the year 01 was remarkable for its warm summer, while that of 02 was exceptionally cold. For further particulars I must refer to the table (p. 29) of the monthly middle temperatures, and of the deviations from the normal temperature of the air from Dec, 00 to Aug. 02. However imperfect the measurements of the temperature of our lakes may be, they show notwithstanding, how closely the temperature of their surface follows that of the air. Naturally, the maximum temperature of our lakes was much higher in 01 than in 02. From July 30 th to Aug. $12 \mathrm{th}, 01$, the temperature registered at our lakes is $21-22^{\circ}$. at Haldsø alone, the temperature is as much as $18^{\circ}$. From July 25th to Aug. 3rd, 02 the temperature registered is everywhere 
only $11-16^{\circ}$, or $6-7^{0}$ less than in 01 . The surlden and enormous lall of the lemperature at the end of Aug. and in the beginning of Scp. 01 is dislinctly apparent in the temperature of the water taken from Sep. Jth to $\mathrm{Se}^{\mathrm{p}}$ ). 20th. "The temperature in most of the lakes fell to $12^{0}$, and the higliest temperature which has been registered is $16^{\circ}$. This cnormous fall of temperature which amounts to at least $6^{\circ}$ and at most $11^{\circ}$, appears to me to be rather incomprehensible, and much greater than was to be expected. The two measurements of temperature, viz. ol Soroso and Tjustrupso, $12^{\circ}$, l have taken myself and I think I can answer for their accuracy. It is also very interesting that the unusually high temperature of the air at the end of Sep. not only raises again the temperature of some of the lakes (Esromso Sep. 30th, Tjustrupso Oct. 16th), but brings about that the temperiture of the water in Oct. generally cloes not sink lower than in Sep.

The lakes diller widely as regards the time for freezing; thus the four lakes: Soroso, Viborgso, Skanderborgso and Julso are frozen over for a short time in Dec., for some 12 to 17 days, while Fureso, Esromso, Tjustrupso and Haldso in this month are not frozen at all. The 4 former lakes are frozen from Dec. 13 th to 1)ec. 29th. From about Dec. 29 th to the end of Jan. all the lakes are open. The 4 lakes frozen in Dec, freeze again from Jan. 28 th to Jan. 31 st, while the others do not freeze until Feb. 7th. The breaking up of the ice takes place subsequently over the whole country, from March 16th to March 22th. For further particulars see table on p. 31.

With regard to the number of days, in which the above-mentioned 8 lakes have been covered with ice, these may be divided into two groups.

The first group, which includes Soroso, Viborgso, Skanderborgsø and Julsø, are frozen over at two different periods, one in Dec. lasting some 12-17 days and one in Feb.-March, lasting 49 to 52 days; they are frozen over all in all for $63-69$ days.

The second group, which comprises Furesø, Esromsø, Tjustrupsø and Haldsø, are frozen once only, viz. in Feb.-March, and the ice lasts only $35-40$ days.

The increase of heat during the spring was not studied very closely; in the early part of summer we get a new proof of the fact how closely the temperature of the lakes follows that of the air, the slight summer heat which occurred at the end of June being sufficient to raise the temperature of the water to $16-18^{\circ}$, but at the end of July it fell to $14-16^{\circ}$, and there has certainly been no rise in the temperaturc of the water later on in the year.

As may be seen from the above, our lakes, setting aside the time for their frcezing over, and the number of days when they are covered with ice, agree remarkably well in regard to their temperature. One lake only, Haldso, presents particular conditions. In this lake the heat increases more slowly than in the others. On May 18 th the temperature is only $10^{\circ}$, while in the samc week in the other lakes the temperature shows $12-14^{0}$, the highest temperature registered is $18^{\circ}$ (Aug. 7 th), while in all the other lakes it is $21-23^{\circ}$. The cooling takes place more gradually. On Nov. 10th the temperature is $10^{\circ}$, while in the other lakes, from Nov. 10th to Nov. 20th, it is as low as $6-8^{\circ}$; generally $7^{\circ}$. We sec,

De danske Søers Plankton. then, that of all the lakes which have been investigated, Haldse is the one which is slowest in following the occiliations of the temperature of the air. It is, moreover, Haldso, whichl, alter the niddle temperature of the twenty four hours has gone down under 0, takes the greatest number of days to frecze over, and is the one which is frozen over the shortest number ol days, vi\%.35. A temperature of the bottom of the lake taken with the dredge on $\mathrm{Aug}$. $7 \mathrm{tl}_{\mathrm{l}}, 01$, at a depth of 35 metres showed an - for our country - exceptionally low temperature of $7^{\circ}$ (surface temp. $18^{\circ}$ ). The botlom temperature, which was measured in all the lakes from Aug. 1st to Aug. 12 th, was in Furesø and Tjustrupses $12^{0}$, and in the others $14-16^{\circ}$, and highest in Viborgs $6,16^{\circ}$.

Of all the lakes which have been examined, IIaldsø comes nearest to the Alpine lakes in the transparency of its water, its precipitous coasts, etc. Almindso which likewise registered $18^{\circ}$ only on Aug. 2 nd comes perhaps as close to the Alpine lakes, but my knowledge of it is limited.

How are we now to understand the wide differences shown by the lakes in regarl to the length of the period in which they are covered by ice, and that Haldsø dillers so widely from the other lakes?

That the reasons for the dilference in regard to the length of the freezing cannot be sought for in the meteorological conditions, is thereby proved that lakes which are situated only 7 Kilometres from each other and on the same height above sea-level (ViborgsoHaldsø, Sorøsø-Tjustrupsø) differ on this point. The reasons must be sought for in the lakes themselves and more particularly in the conditions pertaining to their depth and their form.

It has been proved that the group of lakes, which is frozen over at two dilferent periods, in all about 65 days, includes the two most shallow lakes, Sorøsø and Viborgso and the somewhat deeper Skanderborgsø and Julsø; none of the latter are, however, morc than some 20 metres in depth. The other group of lakes, which is only frozen over once, for a pcriod of some 39 days, includes chiefly lakes of a depth of 30-40 metres, the only exception being Tjustrupsø the depth of which does not exceed 20 metres.

Holmsen $(02$, p. 206) has pointed out, that in shallow lakes, of a depth of as much as $20-25$ metres the cooling of the water, as a matter of coursc, takes place in a very short time; consequently, it may be frozen over a few weeks after the middle temperature has gone down to zern - in deeper lakes (30-100 metres) not until $4-8$ weeks after that time.

Bearing the above in mind it may be understood that the first group of lakes of a depth of as much as 20 metres, is frozen over for a time in Dec., because the slight frost which occurred in this month was sufficient to cool the waters of these lakes so much that they could be frozen over.

On the other hand, the short period of slight frost could not cool the water so far clown in the deep lakes, that they could fieeze over.

But it remains yet to be explained why Tjustrupso which agrees with the former group as regards its depth, follows the latter in regard to its freezing over; as also why Haldso is so much colder than the other lakes and especially colder than Fureso. 
I an not prepared to give any delinite reasons for llasese two phenomena, at present it must sullice, that I point out, that in both rases, we are dealing with long, narrow lalies, which have narrow littoral \%ones, and very perpendicular coasts, this applies more particularly (o) Ilaldso, and I ant inclined lo bedieve dhal the bong natrow lorm ol the lakes in eonnection with the abrupt sloping angles ol their coasts is the reason why they dillere in regard to lacir temperature.

llowever imperfect the meisurements of lemperature maly be. I an convineed that the above conclusions may be arrived at will some certainty through a study of the ligures recorded

\section{CHAPTER IV}

\section{CYANOPHYCEAE.}

Cyonophycer play a great part in the pelagic region of the l)anish lakes; they are poor in species, but rich in individuals, and olten produce the well-known phenomenon known as arjuatic-llower. The I'lankton-cyanophycea do not belong to any distinet systematic section. frepuently they have the lollowing features in common, vi\%. "air-valuoles (Luftvacuolen); large hyaline formations of slime; and slender trichomes, all of which may be regarded as planliton-characters, as is the case will filaments terminating in a thin whip-like part in the Gloiolrichio. The main part of the Plankton, especially the Coccogonew, belong originally to small lakes. In the pelagic region of the sea the Cyan. (lo not occur so numerously as the Diatoms, the Hormogonea only especially in the tropical seas - oceur in the majority. Freshwater Planktoncyanophyces may be carried out into brackish water (Aphanizomenon, Gloiotichia in the Baltic). In many cases a close relationship may be shown to exist between the freshwater Planktoncyanophycer and the bottom forms from which they descend (Anabana-species, G. echinulata and G. natans).

Coccogonea. Chroococcus. C.-species are mostly pond and littoral forms; the following only are recorded as Plankton forms: C. limneticus Lemm., C. minutus Näg., C. turgidus Näg., C. minutus (Küt\%.) Näg. var. carnès and C. minor (Kütz.) Näg. var. viridis. C. minulus var, carneus is according to Chodat especially characteristic of the lake of Neuchatel.

1). 34. C. limmeticus Lemm, has been met with in Sorosø, Viborgso, Skanderborgso, Mosso and Julso, but is common only in the two latter. It appears to reach its max. during winter (temp. 5-20); if this is normal for this species, then it dillers on this point from all the other Planktoncyan., as they reach their max. at a higher temperature. Lemmerman n (98 c., p. 153;99, p. 132) records it from the north of Germany.

C. minutus may doubtless be met with in the pelagic region of all our lakes; especially in May and June. It is common in Esromso.

p. 31 Merismopedium. Pond forms: M. glancum (lihr.) Näg. : Heleoplankton $\mathrm{Z}$ ach arias, Balatonsee lstvánffi. Airvacuoles have been met with only in M. Marssonii Lemm.
M. elegans A. Braun occurred sporadically in Esromso, Soroso, Mosso and Julso.

Gomphospharin. One species only is a Planktonorganism: G. lacustris Chodat; in ponds G. aponina küt\%. G. lacustris is mol with sporadically in lureso, Esromso, Sor(uso, 'Tjustrupsa, Viborgso and Julsa; it occurs most lrepuently during the summer. It appears to be more common in the Swiss lakes (Chollat 98, p. 182) than in the lake's of the low-lying plains ol Central Europe.

Coelospharitum. All the Coetospharinm species oceurring in the pelagic region of our lakes are relerable to C. Kä̈zingionm Näg. It is doubtful whether the species recorded by L, e mm erman n (see p. 35) are recognizable. In the experiment pond $\mathrm{Nr}, 3$ (sce p, 13) W.-1.. pointed out in 98 an enormous max, in Aug. - Sep. The pond was covered with huge apuatic-flowers.

C. Kützingianum has been recorded lrom all the lakes except Soroso; it is rare in Fureso, 'Tustrupso and Haldso, but common in all the others. C. $K$. occurs everywhere in single specimens in Dec.; in $\Lambda$ pril and May only a few examples were met with; reaches its max. during the autunin (temp. $17-15^{\circ}$ ) and very commonly forms acpualic-llowers. As regards its geographical distribution see p. 36. Its survival through winter and especially its resting-stages unknown.

Polycystis. In our determination of the $P_{\text {r-species }}$ we have lollowed Hansgirg, who $(92$, p. 144) records the general Anacystis and Clathrocystis as sections under the main genus Polycystis, which thus includes the two Plankton forms P. (Anacystis) flos aque Wittr. and $P$. (Clathrocystis) arnginosa Küt\%. besides some forms which are generally not detached and of which we have no knowledge. P. flos aqua represents then all the irregular lump or ball-shaped cell-aggregates, without fixed outlines, - not surrounded by a clearly defined gelatinous-envelope - , and when slightly magnified mostly of a pale-yellow colour; when examined microscopically they prove to be grey (Formol) (Tab. lll, Fig. 31). $P$. aruginosa includes all the flat, sometimes clongated, sausage-shaped colonies, which are always surrounded by a clearly defined covering of slime and the colour of which, when examined either microscopically or seen through a magnifying glass, proves to be rerdigris green (see specially Tal). VI). When Hansgirg mentions as the essential dillerence between Anacyslis and Clalhrocystis, that the cell-aggregates of the former are never divided into reticulated bodies (»nie netzförmig zerrissen «), while this is characteristic of Clathrocystis, then we cannot follow him in this point. Mostly in the summersamples from Viloorgss $P$. flos aqua forms occur, which are greatly divided, but this is generally not very noticeable, because these colonies have not the sharp outlines, which the Clathrocystis-colonies have, with their distinctly defined covering of slime.

To begin with we separatel the two forms $P$. flos aqua and $P$. artuginosa, but afterwards we were obliged to unite them, and in the tables recording the frequency of their occurrence, they are placed under one name. Both these forms occur in all the lakes which have been examined excepting Esromso. The two species are connected by numerous transitional stages. In Viborgso (Aug. 7th, 01) colonies have been observed, the one half of which resembled $P$. $/ l_{0} a_{v}$, and the other $P . \alpha$. We cannot follow l, emmermann in his attemps towarls p. 35.

p. 35. 
further separaling llose two species into other l'lankton species (see p. 37). The colonies ocent in many diflerent shapes. P. fl. a. in regular globular stages (Tjustrupso, Soroso. Tal). IV, Fieg. 46); and in druse-shaped colonies, ol" a milkish white colour, and with homogeneous refraclive cell-comlents, devoid ol grains (Mosso, Mug. 1stOct. 15th, ()1, 'Tah. VIH, lïg. 86), P. $x$. in hollow globular bodies (Talb. VI, Fig. (62); in cylinder-shaped colonies (Tal). VI, [ïg. 61); and in slender threarlike colonies (Tal). V'I, lig. 72).

As regards Viborgso, it was mostly the cylinder or sausage-shaped colonies which proved to be common during spring. Later on they flow out and forn large llat colonies, which dividing into clefts and lobes are transformed either into hollow balls or reticulated bodies. from the surface of these a few lobes may stand upright detached, and assume a sausage-shape without the transverse scction increasing, and keep on growing in the same direction; this orcasions long, string-shaped bodies, which, subsequent to a constriction divide into cylindershaped parts, which are independent, and from which new colonies originate.

Later on in the autumn, very essential alterations occur which preface the winter resting-stages. The colonies change colour and turn brown or brownish-yellow; the single cells decay into a brownish-yellow powder, which causes the gelatinous envelopes to become much more distinct. In Dec. one meets with, e.g. in the pond in the palace gardens numerous clearly defined envelopes, on the outer flaps and lobes of which a brownish-yellow, powderish mass is deposited. These gelatinous envelopes sink to the bottom during winter and are destroyed, at least, they could not be found when the ice broke up in March 02 .

But it is not all the $P$. aruginosa-colonies which are transformed in this way. In Nov.-Dec. the lobe-formation in many of the large colonies goes on differently than during summer. The lobes occur now, not as long, sausage-shaped bodies, the transverse axis of which is to the longitudinal axis as about 1 to 20 , but the sausageshaped bodies divide into small, short, globular or elliptical parts where the relation between the transverse and longitudinal axis is as 1 to 1 or at the most 1 to 3 . The slime-envelope of these small parts is very thick, and is often arranged in distinct layers (Tab. Vl, Figs. $66-68)$; their contents: the numerous single cells, which, when examined microscopically, are bluish-black, have contracted into a compact mass in the centre of the slimeenvelope. As regards these bodies no lobe-formation or growth takes place from Dec. to the time when the ice breaks up. It is the wintering-stages of $P$. coruginosa, which occur in the Plankton during winter, but some of these presumably also survive the winter at the bottom of the lakes.

The following remarkable fact is noticeable as regards Viborgsø, viz. that the main part of the wintering-stages is covered with long, jointed hairs of bluish-green colour, which proceed from reddish-brown protuberances on the gelatinous membrane; presumably, we are here dealing with an epiphyt unknown to us (Tab. VI, Figs. 66 and 67). In April again, wintering-stages are net with; these develop into the sausage-shaped stages, and then they divide into colonies. The wintering-stage was probably observed by C. Schröter in the lake of \%ärich $(97$, p. 22) and by $\Lambda$ mberg in lago di Muz:ano (00 a., 1). 42).

I. occurred in all the lakes which lave been examined; il reaches its max. in July sometime before the valer has allained its highest temperature. It can rearll to a very high nlax. and can lorm thick atpatic-tlowers, the latler takes plare, lowwever, chielly in small lakes and ponds (Frederiksborg). As regards its geographical distribution and its periodicity see p. 39.

Hormogonea. Lymgbya. 4 European lPankton-species. L. Lacustris Lemm. and L. limnetica Lemm. can only with difficully be kept distinct from each other.

L. limnelica J.emm. occur's in Fureso, Esromso and Skanderborgso; the species is presumably perennial; it reaches its max. in Sepl.-Ocl. (temp. 16-120). In Furesø, in 00 , the max. was enormous from 30 th $\Lambda$ ug. (temp. $\left.17^{\circ}\right)$ to 21 st Oct. (temp. $\left.11^{0}\right)$; the water was brownish, the inside of the Plankton net was covered with a thick layer, which when washed out into a pail turned a resldish-brown. In vessels the Algr collected at the bottom, and dicl not rise to the surface; no airvacuoles. - As regards its geographical distribution and its periodicity see p. 40.

L. bipunclata Lemm. The species is characterized by the occurrence of a round borly at each end of the cells, the function of which is unknown. The species was observed in Skanderborgsø, Mossø, Julsø, but shows a max. only in Skanderborgso, during spring after the lake is covered with ice (temp. $2-10^{\circ}$ ).

$L$. contorta Lemm. occurs in single specimens in the Plankton of the Furesø; it reaches its max. probably in July, when the water attains its highest temperature. We cannot follow Chod at in supposing, that $L$. contorta is an Ulothricacee.

Oscillatoria. Numerous Oscillatorias have been described as occurring in the Plankton (see p. 41). Most of then belong to the Swiss lakes; and only a few are from the lakes of the plains of Central Europe, where they do not appear to play a prominent part. They doubtless often escape notice because the $O$. do not, as the rest of the Planktoncyan. which have air-vacuoles, collect at the upper edge of the vessels filled with Formol, but for several months rumning, float about in the fluid and therelyy give it a milky white appearance. If this be not noted, too few Algæe are recolded from the samples, according to which the scale of frequency is compiled. O. rubescens appears to play a much greater part in the Swiss lakes than in the north of Central Europe.

O. rubescens De Candolle has been observed in all lakes and is the dominant species in Furesø and Skanderborgsø, also in small lakes and ponds. It reaches its max. everywhere during winter or early spring (temp. $\left.4-10^{\circ}\right)$; in May 01 it coloured the waters of Fureso a milky white; aquatic-flower was never observed. Bachm an $n$ records $(01, p .241)$, that during summer in the lakes of Zürich and Baldegger O. rubescens sinks to a depth of 16 metres at least below the surface; this sinking process has not been observed in the Danish lakes. How O.r. survives the winter, and how the great max. occur, is not known. In our shallow lakes they possibly occur during winter as bottom-forms, spreading over the whole of the bottom of the lake, and rising 


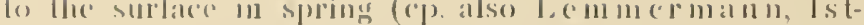

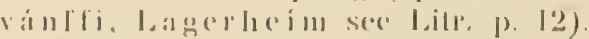

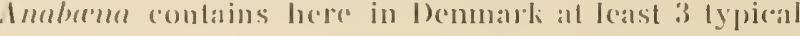
P'lanlitoncy:in.

d. flos andur l.ymgh. (Brrél) has been observed in all

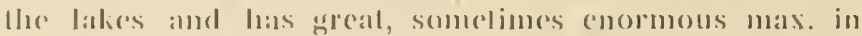
limeso, lispoumso amol llaldso.

fouresu. A. fl.a. Which lats been nuct with in a small quantity only during the three previous years, wecured on the 27 th

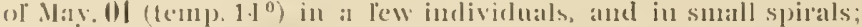

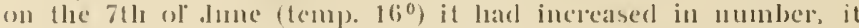

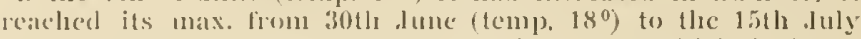
(temu), 200): dnoing this period the lake was, which hat not been the ease for ming vears, linitly green, especially during the early morning hours. At this time the species oecurred as described ly lílebahn (95, p. 2(i7) in spoider-like balls (Tah. I, lejg 5) which, fowards the end ol the max. Were furnisherl with spores. 'Tlee stages develop - as far as is linown - out of a small liliment: all the spores are atecumulated in the midlle ol the ball, the portions of threal between two spores are twisted outwards; this grives rise to stages of a rare beatuty and regularity. It appears that all the fignres shown are drawn firm cxamples preserved in spirit. the threads ol which slurink, and the slime, which encompasses the ball of thread sphericalls; acts destrosed. (On duly 30th (temp. 210) the species wals rare; it oceurs now as ballis ol slime, enveloping deep bluish-grecn accumulations ol spores, $20-30$ in number; the other parts of the filanents Irave disalpesared; the aecumulations ol spores were visible in the l'anliton up to 7 th Sep. (temp) $16^{\circ}$ \% after that time they hat probably sunk to the bottom. The adpatic-flower phenomenon did not last more than a fortnight and had disappeared OII duly $30 t h$ (temp. $\left.21^{\circ}\right)$; ly this time the surface was swept clean. and is great quantity of the algae had rotted away, and oceured as a bluish-white stripe of foam in the Phragmilesbelt. The species did not appear again until June 5th, 02 (temp. $\left.12^{0}\right)$, and then it did not oceur more conmonly than in o1 until Aug. 31d (temp. 150); the alpuatic-flower showed faintly; the conditions were otherwise exactly as in the preceding year.

The development is very mucli the same in all the lakes. A. /l. a. is generally visible on May 15 th (temp. $10^{\circ}$ ) and reaclles its max. during June-July (temp. 16-18 ${ }^{\circ}$ ); during May it is met with everywhere as small, irregular filaments; the large spider-like stages (Klebahn) do not appear until lowards the time the spores are developed. The accumulation of spores contained in the old slimeenvelopes float about $1-2$ months in the water, after having reached their max. - $A$. $/ l$. $a$. is widely distributed in the lakes of the plains of Central Europe, and in the Swiss lakes it is one of the most frequently occurring Planktoncyan. (sce Litr. p. 45). Most of the investigators record the max. as we do, but C. Schröter $(97$, p. 23) in Dec.

1). 1.). A. spiroides Klebahn has been observed in Viborgso, Julso, Mosso and Skanderborgso and in numerous small lakes; it reaches its max. at the same time as the water attains its highest temperature, viz. in Aug.; it reaches a great max. and forms aquatic-flowers in small lakes, but not in large ones. The specimens from Viborgso have from 6 to 8 spirals between each lieterocyst; in the specimens from .Julso a heterocyst occurs between every second twist, the difference is noticeable both in 01 and in 02 . This species has doubtless often been confounded with $A$. circinnalis (Kütz.) liabenhorst, but the spore in spiroides is spherical, while it is oblong in circinnalis.

1). If A. macrospora kilebahn is identical with the A. s/ricta described by Ostenfeld (95, p. 203). This species has been observed in Julso and Mosso and in numerous small lakes; it reaches its max. in Aug., when the water attains ils highest lemperalure; it forms afuatic-flowers in small lakes ouly. It is visible in May and June and (lisappears as carly as the end of Sep. It is very seldom recorded lrom alsoad (Seligo 00, p. 54).

Aphanizomenon flos ayua Alln. Las been met will in solitary individuals in all the lakes except Soroso, but only in Vilonrosso and Julso does it reacle to a great max., also in llaldso it partly attains a great max.

'Phe lakes of Viborg. Only a very few filaments of $A$. flu.

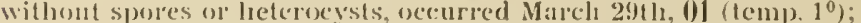
they are cloubless filanents which have survived the winter; on May $18 t h$ (temp. $\left.14^{\circ}\right)$ the number of the filaments latec obviously increased: they are very long, and they all doubtless contain at least one heterocyst, sometimes two-tluee When only one heterocyst ocemrs in a filament, it is generally situited somewhere in the midlle of the filament; on the spot where the heterocyst is situated, the filament slows a rupture as if it were on the point of breaking, this applies more particularly to the long lilaments with more than onc licterocyst. Spores are absent. Afuatic-flowers extremely faint. On the 10th of July (temp. 210) the quantity of the threads has somewhat increased, they still contain leterocysts, but no spores. Aug. 7th (temp. 23") the number las increased still further; it forms now, in connection with Polycyslis and Anabsenes, al lairly large aquatic-flower. Heterocysts occur in the greater part of the filaments, but are often alssent in the short ones, and there is rarely more than one heterocyst in each filament; at the same time unripe spores oceur in some of the filmments. (On Sep. $15 t h$. (tcmp. $12^{\circ}$ ) the number of the plant has inereased enormously and forms a luge apuatic-flower which overspreads all other P'jankton; there are now uumorous filaments without heterocists; the formation of spores is in full aetivity, and many filaments have unripe spores, but never more than onc spore has been observed in the sane lllament; it generally occurs not far from one of the ends; as i rule heteroeyst and spore are not met with in the same filament. On Oct. $14 t h$ (temp) $12^{0}$ ) the great max. still exists; heterocssts alle rare, numerous filaments contain spores which are now ripe. Nov, 10th (temp. $\left.8^{0}\right)$ : - according to the fisherman's report the aquatic-flower disappcared at this time; great quantities of it werc cast on the shore by the wind, and there it rotted away. Henceforth heterocests are rare; about one half of the filament contains spores with thick walls. Besides the single filaments numerous spore-bearing bunches or tufts occur; all the spores in the sanc tuft arc situated opposite each other, thus forming a belt ol spores right across the tuft (Tab. V1, Fig. 65); very often, these belts only are to be scen, as the rest of the filaments have fallen off. A great number of dead filaments occurs in the Plankton; the filaments are destroved more and more, the cells being emptied of their contents and becoming limpid; judging from a cursory examination these filaments appear to contain heterocysts. Lastly, filaments oecur without transverse sections and contain a brown. graincd, and irregularly dispersed mass. On Dec. 8th (temp. $2^{0}$ ) only a small number of short, loose, filaments was observed, without heterocysts and very rarely containing spores: many occur in a state of decay. Jan. 3rd, (0) $2\left(\mathrm{temp}, 1^{\circ}\right)$ only a few filaments are met with containing neither spores nor heterocysts. After the second breaking up of the ice the samples from March 22 nd (temp. $2^{0}$ ) do not contain a single filament: on April 30 th $\left(\mathrm{tcmp}\right.$. $8^{0}$ ) some short individuals oceur. some of these have heterocysts; May 30th (temp. $8^{0}$ ) the number has gleatly increased; the filaments are longer, and the heterocists common. In the three following

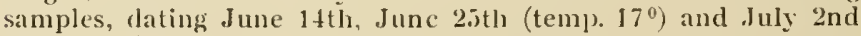
(temp. 150 ), the species decreases steadily; only a few filaments occur, generally with heterocysts. The fishermin reported that up to the 1 st of Sep. no aquatic-llower occurred on the decper Norreso near Viborg while therc was one on Sonderso whieh is shallower, as mentioned in (hap. 1. This shows that quite diflerent conditions prevailed in the cold summer of (t) and in the warm one of $(1)$.

The prevailing conditions in Julso are quite similar to those in the Viborg lakes, lacre also no max. oceurred in (0.).

Haldso. The conditions obtaining in Haldso are very confused. Up to Nor. 10th, (0) (tcmp. 10 $\left.{ }^{\circ}\right) \mathrm{A}$. $f l$. $a$. occur's in almost all the samples, but only singly; then the alga suddenly grows eommon and on Dec. 8 th (temp. $4^{\circ}$ ) attains a great mis. which eontinues to dan. 3rd (temp. $\left.2^{0}\right)$. After the breaking up of the ice on March $22 n d($ tcmp. 20 ) it is very rarely met with, but 
frerpuently ocems atain on May $30 t h$, (temp, $\left.8^{0}\right)$; it keeps to a smalle max. up to dune $11 t_{1}$ (temp. 120 ), then the species decreases and disappears almost entirely duly 3rd (temp. 140). We atre not anite ecetain whether the individuals occurring in the samples of Nov- Dece (0) eontain heterocysts.

This curious instance of an Aphan. reaching its max. at a temperature of $4-2^{0}$, while it ollerwise always oecurs at the highest temperature of the water, very strongly suggests that we alle here dealing wilh a distinct species. And in this calse it can be no other than Oscillaloria Agardhii, which P. Richter $(6)(;, p .2(i 3)$ has declared to be identical with the sterile examples of Aphan. flos aqua' which are devoid of heterocysts. But this assumption has been disputed by Schmidt (99, p. 351), who points out that the calp (calyplra) is always wanting in Aphan. while it is well-developed in O. Agardhii. As we have never come across calyplras in the specimens from Haldso, relying on Schmislt, we refer the alga temporarily to $A$. flos aqua especially, as the individuals which again appeared in May-June were typical Aphan. filaments, with well-dereloped heterocysts (Tal) Vil, Figs. 82-83). We have not been able to find spores in any of the Aphan. from Haldso, neither have we observed any of the filaments from the latter place githered into tufts.

We may point ont that $A$. f. $\alpha$. has also been recorded from other places as occurring during winter (Magnus, 65 p. 129; Lerander $(00 a ., p .13,00 b ., p, 36)$; in the following we shall not refer to these winter-aphanizomenon, as they repuire to be more elosely examined.

Excepling the conditions in Haldsø Aphan.'s mode of life is probably as follows: - The spore-bearing filaments, which sink to the bottom during Nov-Dec., are parlly by the agency of the wind, washed up on the coast, and there rol away with the exeeption of the spores; none, or only a very few of the filaments survive the winter; these have neither heterocysts nor spores. During May (temp. $10-12^{\circ}$ ) the spores begin lo grow, and the filanients now appear in the Plankton; these filaments contain heterocysts, generally only one, sometimes two. The number of the filaments increases during May-Sep., at first (temp. $12-18^{\circ}$ ) rather slowly, but later on (temp. $18-22^{\circ}$ ) very quickly, this produees during Aug. -Oet. an enormous aquatie-llower. Till Aug. the heterocysts oeeur almost constantly in the filaments; later on they grow rarer by degrees; the development of the spores begins at the end of Aug., and reaches its max. during Sep.-Oel. (temp. 12-10 ${ }^{\circ}$ ), when the heteroeysts are only met with in a few individuals; in Nov--Dec. they disappear entirely.

The great difference in the oceurrenee of Aphan. in $J u l s o$ and in Viborgso in 01 and 02 may, without doubt, be referable to the very different eonditions, as regards temperature. The temperature for growth (temp. $10-12^{\circ}$ ) oecurs of course in both years, and the growth proceeds, consequently, normally, both in 02 and 01 . The high summer temperature (temp. 20-220), whieh is necessary for the quick formation of hormogons, on whieh again, the great max. wilh its enormous acuatic-flower is dependent, oceurs only in 01; accordingly, we sec that the acpuatic-llower phenomenon is faintly developed in 0.2 . As regards the importance of the heterocysts, it is generally supposed ( $\mathrm{Kirehner} 00$, p. 71), that they serve to cut short or limit the growth of the filaments. This assumption is supported, firstly, by the lact that filaments are olten met with, which terminate in a helerocyst, which may suggest, that at this point, the filament has divided into two, secondly and especially because filaments constantly occur, which show a very characteristic rupture just opposite the place where the heterocyst is situated, as if the filament were breaking in two at this point.
Il we lake it lor granled that lieterocysts are neces sary lor the development of new filaments, or lateilitale it greatly, then il may be understood that helerocysts develop, as mentioned above, simultaneously wilh the filaments, and lhal they cease when the max. is reached, and a further development ol filaments has essentially ended; when this happens the spores begin to develop. There has existed previously, some uncertainty, as lo the lacl whether a lilamenl could bear a helerorysl as well as a spore ( $111 \mathrm{mann} 55, \mathrm{p}, 23$; 13ichler 96, 1. $269)$; at the first stage in the development of spores, unripe spores and helerocysts may be observed on the same filament (Aug.-Sep.), but olherwise we may be juslified in believing that the filaments which have begun to develop spores, (cease developing heleroeysts and consequently also new filaments.

Bruno Sehroder $(00$, p. 76$)$ was the firsl to point out hal the helerocysts, mostly, oecur during early sunmer. We have found Allman n's observations regarding the development of spores (55, p. 21) correct. Aphan. is almost always recorled as occurring in tufls. li i chter $(96, \mathrm{p} .263)$ and Lem mermann $(00 \mathrm{~g} ., \mathrm{p} .141)$ demonstrate that the alga also occurs as detaehed filaments.

In $9 \% \mathrm{~W}$-L, had occasion to closely observe the development of the tufts. A pond in the palace gardens of Frederiksborg was covered at six o'clock one July morning, with a very thick continuous layer of Aphanizomenon; an hour later the very first, faint, morning breeze had seattered this continuous layer; and a eloser examination showed, that the afuatic-flower liad turned into numerous, broad tufts, some $2 \mathrm{~cm}$. long and $3 / 4 \mathrm{em}$. broad, tapering towards the ends, and slightly twisted; all the tufts stood up vertically in the water. At 12 o'clock, midday, when the wind had grown stronger, and the surface of the pond was in continual movement, the tufts were only half as large, and during the following very windy days, they had atlained a normal size, and there occurred simultaneously, numerous, single filaments, in the water. When the plant appears in the Plankton in May, il occurs, as far as is known, only as single filaments. The development of tufts is a phenomenon which becomes more and more conspieuous, the more freely the development takes place; according to our opinion, it is dependent on the development of ayuatic-flowers, and does not take place until the pond contains so considerable an amount of Aplanizomenon that the single filaments may meet on the surface of the water and here stick last to each other. - Aphan. is not very olten reeorded as occurring abundantly in the lakes abroad; there also, it reaches its max., generally at the same time, as the water attains its highest temperature (Litr. see p. 49).

Gloiolrichia echinulala Richter was lound in Silkeborgso, Langso and Thorsso, previously it had been found in the north of futland by the author J. P. Jacobsen only. On looking through the literature dealing with this plant (sce p. 53) we find that two points require a more exhaustive examinalion, viz. the wintering, and the development of the globular stage. From bottom samples from Thorsso collected in May 02 it was proverl that a great abundance of $G$. echinulala balls had been deposited at the bottom of Thorsso; they occurred dispersed over the entire bottom of the lake; the depth of the 
lake did not exceed 9-10 metres, and was generally mucle less. 'The filoiolrichior-balls were evidently in a resting stage, all the vegelative lilaments were broken oll, and lhere was lelt only (1) Hhe helerocysts al the base; (2) llo spores siluated above it, enclosed in a sheall will thick walls: (3) the walls ol the directly aljacent 2 - 3 vegetalive cells; (1) and the mass ol slinc which enclosed all these parts. The spores were made (o) nrow in cultivalion; by sfucezing the mother-ball, llecy could be lorecel out in great guantities; each ol the cmloryo plants, pushed out in fromt of it, the rest ol the walls of the dead cells, situated above it (lig. 1, p. 3!) . Al the sime lime numerous mother-balls were mel with, on lhe surfice of which, small tufts ol embryo plants oceurred; a lew days after our cultures were full ol" snch lufts (lïg. 2). (Aphanizomenon stage)

'The transition to the rommon, well-known globular (iloiolrichior-slage oreurs as follows: liliments in the tults grow in length; (2) the filament bends into a crescent shape (Fig. 3).

As the filament gradually bends and grows longer, the cells develop in various ways; lluc outer colls grow longer, narrower, and poorer as regards contents, than the cells towarls the midlle; at last they occur as the well-known, fine, filiform apices. At the same time as these lormations appear two heterocysts develop in the midsle of each filament; they are only loosely connected, and the filament breaks in two at this point; on being stained the beginning of a sheath-formation may be traced (Figs. 4 and 5 ).

The last stage in the development is the young Gioiotrichia-ball with all its heterocysts gathered towards the contre, ancl its filaments radiating in all directions from this point, the filaments are thickest at the base and terminate in fine hairs at the outer rim of the ball; this young ball grows further by means of false branching.

General remarks. As regards the occurrence of l'lanktoncyanophyces in the Plankton of the Danish lakes see table p. 56. Their max. occur at temperatures which is different in the case of the different species, but very constant for every single species.

Chroococcus limnctica, Lyngbya bipunctata and winteraphanizomenons reach their max. at a temperature of $2-5^{\circ}$ (Dec.-April); Oscillatoria temp. 5-10 (AprilMay); Anabona flos aqua tenp. $16-18^{\circ}$ (June-July); Anabana spiroides, macrospora, Aphanizomenon, Gloiotrichia and Polycystis temp. $18-22^{\circ}$ (Aug.-Sep.). Not until the temperature of the water has begun to fall (temp. $17-15^{\circ}$ ) does Coelosphorium reach its max.

The max. and min. is most clearly defined in the IIcterocyslca (a resting-stage and resting-organs have been shown to exist together with the min.); it is less clearly defined in the Coccogonea. The greater part of the Planktoncyan. occurs in a large number of lakes, but only in a very few of them they reach their great max. (Consult Table 56 on this point, where a \pm indieates in which of the lakes the species in question attains, at the present time, its greatest max.). The reason must be sought for in the fact, that the main part of the Pl.cyan. belongs to the small, shallow lakes, where the enormous max. occur, during which the huge masses are carried into the larger lakes, which must, properly speaking, be regarded as their graves. The slatlow ponds lave a temperalure at $20^{\circ}$ during many ol the summer months; in the larger lakes the lemperalurc does not remain at $20^{\circ}$ long enough to permit the ocrurrence of the greal max. On investigating the country about Silleborg it was proved that Aphanizomenon reaches its max, in the small Salten Langso, which is $1-5$ metres in leptlu, whence its outlet Saltenaa, during the max., llows into (iudenal as yellowish groen syrup) 'The max. ol filoiotrichia oceurs in the small Thorsss, 10- 13 metres (leep. The max. was enormous in (1) and here also, the balls flow into one of the rescrvoirs of Cudlenat (Borreso) through the outlet of the lake; and in a similar manner Anabena spiroides and $A$. macrospora reached their max. in the small, shallow Grnso, and then through Lysaa were carried out into Gudenaa. (consult mal) N. ViII).

Of course some of the Cyan. on their passage through the larger lakes sink to the botton, and the following year the specimen which survive the winter grow in the lakes. W.-L. has had an opportunity of observing the young acpuatic-flower which occurs in May in the dammed up inlets of larger lakes. - How greatly the development of Cyan. is dependent on the temperature, is best seen, by comparing the investigations from the warm summer of (01, with those of the cold summer of 02. The max. of the Cyan. which occur at a low temperature, and especially of those of $L$. bipunctate and Oscillatoria rubcscens were equal in 01 and 02 , also the max. of Anabona flos aquae in 02 were hardly lower than that in 01; the max. of the latter occurred at a temperature of $16^{\circ}$, which was the max. temperature of our lakes in 02. All the Cyan. the max. of which, occurred at above temperature $16^{\circ}$, had enormous max. in 01, when the max. temperature of the lakes was $20-22^{\circ}$, but hardly developed at all in 02 , the temperature being then for below that of 01 . The investigations have also further proved, that, the germination in 02 was quite normal, which is to be understood, as the requisite temperature for germination (about $10-12^{\circ}$ ) was present, but the great max. did not occur, because the temperature, which is necessary for a lively vegetative development was not reached.

The results arrived at here, correspond exactly to those attained abroad.

The only Pl. cyan. which plays a somewhat important part in the cold, clear Alpine lakes is Oscillatoria rubescens (Chodat, Bach mann). Anabona flos aquace is the only Cyan. which here forms aquatic-flowers (Chodat). All the Cyan. which reach their max. at a temperature of $20^{\circ}$ are wanting. In the lakes of the plains of Central Europe, which essentially correspond with ours as regards depth, size, etc. the Oscillatoria play a secondary part, and the Cyan. which reach their $\max$, at a temperature of $20^{\circ}$ form aquatic-flower in abundance. Judging from our slight knowledge of the Plankton of the Arctic lakes, the Cyan. appear to play a secondary part there. As regards the Cyan. we arrive at the following main result: -

The bulk of the Cyan. does not belong to deep and clear lakes - excepting perhaps the Oscillatoria -; a great part belong; to the so-called pond-like lakes with shallower and warmer water; viz. Coclospharium, Anaborna flos aque and the Lyngbya; the main part occurs in quite small, shallow lakes with warm water, and 
rich in organic miller (A. spiroides, macrospora, Aphanizomenon, Gloiotrichiol); is regards these, he large lakes into which they are carried by means of the outlets, scrve them only for a grave, and only rarely do they meet with those life conditions in these lakes such as is necessary in order for them to thrive. Whenever these species in large lakes altain a considerable max. it is mainly owing to an accumbuation of imported niaterial. In Europe the Cyanophyrea belong to the vast plains of Central Europe; but the Oscillatoria form an exception to this rule.

At p. 60 the olsservations of foreign authors, on the formation of the alpuatic-flower, have been recorded. As is well-known, the aquatic-flower, often occurs in stripes running parallel to the direction of the wind. These stripes which have often been observed, occur, according to W.-L.'s experience, through the wind not blowing equally over the whole surface of the lake; where the wind blows strongest, the surface of the water is rippled, and the ayuatic-flower is found broken and blown onwards just under the surface of the water. In those parts of the lake, where the surface is yet unmoved, i. c. parts lescribed by investigators as stripes, the transport occurs in this part, with the result, that the aquatic-flower is swept ofl the lake and heaped up on the coast.

When the acpuatic-flower, after a period of very warm days, and a longer period of calm weather with burning sunshine, has occurred in abundance on the surface of the water, then the great quantity of organic material gathered in the upper layer of the water, is suddenly and almost entirely destroyed. Bluish white spots now occur in the homogeneous green covering, they increase in size, and at last unite and form large patches. The acpuatic-flower is dead in these parts; the cells have been killed and the bluish white colour is probably due to the fact that the cells have been emptied of their phycocyanin. The death is probably due to the intense sunlight, but numerous Phycomycetes and Bacterias also occur in the spots.

The aquatic-flower may be injurious to lishes, and regarded from a sanitary point of view, it is doubtless objectional. In the case of the aquatic-flower being formed of spore-bearing Cyanophycees, satisfactory results may be arrived at by skimming the surface of the water in Aug.-Sep., for two consecutive years.

\section{CHAP'TER V. DIATOMACEAE.}

In the formation of the Plankton of our lakes the Diatoms play as great a part as the Cyanophycees, but in contradistinction to the latter they very seldom form the Plankton of small lakes and ponds. The PlanktonDiatoms are chielly characterized by (1) their thin cellwalls and great hyalinity; (2) their spines and their awl-shaped cells; (3) their slime envelopes or slimetubes; (4) their formation into colonies - chains, stars; (5) and by their raphe being either absent or faintly devcloped.

As regards the freshwater-Plankton-Diatoms, we may record with as great a certainty as it is possible in such departuents, that the great majority of them originate from the biatons of the bottonl, and coasts of the lakes. A few of the species are imported mirine-diatoms ( $A t$ theya, Rhizosolenia).

Centrica. Melosirr: The following occur mostly as l'lankton organisuns: M. crenulata KüL\%, grronulatr (lihr.) lialfs, verians Ağ., linrolnla Grun., dislans Kül\%, laevissina Grun., arenaria Moore, orichalcea Mert.

$M$. crenulatn Kül\%. has been observed in all the lakes which have been invesligated, and atlains a very high max. in Furesø, llaldsø, Skanclerborgsø, Mossø and Julsø; the max. occurs almost everywhere in Nov. and Dec (tenip. $6-4^{0}$ ) and generally disappears while the lakes are covered with ice. A smaller max. may occur immediately after the breaking up of the ice, and nuay last till Aug. (as is the case in Julso, 02) and then become very great.

M. granulata (Ehr.) Ralfs has been met with in all the lakes except Furesø. In Sorøsø, Tjustrupsø and Haldsø this species reaches an enormous max., which occurs everywhere in Sep. and Oct. (temp. 14-12 ${ }^{\circ}$ ). During the max. the water is coloured yellowish-green it is odd how suddenly the max. may occur and disappear.

The two botiom-forms $M$. varians and arenaria have often been observed in the samples, but only in a few specimens.

M. cremulatu and granulatu therefore occur together in all the lakes which have been investigated (except Fureso); but their max. never occurs simultaneously. In Haldso the max. of the two species are enormous, almost equal and follow each other. In most of the other lakes only one of these 2 species attains a great max.

It is beyond doubt, that M. granulata has only one max. in Denmark. As regards $M$. crenulata, circumstances secm to favour the theory of two max, because the freezing of the lakes, or its competition with other species, may interrupt its autumn max.; then a new one begins after the ice has broken up for the last time (Sorøsø, V'iborgsø).

It appears as if a sudden freczing over in the midst of the max. in Dec. occasions this cessation, even if the ice breaks up again soon, about a fortnight after the freezing (Soroso, Viborgsø). This can only be explained by the fact that the Melosira, cluring the entirely quiet period, sink to the bottom, and other species furnished with better floating apparatus take their place (see under Asterionella). The nax. of $M$. crenulata is, however, best cxplained, by regarding it as a continuous max., attained at a temperature of about 4 to $10^{\circ}$.

As a rule, the max. of both species appear to be almost equal, in small, warm lakes, as well in largc, cold ones; but in the smaller lakes the great max. begin earlier than in the larger ones, in return, the durability is generally somewhat greater in the latter. But there are exceptions to both these rules.

In ponds the two species play only a secondary part

$M$. belongs chielly to the shallow and warm lakes of the plains of Central Europe, and it occurs only in very small quantities in the Swiss Alpine lakes (see p. 65).

Cyclotella. As regards the systematic see Schröter $(97$, p. 32); B a ch mann $(01$, p. 231); L emm crmann $(00$ c., p. 29). 


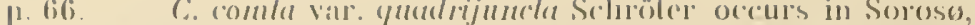
Tjuslrmpso, Skind(rolorgso, Masso alud Julso). It is nuosl liecpuently med will in lhe lwo lirst lalies, but is on the whole, rare, and nowhere in bemmatk does it play a prominent part as a Planklon organism. The Cigclolella

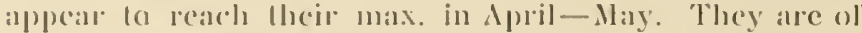
no breal importance in any of the plans of Central Europe, but belong to the chicl l'hanklon organisms of the Swiss nomblan-lalies (see p. (66). This shows that the Melosira are characteristic of the lakes of the plains, and the Cigclotelle ol the Alpine lakes. In Norway also the delosine appear lo be more common than the Ciyclotella. (110lmboce 00, p, 9 and p. 20).

Sleplanodiscus. 'Three Plankton organisms oceur in lieshwaler": S. astraea, Hankschii, Niagare, and \%achariasi.

S. aslrara (klar.) Grun. has been observed in all the lakes. Is a Plankton organism it appears to be of much more importance in the Danish lakes than in those aloroad. Il atlains a considerable max, in Fureso, Esromso, llaldso and partly in Viborgso. There is a similar clapse ol its periodicity in all the lakes. When the temperilure falls during antumn, and reaches a lenperature of $7-6^{\circ}$ C. it increases slighlly, and very slowly, in number, but keeps on increasing while the lake is as yet lirozen over. lmmediately alter the breaking up) of the ice a very great max. (temp. $4-6^{\circ}$ ) may sometimes occur, which disappears before the temperature $10^{0}$ has been reached, but somelimes it may exist at a lemperalure $13^{\circ}$ (June 01, Haldso), then the species decreases rapidly and is rare in all the summer months. S. $a$. formis an exception to this rule in Viborgso where it reached, (but it was only in the cold summer of 02 ) a great max. on July 27 th (temp. $15^{\circ}$ ).

lu the ponds investigated in $98 S$. $a$. was not found. 1)uring the great max. the species may occur in rouleaux consisting of 4 to 6 individuals. It is often recorded from the Swiss lakes and from the lakes of the plains of Central Europe, but nowhere does it appear to reach such great max. as with us (see p. 68).

$S$. Zachariasi Brun has been observed in a single sample from Aug. 30th, 01 (temp. $17^{\circ}$ ), from Fureso, and by Dr. Rosenvinge in Jan. 02 in the pond in the Botanic Gardens in Copenhagen.

p. 68. S. IIanlsschii var. pusilla Grun. has been found in Viborgso, in a single spring sample.

Rhizosolenia. While the Rhizesolenia play a very prominent part in the Plankton of the sea, they are very poorly represented in the freshwater Plankton. Only three forms occur in fresh water ( $R$. longiseta, $R$. longisela var. slagnalis and $R$. eriensis $\mathrm{H}, \mathrm{Sm}$.).

p. 6is. $R$. longisela Zach. has been met with in Soroso, Tjustrupsø, Haldsø, Skanderborgsø and Julso. It occurred abundantly in Almindsø near Silkeborg on Aug. 3th, 01 (temp. $18^{\circ}$ ). Nothing definite can be recorded as to its periodicity; resting-spores (》Dauersporen *) have often been met with in the winter-samples. Filanents consisting of 3 to 4 individuals have been observed.

Allheya. Of this well-marked marine genus only one species occurs as Plankton organism in fresh water.

p. 69. A. Zachariasi Brun has been found in Furesø, Sorøsø, Tjustrupso, Haldso, Slianderborgso, Mosso and Julso. It appears to be rare everywhere, most common in Aug., Sep. Resting-spores have been observed in Oct., Nov.; liluments, consisting of lwo individuals, have becn observerl. (Literalure see pp. 69-70).

Pennata. Fragilurio. In freshwaler there occur three Plankton organisms. Fragilaria crolonensis Kilton has been nel with in all the lakes and in several ponds which have been examined.

I. crolonensis is widely distribuled in 1)enmark, and it is perconial in most of the localities; it may at times, allain a very considerable max., whicll is, however, mostly of short duration. It is everywhere extremely rare, during the winter months, al a temperalure of about zero, and occurs only in a few specimens immodiately after the loreaking up of the ice. A montl later it begins to in crease in number at a temp. of $13-16^{\circ}$, llen a spring max, occurs from May 15 tlı to June 15 th (tenip. 13-160) in Sorose it occurred somewhal earlier (May 5th, 01 temp. $10^{\circ}$ ), lout ceased when the greal max. of the Dinobryum began; in Esromso it was very considerable on June 26th, 01, and in Furess on June 7 th, (01. As soon as the tenp. $18-20^{\circ}$ has been reached the number decreases, and the species was rather rare in all the summer months of ()1. In the autumn of 01 a new max. occurred at a temp. of about $16^{\circ}$ (Fureso Sep). 7th; Esromsø Aug. 12th--Sep. 30th; Tjustrupso Sep. 17th); then the species decreased gradually everywhere.

The results of the investigations of 01 and 02 bear each other out fairly well; but during the summer months of 02 , there is a curious irregularity, as regards the number of the individuals. As in 01 the species is on the point of disappearing on, or about, June 15th, but as the temperature, on account of the cold summer, nowhere rises much above temp $16^{\circ}$, which appears to indicate the boundary line for the max. of the species, a second summer max. happened in 0.2 to which there is no parallel in 01 . These summer max., which were more or less a continuation of the spring max. (Fureso July 11th; Sorøsø June 7th; Haldsø Juli 3th-Aug. 2nd), could be exceedingly great (Haldsø).

It appears that $F, c$. does not thrive at a temp. of $16-22^{\circ}$; this results in the species having in most of the lakes and in nearly every year in Denmark a double max; one in May-June and another in Sep.; both occurring at a temp. of $13-16^{\circ}$; in particularly cold years (02) the two max. can almost reach each other and merge into one.

The length of the bands is greatest under the max. towards winter the bands break up into pieces (cp. Z acharias 95, p. 140). $F . c$. is widely distributed, and appears to be as common in the Alpine lakes as in the lakes of the plains (see p. 71).

$F$. virescens Ralfs is a bottom form and occurs often in single specimens in the samples.

Synedra contains mostly bottom and coast forms. Plankton organisms are: S, acus var. delicalissima, S. ulna var. longissima and var. aclinastroides, and $S$. berolinensis Lemm.

S. acıs Kütz. var. delicalissima Grun. has been observed in all the lakes; it reaches its max., which is rather considerable, in Fureso and Skanderborgso in April and May (temp. $1-10^{\circ}$ ), but it may begin earlier (temp. $1-3^{0}$ ). S. $a$. has been recorded from some lakes abroad, but it has doubtless often been overlooked.

S. ulna Ehr. var. longissima Lemm. has only been p. 73 . met with in Tjustrupsø, where it occurred abundantly 
on May 16 th, 02 (temp, $8^{\circ}$ ). It is only exceplionally mentioned in liankton-papers from abroad. (\%acharias 96 a., p. 157; Hol mb be 00, p. 9).

p. 73. S, nluc lilir. var, actinastroides Lemn. has probably been nel witl in Gudenaa; il is, together will Actinastrum Hantzschii said to be characteristic of the so-called l'otamo-planktou; bul we think it quite unnecessary to lound a separate Potano-plankton, witl these two colonies as its chiel forms (Bruno Scluroder 99 a., p. 20); we agree with Schnidle $(98$, p. 9) in not acknowledging the term Potamo-plankton, and regard $S$. ulna var, actinastroides simply as a bottom folm, occurring in busl1formed colonics, which has been broken off from the bottom by a strong stream, and which therefore, as long as the colony kceps lloating in the strean, leads a quasi-pelagic lile.

Aslerionella. The two species A.gracillima Hantzsch and $\boldsymbol{A}$. formosa Hassal have been united. They are recorled as diflering from each other, by the fact that the individuals in $A$. gracillima touch each other in a point, while those in formosa touch each other in a line. But in the Plankton samples all transitional stages are met with; in the 4-rayed colonies the individuals doubtless touch each other only in a point; in the manyrayed most frequently in a line.

p. 74. A. gracillima Hantzsch has been observed in all the lakes which have been examined and reaches a considerable max. everywhere; it appears, noreover, to be the only Planktondiatom which is capable of forming a considerable max. in small lakes and ponds. In 98 it was met with in the lake at Frederiksloorg palace and in the ponds 3-4-5-6-7-8. In the lake at Frederiksborg palace, it had attained to such an enormous max. in April-May that the water was quite thick; very great max. occurred also in No. 6, Teglgaardsso, and in No. 7, Virummose, but in the latter they did not occur until July 1st, and in both places they lasted till about Aug. 1st. From the above we see that $A$. gracillima belongs to the most common Plankton organisms of our larger lakes as well as of the smaller ponds, and that it occurs everywhere as perennial, sometimes reaching a very great max.

Of the present investigations, only the following more general points, may be mentioned.

The investigations of 01 show that Asterionella in April-May (temp. $1-12^{\circ}$ ) had reached a max. in all our lakes, after which (excepting Esromso) a min. occurred, which lasted in all the lakes till at least Sep.-Oct.; at this time there occurred in Furesø (Sep. 7 th, temp. $16^{\circ}$ ), Tjustrupsø (Sep. 17 th, temp. $12^{\circ}$ ) and in Viborgsø (Oct. 14th, temp. 120) a new, small max, which was either extremely small or quite wanting in all the other lakes.

In Dec. 01 a short period of frost occurred, which resulted in all the shallow lakes, viz. Sorøsø, Viborgsø, Skanderborgs and colder lakes viz. Furesø, Esromsø, Tjustrupsø and Haldsø were free from ice. It was now proved that in the three first lakes, an enormous Asterionella-max. occurred, which appearcd either immediately before the freezing over, or just after the breaking up of the ice, which was during the last day's of Dec. The max. lasted in these lakes the whole of Jan., as long as the lakes were free from ice, but during the second freezing over, which lasted lrom the end of Jan. to about March 20th, the number of the species generally lessenerl perceptibly.

On the other liand, in those lakes which thid not freeze over in Dec, the Asterionella developed quite diflerently; no max. worthy of notice occurred licere during the whole of Dec.-Jan., and when these lakes were frozen over at the end of Jan., the species was very rare. 13ut after the breaking up of the ice at the end of March a very grcat Asterionella-nax. occurred whiclı lasted till about April 15th (Lenıp. about $5^{\circ}$ ).

Consequently, the quantity of the Asterionella differed greatly in our lakes in April-May. One of the conditions for enabling the Asterionella to reach their enormous max. at a low temperature, appears to be, that the lake must be frozen over; at least the facts we have at our command point to that conclusion, and at any rate it may be taken for granted that the freezing over does not check the Asterionella-max., which, in the lakes mentioned above, is as great immediately after the freezing over as it is before. This circumstance can only be understood by the fact that the Asterionella are able to keep floating in the layers of the water, even when they are in repose during the time the lake is frozen over. In this conncetion the floating apparatus of gelatinous membrane, observed by Max Voigt must be of great importance; it may moreover, be assumed, that neither the assimilation, nor the division entirely ceases, as long as the lake is ice-bound.

It is very interesting to observe, how very diversely the freezing over of the lakes influcnces the two Diatomgenera, Asterionella and Melosira, which here in Denmark attain the greatest Diatom-max.

If anything, the freezing over of the lakes appears to act in a stimulating manner on the max. of the Asterionella, at any rate it does not check it, while it checks, or even puts a stop entirely to the max. of the Melosira. The latter, which, as far as is known, have neither gelatinous membranes nor other floating apparatus, probalbly sink to the bottom when the lake is ice-bound. In Jan 02 when all our lakes were free from ice, the great Asterionella-max, occurred only in those lakes which had been frozen over in Dec. (Viborgsø, Sorøsø and Julsø), and in these the Melosira occurred in the minority. On the other hand, in Jan. 02 the Asterionella were met with only in small quantities in those lakes, which had not been frozen over in Dec., but here, on the contrary, the Melosira often attained during the same month considerable max. (Furesø, Tjustrupsø and Halds $ø$ ).

As is wcll-known the Asterionella almost always occur stellate-shaped, very rarcly turned into cliains. As far as is known, the species has never been met with attached to any substratum. The number of the rays (cells) in a star is mostly 8 . On examining an eight-rayed star more closely, it will be scen that one of the individuals always overlaps the following individual, which results in the star not forming a closed circle, but a spiral, as has already been pointed out by $\mathrm{H}$ eiberg $(63$, p. 68$)$. In the case of the star containing more than eight individuals, the growth takes place spirally. According to the number of the individuals, the colonics consist of $1-2-3-4 \ldots$ spirals; when the latter are few in number $(2-3)$ they are generally situated in one plane, and then the colony is risc-shaped; 
bul il the number increases the individuals are displaced and spread out in all directions; now the colony is no lomger discoshapoed, lout globular.

Sonnctimes the circle is not rescol with 8 rays, but will a smaller numlecr, 5-6i-7; when the circle is resed loy d, these are siluated cross-wise two and lwo, and alunost in prolongation of carelo otloce (angle 90 $0^{\circ}$ ); in colonics consisting ol three individuals there are $120^{\circ}$ molwecon 2 lays.

The chain-colonies (Tab. Vill, lig. 92) are generally not \%igzag-shaped, as is the casc wilh Dialoma lenue and Tabellaria fenestma; they may be described as conlinuous 3-payerl colonies, which form a long, continuous riblon, for the most part bent and somctimes closed (Julso April 2.th, 11 ; Mosso May 5th, (1). On examining He considcrable material, it was proved that by far the greater part of the Asterionella of a lake, containcel in the sime sample, are always cither ribbon-sliajocl or stellate; that the number ol the rays in the stars varied groatly at different seasons in the differcnt lakes, but that the number of the rays in all the Asterionellacolonies nuct with in a single sample are mostly remarkably constant. Thus, the colonies which develop into ribloons occur only in April and May (Julso, Skanderborgso, Mosso); the 4-rayed ones only in May (May 5th Tjustrupso, in the lake at Frederiksborg palace, pond $\mathrm{Nr}$. 7). The globular, many-rayed colonies, are essentially dominant after the great spring-mas., but may also be met with later on in the year. From July, to as late as lieb., the 8-rayed stage appears to be the most common, but sometimes many-rayed colonies break into the series, apparently without any rule whatever.

Moleover, there are lakes, e. g. Haldso, where the Aslerionella appear to be mostly 8-rayed; while in others the many-rayed ones are very common and occur almost all the ycar round. In Esromso, in 01, the autumn max. was, so to speak divided into two, one occurring Aug. 12 th (temp. $21^{\circ}$ ) and the other Sep. 30th (temp. 17 ${ }^{\circ}$ ). In the former the Asterionclla were chiefly 8-rayed; in the latter almost exclusively 16-20-30-rayed.

lt may doubtless be taken for granted that the 8-rayed stage is the typical one. Therefore, if it be proved, that all the Asterionella of a lake either occur in chains or are t-rayed or many-rayed, and moreover, from the fact that this phenomenon, at any rate in part, occurs simultaneously and at stated seasons in all the different lakes, we may conclude with some certainty, that it is occasioned by the cooperation of outer circumstances.

A. grac. has a very great geographical distribution; on this and on its periodicity see p. 76. Marsson (01, p. 113) and $\mathrm{Bruno}$ Schroder (99 a., p. 33) have found colonies, as we also, with the least number of rays in spring. As regards the pollution of drinking water ly the Asterionella see Whiplole's excellent works on this subject $(94-00)$.

Centronclla Reichelli M. Voigt has been observed in a single spring-sample from Soroso.

Tabellaria occurs only in one decided Plankton-species.

p. 78 . T. Teneslrala (Lyngb.) Kütz. has been met with in the greater part of the lakes, but only abundantly in Fureso. It reached its max. here in 01 and 02 in May (temp. $10-13^{0}$ ). In 02 a new max. occurred Aug. 3rd (temp.150). lt appears to be rare everywhere as Plankton organism (see 1). 78).
T. forestrata (c). specially Tal). 11) occur in the Plankton botll in clains and in stars, var. asterionclloides (irunow. In all the samples from Jan. 10th, (1), up to the time the species los reached its max., May 15th, (0), it is met will chiclly in chains; when stars occur, these are selom more than 7-8-rayed, and generally not rosed. At the same time as the max. is attained several 7-8-rayed stars occur, and in the following samples, May $27 \mathrm{th}$ and Junc 711 , $T$. feneslrala is met with only in stars, with a constantly increasing number of rays, May 15th, 10-12-rayed; May 27 th and June $7 t h, 20-30-40$-rayed. During the rest of the year, only stars wilh varying numbers of rays arc observed (mostly only 12-16-rayed); it is not until Jan. 2nd to Jan. 31st that chains again begin to appear in the samples. In 02 the conditions are quite similar to those in (01. Up to April 25th the number of chains constantly increases, then the division into stars begins; the latter are generally 8-rayed, May 21st; 12-16-rayed June 5th-June $17 \mathrm{th}$; during the enormous max. July $11 \mathrm{th}$, many-rayed stars were predominant.

This shows that both Asterionella and Tubellaria are divided into chains at the same season of the year, April-May; both of them are nany-rayed after the great spring-mas.; and both occur later in the summer and during autumn with very varying, but mostly with far less number of rays. But the star and chain development takes place, however, very differently in the two species. While 3 or 4 individuals are sufficient to close an Asterionella-star, with angles of relatively $120^{\circ}$ and $90^{\circ}$ between each individual, Tabellaria-stars have never been met with that have been able to close with less than 7 individuals. If the star consists of fewer individuals, either a $1 / 4,1 / 2,3 / 4$ circle occurs, according to the number of rays being $3-4$ or 5 . In the case of the number of individuals in Aslerionella and Tabellaria increasing, they shoot in both instances up spirally over each other. But while some individuals in Asterionella differ from the original plan and place themselves in all sorts of reciprocal angles, the star in Tabellaria straightens after a lapse of time and joins again, forming a larger circle which is now able to contain a greater number of individuals; colonies with the individuals displaced and spread out in all directions as in Asterionclla have never been observed in the Tabellaria.

The chains in the two genera also develop quite differently. In the Asterionella these chains develop, either by the linking together of simply three-rayed colonies or very seldom by the individuals being situated almost in a continuous row, - in that case the angles between them are often nearly $180^{\circ}$. In the Tabellaria the chains may also develop in the first mentioned manner, but in that case the angle between the individuals which meet, is very pointed and rarely exceeds $45^{\circ}$; this produces the characteristic zigzag-chain. But the chain consists mostly of semi-circles each containing $5-6$ individuals, which are always arranged alternately, so that the convex side of the first semi-circle is turned away from the onlooker, while that of the second is turned towards hin, etc.; sometimes a chain, consisting of single individuals placed zigzag is inserted between the semi-circles (cp. Schrooter 97, p. 35).

T. flocculosa Kütz. This well-marked bottom-form was found in chains in most of the lakes. In סxeso near Skorping in the north of Jutland it occurs as stars; 
lloluboe $(00$, p. 11) records it also as stellate from Norway and calls it var. pelagica.

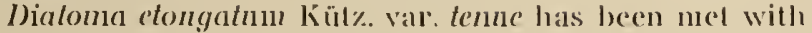
in all the lakes except Soroso and Viborgso, but attains great max. only in Skanderborgso, Mosso and Julso. The max. occurs everywhere in April May (tentp. 4-100). It is recorded fairly often as Planktondiat. from the lakes abroald. It is met with everywhere as chains. The nax. is recorded as occurring in April-May. Bruno Schroa er $(00, p .7 .1)$ only records the max. occurring in June in Barlewitzersec, and here the species is met with as stars.

The researclies prove that Tabellaria, Aslerionella and Dintoma according to the records of all the investigators, are divided into chains simultaneously in April and May; then the Dialona disappears from most of the localities, and no stars are developerl; on the other hand Tabellaria and Asterionella keep on existing as Plankton organisms till June, but occur now almost exclusively as stars. Now it is very interesting to note that in the case of Diatoma not reaching its max. before June, then it also develops into stars, as recorded by $\mathrm{Br}$. Schrøder.

On mentioning the star-forming Plankton-Diatoms, Aslerionella, Tabellaria fenestrala and flocculosa and Diatoma elongatun it should be pointed out (see also Holmboe 00 , p. 11) that at least Tabellaria and Diatoma are forms which mostly occur attached to some substratum; and in that case they, as far as is known, never occur as stars, but as chains only. As Plankton organism it is characteristic of the species to occur in stars, but the star-stage does not seem to appear at a low spring temperature $\left(1-8^{0}\right)$, but at a somewhat higher temperature $\left(8-12^{\circ}\right)$ and it appears, simultaneously, in all the forms. Plankton-investigations have proved that when the Diat. in May-June disappear from the Plankton, it is always as stars, but when they reappear next spring, in March, it is chiefly as chains. It is therefore possible that these Plankton organisms are recruited every year from forms which are attached to some substratum, and that these Diatoms change, consequently, between a chain-forming stage when they occur attached to some substratum, and a star-forming, pelagic stage.

Here is evidently a wide field open for a closer study of the reasons why these bottom-forms turn into Plankton organisms, and the conditions which cause the form of the colonies to undergo such considerable changes. What is here required is regular, daily investigations in nature, supplemented by cxperiments in the laboratory (especially with light of different strength); as long as these means are wanting; a further treatment of this subject will only lead to fruitless speculations.

p. 81. Bottom Diatoms in the Plankton. In the Danish lakes also, some bottom Diatoms occur. The Plankton consists chiefly of Cymatoplenra elliptica W. Sm., which, especially in the Furesø, appears to be a typical Plankton organism, and it is, during spring and autumn, one of the main forms in the Plankton (cp. Litr. p. 81).

It is after the severe autumn storms (Nov.-Dec.) that the bottom- and coast-forms are most conmon in the Plankton. The broad belt, which almost always occurs in our lakes outside the Scirpus-Phragniles growths, and which consists chiefly of Potamogeton lucens and $P$. perfoliatus, is at this time in a half rotten condition; it is loosened by the dash of the waves, and carried with its Dialom-coatings to the roast, where a broall belt of washed up vegelation occurs. When the lake rises, this bell is washed away, and the rotting heaps, wilh the material accumulated on them during the sumner, consisting of Diatoms, livularias, Chlorophycees, ete, are scattered over the lake. The Plankton simples of Dec. from Tjustrupso, Esromsa and Skanderborgss which I know for certain to have been collected from the midlle of the lakes, contained such great guantities of these epiphyte-societies, that one could well believe them to have been taken from the vegetationbelt on the coast.

Bottom Diatoms are especially common in such lakes, which are very shallow, thus they play a prominent part in the Plankton of the lake Ballaton (Istvanffi 98, p. 22); I have found them in quantities especially in the Plankton samples from Sjælso which is only a few metres in deptl.

General remarks. The table on p. 82 shows that 25 Diatom-species occur in the Plankton of our lakes; the 8 are tycholimnetic, and the greater part of the others is met with in a few of the lakes; even if their max. be fairly great, it seldom lasts long. The four main forms of our lakes are: Melosira crenulata and grannlata, Fragilaria crotonensis and Asterionella gracillima. The great Diatom-max. occur at a temp. of below $10^{\circ}$, but never above $16^{\circ}$ (excepting Asterionella). The Fragilaria reaches its autumn max. at temp. $16^{0}-13^{0}$ (Sep.); that of the Melosira granulala at a temp. of $14-12^{\circ}$ (Oct.). M. crenulata and Asterionella begin their max. at a temp. of $6-4^{0}$ (Nov.). If an early frost occurs in Dec., Asterionella attains an enormous max. during it and after; should the lake keep free from ice, it is $M$. crenulala which forms the main part of the Plankton of the lake. Both of these species may attain great max. after the final breaking up of the ice in March-April the following year. The max. of the Cymalopleura occurs at a temp. of $3-4^{0}$, March-April; that of the Stephanorliscus at a temp. of $4-6^{0}$, April; Synedras May, at a temp. of $10^{\circ}$; Tabellaria, May, at a temp. of $10-13$; and the spring-max, of Fragilaria crotonensis at a temp. of $13-16^{\circ}$. Diatoms may attain double max., especially those forms the max. of which occur at a high temperature (F. crotonensis). Only the Asterionella appear to be able to reach a max. at all temperatures. During a decided min. the Diatoms do not entirely disappear as is the case with many of the Cyan.; some of the individuals generally survive.

The Plankton Diatoms appear to be more local than the Cyan.; a great many of the forms belong each to its own particular lake. There are lakes where the Diatoms appear to thrive more particularly, and where one great Diatom-max. succeeds the other, e. g. Furesa (with 6 species, each attaining a great max.; Haldso with 5 species, each attaining a great max.; other lakes are poor in Diatoms, e. g. Viborgsø, where only one of the Diatoms attain a great max,, viz. Aslerionella). The different Diatom species do not attain every year the same max, in the lake in question. The occurrence of the numerous and great Diatom-max. appears to be dependent on the following circumstances: -

It is proved that the Diatoms attain their great max. at a temperature of under $15-16^{\circ} \mathrm{C}$. Hence the great 
niax. acour especially in the deep and rold lakes. The lieall al Ilese lakes increases rery gradual; linem the time the iec hreaks up nontil the waler has reached a lemperature ol $16^{\circ}$, so long a lime elajuses that a develapment al He greal max. ('an lake place, and vice-versa during antumn so lang a lime passes by before the lakes are liowen llat there is also time for the developunent ol Hhe nils.

ln the small warm lakes, in which the waler, as carly as May, allains a lemp). of $15^{\circ}$, and which are frozen over a process which appears to linder the greater fart al the forns lrom increasing in number — as early as Nav., llo time allowed lor the development of the l)ialom-max. is so limited that it generally prevents llese max. from growing particularly great.

The investigations have now also fully proved, that the lialoms play the most prominent part in our coldest lakes. The max. begin here first and ceases last. In llaldso, Tjustrupso, Fureso and lisromso the Diatoms are dominant as early as in September, and continue la be so till Iune in the following year; Oscillatoria and Lyngbya only, will short intervening periods, dispute lheir clains to be the dominant ones; in the shallow lakes with high summer temperature the Diatoms begin to develop much later and disappear as early as in May.

There are, however, exceptions to this general rule, but they are mastly applicable to the Asterionella, the only Iiatom which can attain an enormous max. even in small lakes and ponds, e. g. in the small Sorøsø, and which, moreover, is the only Diatom which has been proved to reach a nax. at a temperature of above $16^{\circ}$ (Esroniso, Aug. 12th, 01).

So long as more exluaustive examinations are wanting, it seems mosl natural to presume that the temperature of the water is the chief agent in determining the occurrence of the numerous and great Diatom-max. in a lake. That the temperature at any rate plays a very prominent part is distinctly shown by comparing the bulk and duration of the Diatom-max. of 01 and 02 . In the warn, early part of the summer of 01 all the Diatoms had disappeared as early as the end of May and the beginning of June; the Fragilaria crotonensis only, remained till about June $15 \mathrm{th}$, and the Asterionella attained in 01 its max. in Esromsø. In $0^{\circ}$, on the other hand, the max. of the Fragilara in most of the lakes continued to the end of July; the Tabellaria fenestrata had a very large max. in July (Furesø); the Melosira formed in July the main part of the Plankton of Julsø and Esromsø; the Stephanodiscus occurred numerously in Viborgsø at the end of July; and the Asterionella attained great max. in most of the lakes in June-July.

Several investigators have assumed that light and not temperature is the chief agent in deternining the occurrence of the great max., but the above statements do not appear to favour this theory. 'The number of sunny days in the months May-Aug., 0 , were much fewer than in 01; the great Diatom-max. which occurred in these months in 0.2 , and which were unguestionably abnormal for our lakes; appeared in the very year, in which the total amount of light during the period in question was decidedly less.

All our lakes, at a certain time of the year, attain the temperature which is primarily requisite for the development of the great Diatom-max., but, some of
Hrem do not attain the temperalures, which, in cooperation will aller lacturs, are necessary for the thriving of several of the Cyanaphycees (Aphanizomenon, Gloiotrichia, Anabana spiroides, macrospora, Polycystis); it is therefure easily understood, why the Diatoms during the winter hall year almost everywhere altain larger ar smaller max., while on the other hand, many of the Cyanopliycees during the summer half year, hardly (levelop) at all in the characteristic lor their many and great Diatom max.

The Diatoms and the Cyan. generally diller, not only in regard to the locality, but also in regard to time. The great Cyan.-max, never accur at the same time as the greal Dialom-max. The Anabena flos aqua only reaches its max. just at the end of the spring max. of F. crotonensis. In several of the lakes - generally at the end of May - the great Diatom-max. cease before the Cyanophyee-max. begin. Provided no great Dinobrym-max. occur in these lakes the main part of the Plankton will be found to consist of \%ooplankton: $\mathrm{Cr}$ stacea and Rolifera. At this time the lakes are very poor in Plankton and the water is unusually clear. The max. of the Fragilaria begins as a rule, before that of the A. flos aquo ceases, and in such a case the lake is at no period during early summer, devoid of Phytoplankton.

With the exceplion of Asterionella and partly of Rhizosolenia, Plankton-diatoms do not occur generally in pond-Plankton. The reason for the fact that the Plankton-diatoms play so insignificant a part in small lakes and ponds must doublless be sought for especially in the great daily fluctuations of temperature, which, during the summer half year in Denmark, may amount to $10-15^{0} \mathrm{C}$. The Plankton-cyanophycees, which, as mentioned above, constitute the greater part of pond-Plankton, are, on account of their air-vacuoles, independent of the vertical currents which occur in connection with the fluctuations of temperature. The Diatoms, on the contrary, are kept continually rising and falling, they being entirely at the mercy of the vertical currents, which are doubtless chiefly responsible for their place in the layers of water. The danger run by the floating apparatus, especially the gelatinous membranes, of being damaged or polluted by the quantity of floating detritus, and of being weighed down during the sinking process, to the bottom, or of coming in contact with vegetation, is unquestionably greater in ponds than in large, deep lakes.

$\mathrm{WT}^{\top}$. $\mathrm{L}$. tried to arrive at an underslanding of the nature of the resting-stages of the Plankton-diatoms, and was for some time of the opinion, that the auxospores were not only organs of propagation, but might also be restingstages. But the investigations led to no definite results. Excepting the resting spores in Allheya and Rhizosolenia which we know for certain to exist, it must be owned, that at present, nothing is known regarding the restingstages of the freshwater Plankton Diatoms, nor, consequently, have we any posilive knowledge of their restingperiods; we know, that yearly, there occur very marked min., but how far these min. are identical with restingperiods, and in such a case under what form, and where they occur, we know nothing at all.

It may be taken for granted, that after the great max. the Diatoms sink to the bollom. This slow sinking 
process has been distinctly pointed out (W.-L. 00, p.650), and Plankton Dialoms have been nret with abunclantly in lake Gyties (W.-I.01, p.116, etc.). It is a well-known lact lliat Diaton-Plankton when poured into a bowl, very soon sinks to, the bottont to rise no nlore; it apparently keeps alive for montlis, at the bottom of the glass. Zacli arias has made a special study of this sinking process, and lie has calculated, that a Melosira filament requires 50 minutes to sink 1 metre $(95 \mathrm{~b}$., p. 105). When the great max. is at an end in nature, the Diatonıs disappear, so to speak, almost entirely, and juclging from the above, we may conclucle that they have sunk to the bottonr.

We know, that the Cyanophycees are able to rise from the bottom and keep floating in the surface layers of the water by the agency of the air-vacuoles, but nothing is known for certain, regarding the factors, by means of which the Diatoms which have once sunk to the bottom are again able to rise to the surface; also we have very slight knowledge regarding their floating apparatus; on this point, however, some light has been thrown by the excellent investigations of $\mathrm{Max}$ Voigt $(01$, p. 36) on the gelatinous membrane in the starforming Diatoms and in the Cyclotella. But even if these gelatinous membranes be of importance in preventing the organisms from sinking too rapidly, they are of no help whatever in the rising process, which process is primarily necessary in order that the organisms may pass from the bottom stage, to the floating one. At present nothing is known regarding the agency by means of which, the Diatoms which have once sunk to the bottom, again rise to the surface, consequently we are unable to explain the occurrence of the great max. The suddenness with which they often occur, clearly shows, that they cannot develop out of the small number of Diatoms which, as mentioned above, is always found in the water, during the intermediate time between the occurrence of the great max.

As it must, consequently, be taken for granted, that it is the bottom material which rises to the surface, and as this presumably lacks the means in itself of rising again to the surface, it has been maintained, that the rising process occurs by the agency of the vertical currents in the water.

It is especially the works of Whipple which have thrown light on this point; he demonstrates, that the great Diatom-max. occur during periods of complete vertical circulation. I agree with Whipple on this point, but I want to add that it is especially in the shallow parts of the larger lakes, that the vertical currents are important as factors in the rising process of the Diatoms; it is clear that in lakes, which are so deep, that they contain layers of water, which are undisturbed by the yearly vertical currents, there will be large central portions at the bottom, from whence none of the organisms rise again to the surface. But also in lakes that are not very deep, the material which has sunk to the botton will probably rise again to the surface, chiefly from a circular area, which extends from the coast more or less towards the middle of the lake. The Diatoms, which occur at the bottom outside this area, never rise to the surface again, but are destroyed sooner or later. In the shallow part of the lakes along the coasts the wash of the waves unite with the vertical currents in raising the bottom material. The question regarding the sucklen appearance of the gleat l)iatom-luax. can hardly be solved otherwise at present than by presuming, that they are produced by a rapicl multiplication ol the cleposited material, which liave risen to the surface lrom the shallow part of the lake by the agency of the vertical currents and of the waves.

This view of the nuax. is supported by the following observation. On conplaring the way in which the great Diatom-max. occur in (leep) lakes, e. g. Haldsø, with their rise in our smaller, shallow lakes, e. g. Sorwsø, it will be seen, that the Diatom-max. in Haldsø develop very slowly; from $r$ they go through + to $c$ and further through $c c$ to $c c c$; in Sorøsa, on the other hand, they increase with enormous rapidity, sometimes from + to ccc (Aslerionella from + on Oct. 17 th to $c c c$ on Nov. 18th; Melosira from $r$ on Aug. 9th to $c c c$ on Sep. 18th). According to the above observation this is explained by the fact, that every spring and autumn a rising occurs from the whole bottom of Sorøsø, which is 13 metre deep) with evenly sloping banks, but in Haldsø, 40 metres deep with almost perpendicular banks there is a rising from a small circular area only.

In the former case the material, which rises to the surface, is from the beginning, very considerable; in the latter, it is slight, and therefore attains to a great max. by slow degrees only.

\section{CHAPTER VI. CHLOROPHYCEAE.}

The systematic classification is based on Cho dat's excellent work: Algues vertes de la Suisse.

In Denmark and everywhere else the Chl. do not play a prominent part in the pelagic region of the larger lakes; they are chiefly pond-forms. We have gathered a large material from ponds and bogs which has not yet been determined; it is not included in this paper partly because a closer study of these algæ are of secondary interest in connection with the objects aimed at here, and partly, because one of us intends to make an exhaustive study of them. Regarding the features special for the Planktonchl. see Chodat (02, 1). 93). In the pelagic region of the sea the Halosphara only play a prominent part.

Euchlorophycex. Of the Cladophoroidece the Egagropila may sometimes occur as Plankton organisms, (cp. W.-L. 03); of the Confervales a few forms only; the rest of the Plankton organisms belongs to the Plenrococcoidece; and amongst these the following only contain Plankton organisms, viz. Palmellacea, Volvocacea and Protococcaceo; of the Ulothricacece U. (Hormospora limnetica) Lemmermann (98c., p. 150) appears to occur in Plankton.

Palmellacea. At present it must suffice to refer all the Planktonpalmellacees to the two genera Tetraspora and Spharocyslis. We are inclined to believe that Tetraspora lacustris Lemm. is not identical with Spharocystis Schroeteri (cp. Chodat 02, p. 115).

Tetraspora lacnstris Lemm. has been met with in p. 90. Furesø, Esromsø, Sorøsø, Tjustrupsø and Mossø; it ap- 
pentes in Maly (lass max. in duly) and disappears in Oct.Noy, Il is most rommon in lispomso. (literalure, sec 1). (1)

Spherecystis Schrocteri Choclat occurred in Viborgss and Itallso; il appeats in May (has max, in June) and disapperals in Aug, Sep.

Polvorecese. All tho Volvocacees belong lo small, shallow ponds and lakes; only Ludorina, which was mel wilh in all the lakes which have becn examined, oceors as l'lankton organism ceven in larger lakes.

(of Ihe lotvon-species, I', aureus lihr. (nimor Stein) is the onc which is most liecpuenly met with. It survives the winter under the ice, but rarely in great guantilies; all the colonies ale vegetative at this time of the year; a distinct max. was not observed, though it occurred most abundantly during the summer lialf ycar. \%ygoles were not found till aulumn; at this time we lound both vegetative Folvox-colonies, and those containing \%ygotes. ln early spring, shortly after the breaking up of the ice, a quantity of (puite small colonies which had doubtless developed from the Zygotes was observed in most of the lakes.

The period during which Volvox globator occurs as a free-floating organism appears to be much shorter. It was fairly common in May-June; within the years 93-()1 it was observed everywhere in the neighbourhood of Frederiksborg, and during June-July reached an enormous mas. which occurred almost simultaneously in all the small lakes and ponds around Frederiksborg, and in 94. from June 15 th to July 7 th, this alga occurred in great masses especially in the lake at Frederiksloorg palace. The nets were filled with an emerald green plankton with a golden hue, which consisted almost exclusively of $V . g$. Then the alga clecreased in number, and at the end of July it scemed to have disappeared altogether. After Sep. all the Volvox forms were referied to $I$. alureus. Up to June 1 st vegetative colonies only were observed, but at the end of June ahmost all the colonies contained \%ygotes. As the Zygote in V.globalor is furnished with long spines, while the Zygote-membrane in $V$. aureus is smooth, these two species at this slage are distinguishable at a glance; afterwards this is only possible, by a closer examination.

How far $V$. globalor occurs more rarely than $V$, aureus l am not prepared to say; as the former doubtless rests the greater part of the year as $7 y$ gote, the impression is, that, V. rureus, which occurs all the year round, is the most common. The third Volvox-species, V. lerlins lleyen, is unknown to us.

Prolococcacea. Pond-forms, for the most part, have been met with in single specimens in some samples from a few of the lakes; very few species belong to the pelagic region of the larger lakes.

Dir:lyospharillm. cp. Masse e 91, 1). 457; Zopf 93, p. 15 ; and $\operatorname{Senn}, 99$, p. 74.

D. pulchellum Wood has been olsserved in Esromso. Soroso, Viborgsø, Skanderborgso, Mossø and Julsø. It was common in Esromso only, where it reached a great max. on Sep. 30th, 01 (temp. $17^{\circ}$ ).

Oocystis. O. Nogeli A. Braun. Found in all lakes which have been examined except Tjustrupso. O. lacustris Chodal in Viborgso, Skanderborgso and Julso; the species occurs in some of the samples and always in single specimens.
Chodalella ciliata (bagerhein) Lemm. In single spe- p. 9) cimens in the summer samples lrom Mossu and Julso. Richteriella botryoides (Schmidle) J.cmn. In single specimens in the summer simples from Mossu and Sorusu.

Nephrocylimm Aghardianmm Nag. $\Lambda$ single specimen found in a summer sample from Esromss.

Raphidium fosciculalım küt\%. Found singly in lisromso and Julso. vas. spirale was not observed; vát. aciculare occurred in Bagsvaerdsu.

Kircluneriella lnnaris Moeb. was met with in Fsromso and Viborgso; in lisromsg it had a rather considerable max. in (01, from Sep. 5th to Sep. 30th.

Selenastrum Bibraianum Reinsch. Found in Esromsg, Tjustrupso, Viborgso, Skanderborgso, Mosss and Julso in some of the samples and alvays in single specimens.

Crucigenia triangularis Chodat was found in a small pond in Fyen (cp. Chodat 00, p. 8).

Crucigenia Lauterborni (Schmidle) Chodat occurred in single specimens in the summer samples from Esrollsso.

Crucigenia rectangularis (A. Braun) Chodat was met with in single specimens in Esromsa.

Scenedesmus quadricaıda (Turp) Brél). was found in all the lakes which have been examined, it occurred singly, in a few samples.

Scenedesmus bijugalus (Turp) Küt\%. Found in a few specimens in Esromsø, Sorøsø, Skanderborgsø, Mossø and Julsø.

Dimorphococcus lunalus A. Braun. A small specimen occurred in Julsø on June 30 th, ()$^{\circ}$ (temp. $\left.16^{\circ}\right)$.

Polyedrium regulare (Kütz.) Chodat. Olserved in Julsø on June 30 th, 02 (temp. 16 ${ }^{\circ}$ ).

Polyedrium linıneticım Borge. Sorøsø, Tjustrupsø, Skanderborgsø, Mossø and Julsø. Doubtless occurs as a regular Plankton organism even in larger lakes.

Pediastrum. The main part of the Pediastrum-individuals which occurs in the Plankton of the larger lakes has been imported; they do not belong to the pelagic region; no special max. luas been observed; a great many of the coenobia especially of $P$. boryanum are empty, the colonies being dead. We do not agree with $\mathrm{Lcm}$ merman $n$ in his interpretation of the Pedias/rum-species $(99$, p. 114 and $00 l ., 1) .523)$. We had hoped to make more exhaustive studies of the temporal and local variations; at present we must confine ourselves to the following noles: -

The different species differ from each other amongst other things both in the way in which the peripheral cells terminate $(1-2$ apices, the length of the apices and their arrangement), and in the shape of the central ones ( $X$ shaped; $\triangle$ shaped; and $\square$ shaped); which again causes the formation of larger and smaller spaces between the single central cells, and between these and the peripheric ones; in certain species, e. g. P. telras (Ehr.) Ralfs, the central cells are, so far as is known, always joined close together, and the peripheric ones are not furnished with projecting apices of any importance; others, e. g. $P$. simplex have $\times$ shaped central cells; large clefts; and peripheric cells furnished with highly projecting apices; linally, species occur, in part $P$. boryanım, but especially $P$. duplex, which exhibit numerous variations both as regards the shape of the central cells, and the peripheric ones; it appears, however, as if both these variations have a tendency to p. 96.

P. 96 . 
follow hand in hand: - the more $x$ shaped the central colls are, the more perforated the coenobia appear to be, and the longer and more projecting are the apices of the peripheric aclls.

There now remains no doubt regarding the fact that the compact colonies mostly occur in small lakes and ponds; species such as P. letras; tricomultum l3orge; $P$. Kauvraiskyi and mostly also — as living colonies $P$. boryanum generally does not occur in the Plankton of the larger lakes; on the other hand, the very open $P$. simplex individuals, with much perforated coenobias and cells with long, spine-shaped apices, are most common in larger lakes.

We are inclined to regard the facts of the colonies being more or less divided into clefts and holes, and of the peripherical cells being more or less armed with spines, as modifications to adapt them for the life in the free-floating condition.

As regards the setre at the apices of the peripherical cells see p. 98. We have not observed many of these setre; those we have seen agree very closely with the (lescription given by \%acharias $(99 \mathrm{c}$., p. 85).

We have found the following species: -

p. 98. $P$. boryanum (Turp) Menegh. met with in all the lakes; $P$. duplex Meyen also; $P$. simplex Meyen and P. Kauvraiskyi Schmidle only in the lakes of Silkeborg. $P$. biradiatnm Meyen in the latter and in Sorøso.

Coelastrum. Cp. especially Senn (99, p. 40). Chietly pond forms.

C. microporım Næg. Met with in all the lakes; and occurs in single specimens in a great many of the samples. It was common in Viborgso, where it had a large max. in June-July 02.

C. cambricum Archer was met with in single specimens in Tjustrupsø and Viborgsø. Found in considerable quantities in a small bog near Julsø in Aug. 01.

Itariolina with the species $H$. reliculata Dang was met with sparingly on July 10th, 02, Esromso (cp. Senn 99, p. 40).

Bolryococcus only one good species (cp. p. 99).

$B$. Braunii Kütz. occurred in all the lakes, and has been met with though sparingly, in most of the samples; it never had any great influence on the general character of the Plankton, and never coloured our lakes red; it occurred most abundantly in the cold, clear Almindsø near Silkeborg. As is well-known the alga occurs now green, now red. Cp. Chodat $(96$, p. 333$)$. In the Swiss lakes it is recorded as red during winter, but green during summer. With us it is the reverse, the alga here being green during winter, red during summer. Granted that the red oil, as recorded by $\mathrm{Chodat}$, serves to protect the chlorophyll from the too intense light, therefore the alga is red during the winter in Switzerland, but with us during the summer. The greatest number of clear days occur during winter in Swilzerland while in Denmark they occur during summer; the alga consequently in both countries protects its chlorophyll at the time of the year when the light is most intense. $B . B$. is most commonly met with in cold Alpine lakes with clear water (cp. p. 100).

Confervales. Of this alga only one species is a wellp. 100. marked Plankton organism, viz. Tribonema bombycinum, which has been kindly determined by Wille.
He records the following regarding this species, which he thinks is a new form depauperala: - The breallh of the cells $3 \mu$, length $18-33 \mu$; the cells are almost eylindrical with slightly eonstricted transverse walls; the longitudinal walls are thicker; chromatophores 2-1 in every cell; the number of the latter has not been ascertained with any certainty. The filaments are in a free floating conclition, without organs of attachment. If the chromatophores do not exeed 4 in number, then the alga approaches T. minus (Wille) Hazen, T. bombycinum having more than 4 .

$T$. bombycinum has been found in all the lakes and it attained an enormous max. in Esromss in 01 from June 29 th (temp. $15^{\circ}$ ) to July 20 th (temp. $17^{\circ}$ ). As far as we know, Conferva generally do not occur as Plankton organisms (cp. p. 101), therefore T. b.'s frequent occurrence in the Danish lakes is very odd. The filamentous alga belonging to freshwater Plankton doubtless require to be studied more closely

Conjugatæ. Occur chiefly in small lakes and ponds (c). pp. 101-102).

Closterinht. It is very difficult to determine the Plankton-Closteries. We have refcred the Danish forms to: -

C. ceratium Perty. It has been met with in all the lakes, but in small quantities only; it appears to be most common during winter and early spring.

Cosmarium. Of this genus, which only contains pond forms, C. scenedesmus Delp. has sometimes been met with in the Plankton from Skanderborgsa and Mossø, but the individuals in question were doubtless damaged.

Staurastrum has two species which occur as Plankton organisms.

S. gracile Ralfs was met with in all the lakes, generally in small quantities; it occurred most abundantly in the smallest and shallowest of the lakes, Viborgso, where it had a great max. in 01 on Aug. 7 th $\left(\right.$ temp. $23^{\circ}$ ) and in 02 on July 27 th $\left(\right.$ temp. $15^{\circ}$ ).

$S$. paradoxum Meyen var. longipes Nordst. was found in Furesø, Esromsø, Sorøso, Tjustrupsø and Haldsø, always in single specimens, and only in a few of the samples. It appears to be somewhat more of a pelagic form than $S$. gracile.

General remarks. The list on p. 104 shows that no less than 33 Chlorophycees occur in the Plankton of our lakes, but only a very few of them are of any importance, the majority of them are tycholimnetic. Only those species mentioned at the top of p. 105 belong to the pelagic region of our larger lakes, and only Tribonema bombycimum constitutes the main part of the Plankton of a lake a longer period at a time. Investigators in other countries have arrived at the same general result.

When we, in contradistinction to Chodat, who only mentions a very few typical Planktonchlorophycees from the Swiss lakes, viz. Bolryococcus and Sphorocystis, have recorded such a large number of Chlorophycees from the pelagic region of our lakes, then the fact of their occurrence in our lakes shows clearly, how greatly the Danish lakes resemble ponds, and what small claims they have to being called lakes at all. Chodat's investigations prove further, that the small society of pelagic Chlorophycees, which occurs in the Swiss lakes, consists of species which are either quite wanting or play a very small part in this country. Thus Raphidinm Braunii Nreg. and Closterium Nordstedtii Chod, appear to 
be tolatly alosent in our lakes, while lley oceur, though sparingly, in the Swiss lakes; moreover, Botryococcus and Spluerocystis tave been met with nore abmolantly in the Alpine lakes than in the lakes of the plains. On Hic other liand, sereral of the forms which, in the pelagic region ol our lakes commonly occur, are ahnost wanting in llie Apine lakes. (Pediastrum, Staurastruu, Closteriun ceratiun, etc.).

\section{CHAPTEK VII.}

\section{PROTOZOA.}

\section{Flagellata. Dinoflagellata.}

All the fresliwater P'ankton-P'eridinees belong to the two families, Gymnodiniacere and Peridiniacece. The Cerefium hirundinella only is of importance in the formalion of greal plankton-max.

Gymmodiniacea. Of this genus, the Gymnodiun $(G$. fuscum Ehr.) occur commonly as Plankton ofganisms in larger lakes; they liave been observed - though sparingly - in all the lakes which have been exanined. As regards animal nutrition see Schilling (91 a., p. 199) and $\%$ acharias $(99 d ., p .136)$. The division takes place both in an encysted and during a motile state (Penarl 91 b., 1). 33; Levander 94a., p. 49); as regards the resting-cysts see Schilling (91b., p. 41); on conjugation see l'enard $(91$ b., p. 34$)$.

Peridiniacee. Glenodinium are mostly pond and coast forms, among them $G$. cinclum has been observed in a few lakes, e. in the pelagic region of Furess, and G. aculum Apstein hitherto found in the lakes at Ploen (Apstein 96, p. 152) and in the lake Balaton (Francé 97, p. 52), has moreover been met with in Furess, Soroso, Haldsø, Mosso and Julsø, most commonly in the latter lake. $G$. is reproduced by division in an encysted state, during which it looses its flagella, and the organism sinks to the bottom.

Peridiniunt. A great many species have been described (see p.108). I have referred the forms found by us to $P$. cinclum Ehr, and P. Labulatum Clap \& Lachm. The former is a more decidecl planliton form than the latter, which belongs to ponds, but both of them have been met with in all the lakes which have been investigated. The investigations of the ponds carried out in 98 proved that $P$. fabulatum attained, everywhere, a large spring-max in April, and a smaller autumn-max. in Oct.

The reproduction goes on, as far as is known, during the whole of summer, and occurs by division while the alga is in a brief, transitory state of encystment. This mode of reproduction only occurs during the night as Schilling $(91$, p. 38) was the first to point out; the whole process lasts only a few hours. I have never met with this resting-stage during the lay, but have observed it in quantities in material gathered and put in spirits during the night. - The resting-cysts, within which the individual vegetates for weeks or months I have mostly met with after the great Oct.-max. The species doubtless survives the winter in this stage; some individuals always occur under the ice in a free-floating condition, and a rather considerable number occur in ponds just after the breaking up of the ice. Resting- cysts were also lound during summer in such ponds which were eiller quite dried up or where the water laal sunk considerably, and the temperature had risen very lighh (temp). $28^{\circ}$ ).

Ceratium. Of the two freshwater species, C. cornutum (lap \& Lachm, is a pond-form which is only a clance visitor in the pelagic region of the larger lakes, and C. hirundinella is a well-marked pelagic form. In both these forms the division takes place willout a foregoing encystment, while the organisms swim about by means of their llagella. Resting-cysts lave been found only in C. Lirundinella. As regards C. cornulum, its dividing process in the free-swimming stage may be observed in every collection rich in species; it appears to occur nearly at all times of the day almost, and is not restricted to certain hours of the night as is the case in C. hirundinella. The dividing process was first observed by Bergh (82, p. 214), who dicl not, however, fully understand it at the time, but later on he $(98$, p. 76$)$ and $\mathrm{Sch}$ illing $(91 \mathrm{~b}$., p. 31$)$ studied it more thoroughly.

On the water evaporating from a ressel containing a large quantity of material, a damp, brownish layer occurs at the bottom, which will afford us an opportunity of watching the process by means of which C. cornutum throws off its flagella and, within the old cell-wall, forms a cyst, in which the organism vegetates. On adding water, the old shells burst, and the contents grow out into new individuals without any further division. These cysts which have been described by Schilling (91 b., p. 46) are not known as having occurred in the C. hirundinella; they are net with in nature, mostly during summer, and help the individual through such periods when its existence is threatened; primarily, they doubtless protect the individual against drought, to which this species is especially exposed being a well-marked inhabitant of ponds. Resting-cysts have not been noted, and excepting the few individuals which are generally found under the ice whenever they are searched for, nothing is known as to how it survives the winter.

The investigations of the ponds in 98 proved that C. cornulum has two max., one luring April-may and another during Sep.--Oct.

C. hirundinella has been met with in all the lakes which have been examined; it begins to appear in May; the max., which is sometimes enormous and colours the water a yellowish-brown and makes it thick, occurs when the temp. of the water is highest. Two max. have never been noted. During Sep.-Oct. C. h. disappeared, and often in an incomprehensibly sudden manner. Through the above-mentioned investigations of ponds in $98 C . h$. was proved to exist in one of them in enormous quantities during Sep. The pond was quite small, and only 2 metres in depth, but during the whole of summer its central part was free for vegetation; it was absent in most of the other ponds. It is a well-marked pelagic form, which occurs in clear, pure water for preference, and generally does not develop in lakes with great $\mathrm{Cy}$ anophycee-max.

As regards the biology of the species the following may be added: - C. hirundinella cannot with us be classified amongst the perennial Plankton organisms; from Dec. to March-April for all practical use it disappeared from the pelagic region of our lakes. On examining the winter samples from Haldso (Jan. 30th, 02) and Skander- 
bolgso (Jan. 271h, (02), some sperimens have been met witlı, but these free-floating inclividuals which have surviverl the winter, arc so few in number that they can be of no importance in the locality in question.

With us the species survives the winter as restingcysts - the well-known 3-4 horned cysts - whieh are especially met with during Sep.-Oct. after the mas.; they decrease in number towards winter. After the breaking up of the ice the resting-cysts again appear in the pelasic region until May-June, and then they disappear. The bottom samples which I had taken in May from the decpest part of Thorso for the purpose of studying the balls of the Gloiolrichia, proved to contain large quantities of cysts of C. hirundinella, furnished with horns. On putting these cysts into a glass vessel and exposing them to strong daylight they burst after a period of 8 dlays, and the water was filled with numerous $C$. $h$. which were characterized either by the absence of horns, or by thcir soft nembrane, which was not distinctly faceted. Later on they developed into typical C. h. Investigations of quite a different kind, which I could not lay aside, prevented my making a more exhaustive study of these stages.

Plankton investigations make the fact clear, that the number of the cysts which occurs in the water decreases during winter, only to again increase duriug spring, after the violent storms. I am inclined to believe that these cysts belong to the littoral zone, where they have been deposited during winter and in spring, and whence they are loosened by the dashing of the waves, and then carried out into the pelagic region; and it is here that the germination takes place according to my thinking. The extremely few individuals of $C$. $h$. which occur during April-May, probably originate from these cysts. It is of great interest to observe, how very slowly and gradually, the max., often enormous, of July-Aug. develop. As the cysts seen to have disappeared entirely from the Plankton in May, it is to be presumed that after this month very few cysts are hatched, and as thc species is, moreover, up to May everywhere rare, or at least of very little importance, the number of individuals, which develops every spring from the cysts, is comparatively small. The individuals increase in number by division, while they are in their free-floating stage, and this division evidently increases in intensity together with the temp. of the water, with the result, that the enormous max. of July-Aug. occurs at the highest temp. of the water. The division takes place as mentioned above during the night and the early morning hours; see Bergh $(87$, p.77); Blanc $(98$, p. 230); and L, auterborn $(95$ a., p. 177).

When I worked out the investigations of the bottom deposits of our lakes (W.-L. 00), I was surprised to find that the enormous max. of the $C$. h. were not more noticeable at the bottom of the Iakes, and that no deposits of parts of the skeletons of the alga were to be found. On studying the $C$. $h$. more closely at the end of their max., i. e. in a state of decay, especially those from Sorøsø and Tjustrupsø, it appeared that they fall away while they are as yet pelagic organisms, by the shells breaking up at the single plates, whereupon the eontents escape as shapeless green patches. The breaking up process appears to occur simultaneously; for a few days the lake was filled with numberless parts of skeletons. The fisherman from Haldsø told me that after the large Cerntium-max, in Aus. the lake (leared up: and at the same time large, floating, yellowish-brown flags occurred on the shore, unfortunately no samples of these were forwarderl to me. It is possible that these tlags consisted of parts of the skeletons of Ceralinm; they were searched for in Sorass and Tjustrupsos, but without suceess. ((c). P'enard 91 b., p. 45).

11 appears as il the individuals which develop into resting-cysts, only are very few. As regards the periodicity and the geographical distribution of the $C, h$. see p. 112.

General remarks. The list on p. 112 shows that C. himndinello is the only l'eridinee which occurs in the majority in the pelagic region of our lakes. IVith IIs the Peridinea have sharply defined max. and min. They survive the winter mostly in a resting-spore stage. A greal many of them have two well-marked max., one during spring (April-Maj) and another during autumn (Sep.Oct. tcmp. $10-12^{0}$ ). Ceratium hirundinclla has one max. only which occurs at the highest temp. of the water. A great number of the small pond Peridinees, which have been very little investigated, have probably their max. at the same time. The max, often very considerable, probably occurs through the division of the small number of individuals developed from the resting-cysts. The division takes place either in the encysted stage, with the flagella thrown off, and in that case generally resting on a substratum or in the free-swimming stage, in the layers of water. In the former case the division may also take place in the layers of water, provided the dividing-cysts are surrounded by large globular gelatinous layers which keep the organisms floating, after they have thrown off their flagella. It is very interesting to note, that only those forms occur in the pelagic resion of the larger lakes, the dividing process of which either for one reason (Gymnodinium) or other (Ceratium) may take place in the layers of the water. All the forms, the division of which occurs in cysts resting at the botiom of the lakes, are pond-forms.

Ludwig $(98$, p. 295) has raised the question, how far freshwater Peridinces are luminous; he answers it in the negative; so does Waldvogel $(00$, p. 49), and I also have arrived at the same conclusion. During the Ingolf Expedition I had occasion to observe the strong rays of light given out by the Plankton gathered during the night, when the preserving fluid was poured into the sea water containing the living Plankton. Therefore, several times during last summer I took Plankton which contained considerable quantities of Ceratium, and poured alcohol into the glass containing these numerous living Ceraties; the experiment was made in a lark room, but not the least ray of light was to be observed.

\section{Flagellata. Euflagellata.}

To the family Chrysomonadinea belongs all the chicf freshwater and marine Plankton forms of the Euflagellata.

Mallomonas. I liave referred all the Mallomonas found in Denmark to M. acaroides Zach. I w a n of $\mathrm{f}(00, \mathrm{p} .247)$ appears to have been the very first to point out such specific characters as are reliable, but unfortunately his paper did not come under my notice until I had finisled my investigations. (cp. Lem mermann 99, p. 109 and 01 a., p. 87; and $Z$ a charias 93, p. 17 and 94 a., p. 73). 
M. a. Was linund in Sorose, 'ljustrupso, Viborgso and

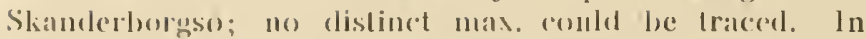
the pouts investigated in 9S five of them were lound to contain an enormons max.; the water was coloned yellowish-urecon, and was quite thick: resling-ysts were olserverl in 11:-3.

1) 111 . Dinobrymu. 11 dillerent limes very conllicting views have existed as to the systemaltic value ol the Endinobryau speries. Two opinions assert themselves more patricularly, the one, which may be called the olfler vicw, and which has heen specially helel by lö̈lschli, \%acliarias, Apslein, Seun, and mysell, and, it appears, was partly hold by Lauterborn, admits the presence ol only a few number ol species, and relers the main part of all the hitherto known forms lo the lwo old lorms, which have heen founded and olten ligured, viz. D). sertularia Ehr. and D. stipitatum stcin.

The other and younger one, which now appears to have (quile outstripped the older one, was first held by I molol (90, 1). 183), and alterwards by liach lo a n n (01, 1. 201); 13runnthaler (01b., p. 293); Chodat $(97-9 s)$; bul especially by lemmermann (00l., p. 500): Ly the combined exertions ol these authors the number ol the species has increased to about 30 ; but the conlinsion is completed by the fact that the diflerent authors disagree regarding the greater part of these delinitions of species: for l'urther particulars on this point I must refer to the works of the authors in (juestion. Even if the Dinobryum in nature be ever so much in a "Werdeprocess neuer Formen" (Bachmann (01, p. 231), I an rather doubtlul whether this proc'ess occurs so intensivly here as it does at present in our periodicals.

It appears to me that experience teaches us, that an extreme division into species only serves to create a confusion which prevents a clear view of the subject. It created for a long time a great confusion as regards our interpretations ol the IIyalodaphnia and the Anurera; it was I mhof's works especially which very nearly confused our idea of the species Ceralium lirundinella, also they were misleading in regard to our interpretation of the two old species $D$. sertnlaria and stipilatum. This method may be of importance in serving to confirm the final truth, but it is not a necessary link in the development ol it. Our entire knowledge ol the Dinobryum species confines itself to the following: - The genus Dinobryum is locally, exceedingly variable, and there is every reason to believe that like many other Plankton organisms it also varies temporally, following the common laws lor the temporal variations ol these organisms. As at present we are unable to distinguish the lixed, inherited characters from such which are influenced by the actions of outer factors, I think that all further division of the species Dinobryum is not justifiable lrom a scientilic point of view. I have provisionally retained the old species $" D$. serluluria Ehr. and $\gg D$. stipilatum Stein, which according to my view should be regarded as seasonal forms of the same extremely variable main form.

Our lakes appeared to be very poor in Dinobryum; they were met with only in 7 out of the 9 lakes examined; great spring max.. but of short duration, occurred only in Soroso and Fureso, the water in these lakes was yellowish-green in May (temp) 13-14 $4^{0}$ ). In ponds great max. very seldom oecurred; they are mostly met with during the summer laalf year. The Dinobrym have an conormous geographical (listribution (sec p. 117 ; cp. also

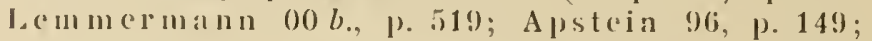
\%acluarias 99 b., 1). 72; and Waldvogel 00, p. 50).

Synura. Regarding the relation ol Artinoglena Klebsinna to Symura and Chrysopherella see \%acharias $(97 u ., 1.5)$; I, emm ermann $(99$, p. I 10); and La uterborn (99, p.383). S. uvella lihr. is a pond and littoral form, and does not oceur in the pelagic region of the larer lakes. In the ponds investigated in 98 a large spring max. and a small autumn max. was met with everywhere. l)uring $A_{\text {pril }}$ the 11 ponds teem will brownish-yellow: pear-shaped bodies, furnished wilh eyespot and two llagella of the same length. In the same sample ol water, colonies consisting of 2-3-4-5-8, etc. individuals are also met with, quite similar to those which oceur solitarily. The position of these individuals in the colonies is always the same; the pointed ends lurn towards each other, and appear to coalesce slightly; the broad ends with the eilia turn towards the periphery. I have seen a single free-swimming individual first go round a colony consisting of $2-3$ individuals, and then joining it. This phenomenon was only observed cluring April; I believe the single free-swimming individuals must have been produced from cysts which survived the winter, I have, however, sought in vain for the latter. (cp. Lauterborn 94 a., p. 391).

Uroglena. Regarding Uroglenopsis see $\mathrm{I}$, e m merman n $(99$, p. 107 and $01 a .$, p. 86). U. volvox Ehr. was met with in most of the lakes; it is a pond and littoral form. On investigating the ponds in 98 it was found to have a large max. during April-May. Nothing is known as to the origin of the colonies. It is easily preserved in Formol (cp. Z a charias 98 b., p. 106).

General remarks. While the max, of the Mallomonas generally occurs at the highest temperature of the water, the max. of all other forms mostly occur during spring (April-May); sometimes an autumn max. also has been observed.

As regards the Dinobryum we know for a certainty that during their min. they occur as resting-cysts, which sink to the bottom together with their empty houses after having kept lloating in the water (cp. W.-L. 00 , p. (650) lor a considerable time; the same is doubtless also the case with the Mallomonas and Synura. As regards the eysts of the Euflagellala which sink to the bottom in deep water, it is an open question, whether they or their contents ever rise to the surface again, and whether the fresh supplies in the pelagic region, are not chielly owing to cysts. which have sunk to the bottom in shallow water, or to material. imported from the small lakes of the neighbourhood.

\section{Rhizopoda.}

Amoebix. Amongst these the Difflugia only are met with in the freshwater Plankton. As regards lheir occurrence in the European lakes see p.120. D. limnetica Levander occurred in Haldso and Julso. D. hydroslatica Zacharias in Tjustrupso. Difllugia also occurred in the pelagic regions of the other lakes, but they were not closely cxamined. 
1. 121. Foraminifera. Cyphoderio ampula Ehr, which is a well-narked bottom form, occurred occasionally in the Plankton from Fureso, Tjustrupso and Mosso.

Heliozoa. The Plankton-Heliozon known to me, are mentioned on p.121. Rhaphidiophrys pallida F. li. Sch. was found in Fureso, Esromso, Haldsø and Mosso. It occurs as an autumn lorm in Fureso, and is very eommon during Sep.-Oct. It lorms large, rlosely connected patches several mm. in size consisting of about 50 individuals (cp. \% a cha ri as 95 (l, p. 131).

Acunthocystis. As regards the pelagic Acunthocystisspecies ep. P'enard $(91 a ., p .152)$; Zacharias $(94 a$., р. $70 ; 95 a .$, p. $73 ; 97(a ., 1) .1)$; Prowazek $(01 a ., 1.4)$; and ll inkewitsch (00 a., p. 621). A. conspicua \%ach. occurred in Fureso during April-May; but it is somewhat doubtful if the specimen in question is a Rhi\%opod. The list on p. 122 shows that Plankton-Rhizoporla play a very small part in the pelagic region of our lakes.

\section{Infusoria.}

p. 123. Ciliata. Holotrichida. Coleps hirtus O. F. M. was noted in some of the samples from most of the lakes which have been examined; it was mueh more eommon in the ponds examined in 98 .

Several times I have had oceasion to observe, that Coleps developed in more or lesser quantities in Plankton samples which had been kept for some days; in proportion as the rest of the Plankton died out, the Coleps increased in number, and often occurred abundantly after a lapse of about a week. They are mostly carnivora, and in the aquariums they attack the Infusoria and Flagellata, but occur most abundantly on the dead bodies of the Daphnias, etc., at the bottom of the vessels; very often individuals occurred, the hind part of which was dark, with thick armour and the fore part hyaline with quite a thin armour - stages produced by division (Bütsehli 80, table 58, fig. $1 \mathrm{f}$; ll aupas 85 , table 17 , figs. $5-6$ ); (see also $Z$ a charias 93 , p. 32 and p. 48; Amberg $00 a$., p. 49; and Waldvogel 00, p. 50$)$.

1. 124. Didinium nasulum O. F. M. has been found in Fureso and Esromsø, as a rare exeeption; it is a well-marked pond form, it has previously been recorded by $\mathrm{Zach}$ arias $(93$, p. $32 ; 94$ b., p. 105 and $95 d .$, p. 136) as a Plankton organism.

Dileplus trachelioides Zach. oecurred in all the lakes which have been investigated.

The max. was small in 01 ; in 98 when I travelled through the country from May 17 th to June 1st, from Skagerak, through Jutland, Funen and Zealand, the time of my journey coincided with the max. of the Dileptus, and it was very remarkable to see this otherwise rare form, oecur abundantly in numerous larger and smaller lakes, as well as in ponds. It had a large max. in the extremely warm lakes on the downs at Raabjærgmile, and in Raabjærg Kirkesø, also in the lakes at Viborg and in Madumsø; it was eommon in the lakes at Silkeborg and had a large max. in Sorøso; ep. Zacharias (94 a., p. 78 and 94 b., p. 107). The trunk-like, tapering, flexible fore part of the body is extremely variable, and the movements made by it resemble those of feelers or antennæ. Sometimes the fore part did not end in one antenna-like growth, but in $3-4$ thin threads which were longer than the rest of the body, and twisted round, spirally. Individuals resembling those described here were olten met with on the above-mentioned fourney; they oceurred abundantly, especially in Raabjaros Kirkeso. Zacharias calls these specimens monstrosities, but I lo not think he is justilied in doing so. It appeared to me that they were most common at the end of the max. l do not agrec with \%acllarias in his very far-fetched hypothesis $(94$ a., p. 80).

Trachelins ovum Ehr. is a common pond form (\% aleharias 93, pp. 32 and 48); has been met with in Ploenersee.

Helerotrichide, Bursaria truncatella O. F. M. occurs as a Plankton organisms in Esromso during April-June; it is a well-marked pond-form.

Slenlor sp. occurred abundantly in a single sample from Esromsa gathered Sep. 5th, 01. Stentor has been recorded from the Plankton of the larger lakes by $\mathrm{Z}$ acharias $(93$, p. 48); and from Neuenburgersee by Fuhrmann $(00,1.94)$; it is said there to eonstitute here the main part of the Plankton of the surface during Nov.-Feb.

Tintinnidiun fluviatile Stein was found in all the Iakes; it had a well-marked spring max. (May) which was very large in Haldsø on May $30 t h, 02$. It appears to be less common in ponds. As regards its geographical distribution, and its max. see p. 126 .

Codonella lacustris Entz. was observed in all the lakes which have been examined. It attains its max. doubtless at a low temp. $\left(8-12^{\circ}\right)$. A winter sample from Esromsø, from 98, when the lakes were not frozen, showed an enormous max. C. $l$. occurred as the main species of the Plankton. $\mathrm{Il}$ is eommon in ponds. The pond specimens are lighter in colour than those met with in lakes.

The Codonella which occurred in Haldso dilfered considerably from those found in the other lakes as regards the shape of its shell. In the specimens from Haldso the hindmost part of the shells are thickest in the middle, eoncave posteriorly, and terminated in a sharply defined point; the eollar was well-defined, turned upwards, broader than the hinder part and furnished with, at the nost only $3-4$ strings. Regarding its geographical distribution and max, see p. 126.

Acineta. Staurophrya elegans Zacharias occurred in a spring sample from Furesa, ep. Zacharias $(93$, p. 18 and $94 b .$, p. 118); and A pstein $(96$, p. 154)

General remarks. The list shows plainly that the Infusoria are of harlly any importance in forming the Plankton of our larger lakes, in the pelagic region of which only the following are met with, viz. Staurophrya elegans, Dileptus trachelioides, Tintinnidium fluviatile and Codonella lacustris. The latter form must more partieularly be regarded as perennial; excepting Coleps hirfus, which do not at all belong to the pelagic region, all the other Plankton-infusoria have astonishingly short and clearly lefined max., which rarely extend over a longer period than $1-1 \frac{1}{2}$ month, and which generally occur during spring (Didininm, Dileptus, Bursaria, Tïntinnidium, Staurophrya).

Very little is known about the habitat of the Infusoria, and under what form they occur, as they do not appear in the Plankton. Cysts occur in the Dileptus, Stentor, Stauroplirya, but, as far as is known, neither in 
the Tintimnidinm nor in lle Codonelte. It may be prestmmed, that during the time they are not met with in

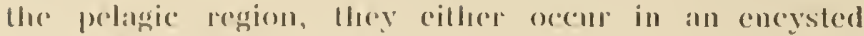
restimg-stage at the bollom ol the lake, of are to be foumd in llar littoral renion. "The lormer is doublless

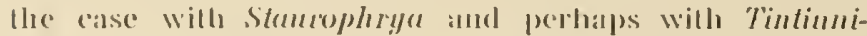

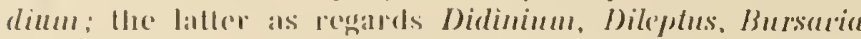
and stentor: All these speries oreur, all the year roumd, in small lakes and shallow ponds, and during their max. - mostly during spring - they are carried alomg will the alfluents of the large lakes into the small lakes and ponds, where they vegetite lor a short time, but do not thrive. A small socioty of liec-dloaling Inlusoria, which have only been studied in a cursory manner, ocerur in the central part ol ponds and small lakes void of regelation; one of the main lorms is Bursaria

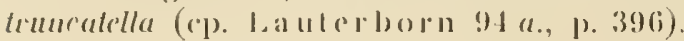

\section{Passiv-Pelagic Organisms.}

By the term passiv-pelagic organismse is understood all such organisms as are met with attached to lorms which occul regularly in the Plankton, and are liept floating by means of the latter, and they conseyuently, also belong to the pelagic region. These forms present many points of interest, but our knowledge of them is very slight.

Almost all the passiv-pelagic forms are Protozoa, some of them are lnlusorias, some Flagellates, so they may most properly be mentioned here. On Clathrocystis from Plocnerso Apstein $(96$, p. 135) has. however, found a Diatom (Diatoma or Syurelra).

All the passiv-pelagic Protozoa, so far as is known, as a rule procure their own food; and the olganisms to which they are attached are generally of no more importance to them beyond carrying them, and making it possible for them to live in the pelagic region; on the other hand it is very probable that these small organisms are of great importance to their hosts, as their lood-catching organs are also used for locomotion; by means of these organs the Diatoms or Cyanophycees to which the Proto\%oa are attached are put in motion. On looking at living Asterionella-Plankton in which the Asterionellas are beset with Diploziga frequentissinta Zach. (tab. 111, fig. 34) we observe that the stars swim quickly forward; a single Diploziga can set an Asterionella rotating and make it move along in the water. If 5-6 of them are attached to the slars they then move very quickly.

It is remarkable to note the marked preference of the passiv-pelagic forms to certain Plankton organisms. In a Cyanophycee-Plankton consisting of Amaboua and Clathrocystis, the Anaboua are often beset with numerous Vorticella (tab. I, figs. 5 and 6) while the Clathrocystis are quite devoid of them. This has been observed by many other investigators (see p. 128).

Very often organisms are met with which, judging from their general habit appear to belong chiefly to the passive-pelagic region even if their host organisms cannot be pointed out. To these belong, e. g. Trichodina pediculus Ehr., Colacium sp.. Carchesium polypiunm 1. and Epistylis lacustris Inh. As is well-known Trichodina occurs as a parasite on lish, Spongilla, Planaria, snails, Cristatella, ete. It olten occurs in a lree-lloating condition in the pelagic: region, and Seligo $(00$, p. 59) also records it from the Stuluner-lakes as a l'lankton organism.

Amongst these Carchesium and Eipistylis are especially common in the J)anish lakes, mostly during spring and autumn. See also p. 129 where the chicf passive-pelagic organisnis are mentioned.

\section{CHAPTER VIII. VERMES.}

Besides the Rotifora it is especially the Turbellaria, Castrada radiata v. (iralf which is common in the pelagic region of our larger lakes (cp. \%acharias 93, p. 6 ; $\Lambda$ pstein $96, \mathrm{p}$. 155 ; and v. (irafl 82, p. 314). Further, in our shallow lakes Nematoda are very olten whirled up); the Oligochat Stylaria proboscidea (O. F. M.) and Nuis elinguis O. F'. M. are also met with. Both these species, which are characterized by their very long setæ, are often found in a free-lloating condition in such central parts of small lakes as are free from vegetation. Moreover, the pelagic regions of the lakes doubtless contain several larval stages of groups of worms which as ful-grown either live as parasites on lish or belong to the stones and plants of the littoral zone: - the larval stage of the Bothriocephalus (observed 3 times in the Plankton of Fureso), the larva of the Bucephalus, Aeolosoma, etc. (R ay Lancaster 69, p. 631). As 1 have pointerl out $(96 \mathrm{~b}$., p. 352) the larval stages of the Bryozoa live only for a few hours, and they occur as white, cloudy masses round the colonies; perhaps this does not apply to the larva of the Paludicella (B ra ëm 96 b., p. 54).

\section{Rotifera.}

Next to the Crustacea the Rotifera constitute the main part of the Zooplankton of our larger lakes, but they are dominant only during May-June.

The thin and hyaline membrane is common to the main part of the Plankton-Rotifers; this also applies to those species which belong to the so-called loricate Rotifers; spines are common (Anuraa, Notholca, Triarthra, Polyarthra), the organ of attachment is often either wanting or greatly reduced; (Ascomorpha, Synchala, IIudsonella, Anurea, Notholca, Triarthra, Polyarthra); the wheel-organ, the structure of which differs greatly, always represents within each type the highest stage of development. Gelatinous-formations occur in the Melicertida and Floscularida. The eggs, which are generally laid by the Rotifers, sometimes occur attached to other Plankton organisms (Rattulus, Hudsonella, etc.); they are sometimes pelagic (Ploesoma); this is also the case with the resting-eggs (Brachionus and perhaps Asplanchna); occasionally they are carried by the mother (Alluroa. Notholca, Triarthra, Polyarthra); 1 regard all these characters, as acloptations to life in the pelagic region. As I have mentioned elsewhere, everything shows that the Rotifers originate from the free-lloating Rotifers of the ponds, and these again from the bottom and coast forms.

The Rotifers are very liable to variation; the indivicluals lrom the larger lakes with their great Iranspa- 
rency and oflen longer spines, are distinct from those belouging to ponds. I.ocal varialions are not sperially wortly of note in the individuals from the diflerent larger lakes; bul, al any late a single form (A. priodonta) may be subject to a very considerable temporal variation (see tlic following Parl).

In lite pelagic region of the sea the Rotifers occur very sparingly; they are chiclly coast and fjord forms. The most well-defined narine-pelagic-group is the Synchata containing a few species peculiar to the sea. (litr. sec p. 131). The following classilication is based on the system worked out by me in $99^{1}$ ), but due consideration has been given to Weber's excellent work (98).

3) In this paper I advoeated the following views: - H uds on and Gosse's classification into Loricata and Ittoricata, I eonsider quite wrong. The body of the Rotifers is originally segmented; the so-called lorica arises from the eoalescenee of a number of rings. The original wheel-apparatus of the whecl-animals is a eiliated dise plaeed ventrally, without marginal cilia, and with an eeeentric mouth-opening. Animals provided with sueh a wheel-apparatus ereep about slowly; their power of swimming is slight, and they move in a reetilinear manner while swimming. The wheel-apparatus is not able to eateh food while swimming. The more the wheel-animals become independent of the substratum, and develop into fiee-lloating organisms, the more terminal beeomes the position of the eiliated clise; and the marginal eilia beeome more and more eonspicuous; at the same time the eilia on the eiliated dise are reduced in number. The movement ehanges from reetilinear to helieoid. At the same time the wheel-apparatus undergoes a modifieation. so that it ean also serve as a food-eatehing apparatus for freeswimming organisms. Aceordingly, the dise of the wheel is severed into two more or less distinct halves, between which the mouth is situated, then, either inside or outside the marginal wreath, a seeond wreath of eilia is developed, whose ehief funetion is to prevent the partieles of food eaught by the marginal wreath eseaping. At the same time as the wheel-apparatus undergoes these eonsiderable modifieations, the different parts of the mouth are also transformed. As long as the wheel-apparatus is not food-catehing, the trophi seize the prey and draw it down into the opening of the mouth (Diglena, Synchicta a. o.); but, the more the wheel-apparatus, by the formation of a second wreath of eilia, serves to waft down the food which oeeurs near the wheel-apparatus, the more the importanee of the trophi as prehensile organs is lessened (Brachionus a. o.); and in those eases, where the wheel-apparatus is provided with a special feeding eanal, through whieh the partieles eaught are earried into the opening of the mouth, they are of no importanee whatever in the above sense (Philodinido, Ftoscularida). The foot of the Rotifers in its most primitive form is not sharply defined from the rest of the body; it terminates in two short toes; it is exeeedingly variable, and is highly modified aecording to the use which is to be made of it. Consequently; it eannot serve as a systematic charaeter. The Rotifers are provided with two pairs of lateral organs of sense, of which the anterior pair eoalesee at the median line of the back and form the dorsal organ; the two posterior ones remain separated and form the so-ealled lateral organs. The Notommatida are the most primitive forms of the Rotifers, they have a distinctly segmented body; ventrally placed. eiliated dise; foot, not differentiated from the rest of the body; mouth, sometimes foreipated, sometimes malleat, sometimes transitional between these two types. Lastly, the males are the most developed we know. Lines of development running parallel to eaeh other appear to have developed from the Notommatida; some of these lines may be traced with fairly great distinctness, others are as yet only faintly diseerned. The system worked out by me demonstrates the view that Rotifers are originally ereeping organisms, which, transformed in various ways, develop from creeping organisms to free-floating ones, independent of their substratum. These transforming processes, whieh eonstitute the sole key to our understanding of many of the most eha-
Digononta (Ord. I. Bdelloida, Ord. II. Seisonacea).

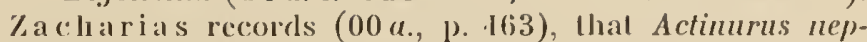
tunius Elur. may oceur abundantly in the Planklon from Wakenit\% Ilurs (l,übeck).

Monogenonta is divided inlo 3 orders: (O) d. Ill. Notommatida, Ord. I V. Brachionida, () r (l. V. Meli= certida).

Or(I. II I. Notommatida is divided into four suborders :

1. Notommatinx contains llie two families: Notommatidee and Synchatade.

a. Notommatida are bottom and coast forms. In part creeping forms.

b. Synchatada contains two genera Synchata and Polyarthra.

Synchota. I have accepted only two freshwater species, viz. S. pectinata Ehr. and S. tremula Ehr. I have regarded S. grandis Zach. as a temporal form of $S$. pectinata, it may be I am mistaken in doing so (cp. Rousselet's excellent work 03 , p. 596). As regards the way in which the Synchætas dispose of their eggs see p. 133. In Denmark the eggs of the S. neglecta Zach. are always carried.

$S$. tremula Ehr. is rare in the Plankton of the larger lakes. It usually occurs in ponds. In the ponds examined in 98 the species was met with in almost every pond, and proved to belong to their most commonly occurring Rotifers. It is perennial everywhere, and is doubtless the form which occurs most frequently during winter. It has two max., one during April-May, and another during Oct.-Nov.; with the former max. which was the greater in all the ponds, a sexual period occurred with numerous males; with the latter the males occurred occasionally only. During summer the species sometimes entirely disappeared; during spring, before the vegetation had covered the surface of the ponds, it was met with abundantly; amongst other things it feeds on Peridinium tabulatum which it catches with its teeth and devours whole. $S$. $t$. has been observed in heathtarns, sloughs, and in fact in every place which has been investigated (cp. La u terborn 98, p. 174; 93 a., p. 9 ; Zacharias 94 b., tab. p. 100).

S. pectinata Ehr. is more of a pelagic form; it is perennial in our lakes; with us it has only one max. (May-June, temp. $13-16^{\circ}$ ). In all the ponds investigated in 98 this species was met with; and in all of them two nax. were observed, of which the spring max., which began April 1st and lasted generally to May 15th, was the greater and more easily discerned. In the lake in the palace gardens of Frederiksborg and in ponds Nos. 2-4-5-6-9-10-11 males were met with abundantly, from April 5th to May 1st. As I found males also at the end of Nov. in pond No. 6, I believe this species, at least in small lakes and ponds, to be dicyclic. As regards its geographical distribution and the occurrence of its max. in other countries see p. 134.

Polyarthra. The main form is P. platyptera Ehr. $P$. aptera Hood is a pond form.

raeteristie struetures of the Rotifers, do not proceed from a single form of Notommatida, but from different forms, whieh have produced different series of development, whieh run parallel to eaeh other. I regard Hudson-Gosse's systen as artifieial and quite worthless. Plate's elassifieation into Digononta and Monogononta is hardly natural, but l lave retained it for the present. 
1. $131 . \quad$ P. platyplere line The observalions recorded on p. $1: 31$ prove that $l^{\prime}$. $p$, is dieyclic in the langer lakes, and the sexual period occurring during spring is the nost marked onc. 'The investigations ol' the ponds in 98 however, showed quite a dillerent result. In these ponds 1 observed that the sexual period oecurs all the year round execpt in .lan. and licels. And the only point to be uoted regurding them, is the regularity of the first sexual period which invariably oceurs during MarchApril; later on there is no regularity whatever in this regard, the sexual periods occurring both in dune, Aug., ()et., and Nov. In three of the ponds I observed the sesual period to oceur in Marcli, Aug. and Nov.; the species is conseguently polycyclic in ponds and small lakes. Vare. curyplera occurs quite sudkenly in the swarns and does not ippear to develop lrom $P . p l$. by neans of easy transitional stages, as I lirst thought. It disappear's in ()ct. - Nov., as lin as I know it never carrics cither mille eggs or resting eggs; the male eggs always appear to be borne by quite small individuals with silootl spines and a sharply pointed posterior part. As regards the geographical distribution and the occurrence of the max. in ofluer countries see p. 135.

2. Rattulinat consists ol the two fam.: Rallulide and Dinocharilar.

a. Rallulicla. I do not agree with Weber in his limitition of the genera, and regarding this point, I prefer, lor the present, to follow the classilication of ll udson and Gosse. The forms in cjuestion are chiefly pond forms. There are three pelagic species, these lay their eggs on other Plankton organisms; the other species belonging to this order generally lay them at the bottom.

p. 135. Mastigocerca, chiefly pond forms. M. setifera Lauterb. belongs to the central parts of small lakes, where it may occur abundantly. In contradistinction to all the Rattulina it carries its eggs. The max. and the sexual period occur at the highest temperature of the water.

1). 136. M. capuzina Zach. \& Wier\%. is a decidedly summer form and occurs from May to Oct.-Nov.; it is a constant inliabitant of the pelagic region of our Iarger lakes; but it has also been met with in Furesø Jan. 31st, 02. Males were met with in Tjustrupsø Aug. 8th, 01. On examining the ponds in $98 \mathrm{M} . \mathrm{s}$. was observed in those whose central parts were void of vegetation; it lays its eggs on other Plankton organisms (cp. Lauterborn 98, p. 180). It appears to vary somewhat in length (cp. Stenroos 98, p. 142 ; A pstein 96, p. 160); see also p. 136 .

p.137. Rallulits. Only one of them occurs as a Plankton olganism in the larger lakes, viz. R. bicomis Western. It is a summer form in all our lakes; also a well-marked pond form. In a single pond (No.8) 1-2 netres in lepth and free from vegetation, $R$. bicornis attained a considerable max, which lasted from July 15 th to Sep. 1st. The sexual period occurred during this max. The same pond contained swarms of Brachionts angularis, which, at the time in question were quite covered with eggs; the females can have $18-22$ eggs lying on the top of each other along the whole of their dorsal shield. By holding B. angularis in a suspended drop it was proved that the eggs hatched by them belonged to $R$ bicornis, and that the eggs developed males as well as females. The phenomenon lasted during the whole summer, but was most conspicuous during July-Aug. lt is unknown where the resting-eggs are laid.
Coelopns contains only one pelagic speries, viz. C. lonnior (iosse; it occurred in liuress and the lakes at Silkeborg. C. l. lays its eggs on Melosira-filaments (cp). A pste i in 96, p. 160$)$.

3. Euchlaniua includes the two fanilies - Euchtanida and Salpinada, both of which are pond forms. The Euchlanis-species, especially E. Lrquetra Ehr, occur in such central parts of small lakes and ponds as are liree lrom vegetation; a lew ol the species appear to occur mostly as littoral forms in larger lakes.

4. Notopsinde contain 3 families: - a. Nolopsida, 1) 137. b. Asptanchnade and c. Apsilida, of which Apsilide occur fixed as adults.

a. Notopside. To this I refer: Notops hyptopus Ehr., Triphylus, Gastropus, Ploesoma, also Anapus, Ascomorpha and Sacculus.

I do not agree with Weber, on two points, as I think it wrong to include Notops hyplopus Ehr. under the genus Gastropus co-ordinately with $G$. stylifer $=$ Indsonella picta); also, I cannot allow Sacculns viridis Gosse to be placed in the genus Ascomorpha; they diller totally in all respects. I keep Nolops with its only species N. hyplopus; and Sacculus with its single species S. viridis distinct from the genera Gastropns and Ascomorpha.

In the restricted sense in which the order Nolopsida is taken here, it includes chiefly pond forms which belong to ponds containing a rich vegetation (Triphylus lacustris Ehr., Gastropus minor Rousselet; Ploesoma triacanthum Bergen(l., Anapus ovalis Bergend., Sacculus viridis Gosse); some occur in the central parts of small lakes void of vegetation (Nolops hyplopus; partly Gastropus stylifer, Ascomorpha agilis Zach.), and a very few, such as Ploesoma Hudsoni, Gastropus stylifer, also Anapus testudo are Plankton organisnis in the larger lakes. Nolopside consist chiefly of carnivora which prey on Flagellata and Rotifers; the prey is sucked out, the shells thrown away, and the contents pumped into the stomach. All the pelagic forms are summer forms; the max. of the pond forms occurs mostly during AprilMay. I have met with males in Ascomorpha agilis, Nolops hyptopus and Sacculus viridis, they will be described in the following. Very little is known about the eggs.

Gastropus include the pond forms: - G. minor Rousselet and G. stylifer Imh. G. stylifer was found in all the lakes which have been examined. It appears in May, and disappears during Oct.-Nov. The max. occurred during July--Aug. In 98 it was found in all the ponds the central parts of which were free from vegetation; it is common in the heath-tarns of Jutland; the brilliancy of its colours is most conspicuous in small lakes. Its movement is a general rotation round its main axis (cp. the wrong statement of Zacharias 93, p. 25). The summer eggs are laid on other Plankton organisms. The resting eggs which are covered with bristles are pelagic (Lauterborn 98, p. 180). Regarding its geographical distribution see p. 138.

Ploesoma. Weber records 6 species, three of which, p. 138. viz. $P$. lynceum Ehr., $P$. Iruncalum Levander and $P$. molle Kellicot appear to me to be doubtful. P. Iriacanthum Bergendal is a pond lorm and is extremely common in Denmark, at least in the north of Zealand. $P$. lenticulare Herrick was found in the lakes at Rabjargmile. 
P. Hudsoni hmh, is the only species which ocen's as a Planklon organism. Il lias been mel with in all the lakes which have been investigated; it appears in Mary and (lisappears during ()et.-Nov. It is very ravenous, and preys mostly on Ceralinu hirundinella; it bores a liole in the sliell of the prey and sucks it out. The summer eggs are pelagic $(\Lambda p s t e$ in $96, p, 160$; $Z$ ach arias 93 , p. 35, lab. 1, fig. 16). The resting eggs are probably attached to Melosira; the fact is, I refer to this species an egg, enclosed in a pale-yellow cnvelope and allached to Melosira-filaments. Regarding its geographical distribution see p. 139. All the different authors record it as a summer form.

1. 139. Ascomorphe. Two species A. sallans Bartseh and A. agilis Zacharias. A. agilis was met with in Furesø, Tjustrupse and Haldso; it is a summer form, and chiefly occurs in ponds. In $98 A$. $a$. was observed in the shallow ponds 7-9-10. In the latter pond, which is very sniall, and in spring is free from vegetation, but whose surface later on in the year is quite hidden by Polamogelon ualans and Lemna livisulca, the species oceurred as early as Feb., was common in March, and appeared in enormous quantities during April. The sexual period occurred at the same time, and astonishing quantities of the hitherto unknown male appeared in the swarms. The max. of the species oceurred together with that of Nolops hyplopus, but not so frequently as that of the latter. Both prey on Peridinium labulalum and Synura uvella. A. a. dlisappeared in June-July, when the surface was covered with vegetation. In ponds, Nos. 7 and 9, which had always a central part free from vegetation, the species occurred all the year round, but was common only during April-May* Here also sexual periods occurred in April.

p. 140. Anapus. To this genus two species are referred, $A$. lesludo Lauterb. and A. ovalis Bergendal. The former was observed in Furesø, Esromsø, Tjustrupsø and Haldsø. It is a summer form. Sexual period unknown. I have only found $A$. ovalis in ponds.

Asplanchnadoe contain Asplauchuopus and Asplanchua, the former has not been observed in Denmark. Some 20 species of Asplanchna have been met with; and at lcast 4 of them are quite distinct, viz. A. priorlonla Gosse: A. Brighlwelli Gosse; A. Sieboldii Leydig; and A. Herrickii De Guerne.

p. 140. A. priodonla Gosse was observed in all the lakes which have been examined; it is perennial; in our larger lakcs its max. and sexual period in 01 usually oecurred from May 18 th to June 22nd. In Esromso an enormous max. with a sexual period was observed on Sep. 5 th, 01 (temp. $16^{\circ}$ ). When the ponds were investigated in 98 , it was found in the greater number of them; in the ponds in question it was decidedly dicyclic. The males occur mostly during May--June and Sep.-Oct., but may be met with during the whole of the summer, and have also been observed in Dec.-Jan. The resting eggs are most common in June and in Nov. During the winter min. the production of eggs appear to have stopped almost entirely. Resting eggs were found in the pelagic region, but in surprisingly small quantities. Regarding its geographieal distribution and it's max. see p. 141 .

p. 141. Ord. IV. Brachionida contains the two suborders:Brachioninx and Microcodina.
1. Brachionin ic, to which belongs the two fanilies: IIyslatinielde: and Brachionida.

a. Inydalinila (contain Nolops brachionus, Rhinops, IIydetina) are all pond forms.

b. Brachionida (contains Nolcus, Brachionus, Schizocerca, Notholca and Anurea). Noleus occurs usually as a bollom form. Schizocerca belongs to such central parts of small lakes as are free from vegelation (see 1). 143). Brachionus. Anurcea and Nolholca are subject to a very strong local and teniporal variation. Weloer's limitation of the species has been followed.

Brachioulus consists of some 70 species which nua be reduced to 5-6. (Weber 98, p. 665 and liousselet 97, p. 328 ).

The Brachionus-speeies belong to the central parts of small lakes; they are mostly dicyclic; the parthenogenetic eggs are carried, the female eggs from $2-6$ in number, and the male eggs in numbers of 12 to 20 ; only one resting egg, which is sometimes provided with spines and is often pelagie (B. pali Ehr., amphiceros E.hr.).

In the inlets of the lake in the palace gardens of Frederiksborg (94) large quantities of the resting eggs of $B$. pala were washed up in vast numbers together with statoblasts and ephippies. The egg is cireular, but is enclosed in a triangular, brown eggshell, devoid of spines, and the three sides of which are of unecuual length and have the angles rounded off; the shell is much larger than the egg so that there is plenty of space between the two; there is every reason to believe that the space between the egg and the shell is filled with air, which serves to keep it floating

In the winter of $94-95$ the eggs were found frozen in the ice together with ephippies and statoblasts, which had accumulated in such great quantities in the inlets, that they coloured the ice brownish-black. The ice was brought to the Laboratory and thawed, and then the resting eggs were hatched in the course of $2-3$ days.

Of the genus Nolholca 20 species have been deseribed, which WV eber $(99$, p. 716$)$ has reduced to 4 , viz. $N$. foliacea Ehr., N. striala Ehr., N. spinifera Gossc and $N$. longispina Kellicot. The latter species, which in contradistinetion to the others is a well-marked pelagic form, is very distinct. $N$. spinifera is not well-known; to the two first-named species Weber has refcrred all the olher suceies which have bcen described. I cannot quite agree with Weber on this point. Investigations carried on in nature show, that two types occur in small ponds: - a shorter form, rounded off posteriorly, viz. N. striala, and a longer form with posteriorly drawn out lorica, without terminating in a distinctly pointed part, viz. $N$. foliacea; numerous transitional slages occur between these two, and it is possible that thcy ought to be regarded as local forms of one and the same extremely variable species; but this cannot be proved at present. In larger lakes a third very slcnder form is met witl, which is generally called acuminala Ehr. in Plankton works; its posterior end is provided with a sharply defincd spine; this form has exactly the same appcarance in all the larger lakes, but it is connected with foliacea through numerous transitional forms which all belong to ponds. For the present I think it best to retain the threc forms, $N$. striala, foliaced and acuminalu. 
1. 114. N. striala Elu. Was found in most ol the lakes; it is a winter lorm and attains its max. in bec:- $\Lambda_{p}$ ril. I never olserver it during stmmer. Laulerborn records it as peremial $(98,1), 17.1)$. N. acuminala lihr. orecured in most ol the lakes; it is also a winter form and allains its max, in Dece-April; Lat le leorn mentions this speries an perennial also, but I dirl not observe it during the summer half year. As regards its gecorraphical distribution and its max. see p. 11.

$\boldsymbol{N}$. longispina kiellicot was observed in all the lakes which have been investigated. In the ponds investigaled in as it occurred most commonly in the largest ponds which had a central part liee from vegetation. It is peremial everywhere in larger lakes, where the sexual period is not noted as occurring for certain together with the max. in May-Aug.; in ponds and small lakes the sexual period occurs in May and Sep., hence, it is clicyclic in these localities. Alter the occurrence of a large max. in Madumse on May 20th, 98 the l'ankton consisted mainly of dearl animals and empty skins. Ol all the Nolholca-species, N. longispina is most commonly mel with in the pelagic region of larger lakes; it is the main form in Alpine lakes situated at a high level (see p. 145). Laterborn records it as most common during winter, but $l$ as well as all the other authors have lound the max. occurring during the summer liall year.

1. 1.15. Antura' Weber has reduced the 30 species to $3-4$ species. The main species are $A$. aculeata, cochlearis and hyprolasma.

A. cochlearis Gosse. The table on p. 146 gives the occurrence of the mix. in the lakes which have been examined. In all these lakes a marked sexual period occurred both in May and Sep., and on investigating the experiment ponds in 98 sexual periods were demonstrated in the same months, but also in most of the other months of the year (even in Jan.). This proves that the species is perennial everywhere; in larger lakes dicyclic, in smaller polycyclic.

A. $c$. has been found in Denmark in all kinds of water except dung-water which it seems to avoid. It occurs in small ponds of some hundred square metres in size, the surface of which is either devoid of, or covered with vegetation. In ponds which had been desiccater in July-Aug., the species occurred as early as Dec. (temp. $2^{\circ}$ ), when rain water and melled snow had gathered in puddles at the bottom. It is common in the lakes in the downs of the west of Jutland; in the lakes at Raabjærgmile; in heath tarns and in puddles on the heath which dry up in June-July; it is one of the few species which occurs in our larger streams which do not serve as outlets for lakes (e. g. Karupaa at Karup; Gudenaa, before the stream enters Mossø; Skjernaa; Vejleaa). It is also common in brackish water, viz. Ringkobingfjord (as form lecta: Mortensen 00, p. 52), Stadilfjord, Limfjorden.

A. $c$. is extremely variable, and thoroughly well-known through Lauterborn's $(00$, p. 412 ; and 03, p. 529) exhaustive and excellent investigations. To L a u terborn's investigations of 00 , which are mentioned on pp. 146-47, 1 want only to add, that A. tccta does not occur in all lakes as a marked summer form; it was very common during the winter in the lake in the palace gardens of
Prerleriksborg; my investigations bear out those of Lauterborn's, with the following additions: -

The individuals ol $A$. cochlearis which occur in lakes, are not so apt to vary as those met with in ponds; hitherto I have neither observed the A. hispida nor A. irrignlaris-series in lakes; $A$. lectu has, on the other hand, been lound in the lakes at Silkeborg, mostly during summer, but never in so large a number that it excects that ol the typical form. The pelagic forms of $A$. cochlearis are on the whole quite distinct from those of the ponds; they are more light coloured; are never brownish-yellow and usually have a long, sometimes very long, posterior spine. I loubt whether the diflerent tentporal variations pointed out by Lauterborn, can be demonstrated in the pelagic lorms of larger lakes, and am of opinion, that the final stages of these series of variations which are to be met with in the Plankton ol the larger lakes, are probably owing to material, which has been carrierl into the lakes by means of their affluxes, and not to forms, the primary stages of which originate from the pelagic region of the larger lakes.

It was the long-spined hyaline forms of $A$. cocllearis belonging to this region which induced $1 \mathrm{~m}$ hof to create the species A. longispina (1). 170); for particulars regarding the very considerable local variation, I refer to Weber.

A. aculeala lihr. Notes regarding the occurrence of the max. in all the lakes which have been investigated, are given on p. 148 . In the ponds investigated in 98 sexual periods were observed in April-May and a max, in Oct. The species is perennial, at any rate dicyclic in ponds; but there are no evidences as to its being polycyclic. Its distribution and occurrence are somewhat similar to those of A.cochlearis, but it presumably does not occur in so many different localities as the latter. The different species vary greatly. Weber included 14 species under A. aculeata: - A. serrulata Ehr. is chiefly to be found in Spagnum, and may perhaps be regarded as a distinct species. A. brevispina Ehr. of which I only observed females - with parthenogenetic female as well as male eggs - is a summer form, and its development into $A$. aculcata, during the course of the year, has been traceable. A. valga occurs simultaneously with the development of resting eggs; in many ponds the main part of the individuals, which carry resting eggs belongs usually to this form. As in the case of A. cochlearis the pelagic forms of $A$. aculcata from larger lakes do not vary so much as the pond forms. A. curvicornis Ehr., A. falculala Ehr., A. testudo Ehr. and the above forms are all pond forms; and are also summer forms which usually disappear towards winter. Common to the A. aculeata of larger lakes is the hyaline lorica and the long, often well-developed posterior spines (cp. Lauterborn 98 , p. 18).

A. hypelasma Gosse. This small pond form was observed in summer samples from Skanderborgso and Julso.

The suborder Microcodinæ includes the two families: Microcodida and Flosculariadxe.

a. Microcodida. To this is referred Microcodides and Microcodon, both of which are pond forms, cp. Apstein (96, p. 157).

b. Flosculariade. In Plankton one genus only occurs, viz. Floscularia with three pelagic species: $F$. mutabilis 
Bolton; F. pelagiea Rousselet and F. libera \%ach. Hillerto F. libera only has been fomel in Denmark; it was observed in lureso, Esromso, Tjustrupso, Viborgso, Skanacrboryso and Julso; it occurs cverywhere as a summer form. The litcrature dealing with these three species is mentioned on p). 1.19-50.

p. 150. Ord. V. Melicertida. To this order I have referred the three fanilies: Melicertida, Pedalionida and Pterodinida.

of the lamily Melicertillo one genus only has been observer in the pelagic region, viz. Conochilus. Three pelagic species have been referred to this genus: C. volvox, C. llnicornis and C. natuns.

C. volvox Ehr. occurred in all the lakes; it is doubtless perennial; it had an enormous max. in Esromsø on May $23 \mathrm{rd}, 02$ (temp. $9^{0}$ ), and in Haldso on May $3 \mathrm{rd}, 02$. It was observed in 7 out of the 9 experiment ponds; in No. 7 it attained an enormous max. in June.

C. unicornis Rousselet has not been observed with any certainty. C. uatans Seligo occurred in May-June in Esromsø, and in 98 in pond No. 5.

p. 151. Pedalionida. To this I refer the genera: Triarthra and Pedalion; the latter is a common pond form in Denmark.

Triarthra. The main form is T. longiseta, to which perhaps T. mystacina Ehr. may also be referred; T. breviseta Gosse and T. brachiata Rouss. are pond forms and have been found in several small ponds.

$T$. longisela Ehr. was met with in all the lakes, and on investigating the experiment ponds in 98 it was found to occur in all the ponds. It is perennial; in lakes it is presumably monocyclic with sexual period in May, in ponds dicyclic with max. in May and Oct. As regards the spines see Zacharias $(93, \mathrm{p} .23$ and $98 \mathrm{~b}$., p.112). The latter remarks that the length of the seta are not dependent on the size of the lake, but this statement is not of much value, as it appears that the material has not been collected simultaneously from the different localities. As regards its geographical distribution and its periodicity see p. 152 .

p. 152. Plerodinida. Two genera, of which Pterodina lives in ponds.

Pounpholyx. Two species, of which $P$. complanala Gosse is a pond form. P. sulcala Hudson was found in all the lakes which have been investigated; it is a marked summer form, with sexual periods in July-Aug. (Literature, see p. 153).

p. 153. General remarks. The list on p. 153 shows, that 22 species of Plankton Rotifers occur in Denmark; the main part of them occurs also in small lakes and shallow ponds. The periodically occurring monocyclic Rotifers, almost all of which are summer forms, generally attain their greatest max. in fairly large lakes, but the max. notwithstanding always appears to be small - at least in Denmark. The perennial Rotifers, which occur in ponds as well as in larger lakes, generally attain their greatest max. in ponds, but may also reach considerable max. in larger lakes. These forms are very often polycyclic in ponds, but in larger lakes they appear to be mostly dicyclic. Excepting Nolholca acuninata and slriala the monocyclic Rotifers attain their max. at the highest temperature of the water; the polycyclic or dicyclic ones reach their chief max. in
May and Sep.-O(t. With us, the spring max. genclally appears to be the greatest. The reason why the liotifers in May somelimes oecur so abundantly in the Planklon of our larger lakes, must be explained especially by the fact, that the spring max. of all the dicyclic Rotifers, occur almost simultaneously and at a time when the Diatons are on the point of disappearing, and the max. of the Cyanophycees and Ceratiun have not as yet begun.

In 98 I had completed my examination of the occurrence ol the sexual period in the liotifers, and was just going to have the result published, when I received L a u terbor's's work $(98, \mathrm{p} .173)$. As our investigations proved almost the same points, and we had followed the same principles in our work, I abandoned for the time being the publication of my research, and have now emborlied it in the present paper. Wherever infornuation is required as to the occurrence of sexual periods I refer to La uterborn.

On comparing the results of the investigations of the ponds in 98 with those of the investigations ol the lakes in $00-02$, some interesting conclusions may be drawn.

in such parts of ponds as are free from vegetation the same pelagic forms are met with as in the lakes, especially the perennial species of the latter, which attain a much greater max. in the ponds, especially Asplanchna priodonta, Polyarthra platyptera, Triarthra longiseta and Synchata pectinala. But the periodically occurring pelagic Rotifers, chiefly all the summer forms, are either wanting in the ponds, or rarely attain greater max. here than in the lakes.

In the central parts of ponds and small lakes free from vegetation some Rotifers are met with, which have either never been observed in the pelagic region of larger lakes, or at any rate occur sporadically only, viz. Brachiomus pala and angularis, Anurcea hypelasma, Synchata tremula, Notops hyptopus, Ascomorpha agilis, Pompholyx complanata, Shizocerca diversicomis etc. I have often had occasion to observe, that several individuals of these forms. especially of B. pala, Synchota tremula and Ascomorpha agilis, occurred chiefly during spring, in the pelagic region of our largest lakes; but I got the impression, that the species in question did not belong to the pelagic region of the lakes, but harl somehow or other been conveyed thither. In order to have this supposition more fully confirmed, in the spring of 02, at the same time as the Plankton samples were taken in Fureso, I examined the Plankton ol the central parts of small lakes, which discharge their water into Fureso, especially of Vejlesø and Søllerodsø. I succeeded in substantiating the following data: -

1. Species, which were constant inhabitants of the central parts of the above-mentioned small lakes and of the pelagic region of Furesø, attained their max. some three weeks earlier in the small lakes, than in the large ones (Polyarthra, Triarthra, Asplanchna).

2. Species, which belong only to the central parts of small lakes, especially Brachionus pala, angularis, Synchata tremula, Asconorpha agilis etc., of which the three first-named attained very high max. in Vejlesø, occurred simultaneously but in small quantities in the pelagic region of Furesø and in the small lakes, but then disappeared entirely in Fureso

3. These forms reached their greatest max. in that part of the lake which was nearest to the aftluents. 
dudging fiom Nos. 2 and 3 it may be ronchloded lhat in the rase ol some individuals ol species oceurring suddenly in the preligir region ol larger lakes, which do not beloner lo llow latler, and then disappearing as quickly as they appeared, the malerial in question musl have been conveyed to the lake lirom elsewhere. They are lorms which eilher perish in the lakes, or reach sildely within the littoral region, where they lind a new home in its encolosed spots.

firom the examination of No. 1 il may forlher be presumed that some ol the Rotiler-liauna which oecur regulanly in the lake also are supplied linom material which has been carried to the lake, and if these fresh supplies ceased, the Rotifer-fauna womlel not be able to hold out lor any length ol lime in. the pelagic region ol larger lakes. This may be possible, but on the other loand, it is beyond doubi. that liotifers whicl liave developed in the lakes, and have not been conveyed thilles lirom neighbouring waters do occur in the pelagic region of larger lakes.

In the above, examples have been given of the lact that the individuals occurring in the larger lakes have a very decided stamp which distinguishes them from those met with in shallow ponds and small lakes. The greater length of the spines in the pelagic lorms, a characteristic which induced luhof to found new species and varieties (Anuroa longispina, regalis) have especially been pointed out; also the thinner, and far more liyaline lorica, which never shows a yellowish colour, and whicl is often characteristic ol pond forms; and to this may moreover be alded, that the outcome of the power of variation is very dilferent in ponds and lakes, with this result, that in the ponds series of variations occur, which never occul in larger lakes, (Anuraea (cochlearis, A. acnleata); and on the other hand, in larger lakes series of variations may occur within certain species, which have not been observed in small lakes and ponds, (Asplanclua, Syncheta). As however the Rotifer-Plankton of a lake is, as a matter of fact, mostly developed in the lake itself, then the question again rises regarding the resting-stages and the resting-periods. Regarding the periodically occurring Rotifers, it is known that they disappear totally for $6-8$ months. The perennial Rotifers are always present, but they generally occur in such small numbers, that the sudden occurrence of the great spring max. cannot possibly be due to the parthenogenetic reproduction of the few individuals, which have survived the winter in the water. It has been observed in the main part of the species that resting-eggs are produced after sexual periods, and it may be concluded that they are developed in all the species.

Starting from the considerations which have also been maintained elsewhere, it may further be presumed, that all the resting-eggs which sink to the bottom at great depths, perish, and that the pelagic Rotifer-society year by year develops chiefly in the littoral zone and is produced by the resting-eggs which have been deposited there and which have been raised to the surface by waves and vertical currents.

During my journeys in Jutland in May, I often had occasion to observe in the country round Silkeborg and in the great lake district of Viborg--Hald, that the quantity of the liotifers of the larger lakes, was much greater in the shallow inlets than in the open lake; in the latter locality the great max. dicl not oceur till a week latel than in the former, and were produced presumably by the numerous individuals of the littoral \%olle, which had been spread out over the whole lake, by the spring storms.

On p. 156 I have given all lata regarding the ways in whicl the l'lankton liotilers lay llieir eggs. At the same lime as I pointed out that the Rotifers lay their eggs on the bottom, l drew attention to the following facts: that, the placing ol the eggs on other Plankton organisms: all tle lloating apparatus of the eggs; vivipary; and the power of bearing the eggs posteriorly; these must all be regarded as adaptations to conditions which liave arisen through the struggles made by originally creeping forms, to develop into free-swimming and pelasic animals.

\section{CHAPTER IX. ARTHROPOI)A.}

Plankton-organisins only occur among Crustaceu, Insecla and Aranea. In the pelagic region ol our lakes only one species of insects is found, viz. the larva of Corethra plumicornis. Its existence has been proved in the lakes of Furesø, Esromsø, Sorøsø and Tjustrupsø. It has been taken by hundreds in deep water, horizontal samples from Esromso. Specimens obtained from larger lakes are smaller and far more hyaline than those obtained from ponds. The mother animals lay the egomasses in the central parts of the lakes, - the hatched larve then move downwards.

\section{Crustacea.}

With the exception of Mysis oculata Fab. var. relicta G. O. S., which perhaps ought to be classified amongst Plankton organisms (W.-L. 02, p. 257) all the fresh water Plankton-crustacea belong to the Entomostraca. In this respect there is a very great difference between the pelagic region of the sea and that of the fresh water.

\section{Cladocera.}

Common to all the Plankton-cladocera are great hyalescence, long spines and a small number of eggs; a pronounced temporal variation is frequent. Spines are often developed in Plankton varieties of species which otherwise are pond and shore species. In the sea occur Podorl and Evadre; the Bosmina are only found near the coast.

Holopedidæ. Holopedilln gibberum Zaddach is rare in our country, its existence was proved for the first time by P. E. II üller (68 a., p. 103), for my part I found it on May 20th, 98 in Madumsø. H. $g$. is probably a special high-northern and alpine form, largest in the far north (see p. 159).

Sididæ. Plankton organisms only occur amongst p. 159. Sida, Limnosida and Diaphanosona. Sida crystallina O. F. M., which in large numbers cling to the underside of the leaves of water-lilies lead now and again a pelagic life. S. limnetica Burckhardt has not been found p. 157.

p. 158. (159. 
in our comntry. Limuosida, which has hitherto only been found in Norwegian, Swedish and Finland lakes (sec p). 159) has not been found in this country.

Diaphonosoma. For the present I maintain lle existence of the lwo species D. brachynrum (Liévin) and D. lenchlenbergionum Fiselice, but I acknowledge that li urckliard's arguments for uniting the two species into one are somnd.

p. 159. D. brachyurum (Liévin) has been proved to oceur in all the lakes examined.

It will be seen from the statements p. 160 that $D . b$. appears in all the lakes about the middle of May, temp. $13-15^{\circ}$; the specimens first observed are small females - young ones without eggs; in June they carry eggs though seldom more than one, later on the number of eggs increases and is greatest in the beginning of July, as a rule it does not exeeed 3-4; max. is reached at the highest temp. of the water and lasts from the middle of July to the middle of Aug.; at the end of July the number of eggs already deereases and seldom exceeds $1-2$; imnediately before and at the beginning of max. there is an abundance of young ones; in Sep. the species decreases markedly and suddenly, at the same time (temp. $15-13^{\circ}$ ) the males often appear in great numbers; some of the females moreover have winter-eggs, but only a minor part seem to produce these eggs. Males may still be found in Oet, and even exceptionally in Nov.; females with winter-eggs generally disappear in Oct.; the last specimens observed in Nov. are barren females. No Diaphanosoma has ever been observed in our lakes from the end of Nov. until the middle of May. Thus D. brachyurum is periodical in our country with only one sexual period which occurs during Sep.-Oct. Max. is of short duration, lfat can be very great, it was greater in the hot summer of 01 than in the cold summer of 02 .

The first specimens in spring are always obtained from the surface, and it seems as if by far the greater part of the Diaphanosoma remain there till autumn; from Oet. however the animals move downwards into deep water, and all the specimens caught in Nov. were obtained from 20-40 metres, and at this time the surface contains no $D . b$.; it seems everywhere to belong to the periodical Plankton, only at the southmost point, lake Garda, it is supposed to be perennial (Garbini 95, p. 4) for further particulars see p. 161.

p. 161. D. lenchtenbergianum Fischer has only been found in Esromsø; periodicity and propagation are the same as in the above mentioned species.

Daphnidæ. Pronounced Plankton organisms are really only found in the genus Daphnia. Scapholeberis mucronala var. longicornis Lutz has not been found in this country.

p. 162. Daphnia. It is a well-known fact that the species of the genus Daphnia vary exceedingIy, this is especially the ease with the Plankton-forms. Only through the Iatest PIankton-explorations we have obtained a closer knowledge of these PIankton-daphniæ, their faculty of variation, their affinity and mode of living.

They are all greatly hyaline and of slight size $(1-2 \mathrm{~mm}$.$) ; the eye is rather small, and the individual$ crystalline Ienses protrude freely from the pigment; the pigment-fleck is but slightly developed and seems aI- together absent in many cases; the lerminal claws of the postaludomen have, with one single execplion, no

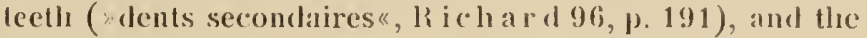
number of tecth on the posterior margin of the postabdomen is slight. The contours of the body vary exceedingly, especially as regards the form of the head and the position and length of the shell-spine (spina). The number of eggs is generally very small $1-3$. Moreover may be added that the examinations which have taken place up lill the present day have proved that males and ephippla-carrying females are very rare, and it thus seems as if these forms principally propagate acyelically (B irge, B urckh ardt a. o.).

As several of the above mentioned features are more or less found in all Plankton organisms, they must be considered in connection with the mode of living, and be explained as being adaptations to the surroundings thus the liyalinity the small size and the slight number of eggs. As it is moreover proved, that the teeth on the cIaws of the postabdomen itself are far more strongly developed in the bottom- and shore-species of the Cladocera than in the Plankton organisms, it seems likely to suppose, that the absence, or slight development of these teelh, wherelyy the serviceableness of the postabdomen as an instrument for crawling and elinging purposes is greatly diminished, is in accordance with the life in open water where there are no supporting planes. That also the great variation of the contours of the body must be explained as being in correspondence with the surroundings I have tried to point out elsewhere, $(00)$. In the course of time a great number of species have been set up (c. 40). By degrees it was found out that aII the features hitherto employed as good specific characters couId by no means be considered as such (for further particulars see p. 161). A reduction was then performed chiefly by $\mathrm{Richard}$, Burekhardt and Lilljeborg; pp. 163-65 I have rendered an account of the principles on which the systems of these writers are based.

My own view with respect to the affinity between the Plankton-daphnix is mostly in accordance with Lilljeborg, whose system on the whole seems to me to be the most clear; on a single point however the result I have arrived at differs from his. In the following I shall employ Lilljeborg's nomenclature.

In the pelagic region of our larger lakes only two species of Daphnia occur; during summer we meet everywhere with enormous quantities of Daphniæ without eye-spot and with the antennæ pIaced at the end of rostrum; these represent the typical Daphnia subgenus Hyalodaphni acucullala G. O. S., which for brevity's sake will be designated in the following simply as the Hyalodaphniæ. With the exception of difference in size the Hyalodaphnia of all our larger lakes resemble each other very much, they are, as will be seen in the folIowing, forms subject to a very great seasonal-variation, but whose local-variation is very slight.

Forms with eye-spot and 1 st pair of antennæ placerl somewhat behind the end of rostrum seem to be much more uncommon in this country, at any rate in the larger Iakes. They are all classed as belonging to the species Daphnia hyalina and have been proved in Esromsø, Sorøsø, Tjustrupsø, Viborgsø and Haldsø, but are absent in all the Gudenaa lakes which have been 
sulujeredel to regular l'lankton-explorations, neilher are they founcl in linreso; in some material from Almindsu (0) Aug. 2nd I have lound a lorm belonging to this speceses, and ollures were found in Planklon-samples lrom several Julland lalies in the neighbourhood ol Viborg, and in lakes in the soulle ol fiunen, lut no cosel examination of them has taken place.

In Soroso and Tijustrujuso these forms were in (1) - -2$)^{2}$ only present in very slight fuantities, and only during a proportionately short linte ol the year, but in the other three aloove mentionerl lakes, especially Esromso, they have hat very greal max. In mone of the lakes lhey are subject to so great a temporal-variation as the $/ / y$ olodophnier; in Sorose and l'justrupsos it was indeed impossible to prove any such variation at all, but hey vary greatly in the dilferent lakes and it seems as if a special race has developed in each lake; thus we have a very great Iocal-variation will respect to Dophnia hyalina, but only a slight temporal-variation.

The two species Dophnio hyolina and Hyalodaphnia cuculloto are very distincl species, and can at most times ol the year easily be distinguished liom each other by the presence ol alosence ol an eye-spot, and the position ol $1 \mathrm{st}$ antennae. From June to Nov. it will as a rule even be unnecessary to look lor these liner distinctions, as the very dilferent appearance of the crest in the two species will sullice at a lirst glance to distinguish them from each other. During the above mentioned period the size of the rrest of the Hyalodaphnice, in the lakes I have explored, amounts to $1 / 3$ or $1 / 2$ ol the total length; no distinclly marked apex is observable, but according to the lesser or greater height the crest forms an equilateral or isosceles triangle. In $D$. hyalina on the contrary there is often no crest at all (Sorøsø, Tjustrupsø), but when present it is either formed by the headcarapace carrying a point (apex) in lront (Esromsø), or by the whole head-carapace having increased in height, the point then being evenly rounded (Haldsø, Viborgsø).

During the winter half-year the crest is reduced in all l'lankton-diphnice, which causes a great resemblance in the two species; still until Dec. they can be distinguished from each other by means of the above named characters. The generation on the contrary, produced by the last autumn-generation, and which as young ones winters below the ice, arrives at puberty in April-May and dies out in June, is very much alike in both species. Rostrum, which in all other cases is more or less downwards-bent and pressed against the valves, is in this generation, at any rate during March-April, freely projecting; the ventral margin of the carapace of the head is curved inwards and the antennæe are in these Hyalodaphnice sometimes situated at some distance from the end of rostrum. On the other hand the pigmentflecks are not always perceptible in the $D$. hyalina-lorms, and it is thus sometimes rather dilficult, nay even impossible, to distinguish the two species from each other in the material collected Irom Jan.-April.

Out ol Lilljeborg's 4 sub-species three have been found here: D. pellucida, lacustris and galeata. Neither P. E. M üller nor I have been able to find the sulb-genus Cephaloxiss.

According to lilljeborg $(00, p, 136)$ the feature which mainly distinguished this sub-genus lrom the other Plankton-daphnix is the slightly developed abdominal-processes, ol which only one anterior process is well developerl, the two posterior ones being only rudimentary.

The appearance and position ol the abdominal-proresses were lormerly employed as systematic characters; they are solt organs resembling the lingers ol a glove, Heir appearance varies in the dillerent individuals. II examined at dillerent times ol the year one cannot help) molicing that they also seem to vary greatly at the dillerent seasons. They are scarcely subject to a direct seasonal-variation, but their position and lorm is dependent on the number of eggs found in the matrix; they are neither in Jophnia hyalina nor in Myalodaphnia very conspicuous in the last barren, dying autumn generation in Dec.-Jan., nor in the lirst young summer generation in May, but sometimes grow to a considerable size in the later summer generations. The more the broorl-room is filled up with eggs, young ones, or with only one single very large young one, and the more the back of the postabdomen is pressed downwards, the more the posterior part of the back, which forms the posterior margin of the brood-room will curve upwards and forwards. This causes the first abdominal process to bend upwards, and hereby also the second abdominat process will be pushed upwards. The degree in which this takes place depends on the greater or lesser filling up of the brood-room.

I agree with lilljeborg and earlier writers that the position and form of the abdominal processes is not the same in D. hyalina and Hyalodaphnia, yet 1 do not believe that they are well adapted for systematical purposes on account of their very irregular forms and varying positions; at any rate I think that Lilljeborg goes too far in placing them at the lront, ancl employing them as main-characters in distinguishing the three subgenera.

In the second part of this work a cletailed account will be given of the temporal variation, sexual period, number of eggs etc.

D. Iyalina subsp. galeata has only been taken in Esromsø, D. hyalina subsp. pellucida only in Sorøsø and Tjustrupsø. D. hyalina subsp. lacustris las only been found in Viborgsø and Haldsø. The three subspecies ol $D$. hyalina vary exceedingly with respect to frequency, periodicity and sexual periods. Galeata has a double max. both ending in sexual periods occurring in the early summer and autumn; pellucida has a small max. at the highest temp. of the water, but no sexual period was proved until late in the autumn; lacustris attains in Viborgsø a great max. all summer, and a second great max. towards winter, after which it quite disappears; in Haldsø it has a great max, in the early summer, a smaller max. towards winter, and is then rather frequent all through the winter; the sexual period possibly occurs during spring

In our country we know no other inslance of a species varying so much in the different localities with respect to sexual periods and max.; on account of the deficiency of the methods of examination 1 shall refrain from remarking on the results which these examinations seem to intimate.

Daphnia (subgen. Hyalodaphnia) cucullata G. O. Sars has been found in all the lakes explored. As regarls the biology of the species I shall only make the following short remarks. 
It will be seen from the above that only certain specimens of $I I . c$. winter pelagically in all the lakes explored, the exceptional cases in which in a few samples taken in winter and early spring it was absent only prove, that the species is very rare at this season, but scarcely that it disappears totally. During spring it increases slowly, and max. is reached at the end of June, temp. $16-18^{\circ}$; it lasts till ca. 15 th of Sep., temp. $12-14^{0}$, and is generally greatest at the highest temp.; a sexual period has been proved in Esromso, Soroso, Tjustrupso, Viborgso, Skanderborgsø and Julso; in Nov. II. c. decreases consislerably; for further particulars I refer to the second rolume of this book.

p. 170 . Ceriodaphnia is especially characteristic for the central parts of smaller lakes devoid of vegetation. In our larger lakes only C. pulchella G. O. Sars and C. quasrangula (O. F. M.) are found sporadically. The characteristic var. hamata G. O. Sars, which differs from quadrangula in having strong spines on fornices, is a typical Plankton organism in Mossø, where it has an immense max. in July-Aug, and a sexual period in Oct.-Nov.

p. 171. Bosminida. Bosmina. As is well-known a very large number of Bosmina-species (ca. 60) have been described, but earlier writers have not been acquainted with the local and temporal variation which is also very pronounced in this genus. Quite Iately the local variation has been carcfully studied (Sting elin 95, Sten roos 98, but especially Lilljeborg 00 , and Burckhardt 99). A closer examination of the temporal variation has not taken place as yet, and this is the reason why most naturalists are postponing a reduction, though the necessity of such a reduction is probably universally acknowledged. Lilljeborg has not thought fit to undertake such a task. A reduction has only been attempted by Burckhardt (99) in his excellent explorations; p. 172 I have rendered an account of his views. The examinations of the Plankton-Bosmina of our lakes have however given a quite different result. Whereas the pelagic region of the Swiss lakes are inhabited partly by $B$. longirostris, partly by the longispina-bohemica group of $B$. coregoni, and $B$. coregoni s. str.; the so-called large Bosmina being almost entirely absent, the latter forms on the contrary constitute the main forms of the Danish Iakes; the longispina-bohemica group is almost entirely absent, and B. longirostris is with us for the greater part a pond-species. This result is presumably correct as P. E. M., who was not accuainted with the reduction and set up 4 species himself, arrived at a similar result. Of the species mentioned by him B. longirostris (O. F. M.), $B$. cornuta (Jurine) and B. microps P. E. M. belong to forms termed at the present day B. longirostris. $B$. diaphana P. E. M. and B. Lilljeborgii belong to $B$. coregoni s. str. Only two species B. inaritina P. E. M. and $B$. brevirostris P. E. M. belong to the longispina-boltemica group. Of these $B$. maritima is marine, and according to Lilljeborg $(00$, p. 245) a marine form of $B$. obtusirostris; $B$. brevirostris is only known from one single locality.

In Sweden Lilijeborg has arrived at a similar result as P. E. M üller and $I$ in Denmark. Lilljeborg mentions 9 species. B. crassicornis Lilljb. and B. globosa Lilljb. represent a new and from a morphological point of view, very interesting group which has also been found in our country. B. longirostris (). F, M. and $B$. longicornis Schoedler must be classed under Bulekhar (l t's B. Longirostris O. F. M. Undoubtedly $B$. mixta nov. nom. B. coregoni baird betong to the eoregoni group) of B. coregoni; and B. coregoni, B. longispina Leydis's and B. insignis Lilljb. to the longispina-bohemica group of the same species. Then we have only one species left vi\%. B. oblusirostris G. O. Sars. It seems to be absent in Switzerland as well as in North and Central (iermany, and is scarcely found in our country either. To this species L illje b. also classifies B. brevispina P. E. MI. and $B$. marilima $\mathrm{P}^{\prime}$. E. M. It is a northern, partly aretic form (see Lilljeborg 00, p. 256).

It appears from Lilljeborg's statements that the Bosminoe which occur most frecjuently in Sweden besisles $B$. oblusirostris, are B. longirostris and the Coregoni group of $B$. coregoni. The longispina-bohemica group which in Sweden is represented by two species $B$. longispina and $B$. insignis is rare.

With the exception of B. obtusirostris Lilljeborg according to the above as regards Sweden has thus arrived at the same result as P. E. M üller ancl myself with respect to Denmark; nothing can as yet be sairl with certainty respecting the Norwegian Bosminx, though $B$. obtusirostris undoubtedly plays a prominent part here. (G. O. Sars 90, p. 40)

From the numerous. Cladocera-explorations all over North and Central Germany as well as from the Plankton-explorations it is evident that the Bosminae in these parts principally are the same as in Denmark and Sweden. The main forms are $B$. longirostris and the Coregoni group of $B$. coregoni; the longispina-bohemica group is stated to be very rare.

With respect to the Bosnina we may then distinguish between three territories, one northern, partly arctic territory, mainly characterized by $B$. obtusirostris in the numerous races of this form; the longirostrisbohemicn group of $B$. coregoni is rare; the $B$. coregoni group is on the other hand rather common, but seems to become rarer towards the North, where B. obtusirostris is probably the last existing form. This territory embraces the Scandinavian peninsular, Northern Russia and the arctic countries as far as these have hitherto been explored.

The Central-European teritory is characterized by the absence of $B$. obtusirostris; at any rate it is very rare, which is also the case with the longirostrisbohenica group of $B$. coregoni; the $B$. coregoni group, »die grosze Bosminen«, on the contrary has a very wide distribution in this territory, and is found here in a great number of different races; the Alps must probably. be considered as the southern boundary of this territory.

The southmost territory is characterized by the longispina-bohemica group which here attains its highest development. The Coregoni group is almost totally absent, and B. obtusirostris has never been recorded from there.

$B$. longirostris seems, especially in the form cornuta, to be distributed everywhere throughout this immense territory.

The question now involuntarily arises: What is $B$. obtusirostris? What affinity is there between this species and $B$. longirostris and $B$. coregoni? According to the 
salements ol l.illjeborn B. oblusirostris is in rose

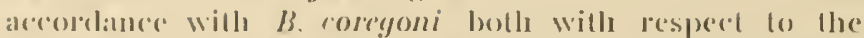
persilion of the antenna-bristle and the rurve and terelle

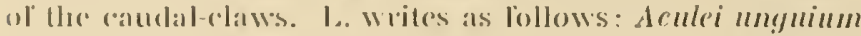

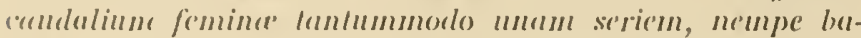
sulem formant. l'nyues rendales femina non prope basin

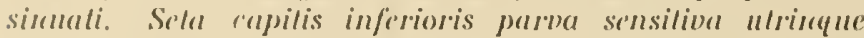
mope lincem sejunctionis antennarm 1:mi paris posila (1). 237). As neither lalljeborg nor any other naturalist as lar as l know, lave pointed out specific characters which could be employed in distinguishing B. obtusigrostris and B. coregoni from each other I am of opinion that lo: the present we must classily the lornce as belonging to B. coregoni, and more especially to the tonyispint-bohemicu group). The characters which live hitherto been employed to separate $B$. obtusirostris are the length of the antenna and the mucrones, features which according to Burckliall's examinations we know to be subject to great variation. Previous to this reduction the large aretic and northern material of $B$. oblusirostris ought to be closely examined and compared with the Swiss material of B. lonyispina-bohenica group; for my own part I am not able to undertake this, because oblusirostris is very rare, at any rate in our country. I know it from Greenland (94, pp. 119 and 120), but I have scarcely found it in Danish lakes, l once thought (94, p, 122) that I had met with this species in ponds in the neighloourhood of lirederiksborg, but after having studied 13 urckliadt's and Lilljeborg's statements I grew doubtful.

Supposing it to be proved that B. obtusirostris cannot be separated lrom the longispina-bohemica group of $B$. coregoni, and that oblusirostris is only the name, which naturalists in the north give the species found in the Swiss lakes, then it will also be proved that with respect to the geographical distribution of the Bosmince we can only maintain two territories of distribution viz. a northernarctic-alpine territory, and a central-European-plain territory the cold, clear arctic and alpine lakes with their slight variation of temp. being characterized by $B$. coregoni of the group longispina-bohemica, and the warm lakes of the plains, with their great variation of lemp. and the water of which is very rich in detritus and Plankton, by $B$. coregoni of the group Coregoni; $B$. longirostris seems to thrive in both these groups of lakes. In the second volume of this work, the temporal variation, sexual period etc. will be further treated on.

We are here touching on questions of universal zoological importance which can only be solved by taking into consideration many different fields of exploration. In the lirst place a more detailed and illustrated account of the propagation and temporal variation of these animals is necessary, but especially the illustrations would be beyond the limits of this work and must be postponed till the second part, in which we shall also have an opportunity of mentioning in detail Steucr's (01) contribution to the distribution of the Bosmine, and his views respecting this question.

p. 175. B. coregoni. I here restrict myself to the following remarks. B. c. is found in all the lakes except Esromsø. In all the lakes we have a pronounced min. immediately after the melting of the ice in April; a considerable max. then seems to occur in May and in the beginning of June; during summer the species generally becomes raner, but is however always to be found in considerable quanlities; they again increase in autumn until the greal max. oceurs in Nov., sometimes this max. lasts part ol Jan. (Julsa). A sexual period las never been proved (luring spring, but in autumn it has been proved in Furesa, Sorosa, Tjustrupso, Skanderborgsa and Julso; as a rule there were only a slight number of ephippial females, males were rare, only in Julso both were numerous; the sexual period may last until Jan. (cp). li urckharlt 00 , p. 137), who mentions a similar periodicity but has olsserved no sexual period.

B. tongirostris is proved as P'lankton organism in all the lakes explored. Max. has been obscrved in May and the heginning of June; then the species suddenly disappears lirom the pelagic region but is constantly found in the littoral region; in the pelagic region it reappears in Sep., and is found here in small quantities all winter until April-May, when max. occurs. Sometimes an autumnal max. has been proved.

Lynceida. Species of Pleuroxus, Alona and Acroperus are found pelagically in larger lakes. Only the genus Chydorus with a species C. sphcericus (O. F. M.) is a Plankton organism. It is a bottom and littoral form, but olten occurs pelagically in larger lakes, this seems more often to be the case in shallow lakes than in deep, cold and clear lakes. As Plankton organism it has a pronounced max, during summer (remarkably great in Mossø); males or ephippia were never found among specimens from the pelagic region. As is also the case with B. longirostris, a migration scems to take place at a certain time of the year from the littoral zone to the pelagic region; lurther particulars will be given in volume II.

Polyphemidæ. Polyphenus pediculus (Linné) was taken pelagically in Almindsø 01 Aug. 3rd; the banks of the lake are steep, the littoral zone is very narrow.

Bytholrephes was first pointed out in our country in Esromsø by P. E. Müller; he classed the specimen as belonging to $B$. Cederströnii Schoedler. Closer examinations proved the species occurring in our country to be $B$. longimanus Leydig; Cederströmii has not been taken here. B. longimanus was taken in Furesø, Esromsø, Skanderborgsø, Julsø and Almindsø. It is widely distributed in our larger lakes; it appears in May, max. occurs at the maximal temp. of the water, the sexual period in Oct.-Nov, after which period $B$. $l$. disappears, and from the end of Nov. till May it has never been observed. In the spring-samples it has only one pair of caudal-claws, later on it has three pairs, which is the greatest number of caudal-claws observed (P. E. M ùlle r 68 a., p. 66).

Leptodorida. Leplodora Kindtii. P. 182-83 I have endeavoured to prove, that our knowledge of the biology of $L, K$. is only imperfect. We have no experience for instance with respect to the larva-stage proceeding immediately from the winter-egg (Sars 73, p. 8 . Sars's supposition, that the disappearance of the nauplius-eye $(73$, p. 3$)$.is due to an early dying away of this generation I consider incorrect; I am of opinion that the nauplius-eye disappears during a moulting process. IVe have only an indifferent knowledge of the construction and location of the winter-egg. The Plankton-explorers generally mention Leptodora as a rather uncommon species, but I believe this to be a mistake. p. 176. 
Througlı P. l:. Mäller's $(68$ b. $)$ and Weismann's (7.) and 76) exaninations we learn the lollowing lacts wilh respect to the appearance and location of the winter-egg: When lound outside the body of the animal the winter-eggr is unconmunly large, $0,8-0,9$ mull. The egg does not either in Leptodora or in any other ol the Gymnomera winter in a special ephippium, but whilst the winter-egs of all other Gymnonter is surrounded by a thin, brownish-black chitin shell, harr and solid, the shell of the winter-egg of Leptodora is hyaline, very thick and gelatinous (the shell of the summer-egg on the contrary is very thin); the yolk-mass is only very small, so that when P. E. Müller (68 b., p. 302) states, that the winter-egg is smaller than the summer-egg, which as a rule is not the case in the Daphnioe, he is certainly right in as much as he has only studied the eggs in the ovaries, where the difference in the thickness of the membranes does not appear very distinctly; but he has not studied them pelagically, outside the bodies of the animals. It would however be more correct to say, that the winter-egg in its entirety is not smaller than the summer-egg, but that the yolk is much smaller in the former. On account of the gelatinous substance which surrounds the winter-egg, and which swells in water, this egg is in toto enormously large.

According to Weismann $(76$, p. 58) the egg enters the brood-room and continues here for some time, whereupon it is extruded into the surrounding body of vater; what further happens to it is unknown, Weismann supposes $(76$, p. 59), that the eggs are either washed on to the beach, or that they sink to a greater depth, where they remain suspended during winter in the layers of water near the bottom.

L. Kindtii is widely distributed in our country, it appears in the Plankton at the end of May and the beginning of June, temp. $12-16^{\circ}$. With respect to Furesø I have every year from $98-02$, during the month of May, studied the larva which were all at an advanced metanauplius-stage, the first specimen was taken in $\mathbf{9 7}$ by Mag. Søren Jensen, who found a few metanauplix in some mud fetched up from a considerable depth and which he had kept for some time. The nauplius-eye remains until ca. June 15 th; exceptionally a few forms with nauplius-eyc may still be found ca. July 1st, later I liave never observed it. Forms with nauplius-eye never contained brood, wherefore I am inclined to believe, that it is a larva-organ which disappears during a moulting; that it should be an organ belonging solely to a certain brood, which already dies away in May, I consider most improbable.

All through the summer a lively parthenogenetic propagation takes place, from which the great masses of Leptodora result; they abound in all our lakes at the highest temp. of the water, or perhaps somewhat later, Aug. 15th-Sep. 1st. I am quite of opinion with P. E. Müller as to the existence of enormous quantities of Leptodora during summer and early autumn; when other Plankton-expIorers have arrived at the result, that Leptodora only exists in small quantities and is often found in swarms, this must partly be due to their having used too fine nets, partly to their having principally relied on vertical samples. If the fishing be performed horizontally, and with coarse-meshed Plankton-nets, we may rest assured that Leptodora will be found in great quan- tilies, and as far as I have been able to judge, pretty equally distributed - 1 have never observed swarms in any of our lakes from July-Sep.; whilst a verlical sample taken with net $\mathrm{Nr} .20$, at most yields 10-20 Leptodora and sometimes none at all, according to the quickness with which the net is clrawn, a horizontal sample obtained from the same locality with the Lep)todora-net with ordinary rowing, will yield hundreds of specinens in two to three minutes.

$L . K$. is also in our country mono-cyclical; the nuales appear towards the end of the max. ca. Sep. 15th, and may still be found at the end of Nov.; in Sep. They are most numerous, and are then present in great abundance. About the same time the resting-eggs appear; they occur during the months of Sep.-1)ec. pelagically, but are rare at the surface, and by far the greater part keep to the middle and lower layers of water; during the period stated they were never sought for in vain in any of the lakes explored. There is no doubt, that the egg during the period Sep.--Dec. is purely pelagic, but with the exception of a single sample obtained in Jan. from Haldsø I never found any eggs in samples from Jan. to Sep. I cannot decide whether the egg is also pelagic during winter, or whether at this period it sinks to the bottom. This question must presumably be solved by the exploring of lakes deeper than those I have had the opportunity of exploring; and besides more perfect apparatuses will be needful.

As far as I know, Apstein is the only writer who makes any direct statement as to the location of wintereggs; he says $(96,1.176)$. that the nauplia are always produced by "freischimmenden Eiern". But Apstein's statements regarding the resting-eggs and the propagation of Leptodora are unfortunately very vague, and partly contradictory. Apstein reports that he has found naupliæ as early as July, and illustrates such a nauplius in fig. 100 , p. 175 . I doubt that this is a nauplius proceeding from a winter-egg; at any rate it has nothing in common with those illustrated by Sars. I have myself during July in material from Mossø regularly seen corresponding stages in the brood-room of the mother-animals. I am much more inclined to consider them as stages just proceeding from the summer-eggs, those stages also occurred free in the samples, where they have probably come either by their own aid, or by the bursting of the brood-room. At the end of Nov. Leptodora totally disappears, and from Nov. to May no specimens have ever been observed.

I wish to make the following remarks with respect to the systematical view of Leptodora.

It is not to be denied, that there is a very great inconsistency between Polyphemidae and Leplodora in all important particulars.

In the Polyphemidae the first pair of antenna are pressed against, or immovably grown together with the underside of the head; they are directed forwards, and of an almost similar construction in both sexes; the two branches of the second pair of antennæ are, as is the case in most Daphnia, only provided with a small number of swimming-setæ $(6-8$ each $)$, maxilla are present; they have four pairs of legs. The part of the body which comes after the segments bearing the legs is of a most varying construction, but always short and is either not divided into segments or at any rate only 
slightly so, and most pronouncod in Bylholrophes. In Polyphemes the abdomen and post-abdomen ale merged into a short rudincent, devoid of rlaws and joints; the protuberaner which carries the loug bristles is long and spinc-lorned; in Bytholsephes the postalubonen with the chaws is rery romspicuous, the protuberance immense, the bristles very small. In Podon and Evadne the claws are well developed, a protuberance as a rule slightly distinet and the bristles conspicuous. A dorsal-organ appears in all Polyphemide, and gencrally strongly developed. "lhe construction of the brood-room varies greatly in the dillerent forms, but as I do not consider ils formation and development as quite understood, and must for my own part regret, that l have not attained to any certain linowledge of it cither through literature or personal eximinalions, I shall not mention it further. I shall only remark that the botton of the brood-room, at any rate in Polyphemns and Bylholrephes, is furnished with a cellular, nutrimental lissue, which yields the nutrious juice, on which the development of the egg in the brood-room is dependent. The resting-egg is only produced by one germ-group (We ismann 76 , p. 135); it is surrounded by a brownish-black chitinous shell; as far as we know it is deposited on the boltom of the lake

Leplodora almost totally varies in all these features. In the male lirst pair of antenna are very long, almost half the length of the whole body and much longer, than those of the female; as a rule they are directed backwards; the short antenna of the female are bent downwards, and are never directed forwards or pressed algainst the head. The two branches of 2nd pair of antenna bear a great number of swimming setæ $(25-30)$, each joint up to $10-12$; maxillæ are wanting; 6 pairs of legs. The posterior part of the body is very long, and distinctly divided into four longish, cylindrical segments, the last segment terminating in two, dislinct claws, soft and pliable, which are probably quite rudimentary. There is no trace of spine-formation, and the bristles are so small that it is difficult to distinguish them. No dorsal organ has been proved; at any rate it is not conspicuous. The brood-room has no nutrimental tissue: the shell of the winter-egg is thick, limpid and gelatinous; the eggs are, at any rate at a certain period, pelagic, the young ones are nauplii. The resting-eggs proceed from two or more germ-groups.

If to these very considerable differences we add, that differences may also be pointed out in many features of minor importance, f. i. with respect to the eye, we feel prompted to examine more closely, what has been the cause of Leptodora and Polyphemide having been placed in one and the same sub-order. As is well known Sa rs divides the Cladocera into two large tribus, Calyptomera and Gymnomera, and as distinguishing characters employs the development of the carapace, the nervous system and second pair of antenna. P. E. Müller is quite justified in drawing the attention to ( $68 \mathrm{a} ., \mathrm{p} .88$ ) the defectiveness of these principles of division; on the whole, however, he adheres to Sars's classification, but lays the stress on the great difference in the bonestructure, also emphasizing that the first suborder (fam. in P. E. M üller) contains more or less pronounced herbivorous, and the second the most pronounced carnivorous animalcules. Müller moreover maintains, that
Sars, in classilying Polyphemide and Leptodorider as two lamilies, has separated them loo far lrom each other and wants them to be classed as one lamily, his main reason being, that Leplodora also las a distinctly developer, though smaller inner appendage (68u., p. 92) on the 1st pair of legs, a lact which Sars does not seem to have olsserved. Nor can it be denied, that the naked, raptorious legs, covered will spines, and where in both cases the lirst pair of legs are far more developed than the lollowing, at first sight is the most pronounced common feature in the organisation of these remarkable Cladocera. A leature which contributes to augment the common stamp is, that the legs in all these forms, contrary to all other Daphnia, are placed on a line, which is always oblique on the longitudinal axis ol the bocty, and at times to such a legree, that the line is about at right angles with this axis; in all other Cladocera the line on which the legs are alfixed is parallel with the axis of the body. This curious arrangement, unto which only slight attention has hitherto been paid, occasions the legs to be directed forwards, and below the mouth.

If however we examine the construction of the legs more closely in Polyphemidae and Leplodora, we shall notice sone rather important differences; even if we do not take into consideration the very important fact, that the former has but 4 pairs of legs, and Leplodora 6 , the individual limbs are quite differently constructed, especially with respect to 1 st pair of legs. I shall here only refer to the illustrations and statements of Claus, We is mann and Lilljeborg. It seems evident to me, that even if those processes, which have brought about the raptorious legs of the Gymnomera, seemingly have produced a result common in both, yet the material transformed was originally of a quite different nature. According to my view the same position of the legs and the seemingly homogeneous construction as raptorious legs in the two families Polyphemidae and Leplodora, are characters which were caused by a similar mode of life and way of procuring food. - All Gymnomera are more or less pelagic Cladocera, descending from bottom and shore-species, and subject to the mutual laws of transformation of the original organisation, the laws to which all pelagic organisms must adapt themselves, though in different ways. In Leplodora as well as in Bylholrephes and Polyphemus the legs are first of all prehensile and raptorious legs, which while the animal stands hovering in the water are stretched forwards and outwards, ready to grasp the food which happens to present itself, and when the animal moves about they are the means of catching the prey it is in pursuit of. Noreover the legs probably act as organs that prevent its sinking too quickly downwards. In large aquariums everywhere equally well lighted, the functions of the legs of Bylholrephes and Leplodora may be easily studied. I am not acquainted with the functions of the limbs of Podon and Evadne, as I have never examined these forms.

In order to further accentuate the similarity of the position and construction of the legs as biological characters, produced by a similar use and mode of living, I draw the attention to the fact, that we find a cuite corresponding structure of legs amongst other groups of animals, where the legs in the same manner are 
constructerl, so as to enable the animals to catch their prey in the flight.

In the lirst place we meet with it in many pelagic malacostracan larva, but it is also met with in insects f. i. in the dragon-flies which, as is well known, for the greater part catch their prey in the flight. Also here the legs are directed forwards and down below the mouth, and are likewise raptorious legs with strong spines; in all these cases a kind of basket is formed owing to the position of the legs and the spines; the basket is open in front, but closed at the back, and in these baskets the prey is caught, whether it be in the air or in the water, the sides of the basket close in upon the prey, which is then speared on the numerous spines.

As I do not consider the great homogeneousness of the structure and position of the legs in Polyphemidae and Leptodora as proofs of a common descent, but as common features which are occasioned by a similar mode of life, and as I strongly wish to emphasize, that a closer examination will prove very distinct differences, it will be clear that I cannot agree as to the correctness of dividing the Ctadocera in Catyptomera and Gymnomera. Sars was evidently correct in his view, that the homogeneous structure of legs, which is the most prominent common feature in the organisation of the $\mathrm{Gym}$ nomera, ought not to be employed as a mark of division of the 1 st order, and admitting the great differences between Potyphemida and Leptodora he places them as far apart as possible in two separate orders. With respect to $P$. E. Müller's view I cannot share it; in basing the main classification of the Daphnice on the structure of the legs, and in considering the Potyphemidoe and Leptodora as one family he has according to my view by no means improved upon Sars's system, but rather the reverse. P. E. Müller's appendage on the 1st pair of legs cannot be employed as a proof of affinity between Polyphemidoe and Leptodora. As the raptorious legs in both families are transformed legs of Catyplomera (P. E. M., p. 88) it is but natural, that remnants of the inner appendages have been preserved on the raptorious legs of both families; these appendages characterize the legs of all Calyptomera.

In thus giving up the systematic division Calyptomera and Gymnomera, the question is, whether the Potyphemida and Leptodorida can be grouped in relation to each other in any other and more satisfactory manner.

As a rule we may take it for granted, that the primitive forms will scarcely be found among the Plankton organisms, but on the contrary amongst the bottom- or littoral-species; with respect to the Rotifera I have tried $(99$, p. 115) to point out the manner in which parallel lines of development have arisen from the Notommatidoe which only embrace bottom-species; these lines all terminate in forms which at any rate are free-swimming, and whereof a great many are pelagic. In the same way I am inclined with respect to the Cladocera, to seek the primitive forms in the division of crawling Lynceidoe, and to consider the pelagic forms as the most specialized, and in many cases as the youngest forms. I am unable at present to set forth my views in detail with respect to the affinity of the Cladocera, I shall here restrict myself to mention the position which Leptodora ought to occupy in the system. - Leptodora is first of all a form which diflers excecdingly from all other Cladocera; the construction of the lindmost segments of the body, the shell-structure of tlic resting-egg, the nauplius, besides the fact that the animal is so excessively hyaline, are all features that in Leplodora offer some striking points of difference. Accorling to my view these characters must all be classed as Plankton-characters; I scarcely need to point out, that the length of the bolly and the hyalinity must be defined from this point of view, and besides I am inclined to consider both the construction of the resting-egg and the nauplius as features being due to Leptodoras life as pelagic organism.

With respect to the nauplius it must be remembered, that the peculiar features of development in Leptodora do not commence here, but in the resting-egg which in its construction differs from the resting-eggs of all other Ctadocera, we notice especially that as far as is yet known, the resting-egg of Leptodora has the smallest amount of yolk-mass of all. As is well known the small quantity of yolk-mass is a common feature in pelagic eggs; the chief condition for an egg to become pelagic must either be a reduction of the yolk-mass - the yolk consisting chiefly of albumen will drag the egg downwards - or an increase of the factors which contribute to keep the egg suspended (spine-formations, oil etc.), or both these features combined. It is a commonly acknowledged rule, that the stage at which the youngone leaves the egg depends on the amount of nutriment it has received during the egg-stage, and that eggs with a small quantity of yolk-mass produce animals which differ most from the adults.

Taking these facts into consideration we shall, with respect to the nauplius, arrive at a different conclusion from that of most of my predecessors.

In developing into a pronounced Plankton organism the appearance of Leptodora as such must be essentially dependent on the structurc and location of the restingegg. If a reduction of the yolk-mass has taken place, which seems to be the case in Leptodora, this will occasion the young one to proceed from the egg at a much earlier stage than the young-ones of the forms, from which the species descended, and in which no reduction of the yolk-mass takes place. Consequently a larva-stage must proceed from the resting-eggs of Leptodora, a stage which proves to be essentially characteristic for this class, viz. a nauplius.

In accordance with this view I consider the nauplius in Leptodora as a new development occasioned by the life in the pelagic region.

Though Leptodora thus strongly bears the stamp of being an animal transformed into pelagic life, this transformation is not so great but that its affinity according to my opinion can be determined with perfect certainty Leptodora belongs to the Ctenopoda and may be considered as a Sidid transformed into pelagic life. In the Sidida the 1 st pair of antennæ are, as in Leptodora, more strongly developed in the males than in the females; in the former they may almost attain the entire length of the body, and are of quite the same form as in Leptodora; the upper branch of 2 nd pair of antennæ on both segments carry a large number $(10-12)$ of swimning setæe whilst the other Daphnia have only a small number (5). There are six pairs of legs, as in Leptodora, and the resting-eggs likewise proceed from 
Iwo ol more germ-groups. Moreover hille is a great comlormity with respect to some less imporlant structures, l. i. Hoe lome of the eye, the position of the lenses and the lorm of the liead; areording to my view there is a close relationship belween Diaphanosoma and Leptodore. From this will be seen that I strongly disagree wilh Her view mantaned hy Woismann (74, p. 59 a. o.) lhat leptodora, amongst other things on aceount of the presence of a namplius, should be a very old form, an "Irdaphnider, as he terms it. Weismann's view with respecel to Leplodoret olfer's a striking instance of misinterpretation on part of so cminent a seientifist.

I an moreover inclined to bolicve, that in the same way as Leptodora through Diaphanosoma is connected with a pronounced bottom-species such as Latona, the Bosminure are likewise connectel with Chylorus and other Lynceide through the forms mentioned and deseribed by Lilljeloor gs (00, p. 222), and that Polyphemus and Bythotrephes are connected with Ccriodaphnia and baphnia through Moina.

Some general remarks with respect to the biology of the baphnia I have for the greater part deferred to the second volume of this work.

\section{Copepoda.}

1. 190. Cyclops. Only three species of Cyclops have been proved in our larger lakes. C. Lcuckarti Claus seens only to play a minor part. C. oithonoides f. O. Sars occurs in somewhat greater quantities. Max. is generally reached during the summer half-year, most frequently in April-May. C. strcnuus Fischer only occurs abundantly in Esromsø and Viborgsø. It seems to have two max.. one great autumn-max., and one inferior in spring. Burckliaril arrives at a similar result. (Lit. see p. 193),

1). 193. Heterocope has strange to say not been found in this country.

p. 193. Eurytemora lacinulata Fischer, and E. lacustris Poppe have been found in a few localities by S. Jensen.

p. 194. Diaptomus is only represented by D. gracilis G. O. Sars and D. graciloidcs Lilljh. in the pelagic region of our larger lakes. I consider these two as good species, but they are difficult to distinguish from each other. D. graciloidcs has been proved in Esromsø, Sorøsø, Tjustrupsø and Haldso. As an illustration of its mode of life in one of our larger lakes I shall here state my observations lirom Esromso.

Esromso. D. graciloides is the Crustacea which occurs most frequently in this lake.

In the sample 00 Dec. 17 th $\left(\right.$ temp. $\left.5^{\circ}\right)$ were found for the greater part young females without eggs and spermatofores, some males, seareely any nauplix and but few individuals not yet arrived at puberty. 01 April 10 th (temp. $3^{\circ}$ ) D. gracil. was evidently in the midst of a great sexual period; the females almost all earried eggs (7-9), and frequently bundles of spermatofores: males appeared in great numbers, but only little brood. Niay 6 th (temp. $8^{\circ}$ ) circumstances are about similar; number of eggs somewhat inereased (10-12), males perhaps fewer in number; many naupliæ and metanaupliæ were observed, but only few older stages. May 25th (temp, $13^{\circ}$ ) the number of animals arrived at puberty liad perceptibly decreased; the females only carried $4-5$ eggs; on the contrary great quantities of young animals were present forming the main-part of all Crustacea-plankton. In the following samples from June 26 th (temp. $15^{\circ}$ ). July 20th (temp. $17^{\circ}$ ) and Aug. 12th (temp. $21^{\circ}$ ) young animals likewise abound; males are rare, and very few females with eggs (ea. 4) are observed (perliaps 1 out of 1000). Sep. 5th (temp. $\left.16^{\circ}\right)$ and 30 th (temp. $\left.17^{\circ}\right)$ the number of indi- viduals secoms to decrease, several proved to be males, but females with eghss (ca. 4) were still equally rare; the next two or threc samples from Oct. 15th (temp) 12"), Nov. 10th (temp. $7^{\circ}$ ) and Dece 17 th $\left(\right.$ temp. $\left.1^{0}\right)$ give chiefly the same result. flie males; lowever, increase in number, females with eggs arc still rare fee. 17 th, but the 13 mber of eggs has increaserl to $5-6$. 02 Jan. 27 th (temp. $1^{\circ}$ ) several females witls eggs $(4-6)$ are observed, and numerous males; Marel $22 n d$ (temp. $2^{\circ}$ ) alonost all the females carry eggs (7-9), males are numerous; April 17 th (temp. $4^{\circ}$ ) very little change, only the number of eggs is 12-14; the greatest number was found May 13th (temp. $8^{\circ}$ ), (10-18). Througliout the whole of this period males appear in great numbers, and the females often carry clusters of spermatofores; empty, drifting clusters of spermatofores are conlmon in the l'lankton. May $231^{\circ}$ (temp. $9^{\circ}$ ) most of the females still earry eggs, but only amounting to $7-8$; males are rare; from April 17 th (temp. $4^{\circ}$ ) increasing quantities of naullia and metanauplise are observed, the max. of which occurred ca. May 23 rd (temp. $9^{\circ}$ ); June 13 th $\left(\right.$ temp. $13^{\circ}$ ) only a few adult animals were olsserved, number of eggs 5-6, but enormous masses of half-grown individuals; July 10th (temp. 14 ${ }^{\circ}$ ) and July 31 st (tcmp. $15^{\circ}$ ) cireumstances unchanged.

With respect to the propagation of D. gracil. in Esromso it is uncommonly manifest and intelligible.

From the end of March to the end of May a pronounced sexual period occurs, after which great quantities of brood appear which form the immense l'lankton-swarms of Copepoda during summer and autumn; from June till Dee. only very few females with eggs are 'seen, the number of males constantly increases, but the propagation is searecly eonsiderable, f draw this conclusion partly from the spermatofores being rare in the females and partly from the fact that only small quantities of nauplia were found all the summer; the pairing does not generally commenee until Dec., when the spermatofores in the females are frequent.

The number of eggs increases and decreases quite regularly in the course of the year, it is $5-6$ during winter, increases to 7-9 at the beginning of the sexual period (Mareli), and at the end of this period (May) it is $10-12$, then it deereases to $7-8$, and in the time from June till Dee. we scarcely meet with females earrying more than 4 eggs.

Everywhere in our lakes a sharply defined sexual period occurs during March-May; males are then found in great abundance, the females almost all carry eggs; there is hardly any brood. At the end of May the sexual period ceases, and immense quantities of naupliæ and metanaupliæe appear in all the lakes associated with the Rotifera and the commencing summer-generation of Daphnia; jointly they form the exceptionally pure zooplankton of early summer, which more or less characterizes our lakes at the time, when the Diatoms are disappearing, and the Cyanophycea and the Ceratium are not yet developed. Summer and autumn the Copepodastock consists of young animals, females with eggs being exceedingly rare as also adult males; the females only exceptionally carry spermatofores, and no spermatofores ready to be projected are visible in the body of the males; there is scarcely any brood. Circumstances are unchanged till Dec.-Jan., when the males seen fully developed, but the pairing and propagation is not general until March- April after the final breaking up of the ice; sexual periods during the autumn have nowhere been proved.

The number of eggs is at no time considerable, but greatest about the end of the sexual periods (12-14, exceptionally $14-18$ ), after which it suddenly decreases to $6-8$, and during summer and autumn is rarely above 4; in Aug.-Sep. it is not uncommon to find only 3 , often only one egg is observed; from Dec.Jan. the number of eggs increases slightly (5-6), and after the final breaking up of the ice it is generally ca. 7-9. 
1). graciloides in our larger lakes requires a year to be fully developed; it is hatehed in April-May, and does $110 t$ pair and propagate until March-May the lollowing year; by far the greater part of the stock of 1). graciloides of a lake will be ol the same age, viz. hatched at the same time. The strongly marked sexual period, the almost tolal disappearance ol males in June, the very few females carrying eggs during the time from Itune till bec., and the very small quantities of brood are phenomena which taken together do not allow of any other explanation.

p. 196. D. gracilis G. O. Sars has been proved in Furesø, Viborgsø, Skanderborgsø, Mosso and Julsø. The propagation of this species differs greatly from $D$. graciloides, but cannot be recorded with the same degree of certainty. We have here no strongly marked sexual period as in the lormer, whereas a considerable number of females carrying eggs are found all the year round; males are met with at all times of the year, and the females carry spermatofores at all seasons; brood is never entirely wanting. Females with eggs are however most frequent in May; at the same time numerous males appear with an immense transformed right antennæ, and at this period brood is most scarce; a sexual period seemingly occurs in all the lakes in Sep.-Oct., but even less distinct than in the spring.

Also in this species the number of eggs is largest in spring and steadily decreases until autumn, when there is a slight increase, towards winter it again decreases. As above mentioned the number of eggs is far greater than in D. graciloides, in April-May often 20-30, and in summer it is seldom lower than 10. Only in Furesø $D$. graciloides forms an exception, here the number of eggs generally increases to ca. 12 during the autumn, and during winter decreases to 8 .

$\mathrm{Burckh}$ ardt has studied all these particulars very closely in the Vierwaldstättersee in Switzerland, so I refer to his work $(00$, p. 153).

With respect to the max., min. and sexual periods of the Copepoda in our lakes I refer to the above, and shall here only direct the attention to a few particulars of more general importance.

It is thus rather remarkable to notice not only how constant the number of eggs always is at certain times of the year in the different Copepoda-species, but also how rentarkably alike the different species of Copepoda appear with respect to the number of eggs; both in Cyclops strenuus, Diaptomus gracilis and D. graciloides the number of eggs is greatest in the spring, respectively ca. $40-50,25-30$, and $14-16$, smallest during summer, $20-30,10-12,2-4$; then again it increases towards autumn.

But what is still more remarkable is that the size of the egg, in all three species is decidedly smaller during spring, when the species carry a great number of eggs, and of the largest size during summer when the number of eggs is only small.

The diameter of the egg in $D$. graciloides is during spring ca. $120 \mu$, during summer ca. $160-200 \mu$. I shall here only remark that, as it is supposed that the stage of development at which the young-one leaves the egg is dependent on the quantity of yolk-mass in the egg, I am inclined to believe, that at any rate young-ones proceeding from the summer-eggs must be larger tlian those proceeding from the springeeggs, and that perhaps a lecline in the metamorphosis might be proved in consequence of which the young-ones hatched during summer would appear at, a metanatplius-stage and not as natuplius.

The examinations relating to this question are however only in their infancy; the pronounced cannibalism of the Copepoda presents a great hindrance in this respect, as the mother-animal almost instantly devours her own brood; to separate the eggs from the animal and keep them apart does not avail, as eggs that sink to the bottom always seem to become coated with phycomycetes. My object here has only been to draw the attention to a point which needs a careful examination.

By every month regularly examining the pelagic $\mathrm{Co}-$ pepoda of our lakes, we cannot fail to notice, that at any rate several of these creatures change their colour in the course of the year (Litr. see p. 202). While the Copepoda during summer are either colourless or of a fine blue metallic-colour, there are species which during winter regularly attain a crimson colour; with respect to our lakes this is especially the case wilh D. graciloides, D. gracilis and C. strenuus; in the four lakes Furesø, Esromso, Tjustrupsø and Sorøsø, where 1 myself have fished Plankton and examined it while it was alive, I have each year from Nov.-Dec. seen the red colour become predominant and keep so all through the winter, and then disappear in April-May. With respect to D. graciloides it must be supposed, that it is the generation hatched in spring, which changes its colour in Nov. and remains red until its death; the nauplia which appear during the early summer are, as far as is known, always red; when the animals grow older, the red colour disappears, and does not reappear till Nov. With respect to Cyclops strenuus and D. gracilis, in which forms we may suppose the existence of two generations, it seems as if the red colour is most pronounced in the generation, whose sexual period occurs during winter.

The deeper or paler colour is directly proportional to the quantity of oil in the Copepoda; the oil appears in the form of large globules, for the greater part situated along the back of the animal. In $D$.graciloides of Esromsø one large globule, often three-lobed at the frontside, constantly appeared in the anterior part of the body somewhat behind the eye, and at some distance from it a larger or smaller quantity of oil globules grouped around and somewhat behind the mouth; this area was by strings of globules connected with a third area situated at the posterior end of the fore-part of the body. The foremost globule is constant all through the year, but the quantity of oil in the two following areas varies at the different seasons; yet it is always most considerable at a low temp.; the greatest quantities of oil, and the red colour arising from it, was found shortly after the great Diatom-max.

In comparing the oil globules in the Melosira-cells with those of the Copepoda the thought struck me that the oiI globules of the Copepoda may be identical with and originating from the oil globules of the Melosira-cells.

It may still be added that Ergasilus is rather common p. 202. in the pelagic region of most of our larger lakes, espe- 
rially during summer. Caligus lacustris Slp. d Idk, has fren proverel in fiureso; Argulus is very oflen brought (1) Jight in lhe Planlifon-nels, it secoms lo be more firefurmlly fommd lies-living than is enenemally supposed.

\section{Aranea.}

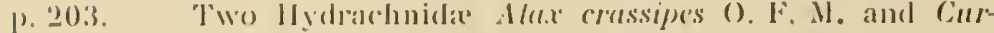
vipes rolundus libumer have been taken, but lave not bero relosely exanined.
As is well known the Alax-species are supposed to deposit their eggs in the mantle cavity of the mussels; will respect to A.crassipes l'iersig is of opinion, that the egrgs are not deposited in mussels, but on Spongille. In some smatl lakes near frederikshorg, where $A$. crassipes occurred in great puantities, I found during JulyAug. an Ala.r-species by hundreds in the outer layers of some large Spongilla-clumps; they were not closely cxamined, but have must probably been stages of Alax crassipes. 


\section{STUDIER}

\section{OVER \\ $\mathrm{DE}$ \\ DANSKE \\ SØERS \\ PLANKTON \\ AF}

Dr. C. WESENBERG-LUND

FOR DE BOTANISKE AFSNitS VEDKoMmende MED BISTAND AF MAG. SG. E. LARSEN

SPECIELLE DEL

II. BILAG

8 KORT, 10 TAVLER OG 9 PLANKTONTABELLER

PAA CARLSBERGFONDETS BEKOSTNING

KJØBENHAVN

GYLDENDALSKE BOGHANDEL • NORDISK FORLAG 



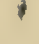




\section{PLANKTON}

I N V ESTIGATIONS OF

\section{THE DANISH LAKES}

I3 Y

Dr. C. WESENBERG-LUND

ASSISTED BY Mr. E. LARSEN IN THE BOTANICAL RESEARCHES

\section{SPECIAL PART}

II. APPENDIX

8 MAPS, 10 TABLES AND 9 PLANITON-PLATES

PUBILSHED BY THE AID OF THE CARLSBERG FUND)

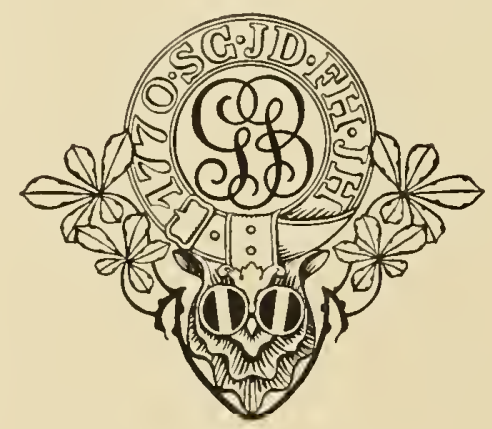

COPENHA GEN

GYLDENDALSKE BOGHANDEL・ NORDISK FORLAG PIRINTED BY NIELSEN di LYDICHE 


\section{STUDIER}

OVER

\section{DE DANSKE SOERS

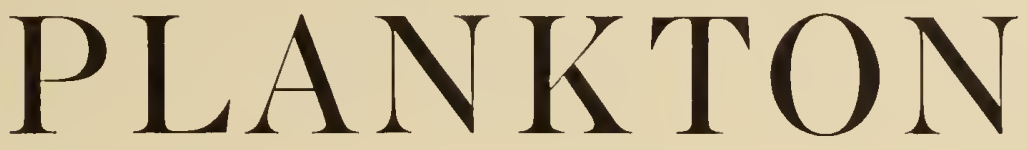 \\ $\mathrm{AF}$}

Dr. C. WESENBERG-LUND

FOR DE BOTANISKE AFSNITS VEDKOMMENDE MED IBISTAND AF MAG. SC. E. LARSEN

SPECIELLE DEI.

II. BILAG

8 KORT, 10 TAVLER OG 9 PLANKTONTABELIER

PAd CARLSBERGFONDETS BEKOSTNING

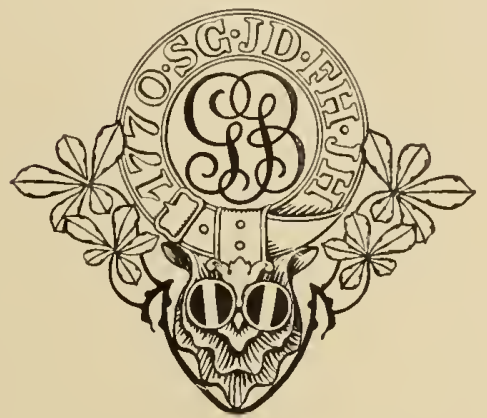

K.J OENHAVN

GYLDENDALSKE BOGHANDEL - NORDISK FORLAG 


\section{THYKT HOS NIELSEN \& LYDICHE.}


K O R T. 


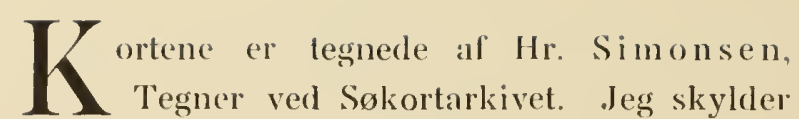
Sokorlarkivel, hror Birkedommer Fiedlers Kort over Esromsø opbevares, min Tak, fordi det har tilladt mig Benyttelsen al Kortet; samme Tak retter jeg til Hr. Kammerherre E. Vedel, tidligere Amtmand over Sorø Amt, og $\mathrm{Hr}$. Ingeniør Wolff for Benyttelsen af de al dem opmaalte og udarbejdede Dybdekort, henholdsvis over Sorøsø og Furesø. 
Kort Nr. I.

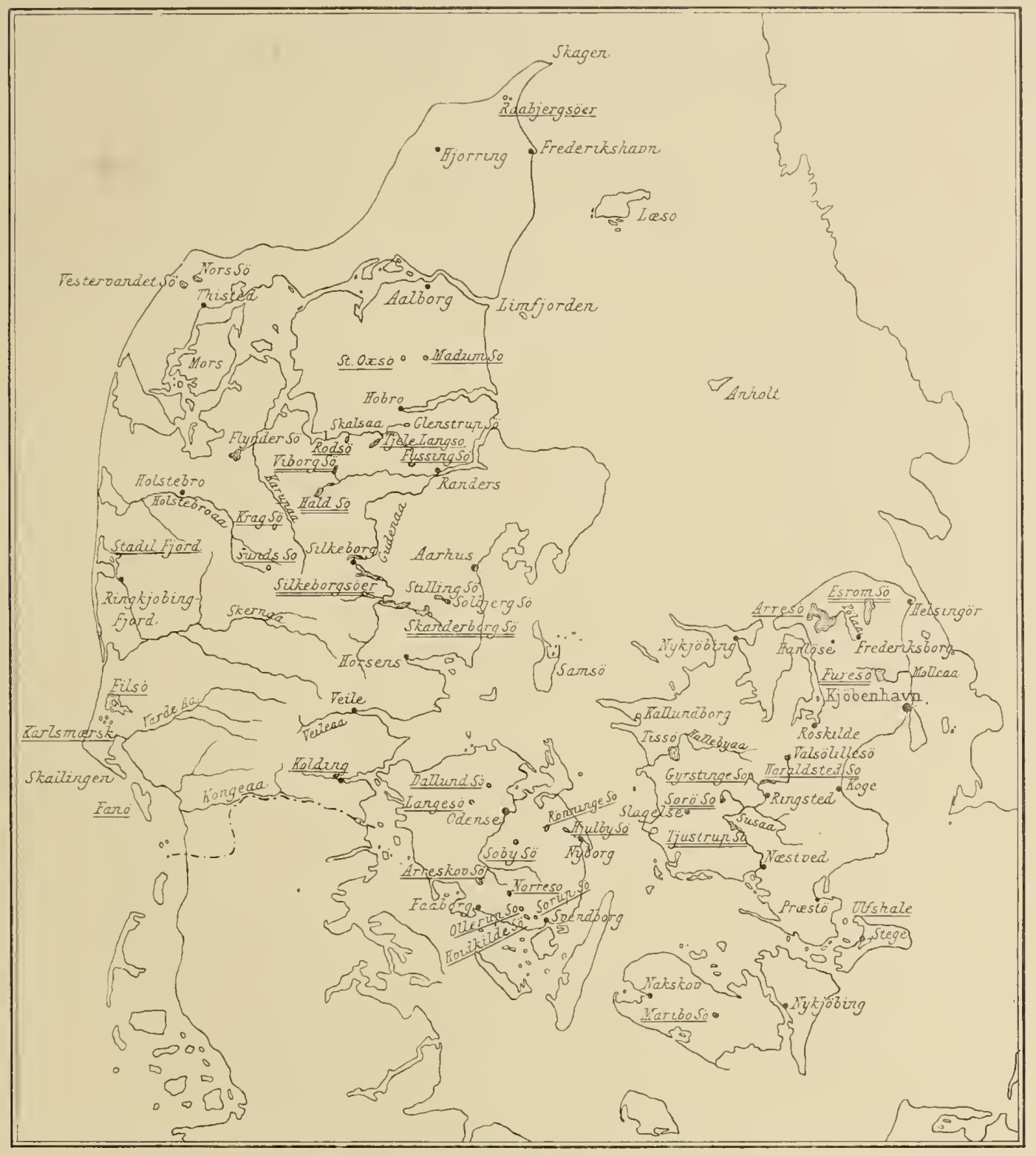

\section{Danmarkskort,}

der angiver de Steder, hvor Planktonundersøgelser er bleven anstillede; efr. dog ogsaa Speeialkortene II, V, VIl og VIII.

angiver de 9 Søer, der er bleven Genstand for den regelmæssige Undersogelse.

(Silkeborgsøer $=$ Mosso og Julsø; efr, Kort Nr. VlII).

angiver, at Plankton her kun er indsamlet enkelte Gange. 
Kort Nr. II.

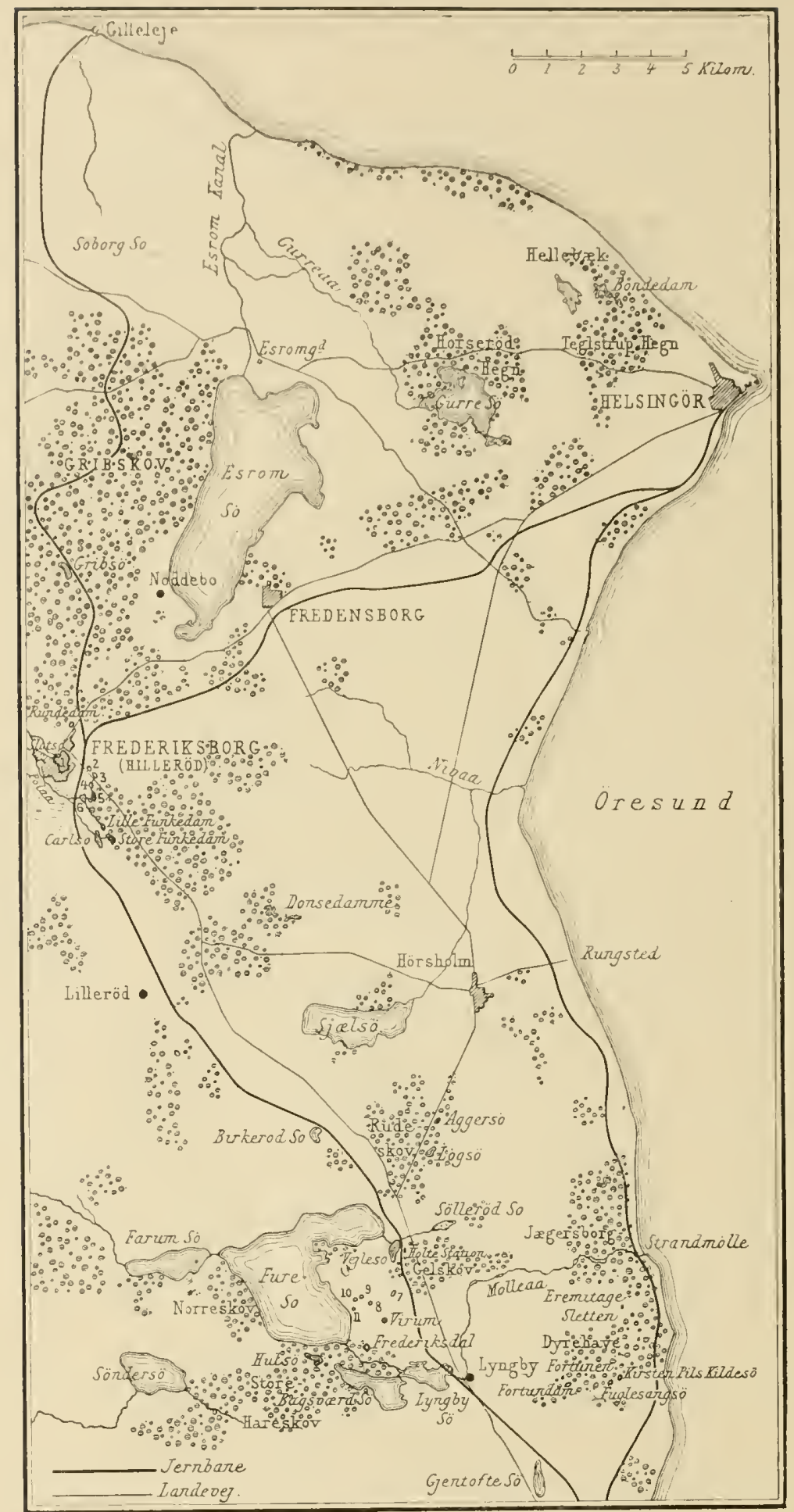

\section{Kort over det nordøstlige Sjælland}

med Angivelse af de vigtigste Lokaliteter, hvorfra der indenfor dette Terrain foreligger Planktonundersogelser. Mrk. særlig Frederiksborgdammene 1-6 og Holtedammene 7-11 (se p. 13). 
Kort Nr. III.

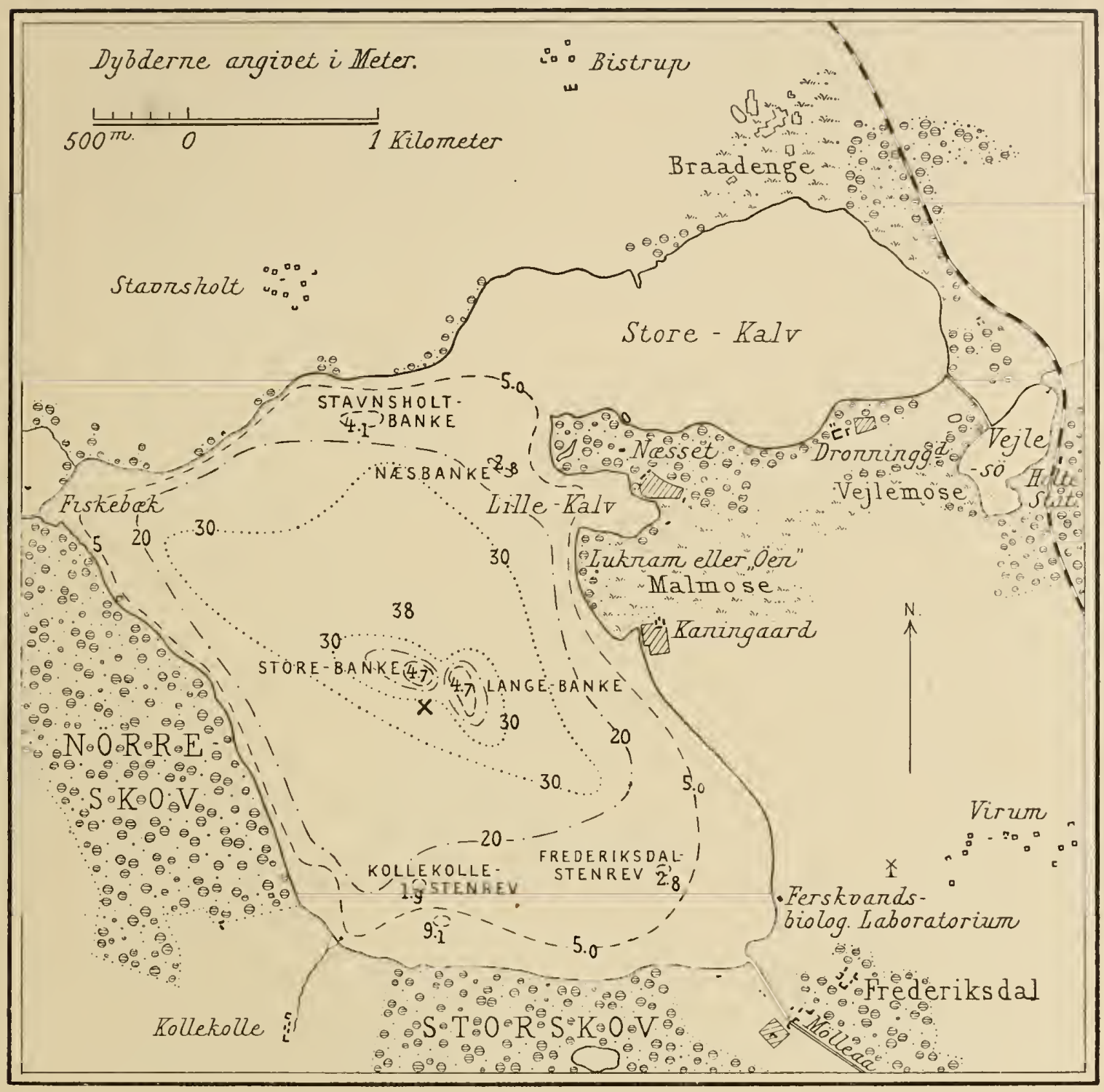

Kort over Furesø med Dybdekurver.

X Stedet, hvorfra Planktonproverne stammer.

Dybdekurverne efter et af Hr. Ingenior O. Wolff udarbejdet Kort. 
Kort Nr. IV.

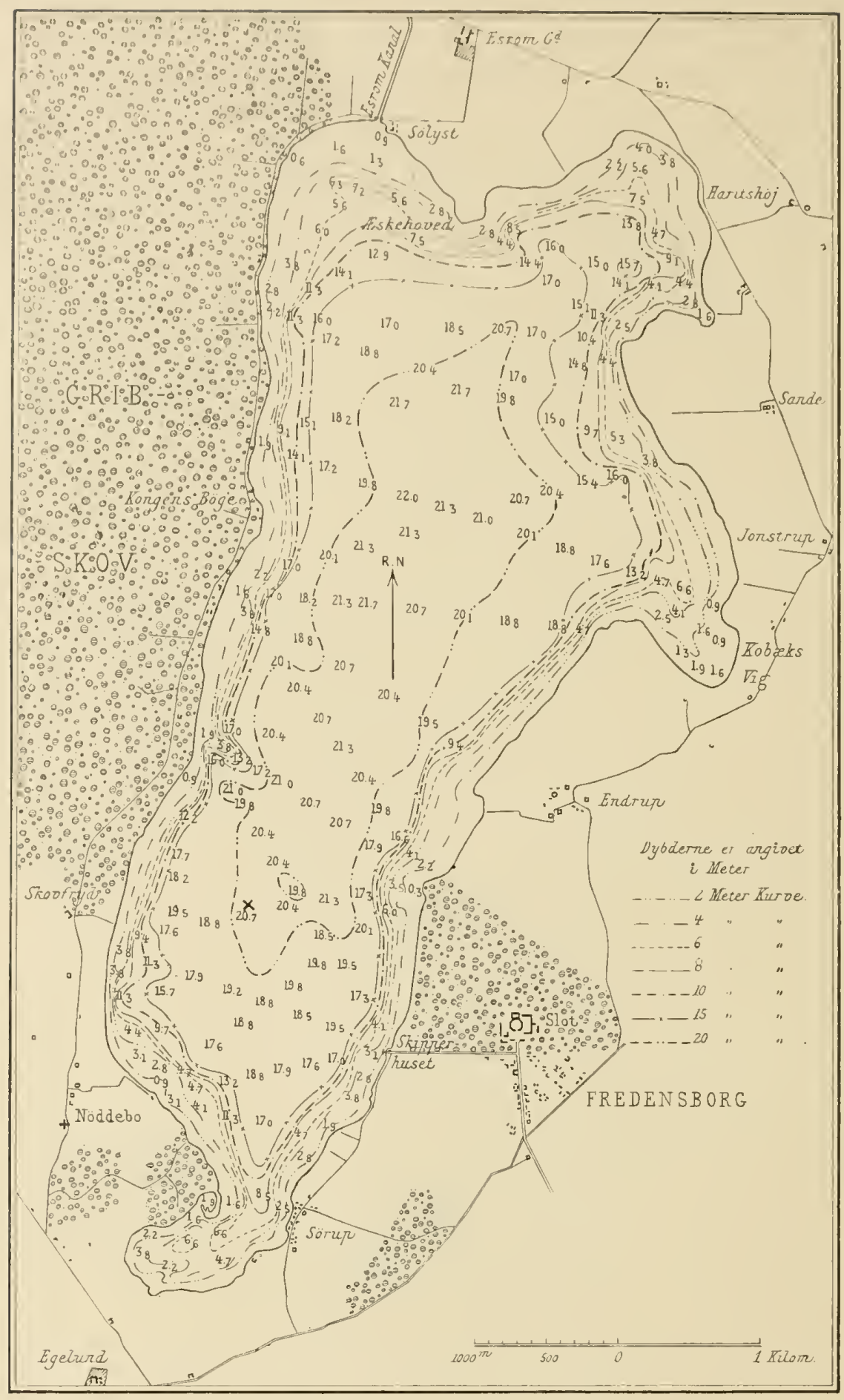

Dybdekort over Esromsø.

Maalt og udarbejdet af Birkedommer Fiedler 1871.

$X$ Stedet, hvorfra Planktonproverne stammer. 
Kort Nr. V.

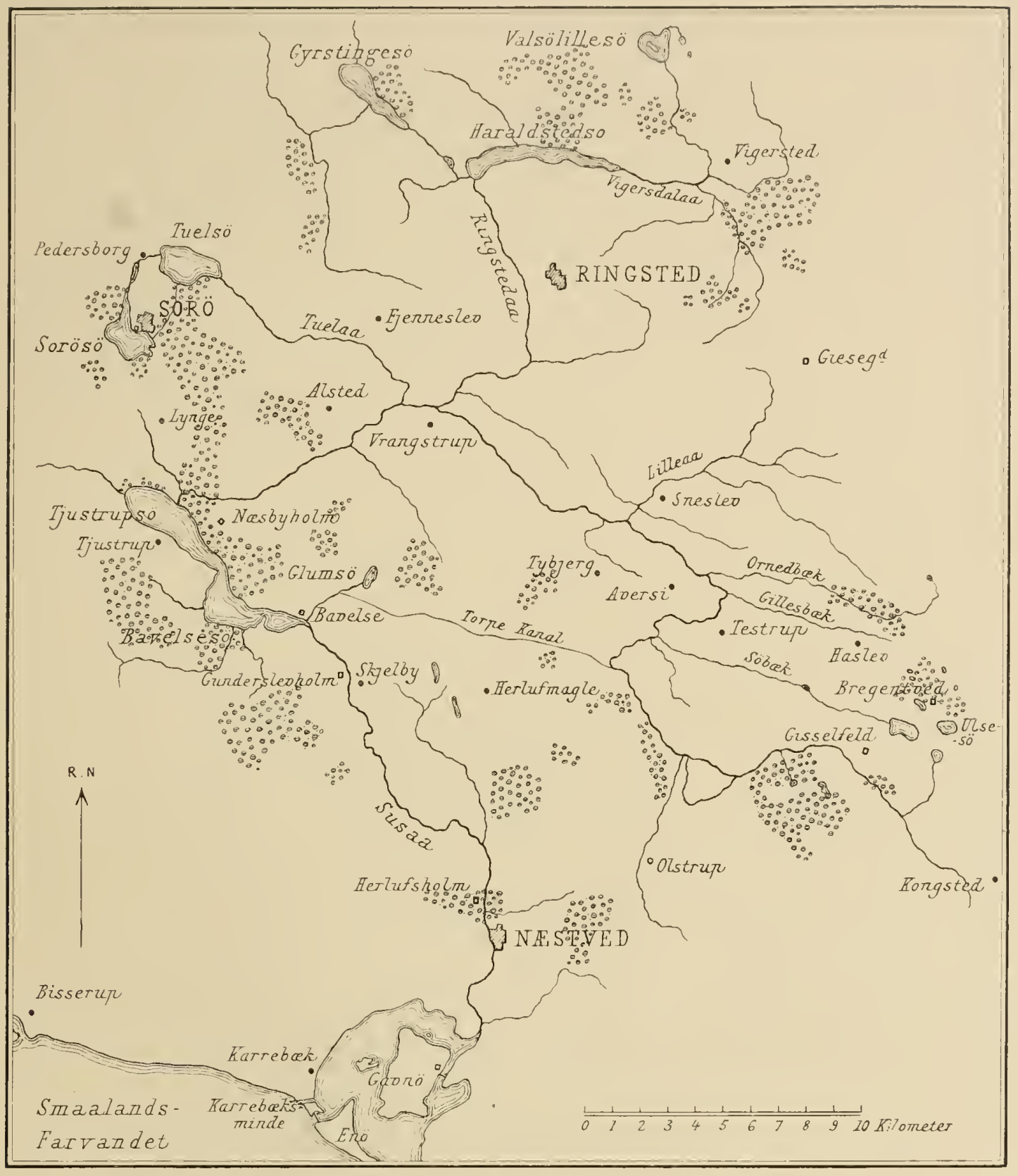

Kort over Susaaens Afvandingsomraade.

PIanktonproverne fra Tjustrupsø tagne midt mellem Landsbyen Tjustrup og Susaaens Indmunding. 
Kort Nr. VI.

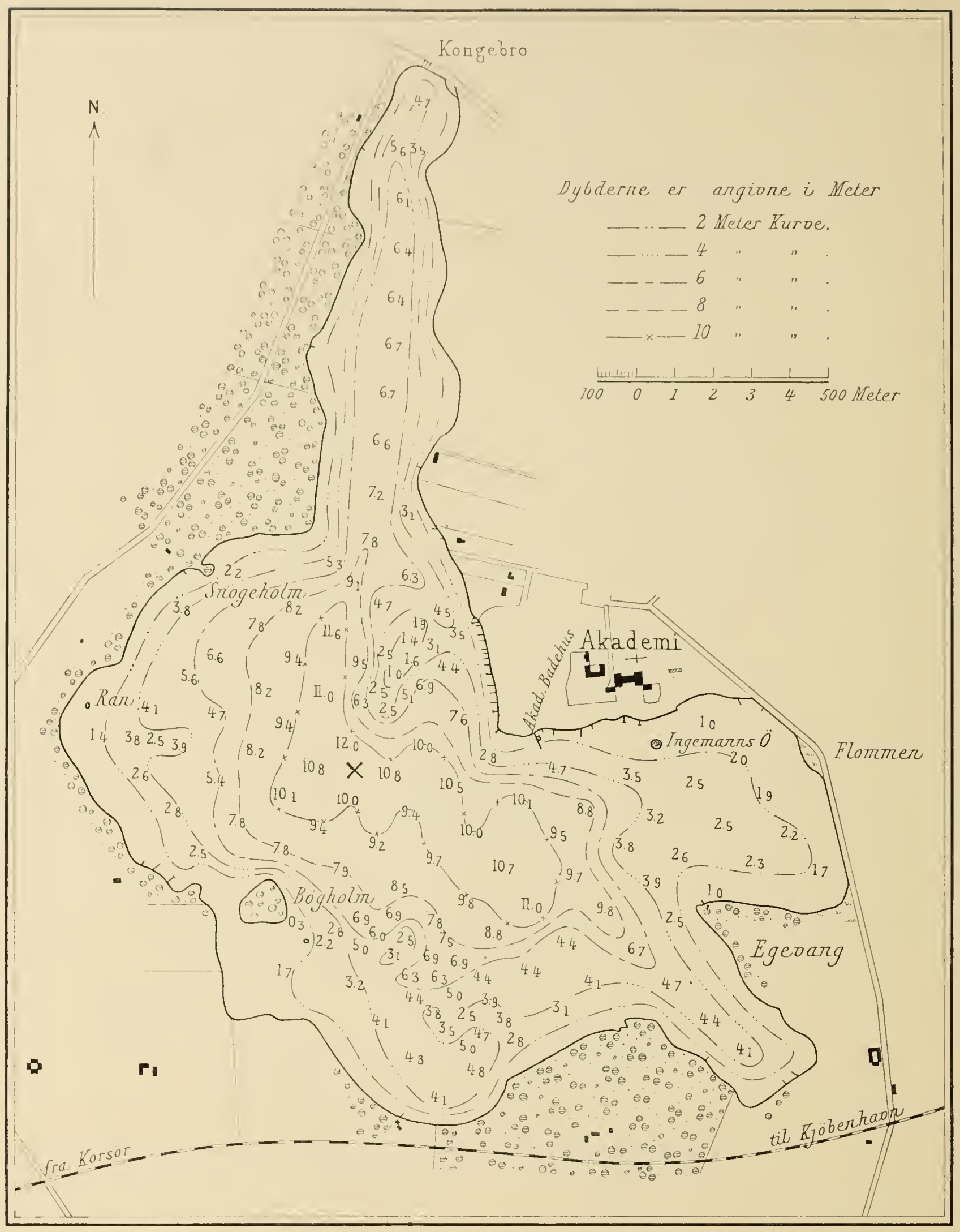

\section{Dybdekort over Sorøsø.}

Maalt og udarbejdet af Kammerherre, Amtmand E. Vedel.

$\mathrm{X}$ Stedet, hvorfra Planktonproverne stammer. 
Kort Nr. VII.

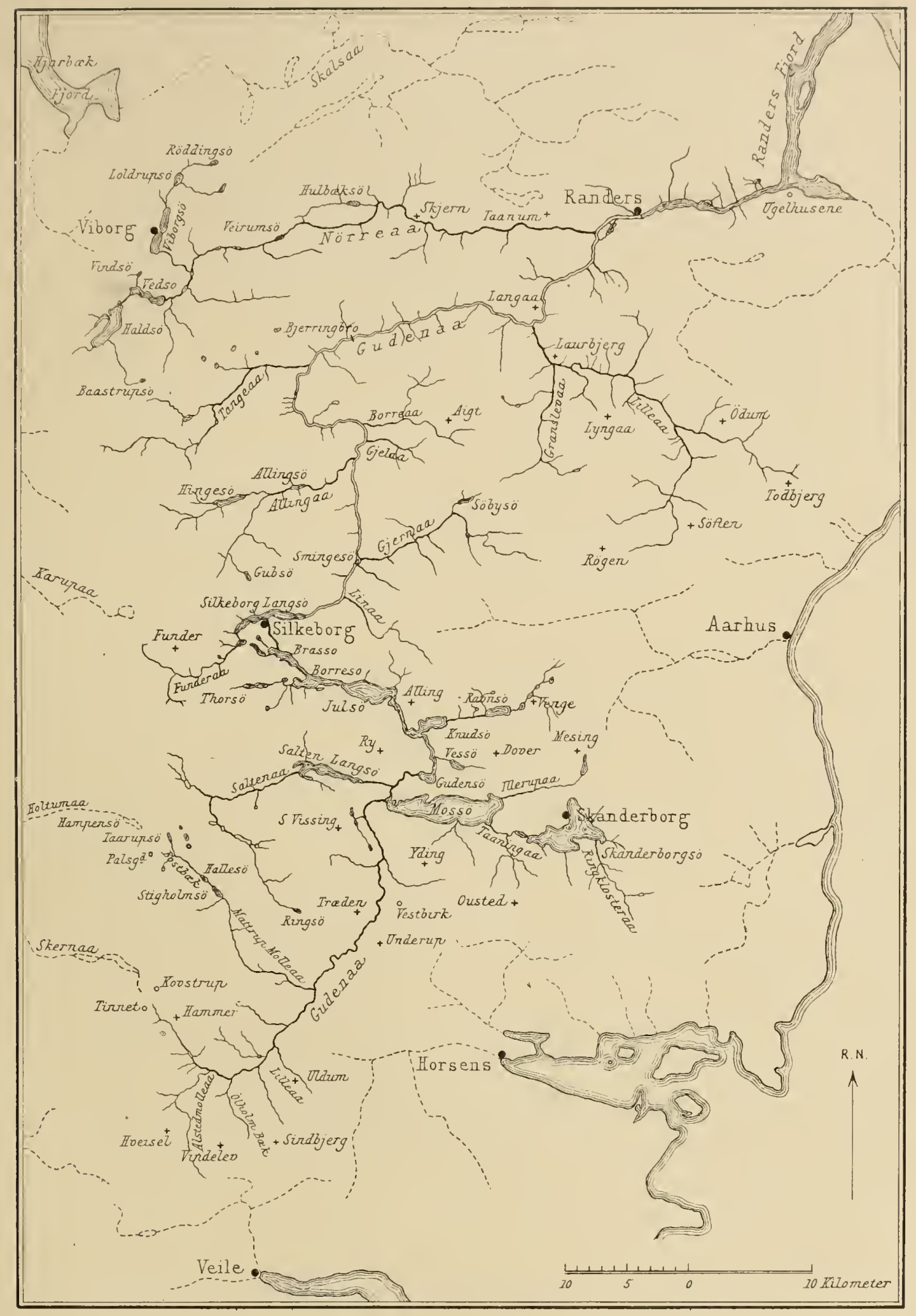

Kort over Gudenaaens Afvandingsomraade. 
Kort Nr. VIII.

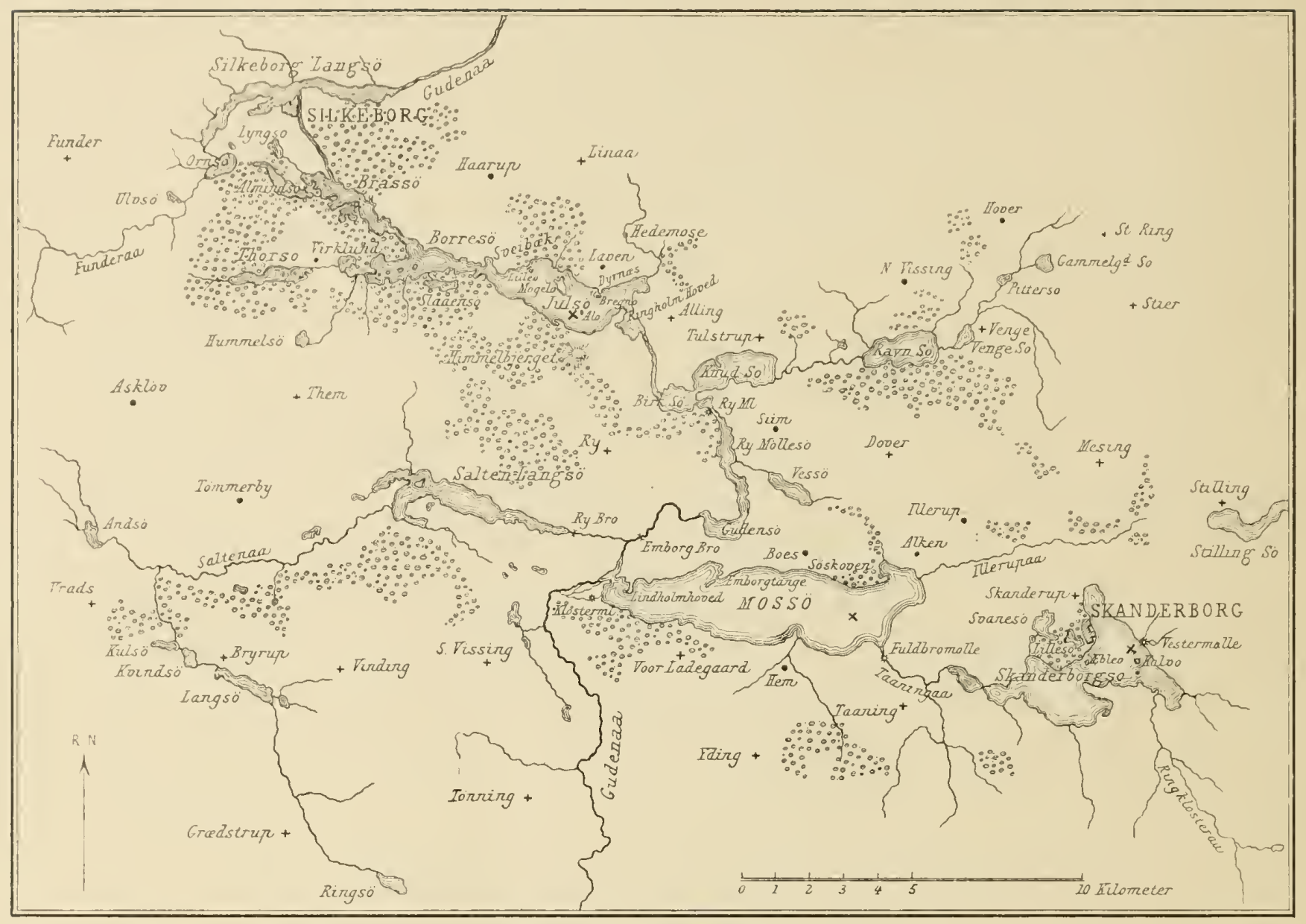

Kort over Gudenaaens mellemste Løb.

$X$ angiver Stedet, hvorfra Planktonpıoverne i Skanderborgso, Mosso og Julso stammer. 


\section{MIKROFOTOGRAFIER.}

TAB. I-X.

VEGETATIONSBILLEDER AF VORE SøERS VEKSLENDE PLANKTONSAMFUND. 
B

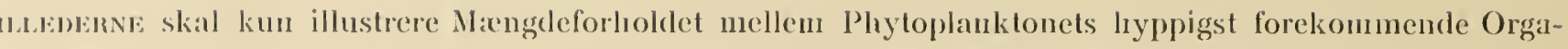
nismer; af Gruncle angivne p. 21 cr der gennemganende intet Hensyn taget til \%ooplanktonet. Overalt, livor der er Uoverensstemmelse mellem Tavier og Hyppigltedsangivelser, logr man holde sig til disse sidste (Tabeller og Tekst).

V'il man al Tavlerne soge at udrede, om en So paa samme Tidspunkt af to paa hinanden følgende Aar lar ensartet I'lankton, bedes man erindre, at man ved Samnenligningen altid naa have sin Opmærksombed henvendt paa Tidspunkternes Temperaturer; kun i de Tilfxlde, hvor disse nogenlunde er de samme, kan ensartet Plankiton ventes.

For at gore Manglerne ved Billederne saa iøjnefaldende som mulig og herved forøge Tavlernes Brugbarlıed, lıa jeg i Tavleforklaringen angivet de vaesentligste Mangler ved Billederne. Jeg følte mig saa meget desmere foranlediget herlil, som adskillige Billeder under Reproduktionen netop med Hensyn til Hyppighedsangivelse har tabt en Del i Værdi. Materialets Beskaffenhed havde $\mathrm{i}$ visse Tilfælde ganske særlig vanskeligg.jort Bestrabelserne for at skaffe ensartet Fokaldistance for alle Billedets Planktonorganismer. Dette gjaldt særlig de Prover, som baade indelıoldt store Mængder Cyanophyceer og Diatomeer. Man maatte i saa Fald indstille paa et enkelt Lag af Organismer $i$. c. enten et overste (Cyanophyceerne) eller et nederste (Diatomeerne). V'cl Øvelse opnaaedes det dog, at ogsaa de Lag, paa hvilke der ikke kunde indstilles skarpt, kom med, on end de blev mindre tydelige. I Reproduktionen gik disse Lag undertiden tabt eller svækkedes i hvert Fald yderligere; i Billeder, der indeholder mange Cyanophyceer, findes undertiden et underliggende Lag af Diatomeer, som kan paavises i Originalerne, men som i Reproduktionen i alt Fald kan være stærkt svækket; lnvor dette er Tilfaldet, findes det angivet i Figurforklaringen. Iøvrigt er Reprodultionerne mønsterværdige; i de fleste Tilfælde kommer de Originalerne meget ner eller er endog fuldt saa gode som disse. Tavlerne 'r udforte af Neue Photographische Gesellschaft, Berlin.

Jeg maatte desværre opgive Forsøgene paa skarpt at markere en bestemt Planktonorganisme i Billederne; den, der er kendt med Ferskvandsplanktonet, vil dog hurtigt finde sig til Rette i disse; iøvrigt kan det anbefales at sammenligne Fotografierne med Illustrationerne f. Eks. hos Apstein (96) eller C. Schröter (97); Identificeringen vil da ikke kunne volde Vanskeligheder. Ved de sjæeldnere og mindre nemt paaviselige Organismer er der tilføjet Betegnelserne t. h. f. o.; t. h. f. n.; t. v. f. o.; t. v. f. n.; i M., der betegner henholdsvis til højre for oven; til højre for neden; til venstre for oven; til venstre for neden; i Midten. Da Billederne selvfolgelig ikke altid gengiver Arten tilstrækkelig godt, er der i Teksten under hvert Artsnavn saa vidt mulig anført den mig bekendt bedste Illustration af Arten. 
TAB. I.

F URES Ø. I. 


\section{FURESØ. I.}

$$
\mathrm{Nr} . \quad 1.23 / .101 . \quad \mathrm{J}) . \quad(i .
$$

Oscrillaloriar rubescons.

Melosira cẹnulala. Stephanodiscus astrea. Tabellaria fencstrata. Asterionella gracillima. Cynalopletra clliplicas.

low liclt Oscillatoria.

$$
\text { Nr. 2. 15/5 ()1. T1). } 13 .
$$

Oscillatoria rubrscens.

Melosira rentulat Tabellaria fenestrata. Diatoma elongalum. Asterionella gracillima. Cymatopleura elliptica.

Podiastrum boryanum.

Antraea aculcata. Triarthra longiseta.

.lt for liclt Oscillatoria efr. pag. 11

$$
\text { Nr. 3. } 27 / 501 . \quad \text { Tp. } 14 .
$$

()scillatoria roblescens.

Mclosira crenulata. Tabellaria fenestrata. Asterionella gracillima.

Dinobryum sertularia. D. stipitatum.

$$
\text { Nr 4. } \% \text { 01. Tp. } 16 .
$$

Oscillatoria rubescens. Anabæena flos acpuæ.

Melosira crenulata. Tabellaria fenestrata. Fragilaria crotonensis.

Staurastrum gracile.

Notholca longispina. Triarthra longiseta.

Noget for lidt Anabaena.

$$
\text { Nr. 5. } 30 / 6 \text { 91. Tp. } 18 .
$$

Anabrena flos aquae.

Ceralium hirundinella.

Talrige Vorticeller, der har siddet fast paa Anabrenerne.

Notholea longispina.

$$
\text { Nr. 6. } 15 / 7 \text { 01. Tp. } 20 .
$$

Polycystis flos apux. Anabena flos aqux.

Fragilaria crotonensis. A Asterionella gracillima.

Eudorina elegans.

Ceratium hirundinella. Dinobryum sertularia.

Polyarthra platyptera Hud. ı.h. i u. Notholca longispina.

$$
\operatorname{Nr} .7 .30 / 701 . \quad \text { Tp. } 21 .
$$

Lyngbya limnetica.

Fragilaria crotonensis med Bicocoeca oculata. Asterionella gracillima.
Ceratium lirundinella.

Anuraca cochlearis.

I) eltilus.

Det runde Legence I. L. I. o. vistnok el Rotiferag

L.yngloya limnetica.

$$
\text { Nr. 8: } 15 / 8 \text { 01. Tp. } 22
$$

Stephanodiscus astrea. Tabellaria fenestrata. Fragilaria crotonensis. Asterionella gracillima.

Codonella lacustris.

Polyarthra platyptera. Anurxa cochlearis. Triarthra longisela.

Diaphanosoma brachyurum t. h. i M. Hyalodaphnia cucullala I. v. i M. Nauplie af Diaptomus.

$$
\text { Nr. 9. } 7 / 901 \text {. Tp. } 16 .
$$

Lyngbya limnetica. Oscillatoria rubescens.

Fragilaria crotonensis. Asterionella gracillima.

Eudorina elegans.

Ceratium hirundinella. Raphidiophrys pallida i de morke, runde Pletter t. h. i M. Codonella lacustris.

Polyarthra platyptera. Pompholyx sulcata med Æg, tæt op til Raphidiophrys. Anapus testudo, det mørke Legeme i M.

Nauplie af Cyclops.

I Bunden lalrige Fragilarier, der delvis er gaaet tabt under Reproduktionen.

$$
\text { Nr. } 10.2 / 10 \text { 01. Tp. } 16 .
$$

Lyngbya limnetica. Oscillatoria rubescens.

Ceratium hirundinella.

Anuræa cochlearis og aculeata.

Detritus.

$$
\text { Nr. 11. 21/10 01. Tp. } 11 .
$$

Lyngbya limnetica. Oscillatoria rubescens.

Melosira crenulata. Asterionella gracillima.

Eudorina elegans.

Lyngbya limnetica.

$$
\text { Nr. 12. } 16 / 1101 \text {. Tp. } 4 \text {. }
$$

Melosira crenulata. Tabellaria fenestrata. Fragilaria crotonensis. Asterionella gracillima.

Dinobryum sertularia. Raphidiophrys pallida.

Anuraea cochlearis. 
Studier over de danske Søers Plankton
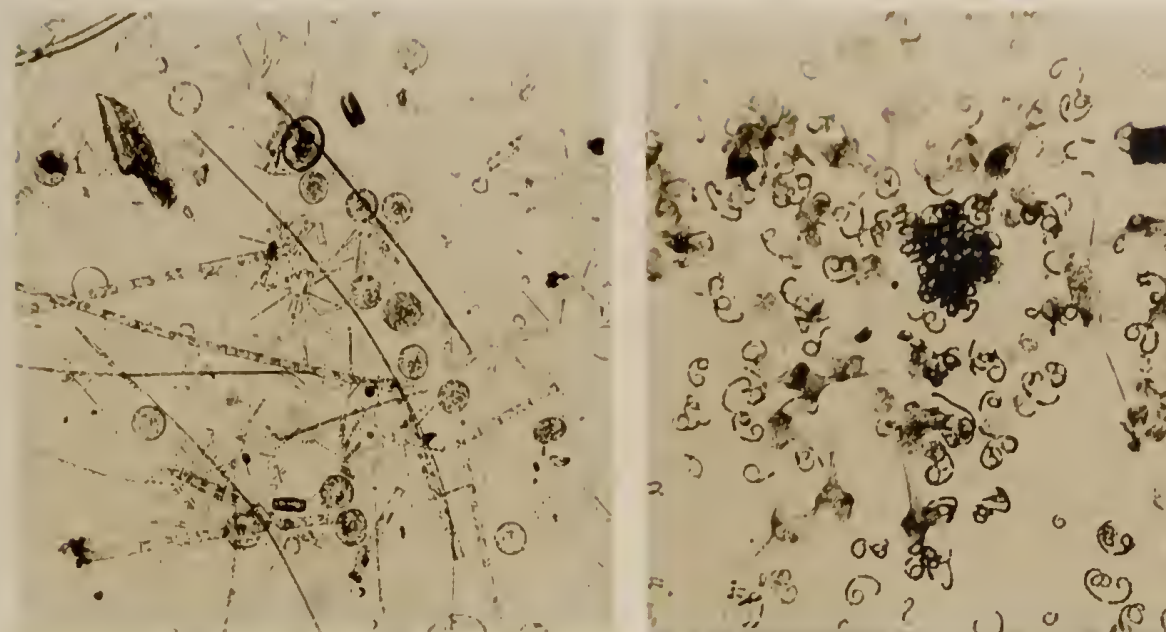

* s c if

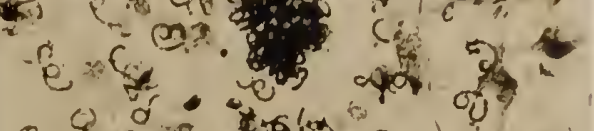
c. con

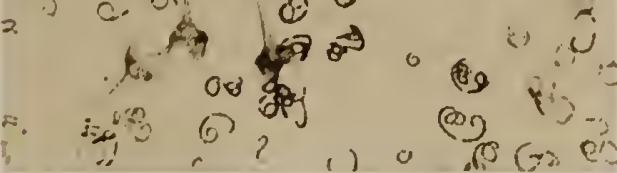

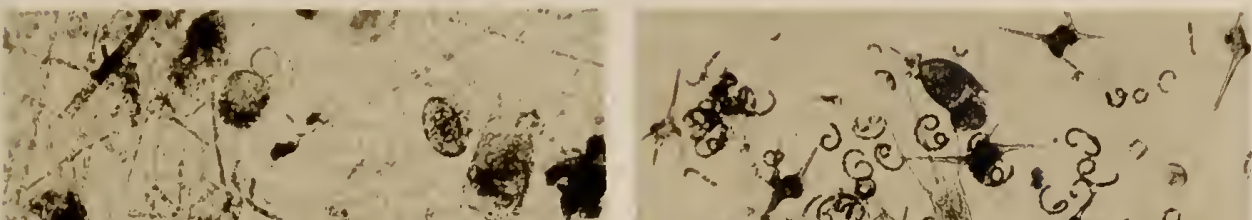
(1)

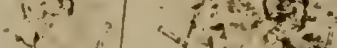

- $\quad 1$ $40^{4} 00^{\circ}$.

D $14 x y$
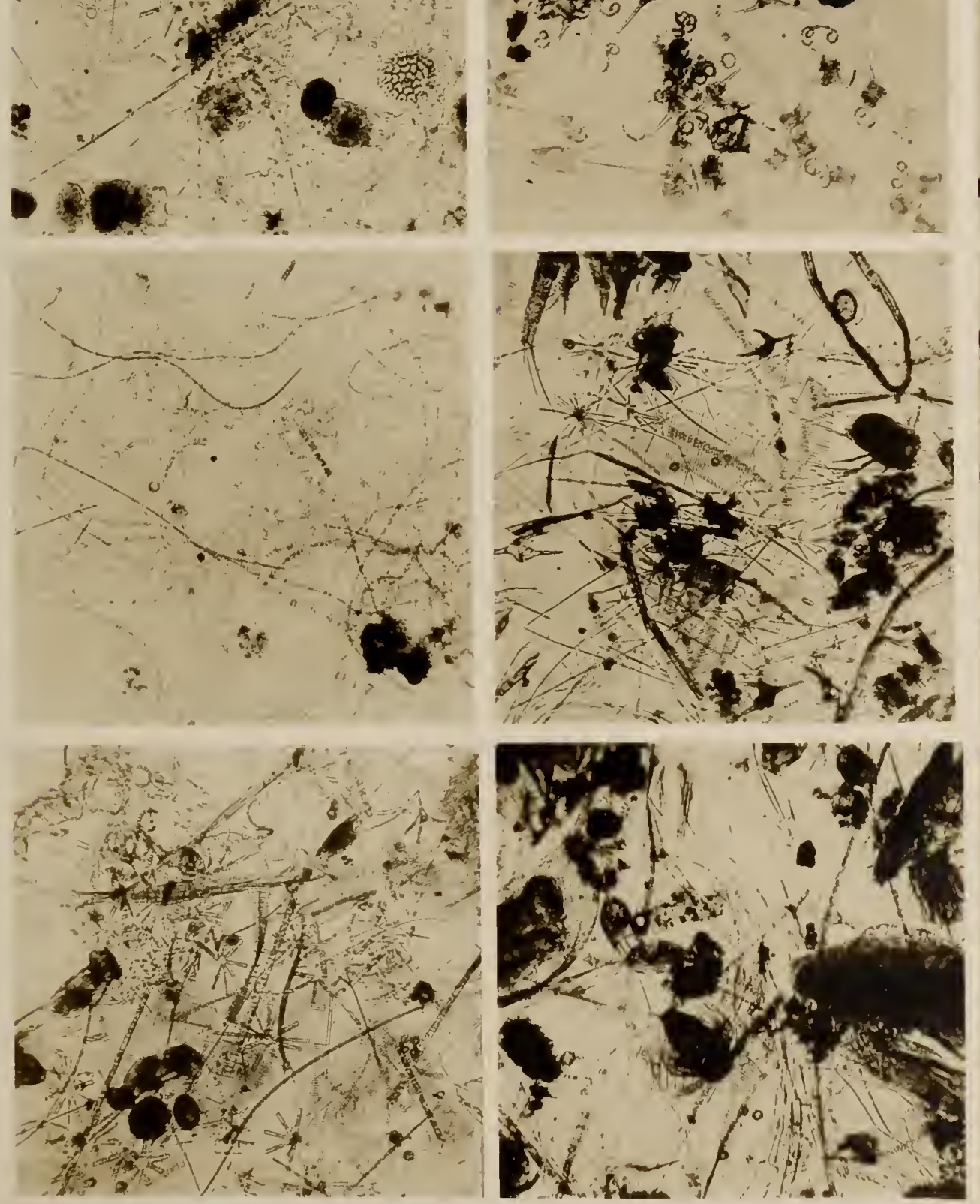

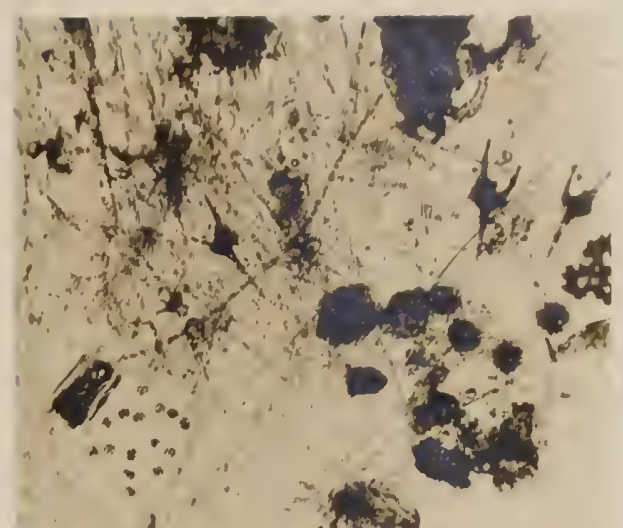

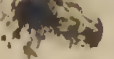

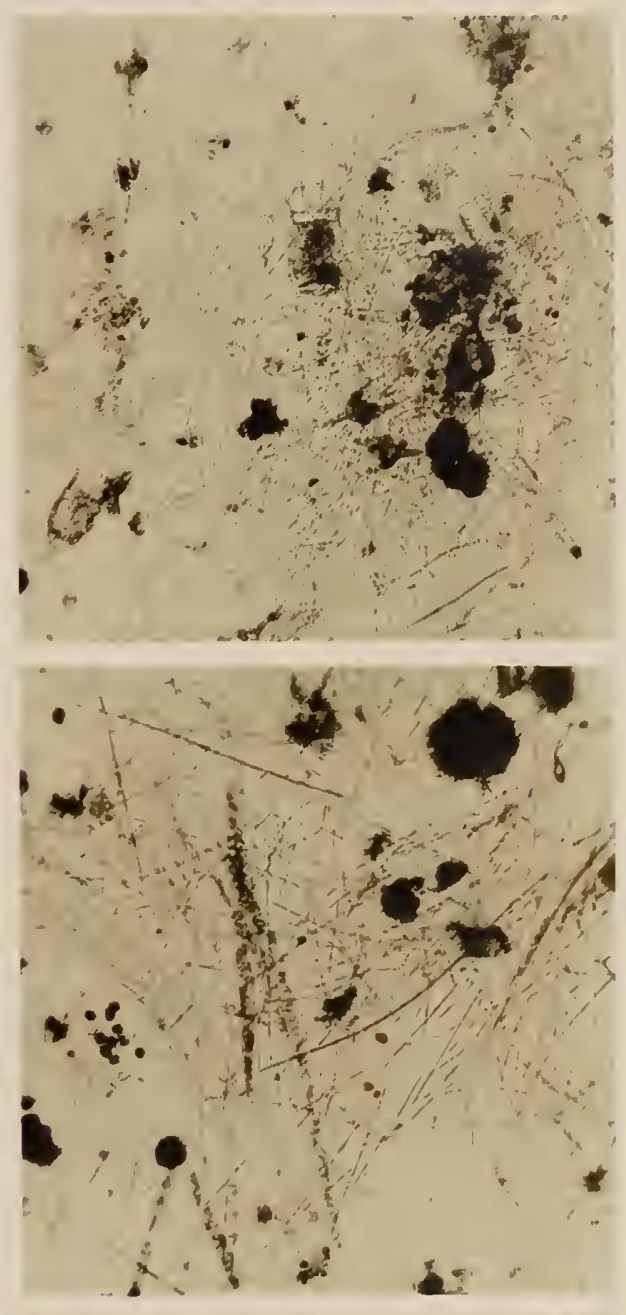

$+2 c^{2}+c^{2}$

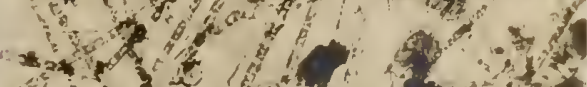
*) -4 of a $k_{-2}=c^{2}$ 

TAB. II.

F U RES Ø. II. 


\section{FURESØ. II.}

$$
\text { Nr. 13. 17/1201. T). } 1 .
$$

Lyongloya limnctica. Oscillatoria rubescens.

Melosira crenulata. Stejhlanodiscus astrea. Tabellaria fenestrata. Fragilaria crotonensis. Asterionella gracillimit.

Euturina elegans.

Amurea cochlearis.

$$
\text { Nr. 11. } 7 / 102 . \quad \text { T). } 2 .
$$

Lyngbya limnetica.

Mclosira cremulata. Tabellaria fenestrata. Asterionella gracillina. Cymatopleura elliptica.

Detritus.

$$
\text { Nr. 15. 31/1 02. Tp. } 1 .
$$

Lyngbya limnetica. Oscillatoria rubescens.

Melosira crenulati. Stephanodiscus astræa. Tabellaria fenestrata. Fragilaria crotonensis. Asterionella gracillinla.

Nr. 16. $28 / 2$ 02. Sluseprove. Soen tillagt.

lynglya limuetica. Oscillatoria rubescens.

Melosira crenulata. Stephanodiscus astræa. Tabellaria fenestrata. Fragilaria crotonensis. Asterionella gracillima.

Codonella lacustris.

Stnedra acus mangler.

Oscillatoria rubescens.

$$
\text { Nr. 17. } 23 / 3 \text { 02. Tp. } 1
$$

Melosira crenulata. Stephanodiscus astræa. Tabellaria fenestrata. Fragilaria crotonensis. Asterionella gracillima.

$$
\text { Nr. 18. } 11 / 402 . \quad \text { Tp. } 4 .
$$

Oscillatoria rubescens.

Melosira crenulata. Stephanodiscus astræa. Tabellaria fenestrata. Fragilaria crotonensis. Asterionella gracillima. Cymatopleura elliptica.

Tintinnidium fluviatile t. v. f. o.

Synedra acus mangler.

$$
\text { Nr. 19, 25/4 } 02 \text {. Tp. 5. }
$$

lyngbya limnetica. Oscillatoria rubescens.

Melosira crenulata. Stephanodiscus astraea. Tabellaria fenestrata. Fragilaria crotonensis. Synedra acus. Asterionella gracillinia. Cymatopleura elliptica.

Polyartlira platyptera.

$$
\text { Nr. 20. } 21 / 502 . \quad \text { Tp. } 9 .
$$

Lyngbya limnetica. Oscillatoria rubescens.

Melosira crenulata. Stephanodiscus astræa. Tabellaria fenestrata. Fragilaria crotonensis. Synedra acus. Asterionella gracillima.

Eg af Polyarthra 1. v. f.o.

$$
\text { Nr. 21. } 5 / 602 . \quad \text { Tp. } 12 .
$$

Lyngbya limnetica. Ocillatoria rubescens.

Melosira crenulata. Tabellaria fenestrata. Fragilaria crotonensis.

Ceratium hirundinella. Dinol,ryum sertularia.

Notholea longispina.

Bosmina longirostris.

$$
\text { Nr. 22. }{ }^{17} / 6 \text { 02. Tp. } 14 .
$$

Oscillatoria rubescens.

Tabellaria fenestrata. Fragilaria crotonensis.

Ceratium hirundinella. Dinobryum sertularia med Hvilecyster. Conochilus volvox.

$$
\text { Nr. 23, 11/7 02. Tp. } 14 \text {. }
$$

Oscillatoria rubescens. Anabæna flos aquæ med Vorticeller. Stephanodiscus astraea. Tabellaria fenestrata. Fragilaria crotonensis med Bicocoeca oculata. Asterionella gracillima.

Ceratium hirundinella.

Staurastrum gracile.

$$
\text { Nr. 24. } 3 / 8 \text { 02. Tp. } 15 .
$$

Gomphosphæria lacustris. Lyngbya limnetica. Oscillatoria rubescens. Coelosphærium Kützingianum.

Melosira crenulata. Asterionella gracillima.

Ceratium hirundinella. 

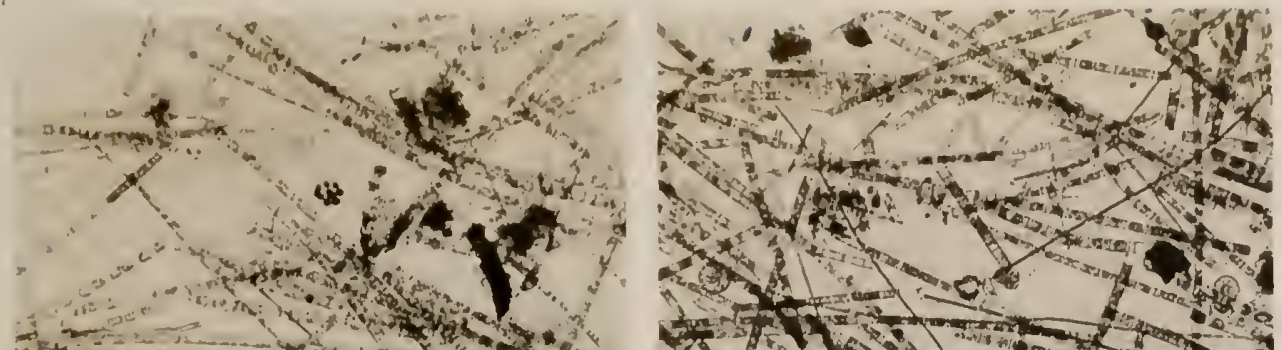

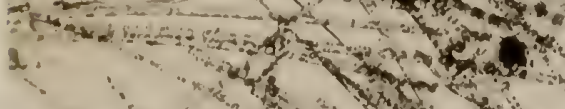
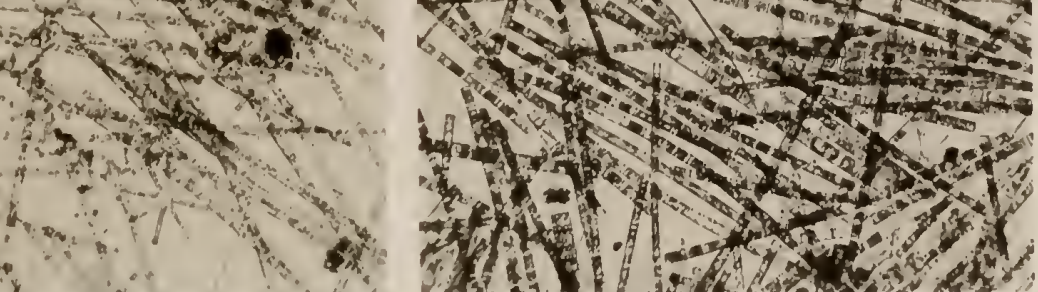

$-13$
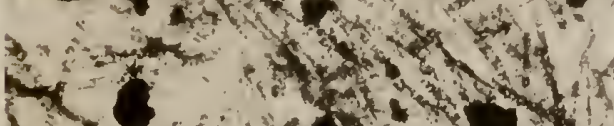

- at 1

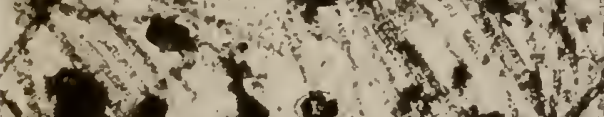

$1+2+100$

$(1+1-1+1)+1$

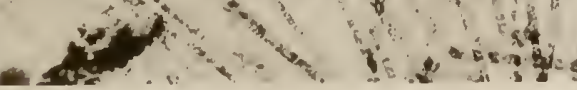

* $6+\%=0$

s.
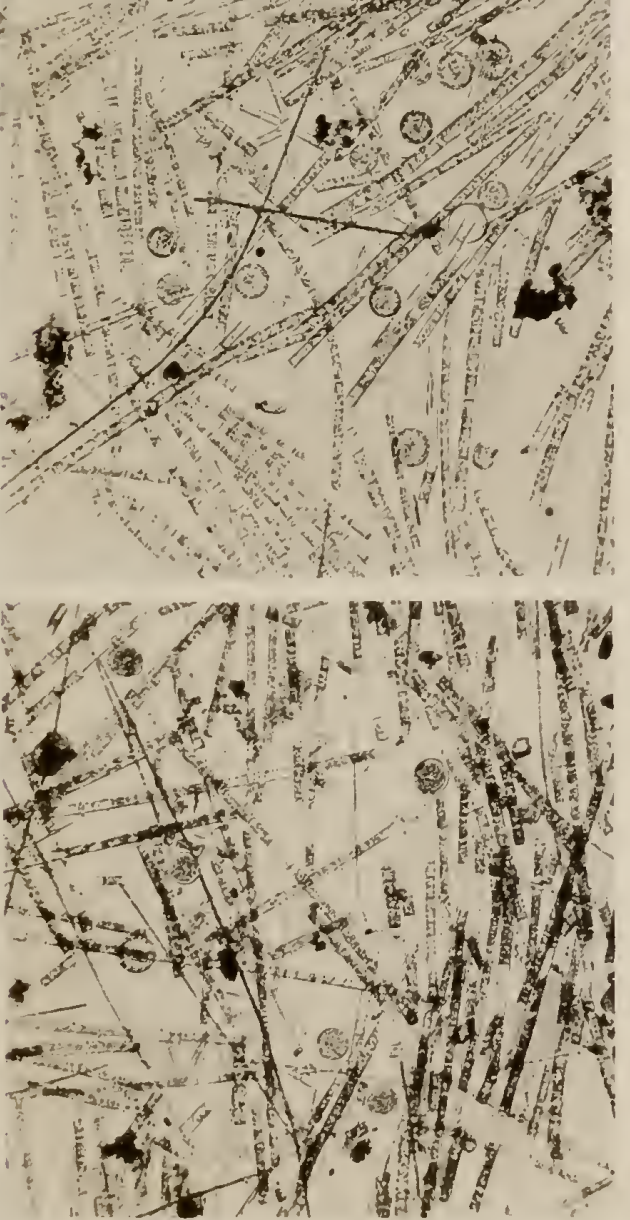

C. Wesenberg-Lund, phot.
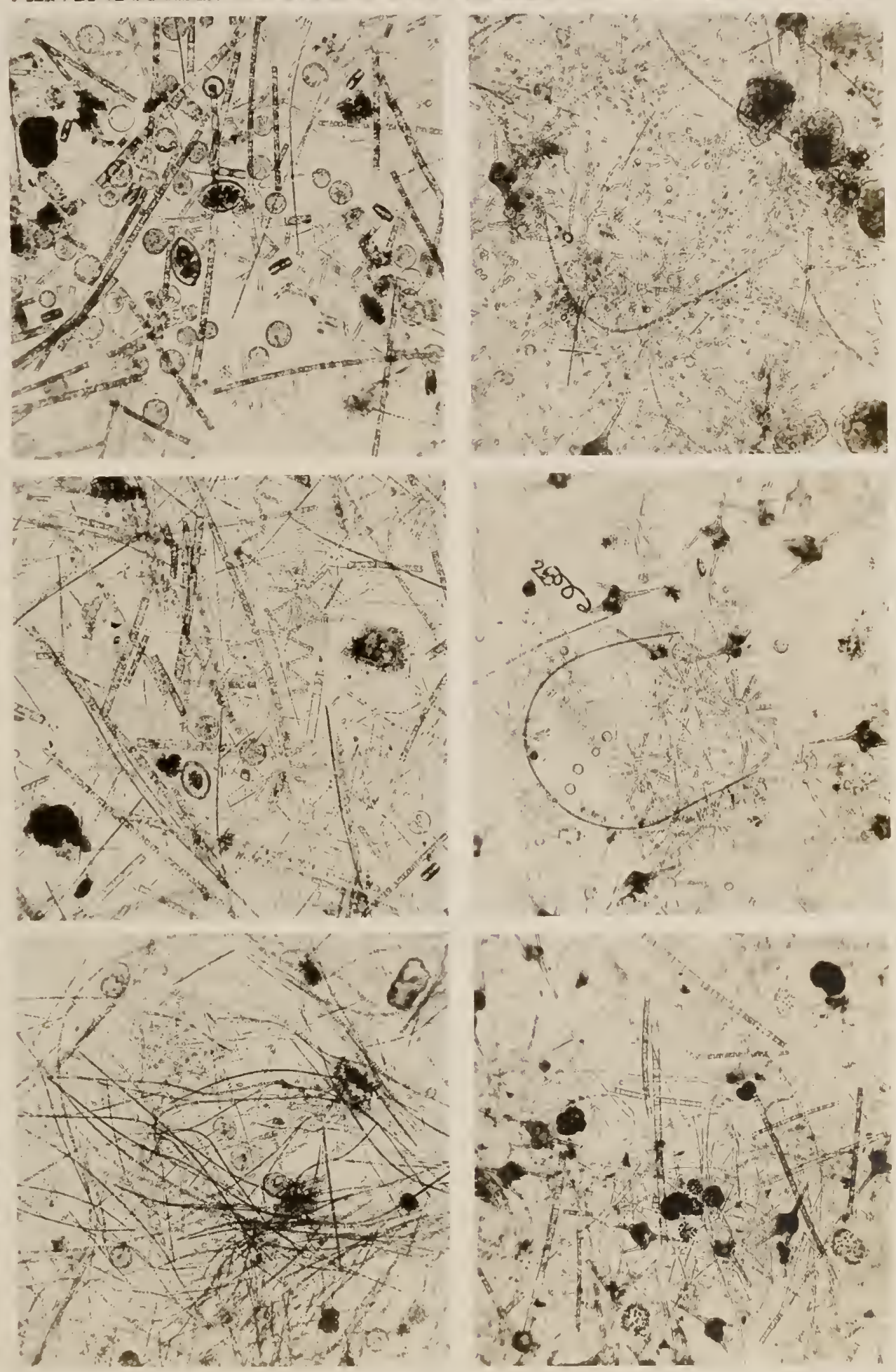

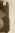

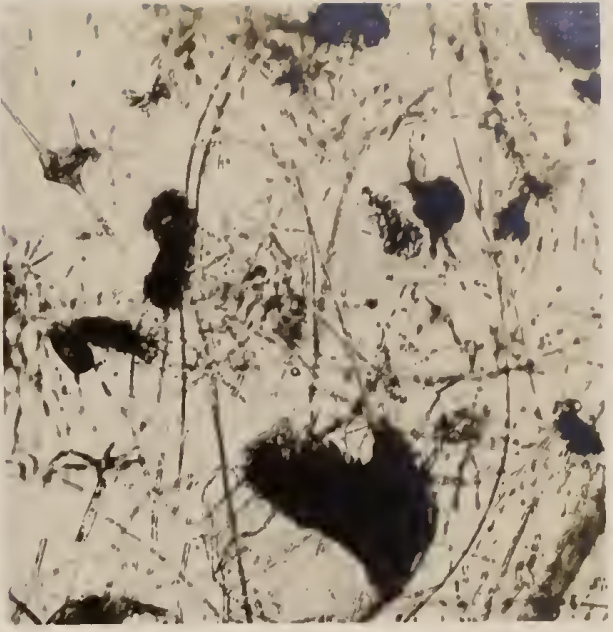

22

23 

TAB. III.

E S R O M S Ø. 


\section{ESROMSO.}

$$
\text { N1. 2.5. } \left.29 / 6,01, \mathrm{~T}_{\mathrm{p}}\right) .15 .
$$

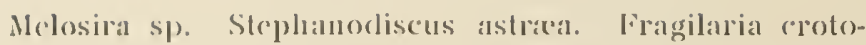
ncensis og virescens.

Trotraspora lacenstris. Eudorina clegans i store og suna loblonicr. Pediastrum boryanum. Tribonema bombycinum.

Ceratimn hirundinellin.

biaptomus graciloides 1. It f. u.

$$
\text { Nr. 26. } 20 / 701 \text {. Tp. } 17 .
$$

Polycystis flos aquae. Anabena flos aqux.

Melosira sp. Asterionella gracillima.

Tribonema bombycinum. Staurastrum gracile.

Anuraea cochlearis.

Bunden i dettr og foregatrmale fot. er i Virkeligheden gennemlirydset al" "lribonema, men de er gatact talot i lisprodulitionen.

$$
\text { Nr. 27. } 12 / 8 \text { 01. Tp. } 21 .
$$

Melosira sp. Stephanodiscus astræa. Fragilaria erotonensis. Asterionella gracillima.

Tribonema bombycinum. Eudorina elegans.

Staurastrum paradoxum, Ceratium hirundinella. Anurea cochlearis.

$$
\text { Nr. 28. } 5 / 901 \text {. Tp. } 16 .
$$

Polycystis flos aqua. Anabæna flos aqua.

Melosira sp. Stephanodiscus astræa. Asterionella gracillima.

Dictyospharium pulchellum. Tribonema bombycinum. Staurastrum gracile og $\mathrm{S}$. paradoxum

Ceratium hirundinella. Stentor den morke, runde Plet i Billedet t. v. r. n. omgiven af Gele med Detritus. Floscularia libera i м. Anuraea coehlearis. Pompholyx suleata.

Billedet valgt af Hensyn til Stentor og Floscularia; for lidt Asterionella.

$$
\text { Nr. 29. } 30 / 901 . \quad \text { Tp. } 17 \text {. }
$$

Coelosphrerium Kützingianum. Polyeystis flos aquæ. Anabrena flos aquac.

Melosira sp. Stephanodiseus astræa. Fragilaria crotonensis. Asterionella gracillima.

Tetraspora lacustris. Eudorina elegans. Dictyosphærium pulehellum. Ooeystis Nägeli. Kirehneriella lunaris. Staurastrun graeile.

$$
\text { Nr. 30. }{ }^{15} / 10 \text { 01. Tp. } 12 .
$$

Coelosphærium Kützingianum. Polyeystis flos aquæ. Anabæna flos aquæ.
Mclosira sp. Stephanodiscus astrea. Fragilaria crotonensis. Asterionella gracillima.

lirchneriella lunaris t. lt. i .

$$
\text { Nr. 31. 10/11 01. Tp. } 7 .
$$

Coclospharium kützingianum. Polyeystis flos aquae. Anabaena flos aquae.

Melosira sp. Stephanodiscus astraca.

Eulorina elegans. Pediastrum duplex. Botryococcus Braunii den sorte, tredelte Plet t. h. f. o.

$$
\text { Nr. 32. } 13 / 102 . \quad \text { Tp. } 1 .
$$

Melosira sp. Stephanodiscus astrea. Fragilaria crotonensis. Asterionella gracillima.

Tribonema bombyeinum.

Anuræa cochlearis.

Detritus.

$$
\text { Nr. 33. } 22 / 302 . \quad \text { Tp. } 2 .
$$

Stephanodiscus astræa. Asterionella gracillima.

Eudorina elegans.

Bursaria truneatella (?) de axgdannede Legemer t. h. f. o.

Bunden i Folograliet gennemkrydsct af Asterionella og Tribonema; de ei garet talt i Reproduktionen.

$$
\text { Nr. 34. } 17 / 4 \text { 02. Tp. } 4 \text {. }
$$

Melosira sp. Stephanodiscus astræa. Fragilaria crotonensis med Bicococea oeulata. Asterionella gracillima med Vorticeller.

Eudorina elegans. Tribonema bombycinum.

$$
\text { Nr. 35. } 13 / 5 \quad 02 . \quad \text { Tp. } 8 \text {. }
$$

Melosira sp. Fragilaria erotonensis.

Tribonema bombyeinum.

Ceratium hirundinella.

Triarthra longiseta. Conoehilus natans.

Nauplier af Cyelops. Metanaupliet af samme t. h. f. n. Fragilarier og Asterioneller gaaet tabt red Reproduktionen.

$$
\text { Nr. 36. } 13 / 602 . \quad \text { Tp. } 13 .
$$

Melosira sp. Stephanodiseus astræa. Fragilaria crotonensis. Asterionella gracillima.

Tetraspora laeustris. Dictyosphærium pulchellum. Tribonema bombyeinum.

Ceratium hirundinella.

Polyarthra platyptera. Triarthra longiseta. Anuræa cochlearis.

Coniferpollen t. h. f. n. 

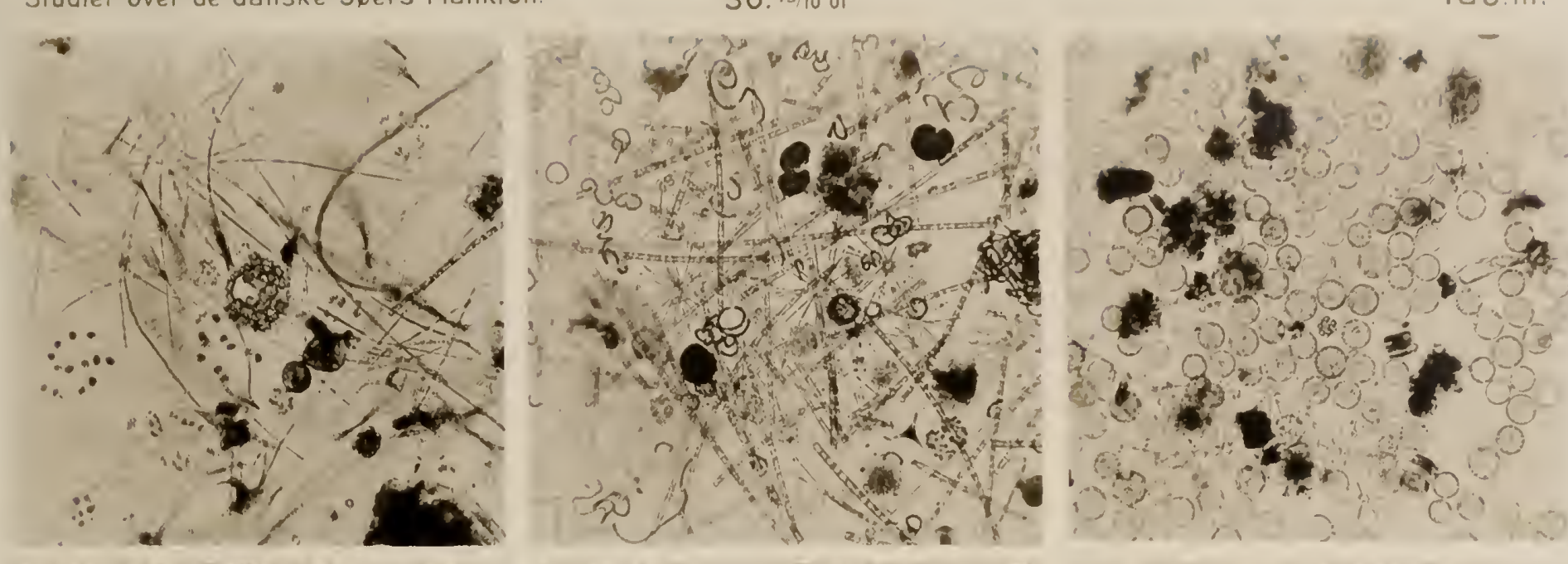

$+18 x^{2}$

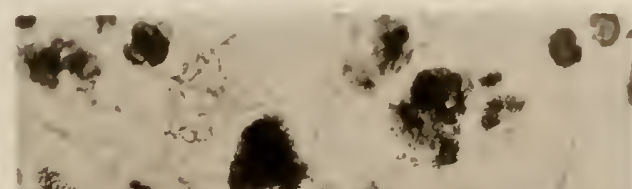

(5) 6 ?

$4.8+10$
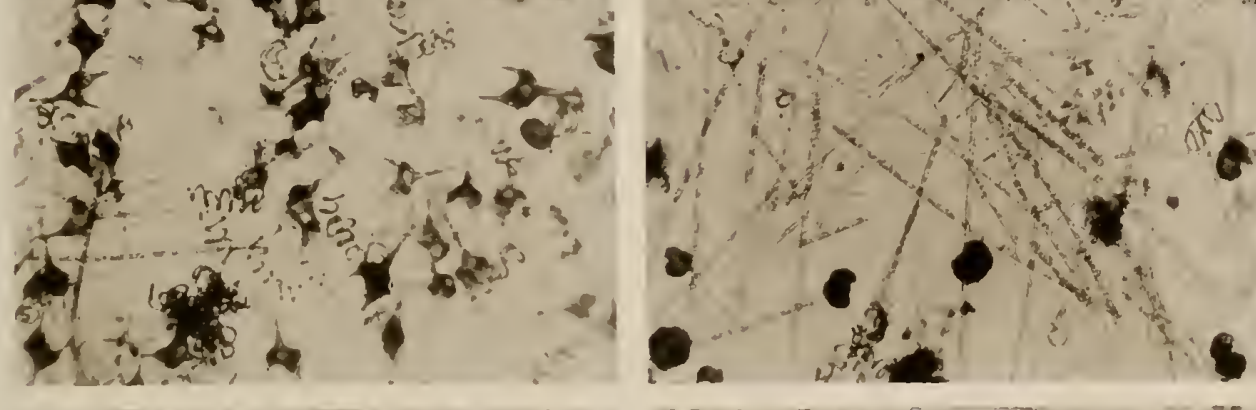

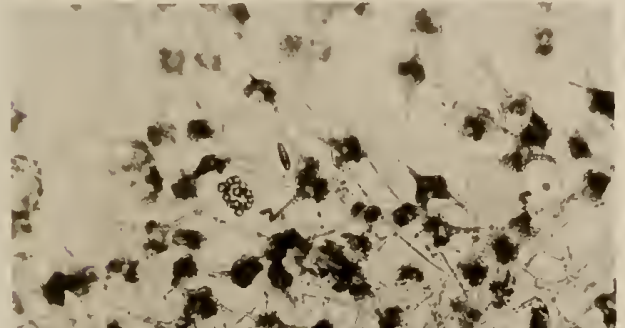

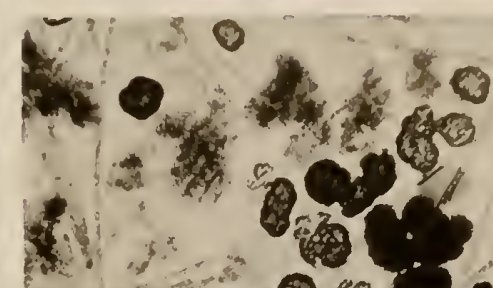

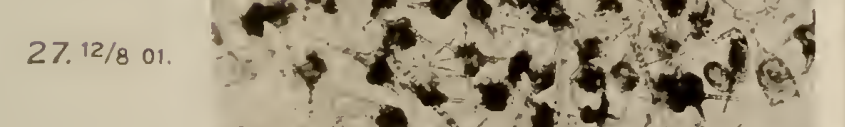

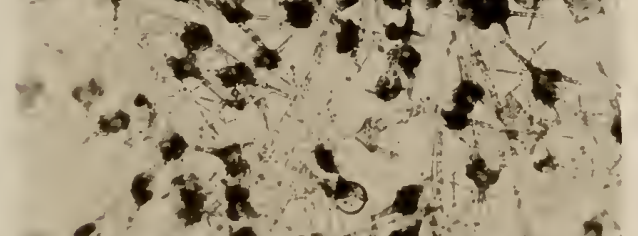

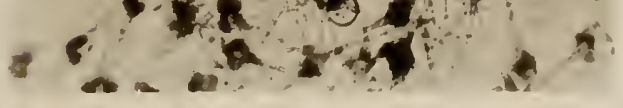

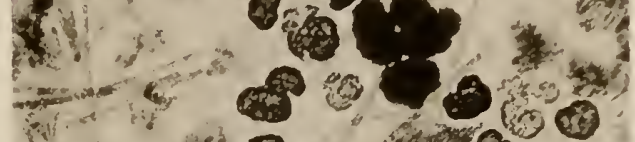

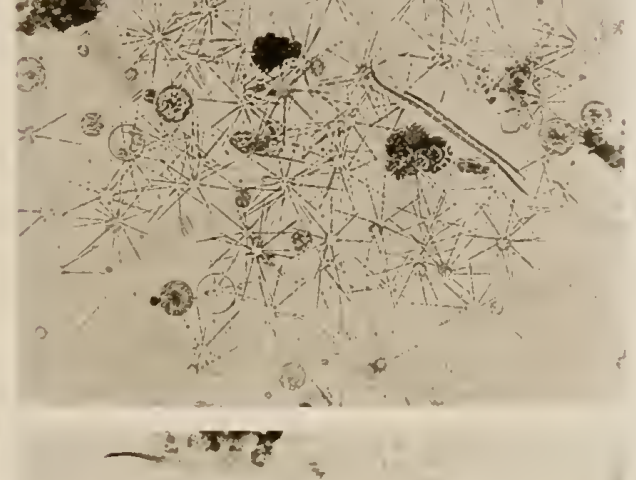

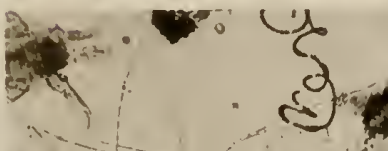

$+\infty$

- $0^{3}{ }^{3}$

10.

(6)

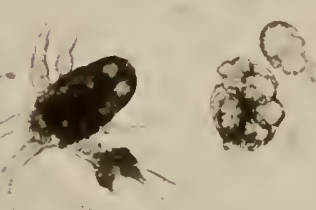

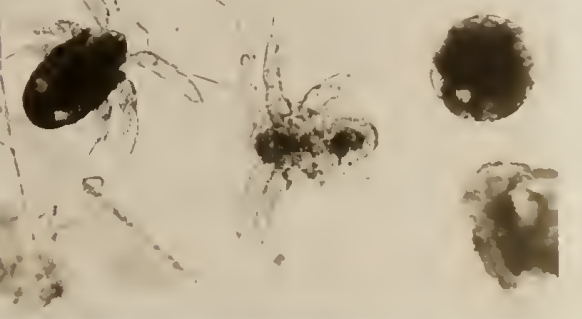

$28.5 / 901$

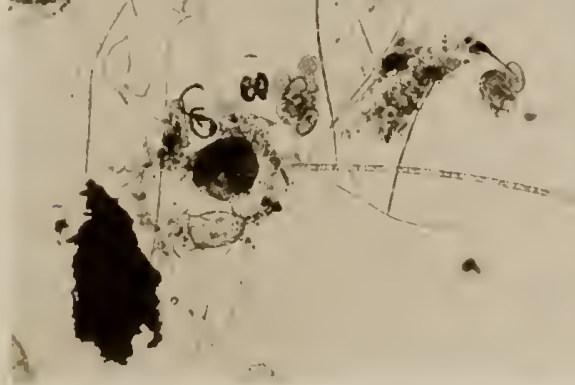

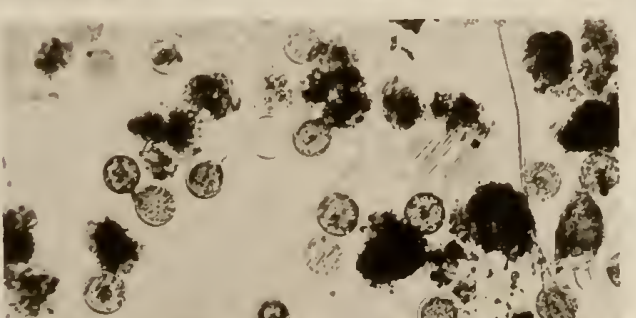

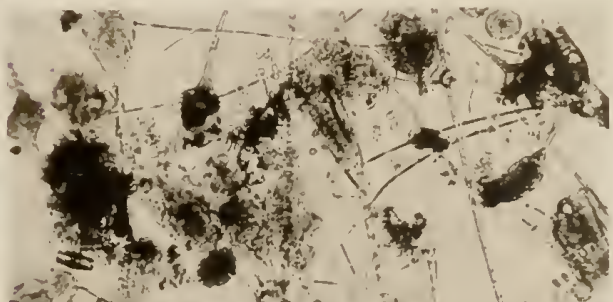

9.

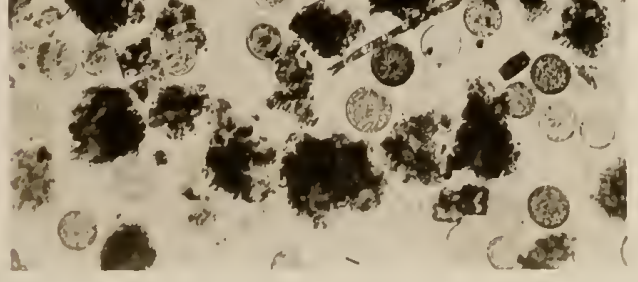

3

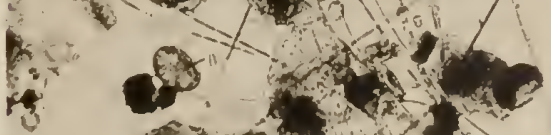

$\operatorname{lom}_{x \rightarrow 2}$

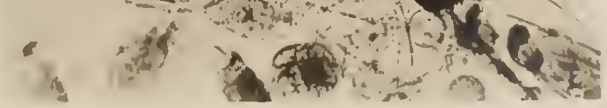

C. Wesenberg-Lund, phor. 

TAB. IV.

SORØSØ. 


\section{SORØSØ.}

$$
\mathrm{Nr}, 37.26 / 501.9 \mathrm{p}, 13 .
$$

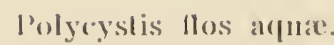

Melosira sp.

Ceratimm hirtmdella. Dinobryum sertularia og stipitatimil med ciystrer.

Polyarllara platyplera. Asplanchna priodonta. Hvileagg al sirmme t. 1. r. o. Anurea cochlearis og actuleata.

Nattplic af Cyclops.

bunden falat noget tillage i feproduktionen.

$$
\text { Nl. 38. } 3 / 701 . \mathrm{T}_{\mathrm{p}} .21
$$

l'olycystis flos aquac 1. h, i . I. P. eruginosa f. o. t. v.

Melosira sp. Irlagilaria crotonensis.

Eudorina elegans. I'ediastrtm duplex og P'. biradiatum i 1.

Dinoloryum sertularia. Ceratium hirtmdinella. Carchesium ontrent i $\mathrm{y}$

Diaptomus glacilis vesentlig kun Antenne.

For liclt Ceratium.

$$
\text { Nr. 39. } 9 / 8 \text { 01. Tp. } 23 .
$$

Polycystis llos aquae.

Pediastrum biradiatum (?). Botryococcus Braunii.

Ceratium hirundinella til Dels henfalcen.

Nauplie af Cyclops.

$$
\text { Nr. 40. 18/9 01. Tp. } 12 .
$$

Melosira granulata. Asterionella gracillima.

Epistylis. Difflugia.

Copepodekskiement i $\mathrm{s}$.

$$
\text { Nr. 41. } 17 / 1001 . \text { Tp. } 12 .
$$

Polycystis flos aquae. Lyngbya limnetica.

Melosira granulata. Asterionella gracillima.

Anuraa aculeata.

Detritus.

$$
\text { Nr. } 42 . \quad 30 / 102 . \quad \text { Tp. } 1 .
$$

Melosira sp. Stephanodiseus astraa. Asterionella gracillima.

$$
\text { Ni. 43. } 24 / 3 \text { 02. Tp. } 1 .
$$

Melosira sp. Stephanodiscus astrrea. Rhizosolenia longiseta 1. h. f. o. omtrent i M. Kromatoforen synlig som en Plet. línturerne neget srage. Asterionella gracillima. Centronella Reichelti det trestraảede Legeme i werste hojre Hjorne; markeret red en Streg. Synedra acus.

Dinoloryum stipitatum.

Detritus.

$$
\text { Nr. 44. 19/4 02. Tp. } 1 .
$$

Melosira sp. Stephanodiscus astraea. Cycotolla comta. Asterionella gracillima. Cymatopleura elliptica og soleal (?).

Dinoluryum sertularia og stipitatum.

Nauplic al Cyclops.

Fragilaria maugler.

$$
\text { Nr. 45. 16/5 } 02 . \text { Tp. 7. . }
$$

Melosira sp. Stephanodiscus astráa. Synedra acus. Asterionella gracillima. Rhizosolenia longiseta markerel ved Streg.

Pediastrum biradiatum 1. 13, f. o.

Dinobryum sertularia og stipitatum.

$$
\text { Nr. 46. } 7 / 602 . \quad \text { Tp. } 15 .
$$

Croococcus limneticus t. v. f. n. Polycystis flos aquæ $t$. . f. n. og t. h. ovenfor P. a. P. aruginosa t. h. i M.

Melosira sp. Asterionella gracillima. Fragilaria crotonensis med Bicocoeca oculata.

Ceratium hirundinella. Dinobryum divergens.

Cyclops oithonoides.

Nauplie af Diaptomus.

Codonella mangler.

$$
\text { Nr. 47. } 28 / 6 \text { 02. Tp. } 17 .
$$

Croococcus limneticus t. l. i I. Polycystis æruginosa t. h. f. o. P. flos aquæ. Anabæna flos aquæ.

Melosira sp. Stephanodiscus astræa. Fragilaria crotonensis. Asterionella gracillima.

Tetraspora lacustris. Eudorina elegans. Pediastrum duplex. Staurastrum gracile.

Ceratium hirundinella. Dinobryum sertularia. Codonella lacustris.

Anurza cochlearis.

Nauplie af Cyclops.

$$
\mathrm{Nl} .48 .27 / 702 . \quad \text { Tp. } 16 .
$$

Polycystis flos aquæ. Anabæna flos aquæ.

Melosira crenulata. Fragilaria crotonensis.

Tetraspora lacustris. Pediastrum duplex. Staurastrum gracile.

Ceratium hirundinella.

Bunden diekket af Fragilarier, der delvis er gaaet tabte i leproduktionen. 
Studier over de danske Søers Plankton.

42. 30/1 02 .

Tab.IV
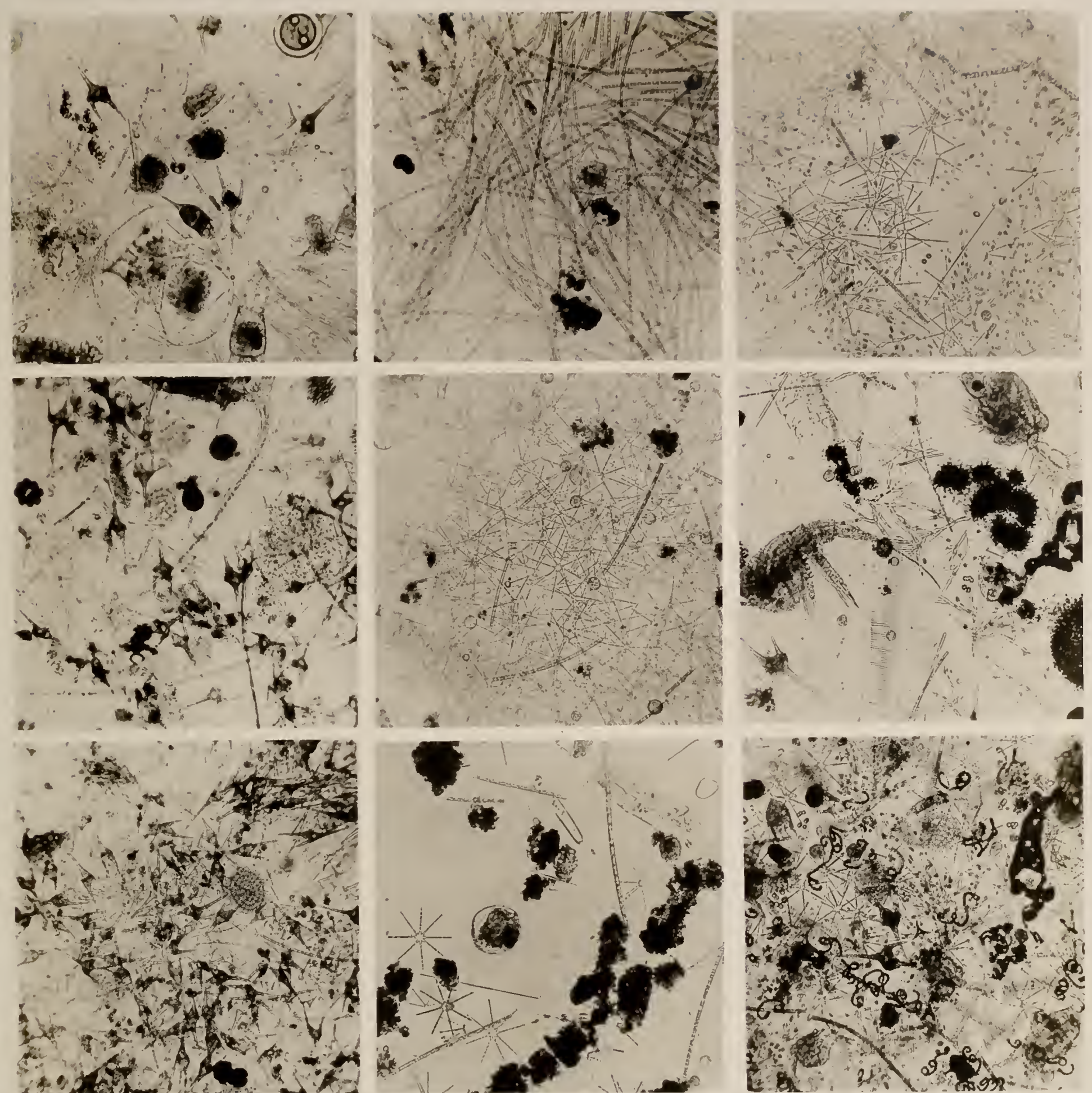

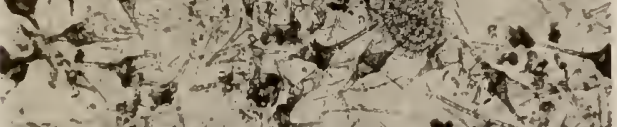

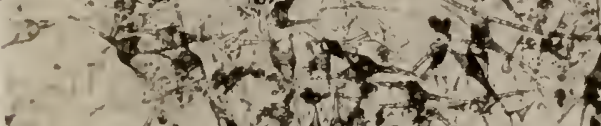

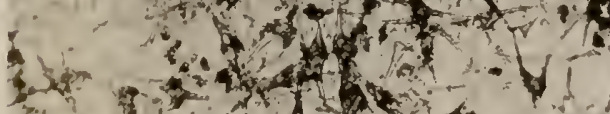

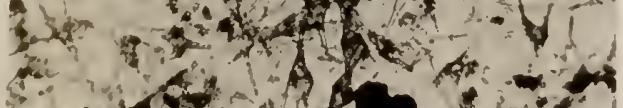

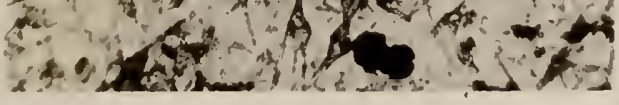
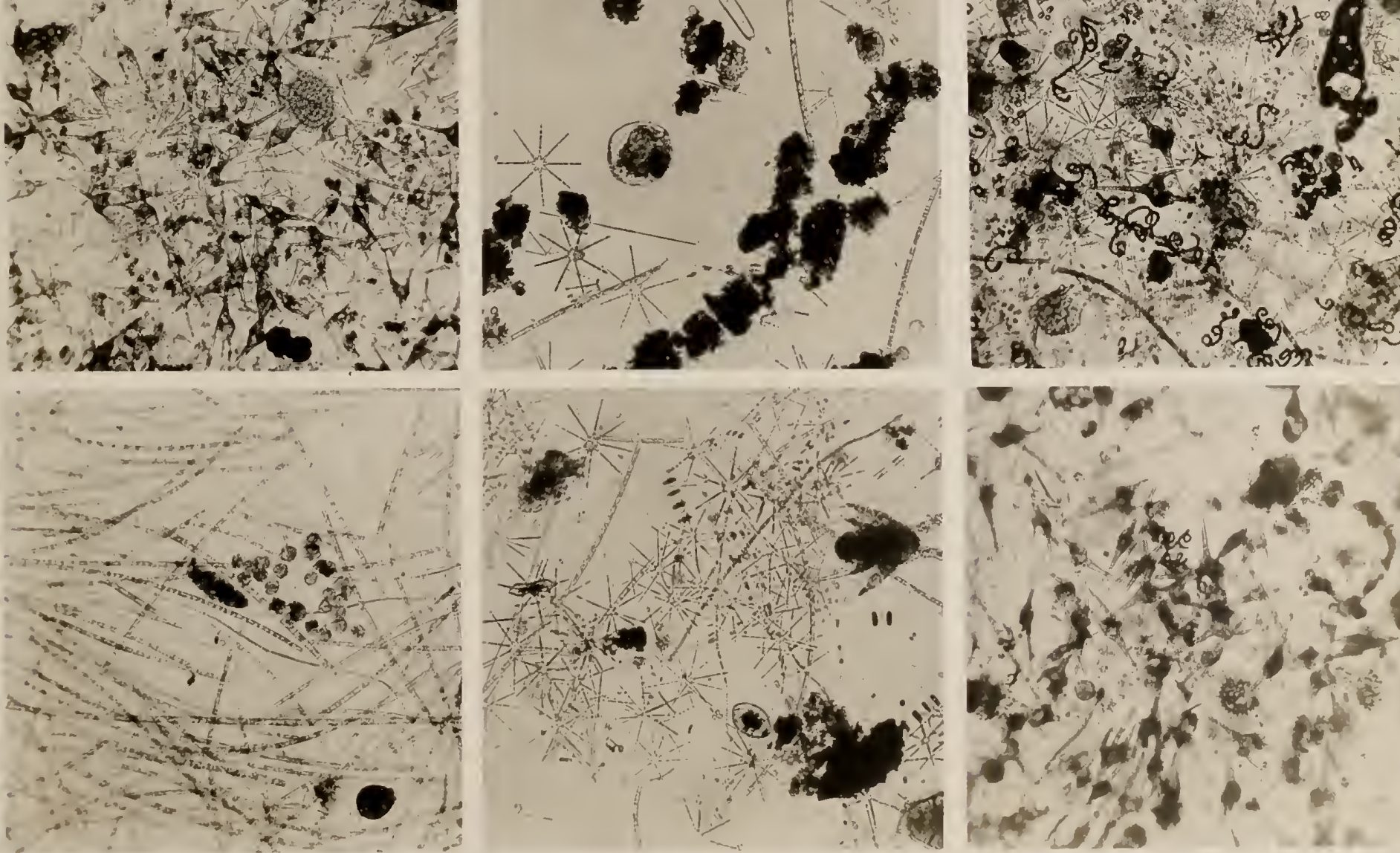
of $2 \times+1$

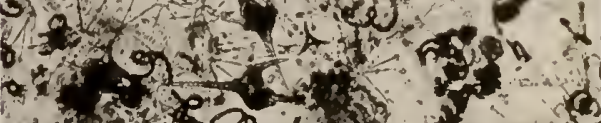
64020

4.

47. $28 / 602$

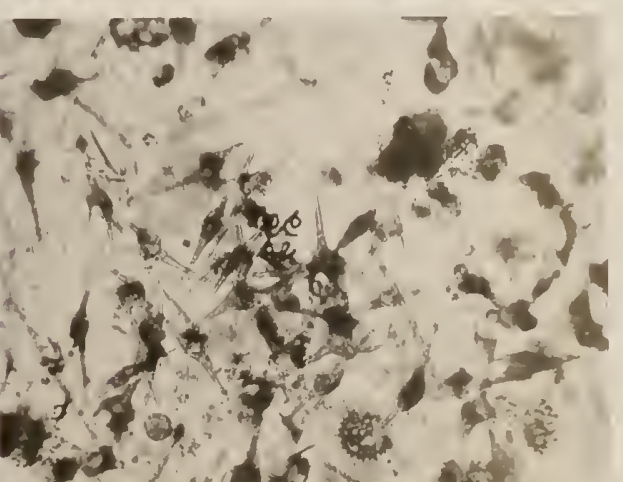




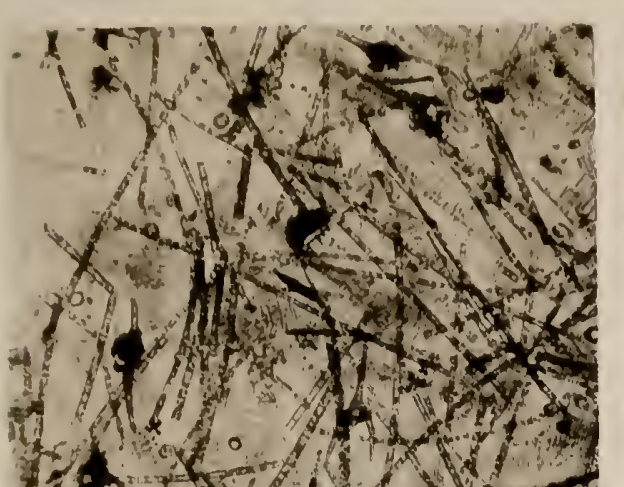
lin 10

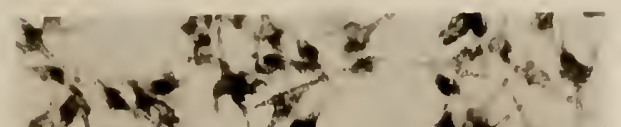

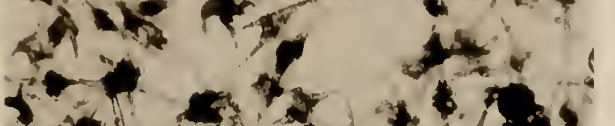

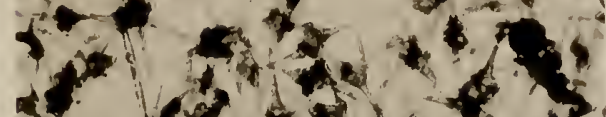

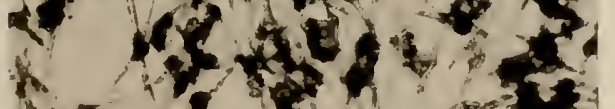
r.t. 3 ,
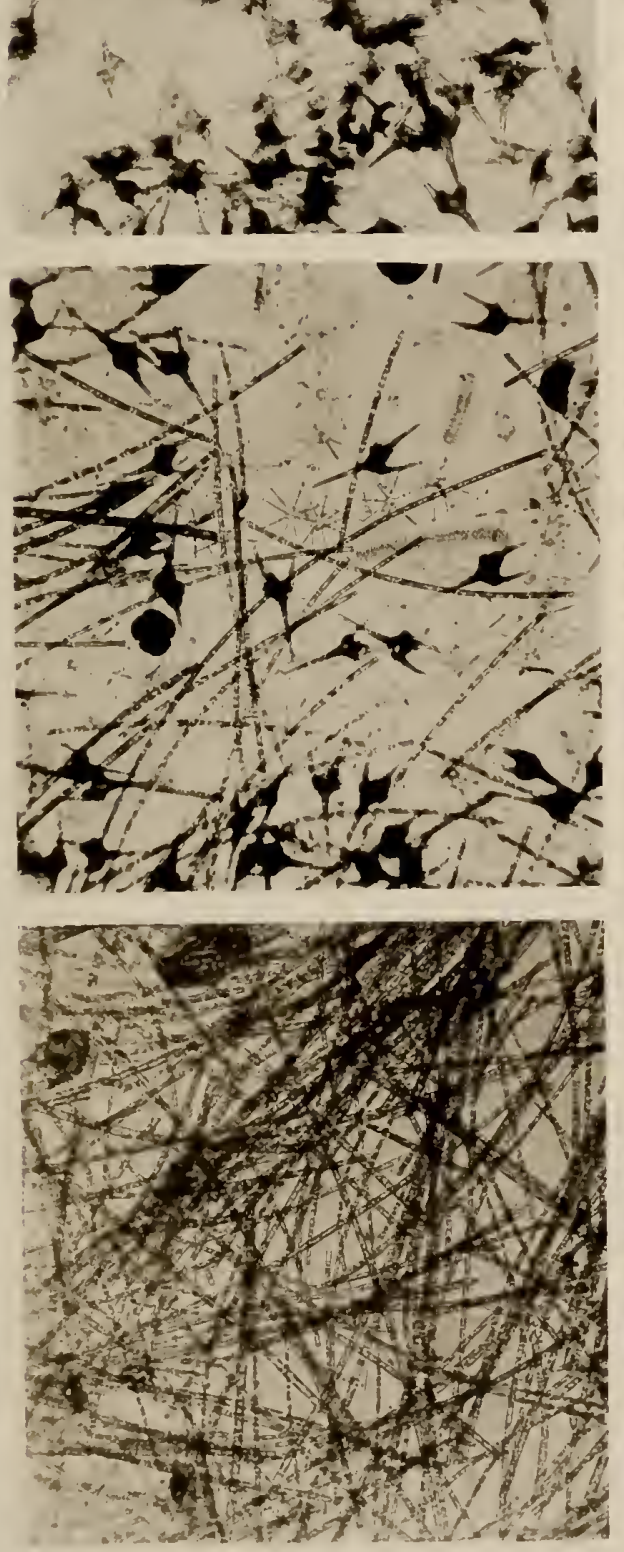
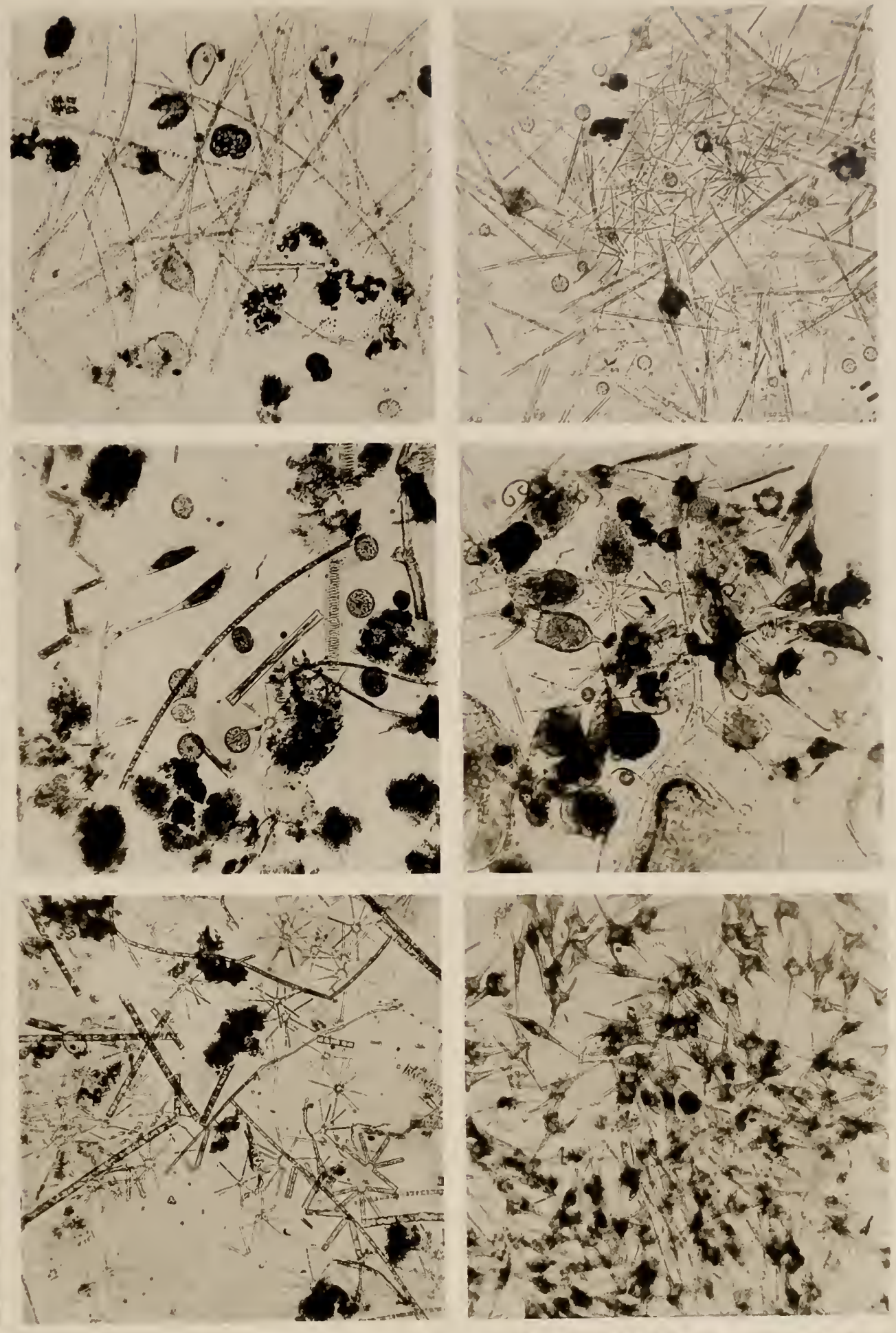

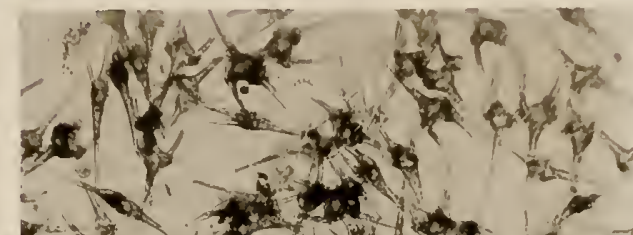

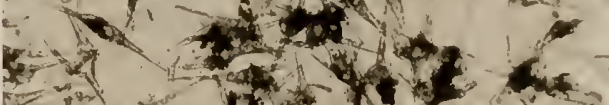
$F$ ond

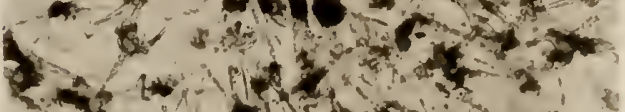
$x^{2}+12 t<+$

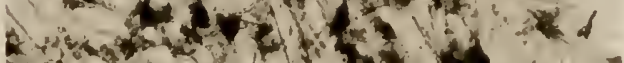

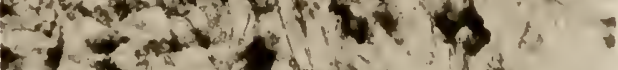
i. butady a 4

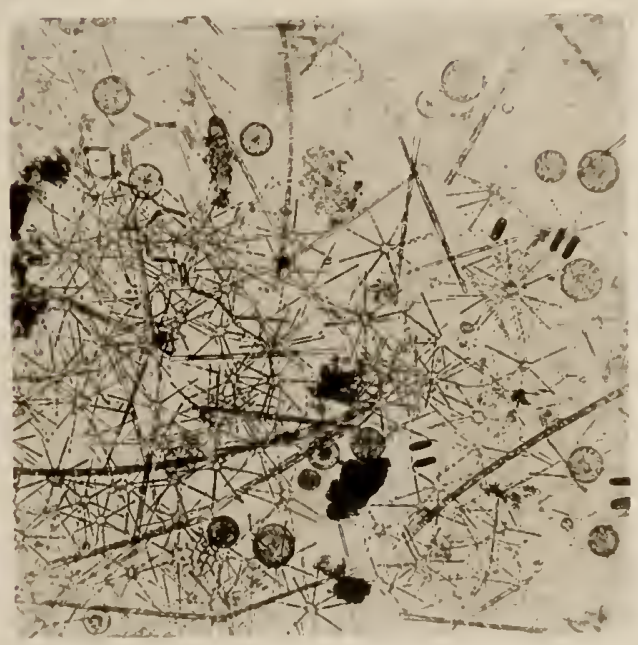

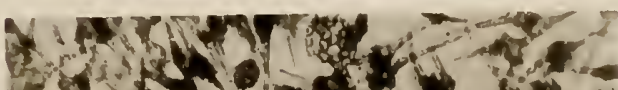

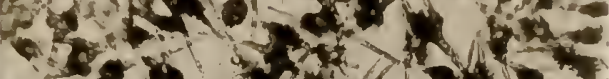

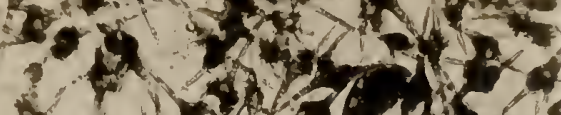

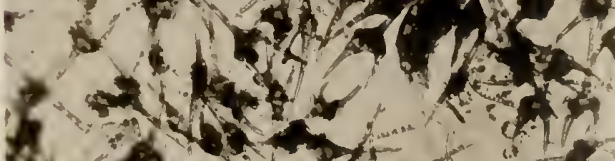

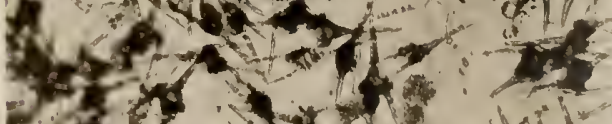
$52(x+1)$

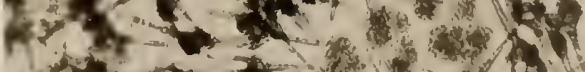

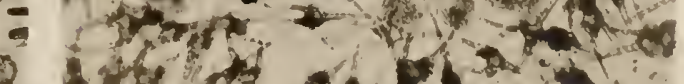

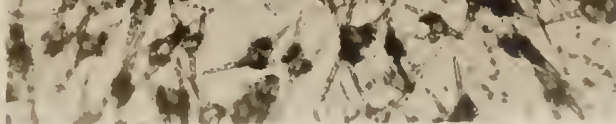



TAB. VI.

V I B O R G S Ø. 


\section{VIBORGSØ.}

$$
\text { Nr. (61. 18/5,01. T') } 11 .
$$

Polycystis artuginosi og l'. flos acpua. Aphanizonnenon llos actuar

Melosima remulata.

l'ediastrtm boryantm.

Allturar cochlearis.

$$
\text { Nr. (i2. } 10 / 7 \text { 01. T T. } 21 .
$$

lolycystis aruginosia og P. flos aqua. Aphanizomenon llos aqual i linug. Prowen er lionserveret i Sprit i Mlodsetning til alle de andre, der es konserverede i Furmol.

Mclosilua.

Anurata aculeata. Notholca longispina.

Nauplie af Ciyclops.

$$
\text { Nr. 63. } 7 / 801 . \quad \text { Tp. } 23 .
$$

Gomplospharia lacustris t. h. i M. Polycystis aeruginosa og P. llos aquae. Anabrua flos aqua og A. spiroides 1. v. f. n. Aphanizomenon flos aqux.

Melosira sp. Asterionella gracillima.

Coclastrum nicroporum t. l. f. n. Staurastrum graçile.

Ceratiun lirundinella.

Fol lidt $\lambda$ phanizomenon: for at kunne vise de ovrige Planktonorganismur er der med Vilje valgt et Sted i Priparatet, hvor deune var i Mindretal.

$$
\text { Nr. 64. 15/901. Tp. } 12 .
$$

Polycystis aruginosa og P. flos aqua. Aphanizomenon flos aquac.

Eudorina elegans (?). Staurastrum gracile.

De enorme Aphanizomenonmasser maskerer alt andet Plankton.

$$
\text { N1. 65. } 10 / 1101 . \text { Tp. } 8 .
$$

Polycystis flos aquæ. Aphanizomenon flos a(juæ mrk. de Ire sporebierende Bundter.

Aphanizomenon maskerer alt.

Stephanodiscus astræa.

Bundeu clecklet af Asterioneller, der er gaaet tabt i Reproduktionen.

$$
\text { Nr. 66. } 8 / 1201 . \text { Tp. } 2 .
$$

Polycystis flos aquæ. P. aruginosa i Overvinlringsstadier, f. n. i .l. en tømt Gelemasse. Aphanizomenon flos aqua.

Melosira sp. Stephanodiscus astraa. Asterionella giacillima.

Staurastrum gracile.

Anuraea cochlearis.

Nauplier af Cyclops.

Noget for lidt slelosira.

$$
\text { Nr. 67. } 3 / 102 . \quad \text { T). } 2 .
$$

Polycystis aruginosa; Gelchylstrene delvis tumte, af det overste "' et l'arti bestemt til Overvintring i Faerd ned at afsnores.

Melosira sp. Stephanodiscus astraea. Asterionella gracillima.

Nauplie af Cyclops.

$$
\text { Nr. 68. } 2 \% / 302 . \quad \mathrm{Tp} .2 .
$$

Polycystis aruginosa 1. v. I: n. et smukt Overvintringsstarlium.

Mclosira sp. Stephanodiscus astraea. Asterionella gracillima.

Eudorina elegans.

$$
\text { Nr. } 69.30 / 402 \text {. Tp. } 8 \text {. }
$$

Polycystis flos aqua. P. aruginosa tomme Gelehylstre.

Melosira sp. Stephanodiscus astraea. Fragilaria virescens. Asterionella gracillima.

Anuræa cochlearis og A. aculeata. Triarthra longiseta.

$$
\text { Nr. 70. } 30 / 502 . \quad \text { Tp. } 8 .
$$

Polycystis flos aqua og P. æruginosa. Aplianizomenon flos aquae med Heteroeyster.

Melosira sp. Fragilaria virescens.

Pediastrum boryanum. Staurastrum gracile.

Notlıolca longispina. Anuræa cochlearis.

$$
\text { Nr. 71. } 25 / 602 . \quad \text { Tp. } 17 .
$$

Polycystis flos aqua og P. æruginosa.

Asterionella gracillima.

Sphærocystis Schroeteri t. $\mathrm{t}$. n. Coelastrum microporum. Botryococcus Braunii. Staurastrum gracile.

Anuraa cochlearis.

Diaphanosona brachyurum t. v. f. n.

Nauplie af Cyclops.

$$
\text { Nr. } 72.26 / 702 \text {. Tp. } 15 .
$$

Gomphospharia lacustris. Polycystis flos aquæ og P. aruginosa.

Melosira sp. Fragilaria virescens. Stephanodiscus astraea.

Sphærocystis Schroeteri. Pediastrum duplex. Coelastrum microporum. Staurastrum gracile.

For lidt Stephanodiscus. 
Tab.VI
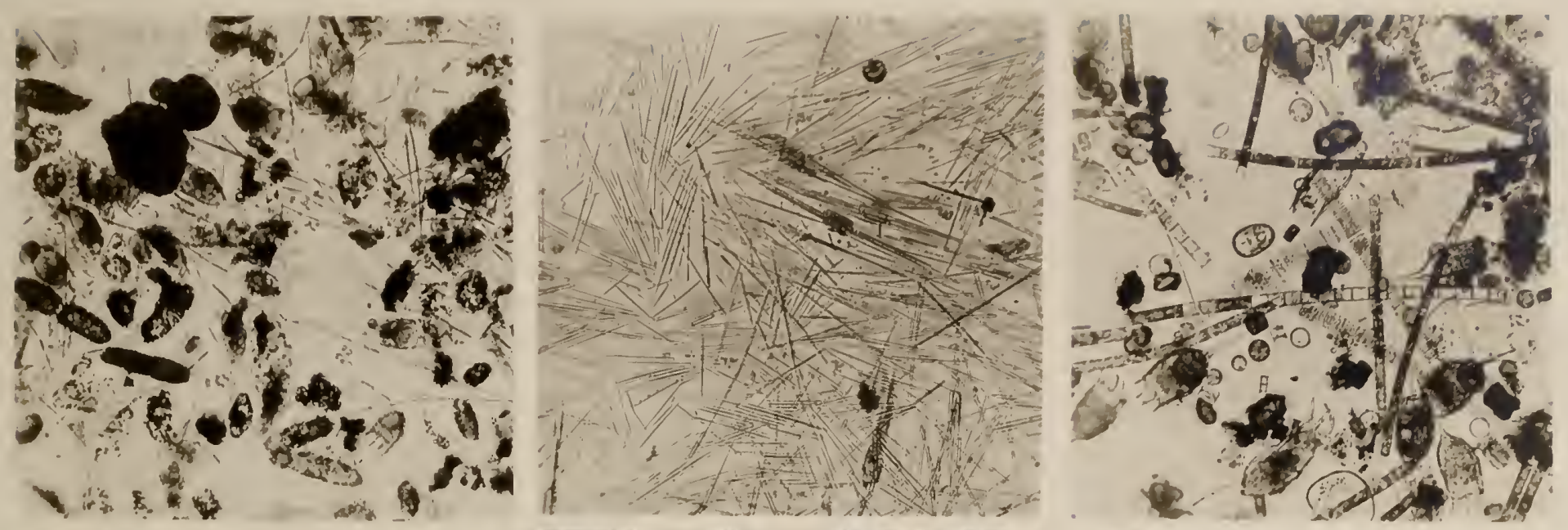

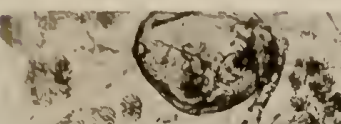

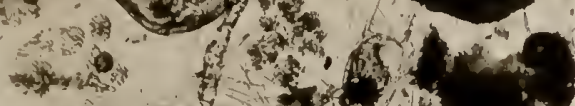

1.

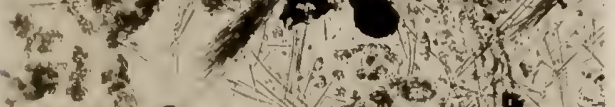

Hcing on

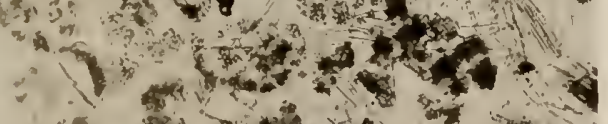

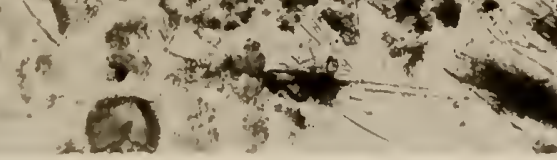

$$
\text { L. }
$$

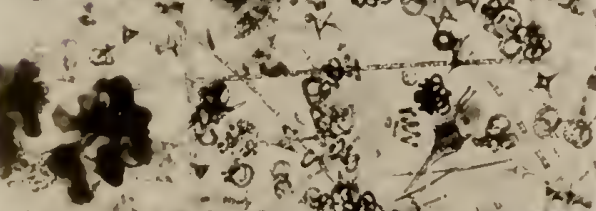
-10 a

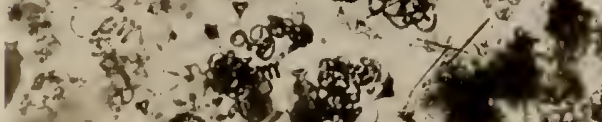
G9.

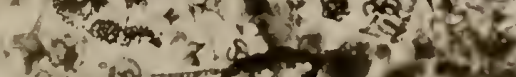
ivinistes?
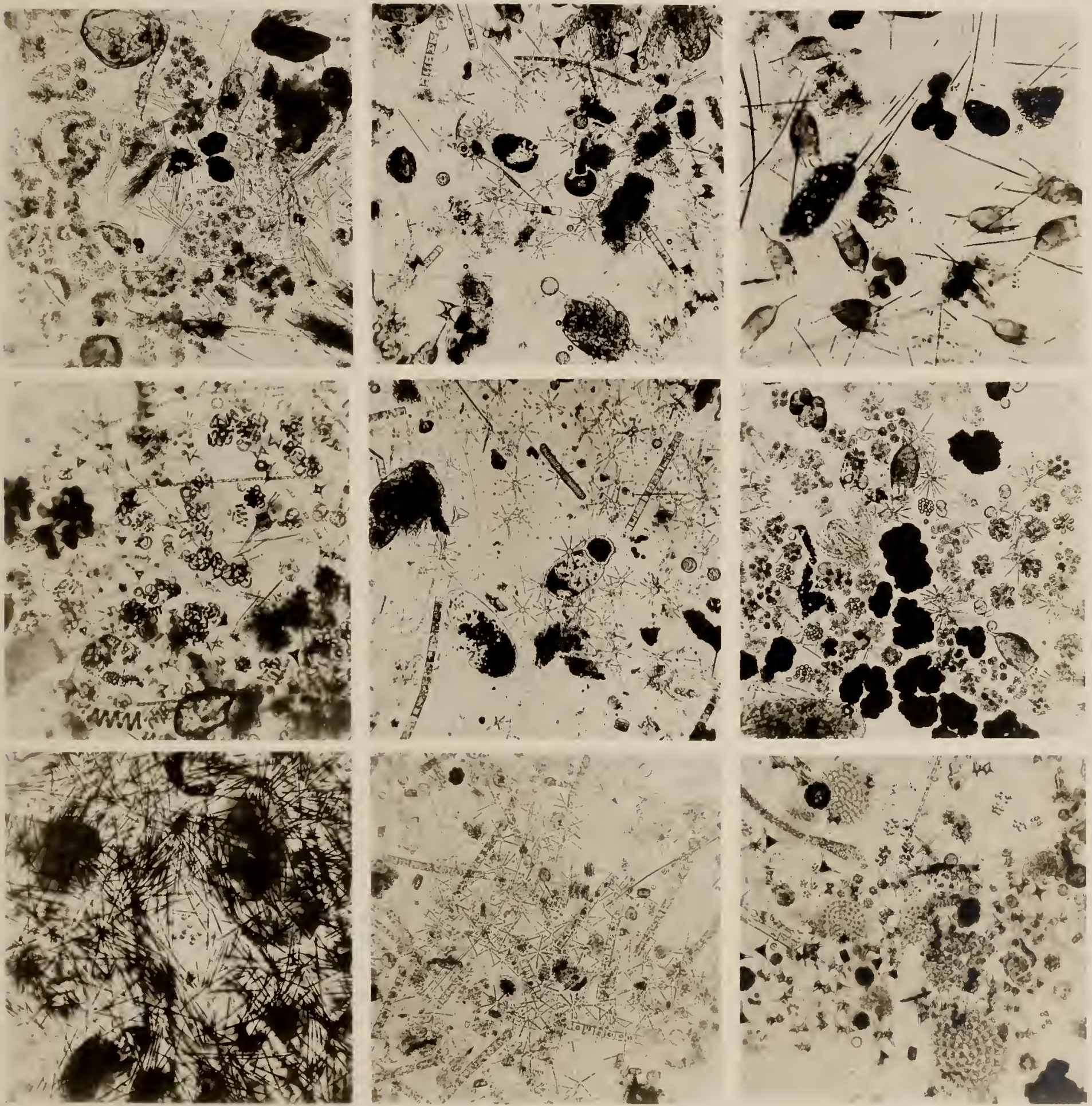

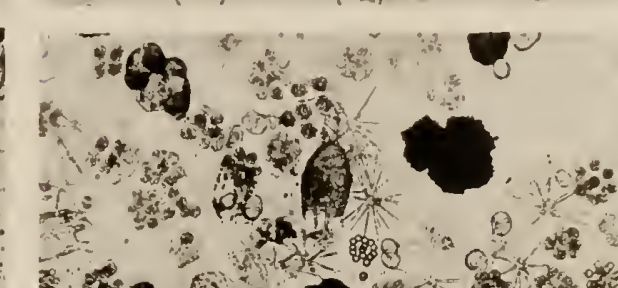
A. 1 .
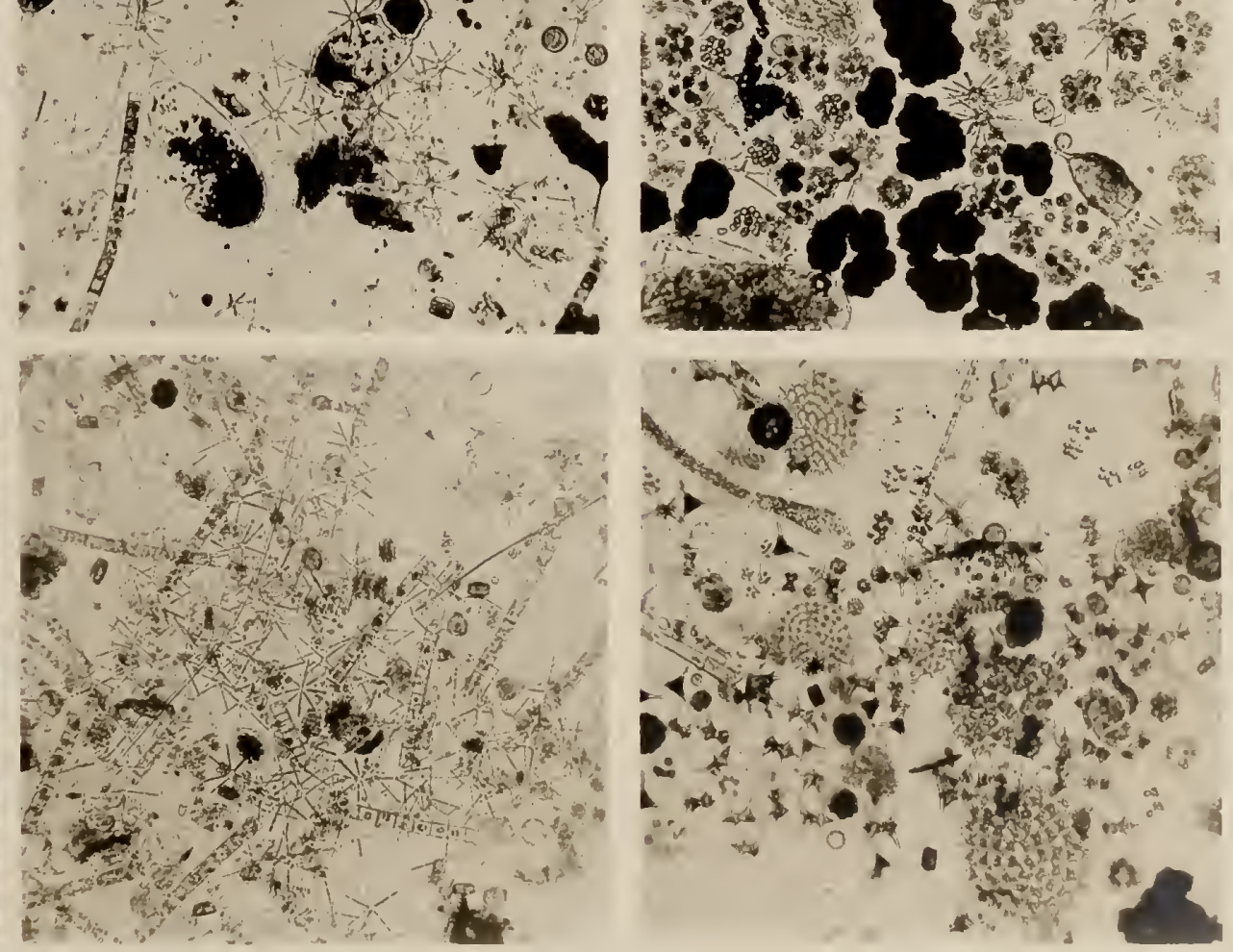

Tab. V.

\section{T J U S T R U P S Ø.}




\section{T.JUSTRUPSØ.}

$$
\text { Nr. 19. } 3 / 701 . \mathrm{T}_{1}, 17 .
$$

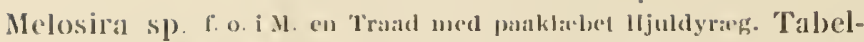
laria fenestrata. Firagilaria crotonensis.

Ceratiun hirundinella alt for lidt :. h., denne solelagt ved p'rsens Il'nstind i'? Aar.

$$
\text { Nr. 50, } 8 / 8 \text { 01. Tp. } 22 .
$$

l'olycystis flos aquice.

Melosira sp.

Ceratium hirundinella.

$$
\text { Nr. 51. 17/9 01. Tp. } 12 .
$$

Coelosphærium Kützingianum.

Melosira sp. Fragilaria crotonensis. Asterionella gracillima.

Ceratium hirundinella.

$$
\text { Nr. 52. }{ }^{16 / 10} 01 \text {. Tp. } 13 .
$$

Melosira granulati.

Anuraa cochlearis.

Nauplic af Cyclops.

$$
\text { Nr. 53. } 18 / 1101 . \text { Tp. } 7 \text {. }
$$

Gomphosphæria lacustris t. h. f. n. Coelosphærium Kützingianum. Polycystis flos aqua. Lyngbya limnetica.

Melosira crenulata. Fragilaria crotonensis. Asterionella gracillima.

Staurastrum gracile og $\mathrm{S}$. paradoxum i $\mathrm{M}$.

Ceratium hirundinella.

Anuræa cochlearis.

$$
\text { Nr. 54. } 27 / 102 \text {. Tp. } 1 .
$$

Overvejende Detritus og Bundformer.

Fragilaria virescens. Tabellaria flocculosa. Stephanodiscus astræa. Melosira sp. Asterionella gracillima. Cymbella sp. (lanceolata Ehr.?) i M., velvilligst bestemt af Insp. Ostrup.

Staurastrum paradoxum.

$$
\text { Nr. } 55 . \quad 23 / 302 . \mathrm{T}_{\mathrm{l}} \text { ). } 1
$$

Melosiral sp. Stephanodiscus astraea. Tabellaria fenestrata. Iragilaria crotonensis og $\mathrm{F}^{*}$, virescens $\mathrm{t}$. h. i . . . Asterionella gracillima.

betritus.

$$
\text { Nr. 56. } 19 / 4 \text { 02. Tp. } 4 .
$$

Polycystis flos acpuae.

Melosira sp. Cyclotella comta. Tabellaria flocculosa (?). Stephanodiscus astraea. Fragilaria crotonensis. Synedra ulna og S. acus. Asterionella gracillima.

Pediastrum boryanun. Closterium ceratium f: o. i M.

Tintinniclium fluviatile f. o. 1. v.

$$
\text { Nr. } 57 . \quad 16 / 502 . \quad \text { Tp. } 8 .
$$

Melosira sp. Stephanodiscus astræa. Fragilaria crotonensis. Synedra acus og S. ulna. Asterionella gracillima.

Ceratium lıirundinella.

$$
\text { Nr. 58. } 7 / 6 \text { 02. Tp. } 12 .
$$

Anabæna flos aquæ.

Fragilaria crotonensis. Asterionella gracillima. Cymatopleura elliptica.

Tetraspora lacustris. Eudorina elegans. Pediastrum boryanum. Tribonema bombycina. Staurastrum gracile.

Ceratium hirundinella. Codonella lacustris.

Anuræa cochlearis og A. aculeata. Conochilus volvox, løsrevne Hoveder. Triarthra Iongiseta.

HyaIodaphnia cucullata. Bosmina Iongirostris.

$$
\text { Nr. 59. } 30 / 602 . \quad \text { Tp. } 15 .
$$

Fragilaria crotonensis. Asterionella gracillima.

Ceratium hirundinella.

Bunden dxlkket af Fragilarier, der under Reproduktionen nirsten er ganet tabt. Mclosira mangler.

$$
\text { Nr. 60. }{ }^{27} / 7 \text { 02. Tp. } 15 .
$$

Polycystis flos aquæ. Anabæna flos aquæ.

Melosira sp. Asterionella gracillima.

Pediastrum boryanum.

Ceratium hirundinella. Dinobryum divergens.

Coelopus tenuior (?) t. h. f. o. 
TAB. VII.

H A L D S Ø. 


\section{HALDS $\varnothing$.}

$$
\text { Nr. 73. } 20 / 701 . \text { Tp. } 17 .
$$

Mnabrua flos acpux.

Euslorina elegans (?). Staurastrum gracile.

Ceratimn hirundinella.

l)iaplaanosomal livachyourum 1. h. l: o.

$$
\text { Nr. 7.1. } 7 / 8 \text { 01. Tp. } 18 .
$$

Coelosphariun Küitzingianum l. v. f. n. Anabana flos aqua 1. l. f. o. et sporebundt.

Fragilaria crotonensis.

Eudorina elegaus.

Ceratium hirundinella.

Nauplie.

$$
\text { Nr. } 75 . \quad 16 / 901 . \quad \text { Tp. } 13 .
$$

Coelosphærium Kützingianum. Aphanizomenon flos aquæ. Melosira sp. Stephanodiscus astræa. Fragilaria crotonensis. Asterionella gracillima.

Ceratium hirundinella.

Detritus.

$$
\text { Nr. 76. 14/10 01. Tp. } 13 .
$$

Aphanizomenon flos aqua.

Melosira granulata. Steplıanodiscus astræa. Fragilaria crotonensis.

$$
\text { Nr. } 77.1 \% / 1101 . \text { T). } 10 .
$$

Aphanizomenon flos aquæ.

Mclosira granulata. Stephanodiscus astræa.

For lidt Aphanizomenon.

$$
\text { Nr. } 78.8 / 12 \text { 01. Tp. } 4 \text {. }
$$

Aphanizomenon flos aquæ.

Melosira crenulata. Stephanodiscus astræa. Asterionella gracillima.

For lidt Aphanizomenon.
Nr. $79.3 / 102 . \quad$ Tp. 2 .

$\Lambda$ phanizomenon flos aquæ.

Melosira crenulata. Stephanodiscus astræa. Asterionella gracillima. Fragilaria crotonensis.

$$
\text { Nr. 80. } 22 / 3 \text { 02. Tp. } 2 .
$$

Aphanizomenon flos aquac.

Melosira sp. Stephanodiscus astræa. Fragilaria crotonensis. Asterionella gracillima.

$$
\text { Nr. 81. } 3 / 502 . \quad \text { Tp. } 7 \text {. }
$$

Melosira sp. Stephanodiscus astræa. Asterionella gracillima.

Tintinnidium fluviatile.

$$
\text { Nr. } 82.30 / 502 . \quad \text { Tp. } 8 \text {. }
$$

Aphanizomenon flos aquæ.

Stephanodiscus astræa. Fragilaria crotonensis.

Ceratium hirundinella.

Anuraea cochlearis. Conochilus volvox.

$$
\text { Nr. 83. }{ }^{11} / 6 \text { 02. Tp. } 12 .
$$

Anabæna flos aquæ. Aphanizomenon flos aquæ.

Melosira sp. Stephanodiscus astræa. Asterionella gracillima. Fragilaria crotonensis.

Sphærocystis Schroeteri.

Ceratium hirundinella.

$$
\text { Nr. 84. } 2 / 802 . \quad \text { Tp. } 15 .
$$

Oscillatoria rubescens. Anabæna flos aquæ med Vorticeller. Melosira sp. Stephanodiscus astræa. Fragilaria crotonensis.

Eudorina elegans. Tribonema bombycinum.

Ceratium hirundinella.

Mastigocerca capuzina i M. Notholca longispina t. v. f.n. 
$-56$ Hen 2. ent. the s.

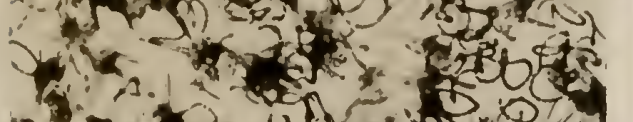
$3+23$

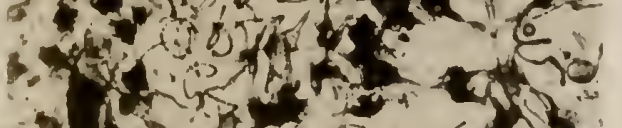

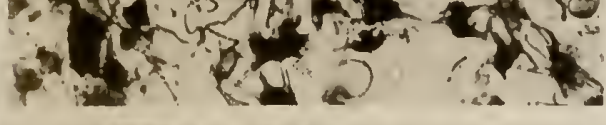

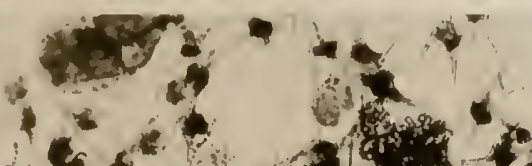

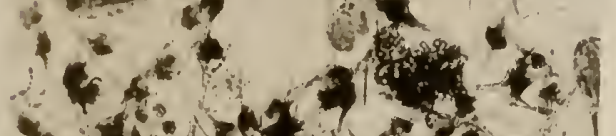

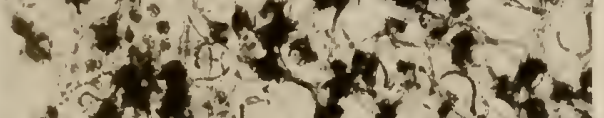

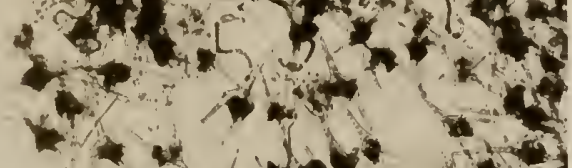

- $9 \operatorname{lotal}^{4}$ an $2 x(y)$
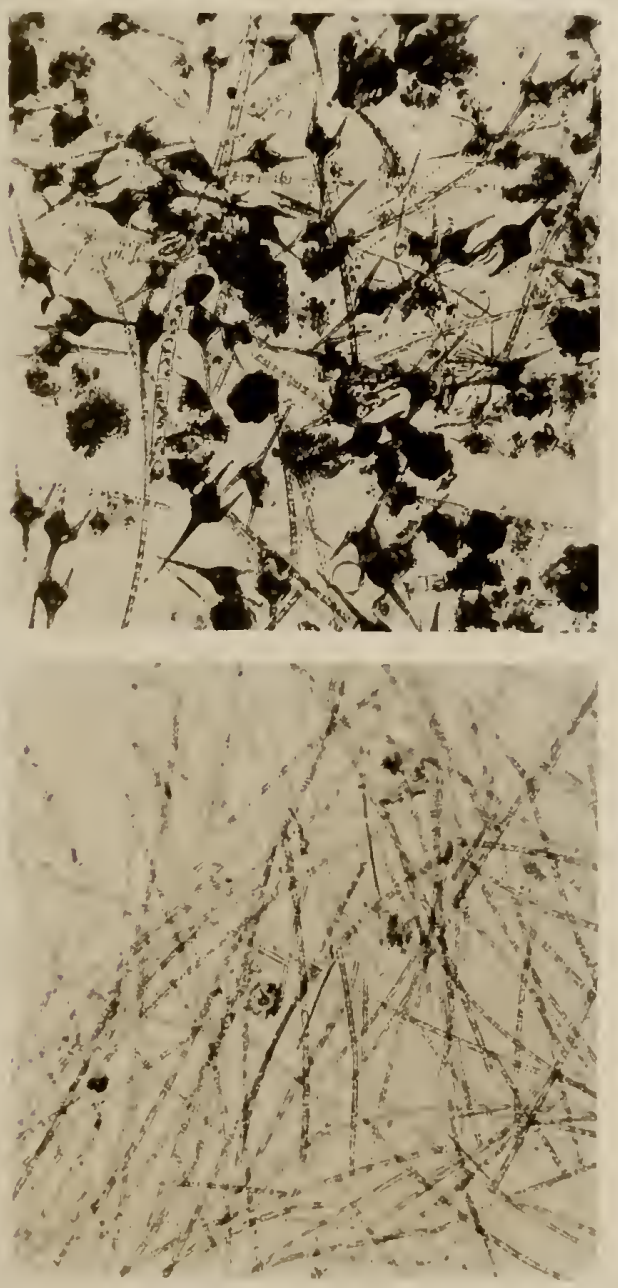

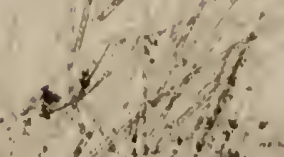

$1+1$
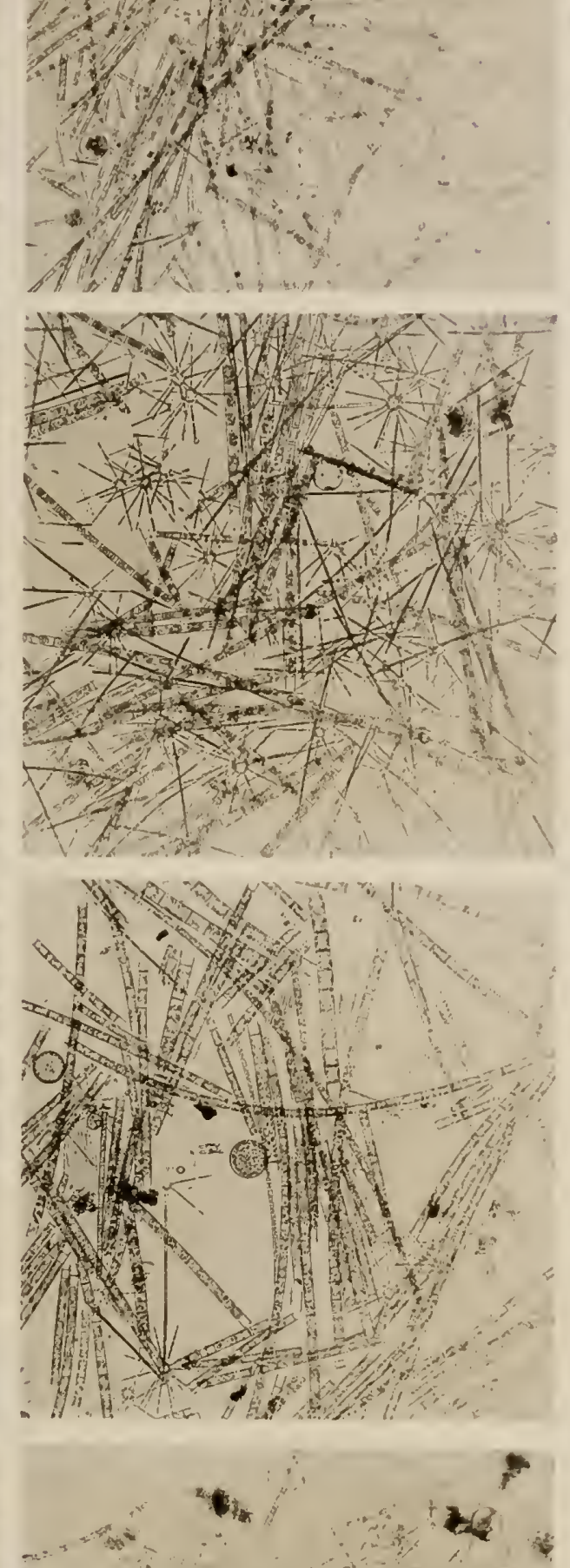

6...

告。
- 4 数

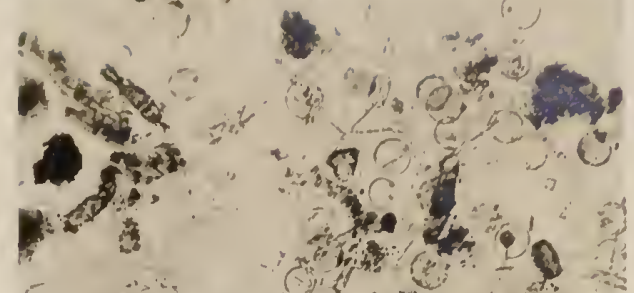

400

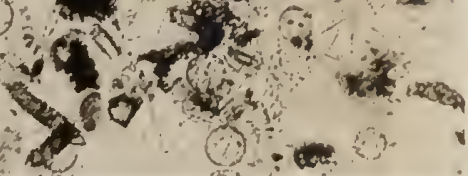
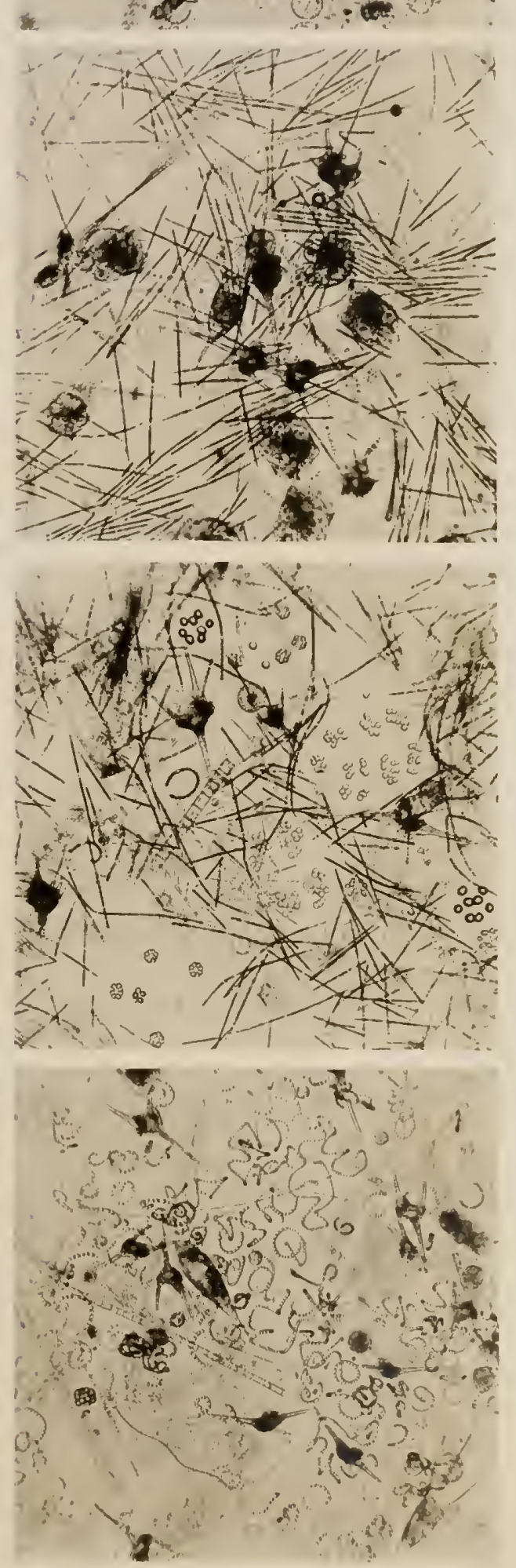

TAB. VIII.

S K A N D E R B O R G S Ø. 


\section{SKANDERBORGSO.}

\author{
Nr. 8:. 1!1/, (01. '11. 13

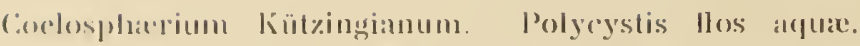 \\ l. ynghya limmolican. Oscollatoria rubescens.

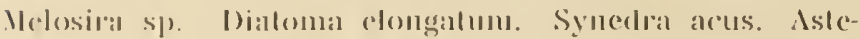 \\ romella gratcillima. (ivmatopleura colliplica. \\ l'ediastrum boryanum. 'loibonema bombycinum.

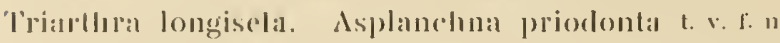

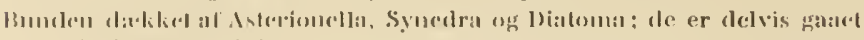 \\ |:11) i licprosluktimetu.

$$
\text { Ni. } 86.5 / 801 . \quad \mathrm{T}_{\mathrm{p}} .21
$$

Coococeus limnclicus. Cocolosphereiun lö̈tzingianum.

Polycyslis llos andue. lynglyar limnetica.

Melosila sp. Asterionella grateillinia.

Peoliaslrum boryanum.

Comtium lioundinclla.

l'omploblys sulcaltil.

Hyalodaphnia cucullala. Bosmuina coregoni.

Nauplic.

$$
\text { Nr. 87. 15/9 (01. Tp. 12. }
$$

Coococeus limneticus. Coelosphaerium Kützingianum l.jngloya linuctic:a.

Melosiona sp. Steplanodiscus astrea. Aslerionella gracillima.

f'ediastrum boryanum og P'. simplex i a. og t. h. f. o. Botryococeus Braumii ı. v. r. 1 .

Ceratium lioundinella.

logel for lidt coelosploxium.

$$
\text { Ni. 88. 18/10 01. Tl. } 12 .
$$

Coelespharium kützingianum. l’olycystis llos arpæ. lunglyal limmetica.

Melosira sp. Stephanodiscus astrax. Asterionella gracillima.

P'ediastrum boryanum.

Bosmina coregoni.

$$
\text { Nr. 89. } 20 / 1101 . \text { Tр. } 6 .
$$

Coelosph:erium Kützingianum. Polycystis llos aquae. Lyngbya limmetica. Oscillatoria rubescens.

Melosira sp. Stephanodiscus astraa. Synedra acus. Asterionella gracillinia.

Pediastrum boryanum og P. Kawraiskyi i s.

Anuráa cochlearis.

$$
\text { Nr. 90. 3/1 } 02 . \text { Tp. } 1 .
$$

Croococcus limneticus. Coclospharium Kützingianum Polycystis flos aquae. Lyngbya limnetica. Oscillatoria rubescens.
Mclosiral s'p.

Amurea cochlearis

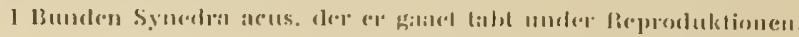

$$
\text { No. !1. } 27 / 202, \quad \mathrm{~T}, 1 .
$$

Polycystis llos acpure. Lyngloya linunetica og 1. bipunetatil. Oscillatoria rubescens.

Melosirá sp.

$$
\text { Nr. 92. 1/4 02. Tp. } 2 .
$$

lolycystis flos aquac, Lynghya limnetica og l. hipunetata. Oscillatoria rubescens.

Melosira sp). Steplanodiscus astraea. Diatoma elongatunt. Fragilaria crotomensis. Synedra acus. Asterionella gracillima.

Scenerlesmus quallicauda 1. 1.. f. o. Pediastrum boryanum.

$$
\text { Nr. 93. 1/502. Tp. } 7 .
$$

l.ynghya limnetica og 1 . bipunctata. Oscillatoria rubescens.

Melosira sp. Cyclotella comta t. h. i. o. Stephanodiscus astraea. Diatomia elongatum. Fragilaria crotonensis. Synedra acus. Asterionella gracillima.

Pediastrum simplex.

Bunclen, dw (re gennemkiydset af' Diatoma, Fragilaria ng Symedra, er $\mathbf{i}$ Reprorluktionen gataet stierkt tilbage.

$$
\text { Nr. 94. 3/6 } 02 . \text { Tp. } 15 .
$$

Lynghya limnetica og $\mathrm{L}$. bipunctata. Oscillatoria rubescens.

Melosira sp. Stephanodiscus astraea. Diatoma elongatum. Fragilaria crotonensis. Synedra acus.

$$
\text { Nr. 95. } 28 / 602 . \text { Tp. } 18 .
$$

Coelospharium Kützingianum. Polycystis flos aquæ. Lynghya bipunctata.

Melosira sp. Stephanodiscus astræa. Fragilaria crotonensis. Synedral acus. Asterionella gracillima.

Codonella lacustris 1. r. I: o. og f. $\mathrm{n}$.

Polyarthra platyptera. Anur:ea cochlearis.

$$
\text { N1. 96. } 30 / 702 . \quad \text { Tp. } 14 .
$$

Coelosplıxium Kützingianum. Lyngbya lacustris.

Mlelosira sp. Stephanodiscus astræa.

Oocystis Nregeli t. h. f: o. Pediastrum boryanum. Coelastrum microporum I. v. f. o. Staurastrum gracile I. v. f. n.

Ceratium hirundinella.

Anuræa aculeata. A. cochlearis. Anuræa hypelasma E ı. v. i .l. Pompholyx sulcata. 

TAB. IX.

M O S S Ø.

FIG, 97-107.

FIG. 108. THORSØ. FORST. c. 25 GANGE. 


\section{$\operatorname{MOSS}()$.}

$$
\text { Nir. 97. 2x/1.000. 19. } 1 .
$$

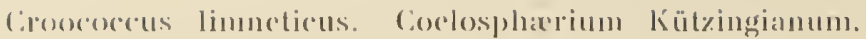

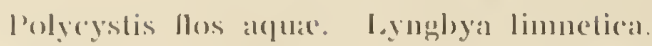

Melosira sp). Steplanorliscus astraca. Asterionella grat(•illimiı.

$$
\text { Nr. 98. 5/501. 'T. } 6 \text {. }
$$

Molosira sp. Stephanodiscus asträa. Diatomal clongalum. Asterionella grantillima.

Brachlionus pala.

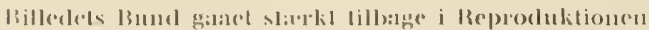

$$
\text { N'r. 9!). } 20 / 501.21 \% .12 .
$$

Croococeus limncticus. Polycystis atouginosa. Oscillatoria rubescens

Melosiral sp. Diatoma clongatum. Fragilaria rotonensis. Asterionella gracillima.

Pediastrum boryanum.

l'eridinium cinctum ontment is. Anuráa cochlearis. Triarthral longiscta.

$$
\text { Nr. 100. 1/8 01. 'j. } 22 .
$$

Croococens limncticus. Coelospharium liüzingianum. l'olycystis aruginosa. Inabena llos aquac.

Melosira spe.

P'odiastrum límwaiskyi.

(ieratium hirundinetlas. I)ifllugia sp. I. v. f. n

lompholyx sulcata.

$$
\text { Nr. 101. } 20 / 901 . \text { Tp. } 11 .
$$

Croococcus limneticus. Coelospherium Kützingianum. lolycystis aeruginosa. Anabena flos aquae.

Melosira sp). Stephanodiscus astrae.

liaphidiophrys pallida t. v. I. o.

$$
\text { Nr. 102. 15/10 01. Tp. } 10 .
$$

Croococeus limneticus. Coelosphaerum lï̈tzingianum. Polycystis flos arpux og P. aeruginosa.

Melosira sp. Stephanodiscus astræa. Asterionella gracillima.

Oocystis Nageli.

$$
\text { Nr. 103. 10/12 01. Гр. 5. }
$$

Croococcus limneticus. Coelospharium Kützingianum. lolycystis llos aquae. Oscillatoria rubescens. Ilelosira sp. Asterionella gracillima.

$$
\text { Nre. 10.1. 10/5, } 02.9 \%, 8 .
$$

Croococeus limnelicus. Oscillatoria rubescens.

Melosila sp). Stephanodiscus astriea. Diatomal clongatum. Fingilaria ceotonensis. Symerlà acus. Asterionella groacillinas.

Sconcelesmus yuadricauda 1. v. f. o

$$
\text { Nr. 105. } 3 / 6,02 . \mathrm{Tp}, 12 .
$$

Croococens limneticus. Polycystis flos apuac. Oscillatoria rubescens. Lyngloya limnetica.

Melosira sp). Stephanodiscus astráa. l)iatoma elongatum. Liagilaria crotonensis. Synedra acus. Asterionella gracillima.

pediastrum duplex.

$$
\text { Nr. } 106.2 \times / 6,02.91) .16 .
$$

Croococeus limneticus. Polycystis flos ayuae. Lyngbya bipunctata. Oscillatoria rubescens.

Melosira sp. Stcphanodiscus astraea. Fragilaria crotonensis og $F$. virescens. Asterionella gracillima.

Pediastrum duplex og l’. Kawraiskyi t. v. i. o. Scenedesmus bijugatus t. Is. f. 11 .

Periclinium cinctum (?) t. 1. l. o. Codonella lacustris.

Anuraxa cochlearis.

Noget for liclt Fragilaria.

$$
\mathrm{Nr} .107 . \quad 30 / 702 . \quad \mathrm{Tp} .15 .
$$

Groococcus limneticus. Polycystis flos aqux. Lyngbya bipunctata. Oscillatoria rubescens.

Melosira sp. Stephanodiscus astrae. Fragilaria crotonensis.

Pediastrum boryanum.

Glenodinium acutum t. h. f: n. Cyphoderia ampulla i ...

Detritus.

\section{THORSØ.}

$$
\text { Nr. } 108.3 / 801 . \quad \text { Tp. } 22 .
$$

Gloiotrichia echinulata.

linglernes cielcomhylninger markerede af Ceratier. Forneden Asplinchna priorlonta og en Naluplie. For's! kun c. 25 Gange. 


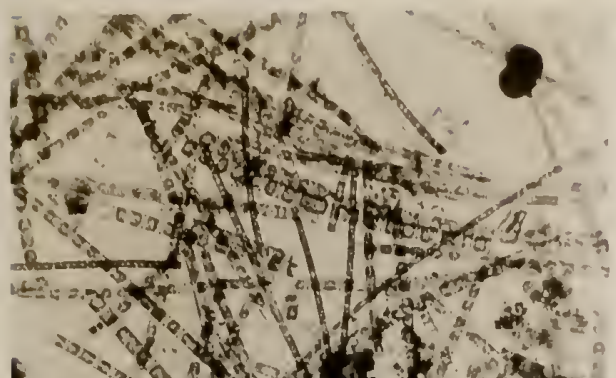

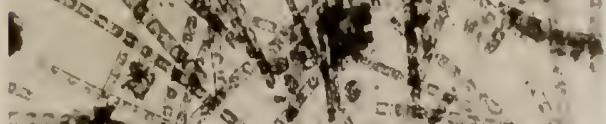
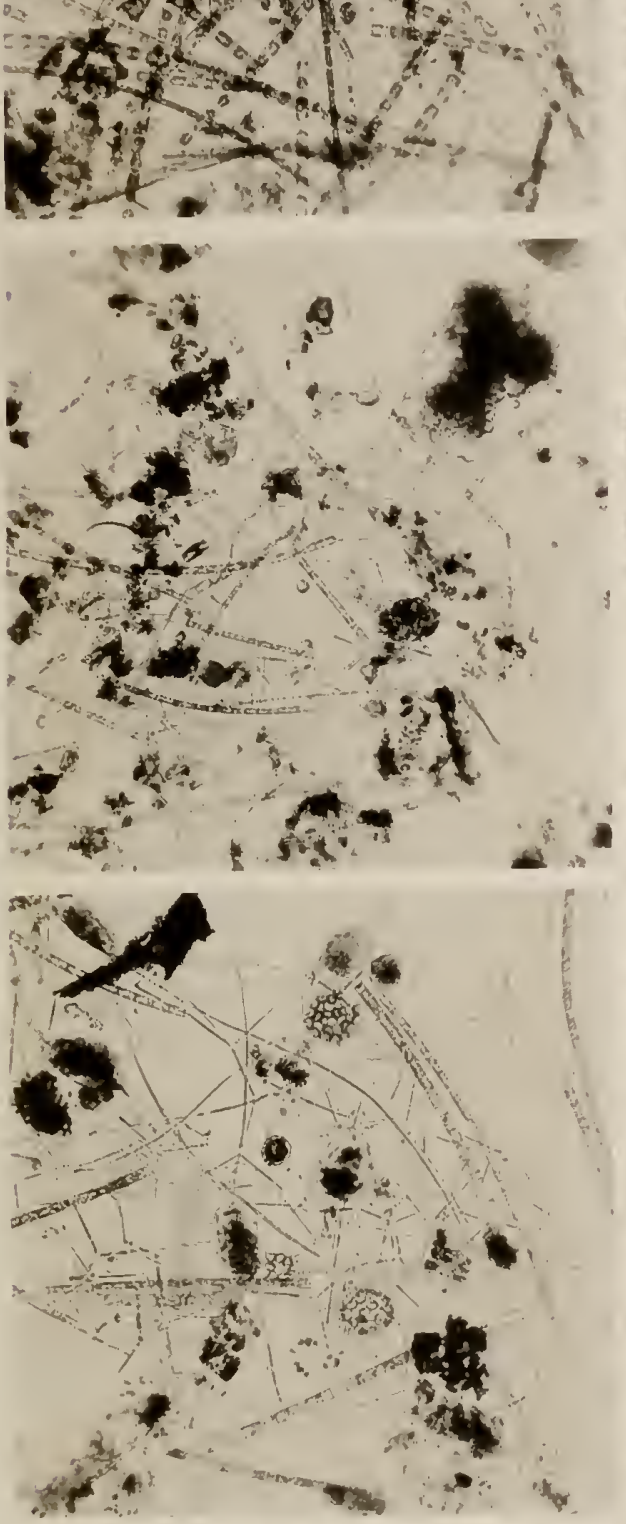

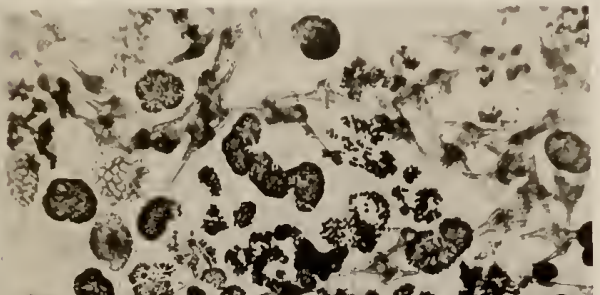

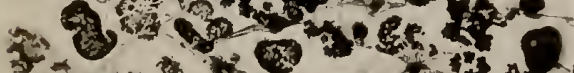

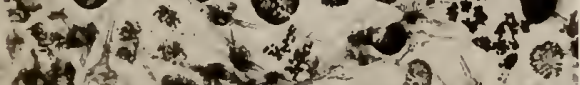

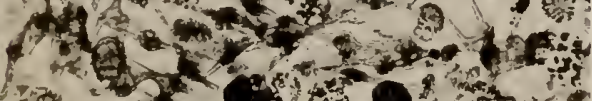

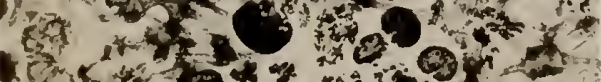

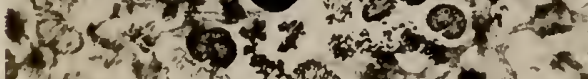
- $18 e^{2}+4$

C. Wesenberg-Lund, phot.

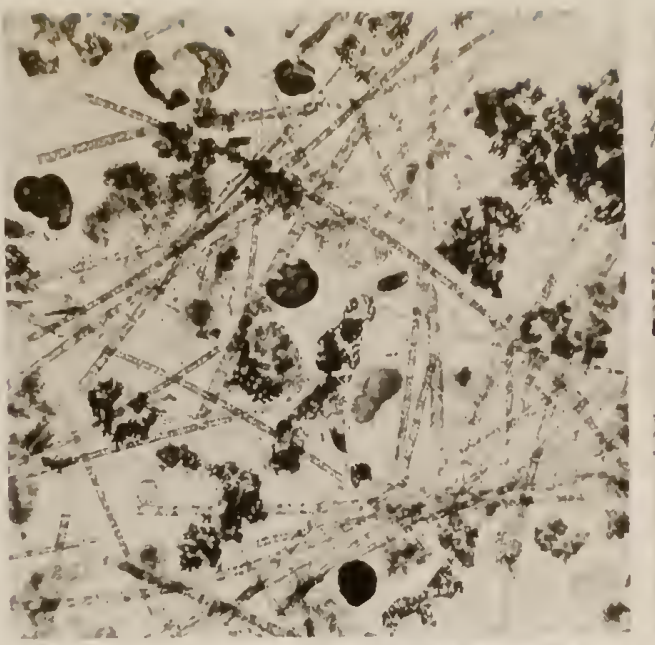

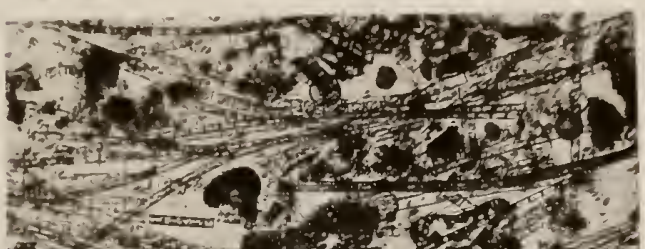

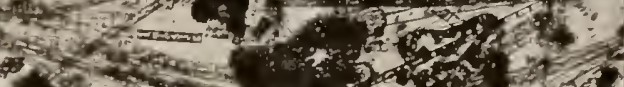

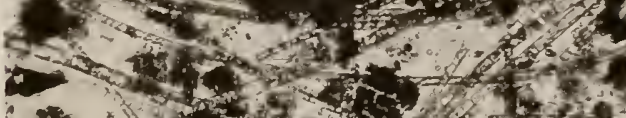

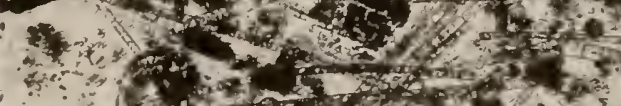

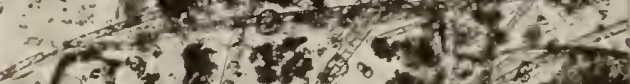

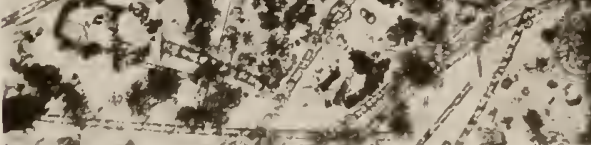

(x)

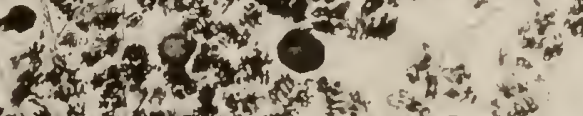
3.

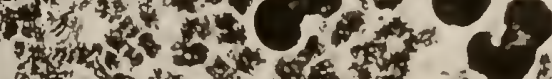
(1) 2. 1. Jot mo 2.
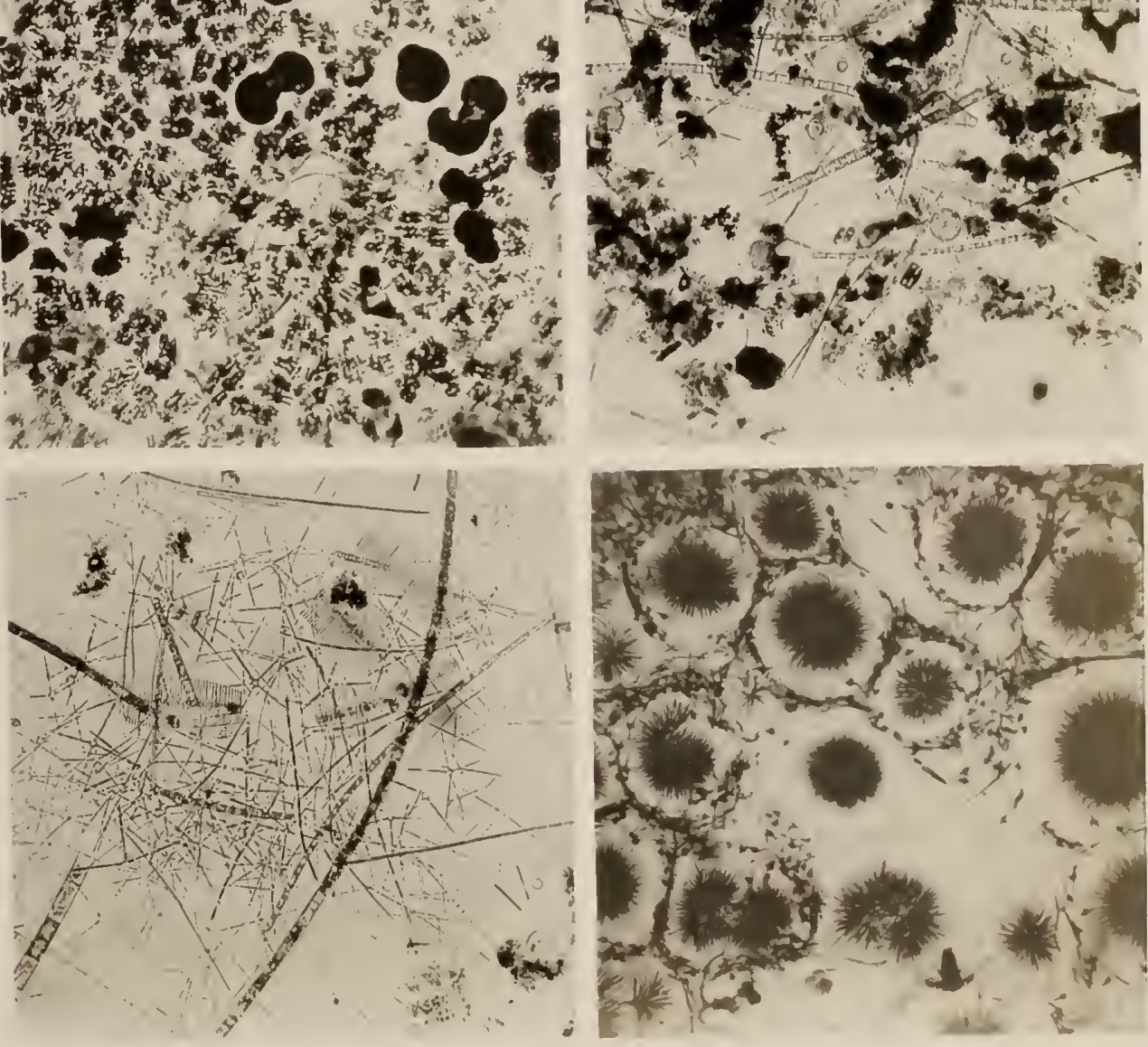

108 
、

TAB. X.

J U L S Ø. 


\section{JULSO.}

Ciroucocous dimnelicus.

$$
\text { Ne. 109, 24, (01, Tp. } 3 .
$$

Molosidal sp. Shophanodiscus astraca. Dialoma clongatum Fragilaria crotonensis. Asterionella gracillima.

$$
\text { Nr. } 110.20 / 01.213 .
$$

Melosira sp. Stephanodiscus astraxa. Dialoma elomgat fum. Fragilaria roblonensis og l’ virescens. Asterionolla gुracillima.

$$
\text { Nr. 111. 10/, } 01.90 .20 .
$$

Xphanizomenom llos acpue

Ilosira sp.

Fiudorina clegans.

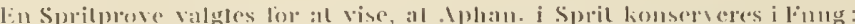
i alle de lishende prover (lFormol) optrateler .tphan. lim som riarle.

$$
\mathrm{Nr} .112,1 / 801.7 \mathrm{~T} .22 .
$$

Croococous limnelicus. Amabena macrospora og A. spiroides. Aphanizomenon llos aguae.

Melosira sp).

$$
\text { Nr. } 113.15 / 1001 . \mathrm{T}_{\mathrm{p}} .12 .
$$

froococcus limneticus. Cocospharium líützingianum. l'olycystis flos apuae. Iphanizomenon flos acpa.

Melosirar sp.

l'rovens honserveringstilstund ikke grod

$$
\text { Nr. } 111.20 / 1101 . \mathrm{T}_{\mathrm{p}} .6 .
$$

Croococcus limneticus. Coelospharium liützingianum. Polycystis flos aquae. Inabrena flos aqux. Aphanizomenon flos aquae.

Melosira. Stephanodiscus astraea. Fragilaria crotonensis. Asterionclla gracillima.

Codonella lacustris

$$
\text { Nr. } 115.15 / 102 . \text { Tp. } 1 .
$$

Croococeus limneticus.

Melosira sp. Stephanodiscus astraea. Asterionella gra(illima. Diatoma elongatum.

$$
\text { Nr. } 116.5 /, 02 . \% \text { T. } 3 .
$$

Croococous limnélicus

Melosira sp. Slephanorliscus astráa. Dialoma elongatum. Astrerionella şracoillima.

$$
\text { Nr. } 117.5 / 502 . \quad \mathrm{Tp} .6 .
$$

Croococeus limnelicus. Oscillatoria rubeseens.

Melusira sp. Stephanodiscus astraxa. Diatoma clongatum. Asterionella gracillima.

$$
\text { Nr. } 118.2 / 602 . \quad \text { T). } 13 .
$$

Croococens limnelicus. Polycystis flos apuce. Lynghya bipunclata. Oscillatoria rubescens. Anabỏena flos arjuat.

Melosira sp). Diatoma elongatmm. Fragilaria crotonensis. Synedra acus. Isterionella gracillima.

Sicenedesmus bijugatus.

$$
\text { Nr. } 119.30 / 6,02 . \quad \text { Tp. } 16 .
$$

Croococcus limneticus. Polycystis aruginosa. Lyngbya limnetica og 1. bipunctata. Oscillatoria rubescens. Inabiena spiroides og A. macrospora. Aphanizomenon flos acjuic.

Melosira sp. Stephanodiscus astræa. 1)iatoma elongatum. Fragilaria crolonensis. Asterionella gracillima. Staurastrum gracile.

Celatium Irirundinella. Codonella Iacustris.

$$
\text { Nr. } 120.31 / 70^{2}, \quad \text { Tp. } 15 .
$$

Polycystis aruginosa. Lyngbya limnetica og L. bipunctata. Anabrena spiroides og A. macrospora. Aphanizomenon flos aquae.

Melosira sp. Stephanodiscus astraa. Fragilaria coolonensis. Asterionella gracillima.

Pediastrum duplex og P. Kawraiskyi t. h. l: u.

Glenodinimm acutum. Peridinium cinctum. Ceratium hirundinella. Diflugia limnetica det murke Legeme omtrent i ... Codonclla lacustris.

Anuraa cochlearis.

Nauplie. 

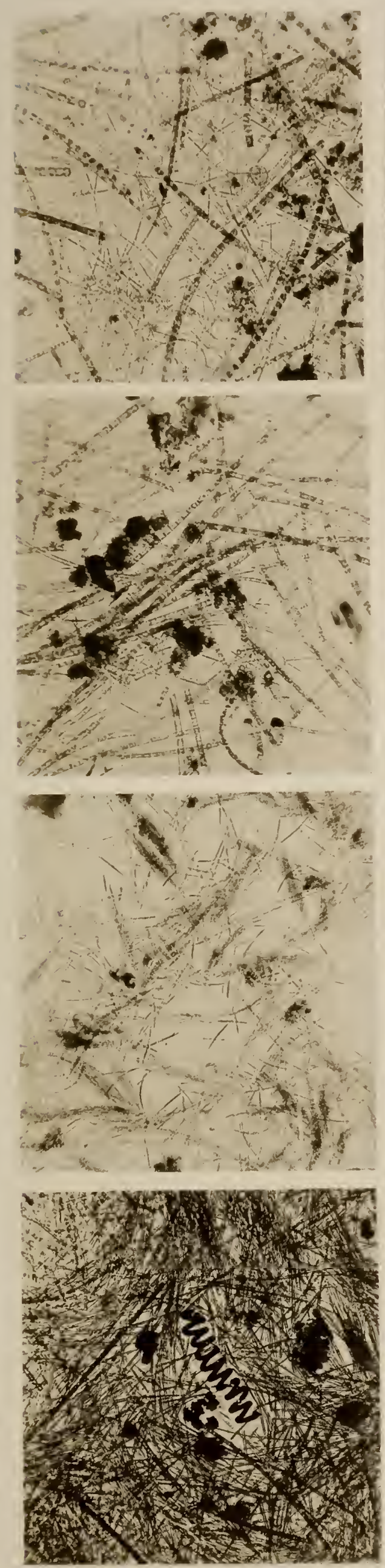

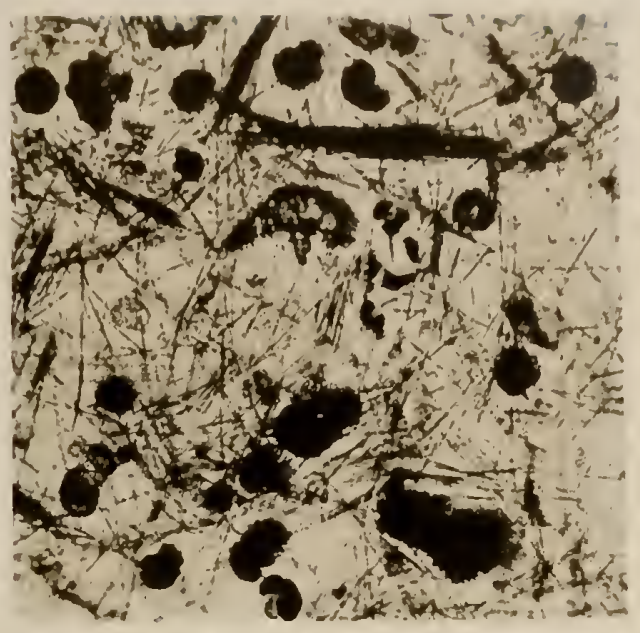

13.

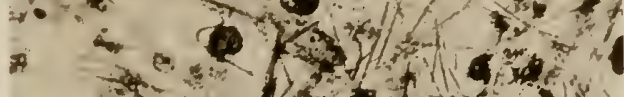

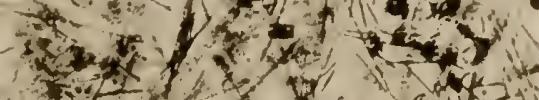

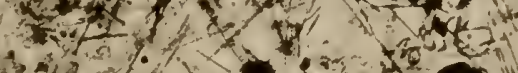

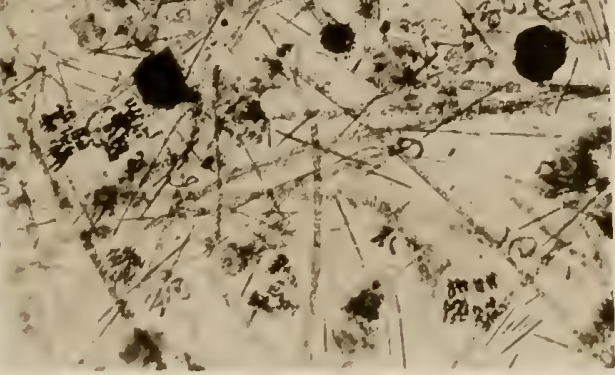

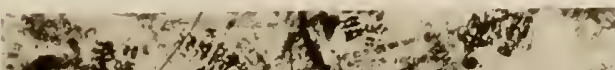
$4+2+1+2$ m.

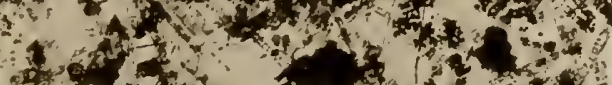

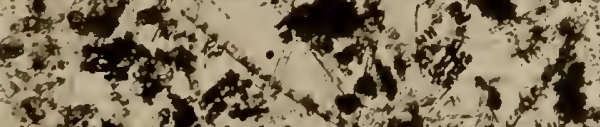

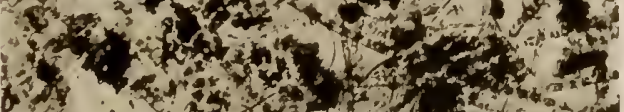
4as

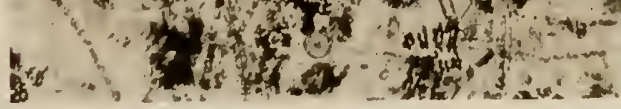

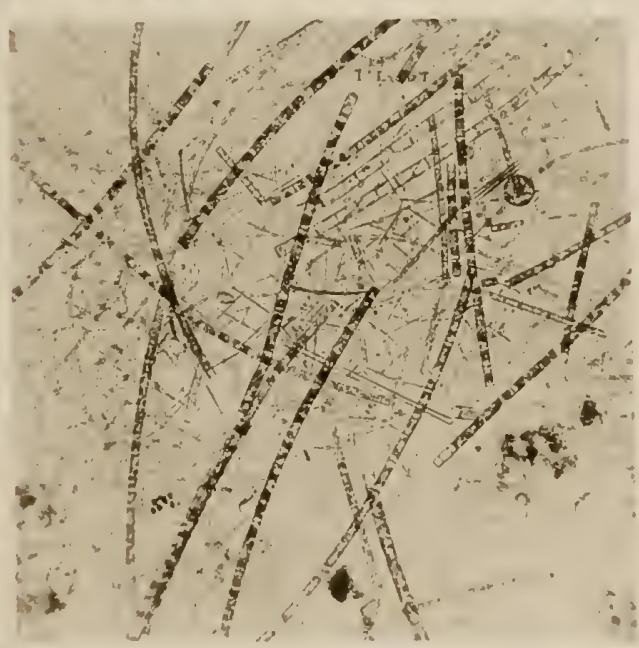

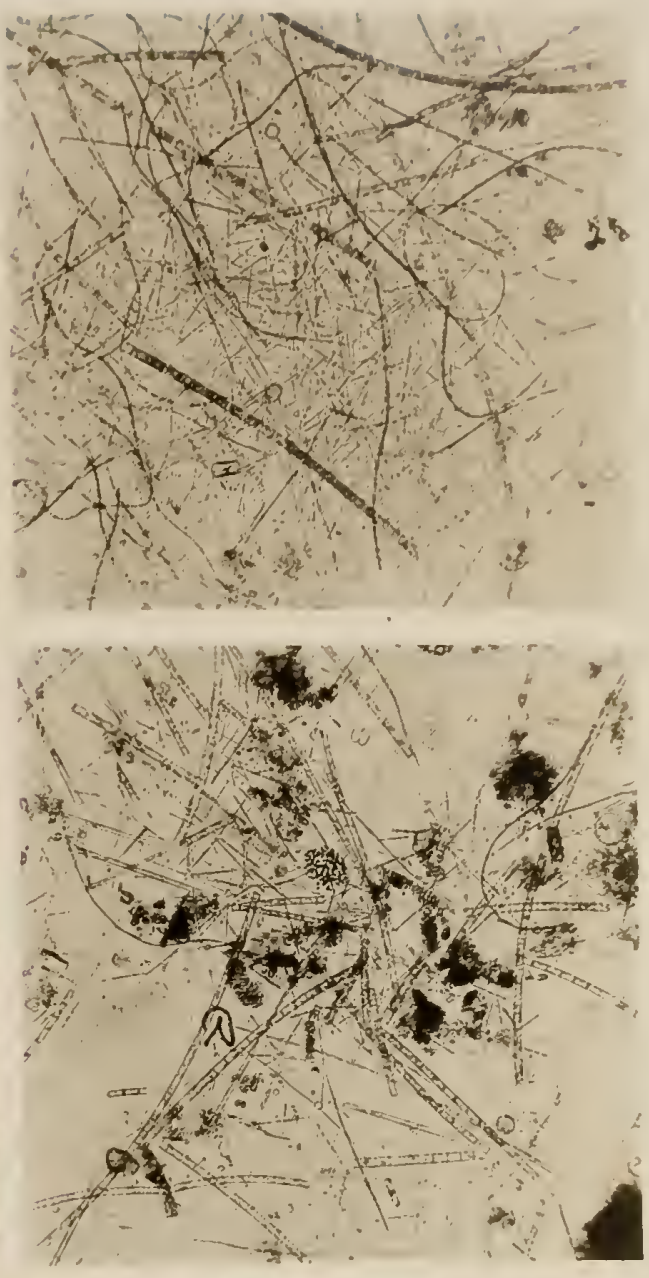

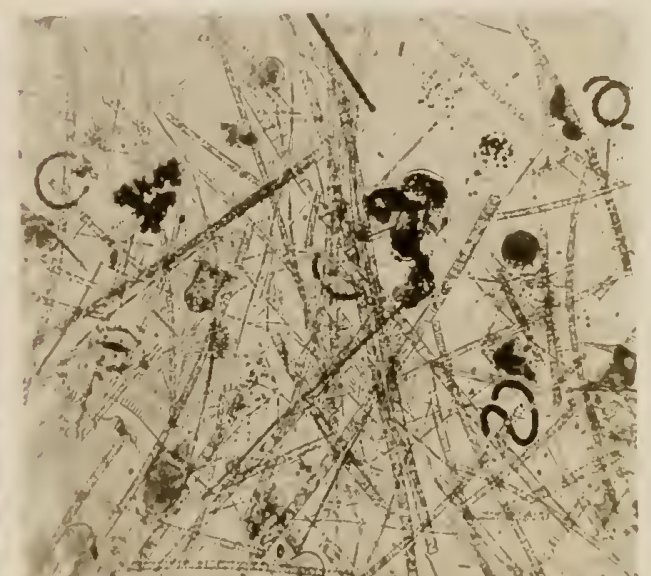

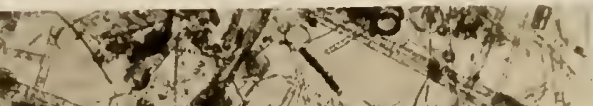

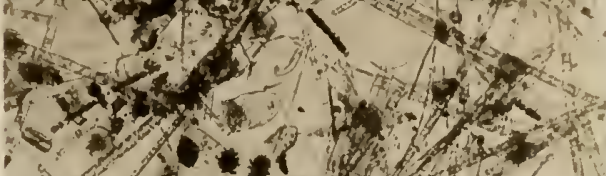

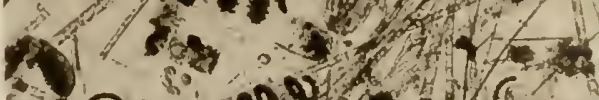

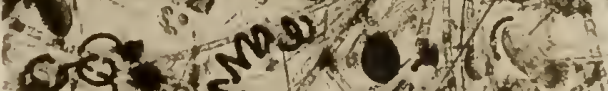

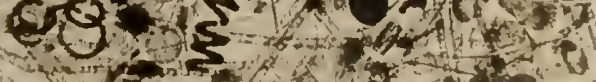

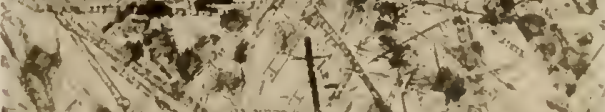
E. (2) 
PLAN KTONTABELLER. 


\section{HYPPIGHEIDSANGIVELSER:}

"ec (overvejende) a at Arten danner den langt overvejende bel af hele Soens samlede Planktonmasse og giver Planktoncl el monotont Pragg.

(c) (meget alm.) o: at Arten findes i stor Mangle, uden dog derfor at give l’lanktonet ot monotont Prag.

(. ): al Arten er alm.

+ o: at Arten findes i ret stort Antal, urlen at den dog derfor kan siges at vare alm.

$r$ o: at Arten er sjalden, kun paravist i ringe Mangde.

re s: at Arten optrader coneltvis, kun paavist i eet eller meget faa Eks.

\section{TRYKFEJL,}

der bedes rettede for Brugen

Tabel Fureso 16. Linie f. n.: H. quadrangula; laes: cucullata.

1. - f. o.: $19023 / 8$ r; laes: c.

- Esromso 5. - f. o.: Polycystis aruginosa og flos a(jux; læs: Polycystis flos acjux.

- Soroso 5. - f. n.: Diaptomus gracilis; Ires: Diaptomus graciloides.

- Haldso 21. - f. o.: Sphærocystris; Iæs: Sphærocystis.

31. - f. n.: Castrada radicata; Ias: Castrada radiata.

— Slianderborgsø: $1900^{23 / 12}$; las: $1900^{29} / 12$.

- Mossø 34. Linie f. n.: Castrada radicala; las: Castrada radiata. 

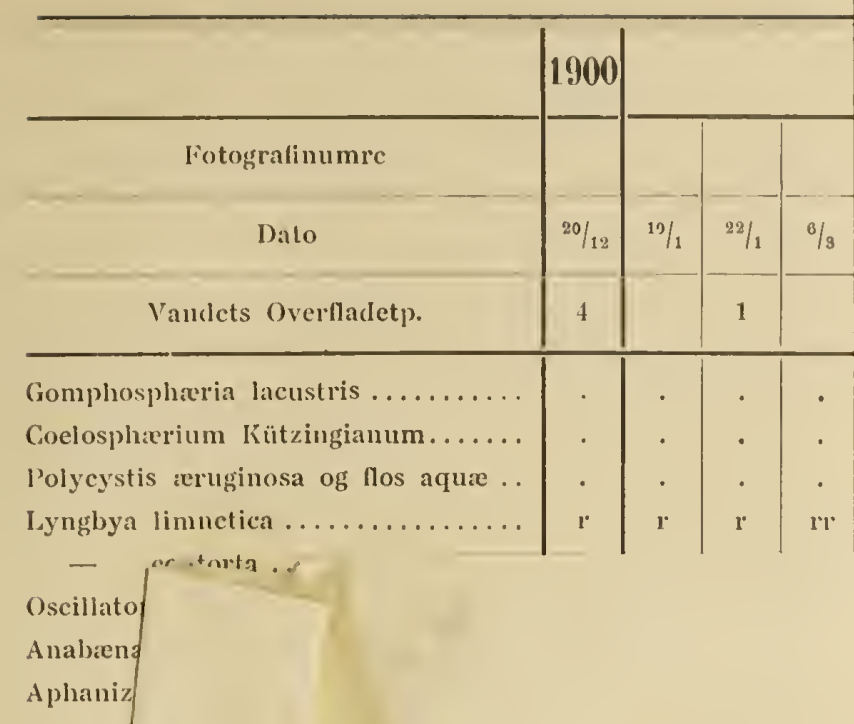

Aphaniz

Melosiro

Stephar

e.to $x x^{2}$

Atthey.d47.

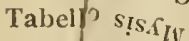

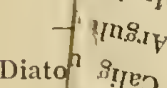

Diato "Ire

fde

Syne

Aste

Cyn ${ }^{2} \mathrm{~S}_{0}$

dat

Sul $\tilde{i}_{y}$

$\rightarrow 0$

$\mathrm{Te}_{H}$

$\mathrm{E}_{\alpha}$

$\mathrm{o}_{S}$

s 



\section{S O R ØS Ø.}

\begin{tabular}{|c|c|c|c|c|c|c|c|c|c|c|c|c|c|c|c|c|}
\hline \multirow[b]{2}{*}{ lotografinumre } & \multirow[t]{2}{*}{1900} & \multicolumn{7}{|c|}{1901} & \multicolumn{8}{|c|}{1902} \\
\hline & & & 37 & 38 & 39 & 40 & 41 & & & 42 & 43 & 44 & 45 & 46 & 47 & 48 \\
\hline Dato & $10 / 13$ & $5 / 6$ & $26 / 5$ & $8 / 7$ & $9 / 8$ & $18 / 0$ & $17 / 10$ & $18 / 11$ & $8 / 1$ & ${ }^{60} / 1$ & $24 / 8$ & $19 / 4$ & $16 / 6$ & $7 \%$ & $28 / 6$ & $27 / 7$ \\
\hline Vandets Overfladetp. & 5 & 10 & 13 & 21 & 23 & 12 & 12 & 7 & 2 & 1 & 1 & 4 & 7 & 15 & 17 & 16 \\
\hline Merismopedium elegans ............. & . & . & . & . & $1 \%$ & $\mathrm{rr}$ & . & . & . & . & . & . & . & - & - & . \\
\hline Croococcus limneticus.............. & . & . & . & . & . & . & . & . & . & . & . & . & r. & $\mathbf{r}$ & r & . \\
\hline Gomplosphlacria lacustris............ & . & $\mathrm{rr}$ & $r$ & . & . & . & . & $\mathrm{r}$ & . & $\mathrm{r} \mathbf{r}$ & $\mathrm{rr}$ & $r \mathbf{r}$ & . & rr & rr & Ir $\mathbf{r}$ \\
\hline Polycystis ceruginosa og flos aquæ..... & . & $\mathrm{rr}$ & 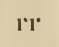 & + & c & + & + & $r$ & $1 \mathrm{r}$ & $\mathrm{rr}$ & $\mathrm{rr}$ & r. & r & + & + & c \\
\hline Lyngbya limnetica................. & $\mathrm{rr}$ & $\mathrm{r}$ & . & . & . & $\mathbf{r}$ & $\mathrm{rr}$ & $\mathrm{rr}$ & - & . & . & . & . & . & . & . \\
\hline 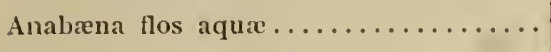 & . & . & $\mathbf{r l}$ & + & 1 & $\mathrm{r}$ & . & . & . & . & . & . & . & $\mathrm{r}$ & c & $r$ \\
\hline$-\quad$ variaus...$\ldots \ldots \ldots \ldots \ldots$ & $\mathrm{rr}$ & $\mathbf{r}$ & . & - & . & rr & . & $\mathrm{rr}$ & $\mathrm{rr}$ & $\mathrm{rr}$ & - & . & . & . & . & . \\
\hline - nranaria & $\mathbf{r r}$ & $r r$ & & & & $r r$ & & $m$ & & 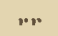 & & & & & & \\
\hline
\end{tabular}


SOROSO

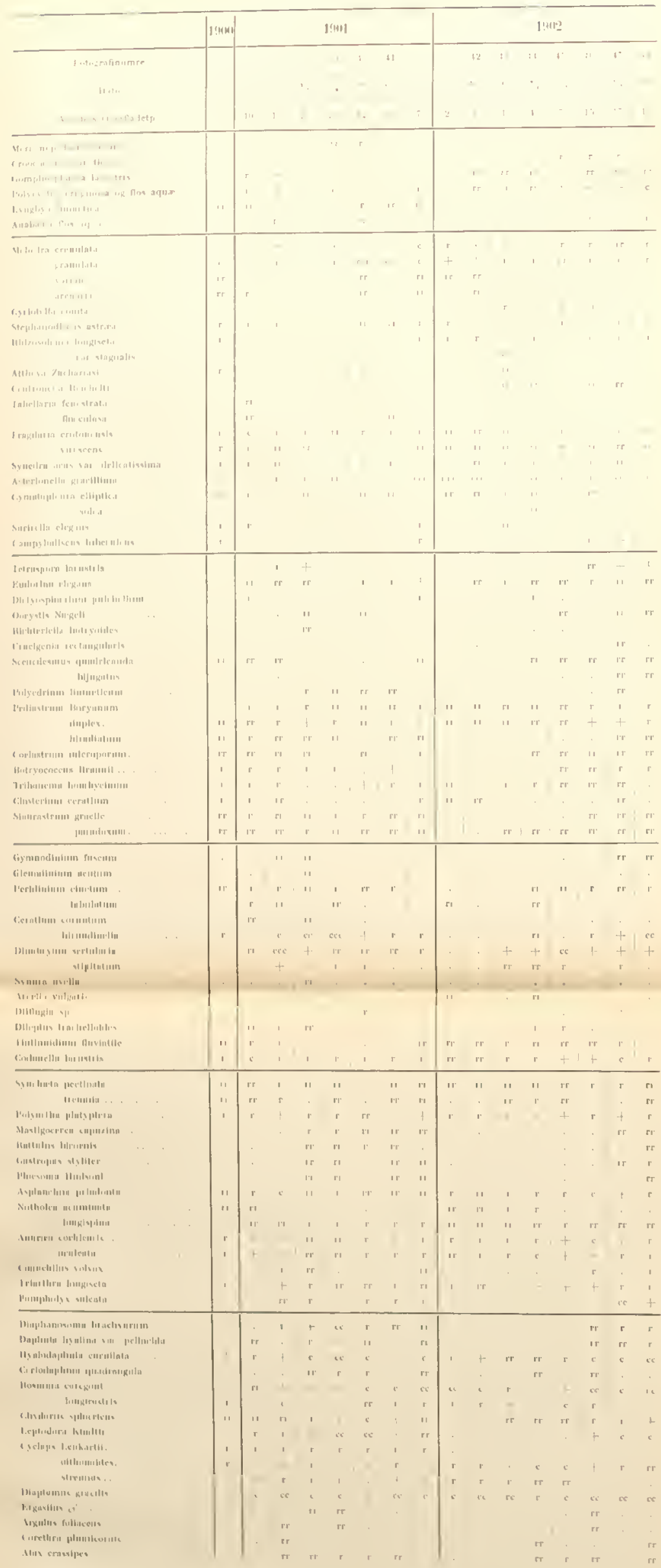


ES

\begin{tabular}{|c|c|c|c|c|c|c|}
\hline \multirow[b]{2}{*}{ lotogrationumu } & \multicolumn{6}{|l|}{1900} \\
\hline & & & & & 25 & 26 \\
\hline Dito & $17 / 12$ & $10 /$ & $3 / 6$ & $26 / 8$ & $20 \%$ & $20 / 7$ \\
\hline Vandets Overlladetp. & 5 & 3 & 8 & 13 & 15 & 17 \\
\hline Merismopedium elegans .......... & . & - & . & - & $\mathrm{rr}$ & . \\
\hline Crooeoceus minutus................ & . & - & . & . & $1 \%$ & $r$ \\
\hline Gomphosphieria lieustris............ & . & $\mathbf{r}$ & $\mathbf{r}$ & - & r & - \\
\hline Coelosphierium Kützingianum ....... & $\mathrm{rl}^{\prime}$ & - & r' & - & $r^{*}$ & $\mathbf{r}$ \\
\hline Polycystis aruginosa og flos aquic .... & ry & $\mathbf{r}$ & $r$ & $\mathrm{rr}$ & $\mathbf{r}$ & + \\
\hline Lyngbya limnetica ................ & - & - & - & - & . & . \\
\hline
\end{tabular}




\section{TJUSTRUPSØ.}

\begin{tabular}{|c|c|c|c|c|c|c|c|c|c|c|c|c|c|c|c|c|}
\hline \multirow[b]{2}{*}{ lolografinummer } & \multirow[t]{2}{*}{1900} & \multicolumn{8}{|c|}{1901} & \multicolumn{7}{|c|}{$190 \%$} \\
\hline & & & & 49 & 50 & 51 & 52 & 5.3 & & 54 & 55 & 56 & 57 & 58 & 59 & (60) \\
\hline 1):ito & $111 / 12$ & $3 / 3$ & $24 / 3$ & $3 / 7$ & $8 / 8$ & $17 / 9$ & $10 / 10$ & $18 / 11$ & $28 / 12$ & $27 / 1$ & $23 / 3$ & $18 / 4$ & $16 / 5$ & $7 / s$ & $30 / 6$ & $27 / 7$ \\
\hline V'auclets Overflaletp. & 3 & 7 & 13 & 17 & 22 & 12 & 1.3 & 7 & 3 & 1 & 1 & 4 & 8 & 12 & 15 & 15 \\
\hline Gomphosplnaria lacustris $\ldots \ldots \ldots \ldots \ldots$ & . & . & $\cdot$ & $\mathrm{rr}$ & $\mathrm{rr}$ & $\mathrm{rr}$ & . & $\mathrm{rr}$ & $\mathrm{rr}$ & $\mathrm{rr}$ & . & . & . & . & . & . \\
\hline Coclospherium ľützingrianum ......... & $r$ & . & $\mathrm{rr}$ & $r$ & $\mathbf{r}$ & $\mathrm{r}$ & + & + & $\mathrm{rr}$ & $\mathrm{r}$ & . & $\mathrm{rr}$ & $\mathrm{r}$ & + & $\mathbf{r}$ & + \\
\hline Polycystis aruginosa of flos acquae .... & $r$ & $\mathrm{rr}$ & $\mathrm{rr}$ & + & + & + & + & $r$ & $\mathrm{rr}$ & $\mathbf{r}$ & $r$ & $\mathrm{rr}$ & $\mathrm{rr}$ & $\mathbf{r}$ & r & $\mathrm{rr}$ \\
\hline Lyngloya limnetica................ & $\mathrm{r}$ & . & . & . & . & $\mathrm{rr}$ & $\mathrm{rr}$ & + & $r$ & $\mathrm{rr}$ & . & - & . & . & . & . \\
\hline Oscillatoria rubescens ......... & $\mathrm{rr}$ & $\mathrm{rr}$ & $\mathrm{rr}$ & $\cdot$ & . & . & $\cdot$ & . & r & $r$ & r & $\mathbf{r}$ & r & + & $\mathbf{r}$ & $\mathbf{r}$ \\
\hline Anabiena flos aquie $\ldots \ldots \ldots \ldots \ldots \ldots$ & $\mathrm{rr}$ & · & $\mathrm{rr}$ & r & r & $\mathbf{r r}$ & . & $\mathrm{rr}$ & . & . & . & . & . & $\mathbf{r}$ & $\mathbf{r}$ & $\mathrm{rr}$ \\
\hline Aphanizomenon flos aqua........... & . & . & $\cdot$ & . & . & $\mathrm{rr}$ & . & $\cdot$ & . & . & . & . & . & . & . & . \\
\hline Melosira crenulata $\ldots \ldots \ldots \ldots \ldots \ldots$; & + & $\mathbf{r}$ & $\mathrm{r} r \mathrm{r}$ & $\mathrm{rr}$ & . & $\mathrm{r}$ & + & + & + & c & c & + & $\mathrm{r}$ & $\mathrm{rr}$ & c & + \\
\hline 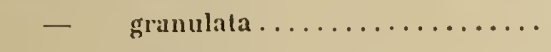 & c & $\mathbf{r}$ & $\mathrm{rr}$ & + & $\mathrm{rr}$ & c & $\operatorname{cec}$ & $\operatorname{cec}$ & c & $\mathbf{c}$ & $\mathrm{r}$ & $\mathrm{rr}$ & $\mathbf{r}$ & $\mathrm{rr}$ & + & $\mathrm{r}$ \\
\hline - varians............... & $\mathbf{r}$ & $\mathrm{rr}$ & . & $\mathrm{rr}$ & . & . & $\mathrm{r} \cdot \mathrm{r}$ & . & . & $\mathrm{rr}$ & . & . & $\mathrm{rr}$ & . & $\mathrm{rr}$ & . \\
\hline - arenaria $\ldots \ldots \ldots \ldots$ & $\mathrm{r}$ & . & $\mathrm{rr}$ & · & $\mathrm{rr}$ & . & $\cdot$ & . & $\mathrm{rr}$ & $\cdot$ & . & $\mathrm{rr}$ & . & . & $\cdot$ & . \\
\hline 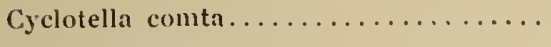 & $\cdot$ & $\cdot$ & $\mathrm{r}$ & $\mathbf{r}$ & $\cdot$ & . & . & . & . & $\mathrm{rr}$ & . & $r$ & + & $\mathrm{r}$ & . & . \\
\hline Stephanodiscus astraea........ & + & + & $\mathbf{r r}$ & . & . & r & $\mathrm{rr}$ & $\mathrm{r}$ & $r$ & $\mathbf{r}$ & $r$ & + & + & + & $\mathrm{r}$ & $\mathrm{r}$ \\
\hline
\end{tabular}


T.J STliepso.

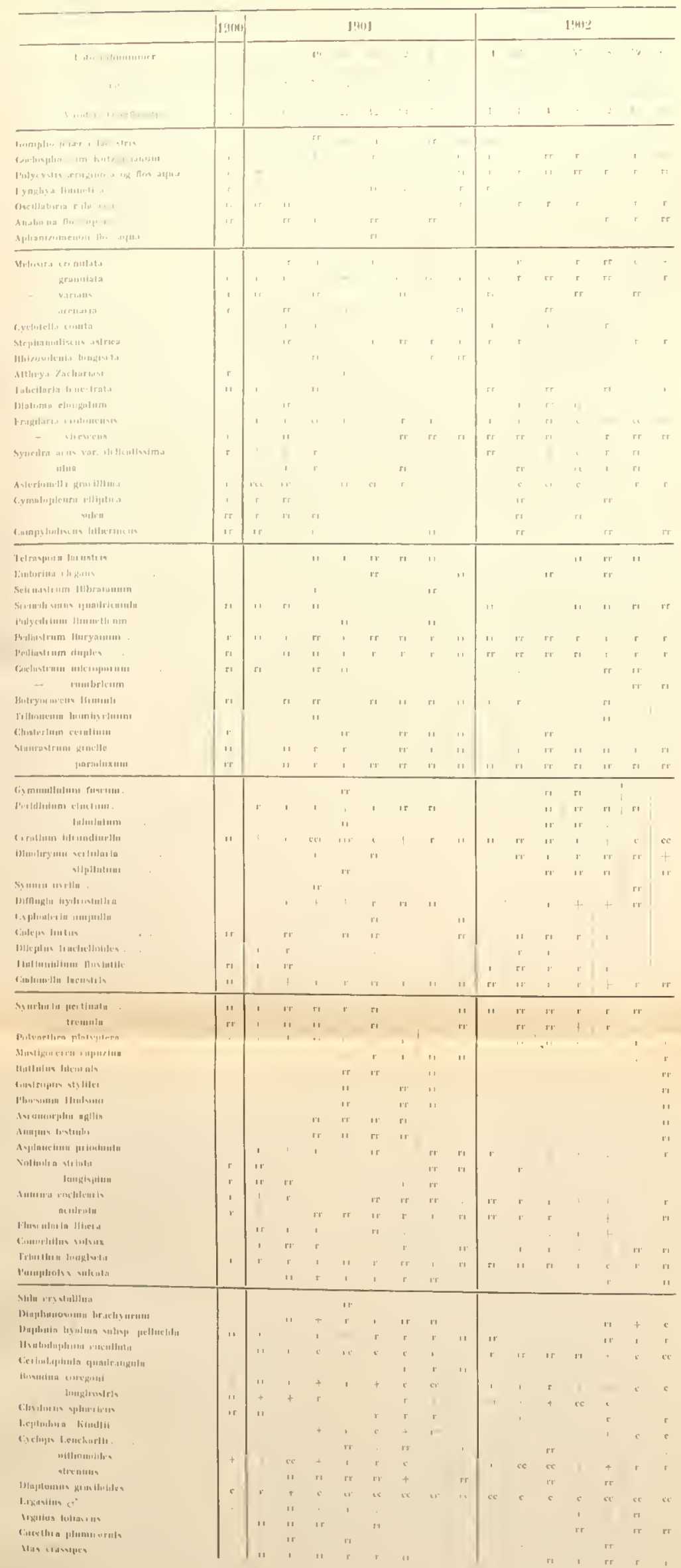




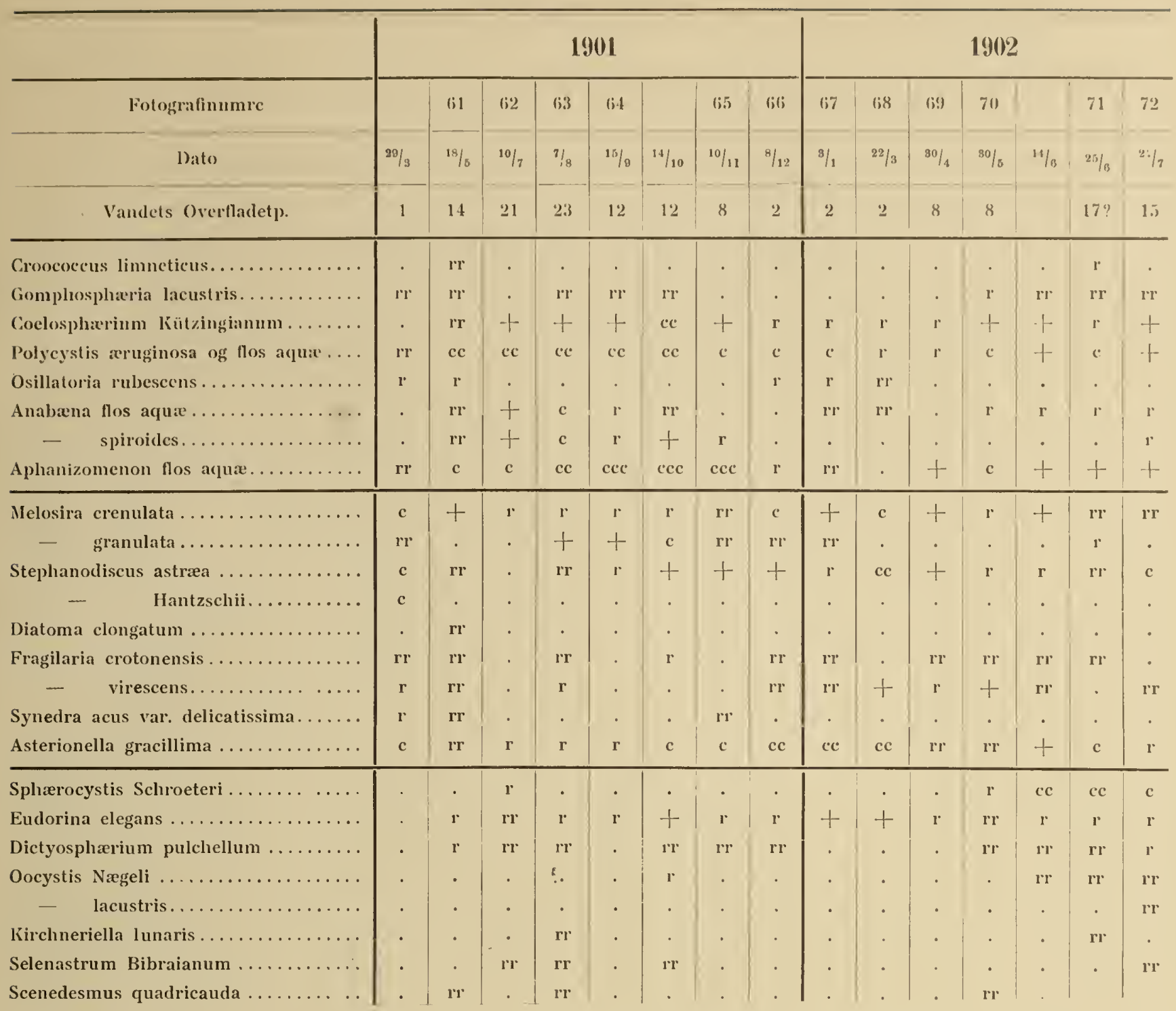


I I BOROASO

\begin{tabular}{|c|c|c|c|c|c|c|c|c|c|c|c|c|c|c|c|}
\hline & \multicolumn{8}{|c|}{1901} & \multicolumn{7}{|c|}{ IEMI2 } \\
\hline Foters'aflumme & & iil & li2 & & (i.) & & (45) & liti & & & & 711 & & & \\
\hline D:110 & & & & & & $14 / 10$ & & & $"$ & & $89 /$, & $80 / \%$ & $11 \%$ & $2 \%$ & \\
\hline Vindets (heldhrdelp. & 1 & 11 & 21 & 23 & $1: 2$ & 12 & s & 2 & 2 & $"$ & K & 8 & & $17 "$ & $1 . i$ \\
\hline 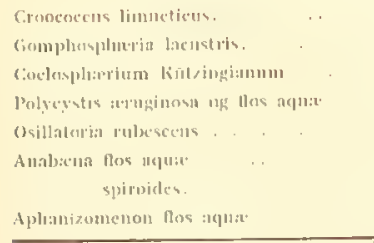 & $\begin{array}{l}m \\
n \\
n \\
n \\
n\end{array}$ & 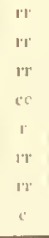 & $\begin{array}{l}1 \\
a \\
\vdots \\
+ \\
+ \\
c\end{array}$ & $\begin{array}{c}\text { it } \\
1 \\
a c \\
c \\
c \\
c c\end{array}$ & 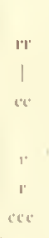 & $\begin{array}{l}\mathrm{r} \\
\mathrm{rc} \\
\mathrm{ec} \\
\mathrm{m} \\
+ \\
\mathrm{ecc}\end{array}$ & $\begin{array}{c}+ \\
r \\
\vdots \\
\text { r } \\
\mathrm{cor}\end{array}$ & $\begin{array}{l}\cdot \\
\dot{1} \\
\text { ' }\end{array}$ & $\begin{array}{l}r \\
r \\
r \\
r \\
r\end{array}$ & $\begin{array}{l}r \\
r \\
r \\
r \\
r\end{array}$ & $\begin{array}{l}\text { r } \\
\mathbf{r} \\
.\end{array}$ & $\begin{array}{l}r \\
1 \\
c \\
\dot{r} \\
c\end{array}$ & $\begin{array}{l}\text { IT } \\
1 \\
1 \\
\dot{1} \\
\dot{H} \\
\dot{H}\end{array}$ & 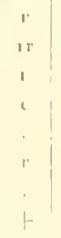 & $\begin{array}{l}. \\
\text { iT } \\
1 \\
1 \\
1 \\
r \\
1\end{array}$ \\
\hline 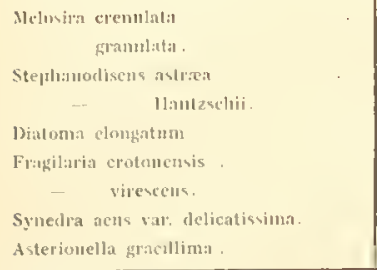 & $\begin{array}{l}c \\
\mathrm{r} \\
c \\
c\end{array}$ & $\begin{array}{l}+ \\
+ \\
r \\
r r \\
r r \\
r r \\
r r \\
r r\end{array}$ & $\begin{array}{l}\text { r } \\
\cdot \\
\cdot \\
\cdot\end{array}$ & $\begin{array}{l}r \\
+ \\
r\end{array}$ & 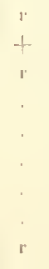 & $\begin{array}{l}1 \\
e \\
+ \\
\dot{r}\end{array}$ & $\begin{array}{l}\cdots \\
+ \\
+ \\
\cdots \\
\cdots \\
\cdots\end{array}$ & $\begin{array}{l}\mathrm{rr} \\
\mathbf{r r} \\
\text { ex }\end{array}$ & 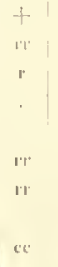 & + & $\begin{array}{l}\mathrm{rr} \\
\mathrm{r} \\
\mathrm{r}\end{array}$ & $\begin{array}{l}\text { r } \\
\text { r } \\
\text { ir } \\
+ \\
\text { ir }\end{array}$ & $\begin{array}{l}+ \\
\mathbf{r} \\
\mathrm{r} \\
\mathrm{r} \\
+\end{array}$ & $\begin{array}{l}\mathrm{Ir} \\
\mathrm{r} \\
\mathrm{r}\end{array}$ & 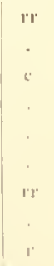 \\
\hline 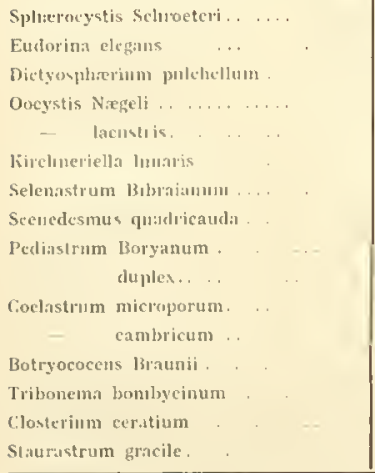 & $r$ & $\begin{array}{l}. \\
\mathrm{m} \\
+ \\
\mathrm{rr} \\
\mathrm{rr} \\
\mathrm{ir} \\
\dot{\mathrm{r}} \\
\mathrm{i}\end{array}$ & $\begin{array}{l}\text { ri } \\
\dot{r} \\
r \\
r \\
r \\
r \\
r \\
r\end{array}$ & $\begin{array}{l}\mathrm{r} \\
\mathrm{Wr} \\
\mathrm{ir} \\
\mathrm{ri} \\
\mathrm{rr} \\
\mathrm{rr} \\
+ \\
+ \\
+ \\
\mathrm{r} \\
\mathrm{rr} \\
\mathrm{rr} \\
\mathrm{r}\end{array}$ & $\begin{array}{l}r \\
. \\
. \\
. \\
\text { i. } \\
1 \\
1 \\
\text {. } \\
. \\
+ \\
+\end{array}$ & 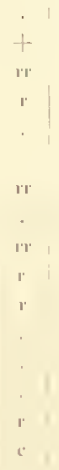 & $\begin{array}{l}W \\
+ \\
+\end{array}$ & $\begin{array}{l}\mathrm{lr} \\
\mathrm{rr} \\
\mathrm{r} \\
\dot{1} \\
\dot{5} \\
+\end{array}$ & . & 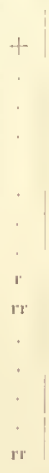 & 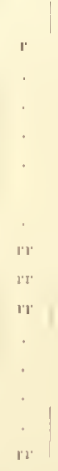 & 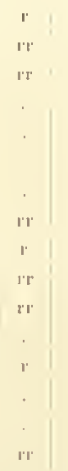 & $\begin{array}{c}\mathrm{cc} \\
\mathrm{r} \\
\mathrm{w} \\
\mathrm{m} \\
\cdot \\
\dot{b} \\
+ \\
\mathrm{r} \\
\mathrm{r} \\
\mathrm{m} \\
+ \\
\cdot \\
\mathrm{rr}\end{array}$ & $\begin{array}{l}\mathrm{er} \\
\mathrm{r} \\
\mathrm{rr} \\
\mathrm{rr} \\
\mathrm{rr} \\
\mathrm{r} \\
\mathrm{r} \\
\mathrm{r} \\
\mathrm{rr} \\
\mathrm{r} \\
. \\
\mathrm{r}\end{array}$ & 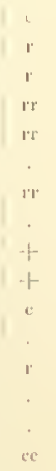 \\
\hline 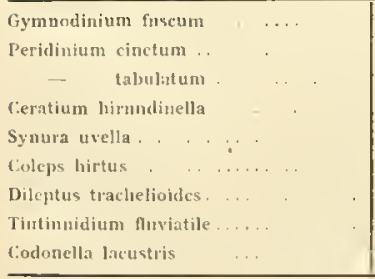 & ' & $\begin{array}{l}\mathrm{rr} \\
+ \\
\mathrm{rr} \\
\mathrm{r}\end{array}$ & $\begin{array}{l}\mathrm{Wr} \\
\mathrm{Ir} \\
\mathrm{r} \\
\mathrm{r} \\
\mathrm{Wr} \\
\mathrm{W} \\
\mathrm{rr}\end{array}$ & + & $\begin{array}{l}\mathrm{m} \\
+ \\
+ \\
\mathrm{m} \\
\dot{\cdot} \\
\dot{\cdot}\end{array}$ & r & r & . & : & 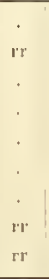 & $\begin{array}{l}\mathrm{Hr} \\
\cdot \\
\mathrm{r} \\
\mathrm{r} \mathrm{r} \\
\mathrm{H} \mathrm{r}\end{array}$ & $\begin{array}{l}\mathrm{rr} \\
. \\
. \\
\text {. } \\
\mathrm{r} \\
\mathrm{r} \\
\mathrm{r}\end{array}$ & 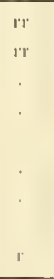 & $\begin{array}{l}r \\
\cdot \\
\cdot \\
\cdot \\
\text { ' }\end{array}$ & 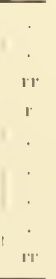 \\
\hline 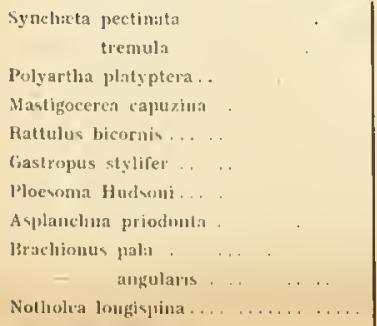 & 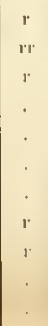 & $\begin{array}{l} \\
\mathrm{w} \\
+ \\
\mathrm{r}\end{array}$ & $\begin{array}{l}\mathrm{m} \\
\cdot \\
\mathrm{y} \\
\cdot \\
\mathrm{rr} \\
\mathrm{r} \\
+ \\
+ \\
\mathrm{r} \\
\mathrm{r}\end{array}$ & 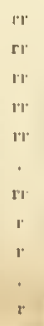 & 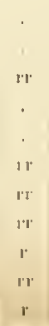 & $\begin{array}{l}\dot{r} \\
+ \\
\dot{r}\end{array}$ & $\begin{array}{c}n \\
\mathrm{rr} \\
\mathrm{r} \\
\cdot \\
\cdot \\
\mathrm{rr} \\
\mathrm{rr} \\
\mathrm{r} \\
\mathrm{r}\end{array}$ & $\begin{array}{l}1 \\
11 \\
11\end{array}$ & $\begin{array}{l}\mathrm{rr} \\
\mathrm{r} \\
\mathrm{r} \\
\cdot \\
\cdot\end{array}$ & $\begin{array}{l}r \\
+ \\
r \\
\cdot \\
\\
\text { n } \\
\cdot \\
0\end{array}$ & + & 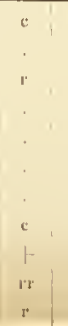 & 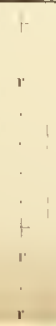 & $\begin{array}{l} \\
\dot{i} \\
\dot{r} \\
\dot{r} \\
\dot{r} \\
\dot{r}\end{array}$ & $\begin{array}{l}r \\
r \\
r \\
r \\
r r \\
r \\
r \\
r \\
r\end{array}$ \\
\hline 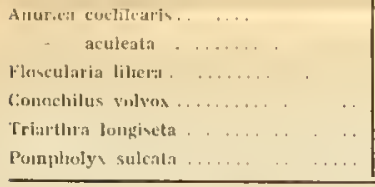 & $\begin{array}{l}\text { I' } \\
1 \\
\text { ' } \\
\text { ' }\end{array}$ & $\begin{array}{l}\dot{i-} \\
\dot{1} \\
\dot{5}\end{array}$ & $\begin{array}{l}12 \\
1 \\
1 \\
1 \\
\end{array}$ & $\begin{array}{l}\mathrm{I} \\
\mathrm{rr} \\
\mathrm{rr} \\
\mathrm{rr} \\
\mathrm{mr} \\
\mathrm{rr}\end{array}$ & $\begin{array}{c}11 \\
y \\
i \\
i\end{array}$ & $\begin{array}{l}\mathrm{r} \\
\mathrm{r} \\
\mathrm{rr} \\
\mathrm{rr} \\
\mathrm{rr}\end{array}$ & "Ir & $\begin{array}{c}1 \% \\
\mathrm{r} \\
\mathrm{r} \\
\mathrm{H}\end{array}$ & $\begin{array}{l}\mathrm{r} \\
\mathrm{r} \\
\dot{\mathrm{r}} \\
\dot{\mathrm{r}}\end{array}$ & $\begin{array}{c}\text { r } \\
\dot{\mathrm{ri}} \\
\mathrm{r} \\
\mathrm{r}\end{array}$ & $\begin{array}{l}1 \\
+ \\
. \\
r \\
r\end{array}$ & $\begin{array}{l}c \\
. \\
+ \\
+ \\
+\end{array}$ & $\begin{array}{l}1 \\
+ \\
1 \\
1\end{array}$ & t & $\begin{array}{l}r \\
1 \\
+1 \\
r \\
+\end{array}$ \\
\hline 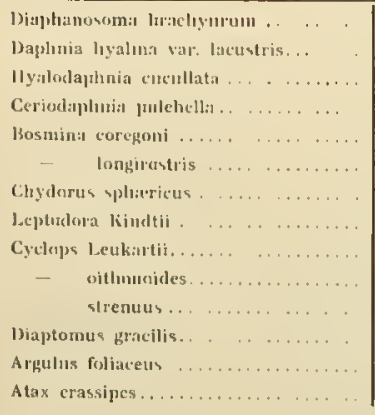 & $\begin{array}{l}\cdot \\
n \\
n \\
r\end{array}$ & $\begin{array}{l}\mathrm{rr} \\
\mathrm{m} \\
\mathrm{rr} \\
\mathrm{r} \\
\mathrm{c} \\
\mathrm{r} \\
\dot{2} \\
\mathrm{t} \\
\mathrm{r} \\
+ \\
\mathrm{r} \\
\mathrm{rr}\end{array}$ & $\begin{array}{l}+ \\
i \\
c \\
v \\
r \\
\dot{y} \\
+ \\
+ \\
r \\
+ \\
+ \\
c \\
. \\
r\end{array}$ & 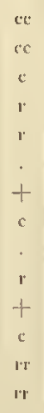 & $\begin{array}{l}1 \\
c \\
c \\
r \\
r \\
r \\
c \\
+ \\
\text { Ir } \\
\text { r } \\
c \\
c \\
\mathrm{n} \\
\mathrm{n}\end{array}$ & 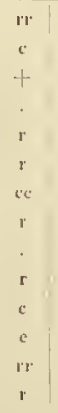 & $\begin{array}{l}\mathrm{r} \\
\mathrm{c} \\
+ \\
\mathrm{r} \\
\mathrm{r} \\
+ \\
\mathrm{r} \\
\mathrm{r} \\
\mathrm{c} \\
\mathrm{c}\end{array}$ & 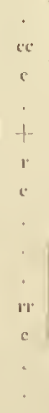 & $\begin{array}{l}\mathbf{r} \\
\mathbf{r} \\
+ \\
.\end{array}$ & $\begin{array}{l}\dot{y} \\
\dot{1} \\
\dot{y} \\
\dot{r} \\
+ \\
\dot{r} \\
\dot{r} \\
\mathrm{r} \\
\mathrm{r} \\
+\end{array}$ & 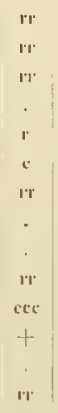 & $\begin{array}{c}\mathrm{r} \\
\mathrm{i} T \\
\mathrm{r} \\
\mathrm{cec} \\
\mathrm{r}\end{array}$ & $\begin{array}{l}\mathrm{r} \\
+ \\
\mathrm{rr} \\
\mathrm{r} \\
\mathrm{r} \\
+ \\
+ \\
\mathrm{rr} \\
\mathrm{r} \\
\mathrm{rr} \\
\mathrm{r} \\
\mathrm{cr} \\
\mathrm{rr} \\
\mathrm{r}\end{array}$ & 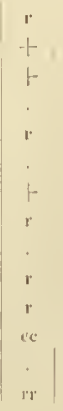 & 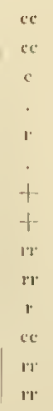 \\
\hline
\end{tabular}




\section{H A L D S $\varnothing$.}

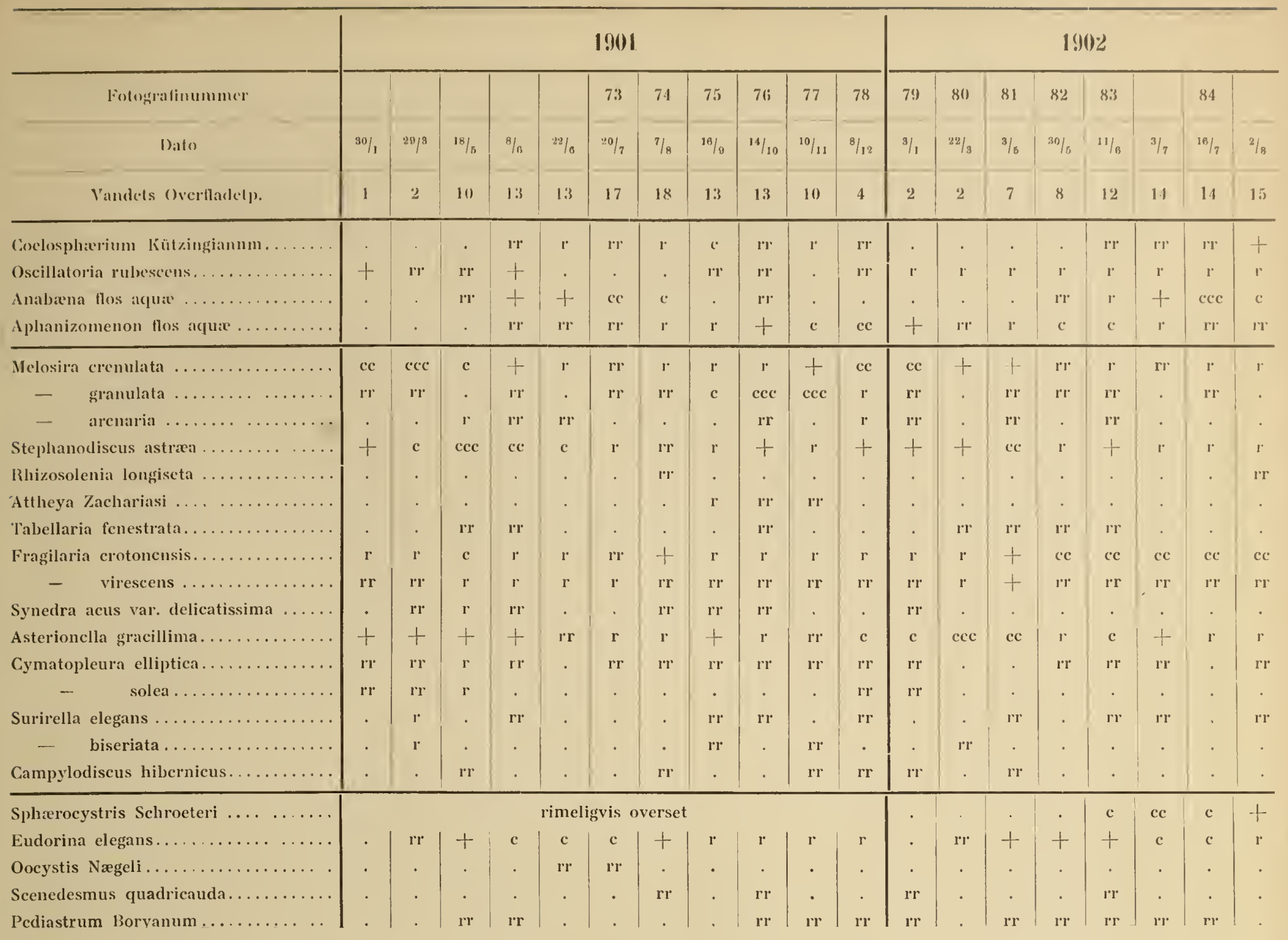




\section{SKANDERBORGS}

\begin{tabular}{|c|c|c|c|c|c|c|c|c|c|c|c|c|c|}
\hline \multirow[b]{2}{*}{ Fotografinumre } & \multirow[t]{2}{*}{$|1900|$} & \multicolumn{5}{|c|}{1901} & \multicolumn{7}{|c|}{$190^{\circ}$} \\
\hline & & 85 & 86 & 87 & 88 & 89 & 90 & !1 & 92 & 93 & 94 & 9.5 & 96 \\
\hline Dato & $29 / 12$ & $19 / 5$ & $8 / 8$ & $18 \%$ & $18 / 10$ & $20 / 11$ & $3 / 1$ & $27 / 1$ & $1 / 4$ & $1 / 5$ & $8 / 6$ & ${ }^{29} / 6$ & $80 / 7$ \\
\hline Vandets Overlladetp. & 5 & 13 & 21 & 12 & 12 & 6 & 1 & 1 & 2 & 7 & 15 & 18 ? & 14 \\
\hline 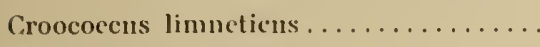 & r & r. & + & + & $\mathbf{r}$ & + & r & $r$ & r & $\mathrm{rr}$ & $\mathrm{rr}$ & $\mathrm{r}$ & $\mathrm{r}$ \\
\hline Merismoperlium elegans $\ldots \ldots \ldots \ldots \ldots$ & . & . & . & $\mathrm{r} r$ & . & • & . & . & . & . & . & . & . \\
\hline Coelosph:erinm Kïtzingianum......... & $\mathrm{rr}$ & c & cc & ce & c & c & + & + & $\mathrm{rr}$ & r & $r$ & + & + \\
\hline Polycystis aruginosa og flos aquie..... & rr & + & $\mathbf{c}$ & $r$ & $r$ & $r$ & 1 & $r$ & . & $\mathrm{rr}$ & $\mathrm{rr}$ & + & $\mathbf{r}$ \\
\hline Lyngbya limnetica; til Dels L. lacustris & $\mathrm{rr}$ & + & + & c & ce & c & c & + & $r$ & r. & + & $\mathrm{r}$ & $\mathbf{r}$ \\
\hline 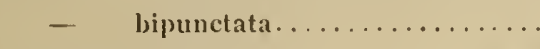 & $\cdot$ & . & $r$ & . & $r$ & $\mathrm{rr}$ & . & + & ce & $\mathrm{ec}$ & cc & c & + \\
\hline Uscillatoria rubescens .......... & + & c & + & + & + & + & c & $\mathrm{ec}$ & c & + & $r$ & $r$ & $r$ \\
\hline Anabrena tlos aquæ $\ldots . \ldots \ldots \ldots \ldots . . .$. & . & . & $\mathbf{r}$ & . & . & . & . & . & . & . & $\mathrm{r}$ & $r$ & . \\
\hline$\rightarrow \quad$ spiroides $\ldots \ldots \ldots \ldots \ldots$ & . & r & . & $\mathrm{rr}$ & . & . & . & . & . & $r$ & . & . & . \\
\hline Aphanizomenon flos aquie $\ldots \ldots \ldots \ldots$ & . & . & . & . & $\mathrm{rr}$ & $\mathrm{rr}$ & . & . & . & . & . & . & . \\
\hline
\end{tabular}


SkIND)

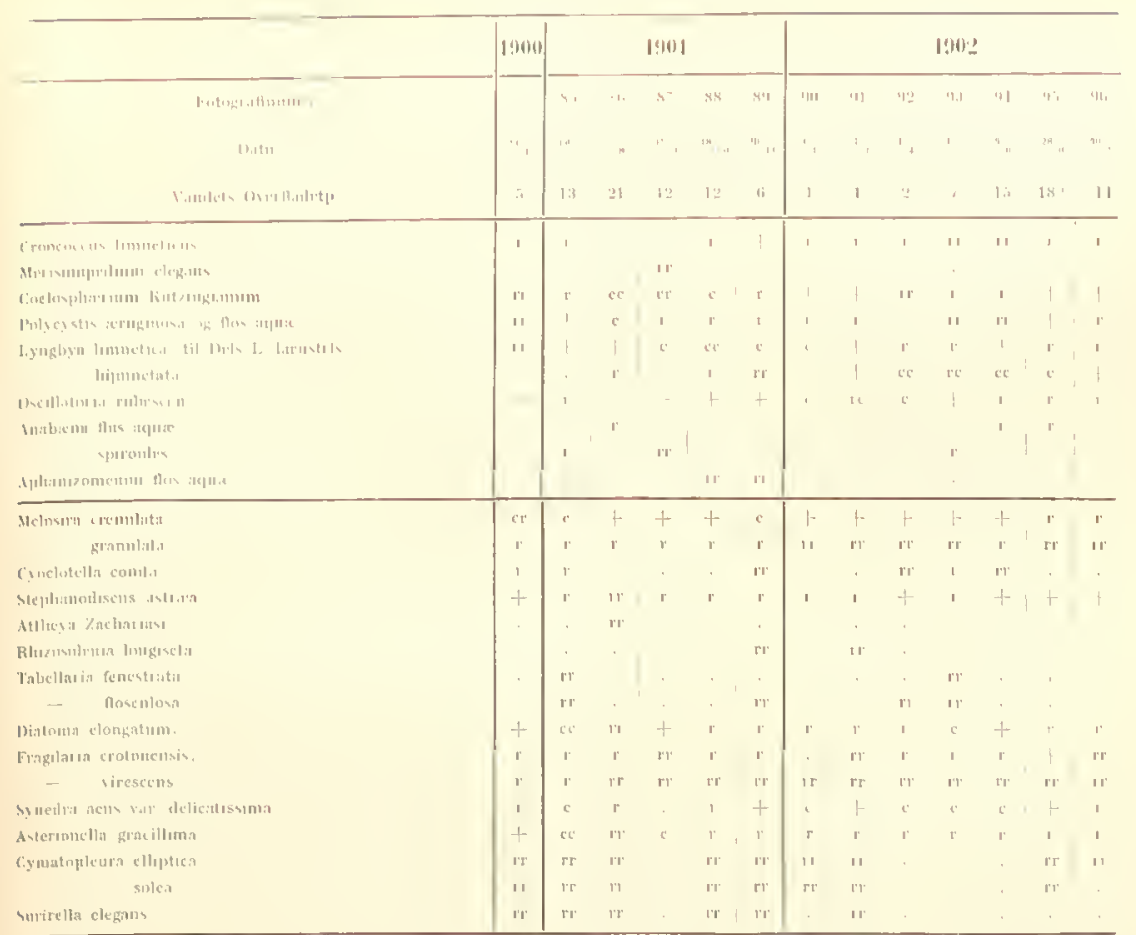

\section{lintorin. clesans}

Dicțysplitietium puleluellmut

Oocystis Nisgeli

- lacustiss

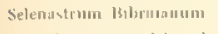

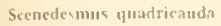
brupsitus

Polsedrium limncticumi

Pediastrultt Boryanmm duptiox simples biradiatumm kimw:tishy

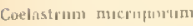
Botryococcllk Br:autuii Tribonen: bomlycinum Clost trium ceritium Closteriopsis longhstm.t Cosmaraus secuertermi staurastrum gracile

\section{Gymnndinium fuschm}

Peridmium cinctum

- tabulatum

Ceratmm hirundinella Dinulryum sertularia - stipitatum.

St nura uvellit.

Civleps hirtur.

Dileptlus tracheletrides

Dileptlus truchelietrdes

Codonellia lacustris

\begin{tabular}{|c|c|c|c|c|c|c|c|c|c|c|c|c|c|}
\hline $\begin{array}{l}\text { Synchiata pectititala } \\
\quad \text { tremula }\end{array}$ & $\begin{array}{r}r \\
r\end{array}$ & r & ir & ; & ir & 11 & $\mathrm{rr}$ & & ri & . & rir & r & $\mathrm{m}$ \\
\hline Polyartltra plitsutera & $\mathbf{r}$ & + & $r$ & -+ & $\mathbf{r}$ & $\mathrm{r}$ & $\mathrm{rr}$ & $\mathrm{rr}$ & $r$ & $r$ & $\mathbf{r}$ & + & $r$ \\
\hline Mastlgocerca capurina. & . & & & $\mathrm{ir}$ & $\mathrm{rr}$ & $\mathrm{rr}$ & & . & . & . & & . & is \\
\hline Rattulus bicor'nis & & & & r $\mathbf{r}$ & $\mathrm{rr}$ & rt & & . & . & & & $\mathrm{rr}$ & or \\
\hline Coelopius tenuior & & & & $\mathrm{rr}$ & $\mathrm{rr}$ & $\pi$ & & . & & & . & $\mathbf{r r}$ & $\mathrm{tr}$ \\
\hline fiastropus stylifer & . & & & $\mathrm{rr}$ & rr & . & & . & . & & . & $\mathrm{rr}$ & $\mathrm{tr}$ \\
\hline Plocsuma Hndsmi & . & & $\mathbf{r}$ & . & n' & $\omega$ & . & . & . & & : & & ir \\
\hline Aspllanchina priblonta & $\mathrm{r}$ & c & r & $\mathrm{r}$ & + & r & & Ir & $\mathrm{rr}$ & $\mathrm{r}$ & t & v & $r$ \\
\hline Hraclionus palu & $\mathrm{r}$ & + & . & . & . & 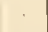 & & . & ' & + & t & r & $\mathrm{r}$ \\
\hline Nutholta strial::. & & rr & & . & . & & & & . & . & $r$ & . & \\
\hline - acuminst & $\mathrm{r}$ & $\mathbf{r r}$ & & ; & $\cdot$ & & & & $\mathrm{rr}$ & ir & & & . \\
\hline Iongispista & & + & c & + & $\mathrm{rr}$ & $\mathrm{rr}$ & & "I & $\mathrm{n}$ & $r$ & 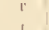 & + & $r$ \\
\hline Anurust cochleiris. & IT & + & $\mathrm{r}$ & $r$ & $r$ & $r$ & . & $\mathbf{r}$ & 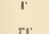 & + & + & ec & c \\
\hline $\begin{array}{l}\text { aculeritiı } \\
\text { _. liypelasıа }\end{array}$ & $\mathrm{rr}$ & r. & $\mathbf{r r}$ & r. & r & r & & $\mathbf{r r}$ & . & ${ }^{r}$ & & + & c \\
\hline Flesculana libelia & & . & $\mathrm{rr}$ & $\mathrm{rr}$ & . & . & & . & . & . & . & . & . \\
\hline Conochutus vis/vix. & & . & $\mathrm{r}$ & $r$ & . & & & & . & $\mathrm{r}$ & . & $r$ & $r$ \\
\hline Triarttra longivela & r. & + & $r$ & $m$ & Ir & $\mathbf{r}$ & ir & $r$ & $\mathrm{r}$ & $\mathrm{r}$ & ' & + & r \\
\hline Punpiloolyx wilcalii & & $\pi$ & c & c & $r$ & $n$ & . & & . & . & . & + & c \\
\hline 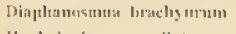 & & $\mathrm{rr}$ & c & + & r. & & . & & & . & 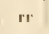 & $r$ & t- \\
\hline Hyolodiphoma cucullita & r. & ir & $\cdots$ & "c & cc & cc & c & Ir & ir & $m$ & . & c & c \\
\hline Ceriuuliaplunia I[uadrangula & & & $3 x$ & ir & $\mathrm{rr}$ & . & & . & & . & . & . & . \\
\hline Bosmuna curegoui & + & $\mathrm{rr}$ & + & $c$ & c & $r$ & + & $r$ & $\mathrm{rr}$ & ir & r & + & t \\
\hline - longlintstris & $\mathrm{r}$ & + & . & r & I & ' & $r$ & r & + & t & wc & $\mathrm{gr}$ & . \\
\hline & ' & + & c & 1 & + & $r$ & $\mathrm{IT}$ & $\mathrm{rr}$ & $\mathrm{rr}$ & $w$ & $n$ & + & $r$ \\
\hline 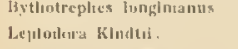 & . & & "si & i & i & $\dot{.}$ & & . & . & & $i$ & $\therefore$ & w \\
\hline Cyclops Leuckartii & i & $\mathrm{rr}$ & $r$ & . & $r$ & in & & $r$ & $i r$ & $\therefore$ & ir & ris & w \\
\hline __ vithunoides & + & + & ce & c & + & $\|$ & 1 & $t$ & + & + & $a$ & $r$ & r \\
\hline utrenuus. & "1 & & & $m$ & Ir & $n$ & $\mathrm{rr}$ & & $\mathrm{n}$ & $\cdots$ & $\mathrm{rr}$ & . & . \\
\hline 1)iaptomus gracilis. & + & + & + & + & + & + & + & c & c & c & + & r & r \\
\hline litginilus of. & & . & $n$ & ' & & & & & & & & $\mathrm{rr}$ & r \\
\hline $\begin{array}{l}\text { Argulu, folinccus } \\
\text { Atax crassipes }\end{array}$ & & $\mathrm{rr}$ & $r$ & ' & $" r$ & & & & . & . & $\mathrm{rr}$ & . & $"$ \\
\hline Atax crassipes & & 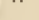 & $r$ & ir & $r$ & . & & & - & & w & ' & $n$ \\
\hline
\end{tabular}


M OS S Ø.

\begin{tabular}{|c|c|c|c|c|c|c|c|c|c|c|c|}
\hline \multirow[b]{2}{*}{ Fotografinumre } & \multirow{2}{*}{$\frac{1900}{97}$} & \multicolumn{6}{|c|}{1901} & & & 02 & \\
\hline & & 98 & 99 & 100 & 101 & $10^{2}$ & 103 & 104 & 105 & 106 & 107 \\
\hline Dato & $28 / 12$ & $8 / 3$ & $20 / 5$ & $1 / 8$ & $20 \%$ & $15 / 10$ & ${ }^{10} / 12$ & $10 \%$ & $3 / 6$ & $28 / 8$ & $30 / 7$ \\
\hline andets Overfladetp. & 4 & 6 & 12 & 22 & 14 & 10 & 5 & 8 & 12 & 16 & 15 \\
\hline
\end{tabular}


J U L S Ø.

\begin{tabular}{|c|c|c|c|c|c|c|c|c|c|c|c|c|c|c|}
\hline \multirow[b]{2}{*}{ Fotografinumre } & \multirow[t]{2}{*}{1900} & \multicolumn{7}{|c|}{1901} & \multicolumn{6}{|c|}{1902} \\
\hline & & 109 & 110 & 111 & 112 & & 113 & 114 & 115 & 116 & 117 & 118 & 119 & 120 \\
\hline Dato & $20 / 13$ & $24 / 4$ & $20 / 5$ & $10 / 7$ & $1 / 8$ & $15 \%$ & ${ }^{15} / 10$ & $20 / 11$ & $15 / 1$ & $3 / 4$ & $5 / 5$ & $2 / 8$ & ${ }^{80} \%_{\circ}$ & ${ }^{31} / 7$ \\
\hline
\end{tabular}


. 
6. 9 E

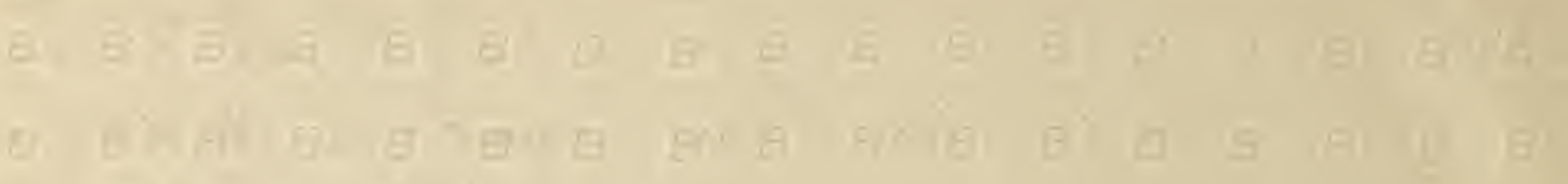

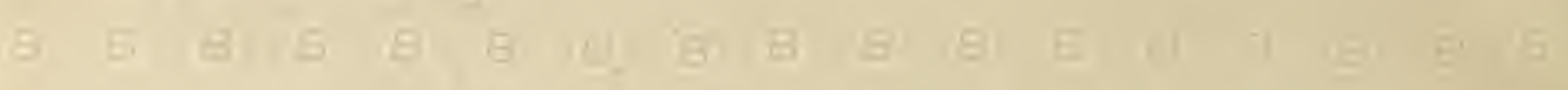
目

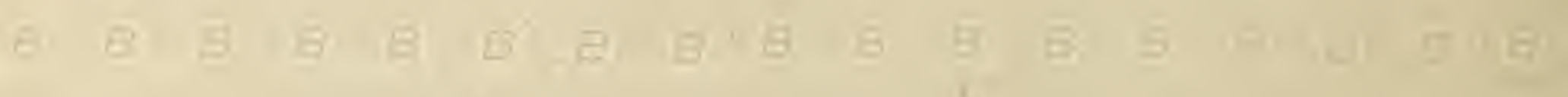
(9)

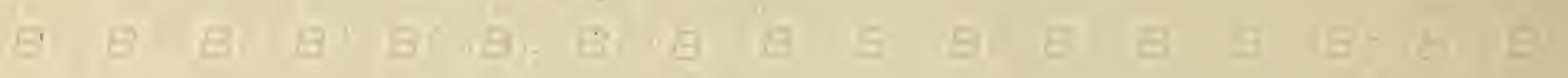

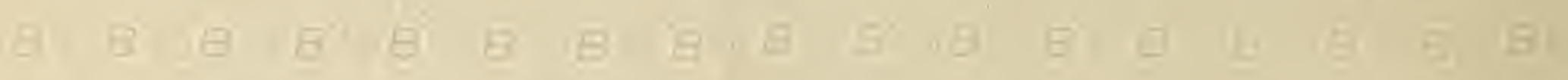

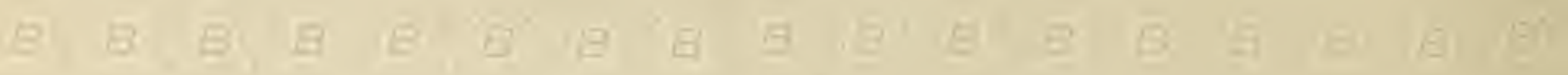

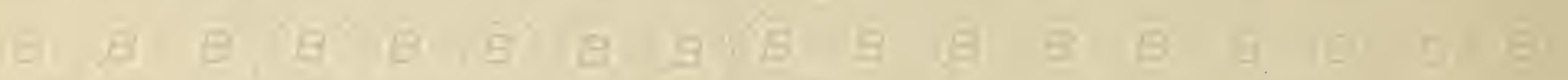

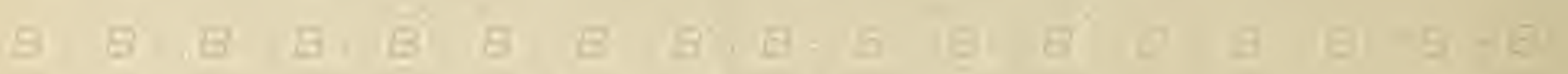

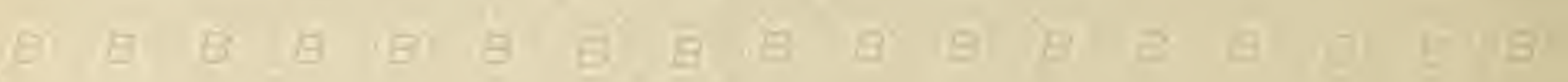

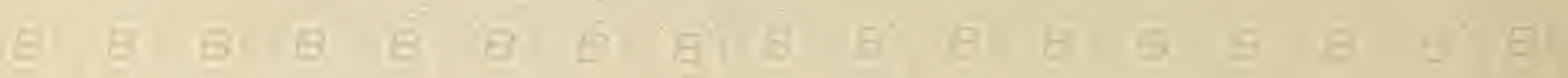

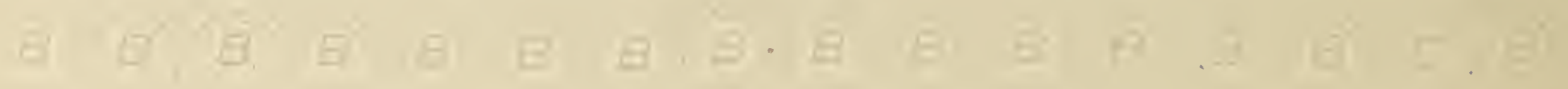

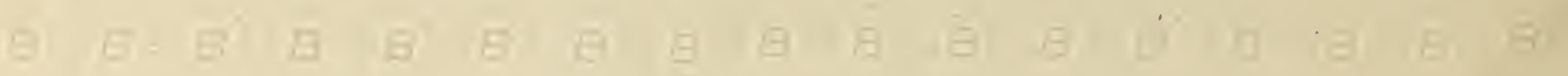

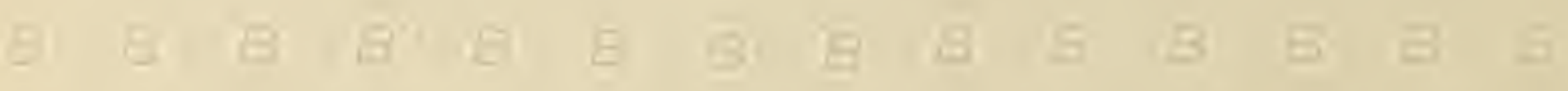
E.

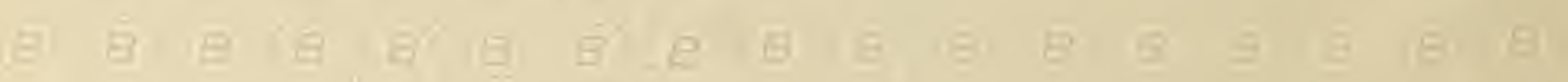
ㅂ.

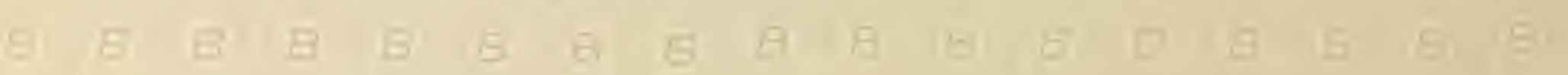

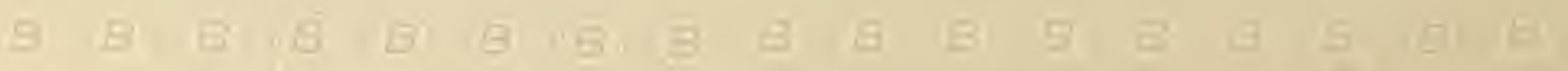




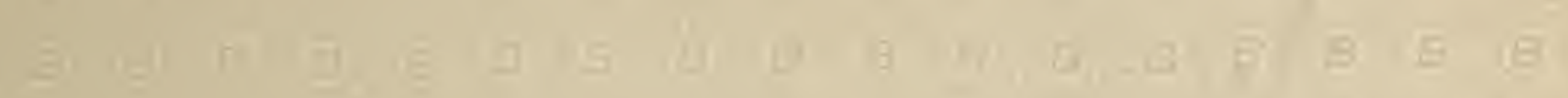
1日)

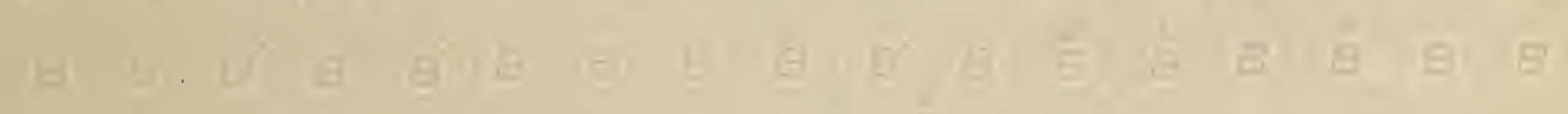

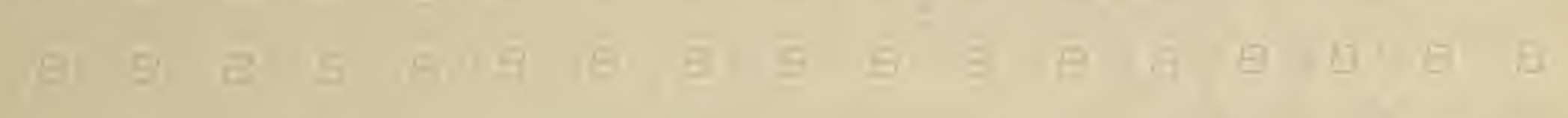

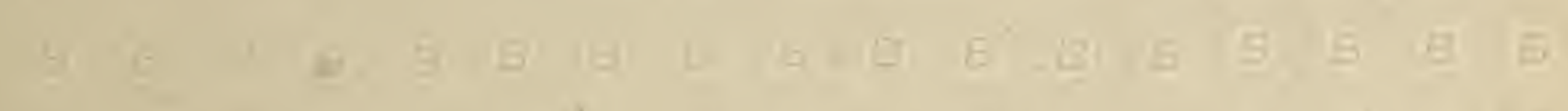

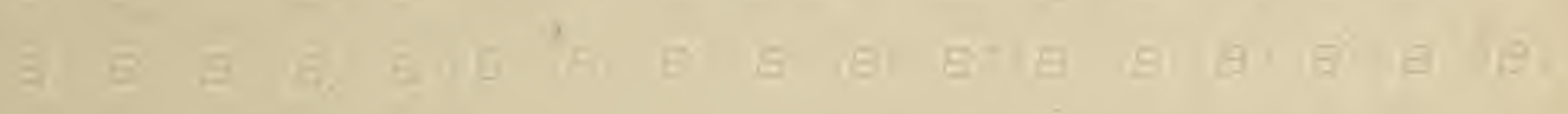

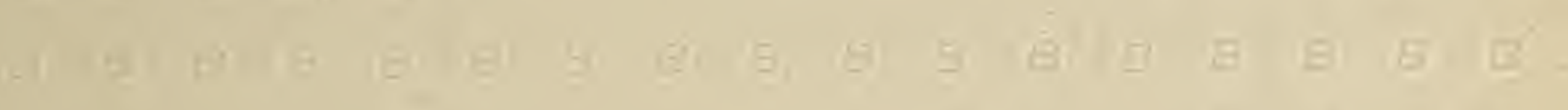

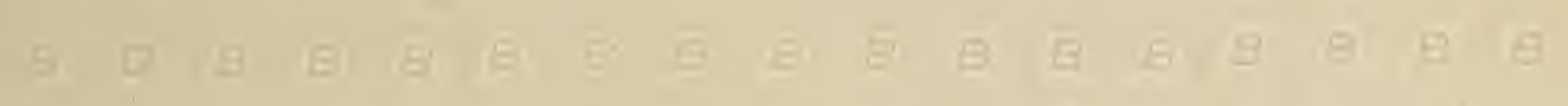
E

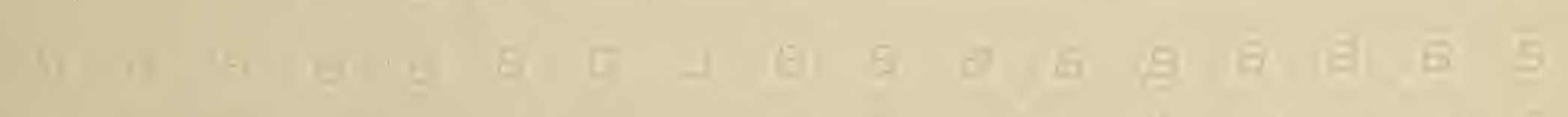

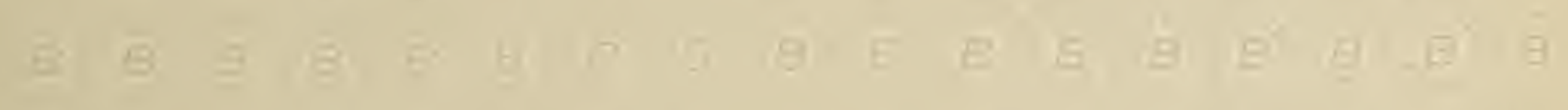

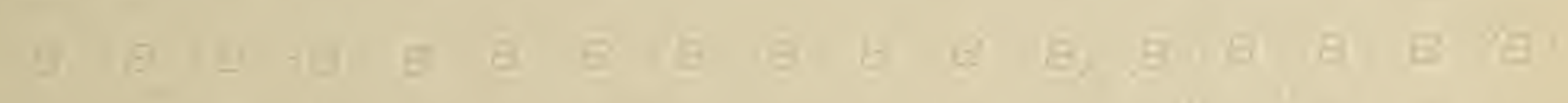
E.

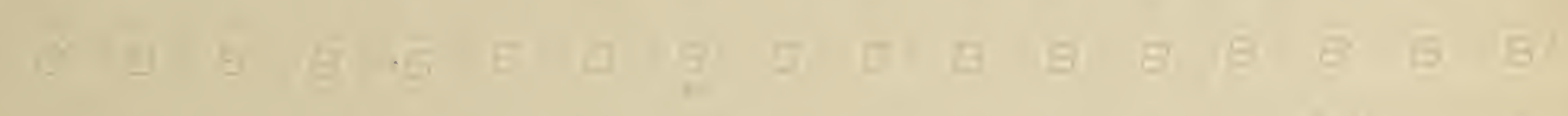

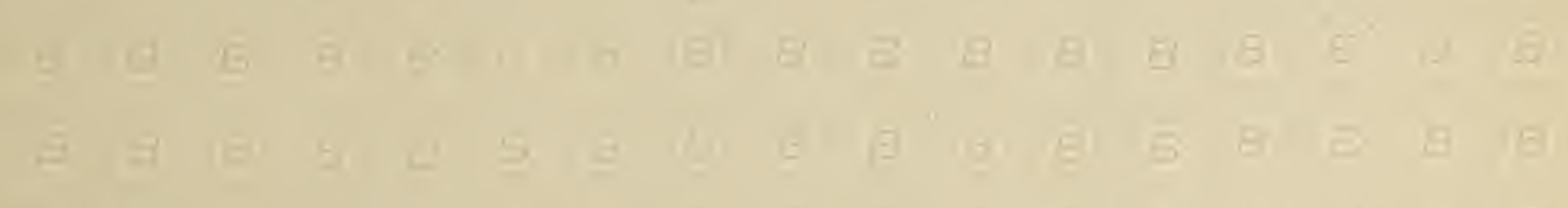

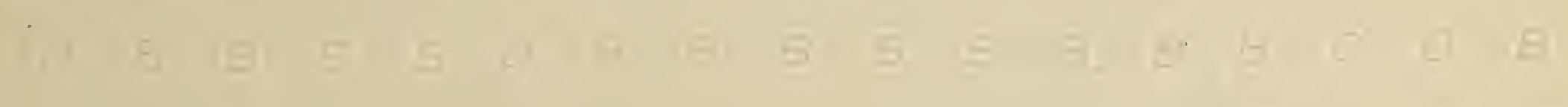

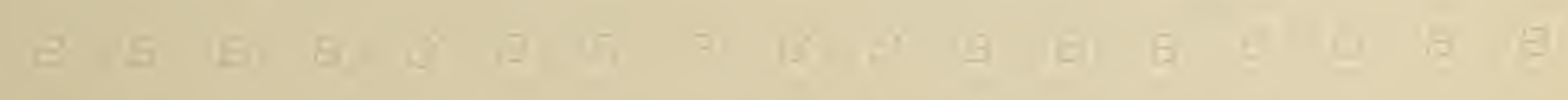

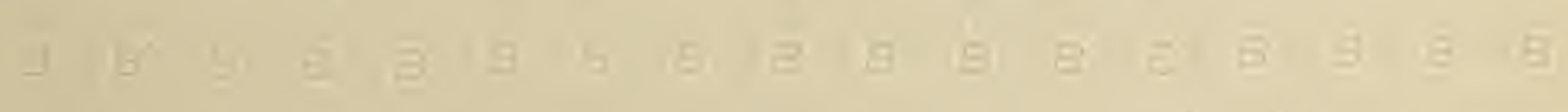

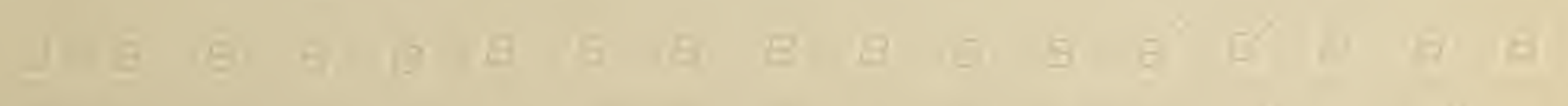

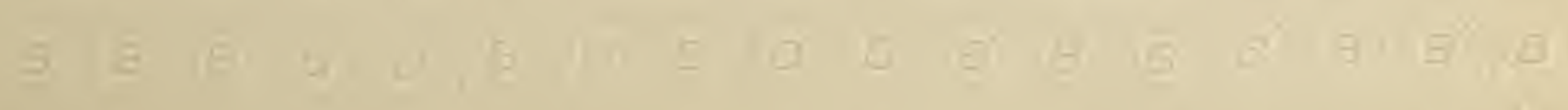
a $B$ G 


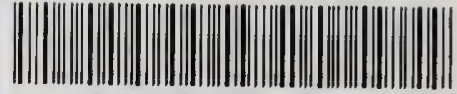

30112104633042 